\title{
LA FORTIFICACIÓN DEL "REINO MÁGICo" DE CABRERA
}

\author{
VIRGINIA NAVALÓN MARTÍNEZ
}

Tesis Doctoral, mayo 2021

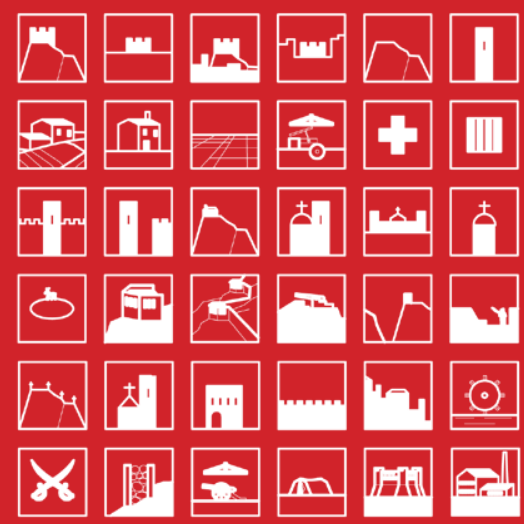

Director: Dr. GUILLERMO GUIMARAENS IGUAL

Departamento de Composición Arquitectónica Instituto de Restauración del Patrimonio 

La fortificaCión del “Reino MÁGICo” de CABRera

VIRGINIA NAVALÓN MARTÍNEZ 


\title{
LA FORTIFICACIÓN DEL “REINO MÁGICO” DE CABRERA
}

\author{
VIRGINIA NAVALÓN MARTÍNEZ
}

Director: Dr. GUILLERMO GUIMARAENS IGUAL
Departamento de Composición Arquitectónica

Instituto de Restauración del Patrimonio

Autora:

Virginia Navalón Martínez (virginianavalon@gmail.com)

Director:

Dr. Guillermo Guimaraens Igual

Departamento de Composición Arquitectónica, UPV

Instituto de Restauración del Patrimonio, UPV

Tesis doctoral en el programa de doctorado en Arquitectura, Edificación, Urbanística y Paisaje de la Universitat Politècnica de València

Universitat Politècnica de València, Camino de Vera s/n 46022, Valencia (España)

Escuela Técnica Superior de Arquitectura (ETSA)

Tesis Doctoral, 2021

Programa de doctorado en Arquitectura, Edificación, Urbanística y Paisaje Escuela Técnica Superior de Arquitectura (ETSA)

Universitat Politècnica de València (UPV)

\section{UNIVERSITAT}

POLITĖCNICA

DE VALĖNCIA 
Estado de la cuestión

Panorámica de la fortificación en la primera mitad del siglo XIX

8 La fortificación del “reino mágico" de Cabrera. Catálogo de fortificaciones identificadas

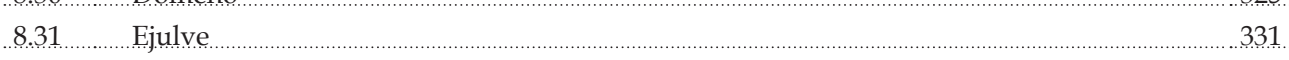




\begin{tabular}{|c|c|c|}
\hline 8.32 & El Collado de Alpuente & 335 \\
\hline 8.33 & Estercuel & 345 \\
\hline 8.34 & Flix ... & 349 \\
\hline 8.35 & Forcall & 355 \\
\hline 8.36 & Garaballa / Tejeda la Vieja & 361 \\
\hline 8.37 & La Fresneda & 367 \\
\hline 8.38 & La Galera & 373 \\
\hline 8.39 & La Hoz de la Vieja & 377 \\
\hline 8.40 & Landete & 381 \\
\hline 8.41 & La Pobla de Benifassà & 385 \\
\hline 8.42 & Las Cuevas de Cañart & 391 \\
\hline 8.43 & La Sénia & 397 \\
\hline 8.44 & Linares de Mora & 401 \\
\hline 8.45 & Manzanera & 407 \\
\hline 8.46 & Mira & 413 \\
\hline 8.47 & Mirambel & 417 \\
\hline 8.48 & Miravet & 423 \\
\hline 8.49 & Monasterio de Santa María del Olivar & 429 \\
\hline 8.50 & Monroyo & 433 \\
\hline 8.51 & Montalbán & 437 \\
\hline 8.52 & Montán & 443 \\
\hline 8.53 & Móra d'Ebre & 449 \\
\hline 8.54 & Morella & 455 \\
\hline 8.55 & Peñarroya de Tastavins & 489 \\
\hline 8.56 & Pinós & 493 \\
\hline 8.57 & Salinas del Manzano & 497 \\
\hline 8.58 & Salvacañete & 501 \\
\hline 8.59 & Samper de Calanda & 507 \\
\hline 8.60 & San Mateo & 511 \\
\hline 8.61 & Sant Carles & 517 \\
\hline 8.62 & Segura de los Baños & 521 \\
\hline 8.63 & Santa Bàrbara & 525 \\
\hline 8.64 & Tales & 535 \\
\hline 8.65 & Torrebaja & 541 \\
\hline 8.66 & Torrecilla del Rebollar & 547 \\
\hline 8.67 & Torre de Castro & 551 \\
\hline 8.68 & Torrijas & 555 \\
\hline 8.69 & Tragacete & 559 \\
\hline 8.70 & Ulldecona & 563 \\
\hline 8.71 & Utiel & 567 \\
\hline 8.72 & Villahermosa del Río & 575 \\
\hline 8.73 & Villar del Humo & 583 \\
\hline 8.74 & Villarluengo & 587 \\
\hline 8.75 & Víllora & 593 \\
\hline 8.76 & Xert & 597 \\
\hline 8.77 & Xerta & 601 \\
\hline 8.78 & Zafrilla & 605 \\
\hline
\end{tabular}

$9 \quad$ Estudio de caso: la fortificación liberal de Requena

Planteamiento geo-estratégico para entender la defensa de Requena

609

9.2 Una historia relativa. Los asedios carlistas de Requena 615

9.3 La fortificación liberal de Requena de la Primera Guerra Carlista a través de los $\quad 631$

documentos históricos: proyecto y construcción.

$9.4 \quad$ Propuesta justificada de reconstrucción del trazado fortificado liberal de Requena _. $\quad 671$

9.5 Puesta en valor: criterios aplicables a la fortificación liberal de Requena 685

9.7 Estudio particularizado: el caso de la casa del retablo 701

10 Fichas de elementos arquitectónicos de la fortificación de Requena vinculados con los $\quad 741$ informes militares

11 Conclusione

11.1 El concepto de "reino mágico" de Cabrera

11.2 El territorio físico y la estrategia defensiva territorial _ _ _ _ 1031

11.3 El paisaje $\quad \ldots \ldots . .103$

$\begin{array}{ll}11.3 & \text { El paisaje } \\ 11.4 \quad \text { El patrimonio fortificado } & 1045 \\ 11.5 & \text { Prom }\end{array}$

11.5 . Procesamiento de datos del catálogo de fortificaciones _...................................................1049

$11.6 \quad$ Las partes y el todo .

$11.7 \quad$ Enfoques para abordar cada caso $\quad 1052$

$11.8 \quad$ Propuesta teórica de una nueva tipología defensiva propia del contexto $\quad 1055$

11.9 Aportación sobre las unidades métricas de la época y el lugar utilizadas …

11.10 Determinación de plazas fortificadas entre 1833 y 1840

11.11 Artífices de la defensa carlista en el Maestrazgo 1065

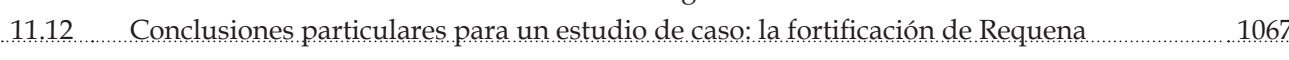

12 Anexos 1073

$12.1 \quad$ Listado de fortificaciones $\quad 1075$

$12.2 \quad$ Listado de recorridos de la tesis _ $\quad 1081$

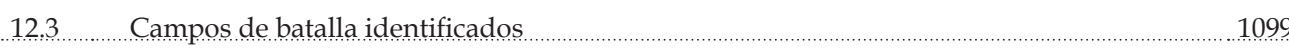

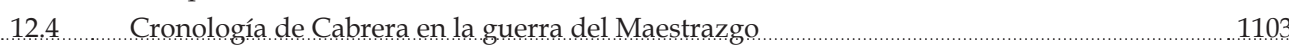

12.5 Cronología y posibles localizaciones de la expedición de Gómez _..........................................1111

12.6 Localizaciones de Baroja siguiendo el rastro de Gómez 1119

12.7 Periodos de la fortificación del "reino mágico" de Cabrera $\quad-\quad 1129$

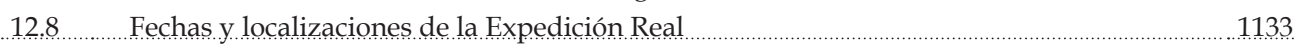

12.9 Recorrido de don Beltrán de Urdaneta en La campaña del Maestrazgo _............................. 1145

12.10 Informes biográficos de los protagonisatas del diseño y ejecución de las fortificaciones 1157 liberales de Requena entre 1833 y 1840

1211 Términos 1163

12.12 Cronología paralela. Interrelación entre los conflictos internacionales, nacionales y 1179 locales

$12.13 \quad$ Transcripción de documentos históricos $\quad 1187$

12.14 Toponimia asociada a la documentación histórica _ _ _

12.15 Archivos consultados $\quad 1235$

13 Bibliografía, documentos históricos y cartografía histórica de Requena $\quad 1239$

14 Créditos fotográficos e índice de tablas 
Otoño, el otoño de los otoños:

La lluvia cae a cantaros a través de la luz.

El bronce se derrite y se solidifica.

La luz cambia de sitio con el bronce.

La muerte cambia de sitio con el bronce que se derrite y se solidifica.

( las campanas para hacer cañones.

El ruido de los cañones fuera de las murallas de la ciudad. El sonido de las campanas en la plaza. La lluvia cae a cántaros a través de la luz.

Espadas convertidas en arados, arados en espadas.

El estrépito de la guerra sobre campos negros.

El estrépito de Dios en la plaza.

La plaza, el sitio de todas las plazas.

La idea de un sitio

en otoño, el otoño de los otoños.

La muerte cambia de sitio con la iden.

La plaza está vacía. La lluvia cae a cántaros.

Los cañones se van acercando.

Las campanas se oyen ahora constantemente.

La idea de Dios. Es otoño.

Campanas en cañones. La plaza de Dios donde esta la iglesia. La lluvia muerta. La plaza está vacía. Es otoño.

La idea de un sitio. El sitio de Dios

está vacío. Las campanas suenan.

La muerte ha cambiado de sitio con el bronce. La muerte ha cambiado de sitio con el sonido.

La muerte ha cambiado de sitio con la idea: La idea de Dios, la idea de la muerte

el Dios de todos los dioses, la muerte de todas las muertes.

Es otoño. Llueve a cántaros.

Henrik Nordbrandt, Piazza Duomo (Nordbrandt, 2005:17-18) 
En el transcurso de la Primera Guerra Carlista (1833-1840) las tropas carlistas incitan a la revuelta por todo el territorio nacional con distinta suerte. Más allá del principal frente de combate que se consolida en el norte, los ejércitos carlistas bajo la dirección del general Cabrera dominan un territorio que se extiende por las actuales provincias de Castellón, Valencia, Teruel, Cuenca y Tarragona. Se desarrolla en este territorio un conflicto bélico de características particulares basado en la estructura de partidas y la movilización de columnas volantes, que, prácticamente hasta 1840, permite a Cabrera consolidar un dominio capaz de dar seguridad al pretendiente Carlos en su marcha hacia Madrid, como también oponerse al armisticio de Vergara para resistir hasta el final. Wilhelm Von Rahden, el que fuera jefe de ingenieros y de los demás cuerpos facultativos del ejército de Cabrera, denomina este territorio como "el Reino Mágico de Cabrera", un territorio convertido en una gran fortificación que se transforma en el tiempo, que se expande y contrae, y cuyos recursos son los propios accidentes del terreno, la arquitectura de toda índole adaptada a las condiciones defensivas y las obras que se construyen de nueva planta para reforzar el sistema, principalmente de campaña.

pretende identificar el patrimonio arquitectónico que pudo formar parte de esta trama defensiva y arrojar luz sobre una etapa de la historia de España diluida en la memoria, especialmente en lo que atañe a un legado arquitectónico recurrentemente olvidado, invisible, sometido a procesos de destrucción durante y tras el conflicto, difícilmente documentado ante la escasez de fuentes y la destrucción de las mismas, y, en muchas ocasiones, confundido con arquitecturas de otros periodos históricos.

Palabras clave: fortificación carlista, Cabrera, Maestrazgo, castillo, fuerte, patrimonio. 
La fortificació del "regne màgic" de Cabrera

Durant la Primera Guerra Carlina (1833-1840) les tropes carlines inciten la revolta per tot el territori nacional amb diferent sort. Més enllà del principal front de combat que es consolida al nord, els exèrcits carlins sota la direcció del general Cabrera dominen un territori que s'estén per les actuals províncies de Castelló, sota la direcció del general Cabrera dominen un territori que s'estén per les actuals provincies de Castello,
València, Terol, Conca $i$ Tarragona. Es desenvolupa en aquest territori un conflicte bèl lic de característiques València, Terol, Conca i Tarragona. Es desenvolupa en aquest territori un conflicte bèl lic de característiques
particulars basat en l'estructura de partides i la mobilització de columnes volants, que, pràcticament fins a particulars basat en l'estructura de partides i la mobilització de columnes volants, que, pràcticament fins a cap a Madrid, com també oposar-se a l'armistici de Vergara per resistir fins al final.

Wilhelm Von Rahden, el que va ser cap d'enginyers $i$ dels altres cossos facultatius de l'exèrcit de Cabrera denomina aquest territori com "el Regne Màgic de Cabrera", un territori convertit en una gran fortificació que es transforma en el temps, que s'expandeix i contrau, i els recursos de la qual són els propis accidents del terreny, l'arquitectura de tota indole adaptada a les condicions defensives $i$ les obres que es construeixen de nova planta per reforçar el sistema, principalment de campanya.

nova planta per reforçar el sistema, principalment de campanya. Aquesta tesi pretén identificar el patrimoni arquitectònic que va poder formar part d'aquesta trama defensiva i fer llum sobre una etapa de la història d'Espanya diluïda en la memòria, especialment pel que fa a un llega arquitectònic recurrentment oblidat, invisible, sotmès a processos de destrucció durant i després del conflicte, difícilment documentat davant la manca de fonts i la destrucció de les mateixes, i, en moltes ocasions, confós amb arquitectures d'altres períodes històrics.

Paraules clau: fortificació carlina, Cabrera, Maestrat, castell, fort, patrimoni.

\section{The Fortification of "the Magical Kingdom" of Cabrera}

During the First Carlist War (1833-1840) the carlist troops incited revolt throughout the national territory with different fates. Beyond the main combat front that is consolidated in the north, the carlist armies under the leadership of General Cabrera dominate a territory that spread through the current provinces of Castellón Valencia, Teruel, Cuenca and Tarragona. A warlike conflict of particular characteristics develops in this territory, based on the party structure and the mobilization of flying columns, which, practically until 1840 allowed Cabrera to consolidate a domain capable of giving security to the pretender Charles on his march to Madrid and also oppose the armistice of Vergara to resist until the end. Madrid and also oppose the armistice of Vergara to resist until the end.
Wilhelm Von Rahden, who was chief of engineers and of the other optional corps of the Cabrera army, calls this territory "the Magic Kingdom of Cabrera", a territory converted into a great fortification that is transformed over time, which it expands and it contracts, and whose resources are the own accidents of the terrain, the architecture of all kinds adapted to the defensive conditions and works that are completely new to reinforce the system, mainly field fortification.

This thesis aims to identify the architectural heritage that could have been part of this defensive plot and it aims to illuminate a period of the History of Spain diluted in memory, especially regarding an architectura legacy that is recurrently forgotten, invisible, subjected to processes of destruction during and after the legacy that is recurrently forgotten, invible, subjected to processes of destruction during and after the conflict, hardly documented due to the scarcity of sources and their destruction, and, on many occasions, confused with architectures from other historical periods.

Key words: carlist fortification, Maestrazgo, castle, fort, heritage.

1 INrrobuccoion 
La presente investigación se inició al detectar determinadas incógnitas relacionadas con el patrimonio fortificado de la Primera Guerra Carlista. Tradicionalmente, ha despertado un mayor interés el patrimonio fortificado de tiempos antiguos y medievales a causa probablemente de la atracción que genera la ruina romántica. A finales del siglo pasado se despertó el interés por el patrimonio fortificado moderno, y la implicación emocional de los supervivientes de los conflictos bélicos del siglo XX propició intervenciones para recuperar determinados lugares de la memoria, como campos de exterminio, Línea Maginot, Atlantikwall, los blocaos de la Guerra Civil... Sin embargo, apenas encontramos trabajos arquitectónicos destacados en relación con el patrimonio fortificado de las encontramos trabajos arquitectónicos destacados en relación con el patrimonio fortificado de las
guerras carlistas, especialmente en un contexto tan particular como el de la guerra del Maestrazgo. guerras carlistas, especialmente en un contexto tan particular como el de la guerra del Maestrazgo. y, además, dicha memoria no es incentivada por la presencia física. Encadenamos esta conclusión con otra serie de preguntas que, ahora sí, son cometido de esta investigación: ¿realmente no existe presencia física de esta fortificación o quizás es preciso replantear cómo entendemos su modo de presentarse? Quizá el error sea pretender localizar una presencia física al uso. Los desconocedores a quizás pretendan encontrar un castillo o una muralla. Aqu as aportaciones arquitectónicas de la segunda mitad del siglo XIX tal vez aspiren a encontrar complejas estructuras acasamatadas, corazas y blindajes. Es preciso estudiar las características particulares de las guerras carlistas para deducir el producto arquitectónico, identificarlo y acometer su puesta en valor. Se trata de definir una nueva metodología en relación con este patrimonio fortificado, aparentemente invisible, y replantearse los objetivos.

Como preámbulo al desarrollo de la presente tesis, y como base de la propuesta, se acometió el estudio de caso de la fortificación liberal de la ciudad de Requena, entendiéndola como un patrimonio invisible que requería (a) nexistencia de vestigios, así como de recuerdos en la memoria popular, salvo la anécdota de que, un día, el general Cabrera atacó la ciudad.

En 1935 Pío Baroja publicó en la revista Estampa el resultado de sus pesquisas persiguiendo el rastro del General Gómez por los alrededores. El reportaje de Baroja registró el poco arraigo de la historia reciente en la población y el desconocimiento general acerca de los acontecimientos que contribuyeron a la conversión de Requena en "Muy Noble y Muy Leal Ciudad": "isabrá en este pueblo alguien algo de Gómez y de su expedicion?", se preguntaba Baroja (Baroja, 1935: 37). "Un viejo que está sentado en la plaza delante de la alhóndiga con quien hablo", explicaba, "confunde a Cucala con Cabrera". Su investigación antropológica le lleva a preguntar en el mesón de la localidad próxima de Utiel, y ya entonces solo se atreven a remitirle a tres personas que saben algo del tema. Uno, muy enfermo, y los otros dos, de ideología contrapuesta, le ofrecen versiones contradictorias (Baroja, 1935: 38). Esta falta de memoria, a la que hoy se suma la ausencia de presencia física, que habría contribuido Esta falta de memoria, a la que hoy se suma la ausencia de presencia física, que habría contribuido a reactivarla, ha ayudado a la disolución de este periodo de la historia local. En el caso concreto de han ido desapareciendo paulatinamente elementos singulares de la época, como sería el caso de los restos amurallados tras el Teatro Principal, los muros aspillerados del Batanejo y la Puerta de Alcalá. En el transcurso de la presente tesis, algunas edificaciones estudiadas han sido completamente alteradas. Hoy, la batalla por la defensa del patrimonio fortificado de la época se dirime en torno al desahuciado tambor de Cantarranas, una pequeña estructura de mampostería y tapia a punto de desmoronarse en un solar, que, de momento, aparece reconocida en el conjunto de elementos patrimoniales del Plan General de Ordenación Urbana de Requena de 2013 (PGOU, 2013). Pero salvo dicho tambor, insignificante para muchos, ya nada queda aparentemente de aquel patrimonio. 
Desde la perspectiva del historiador documentalista tan solo resta la pelea por el recuerdo, que no es poco. La investigación embrionaria que dio paso a la presente tesis, nacía desde la óptica arquitectónica, y pretendía complementar la visión y la aportación de los historiadores locales, tratando de responder a la pregunta: irealmente ha desaparecido dicho patrimonio? Un conocimiento de la ciudad de Requena, desde la mirada de la arquitectura y con el conocimiento de las aportaciones históricas, podría demostrar que la afirmación no es del todo cierta: la invisibilidad del patrimonio históricas, podría demostrar que la afirmación no es del todo cierta: la invisibilidad del patrimonio
no implica su inexistencia. Como diría Ortega y Gasset, la clave reside en plantear el conflicto no en el objeto observado, sino en la mirada que lo observa (Ortega, 2002:18).

La experiencia de Requena impulsó el presente estudio al plantear qué podría haber sucedido en otras localidades en situación parecida, tanto en el ámbito liberal como en el carlista. Dada la amplitud de la investigación, y a fin de acotarla, se decidió centrar la mirada, tal como se indica en el resumen de este trabajo, en el territorio fortificado por las tropas carlistas en el contexto de las campañas del Maestrazgo.

4

ig. 1. Castillo del Poyo, en el Collado de Alpuente. 


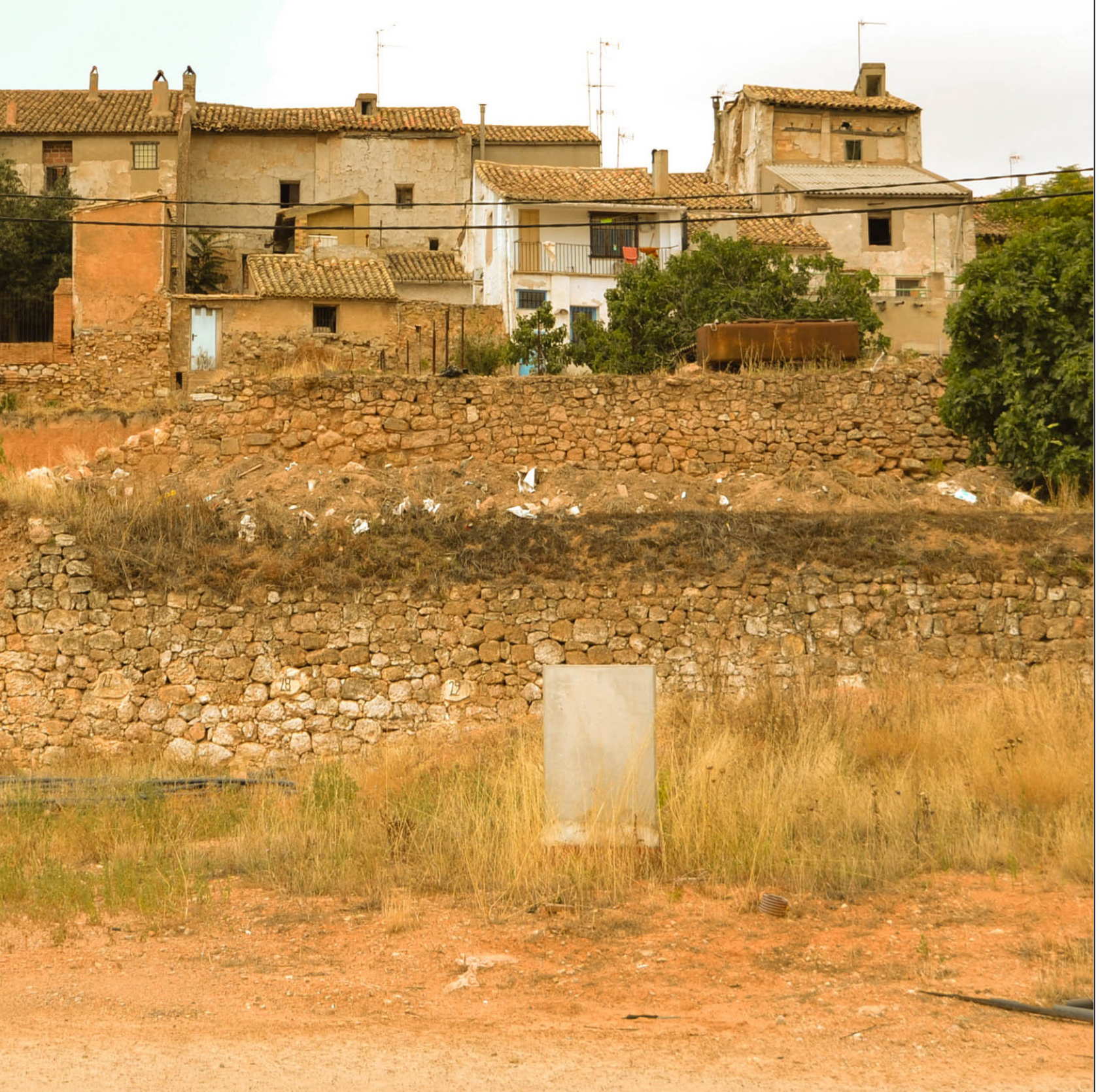

1.2. El "reino mágico" de Cabrera. Construcción, destrucción y memoria de la fortificación en la España despoblada

Cuando a comienzos del invierno de 1840 ve la luz la obra Cabrera. Erinnerungen aus dem Spanischen Bürgerkrieg ${ }^{1}$, del barón Wilhelm von Rahden, la Primera Guerra Carlista acaba de concluir. Dentro de la abundante bibliografía sobre el conflicto, en muchos casos deslegitimada por su claro partidismo, el testimonio de von Rahden, como coronel de ingenieros del ejército prusiano, nombrado comandante general de ingenieros del ejército carlista, resulta relevante para disponer de una opinión ( meten la fortificación del territorio y cuáles son sus propósitos. Apoyan su testimonio los múltiples extractos de la prensa liberal de la época ${ }^{2}$, así como el conjunto de documentos localizados en los diferentes archivos nacionales ${ }^{3}$. Los datos de archivo han sido apoyados por una labor de campo, sucesivas visitas a los emplazamientos realizadas entre los años 2015 y 2021, verificando recorridos, pasos y, especialmente los hitos fortificados, en muchos casos, plazas aparentemente destruidas de las que aún quedaban vestigios.

Del testimonio de von Rahden se identifican objetivos, se encuentran argumentos y se clarifican cuestiones relacionadas con la formación y organización de los responsables, así como otros aspectos de la sociología de la construcción. Llama la atención que el prusiano haga referencia al territorio dominado por Cabrera como el "reino mágico", en un intento de forjar en el imaginario

1 Obra recientemente traducida al español por Daniel F. Hübner (Von Rahden, 2013)

2 En la presente investigación se han consultado referencias del Boletín Oficial de la Provincia de Albacete, Boletín Oficial de la Provincia de Castellón de la Plana, Boletín Oficial de la Provincia de Zaragoza, Boletín Oficial de las Provincias de Valencia, Alicante y Castellón de la Plana, Boletín Oficial de Valencia, Diario Constitucional de Zaragoza, Diario de Avisos de la Ciudad de Valencia, Diario de la Ciudad de Valencia, Diario de Valencia, Diario de Zaragoza, Diario Mercantil de Valencia, El Castellano (Madrid), El Constitucional (Barcelona), El Correo Nacional (Madrid), El Corresponsal (Madrid), El Eco del Comercio (Madrid), El Piloto (Madrid), El Satanás (Valencia) y El Turia (Valencia).

AASC, Archivo de la Academia de Bellas Artes de San Carlos (Valencia); ACCGA, Archivo Central del Cuartel General de la Armada (Madrid); ACMD, Archivo Central del Ministerio de Defensa (Madrid), ACP, Archivo y biblioteca del Real Colegio Seminario de Corpus Christi (Valencia); ACV, Archivo de la Comunidad Valenciana (Valencia); ADPV, Archivo (General y Fotográfico) de la Diputación Provincial (Valencia); AGA, Archivo General de la Administración Defensa (Madrid): AGMM, Archivo General Militar (Madrid): AGMG, Archivo General Militar (Guadalajara); AGMS, Archivo General Militar (Segovia): AGS, Archivo General de Simancas, AHAV, Archivo Histórico del Ayuntamiento de Valencia; AHEA, Archivo Histórico del Ejército del Aire (Madrid); AHN, Archivo Histórico Nacional (Madrid); AIMV/ AIMC, Archivo intermedio Militar de Valencia (Archivo Intermedio Militar Centro) AMR / AHMR, Archivo Histórico Municipal de Requena; ARV, Archivo del Reino de Valencia (Valencia); BCM, Biblioteca Central Militar (Madrid); BIVALDI, Biblioteca Valenciana Nicolau Primitiu (Biblioteca Valenciana Digital); BOE, Agencia Estatal Boletín Oficial del Estado. Gobierno de España. Ministerio de la presidencia. Gazeta: coleccion historica (Madrid); BV, Biblioteca Valenciana (Valencia); BVIFC, Biblioteca Virtual de la Institución Fernando el Catolico. Excma. Diputación de Zaragoza (Zaragoza); BVMC, Biblioteca virtual Miguel de Cervantes. Universidad de Alicante, Banco de Santander y Fundación Marcelino Botín (Alicante); BVPB, Biblioteca Virtual del Patrimonio Bibliográfico; CGE [ACEG-CGE], Centro Geografico del Ejercito (Archivo Cartografico y de Estudios Geograficos del Centro Geográfico del Ejército) Gobierno de España. Ministerio de Hacienda y Administraciones Públicas (Madrid); FSS, Centro de documentación de la cultura vasca. Fundación Sancho el Sabio (Memoria Digital Vasca) (Vitoria-Gasteiz): IGNC. Instituto Geográfico Nacional de España (Madrid); MVM, Museo Virtual del Maestrazgo (Cantavieja); SPAL, Biblioteca de la Dirección General del Patrimonio Cultural Valenciano. Generalitat Valenciana. Conselleria de Cultura, Educació i Esport (SPAI, catálogo de acceso público) (Valencia); UJI, Biblioteca digital de Castellon. Repositori Universitat Jaume I (Castelló de la Plana); ZM, Archivo digital del Zumalakarregi Museoa. Centro de referencia para el conocimiento y disfrute del siglo XIX en el Pais Vasco. Museo Zumalakarregui Museoa, Muxika Egurastokia Ormaiztegi (Gipuzkoa). 
plazas de Castellote, Las Cuevas [de Cañart], Villarluengo y Aliaga. Precisamente en el noroeste, los carlistas consiguen controlar Segura [de los Baños], que se convierte, por la magnitud defensiv de la plaza, en una cuña destinada a avanzar la frontera occidental, una posición avanzada, exterior al recinto, atalaya de envergadura para prevenir ataques a la altiplanicie, pero también para lanza ataques a la cuenca del Cella o el Jiloca y romper la comunicación Zaragoza-Valencia.

La defensa sur del macizo de Cantavieja y Morella se confía a las posiciones de Culla, Villahermosa del Río, Villamalefa y Montán. Estas se emplazan frente a la liberal Lucena, con sus líneas atrincheradas en los montes próximos y que es la llave del enemigo hacia Castellón y Valencia.

Al sudoeste, frente a Teruel, se emplaza Alcalá de la Selva, con el río Mijares de por medio.

En el macizo Cantavieja-Morella destaca el frente occidental, que, dominado por Morella, es flanqueado por Peñarroya [de Tastavins], al norte, y Ares del Maestre, al sur, que extiende su dominio a través de Culla a la rambla de la Viuda, pero, principalmente, se defiende así la carretera desde Valencia. Este frente permite también el control sobre San Mateo, desde el que hacer batidas por las huertas de la costa mediterránea donde el puerto de Benicarló es convertido en el lugar ideat protegido para el atraque de pequeñas embarcaciones. El sueño de Cabrera de conformar una flota carlista, dado el dominio liberal del Mediterráneo, pronto queda desdibujado.

En el frente norte, es clave el control de Beceite, que permite acceder a las fortificaciones de Mora [d'Ebre] y Miravet, controlando el paso del Ebro más allá de Tortosa, lo cual permite mantener la conexión con los territorios carlistas de Cataluña.

Pero el principal objetivo de Cabrera es abrir la Mancha para desparramar sus partidas por el territorio y, especialmente, tener acceso al objetivo final, que no es otro que Madrid. Así, Cañete, Salvacañete y Zafrilla controlan el río Cabriel, Tragacete el Júcar, y Beteta el Tajo
Von Rahden ${ }^{4}$ confirma literalmente esta idea en diferentes momentos de su obra, pero especialmente se confirma con la narración del conflicto a partir del movimiento de los ejércitos en los años de contienda y que son reflejados en la prensa de la época citada con anterioridad. La visita de los lugares y el estudio in situ de las supuestas obras de fortificación han permitido testimoniar en muchos casos la intervención carlista. 

$\int \begin{gathered}\text { Pantì } \\ \text { de Riba-roja }\end{gathered}$

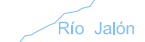

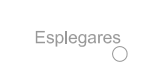

Huerta de Hernando
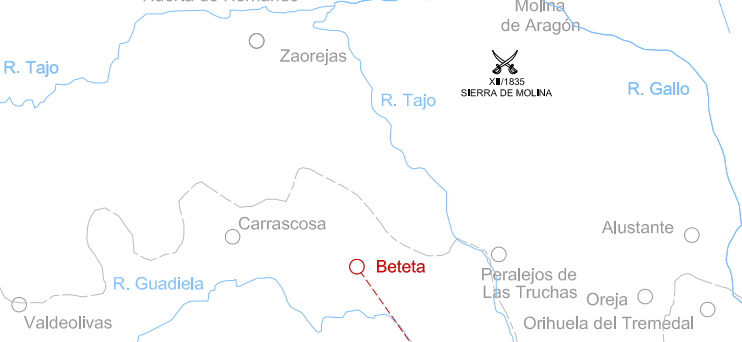

Priego Cañamares$$
\text { R. Escabas }
$$

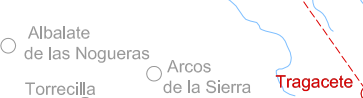

Torreclla de la Sierra Tragacete

Collados Villaba

R. Júcar

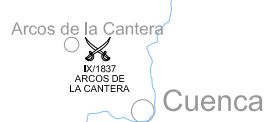

Abia
de la obispalía
R. Júcar

Albadalejo
del Cuende
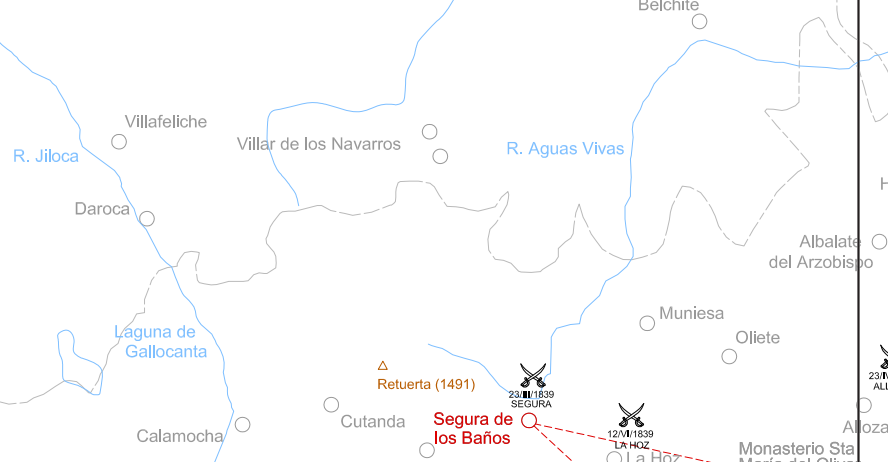

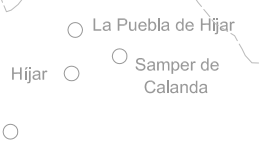

$$
\text { Mel Campo }
$$

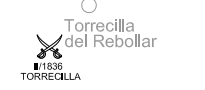

,

$$
\text { Peracense }\left\{\begin{array}{l}
\text { Vilaranca } \\
\text { del Campo }
\end{array}\right.
$$

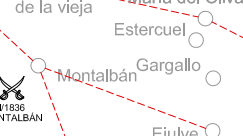

Alcorisa

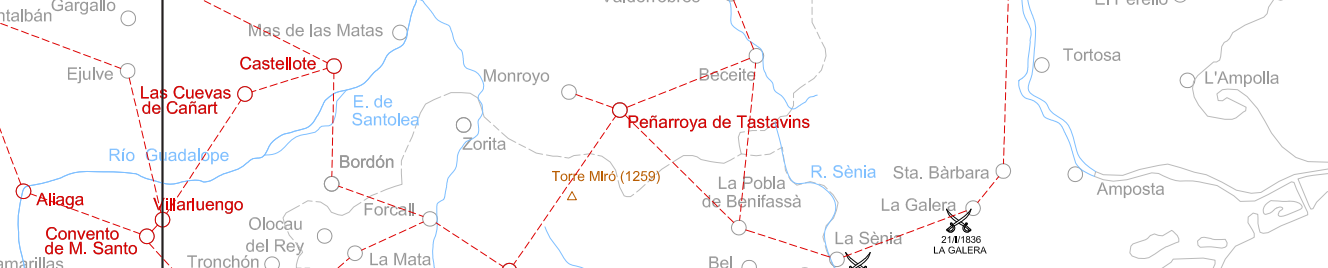

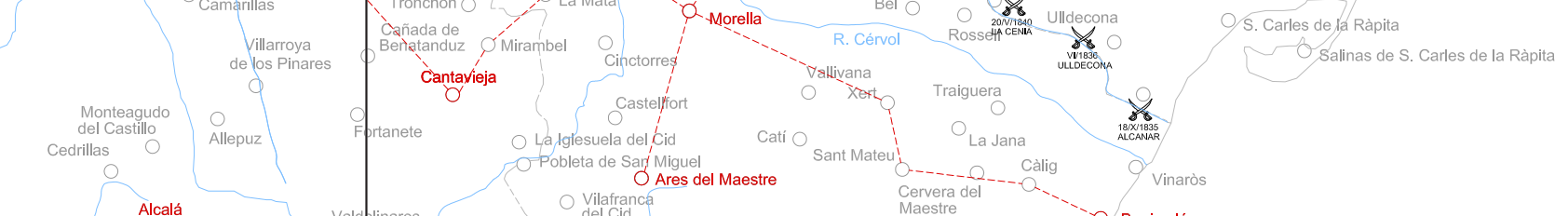

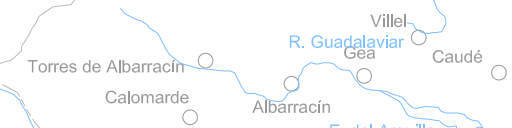

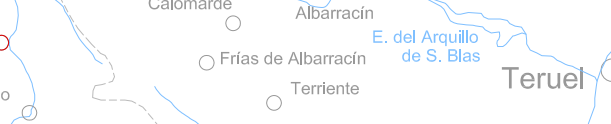
Villastar 0
viliel

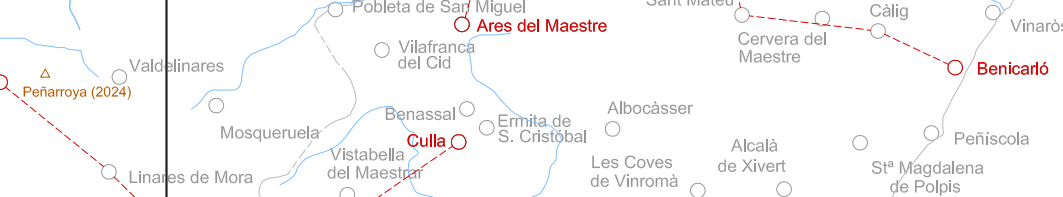
Mora
de Rubielos 
2 овевтио 
El presente trabajo aspira a generar un debate en torno al olvido al que se ha visto abocado determinado patrimonio fortificado de la Primera Guerra Carlista, concretamente en el ámbito de las campañas del Maestrazgo.

La dificultad para abordar este estudio radica en el deterioro de los restos y el hecho de que muchos de ellos hayan sido diluidos bajo construcciones posteriores. Dado que muchas obras carlistas aprovechan el patrimonio ya existente, tampoco han ayudado determinadas acciones de recuperación del patrimonio, que, desconociendo el valor de la fase constructiva correspondiente, han borrado las pocas huellas que podían haber contribuido a su identificación y puesta en valor.

La presente investigación, como ya se ha comentado, se inicia con el estudio de la plaza liberal de Requena, plaza clave en el conflicto por su ubicación estratégica en las rutas que conectan el Maestrazgo o la costa levantina con la capital del Estado.

Entre los objetivos parciales con los que se emprendía el estudio de la plaza de Requena, extensible otros municipios, se encontraban:

1. Proponer una metodología para abordar coherentemente el estudio del patrimonio fortificado invisible de la Primera Guerra Carlista utilizando como prototipo el caso de Requena.

2. Catalogar los restos asocia dos con dicho patrimo . Catalogar los restos asociados con dicho patrimonio, haciendo especial hincapié en su localización, identificación, descripción, tipo de reconocimiento administrativo, estado de conservación, características técnicas constructivas...

3. Definir el recorrido del recinto fortificado de la villa a partir del estudio de las fuentes históricas, especialmente documentos procedentes de los archivos militares, así como de los restos que pudieran identificarse a fin de favorecer futuros estudios particulares.

4. Localizar todas las fuentes históricas en los diferentes archivos históricos y militares, y generar una base de datos documental que pudiera servir de instrumento a futuros investigadores sobre el tema.

5. Definir un conjunto de criterios para la puesta en valor de este patrimonio singular.

A partir de la experiencia de Requena, se aspira posteriormente a lanzar una mirada global al patrimonio fortificado en el ámbito nacional, pero esta se acaba concentrando en el área afectada por las campañas del Maestrazgo, dadas las características singulares que adquiere el conflicto en el territorio, condicionando un modo particular de entender su fortificación. Dada la amplitud del tema y las diferentes condiciones defensivas que en base a las circunstancias ofrecen los bandos en liza, se decide acotar el estudio al ámbito carlista, muy condicionado por los medios de los que disponen sus ejecutores, por las características del territorio a defender y por tratarse de un patrimenio en riesgo, dad en riesgo, dadas las mún pérdida de muchas referencias documentales del ejército carlista.

Desde esta perspectiva territorial se aspiraba a:

1. Identificar en el territorio el conjunto de plazas o posiciones en los que se detectase algún intento de fortificación por parte de las tropas carlistas, ya sea de nueva planta o de refuerzo de lo existente. Para ello se recurre a las fuentes históricas de la época, los estudios históricos recientes y la investigación in situ.

2. Definir los procesos de fortificación, las técnicas utilizadas y los tipos arquitectónicos consolidados. 
3 Método Y FASES DE TRABAJO 
La investigación se inicia con un proceso de consulta de fuentes a diferentes niveles. Por una parte es preciso asumir el contexto de la fortificación desde muy diversas perspectivas: histórica, política, militar, geográfica o arquitectónica. Dadas las características de la investigación, el contexto también debe hacer referencia a diversas escalas:

La escala internacional: en lo referente a los acontecimientos históricos, especialmente conflictos militares, o cuestiones políticas que repercuten en el ámbito nacional. También las influencias teóricas o la realidad de ciertas fortificaciones que condicionan el panorama internacional.

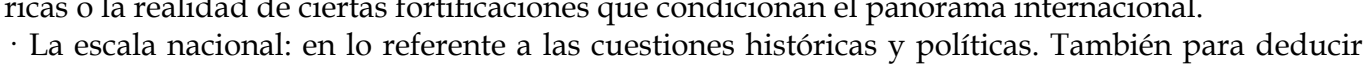
cómo se define la teoría en el ámbito nacional y si existen referencias en él.

El marco territorial concreto: en referencia a los territorios afectados por la guerra de partidas emprendida desde el Maestrazgo.

El marco local: escala de los acontecimientos locales, características geográficas y demás particularidades.

Los apoyos bibliográficos se referencian al final de este trabajo y se han obtenido de múltiples procedencias (biblioteca personal a partir de nuevas adquisiciones, archivos históricos, bibliotecas procedencias (biblioteca personal a partir de nuevas adquisiciones, archivos históricos, bibliotecas
públicas y privadas y archivos digitales). En el apartado del estado de la cuestión se perfilan las referencias más destacadas. Junto a esta información resulta relevante el conjunto asociado con:

1. La teoría de la fortificación a través de los tratados históricos.

2. Las referencias académicas a través de la documentación asociada a las escuelas de formación de ingenieros.

3. Los expedientes biográficos de los diferentes artífices de la fortificación.

4. Documentos asociados a los planes de fortificación de diferentes localidades, incluyendo cartografías.

5. Fotografías históricas de las localidades correspondientes.

Es preciso destacar el conjunto de información documental, cartográfica y tratadística procedente de múltiples archivos municipales, Archivo Intermedio Militar de Valencia (AIMV), Biblioteca Valenciana (BV), Instituto Histórico Militar de Madrid (IHM), Biblioteca Nacional de Madrid (BN), Archivo General de Simancas (AGS), Archivo General Militar de Segovia (AGMS), Archivo de la Academia de Bellas Artes de San Carlos en Valencia (AASC) y, en concreto, para la profundización en el contexto carlista, el Centro de documentación de la Cultura Vasca, de la Fundación Sancho el Sabio. En total se ha recurrido a más de 40 archivos históricos, que se desglosan con sus abreviaturas en las páginas finales de este trabajo, de los cuales 12 han tenido que visitarse físicamente para poder acceder a documentos no digitalizados. El resto de consultas han podido resolverse por vía digital o telefónica.

La documentación se ha obtenido de formas diversas: archivos digitalizados, fotocopias compulsadas o fotografías propias realizadas en el archivo correspondiente.

En el caso concreto de la localidad de Requena, se ha podido acceder a un total de 225 fotografías, muchas de las cuales se han podido obtener por cortesía de César Jordá, Antonio Navalón, el Centro de Estudios Requenenses y el Archivo Municipal de Requena. También se ha podido acceder a través de internet a fotografías puntuales no localizadas en las fuentes anteriores, por proceder de fuentes particulares, en algunos casos no identificadas. En los pocos casos que ha sucedido, las fotografías se han descartado del trabajo. 


\section{Fase de interpretación documental y bibliográfica}

1. Proceso de transcripción e interpretación de documentos históricos. Proceso inducido por la dificultad de lectura o el mal estado de conservación de algunos documentos.

2. Proceso de representación del trazado fortificado a partir de la cartografía histórica y los planos urbanos contemporáneos, donde resulta de interés la definición de las áreas de morfología urbana característica.

3. Proceso de contraste de la información planimétrica con el conjunto de ortofotogrametrías aéreas de los diferentes vuelos históricos, como en el caso de la ciudad de Requena, recogidos en la fototeca digital del Instituto Geográfico Nacional, como los americanos de 1945-1946 y de 1956-1957 o el vuelo interministerial de 1973-1986. A eso se suman fotografías recientes y las herramientas digitales de google maps y google earth para determinadas localizaciones.

4. Como herramienta de trabajo se ha confeccionado una base de datos en Microsoft Acces, para el 4. Co he herama en la que se identifican uno a uno us ele o citados por los informes militares, incorporando las hipótesis de emplazamiento, las referencia al respecto encontradas en los documentos y, en caso de existir y estar contemplados en el catálogo patrimonial del Plan General de Ordenación Urbana de Requena (PGOU, 2013), o haber sido declarados Bien de Interés Cultural, se incorporan los datos de los expedientes correspondientes.

5. Es fundamental recalcar que se recurre a la interpretación de la historia militar en clave arquitectónica. La aplicación de los conocimientos en la táctica y la estrategia militar, aplicados a las narraciones contenidas en la historia militar, en ocasiones permiten esclarecer la existencia de estructuras fortificadas no identificadas en la narración, ante la preferencia por la narración de hechos frente a la descripción arquitectónica.

6. Proceso de redibujado o reconstrucción de entornos o acontecimientos mediante herramientas gráficas de precisión a fin de deducir información que permita la planificación de la investigación in situ. Este aspecto resulta relevante en la presente tesis a la hora de ampliar el conjunto de emplazamientos a visitar. Más allá de las puntos geográficos identificados por las fuentes históricas como lugar de intervención fortificada, el trazado de los movimientos relevantes de las fuerzas carlista en los mapas, sea en forma de grandes expediciones, correrías, o bien a través del testimonio de viajes literarios, como pueden ser los planteados por Baroja y Pérez Galdós décadas después, permite identificar puntos de paso, coincidencias de movimientos sobre el territorio que permiten deducir aquellos puntos que podrían haber servido de apoyo o abastecimiento a la red de posiciones fortificadas por los carlistas.

\section{Fase de investigación in situ}

Se acometen fases de investigación in situ en diferentes ámbitos de estudio:

1. Fase de identificación del trazado. Simultáneamente y posteriormente a la identificación documental se han visitado las diferentes posiciones identificadas en el catálogo de la presente tesis, analizando el supuesto trazado defensivo de las posiciones elegidas, interpretando áreas transformadas, reconociendo vestigios e identificando arquitecturas presentes en la época. Esta fase se ha madas, reconociendo vestigios e identificando arquitecturas presentes en la époc
basado en el registro fotográfico y toma de datos a partir de fichas de campo.

Este apartado ha resultado clave en la presente tesis al haberse ido identificando en su emplazamiento cada uno de los elementos analizados, o verificando la ausencia de vestigios en la actualidad. La herramienta del viaje, dificultada en la fase final por la actual situación de pandemia por Covid-19, se ha extendido en el tiempo definiendo rutas que suman más de 12.000 kilómetros. En el conjunto de itinerarios se han buscado las posibles rutas y paisajes carlistas, que se desglosan en el anexo correspondiente.

2. Fase de levantamiento y análisis arquitectónico de un elemento con el objeto de identificar el trazado y las características de la fortificación en áreas conflictivas. Lanzadas las hipótesis de ubicación del trazado, se procede a seleccionar un área donde se identifique un conjunto de edificaciones para dilucidar su grado de interacción con la fortificación. Resulta clave el análisis gráfico de la edificación, el análisis constructivo y estructural, la identificación de su propiedad, etc., para poder clarificar los procesos de transformación. El objetivo, es preciso recalcarlo, es identificar de qué modo la edificación interactúa con la fortificación para fijar el trazado de la misma y sus elementos constituyentes.

\section{Fase conclusiva}

A partir de las existencias y las hipótesis probadas en la fase de identificación de trazados in situ, se han podido extraer conclusiones para fijar la presencia más o menos consolidada de cada uno de los prototipos de estudio.

\section{Medios utilizados}

La investigación no ha requerido medios complejos para su progreso. Básicamente se han utilizado instrumentos de medición para proceder a los levantamientos requeridos in situ (estación total, distanciómetro láser, unidad gps...), software específico para el diseño de base de datos (Bases de datos de Acces), diseño arquitectónico (Autocad, Photoshop) y maquetación de documentos (InDesign).

\section{Plano de recorridos efectuados para la investigación}

Leyenda del plano de la página siguiente

- 22/05/2016 Rubielos de Mora-Linares de mora-La Iglesuela-Cantavieja-Vilafranca

28/06/2016 Requena-Sot de Chera-Chulilla

- 07/07/2016 Chulilla-Calles-Chelva

06/08/2016 Requena-Ademuz-Cantavieja-Morella-Vinaròs

27/04/2018 Domeño-Chelva-Alpuente-El Collado

- 05/05/2018 Albentosa-Manzanera-Bejís

18/05/2018 Jérica-Montán-Montanejos-Segorbe

22/05/2018 Sueca-Cullera

- 13/06/2018 Onda-Ayódar-Sueras-Tales

16/06/2018 Caspe-Chiprana-Escatrón-Sástago-Alcañiz-Morella

09/04/2019 Teruel-Logroño-Tarazona-Tudela-Calatayud

21/08/2019 Jaca-Blaye-Burdeos-Biarritz-Hondarribia-Irún-Donostia-Andoain

04/08/2020 Chelva-Torrecilla de Chelva-Pico del Remedios-La Yesa

06/08/2020 Chiva-Buñol-Requena-Landete-Boniches-Cañete-Beteta-Molina de Aragón

06/08/2020 Chiva-Buñol-Requena-Landete-Boniches-Cañete-Beteta-Molina de A

19/08/2020 Culla-Benassal-Ares del Maestre-Vilafranca del Cid-Cantavieja-Mirambel-Forcall

- 20/08/2020 Torrecilla del Rebollar-Segura-Montalbán-Estercuel-Alloza-Alcorisa-Castellote-Cuevas de CañartEjulve-Aliaga

- 26/08/2020 Linares de mora-Villarluengo-Bordón-Calanda-Castelserás-La Fresneda- Valderrobres-BeceitePeñarroya de Tastavins-Monroyo

05/09/2020 Mira-Víllora-Cardenete-Villar del Humo-Carboneras-Cañada del Hoyo-Castillo de Torrefuerte-Garaballa

- 24/10/2020 Utiel-Tejeda la Vieja-Salinas del Manzano-Castielfabib-Torrebaja-Ademuz-Requena

31/10/2020 Domeño viejo-Calles-Torre de Castro

24/12/2020 Sant Mateu-Xert-Càlig-Benicarló, Vinaròs

02/01/2021 Ulldecona-La Galera-Molí del Vallés-Xerta-Móra d'Ebre-Miravet-Flix-La Sénia-Sta. Ma de Benifassà 06/02/2021 Morella 

4 Estado de la cusstion 
A la hora de acometer la presente investigación ha sido preciso enfrentarse a una visión panorámica sobre el estado de la cuestión en temas relacionados, desde los más generales, relacionados con la historia del conflicto carlista y las fortificaciones del momento, a los más específicos, vinculados con las diferentes localidades o posiciones fortificadas.

Así pues, distinguimos los siguientes apartados.

\section{Las referencias de los grandes literatos y la evocación de atmósferas desde la ficción}

Queremos hacer un pequeño homenaje desde este trabajo a aquellos grandes literatos que abordaron el conflicto carlista a través de su obra. Se trata de obras que reflejan el ambiente de la época, permiten entender el espíritu del momento con su complejidad y ofrecen visiones idealizadas o críticas, en función de su empatía con las causas en conflicto. Desde el punto de vista descriptivo, serían obras realistas acordes con la voluntad literaria de la época, que encuentran en el reflejo de la realidad un modo de acometer los conflictos del momento con el arma literaria. La idealización romántica y la voluntad escapista de muchos autores contemporáneos al conflicto carlista hacen que las fuentes más fieles sean las de una generación posterior, influidas por el nat voluntad de veracidad de los literatos, especialmente a finales del siglo XIX y a principios del siglo $\mathrm{XX}$, permite encontrar descripciones que favorecen el entendimiento del paisaje y las atmósferas arquitectónicas, que han sido de utilidad en la investigación.

El primer gran autor que es preciso citar es el realista Benito Pérez Galdós (1843-1920) con sus Episodios Nacionales, donde cabe destacar el volumen dedicado a Zumalacárregui (Pérez Galdós, 1993c), y el que destina por completo a la Campaña del Maestrazgo (Pérez Galdós, 1993), con un acercamiento bastante diferente al caudillo vasco y al Tigre del Maestrazgo. Las obras ayudan a entender las campañas correspondientes, además de citar con precisión las localizaciones en las que transcurre la trama. Se aprecia la visión que el autor tiene de los personajes históricos, siempre desde la óptica la trama. Se aprecia la visión que el autorica liberal de un escritor con afán de objetividad y diseccionador de los comportamientos humanos. No se pueden dejar de lado todos aquellos episodios que abordan aspectos directamente implicados en los grandes acontecimientos de la guerra, aunque menos utilizados en este trabajo: Mendizábal (Pérez Galdós, 1993c), De Oñate a la Granja (Pérez Galdós, 1993e), Luchana (Pérez Galdós, 1993f) y Vergara (Pérez Galdós, 1993g).

Pío Baroja (1872-1956) desgrana con su obra múltiple Memorias de un hombre de acción, y concretamente en los apartados Los caudillos de 1830 (1977), La isabelina (1977b), El sabor de la venganza (1979) y Las furias (1979b), la experiencia biográfica de su protagonista, el aventurero Eugenio de Aviraneta (1792-1872). De sumo interés resulta Los caudillos de 1830 (Baroja, 1977), al abordar el final del neta (1792-1872). De sumo interés resulta Los caudillos de 1830 (Baroja, 1977), al abordar el final del
reinado de Fernando VII y el curioso intento de invasión liberal liderado por Espoz y Mina a través de Bayona. La novela ayuda a entender la polarización ideológica española que viene cultivándose desde la invasión napoleónica: el liberalismo frente al absolutismo de Fernando VII. En esta ocasión, los realistas o absolutistas constituyen el ejército gubernamental, mientras que los liberales, las fuerzas militares que tratan de desbancar el absolutismo y reimpulsar el constitucionalismo de 1812. En poco tiempo, la situación cambia. Las fuerzas realistas de la novela representan lo que liberal o cristino a raíz de los sucesos de la Granja. La novela discurre sutilmen geografía vasca y ayuda a entender los modos de vida de la época.

mejor el conflicto que Zalacaín el aventurero (Baroja, 1985), especie de narración que desde la óptica actual se asemeja a una obra juvenil de 
aventuras, donde un personaje hostil a las facciones se desenvuelve por el campo carlista reflejando en sus andanzas los sistemas de recluta y las atmósferas urbanas y arquitectónicas de la geografía vasca. La imaginaria villa de Urbía no distaría mucho en sus características de algunas pequeñas locelch con capital en Estella, y refleja, con la mirada crítica del autor, los posicionamientos políticos de la época, la estructura social y los poderes políticos, militares, morales y económicos. Si bien la novela transcurre durante la Tercera Guerra Carlista (1872-1876), ayuda a entender el conflicto ideológico y la situación rural que ha cambiado poco en el transcurso del siglo.

Miguel de Unamuno (1864-1936) aborda en su primera novela Paz en la guerra (1897) el escenario de la Guerra Carlista, concretamente su experiencia de niñez dentro de los muros asediados de Bilbao en 1874, tratando de comprender la cuestión vasca. Unamuno es uno de los validadores de la opinión hoy discutible que sostiene que el carlismo se cimienta en el mundo rural, mientras que el liberalismo lo hace en el urbano (Unamuno, 2009).

El otro gran referente literario es Ramón María del Valle-Inclán (1866-1936), que, enclavado en el denominado modernismo literario, ofrece la visión idealizada de un joven simpatizante del carlismo en territorio gallego. La visión de Valle-Inclán, por ejemplo, en Los cruzados de la causa, de 1908 (Valle-Inclán, 2011) es una visión de atmósferas negras, de profundidades del carácter humano, que, por ser una obra de juventud, nos atreveríamos a calificar de un idealismo y pesimismo romántico. La inigualable generación de atmósferas que ofrece Valle-Inclán con su lenguaje dista mucho de la intención más descriptiva y serena de los autores anteriores. A pesar de la deslocalización temporal y espacial con el tema que nos ocupa, sirve para entender los ideales y principios que pudieron conducir a muchos españoles a abrazar la causa carlista, como el propio Valle-Inclán, seducidos por una imagen romántica de la corona, del pretendiente al trono, de la propia causa carlista e incluso de la tradición. Se trata de una idealización del pasado puramente romántica y que podrí considerarse patológica cuando abocándose al conflicto militar ofrezca el escenario de la guerra. Los cruzados de la causa, como se intuye en su título, no llega a ofrecernos la conclusión a la que el propio autor llega con los años, y se queda en esa primera exposición de ideales, crítica con las actitudes liberales y sublime en la pintura de atmósferas de la Galicia profunda. La saga es completada con 1909). El resplandor de la hoguera, de mayor interés, ofrece el tránsito de una visión heroica de la guerra al esperpento de Valle-Inclán. La última novela de temática carlista podría considerarse una novela épica de exaltación de la figura individual del cura Santa Cruz (1842-1926), que nos permite conocer, siempre a través del filtro de Valle-Inclán, a uno de estos personajes particulares que producen las contiendas carlistas, en este caso la tercera, en la que se centra principalmente el escrito por su proximidad biográfica. Es conveniente contraponer la visión de este personaje que ofrece Baroja a la de Valle-Inclán.

\section{El testimonio de los viajeros románticos. Una visión pintoresca.}

Un testimonio de sumo interés y de primera mano, especialmente del primer conflicto carlista (1833-1840) es el de aquellos viajeros románticos que se desplazan a España para integrar las filas de uno u otro bando, o bien son sorprendidos por el conflicto. Es conocida la atracción que Españ genera en el mundo romántico por asociarse con lugares de evasión exótica que inspiran a muchos pintores y literatos de entonces. Como sostiene Pedro Rújula (2005:59), el conflicto carlista llega a fascinar a muchos extranjeros, que no dudan en acercarse a la península, pues encuentran en él "un de las claves de lo hispano". La realidad es que detrás de los conflictos que vive España prácticamente a partir de la Guerra de Independencia, la injerencia internacional es flagrante, como citaremos más adelante. Esta injerencia es motivada por un cierto afán de provecho, como la puesta a prueba de la carrera armamentística que se desarrolla en la segunda mitad del siglo XIX, y el debilitamiento de un país que, en el transcurso del siglo, se ve obligado a desprenderse de sus posesiones de ul- tramar, para provecho de otros. Si bien es cierta la única vocación cultural de algunos viajeros, no es extrapolable a la totalidad, pues muchos, de acuerdo con las prácticas que se van consolidando en el transcurso del siglo, actúan de verdaderos observadores militares y transfieren los datos a sus respectivos países.

Muchos de estos observadores ayudan a legitimar ciertas visiones, especialmente una visión exótica basada en los tópicos, como sigue en muchos casos sucediendo con el encasillamiento del espíritu y el carácter español desde países vecinos. En función del oportunismo de la perspectiva internacional, las facciones se apropian de la misma para legitimar y hacer más seductora su causa. La actitud heroica de Zumalacárregui es ensalzada por Henningsen (1836), que se convierte en uno de los literatos precursores del nacionalismo vasco, especialmente al difundir su obra en inglés. A partir de ella, muchos aventureros internacionales se aproximan a la causa carlista.

Wilhelm von Rahden (1851) y Augusto von Goeben (1841) constituyen dos nuevos ejemplos de literatos afines a la causa, claves para la presente tesis, como se observarñá con la continua referencia a los mismos, aunque quizá la obra de mayor interés literario sea la del príncipe polaco Félix Lichnowsky (1841). Lichnowsky, oficial prusiano, trata de plasmar la tragedia romántica de la guerra. Frente a estos autores que se posicionan y participan en el conflicto, existen otros que transitan por España con otros fines y nos muestran una visión particular, como es el curioso caso de un vendedor de biblias, George Borrow, que recoge su propia interpretación del conflicto en La Biblia en España (Borrow, 1843), basada en ciertos tópicos. En territorio liberal también observa Charles Dembowski (1841), que recoge la visión de la guerra, por ejemplo, a su paso por Valencia y Madrid. Amigo del compositor F. Chopin, al que visita en su estancia en Valldemosa, representa el prototipo de viajero romántico.

Los sitios de Bilbao son recogidos en la experiencia personal del cónsul británico, John Francis Bacon (1838), donde destaca la misión principal del gobierno inglés, que es la defensa de los intereses comerciales británicos.

\section{Escritos históricos sobre la Guerra Carlista y el carlismo}

Resulta fundamental para esta investigación aquella bibliografía histórica que, junto a la ya citada de los viajeros extranjeros, es clave en el entendimiento del papel propagandístico de la literatura en el mismo momento en que se desarrollan los conflictos. Es el caso de la obra del vinarocense W. Ayguals de Izco (1849), que ofrece una biografía de Cabrera, publicada por entregas en la época y Ayguals de lzco (1849), que ofrece una biografía de Cabrera, publicada por entregas en la época y
de cierto éxito editorial, que pasa al general carlista por el filtro crítico de un liberal cuyo hermano cayó ante las armas carlistas. Declarado anticarlista, Ayguals es descrito por Baroja como "masón muy activo y entusiasta de la escenografía del triángulo y de la escuadra, tipo pequeño, barbudo y un poco ridículo" (Baroja, 2008:673). Teniendo en cuenta el posicionamiento ideológico de unos y otros, es conveniente cribar los contenidos con cierta cautela.

La obra de Magués ofrece una visión de don Carlos y sus defensores y presenta el interés de haber sido publicada en 1837 (Magués, 1837). La obra de A. Pirala (1869), Historia de la Guerra Civil y de los partidos Liberal y Carlista corregida y aumentada con la historia de la regencia de Espartero también es un referente histórico dentro de la bibliografía de las guerras carlistas. Las referencias manejadas se cierran con la obra de D. Calbo y Rochina, Historia de Cabrera y guerra civil en Aragón, Valencia y Murcia (1845). En algunas de ellas aparecen citas, más o menos pasajeras, a los acontecimientos más significativos y al papel jugado por las defensas.

Como suele suceder, el distanciamiento del conflicto tiende a ofrecer una visión cada vez más objetiva; en caso de ser interesada, responde a intereses ajenos al conflicto en cuestión. El presente trabajo requiere del testimonio de las fuentes directas, y el hecho de que el objetivo sea la identificación de elementos fortificados podría aliviar el supuesto partidismo de las fuentes, pero es cierto que es preciso contar con ello, dado que muchas de ellas, por el modo y la intención con la que son confeccionadas, pueden aportar datos confusos o sesgados sobre aspectos que incluso en esta investigación pueden ser relevantes, desde la narración de capacidades y habilidades, a la autoría de las 
acciones de construcción, mejora o destrucción del patrimonio. En este sentido hemos considerado conveniente abordar unas observaciones acerca de la parcialidad o imparcialidad de algunas fuentes históricas ineludibles en la presente tesis.

\section{Particularidades y observaciones sobre la parcialidad o imparcialidad de fuentes históricas}

Se registran en este apartado algunas de las principales fuentes históricas utilizadas, de las que se han extraído datos que han permitido identificar esfuerzos defensivos y diferentes aspectos del conflicto a partir de una mirada crítica. Las fuentes de la época resultan especialmente exhaustivas en la descripción de acontecimientos militares y políticos, pero no son explícitas en cuestiones sociales y económicas, como sostiene Caridad, para poder explicar el fenómeno del carlismo (Caridad, 2017: 12). La obra de Caridad El carlismo en las comarcas valencianas y el sur de Aragón (2017) a la que accedemos después de haber lé́do much de las fuentes que cita y de haber redactado peractado parte de este apartado, permite corroborar algunas conclusiones, asi como arrojar luz sobre algunos autores no manejados por no aportar datos novedosos en nuestros objetivos. Sus conclusione acerca de la implicación ideológica de las fuentes contemporáneas o inmediatamente posteriores a conflicto (Caridad, 2017: 10-12) coinciden con las observaciones que se deducen tras la aproximación a los textos y la comparación de los mismos en los procesos de búsqueda de acciones sobre la fortificación. Así se pueden destacar autores de signo liberal, unos que escriben textos con una clara falta de objetividad en aras de ensalzar la causa liberal, como podrían ser los textos de Francisco Cabello (1845-1846) o Wenceslao Ayguals de Izco (1849). De otra parte aparecerían aquellos autores de signo liberal más moderados, en cuyo grupo se podría incluir a Antonio Pirala (1853-1856), a pesar de reconocerse progresista. Junto a él, Buenaventura de Córdoba (1844-1846), Dámaso Calbo y Rochina (1845) o el marqués de San Román (Fernández de San Román, 1884). Los principales textos pro-carlistas contemporáneos o inmediatamente posteriores a la contienda son los publicados por . August Von Goeben (1841) o el príncipe Félix Lichnowsky (1841). Finalmente nos encontraríamos con aquel grupo de autores afines a la causa carlista que pueden publicar en España cuando la distancia del fin del conflicto, la consolidación del liberalismo y la llegada al gobierno de opciones moderadas, permiten miradas afines a partir de 1843. Caridad (Caridad, 2017:12) encuadra en este grupo a Díaz de Labandero (1847), González de la Cruz (1849), Flavio (1870) o Segura (1868).

Procedemos a continuación a analizar algunas de las fuentes históricas utilizadas en el trabajo.

Fig. 8. Vista pintoresca de San Sebastián con sus fortificaciones en 1836. (Hornbrook, Thomas Lyde (1840): San erancisco: pontón sobre el Urumea y principio del nuevo puente de madera, mayo de 1836. Grabado. 24x41cm)

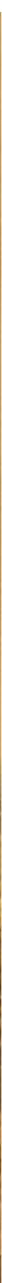




\section{Ayguals de Izco, Wenceslao (Vinaròs, 1801-Madrid, 1873)}

Escritor y editor, procedente de uno de los centros de resistencia liberal como es la ciudad de Vinaròs, llega a comandar la Milicia Nacional y acaba siendo diputado en las Cortes por Castellón (1836, 1839, 1840 y 1843). Estamos hablando de un editor con fuerte implicación política, cuyo supuesto extremismo conduce a su deportación en Baleares en 1840. En aquella época es considerado puesto extremismo conduce a su deportación en Baleares en 1840. En aquella época es considerado
subversión preconizar la igualdad, la libertad de prensa o la separación entre la iglesia y el estado. subversión preconizar la igualdad, la libertad de prensa o la separación entre la iglesia y el estado.
Prolífico autor, su obra conjunta podría considerarse una de las obras de mayor contenido social del siglo XIX. Su obra El tigre del Maestrazgo ó sea de grumete á general. Historia-novela original (18461849) no es bien recibida por la opinión carlista y, de hecho, Rafael González de la Cruz la refuta con su obra El vengador y la sombra de Cabrera: refutación del Tigre del Maestrazgo ó sea De grumete general, historia-novel de D. Wenceslao Ayguals de Izco: advertencias para la historia (1849). La obra de Ayguals de Izco es publicada por entregas en la época y goza de cierto éxito editorial. Es convepues, el vinarocense es un anticarlista declarado que es descrito por Baroja, tal y como se ha citado con anterioridad, como "masón muy activo y entusiasta de la escenografía del triángulo y de la escuadra tipo pequeño, barbudo y un poco ridículo" (Baroja, 2008:673). Considerando su claro posicionamient ideológico, conviene tratar sus afirmaciones con cautela, como ocurre con muchos otros autores.

\section{Bacon, John Francis (sin fecha (s.f.)).}

Los sitios de Bilbao son recogidos en la experiencia personal del cónsul británico, John Francis Bacon, que ejerce como tal entre 1830 y 1837. Escribe las obras Historia de la Revolución de las provincias vascongadas y Navarra. 1833-1837 y Six years in Biscay (1831-1837), en la que aborda los asedios a vascongadas y Navarra. 1833-1837 y Six years in Biscay (1831-1837), en la que aborda los asedios a
Bilbao, traducida al castellano por Víctor Luis de Gaminde en 1838. En su obra, Bacon destaca la Bilbao, traducida al castellano por Víctor Luis de Gaminde en 1838. En su obra, Bacon destá
misión principal del gobierno inglés, que es la defensa de los intereses comerciales británicos.

\section{Borrow, George Henry (East Dereham, Norfolk, 1803-Lowestoft, Suffolk, 1881)}

Frente a los autores que se posicionan y participan en el conflicto, existen otros que transitan por España con otros fines y nos muestran una visión particular, como es el curioso caso del vendedor de biblias, George Borrow, que recoge su propia interpretación del conflicto en La Biblia en España (Borrow, 1843), basada en ciertos tópicos. Su biografía no deja de ser interesante. Impenitente viajero, domina infinidad de idiomas y su trabajo para la Sociedad Bíblica o como corresponsal del Morning Herald le permiten recorrer múltiples países: Francia, Alemania, Rusia, Portugal, España, Marruecos... Transita por España entre 1835 y 1840, con una estancia en la cárcel de Sevilla tras traduci al caló el evangelio de Lucas y abrir una librería en Madrid como despacho de la Sociedad Bíblica Extranjera. Aprovecha precisamente esa experiencia para escribir su The Bible in Spain (1843). Su biografía se ve marcada con una especial sensibilidad por el pueblo gitano (Pujals, 1988: 538-539).

\section{Calbo [Calvo] y Rochina de Castro, Dámaso (s. f.)}

Dámaso Calbo y Rochina es identificado en algunas de sus obras como "maestro de lenguas y catedrático de francés en el Instituto de Cáceres" (Calbo y Rochina, 1865), también como "miembro de varias sociedades y Academias, premiado por la Academia nacional de nobles artes de Sn. Fernando, Secretario de la junta de gobierno en la Academia Real Española de música y declamación" (Calbo y Rochina, 1845). Resulta clave por su obra Historia de Cabrera y guerra civil en Aragón, Valencia y Murcia redactada con presencia de documentos y datos de una y otra parte. Fue editada en Madrid en 1845 en el Establecimiento tipográfico de Vicente Castelló. Pocos datos se encuentran sobre el autor, pero entre sus obra teórica de buenas costumbres morales en 10 lecciones, 1865; Curso de religín y mort cristina cat́lica teórica de buens a apostólica romana, 1864) y un manuscrito sobre historia de la filosofía (Museo filosófico de la historia de
España contemporánea, 1858).
El título de la obra presume una cierta imparcialidad, como sucede en el caso de Pirala, por recurrir a documentos de ambos bandos. Pero nos encontramos con la misma situación que en el caso anterior, donde el valor de la obra radica en su contemporaneidad con los acontecimientos. Obviade un intento de redención. Las palabras del autor en el texto preliminar son reveladoras: "El total de los hechos de una generación gravita en la balanza de los siglos futuros como una paja ligera, y si tal es la importancia de tantos millones de esfuerzos reunidos, cual deberá ser la de las acciones de un solo hombre por más célebre que haya sido? Sin embargo, la fama acompaña algunos nombres, escitará la curiosidad de los que nos reemplacen en la vida, y correrán ansiosos á buscar en la historia quienes fueron los que la tradición denomina héroes ó mónstruos, y á cuyos hechos no siempre se les dió la importancia y calificación debidas porque la época de que fueron contemporáneos los juzgó segun la pasion ó espiritu de partido que dominaba á sus censores ó apologistas.

Muchos hombres contribuyen moralmente á los hechos de uno solo; sobre una sola cabeza pesa el lauro ó exeHeralmente á los hechos de uno solo; sobre una sola cabeza pesa el lauro ó execracion que entre muchos deben repartirse. Dése, pues, en lo posible á cada uno la parte de gloria ó vituperio que le corresponda con la simple y verídica narracion de los sucesos desnudos de comentarios, y en vez de estos una exacta cuenta de las circunstancias que los acompañaron. De siglo, dejando al futuro el cuidar de juzgarlo y sacar partido, si puede, de la experiencia de sus antepasados.

Tal es el objeto de esta Historia: su principal personage aun existe, y solo él puede revelarnos los secretos de su vida privada: pero aquellos que por su relacion con este escrito pertenecen á la publicidad, los diremos con imparcialidad, buena fé y sincero deseo de describir cómo ha sido la última guerra civil en Aragon, Valencia y Murcia: si conseguimos el objeto, los que juzgan de ella segun el espiritu de partido, calificando á Cabrera por sus crencias politicas, no oer maldad de los hechos. Entremos en la materia partiendo del principio que los acontecimientos de ahora estan muy preparados moralmente de antemano, y teniendo presente que el hombre en su niñez, es adaptado á ser malo ó bueno segun las circunstancias que parecen impulsarle á seguir constantemente una senda, á cambiarla por otra, y últimamente á obrar segun las alternativas en que se encuentra fluctuando cual en un mar proceloso y agitado.

Plegue al cielo que la paz y la ventura se arraiguen en nuestro desgraciado pais, tan digno de ellas por lo mucho que las necesita, por los sacrificios inmensos que ha hecho para conseguirlas, á pesar de sus enemigos, y últimamente por el brillante porvernir que le espera si amaestrado en la escuela de la desgracia aprendió á evitar se renueve cuando se halle la prosperidad" (Calbo y Rochina, 1845: preeliminar, 1-2).

Las pretensiones del texto de ensalzar la figura de Cabrera quedan de manifiesto cuando la edición Las pretensiones del texto de ensalzar la figura de Cabrera quedan de manifiesto cuando la edición
concluye con una oda a Cabrera de Francisco Gea, presentada a pie con la siguiente observación del concluye con una oda a Cabrera de Francisco Gea, presentada a pie con la siguiente observación del
editor: "Esta composición poética ha sido escrita expresamente para nuestra obra por el apreciable literato D. Francisco Gea. Hemos creido que solo los hermosos versos de este joven poeta podrían terminar dignamente la historia del caudillo carlista de Aragon, pues habiendo contribuido á realzarla alguna de las bellas artes no podia sin injusticia ser escluida de ella la poesía que es la primera de todas" (Calbo y Rocina, 1845: 575). También quedan claras cuando el mismo Calbo y Rochina escribe "Cabrera, principal personaje que ha ocupado tanto tiempo nuestra pluma; ya habia tenido entretenidas otras mil mas elegantes y bien cortadas; sin embargo sus hechos mas ó menos desfigurados, no habian estado unidos á la descripción general de la guerra en Aragon, Valencia y Murcia hasta que nosotros tomamos á nuestro cargo describirlos imparcialmente sin meternos á censores ó apologistas. Tanto valor y audacia del general carlista y de sus compañeros, tantas glorias militares españolas como se han visto en los campos de las tres provincias que nos han ocupado, merecian á nuestro juicio que, separándonos de todo espiritu de partido, de todo epíteto odioso y degradante..." (Calbo y Rochina, 1845: 574).

\section{D'Alaux, Gustave (1816-1885)}

Se sabe muy poco de este viajero romántico que en su obra Aragón visto por un francés durante la primera guerra carlista, traducida por José Giménez Corbatón, recoge la experiencia del viaje en el año 1838, donde destaca la observación de lugares y personajes, pero circunscrita a un primer apartado, justo antes de llegar a Zaragoza, a un segundo apartado sobre su estancia en la capital de Aragón y a un tercer apartado final que describe su recorrido hasta Guadalajara (Moreno Chacón, 1988:204). 
Ofrece un testimonio del relato pintoresco con una particular vision del concepto pittoresque, que no es aplicado por ejemplo al paisaje aragonés que contempla admirado, pero sí a aquellos elementos relacionados con las costumbres del país, como por ejemplo la indumentaria o los objetos (Ortas Durand, 1999:185).

\section{Córdoba y Miguel, Buenaventura de (Tortosa, 1806-Valencia, 1854)}

Nos encontramos con el autor de la única biografía de Cabrera autorizada por el protagonista, Vida militar y política de Cabrera, publicada en Madrid en la Imprenta y fundición de D. Eusebio Aguado, en 1844. Se le define como historiador y político, con formación en gramática latina, retórica y jurisprudencia. Es oriundo de Tortosa, ciudad natal de Cabrera. Concluye sus estudios muy joven y pasa dos años como pasante en Madrid bajo la supervisión de Joaquín María Freix, que es hermano del arzobispo de Tarragona, uno de los "abogados más notables de la corte". Tras ejercer de Guerra y Marina (1841-1847), justo en el momento de la conclusión de la Primera Guerra Carlista. También ocupa cargo directivo en el Ministerio de Hacienda y ejerce de diputado en Cortes por Tortosa. Fallece en Valencia ocupando el cargo de magistrado de la Audiencia.

Cabrera no solo era paisano, sino también amigo suyo, aunque él no se adscribe al carlismo. La obra de Córdoba es la fuente de numerosas biografías posteriores, dado que cuenta con documentos privados aportados por el general, quien además revisa la obra (Fernández y Domingo, 1867: 307-308).

\section{Dembowski, Barón Karol (Milán, 1808-Préfargier, cantón de Ginebra, 1853)}

Se tiene poca información sobre Dembowski, así como ciertas dudas sobre su nacionalidad. Posiblemente nacido en Milán de la patriota milanesa Matilde Viscontini y un general polaco de Napoléon. Titulado en ingeniería, debe huir a Suiza tras verse implicado en un duelo (Gelli, 1899). Se sabe que en enero de 1838 inicia un viaje por España como observador romántico. Su objetivo es analizar la sociedad y la cultura españolas, atraído por la visión pintoresca que se tiene de nuestro país desde muchos países extranjeros. Su viaje transcurre por territorio liberal y recoge una visión más allá de lo pintoresco, especialmente a su paso por Valencia y Madrid, en su obra Deux ans en Espagne et en Portugal pendant la ouerre civile 1838-1840 (1841 Paris: Charles Gosselin: 2008, Barcelona: Editoria ra genera en la sociedad española, especialmente en las clases populares. Su obra es un ejemplo de la literatura de viajes romántica. Amigo del compositor F. Chopin, precisamente lo visita en su estancia en Valldemosa. El libro de Dembowski es el resultado del conjunto de cartas que redacta durante su viaje a la Condesa de Bourk, a Prosper Merimée, a Stendhal, a las madames Viscontini y Ancelot y a los barones Sigismondo Trechi y De Mareste.

\section{Díaz Corbelle, Nicómedes-Pastor (Viveiro, Lugo, 1811-Madrid, 1863)}

Titulado como abogado en Alcalá de Henares, se trata de un político conservador y monárquico, que ve el alzamiento carlista como una "revolución" contra el sistema democrático y se posiciona del lado liberal. De firme convicción religiosa, es un escritor conectado con el romanticismo literario, que, como muchos escritores y políticos de la época, ejerce de periodista. Su ingreso en la sociedad madrileña lo avala, entre otros, el general Manuel Latre, destacado militar liberal en las guerras carlistas. Entre sus conocidos literatos se encuentran Espronceda, Larra y José Zorrilla, del que se convierte en protector, prologándole su Don Juan Tenorio. Cofundada la revista El Conservador (1841 que representa a los moderados y se opone a Espartero. Cuando este medio es cerrado, cofunda $E$ Heraldo (1842). Más adelante, cofunda El Sol, donde es el primero en solicitar la mayoría de edad de la infanta Isabel, para que pueda reinar como Isabel II Se le podría definir como un moderado que pretende huir de las refriegas políticas y mediar entre las facciones. Pero la situación política española le lleva a centrarse en la vida intelectual. Llega a ser rector de la Universidad Central de Madrid (1847-1850) y en 1856 a ministro de Estado en el gobierno O'Donnell (Navas Ruíz, 1982). Reconocido su amplio bagaje, en sus obras queda patente su perfil conservador, en franca oposición con las nuevas propuestas sociales y apelando al papel de la religión como gran solución a los conflictos contemporáneos. Precisamente en su contribución junto a Francisco Cárdenas en Galería de españoles célebres y contemporáneos o biografías retratos de todos los personajes distinguidos de nuestros días en las ciencias, la política, en las armas, en las letras y en las artes (1842), aborda entre otras la Biografía de on Ramón Cabrera (Madrid: Imprenta de Eusebio Aguado (primera edición de 1841)). Sus palabras al inicio de la obra dejan patente su posicionamiento, donde se descubre a un protagonista amante de la guerra y carente de principios. En ese sentido escribe para cerrar su texto: “Cabrera...no aparece grande en sus principios; pero es una manera muy vulgar de considerarle la de no ver nunca en él más que al estudiante de Tortosa. Cabrera es un personaje que se crece con el tiempo y con los sucesos. Cuanto más dilatada es la esfera de su acción, tanto más dignamente la ocupa. Cabrera no decae nunca. Los que han dicho que no se mostró digno, en los últimos tiempos, de su elevación y de su fama, no creemos que le hayan juzgado bien. Atacado por ochenta mil hombres entusiastas y victoriosos, y reducido a sus propios recursos, la temeridad de resistir era más grande que la gloria de vencer. No somos nosotros los que le tenemos por un gigante, ni por (t) midables aprestos y tan cuantiosas sumas, y tanto número de batallones y de bocas de fuego le circunvalaron. Lejos de nuestro pensamiento la intención de reprobarlo, y de no aplaudir el haberse ahorrado el derramamiento

\section{Fernández de San Miguel y Valledor, Evaristo (Gijón, 1785-Madrid, 1862)}

En el trabajo que nos ocupa se trata de un personaje protagonista de los acontecimientos, ascendiendo al cargo de mariscal de campo durante la contienda carlista y ocupando el cargo de general en jefe de los ejércitos del Centro. Su trayectoria, de marcada implicación por la causa liberal, se inicia ya al comienzo de su carrera militar combatiendo a los franceses. Precisamente tras ser hecho prisionero y trasladado a Francia entra en contacto con compatriotas liberales que intervienen en prisionero y trasladado a Francia entra en contacto con compatriotas liberales que intervienen en
el devenir de la historia de España años después. Se opone a la restauración absolutista, integra los ejércitos liberales del trienio liberal y debe combatir la llegada de los Cien Mil Hijos de San Luis, junto a Espoz y Mina. Trasladado a Francia al ser hecho prisionero de nuevo, es liberado en 1824, pero se mantiene en el exilio en Londres hasta la amnistía general de 1834, donde se incorpora a la causa cristina. Al concluir la guerra es nombrado capitán general de Aragón y apoya el motín de la Granja que hace jurar a la reina la Constitución de 1812. Es diputado y ministro de la Guerra bajo la regencia de Espartero, presidente de la Dipután Provincial de Zaragoza, de la Junta Superior de Gobierno de Aragón y elegido diputado por diversas circunscripciones en una larga carrera política. En nuestro caso interesa su contribución a la historia contemporánea por la que fue nombrado académico de honor desde 1836 de la Real Academia de Nobles y Bellas Artes de San Luis. Su obra De la guerra civil en España, editada en 1836 por la imprenta de don Miguel de Burgos, es una referencia para entender el conflicto español desde la perspectiva liberal, donde se posiciona el autor claramente en contra del despotismo, con el que asocia definitivamente la causa carlista. El autor recurre a su experiencia biográfica para recorrer su perspectiva de la guerra de la Independencia, la guerra Realista que pone fin al trienio liberal y el inicio de la guerra de los Siete Años, permitiendo Miguel advierte "no perdamos de vista que caminamos rodeados de tres clases de peligros: el de la anarquía, el de una dictadura militar, y el de caer en manos del partido de D. Cárlos. La reacción del año 1814 fue terrible, espantosa la siguiente de 1823, ¿Quién abraza con la imaginación los horrores de que iría acompañada la tercera?" (San Miguel, 1836: 95-96). En el caso del autor, también es reseñable en este trabajo su obra Elementos del arte de la Guerra editado en 1826 en Londres por la imprenta española de M. Calero, donde se puede entender la teoría de la guerra en ese preciso momento (San Miguel, 1826), en especial por su modo de entender el papel de la fortificación en la guerra del siglo XIX, y por ensalzar el éxito de la guerra de partidas en la guerra defensiva de nuestro país (ibíd. 233-247).

\section{Flavio, E. Conde de $X^{* * *}$ (s.f.)}

Este escritor desconocido, autor de Historia de Don Ramón Cabrera (1870), deja clara su intención con su escrito al acompañar la portada con un fragmento del poema de Gea, A Cabrera, escogiendo los 
siguientes versos: "...en tu gigante gloria/ una nacion y otra nacion te admira/ y es como el siglo inmensa tu memoria; paginas de esplendor te da la historia/ y en ella un grande universo mira" (Flavio, 1870). En el prólogo, sigue el panegírico al indicar "porque es la historia de un héroe: del héroe de 1839 y 1848. del que trenor ho lán en el que ensalza a Cabrera indicando que es "hoy, mejor que nunca, la esperanza de la pátria" (Flavio, 1870:7). Su aspiración es escribir una "historia popular de Don Ramón Cabrera" (ibid.), en el sentido de los farragosos textos que le han precedido, de contenido "indigesto y pesado" (Flavio, 1870:8). Llama la atención el cierre del volumen 1 a modo de un "continuará", que debe ser afrontado por los nuevos tiempos, cuando escoge la escena en la que Cabrera, acabado de leer el texto del Convenio de Vergara, lo tilda de traición y exclama: "Nos verémos aún. ¡Yo no me rindo, ni me vendo!..." (Flavio, 1870:695).

\section{González de la Cruz, Rafael (s.f.)}

Como se ha comentado en el apartado de Wenceslao Ayguals de Izco, González de la Cruz es el responsable de la réplica a la biografía crítica a Cabrera del vinarocense, réplica que titula El vengador y la sombra de Cabrera: refutación del Tigre del Maestrazgo ó sea De grumete a general, historia-novel de D. Wenceslao Ayguals de Izco: advertencias para la historia (1849, Madrid: Imprenta de Hernández) En la obra Historia de la Emigración Carlista (1846), dedicada a los monárquicos españoles, podemo encontrar la historia de la guerra desde 1838, centrándose en la trama que conduce a Vergara, biografías de Espartero y Maroto como implicados en dicha trama, y con atención a Cabrera Merino y Eguía, así como se recolectan los principales acontecimientos políticos hasta 1844. González de la Cruz presume "narrar con el criterio de fieles y esactos historiadores" (1844: V), pero deja clara su percepción al tratar el Convenio de Vergara como un hecho funesto que conduce a la emigración carlista.

\section{Henningsen, Karl Ferdinand (1815-1877)}

La actitud heroica de Zumalacárregui es ensalzada por el británico Henningsen (1836), que se convierte en uno de los literatos precursores del nacionalismo vasco, especialmente al difundir su obra en inglés The Most Striking Events of a Twelvemonth's Campaign with Zumalacarregui in Navarre and the Basque Provinces. A partir de ella, muchos aventureros internacionales se aproximan a la causa carlista. Henningsen es uno de los voluntarios británicos, concretamente escocés, que se presenta voluntario con 19 años de edad. Es uno de los componentes de la caballería de Zumalacárregui y voluntario con 19 años de edad. Es uno de los componentes de la caballería de Zumalacárregui y
está presente en la firma del Convenio Elliot en 1835. Tras la caída de Zumalacárregui regresa a Inglaterra y se convierte en uno de los valedores de la causa carlista abogando por la neutralidad británica. Precisamente en 1836 publica su obra, de bastante éxito editorial, al traducirse al alemán francés, italiano y castellano. Combate contra los rusos en el Cáucaso, contra lo austríacos en Hungría y por la causa Confederada en Estados Unidos. Al fallecer en 1877 su carrera se puede resumir como una carrera encuadrada en la de los perdedores de las confrontaciones bélicas del sigo XIX.

\section{Lichnowsky, Félix María Vincenz Andreas, príncipe de (Viena, 1814-Fráncfort del Meno, 1848)}

El príncipe Félix Lichnowsky ofrece quizá la obra extranjera de mayor interés literario: Recuerdos de la guerra carlista (1841). Fiel al espíritu romántico y procedente de la aristocracia prusiana, llega a España, con las dificultades propias del viaje y la situación, para alistarse en el ejército carlista. Es un testimonio de primera mano de los acontecimientos que narra, especialmente la batalla de Oriamendi y la Expedición Real. Llama la atención en su obra el interés que presta a la arquitectura que se encuentra a su paso: palacios, iglesias, conventos. De regreso a Prusia, es elegido diputado los intes coincidiendo con la revolución de 1848. En su obra, Lichnowsky trata de plasmar la tragedia romántica de la guerra desde la mirada de un defensor de la vieja Europa.
Magués, M. Isidoro (s.f.)

La obra de Magués, D. Carlos et ses défenseurs (1837) nos ofrece una visión de don Carlos y sus defensores y presenta el interés de haber sido publicada en 1837 (Magués, 1837), obviamente, desde la óptica de un artista admirador de la causa carlista, interesado en representar a los principales protagonistas y desplazándose a Durango y al cuartel general del ejército carlista para abordar su
cometido. En la obra se da una nota biográfica sobre cada uno de los personajes, "representado por Isidoro Maguès, caballero de la orden real americana de Isabel la Católica".

\section{Pirala, Antonio (Madrid, 1824-Madrid, 1903)}

Antonio Pirala, uno de los historiadores de referencia, es un liberal progresista que llega a ser jefe superior de la administración civil, miembro de la Real Academia de Historia y miembro de honor y mérito de la Academia de Profesores de Primera Enseñanza. En nuestro caso interesa especialmente su obra Historia de la guerra de los partidos liberal y carlista aumentada con la regencia de Espartero (1868), una segunda edición ampliada. Pirala trabaja con datos de toda procedencia. El interés de (1868), una segunda edición ampliada. Pirala trabaja con datos de toda procedencia. El interés de
su obra radica en haber tenido acceso a documentos originales que algunos de los protagonistas del conflicto le facilitan, dada su amistad con ellos. Una de las principales críticas que recibe es la de ser un mero transcriptor de dichos documentos, lo cual lleva a ofrecer en muchas ocasiones diferentes versiones de un mismo acontecimiento. A pesar de que historiadores de ideología diversa recurran a su obra, ello no implica que sea conveniente leer a Pirala, teniendo en cuenta su afinidad ideológica. El valor de su obra se habría incrementado si esa disparidad documental que se limita a transcribir originando duplicidad de información, en ocasiones contradictoria, hubiese sido citada convenientemente indicando e identificando la fuente de información.

\section{Von Goeben, August Karl (Stade, 1816-Coblenza, 1880)}

Se trata de un militar prusiano que participa en la Primera Guerra Carlista apoyando cinco campañas al servicio del pretendiente. Es por entonces un joven militar que, a pesar de haber nacido en el reino de Hanóver, aspira a promocionar en el ejército prusiano. Espera encontrar en la guerra española la experiencia bélica que le permita promocionar con mayor facilidad que como subalterno de la infantería prusiana. De alguna manera, engrosa el grupo de aventureros románticos internacionales que se suman al conflicto. Participa en él desde 1836 hasta 1840, cayendo prisionero en sucesivas ocasiones, sufriendo muchas penalidades hasta que, alcanzada la libertad, destaca en las acciones del ejército carlista. Combate junto a Cabrera y, más adelante, con el conde de España, alcanzando el rango de teniente coronel. A su regreso, pocos jóvenes como él pueden esgrimir cinco años de experiencia en un conflicto bélico con apenas 24 años, por lo que su promoción en el ejército prusiano es meteórica y llega a servir bajo el mando de Moltke. Participa en Marruecos en la batalla de Tetuán junto a las tropas españolas como agregado bajo el mando de $\mathrm{O}^{\prime}$ Donnell y destaca en todas las guerras que Prusia acomete con éxito en el transcurso de las siguientes décadas, contra Dinamarca, contra Austria $y$, finalmente, contra Francia, siendo laureado en la batalla de Gravelotte el 18 de agosto de 1870. El 8 de enero de 1871 llega a ostentar el mando del Primer Ejército Prusiano que vence el 19 de enero en San Quintín. Fallece en 1880 con todos los honores, incluida la Gran Cruz de Hierro. Junto a su temprana experiencia bélica resulta clave su texto Vier Jahre in Spanien (Cuatro Años en España), publicado en Hanóver en 1841, que relata su experiencia en el conflicto.

\section{Von Rahden, Wilhelm (Breslau, 1793-Gotha, 1860)}

El barón Wilhelm von Rahden es una referencia ineludible en este trabajo. Sus obras Wanderungen eines alten Soldaten, (I, Frankfurt am Main, 1840; II, Berlín, 1846; III, Berlín, 1847), Cabrera. Erinnerungen aus dem Spanischen Bürgerkrieg (Frankfurt am Main, 1840) y Ein Lebenslichtbild (Berlin 1859) resultan claves para entender el conflicto carlista desde una mirada muy particular, la de un extranjesultan claves para entender el conflicto carlista desde una mirada muy particular, la de un extranje-
ro racional con la sensibilidad para registrar lo pintoresco, en una actitud muy propia del momento. De este modo, la obra de Von Rahden no solo aporta datos concretos del conflicto, y en especial, en 
relación con las posiciones fortificadas, sino también numerosas curiosidades culturales de la España de entonces, hábitos y costumbres, aunque con los prejuicios que el observador ha consolidado. Su mirada hacia determinados protagonistas como Cabrera o el Conde de España delata una cierta bando carlista. En ese sentido es interesante, pues dicho favoritismo se contrapone con las fuente pro-liberales, y su fervor se ve atenuado por la mirada racional germana, que en todo momento parece hacer balance entre el mundo civilizado del que proviene y el supuesto mundo rudo y salvaje al que se enfrenta.

Cuando Von Rahden atraviesa la frontera hacia Perpiñán en 1839 lo hace para recuperarse de las heridas sufridas, con el permiso del Conde de Morella. Deja a medio concluir la dirección de las defensas de esta ciudad, a la que no regresa. Ya es un militar maduro que se enfrenta al mundo con otra mirada. Su experiencia bélica en España se extiende por un total de tres años. Algunas fuentes sostienen que su viaje encubre una misión encomendada por el propio Cabrera para entrevistarse con el pretendiente (Rújula, 2013: 8), pero parece que tras la entrevista es detenido por la policía francesa y enviado a Estrasburgo con la orden de regresar a su país. En ese momento se establece en Fráncfort del Meno y compone su obra Cabrera. Erinnerungen aus dem Spanischen Bürgerkrieg, a en Fráncfort del Meno y compone su obra Cabrera. Erinnerungen aus dem Spanischen Burgerkrieg, Hübner hace a su obra Cabrera. Recuerdos de la guerra civil española, editada por la Institución Fernando el Católico, organismo autónomo de la Excma. Diputación de Zaragoza (2013), con el prólogo de Pedro Rújula, que lo presenta como "una mirada legitimista sobre la guerra civil" (Rújula, 2013: 7-19).

\section{Estudios y publicaciones recientes sobre las guerras carlistas y su contexto}

Los escritos, estudios e investigaciones diversas sobre las guerras carlistas y el carlismo son innumerables desde el campo de la historia. Remitimos al conjunto bibliográfico manejado que se lista al final de este trabajo, pero hacemos hincapié en una serie de obras que han sido de utilidad en la presente investigación. Destaca la obra de Antonio Caridad Salvador, cuyas publicaciones han acompañado el desarrollo de esta investigación y han ido apareciendo mientras esta transcurría. El libro El ejército y las partidas carlistas en Valencia y Aragón (183-1840) (Caridad, 2013), es una ayuda indispensable para entender el funcionamiento de las fuerzas carlistas en el territorio valenciano y fuerzas carlistas en la zona (Caridad, 2013: 245-278) que ha resultado clave para reforzar la identificación de los puntos fortificados rastreados en las fuentes históricas. Cuando se estaba cerrando el presente trabajo, llegaba a nuestras manos la obra El carlismo en las comarcas valencianas y el sur de Aragón (1833-1840), publicado por la Institució Alfons el Magnànim en 2017. En ella se puede encontrar un lúcido análisis sobre la bibliografía en relación con el carlismo y, posiblemente, el estudio más exhaustivo que se haya hecho hasta el momento sobre el conflicto en tierras valencianas y del sur de Aragón. El análisis comarcal del fenómeno carlista permite entender las diversas y complejas variables que operan para determinar las afinidades carlistas en determinados territorios o incluso

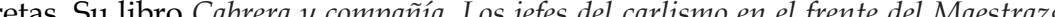
(1833-1840) (Caridad, 2014), permite, junto a las fuentes históricas, rastrear a los diferentes protagonistas del carlismo, identificar posiciones, movimientos y acciones, y ha sido un apoyo complementario en el rastreo de posiciones. Caridad, como principal experto en el tema, ofrece además diferentes artículos que abordan temas parciales asociados con el carlismo valenciano que aparecen referenciados en su momento.

También han resultado trascendentales para el presente trabajo los escritos de Pedro Rújula, que como catedrático de Historia Contemporánea de la Universidad de Zaragoza, se ha centrado en estudiar aquellos fenómenos políticos, sociales y culturales que originan el mundo contemporáneo, en nuestro caso de especial interés aquellos que, desde la Guerra de Independencia, pasando por el Trienio Liberal, conducen a la propuesta carlista. Entre las obras destacadas abordadas en algún momento del presente trabajo citamos aquellos libros y artículos relacionados con el conflicto carlista, como Contrarrevolución: Realismo y Carlismo en Aragón y el Maestrazgo, 1820-1840, publicado en 1998 (Rújula, 2008) e Historia de la guerra última en Aragón y Valencia (Rújula, 2006). De especial tras- cendencia para la presente tesis es la traducción y publicación de la obra de Wilhelm von Rahden, Cabrera. Recuerdos de la guerra civil española (Von Rahden, 2013). En ella, Rújula participa en la introducción a uno de los principales protagonistas de la fortificación del "reino mágico" de Cabrera (Von Rahden, 2013: 1-19). 作 manifiesto razonado de las causas del Convenio de Vergara (2005) o de la de Francisco Cabello, Francisco Santa Cruz y Ramón María Temprado, Historia de la guerra última en Aragón y Valencia (2006). Quizá un referente ineludible en el entendimiento del conflicto en el entorno valenciano a partir de su primera expresión en Orihuela es Jesús Millán, con diversas publicaciones como Transición y reacción en el sur del país valenciano. La formación del capitalismo agrario y los orígenes del carlismo: Orihuela, 1680-1840 (Millán, 1982), y también Els militants carlins del Pais Valencià Central. Una aproximació a la sociología del carlisme durant la Revolució Burgesa (1988). Millán, profesor en la Universitat de València, ha dirigido y participado en diversos proyectos de investigación financiados en relación con la sociedad valen participa Eucación y Cultura titulado La sociedad valenciana entre el fin del Antiguo Régimen y la Restauración: cambios de orientación económica, espacio público y revolución política (PB95-1100, 19961999)

Ya desde la óptica comarcal, es conveniente una aproximación al Maestrazgo, clave en el desarrollo del primer conflicto, abordada por ejemplo por Javier Urcelay $(2002,2006)$.

Junto a esta es preciso hacer referencia a todo el conjunto bibliográfico recopilado por la Fundación Sancho el Sabio, donde ha sido de especial ayuda el libro dirigido por C. Gómez, Los Carlistas, 18001870 (Gómez, 1991).

Afonso Bullón de Mendoza (1992) aborda la Primera Guerra Carlista en general, mientras que diversos autores optan por el enfoque regionalista del tema. Así, Francisco Asín (1983) aborda el carlismo aragonés, mientras que Josep Maria Mundet (1990) y M. Santirso tratan el caso catalán (1996). La ya citada obra de Caridad, El carlismo en las comarcas valencianas y el sur de Aragón (2017), analiza la evolución de las publicaciones del movimiento carlista y los diferentes enfoques de la bibliografía contemporánea, muy marcados por las tendencias políticas del momento. Se destaca cómo durante el franquismo se impone la versión tradicionalista de la historia, predominando estudios que simpatizan con el carlismo como las obras de Melchor Ferrer, Rafael Gambra, Roman Oyarzun, Jaime del Burgo y Federico Suárez, con un discurso muy parecido al de las primeras fuentes del carlismo. Subraya Caridad que en los años setenta se observa la irrupción de un matiz socio-económico con trabajos como los de Julio Aróstegui, Joaquín del Moral, Jaume Torràs, José Extramiana, Enric Sebastià y Josep Fontana. Obviamente los matices en los intentos por explicar el fenómeno carlista desde la perspectiva económica y social divergen en función de las fuentes. Precisamente este enfoque propicia que autores carlistas como Josep Carlos Clemente, Fernando García Villarrubia y Evarist Olcina planteen una nueva visión del carlismo, de tipo progresista, que encuadra al carlismo en un movimiento popular que se enfrenta a la clase burguesa liberal, en una dicotomía pobre-rico y que, además, abandera el estado autonómico al convertirse en defensor de los fueros (Caridad, 2017: 15-16). Si bien Caridad reconoce el atractivo del planteamiento, registra cómo esta visión es criticada por un carácter más conservador del que sugieren las fuentes citadas. Junto a esta opción, se encuentra la de aquellos autores que podrían reconocerse herederos de la historiografía tradicional carlista, como la obra de los historiadores Francisco Asín, Alfonso Bullón de Mendoza, Josep Maria Mundet y Javier Urcelay, citados con anterioridad. Sus planteamientos parecen defender la opción del carlismo en la época por ser la predominante en la población española. Se oponen al enfoque de la guerra como una lucha de clases, destacando el denominador común entre los defensores de la religión y el orden tradicional (Caridad, 2017: 17). La obra de Caridad se hace eco de la complejidad del fenómeno carlista, que ha sido enriquecida con infinidad de estudios regionales y locales de enfoque diverso, ya sea en el caso del País Vasco, Navarra, Cataluña, Andalucía, Galicia, Castilla la Mancha, Cantabria o Aragón. Entre los diferentes autores, sostiene Caridad, la explicación al origen de la rebelión es diversa. Unos hablan de un movimiento canalizado por élites perjudicadas por las reformas liberales (Francisca Castroviejo, Xosé Ramón Barreiro, Jesús Millán, Núria Sauch), otros hablan de un papel más protagonista de las masas de campesinos y artesanos empobrecidos 
(Josep Fontana, Pere Anguera). También quedan las versiones intermedias, que hacen confluir ambos enfoques, es decir, que élites absolutistas y parte del pueblo empobrecido aúnan sus intereses (Juan Pan-Montojo, Vicente Fernández Benítez, Renato Barahona, Pedro Rújula). Caridad llama la atención sobre una opción bibliográfica, la de la obra de Ramón del Río y Manuel Santirso, que resta trascendencia a los aspectos económicos, considerando que el movimiento carlista fue minoritario y las causas de la rebelión son de otra índole: reclutamientos forzosos, atractivo de las pagas... acuy las causas de la rebelión son de otra índole: reclutamientos forzosos, atractivo de las pagas... acu-
diendo en defensa de las reformas liberales, que a su criterio benefician al pequeño campesino y favorecen el progreso del país (Caridad, 2017: 20).

Obviamente, este trabajo no pretende ahondar en cuestiones tan complejas y que son objeto de otros enfoques. La bibliografía del carlismo resulta de utilidad en la medida que permite orientar la investigación a la identificación y justificación del hecho arquitectónico. En este sentido, resultan de especial ayuda el conjunto de investigaciones de carácter local más o menos rigurosas, que permila bibliografía múltiple que se ha encontrado de muchos autores interesados por el fenómeno local del conflicto liberal-carlista en localidades afectadas por las campañas del Maestrazgo, desde San Carlos de la Rápita, Flix, Vinaròs, Benicarló, Alcalà de Xivert, Castellón, Villarreal, Villafranca del Cid, Morella, Forcall, Calanda, Cantavieja, Teruel, Albalate del Arzobispo, Maella, Alloza, Villa del Arzobispo, Ontinyent, Orihuela, Utiel... Omitimos la referencia a esta bibliografía remitiendo al listado bibliográfico final y a las citas correspondientes en el catálogo por localidades.

\section{7.-Estudios sobre el patrimonio fortificado de la época y marco de la investigación}

Existe una amplia tradición en el estudio del patrimonio fortificado y múltiples aproximaciones al mismo. Un ejemplo de trabajo que recoge el estado de la cuestión en materia de fortificación es la tesis doctoral de Guillermo Guimaraens, de consulta abierta a través de la plataforma digital Riunet de la Universitat Politècnica de València (UPV) (Guimaraens, 2008), y a la que nos remitimos en su día para sentar las bases del estado de la cuestión en materia de fortificación hasta la primera década del presente siglo. No obstante, desde 2008 hasta la actualidad, los estudios en materia de fortificación se han intensificado con infinidad de publicaciones y congresos específicos. Aquel trabajo se Arquitectónica y, más adelante, desde el Instituto de Restau Juan Francisco Noguera y Guillermo Guimaraens, a la que se incorporó la autora de este trabajo en 2012. El equipo ha continuado la investigación en el campo de la fortificación con diferentes contribuciones en congresos nacionales e internacionales, alguna publicación sobre aspectos generales o específicos y colaboraciones en estudios previos de patrimonio fortificado como algunas de las fortificaciones de Cartagena (Plan Director del Conjunto Defensivo de la Bahía de Cartagena, estudios particulares del Hornabeque doble de Moros, Castillo de Galeras, Castillo de San Julián o el Fuerte fusilero de Navidad), el castillo de Monzón o los castillos de Petrés y Xió. En el campo bibliográfico destaca el estudio sobre los tratados de fortificación Pie de lámpara. Tratados de la fortificación abaluartada española (Guimaraens y Navalón: 2018).

La línea de investigación, consolidada en el ámbito del patrimonio histórico militar, se originó precisamente a raíz del estudio del patrimonio fortificado de la Bahía de Cartagena. Los trabajos derivados se centraron en su mayoría en el estudio de la fortificación abaluartada y resultaron clave para la puesta en valor de dicho patrimonio. Simultáneamente, se desarrollaban en otros puntos de ámbito peninsular investigaciones paralelas y propuestas de intervención destacables en el ámbito abaluartado. Los años noventa y el comienzo del siglo XXI, hasta la llegada de la crisis económica, registran una intensificación en el debate en torno al patrimonio militar moderno, conforme mu(Plan de modernización del Ejército de Tierra, 1984). No obstion se fijan en sintonía con la sensibilidad social, imbuida de un espíritu romantico que asocia el valor con el desfase temporal, lo cual lleva a desatender el patrimonio fortificado reciente. El caso de Cartagena podría ser un ejemplo, pues ante la abundancia del patrimonio de todo tiempo y con una cierta perspectiva histórica, se observa la secuencia de intervenciones casi por orden cronológico desde el patrimonio fortificado púnico hasta el patrimonio fortificado del siglo XX.

En la tesis de Guimaraens se destacaba un apartado bibliográfico centrado en registrar las investigaciones de relevancia hasta la fecha (Guimaraens, 2008:48-49) y un apartado concreto para las fortificaciones de Cartagena (Guimaraens, 2008:50) así como para las investigaciones particulares de la línea de investigación (Guimaraens, 2008:54) a las que remitimos a través de la obra citada. Apoyándose en la dicha línea de investigación, diversos alumnos del Máster Oficial de Conservación y Restauración del Patrimonio de la Universitat Politècnica de València (UPV), dirigidos por el profesor Guimaraens, han basado sus trabajos final de Máster en sus referencias, pero no han desarrollado los apartados generales, simplemente aspectos muy parciales asociados con la investigación específica, como el trabajo de I. Soriano (2012) sobre las torres de defensa costera en tiempos de Felipe II en la provincia de Valencia, el de J. Rubio (2012) sobre el fortín de Moraira, o el de S. Metair (2013) sobre el fuerte de Orán en Ceuta. Los tres hacen referencia a otro momento de la arquitectura militar el de la fortificación moderna, y por tanto son distantes de las características de la fortificación decimonónica. Quizás el único trabajo académico de relación directa con el tema objeto de la cuestión es el caso de P. Colecha (2013), con su estudio de las murallas de tiempos de las guerras carlistas en Sueca. Sin embargo, este trabajo maneja únicamente bibliografía general adecuada para el conocimiento de los antecedentes, como podría ser la publicación sobre las fortificaciones de Carlos V, coordinada por C. J. Hernando (2000), el estudio recopilatorio sobre la labor de los ingenieros militares de la monarquía hispánica en los siglos XVII y XVIII (Cámara, 2005) y la obra coordinada por J. M. Muñoz Corbalán sobre la Academia de Matemáticas de Barcelona (2004). Las tres son claros referentes de la bibliografía general sobre la fortificación en España, pero extemporáneas a objeto de estudio. El bibro coordinado por Herr tistas de tiempos de Carlos I de España, muy alejadas del marco cronológico. Más próximo, pero perteneciente al mundo de la fortificación abaluartada, es el libro coordinado por Cámara (2005). Si alguno podría resultar vinculante, sería el de Muñoz Corbalán (2004), al abordar el mundo académico del siglo XVIII, en la medida que las escuelas de ingenieros que se refundan en el siglo XIX son todas deudoras de aquella primera Academia de Matemáticas de Barcelona. P. Colecha (2013) es más explícita en lo referente a la bibliografía particular sobre la fortificación de Sueca, pero solo a partir de la aportación de historiadores locales. El trabajo, de sumo interés para profundizar en el conocimiento de la muralla de Sueca, no ofrece una reflexión comparativa o una estrategia de metodología de estudio, siguiendo los preceptos de la línea de investigación, teniendo en cuenta no solo los valores arquitectónicos habituales, sino abordando los valores histórico militares y el estudio de los trazados. Ofrece además un análisis arquitectónico y propuestas de intervención sensibles al patrimonio, basadas en la limpieza, consolidación y culto a la ruina.

\section{Bibliografía sobre el caso concreto de Requena}

En el caso de la fortificación de Requena es fundamental contar con el testimonio de los grandes compendios de historia de la localidad, como la obra de E. Herrero y Moral, Historia de la tres veces muy leal, dos veces muy noble y fidelísima Ciudad Real de Requena que comprende desde la más remota antigüedad hasta nuestros días (1891), en la que el testimonio del autor resulta de interés al contar con fuentes de primera mano que han vivido la Primera Guerra Carlista. De hecho, él mismo recuerda muchos de los sucesos acaecidos al vivirlos en primera persona. Otra fuente ineludible, y que permite actualizar muchos datos de la mirada sesgada de Herrero, es la Historia crítica y documentada de la ciudad de Requena de R. Bernabeu López (1982). También la obra Estampas requenenses (1962) y Requena y sus alrededores (1995), del mismo autor, permiten acercarse a escenas históricas de la ciudad.

Una fuente de contribución importante a la historia requenense es la que resulta de la labor efectuada por el denominado Centro de Estudios Requenenses (CER), que en su publicación periódica Oleana recoge los resultados de las contribuciones de numerosos historiadores a la cultura comarcal. El fácil acceso a través de internet a la publicación permite complementar la bibliografía con todo este con- 
junto de aportaciones, generalmente tangenciales al tema objeto de cuestión. Dentro del conjunto de contribuciones recogidas en Oleana, destacan los artículos de J. Vera Aparici, exclusivos de la fortificación carlista. El primero de ellos (Vera, 1992), sirve de introducción al segundo, más desarrollado (Vera 1993) a partir de las pesquisas que el investigador local efectúa en el Archivo Municipal de Requen. La aportrón de Vera es clave para arancar esta investigación, en la mida que facila Requena. La aportación de Vera es clave para arrancar esta investigación, en la medida que facilita una primera vision para establecer el perimetro fortificado de la muralla carlista. En este marco de searíamos agradecer la colaboración del historiador y archivero municipal, I. Latorre Zacarés, que ha facilitado el acceso a los diferentes documentos históricos localizados en el Archivo Municipal de Requena que se referencian en el trabajo. Este ha publicado en la página web del ayuntamiento de Requena una abundante Bibliografía de la Meseta del Cabriel (Latorre, s. f.). Precisamente su pasión por la historia, y en especial la voluntad de indagar acerca del pasado requenense, ha llevado a Latorre a la publicación de su obra La historia en píldoras: Hechos y sucesos documentales documentados de la meseta Requena-Utiel (2015). Se trata de un ameno compendio de anécdotas históricas acaecidas en la villa que puede constir un instrumento clave en la sensibilizacion hacia el patrimonio que nos ocupa potenciando el interés de los profanos hacia la historia de la ciuda. Estas "pildoras" publicadas periódicamente son fáciles de encontrar a través de la red, en un afán por facilitar la difusión de la cultura por parte de su autor.

Posiblemente herederos de la tradición histórica de R. Bernabeu López y su pasión por la cultura requenense, destacan las contribuciones de la familia Jordá. Precisamente en 2007, César Jordá Moltó donó al Archivo Municipal el documento de la Carta Puebla de Requena, un pergamino de 125 que era atesorado por la familia. César Jordá Moltó, como autor, ha intentado publicar parte de la documentación familiar a fin de facilitar su acceso al público, aportando abundante información fotográfica que ha ayudado sobremanera a entender la transformación en el pasado siglo XX de la ciudad de Requena, así como a descifrar claves del periodo de pervivencia de algunos restos objeto de estudio ya desaparecidos. Podemos destacar las obras Historias y recuerdos (1995), Memoria de de estudio ya desaparecidos. Podemos destacar las obras Historias y recuerdos (1995), Memoria de
unos tiempos vividos (1999) y Requena, imágenes de un siglo (2000).

Un complemento a la investigación que es preciso indicar dentro del estado de la cuestión ha sido el recurso de las fuentes orales, a la hora de identificar topónimos tradicionales que se están perdiendo en la tradición hablada, cuestiones lingüísticas de la zona recogidas en los documentos y, especialmente, recuerdos del posible emplazamiento de restos perdidos. En este sentido es preciso agradecer la colaboración de César Jordá Moltó, Ignacio Latorre Zacarés y Antonio Navalón Cárcel. 


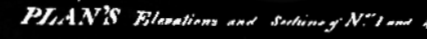

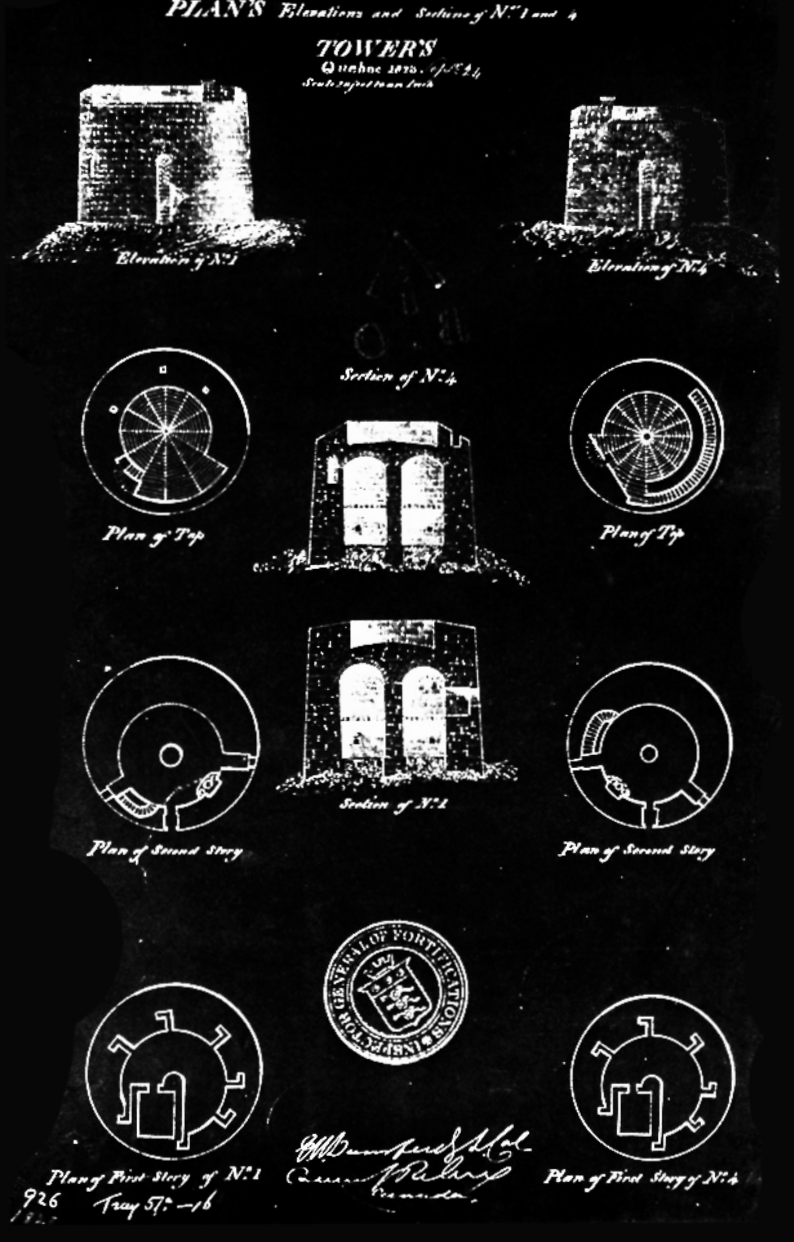

En 1863, en la primera edición de El progreso del arte militar en sus analogías con el progreso de la sociedad, Francisco Villamartín (1833-1872) ponía en relación guerra y sociedad y partía de unos supuestos con el objetivo de generar una teoría del arte militar (Villamartín, 1968), según la cual pretendía destacar la influencia que el arte militar tenía en la sociedad, valorar la utilidad en la guerra que ofrecían los adelantos de la producción industrial y describir "la buenas o malas condiciones de nuestro carácter nacional para dictar leyes a las que debe sujetarse la guerra española" (Muro, 1989:170). Su teoría militar consistía, al estilo de muchos tratados teóricos del momento, en un conjunto de propuestas basadas en la reflexión crítica y en la aplicación de los principios de la política militar, (n) con José Almirante (1823-1894), parece atisbarse una cierta creencia en el progresismo histórico. La evolución de la sociedad conduce al progreso productivo, a la evolución del armamento y, por tanto, a la evolución continua del arte de la guerra, donde se incluye el arte de la fortificación. Ejemplo de ello es la trayectoria del arte defensivo en el transcurso del siglo XIX, con el desarrollo de los obuses o la fortificación acorazada, por poner dos ejemplos determinantes. Sin embargo, en el deteriorado panorama español tras la guerra de independencia, es difícil efectuar un análisis desde la perspectiva global, especialmente en el caso de lo que sucederá a la hora de plantear la defensa de las posesiones carlistas del Maestrazgo. La defensa del territorio y el planteamiento de la guerra de guerrillas parecen devolver la guerra a un estado feudal, caracterizado por las razias o algaras, los golpes de mano.

Como sostiene Pérez Galdós, "la guerra, el país, la raza, renovaban en todos los tiempos medievales. La vida tomaba esplendores poéticos y risueñas tintas que se mezclaban con el rojizo siniestro de la sangre, tan sin medida derramada. Exceso de vida era quizás, plétora de sentimientos y pasiones. El fondo, por añadidura, ofrecía característica decoración natural y el teatro más adecuado a tal desbordamiento de vida. La mezquina civilización a la moderna se desvanecía, se borraba como un afeite mal aplicado, dejando sólo las querellas feudales, el ardor místico, la superstición, las crueldades horrendas y eminentes virtudes, el heroísmo, la poesía, la intervención de los ángeles y demonios, que andaban sueltos y desmandados por el mundo" (Pérez Galdós, 1993:2465-2466).

Es sugerente esta idea de un retorno a tiempos medievales, muy en consonancia con la nostalgia por el pasado del espíritu romántico. En el caso de la guerra española, la guerra y la defensa de las poblaciones adquiere tintes de desesperación y absoluto primitivismo, como sucede en numerosos asedios, en los que se recurre al lanzamiento de piedras como último recurso defensivo por parte de niños, hombres y mujeres.

A principios del siglo XIX el desarrollo y conclusión de las guerras napoleónicas conducen a una situación de reflexión global, tanto en el mundo bélico en general como en el de la fortificación en particular. El valor de la estrategia y la táctica, así como el planteamiento de las campañas entendidas como breves conflictos que aspiran a la victoria decisiva empiezan a cuestionarse. La creencia, das como breves conflictos que aspiran a la victoria decisiva empiezan a cuestionarse. La creencia, respaldada teóricamente por el Barón de Jomini a través de su Traité de grande tactique (Jomini, el dominio de la teoría táctica y estratégica por parte de una personalidad al mando de un ejército era suficiente para decantar la victoria - como en muchos casos había parecido probar Napoleón-, demostraron que no eran acordes a los nuevos tiempos, tal y como había deducido con anterioridad Clausewitz (Clausewitz, 2011). La guerra contemporánea, por una parte, resultaba impredecible y 
difícilmente teorizable. Por otra, estaba supeditada al interés político, el cual debía ser realista. Se había pues puesto fin a la visión romántica de las contiendas, argumentando el fracaso de las exitosas campañas bélicas napoleónicas por la inconsistencia, o más bien imposibilidad, de su proyecto político para Europa (Guimaraens, 2011:1)

Del mismo modo, el concepto de pueblo en armas, germinado con la Revolución Francesa, y del que se había valido Napoleón, alteraba definitivamente un modo de hacer la guerra que ya no quedaba en manos del colectivo profesional, sino que era competencia de cualquiera, implicaba a todos y obligaba a conducir la devastación de la guerra en todas las direcciones y a todos los campos. Parecía indiscutible que la capacidad de movilización de tropas, es decir, la cantidad de efectivos, era crucial para decidir las contiendas. Y si antiguamente se había podido suponer que la genialidad táctica de un caudillo podía encumbrar a un ejército inferior en número, los inmensos ejércitos decimonónicos, extendidos en un amplio territorio, más allá del control de esa cabeza indivisible, flictos que detonaron el fin de la estrategia napoleónica. Surge también el concepto de estado mayor, destinado a asumir parte de las labores que recaían sobre el director de las operaciones, que al final consistirían en una exhaustiva labor organizativa de los innumerables efectivos que se diseminaban en amplios frentes inabarcables con la vista.

Especialmente determinante resultó también el perfeccionamiento armamentístico, que, de entrada, se sintetiza en una mejora de alcances y precisión de los fusiles, gracias al empleo de proyectiles metálicos y al alma rayada que caracterizan, por ejemplo, al fusil Minié. Estas innovaciones son aplicadas más adelante a la artillería, combinando proyectil, carga de pólvora y fulminante en una misma cápsula que facilita el transporte y la carga, especialmente la retrocarga, y el efecto explosivo misma cápsula que facilita el transporte y la carga, especialmente la retrocarga, y el efecto explosivo
ante el impacto, que permite garantizar el control del instante de explosión de los proyectiles frente a las obsoletas bombas de mecha (Martínez, 2001:262-263).

En resumen, se incorporaron una serie de innovaciones, todas ellas posteriores a la Primera Guerra Carlista, que en el campo de batalla se tradujeron en el fin de las formaciones cerradas cargando a bayoneta, esencia de la táctica napoleónica y habituales en la Primera Guerra Carlista. Sus cargas de caballería puntuales y aquel breve y rápido momento de avance de los efectivos de infantería bajo el fuego enemigo, buscando el contacto inmediato, se volvieron inasequibles al verse los batallones de infantería obligados a aumentar el tiempo de exposición bajo un armamento enemigo más preciso, que ocasionaba gran mortandad entre las filas. Se trata hoy en día de evidencias que no quisieron que ocasionaba gran mortandad entre las filas. Se trata hoy en día de evidencias que no quisieron
ver muchos militares apegados a una tendencia romántica por la ofensiva a ultranza, que se sostuvo ver muchos militares apegados a una tendencia romántica por la ofensiva a ultranza, que se sostuvo
prácticamente hasta la Primera Guerra Mundial, y que se saldó con una gran mortandad, que no satisfizo nunca el objetivo alcanzado (Martínez, 2001:257-259).

Recuperando algunos conceptos de la estrategia napoleónica, ya comentados con anterioridad, y que condicionan el papel de las fortificaciones, hay que destacar la primacía de las contiendas entendidas como ejércitos en movimiento que recurren al establecimiento de líneas logísticas de comunicación y, en especial, al abastecimiento a partir de los recursos del territorio conquistado. De ahí la importancia de plazas como Requena para los diferentes ejércitos que se quisieron hacer De ahí la importancia de plazas como Requena para los diferentes ejércitos que se quisieron hacer
con el control del país en el siglo XIX, dominando un nudo de comunicaciones clave en la conexión entre el litoral y la capital del Estado.

Asumida la guerra dinámica de grandes movimientos, no parecía tener sentido apostar por la fortificación de un punto concreto con grandes esfuerzos constructivos y económicos, pues localizado el punto defendido, los ejércitos enemigos podían variar con facilidad su recorrido, sorteando el obstáculo, tal y como sucedió durante la invasión napoleónica con el Castillo de San Fernando de Figueres, la mayor fortificación de Europa en su tiempo. Con esta demostración, la fortificación permanente queda relegada a utilizarse solo en aquellos puntos claves de la defensa del estado permanente queda relegada a utilizarse solo en aquellos puntos claves de la defensa del estado
(llaves del estado), de gran relevancia estratégica, como plazas marítimas, arsenales, capitales de estados, etc. De hecho, esto se demuestra durante las guerras napoleónicas cuando la fortaleza 
de plazas marítimas como Cartagena o Cádiz resulta efectiva para que se renuncie a ellas como objetivo militar. A partir de aquel momento, las fortificaciones dejaron de utilizarse como puntos de apoyo logístico tal y como se hacía en la guerra estática propia de los siglos XVI, XVII y XVIII, donde ejércitos protegían en las plazas aquellos pertrechos, y, en especial, aquellos víveres, necesarios para sostener sus campañas. En el siglo XIX los suministros llegaban gracias a las extensas líneas de abastecimiento o al autoabastecimiento del ejército a partir del propio terreno ocupado. Es preciso no obstante recalcar que el territorio español, como el ruso, a diferencia de los territorios centroeuropeos, no ofreció las mismas posibilidades de abastecimiento, y esa fue una de las dificultades que se encontraron los ejércitos franceses. Al mismo tiempo, Napoleón creyó controlar el país a partir del control de las ciudades, desatendiendo las líneas de comunicación entre las mismas, continuamente hostigadas por la nueva guerra de guerrillas que se empieza a practicar en España y que heredan las guerras carlistas. Es entonces cuando los militares españoles deben ingeniar un sistema para combatir aquel modo de hacer la guerra que ellos mismos habían utilizado, pero ahora con la tragedia de un conflicto fratricida.

El caso de la Guerra de Independencia, además, delata cómo las antiguas fortificaciones despiertan poca confianza entre muchos defensores, a pesar de que ciudades como Cartagena eluden el ataque rancés, amparadas en sus fortificaciones, apelando al efecto psicológico que hace desechar su toma ante la posibilidad de una resistencia más tenaz de la esperada. Del mismo modo, como sostiene Herrera (1846:8), mantener la integridad de la plaza de Cádiz fue mantener "la libertad e independencia de toda Europa".

Sin embargo, al margen del mejor o peor provecho que se pueda extraer defensivamente de las tradicionales fortificaciones abaluartadas, en el caso de España, la lectura efectiva del papel que puedan jugar no parece objetiva. Las plazas tomadas por las tropas francesas nunca estuvieron en estado adecuado para sostener la defensa, mientras que cuando fue el ejército comandado por Wellington el que tuvo que afrontar la toma de alguna, la falta de material específico de asedio acabó limitando las posibilidades de ataque a los habituales asaltos, hazañas individuales, heroicas o golpes de fortuna, explotando las acciones cuerpo a cuerpo, el asalto indiscriminado, etc.

Frente al papel prácticamente presencial de la fortificación permanente, son las construcciones de campaña las que parecen abrirse un hueco en unos conflictos bélicos marcados por la citada movilidad de los ejércitos. La improvisada línea de defensa provisional de Torres Vedrás, erigida entre 1809 y 1810 por los ingenieros de Arthur Wellesley, primer Duque de Wellington para sostener el 1809 y 1810 por los ingenieros de Arthur Wellesley, primer Duque de Wellington para sostener el
avance sobre Lisboa de las tropas francesas de André Masséna, más allá del Tajo, hicieron desistir avance sobre Lisboa de las tropas francesas de André Masséna, más allá del Tajo, hicieron desistir a los franceses de su ataque, a pesar de la aparente superioridad numérica de su ejército. La fortificación de campaña, constituida por ciento catorce reductos comunicados a base de trincheras demostrado la posibilidad de defender materialmente una amplia extensión de terreno en un breve espacio de tiempo.

Conforme transcurra el siglo XIX, la fortificación de campaña se va a erigir como la opción más operativa frente a la tradicional fortificación permanente, lo cual quedará probado, además, a raíz de la Guerra de Crimea, durante el asedio a Sebastopol (1854-1855); en la guerra de los Ducados 
o Segunda Guerra de Schleswig, con el asedio Prusiano a la fortaleza danesa de Dybbøl (Düppel) en 1864; en la Guerra de Secesión Americana (1861-1865), con los ataques en abril de 1862 a Fort Pulaski (Savannah, Georgia) o en 1863 a Fort Wagner (Morris Island, South Carolina) ${ }^{1}$; o en diferentes momentos de la guerra Franco-Prusiana de 1870, como el asedio a la ciudad de Belfort (Guimaraens, 2001: 281-285)

1 En el transcurso de la Guerra de Secesión Estadounidense, numerosas construcciones, principalmente de defensa costera fueron sometidas al ataque de la artillería rayada. Los resultados de estas acciones fueron sorprendentes, pues los fuertes permanentes fueron totalmente devastados mientras que las fortificaciones provisionales resistieron los bombardeos de un barbeta ocupando el terraplén de cubierta - sería asediado en 1862 por tropas Federales, con un tren artillero de treinta y y seí piezas, de las cuales diez eran rayadas. A $1.500 \mathrm{~m}$ de distancia estas últimas rompieron con facilidad uno de los ángulos de fuerte, mientras el resto de piezas lisas dañaban gravemente el resto de la construcción. El Fuerte Wagner, al contrario, integraba un conjunto de fortificaciones provisionales, constituido principalmente por terraplenes de arena y un amplio refugio a prueba de bombas para la guarnición. Ante el ataque artillero, los hombres se ponían a cubierto en los refugios para, aprestarse finalizado este, sobre los parapetos con sus armas ligeras a fin de repeler los ataques. Cincuenta y cinco cañones fueron puestos en acción contra esta construccion, pero, a pesar de que 1.173 obuses alcanzaron el refugio, este mantuvo sus condiciones de
habitabilidad. En cuanto al número incontable de disparos que se perdieron contra los parapetos de tierra es difícil establecer una cuenta, lo cierto es que el fuerte tan solo se rindió tras cincuenta y ocho días de asedio. Estos datos alimentaron numerosas discusiones acerca de la eficacia comparada de los parapetos de fábrica y los de tierra o arena como materiales de protección. De este debate, los norteamericanos llegaron a la conclusión de que era preciso proveer a los fuertes permanentes de casamatas a fin de asegurar la defensa costera, recurriendo a baterías provisionales a cielo abierto (Guimaraens, 2001: 282; Hogg, 1975:100) nordista apoyada en la producción industrial y y el desgaste, frente a las más románticas ideas de un Jominista como Lee oe desenlace del combate naval acorazado de Hampton Roads (marzo de 1862) - no tuvieron una repercusión directa en Europa.

Fig. 12. Fortificaciones de Sebastopol durante la Guerra de Crimera el 17 de junio de 1855.
Como efeméride que marca el antes y el después de la estrategia clásica de asedio, del empleo del cañón liso, y de la insostenibilidad de la fortificación abaluartada, se destaca el asedio de la ciudadela de Amberes, iniciado el 15 de noviembre de 1832, última gran operación de sitio de acuerdo con las reglas clásicas de conducción de los mismos, recurriendo a zapas, paralelas y disparos de artillería de cañón liso. Se trata de un asedio que concluiría un mes más tarde con la apertura de la primera brecha, el día 23 de diciembre. De este asedio, las reflexiones más concluyentes que se pudieron extraer se produjeron una vez la plaza capituló poco antes de que los sitiadores se decidieran al asalto. El empleo masivo de obuses había arrasado el interior (Martinet, 1908:291). La proyección vertical de los disparos artilleros había convertido las fortificaciones, de nuevo, en un simple parapeto que no impedía la desolación interior. De este modo, Amberes corroboraba la necesidad de una nueva fortificación que garantizase, de entrada, la protección frente a los fuegos verticales, al tiempo que debía resolver la contundencia del ataque industrial. Estas conclusiones sirvieron de apoyo a los teóricos de la fortificación en la necesidad de adaptar el sistema tradicional abaluartado a las nuevas de apostar por nuevos defendiendo la necesidad de refugios para los fuegos verticales o casamatas a prueba de bomba.

Paralelamente, la defensa costera se enfrentaba del mismo modo al progreso de los alcances armamentísticos, así como al potencial de la marina de varios puentes, que, en muchos casos, elevaban sus proyectiles por encima de muchas fortificaciones costeras de siglos precedentes. El esfuerzo fortificatorio costero de principios del XIX se acentuó especialmente en Francia, donde las contiendas napoleónicas abocaron al país a una política defensiva costera intensiva, especialmente a raíz de la batalla de Trafalgar (1805). Esta defensa costera recurrió a algunas de las propuestas de Marc-René

Fig. 13. Fotografía de la torre Malakhoff realizada por Jean-Charles Langlois en 1855 en Sebastopol.
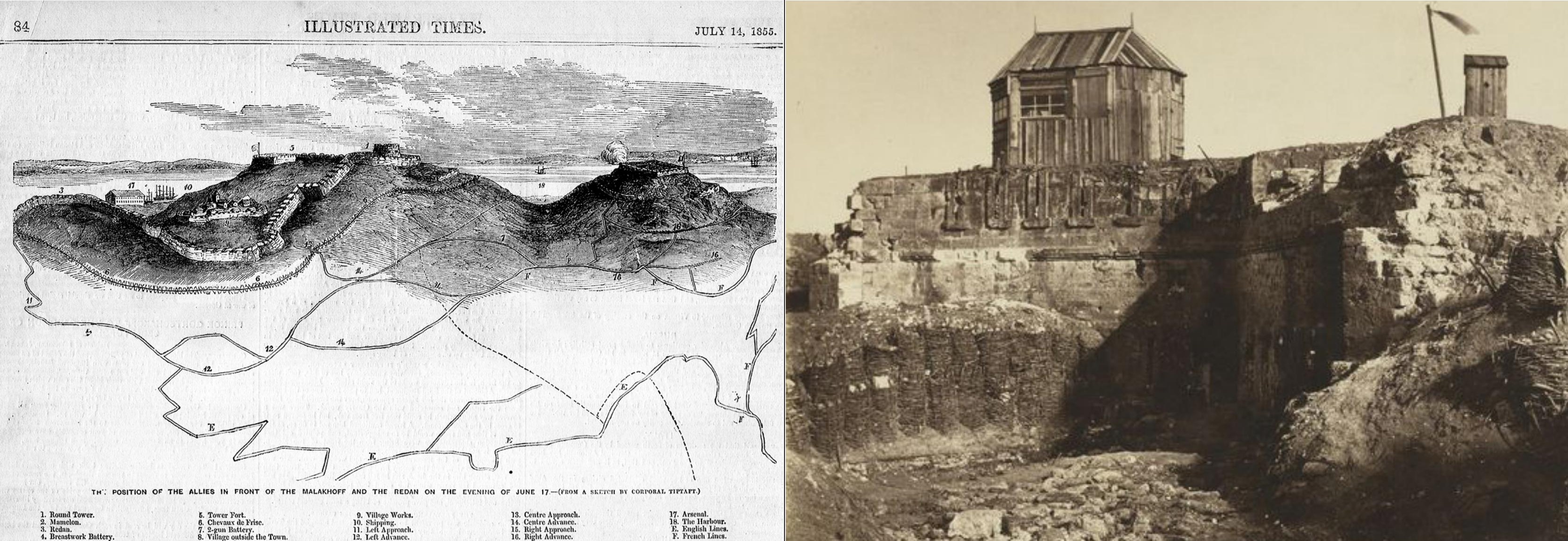

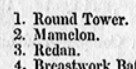

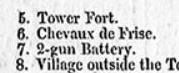

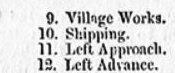


Fig. 14. Fig. Fort Wagner y los aproches del ejército de la Unión. Army \& Navy Journal, Nueva York, Oct. 24, 1863. Fig. 15. Plano del ataque del 54th Massachusetts a la posición de Fort Wagner en julio de 1863.
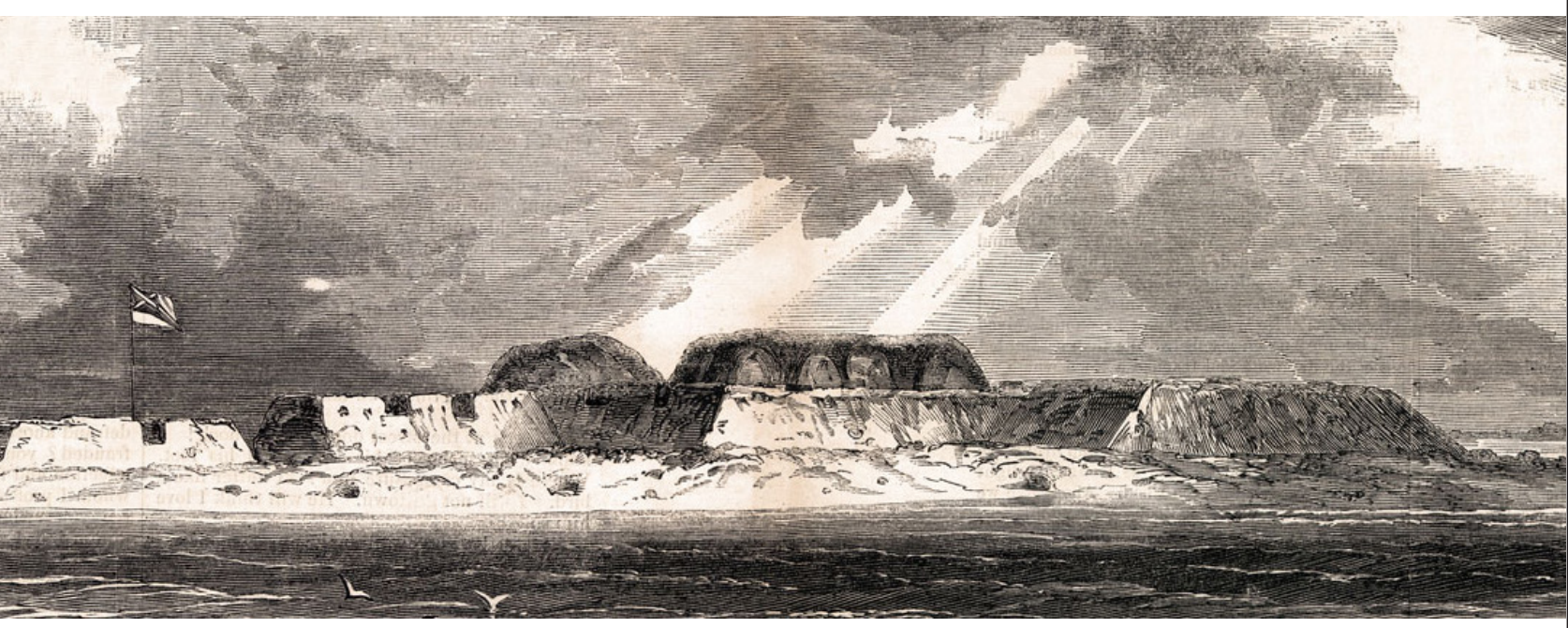

Vincent's

Creek
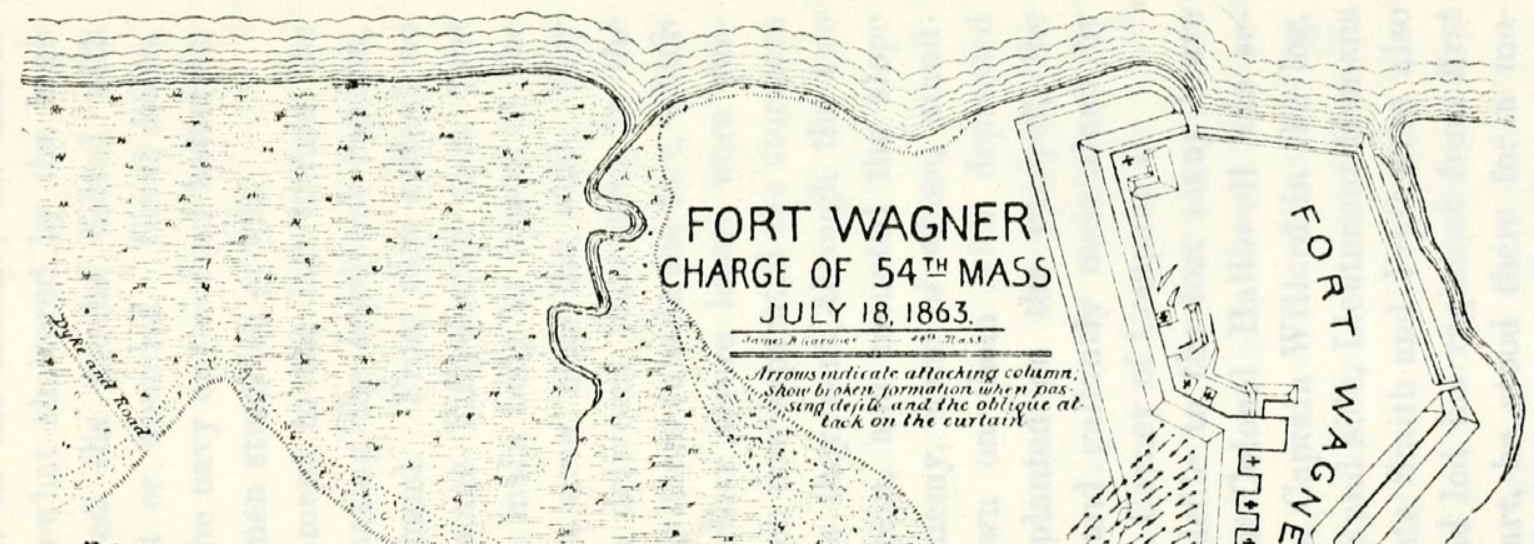

$\equiv \equiv Z Z Z Z Z=$

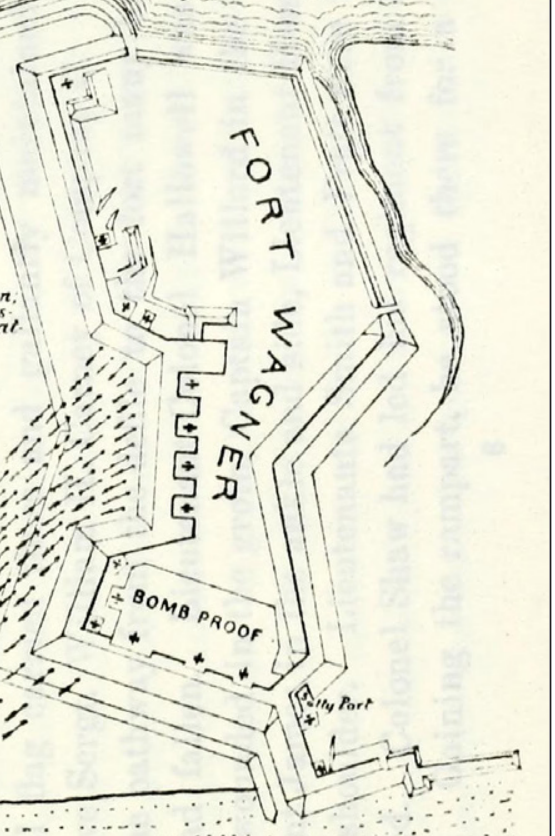

Marqués de Montalembert (1714-1800), con la superposición de casamatas en altura, que aspiraban a concentrar en un punto una potencia de fuego superior a la de los inmensos navíos británicos (Guimaraens, 2006: 315).

Las tesis que argumentaban los inconvenientes de la fortificación acasamatada-especialmente centrados en las mermas visuales, la reducción de espacio para manipulación de la artillería, y el peligro que suponían las deflagraciones confinadas en un recinto o las cuestiones de confort que acentuaban las humaredas de las detonaciones - se enfrentaron a la precisión armamentística, que ponían a los servidores de las piezas defensivas a merced de fusileros de élite que se encaramaban a las cofas de los navíos, o bien al efecto de los shrapnells, navíos bombarderos que proyectaban sus bombas explosivas sobre los terraplenes descubiertos de las fortificaciones costeras.

No es necesario comentar las aportaciones ya citadas de Montalembert a la fortificación acasamatada tratando de solventar los problemas de espacio de maniobra, visibilidad o ventilación tampoco pre halle, aunque es preciso reconocer cómo no se hallaron argumentos para negar la necesidad de la superposición de casamatas en la frontera costera, lo cual resultó sumamente eficaz e imprescindible en la defensa de las costas del Canal de la Mancha en aquel entonces ante la superioridad naval británica (Guimaraens, 2006:310).

En este sentido es preciso recalcar las consecuencias internacionales de estas teorías, que serán adoptadas en los Estados Unidos para plantear la defensa de ciudades marítimas como Nueva York, donde nos encontramos con construcciones como Fort Tompkins (Staten Island, Nueva York), o Fort William (Governors Island, Nueva York), respondiendo a los conceptos repetidos de fortificación acasamatada y la vital importancia de la preeminencia del fuego defensivo. ${ }^{2}$

Si bien es difícil afirmar que entre la conclusión del Congreso de Viena y el ecuador del siglo, Europa viva en paz, como sostienen muchas fuentes ${ }^{3}$, lo cierto es que no se experimenta un enfrentamiento entre potencias que ponga en juego efectivo los desarrollos armamentísticos y fortificatorios. Parece que existe una cierta connivencia por respetar el statu quo que ha dejado el Congreso de Viena (1814-1815), y cuando los ejércitos internacionales se movilizan, lo hacen para acabar con intentos desestabilizadores de algún Estado concreto, tal y como sucede con la invasión de España a cargo de los denominados Cien Mil Hijos de San Luis (1823).

2 Concretamente Fort William, edificado en la isla del Gobernador (Nueva York) y concluido en 1811, consistirá en una torre redonda, de $70 \mathrm{~m}$ de diámetro, distribuida en tres niveles de casamatas, cada uno alojando un total de treinta y seis cañones enfrentados al mar. El terraplén superior, podía alojar a barbeta a otros treinta y seis cañones suplementarios, de tal modo que la 3 Muchas potencias viven conflictos menores, especialmente internos, como puede pasar en España, con la emancipación americana, las insurrecciones liberales o la guerra de los Siete Años (Primera Guerra Carlista). 
6 Sobre la guerra de los Siete Años o Primera Guerra Carlista 
El conflicto carlista, que desgarra España desde los años treinta del siglo XIX, supone, como sostiene Comellas, la primera guerra civil, "realmente organizada y a amplia escala de la historia de España contemporánea" (Comellas, 2009:149). El origen del conflicto arranca con la pretensión al trono de Carlos María Isidro de Borbón (1788-1855), que aspira a suceder a su hermano Fernando VII en el trono de España, relegando a la princesa Isabel, hija de Fernando VII y María Cristina de Borbón. Sus pretensiones en principio eran legítimas de acuerdo con el Auto Acordado de 1713, que establecía en España la ley Sálica francesa, que excluía a las hembras de los derechos sucesorios. Sin embargo, en mayo de 1830 Fernando VII aprobaba la Pragmática Sanción según la cual se derogaba la ley Sálica y bría la posibilidad a que una descendiente femenina del rey heredá la corona, como sucedió nacimiento de la infanta Isabel el 10 de octubre de ese mismo año, destinada a ser Isabel II de España.

Aún así, la estabilidad sucesoria no estaba garantizada si se tienen en cuenta los apoyos entre los sectores tradicionalistas con los que contaba don Carlos. Precisamente la propia reina María Cristina, destinada a asumir la regencia de la corona hasta que Isabel alcanzase la mayoría de edad, no las tenía todas consigo. Los denominados sucesos de la Granja produjeron un cambio en su percepción de la situación, cuando ante la enfermedad de su marido, la reina se encuentra con un apoyo inusitado de los sectores proliberales: aquel mismo liberalismo que su marido había reprimido tras la consolidación de su régimen absolutista.

A partir del otoño de 1832, antes del fallecimiento del monarca en septiembre de 1833 , se produjeron unas vertiginosas transformaciones en el régimen con rápidas sustituciones en los mandos jeron unas vertiginosas transformaciones en el régi

políticos y militares que favorecieron la transición. régimen liberal, dominando gobierno, administración central y territorial, Tesoro y otros servicios, obligando a los partidarios carlistas a operar fuera de los resortes del Estado. Por otra parte, las fuerzas armadas se mantuvieron leales a la reina, dado el trueque de mandos efectuado meses antes, $\mathrm{y}$ los militares afines al carlismo que decidieron pronunciarse se vieron abocados a generar , Zumalárregui, Egúa, Cabrera, Maroto, Santos Ladrón... (Comellas, 2009:149-150).

Los análisis que se desglosan de la situación resultan confusos y no deberían limitarse al problema sucesorio. La simple polaridad entre cristinos y carlistas, entre liberales y tradicionalistas, resume una complejidad ideológica nacional que tiene una historia más dilatada. No se puede obviar la crisis generada en el país ante la invasión francesa de 1808. Las contradicciones generadas en el enfrentamiento contra Francia, donde el invasor es identificado con las ideas, que no son otras que las revolucionarias, aquellas que han desmoronado el Ancien régime, el espíritu romántico nacional que anima la guerra contra el francés, que suspira por el Deseado y que con el grito de "vivan las Cons. absolutismo frente a las ideas de aquelos liberales que har Constitución de 1812 y han defendido el país con igual ahínco. Por medio, no se puede olvidar a aquellos afrancesados que fueron declarados enemigos de la patria. Pero curiosamente fue un ejército francés, en 1823, el que puso fin al trienio liberal y devolvió el país al absolutismo más férreo, inmisericorde con la causa liberal. Muchos militares liberales conspiraron contra la monarquía, como sucede con Francisco Espoz y Mina (1781-1836), protagonista de un intento de invasión desde Francia en 1830 que fracasa estrepitosamente. Curiosamente, Espoz y Mina es el reflejo de esa situación maleable del país, pues de rebelde, tras la amnistía de 1833, acaba convertido en virrey de Navarra, combatiendo a los carlistas, entre cuyos efectivos seguramente se cuentan soldados realistas que lo combatieron en la intentona de Bayona desde la legalidad.

Sobre aquella intentona liberal, narrada por Pío Baroja en Los caudillos de 1830, ya se intuye el trasfondo ideológico que se reproduce en las guerras carlistas y que Baroja conoce bien con la perspec- 
tiva de los años: "el espíritu público no era del todo hostil a los liberales en Santander, donde la mayoría del comercio era liberal y de mucha influencia sobre la masa del pueblo; pero, según él, fuera de la ciudad, en la parte rural, el vecindario estaba sobrecogido por los voluntarios realistas fanatizados por el clero y dominados por los caciques" (Baroja, 1977:24).

Se observa ya que se pretende plantear esa dicotomía entre campo y ciudad. Las ideas liberales parecían fructificar en los núcleos urbanos, mientras que el campo y ciudad. Las ideas tiberales parecian fructificar en los núcleos urbanos, mientras que el campo, con más arraigo de las tradiciones,
se identifica con el tradicionalismo. Como sostiene Miguel L. Gil, citando a M. Fernández Almagro, se identifica con el tradicionalismo. Como sostiene Miguel L. Gil, citando a M. Fernández Almagro,
el conflicto carlista representa "la lucha entre el campo y la ciudad, entre ley general y fuero, entre razón y fe, entre tradición y progreso" (Fernández Almagro, 1966: 133; Gil, 2011: 17), pero como se sostiene en la actualidad, esta polaridad es discutible dada la complejidad del fenómeno.

Cuando se empiezan a desatar las proclamaciones de don Carlos como Carlos V, a pesar de que estas se producen por toda la geografía española, las intensidades de los intentos son bastante des(atribuye a Talavera de la Reina igu de que a mediados de ese mismo mes casi toda España está en calma. No sucede así en Huesca y Bilbao, pues la situación era otra y el carlismo aparecía más organizado. Otro foco, de marcado carácter militar, se localiza en el Maestrazgo, mientras que un conjunto de partidas carlistas se moviliza en Cataluña y La Mancha-Montes de Toledo (Comellas, 2009:150).

La consolidación del carlismo en determinados puntos del paisaje nacional permite extraer algunas conclusiones, de carácter geográfico, quizás ideológico, pero se podrían considerar confusas, como confuso resulta todo el planteamiento del conflicto. ¿Qué ideario identifica al carlismo? ¿Qué modos de entender el liberalismo se aglutinan en torno a la reina regente?

Se podría hablar de la defensa del foralismo por parte de los primeros, frente a la política centralista de los segundos, que justificaría el éxito del carlismo en aquellos territorios con pretensiones forales. A ello se superpone la identificación del ultra-catolicismo con la causa carlista. Quizás podría hablarse de intereses económicos, de acuerdo con los colectivos productivos que respaldan a unos y otros. Los intereses del campo y la artesanía tradicional se posicionan frente a la burguesía industrial y los comerciantes urbanos. Pero se trata de una generalización compleja. Como sostiene Comellas, las zonas dominadas por los carlistas se caracterizan por su régimen de pequeña propiedad, pero zonas de parecidas características como Asturias o Galicia no aparecen tan carlistas como Navarra o Vascongadas. Por otra parte, La Mancha ofrece un régimen agrario muy distinto. Al final, lo único que queda en claro es la bandera sucesoria que esgrime cada uno de los bandos (Comellas, 2009:151).

La "inconsecuencia", sostiene Comellas con buen criterio, parece el denominador común en ambos bandos: "los liberales defienden la legitimidad de Isabel II, amparándose en la pragmática sanción, un documento de 'ordeno y mando' redactado por un rey absoluto sin haber consultado al pueblo ni haber reunido a las Cortes [...] Vemos a los liberales agarrados a la interpretación más 'absolutista' de la ley, y a los carlistas defendiendo la interpretación más 'liberal'. Por otra parte, la ley sálica, defendida por los carlistas, era de origen francés y contraria a la tradición, cuando menos en Castilla y Navarra" (Comellas, 2009:152).

Odalric de Caixal i Mata sintetiza el ideario carlista en el momento de la sublevación de 1833 con el discutible lema "Dios, Patria, Rey y Fueros" que esgrime la defensa de la "monarquía absoluta de origen divino" y "las posiciones ultracatólicas" con la "defensa de la preeminencia de la Iglesia católica, la vuelta de la Inquisición y rechazo de las desamortizaciones eclesiásticas". Por otra parte, también defiende la foralidad, aquel conjunto de leyes propias que poseían determinados territorios como Navarra, Vizcaya, Álava y Guipúzcoa, y que constituían unos privilegios amenazados por la política centralista liberal. Los territorios forales gozaban de ciertos beneficios como el contar con un gobierno propio, jueces, y un particular sistema fiscal que grababa a la población con menos impuestos. A su vez, los ciudadanos de los territorios forales eludían las quintas. Finalmente, había un posicionamiento decidido contra el liberalismo económico, lo que representa el "rechazo de la libertad de comercio e industria y de la propiedad privada libre y moderna" (Odalric de Caixal i Mata, 2015). A pesar de que la síntesis de Odalric

4 
ayuda a entender la orientación ideológica, no puede resultar suficientemente precisa si tenemos en cuenta la diversidad de colectivos que integran la sublevación y que queda patente en el desenlace de la misma. En un trabajo de esta índole, este esfuerzo de síntesis, no obstante, nos permite no abundar demasiado en debates que, si bien son de relevancia política e histórica dada la confusión que se ha generado en torno al fenómeno del carlismo - sumamente controvertido por su capacidad que adaptarse a los tiempos en los dos siglos transcurridos desde su conformación - , resultan tan solo complementarios para el objeto de la investigación, que no es otro que la arquitectura.

\section{Los apoyos internacionales}

Junto al análisis nacional, es imprescindible recordar la intromisión internacional, que, como sugiere Pérez Galdós en Trafalgar (Pérez Galdós, 1993b), aspira a precipitar la descomposición del cadáver de España. La elección del acontecimiento de Trafalgar por Pérez Galdós no es casual a la hora de acometer la narración de sus Episodios nacionales. Es paradójica la situación que lleva a la Corona Española a poner su flota al servicio de Francia para que sea completamente destruida por los ingleses en un combate naval en que, si alguna nación pierde todo, esa es la nuestra. Curiosamente, en poco tiempo los mismos militares se encuentran combatiendo por su independencia contra sus antiguos aliados.

Desde las abdicaciones de Bayona, España se convierte en un pelele de los intereses internacionales, que hacen valer sus pretensiones, ya sea a la hora de escoger un consorte para la reina Isabel en 1846 que no comprometa la neutralidad, como a la hora de definir prioridades defensivas, como sucede en el caso de la defensa de Mahón, donde se sugiere cómo y dónde intervenir, tal y como demuestra el testimonio del coronel Gautier que, en 1849, reconoce la necesidad de fortalecer Menorca como enclave estratégico, dada la coincidencia de intereses geo-estratégicos por parte de Inglaterra Francia: «en la intersección, próximamente, de las líneas que van de Gibraltar a Malta y de Tolón a Argel, está el puerto de Mahón, cuya importancia queda demostrada por esta sola circunstancia» (Terrón, 2004: 86; Gautier, 1851). En el caso de las guerras carlistas la intromisión y puesta en juego de los intereses internacionales es evidente si se observa la presencia de efectivos extranjeros voluntarios, las concesiones políticas o las propuestas diplomáticas. Las potencias extranjeras se convierten en in. una iniciativa humanitaria impulsada por el gobierno británico que pretende poner fin a los fusilamientos indiscriminados entre bandos y que es firmado en 1835 por el carlista Zumalacárregui y el cristino Gerónimo Valdés. Testimonio de la actividad conciliadora de Lord Elliot y el coronel John Gurwood es el del soldado escocés Charles Frederick Henningsen, que combatió junto a lo carlistas y escribió sus experiencias (Henningsen, 1836:3). También encontramos la presencia de la denominada British Legion ${ }^{1}$, según el testimonio de Thomson cuando se hace referencia precisamente a la aplicación del Convenio Elliot: (Thompson, 1836) "los británicos y los chapelgorris ${ }^{2}$ que cayeron en las manos de los carlistas eran ejecutados sin piedad ninguna, algunas veces con torturas dionas de lo yúmero de prisioneros [carlistas]" (Thompson, 1836:29). Clave es la mediación británica también en el 1837. La llamada de ayuda se produjo en 1835 dado que la guerra no marchaba bien para el bando liberal. Francia envió 4000 Gran Bretaña, que había rechazado enviar tropas directamente, optó por enviar ese cuerpo auxiliar constituido por voluntarios. En verano de 1836, sus fuerzas, con un total de 10.000 hombres se posicionaron en San Sebastián. Se asegura que 9600 hombres procedían de los regimientos de línea del ejército, Royal Navy, Royal Marines, Royal Artillery y Royal Engineers. 8.500 efectivos de infantería se organizaron en 10 batallones, aportando además 550 fusileros, 700 efectivos de caballería en dos regimientos, y 300 Treria, junto a cuerpos de zapadores y mineros y cuepos de transport, you fis provincias vecinas. Espartero destinó a estos cuerpos también a los desertores carlistas. Se les denominó así por ir uniformada con chacó rojo (morrión alto, cilíndrico con visera, propio de la época). Denominados también por los carlistas peseteros por el sueldo de peseta que recibían cese del conflicto. Así se testimonia en la Vida militar y política de Espartero (Sociedad de ex milicianos de Madrid, 1844: 485), cuando se habla del papel de Lord John Ilay, acompañado de los coroneles "Wil y Cogun" en el intercambio de propuestas entre Maroto y Espartero en 1839. ¿Cómo se explican los movimientos de don Carlos desde Portugal a Francia para introducirse en España desde esta última? ¿Por qué se facilita a los ejércitos liberales el tránsito por territorio francés para aprisionar en tenaza el frente carlista en territorio vasco, anulando su posibilidad de replegarse a través de Hendaya? ¿Cómo es posible el asilo político que reciben muchos carlistas en París o Londres, como sucede en el caso de Cabrera? La realidad es que existían muchos intereses internacionales en el mantenimiento o cese de la inestabilidad española, en la victoria de uno u otro bando. Quizás, como sostiene Comellas, el bando liberal cuenta con el apoyo de las potencias proliberales como Francia, Inglaterra e, incluso, Portugal, mientras que las potencias absolutistas se muestran relativamente inactivas, como sucede con Austria, Prusia o Rusia (Comellas, 2009:155). La guerra de España desata a su vez un interes romantico que lleva a la participacion de infinidad de voluntarios. arlistas también reciben voluntarios internacionales: legitim británicos, belgas, piamonteses, polacos y, principalmente, alemanes. Destacan aquellos autores de sus experiencias como el escocés Charles Frederick Henningsen (Henningsen, 1836), Wilhelm von Rahden (Von Rahden, 1851), August von Goeben (Von Goeben, 1841) el príncipe Félix Lichnowsky (Lichnowsky, 1841) o Karol Dembowski (Dembowski, 1841), ya citados en el estado de la cuestión.

\section{Las campañas militares en la guerra de los Siete Años}

El desarrollo de la Primera Guerra Carlista está condicionado en parte por las campañas emprendidas en un intento de consolidar un territorio de dominio carlista Si bien, como hemos comentado, el alzamiento se produce desde diversos focos, muy pronto las acciones quedan reducidas a acciones de guerrilla puntuales con pocos puntos de posesión estable por parte de los carlistas, principalmente la zona vasco-navarra. Una duda planea en el planteamiento bélico: ¿cabía meteorizar las acciones por la geografía española o era preciso concentrar la acción? Recogiendo este debate, Valle-Inclán pone en boca del marqués de Bradomín en su novela Los cruzados de la causa, que delata la pasión carlista del escritor en aquella época, la necesidad de "extender la guerra como un gran incendio, no de convertirla en hogueras pequeñas" (Valle-Inclán, 2011:114). Vista la experiencia de los conflictos anteriores, como la guerra de los Siete Años, Valle-Inclán es consciente de la situación en Galicia, por lo que propone para la Tercera Guerra Carlista "concentrar todas nuestras fuerzas en Navarra, en Guipúzcoa, en Álava y en Vizcaya. Mientras se pueda debe conservarse una relación entre todas las varra, en Guipuzcoa, en Alava y en Vizcaya. Mientras se pueda debe conservarse una relación entre todas las
partidas, y utilizarlas prudentemente en algaradas y descubiertas para levantar en armas Aragón y Castilla la Vieja. Una partida que se alzase en esta tierra, si estaba sola, en pocos días caería prisionera... Es preciso reunir aquí [Galicia] dinero para levantar hombres, pero la guerra hacerla en otra parte" (Valle-Inclán, 2011: 114). Valle-Inclán se muestra pues conocedor de lo sucedido en la Primera Guerra Carlista.

Resulta evidente que el carlismo requiere del apoyo popular para su éxito, y si bien, como sostiene Comellas, parece contar con las simpatías de las masas, una cuestión es el carlismo sentimental y otra el carlismo militante. Es fundamental no caer en la homologación entre "liberalismo" y "pueblo", pues sería una asociación errónea: gran parte del pueblo español es tradicional y antiliberal. Pero, ¿qué hace que a pesar de una cierta sintonía general con el carlismo, no exista un respaldo proporcional al alzamiento? A pesar de esta no correspondencia de cifras oficiales, sin embargo, el respaldo popular podría justificar la sorprendente resistencia del conflicto carlista si se tienen en cuenta las condiciones en que se lanza al alzamiento: "soldados sin uniforme, un solo cañón reventado, llamado 'el abuelo', falta de oficialidad competente, aislamiento total..." (Comellas, 2009:155).

En la mente de los mandos carlistas estuvo siempre presente la necesidad de arrastrar y movilizar a sus simpatizantes. Ello justificaría la proliferación de las partidas y, especialmente, la apuesta por las grandes expediciones por España, la Expedición de Gómez de 1836 y la Expedición Real de 1837, que llega a las puertas de Madrid. La prioridad de poder contar con un respaldo internacional 1837, que llega a las puertas de Madrid. La prioridad de poder contar con un respaldo internacional
efectivo por parte de las coronas absolutistas de Europa también condiciona muchas decisiones tácticas como el fatídico asedio de Bilbao. Austria y Prusia habían exigido para el reconocimiento 
de un estado carlista el control de una ciudad de relevancia donde el soberano pudiera establecer su corte, de ahí la obsesión de Carlos V por tomar Bilbao desoyendo los consejos de Zumalacárregui (Comellas, 2009:156).

Si atendemos al análisis que Rodríguez de Coro efectúa de la Primera Guerra Carlista (1833-1840), podríamos distinguir tres fases claramente diferenciadas.

La "fase de Zumalacárregui" (1833-1835) se corresponde con el periodo en el que este general asume el mando único. Oficialmente este mando es reconocido por don Carlos desde Portugal el 18 de marzo de 1834; un mando reconocido sin discusión incluso por jefes de otras zonas como Carnicer en Aragón o Merino en Castilla (Rodríguez de Coro, 1991:70). El genio militar de Zumalacárregui consigue enlazar sucesivas victorias que permiten hacer estable el oeste de Navarra, el este de Álava y el sur de Guipúzcoa para los carlistas.

Mientras en el resto de zonas de conflicto que quedaban activas, Cataluña, el norte de Burgos y La Mancha, la guerra quedó reducida a una acción de guerrillas, solo en el Maestrazgo se conformó un segundo frente, de base principalmente militar.

Zumalacárregui, amparándose en la movilidad, en la orografía y en el apoyo ciudadano, consiguió consolidar un frente estable y llevó el territorio carlista hasta la línea del Ebro. Su objetivo era invadir Burgos, donde el carlismo contaba con partidarios, pero Carlos V obligó a cambiar el rumbo de las operaciones para cercar Bilbao (Comellas, 2009:156). Precisamente en el sitio de Bilbao, en el mes de junio de 1835, una bala hirió al general, que acabó muriendo días más tarde.

Hasta ese momento la guerra se había apoyado en tres sistemas sucesivos: la táctica de guerrillas, el control del territorio rural y de las comunicaciones y la expugnación de plazas fortificadas (Rodríguez de Coro, 1991:72)

La fase que denominamos "de don Carlos" (1835-1838) se inicia cuando el pretendiente decide ponerse al frente de sus ejércitos tras la muerte de su prestigioso general. El 1 de julio de 1835 los carlistas, ante la defensa de Bilbao, se ven obligados a levantar el sitio, e interpretan la necesidad de un cambio de estrategia cuando el frente parece consolidarse y las fuerzas se equilibran. Encorsetados por los liberales en las vascongadas, los carlistas consideran necesario extender la guerra por el país. Así se propone la penetración de columnas ligeras en la retaguardia cristina: serán las expediciones de Gómez, Basilio García y Pablo Sanz.

De las tres expediciones, la más relevante, casi de carácter mítico, es la Expedición de Gómez. Esta expedición parte de Orduña el 26 de junio de 1836 y continúa por toda España durante cinco meses y veintitrés días, recorriendo un total de $4500 \mathrm{~km}$, invadiendo veinticinco provincias, tomando seis capitales y ciudades como Santiago, Ronda, Algeciras o las minas de Almadén (Rodríguez de Coro, 1991:72). Sin embargo, a pesar de la impunidad de sus movimientos, sin que los ejércitos liberales consigan darle caza, la expedición no obtiene el resultado deseado y el mismo Gómez es recluido a su regreso en el castillo de Urquiola, "acusado de malversación de fondos, insubordinación y abuso de autoridad" (Rodríguez de Coro, 1991:74).

En Castilla la guerra concluye en la primavera de 1836 debido al repliegue del cura Merino al País Vasco, mientras en Cataluña se abren nuevas expectativas gracias a la expedición de Juan Antonio Guergué, que atravesaba Huesca y Barbastro. Por su parte, el frente aragonés-valenciano es dominado por Cabrera a sangre y fuego, ganándose el apelativo de "Tigre del Maestrazgo".

El 24 de octubre de 1836, los carlistas se animan a poner sitio de nuevo a la ciudad de Bilbao, que vuelve a representar un nuevo fiasco y el encumbramiento de Espartero tras la acción de Lutxana (Luchana) en la Nochebuena de ese mismo año (Rodríguez de Coro, 1991:76).

4

Fig. 17. Detalle del grabado Acción de Arlabán, de 1845, que ilustra el asedio liberal del año 1836 
Tras el nuevo fracaso en la toma de Bilbao, se propone impulsar la denominada Expedición Real, que aspira a conquistar Madrid aprovechando el tránsito por territorios bajo control carlista. La expedición organizada por don Sebastián, sobrino de don Carlos, alcanza Arganda, las puertas de Madrid, el 12 de septiembre de 1837. Sin embargo, el pretendiente no aprovecha la oportunidad, posiblemente consciente, como sugiere Clausewitz, de que la acción militar debe ir acompañada de la acción política. Quizá no esperó el éxito de aquella operación y, como sostiene Comellas, no contaba con colaboradores de altura para organizar el nuevo régimen desde Madrid (Comellas, 2009: 158). La expedición real, no obstante, es el ejemplo de una afortunada operación de movimiento de tropas en el territorio nacional, que confundió a los ejércitos liberales dejando desguarnecida la capital. Gómez atrajo con su ejército a Espartero hacia los pasos de Somosierra mientras don Carlos, al frente de su ejército, partía del territorio vasco-navarro el 15 de mayo de 1837, para alcanzar Cataluña por Aragón a través de Huesca y Barbastro. Esperaban reforzar el ejército con los partidario carlistas que encontraran a su paso, pero Aragón resultó hostil y, alcanzada Cataluña, la estructura carliste partide de partidas poco conciliables impidió incrementar el jército como se esperaba. La expedición cruzó el Ebro, donde se reunio con las tropas de Cabrera y avanzó hacia Castellón de la Plana.

Los carlistas aglutinaban un ejército suficiente para acometer a cualquiera de los ejércitos isabelinos que su opusiesen a su paso. Tras hacer un amago de avanzar por Aragón buscando los territorios levantinos, se dirigieron a Tarancón para sorprender en Madrid el 12 de septiembre de 1837, solo protegida por la milicia nacional frente a los 30.000 efectivos del ejército de don Carlos (Comellas, 2009:156).

Nadie se explica el motivo por el que don Carlos no acometió la toma de la capital. Entre los testimonios internacionales, algunos, como Barrés, atestiguan que esperaba un recibimiento amistoso por parte de los habitantes de la capital $y$, al no producirse d). para evitar un derramamiento de sangre (Barrés, 1842:225). Von Rahden, sin entrar a valorar los motivos, fue más crítico con la decisión de retirarse: "fue el momento decisivo de toda la guerra. Dejo pasar aquella coyuntura venturosa sin obtener de ella el provecho que, como militar y como jefe, debió haber obtenido" (Von Rahden, 1851: 151). Con Espartero pisándoles los talones, los carlistas fueron poco a poco siendo empujados a su lugar de regreso en una triste retirada agravada por derrotas como la de Aranzueque el 19 de septiembre de 1837.

La conclusión desastrosa de la Expedición Real minó gravemente el carlismo, afectó a su credibilidad y alejó las posibilidades de la victoria final, especialmente si había contado con algún tipo de ayuda internacional. Es en 1837 cuando se puede fijar el comienzo de la última fase de la guerra que podríamos denominar "la fase Maroto" (1838-1839), caracterizada por fuertes disensiones en el que podríamos denominar "la fase Maroto" (1838-1839), caracterizada por fuertes disensiones en el do las facciones más radicales del carlismo hasta un punto de no retorno con el fusilamiento de lo generales Sanz, Guergué y García, el Brigadier Carmona, el intendente Uriz y el oficial de caballería Ibáñez. El enfrentamiento entre facciones en el contexto vasco-navarro conduce irremisiblemente Maroto al Convenio de Vergara, pactando con Espartero el 31 de agosto de 1839 la paz a cambio de reconocimiento de los grados militares carlistas y promesas sobre la concesión o modificación de los fueros. Muchos carlistas consideraron Vergara como una traición por parte de un conjunto de militares que no los representaban. Quizá velaban por sus propios intereses en la negociación, así como por el foralismo vizcaíno y guipuzcoano. Pero ni alaveses, ni navarros, ni castellanos se sumaron a Convenio (Rodríguez de Coro, 1991:80). El 14 de septiembre de 1839, don Carlos cruzaba la frontera acompañado de ocho mil hombres que se negaban a claudicar, mientras en el Maestrazgo Cabrer continuaba una guerra que, a partir del cierre del frente vasco-navarro, concentraba en su territorio todos los esfuerzos liberales con Espartero a la cabeza. Cuando el 30 de mayo de 1840 Espartero toma Morella, la plaza fuerte de Cabrera y, más adelante, el 2 de julio de 1840, toma Berga, donde se refugia el general carlista, a Cabrera no le queda más remedio que el exilio, atravesando la frontera francesa el6 del mismo mes. La Primera Guerra Carlista concluía, pero el carlismo seguía vivo para futuros conflictos. En el exilio, continuaron las pugnas entre moder futuros conflos. por una politica de conciliación queda en un punto muerto cuando don Carlos firma el 18 de mayo de 1845 su abdicación en su destierro de Bourges, cediendo los derechos a su primogénito, Carlo Luis de Borbón y Braganza, conde de Montemolín (Rodríguez de Coro, 1991:86).

7 EL CoNiucto carusta en el MaistrazGo 
Es difícil y confuso hablar de una variable territorial en un conflicto de ámbito nacional, y especialmente de una localización en tierras valencianas, cuando las partidas carlistas en el territorio sortearon las fronteras de las divisiones territoriales. El denominado conflicto carlista del País Valenciano realmente afecta tanto a territorios del Bajo Aragón como de Valencia, y se extiende al sur de Cataluña y a Cuenca, siendo el Maestrazgo el principal núcleo de la actividad carlista. El conflicto carlista en este territorio tiene una identidad propia; generalmente suele asociarse a la personalidad de Cabrera, con un sesgo claramente militar y religioso, y parece desarrollarse de un modo autónomo hasta el punto de que, finalizada la guerra, con el pretendiente ya fuera de España, Cabrera aún se defiende en el Maestrazgo. Cuando sus tropas cruzan el Ebro el 2 de junio de 1840 , el carlismo parece quedar completamente anulado en estos territorios hasta el próximo alzamiento.

Cuando estalla el carlismo en levante lo hace a partir de focos aislados, como son Valencia, Morella, Xàtiva, Orihuela... La nota dominante es la del fracaso, a pesar de ciertos éxitos aparentes. Llama poderosamente la atención que dos focos del carlismo en la zona sean sedes diocesanas, como Tortosa y Orihuela. De Tortosa procede Cabrera, y Orihuela había sido un potente foco del realismo, hasta el punto de que en el momento que se desata la guerra, Panorama Español, de ideología liberal, informa de que el gobernador y el alcalde de la ciudad han sido condescendientes con los partidarios de la revueta principal y el ale religiosos que habín manifestado sus peferencis ya deste 1: 248). Sin embargo, esta afinidad ideológica no tiene una trascendencia de facto, posiblemente debido a su aislamiento en un territorio proliberal.

El primer alzamiento, en octubre de 1832, antes incluso del fallecimiento de Fernando VII, parece encabezado por un fraile, Fray Lorenzo de Bélgida y José Armengol, comandante de los Voluntarios Reales de Valencia, lo que es muestra del motor del carlismo en Levante, basado en el sentir religioso y el carácter militar (La Parra, 1991:247). Aunque la primera intentona es rápidamente sofocada, una vez estalla el conflicto en 1833 empiezan a aparecer diversas partidas relevantes que despiertan la alarma en los cargos políticos y militares, ya sea de Aragón o de Valencia.

El primer chispazo trascendente posiblemente se detecta en Morella y en tierras de Aragón, en zonas limítrofes de la provincia castellonense, bajo la dirección de un aragonés, D. Rafael Ram de Viu y Pueyo, barón de Hervés (1777-1834), asociado a la localidad de Alcañiz, que se convierte en uno de los principales focos carlistas del Bajo Aragón. El barón de Hervés había gozado de ciertos privilegios durante el periodo absolutista llegando a ser nombrado corregidor de la ciudad de Valencia el 20 de junio de 1828 (Izaguirre, 1954:109). Sus contactos personales y su amistad con don Carlos le convierten en uno de los defensores de los derechos del pretendiente. Cuando el 5 de mayo de 1833 se recibieron de la Secretaría del Real Cuerpo de Maestranza de Valencia las indicaciones para las D. Carlos Victoria, propuso al barón su implicación en un alzamiento (lzaguirre, 1954:113), antes de declararse él abiertamente en pro de la causa. Para conseguir controlar la plaza fuerte, el gobernador hubo de recurrir a la estratagema de distanciar de la ciudad a aquella parte de la guarnición fiel al gobierno, lo cual se consiguió bajo el pretexto de ir a la busca de partidas que merodeaban por la zona. Una vez fuera de las murallas, aquellas fuerzas con las que no se podía contar ni confiar, se procedió a la proclama de don Carlos como rey de España. En aquel momento, el barón de Hervés, que ya se encontraba en Morella, a pesar de no ostentar el mando, por contar con una graduación superior a Victoria, aceptó de este el mando del ejército carlista, creando una Junta gubernativa destinada a regir los destinos carlistas en el Distrito de Aragón y Valencia (Izaguirre, 1954:114)

Simultáneamente a estos acontecimientos transcurre la historia de Manuel Carnicer (1790-1835), otra de las figuras relevantes en esta primera fase del conflicto. Aragonés como el barón de Hervés, había sido apartado del ejército por sus convicciones realistas y se encontraba en Alcañiz cuando 
días en 1837, posiblemente la hazaña más relevante del contingente carlista del Maestrazgo sea la conquista de Morella, el 26 de enero de 1838, que, a partir de aquel momento, se convierte en plaza administrativa y militar del carlismo en levante. Cabrera intenta consolidar un aparato adminisgenerales de suministros, sanidad y hacienda e incluso llega a publicar un Boletín del Ejército Real de Aragón, Valencia y Murcia (La Parra, 1991:248).

La obsesión que Cabrera tenía por el control de Morella y que llevan a su conquista lo habían conducido a diversas intentonas previas que ayudan a corroborar las tesis que en esta investigación alejan el estudio de la fortificación de las teorías más innovadoras de la guerra del momento. La escasez de fuerzas y medios no permite asedios en regla y se apela a recursos propios de la fortificación antigua como la sorpresa o el terror psicológico. Las decisiones de defensores y atacantes de la plaza de Morella permiten entender la escala de las acciones asociadas con la poliorcética que caracteriza la guerra de los Siete Años en lMestrazgo. Desde que los liberales recuperan la plaza, se da principio ejemplarizante para disuadir los ánimos de la población. A su vez, del mismo modo que ha sucedido en la campaña napoleónica de Rusia, o como más adelante se hace en Cuba por parte del ejército español bajo el mando de Weyler, se decide minar la guerra de guerrillas tratando de a la plaza, incendiando campos y masías abiertas a fin de recurrir a la estrategia de "tierra quemada". Cuando el 25 de febrero llegó el gobernador militar a Morella, don Fernando Alcocer, se iniciaron las obras de reparación de la muralla, recurriendo a la mano de obra de los vecinos y al gravamen de tasas al clero para sufragar el gasto. Se exclaustró a los frailes del convento de San Francisco y se habilitó un hospital en la Casa Piquer (Ortí, 1979:129).

La posición, la envergadura de las murallas y la presencia de una guarnición artillada hacían muy difícil para los efectivos carlistas volver a recuperar la ciudad. El año 1836 fue complicado además para las fuerzas de Cabrera, pues se enfrentaron a un invierno frío y lluvioso; una climatología hostil que no contribuía al sostenimiento de la vida de guerrilla dura de por sí Cabrera tuvo que fraccionar sus fuerzas e in incrementó la presión sobre el cabecilla hasta el punto de que se detuvo a su madre, que fue fusilada

Fig. 19. Detalle de la Vista del pueblo de Morella y de su castillo (1838).

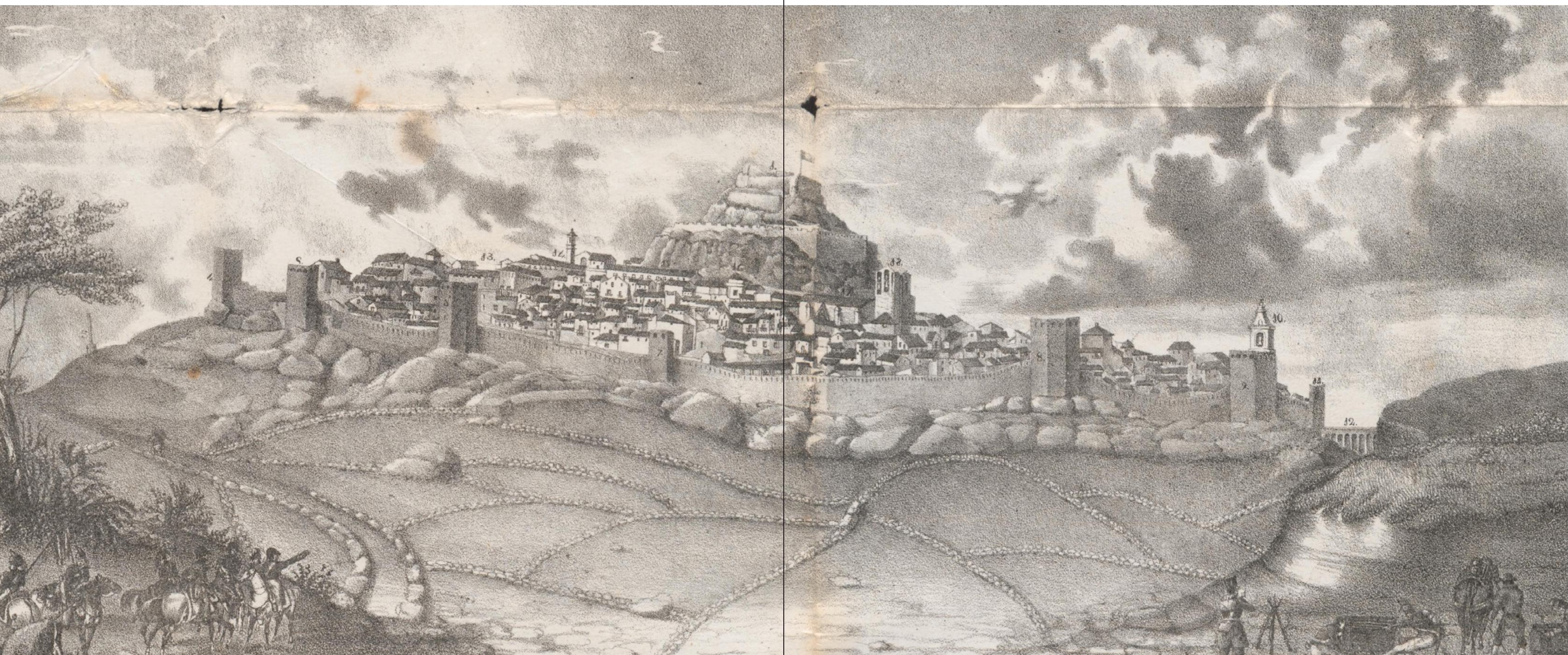


en Tortosa el 16 de febrero de 1836. Esta escalada de terror, de ajusticiamientos sumarios, parecía pasar por alto el reciente convenio Elliot de 1835.

Los liberales frustraron la primera intentona de tomar el castillo por sorpresa en la primavera de 1836. Cabrera pretendía aprovechar la complicidad de un morellano realista, denominado Gargull, a través de cuya casa, adosada a la muralla, se podía camuflar una perforación que permitiría a los carlistas tomar al asalto la plaza. Pero una inspección de las casas desbarató el intento y acabó con el carlistas tomar al asalto la plaza. Pero una inspección de las casas desbarató el intento y acabó con el
fusilamiento del implicado (Ortí, 1979:129). A raíz de esta situación, el gobernador ordenó el derribo de cuarenta y siete casas adosadas, prohibiendo la construcción de edificaciones en zonas polémicas como venía siendo tradicional en tiempos de guerra en todas las fortificaciones urbanas clave.

Llegado el otoño se fraguó una conspiración por parte de un grupo de oficiales y soldados de la guarnición, que también fue sofocada gracias a una delación. Los implicados fueron fusilados en las tapias del cementerio (Córdoba, 1844:144).

La toma de Morella por el carlismo supuso un duro impacto para el gobierno central y tuvo honda repercusión en Europa, teniendo en cuenta que, tras la muerte de Zumalacárregui y el abandono del sitio a Bilbao, se daba al carlismo por desarbolado.

Un ejército liberal al mando del general Oraá, con tropas de Valencia y Aragón, fue destinado a la recuperación de Morella. El ejército, con 23 batallones, 12 regimientos de caballería y 7 baterías de 25 cañones (Ortí, 1979:136), bombardeó la ciudad infructuosamente desde el día 14 de agosto de 1838. Sorprendentemente, Cabrera cercó al ejército sitiador anulando sus líneas de abastecimiento y consiguió, a pesar de que la artillería había llegado a abrir brecha, que Oráa tuviera que abany consiguió, a pesar de que la artillería había llegado a abrir brecha, que Oráa tuviera que aban-
donar el asedio ante la falta de suministros. Este éxito táctico supuso la dimisión del gobierno, la donar el asedio ante la falta de suministros. Este éxito táctico supuso la dimisión del gobierno, la y nombrado conde de Morella (Ortí, 1979:138).

Es relevante destacar el papel que juega este feudo carlista en los sucesos de 1838 y 1839. Los territorios de Valencia y el Bajo Aragón se vieron altamente afectados por la estabilidad de un núcleo inaccesible desde el punto de vista militar, con un ejército conocedor de un terreno fácilmente defendible con la estructura de partidas que había encumbrado a Cabrera.

El abrazo de Vergara, el 31 de agosto de 1839, fue considerado una traición por los resistentes en Morella, que sabían que todos los esfuerzos liberales se concentrarían en la recuperación de Morella por parte del ejército liberal, dirigido en esta ocasión por Espartero. Cabrera, que se había negado a reconocer el tratado de paz, se encontraba en San Mateo, recién repuesto de una enfermedad, cuando, el 26 de mayo de 1840, Espartero iniciaba inmisericorde el bombardeo de la ciudad. Cayeron sobre la ciudad más de 19.000 proyectiles. El estallido del polvorín el 29 de mayo decidió a los carlistas a capitular sin condiciones. Sostiene Madoz que algunas compañías de vanguardia, junto a (Madoz, 1845-1849). Los liberales hicieron 2731 prisioneros y se sostiene que el 30 de mayo de 1840 la oficialidad liberal saqueó la Iglesia Arciprestal, el convento de San Francisco, la Iglesia Mayor y los archivos del ayuntamiento.

El carlismo quedó desarticulado y Cabrera consiguió cruzar el Ebro. Perdidas las esperanzas, atravesó la frontera francesa junto a seis de sus batallones el 6 de julio de 1840, dándose por concluida la prolongación de la guerra en el territorio valenciano.

Quizá entre los diferentes reconocimientos que se han hecho a sus dotes como militar, y que de algún modo sirven para sintetizar su estrategia, destacan las palabras recogidas en el Memorial de Caballería (noviembre de 1927) que indican que "de haber nacido Cabrera veinte o treinta años antes, con lo que hubiera hecho armas contra los invasores de su patria y no contra españoles, ninguno de los guerrilleros que tan famosos se hicieron en la guerra de la Independencia hubiera podido compararse con él. Porque ningu- no poseyó en tan grande escala las dotes de organizador; ninguno tuvo una comprensión tan clara y general del terreno, ninguno supo crear, como él, un verdadero método de guerra, adaptado al tiempo, al adversario y a las circunstancias. Igualáronle varios en audacia y osadía, en rapidez de movimientos, en concentrarse para combatir y dispersarse para desaparecer, en perseverancia y energía pero todos fueron guerrilleros locales, mientras que Cabrera fue un guerrillero que aplicó con pureza verdaderamente admirables los mejores y más fecundos principios militares" (Memorial de Caballería, 137, 1927).

Sería infructuoso hacer un seguimiento del conjunto de operaciones desempeñadas por las diversas partidas bajo el mando de Cabrera en los años que duró el conflicto. En ese sentido remitimos a los estudios específicos tratados con anterioridad y retenemos una idea básica centrada en que la supervivencia del carlismo en el territorio valenciano, como se ha comentado, una vez superada la fase conspiratoria, queda abocada a la fragmentación de partidas que pueden eludir la persecución de los ejércitos liberales en territorios difícilmente accesibles. Saquean, intimidan y tratan de ganar adeptos para la causa en un intento de sobrevivir esperando un desenlace político o militar que debe provenir de otros frentes. Como sostiene Rújula, la partida es la estrategia insurreccional por excelencia, y se mantiene viva aun cuando Cabrera llega a hacerse con el mando supremo de las fuerzas del Maestrazgo. Bajo el mando de Cabrera, se distinguen dos fases clave. La primera arranca desde su legitimación tras la entrevista con don Carlos en Navarra en febero de 1835 y su implicación en una lucha de grandes ambiciones en las que Cabrera hace converger sus fuerzas apoyando la Expedición de Gómez rumbo a Andalucía en 1836. Pero Cabrera regresa herido de Andalucía en diciembre de ese año, justo en un momento en que se puede hablar del inicio de una segunda fase. Hasta aquel momento parecía que el conflicto sonré́a a los carlistas en la medida the consolidaba el control cedían diversas revoluciones en las ciudades del país, donde la opinión pública empezaba a tener trascendencia política. El liberalismo se imponía, se ensalzaba la Constitución de 1812 y se animaba la revolución burguesa, movimientos que decantaban la opinión de aquellos poco implicados con la causa carlista, que se empezaba a ver como única alternativa a la revolución liberal (Rújula, 2008:203). Pero el regreso baldío de la expedición de Gómez, el ascenso de Maroto y las disensiones en el carlismo nacional, incluso las intrigas que conducen al Convenio de Oñate o abrazo de Vergara, acaban recluyendo a Cabrera en su feudo, convirtiéndolo en último resistente, única baza para la victoria del Carlismo, para el cual es imposible esperar el desenlace político favorable o un apoyo militar desde el territorio vasco-navarro.

Posiblemente la primera fase citada resulta clave para las poblaciones del altiplano de Requena, en la medida que las dos grandes expediciones, la del General Gómez o la misma Expedición Real, se aproximan en forma de potentes ejércitos, al tiempo que en esos mismos años cualquier instante puede ser propicio para el golpe de mano de las partidas que campan impunemente por los montes. 
La fortificación del "Reino Mágico" de Cabrera. CATÁlogo de ForTIFICACIONES IDENTIFICADAS 
Leyenda de iconos

* plazas en la que hay constancia de trabajos constructivos carlistas

Fi Fi FUERTE ROQUERO

-

F21 FORTFICACAOION DE UNENDAS

F22 FORTIFICACIÓN DE SALINAS

F23 BATANES FORTIFICADOS

45 F24 HOSPITALES

IIII F25 CÁRCELES

B F26 ERAS

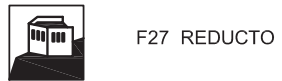

F28 LINEA DE REDUCTOS

F29 BATERIA/ PLATAFORMA ARTILLERA

F30 TORRECILLA EN LOS PASOS

Fy TRINCHERA DE CAMPAÑA

If f32 campo de batalla

Fin RETRINCHERAMIENTO DESMONTABLE 
$01_{\text {ADenuz }}$

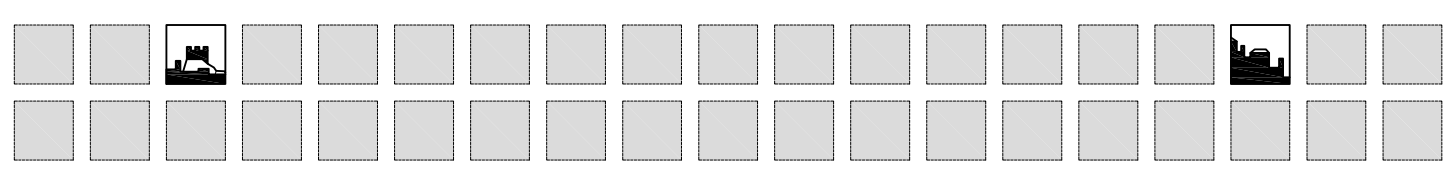




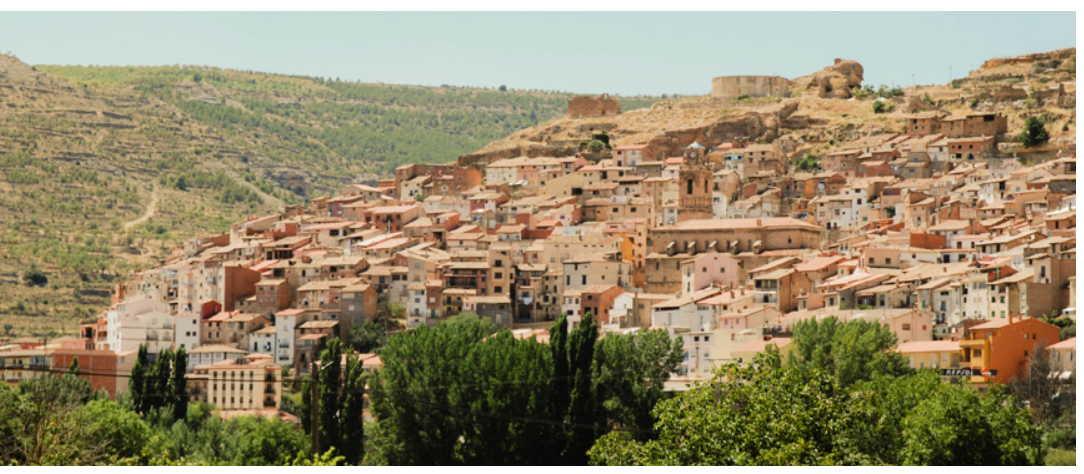

Fig. 21. Localidad de Ademuz, donde se aprecia el frente escalonado y los restos del fuerte.

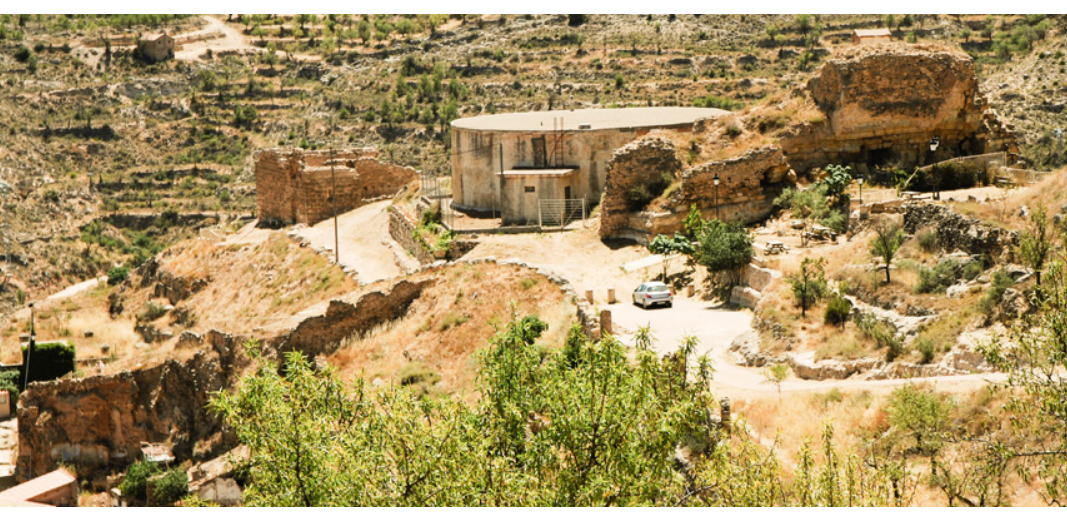

Fig. 22. Restos del castillo de Ademuz y de la Ermita de Santa Bárbara, vistos desde el cementerio.

Fig. 23. Restos del castillo de Ademuz.

Fig. 24. Restos de la Ermita de Santa Bárbara.
Ademuz

Localidad en castellano / valenciano: Ademuz

Provincia actual: Valencia

Comarca: Rincón de Ademuz

Coordenadas geográficas: 40.060236547009566, -1.287338097013503

Tipos defensivos: castillo reforzado que domina la población, frente escalonado.

Acciones y fortificación:

En mayo de 1839 en el rincón de Ademuz los carlistas están efectuando obras dirigidas por Arévalo, comandante de la División del Turia (Diario Mercantil de Valencia, 2 de mayo de 1839; Córdoba, 1844-1846: 11; Caridad, 2013: 258). El objetivo es extender el área de influencia del frente de Valencia, capitaneado por Chelva, hacia la meseta. Así lo recoge la prensa: “Valencia $1^{\circ}$ de mayo [1839].Hemos visto una carta de Ademuz, manifestando el abandono en que yace todo el Rincón dominado por los rebeldes, cuando el buen espíritu de sus habitantes sólo requería un poco de protección de parte del gobierno para mantener aquel país libre de facciosos, y sacarse de él los recursos de que abunda y de que ahora se hordas de Quílez [Joaquín Quílez] y el Serrador [José Miralles Marín] [esto fue en 1836, mayo 23], en venganza de la decisión de los nacionales de aquel distrito, no ha recibido orden ninguna de esta capital, a quien pertenece, ni se ha hecho alguna de las tres quintas verificadas en todo lo restante de la Península; y por cuya razón aquella juventud ha sido arrebatada, y muchos padres presos y conducidos por tercera vez a Chelva, de donde lograron fugarse. Ahora tratan los rebeldes de dar mayor estabilidad a su dominio en el país, para lo cual han construido en Ademuz y Torre-Baja, fortificando la casa palacio de dicho pueblo [la "Casa Grande" o "Casa del Señor del Mayorazgo", en la plaza mayor de Torrebaja], y organizando un batallón de los mozos de la tierra, a quienes tratan con el mayor rigor. Hallase al frente de todas estas operaciones don Ramón Olivares, capitán que fue de Samper [Francisco Puig Samper] en la época pasada, ol cual se fugó a Moya don de residía, a unirse con la facción, y ahora está hostilizando continuamente y bloqueando el citado punto. Tratan además de fortificar el Castillo de Ademuz y de Castielfavit [Castielfabib], inexpugnables por naturaleza, y situados en una ribera abundante, al pie de las sierras de Cuenca y Albarracín. De modo que si el gobierno no echa una ojeada de interés sobre aquel distrito, quedará perdido para siempre, y su decidida y liberal juventud abandonada y desatendida se acostumbrará al yugo, y acabará por perder el afecto a unas instituciones y un gobierno a quien tan poca protección ha merecido" (Eco del Comercio, Madrid, 8 de mayo de 1839). El conjunto del castillo, también conocido como Castillo de Santa Bárbara, erigido en la cima del monte de los Zafranes, domina la población, que se asienta en la ladera del monte. La fortificación, de origen musulmán, es una pieza resistente a la conquista cristiana, que fortifica la línea del Más adelante, tras la conquista cristiana del siglo XIII, juega el papel de castillo fronterizo con el Reino de Castilla. El castillo sufre fuertes desperfectos a raíz del terremoto de 1656, desapareciendo la antigua iglesia parroquial, intramuros. A finales del siglo XVII o principios del siglo XVIII se erige la ermita de Santa Bárbara cuyas ruinas perviven en el interior de la fortaleza. Poca información se recoge de las intervenciones concretas que se efectúan en la localidad por parte de los efectivos carlistas. De hecho, la citada crónica del Eco del Comercio habla de que los carlistas "tratan de fortificar" Ademuz, el 8 de mayo de 1839, por lo que no puede deducirse que lleguen a concluir su propósito. Las ruinas actuales, un conjunto de agrupaciones de muros y cimientos, apenas permiten distinguir las diferentes fases ni intervenciones significativas. La habilitación del castillo como zona un mirador escalonation un mirador escalonado de la zona, permite distinguir las diferentes plataformas que podrían dominar la zona, hoy calificadas como el merendero y el mirador de Santa Bárbara. Llama la atención el conjunto del calvario y cementerio, que se elevan siguiendo la calle Cruces hacia el norte, que, junto 
con el mirador del Recuerdo Eterno, dominan tanto la posición del castillo como el sector septentrional de la localidad. Estas posiciones privilegiadas para el control del territorio podrían haber sido ocupadas defensivamente, pero no queda vestigio alguno de dicha ocupación.

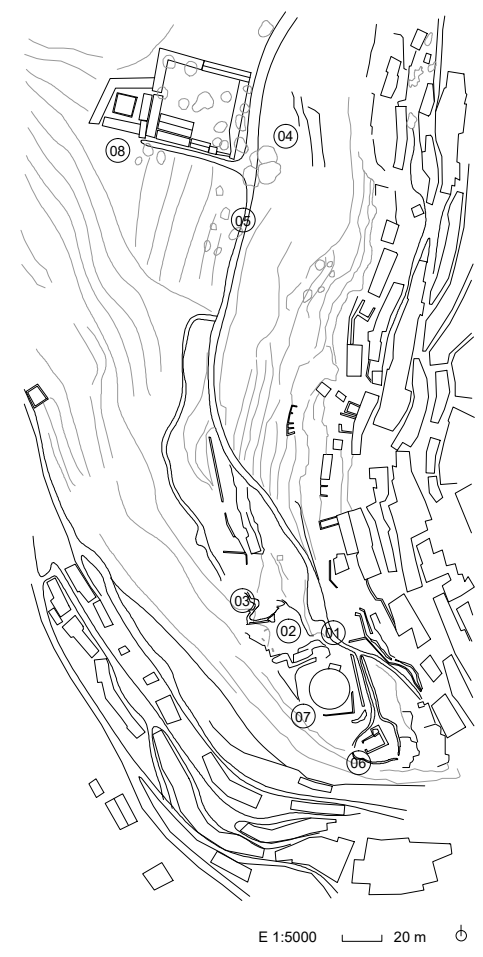

Fig. 25. Esquema en planta del castillo de Ademuz y sus inmediaciones en la actualidad.

01. Restos del castillo

02. Merendero de Santa Bárbara

03. Mirador de Santa Bárbara

04. Mirador del Recuerdo Eterno

05. Calle Cruces

06. Ermita de Santa Bárbara del

Castillo

07. Depósito de agua potable

08. Cementerio

02 alcalá de la Selva $*$ 

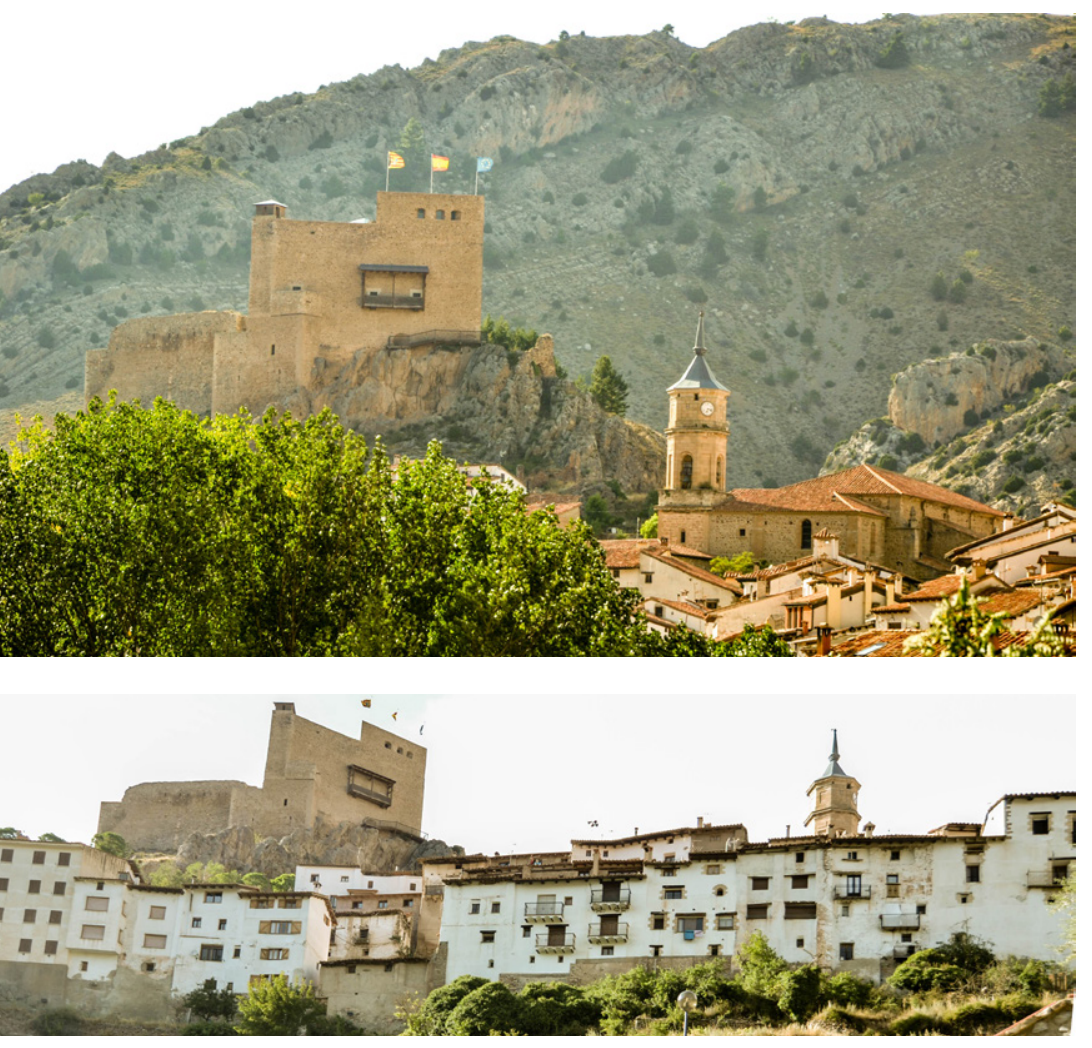

Fig. 26. Posición de los elementos más significativos de la plaza: castillo, iglesia y población.

Fig. 27. Ubicación elevada del fuerte, mostrando su lienzo aspillerado, y frente escalonado de la población.

Fig. 28. Frente sureste del fuerte Fig. 29. Frente sureste del fuerte visto desde el pie de la roca sobre la que se emplaza.

\section{Alcalá de la Selva}

Provincia actual: Terue

Comarca: Gúdar-Javalambre

Coordenadas geográficas: 40.371537107775566, -0.7219202709646311

Datos históricos:

Guarnición 1839-1840: 108 (Caridad, 2013:263)

Inicio bombardeo liberal: 29-4-1840

Rendición o abandono: 30-4-1840

Días de resistencia: 1

Fuente: Diario Mercantil de Valencia, Boletín Oficial de la Provincia de Castellón de la Plana, Córdoba (1844), Calbo y Rochina (1845), Caridad (2013:297)

Tipos defensivos: castillo reforzado que domina la población, torre, torre artillada adosada a muralla tambor, muralla urbana, frente escalonado.

Acciones y fortificación:

En la primavera de 1839 se repara y se refuerza el antiguo castillo (Caridad, 2013: 262). Calbo y Rochina testimonia que la fortificación es circunvalada por las tropas de O'Donnell, que la ocupa el 30 de abril de 1840, después de silenciar la artillería carlista, destruir las defensas y arruinar los torreones con sus cañones. Por lo visto, se establece una mina, se ocupa parte del fuerte y se derriba con hacha los rastrillos. Aun así, los carlistas se defienden con piedras, maderas y granadas. Casi al mismo tiempo deserta la guardia que custodia un fortín exterior, lo que agrava aún más la situación de los defensores, que capitulan poco después (Córdoba, 1844: v. 4: 304-317). Pertegaz, gobernador de la plaza durante el asedio, ordena prenderle fuego, a fin de evitar que los atacantes se cobijen en él (Von Goeben, 1966: 427). Sin embargo, al ocupar el castillo, los liberales hallan dos piezas de artillería, muchos víveres y municiones (Calbo y Rochina, 1845: 503).

El mes de mayo de 1840 supone el desmoronamiento de la línea defensiva carlista, pues con Alpuente caen Alcalá de la Selva (Diario Mercantil de Valencia, 12 de mayo de 1840; Boletín Oficial de la provincia de Castellón de la Plana, 29 de mayo de 1840; Córdoba, 1844-1846: v.4,317; Calbo y Rochina, 1945:505) y Bejís, siendo abandonados Linares de Mora, Villahermosa del Río, Montán, Benicarló, La Galera, Ulldecona, Sant Mateu y Cantavieja (Caridad, 2013: 266).

En la actualidad, el castillo se encuentra restaurado y en buen estado de conservación. Es visitable y se pueden apreciar los distintos cuerpos y espacios del mismo. En planta tiene forma de rectángulo, con un espolon irregular adosado. Las murallas y la torre del homenaje cierran un gran patio que sirve de acceso.

El castillo medieval cristiano dispone de tres recintos: la torre del homenaje o recinto principal, el patio de armas y la albacara. La torre del homenaje en planta tiene forma de triángulo rectángulo cuyos ángulos no rectos están achaflanados. En el frente noreste hay restos de una falsabraga. En alzado, este cuerpo se divide en dos niveles, y en el saliente noreste existe un tercero, dejando sobre los otros dos una terraza con una garita en cada vértice.

En la memoria técnica de restauración de la fortaleza se indica que las estancias estaban llenas de escombros, fruto del derrumbamiento de muros y restos de baldosas de barro (Sanz Zaragozá, 2019: 9-16). También se encontraron mechinales, propios de vigas de madera, a media altura entre una planta y otra del castillo medieval, lo que hace pensar que, dada la gran altura entre plantas, los carlistas decidieron construir forjados intermedios. Los muros son de mampostería, y de sillería en aristas y zonas de especial importancia, diferenciándose la construcción carlista, con piedra sin labrar, de la medieval, con cierta labra en la piedra. 

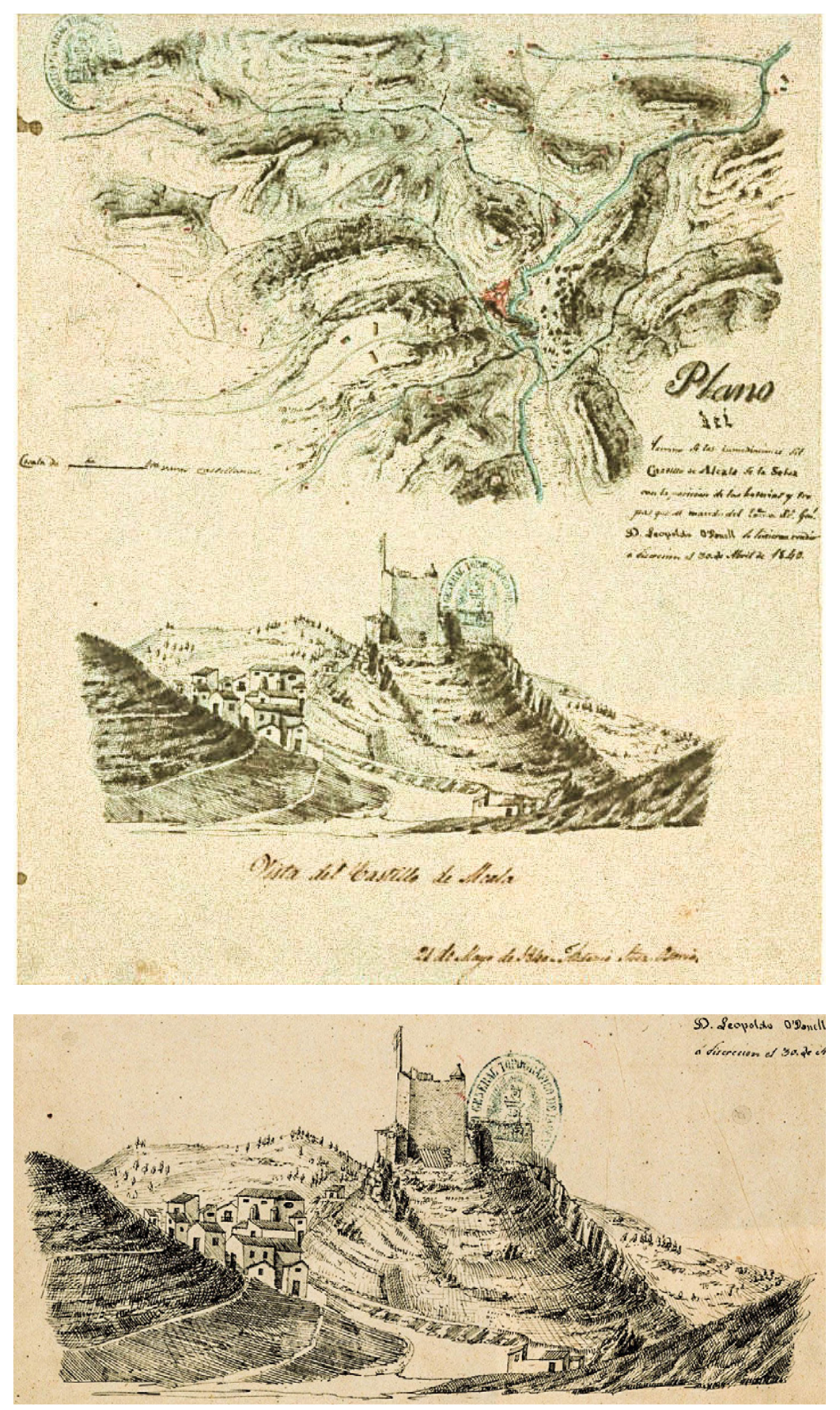

Plano 3

Título: Plano del terreno y las inmediaciones del castillo de Alcalá de la Selva

Publicación: 1840.

Autor: Antonio Sánchez Ossorio

Ejemplares: Archivo Cartográfico de Estudios Geográficos del Centro Geográfico del Ejército.

Plano 4

Título: Croquis de Alcalá, su castillo y sus inmediaciones.

Publicación: 1840 .

Autor: Manfredo Fanti.

Ejemplares: Archivo Cartográfico de Estudios Geográficos del Centro Geográfico del Ejército. Signatura Ar.F-T.5-C.5-200.

Fig. 34. Plano 2. Plano del terreno y las inmediaciones del castillo de Alcalá de la Selva.

Fig. 35. Detalle Plano 2. Vista de Alcalá.
Fig. 36. Ilustración 1. Vista del castillo de Alcalá de la Selva.

Fig. 37. Plano 1. Croquis del fuerte y terreno de las inmediaciones de Alcal

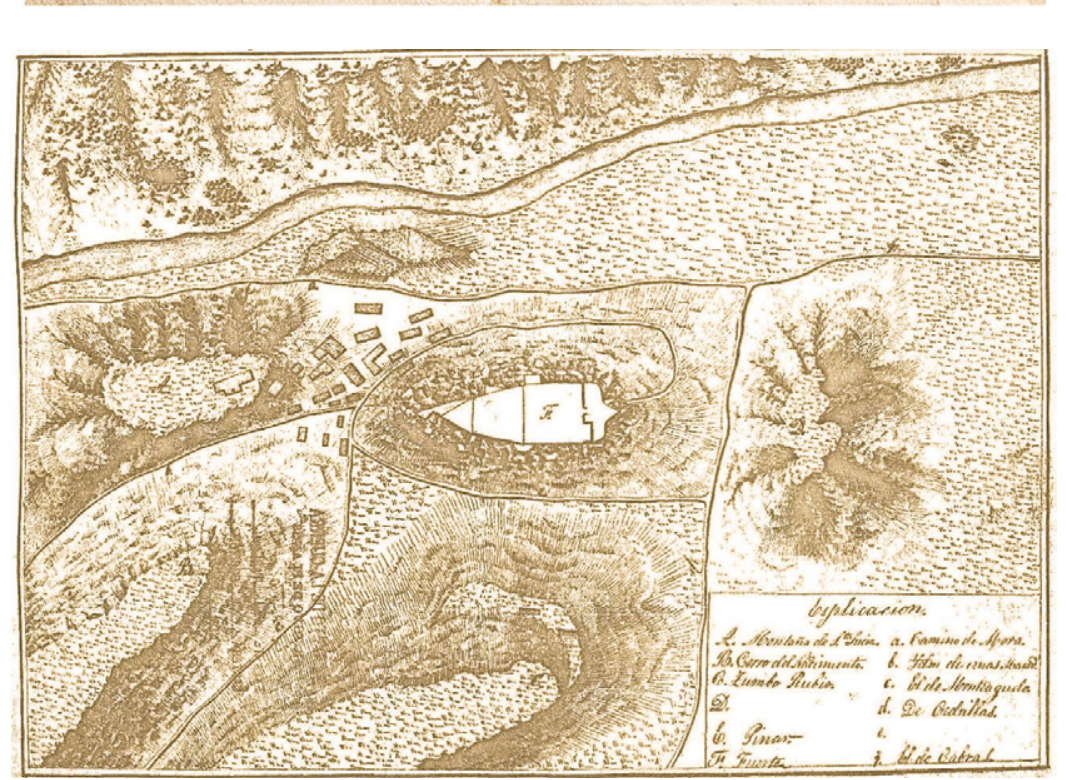

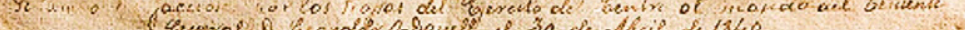

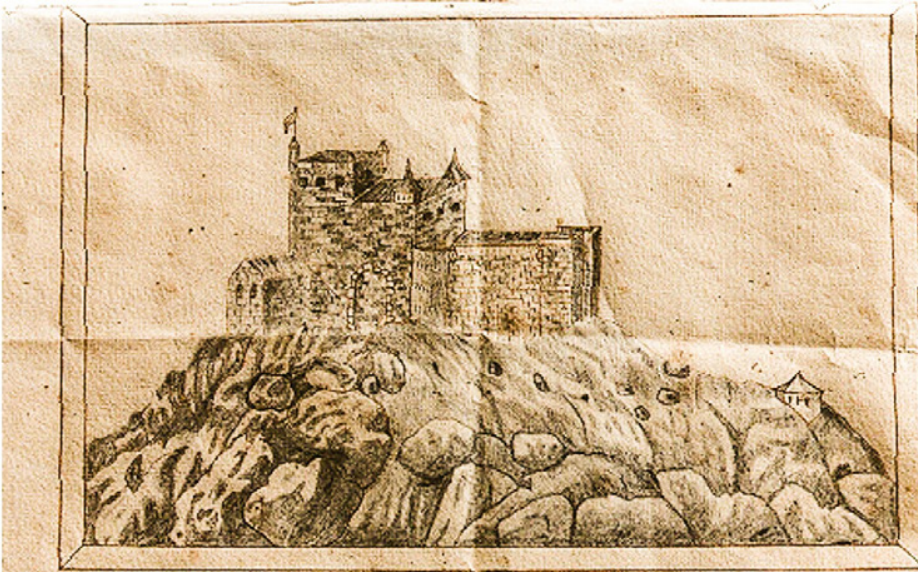

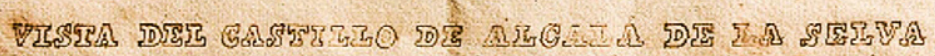



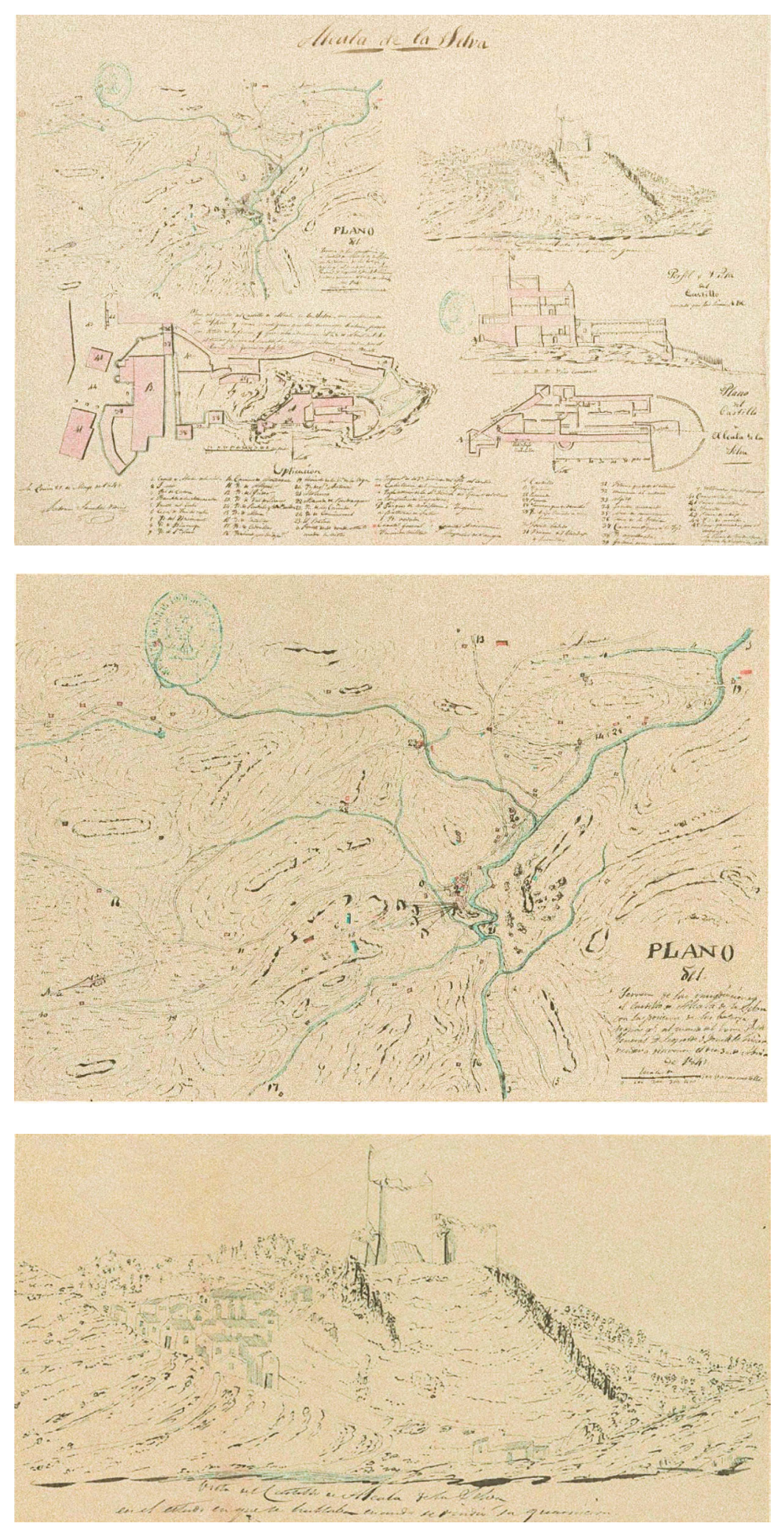

Fig. 38. Plano 3. Plano del terreno y las inmediaciones del castillo de Alcalá de la Selva

\section{Fig. 39. Detalle Plano 3.}

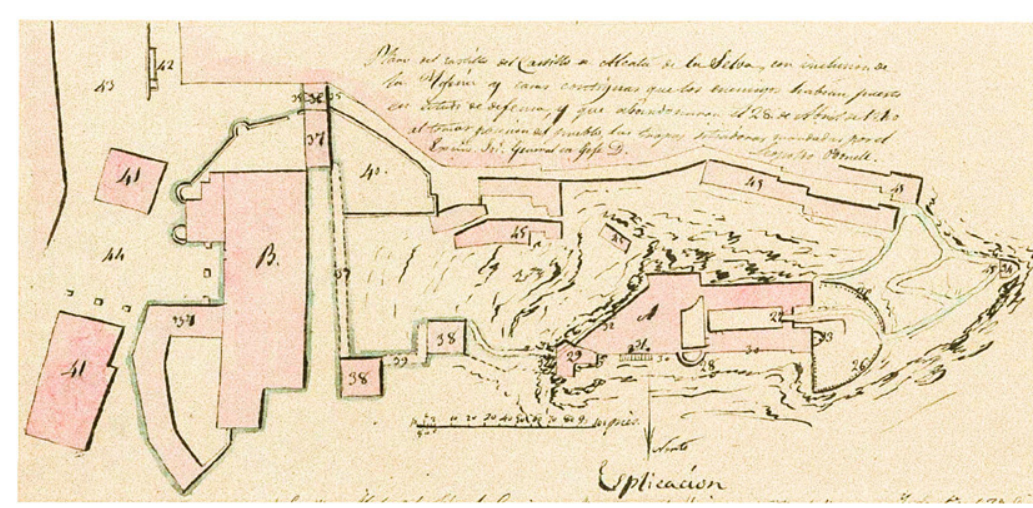

Fig. 41. Detalle Plano 3.

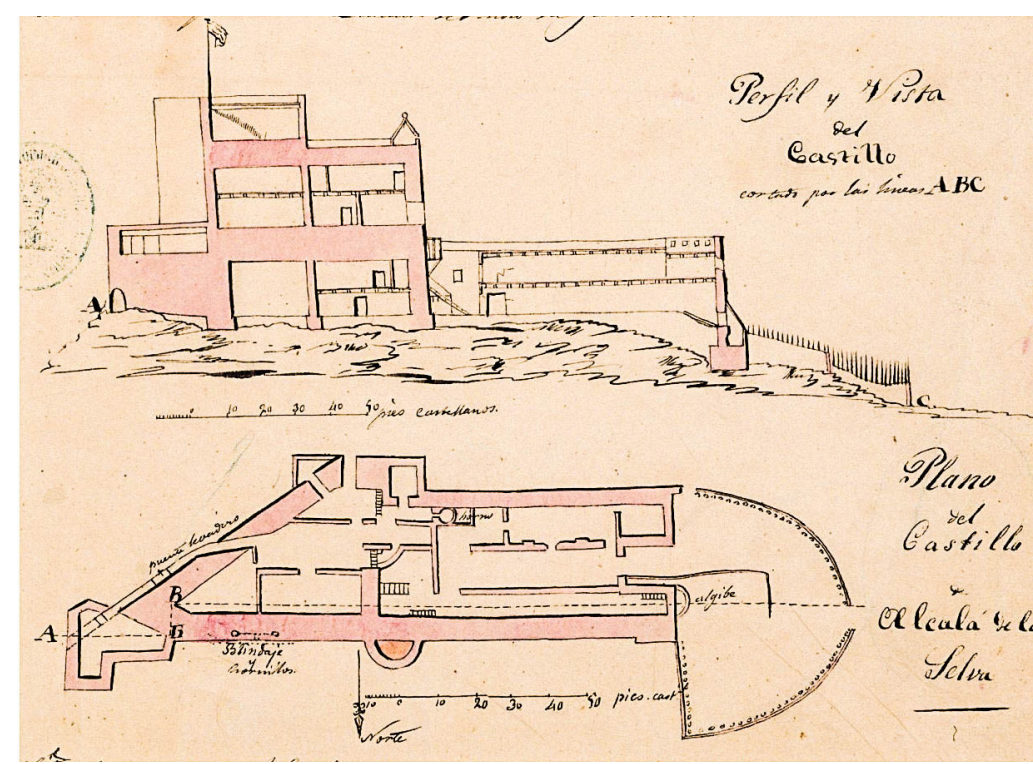

Fig. 42. Detalle Plano 3.

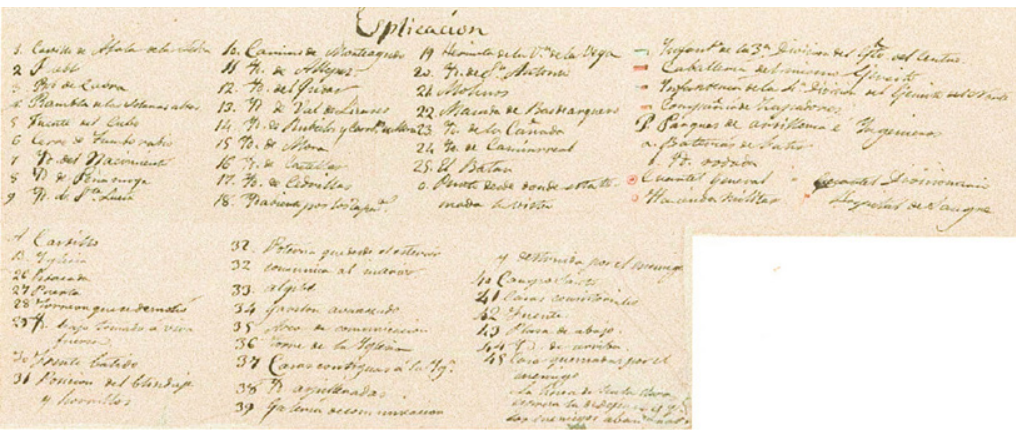



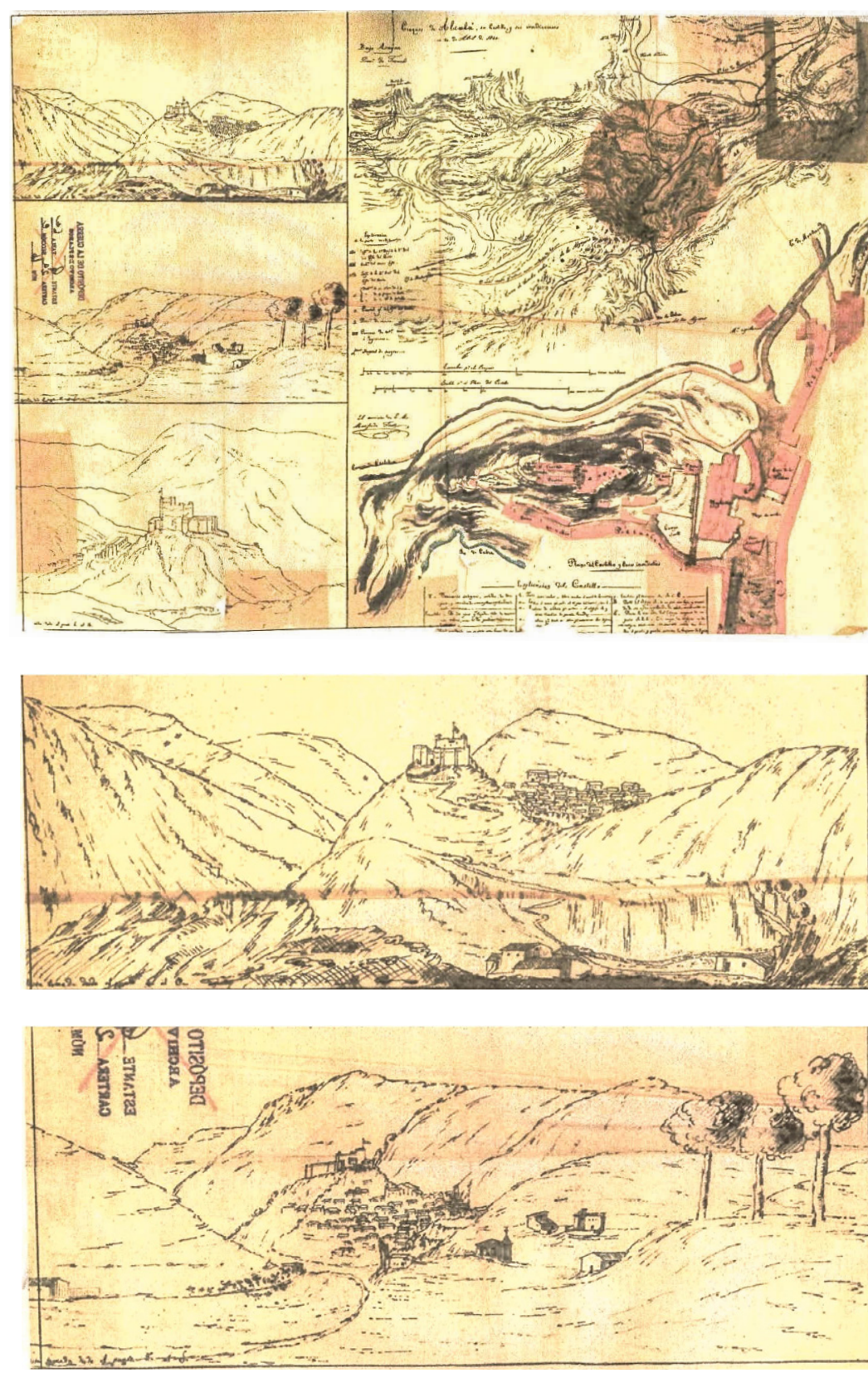

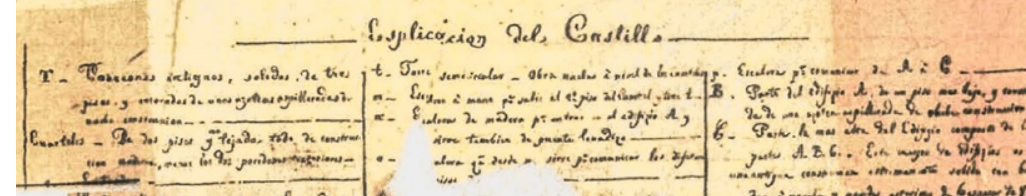

Fig. 44. Plano 4. Croquis de Alcalá, su castillo y sus inmediaciones.

Fig. 45. (Centro arriba) Detalle Plano 4.

Fig. 46. (Centro abajo) Detalle Plano 4.

Fig. 47. (Abajo) Detalle Plano 4 Transcripcion:

T- Torreones antiguos, sólidos, de tres pisos y coronados de unas azoteas aspilleradas de nueva construcción Cuarteles - De dos pisos y con tejado, todo de consrucción moderna menos las dos paredes externas.

e - Entradas

h - Pared aspillerada con en cima una línea de [icabezas de flechas?] con puntas de hierro t - Torre semicircular - Obra nueva a nivel de los cuarteles m- Escalera a mano pa al $2^{\circ}$ piso del cuartel y torre $t$ $\mathrm{n}$ - Escalera de madera para entrar al edificio A y sirve también de puente levadizo

- Escalera que desde n sirve para comunicar los diferentes pisos

p - Escalera para comunicar de A a C

B - Parte del edificio A, de un piso más bajo, $\mathrm{y}$ coronada de una azotea aspillerada de nueva construcción

C - Parte, la más alta del edificio compuesta de las partes A, B y C. Este conjunto de edificios es de una antigua construcción extremamente sólida con bóvedas a prueba y paredes exteriores de espesor de 8 pies. A - [...] bóvedas a prueba [...
Fig. 48. Detalle Plano 4.
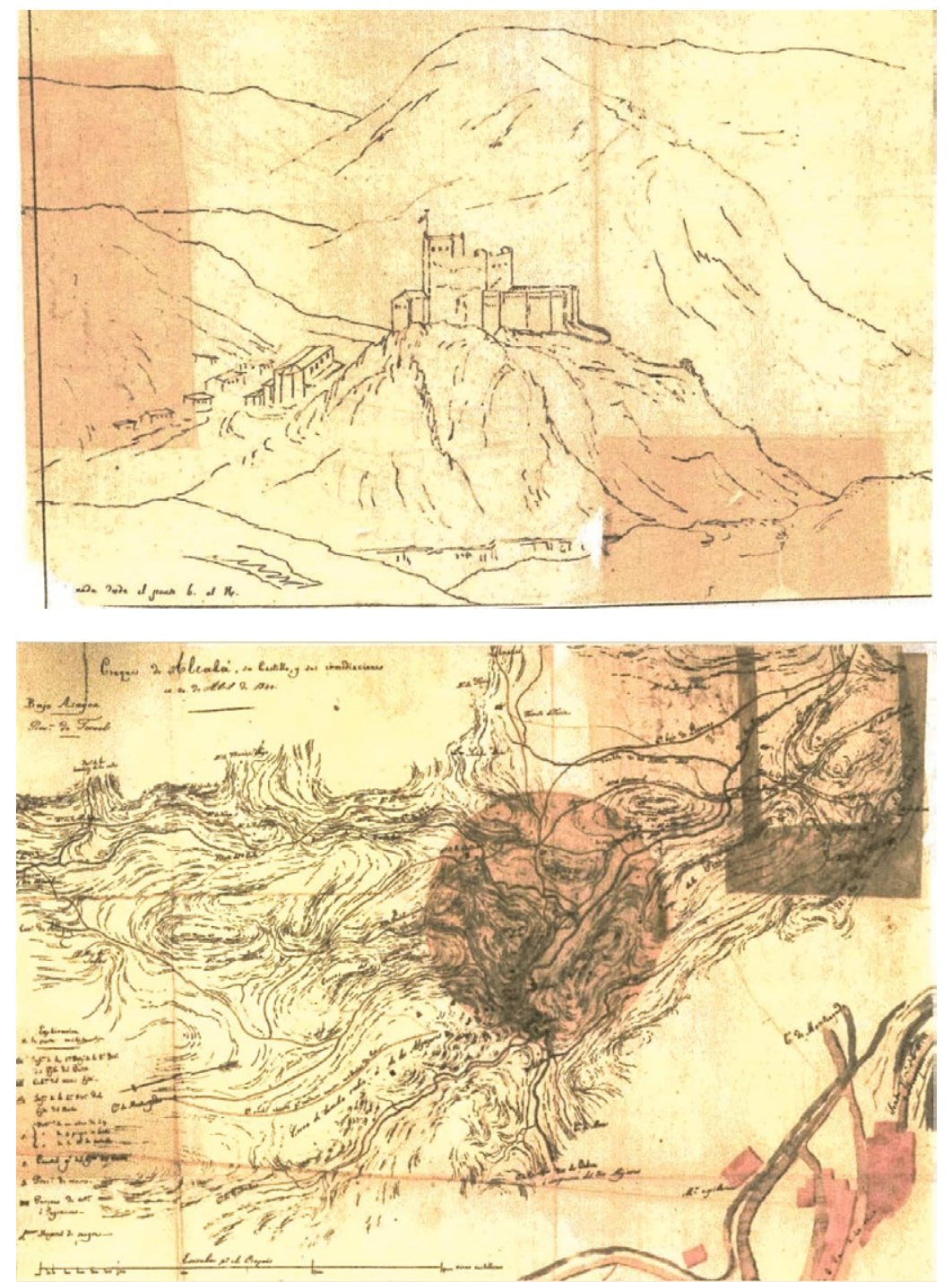

Fig. 50. Detalle Plano 4.

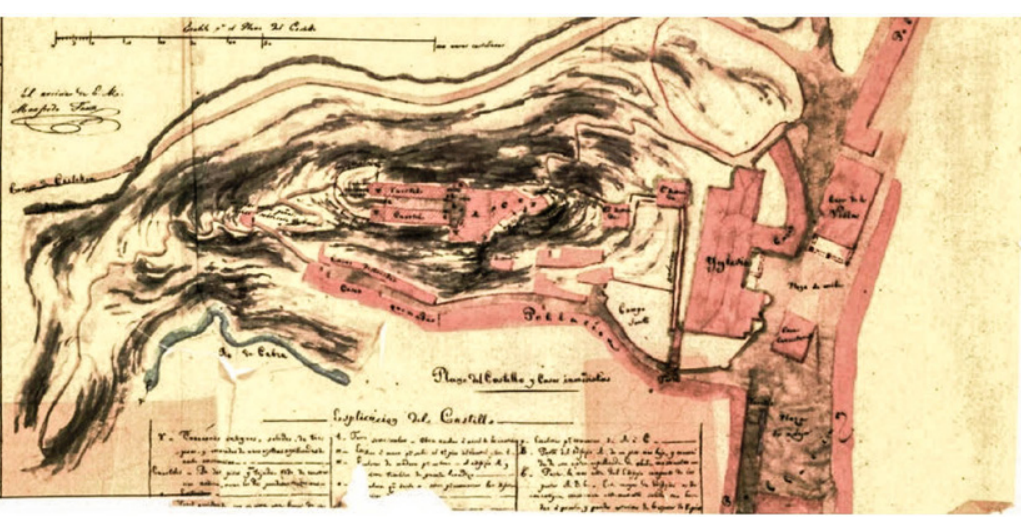




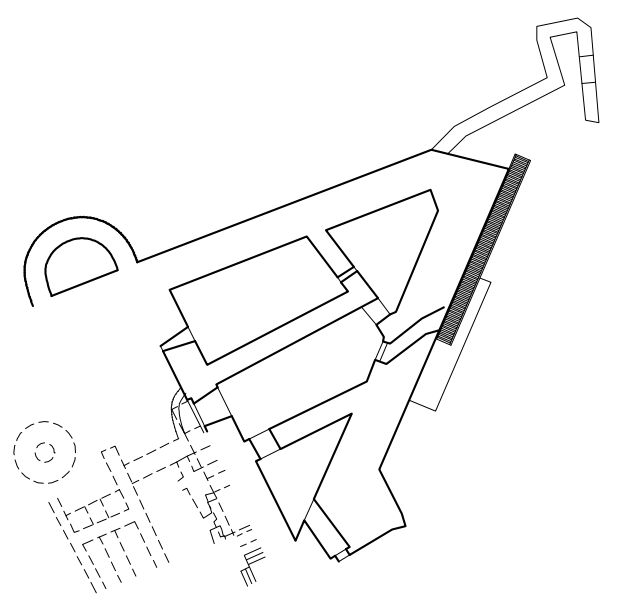

Fig. 51. Planta baja del recinto principal en la actualidad con los restos de la falsabraga.
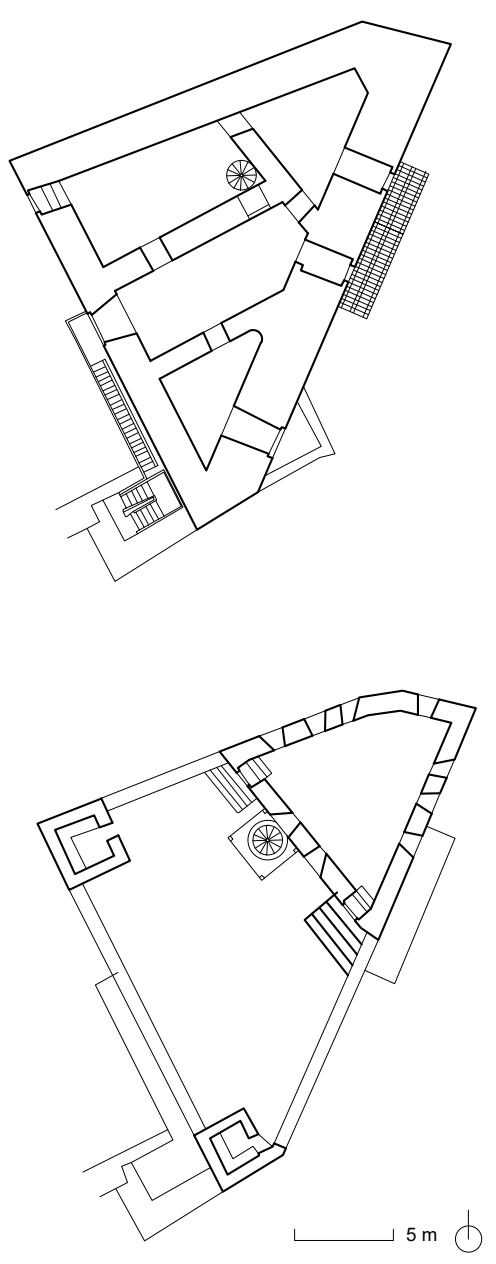

Fig. 52. Planta primera del recinto principal en la actualidad.

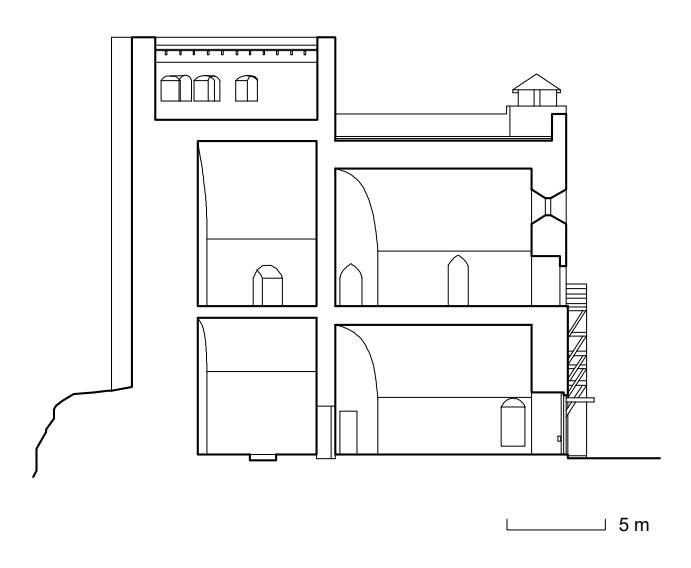

Fig. 55. Planta baja del primer y segundo recinto.

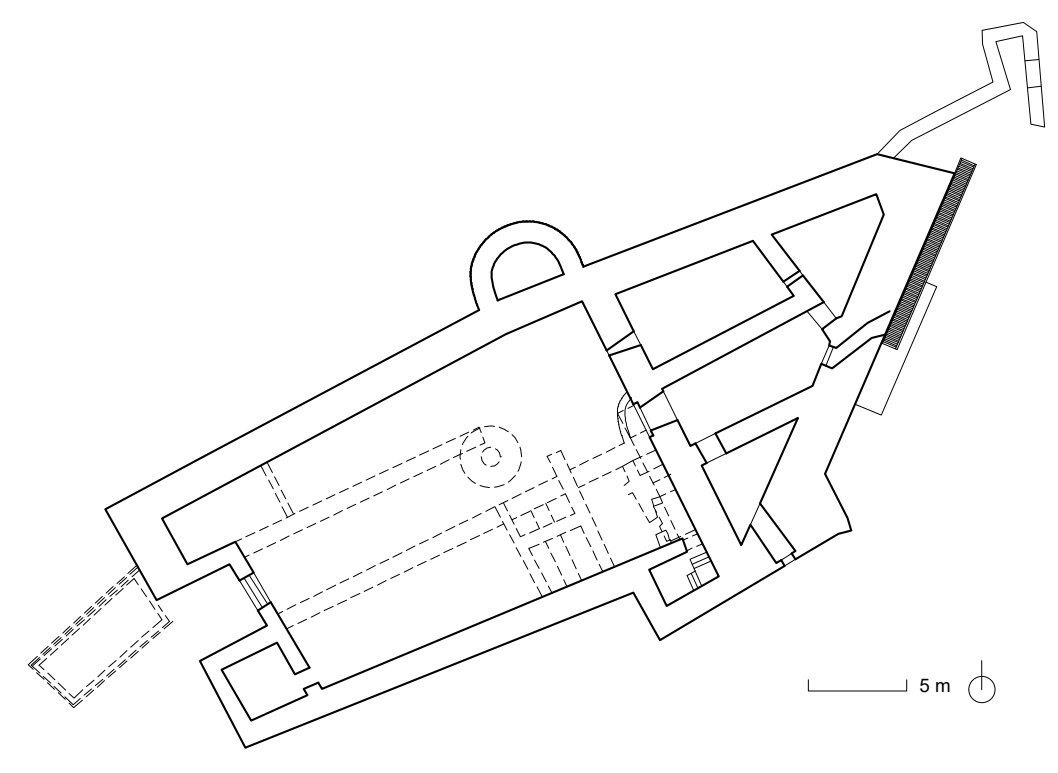


03 Atconss

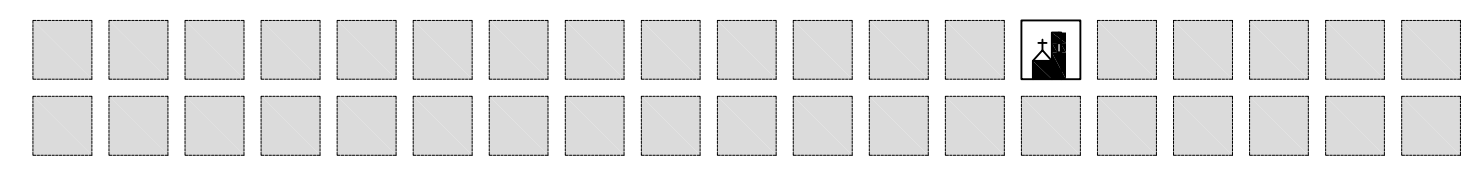




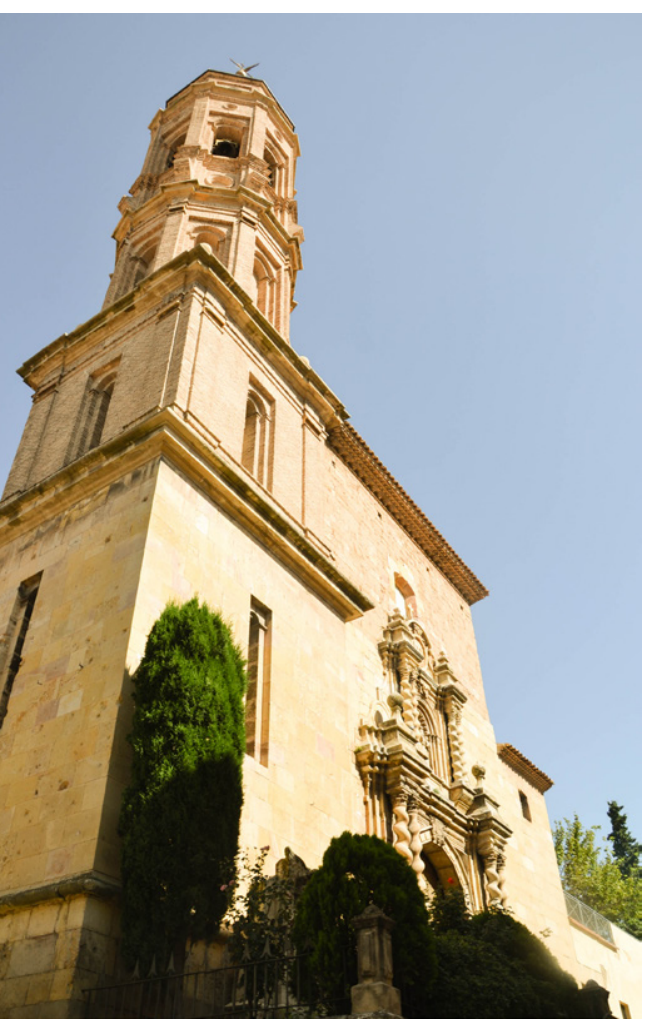

Fig. 56. Iglesia de Alcorisa.

Fig. 57. Torre campanario de la Iglesia de Alcorisa.

Fig. 58. (Derecha) Población de Alcorisa y su contorno.
Alcorisa

Provincia actual: Teruel

Comarca: Bajo Aragón

Coordenadas geográficas: $40.890533919586375,-0.38224441883011195$

Tipos defensivos: fortificación de iglesias

Acciones y fortificación:

En 1834 los carlistas de Quílez tratan de tomar la población y el 29 de junio de 1836 lo intentan de nuevo sin éxito. El comandante liberal Antonio Vicente, con su fuerza y la pequeña guarnición de que dispone, resiste como puede, pero la ciudad es amplia y está escasamente aspillerada, por lo que acaba replegándose en el interior del pueblo y en la iglesia. Los carlistas, tras dos días de ataque, se retiran al tercero, incendiando ciento setenta y tres casas (Pirala, 1869: tomo III, 133; Cabello, Santa Cruz, Temprado, 2006: 85).

En 1838 los carlistas toman Alcorisa gracias a que los liberales la abandonan por estar en minoría y sin posibilidad de refuerzos (Pirala, 1869: tomo V, 40). En 1845, Madoz recoge que, de cuatrocientas casas, ciento veinte quedaron destruidas por la guerra.

La Iglesia de Santa María la Mayor de Alcorisa hace las funciones de fuerte, perdiendo doce de los trece altares que tenía. La construcción data de finales del siglo XIV, aunque la torre y la fachada principal datan del siglo XVII.

Pirala menciona que se recomponen los caminos de Alcorisa y Alcañiz para transportar artillería (Pirala, 1869: tomo V, 40).

Aunque a día de hoy hay evidencias de la existencia de un antiguo castillo en lo alto de la muela que domina la población, no se tiene constancia de su uso o refuerzo por parte de ningún bando en la contienda carlista. Es de suponer que el punto se utilizaría al menos como puesto vigía.

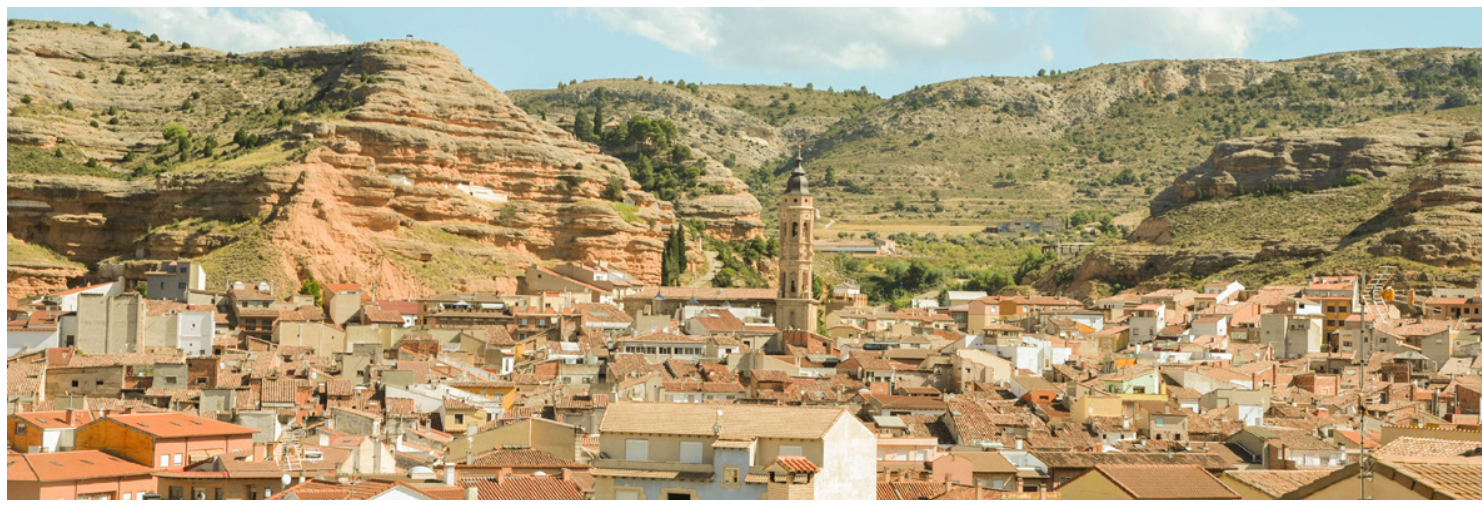


LA FORTIFFCACIÓN DEL "REINO MÁGCO" CABRERA. VIRGINIA NAVALÓN

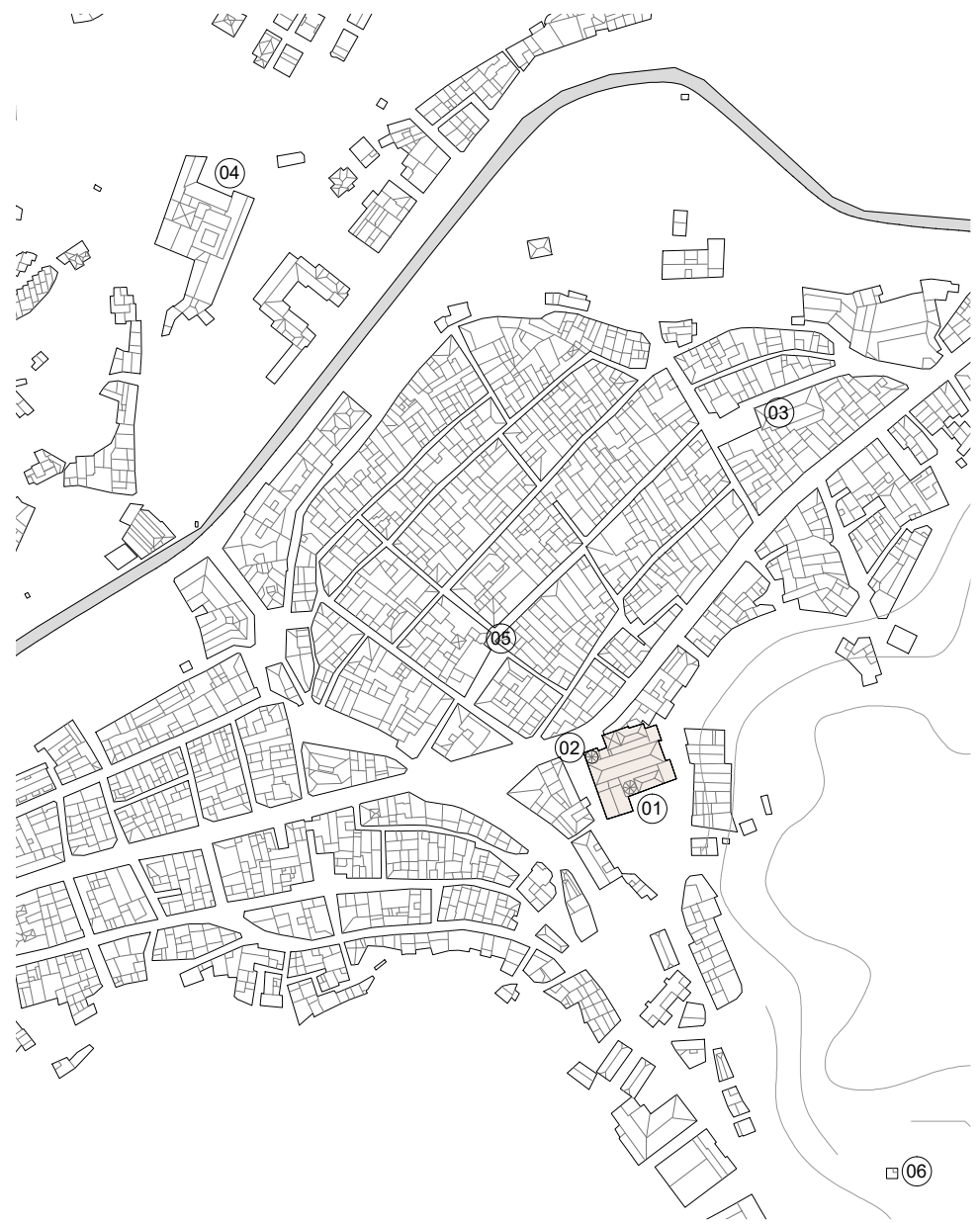

E 1:5000

Fig. 59. Plano de Alcorisa y sus puntos de interés defensivo.

01. Iglesia de Santa Maria la Mayor (fuerte carlista)

02. Torre campanario mudejar

$044_{\text {ALAGA }}$ *

lesia de San Sebastián

04. Iglesia de San Pascual (Antiguo convento Alcantarino, s. XVIII)

05. Ayuntamiento

06. Ermita del Calvario

07. Ermita de San Juan

08. Ermita de San Sebastián

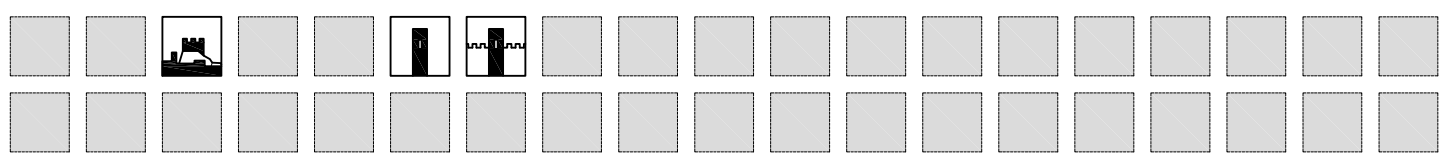


revuelo incluso en la cercana y enemiga Teruel. Pero solo Brusco y yo sabíamos que, en lugar de pólvora, era arena lo que se hallaba en el interior de los dos barriles; en cambio, el religioso ingeniero y carlista malgré lui, que, por supuesto, había estado presente durante el acarreo de la pólvora y la clausura de la mina, recibió de mi la llave con Treguntó Cabrera de dónde había sacado nuestras fábricas y depósitos de municiones de Cantavieja solo eran capaces de suministrar la demanda de pólvora diaria con un gran esfuerzo (sobre todo debido a que el salitre y el azufre únicamente podían obtenerse mediante contrabandistas de Cataluña o Francia). Entonces le revelé al general mi estratagema, que le divirtió aún más en la medida en que su antiguo maestro le había comunicado con detalle y por escrito todo el episodio, tal como se había desarrollado en medio de la noche más oscura y la precaución que había mostrado y que todavía mostraba a diario" (Von Rahden, 2013: 304-305).

Concluidas las obras en Aliaga, la fortificación cuenta, según Calbo y Rochina, con tres recintos comunicados entre sí mediante galerías. Primero una muralla preexistente con doce torreones circulares. Esta comunica con un segundo recinto más elevado con torres de traza cuadrangular, donde se ubican los alojamientos y las habitaciones del gobernador de la plaza. Finalmente, el tercer recinto lo integran dos torres almenadas donde ondea la bandera negra. La descripción recogida en el Diario Mercantil de Valencia (9 de abril de 1840) no coincide con la de Calbo y Rochina (1845: 391, 501), y sí con la de Pirala, pues ambas indican que el último recinto lo integra una única torre. Tampoco coincide el testimonio de Córdoba (1844: v4, 280, 281), que observa simplemente que los rebeldes reparan unos muros carcomidos. Pirala, en una nota al pie, describe: "El fuerte de Aliaga perteneciente a los caballeros de San Juan, y reparados sus deterioros, lo formaban tres recintos: el primero era una muralla de bastante espesor con doce torres circulares y una cuadrada que cruzaba los fuegos; el segundo era otra lo constituian dos grandes torres fundadas sobre rocas y con elevación para dominar los dos grandes patios o plazas anteriores. Un ancho foso en la parte del N. y un escarpe inaccesible en lo restante, completaban la fortaleza" (Pirala, 1869: tomo V, 264).

Fig. 63. Fuerte de Aliaga desde el sureste.

Fig. 64. Fuerte de Aliaga desde el noroeste. Se aprecian los restos de las torres, torreones y lienzos de los diferentes recintos defensivos.

Fig. 65. Restos de las torres del primer recinto y de muros del segundo recinto, vistos desde el nivel del primer recinto. la descripción del Diario Mercantil de Valencia (9 de abril de 1840), coincidente con la de Pirala. Con aproximadamente 4000 metros cuadrados de extensión, el recinto superior se correspondería con la antigua torre del homenaje. La confusión en la interpretación de sus restos se detecta en grabados de la época, que representan dicha torre como una construcción paralelepipédica con un torreón cilíndrico adosado al centro de uno de sus lados. Del recinto intermedio quedan dos tramos en pie. El recinto inferior, que circunvala la totalidad del fuerte y puede considerarse recinto exterior, es el El recinto inferior, que circunvala la totalidad del fuerte y puede considerarse recinto exterior, es el
mejor conservado, con sus característicos torreones semicirculares y una torre de mayores dimenmejor conservado, con sus característicos torreon
siones de traza semicircular en el flanco sureste.

siones de traza semicircular en el flanco sureste.
Las fuentes sostienen que el 26 de marzo Espartero se apodera de Castellote (Diario Constitucional de Las fuentes sostienen que el 26 de marzo Espartero se apodera de Castellote (Diario Constitucional de
Zaragoza, 30 de marzo de 1840; 19 de abril de 1840; Calbo y Rochina, 1845: 493; Caridad, 2013:265) y O'Donnell ocupaba Aliaga veinte días después (Boletín Oficial de la Provincia de Castellón de la Plana, Diario Constitucional de Zaragoza y Diario Mercantil de Valencia, 18 de abril de 1840; Calbo y Rochina, 1845: 503; Caridad, 2013:265).

La toma de Aliaga es acometida por el general O'Donnell, que, saliendo de Teruel, se establece en Campos esperando la llegada de la artillería, dificultada por las lluvias. Aliaga con sus tres recintos parece inaccesible salvo por el norte, cuyo acceso se clausura con un foso. Al mando de la guarnición está Francisco Macarulla. El 13 de abril O'Donnell ordena abrir fuego, derribando aquella tarde las defensas de los primeros recintos. El fuego dura hasta la noche. Al día siguiente, ante la resistencia carlista, el fuego prosigue. Se dispone una batería de obuses de montaña, que son subidos a caballo a las peñas de la Ombría, ayudan a derribar las defensas y baten el torreón cuadrado del extremo derecho. Se testimonia la existencia de unos subterráneos donde los carlistas se refugian para dormir y huir del impacto de los proyectiles. Carentes de ventilación, se describe una atmósfera pestilente, por los cadáveres, pero especialmente por las pieles con que se abriga a los heridos, procedentes de las reses sacrificadas para alimentarse. Los defensores acaban refugiándose en el último reducto del castillo mientras la artillería derriba las torres y se facilita el acceso a los en el último reducto del castillo mientras la artillería derriba las torres y se facilita el acceso a los
patios. Los zapadores, al mando del capitán Clavijo, intentan abrir una mina, pero son rechazados. La guarnición capitula cuando quedan 100 hombres. Se indica que más de tres mil proyectiles caen 
sobre la fortificación. Se constata que, si bien Espartero destruye el castillo de Segura y el de Castellote, en Aliaga conviene rehacer lo destrozado para mantener dos compañías en la zona mientras se cerca Cantavieja. Desde allí, O’Donnell parte para Alcalá de la Selva (Martínez Calvo, 1997)

"Embistiose a la plaza, cuyo castillo conservaba en el mejor estado los tres antiguos recintos; tenía aumenfortificados; era escogida su guarnición de cuatrocientos hombres [...] Concluidas y artilladas las baterías el 13, rompieron sus disparos contra el fuerte, cuyos fuegos se apagaron al medio día y quedaron arruinadas las defensas del segundo y tercer recinto al anochecer. Desde las peñas de la Ombría, una batería de obuses de montaña arruinó las defensas del primer recinto y batió un torreón cuadrado del extremo derecho del frente atacado. Antes de esto se había intimado la rendición y contestaron: victoria o muerte. El 15 prosiguió el fuego, dirigiéndose a la vez los minadores, guiados por su valiente capitán Clavijo, a abrir una mina, y fueron rechazados [...] El teniente coronel de ingenieros, Ubiña, trataba de proteger con otras fuerzas los trabajos de su arma; pero eran inútiles sus esfuerzos. No lo era el fuego de las bateríns, que convirtió el castillo en un montón de escombros" El Castillo de Alia El Castillo de Aliaga es subastado por patrimonio nacional el 27 de abril de 1972 y adquirido en un lote junto a otras propiedades monumentales por un total de 120.500 pesetas. En fecha 22 de julio de 2020, el Diario de Teruel informa de que el ayuntamiento de Aliaga trata de localizar al propietario para instarlo a restaurar el castillo o, en su caso, que sea el ayuntamiento quien asuma la propiedad (Diario de Teurel, 22 de julo de 2020. https:// www.diariodeteruel.es).

Fig. 66. Restos del cuerpo este vistos desde el interior del fuerte.

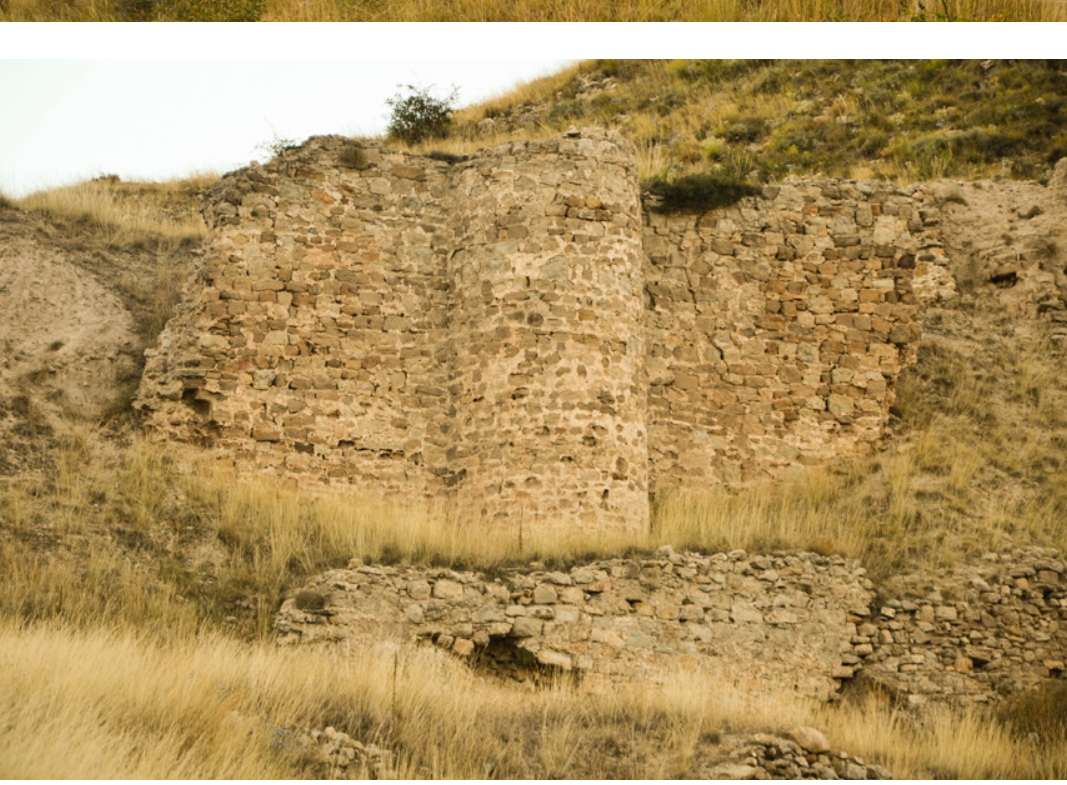

Fig. 67. Restos del primer recinto en su frente sur.

Fig. 68. Población vista desde el fuerte.
Calbo y Rochina recoge la siguiente descripción del castillo: “A la parte oriental del Valle de Jarque, y al estremo de la cordiller de la Lastra que parte desde Cantavieja, se halla asentada la villa de Aliaga entre las sierras que forman el citado valle, corriendo toda su prolongacion el rio Guadalope, que bajando de la Vall de Jarque recibe allí las aguas del Miravete y corre por Alcañiz hasta morir en el Ebro inmediato à Caspe. Situado el pueblo en el anfiteatro al E. de una eminencia peñascosa, lo enseñoreaba sobre ella un antiguo palacio de el pueblo en el anfiteatro al E. de una eminencia peñascosa, lo enseñoreaba sobre ella un antiguo palacio de encomienda bastante capaz y de sólida construcción, aunque por su ancianidad se hallaban algo arruinados
y carcomidos sus muros; no obstante, los carlistas habian sabido aprovechar lo antiguo, y añadiendo muchas
defensas nuevas, lo pusieron en el estado de apreciarlo como una de sus primeras fortalezas. El castillo tenia defensas nuevas, lo pusieron en el estado de apreciarlo como una de sus primeras fortalezas. El castillo tenia tres recintos, apareciendo el total de la obra de figura triangular, ó mas exactamente, de un abanico. El $1^{\circ}$ era una muralla antigua con 12 torreones circulares, y al S. O. tenia una gran torre cuadrada y aspillerada que cuadradas en la que existian los almacenes, alojamientos y habitacion del gobernador: y el $3^{\circ}$ lo formaban dos grandes torreones tambien cuadrados y era la parte denominada castillo, y en la que la guarnicion carlista hacia tremolase un pendon negro. Todos los recintos se comunicaban interiormente cubriendo varias defensas estas comunicaciones. El terreno de la parte $N$. era el mas accesible y de consiguiente el que mas defensa tenia. El E. y O. son escarpados inacesibles. La artillería con que contaban los defensores de Aliaga consistia en 2 cañones de á 8 , un mortero de á 7, y un obus de á 12 , víveres abundantes y 300 voluntarios mandados por un gobernador que aunque joven, tenia entre ellos la reputacion de bizarro y decidido" (Calbo y Rochina, 1845: 500-501). En el ataque, los liberales silencian la artillería enemiga, baten los alojamientos interiores, destruyen las comunicaciones entre recintos y todas las defensas del frente norte, alcanzando el cuartel e incendiando algunos blindajes. Tras intentos infructuosos de ejecutar una mina con dos hornillos para volar la muralla norte, los liberales emplazan dos piezas de a 16 en una batería de a 8 acondicionada frente a la puerta del castillo, "a tiro de pistola". La cercanía y el calibre de las piezas acondicionada frente a la puerta
llevan a los carlistas a capitular.

Ilustraciones de la época:

Ilustración 1

Título a pie: Vista del castillo de Aliaga tomada desde el camino de Teruel

Fuente: Calbo y Rochina, 1845: 495 


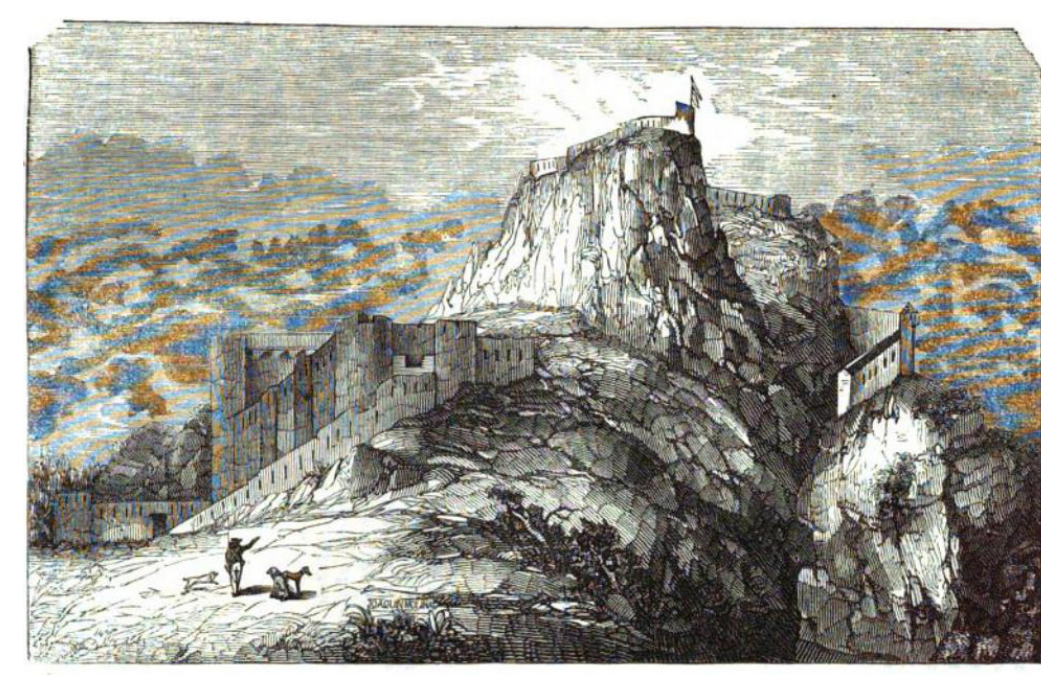

Fig. 69. Ilustración 1. Vista del castillo de Aliaga tomada desde el camino de Teruel.

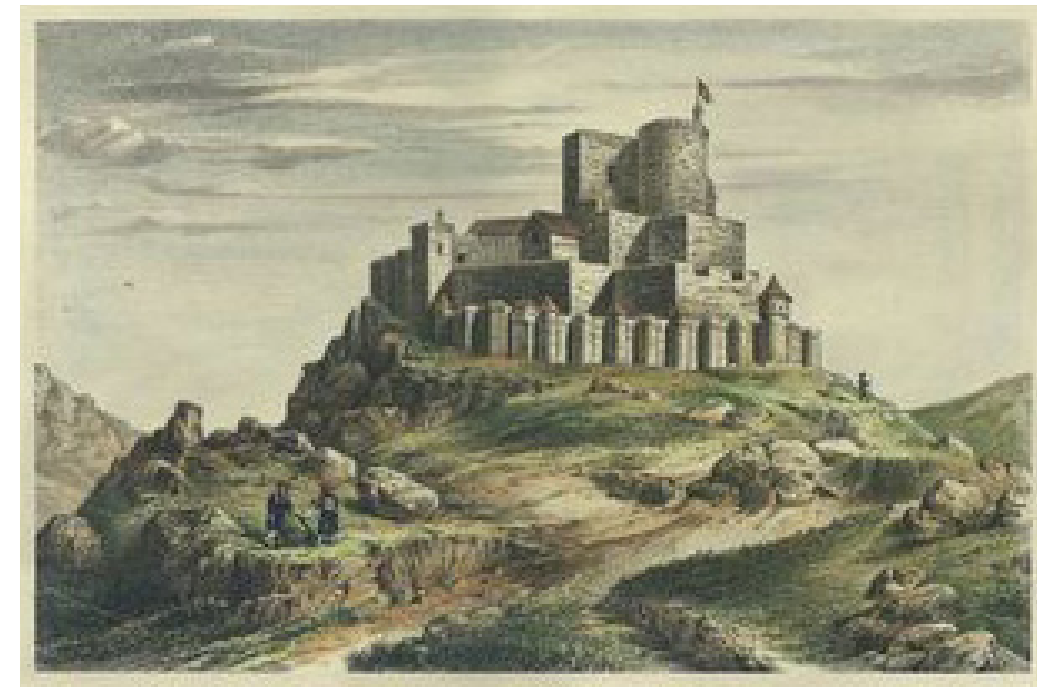

Fig. 70. Ilustración 2. Castillo de Aliaga.

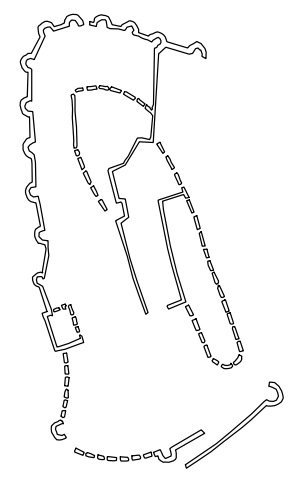

Fig. 71. Esquema en planta del fuerte de Aliaga.

Fig. 72. (Dcha.) Población de Aliaga y ubicación de su fuerte distintas edificaciones de interés carlista.

02. Parroquia de San Juan

Bautista

03. Santuario de Nuestra Seño de la Zarza de la Zarza

Encomiend 05. Molino Alto
Ilustración 2

Título a pie: Castillo de Aliaga

Editor: A. Ronchi

Año: 1853

Fuente: Fondo Documental Histórico de las Cortes de Aragón

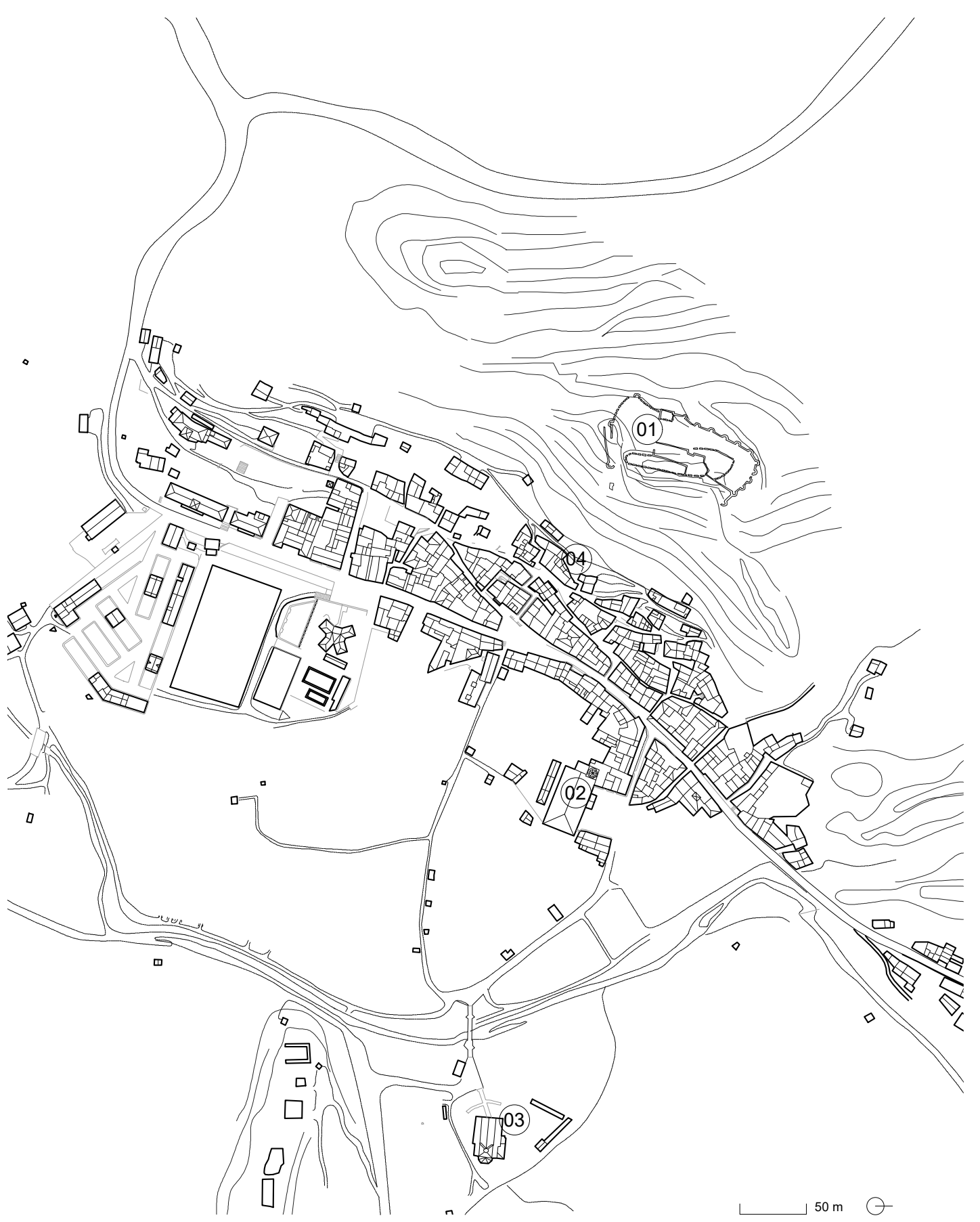


05 Auоza $^{*}$

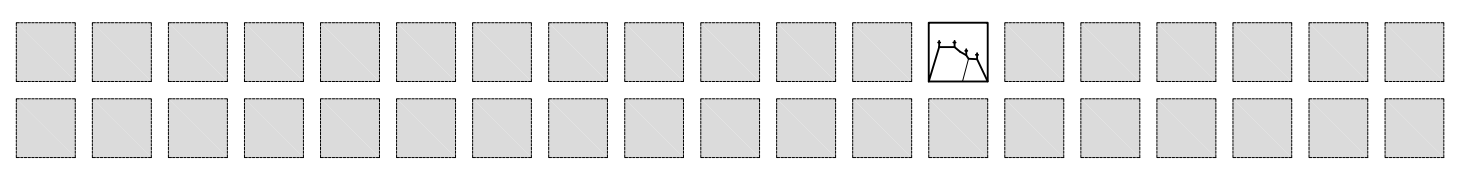




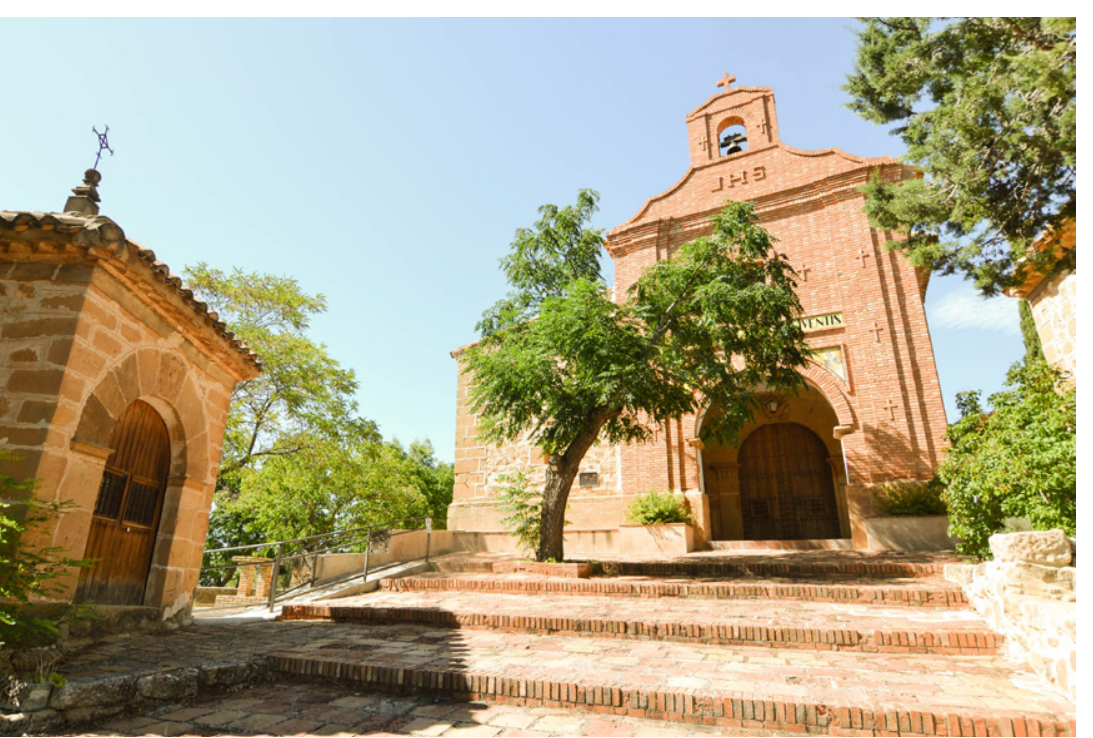

Fig. 73. Ermita del Santo

Sepulcro, en la cima del Monte Calvario.

Fig. 74. Iglesia de Alloza. Se aprecia su posición dominante sobre la población.

Fig. 75. Relación entre la Ermita del Santo Sepulcro, en e extremo del Calvario (derecha), la población y la iglesia (izquierda).

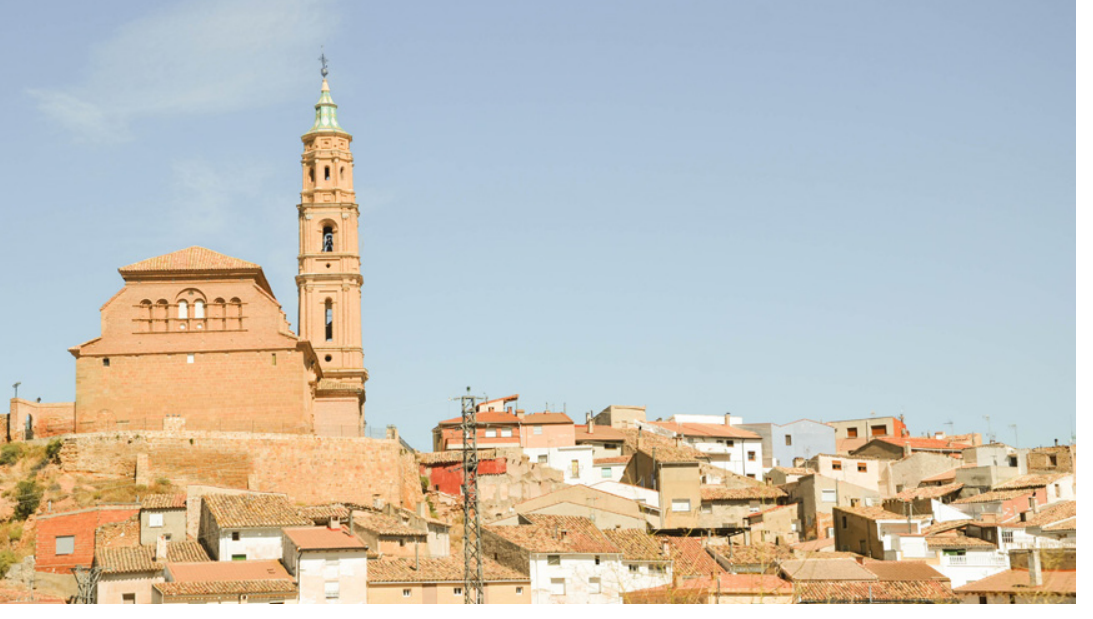

Alloza

Provincia actual: Teruel

Comarca: Andorra-Sierra de Arcos

Coordenadas geográficas: $40.96491882762746,-0.5339132960248492$

Tipos defensivos: fortificación de calvarios.

\section{Acciones y fortificación:}

En el monte Calvario de Alloza se encuentra la ermita o iglesia del Santo Sepulcro, cuyo aspecto actual es de finales del siglo XVII o principios del XVIII. Es un lugar de refugio y reunión durante las guerras carlistas.

En Alloza tiene lugar la acción del 23 de abril de 1835, en la que los combatientes carlistas, extenuados y con Cabrera al frente, son acosados y perseguidos por las fuerzas liberales hasta las montañas de la Sierra de Arcos, combatiendo y resistiendo por el camino en varias ocasiones (Pirala, 1869: tomo II, 56, 57).

El 1 de agosto de 1839, la prensa (Diario Mercantil de Valencia) recoge que Llagostera ha fortificado Alloza, haciendo pedidos de cal, yeso y dinero en las poblaciones aledañas (Caridad, 2013: 262).

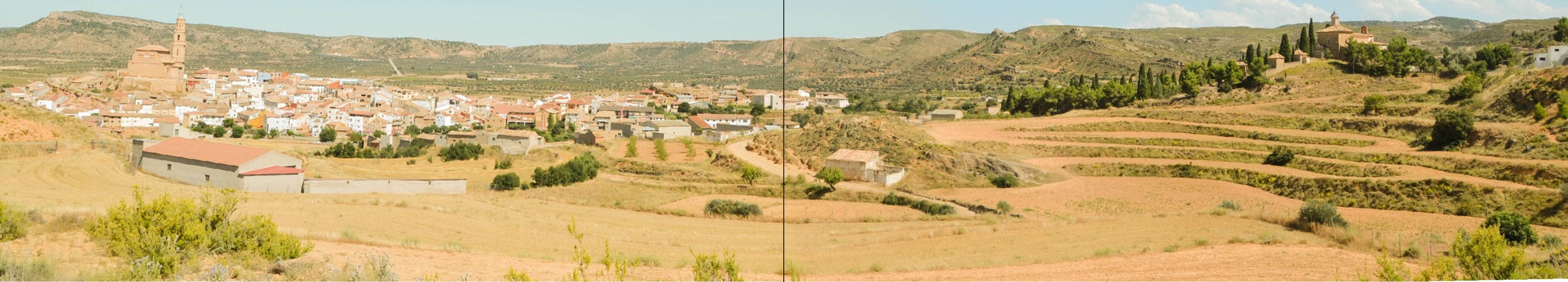




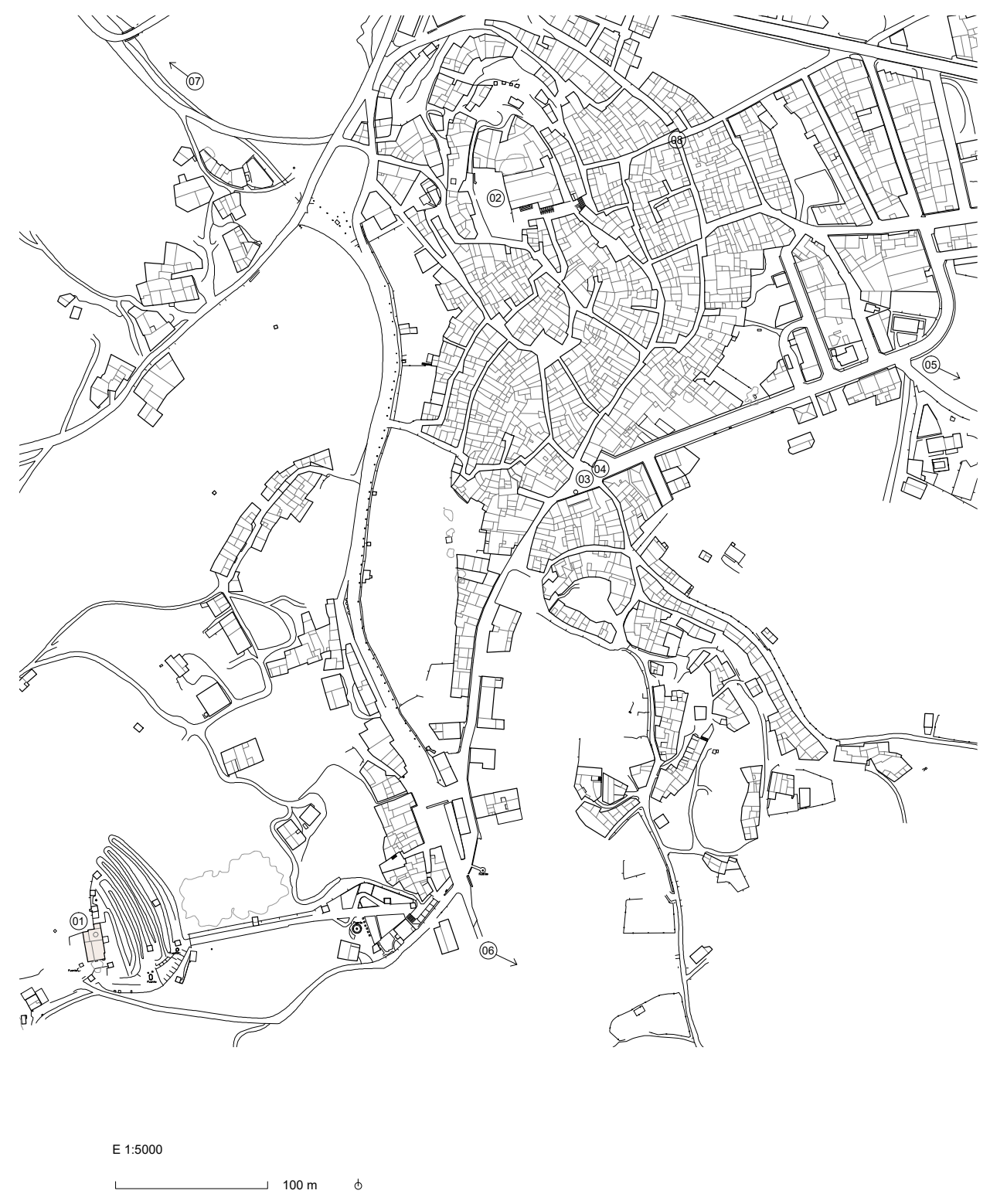

Fig. 76. Alloza y sus puntos de interés.

05. Ruinas de la Ermita de San Benón

06. Ruinas de la Ermita de San Cristóbal

07. Ermita de la Virgen de Arcos

08. Arco Ermita de San Roque

06 Aruvente $^{*}$

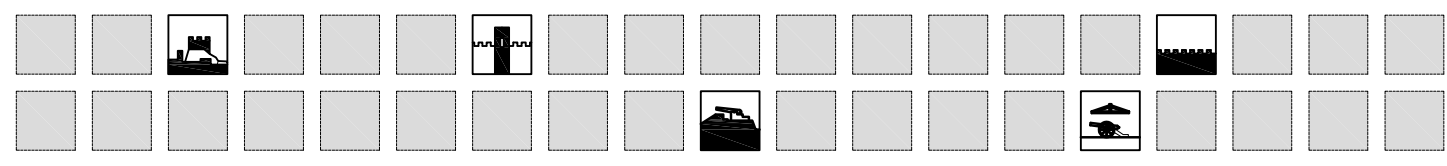




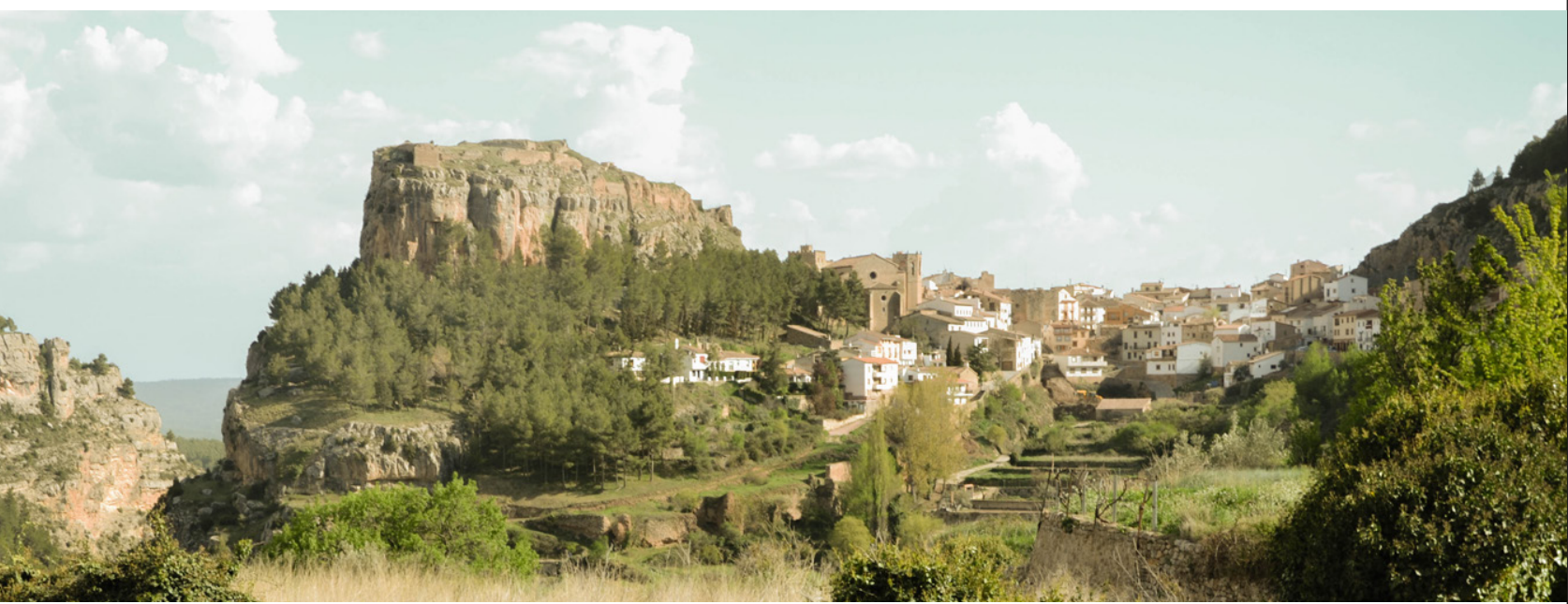

Localidad en castellano / valenciano: Alpuente / Alpont

Provincia actual: Valencia

Comarca: Los Serranos

Coordenadas geográficas: 39.87558475342439, -1.0128479248555777.

\section{Datos históricos:}

Guarnición 1839-1840: 240-254

Inicio bombardeo liberal: 29-4-1840. Según Córdoba el bombardeo empezó el 28 de abril (Córdoba, 1844:297)

Rendición o abandono: 2-5-1840

Días de resistencia: 3

Fuente: Diario Mercantil de Valencia, Boletín Oficial de la Provincia de Castellón de la Plana, Córdoba (1844), Calbo y Rochina (1845), Caridad (2013:297).

Tipos defensivos: castillo reforzado que domina la población, torre artillada adosada a muralla / tambor, muralla urbana, batería / plataforma artillera, maestranza.

Acciones y fortificación:

A finales de 1838 se tiene constancia de que empiezan las obras en Alpuente. Se recomponen las antiguas murallas y se aprovechan piedras del propio castillo que corona el cerro. Se registra que en él trabajan 500 paisanos con sus acémilas bajo la atenta mirada de 400 soldados del ejército carlista. Trabajan en condiciones límite, a golpe de latigazo el que no rinde (Diario Mercantil de Valencia, 11, 17 y 25 de diciembre de 1838. Diario de Valencia, 13, 17,18, 25 de diciembre de 1838, Calbo y Rochina, 1845:457. Caridad, 2013:257). Concluidas las obras la prensa testimonia que en alounos puntos los muros cuentan con espesores de 30 pies, terraplenes y estancias subterráneas a prueba (Von Goeben, 1966: 416)

En julio de 1839 parece que se envía artillería a Alpuente, el Collado, Cañete y Chelva, cuyas obras podrían estar ya concluidas (Caridad, 2013:262)

Sobre el castillo: se emplaza en un enclave que testimonia presencia humana desde la Edad del Bronce, pero no hay evidencias de que el castillo y su núcleo urbano puedan ser anteriores a época musulmana. Estaríamos hablando de un castillo erigido alrededor del siglo X y en relación con el Castillo del Poyo o del Collado, emplazado a 10-12 km al norte. Ambas posiciones dominan las tierras de Teruel, concretamente la Serranía Alta (Gil Llistar et altr. 2016: 6; Mohorte, 17). Se sabe que la coronación del castillo medieval se encuentra desmantelada y en ruinas cuando se instalan en él los carlistas. Ocupan los subterráneos y mejoran sus defensas construyendo cuatro baterías en la ciudadela. El ataque liberal fallido del General Azpiroz implica la destrucción de numerosas viviendas y parte de la iglesia. En tiempos de la ocupación carlista se testimonia que "dos metros antes de la muralla un gran foso circular de tres metros de profundidad por 5 metros de ancho, única entrada por puente levadizo. La puerta defendida por dos pequeños tambores aspillerados y dispuesta al entrar en tres o cuatro curvas antes de la segunda línea de fortificación. Primera línea de pared de medio metro de espesor por dos metros de altura, en una mampostería ordinaria con un circuito de 400-500 metros. Un contrafoso de las mismas dimensiones, separa la primera de la segunda muralla. Desde la puerta principal a primera plaza habia cuadras laterales, que tambien eran cobertizos para guarnicion, prisioneros y rehenes. Al fondo de ta plaza, bajo especial para el gobernador y el Mayor de la Plaza, cuyos altos eran parte de la segunda Plaza o Ciudadela. En la planta baja los calabozos, un horno de pana para cocer y una imprenta de campaña para boletines... La ciudadela no estaba terminada, pero tenía cuatro baterías orientadas a los cuatro puntos cardinales. En la primera plaza estaban los talleres de carpintería, cerrajería, almacén, alpargatas e instrumentos 
de albañilería. Polvorín socavado en la roca, se bajaba por una espiral y en él abundantes municiones para cañón y fusil, aumentadas por el trabajo de ocho hombres, que se dedicaban sin descanso a la fabricación de cartuchos. Cisterna y fuente, a un kilómetro de la fortificación se bajaba por un camino cubierto recientemente construido" (Izquierc albarrana con cargas, abriendo una brecha. A su vez ocupan la montaña frente al castillo desde el oeste (monte de San Cristóbal), donde emplazan la artillería en 1840, con lo que se favorece la toma y destrucción del castillo. En la actualidad se identifican dos de las cuatro baterías de época carlista sobre las construcciones de la denominada zona B en la parte superior del castillo. Las baterías se construyeron sobre los restos de unas habitaciones ejecutadas con pavimentos de mortero de cal y paredes de diverso aparejo (mampostería, sillarejo de tipo califal) y revestimiento con enlucidos de cal. Estas baterías se levantaron con anchos parapetos, ejecutados con taludes de tierra sobre la explanada o mampostería, y muros de contención de las tierras en el trazado interior. En el exterior del recinto de la fortificación, en la base de roca sobre la que se asienta el castillo, se han identificado seis piletas de forma semiesférica, excavadas en la roca y abujardadas, que sostienen algunas fuentes que podrían haber sido utilizadas para la fabricación de municiones (Gil Llistar et altr. 2016: 9). Se sabe también que la entrada al castillo, en cuyos derrumbes se localizaron restos de bala y proyectiles de artillería, fue destruida a raíz del bombardeo liberal de 1840 (Gil Llistar et altr. 2016: 20). Para determinar las posiciones del ataque liberal se dispone de un plano del Archivo Cartográfico de Centro Geográfico del Ejército (sign. Ar.G-T.3-C.1-199), con relación de los puntos estratégicos, fechado en 1840.

Fig. 80. Torre medieval en casco urbano y, a la izquierda arriba, restos de otra torre y muralla.

Fig. 81. Iglesia, muralla y cuerpos de la fortificación sobre la muela.

Fig. 82. Restos de muros del fuerte sobre la muela.

Sobre la batería de brecha del Cerro de San Cristóbal: el 25 de abril de 1840, dos compañías liberales ocupan el cerro de San Cristóbal para construir una batería de brecha que batirá el castillo de Alpuente, mientras el resto de las tropas parten desde Titaguas el 26 de abril. Ese mismo día se emplazan baterías también en el Abrevadero del Fraile, al norte y en Laudiel. Las tres baterías inician el bombardeo el 28 de abril, un fuego que se centra en la iglesia y la torre que defiende la entrada al castillo, el camino cubierto y el baluarte del segundo recinto del castillo. El 29 de abril el fuego se concentra en el segundo recinto y empieza la ocupación del pueblo. El 30 de abril se instala una batería de morteros en San Cristóbal. La artillería de calibre se centra en abrir brecha en la muralla. Mientras se plantea la apertura de una mina, y ante las dificultades, hacen la mina bajo el torreón. La explosión de la mina no derribó ningún elemento del castillo, pero hizo temblar el torreón según alounos testimonios (Mohorte, 2014:21). Existe constancia de que un cuerpo de zapadores fue destinado a desescombrar el castillo.

El mes de mayo de 1840 supone el desmoronamiento de la línea defensiva carlista, pues con Alpuente (Diario Mercantil de Valencia, 3 de mayo de 1840; Córdoba, 1844-1846: v.4,300; Calbo y Rochina, 1945:506) caen Alcalá de la Selva y Bejís, siendo abandonados Linares de Mora, Villahermosa del Río, Montán, Benicarló, La Galera, Ulldecona, Sant Mateu y Cantavieja (Caridad, 2013: 266).

Ilustraciones de la época:

Ilustración 1

Título a pie: Vista de Alpuente. Tomada desde el camino de Cañete.

Fuente: Calbo y Rochina, 1845: 457

Ilustración 2

Título a pie: $\sin$ título.

Fuente: Calbo y Rochina, 1845: 507

Planos históricos:

Plano 1

Título uniforme: Alpuente (Valencia). Operaciones bélicas (1875). 1:13.000

Título: Croquis del Collado y posiciones que ocuparon las tropas de la 1 Brigada el 18 de Julio de 1875 / El Corl. Tente. Corl. del Ejto., Capn. de E.M. Jefe de la sección topográfica Carlos Espinosa de los Monteros

Publicación: 1875 octubre 31

Descripción física: plano: ms., col., tela para planos; 47 × $31 \mathrm{~cm}$ en h. de 32 × $43 \mathrm{~cm}$ 


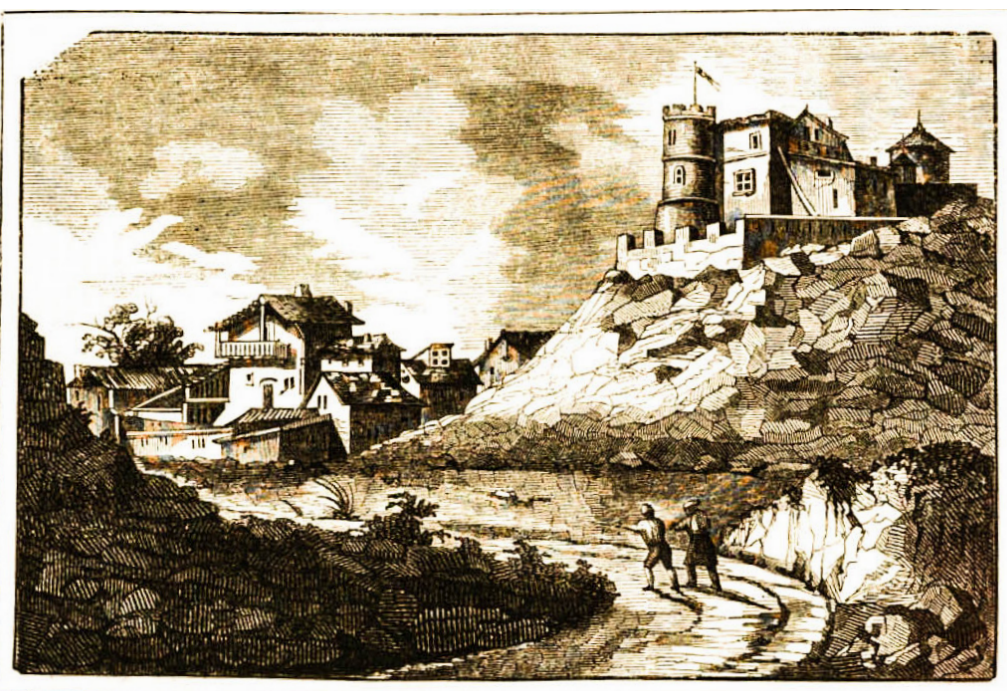

Fig. 83. Ilustración 1. Vista de Alpuente desde el camino de Cañete.

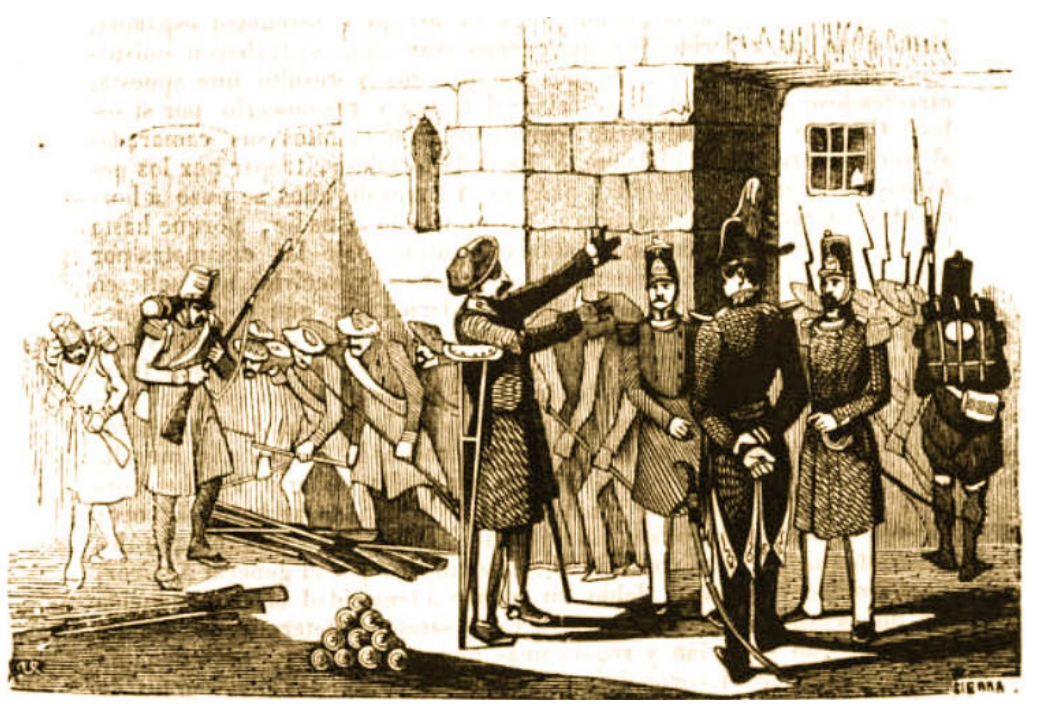

Fig. 84. Ilustración 2.

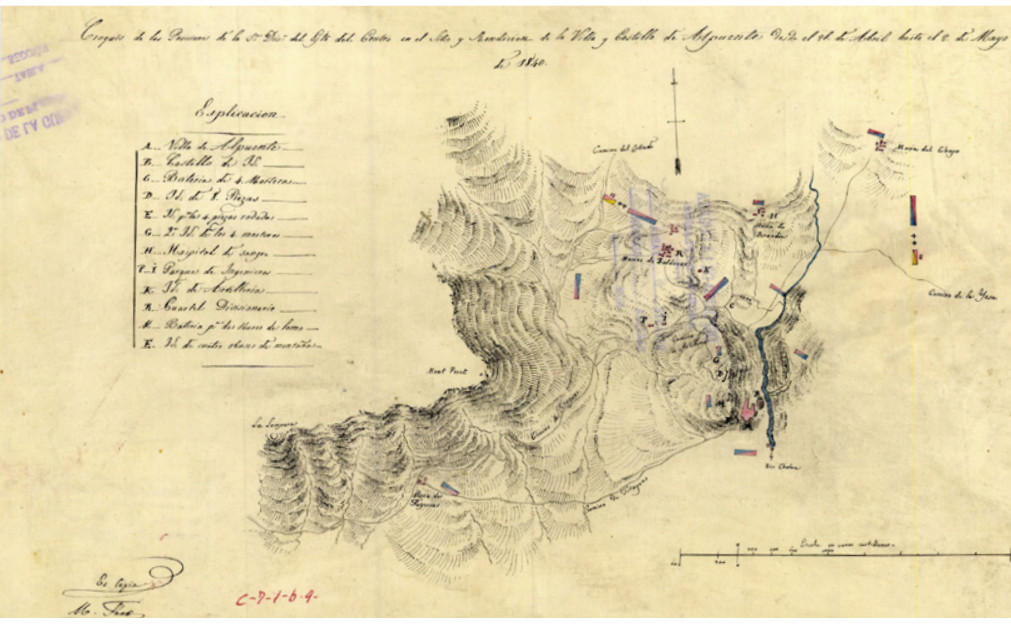

Fig. 86. Plano 2. Croquis de las posiciones ocupadas por el Ejército del Centro en el sitio y rendición de la Villa y Castillo de Alpuente desde el 26 de Abril hasta el 2 de Mayo de 1840.
Notas: Comprende el término municipal de Alpuente. "Visto Bueno": Junquera. Manuscrito firmado. Manuscrito a plumilla en tinta negra y coloreado en carmín, siena y azul. Orientado con flecha. Relieve representado por sombreado. Indica el número de compañías y baterías instaladas en puntos estratégicos.

Fjemplares: Archivo Cartográfico de Estudios Geográficos del Centro Geográfico del Ejército Ubicación: AR - Signatura: Ar.G-T.3-C.1-200 - Código de barras: 2210267.

Plano 2

Título uniforme: Alpuente (Valencia). Asedios. 184 (1840). 1:27.000

Título: Croquis de las posiciones ocupadas por la 1 División del Ejército del Centro en el sitio y rendición de la Villa y Castillo de Alpuente desde el 26 de Abril hasta el 2 de Mayo de 1840 / es copia M. Fanti.

Publicación: Madrid: Lit. del Memorial de Infantería, 184-?

Descripción física: 1 mapa: col montado sobre tela; $19,5 \times 25,1 \mathrm{~cm}$ en $\mathrm{h}$. de $25,1 \times 38,1 \mathrm{~cm}$

Notas: Comprende, además, las inmediaciones de Alpuente. Escala gráfica de 2000 varas castellanas $[=6,3 \mathrm{~cm}]$. Orientado con flecha. Relieve representado por normales. Relación de puntos estratégicos, baterías y dependencias del ejército indicados por clave alfabética. En el ángulo superior derecho: "Lama. 4". Nota manuscrita: ‘[...] por un original del Depósito de la guerra - Es copia. M. Fanti". Indica, en tinta roja, una letra " $\mathrm{L}$ " añadida a la clave alfabética "Bateria de los obuses de montaña" (no se ve en el plano).

Ejemplares: Archivo Cartográfico de Estudios Geográficos del Centro Geográfico del Ejército Ubicación: AR - Signatura: Ar.G-T.3-C.1-199 - Código de barras: 2210266.

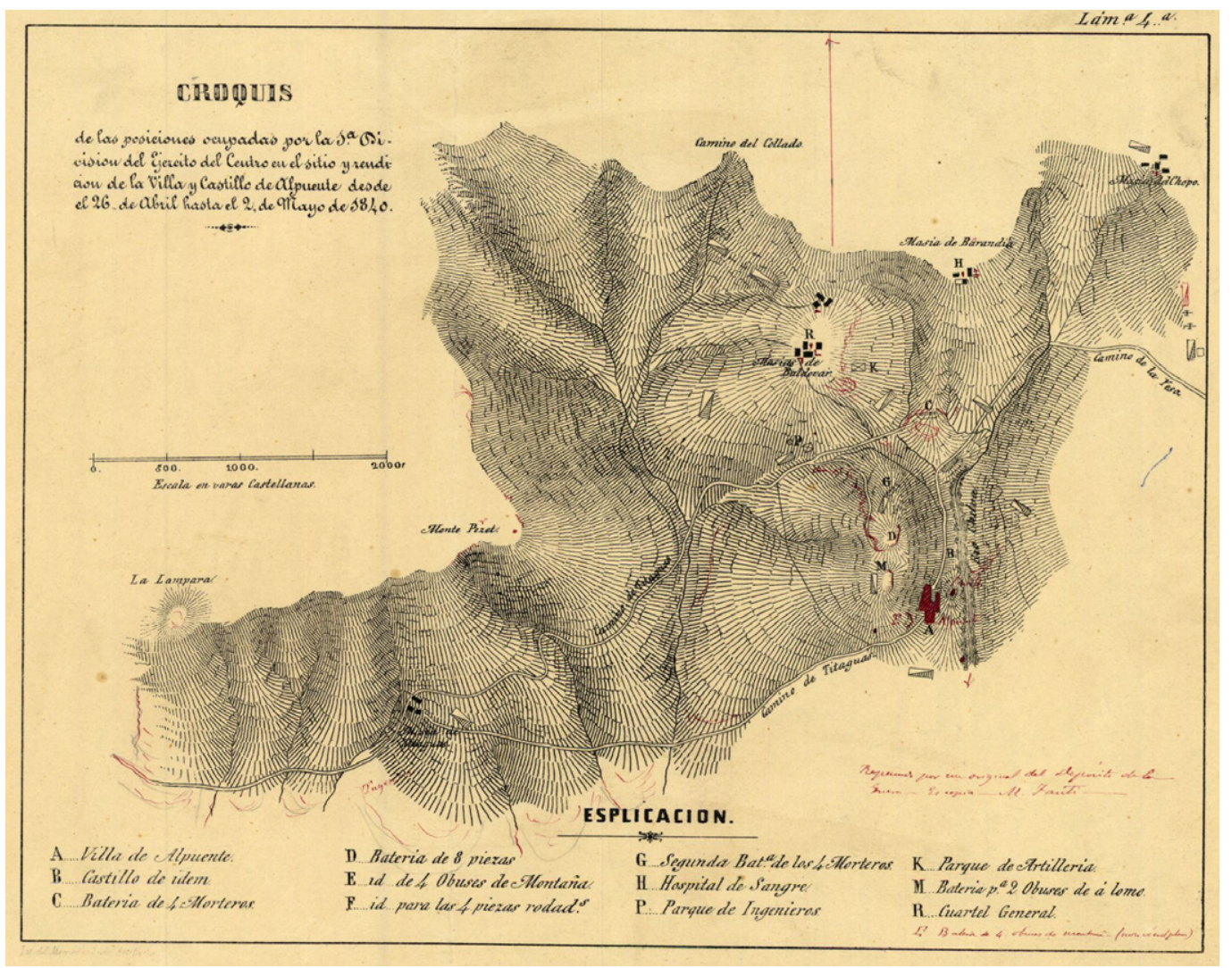




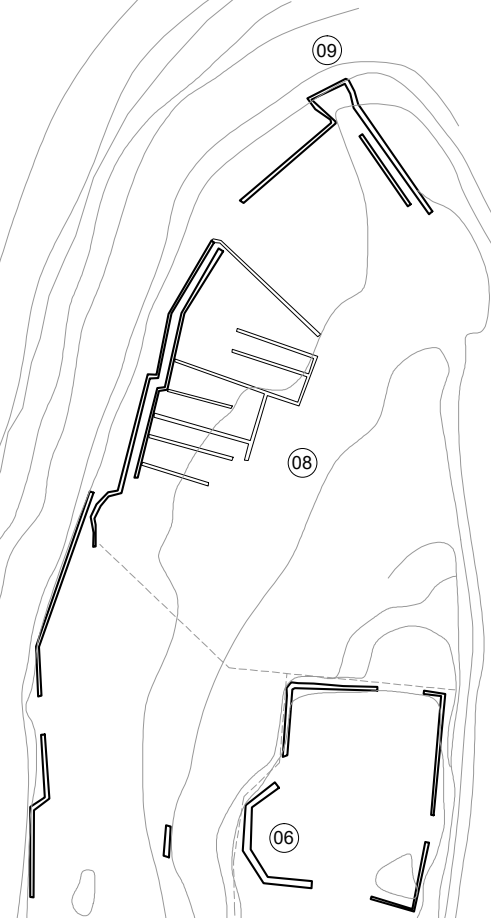

(77)

(04)

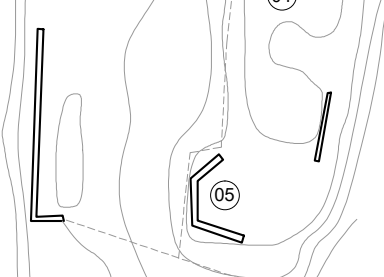

(03)

(1)

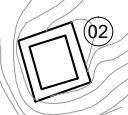

b
Fig. 87. Castillo de Alpuente situado en lo alto del cerro. 01. Zona A, barbacana 02. Torre albarrana

03. Zona E, acceso

04. Zona B, ciudadela

05. Posible batería carlist

06. Posible baterín carista

07. Zon D refia carlist

07. Zona D

09. Torre norte
Fig. 88. Planta urbana de Alpuente

donde se observan los distintos recintos amurallados y demás elementos de interés defensivo.

01. Torre del portillo

02. Torre portal

03. Torre de las escuelas

04. Torre de la Aljama

05. Torre 5

06. Iglesia de Nuestra Sra. de la Piedad

(punto de defensa carlista)

07. Castillo

08. Casa solariega

09. Acueducto de los arcos

10. Ermita de la Purísima

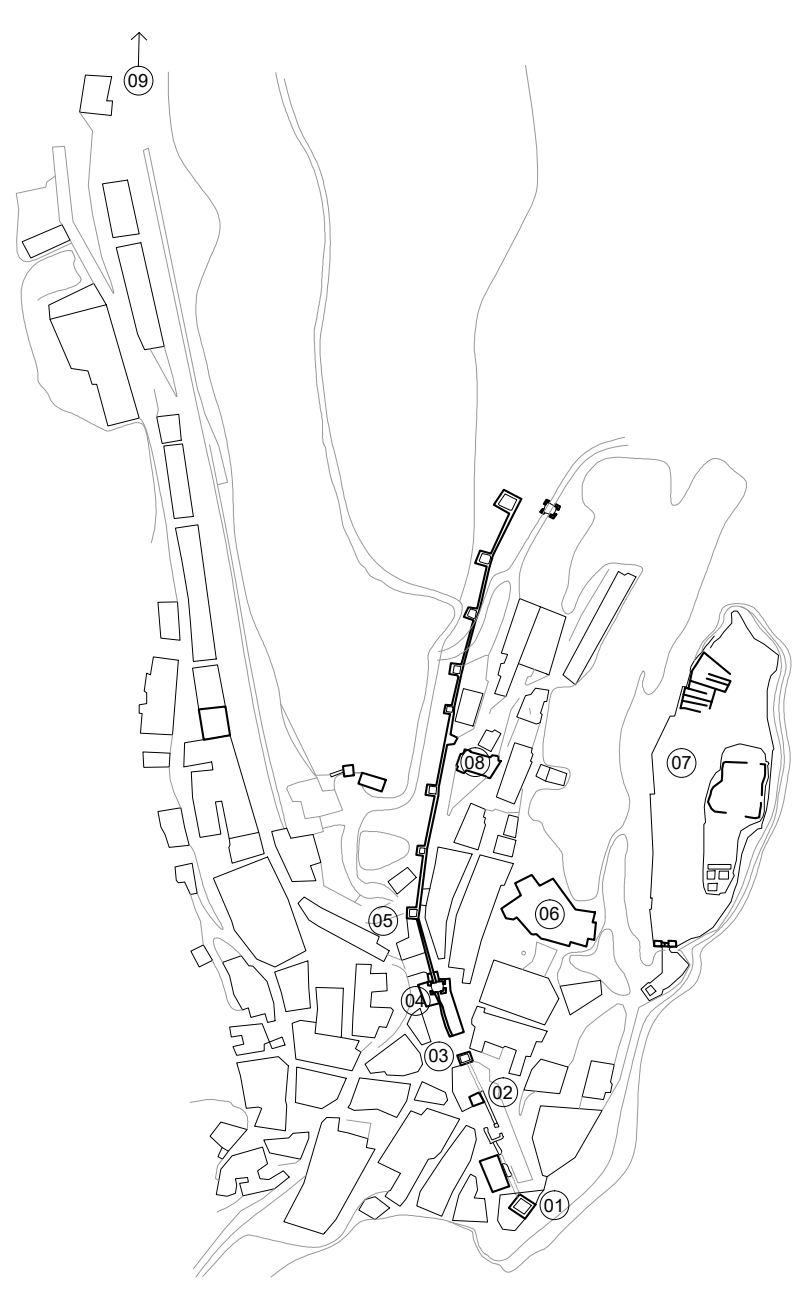




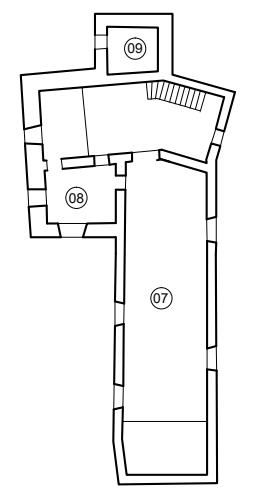

Fig. 89. La Torre Alhama, acceso al primer recinto. Fue dañada en el bombardeo de 1840.

Planta del salón

07. Salón consistorial

08. Archivo

09. Trampilla de acceso a

calabozo

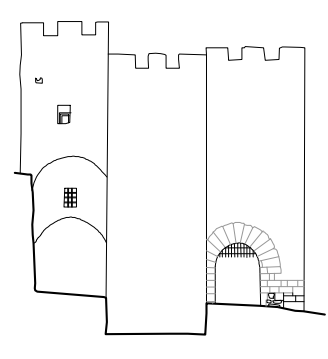

Alzado norte

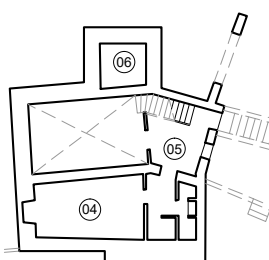

Entreplanta acceso a la torre

04. Salón de juntas

05. Acceso a la torre Alhama

06. Calabozo

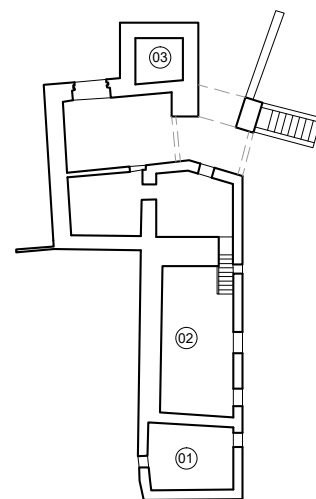

Planta del Salón de las Cortes

01. Dependencias parroquiale

02. Salón de las cortes

03. Calabozo

07 Arcos de Las SALINAS

C) ${ }_{5 M} E 1500$

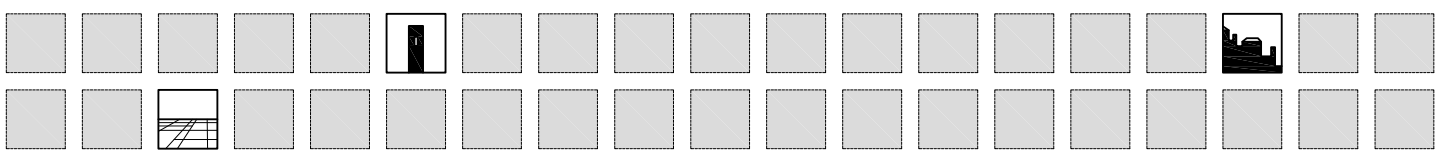




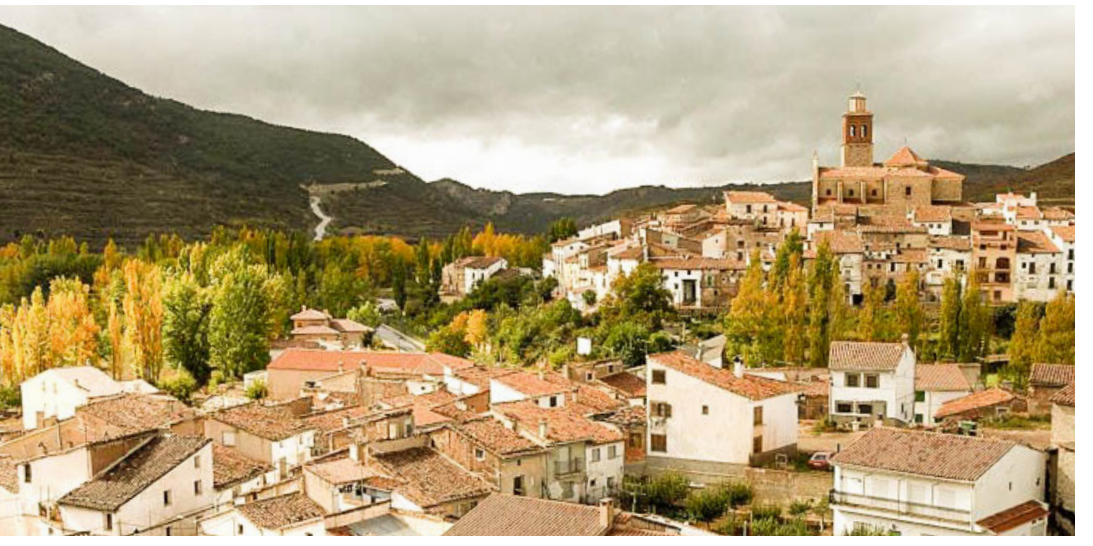

Fig. 90. Arcos de las Salinas en la actualidad. Se aprecia la posición elevada de la iglesia y su campanario.

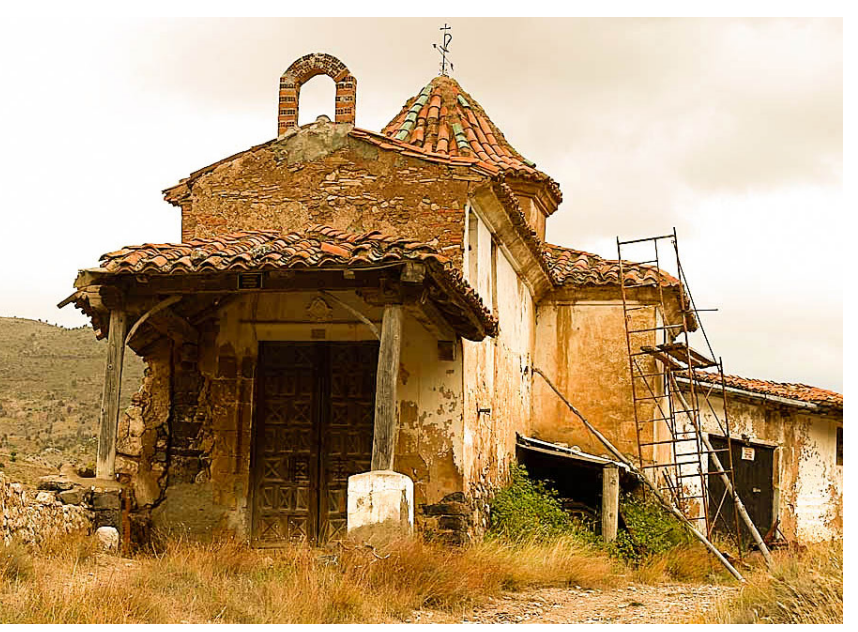

Fig. 91. Ermita situada en las salinas antes de su reciente restauración.

Fig. 92. Fotografía histórica de las salinas.

\section{Arcos de las Salinas}

Provincia actual: Teruel

Comarca: Gúdar-Javalambre

Coordenadas geográficas: 39.99127232027993, -1.062350233119787

Tipos defensivos: torre, frente escalonado, fortificación de salinas.

Acciones y fortificación:

Esta localidad debe su nombre a las salinas que existen a dos kilómetros de la población, que ya están activas a mediados del siglo XII. El emplazamiento del pozo se fortifica en 1357, convirtiéndose en una torre defensiva. Las salinas se han mantenido hasta la actualidad, lo cual les otorga cierta relevancia durante las épocas de conflicto. Se localiza en su emplazamiento una ermita (ermita de Bien de Interés Cultural desde 2010. La iglesia de la Inmaculada es incendiada durante la Primera Guerra Carlista.

Recoge Pirala que el Royo de Nogueruelas y Peinado sorprenden a la guarnición de Arcos y los liberales se refugian en la iglesia (Pirala, 1869:149). Arcos de las Salinas es convertida en punto estratégico de salida de la Serranía, y así lo hace Gómez en 1836. Las salinas cuentan con unas garitas de vigilancia en el cerro suroriental, posteriores al conflicto y construidas para el guarda de las salinas.

Fig. 93. Salinas de Arcos de las Salinas.

01. Casa de la Torre de la Sal con

la noria

02. Red de conducciones de

madera

03. Cuatro balsas

04. Tablares (entre 8 y 10)

0

5. Almacenes para la sal

06. Cuadras

07. Carpintería
08. Casas de las salinas

08. Casas
09. Pajar

10. Casa de empleados

11. Ermita de las Salinas o de la

Virgen de los Dolores

12. Garita de vigilancia

13. Caminos y canalizaciones de

drenaje

14. Palacio del administrado 


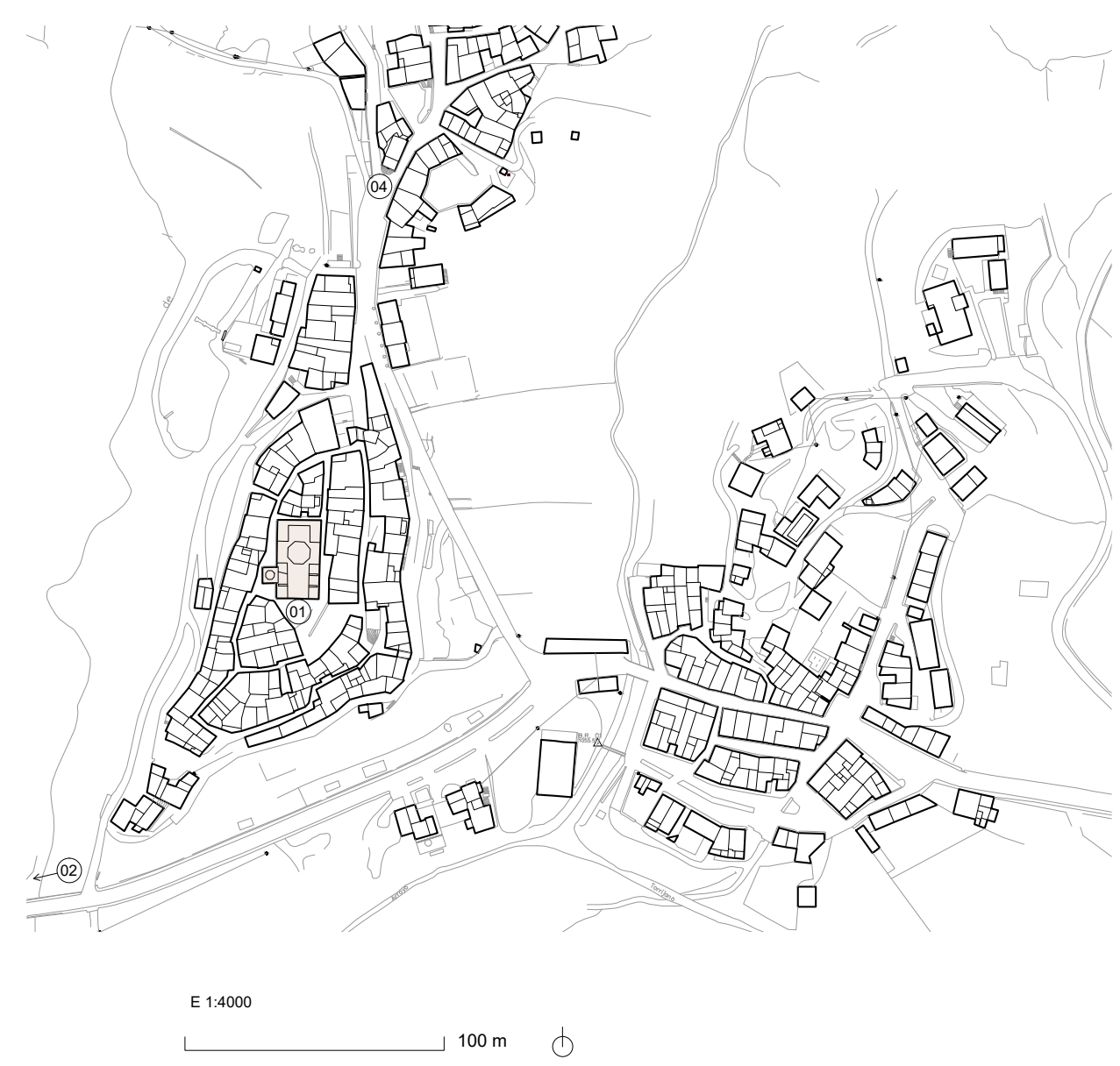

08 ares del Maestre $*$

Fig. 94. Planta urbana de Arcos de las Salinas con emplazamiento de la iglesia ocupada por los carlistas. 01. Iglesia de la Inmaculada 


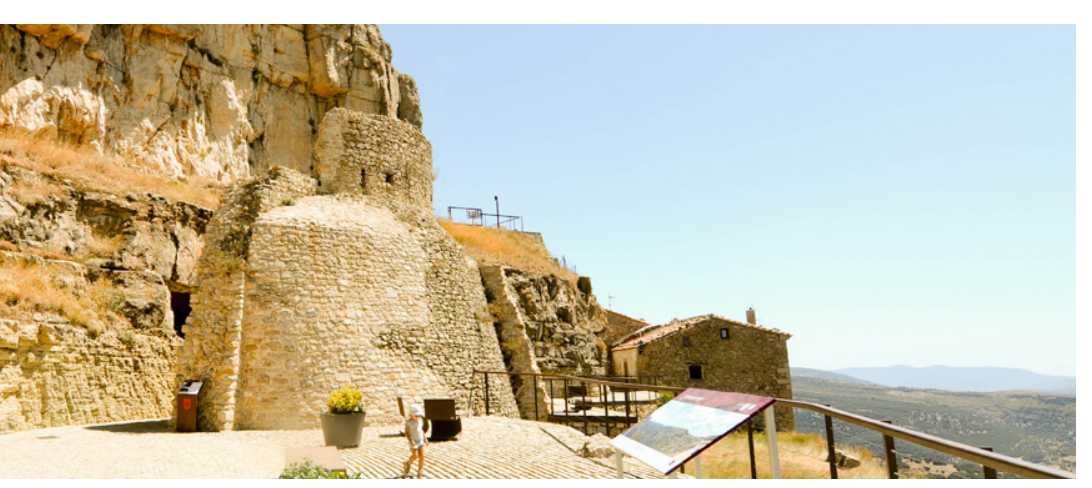

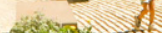

Fig. 98. Restos de torre semicilindrica con alambor y aspilleras. Todo indica que se trata de una construcción carlista, al menos la parte superior.
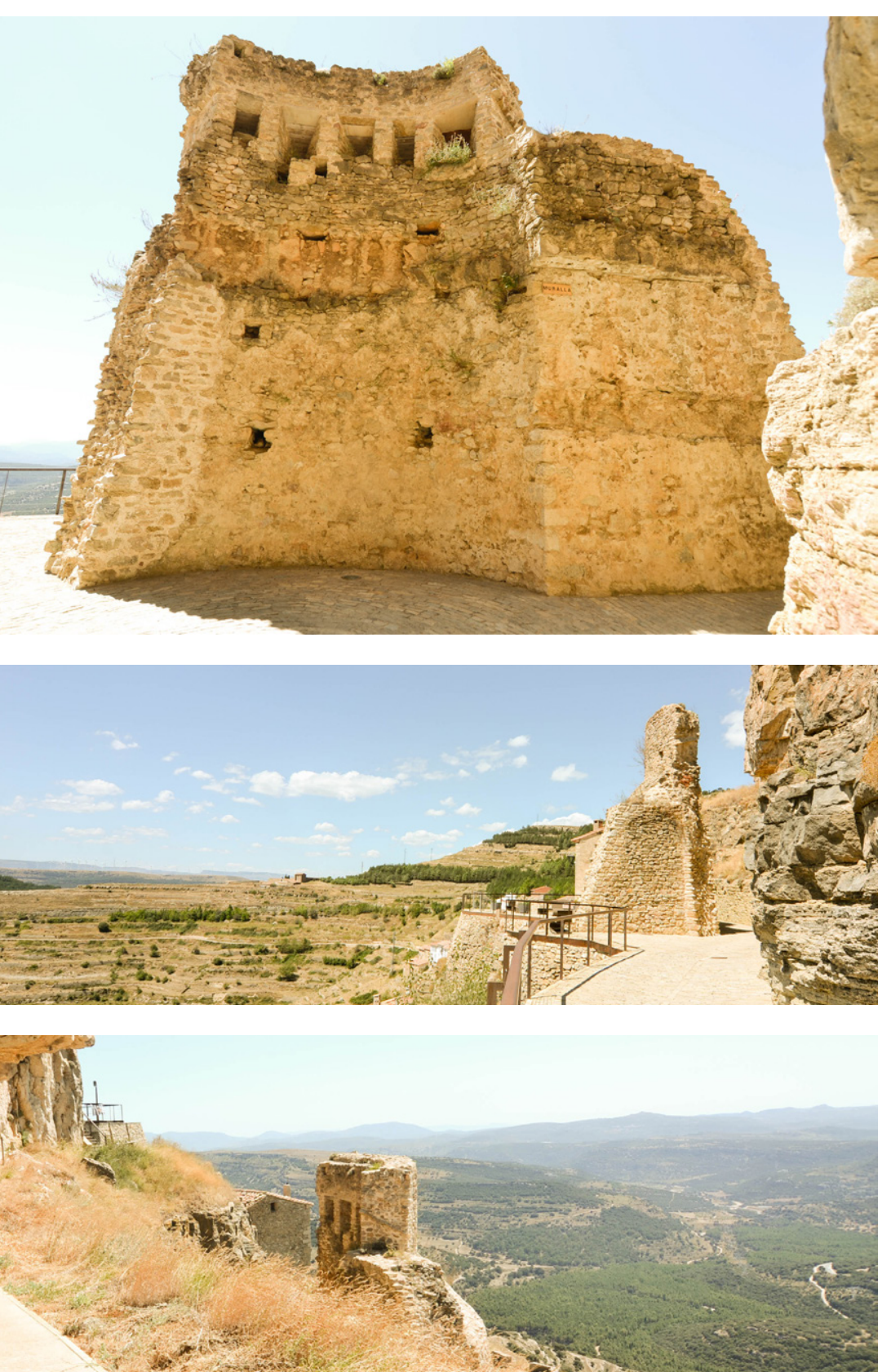

Fig. 99. Parte interna de la torre con alambor y aspilleras. Se identifican los distintos niveles gracias a los mechinales, como también los cambios de aparejo y tipo de piedra: la carlista más oscura y pequeña que la medieval.

Fig. 100. Posición de dominio de la torre sobre el paisaje.

Fig. 101. Posición de dominio de la torre sobre el paisaje.
Cabe la posibilidad de que existiera una rampa que los conectara y que hoy se ha perdido, quizá fruto de los bombardeos producidos por los liberales. De los muros del extremo sur, que harían de subida y acceso a la cumbre, quedan pocos restos, como también de lo que en el plano figura como "caseta", situada en lo alto. Esta sería un cuerpo con forma de prisma rectangular que podría tener diversos usos. De esta caseta tan solo queda hoy la base de sus muros exteriores. Lo identificado en el plano como "ruinas del antiguo castillo" correspondería con unas ruinas que hoy tienen la misma forma en planta que entonces, lo que aporta información sobre el estado en el que los carlistas encuentran el castillo. Esto hace pensar que el resto del castillo estaría en pésimas condiciones y que lo que hoy contemplamos es sobre todo obra carlista.

El plano titulado "Croquis del Sitio y Toma de Ares del Maestre el 27 de Abril de 1840" (Signatura: Ar.G-T.2-C.2-45) es una representación de la batalla producida en 1840 que aporta información sobre la destrucción del fuerte. Toda la artillería liberal se situó en el noroeste, lo que justifica la desaparición de grandes frentes amurallados que aparecen grafiados en el plano anterior.

El fuerte de Ares ha sufrido una gran transformación desde la intervención carlista, pues primero fue atacado por los liberales en 1840; después, durante la Guerra Civil, se bombardeó toda la población; y recientemente se ha realizado una intervención con voluntad restauradora que ha restituido faltantes necesarios para la interpretación de los restos, pero que también ha reconfigurado el sistema de accesos y recorridos, desvirtuado la morfología del fuerte.

\section{Ilustraciones de la época:}

\section{Ilustración 1}

Título a pie: Vista de la Villa de Ares del Maestre.

Fuente: Cavanilles, 1795: v. 1, 77.

Planos históricos:

Plano 1

Título uniforme: Ares del Maestre (Castellón). Fuerte de Ares de Maestre. Fuertes (1840). 1:800

Título: Plano del fuerte de Ares del Maestre tomado el 27 de abril de 1840 / por la 3 División del Ejto. espo. del norte

Publicación: 1840?

Descripción física: 1 plano: ms., montado sobre tela ; 17,6 x 24,1 cm

Notas: Manuscrito a plumilla en tinta negra. Relieve representado por normales.

Ejemplares: Archivo Cartográfico de Estudios Geográficos del Centro Geográfico del Ejército Ubicación: AR - Signatura: Ar.G-T.2-C.2-46 - Código de barras: 2210302

\section{Plano 2}

Título uniforme: Ares del Maestre (Castellón). Asedios (1840). 1:9.300

Título: Croquis del sitio y toma de Ares del Maestre el 27 de abril de 1840 / [Ejército español] Publicación: 1840 ?

Descripción física: 1 plano: ms., montado sobre tela ; 20 × 30,2 cm

Notas: Manuscrito a plumilla en tinta negra. Relieve representado por normales. Indica la situación de los batallones por clave numérica.

Ejemplares: Archivo Cartográfico de Estudios Geográficos del Centro Geográfico del Ejército Ubicación: AR - Signatura: Ar.G-T.2-C.2-45 - Código de barras: 2210301. 

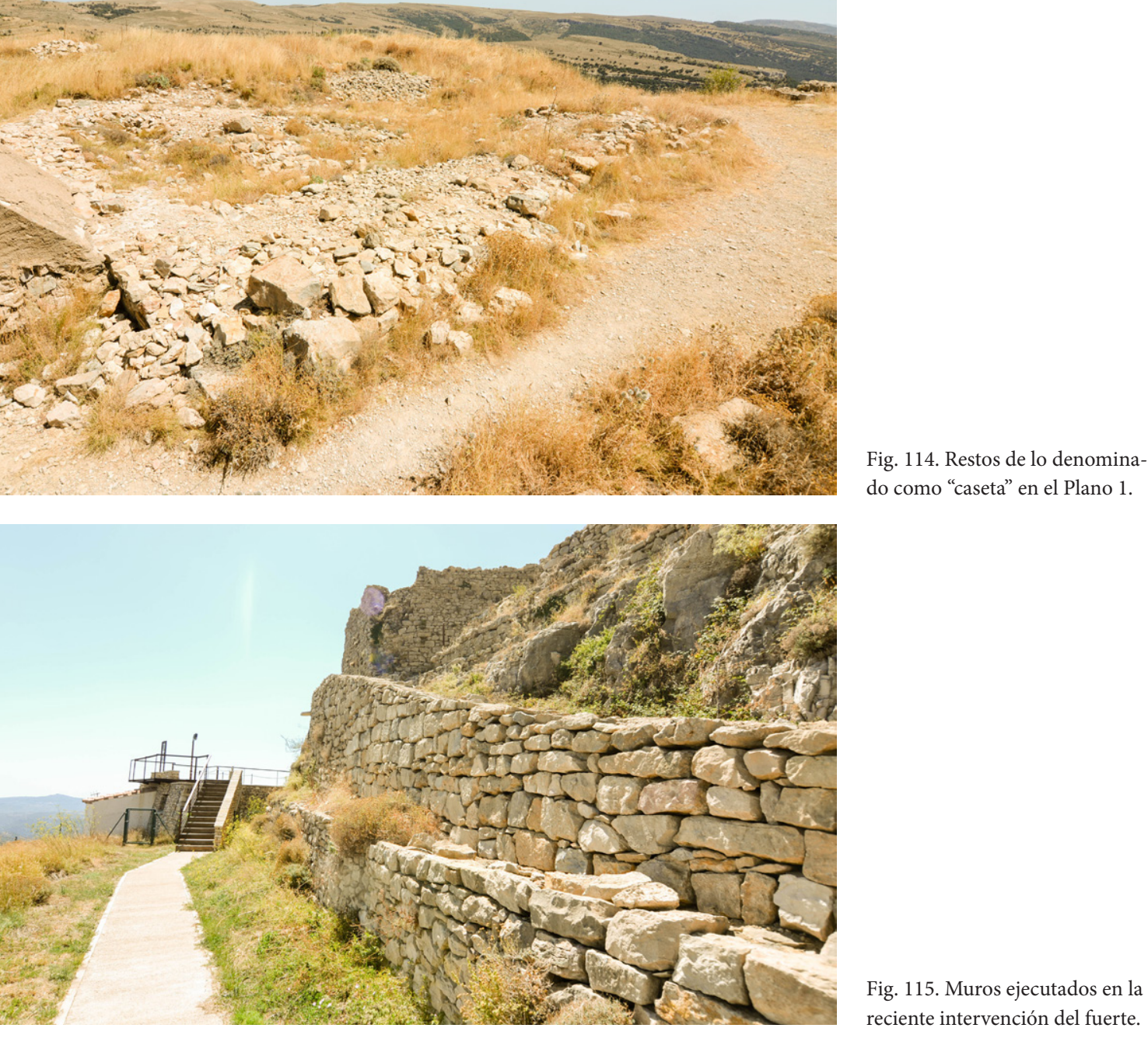

9 AYódAR 
Localidad en castellano / valenciano: Ayódar / Aiòder

Provincia actual: Castellón

Comarca: Alto Mijares

Coordenadas geográficas: $39.99436277644682,-0.3752570176128245$

Tipos defensivos: castillo reforzado que domina la población, torre, fortificación de conventos, hospitales.

Acciones y fortificación:

A finales de 1838 y principios de 1839 comienzan las obras de fortificación en Ayódar, simultáneamente a las de Bejís, tratando de reforzar la conexión defensiva entre Chelva y Cantavieja (Diario de Valencia, 18 de diciembre de 1838, Diario Mercantil de Valencia, 12 y 19 de enero de 1839. Archivo de la Diputación Provincial de Castellón, colección de actas de 1838, folio 394; Caridad, 2013: 258). Las fuentes hablan del fuerte de Ayódar refiriéndose a un convento preexistente, el convento de los dominicos, que, con toda probabilidad acaba cumpliendo las funciones de hospital de sangre, (Von

Fig. 118. Restos del castillo de Ayódar. El cuerpo de la torre es el único con presencia significativa.
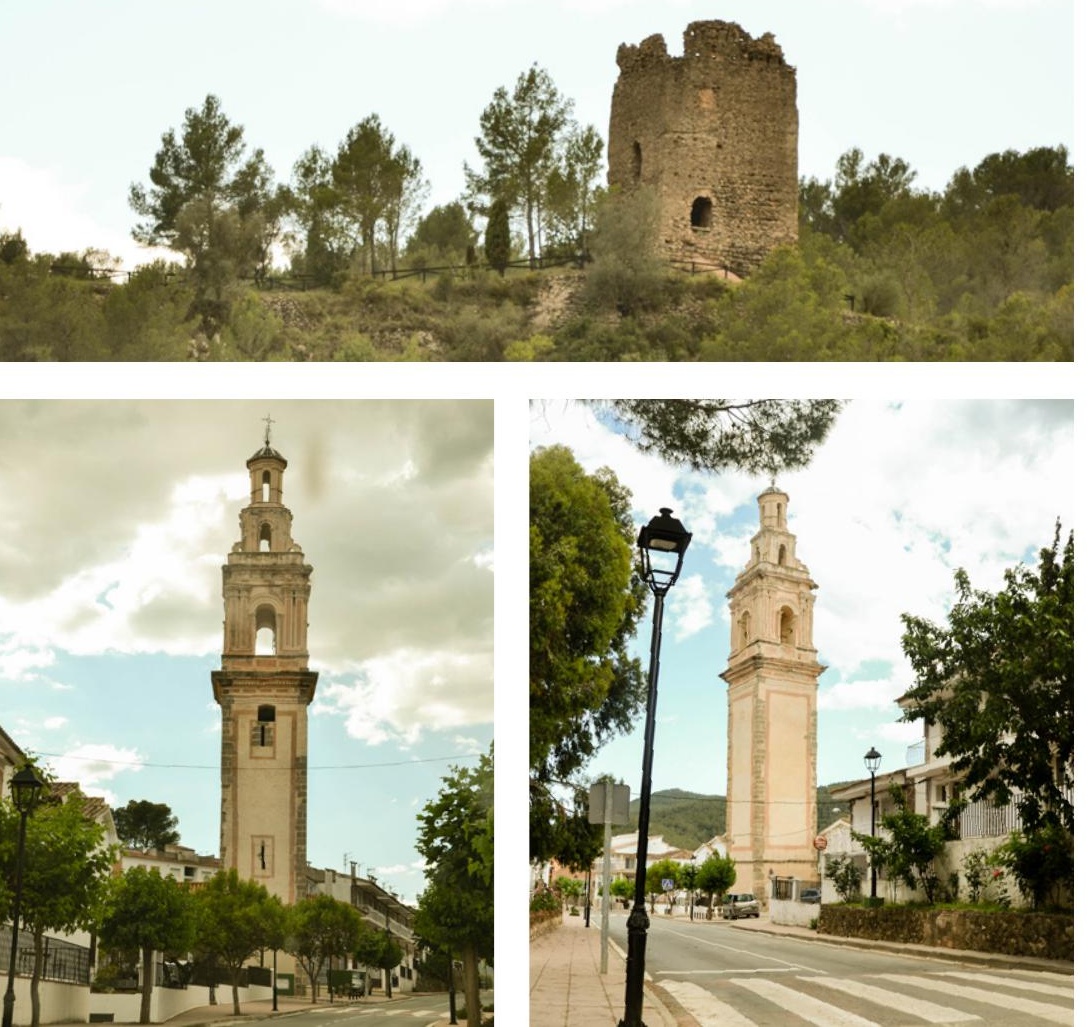

Fig. 119. Restos del castillo de Ayódar.

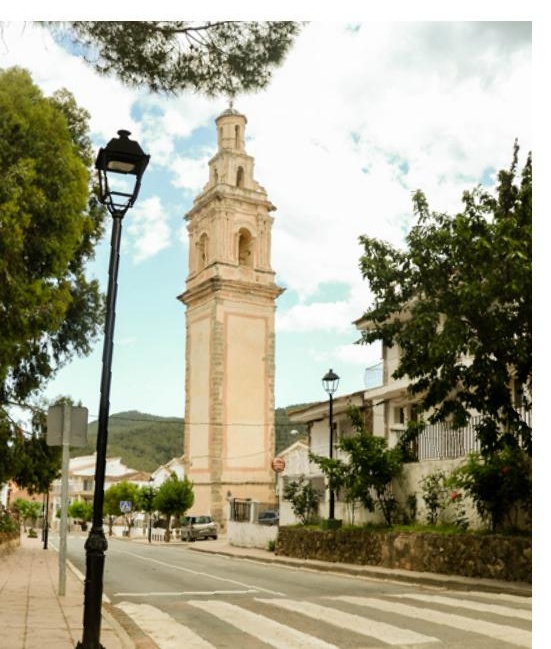

Fig. 120. (Izq.) Torre campanario del Convento de los Dominicos, único vestigio del mismo

Fig. 121. (Dcha.) Torre campanario del Convento de los Dominicos vista desde el interior de la población. No se aprecian aspilleras en esas dos fachadas. Rahden, 2013:477).

Ayódar es abandonado en el mes de junio de 1840, tras los meses de abril y mayo, en los que se desmorona la línea defensiva carlista con sus principales fuertes (Diario Mercantil de Valencia, 10 de junio de 1840; Caridad, 2013: 266).

La población y el castillo de Ayódar son probablemente de origen musulmán, pues parecen haber pertenecido al menos a los dominios de Abu Zayd, el último gobernador almohade de Valencia. El castillo de Ayódar, que domina la población, sobrevive hoy en ruinas, siendo su elemento más destacado su torre mayor, excéntrica, que refuerza su flanco. Las tropas carlistas ocupan la población, aunque no se tiene constancia de si efectúan alguna intervención en el mismo. el Convento de los dominicos, de 1575, del cual solo se conserva la torre conocida actualmente como "torre campanario del Convento de los Dominicos", de $36 \mathrm{~m}$ de altura, construida posteriormente, en 1601. Dominando la población, debe de constituir un elemento clave de la posición carlista, y prueba de ello son las aspilleras habilitadas en su fuste. El convento debe de ser utilizado en un inicio como cuartel de tropa y más adelante como hospital, si atendemos a la indicación de Von Rahden citada con anterioridad. El convento es derribado en 1950. 
Fig. 122. Planta general de Ayódar con emplazamiento de torre y castillo.

01. Campanario de los Dominicos (posición cuartel carlista) 02. Iglesia de San Vicente Ferrer (S. XIX, posterior a la Primera Guerra Carlista)

03. Restos del castillo

04. Sendero

06. Castillo

07. Restos del Palacio del Dique

de Villahermosa convertidos en

vivienda

\section{Becerte y sus puertos*}

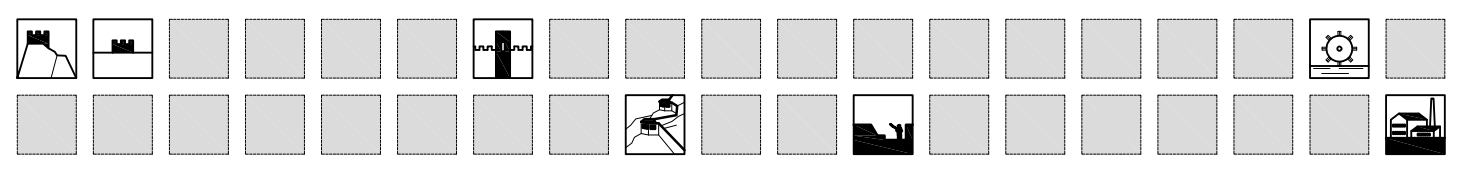



Fig. 138. Vista panorámica del fuerte principal desde el interior. Se aprecia el dominio del fuerte sobre el territorio. Fig. 139. Restos del fuerte principal vistos desde el este, desde el exterior del fuerte. Se parecia la altura del fuerte respecto al contorno.

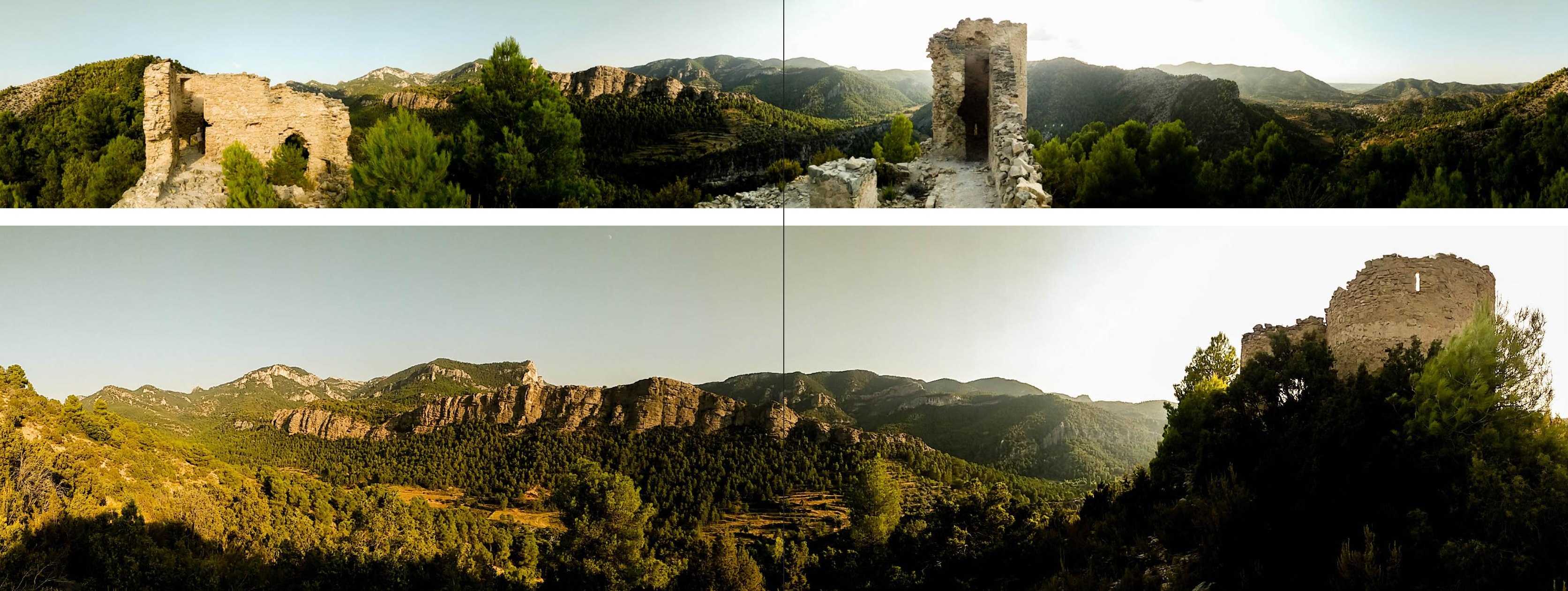




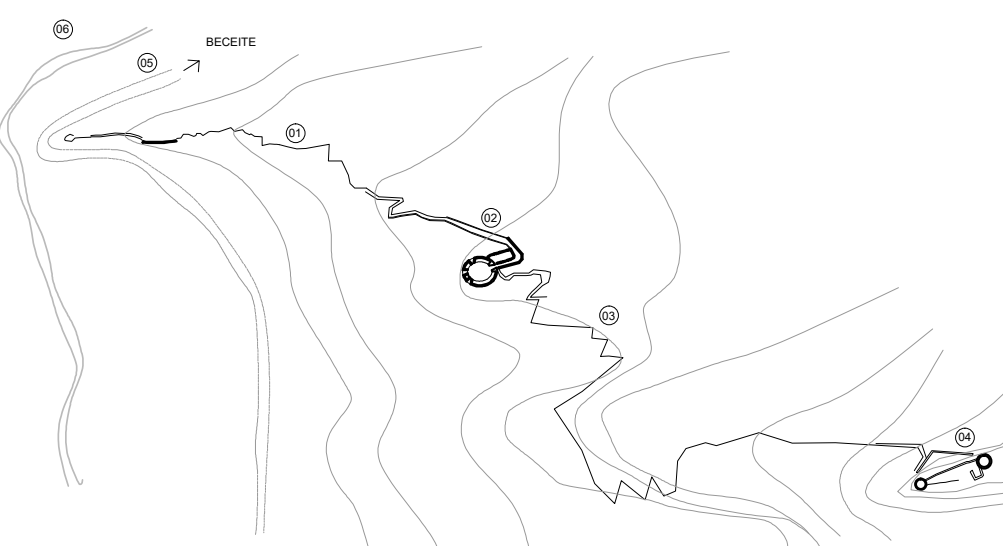

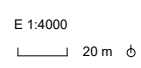

Fig. 140. Posición del tambor intermedio y del reducto principal de los fuertes de Cabrera en los puertos de Beceite.

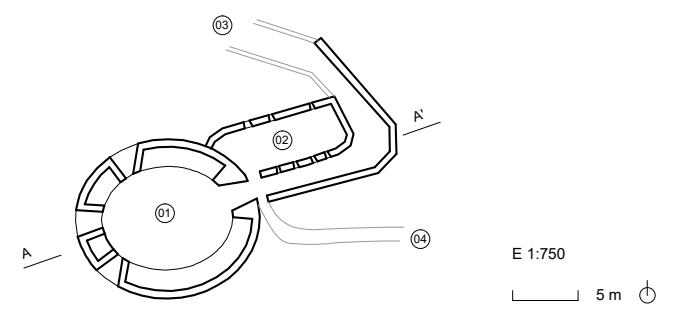



Linares de Mora, Villahermosa del Río, Montán, Benicarló, La Galera, Ulldecona, Sant Mateu y Cantavieja (Caridad, 2013: 266).

Se dispone de descripciones del castillo del año 1610 y 1734, además de dos planos de Manfredo Fanti levantados justo antes del sitio y conservados en el Archivo Geográfico del Ejército. En el primero, titulado "reconocimiento hecho por las tropas constitucionales sobre el fuerte enemigo de Bexis primero, titulado "reconocimiento hecho por las tropas constitucionales sobre el fuerte enemigo de Bexis
el día 29 de diciembre de 1939" y fechado el 1 de febrero de 1840, incluye una sección horizontal del el día 29 de diciembre de 1939" y fechado el 1 de febrero de 1840, incluye una sección horizontal del
castillo, una sección transversal y una perspectiva (Archivo Cartográfico de Estudios Geográficos del Centro Geográfico del Ejército, AR, signatura: Ar.G-T.2-C.2-104).

En las diferentes representaciones se observan las prioridades que se corresponden con el desarrollo del asedio. Se indica que el pueblo, emplazado al este, cuenta con 250 vecinos (1) y que el castillo está ocupado por las tropas carlistas y artillado en diferentes puntos (2). Se indica la posición de la puerta principal (4), en el norte. Esta puerta permite acceder a un primer recinto, el septentrional. Tal y como se observa en la sección, la puerta es flanqueada por un torreón aspillerado de traza circular que cubre el camino. Por las características de la representación en sección, este torreoncillo cubierto de altura más baja que las escarpas parece un añadido que, al estar aspillerado, podría ser un añadido de la época.

Fig. 146. Restos de la torre de traza cuadrangular de la esquin sureste del fuerte.

Fig. 147. Interior del cuerpo central.

Fig. 148. Restos del cuerpo principal.
El primer recinto conecta con el recinto central, que ocupa el punto más elevado del peñasco, a través de un muro de gran altura en el que se practica una puerta. Este recinto central domina con sus muros la totalidad del castillo y dispone de cañoneras o aspilleras habilitadas para disparar desde la cota de suelo.

En mitad de la cortina oeste se ubica un gran torreón rectangular de dos pisos. En el recinto intermedio, y apoyado sobre el muro que separa el primer recinto del segundo, aparece el cuerpo de alojamiento de la tropa (6) con un aljibe anexo (7). Con el objetivo de cubrir el camino de acceso que serpentea desde el norte, el frente este se refuerza con un torreón semicircular en su punto meque serpentea desde el norte, el frente este se refuerza con un torreón semicircular en su punto me-
dio, y una torre rectangular, definidos como torre y baluarte aspillerados. Con toda probabilidad, adosado a este muro y dentro del recinto intermedio se habilita un espacio para acuartelamiento de la tropa y el aljibe. El muro divisorio acaba en el frente oeste en un gran torreón rectangular que aparece en medio de la cortina oeste proyectando sus fuegos a norte y sur. Este torreón (5) cuenta con dos pisos, donde el inferior sirve de almacén.

Llama la atención que el último recinto, el meridional, por debajo del recinto central, tiene una clara configuración abaluartada conformando una especie de obra coronada destinada, con toda probabilidad, a cubrir la villa o prevenirse de un ataque desde la villa. Este frente, que debió de tener su origen en algún conflicto precedente, arranca desde la mitad del frente este con un potente torreón origen en algún conflicto precedente, arranca desde la mitad del frente este con un potente torreón
circular, una cortina de gran espesor hacia el sur, en cuyo vértice aparece el baluarte sureste, una circular, una cortina de gran espesor hacia el sur, en cuyo vértice aparece el baluarte sureste, una
nueva cortina y el baluarte sur. Dentro del terraplén de este último recinto se localiza la casa del gonueva cortina y el baluarte sur. Dentro del terraplén de este último recinto se localiza la casa del gobernador (9). Se tiene constancia de que en 1554, siendo comendador de la orden de Calatrava fray La Cuesta y Pedro de Ribas para realizar operaciones en el castillo. En la Guerra de Sucesión, en 1709, se instalan tres compañías de soldados y probablemente reaprovechan lo existente.

Las intervenciones carlistas debieron de centrarse en reforzar los muros del recinto norte, así como los torreones aspillerados que cubrían el camino de acceso. Si nos detenemos en la representación en perspectiva del mismo documento, observamos cómo los adarves del recinto abaluartado, que según el dibujo en planta aún se representan como cañoneras, aparecen representados con aspilleras. Se observa cómo este doble frente abaluartado-aspillerado concentra sus fuegos contra la población, y su remate podría responder a las intervenciones carlistas.

\section{Planos históricos:}

\section{Plano 1}

Título uniforme: Begis (Castellón). Asedios (1839-1840). 1:12.000

Título: Bexis: reconocimiento hecho por las tropas constitucionales sobre el Fuerte enemigo de Bexis en el dia 29 de Diciembre de 1839 / Manfredo Fanti Cap. Go. agregado al E.M. del Ejército del Centro 


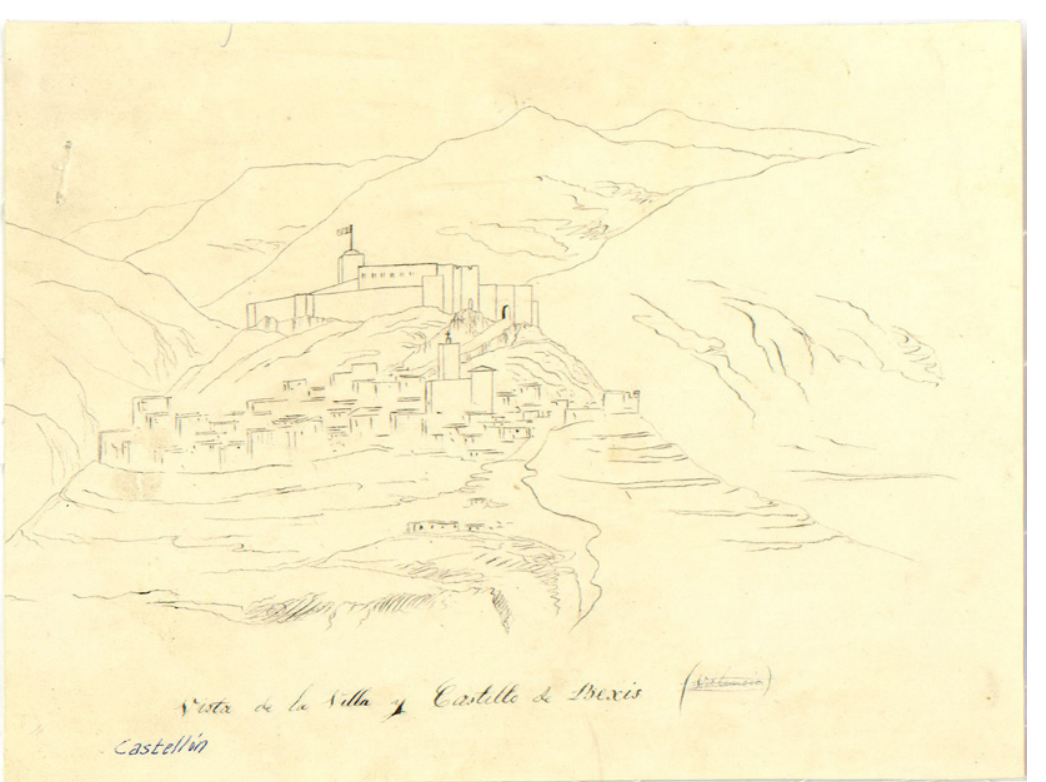

castellin

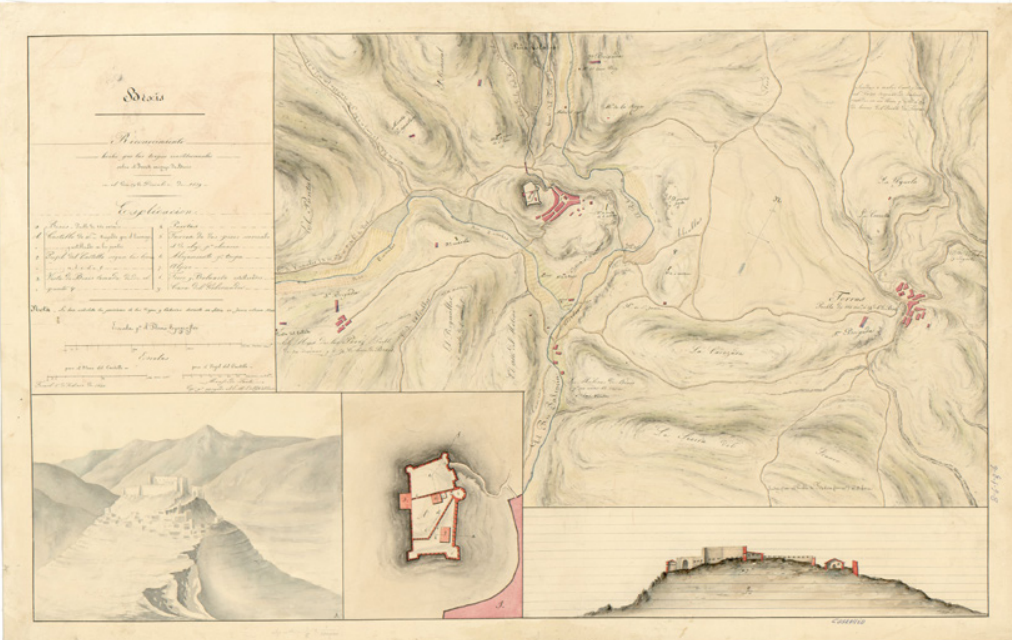

Fig. 150. Plano 2.

Fig. 151. Sección del castillo de Bejís en 1840

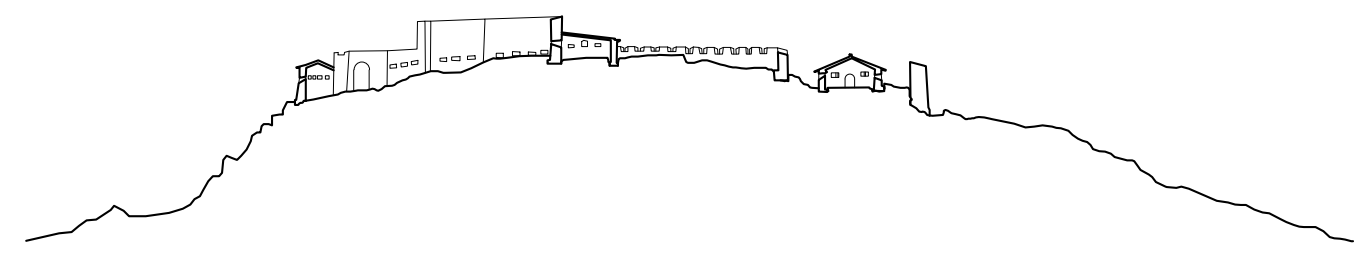

Fig. 152. Planta del castillo de Bejís en 1840

04. Puertas

05. Torreón de dos pisos (el infe-

rior es almacén)

06. Alojamiento de la tropa

07. Aljibe

08. Torre y baluarte aspillerados

09. Casa del Gobernador

E 1:1000

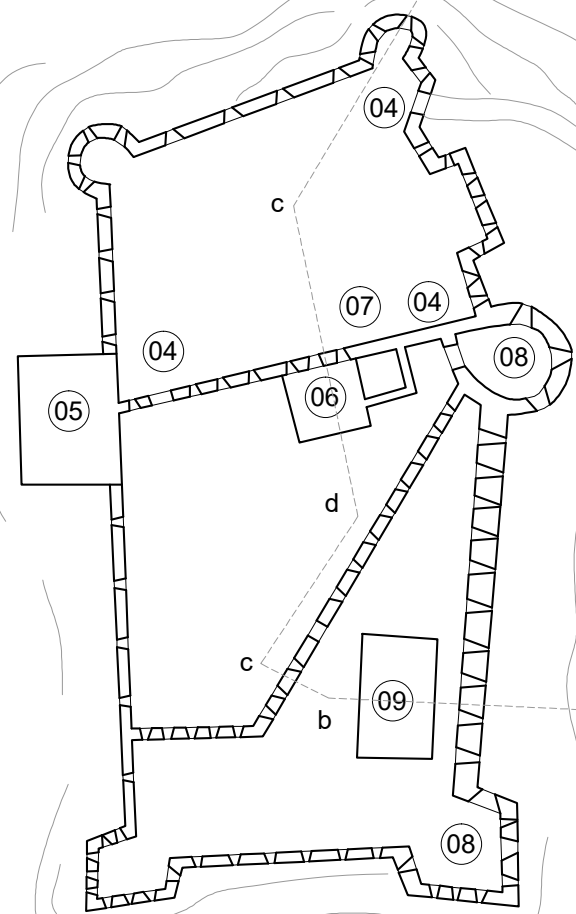


Fig. 153. Planta del territorio con el castillo de Bejís en 1840.

01. Castillo

02. Población de Bejís

03 . Ronda de las calzadas

04. Acequia

05. Camino del Toro

06. Camino carretero de Alcublas

07. Río Palancia

08. Río Canales
12 Benicarlo $^{*}$

..


Fig. 157. Frente oriental, sin aspilleras, de la torre campanario de Benicarló.
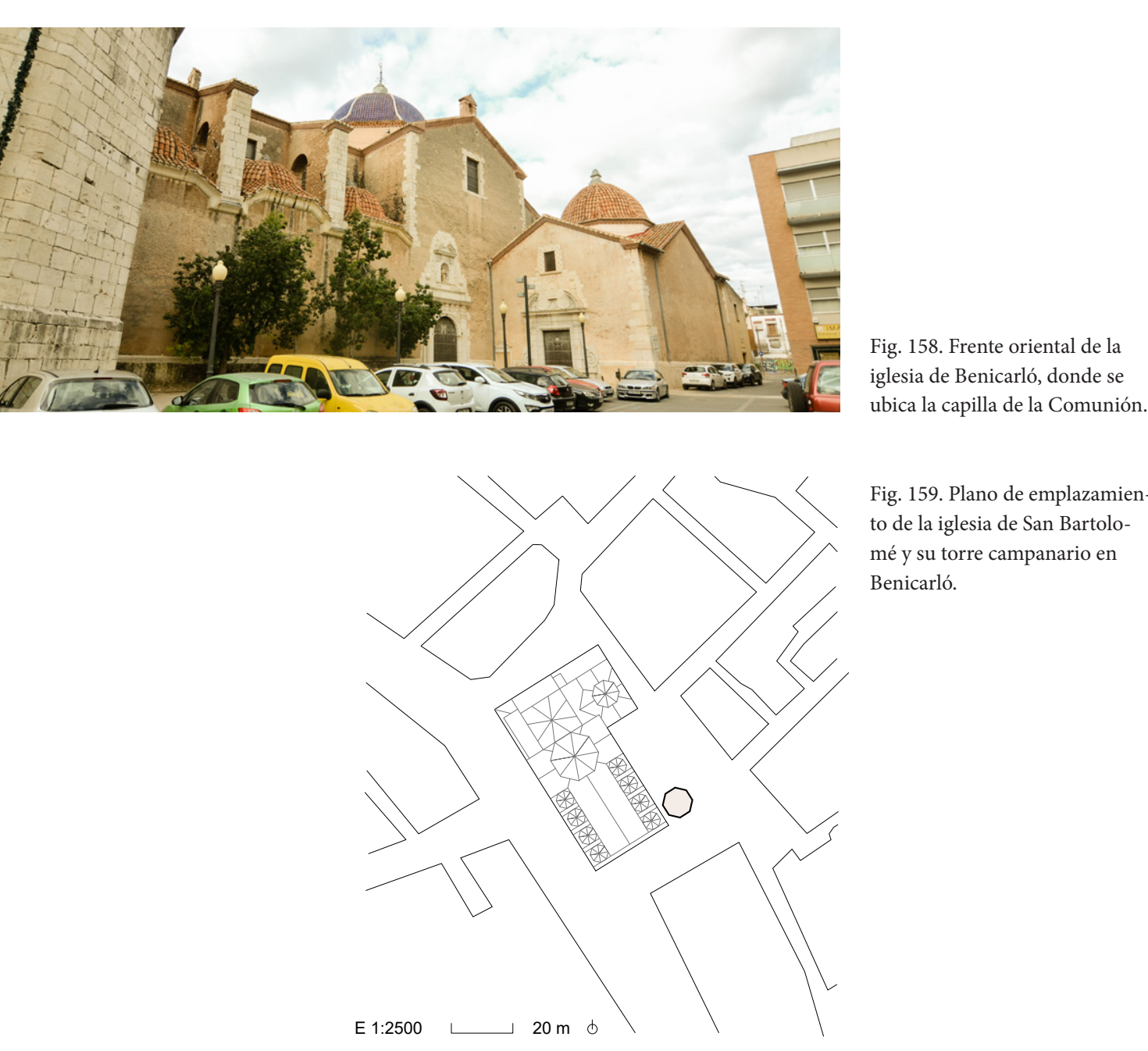

Fig. 158. Frente oriental de la iglesia de Benicarló, donde se ubica la capilla de la Comunión

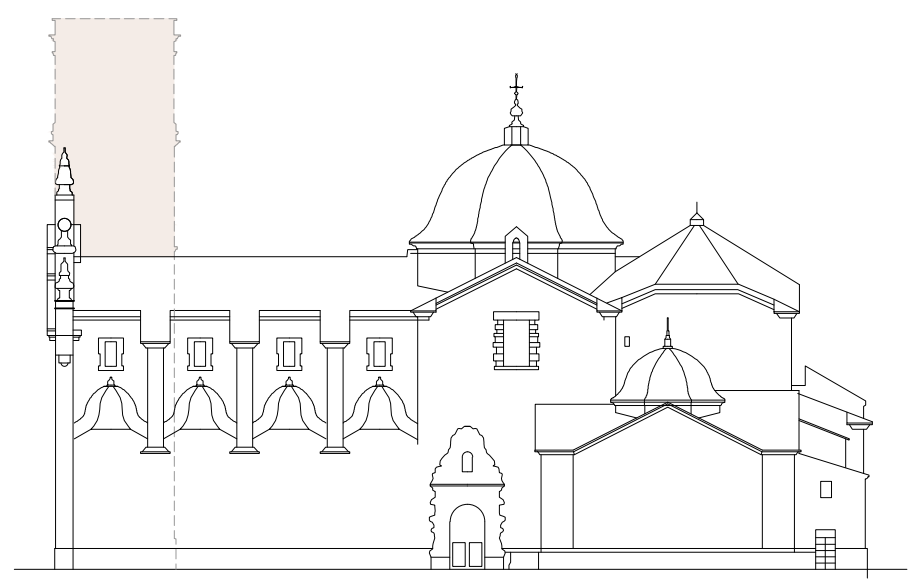
la iglesia de San Bartolomé de Benicarló.

Fig. 161. Planta de la iglesia de San Bartolomé de Benicarló.

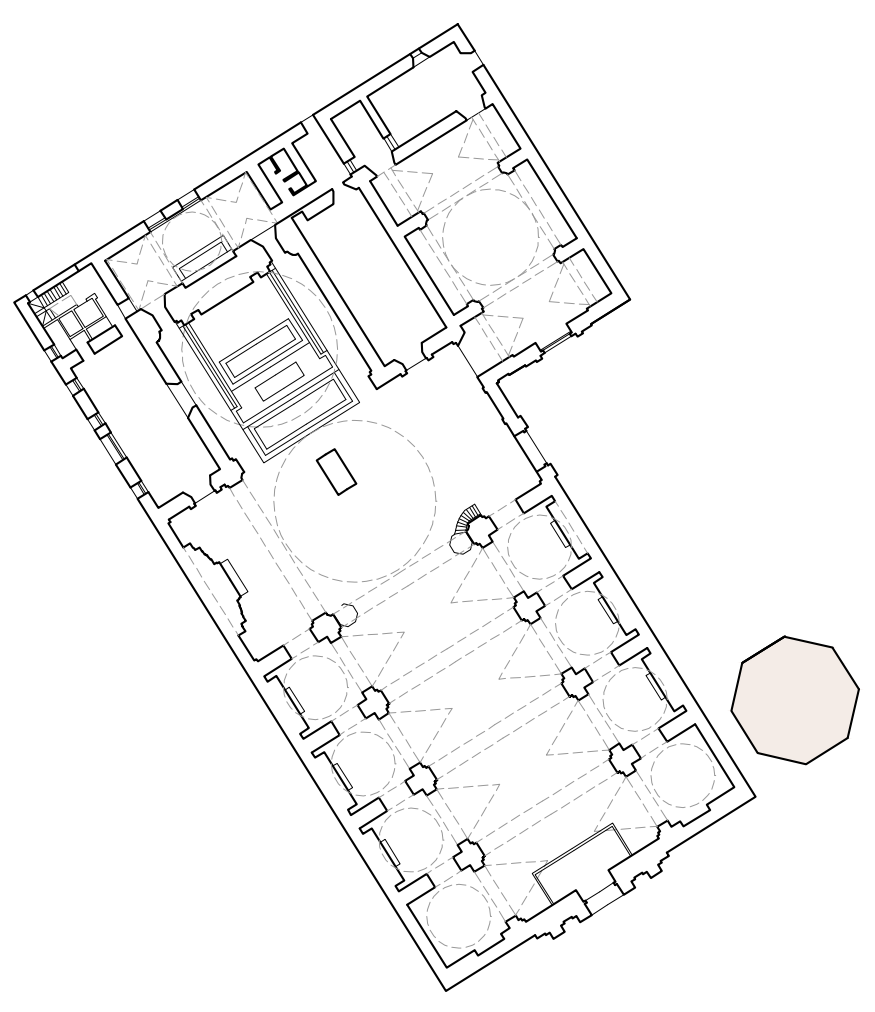


13 веRGA *

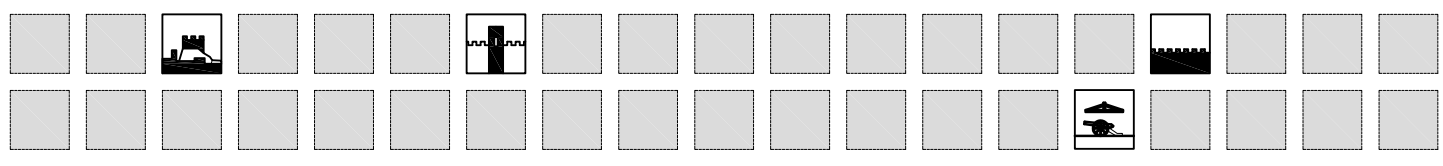



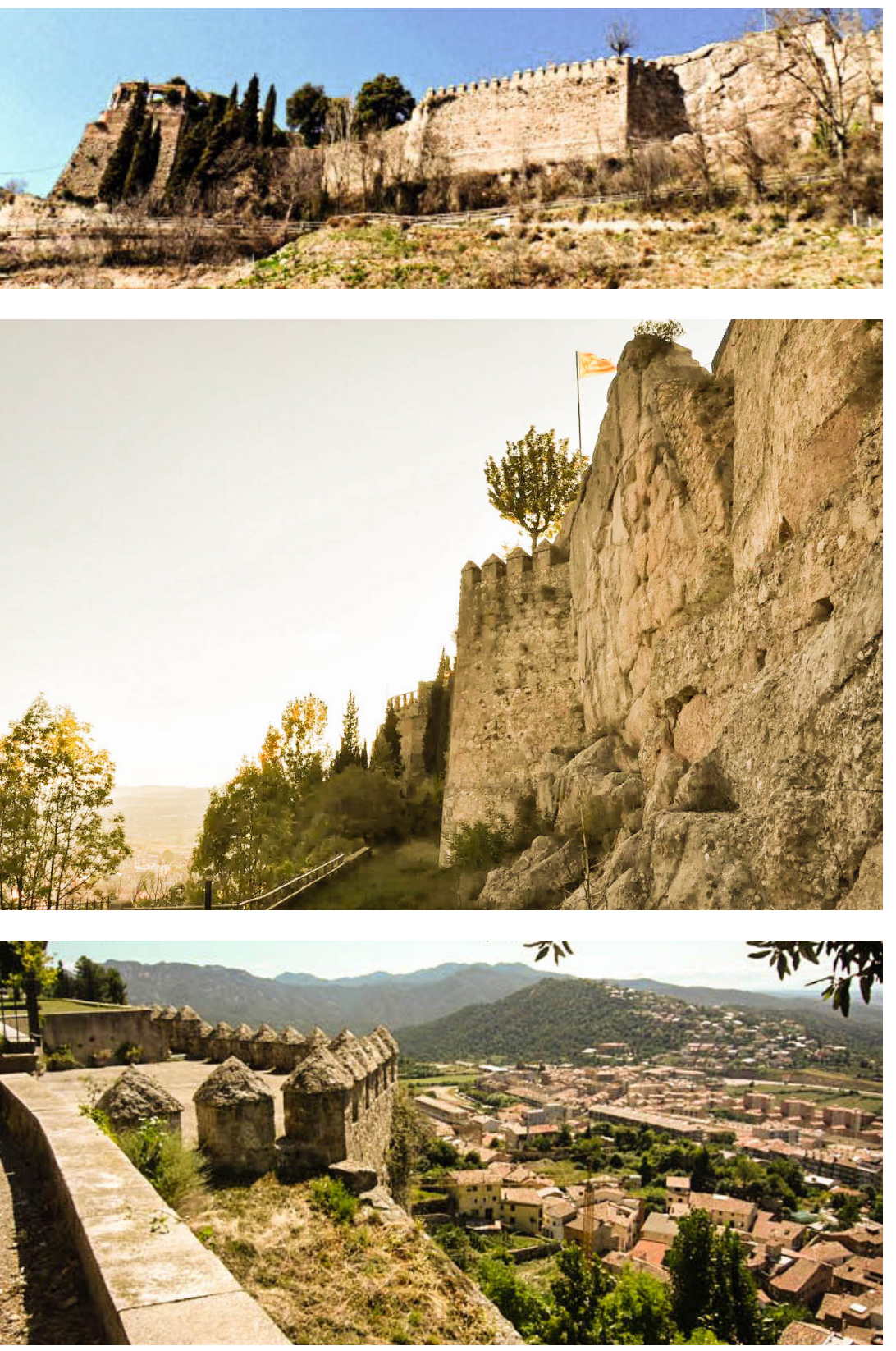

4

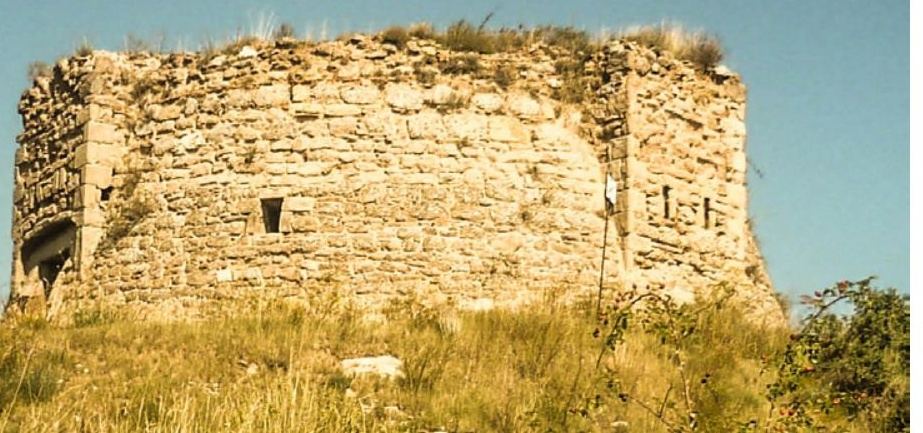

Fig. 162. Castillo de San Fernando de Berga fotografiado desde la base.

Fig. 163. Castillo de San Fernando de Berga.

Fig. 164. Vistas de Berga desde el castillo de San Fernando. Se aprecia la posición de dominio del castillo sobre la población y su ubicación en el territorio.

Fig. 165. Fuerte de María Luisa Fernanda, conocido como torre de la Petita, en Berga.
Berga

Localidad en castellano / catalán: Berga

Provincia actual: Barcelona

Comarca: Bergadá

Coordenadas geográficas: 42.10633155843638, 1.8464016982423743

Tipos defensivos: castillo reforzado que domina la población, torre artillada adosada a muralla / tambor, muralla urbana, maestranza.

Acciones y fortificación:

Berga es tomada por las tropas de Urbiztondo el 12 de julio de 1837 para ser convertida en capital del carlismo catalán. Por primera vez las tropas carlistas tienen un territorio propio bajo control (Gironella, Prats de Lluçanès, Bagà y Tuixèn) (Pirala, 1889-1891, II-826-824; Santirso, 1999:158).

En el repliegue carlista del año 1840, Cabrera llega a Berga. Su recorrido pasa desde Mora por Ervia, la Juncosa y Albí, la sierra de Liena, la carretera de Barcelona hasta alcanzar Berga. La división aragonesa pasa el Ebro por Flix, sorteando Lleida por el este hasta Pons, pasa por el Segre, Oliana alcanza Tiurana. Berga ya pertenece a otro frente de guerra, el catalán, donde existen dificultades para reconocer en Cabrera a su mando. De hecho, recoge Calbo y Rochina que se teme que Berga no le abra sus puertas (Calbo y Rochina, 1845:356), hasta el punto de que Cabrera llega a arengar a sus hombres para tomar la plaza por la fuerza si los carlistas de Cataluña se oponen a su mando. Pero, contrariamente a lo esperado, Berga recibe entre aclamaciones a las tropas del Maestrazgo. La plaza es descrita por Calbo y Rochina del siguiente modo: "La villa de Berga está rodeada de 14 torreones y una dilatada serie ó cordillera de parapetos. El antiguo castillo que la dominaba era fuertísimo tanto por su posición como por lo sólido de su obra, de modo que en varios trozos le sirve de muralla la peña viva, siendo de unos 50 palmos la elevacion de aquellas. Situado sobre una colina muy escarpada y ademas de un pequeñ foso, tenia tres lineas de muralla: no siendo muy grande bastabon 150 hombres para su de máxime cuando la artilleria que en él halló Cabrera consistia en 25 piezas de varios calibres, entre ellas dos de
hierro de Ripoll y un obus de 36 .

Al oriente de dicho castillo habia otro fuerte de construccion moderna cuyo objeto era defender las avenidas de la parte del norte, pero su obra era tan poco sólida, que habia caido un trozo de muralla de mas de cuatro varas. Este fuerte situado en la falda de la sierra llamada de la Petita estaba tambien artillado, y en la cumbre de la misma sierra habia otro castillo grande construido con magnificencia, que dominaba todas las demas obras de defensa escepto la Virgen de Queralt que está á su poniente. Al castillo de la Petita daban los carlistas la mayor importancia que al antiguo, pues ademas de ser capaz de contener 2000 infantes y 200 caballos, sus obras de defensa estaban bien concluidas y tenian trazas de una verdadera fortaleza. Entre otras piezas de artilleria existia la mayor que de su fundicion habia salido, pues pesaba setenta y cuatro quintales. A la parte del medio dia y sobre el camino de Barcelona habia otro fuerte llamado de las Forcas, pero estaba reducido á una peña fortificada que cubria la villa por dicha parte. Ademas de lo referido existen una multitud de eminencias, entonces fortificadas, que en el caso de un ataque decidido no podrian sostenerse mucho, sin embargo estaban guarnecidas lo suficiente á dilatar y entorpecer las operaciones contra la plaza.

Los carlistas de Berga tenían establecida la maestranza en el claustro del convento de San Francisco, y empleaban en ella (dirijidos por ocho o diez vizcainos) á 40 mozos del pais para recomponer fusiles y hacerlos nuevos. En los sótanos del mismo convento trabajaban igualmente una porcion de herreros en la fabricacion de balas de fusil; y á muy corta distancia de la villa sobre la carretera de Barcelona tenian situada la fábrica de proyectiles para la artillería: la pólvora se elaboraba en la casa mas inmediata al castillo, trabajando en ella casi continuamente, del mismo modo que en la fundicion de cañones situada dentro de la villa junto á la puerta llamada Pinceria" (Calbo y Rochina, 1845: 556-557). 


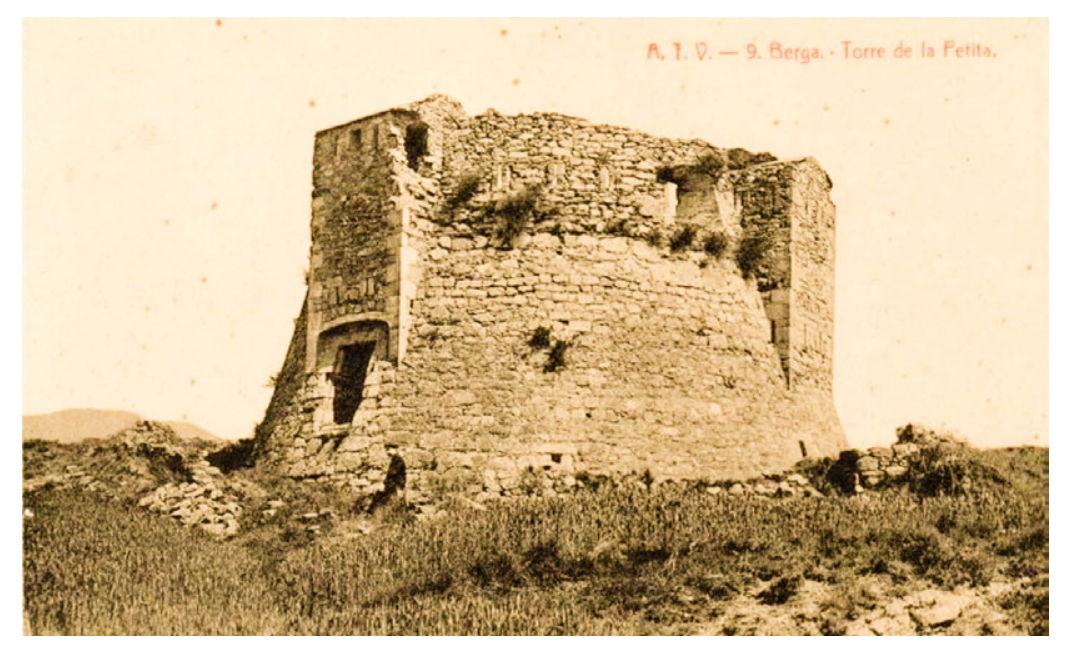

Fig. 166. Antigua postal que muestra el fuerte de Mari Luisa Fernanda conocido torre de la Petita forto como mediados del siglo XX
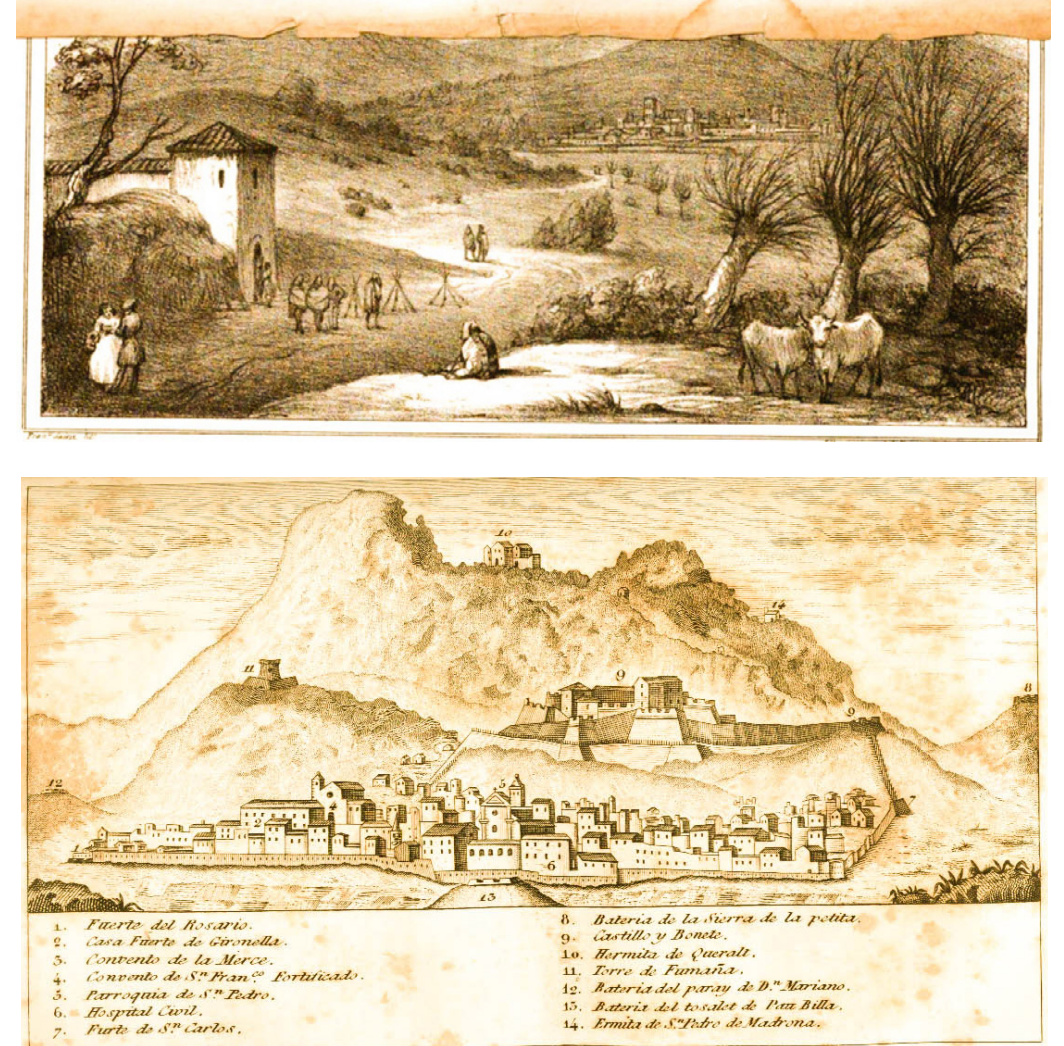

El antiguo castillo al que hace referencia Calbo y Rochina es el antiguo castillo de San Fernando, construido sobre un antiguo emplazamiento íbero. Se encuentra documentación del castillo desde 1095. Bastante activo, tiene que ser reconstruido en diversas ocasiones, tanto a raíz de la guerra de Sucesión como en las guerras carlistas. Es vendido a un particular en 1928 y en parte tratando de construir un hotel y centro turístico, quedando únicamente un muro que se corresponde con las alturas de la fortificación. En 1988 el consejo comarcal del Bergadá lo transforma en su sede.

En mejor estado se conserva la denominada Torre de la Sierra de la Petita. Ese castillo que Calbo y Rochina define como moderno es proyectado por el ingeniero militar Antonio López Sopeña en 1797, como parte del plan de fortificación para el castillo de San Fernando. Según la terminología del siglo XVIII, se corresponde con un fortín de traza circular y escarpas con declive. Semienterrado, con dos niveles, donde el superior, abovedado, cuenta con aspilleras y matacanes. Una línea fortificada une el fortín con el castillo, línea de la que aún sobreviven restos en avanzado estado de degradación.

Respecto a las murallas urbanas, tan solo resta el vestigio del portal de la Magdalena, única puerta medieval de las siete con las que llega a contar.

Existe un "plano del castillo de Berga y croquis del terreno inmediato a él" fechado el 15 de febrero 1811, por Esteban Gutela (SGE-Ar.F-T.7-C.2-197(2)). En él se indica la relación de las torres ubicadas en las inmediaciones, caminos y montes, indicando distancias entre ellos y hasta el castillo. Otro plano del mismo alcance de Félix Toda y Ruiz, fechado también en 1811, nos indica que el recinto amurallado de la ciudad "apenas existe" (SGE-Ar.F-T.7-C.2-197(1))

En otro plano de 30 de abril de 1811, Estaban Gutela representa los perfiles y planta del castillo y sus torres (SGE-SGE-Ar.F-T.7-C.2-198(2)).

Según Von Rahden, Berga constituye "a excepción de dos fuertes de montaña irrelevantes, la única plaza fuerte de importancia, de ahí que estuviese dotada de piezas de artillería. Una compañía de zapadores estaba a cargo de las obras de fortificación y atrincheramiento, que más allá de las torres amuralladas se limitaban a algunos parapetos y sencillas líneas de defensas de este tipo. El Estado Mayor solo existía sobre el papel, oficiales de ingenieros, ni siquiera como tal, ya que el conde de España, enojado por alguna experiencia desagradable en tiempo reciente, prácticamente había suprimido la actividad de ambas ramas.

Durante mi estancia de varias semanas en el cuartel general del conde, este me encargó en persona la reorganización de las dos ramas facultativas del ejército mencionadas arriba, así como la revisión de todos los depósitos militares, talleres de artillería y obras de fortificación. Además quería que se introdujesen piezas de artillería de madera y cuero, petardos y granadas de vidrio y reductos y fortines ambulantes. También debía dibujar grandes porciones del terreno a vista de pájaro (y realmente hubiese tenido que ser un pájaro para obtener una panorámica de los inescrutables barrancos y precipicios rocosos), así como trazar un sistema completo de fortificaciones comunicadas en las crestas de las sierras más elevadas. A las órdenes les debian seguir las acciones a la velocidad del rayo. Los medios materiales a veces no eran suficientes, pero cuando el general daba una orden, todos se apresuraban a obedecerla ciegamente. Cómo hacerlo, esa era una pregunta que el general, en su impaciencia nunca tomaba en consideración. Por esta causa y por el deseo de realizarlo todo a la vez se impetuosidad auténticamente francesa era, sin duda alguna, el peor defecto del general y, al toparse con la gravedad, dejadez y torpeza españolas, degeneraba a menudo por su edad y posición en situaciones harto cómicas. Las piezas de artillería de madera, de calibre muy grande pero de caña reducida, con alma de chapa de hierro, atada por cuerdas, y bastidor de hierro, estaban previstas para ser desmontadas y debían colocarse en las cimas más altas y los puntos más dominantes, a menudo en el flanco o a espaldas de la posición enemiga, para dispararle a este de forma inesperada algunas granadas y balas. Las granadas de vidrio y porcelana y los fortines y reductos ambulantes, que al final también se introdujeron en el ejército de Cabrera, solo lograron alouna utilidad práctica gracins a la experimentación. Los fortines ambulantes son fáciles de comprender. Los reductos estaban preparados igualmente para ser desmontados y cargados en mulas, con el objeto de poder ser transportados con rapidez de un lugar a otro. Las paredes interiores y exteriores de sus parapetos se levantaban encajando los tablones y se colocaban a escasa distancia unas de otras, rellenándolas con piedras; con frecuencia se dejaban incluso sin rellenar. Como es obvio, estas protecciones solo servían para el fuego de 
fusilería. Su finalidad principal también se alcanzaba a veces ofreciendo simplemente a la vista del enemigo, de forma inesperada, una línea prolongada de atrincheramiento. 'Que traigan la artillería', se oía entonces de inmediato y, como en una guerra de montaña la artillería solo puede ser acarreada en raras ocasiones y aun eso solo de forma muy lenta, el enemigo renunciaba, por lo general, al ataque de alguna posición y el propósito se veía cumplido. Solo el conocimiento de las circunstancias particulares y de la dirección de la guerra espase veía cumplido. Solo el conocimiento de las circunstancias particulares y de la dirección de la guerra espa-
nola permite utilizar este tipo de defensas basadas en el engaño, que en realidad jamás deberían usarse en una nola permite utilizar este tipo de defensas
guerra" (Von Rahden, 2013: 242-243).

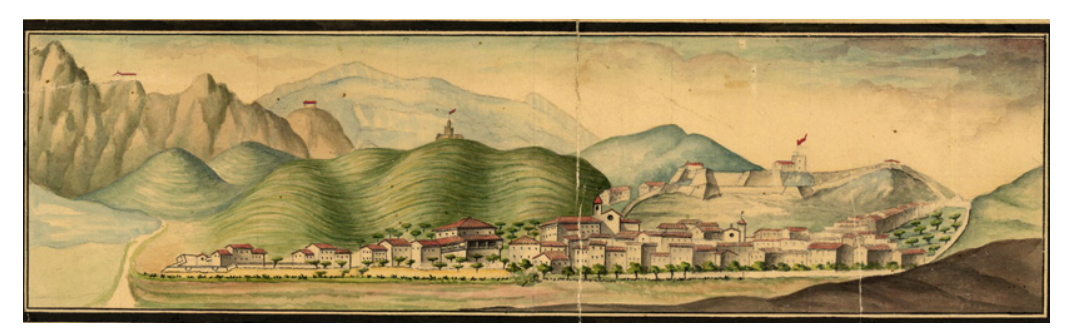

Fig. 169. Detalle del Plano 1 en el que se representa una vista de Berga.

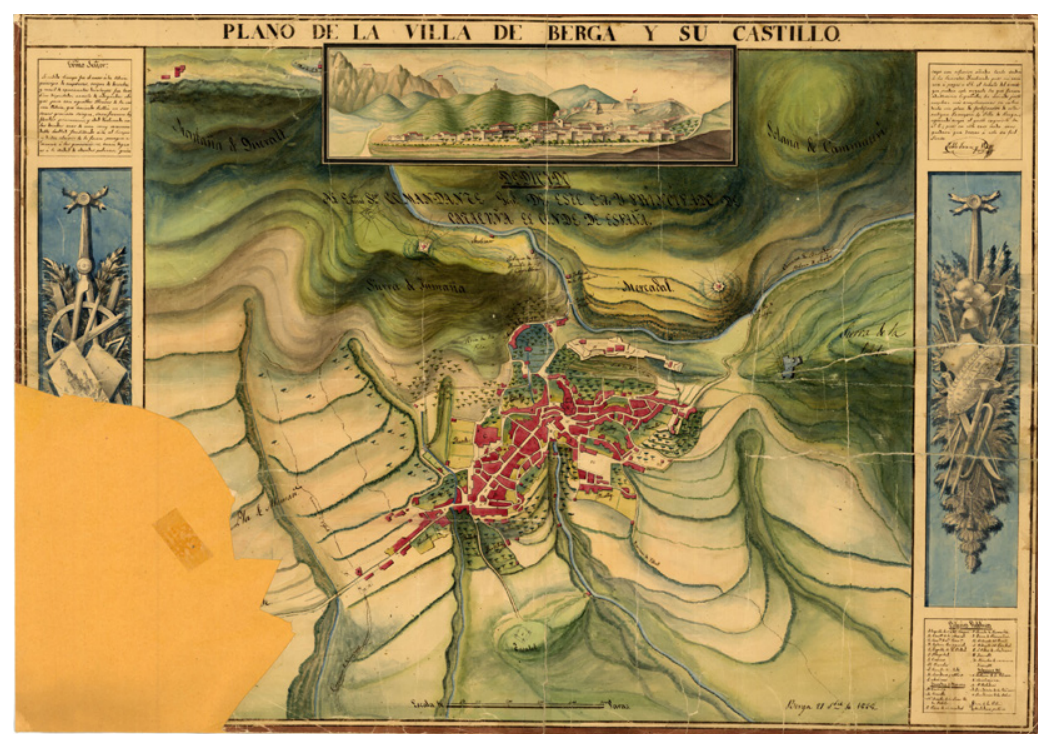

Fig. 170. Plano 1. Plano de la villa de Berga y su castillo fechado en 1838

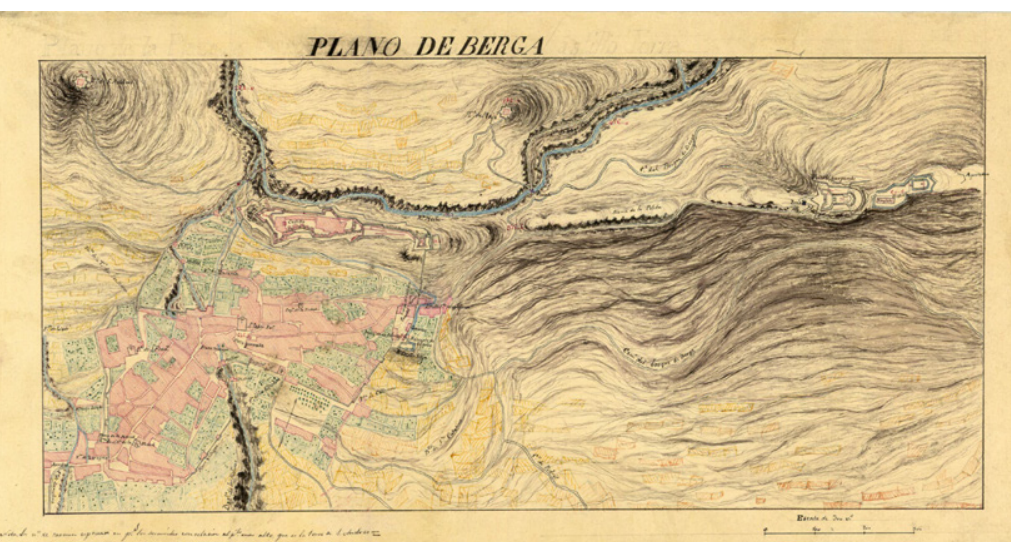

\section{Ilustraciones de la época:}

Ilustración 1

Título a pie: Vista de Berga

Fuente: Calbo y Rochina, 1845: 553

Ilustración 2

Título a pie: Vista Meridional de la Villa de Berga

Fuente: Chao, 1847: 235.

\section{Planos históricos:}

Plano 1

Título: Plano de la Villa de Berga y su castillo [Mapa] / Pablo Janzí y Villa.

Publicación: 1838

Descripción física: 1 plan.: ms., col., montado sobre tela ; 56,1 x 79,2 cm

Notas: Comprende parte de los alrededores de la ciudad de Berga, hasta una distancia aproximada de $1 \mathrm{~km}$. Dedicatoria: "Dedicado Al Exmo. Sor. Comandante Gral. de Este Exto. y Principado de Cataluña El Conde de España". Fechado en: "Berga 17 Sbre. de 1838". Firmado y rubricado por el autor. Escala gráfica de 500 varas [ $=12,1 \mathrm{~cm}]$. Orografía por sombreado. Relación de los principales edificios, especialmente los de carácter militar, así como las fábricas y fortificaciones situadas en sus inmediaciones indicadas por clave alfabética. Señala los caminos, fábricas y elevaciones más destacadas del entorno. Contiene un panegírico dedicado a los héroes de la patria. Decorado, en ambos márgenes laterales, con alegorías de la Guerra y la Cartografía. Iluminado en varios colores. Inserta una perspectiva de la ciudad y su castillo.

Autor: Pablo Janci y Villa.

Ajemplares: Archivo Cartográfico de Estudios Geográficos del Centro Geográfico del Ejército Ubicación: AR - Signatura: Ar.F-T.7-C.2-199 - Código de barras: 2207830.

Plano 2

Título: Plano de Berga [Mapa]

Publicación: 1840.

Descripción física: 1 map.: ms., col., montado sobre tela ; 18,1 × 35,3 cm.

Notas: Presenta el plano de la ciudad de Berga en la provincia de Barcelona y sus alrededores, mostrando el fuerte que se proyecta construir en Sierra Petita. Fecha tomada del catálogo del SGE: "Cataluña. Provincia de Barcelona. Siglos XVI a XIX". 1970, p. 203. Escala gráfica de 300 varas castellanas $[=5 \mathrm{~cm}]$. Orientado con cuadrante. Orografía por curvas de configuración y puntos acotados, expresados en pies, y referidos a la torre de San Andrés. Toponimia de las principales calles y edificios de la ciudad. Iluminado en varios colores.

Ejemplares: Archivo Cartográfico de Estudios Geográficos del Centro Geográfico del Ejército Ubicación: AR - Signatura: Ar.F-T.7-C.2-203 - Código de barras: 2207834 


\section{Plano 3}

Título: Plano de la Villa de Berga y fuertes exteriores [Mapa] / R. Soriano, L. de Velasco, J. R. Porras. Publicación: 1840

Descripción física: 1 plan.: ms., col., montado sobre tela ; 41,2 ×51,9 cm.

Notas: Presenta, por un lado, el plano de la ciudad de Berga, y por otro, las plantas y perfiles de varios de los fuertes que la defienden. Firmado y rubricado por los autores. Fechado en: "Berga 28 de Junio de $1840^{\prime \prime}$. Escala gráfica de 500 pies $[=7,7 \mathrm{~cm}]$ para el plano y de 100 pìes $[=5,0 \mathrm{~cm}]$ para las plantas y perfiles. Coordenadas de la ciudad referidas al meridiano de Madrid (E $5^{\circ} 33^{\prime} / \mathrm{N}$ $42^{\circ} 7^{\prime}$ ). Orografía por sombreado. Relación de las principales calles, puertas, fuentes y edificios de la ciudad indicados por clave alfabética. Nota explicativa sobre la situación geográfica, número de casas y habitantes, producción, estado de defensa e historia de Berga. Iluminado en varios colores. Las plantas de los fuertes aparecen numeradas, correspondiéndose dicha numeración a la reflejada en el documento: "Plano topográfico de Berga y de los fuertes que la circuyen" de sign. SGE-Ar.FT.7-C.2-200.

Autores: Joaquín Ruiz de Porras, Luis de Velasco, Ramón Soriano.

Ejemplares: Archivo Cartográfico de Estudios Geográficos del Centro Geográfico del Ejército Ubicación: AR - Signatura: Ar.F-T.7-C.2-201 - Código de barras: 2207832.

\section{Plano 4}

Título: Plano de la villa de Berga, su castillo y fuertes esteriores conforme se hallaba el 4 de Julio de 1840, día en que fue tomada a los carlistas, por el Egercito espedicionario del Norte [Mapa] / Berga 7 de Julio de 1840. Por el adicto al Cuerpo de E.M Joaqn. de Zayas y Vega.

Publicación: 1840.

Descripción física: 1 map.: ms., col., montado sobre tela ; 47,9 x 64,4 cm.

Notas: Firmado y rubricado por el autor. Escala gráfica de 1500 varas castellanas [ $=12,6 \mathrm{~cm}]$. Orientado al norte con flecha. Orografía por curvas de configuración y sombreado. Indica las fortificaciones de los arrabales de la ciudad, así como de susalrededores en una distancia aproximada de 1,5 kilómetros. Iluminado en varios colores. Figura el sello estampado de: “Ejercitos Reunidos. Estado Mayor General".

Fig. 172. Plano 4. Plano de la villa de Berga y fuertes exteriores conforme se hallaba el 4 de julio de 1840 , día en que fue tomada por los carlistas.

Autores: Joaquín de Zayas y Vega.

Ejemplares: Archivo Cartográfico de Estudios Geográficos del Centro Geográfico del Ejército Ubicación: AR - Signatura: Ar.F-T.7-C.2-202 - Código de barras: 2207835.

\section{Plano 5}

Título: Plano topográfico de Berga y de los fuertes que la circuyen [Mapa] / Ramón Soriano, Ladislao de Vilano, Joaquin Ruiz de Porras.

Publicación: 1840.

Descripción física: 1 map.: ms., col., montado sobre tela ; 41,4 x 51,2 cm.

Notas: Presenta el perímetro de la ciudad de Berga, y su castillo y parte del terreno adyacente, hasta una distancia aproximada de $2 \mathrm{~km}$. Fechado en: "Berga 28 de Julio de 1840". Firmado y rubricado por los autores. Escala gráfica de 300 pies $[=11,6 \mathrm{~cm}]$. Orientado con flecha. Orografía por normales, curvas de configuración y sombreado, reflejando el nombre de las sierras que la circundan. Señala los caminos que parten de la población. Tabla de signos convencionales para indicar la primera y segunda posición de ataque, situación de la caballería de ambos ejércitos contingentes, localización de la 1a. compañía de pontoneros y de las tropas enemigas en retirada. En nota: "Los detalles de la plaza, castillo y fuertes estan en el 2o. plano adjunto, bajo los mismos numeros", que corresponde al documento: "Plano de la Villa de Berga y fuertes exteriores", de sign. SGE-Ar.F-T.7-C.2-201. Se inscribe dentro de la primera guerra carlista o guerra de los Siete Años (1833-1840). Iluminado en varios colores.
Fig. 173. Plano 5. Plano topográfico de Berga.

Fig. 174. (Pág. siguiente) Plano 3 y detalle. Plano de la villa de Berga y fuertes exteriores.

Autores: Ramón Soriano, Ladislao de Vilano, Joaquín Ruiz de Porras.

Ejemplares: Archivo Cartográfico de Estudios Geográficos del Centro Geográfico del Ejército Ubicación: AR - Signatura: Ar.F-T.7-C.2-200 - Código de barras: 2207833. 


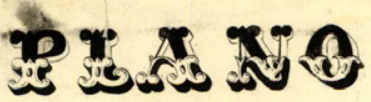

de la brilla de socrad y fuertes esteriones.

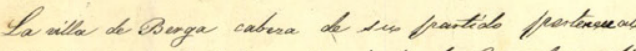

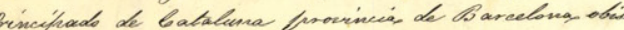

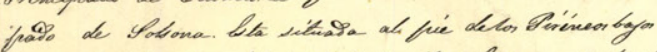

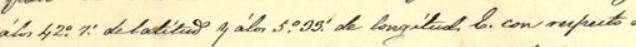

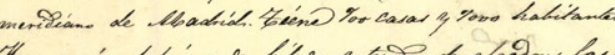

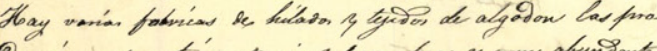

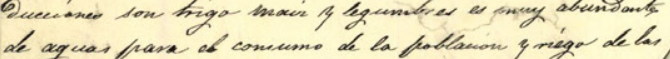

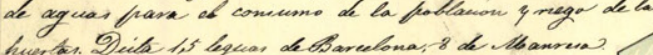

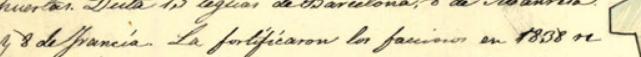

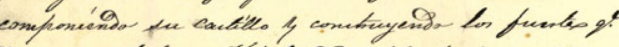

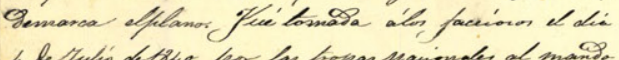

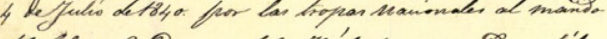

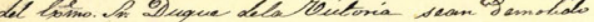

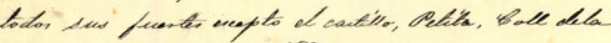

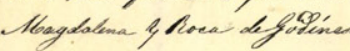

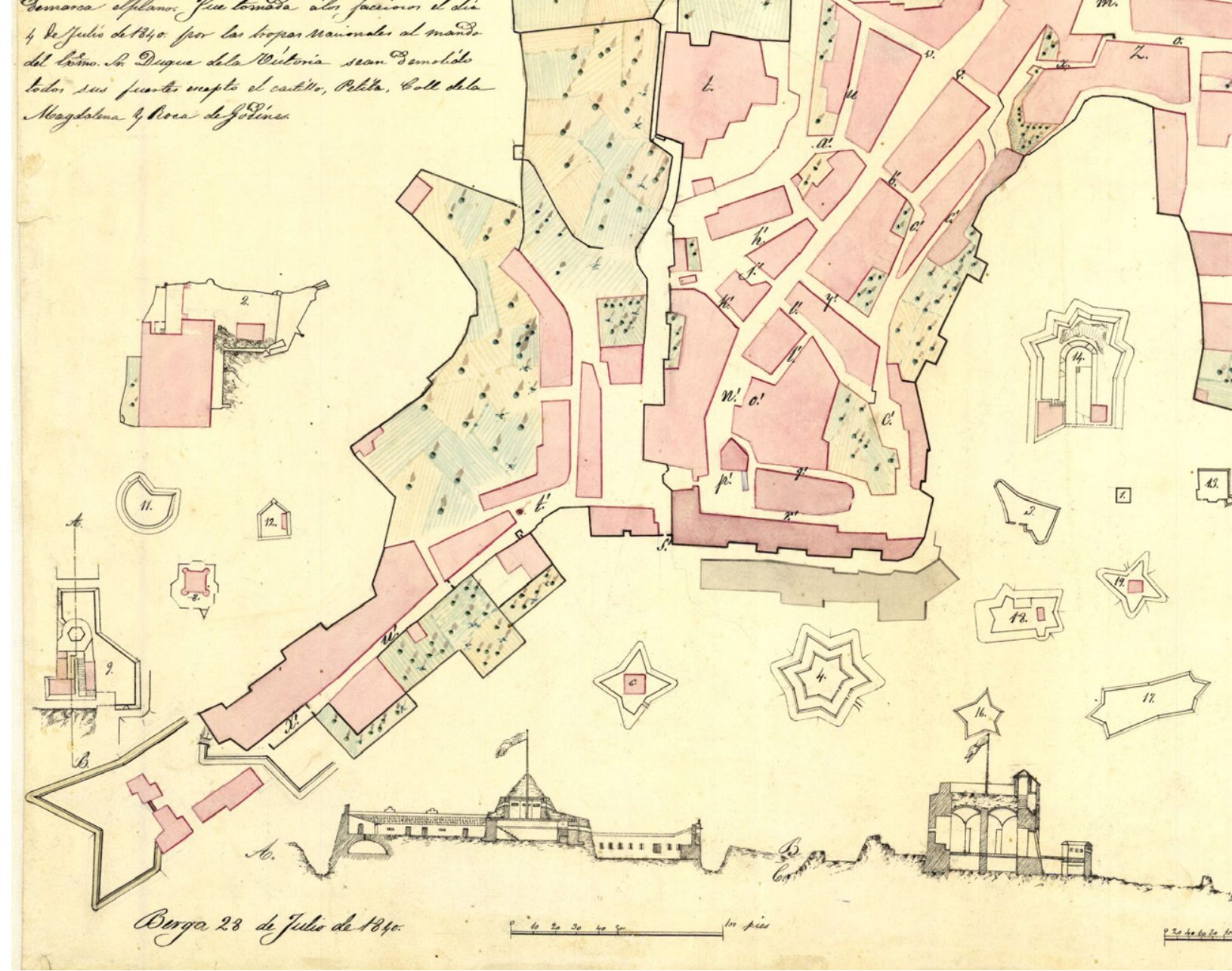

LA FORTIFICACIÓN DEL “Rf

a. Puenta de Pimanin b. Sumbatal barcis L Calle de rimanio ... Callepm de Caravarat

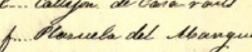
g. balle de bamals h. S"e barlo

4. Toure deles ho

j. Slanes wa

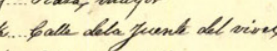
4 balt dell yolf

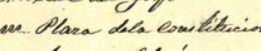
ne treses slani O. balle mueva p. balle de bomigo 9.. bath de Gaturthen. 2. bumentenis. S... bementani:

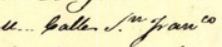
1... Geatro equinas. 2. Lle vat

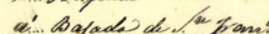
L" ballin an for

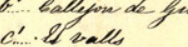
din. Vall dab studio e' Oosfoda de Gitanes. fiballe ale Cumenteri: g'. Ouarta del Comonterik' balle del Horm

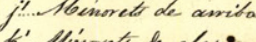
h' clisionats bs atajo. min valles de atofo n' Slascula dia lleveses o.' Bonvento dela deerses fe'. Furente nuevire. 9'. Vall de aurita "' Wall 2 aboge 1! Ruerta dala baña

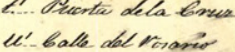
2" Puerta del rovan 20.03 $\sqrt{15}\}$

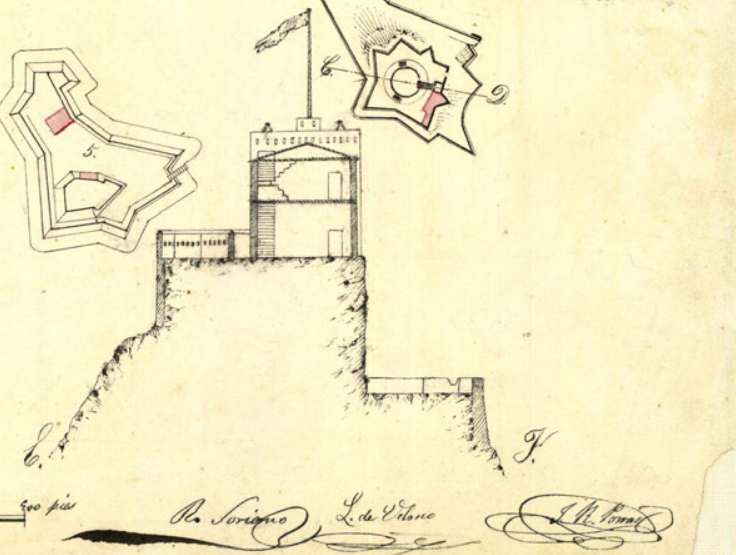

cortas de Pemasnin

b... Buerta dal bartilles

c. Mglecía feanoquial

L bate de Píneasnia

C... Callepor de lase ravib

forsancela del Manquadt.

q balle de lo anats

2., Sum baslos

q. Torre delar horras

j. Slaray mayor

ka. Falle dela priente all vivel

6...balle dét folfo

us Plara dala esontitucion

ex...tres of Glares

o. Galle nueva

pa balle de Bomiga

A c...balle de fatuellas

25... Sherda dat Comenteris

P. besmentemis

t... St. Tran."

Le... Balle Lin fraseco

1. Scceatio enquimas

2... Se trats

2... Hoophital

a'... Bayada de In joun:

b' ballejion de finco

c.... L valls

d'." vall dab estudio

e'. Bofada de fillanas. f'B Balle dal Cemsenteri: g'. Suenta del Cemanterio la' Galle det Hormo

j". Heinoret de cimita

h'. lesinorets be atajo.

l'.. ballyon de din fuan

mi. Vatles de atajo

n' Blanesala déa dieverd

o' bouvento dela dieries

fe'. Huente nuvera.

q'.. Vall de arriba

t' vall de aboge

$\therefore$ Suenta dela baña

L'. Puortic dela Gmu

ll'- balle del Nrisamo

X'" Puerla del Noraño 


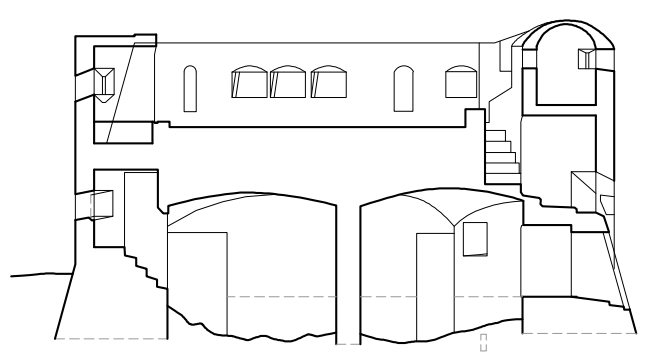

$\underbrace{1: 250}$

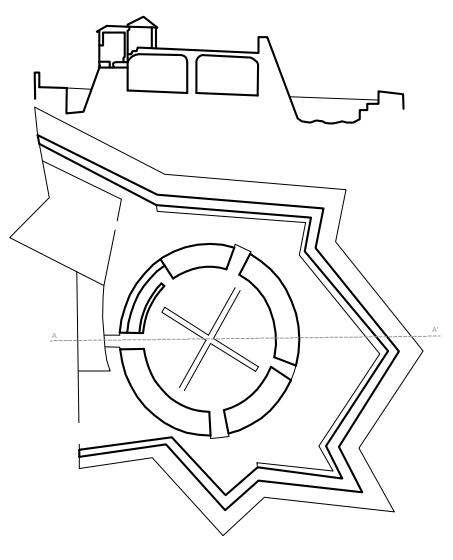

$\stackrel{E 1: 750}{\longrightarrow} 5 \mathrm{~m} Q$

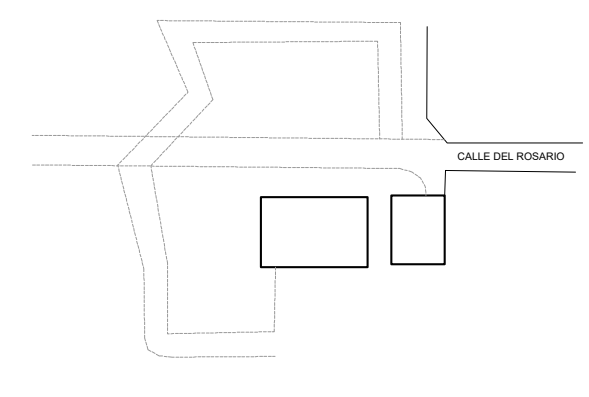

Fig. 175. Sección de la fortaleza de María Luisa Fernanda, conocida como torre de la Petita, a partir del plano de Corominas de 1976.

Fig. 176. Planta y sección de la torre y foso de la fortaleza de María Luisa Fernanda, conocida como torre de la Petita, construidos en julio de 1840 . 

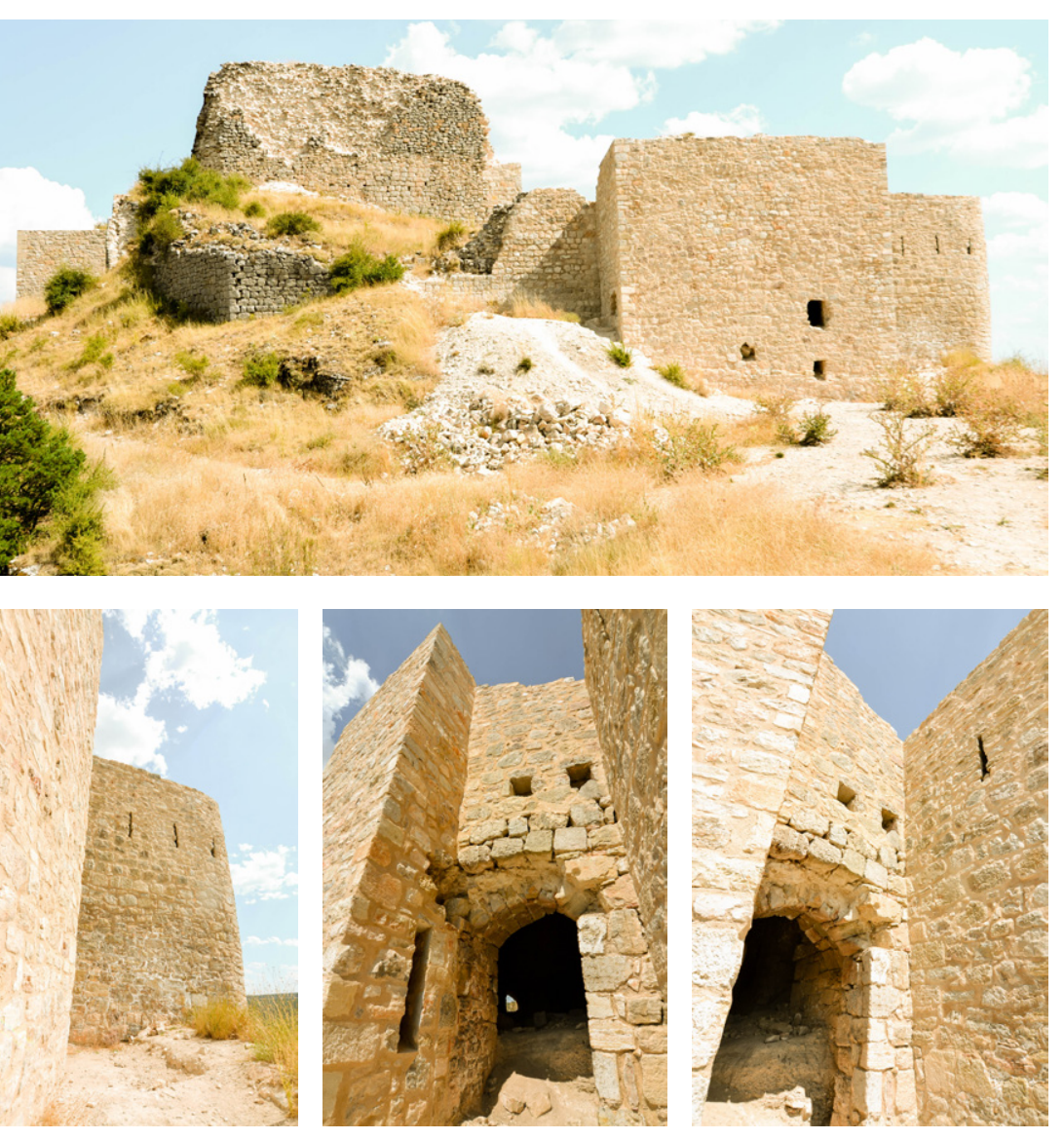

Fig. 181. Frente norte del fuerte.

Figs. 182, 183, 184. Acceso entre aspilleras orientado al noroest.

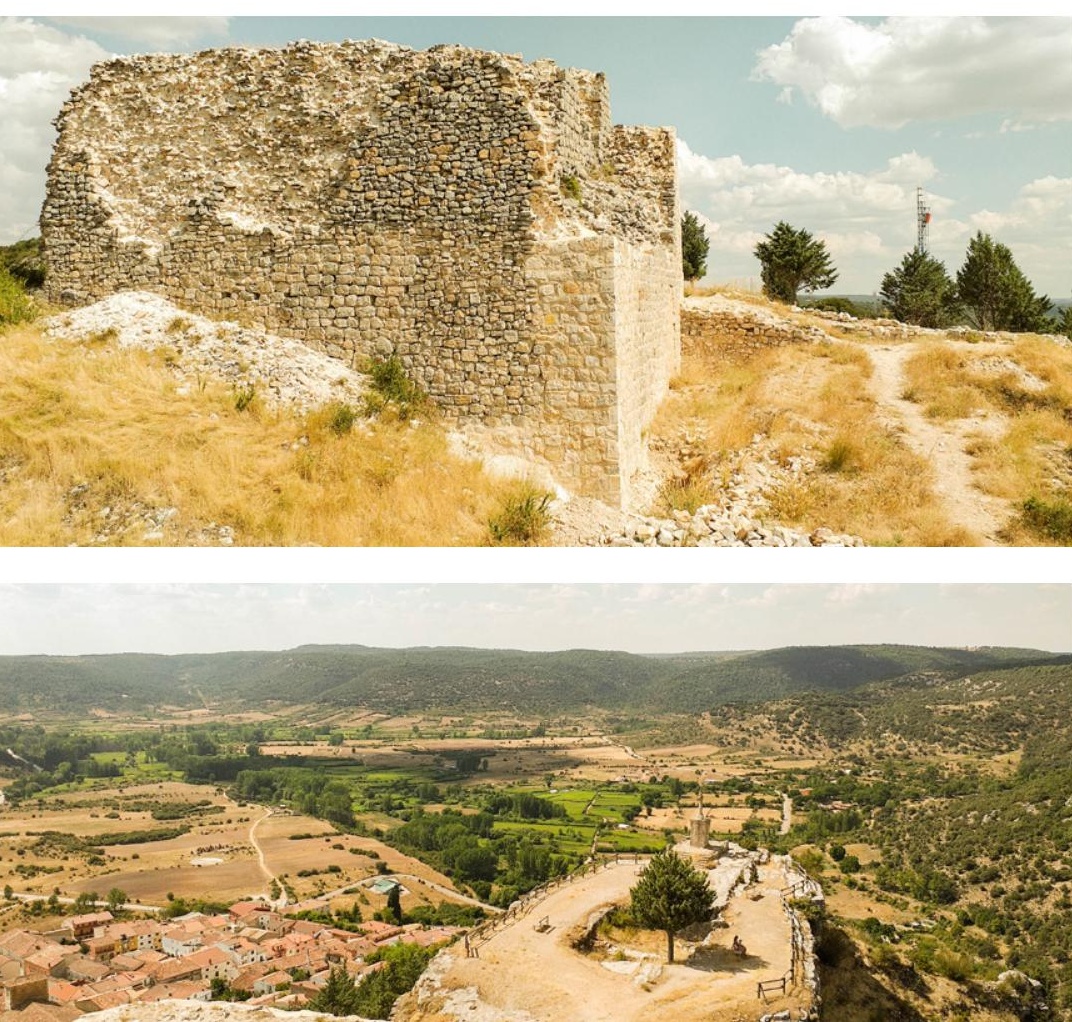

Fig. 185. Restos del cuerpo más elevado del fuerte.

Fig. 186. Vista desde el punto más elevado del fuerte. Se

aprecia su predominio sobre el paisaje. acceder a Madrid y bloquearla. Cañete y Beteta son el refugio de las columnas y partidas que operan a mucha distancia alrededor, cobran impuestos, atacan por sorpresa, y si son perseguidos por fuerzas a las que no pueden hacer frente, se apresuran en guarecerse en estos fuertes. El gobierno liberal está en tal estado de alerta a acusa de estas plazas que intenta por todos los medios recuperarlas (Pirala, 1868: tomo V, 278).

El 30 de abril de 1840 se notifica en prensa que Beteta y Cañete están bloqueados y que "dicen los de Ademuz que se oye fuego de cañón" (López Marín, 2014: 8). Se sabe que, a raíz de la recuperación de Cabrera tras su convalecencia, se oficia un Te Deum en la iglesia de Cañete y se disparan salvas artilleras en Beteta (López Marín, 2014: 385).

Según Calbo y Rochina, mientras las fuerzas de Cabrera destruyen toda fortificación o edificio que pudiera servir a las tropas liberales, como en Talayuelas, donde se derriba la posada y la Iglesia, o en Caudete, donde se derriba la iglesia y una manzana de casas, intensifica la fortificación de Beteta "empleando mas de 2000 paisanos y 800 caballerías, habiendo logrado abastecer el fuerte de todo lo necesario para una obstinada defensa, y guarnecer sus torreones con 4 piezas de artillerín. Prevaliéndose además de tener bajo su dominación las fábricas de vidrio del Recuenco y Vindel, las utilizaron para hacer granadas y consiguieron tener un inmenso depósito de estos proyectiles" (Calbo y Rochina, 1845:483).

El mes de junio de 1840, tras los meses en los que se desmorona la línea defensiva carlista, el fuerte de Beteta es tomado por los liberales (Córdoba, 1844-1846: v4, 330; Caridad, 2013: 266).

En la actualidad, el fuerte de Beteta, también llamado de Rochafrida, se encuentra en estado de ruina consolidada, habiéndose intervenido en 2017 en la consolidación y reparación de algunos frentes. Se conserva gran parte de los muros que cierran el recinto, de planta poligonal. La torre del homenaje del siglo XIII conserva una de sus bovedas interiores y se puede uno imaginar facilmente su volumen. Los fosos medievales se aprecian todavía y se conserva parte de la coracha, que acaba en un espolón. También en la población existen restos de muralla.
Fig. 187. Aspilleras horizontales en el frente sureste, cuyos muros son reparados por los carlistas,

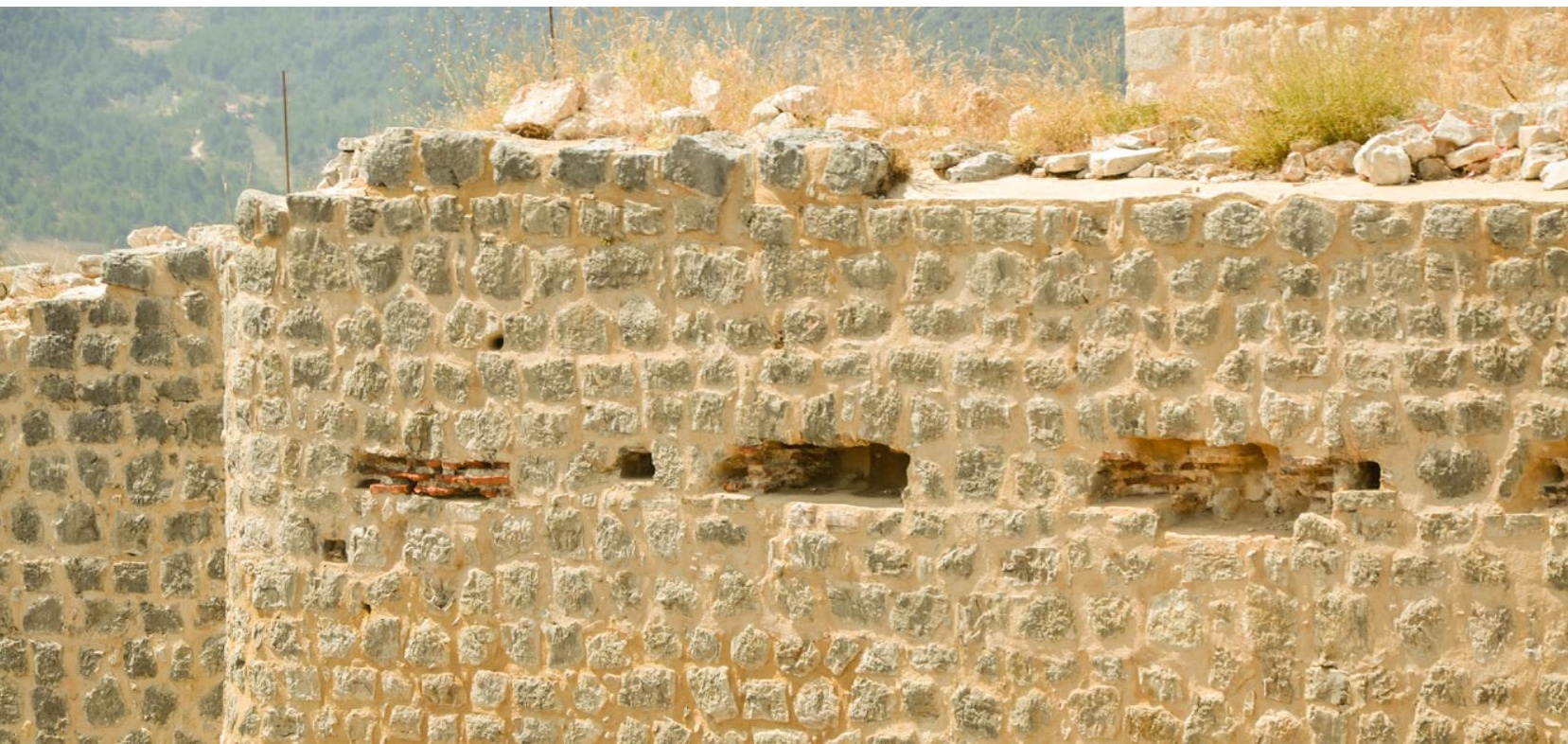




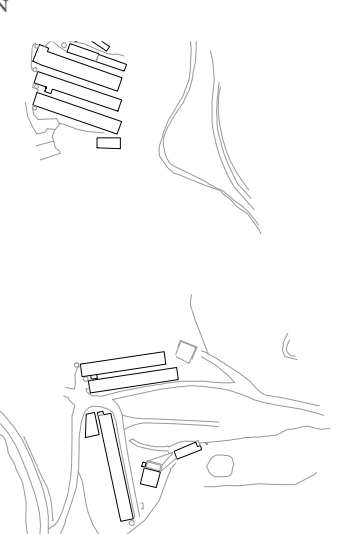

甲

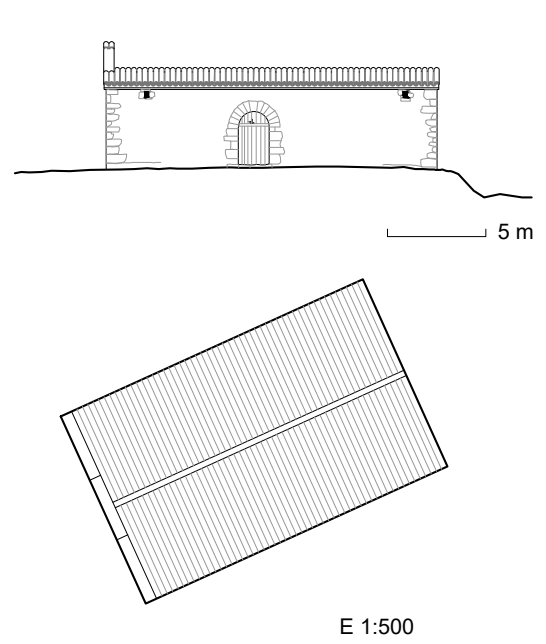

Fig. 195. Planta de emplazamiento de la ermita del Calvario de Bordón.

01. Ermita del Calvario 02. Iglesia de la Virgen de la Carrasca

Fig. 196. Esquema en planta y alzado longitudinal de la ermita del Calvario de Bordón.

\section{CaLANA $^{*}$}




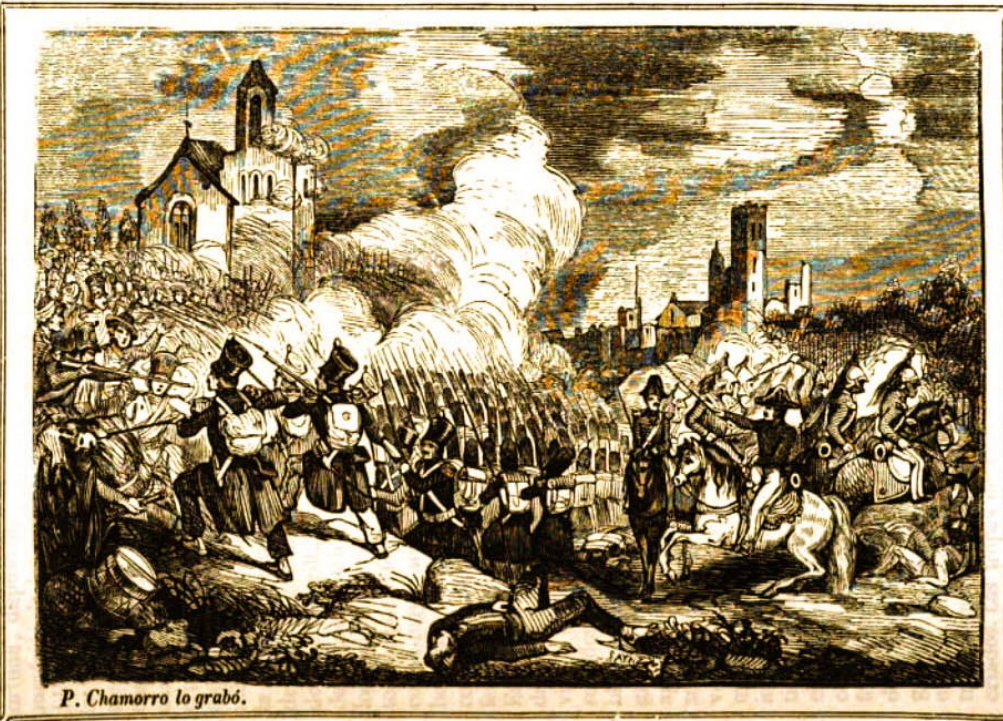

Fig. 200. Ilustración 1

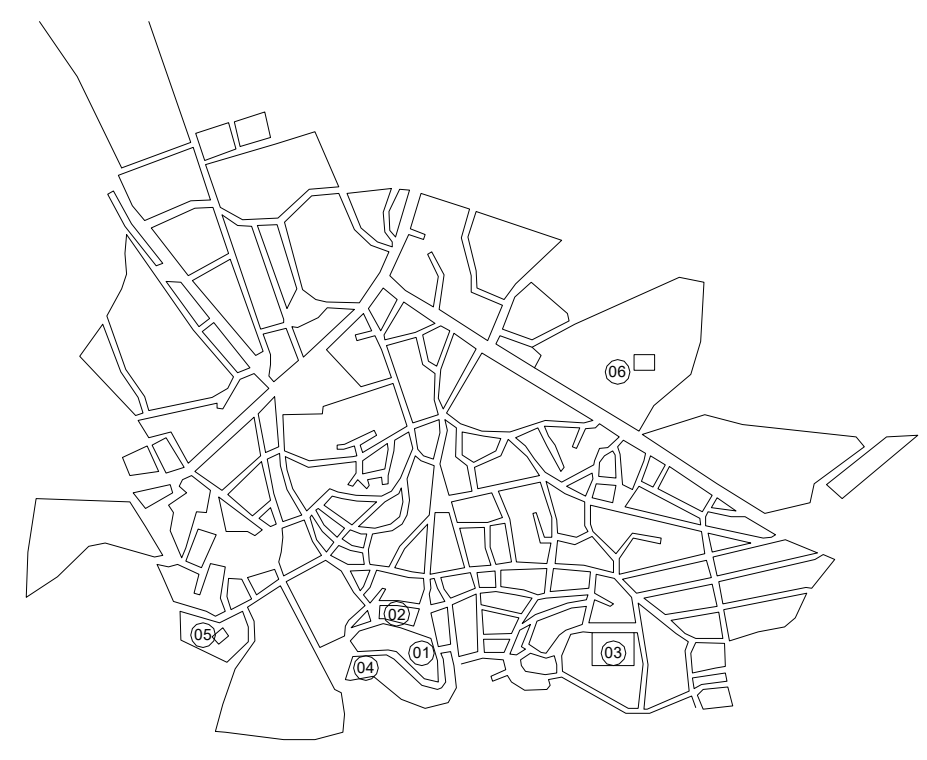

Fig. 201. Esquema en planta de Calanda en la actualidad con los puntos de interés defensivo. 01. Ruinas del castillo. 02. Iglesia

03. Convento de Capuchinos

04. Ermita en Calle de las Torre

05. Ermita de Santa Águeda

06. Ermita de Santa Bárbara 
Fig. 208. Cantavieja y su dominio sobre el valle.

Fig. 209. Frente oeste de la población, amurallado, y del castillo de origen templario.

Fig. 210. Frente este del castillo y su muralla, completamente aspillerado.
Cantavieja

Provincia actual: Terue

Comarca: Maestrazgo

Coordenadas geográficas: $40.52957923938811,-0.4047161749413135$

Datos históricos:

Guarnición 1839-1840: 500

Inicio bombardeo liberal:

Rendición o abandono: -

Días de resistencia:

Fuente: Caridad, 2013: 263

Tipos defensivos: castillo reforzado que domina la población, castillo en casco urbano reforzado, fortificación de calvarios, muralla urbana, hospitales, cárceles, batería / plataforma artillera, maestranza.

Acciones y fortificación:

En 1836, Cabrera fija su atención en Cantavieja con el objeto de convertirla en plaza fuerte del carlismo en la región. "Cabrera [...] sabe que trataban los liberales de fortificar á Cantavieja, y manda á Quilez se dirija á Aragón, á Forcadell á la Cenia y á Llangostera á Beceite, y él con ocho hombres solamente, corre á reconocer escrupulosamente aquel punto.

Convencido por sus propios ojos de lo que le importaba anticiparse al proyecto de sus adversarios, y creyéndose con fuerzas suficientes para ejecutarle por sí, lo puso al punto por obra, y en pocos dias acopia materiales, reune operarios y víveres: las compañías protejen los trabajos, partidas sueltas hacen cumplir en los pueblos inmediatos las órdenes de Cabrera; él mismo dirige é impulsa las obras, y fijando el plazo de quince dias para su término, marcha á la Cenia [...].

in de Cantavieja, que era por entonces su sueño dorado; porque, con las porque, con las fuerzas que ya mandaba, creia de indispensable necesidad una plaza fuerte, un punto siquiera de apoyo seguro para sus operaciones, y donde tener tranquilos los almacenes y hospitales" (Pirala, 1869: tomo III, 126) "Es pueblo cercado de antiguas murallas. [...] [Las ventajas de su ocupación] no pasaban desapercibidas á Cabrera, y por eso fortificándola mas de lo que naturalmente estaba, añadiendo alguna que otra defensa y reparo á sus antiguas murallas, puso la villa en regular estado no de resistir un sitio continuado, ó un ataque decidido de fuerzas muy superiores, pero sí en el caso de poder defenderla de un golpe de mano y de que sirviese de refugio mas cómodo que los barrancos y cuevas de los Puertos. La situación de Cantavieja, casi en el centro del pais que principalmente era el teatro de las operaciones de Cabrera, influia muchísimo para que este caudillo situándose en ella estuviese como en medio de un círculo pronto á poder trasladarse adonde su presentica fuese necesaria y regresar á dirigir en la poblacion los trabajos que con tanto ainco tenia empezados. Esperaba fuese necesaria y regresar á dirigir en la poblacion los trabajos que con tanto ainco tenia empezados. Esperaba
ademas Cabrera que una vez atacados los pequeños fuertes (que aun estaban ocupados por las tropas de la Reina) con elementos mas á propósito para conseguir mejor écsito que hasta entonces habia obtenido, llegaria á señorearse completamente en el pais" (Calbo y Rochina, 1845: 191).

Cantavieja hace las funciones de gran centro carlista donde Cabrera activa almacenes de víveres, hospitales, una fábrica de armas y munición, con abastecimiento de salitre, azufre y plomo, así como garantiza el acopio de vestuario y calzado (Córdoba, 1844-1846: vill 30-37) . La maestranza de tillería fabica los primeros cañ piezas del 4 no muy precisas, como tambien las primeros cañones del 8 que coronan las defensas de Cantavieja. Cabrera agiliza la puesta en marcha de un centro de formación de artilleros, a cargo del capitán graduado de artillería Luis Soler. 

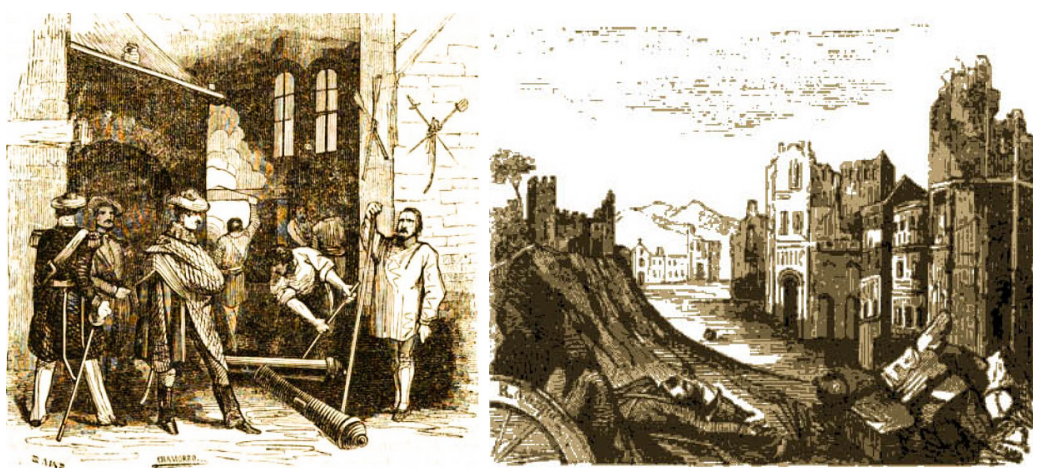

Fig. 223. Ilustración 1. Maes-

tranza establecida por los

Carlistas.

Fig. 224. Ilustración 4. Ruinas de Cantavieja.

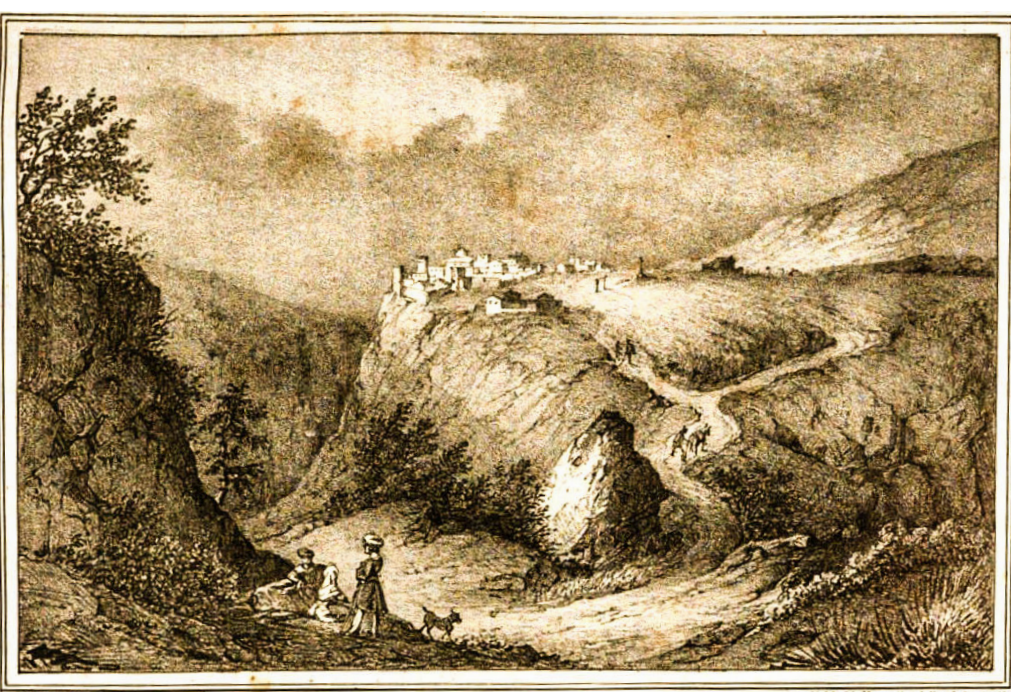

Fig. 225. Ilustración 2. Vista de Cantavieja desde el camino de Mirambel.

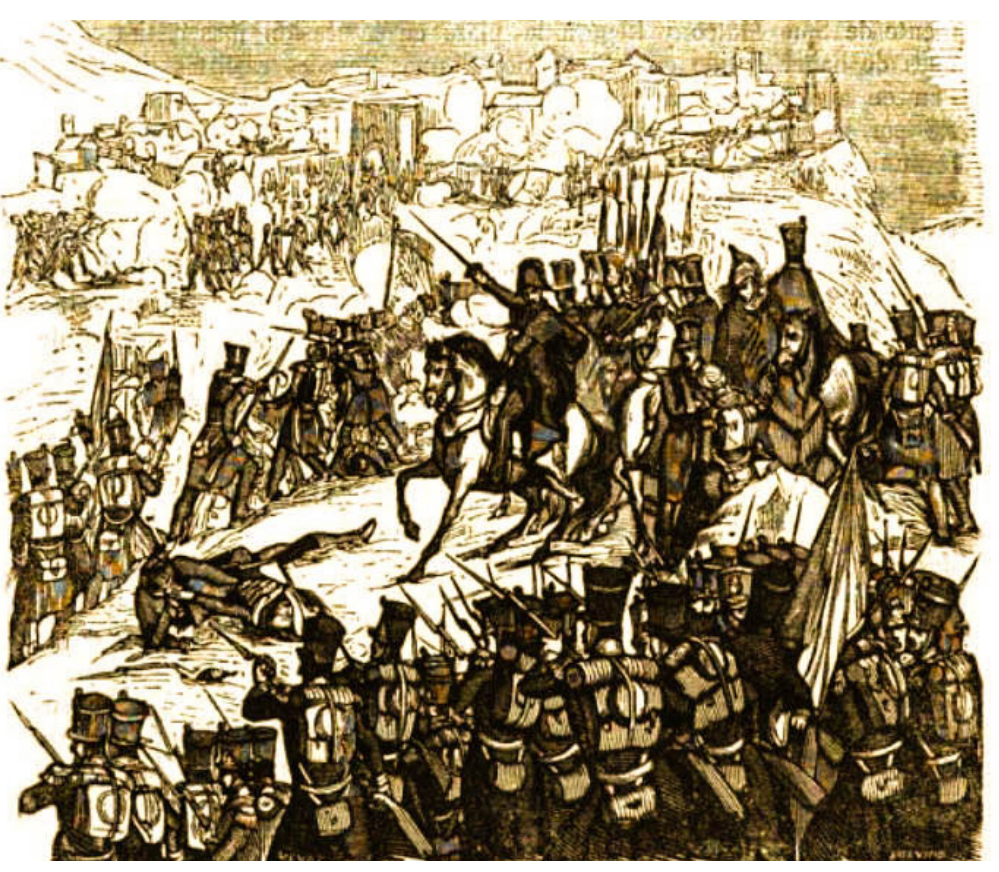

Fuerte de San Blas: está emplazado en las afueras, en lo alto de un cerro junto al depósito de aguas municipal, en ruinas. En 1836, al inicio del conflicto, los carlistas derriban la ermita de San Blas. Al estar ubicada próxima a las murallas, alrededor de $500 \mathrm{~m}$, la ermita es un obstáculo y ocupa un emplazamiento privilegiado para controlar los accesos desde La Iglesuela Mosqueruela o Fortanete y . planta de trazado semicircular con cinco torretas que dominan los puntos cardinales, con capacidad cada una para tres cañoneras. Los muros son de mampostería y un grosor de $40 \mathrm{~cm}$. El acceso al fuerte se emplaza en el norte, en la espalda, para facilitar la huida de la guarnición hacia el núcleo urbano. El fuerte es asediado por el general San Miguel a finales de octubre de 1836. El brigadier Nogueras lo toma apoyado por un grupo de tiradores ante la desbandada de la guarnición a poco de iniciarse el asedio. Tomada Cantavieja por los liberales, el fuerte sigue activo y se construyen dos estancias en el interior como cuerpo de guardia. El 26 de abril de 1837, cuando la población es recuperada por los carlistas gracias a varios vecinos que facilitan la entrada a varios guerrilleros que sorprenden a la guarnición, algunos liberales se refugian en este fuerte y capitulan a cambio del respeto a sus vidas. El fuerte aloja una pequeña guarnición artillera que recibe con salvas de honor al pretendiente en la Expedición Real en julio de 1837. Cuando Cantavieja es ocupada definitivamente, la guarnición se instala en el pueblo, por lo que el fuerte queda desocupado.

En cuanto a su uso en la Tercera Guerra Carlista, disponemos de unos datos cedidos por Antonio Caridad, quien se encuentra en estos momentos investigando el tema. Hay constancia de que el fuerte de San Blas fue reconstruido por los carlistas (Las Provincias, 2 de febrero de 1875), quienes atrincheran el cerro, en el que también constuyen murallas y fosos (Diario Mercantil de Valencia, 1 de marzo de 1875), haciendo trabajar en las obras a prisioneros (Diario Mercantil de Valencia 5 de marzo de 1875. Las Provincias, 4 de marzo de 1875). En la prensa se cita que el cerro de San Blas está atrincherado (Las Provincias, 1 de marzo de 1875) y se habla de un fuerte en San Blas, donde acaban las trincheras (Las Provincias, 1 de abril de 1875). Hoy pervive una estructura en forma de $\mathrm{u}$, abierta hacia el norte, de la cual se conservan muros de mampostería, requiriéndose una excavación arqueológica para determinar el perímetro exacto. Solo quedan las ruinas de dos de los cinco torreones. En el interior del recinto se observa la base de dos construcciones, posiblemente el cuerpo de guardia. La de mayor dimensión en la parte occidental. La menor, con dos estancias, en la parte oriental. En el sur del fuerte perviven restos de muralla semienterrados y la base de un segundo muro de $50 \mathrm{~cm}$ de espesor paralelo a la muralla, y que confluye con ella a la altura del segundo torreón conservado. Muchos materiales son reutilizados para la reparación y ejecución de campos de cultivo. Del Romero, Sánchez y Mallén cifran la extensión del fuerte en $5600 \mathrm{~m} 2$, lo cual, a su criterio, hace difícil la construcción del fuerte desde el momento en que Cabrera se plantea la fortificación de Cantavieja, en abril de 1836, hasta la primera toma liberal, seis meses después, cuando los ocupantes testimonian que ambos fuertes están operativos. Así, se esgrime que este fuerte podría ser anterior a las guerras carlistas, o que fuese ampliado a partir de una preexistencia, un fortín o puesto de vigilancia reforzado con muros y baluartes para la artillería (Del Romero et altr., 2010:22-23). En cualquier caso, otros fuertes como los de los puertos de Beceite, de similar volumen y complejidad constructiva, son de nueva planta y las obras también duran seis meses.

Ilustraciones de la época:

Ilustración 1

Título a pie: Maestranza de Cantavieja establecida por los carlistas.

Fuente: Calbo y Rochina, 1845: 190

Ilustración 2

Título a pie: Vista de Cantavieja. Tomada desde el camino de ba a Mirambel. Fuente: Calbo y Rochina, 1845: 199

Ilustración 3

Título a pie: Toma de Cantavieja por el general D. Evaristo San Miguel.

Fuente: Calbo y Rochina, 1845: 254

Ilustración 4

Título a pie: Ruinas de Cantavieja.

Fuente: Calbo y Rochina, 1845: 260 

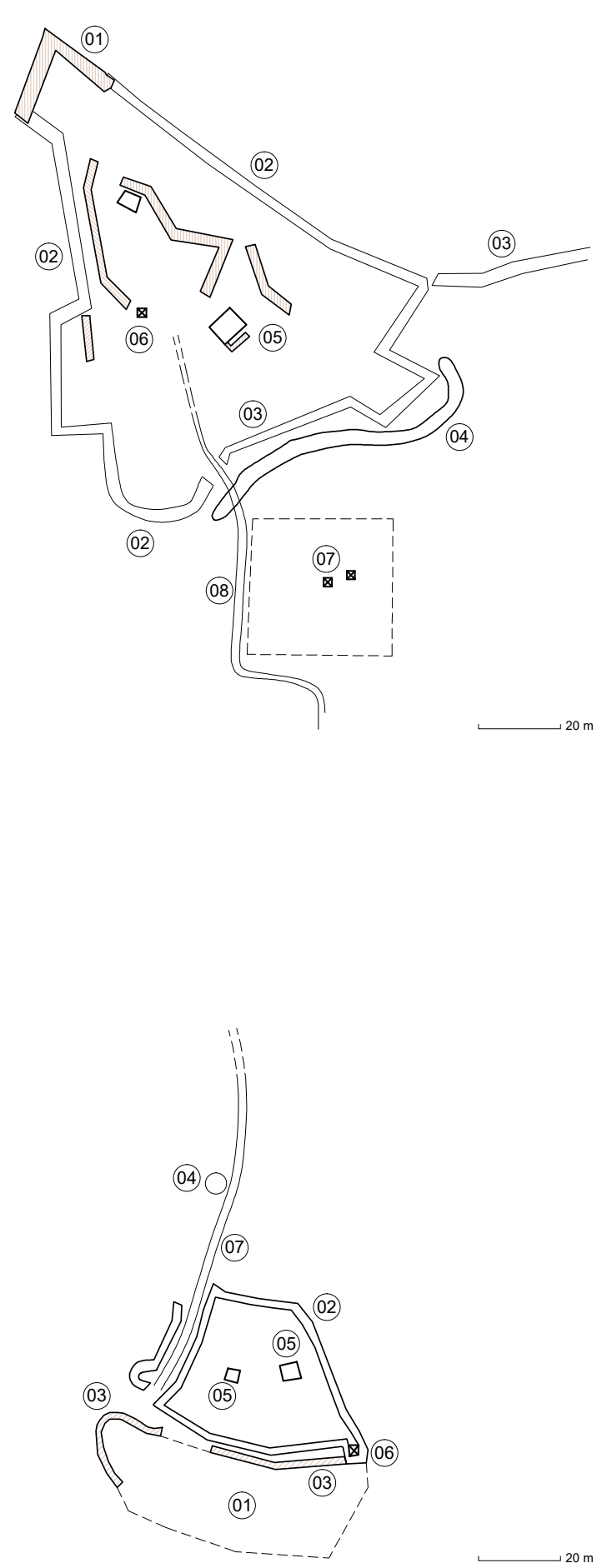

Fig. 228. Esquema en planta del fuerte de las Horcas en la actualidad, Cantavieja.

01. Trinchera visible

02. Posible escarpa

03. Trinchera antigua

04. Foso

05. Polvorín abovedado

Fig. 229. Esquema en planta del fuerte de San Blas en la actualidad, Cantavieja.

01. Campos

02. Posible escarpa

03. Trinchera antigua

04. Depósito de aguas

05. Construcción en ruinas

Cons
Fig. 227. Planta de Cantavieja en

08. Cuartel General

09. Fuerte de las Horca 
19 Cañada del Hơo

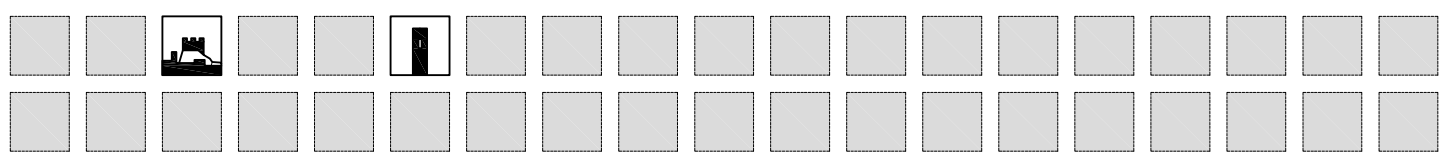




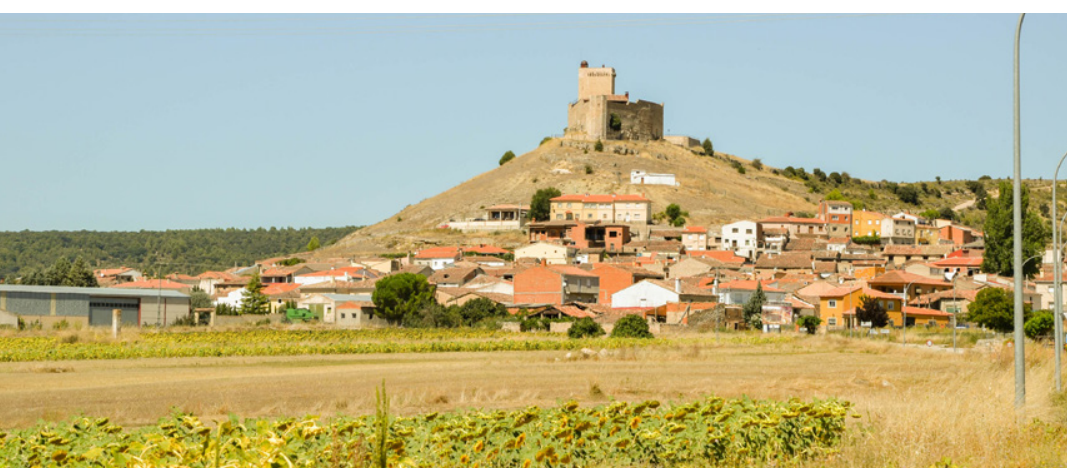

Fig. 230. Cañada del Hoyo y su castillo.
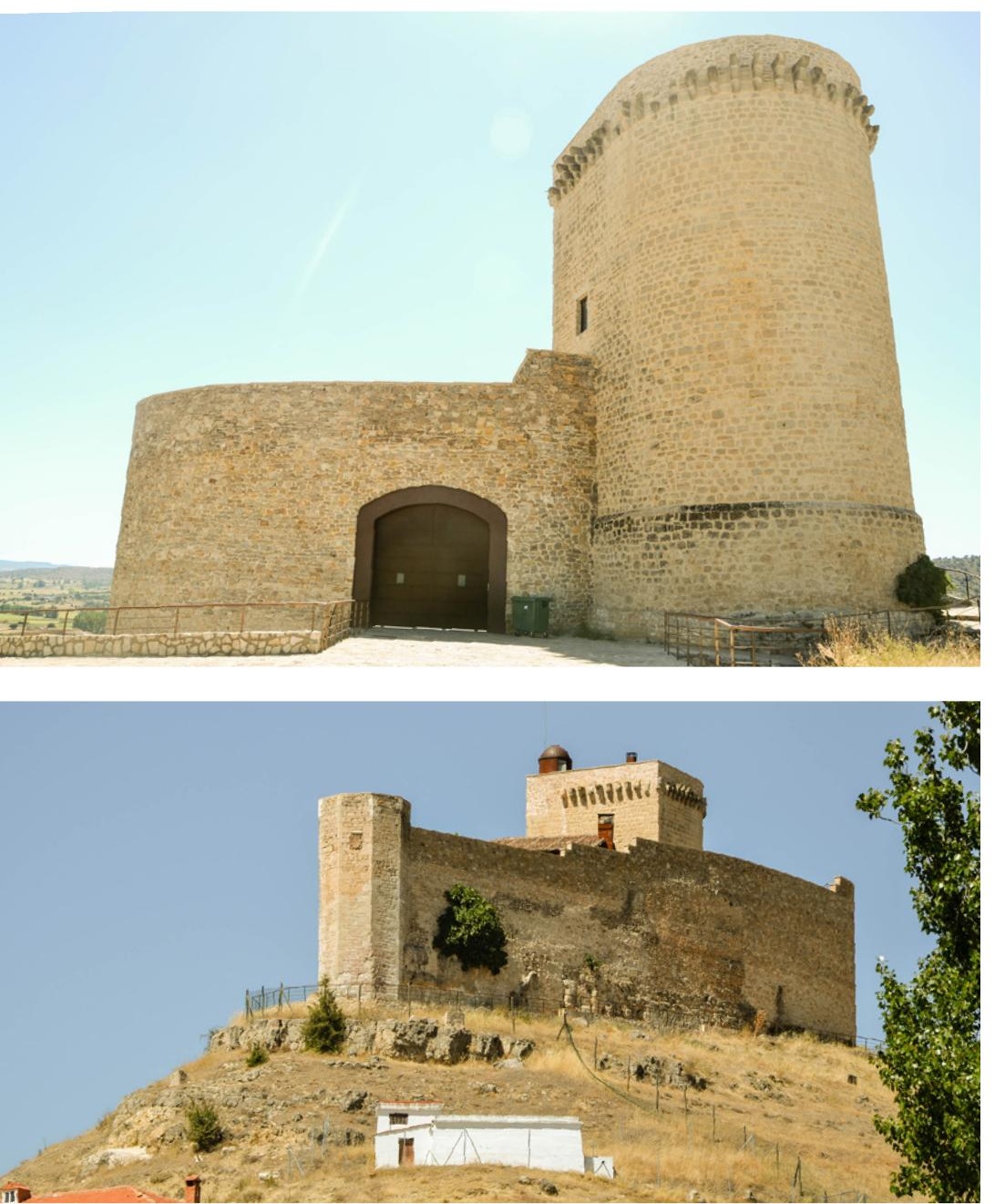

Fig. 231. Acceso al castillo, orientado a norte.

Fig. 232. Frente este del castillo los muros originales integrados en los recién construidos. donde se aprecian los restos de

\section{Cañada del Hoyo}

Provincia actual: Cuenca

Comarca: Serranía Baja

Coordenadas geográficas: 39.97073599153134, -1.901861473644857

Tipos defensivos: fuerte aislado, torre.

Acciones y fortificación:

En la primavera de 1839 se recoge en la prensa: "En Cañete y sus inmediaciones ha quedado alouna fuerza protegiendo la fortificación del pueblo, y si se les deja concluirla principian en seguida la del castillo de Cañada del Hoyo, distante cuatro leguas de esta ciudad, que está también acordada por Cabrera después de haberlo reconocido por sí mismo. Si lo consiguen tiene Moya que sucumbir por necesidad, y esta capital [Cuenca] corre peligro" (El Eco del comercio, 26 de mayo de 1839, $\left.\mathrm{n}^{\circ} 1.851, \mathrm{p} .4\right)$.

Ante la impunidad de los carlistas que se hacen fuertes en la zona, el Comandante en Jefe y Capitán General del Ejército Francisco de Narváez ordena la fortificación de Cañada del Hoyo, indicando: "A todos los habitantes de la provincia de Cuenca. He forzado a los enemigos a levantar el bloqueo de Moya: tamiento tenido lugar en Salinas del Manzano, a los pies de su castillo de la Magdalena; en el corto espacio de tiempo de ocho días, he levantado una fortificación sobre las ruinas del antiguo castillo de Cañada, capaz ya con una pequeña guarnición de resistir a las facciones unidas de Aragón. Con ella está defendida vuestra capital, la subsistencia del ejército asegurada. Por ello me marcho dejando ahora todo en el orden esperado. Francisco Narváez. Cuartel General de la Cañada. 13 de julio de 1839" (Romero Sáiz, 1993:60-61).

El 14 de julio, precisamente, se produce un enfrentamiento en Cañada del Hoyo, donde los carlistas son repelidos, quedando relegados a la posición de Cañete.

La población actual de Cañada del Hoyo se encuentra en una vega al pie del castillo medieval que perteneció al marqués de Villena y se convierte en el fuerte que es reforzado por los liberales en 1839. El castillo se conoce también como el Castillo del Buen Suceso o de los Hurtado de Mendoza. Presenta un trazado poligonal en planta, con una pequeña torre hexagonal perimetral y una gran torre del homenaje de traza rectangular que domina el conjunto. Surge primero como atalaya y punto de vigilancia en tiempos de árabes y musulmanes, para erigirse como castillo en el siglo XII, dada su posición fronteriza. Sufre una serie de transformaciones y refuerzos a lo largo de su historia hasta que en 1839 intervienen en él los liberales. En 2010 se efectúa una restauración "en estilo" que recompone estructuras desaparecidas, por parte de su propietaria actual, la cual lo destina a alquiler por días. Debido a ello, el castillo reconstruido no conserva huellas del conflicto carlista. 


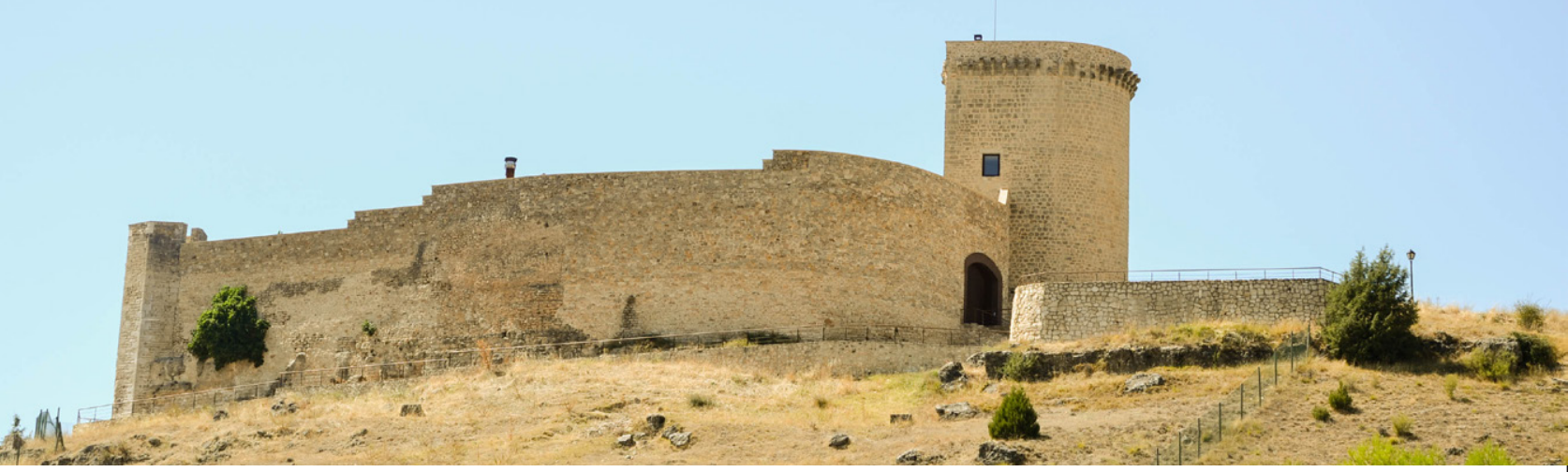

Fig. 233. Castillo visto desde el noreste. En la mitad izquierda s aprecian los restos de los muros originales, integrados en los recién construidos.

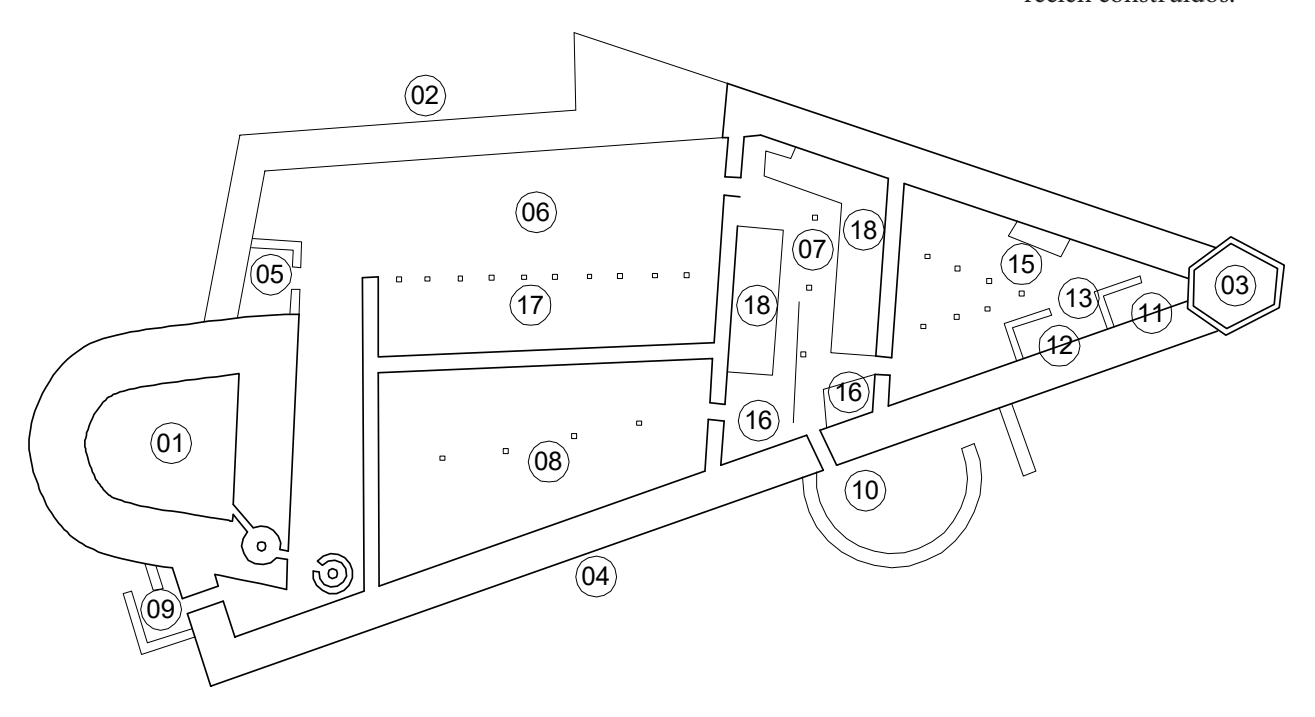



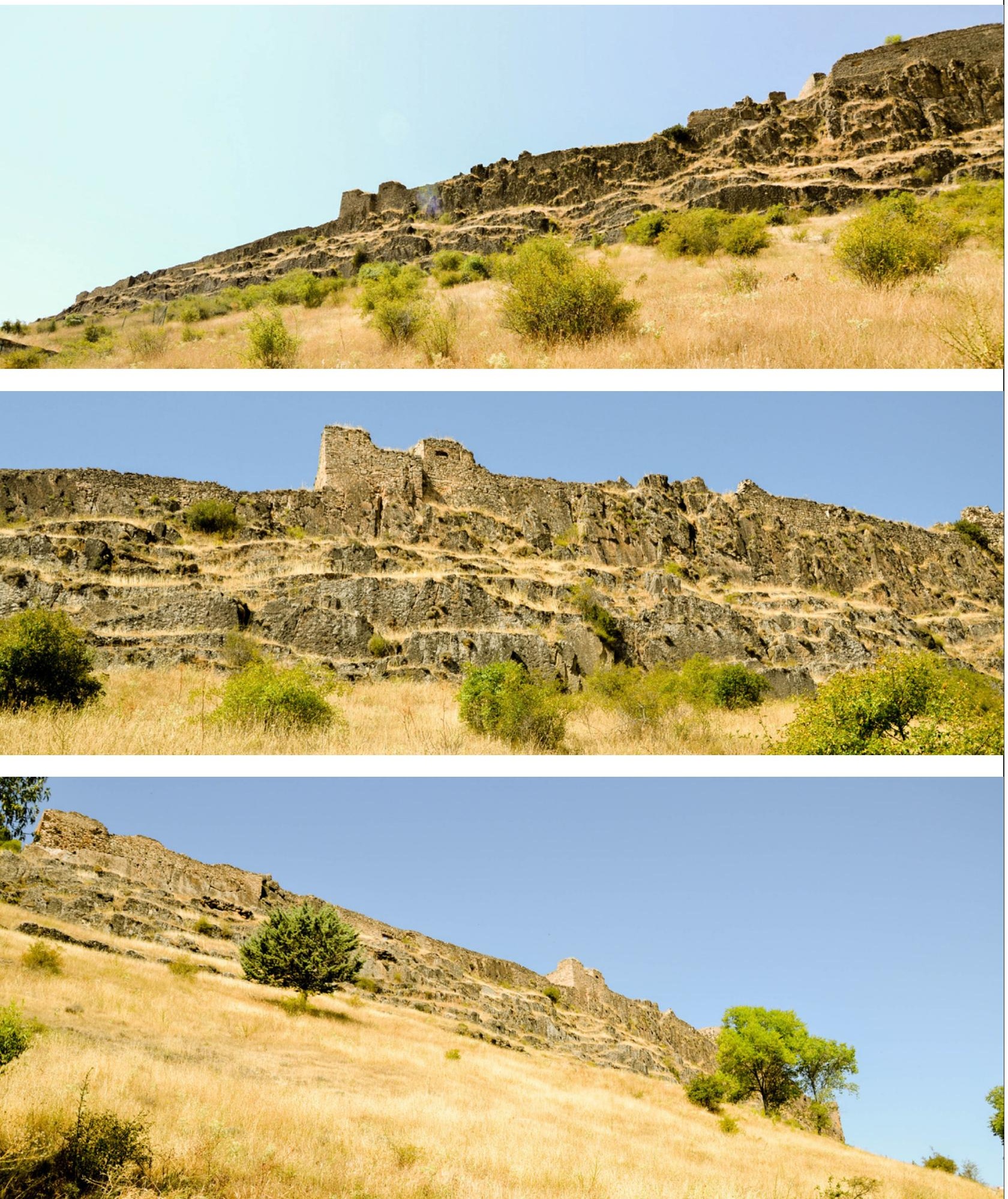

Provincia actual: Cuenca

Comarca: Serranía Baja

Coordenadas geográficas: $40.04164531950613,-1.6502585708938682$

Datos históricos:

Guarnición 1839-1840: 600. Solo la mitad estaban armados (Calbo, 1845:547). Según Von Goeben, serían 730 armados y 400 desarmados (Von Goeben, 1841:417).

Inicio bombardeo liberal: -

Rendición o abandono:

Días de resistencia:

Fuente: Calbo, 1845:547; Von Goeben, 1841:417

Tipos defensivos: castillo reforzado que domina la población, torre artillada adosada a muralla / tambor, muralla urbana.

\section{Acciones y fortificación:}

A raíz de la muerte de Tallada en marzo de 1838, Arnau se hace cargo del mando y organización de las tropas carlistas en Cuenca, creando a su vez la Brigada de Castilla. Ese mismo mes, Forcadell, con la brigada de Arnau, consigue ocupar Cañete e inicia la organización de la nueva posición carlista que debe darles el control del área del Cabriel en Castilla la Nueva. Se reorganiza el pueblo y se hace acopio de armamento, así como se destina una guarnición (Von Goeben, 1966: 266).

Cuando Cabrera se lanza en 1838 hacia Guadalajara, tras los enfrentamientos entre carlistas y liberales por las tomas de Montalbán y Segura, regresa por Cañete a la zona del Turia. Es a su paso por la plaza cuando el general valora sus cualidades estratégicas, entre el Turia, Alpuente y Bejís, y se marzo se han producido enfrentamientos entre carlistas y liberales en Santa Cruz de Moya, punto de conflicto que interrumpe la continuidad de las áreas controladas por Cabrera, ante la presencia del castillo liberal de Moya. Cabrera pretende en Cañete tener un punto de avanzada sobre el castillo, del mismo modo que Segura de los Baños es una avanzada en Aragón. Casi simultáneamente, Cabrera ordena fortificar también Beteta.

Un momento crítico en la zona liberal se produce cuando Cabrera y Forcadell unen sus fuerzas para saquear los alrededores, tratando de sorprender al ejército liberal de Iriarte y Valdés, emplazado en Motilla del Palancar. La expedición conjunta recorre desde Almodóvar del Pinar hasta Huélamo, Fuentes, Cañada del Hoyo y, precisamente, Cañete, donde confinan una guarnición cuya misión es defender la fortificación y concluirla. Tanto Moya como la propia Cuenca se sienten amenazadas. En la prensa de la época se recoge: “En Cañete y sus inmediaciones ha quedado alguna fuerza protegiendo

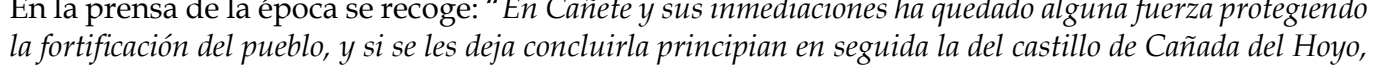
distante cuatro leguas de esta ciudad, que está también acordada por Cabrera después de haberlo reconocido por sí mismo. Si lo consiguen tiene Moya que sucumbir por necesidad, y esta capital [Cuenca] corre peligro" (El Eco del comercio, 26 de mayo de 1839, $\mathrm{n}^{\circ} 1.851, \mathrm{p} .4$ ).

El Diario Mercantil de Valencia de esas fechas (26 y 28 de mayo de 1839) recoge que la muralla de Cañete se ha empezado a reparar por 200 prisioneros de guerra y 600 paisanos de las poblaciones aledañas. Se indica que bajo el castillo se han excavado cuarteles, almacenes y cisternas a prueba de bombas (Von Goeben, 1966 (1841):422, 423; Caridad, 2013: 259). En julio de 1839 parece que se envía artillería a Alpuente, el Collado, Cañete y Chelva, cuyas obras podrían estar ya concluidas (Caridad, 2013:262). Cabrera y sus tropas pasan también por Cañete tras la victoria en Carboneras 


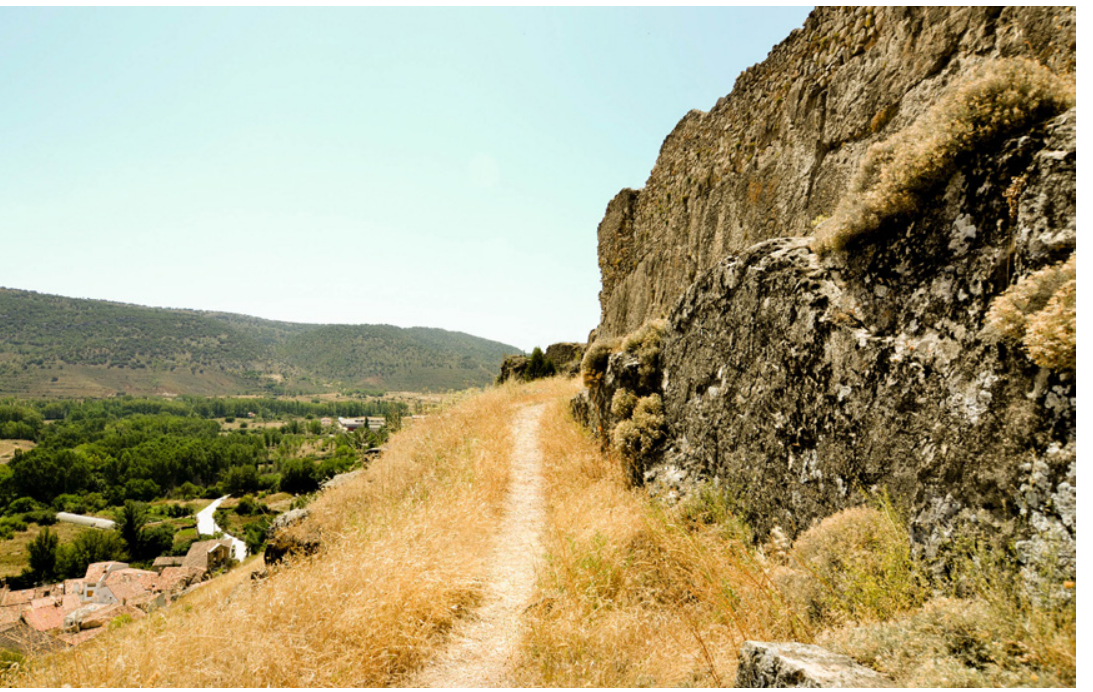

Fig. 238. Parte del frente este del castillo, por donde se produce ción. Fotografía hacia el sur.

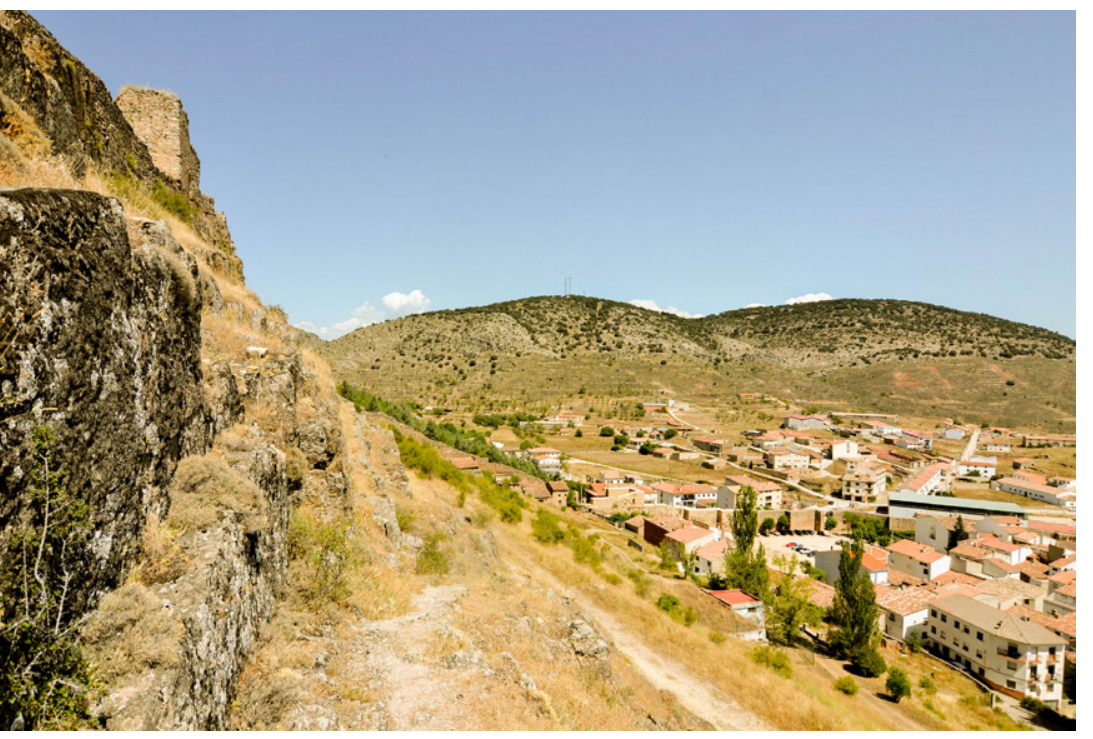

Fig. 239. Parte del frente este del castillo, por donde se produce el acceso, y relación con la población. Fotografía hacia el norte.

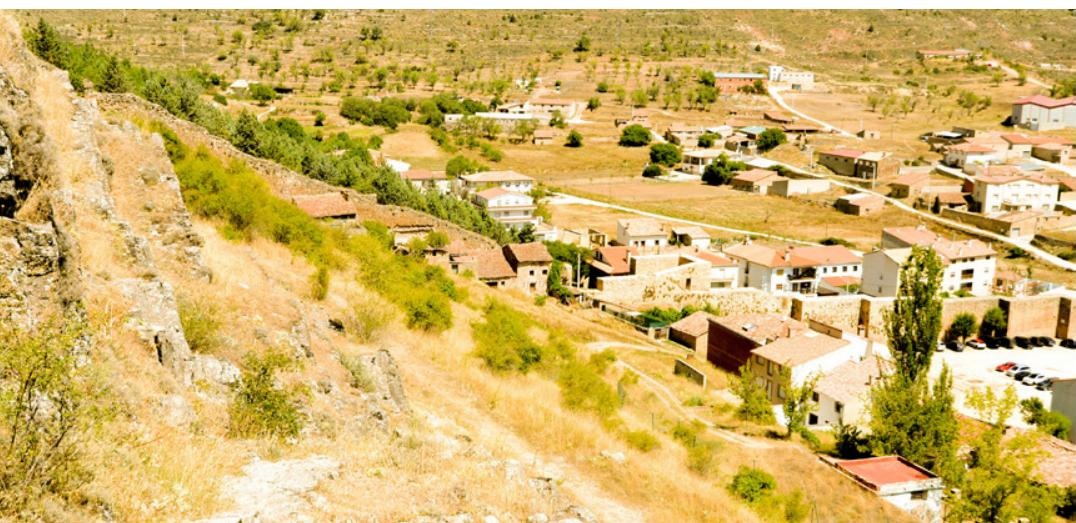

el 1 de septiembre de 1839. Cuenta con un destacamento de zapadores. Allí reorganiza sus tropas y descansan junto a las de Arévalo. Se alojan en casa del alcalde y preparan el viaje a Morella (López Marín, 2014: 382-383).

Durante un tiempo, Cañete es la referencia de la que salen partidas para expoliar la zona centro. En febrero de 1840, los generales carlistas Llagostera y Polo parten de Morella con 1700 soldados de infantería y 1500 jinetes. El brigadier Arnau, al mando de una de las columnas carlistas, se establece en Santa María del Campo y grava impuestos en las poblaciones de la zona. El 14 de febrero Arnau entra en la fortificación de Beteta. Con el apoyo de los fuertes de Cañete y Beteta, la expedición es un éxito y regresa con un amplio botín al Maestrazgo (López Marín, 2014: 384).

El 30 de abril de 1840 se notifica en prensa que Beteta y Cañete están bloqueados y que "dicen los de Ademuz que se oye fuego de cañón" (López Marín, 2014: 8). Se sabe que, a raíz de la recuperación de Cabrera tras su convalecencia, se ofició un Te Deum en la iglesia de Cañete y se dispararon salvas artilleras en Beteta (López Marín, 2014: 385).

A pesar de las dificultades que a comienzos de año tienen los carlistas para actualizar las soldadas o garantizar los suministros, no parece haber problemas con el abastecimiento de armamento en los puntos clave de la fortificación de Cabrera. Así sucede con la artillería de Cañete y Beteta.

puntos clave de la fortificación de Cabrera. Así sucede con la artillería de Cañete y Beteta.
El responsable de la dirección de las fortificaciones en la línea del Turia y Castilla es Manuel Brusco, El responsable de la dirección de las fortificaciones en la línea del Turia y Castilla es Manuel Brusco, que dispone solo de dos compañías de zapadores, pues recientemente han sido hechos prisioneros el teniente de ingenieros Aparicio y sus hombres. Brusco envía un comunicado a Cabrera, que está
descansando en la línea del Ebro, para que le abastezcan de armas y hombres en las fortalezas a su cargo, como son Bejís, El Collado, Alpuente, Castielfabib, Cañete y Beteta.

En el mes de marzo llega a Cañete Von Goeben, pasando por Castielfabib; le acompaña el oficial Matías, enviado por Brusco. El 30 de marzo, Brusco y el teniente Norma reciben a los recién llegados y les presentan a vecinos afines al carlismo. Precisamente la familia Jiménez acoge a Von Goeben en su domicilio (López Marín, 2014: 385).

La línea defensiva de Cañete está en este momento al cargo del coronel Heliodoro Gil, gobernador de la plaza; Beteta, del brigadier Balmaseda; y la línea del Turia, del brigadier Palacios. Cabrera los conmina a reunirse en Beteta para pactar el auxilio recíproco en caso de necesidad defensiva. El coronel Gil defiende Cañete con un batallón de Castilla de nueva formación con 700 reclutas del pueblo y los alrededores. El resto de fuerzas las integran voluntarios, concretamente 4 compañías armadas, destinadas en Castielfabib, una guerrilla con dos compañías (250 voluntarios) y un escuaos de los batallones de Tortosa al mando del capitán de brigada José Echevarría. En resumen: 650 hombres armados, 400 desarmados y 80 caballos. Con estas fuerzas al mando del coronel Gil se domina la provincia de Cuenca y se hacen incursiones en Aragón y la Mancha para recoger víveres. Todos aquellos que no se alistan son destinados a construir fortificaciones.

A mediados de abril de 1839, Augusto von Goeben se hace cargo de la fortificación de Cañete. En su obra hace referencia a su paso por la plaza e indica: "nos pusimos rápidamente a preparar una fábrica de pólvora, horno de fundición dentro del recinto del castillo y también fundición de balas, a pesar de las dificultades y maldiciones de algunos soldados y habitantes. Producimos una importante cantidad de pólvora, aunque basta, pero suficiente e igual que la que Balmaseda fabricó en Beteta. Curiosamente, de algunas vidrieras inutilizadas del pueblo y de los pueblos de alrededor pudimos hacer unas seiscientas granadas de cristal, que con una carga ligera eran muy mortíferas contra el asalto. Llegamos incluso, a fundir algunos cañones pesados, y aunque transportamos unas veintitrés campanas para su fundición, con las propias lamentaciones de los curas que veían saqueadas sus iglesias, al fundirse también los tubos de sus órganos y botones de uniformes, no pudimos conseguir toda la munición que hubiéramos deseado ya que nos llegó antes el ataque cristino. Yo mismo confeccioné el molde para esos botones reglamentarios de una piedra blanda que se obtenía de un barranco próximo a Salvacañete.

Con objetivo de mantener el armamento necesario para los reclutas, se impuso a padres y parientes de los desertores como castigo, la entrega de un cierto número de fusiles o varas de paño que traían de las fortificaciones enemigas y del interior del reino, ya que sino se le confiscan los bienes. Recuerdo como Faustino Saiz, vecino de Salinas del Manzano, se le obligó a traer diez fusiles en compensación por no haber querido colaborar en la fortificación de Cañete, y al cabo de doce días regresó con seis y herido en un brazo, sin que nos dijese donde los había obtenido. 


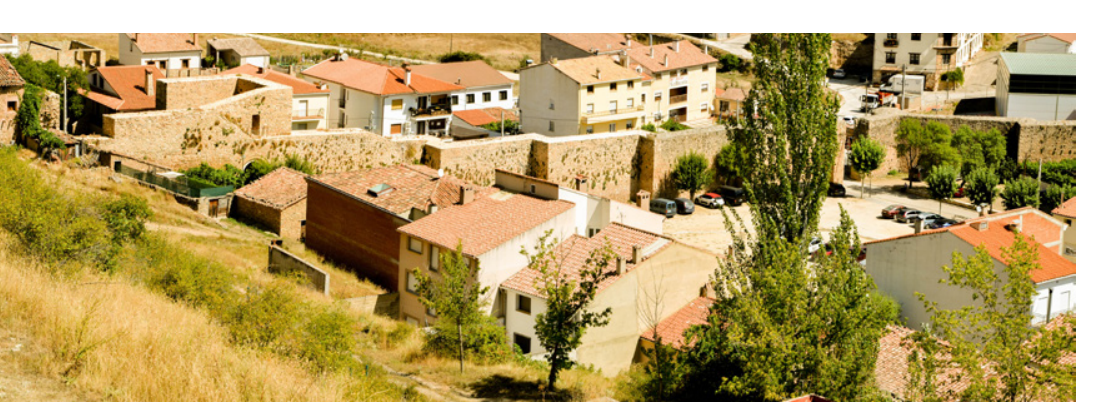

Fig. 241. Torre y parte norte de la muralla urbana vistas desde e acceso al castillo.

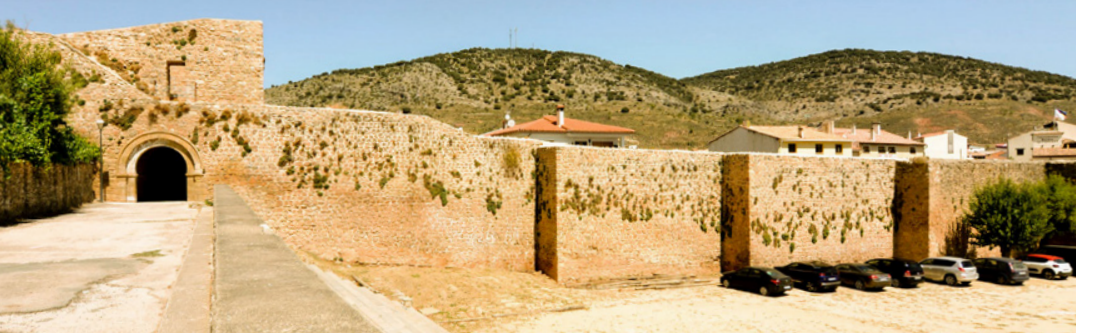

Fig. 242. Torre y parte norte de la muralla urbana vistas desde interior del núcleo urbano.

Fig. 243. Frente norte de muralla urbana visto desde el exterior

Fig. 244. Muralla urbana, torre relación con el castillo
Pero aún seguian faltando numerosas cosas necesarias para mantener la seguridad en caso de estar sitiados. Faltaban herramientas, sacos de arena, y algunas otras cosas, por lo que decidí yo el encargado por mi cometido de obtener. Con 40 zapadores, 25 soldados de infantería y 10 cosacos, salí de Cañete, penetrando

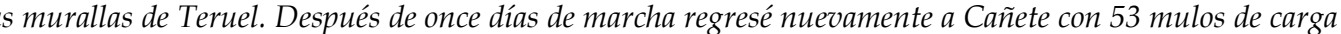
y después de haber recorrido 120 leguas de distancia y visitado 50 localidades. Había tenido que enfrentarme a dos guerrillas enemigas, haciéndoles nueve prisioneros que traje conmigo y pudimos escapar de 300 hombres que nos persiguieron, gracias a unos habitantes de Salvacañete que me ayudaron a pasar por Torrefuerte y su valle, para llegar a Cañete sin ser visto.

Mientras yo hice esta salida, el teniente Norma con un grupo de soldados salió hacia el sur consiguiendo un gran botín al ampararse en la noche, y apresando un espía cuya cabeza fue colocada en una larga pértiga, por orden del coronel Gil, cerca de la casa ayuntamiento de su lugar natal Salvacañete" (Von Goeben, 1966:423). El Eco del Comercio confirma este hecho, un testimonio más de las atrocidades de la guerra: "El goberde Daraca o si se presentó viendo que se le iba a los alcances, entre las muchas atrocidades que tiene a su cargo, cometió pocos días antes de evacuar la plaza el crimen horrendo de obligar a Ambrosio Marín a cortar la cabeza con una hacha al desgraciado nacional de la partida de Salvacañete Joaquín Hernández, dando en seguida la orden de que el ejecutor fuese también fusilado. ¿Y quedarán impunes estas atrocidades a la sombra de un indulto que en todo caso solo puede comprender el delito de infidencia?" (El Eco del Comercio, 9 de julio de $1840, \mathrm{n}^{\circ} 2265, \mathrm{p} .1$.

En junio de 1840, desmoronada la línea defensiva carlista, el fuerte de Cañete es abandonado por los carlistas (Córdoba, 1844-1846: v4, 377), aunque hay dudas sobre la decisión a tomar previamente, pues las noticias de la caída de Morella llegan solo a través de desertores y fuentes poco fiables. te, pues las noticias de la caída de Morella llegan solo a través de desertores y fuentes poco fiables.
Tras dudar, deciden en primer lugar echarse al monte y formar guerrillas, sostenidas por Norma Tras dudar, deciden en primer lugar echarse al monte y formar guerrillas, sostenidas por Norma
y Brusco. Más adelante se decide permanecer y defender la fortaleza hasta el final. Pero tras varios movimientos de la oficialidad (Brusco y el capitán Echevarría se desplazan a Castielfabib y von Goeben se dirige a Beteta para preparar su defensa), finalmente se reciben órdenes de abandonar Beteta y volarla una vez salida la guarnición. El general Azpiroz ataca Cañete desde Salvacañete. Von Goeben, enterado solo de la decisión inicial de Cañete de resistir, se encamina desde Beteta, pero las deserciones eran continuas. Hasta los dos asistentes que le acompañan acaban desertando. mos un valle, llamado por los habitantes de la zona Unete, muy próximo adonde nos encontrábamos, estaban 6000 cristinos al mando del general Aspiroz, preparando el ataque a Cañete. Aceleramos el paso para intentar llegar a la desgraciada fortaleza y avisar de lo que se les aproximaba. Cuando habíamos andado unas dos horas, el campesino que nos guiaba nos avisó que a muy pocos metros delante de nosotros se encontraban bastantes soldados, que comenzaron a disparar en el momento que nos vieron. La situación era trágica para nosotros, ya que había centenares de soldados enemigos alrededor nuestro y temíamos lo peor. Agachados, después de que nuestros caballos y mulos habian huido ante el estruendo, intentábamos aguantar hasta que llegase la noche y poder entre la maleza y la ayuda del aldeano, tener posibilidades de huida. Se llamaba el buen hombre Anastasio Jiménez y ́l junto a su amable mujer, que desde Cañete nos trajo comida, nos salvaron la vida a que deste Cañete nos trajo comida, nos saloron la vida a e Cañe estabacoucuado de carlistas, quid huido ante la llegada de tropas de la Reina. Respiré alegremente de la situación y una gran tranquilidad llenó mi corazón. Por fin se habían podido salvar" (Von Goeben, 1966:446).

Calbo y Rochina describe brevemente la población y su fortificación, aportando que Cañete está circundado de una "soberbia muralla de cal y canto muy sólida de diez varas de altura, y mas de tres de grueso; de tránsito en tránsito de bien labrados torreones, con un castillo fortalecido por la naturaleza y el arte á la parte de $O$. La obra de las murallas y castillo cuenta tres reedificaciones y su primera fundación remonta hasta los romanos. Fue plaza fuerte de armas por estar fronteriza al reino de Aragon, de cuya raya solo dista cuatro leguas, pero se abandonó cuando se unieron ambas Coronas. Tantas ventajas habian impulsado á Cabrera para que se aprovechase del buen estado en que se conservaban sus murallas, á pesar de haber parado por ellas mas de tres siglos, y aunque de antemano ya estaba en buen estado de guerra en la incursion de que hablamos, acabaron de guarnecerla Forcadell y demas gefes de esta espedicion, que la ocuparon y se preveyeron 


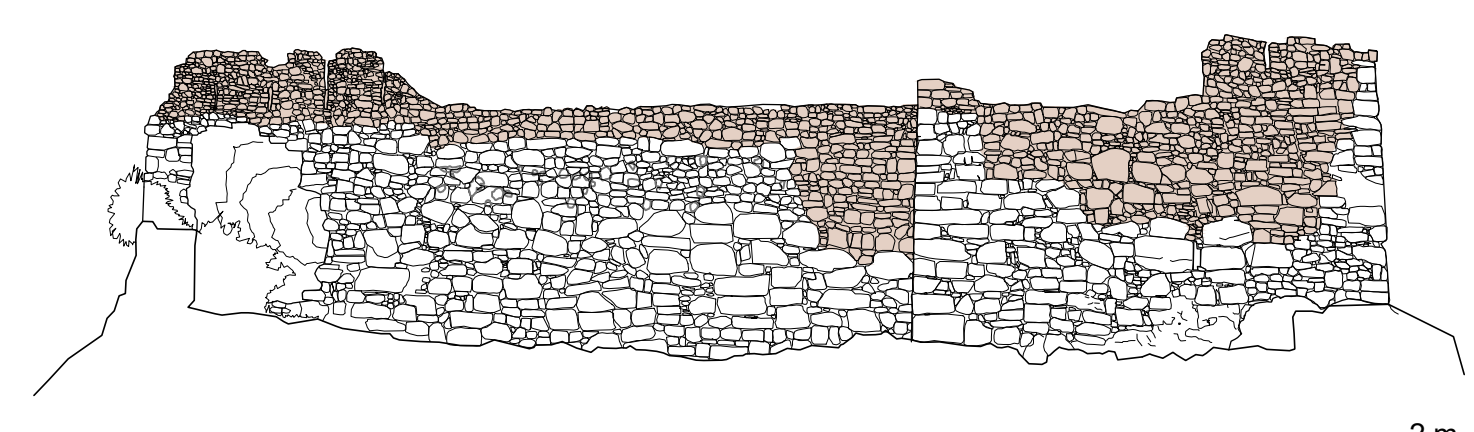

Fig. 251. Sección transversal del castillo de Cañete en la actualidad.

$2 \mathrm{~m}$

Se marcan las reparaciones ejecutadas por los carlistas en los muros rebajados.

\section{Carboneras de Guadazaon*}

Fig. 252. Planta de Cañete en la actualidad.

1. Castillo-alcazaba

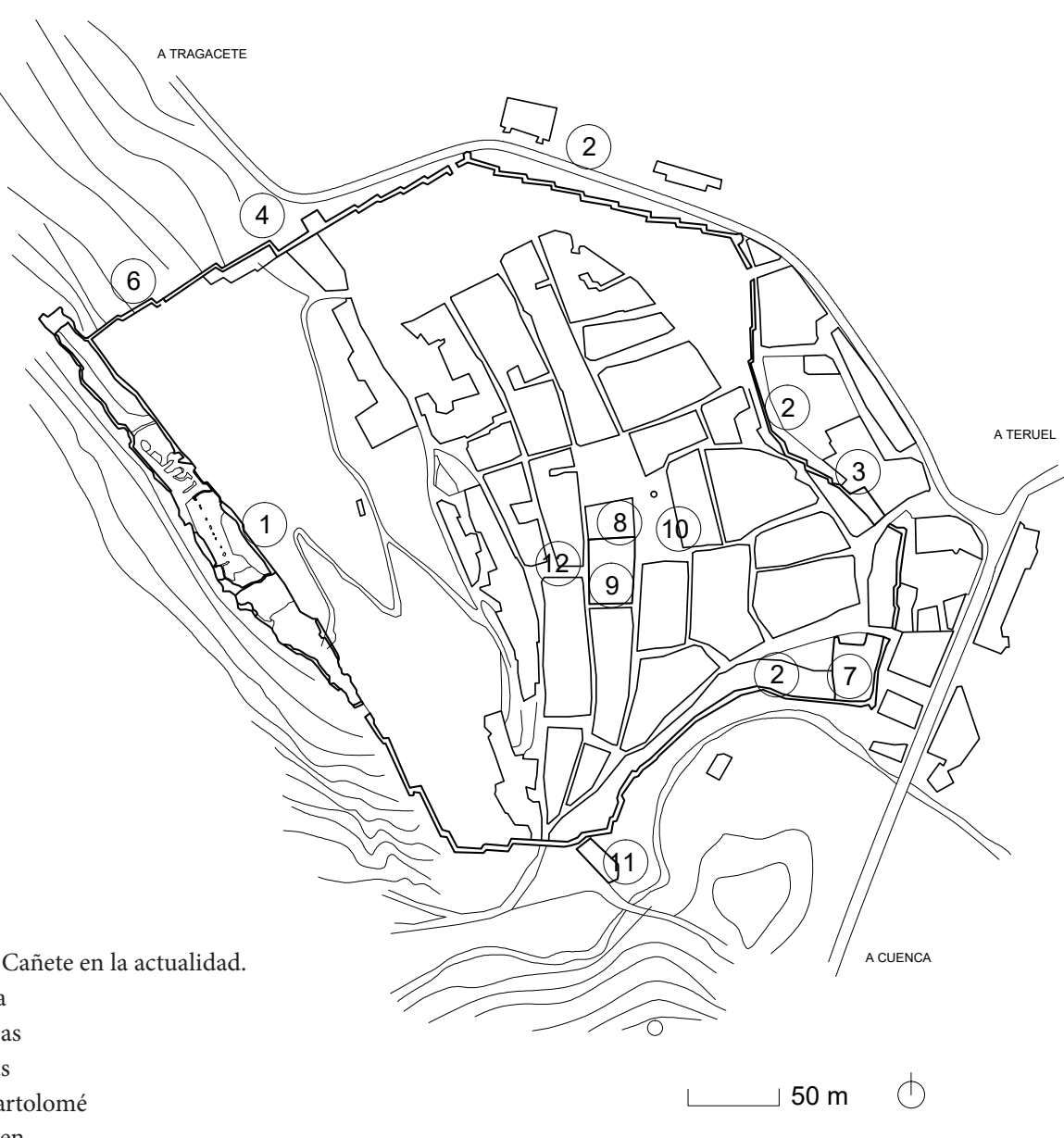

4. Puerta de San Bartolom

6. Puerta del rey

7. Iglesia de Santiago

8. Iglesia de San Julián

9. Ayuntamiento

Plaza Mayor

11. Ermita de la Virgen de la Zarza

12. Puerta de la Sinagoga

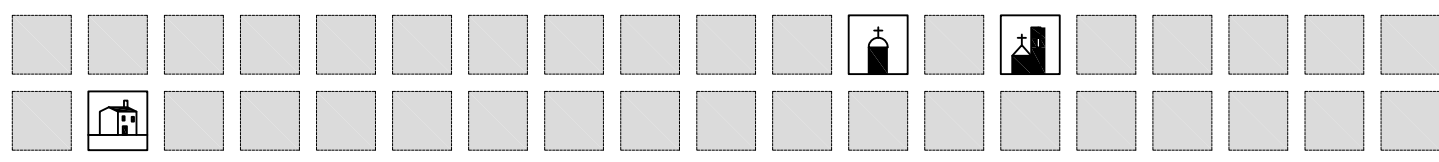




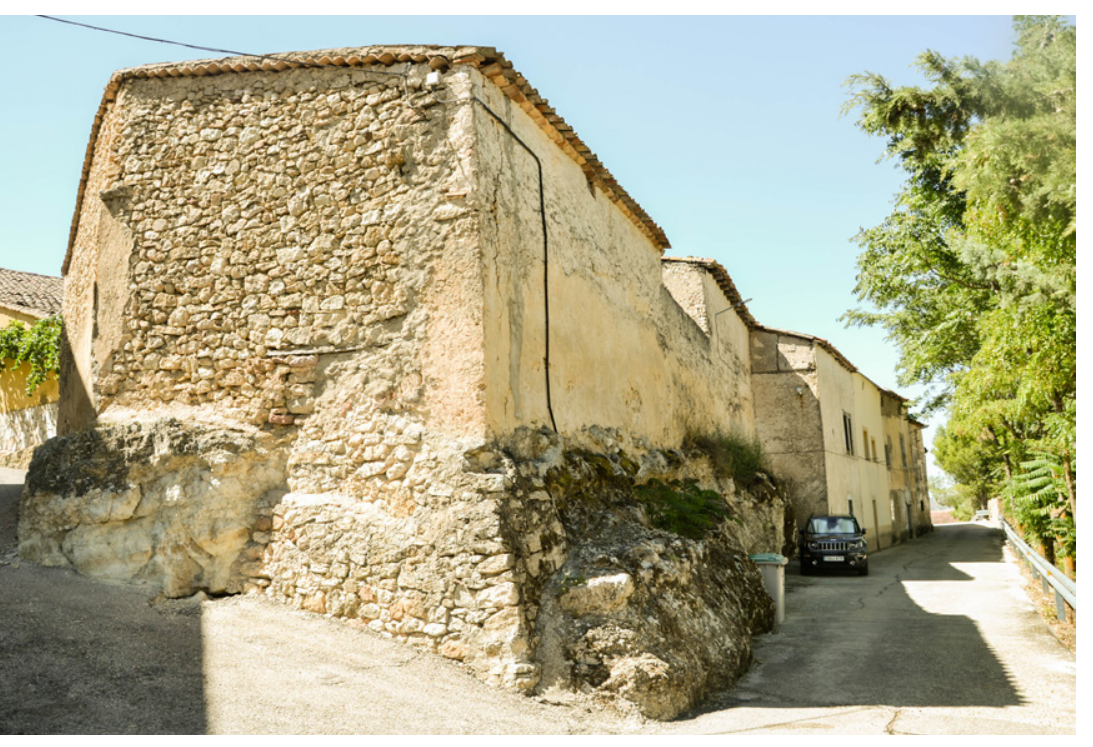

Fig. 258. Viviendas cercanas a la iglesia recayentes al perímetro.

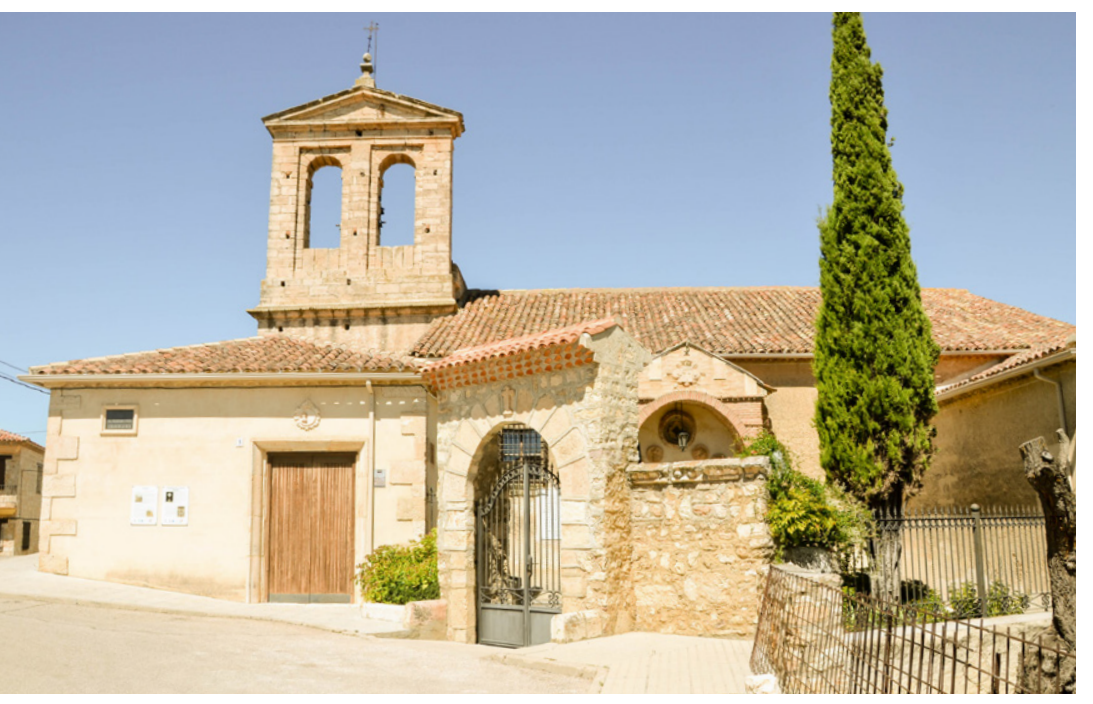

Fig. 259. Portada de la iglesia.

Fig. 260. Cabecera de la iglesia vista desde el exterior. Se aprecian aspilleras en los muros posiblemente abilitadas en la Primera Guerra Carlista. Están orientadas a noreste, donde hay un fuerte desnivel del terreno. puesto de vigilancia. Sabemos que no es uno de los últimos reductos a los que se ven abocados los cristinos en la batalla narrada, pues según Calbo y Rochina se confinaron en la iglesia y unas veinte casas, suponemos que de los alrededores de la iglesia. En la actualidad, la iglesia se conserva en perfecto estado, presentado algunas aspilleras medievales utilizadas sin duda en la defensa, como también las casas colindantes. No encontramos vestigios de obras defensivas carlistas más allá de la hipótesis de que pudieron haber fortificado ligeramente el punto más elevado de la población, ya citado anteriormente.

Fig. 261. Esquema en planta de Carboneras de Guadazaón con los puntos de interés defensivo. 01. Iglesia

2. Viviendas perimetrales

cercanas a la iglesia

03. Calvario

4. Panteón de los marqueses

de Moya

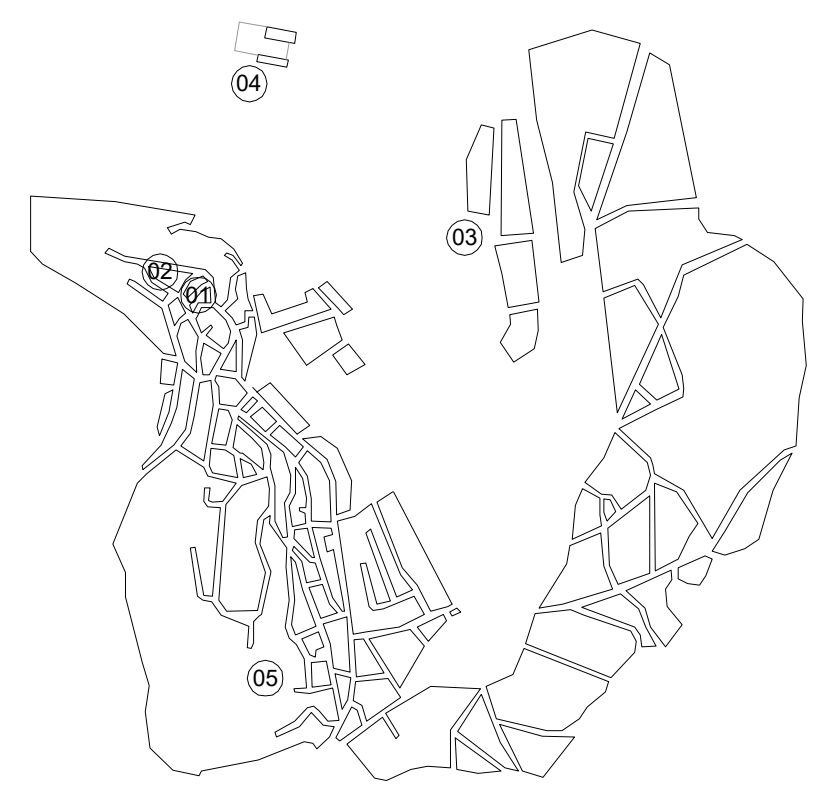

$100 \mathrm{~m} \mathrm{E} 1: 7500$ 


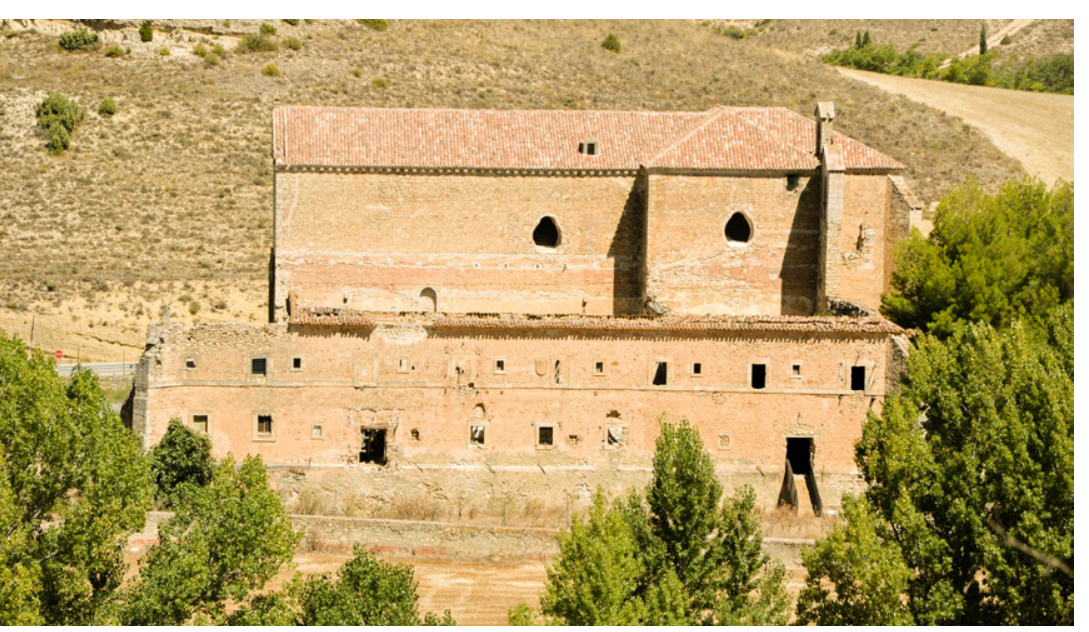

Fig. 262. Panteón de los marqueses de Moya visto desde iglesia.

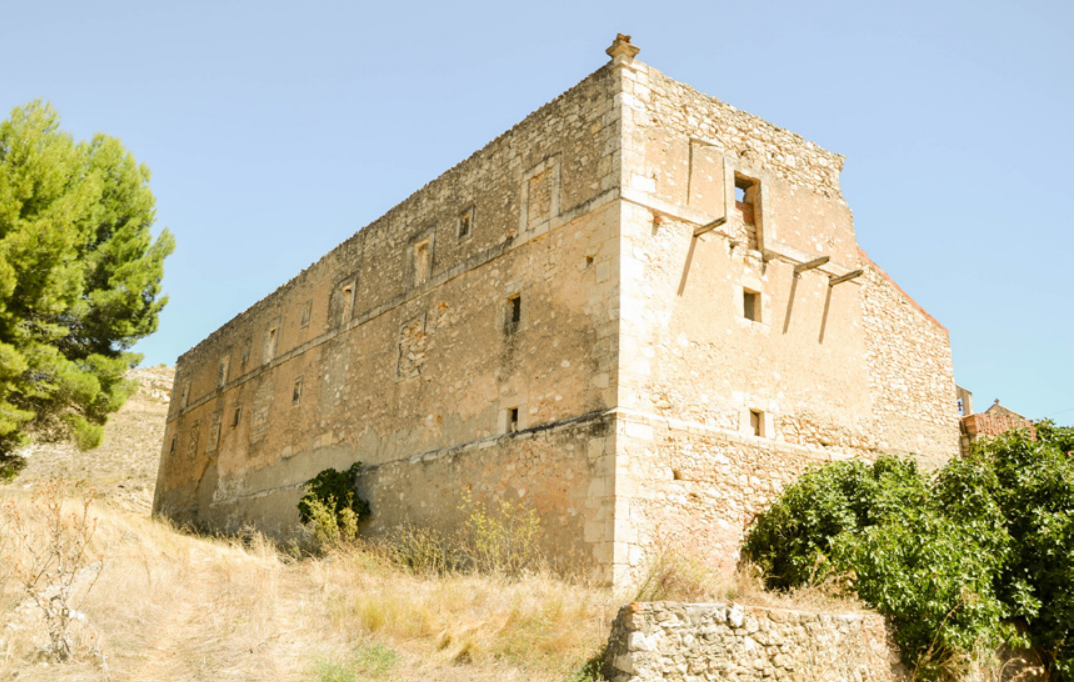

Fig. 263. Panteón visto desde el suroeste.

Fig. 264. Calvario. En este punto fueron enterrados las 3000

personas de ambos bandos que

fallecieron en la batalla del 31

de agosto y 1 de septiembre de

22 CARDENete $*$

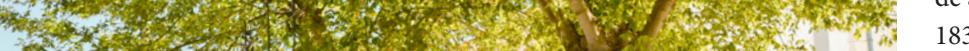


23 саятtelote $^{*}$ 


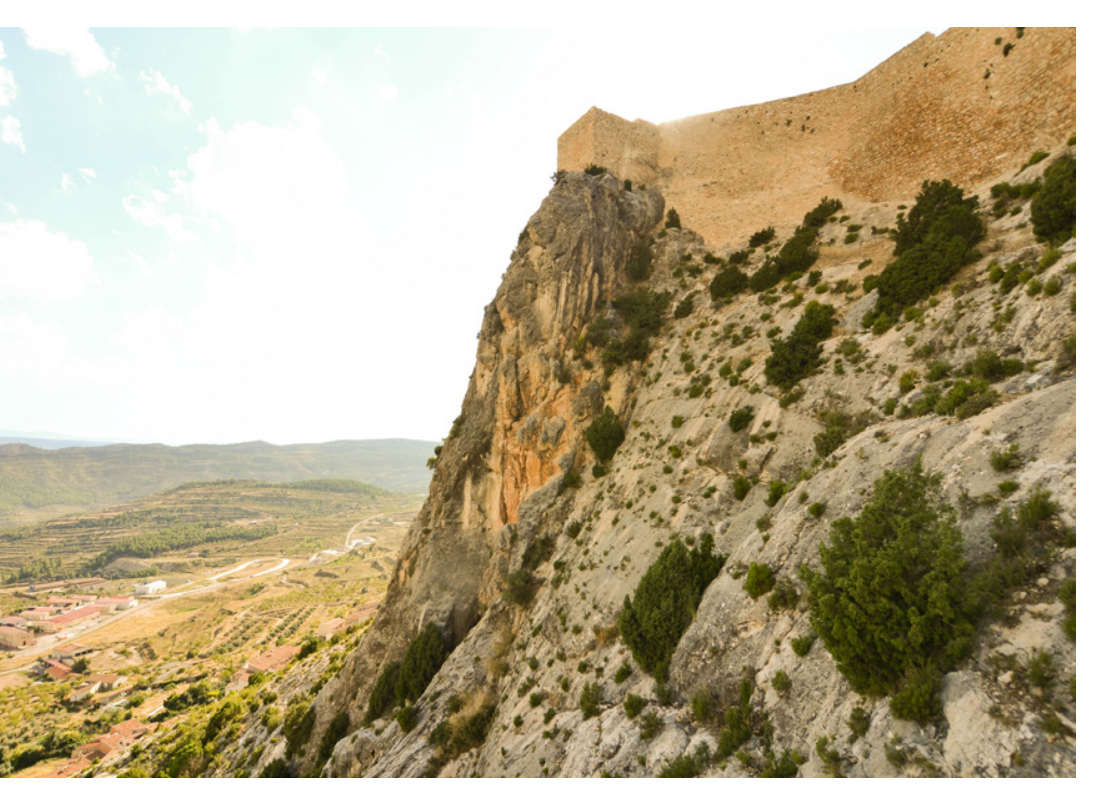

Fig. 277. Valle sur del castillo.
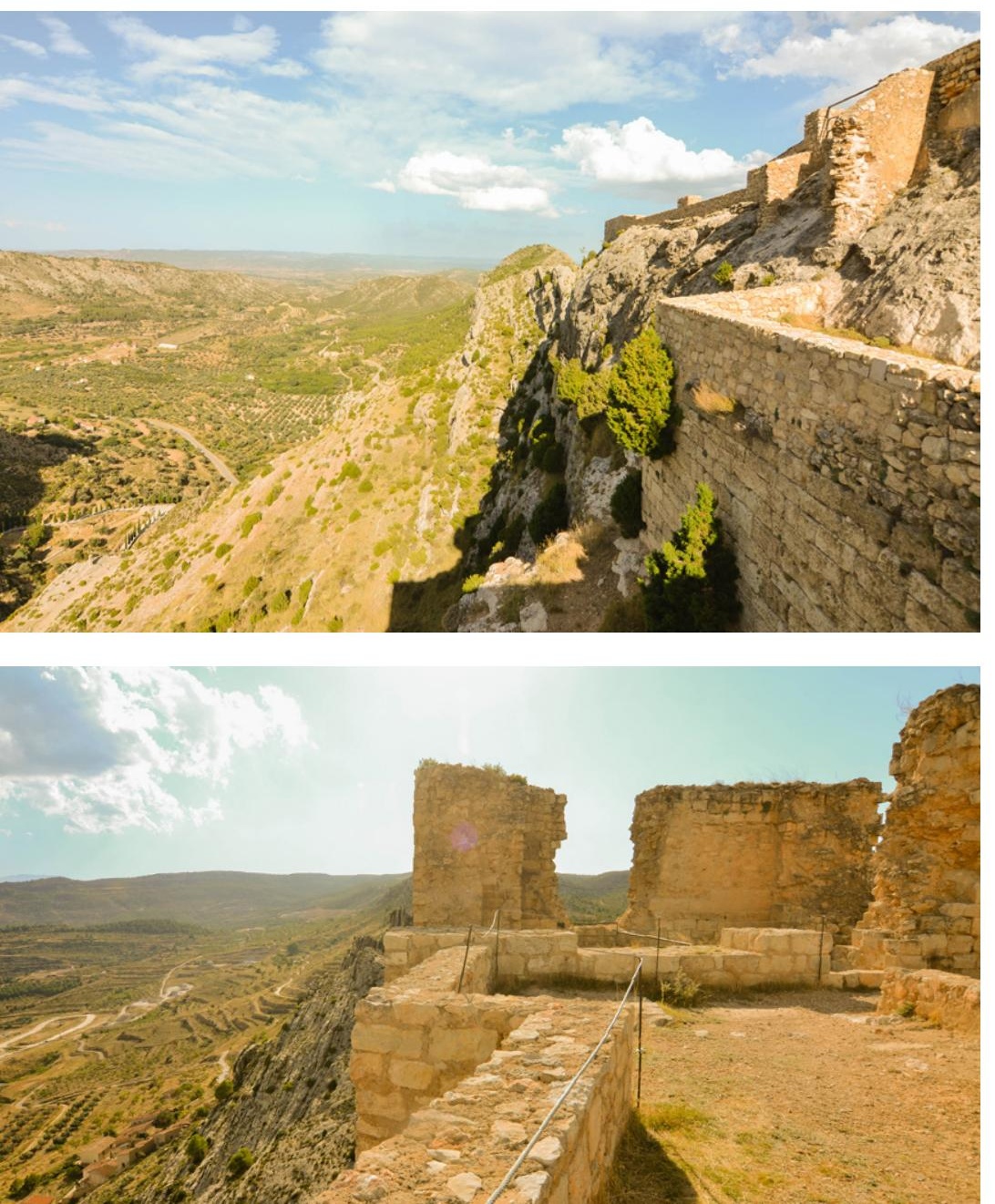

trucción de un torreón y un recinto aspillerado. Aparte del castillo, se fortifican la iglesia, el cerro del Calvario con el Reducto de la Ermita de San Macario, el fuerte del monte San Cristóbal y una caponera aspillerada. Se une concretamente la ermita de San Cristóbal al recinto con una tapia aspillerada de seis palmos de altura. Se constuye un tambor frente a la puerta principal y se fortifica una vivienda, aspilleránd una vivion 1840; Von Rahden, 2013: 317-318; Córdoba, 1844-1846: v. 4, p. 250; Forez, 1845; Caridad, 2013: 261262). Los materiales y la mano de obra se obtienen obligando a colaborar a las poblaciones cercanas (Allanegui, 1998: 142; Caridad, 2013:262).

El castillo medieval ha sido restaurado recientemente y se aprecian sus estructuras. En 1986, Cristóbal Guitart publica una descripción del mismo en Castillos de Aragón II que todavía resulta de utilidad: "A juzgar por sus restos, la fortaleza pertenecía al tipo de planta irregular dispersa de gran extensión, unos 130 metros de eje máximo por una anchura variable que llega a alcanzar unos $50 \mathrm{~m}$. Por sus desniveles tenía hasta cuatro recintos y el acceso principal se realizaba por un puente tendido sobre un barranco. Hay ectangulares, otro triangular, mís las unicas piezas que conservan algo más, que son la sala capitular y la torre del Homenaje. Esta sería grandiosa a juzgar por su planta de 11,50 m de lado y su buen aparejo de sillería, estando emplazada en el borde de precipicios rocosos por tres lados; [...] tuvo garitones de esquina. A su lado hay restos de una cámara. Un muro exterior, que conserva un portillo semicircular con dovelas, la une a la sala principal, que también pudo ser capilla" (Guitart, 1986: vol. II, 50).

Existen tres representaciones de la fortificación de Castellote de la época, una publicada por Pirala y dos por Calvo y Rochina. En ellas se aprecian las torres y los lienzos aspillerados.

El 26 de marzo de 1840 Espartero se apodera de Castellote (Diario Constitucional de Zaragoza, 30 de marzo de 1840; 19 de abril de 1840; Calbo y Rochina, 1845: 493; Caridad, 2013:265) y O'Donnell ocupa Aliaga veinte días después (Boletín Oficial de la Provincia de Castellón de la Plana, Diario Constitucional de Zaragoza y Diario Mercantil de Valencia, 18 de abril de 1840; Calbo y Rochina, 1845: 503; titucional de Zaragoza

Los carlistas, en el asedio, abandonan el Calvario y la población, concentrándose en el castillo, el reducto de San Cristóbal y la gran caponera aspillerada. "En la arriesgada operación de construir espaldones, experimentaron los ingenieros muchas bajas" [...] Los carlistas tuvieron que abandonar toda la línea exterior y prender fuego a los edificios para que no los utilizasen los sitiadores. Quedaron destruidas la ermita fortificada, la casa aspillerada y la caponera" (Pirala, 1869: Tomo V, 261, 262, 263). Más adelante, los liberales realizan una mina en la torre principal y acaban por reducir a escombros la mayor parte del castillo (Pirala, 1869: Tomo V, 263). Una de las ilustraciones de Calbo y Rochina muestra la realización de esta mina (Calbo y Rochina, 1845: 491).

Este autor hace una descripción pormenorizada de la toma de Castellote que permite entender los puntos clave de la fortificación. Según Calbo y Rochina, los carlistas fortifican el antiguo castillo, pero también reparan algunos trozos de la muralla urbana. En el asedio se habla de un primer ataque a un "fuertecito que los carlistas habían hecho de la ermita de San Marcos" (ibíd, p. 489). Desde allí los carlistas se repliegan al castillo, abandonando el pueblo y quemando " a su paso los trabajos que habian hecho en un reducto construido á la cabeza del camino cubierto". Espartero aprovecha para establecer baterías, una de las cuales la sitúa precisamente en la abandonada posición de San Marcos. El día 25 de marzo de 1840 truenan los cañones sobre el castillo "causando gran destrozo. particularmente en (desmontando una pieza que habia á este lado, y rompiendo el asta de bandera". Los arlistas, destruidas sus aspilleras, se sirven de los huecos de los proyectiles. Los carlistas destruyen definitivamente el reducto del camino cubierto y el puente de madera de la entrada del castillo. El siguiente paso de los liberales es ocupar la posición del reducto del camino cubierto para emplazar una batería de a ocho y proteger el avance de zapadores, que deben practicar una mina para volar el torreón antiguo, pues lo identifica Calbo y Rochina como "obra de moros" (Calbo y Rochina, 1845:490). En dicho torreón, estrechamente vigilado, se guarda la pólvora y los comestibles. Aun así, los zapadores consiguen abrir un hornillo de ocho pies para dos quintales de pólvora. Calbo y Rochina indica que aquel día se desmorona el primer recinto del castillo y parte del segundo, pero los carlistas refuerzan los estragos con sacos de harina, arroz y demás vituallas. El día 26, bajo el fuego artillero, los soldados liberales inician el asalto desde el camino cubierto, alcanzando el primer recinto entre escombros. Al poco tiempo, la guarnición se rinde. 
Fig. 286. Acceso a la caponera desde el cuerpo central del castillo.

Fig. 287. Iglesia vista desde el inicio del ascenso al ca observan aspilleras.

g. 288. Ermita del Llovedor

Fig. 289. Ermita de San Macario, en el cerro del Calvario, fortificada por los carlistas.
Fig. 290. Ilustración 2. Mina realizada bajo una de las torres.

Fig. 291. Plano del castillo de Castellote en 1840, a partir del plano del Capitán de Ingenieros

D. Ramón Ugarte.

01. Torreón antiguo.

02. Casa del gobernador

03. Cisterna

04. Cuadras

05. Cuarteles

06. Cuerpo de guardia

07. [ininteligible]

08. Común

09. Torre antigua

10. Fragua

11. Cuerpo de guardia

12. Avanzadilla

13. [ininteligible]

14. Blindaje de la mina

15. Hornillo

16. Salida a [...]

17. Punto del asalto
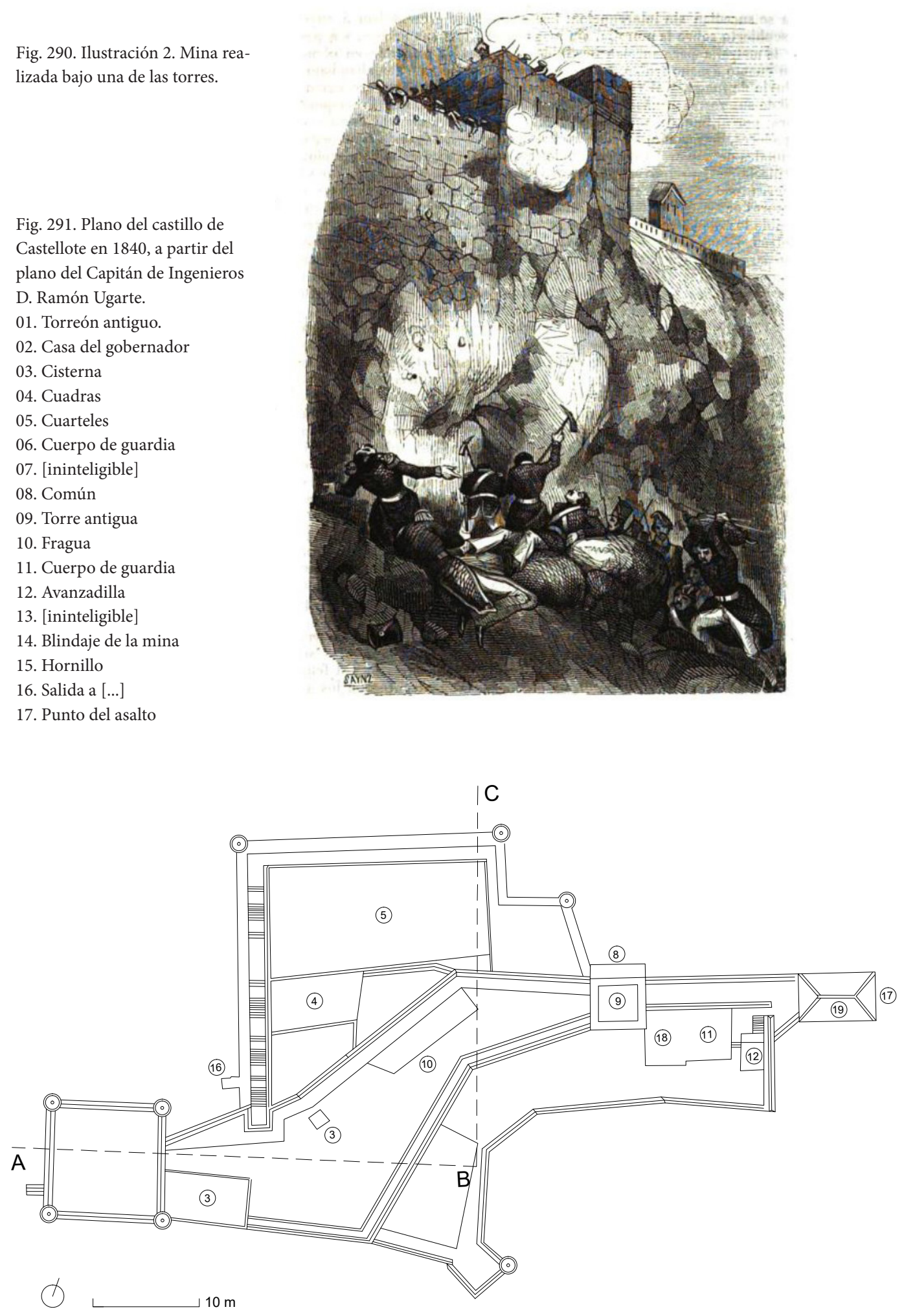


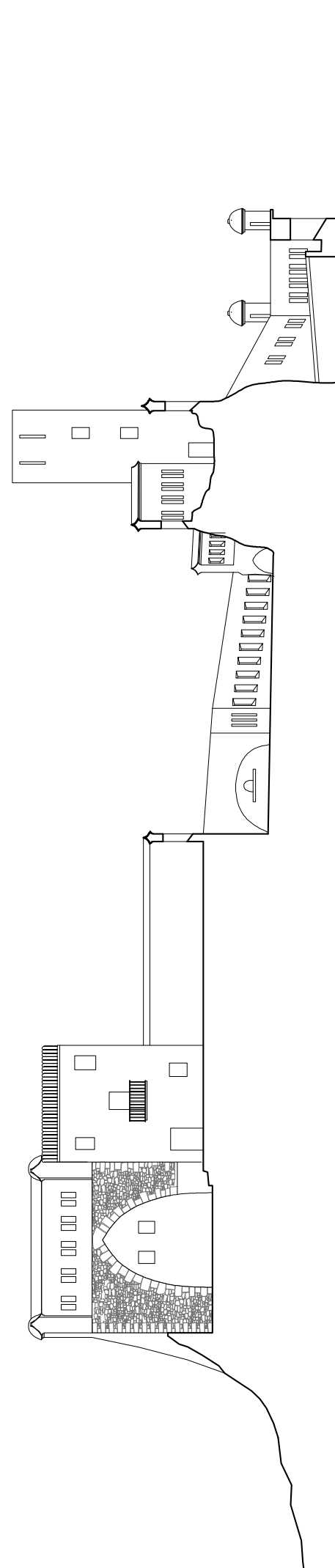

Fig. 293. Plano del castillo de

Castellote en 1840, a partir del

plano del Capitán de Ingenieros

D. Ramón Ugarte.

01. Torreón antiguo.

02. Casa del gobernador

03. Cisterna

05. Cuarteles

06. Cuerpo de guardia

07. [ininteligible]

08. Común

09. Torre antigua

10. Fragua

11. Cuerpo de guardia

12. Avanzadilla

13. [ininteligible]

14. Blindaje de la min

15. Hornillo

16. Salida a $[\ldots]$

17. Punto del asalto

(6)

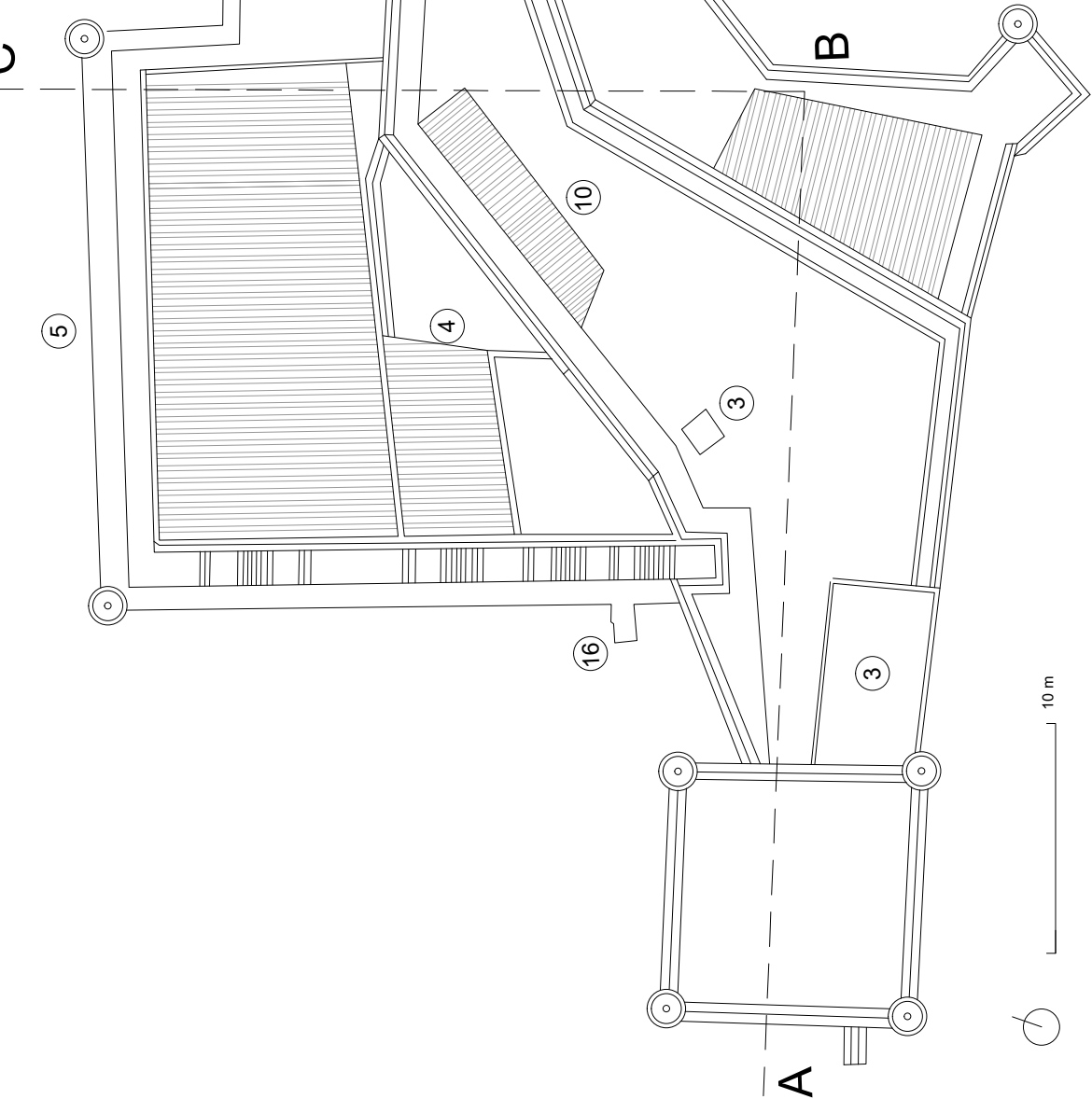




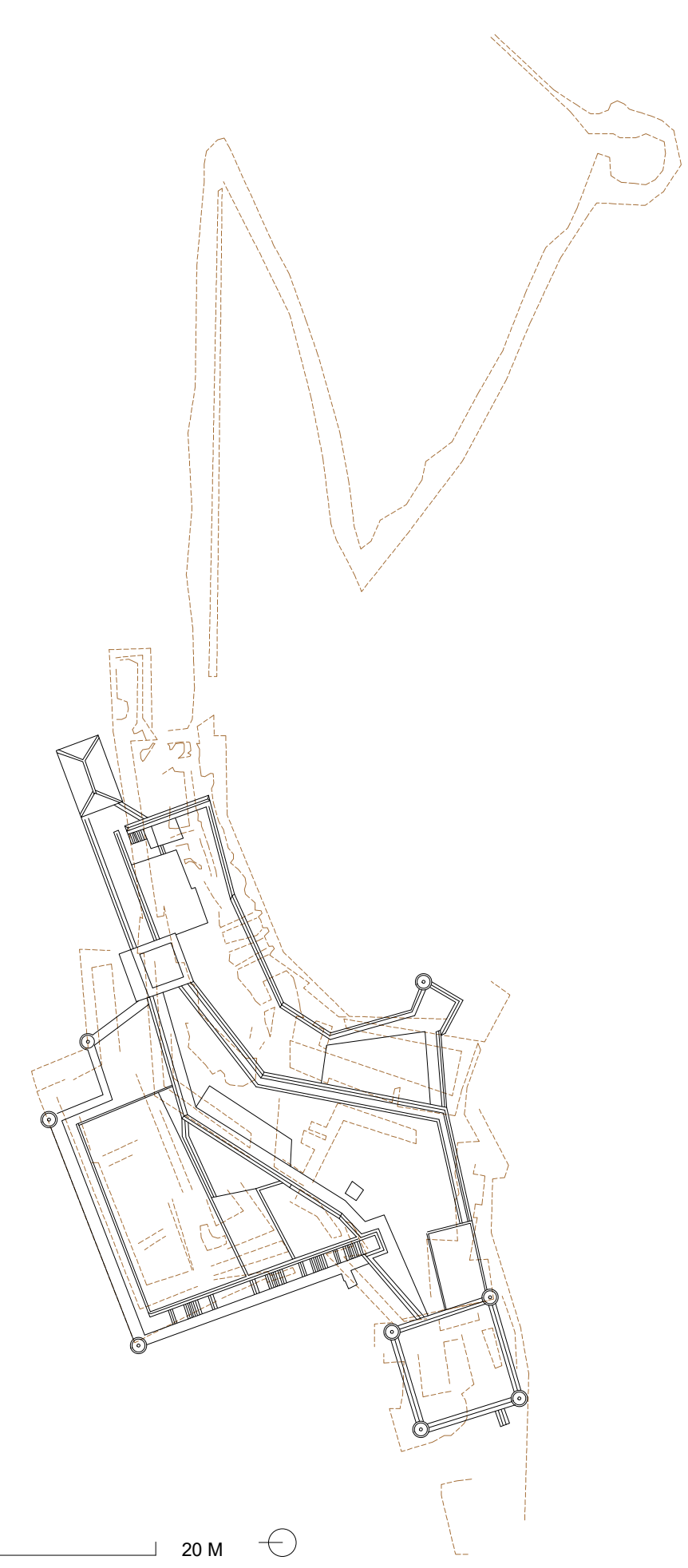

Fig. 294. Superposición del plano trazado por el Capitán de Ingenieros D. Ramón Ugarte y el Ingenieros D. Ramón Ugarte y el
plano de las ruinas actuales del castillo de Castellote.

\section{CASTELSERAS}

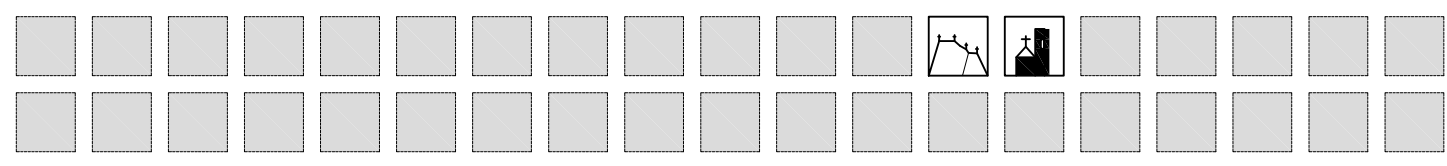




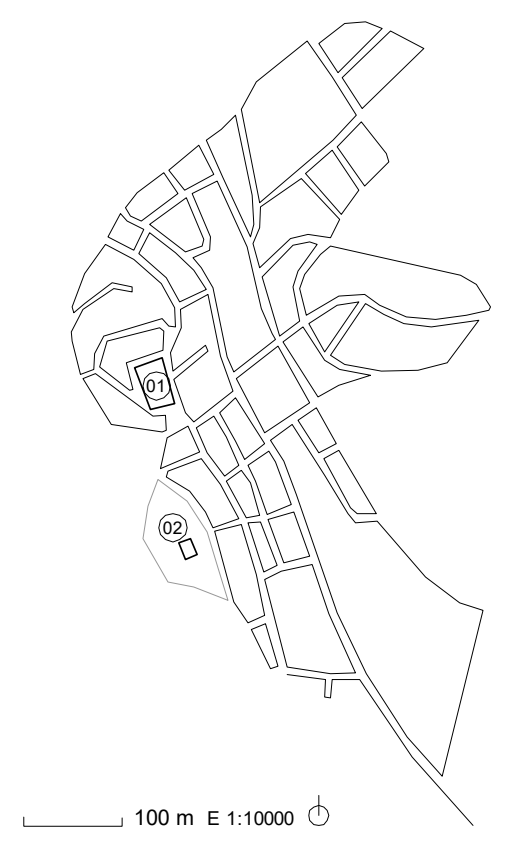

Fig. 299. Esquema en planta de Castelserás con los puntos de

interés defensivo.

01. Iglesia parroquial

02. Ermita del Calvario

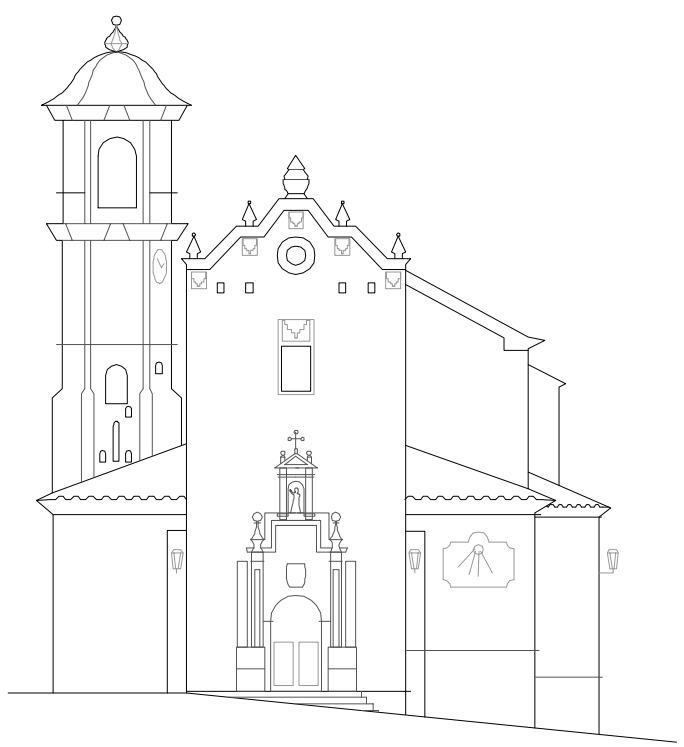

Fig. 300. Alzado de la fachada principal de la iglesia parroquial de Castelserás, ocupada por los carlistas.

25 салтинанвів $^{*}$ 

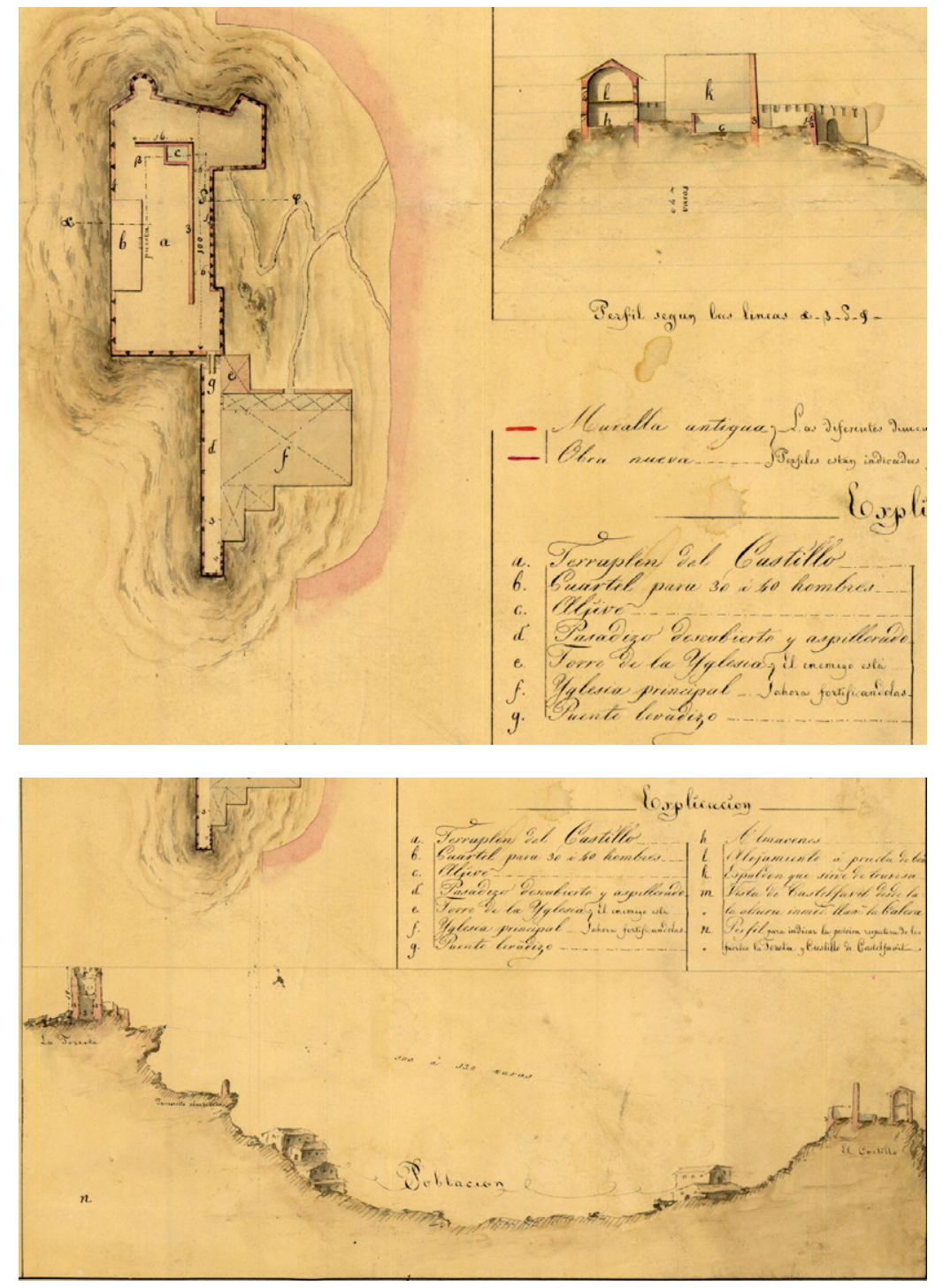

Fig. 315. Planta del segundo nivel, correspodiente al almacén y planta a nivel de la iglesia-fory planta a nivel de la iglesia-for-
taleza de Castielfabib. Sección longitudinal de la misma
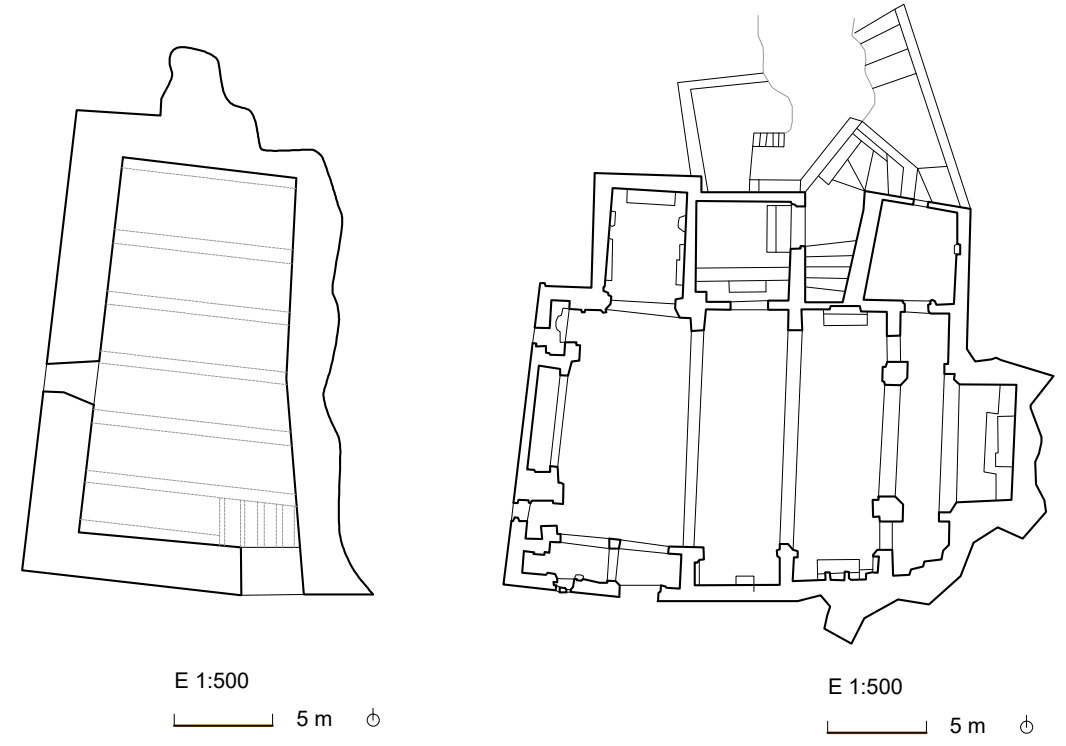

Fig. 313. Detalle del Plano 1 Muestra la planta del castillo, reforzado por los carlistas, y un sección transversal.

\section{Fig. 314. Detalle del Plano 1.} Sección que muestra la relación de altura y distancia entre los distintos elementos defensivos, como son el castillo y la Torreta.

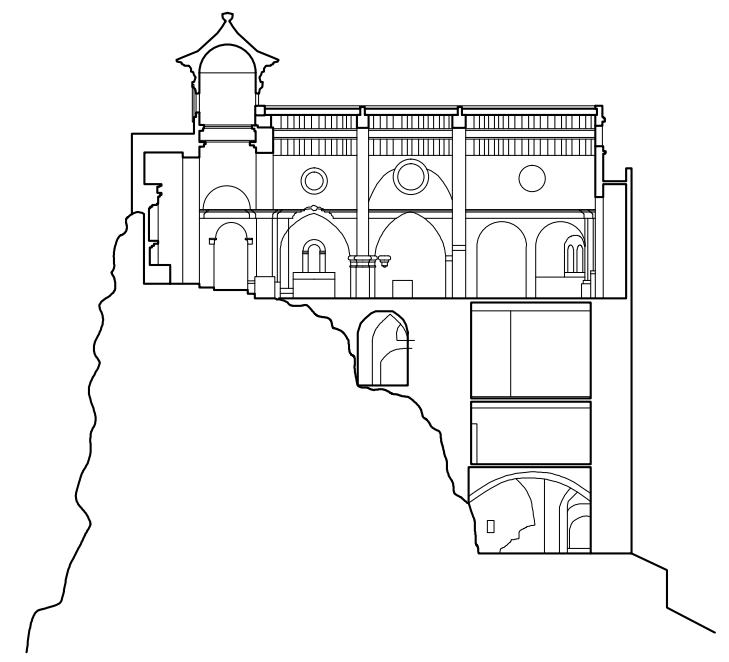

E 1:500 
Fig. 316. Planta del estado actual

de la localidad, con los restos

identificados por A. Vázquez

Esparza (2014) y sus hipótesis

de los recintos urbanos amura-

llados.

01. Iglesia fortaleza de Nuestra

Señora de los Ángeles

- 02. Castillo

03. Primer recinto amurallado

- urbano

— 04 . Torre del Hospital

— 05. La Torreta

06. Segundo recinto amurallado

— urbano

- 07. Torre almenada

— 08. Torreón

09. Palacetes adosados a la

- antigua muralla

- 10. Tercer recinto amurallado

- 11. Torre del blanquillo

- 12. Casa del cura

- 13 Casa de la villa

14. Trazado norte

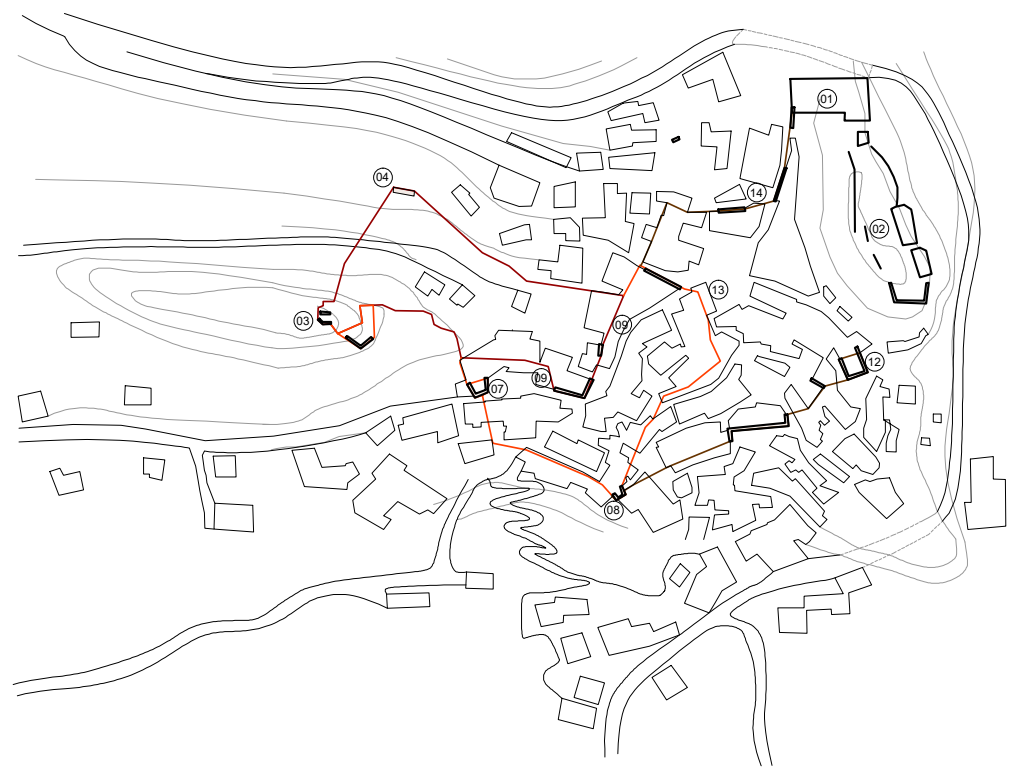

26 castillo de Villamalefa 

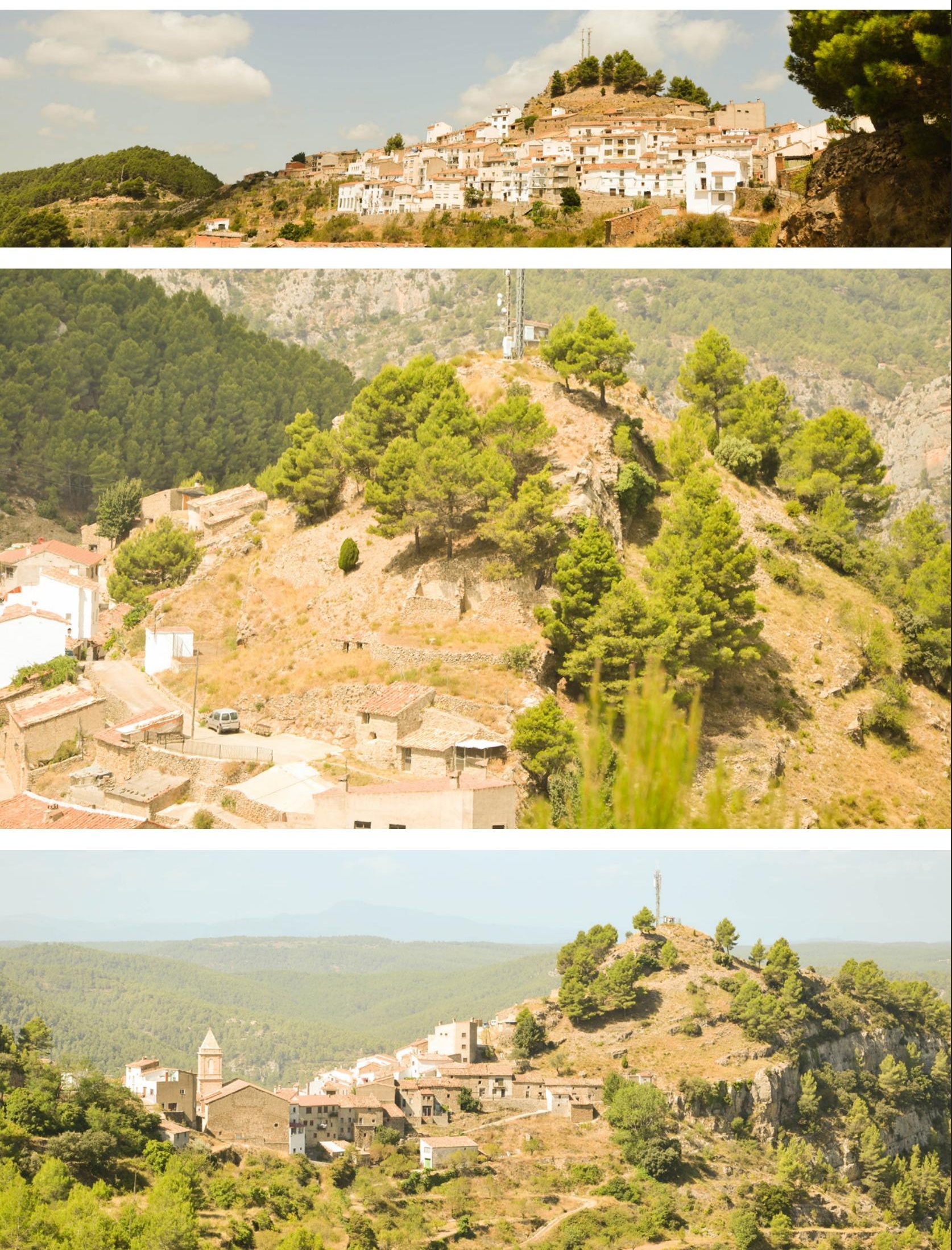

Castillo de Villamalefa

Localidad en castellano / valenciano: Castillo de Villamalefa / Castell de Vilamalefa Provincia actual: Castellón

Comarca: Alto Mijares

Coordenadas geográficas: $40.13102118413232,-0.3807189866540739$

Datos históricos:

Guarnición 1839-1840: 100

Inicio bombardeo liberal: -

Rendición o abandono: -

Días de resistencia: -

Fuente: Caridad, 2013: 263

Tipos defensivos: castillo reforzado que domina la población, muela fortificada, torre, fortificación de ermitas, fortificación de calvarios, frente escalonado.

Acciones y fortificación:

A finales de 1838 comienza la fortificación del castillo (Diario mercantil de Valencia, 10 de diciembre de 1838; Caridad, 2013:257), que termina a mediados de 1839 (Diario mercantil de Valencia, 29 de mayo y 25 de julio de 1839; Caridad, 2013:257). Los carlistas prenden fuego al castillo antes de retirarse a Zucaina (Caridad, 2013:266; Diario mercantil de Valencia, 6 de junio de 1840; Boletín Oficial de la Provincia de Castellón de la Plana, 9 de junio de 1840; Córdoba, 1846:370; Calbo y Rochina, 1845:546). Von Rahden lo define como "un castillo rocoso casi inexpugnable [que] había sido asaltado en 1845:546). Von Rahden lo define como "un castillo rocoso casi inexpugnable [que] había sido asaltado en
septiembre de [1838] por unas pocas compañias de voluntarios realistas, que lo escalaron igual que en Moseptiembre de [1838] por unas pocas compañias de voluntarios realistas, que lo escalaron igual que en Mo-
rella" (Von Rahden, 2013: 88). Sin embargo, autores como Córdoba (Córdoba, 1844: v. 3, 426) y Caridad, apoyándose en Córdoba (Caridad, 2014: 278) señalan que lo toma Francisco Gasque gracias a una traición el día 25 de octubre, y otros como Von Goeben, que es Forcadell quien lo toma (Von Goeben, 1966: 291). Parece claro que el año anterior, el 9 de febrero de 1837, La Cova ataca Castillo de Villamalefa junto a otros cabecillas, sin conquistarlo. Fracasa tres veces y, antes de retirarse, manda incendiar la a otias y algunas casas y cortijos del pueblo (Caridad, 2014:276, 277). Se o (Caridad, 2013:257). El Rateridion fuerte, junto al de Montán y al de Villahermosa del Río, protege la vertiente meridional de todo el macizo, sobre todo contra las salidas de la guarnición liberal de Lucena (Von Rahden, 2013: 88). En junio de 1839, Cabrera ordena al gobernador que abandone e incendie la fortaleza (Caridad, 2013: 280). Algunas fuentes sostienen que es Espartero quien ordena destruir el castillo. Sea quien sea el culpable de la destrucción, resulta evidente que es eliminada toda edificación útil militarmente y que los restos se utilizan en la construcción de otros edificios. A pesar de todo, en la cima de lo que fue el castillo existen todavía restos de murallas, de un posible aljibe y de un emplazamiento artillero. A los pies del fuerte se aprecian construcciones de apoyo para la guarnición, algunas de a posiblemente tal y como las abandonan en la epoca. Desde el catillo se aprecia, en la loma contigua, a la misma altura del castillo, la Ermita del Calvario, un punto desde el cual se podría atacar el castillo sin dificultad, por lo que se conjetura que los carlistas lo habrían ocupado y posiblemente fortificado. En la cima de la loma de la ermita, a mayor altura que Castillo de Villamalefa, se encuentran restos de otro emplazamiento artillero, o bien un punto de observación o de tiradores. Llama la atención que llamándose la localidad Castillo de Villamalefa, al preguntar por el castillo a los habitantes de las viviendas más cercanas al mismo, estos negasen que existiese un castillo o restos del mismo en la localidad.

Fig. 317. Frente escalonado de Castillo de Villamalefa y ruinas del fuerte ubicado en el punto más elevado de la loma. Fig. 318. Restos de construcciones del fuerte vistas desde la loma de la ermita.

Fig. 319. Frente noreste de la población, donde se aprecia la iglesia, el castillo y el frente escalonado. 


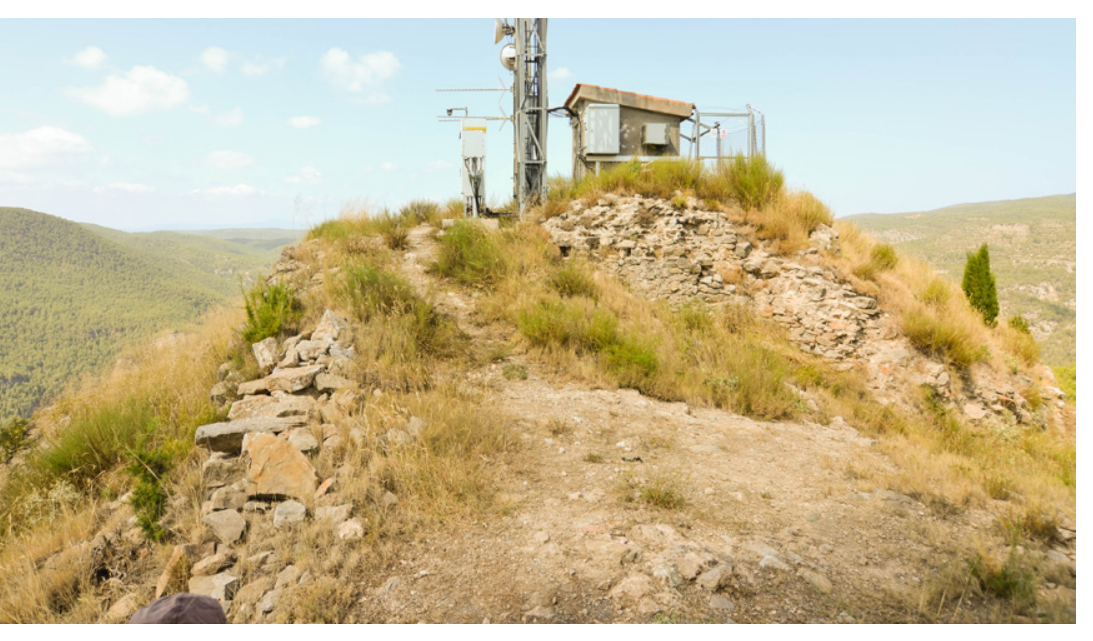

Fig. 320. Ruinas del castillo

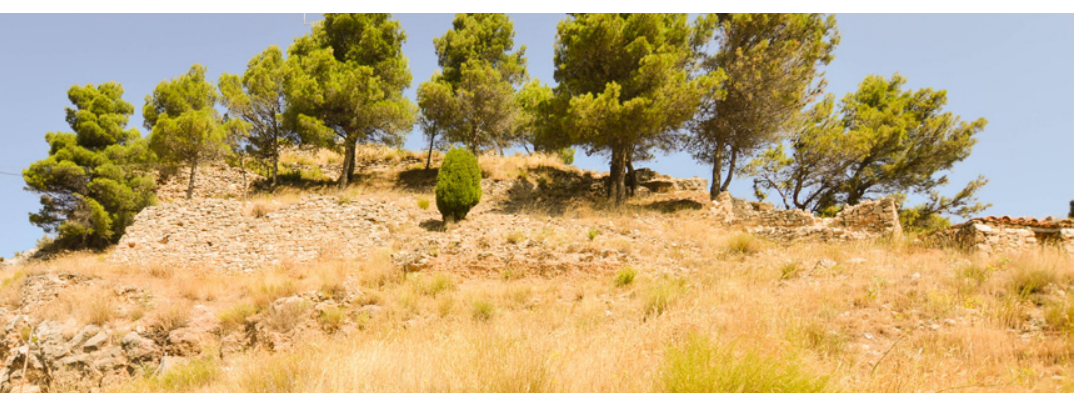

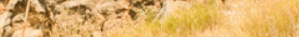

Fig. 321. Ruinas del castillo en la ladera este.

Fig. 322. Ruinas del castillo en la ladera sur.

Fig. 323. Ruinas del castillo en la cima.
Fig. 324. Frente noreste del núcleo urbano, escalonado, y posición elevada del castillo.

Fig. 325. Viviendas más cercanas al castillo, posiblemente usadas como alojamiento para las tropas carlistas.

Fig. 326. Viviendas cercanas al castillo vistas desde la calle Alta.

Fig. 327. Construcción curva
(izquierda) y cabecera de la igle(izquierda) y cabecera de la igle-
sia (derecha). La forma curva sia (derecha). La forma curva dominando el valle, hace pensar que podría tratarse de los restos de una plataforma artillera o una antigua torre.
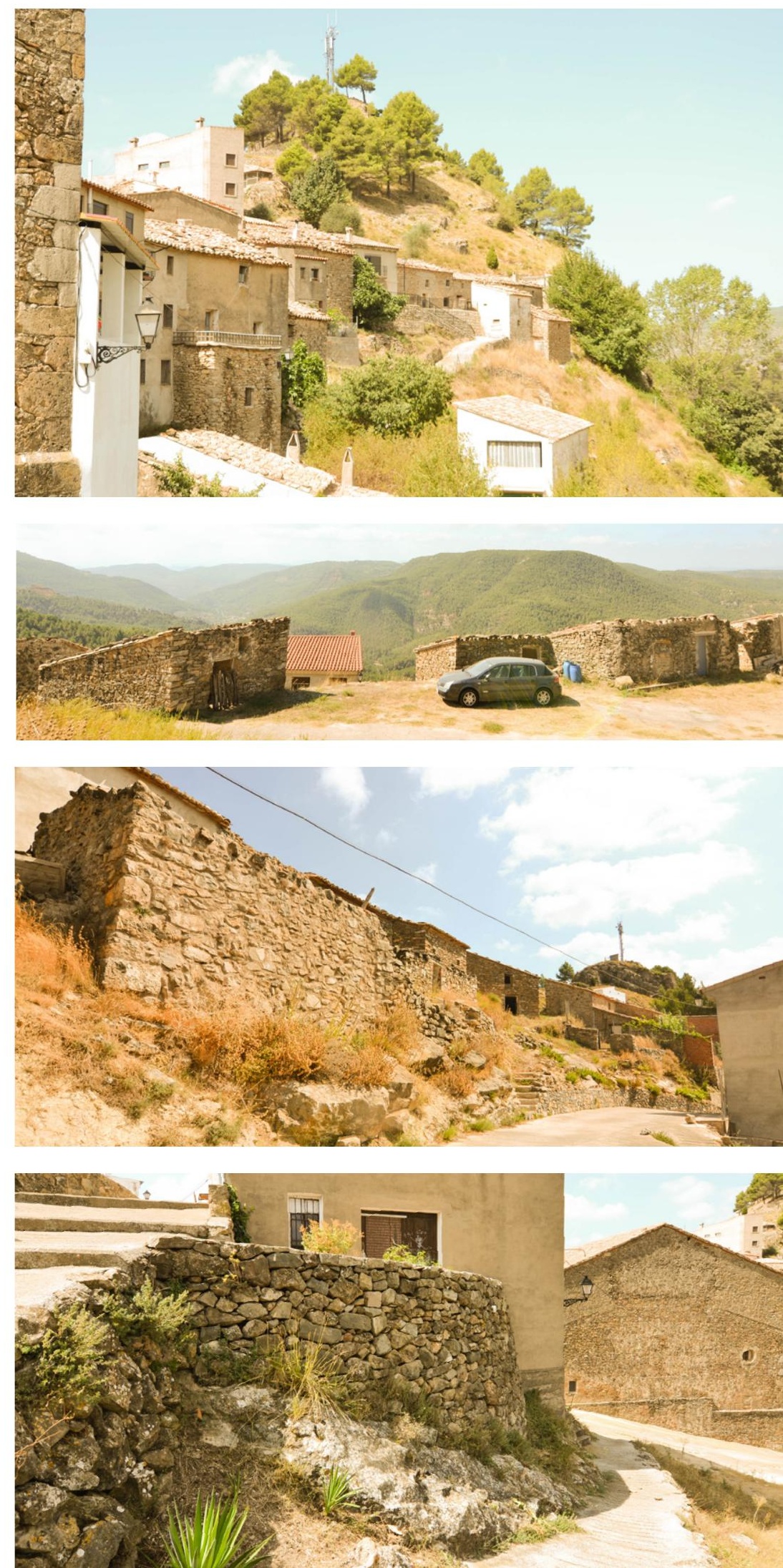
27 Снеул * 


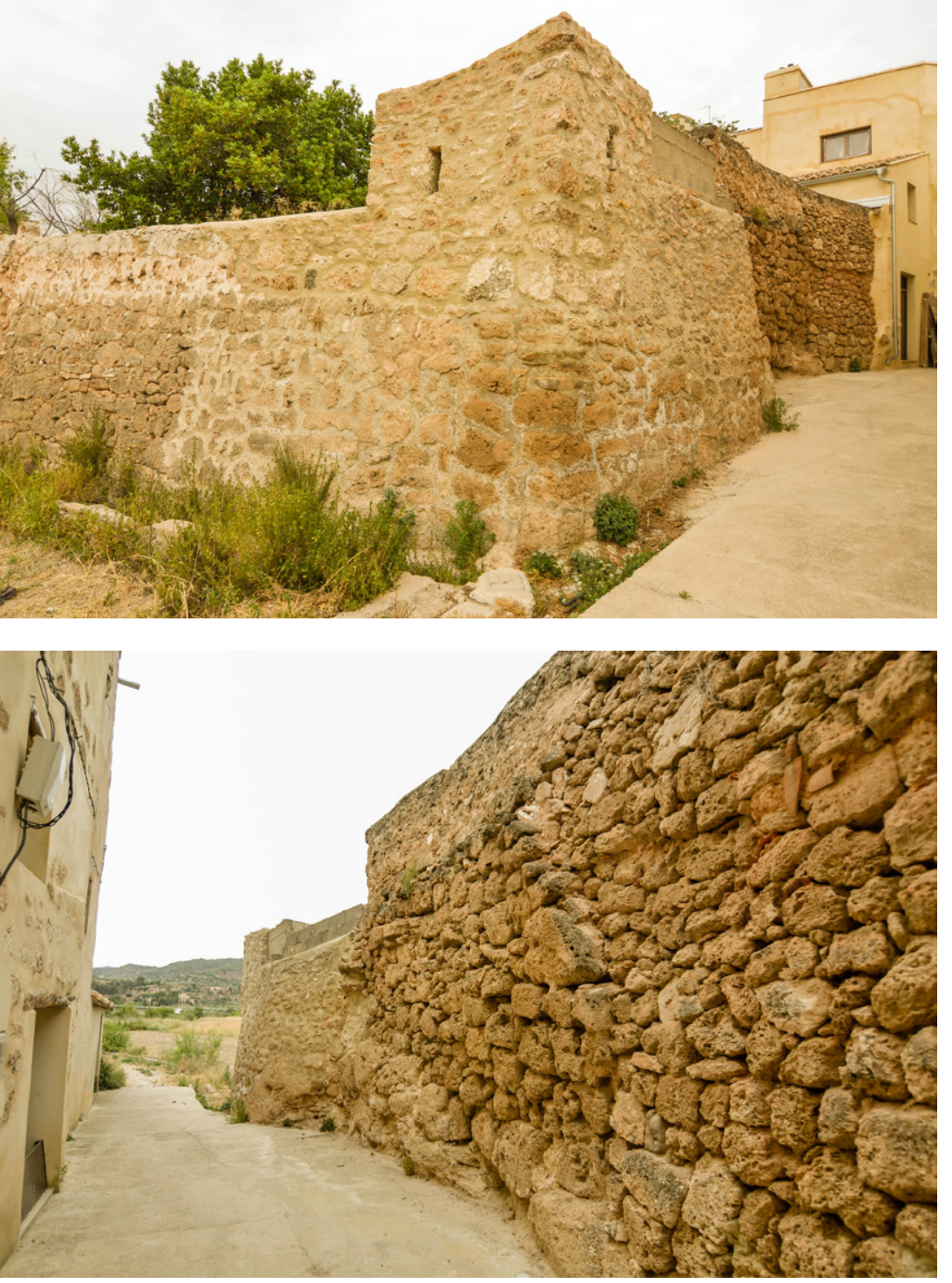

Fig. 338. Parte de la muralla urbana, donde se observan distintas fases en la construcconstrucción carlista.

Fig. 339. Restos de muralla y torre medieval reforzada por los carlistas y aspillerada.
Fig. 341. La Torreta o Castillo de Chércol en el paisaje.

Fig. 342. La Torreta y restos de la muralla que rodea la torre.
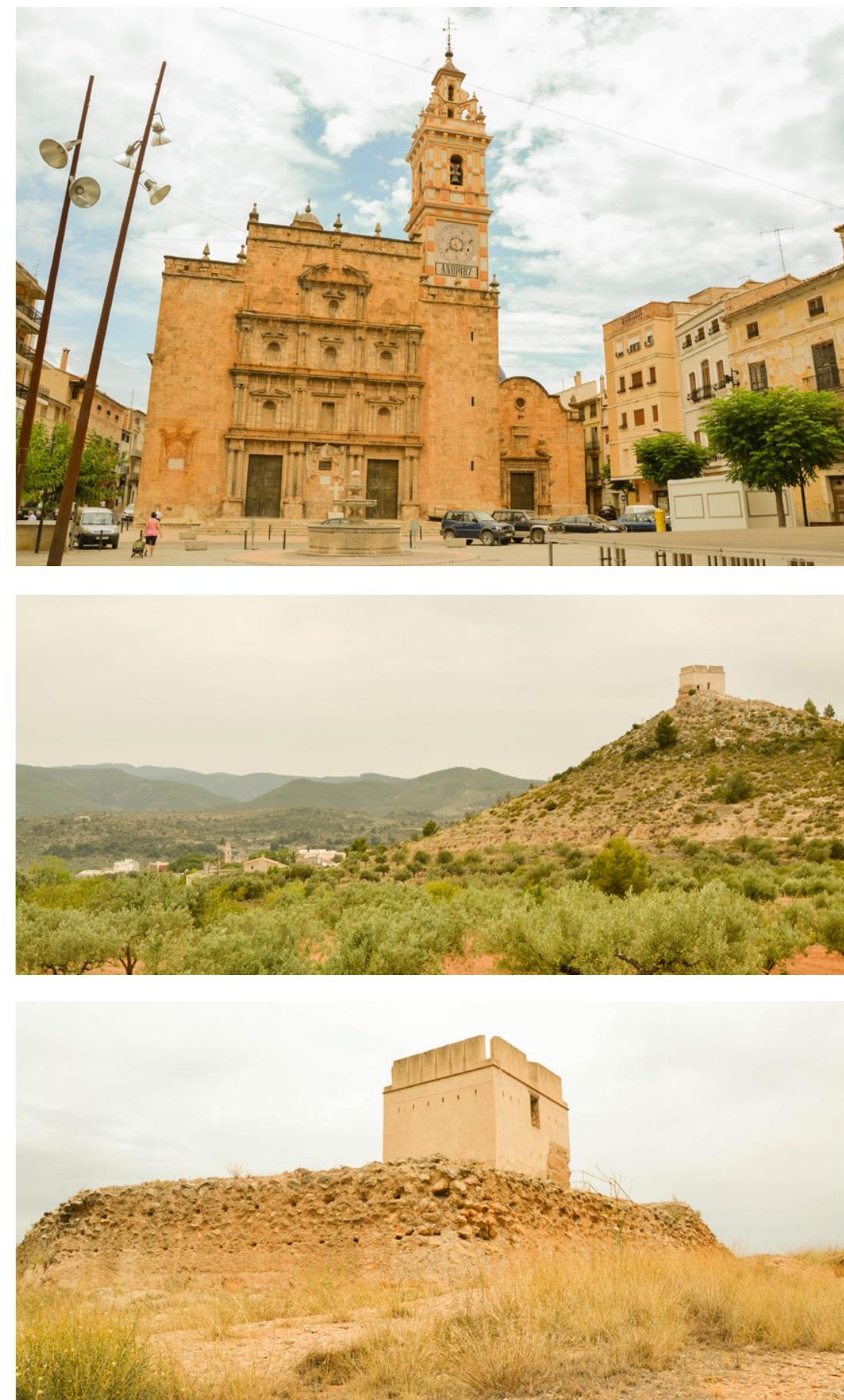
Fig. 350 Esquema en planta de

Chelva con los puntos de interés

defensivo.

01. Iglesia Arciprestal

02. Portal de San Cristóbal

03. Portillo

04. Restos de la muralla urbana

aspillerada en esquina

05 . Vivienda fortificad

06. Restos de un fuerte

07. Portal del Azoque

08. Restos de portal medieval

09. Ermita de Monserrate

09. Ermita de Monse

11. La Torrecilla

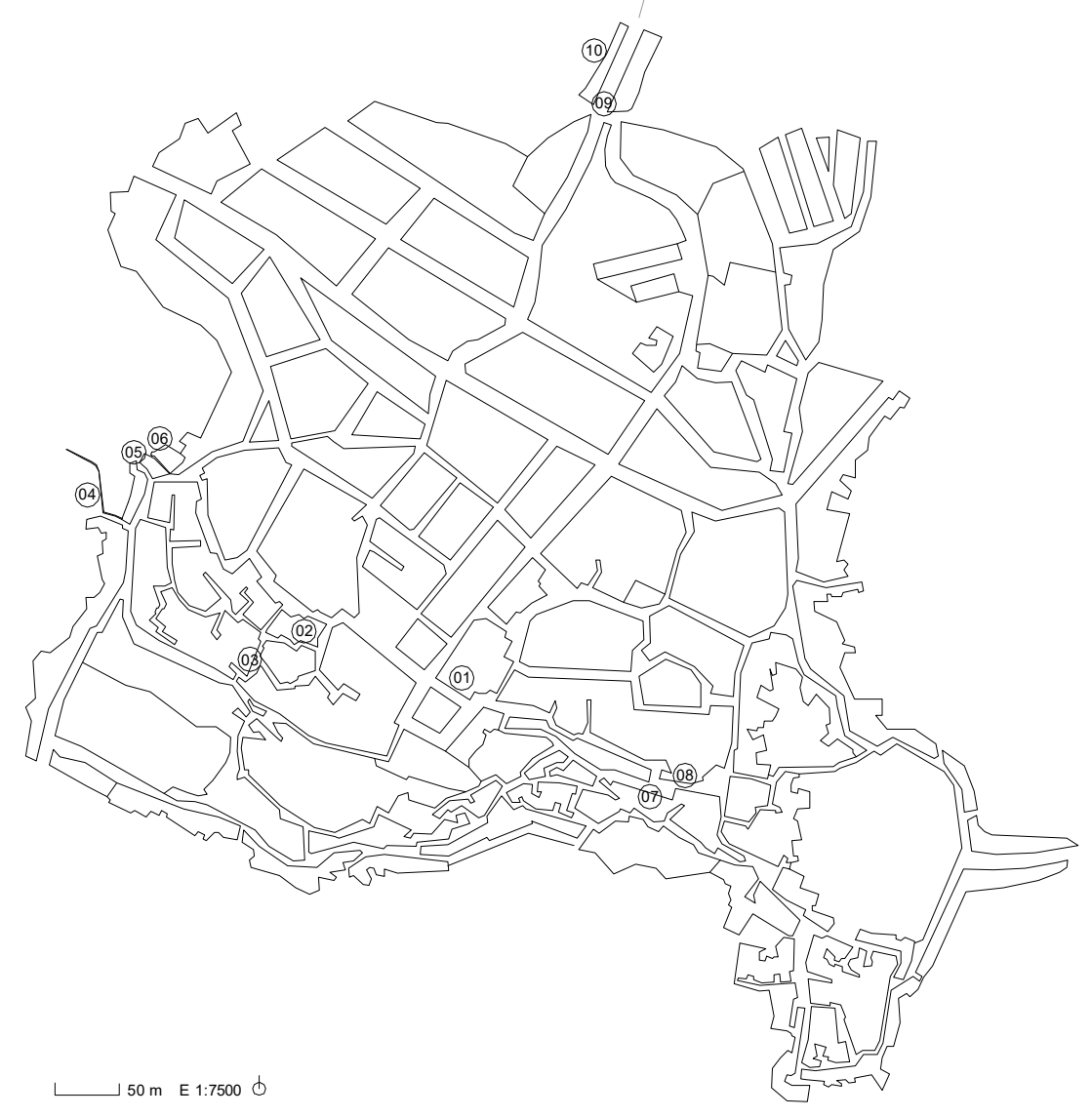

28 сницाца $^{*}$

mam




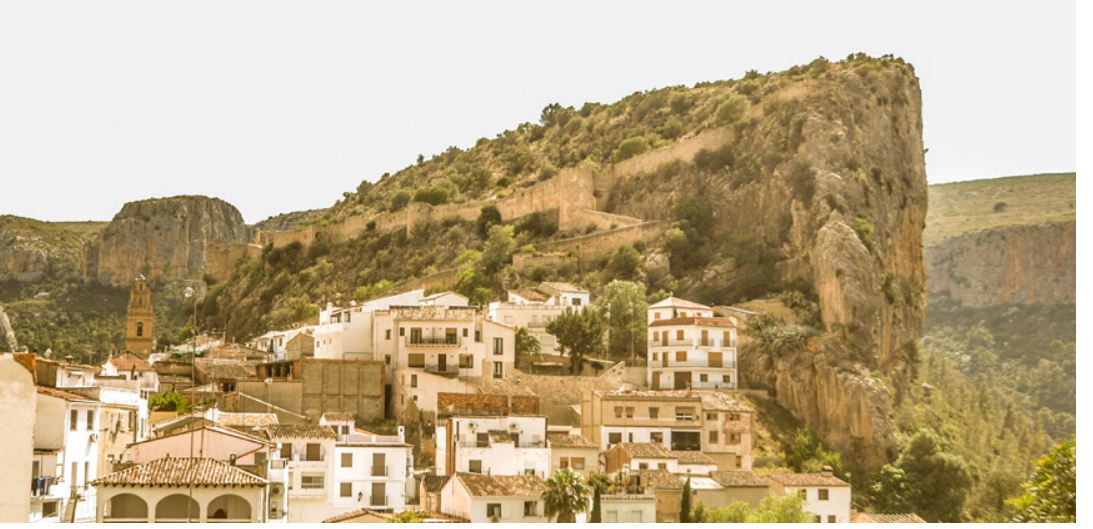

Fig. 354. Fuerte de Chulilla encaramado a la roca.
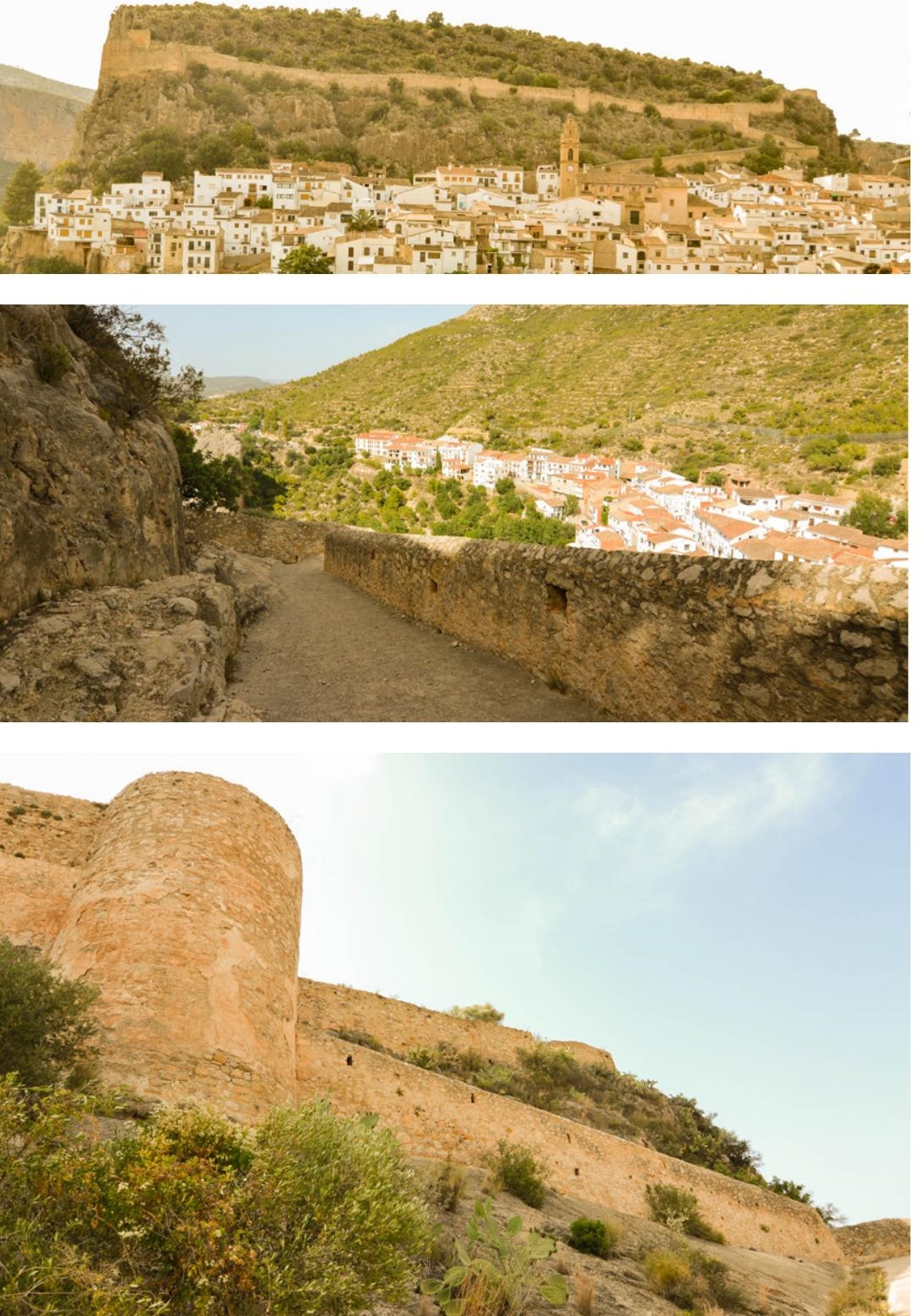

de 1838, 10 de agosto de 1839, 3 de septiembre de 1839; El Guardia Nacional, 10 de agosto de 1839, 31 de diciembre de 1839; La Tribuna, 17 de enero de 1840; La Gaceta de Madrid, 29 de diciembre de 1839). Como réplica, la campaña liberal de invierno lanza el contraataque que concluye con la toma de Chulilla el día de Nochebuena de 1839.

Los acontecimientos bélicos son registrados por fuentes de la época (entre otras la prensa citada con anterioridad), pero especialmente en la memoria militar de Azpiroz (1842) y los documentos derivados del expediente a raíz de la derrota liberal del 2 de agosto (Cincunnegui, 1839; Lemmi, 1840), siendo especialmente recogidos por el historiador Vicente Sebastián Fabuel en su libro ilustrado Asalto al fuerte de los ángeles (Sebastián Fabuel, 2016).

La derrota liberal de la Brigada de la Ribera el 2 de agosto de 1839 es fruto del intento liberal por detener las obras que se impulsan en Chulilla. Según Calbo y Rochina (1845: 430), el comandante Arévalo, tras ocupar los pueblos de "Sote y de Chera" inicia la fortificación de los mismos recurrienestas fortificaciones, pero es de suponer que consisten en obras de acondicionamiento de las preexistencias y de habilitación de puntos de defensa de campaña en el territorio.

Cuando el general Azpiroz inicia la campaña de invierno y ocupa Chelva requiere la toma de Chulilla y la Torre de Castro para asegurar la comunicación con Liria y, por tanto, con Valencia. En una guerra de movimientos donde el control de las comunicaciones constituye la clave del éxito, es preciso controlar las plazas que las entorpecen. De ahí la trascendencia estratégica de Chulilla.

Precisamente las primeras operaciones de sitio acometidas por Azpiroz tienen por objeto alejar la llegada de apoyos y evitar maniobras de distracción carlistas sobre posiciones liberales, por ello resulta imprescindible para él emplazar efectivos en Chera y posicionar las tropas de reserva en Liria para impedir la amenaza sobre la huerta de Valencia. En torno a Chulilla intercepta el puente que aísla a la guarnición que ocupa el castillo de los efectivos carlistas emplazados en la ribera opuesta del río y espera al montaje de las baterías de sitio. Azpiroz es conocedor de la eficacia de la artillería contra la fortificación neurobalística, y por primera vez, gracias a garantizar las comunicaciones, puede posicionar en el cerco de Chulilla obuses de a siete, cuatro y medio, y piezas de dieciséis. El apoyo artillero precisamente, aunque limitado, es el que resulta clave para acometer por primera vez en condiciones el asedio. Llama la atención la novedad que supone para muchos el obús como pieza de artillería. En el ataque del 1 de agosto de 1839, Cincunnegui revela este hecho indicando que "esta arma, nueva para la brigada, era curiosa: algunos había en ella que jamás conocieron sus efectos, y sus deseos de ver una granada en el aire pudieron mas que la prudencia" (Cincunnegui, 1839:17).

El cerco artillero de la campaña de invierno resulta definitivo, pero, aun así, los sitiados conseguirán sostenerlo hasta el día de Nochebuena recurriendo a las artimañas tradicionales de la guerra de sitio, al disponer de suficientes materiales acopiados y suministros para sostener el asedio. Durante los días del bloqueo, las labores se centran en reparar al anochecer los daños producidos por la artillería enemiga y, especialmente, elevar ante la puerta un sólido de tierra de 15 varas de espesor destinado a impedir cualquier apertura de brecha y cualquier asalto posterior. La estrategia defensiva no puede ser otra: resistir hasta la llegada de refuerzos que deben suministrar los comandantes carlistas Arnau, Arevalo y Forcadell, tratando de obligar a los liberales a levantar el sitio. ivos funcionan, pero los refuerzos no llegan. obligado a forzar un ataque en regla, tratando de minar la peña. Para ello ha de organizar aproches con fajina y sacos de estiércol (Azpiroz, 1842:28). Ante la imposibilidad de abrir brecha en la puerta y de acceder por la misma, se procede a la escalada con escaleras, que es rechazada por el fuego de fusilería e incluso por el lanzamiento de piedras de los defensores (Azpiroz, 1842:30). De un modo u otro observamos que se aplican en Chulilla todas las técnicas de asedio tradicionales, que si obran efecto es precisamente por la rendición de una guarnición que el día 24 comprueba que, a pesar de la resistencia, no va a poder recibir los refuerzos esperados.

El emplazamiento de campos atrincherados, la habilitación de fusileras potenciando el fuego, la disposición adecuada de la batería defensiva y la construcción del potente talud bloqueando la puerta se convierten en actuaciones más que suficientes para prolongar la resistencia de una fortificación neurobalística desde el 15 al 24 de diciembre de 1839, con una escasa guarnición, sometida a una incomunicación total y al efecto de un tren artillero de la época. 


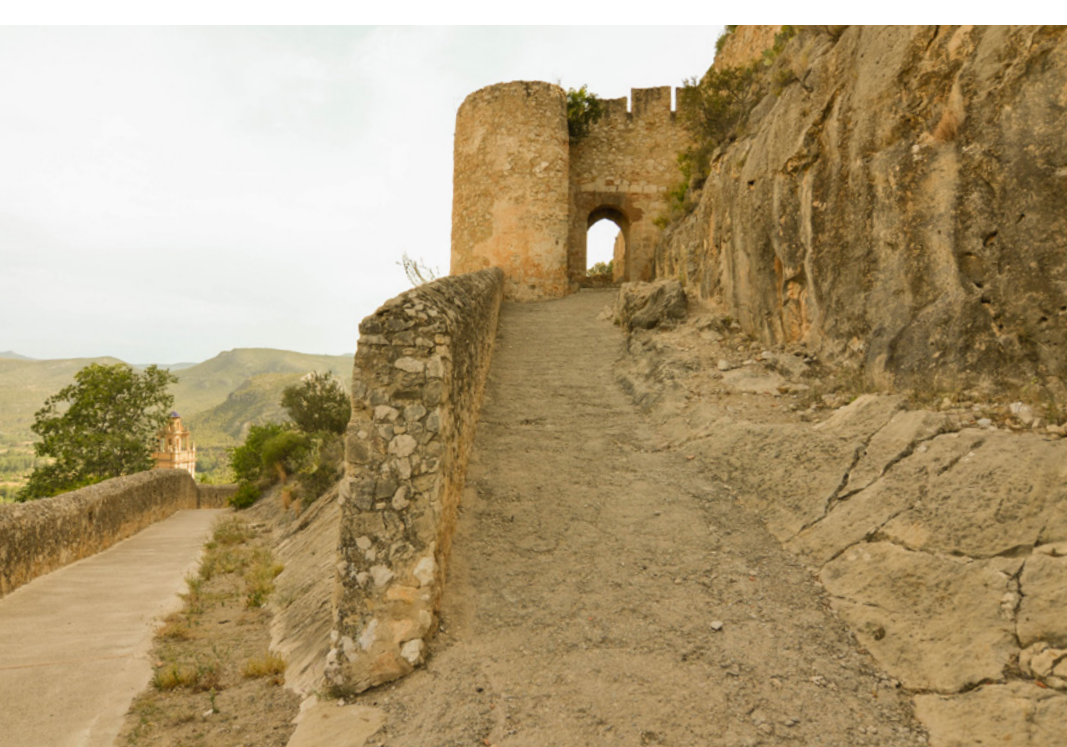

Fig. 358. Acceso al fuerte y parapetos aspillerados que conducen al mismo.

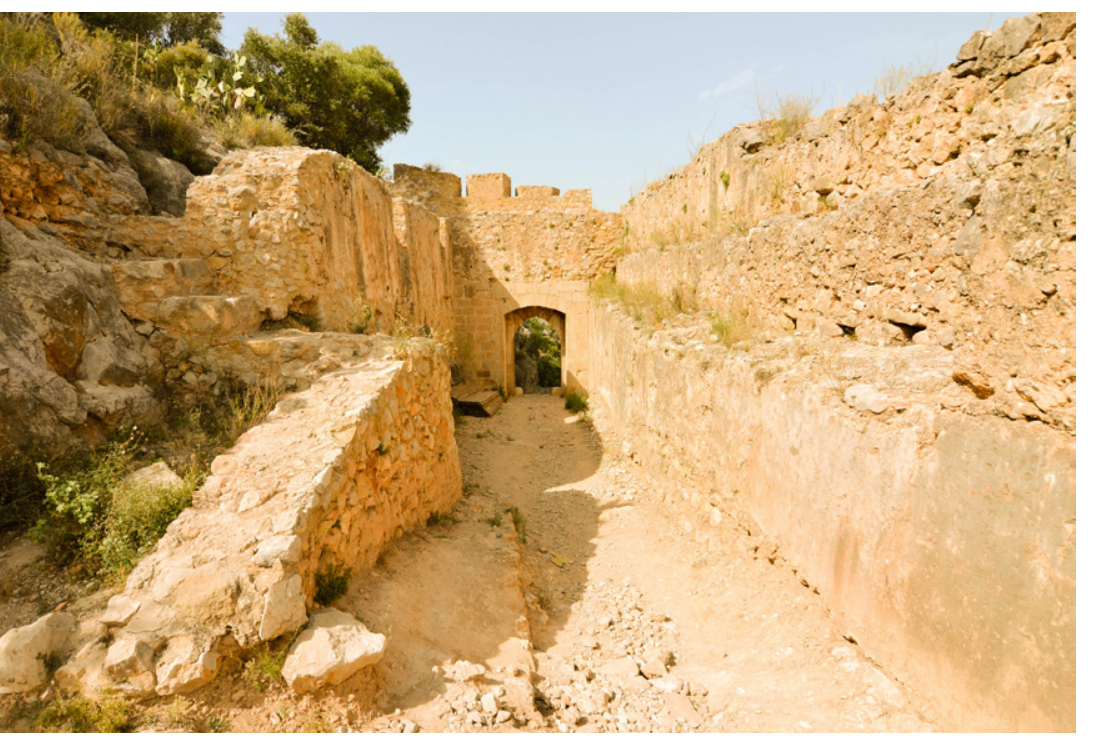

Fig. 359. Acceso al fuerte visto desde el interior del mismo.

Fig. 360. Fuerte de Chulilla fotografiado desde la coronación del muro de acceso.
Tras la claudicación del castillo de Chulilla, los liberales proceden a la reconstrucción de las partes clave de la defensa, estableciendo una línea fortificada de campaña junto al río Blanco para favorecer las penetraciones del ejército en territorio carlista. La devastación de las construcciones sometidas al fuego de artillería debe ser considerable. Los Episodios regionales de José Monleón Francés recogen que el armisticio de la plaza se produce precisamente cuando se agotan las provisiones y el conjunto de habitaciones interiores, "incluso el oratorio dedicado a S. Miguel", han sido completamente destruidos (Monleón Francés, 1910: 64-68). Pero considerado el estado de la fortificación en nuestros días, dos (Monleón Francés, 1910: 64-68). Pero considerado el estado de la fortificación en nuestros días, se deduce que dicha reconstrucción se centra en eliminar el talud provisional frente a la puerta, que
impide, según el testimonio de Azpiroz, el acceso de los sitiadores al interior teniendo que "subir al castillo con escalas" aún transcurridos muchos días después del armisticio (Azpiroz, 1842:33).

El castillo de Chulilla responde a una tipología de simple frente longitudinal, característica de emplazamientos montañosos con una única ladera accesible. Precisamente el monte del castillo aparece cortado a pico por todos sus frentes salvo en la ladera oriental, donde se enclava la localidad de por los frentes inaccesibles, discurre un meandro del río Turia. De este modo el castillo domina todo el tránsito por el Turia en los alrededores, así como la posible llegada desde el camino de Valencia. Su localización plantea escasos inconvenientes defensivos, salvo la presencia de dominaciones montañosas que en 1839 se contemplan para el posicionamiento de baterías o la disposición de tiradores para acosar a los defensores, como el denominado Cerro del Fraile, al oeste del Castillo, que permite enfilar la cortina, o especialmente la vasta extensión de la Muela o Monte de la Muela (según la denominación de los planos de la época) que es uno de los principales puntos de enfrentamiento entre liberales y carlistas en 1839 como objetivo previo a la toma del castillo. Cincunnegui (1839:12) llano del Villar-del-Arzobispo y á una hora de la Losa. Formada de altos y sucesizos escalones de piedra viva, se encuentran en ella algunos árboles y arbustos, formando su cúspide como un torreón natural cortado á pique, que concluye en una espaciosa meseta solo accesible por el este y por el sur, hacia donde se halla el pueblo de Chulilla, bajo el castillo de los Ángeles, ambos dominados por el terrible peñasco á poco mas de tiro de fusil". El castillo que encontramos cuando detona la primera Guerra Carlista es una estructura alterada por los sucesivos conflictos. Se trata de un conjunto arquitectónico cuyo emplazamiento constituye el origen de la villa a raíz de un posible asentamiento de tiempos prerromanos, pero cuya construcción más relevante procede de época islámica. Las excavaciones arqueológicas parecen haber podrían datar antiguas estructuras sobre la cima y un aljibe excavado en roca. El germen de la fortaleza podría ubicarse entre el siglo VIII y el siglo XII, quizá aprovechando estructuras preexistentes, a fin de integrar la red defensiva dependiente del denominado hisn de Djulayla, o castillo islámico de Chulilla.

Se localizan diversos testimonios históricos que atribuyen el origen de Chulilla, y por tanto, de sus primeras estructuras arquitectónicas, a épocas precedentes, centrándose principalmente en el siglo I a. C. Marés indica que "su primer origen es de Romanos, poco después Julio César en memoria del cual monarca, se llamó Iulioa o Iuliela" (Marés, 1681). Otros autores le atribuyen un origen godo, pero parece existir una cierta unanimidad en las fuentes de los siglos XVII y XVIII en remontarse a o romanos. Gaspar "Deste tiempos de mos lo romanos. Ge liella: y según Beuter los Romanos Iuliola, por honra de Julio Cesar" (Escolano, cap 21, col. 873, n.2, cit. en Gil de la Sierpe, 1787: 60-61). No obstante, las excavaciones arqueológicas demuestran la existencia de presencia prerromana.

En los estudios sobre Chulilla se encuentran diversas interpretaciones. Algunas fuentes apoyadas en la tradición narran que la estructura islámica resulta inexpugnable para Jaime I, que tiene que pactar la rendición en 1238 garantizando las vidas y haciendas de los refugiados. Una vez en poder aragonés, el castillo es donado al caballero Rodrigo Ortiz, tal y como recoge el Llibre del Repartiment, sin embargo, el 26 de febrero de 1273, es cedido al obispo Andrés de Albalate (Palaia \& Chapapría, s.f.:1-2; DGPA, 2016). Los paneles de la propia Conselleria de Turismo y el Ayuntamiento de Chulilla matizan que en 1236 el rey de Valencia Abú Zahid dona Chulilla al obispo de Segorbe, que en 1248 Jaime I lo traspasa a Pere Escrivà de Narbona - "castrum et villam de xuleia" - y que, que en 1248 Jaime I lo traspasa a Pere Escrivà de Narbona- "castrum et villam de xuleia" -y que,
finalmente, en 1274, la Baronía de Chulilla es entregada al Cabildo y al Obispo de Valencia, por lo 


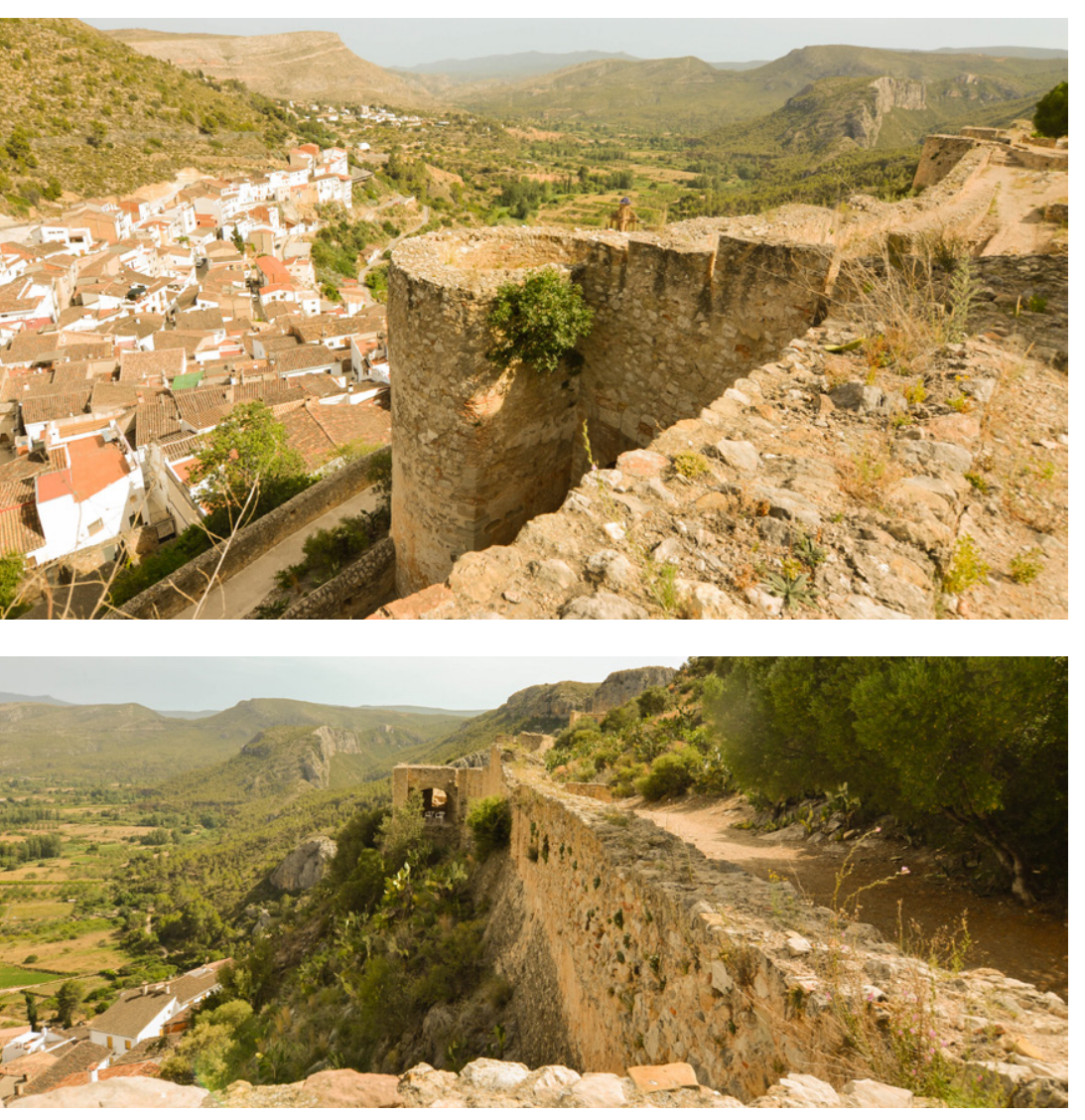

Fig. 362. Zona central del fuerte.
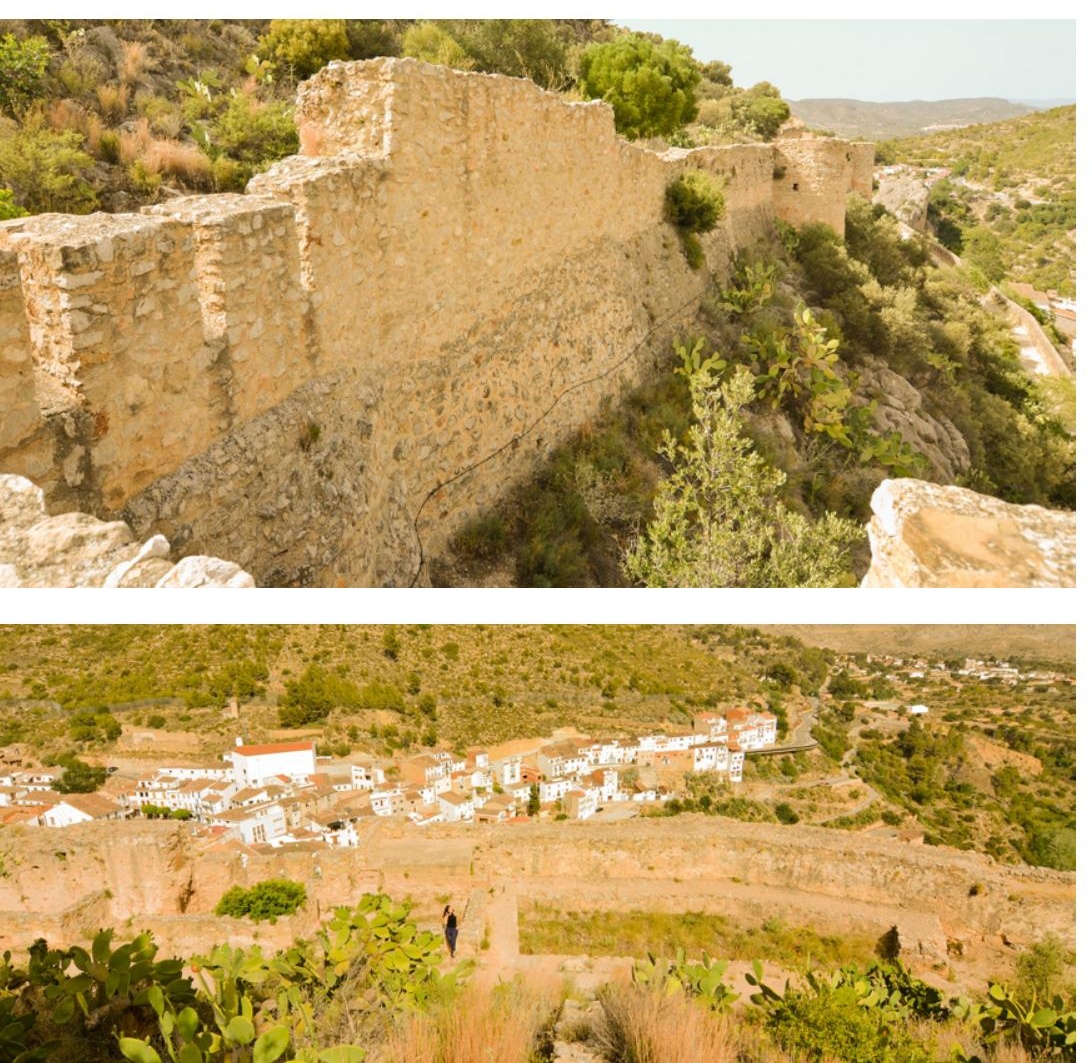

Fig. 361. Torre de traza circular que flanquea el acceso, zona norte del fuerte y relación con la población. Se observa la gran diferencia de niveles.

Fig. 363. Zona norte del fuerte fotografiada desde la torre de traza cuadrangular que sobresale de la muralla en el centro aproximado del fuerte.

Fig. 364. Zona central del fuerte fotografiada desde la elevación de la montaña en la que se encuentra. que la propiedad no se concentra en manos del obispado hasta que en 1373 este asuma los derechos del Cabildo.

En 1331 el rey Alfonso IV el Benigno otorga privilegios a los nuevos repobladores cristianos y decreta la expulsión de los musulmanes. Esta se concreta en 1340 cuando el obispo Ramón Gastán expulsa a los moros y favorece nuevos asentamientos. Precisamente el primer sínodo de la iglesia valenciana aparece firmado por dicho obispo en el castillo de Chulilla (DGPA, 2016).

En el siglo XIV parece que el castillo sufre reformas trascendentales a raíz de las guerras con Castilla, reformas que se acentúan en los siglos XV y XVI, cuando la irrupción del armamento de fuego exige en muchos castillos neurobalísticos obras de adaptación. No se ha tenido constancia en esta investigación de documentos que especifiquen el tipo de intervenciones. Parece que son de menor trascendencia que las que se exigen para su utilización como residencia y prisión del obispado. Es en el siglo XVI, tras servir de prisión después de la guerra de Germanía, cuando el castillo adquiere escabrosa celebridad eclesiástica. La amenaza inquisitorial de ser encarcelado en el castillo de Chulilla resulta intimidatoria para la época.

Pocas noticias quedan hasta la llegada de los efectivos carlistas. Parece que es ocupado por fuerzas inglesas durante la Guerra de Sucesión, siendo desocupado tras la batalla de Almansa y que, un siglo después, en el transcurso de la Guerra de Independencia, es ocupado por las fuerzas francesas (Palaia \& Chapapría, s.f.:1-2; DGPA, 2016).

Pero es durante Las Guerras Carlistas cuando el castillo de Chulilla entra en acción por última vez y se ve sometido a las principales acciones destructivas y posterior abandono.

En este conjunto de procesos de ocupación y desocupación hasta el estallido de la Primera Guerra Carlista, el castillo cumple siempre una misión eficaz como punto de control del territorio, sea o no partícipe de acciones de guerra. Se interpreta que, en el transcurso de los siglos, la estructura sufre reconstrucciones, transformaciones espaciales y adecuaciones funcionales que se diluyen ante la ausencia de documentación al respecto. Tan solo el documento histórico del propio hecho arquitectónico puede servir de guía interpretativa.

Hoy en día nos encontramos con una construcción caracterizada por un acceso en pendiente de sur a norte que arranca de la última alineación de casas del pueblo, defendido por un muro aspillerado posiblemente fruto de las intervenciones de 1838. Esta rampa de acceso produce un recodo de $180^{\circ}$ en el tramo final para encarar la puerta principal, tramo de unos 27 metros. La rampa de acceso asciende un total de 24,88 metros y constituye un elemento defensivo de primer orden; en primer lugar para la defensa lejana, favoreciendo una primera línea defensiva distante sobre la localidad y las vías de acceso a la misma, en segundo lugar para la defensa próxima, interceptando y segmentando el acceso a la puerta principal y exponiendo a los ocupantes del camino que aspiran a acceder al castillo al fuego desde la cortina principal.

El acceso principal o portal constituye una de las estructuras arquitectónicas más potentes del conjunto. Un torreón semicircular flanquea el acceso y la rampa, dominando las alturas. Junto a él se encuentra la pequeña cortina con el vano de acceso, retirada para favorecer el flanqueo. Curiosamente, este vano ofrece en su cara exterior un arco de medio punto de ladrillo, mientras que el interior ofrece un arco rebajado de sillería que permite dilucidar intervenciones sobre la misma en la puerta discurre un adarve almenado que conduce desde la plataforma de roca occidental a la plataforma de la torre. El conjunto constructivo de la puerta es otro de los puntos sobre los que se interviene durante la ocupación carlista, aportando la puerta de la iglesia y cubriendo - más bien taponando - el acceso para impedir el asalto y el acoso de la fusilería apostada en el Cerro del Fraile en 1839

Agregados interiormente al conjunto de la puerta aparecen una serie de restos constructivos de lo que pudo ser el cuerpo de guardia que flanquearía el acceso por su cara interior.

A partir del punto neurálgico de la puerta, el castillo se extiende en dirección sur con la amplia cortina, pero también se prolonga brevemente en dirección norte hasta alcanzar el límite del cerro del castillo en dicha dirección. Para ello se construyen escarpas y se aprovecha el escalonamiento del terreno que se eleva dominando el recodo del acceso y la puerta. En el espolón septentrional que del terreno que se eleva dominando el recodo del acceso y la puerta. En el espolón septentrional que
configura este extremo del castillo, se consolida una batería que permite flanquear el recodo de la 


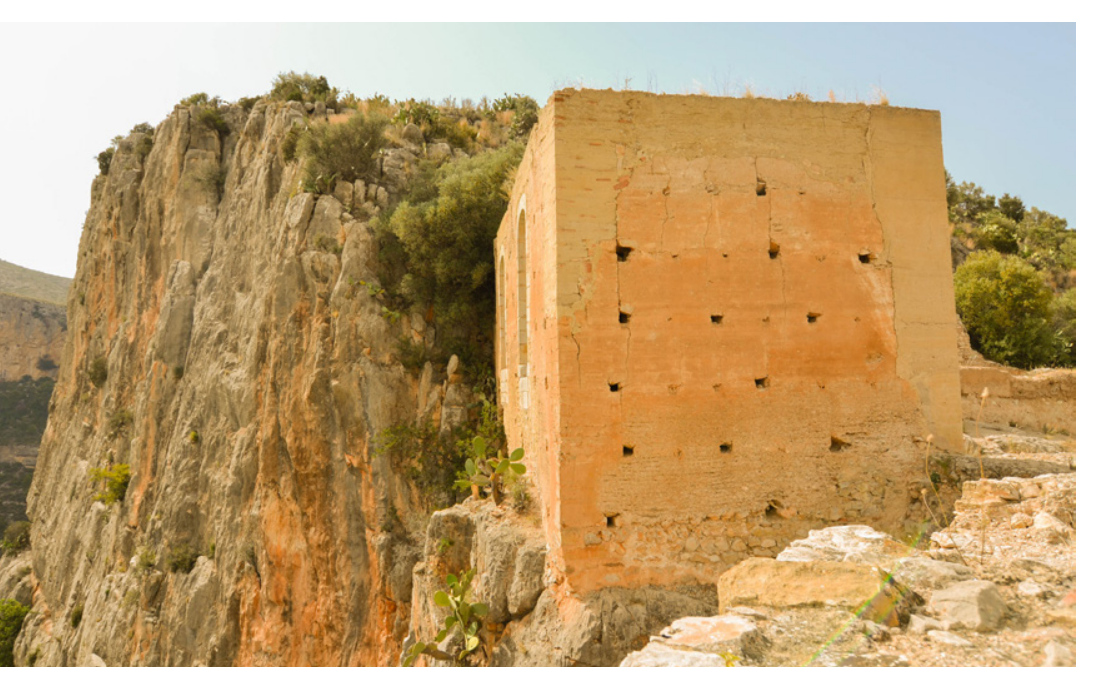

Fig. 365. Extremo suroeste del fuerte, rematado con los restos de este cuerpo.

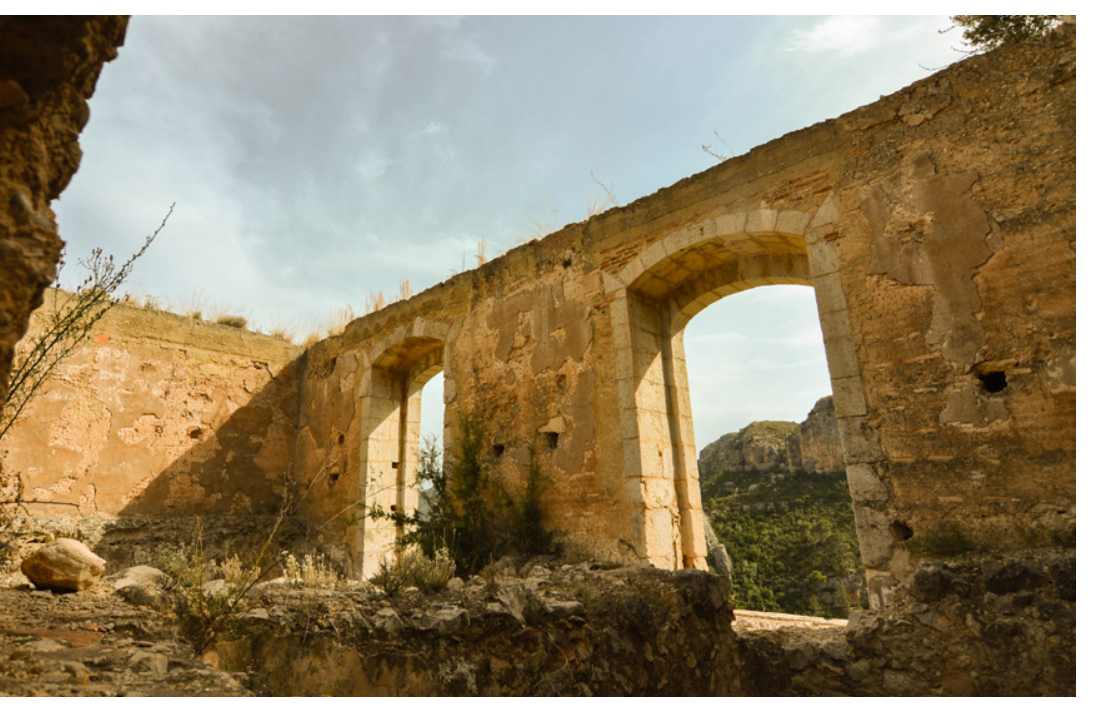

Fig. 366. Interior del cuerpo.

Fig. 367. Interior abovedado de la torre de traza cuadrangule ubicada en el centro del fuerte. rampa de acceso, pero, especialmente, dominar con su fuego el Cerro del Fraile y, con él, cubrir las afueras del frente septentrional del castillo.

La zona previa a la que podemos denominar celoquia, o espacios de la gobernación del castillo, contra la ladera de la montaña se escalona en planta configurando lo que en tiempos de la fortificación moderna se denomina una cortina abaluartada. No es una estructura moderna, sino que se trata de un recurso ya localizado en estructuras de la antigüedad y que tiene por objeto ofrecer puntos de flanqueo de la cortina desde la propia cortina. Entre el flanco de la cortina y el torreón de acceso se emplaza un torreón semicircular de pequeñas dimensiones que sirve de apoyo en las tareas de flanqueo acometidas por el torreón de acceso y la cortina flanqueante.

Realmente, si seguimos el trazado del lienzo amurallado, podemos deducir que es el resultado de un criterio práctico de adaptación a las condiciones del terreno que exigen la aparición de estas estructuras flanqueantes para impedir la pérdida de perspectiva visual. En el saliente que configura cortina, con el objetivo de definir el flo que se identifica con un calabozo, pero que, con toda probabilidad, cumple también misiones defensivas por su posición privilegiada.

El segundo tramo de cortina, que se extiende desde el centro de la estructura hasta el límite meridional del cerro, donde se emplaza la celoquia musulmana, tiene un trazado poligonal tendido, fácilmente cubierto por el saliente de la cortina flanqueante central y la plataforma saliente de la celoquia que conforma un baluarte cuadrangular, en el que se habilitan cañoneras, con toda probabilidad para cubrir la localidad.

En el extremo meridional se localiza la principal concentración de dependencias. Tres definidas con tapia, que se adosan a la montaña y se sostienen sobre el despeñadero. Resulta difícil precisar el uso, pero con toda probabilidad, dada su posición resguardada, sirven en momentos de asedio como puntos de resguardo, bien para alojamiento de la guarnición, disposición de la cocina, el almacén de víveres o aljibe.

En la cima de la meseta inclinada quedan restos de dos aljibes que recogen el agua, favorecidos por la gran superficie de la cima. El mayor de los aljibes es el meridional, con unas dimensiones de 6,5 $\mathrm{m}$ por 3,1 m en planta y 1,8 $\mathrm{m}$ de profundidad (un total de $36,27 \mathrm{~m}^{3}$ ). El aljibe septentrional es de menor capacidad, con unas dimensiones de 7,9 por $1,5 \mathrm{~m}$ en planta y $2,2 \mathrm{~m}$ de profundidad $\left(26,07 \mathrm{~m}^{3}\right)$. Llama la atención el testimonio que ofrece el general Azpiroz en su memoria de 1842 (Azpiroz, 1842:25) cuando analiza la respuesta del castillo. Observa que el principal valor defensivo del castillo lo concede la naturaleza del lugar. Considera inaccesible la fortaleza por tres de sus caras, aquellas coincidentes con los escarpes que contornea el río que él denomina "río Blanco". Cuando hace referencia al frente sur, es explícito al indicar que la cortina está "guarnecida de cubos y torreones antiguos" y destaca la existencia de "obras modernas en sus estremos". Estas obras hacen referencia a los puntos de concentración artillera ya indicados. Utiliza el término teórico "espaldón" para hacer referencia al papel que juega la propia pendiente natural de la cima, que, como un espaldón, cubre la espalda de la cortina sur.

No cabe duda de que gran parte de las adecuaciones de tiempos de la ocupación carlista son de carácter estrictamente utilitario, tratando de satisfacer requisitos básicos de habitabilidad, como reparación de cubiertas o cierre de tabiques desmoronados, y, especialmente, tratando de cubrir los aspectos defensivos. Estos se ciñen generalmente a la perforación sistemática de muros y tapias los aspectos defensivos. Estos se ciñen generalmente a la perforación sistemática de muros y tapias
para habilitar el mayor número posible de aspilleras rudimentarias, reconstrucción de parapetos,
elevación de nuevos, y habilitación de plataformas para la disposición de alguna pieza modesta de elevación de nuevos, y habilitación de plataformas para la disposición de alguna pieza modesta de posibles emplazamientos propios de la fortificación de campaña en las afueras del castillo, tratando de guarecer a los defensores en puestos avanzados, bien para vigilancia de las aproximaciones, bien para sostener la defensa de puntos susceptibles de ser tomados por el enemigo para atacar de un modo favorable, como podría ser el monte de la muela. No cabe duda, dado que se trata de una intervención frecuente en otras localidades como Requena (Navalón, 2016: 92), de que el recrecido de parapetos en la rampa de acceso y su aspilleramiento podrían constituir parte de las obras acometidas en este periodo. Las alteraciones localizadas en la puerta principal de acceso, y la plataforma artillera que se configura en el espolón septentrional, podrían ser también fruto de 
Plano 4

Título uniforme: Chulilla (Valencia). Castillos (184-). Escala indeterminada

Título: Croquis del Castillo e inmediaciones de Chulilla

Publicación: 184-

Descripción física: 1 mapa: montado sobre tela; $20,6 \times 30,1 \mathrm{~cm}$, en h. de 23, $1 \times 34,4 \mathrm{~cm}$

Notas: Presenta ademas el plano de la planta del Castillo y una vista de la Torre de Castro de Calles. Relieve representado por normales. Relación de baterias indicadas por clave alfabética, y de brigadas en clave numérica. En el ángulo superior derecho: Lama. 3.

Ejemplares: Archivo Cartográfico de Estudios Geográficos del Centro Geográfico del Ejército Ubicación: AR - Signatura: Ar.G-T.3-C.1-223 - Código de barras: 2210775.

Fig. 372. Plano 1. Plano del fuerte y sitio de Chulilla.

Fig. 373. Plano 2. Croquis de Chulilla, su castillo e inmediaciones.

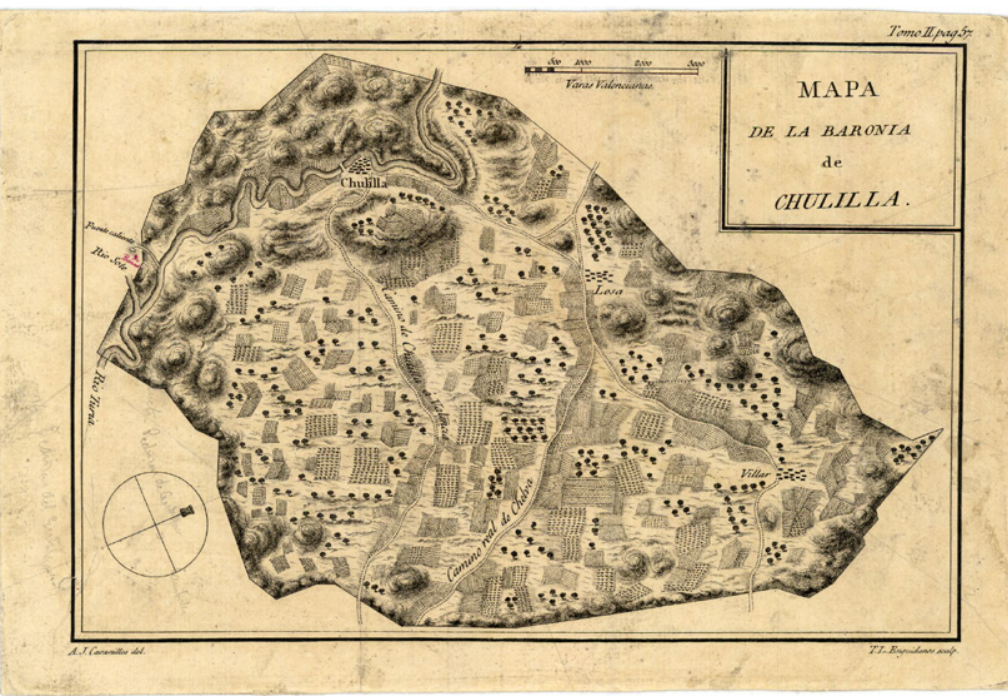

Fig. 374. Plano 3. Mapa de la Baronía de Chulilla.

Fig. 375. Plano 4. Croquis del castillo e inmediaciones de

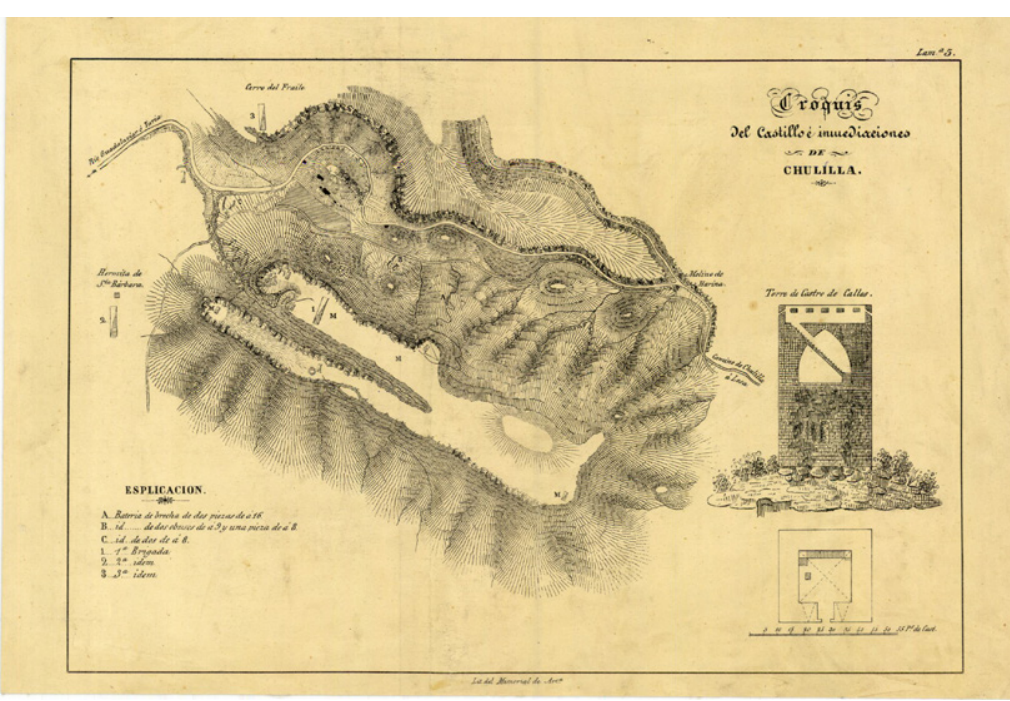




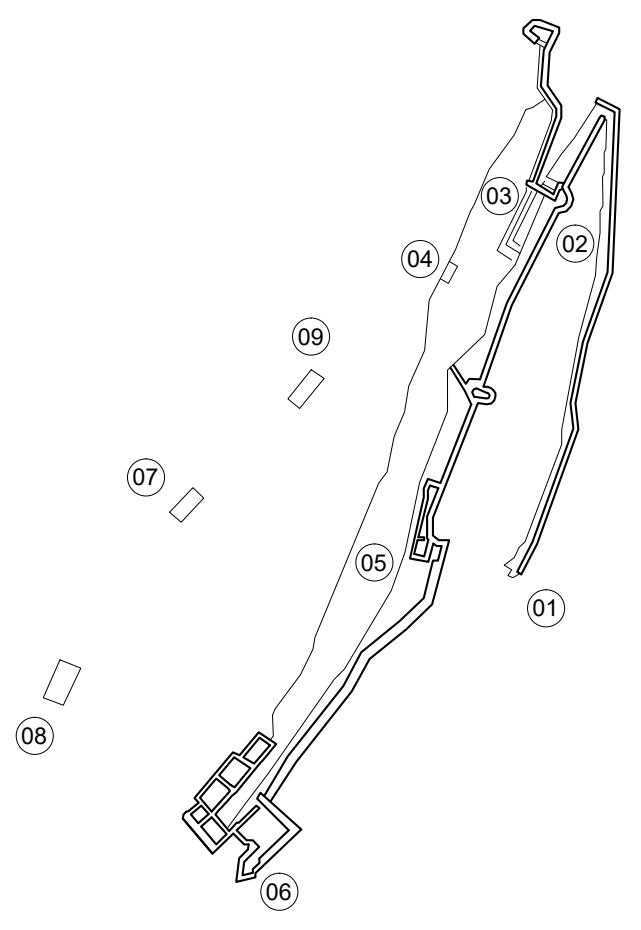

Fig. 376. Esquema en planta de

01. Rampa con parapeto aspi-

llerado.

03. Cuerpo de guardia

04. Aljibe

05. Zona de dependencias de

tropa y auxiliares

06. Gobernación

07. Resto del hisn islámico

(celoquia)

08. Aljibe islámico

09. Aljibe prerromano

29 CuLA $*$ 
Fig. 392. Restos de la torre del

homenaje medieval, en la cima

del montículo, y relación de alturas con respeto a la torre de la iglesia.

Fig. 393. Restos del segundo recinto y su relación con el paisaje y el núcleo urbano.

Fig. 394. Restos del segundo recinto, en la cima del montículo que domina la población.

Fig. 395. Restos de una de las torres cilíndricas del segundo recinto y su dominio del territorio.
Fig. 396. Casco urbano de Culla

en la actualidad con los puntos

de interés defensivo.

1. Zona conocida como "baix lo mur"

22. Mirador de Sant Roc

03. El Carrer Pla

04. La Plaça del Pardal

05. 1 Pelleric (picota)

06. Antiguo hospital

07. Mirador del single

08. Pies del castillo

09. Puerta de la Barbacan

10. Ruinas del castillo situadas

en la cima

11. Era de la Tahona

12. Calvario y muralla sur

13. Puerta nueva

14. Iglesia del Salvador

15. El Perxet

6. Prision

17. Portal de la Fuente

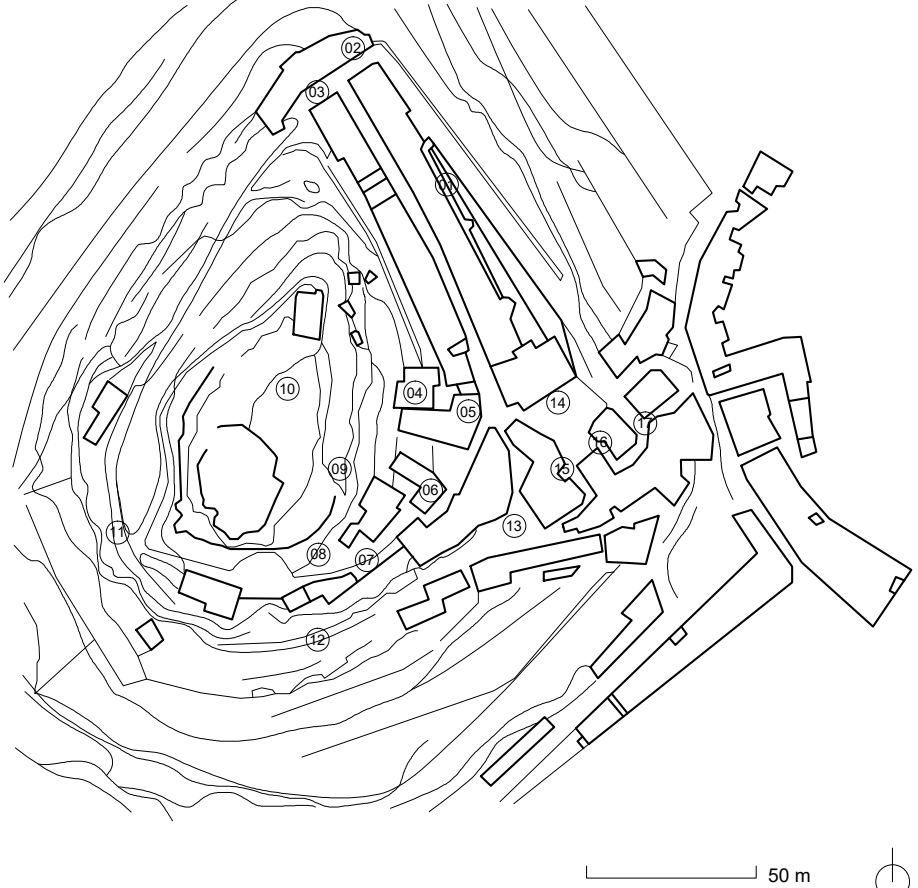


30 Dомегіо *

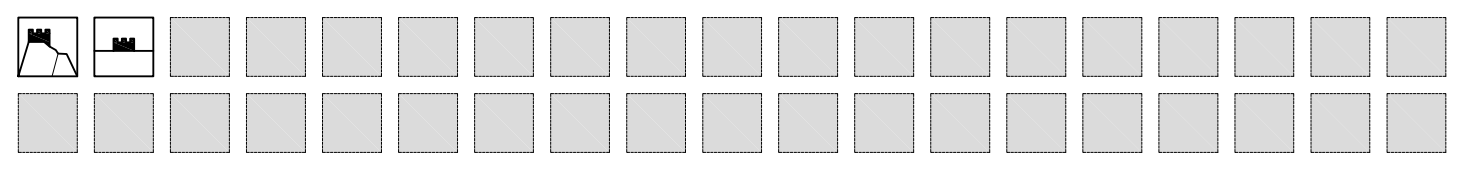




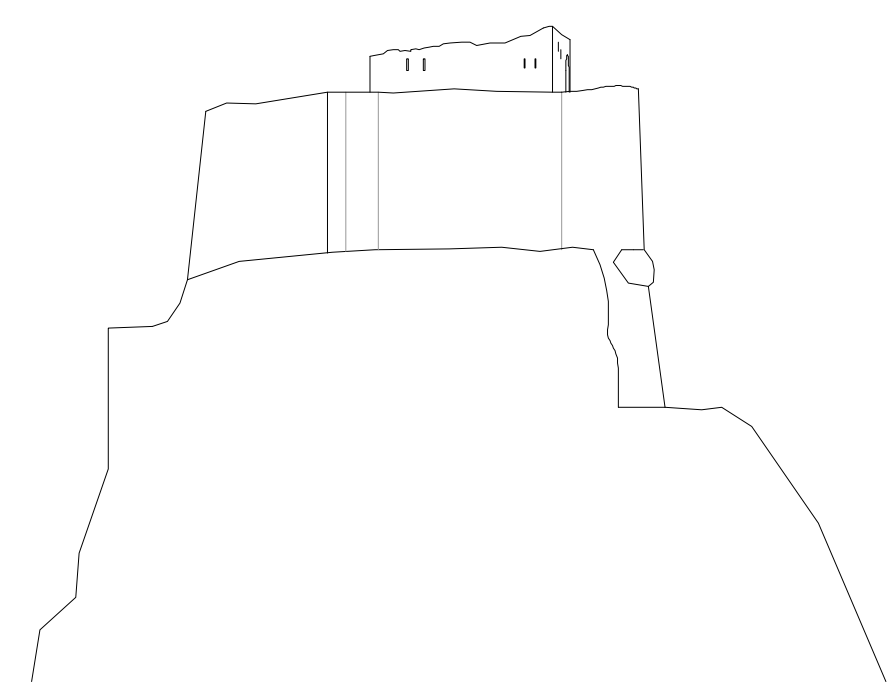

$5 \mathrm{~m} \quad \mathrm{E} 1: 500$

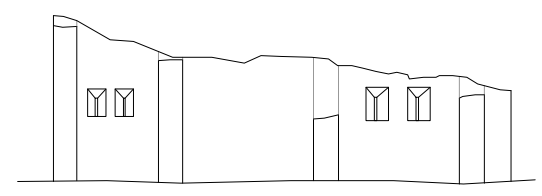

2 m E 1:500

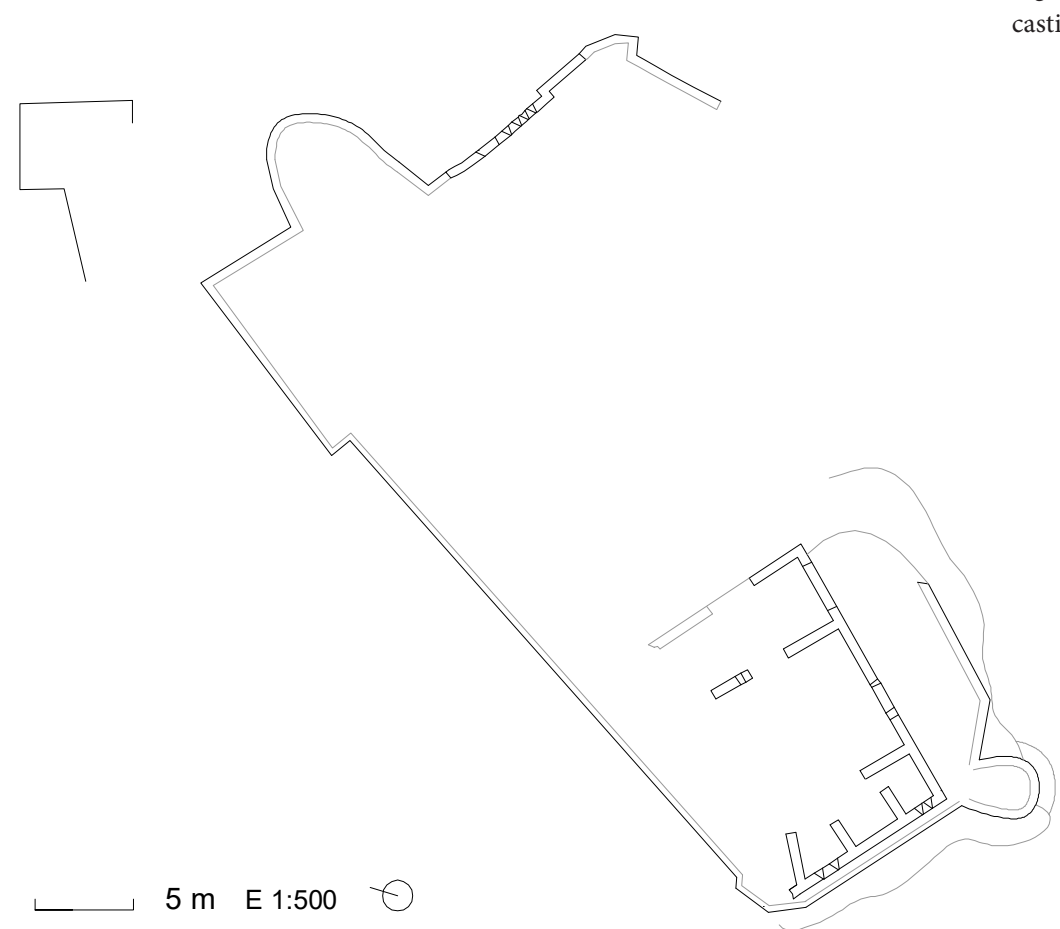

Fig. 408. Alzado sureste del

castillo de Domeño.

Fig. 409. Sección transversal del fuerte. Fachada sureste vista deste el interior.

Fig. 410. Esquema en planta del castillo de Domeño. $311_{\text {EUUVE }}$ *

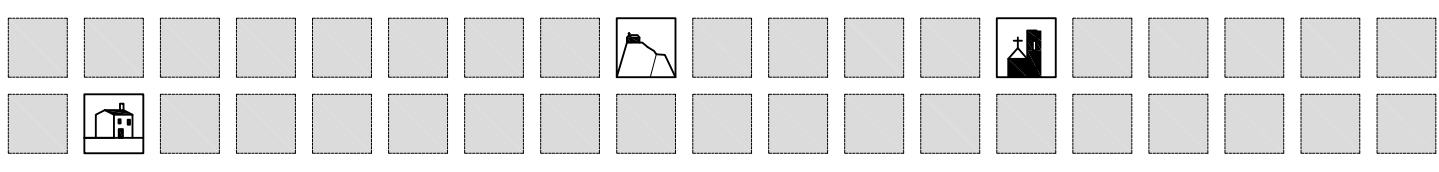




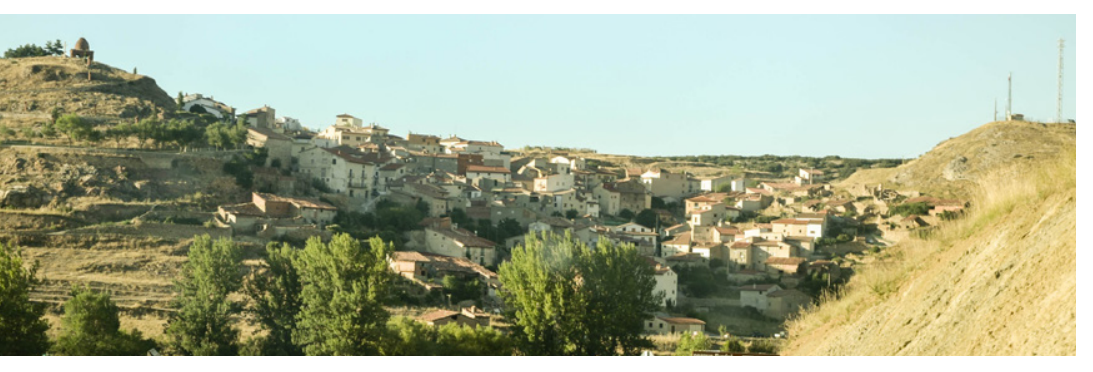

Fig. 411. Núcleo urbano de Ejulve y las dos colinas que flanquean la población. A la languean la población. A la izquierda, el monte Calvario y la coronación de ladrillo $\mathrm{d}$ campanario.

Fig. 412. Campanario visto desde su pie. Se observan aspillera y distintos materiales y distintos tipos de mampostería

Fig. 413. Iglesia de Santa María la Mayor vista desde el oeste.
Ejulve

Provincia actual: Teruel

Comarca: Andorra-Sierra de Arcos

Coordenadas geográficas: $40.77496410863256,-0.5549096913394749$

Tipos defensivos: fortificación de ermitas, fortificación de iglesias, fortificación de viviendas.

Acciones y fortificación:

De su fortificación se tienen pocos datos. Sabemos que en 1836 los liberales están asentados en la localidad y "a las 9 de la noche se produjo el ataque llegando los carlistas hasta la Plaza, donde fueron rechazados dejando más de 60 muertos y 50 heridos. Durante la acción la mitad de los oficiales se batían y la otra mitad se ocupaba de fortificar la iglesia, el ayuntamiento y casas colindantes" (Diario Constitucional de Zaragoza, del 18 de mayo de 1836).

Más adelante, la plaza es tomada por los carlistas. En la gran ofensiva liberal del año 1840, los carlistas tratan de fortificar Ejulve y una ermita cercana, pero tienen que desistir ante la amenaza de las tropas enemigas y destruyen las obras realizadas (Diario Mercantil de Valencia, 12 de enero de 1840; Caridad, 2013:265).

En la actualidad, la población se halla entre dos cerros, uno de ellos con subida en calvario hasta la iglesia y el otro coronado por antenas. En la torre de la iglesia se aprecian algunas aspilleras, así como en una edificación anexa a la misma, todas ellas de origen medieval.

Fig. 414. Esquema en planta de Ejulve con los puntos de interés defensivo.

01. Iglesia Santa María la Mayor

02. Mirador de San Pedro

03. Ermita de San Pedro

04. Ermita de San Pascual

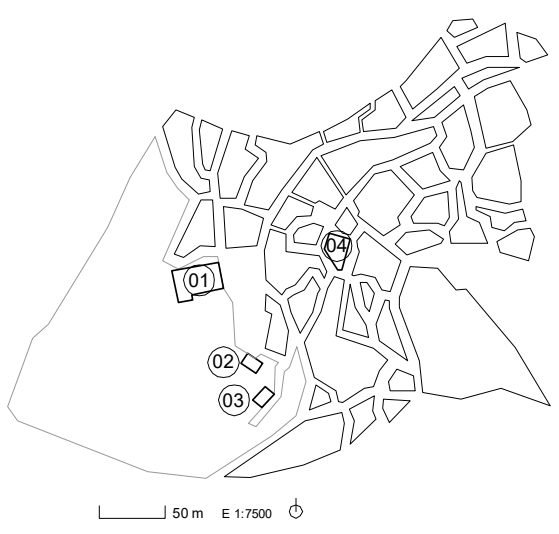


2 el Collado de Alpuente /
Castillo del Poyo

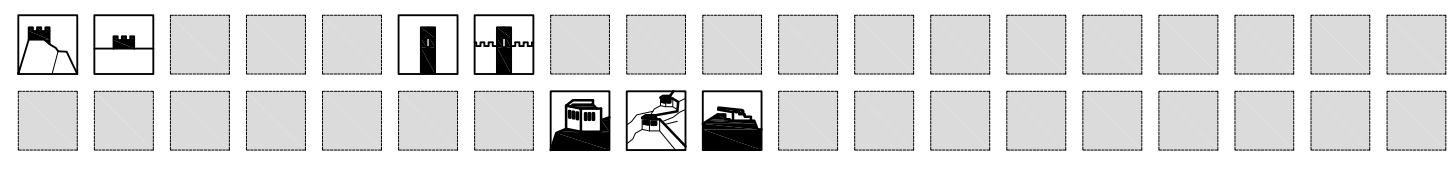




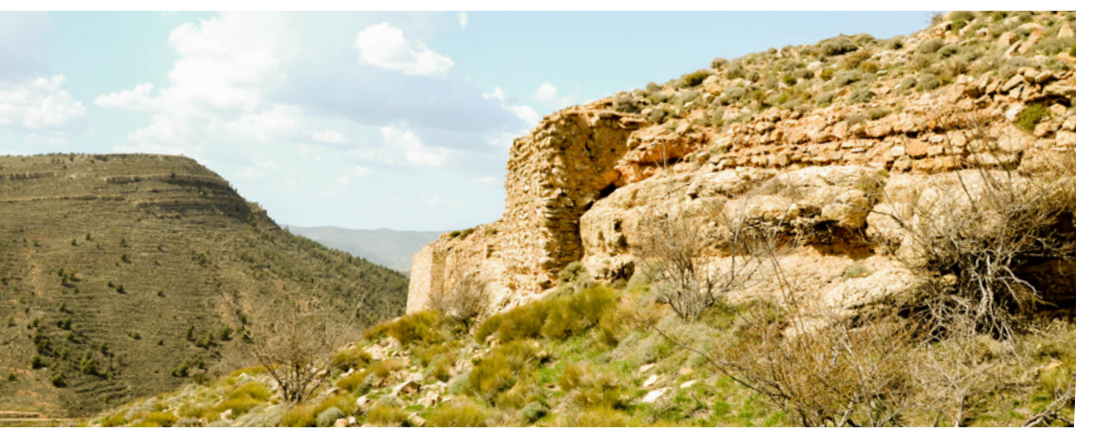

Fig. 419. Ruinas de la parte noroeste del fuerte, con las ruinas de dos torres de traza cuadrangular adosadas a la muralla.
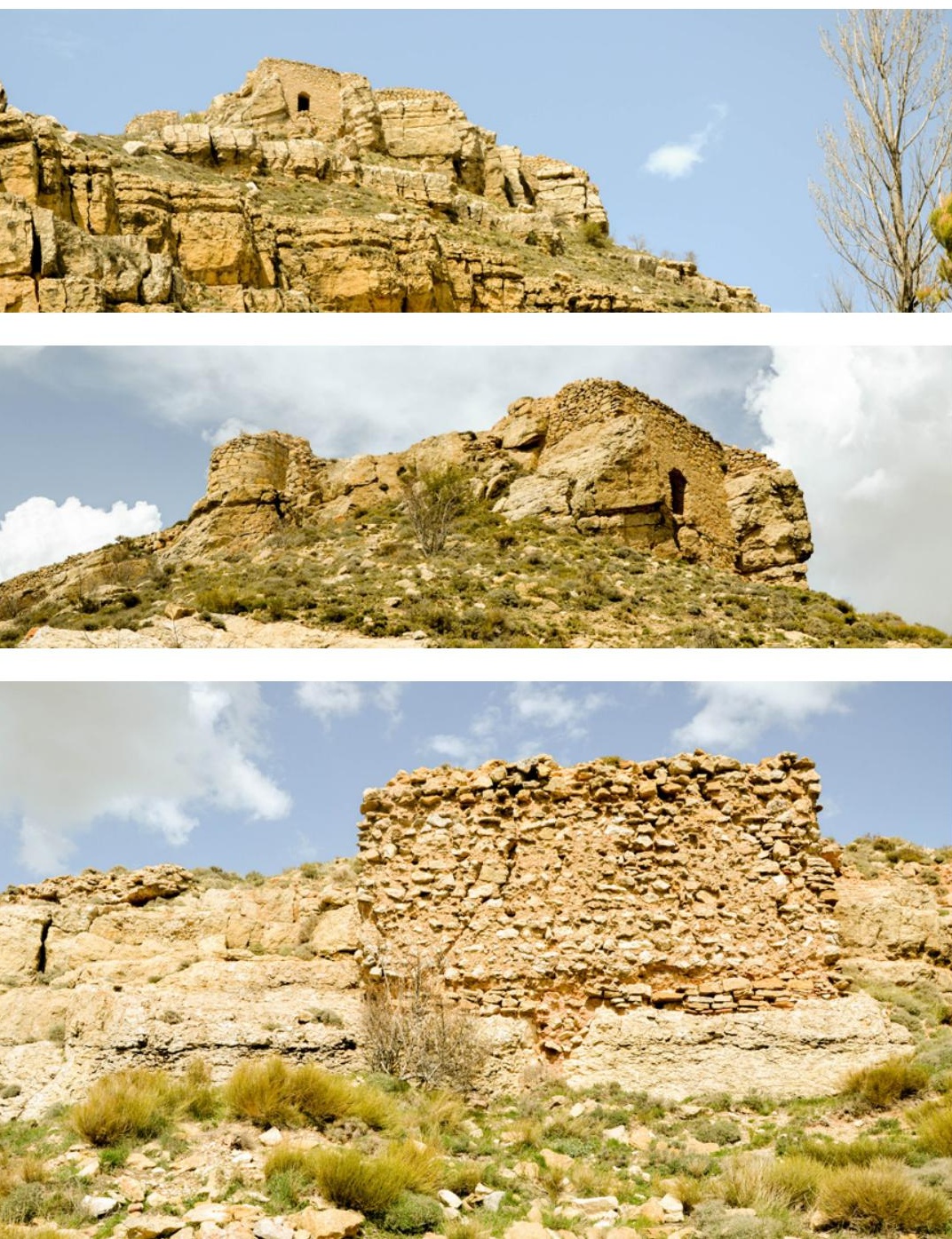

sur por un torreón circular que domina lo que se denomina la cortina del Príncipe y por un saliente triangular al norte. Realmente, este saliente es el resultado de un frente poligonal denominado cortina del Infante. Responde a la tipología de frente poligonal en la medida que el elemento saliente extremos de la cortina. Un gran baluarte de traza pe el centro de este frente oeste, identificado como el bastión del Turia, en el que se emplaza una pieza artillera. La cortina prosigue en el sector septentrional del baluarte con entrantes y salientes, con la llamada cortina del Voluntario y, más al norte, con la batería de Cabrera. Se aprecia en el trazado el espesor del parapeto y la disposición de cinco cañoneras. El frente este también se adapta a la orografía a base de entrantes y salientes irregulares y de todo tipo. De norte a sur, se distribuye la batería de la Muerte, con cuatro cañoneras, la cortina abaluartada de Zumalacárregui, la torre de Arnau, de traza rectangular con una pieza artillera, la cortina del Infierno y la cortina de Aníbal. Desde el vértice suroeste, una línea de reductos desciende como pretendiendo resguardar el camino de acceso. Un documento del mismo archivo (sign Ar.G-T.3-C.1-196) e identificado como "Croquis el bloqueo en los días comprendidos entre el 10 de julio y 5 de agosto", ejecutado por Nicolás Valdés y fechado en agosto de 1840, permite confirmar el trazado del perímetro exterior, así como el camino de acceso. Sin embargo, cambia sustancialmente la disposición de las construcciones interiores. En este plano se observa cómo se inició una mina, que no llegó a detonarse, y que tenía como objetivo alcanzar el aljibe para hacerlo actuar de hornillo. El trazado del cuerpo interior se identifica como ciudadela (c), que delimita una zona de resguardo respecto al resto de la plataforma del castillo, de tal modo que se distingue una Plaza Mayor (a), y una Plaza Menor (b) asociada a dicha ciudadela y que ocupa todo el sector sur, donde se emplaza la cisterna (d). El frente sur de la ciudadela conforma el muro de separación entre ambas plazas, dejando puertas de acceso a ambos lados (I). A diferencia del documento del año anterior, en la plaza mayor, adosados al perímetro este, han aparecido dos construcciones que se identifican como alojamiento para la tropa (h) y casa del gobernador (g). En el perímetro oeste sucede lo mismo, solo que aparece un único cuerpo adosado a la puerta de acceso, también identificado como alojamientos para la tropa (h). Estos cuerpos, tal y como se observa en las secciones correspondientes, se tratan como casamatas huecas conformando los terraplenes defensivos. El acceso, a través del camino serpenteante que asciende por el oeste, cuenta con un puente levadizo (k), así como el acceso a la ciudadela (f). Poco más se puede deducir del dibujo, salvo que la ciudadela se remata con cañoneras abiertas, y las escarpas del recinto exterior con fusileras o troneras de buzón (no se puede precisar dada la imprecisión del dibujo). Se intuyen espacios abovedados para los alojamientos.

Los trabajos carlistas de fortificación del Collado se extienden en el tiempo, en comparación con otros, debido a diversos conflictos. Utilizan cientos de trabajadores, la mayoría prisioneros de guerra, aunque se obliga a los pueblos cercanos a proporcionar operarios. También materiales, entre los cuales destaca el yeso, cal y el ladrillo. El Diario Mercantil de Valencia recoge la noticia de que incluso se llegan a retirar las tejas de las casas de muchos liberales con el fin de acelerar las obras (Diario Mercantil de Valencia, 3, 19, 28 de diciembre de 1838; 11, 12 y 19 de enero de 1839; Caridad, 2013: 257). Parece que en enero de 1839 han cerrado el recinto y construido habitaciones de tablas, instalándose una guarnición de 200 hombres. Sin embargo, las obras no se consideran concluidas ni se ha montado la artillería. Parece que en enero de 1839 un temporal de viento y nieve causa desperfectos en las obras, pues la mala calidad constructiva agrava los daños con desprendimientos (Diario Mercantil de Valencia, 28 de enero de 1839; Caridad, 2013: 257). Las obras parecen concluidas en marzo de ese año (Diario mercantil de Valencia, 8, 19 de febrero de 1839; 8, 20, 21 de marzo de 1839; Caridad, 2013:257). En julio de 1839 parece que se envía artillería a Alpuente, el Collado, Cañete y Chelva. Las obras en su conjunto podrían estar concluidas en estas fechas (Caridad, 2013:262)

Cuando entre abril y junio caen todas las líneas defensivas, cuando Cabrera ya ha abandonado el país, el fuerte del Collado resiste, siendo evacuado el 6 de agosto de 1840 (Diario Mercantil de Valencia, 8 de agosto de 1840; Córdoba, 1844-1846: v4, 378; Calbo y Rochina, 1845:572; Caridad, 2013: 267). 


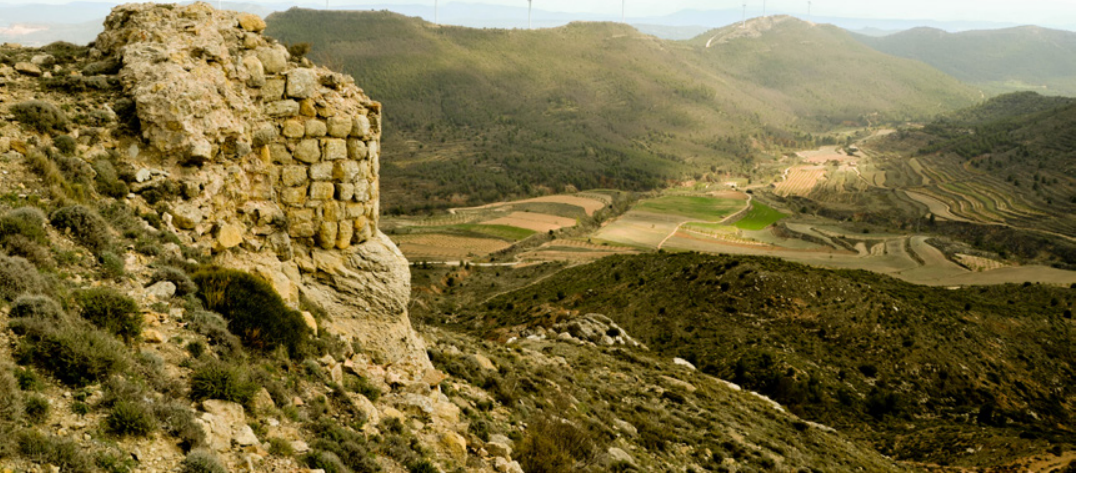

Fig. 423. Panorámica desde el fuerte hacia el este. Se muestra la base de una torre semicilíndrica anterior a los carlistas.

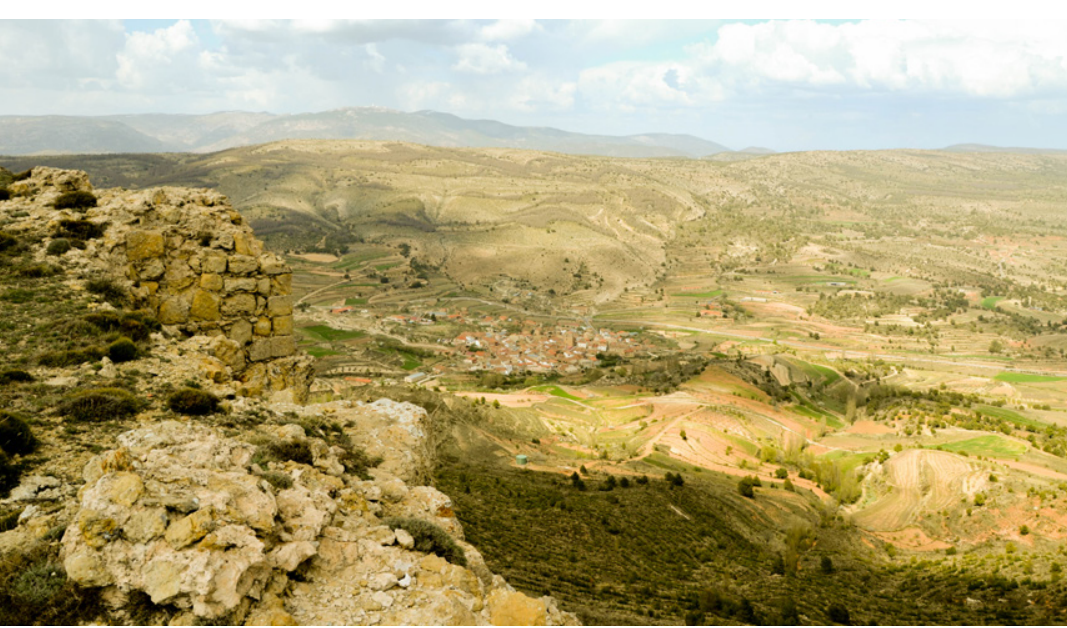

Fig. 424. Panorámica desde e fuerte hacia El Collado de Apuente, al noreste del mismo.

Fig. 425. Panorámica desde el fuerte hacia el sureste.

\section{Planos históricos:}

Plano 1

Título uniforme: Alpuente (Valencia). Castillos (1839). 1:760

Título: Plan del Castillo del Collado / Levantado por el Teniente del R.C. de Ingenieros M. Brusco Publicación: 1839

Descripción física: 1 plano: ms., col., montado sobre tela ; 16,7 × $26 \mathrm{~cm}$ en h. de 20 × 29,2 cm

Notas: Manuscrito a plumilla en tinta negra y coloreado a la acuarela en siena, verde, carmín, gris y azul. Escala gráfica de 40 varas castellanas $[=4,4 \mathrm{~cm}]$. Orientado con flecha en cuadrante. Relieve representado por sombreado. Relacion de las principales fortificaciones y dependencias indicadas por clave alfabética. Indica campos de cultivo. Título enmarcado en muralla, al igual que la escala y la clave alfabética. En el margen inferior, motivos militares. Se dispone ademas, del documento con sig. SG. Ar.G-T.3-C.1-197, con perfiles, elevaciones y vistas del castillo.

Ejemplares: Archivo Cartográfico de Estudios Geográficos del Centro Geográfico del Ejército Ubicación: AR - Signatura: Ar.G-T.3-C.1-196 - Código de barras: 2210263

Plano 2

Título uniforme: Alpuente (Valencia). Castillos (1840). 1:50.000 y 1:31.000

Título: Croquis del Collado y Castillo con perfiles elevaciones y vistas del mismo: y las posiciones que tuvieron las tropas en el bloqueo en los dias comprendidos entre el 10 de Julio y 5 de Agosto / Nicolas Valdes

Publicación: 1840 agosto 6

Descripción física: 2 mapas en 1 h.: ms., col., montado sobre tela ; 18,6 × 23,5 cm y 9,5 × 23,5 cm en h. de $37,1 \times 52,1 \mathrm{~cm}$

Notas: Presenta el mapa de la zona, el plano de la planta del castillo, dos perfiles y dos vistas. "Visto Bueno": Apeolaza. Manuscrito fechado en Corcolilla. Manuscrito a plumilla en tintas negra y roja y coloreado a la acuarela en siena. Escala gráfica de 5000 varas $[=8,3 \mathrm{~cm}]$ y 300 varas $[=8,1 \mathrm{~cm}]$. Orientado con flecha. Relieve representado por normales y sombreado. Relación de los principales lugares estratégicos, puente, puertas y del círculo de acción de una mina que, al parecer, no explotó, indicados por clave alfabética. Señala la posición de las tropas durante el bloqueo. Se dispone del documento con signatura SG. Ar.G-T.3-C.1-196, con la planta del castillo.

Ejemplares: Archivo Cartográfico de Estudios Geográficos del Centro Geográfico del Ejército Ubicación: AR - Signatura: Ar.G-T.3-C.1-197 - Código de barras: 2210264. 


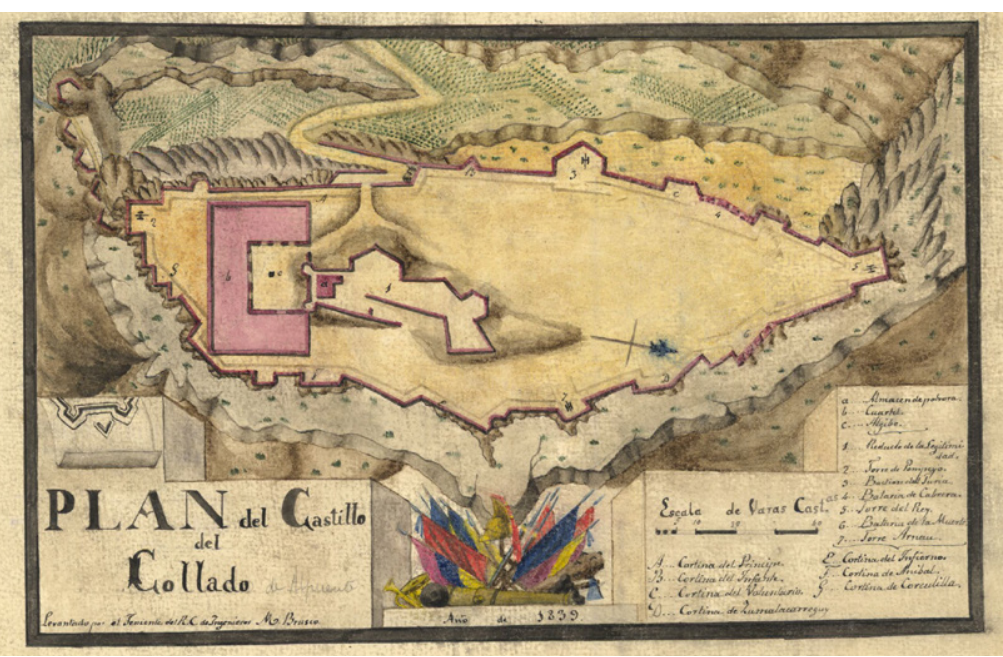

Fig. 426. Plano 1. Planta del castillo.

Fig. 427. Plano 2. Croquis del Colle $y$ castlo con paris Covios $\mathrm{y}$ las posiciones que tuvieron las tropas en el bloqueo en los día comprendidos entre el 10 de julio y 5 de agosto.

Fig. 428. Detalle del Plano 2. Planta del mismo.

Fig. 429. Detalle del Plano 2. Sección PK.

Fig. 430. Detalle del Plano 2. Sección RS.
Fig. 431. Planta del castillo del Poyo según el ingeniero carlista Manuel Brusco en 1839. 01. Cortina del Príncipe 02. Cortina del Infante 04. Cortina de Zumalacárregui 05. Cortina del Infierno .6. Cortina del 06. Cortina de Aníbal 07. Cortina de Corculilla 08. Almacén de pólvora 09. Cuartel

10. Aljibe

11. Reducto de la legitimidad

12. Torre de Pompeyo

13. Bastión del Turia

13. Bastión del Turia

4. Bateria de Cabrer

15. Torre del Rey
16. Batería de la muerte

17. Torre Arnau

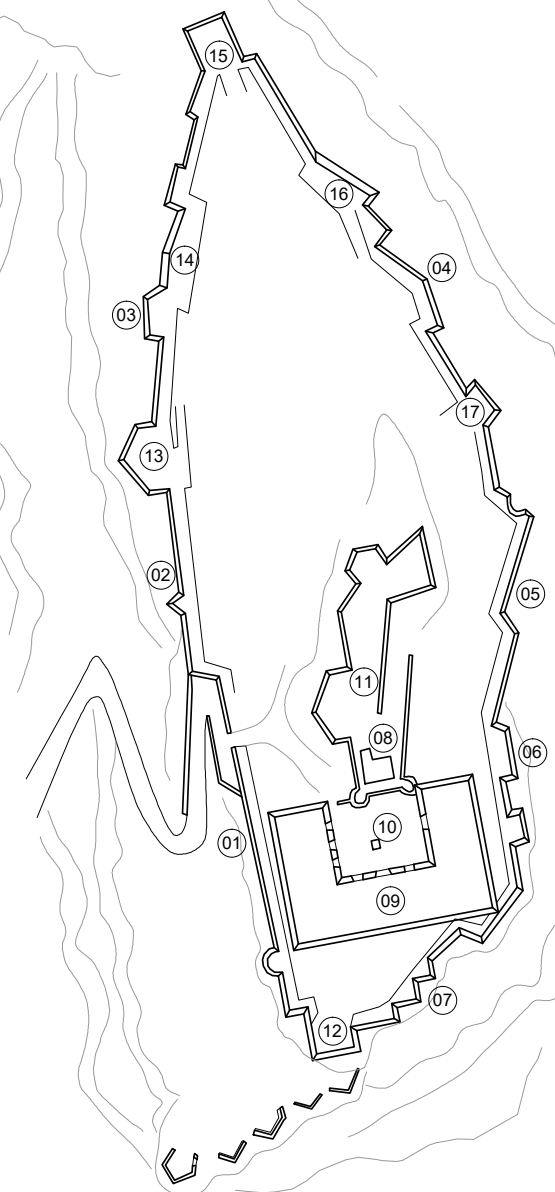

E 1:1500 
33 Еsтrвcur 


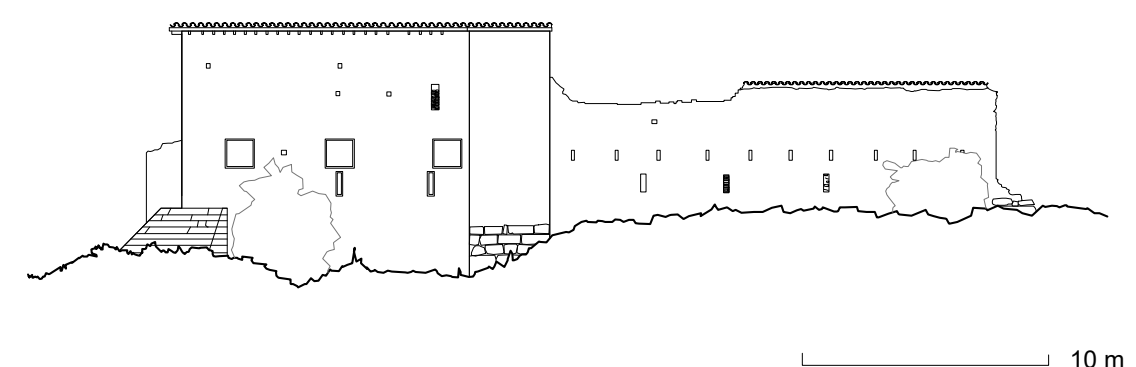

Fig. 436. Frente oeste.

Fig. 437. Planta del fuerte de Estercuel.

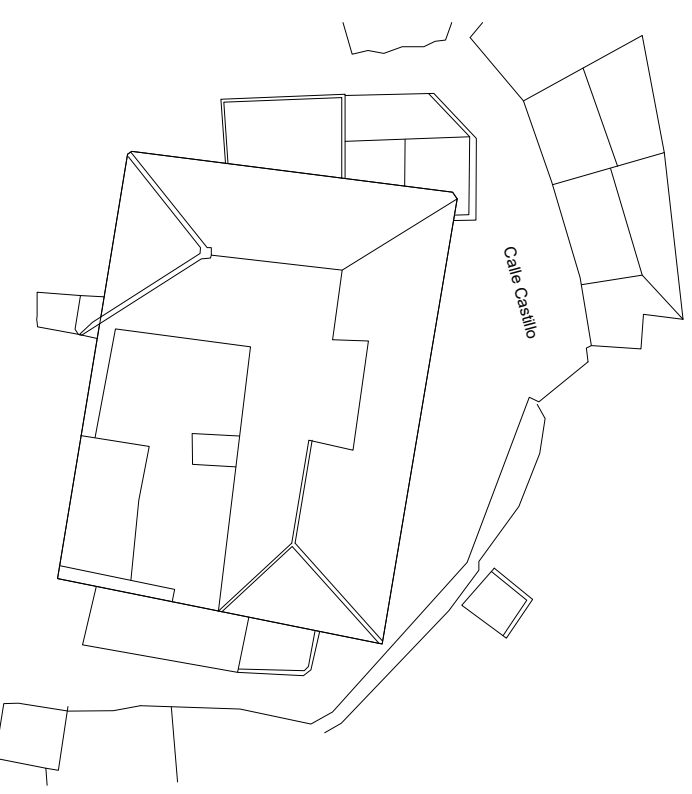

34 Fux* 


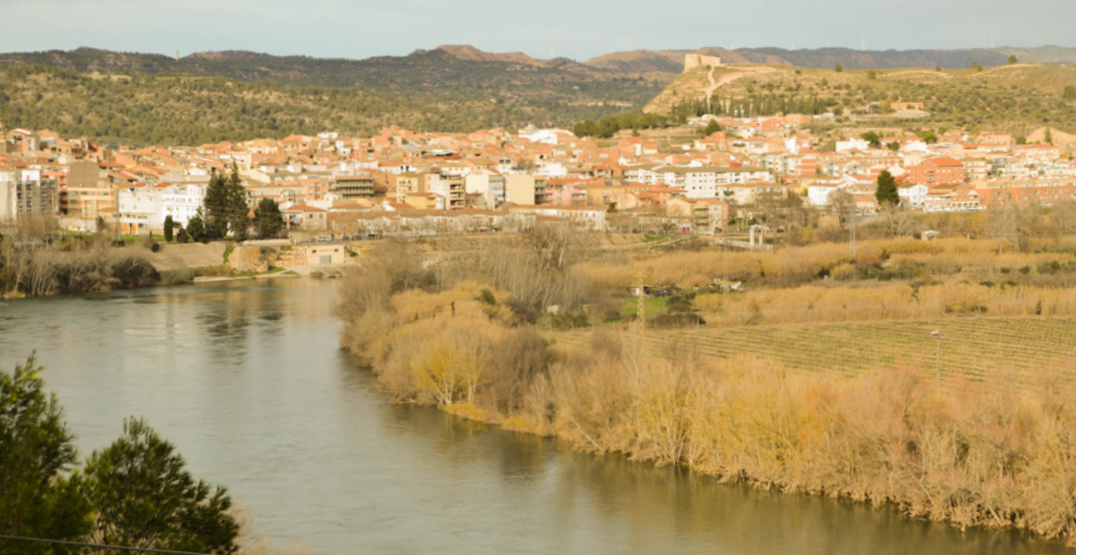

Fig. 438. Población de Flix con el castillo en la colina próxima.

Fig. 439. Frente sur del castillo desde la lejanía y su posición en el borde del precipicio.

Fig. 440. Frente oeste del castillo y su ubicación.

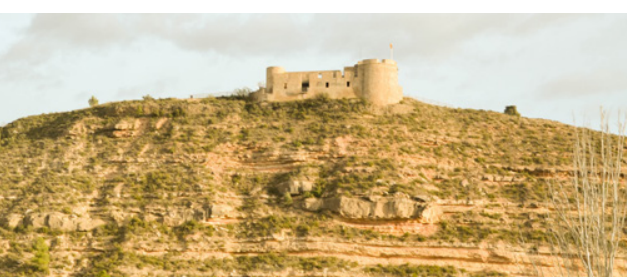

Fig. 441. Frente oeste del castillo y su ubicación en la loma.

Fig. 442. Posible ubicación de la fortificación medieval de Flix.
Flix

Localidad en castellano / catalán: Flix

Provincia actual: Tarragona

Comarca: Ribera de Ebro

Coordenadas geográficas: 41.237933314823806, 0.5554732970913676.

Tipos defensivos: castillo reforzado que domina la población.

Acciones y fortificación:

Se sabe que en el verano de 1835 en ambas riberas del Ebro y en territorio catalán operan las partidas de Cabrera y el Padre Luis. En septiembre los carlistas ocupan pueblos del Priorat y del Camp de Tarragona y, concretamente en agosto, Cabrera controla la franja catalana del río Aragón y desde dicho territorio conquista y ocupa pueblos entre los que se encuentran Flix, Horta de Sant Joan, Bot o Arnes (Quintana Segalà y Morillas Torné, 2012: 197). Se podría decir que a finales de 1835 los carlistas dominan gran parte de las tierras catalanas del Ebro. Cuando en 1837 se conquista Solsona y Berga, los carlistas materializan el asentamiento en Cataluña haciendo de Berga plaza fuerte y estableciendo en ella algunos órganos de poder carlistas (Quintana Segalà y Morillas Torné, 2012: 197). La ocupación de Berga pone bajo su protección diferentes poblaciones que generan una transformaLa ocupación de Berga pone bajo su protección diferentes poblaciones que generan una transforma-
ción del mapa territorial desde 1837 hasta 1840 . Los carlistas controlan el territorio y las principales posiciones liberales se sostienen, pero completamente aisladas, como es el caso de Cardona, Tremp o Torà. A finales de 1837 la diputación de Lleida, por ejemplo, admite dominar únicamente 27 puntos fortificados en la provincia (Lladonosa, 1993: 244; Quintana Segalà y Morillas Torné, 2012: 198). Las noticias del fin de la guerra en el frente norte llegaron al ejército del Maestrazgo en el mes de septiembre de 1839. Pero ello no detiene los procesos constructivos, sino que los intensifica. Cabrera ordena nuevas fortificaciones, entre ellas la de Flix (Diario Mercantil de Valencia, 23 de diciembre de 1839, 22 de enero de 1840, 29 de abril de 1840; Córdoba, 1844-1846: v.4, 119; Calbo y Rochina, 1845: 454; Caridad, 2013: 264).

Flix representa el punto de entrada al "Reino Mágico de Cabrera" según Von Rahden, frente a los inseguros territorios catalanes por los que debe transitar a finales de 1839. Ya en su día es un punto de paso de la Expedición Real. En 1840, Von Rahden, que regresa de servir con el Conde de España en Cataluña, confiesa haber descansado por fin en Flix "durante dos días, en el hermoso valle del Ebro, donde disfrutamos de todas las delicias que agua y tierra nos ofrecían en sobreabundancia, recreándonos con la visión de la naturaleza que aquí, en el ancho valle del Ebro, siempre se muestra verde y floreciente. Era el 26 de febrero [de 1840], pero toda la zona llevaba ya los hermosos ropajes de la primavera, cubiertos de las flores rosadas de los almendros; todo respiraba vida y nosotros agradecimos al cielo haber llegado al reino mágico de Cabrera. Nuestros sufrimientos habían sido olvidados y después de tres jornadas de cómoda marcha entramos en Morella" (Von Rahden, 2013: 271).

En algún momento del conflicto, probablemente con el fin de la guerra en el norte, Cabrera parece dar orden de fortificar Flix (Caridad, 2014: 152), pero las diferentes fuentes resultan contradictorias, pues unos no atribuyen obra alguna al período, otros citan el año 1837 y 1838 y otros obvian intervenciones y las concentran en la Tercera Guerra Carlista. Con toda probabilidad, las obras carlistas podrían concentrarse en el denominado castillo de Flix, el castellet o castell nou. Cabrera pretende resguardar la ribera derecha del Ebro, y así sucede cuando el castillo protege la retirada de sus tropas en junio de 1840 hacia el exilio. No obstante, el castillo también es reformado con la Tercera Guerra Carlista, bajo la dirección del maestro de obras de Tortosa, Gaetà Blanch Sebastià, hacia 1872 y 1873. Cuando el 19 de junio de 1875 el castillo es tomado por las tropas de Eduardo Gamir y se instala una guarnición liberal hasta el 28 de junio de 1876, momento en el que es abandonado, algu- 
nas fuentes sostienen que la fortificación es ampliada con la torre mayor y el muro que mira al río en ese periodo de ocupación liberal. Otras fuentes afirman que el castillo estuvo activo, dotado de guarnición hasta 1885. El denominado Castell vell, con el que también se producen identificaciones erróneas, se correspo Erificación islámica destruida durante la Guerra de Sucesión, que ocupaba una posición diferente. La posición estratégica del nuevo castillo, por lo visto, ocuparía la posición de una supuesta atalaya íbera, lo cual no se ha podido confirmar, pero la presencia de una construcción ya existente haría más factible la decisión de Cabrera de fortificar el lugar.

La fortificación, muy dañada por los bombardeos de la Guerra Civil en el silo XX, permanece convertida en ruina hasta el proceso de transformación en equipamiento cultural municipal iniciado en 2004. Las obras de restauración comienzan en 2009 y se centran en restituir la coronación de los muros, reconstruir la torre en ruinas e instalar plataformas de madera.

Nos encontramos con un fuerte de traza triangular con torreones circulares en las esquinas, uno de os cuales sobredimensionado para el emplazamiento de piezas artilleras. Una tipología habitual como fortificación de campaña, con muros de mampostería aspillerados. En el patio se localiza una cisterna de traza ovalada. Hay una clara distinción entre la gran torre circular de escarpas ataludadas y con terraplén con parapetos destinados a piezas artilleras, junto a la cortina que mira al río, de escarpa también con declive, que responderían a tipologías propias de los siglos XVII y XVIII, frente a las torrecillas circulares ubicadas al norte y al nordeste, y las cortinas correspondientes, sin pendiente en sus muros y aspilleradas, más frecuentes en estructuras decimonónicas. Esta interpretación, que se contradice con las diversas fuentes que han tratado de fechar las intervenciones, como L'Inventari del patrimoni arquitectònic de Catalunya, de la Direcció General del Patrimoni Cultural de la Generalitat de Catalunya, clarificaría el tipo de intervenciones acometidas en los diferentes momentos.

Fig. 444. Frente este del castillo.

Fig. 445. Frente sur del castillo. La torre izquierda presenta cañoneras y su forma recuerda a otras torres construidas por los carlistas.

Fig. 446 Frente oeste del castiillo, que vuelca al precipicio y al río Ebro.
Fig. 447. Frente sur del castillo y su relación con el río Ebro, la población y el territorio.

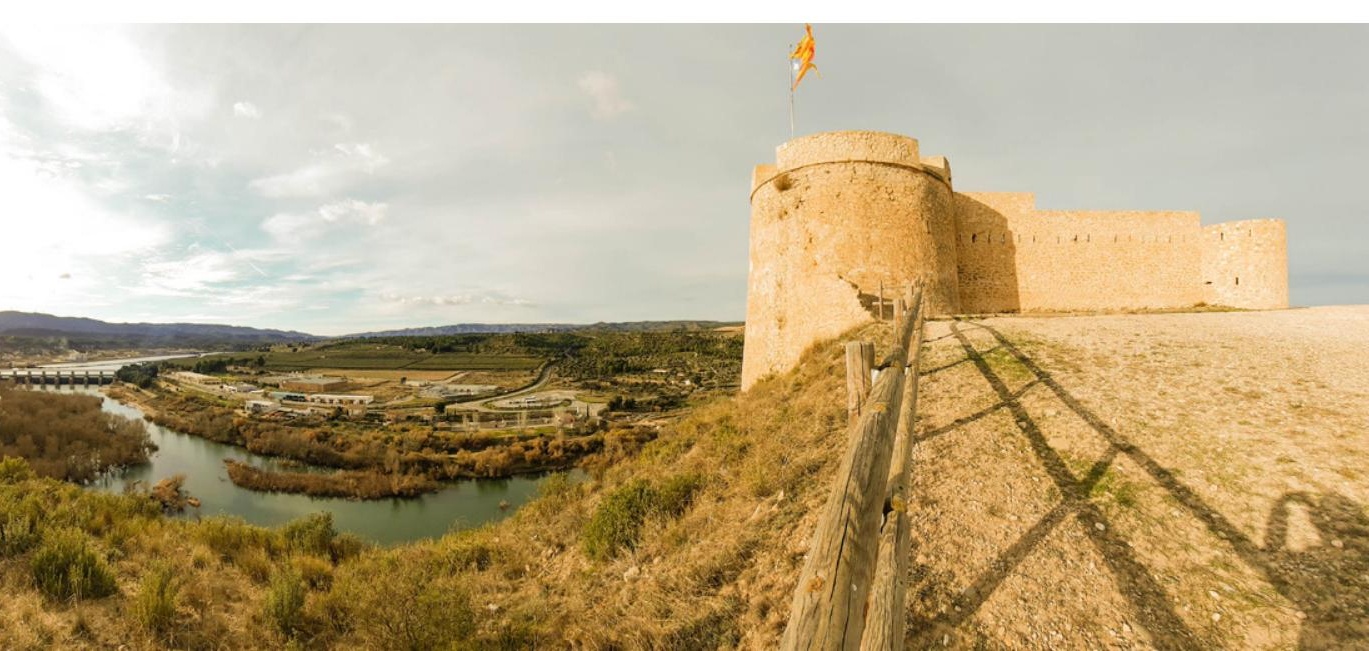




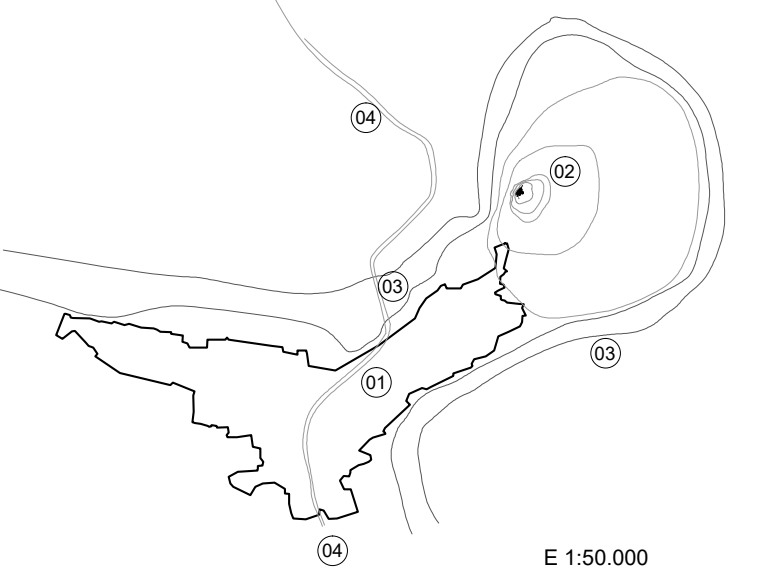

Fig. 448. Planta de situación de los elementos de interés en la actualidad.

01. Población de Flix

02. Castell nou (fortificación carlista)

03. Río Ebro

04. Carretera C-12

35 Forcast

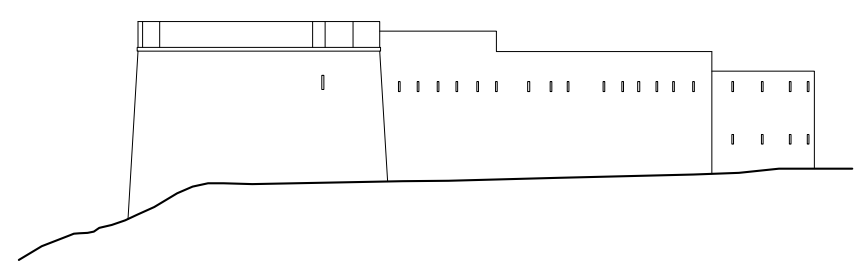

E 1:500

Fig. 449. Alzado oeste del castillo de Flix.

Fig. 450. Planta del castillo de Flix

E 1:1000

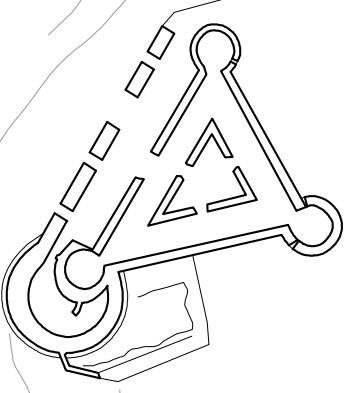

$5 \mathrm{~m} \quad$ b 


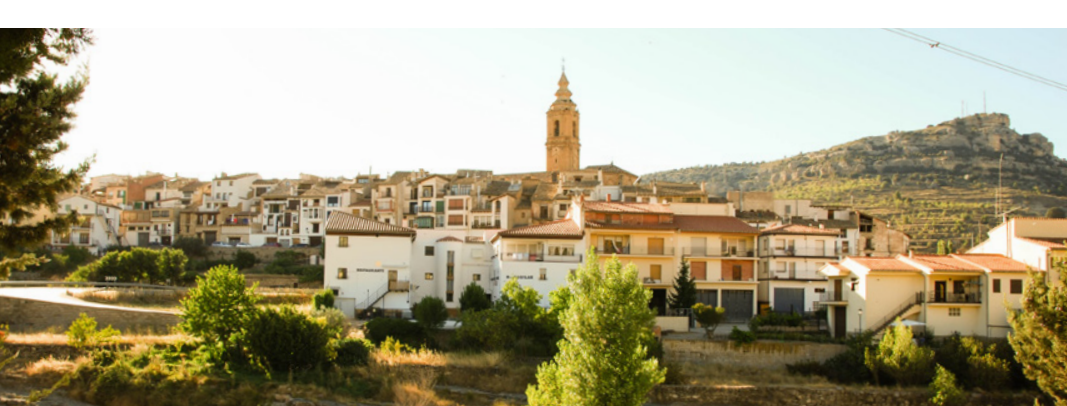

Fig. 451. Población de Forcall, donde destaca la torre campanario de la Iglesia de la Asunción de María.

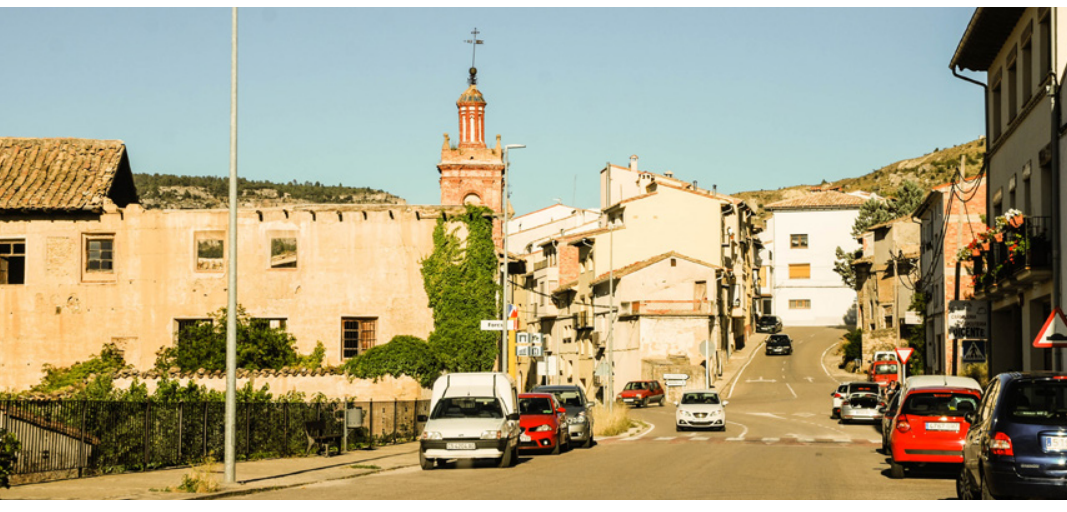

Fig. 452. Acceso occidental a la población, con las ruinas y la torre del Antiguo Convento de los Dominicos a la izquierda de la imagen.

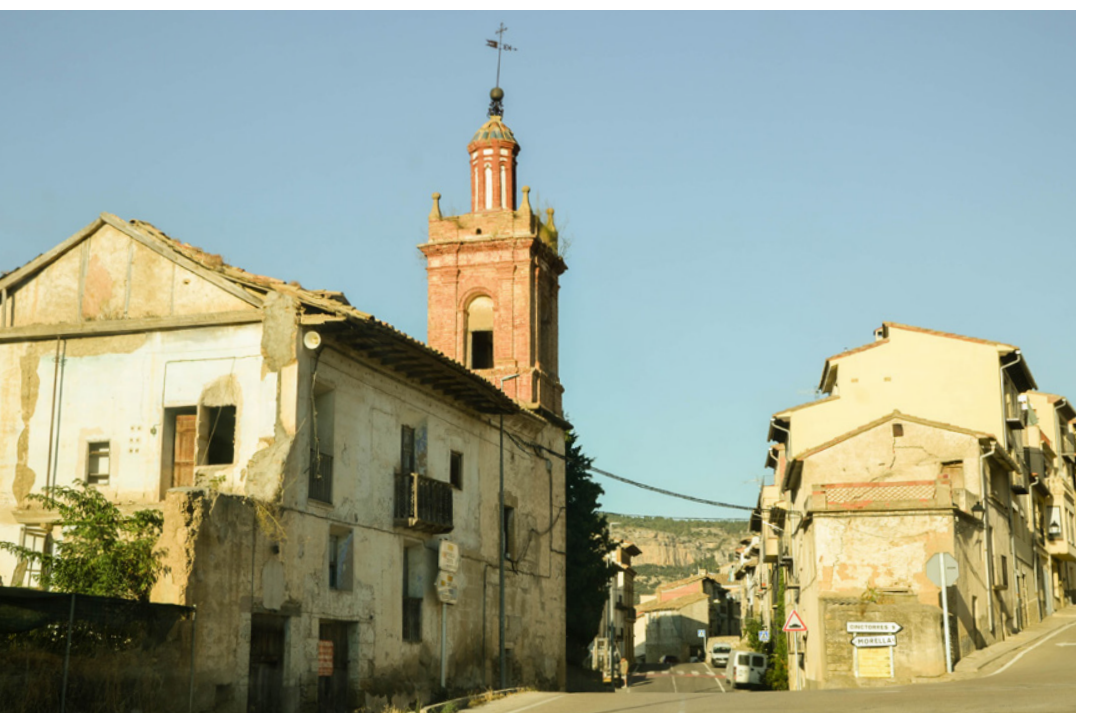

Forcall

Localidad en castellano / valenciano: Horcajo / Forcall

Provincia actual: Castellón

Comarca: Los Puertos de Morella

Coordenadas geográficas: 40.64627430218255, -0.19804717002301686

Tipos defensivos: fortificación de conventos, fortificación de iglesias, muralla urbana.

Acciones y fortificación:

Forcall, a la que se refieren los textos de la época como Horcajo, es presentada por Von Rahden con precisión y curioso pintoresquismo:

"Horcajo se encuentra ya en el Reino de Valencia, pues la frontera aragonesa entre la Mata y Mirambel salta de una cresta a otra. El pueblo presenta una planta regular. Las paredes exteriores de las casas pintadas de blanco hacen pensar en vano en la limpieza y cuidado del interior. Uno se convence pronto de que una holgazanería auténticamente valenciana ha impedido la entrada a los lares del hogar o bien ha dado ocasión de ahuyentar a ese ser inquietante que tienen que soportar las casas sin ventanas, puertas ni chimeneas.

Era domingo y el sol de marzo ya irradiaba su agradable calor. En la amplia plaza de mercado se había reunido se habia reunido

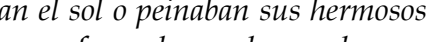
cabellos, haciéndose largas trenzas con cintas de colores. Muchas se hallaban enfrascadas en desenredar con preocupación maternal las matas de pelo de sus pequeñuelos. Solo en tales ocasiones se muestra ágiles y veloces sus dedos morenos. Los hombres, con sus largas capas negras y sombreros del mismo color, cuyas grandes alas se extendían formando un amplio techo sobre ellos, estaban reunidos en amplios grupos, bien caminaban arriba y abajo, ocupados en tomar el aire, como se dice en España, es decir, respirando el agradable aire valenciano, al tiempo que exhalaban enormes nubes de humo. Aquí cualquiera fuma su cigarrillo de papel, que lleva a la boca solo de tanto en tanto, y mantiene una conversación entre bostezos, ocasión en la que, en lugar de cubrir la boca con la palma de la y mo, sehace cruces con el pulgar de la mano derecha delante de la misma asta que calma la convulsión. Algunos ;Carajos! y varios juramentos habituales más, por los que hay tanta predilección, acompañan sin otras explicaciones los momentos brillantes y los giros en el discurso del interlocutor". Narra Von Rahden que al final es alojado en casa del sacerdote del pueblo, "cuya vivienda podía ser cerrada con llave" (Von Rahden, 2013:317-318).

A $12 \mathrm{~km}$ de Morella y $30 \mathrm{~km}$ de Cantavieja, Forcall sufre la contienda especialmente, a criterio de Menéndez Pelayo, "una guerra de tribus salvajes lanzadas al campo en las primitivas edades de la Historia, ouerra de exterminio y asolamiento, de degüellos y represalias feroces" (Eixarch Frasno: 1994:83). Entre los avatares sufridos se encuentra la quema de la antigua iglesia parroquial el 9 de agosto de 1835. "Reducida toda ella a cenizas, con motivo de haberse fortificado en la torre-campanario en este mismo día la tropa de la Reyna, nuestra Señora Da Isabel II, que guarnecía este pueblo" (Archivo Parroquial de Forcall (APF). Libro de Defunciones. A. 1778-1839, fol. 261). La iglesia, una construcción de finales del siglo XIII o principios del XIV, es víctima de una voladura según el testimonio del arquitecto académico D. Vicente Belda Selva: "las paredes que permanecen de la antigua, por el sacudimiento tan fuerte que provocó la pólvora que explotó en ella, quedaron todas conmovidas y al mismo tiempo calcinadas por el grande fuego que hubo dentro de ella antes de desplomarse; de que resulta ser enteramente inutiles y ser preciso derribarlas de Forcall, sobre tasación de limosnas en funciones religiosas, $\mathrm{A}$ mando de las tropas carlistas se encuentra Quílez según Eixarch (1994:84). Ese mismo día, se fusila en el cementerio nuevo (bendecido en 1816), a los soldados que habían resistido en el campanario: "26 soldados o urbanos de la Compañía de Seguridad de Alcalá de Chivert con el Subteniente D. Agustín Zaragoza, de Alcalá" (APF, Libro de Defunciones, A. 1778-1839, fol. 261. Nota). 
Este mismo acontecimiento es recogido por Von Rahden para justificar la desconfianza de los habitantes. Von Rahden, sin embargo, atribuye estos sucesos al Serrador, en el momento de represalias por la muerte de la madre de Cabrera, y su testimonio es revelador: "Brusco intentaba calmar mi enojo - en las esperas injustificadas, este enfado siempre aumentaba en la medida en que aquellos a los que increpaba

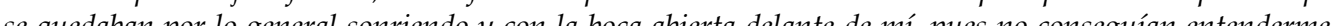
se queduan por lo general sontiendo y con la boca abierta delante de mi, pues no conseguian entendermeseñalando que en Horcajo todavia habia mucha sangre cristina y que por ello predominaba la mala fe. Tambié mi amable anfitrión se quejaba de lo mismo, pero disculpaba a las ovejas negras de su rebaño recordando lo estremecedores acontecimientos de la guerra, que aquí había causado estragos. Los facciosos, bajo la denominación de carlistas, habían cometido atrocidades inauditas. Los sucesos y el momento corresponden a la época de las represalias tras la muerte de la madre de Cabrera. El Serrador, como era conocido José Miralles, había sitiado la ciudad, en la que se defendían con valentía los urbanos de los alrededores. Al final se vieron obligados a refugiarse en la sólida iglesia que por ello fue reducida a un montón de escombros por las balas y el fuego. 32 urbanos se rindieron con sus mujeres e hijos y fueron fusilados (niños que quizás son los nietos o familiares de los desgraciados juegan ahora La elevada torre rectangular fue la única que resistió a las llamas y 18 urbanos huyeron todavía a tiempo, antes de que fuesen fusilados como sus hermanos prisioneros, al espacio superior en el que la campana y el mecanismo del reloj les anunció su última y terrible hora. La escalera de madera por la que se subía fue incendiada y el fuego se mantuvo viva con vigas y otros materiales semejantes hasta que los 18 cristinos, ahogados y abrasados, cayeron como moscas. Poco después les siguieron el reloj medio fundido y la campana. En unas excavaciones posteriores en la torre se encontró un nicho sano y salvo el cuerpo del patrón de la iglesia, el santo Leonardo, y, joh milagro!, también se halló intacta una redoma de cristal que guardaba la sangre de su corazón, sangre que estaba todavía en estado líquido. En su recuerdo se ha levantado en el mismo lugar una pequeña capilla, en la Para mitigar el or Para mitigar el odio que, cultioado en este lugar sagrado, iba a echar raices cada vez más profundas, ha desarrollado su poder conciliador el arte divino. Un honrado morellano, el hábil pintor don Francisco Cruella, un antiguo profesor de la Academia de Bellas Artes de Valencia que desde hace años es capitán de los batallones realistas en su ciudad natal y que como tal ha merecido los máximos honores, ha realizado en la capilla de Horcajo una espléndida imagen para el altar. El Santo Leonardo, un hermoso caballero de rizos dorados, reza a la madre inmaculada de su salvador. En el fondo se observan las ruinas humeantes de la casa del señor, pro sobre estas vemos también al santo Leonardo ascender al cielo de la mano de los ángeles, portando la palma que anuncia su martirio" (Von Rahden, 2013:319-320).

Von Rahden recoge también la estancia del pretendiente en Forcall, el 31 de julio de 1837, “durante unos instantes en este mismo balcón en el que hoy estoy anotando mis impresiones en el diario. El mismo sacerdote venerable se hallaba también a su lado y el rey le prometió que, cuando llegase a Madrid, haría construir sobre esas ruinas una espléndida iglesia. Apenas había besado sus manos en señal de agradecimiento este pastor de su rebaño, cuando el estruendo de la guerra ahuyentó el breve momento de calma. Espartero, Oráa y Nogueras se aproximaban por diversos caminos para apresar a don Carlos, pero súbditos leales lo guiaron por la escalera rocosa a la Muela de la Garumba y desde allí de forma segura a Cantavieja. Menos de un cuarto de hora después de que el rey hubiese abandonado la casa del cura, irrumpía Nogueras, el asesino de la madre de Cabrera, en el balcón en el que todavía se hallaba el fiel siervo de la Iglesia enziando a su legitimo señor sus oraciones para su salvación.

- ¿Dónde está don Carlos? - gritó Nogueras al sacerdote.

- Allá arriba, a buen resguardo - le respondió con calma.

$Y$ en efecto, Carlos $V$ acababa de llegar a la inmensa atalaya rocosa, en la que podía ser reconocido a simple vista, pues solo se hallaba a una distancia de unos cientos de pasos en línea recta. Los enemigos hubieron de conformarse con perseguirlo únicamente con la mirada" (Von Rahden, 2013:320)

Un año antes del paso de Von Rahden por la población, hacia el otoño de 1836, con Cantavieja bajo control de Cabrera, que planea la conquista de Morella, y Forcall, bajo la esfera de control liberal, el brigadier Borso di Carminati aplicó un castigo colectivo a la población, azotando y apaleando a sus habitantes por negarse a suministrar bagajes. En principio el pueblo no es conocedor de aquella negativa, que había comunicado únicamente el alcalde. A uno de ellos, responsable de las caballerías, gativa, que había comunicado únicamente el alcalde. A uno de ellos, responsable de las caballerías,
se le tuvo colgado de las rejas de la casa de Osset, situación que generó el dicho popular "allo que va donar Borso a les reixes de casa Osset" (Eixarch Frasno, 1994: 85).
El 6 de octubre de 1838, por Forcall discurren los prisioneros que Cabrera captura tras la batalla de Maella. Son conducidos al convento de dominicos, que habían sido exclaustrados en el año 1835. Este convento se convierte en cárcel provisional. Allí, según algunas fuentes, mueren muchos prisioneros a causa de las privaciones, principalmente por desnutrición (Eixarch Frasno, 1994: 87). En los Llanos de la Grellera se fusila a 96 sargentos enemigos, el 15 de octubre de 1838, ordenándose que fuesen enterrados en el mismo campo (APF, Libro de Defunciones, años 1778-1839, fol. 277, v). De Forcall es el guerrillero Tomás Peñarrocha, apodado "El groc", impulsor del primer movimiento insurreccional, anticipándose a los "matiners catalans" o Segunda guerra carlista. Las actuaciones del Groc se extienden entre 1841 y 1844 (Eixarch Frasno, 1994: 88). A raíz de la Guerra "del Groc", se establece un destacamento de tropa en Forcall, que se instala en la casa de Osset, "cerrando con muro las cuatro boca-calles y todo lo ancho de la plaza: todo estaba de aspilleras" (Eixarch Frasno, 1994: 94). Precisamente a esta posición se hace referencia como "el fuerte de casa Osset". Se trata de una construcción de la segunda mitad del siglo XVI, construida por la familia Miró al estilo de los palacios Oro de talla de madera y logia superior con 36 arcos. En el siglo XVIII es ocupado por la familia Osset, que le da nombre. Hace las funciones de ayuntamiento provisional y en la actualidad es un hotel por iniciativa de la Diputación de Castellón.

Sobre el convento de los dominicos, también denominado Convento de Nuestra Señora del Rosario y de San Blas, que data del siglo XVII, que hace función de prisión, se sabe que en mayo de 2013 se produce un derrumbe de parte de sus estructuras tras haber sido utilizado como granja entre los años 50 y 80 del siglo XX. En octubre de 2018 se inicia la reparación del tejado ante el mal estado de su estructura que amenaza derrumbe de nuevo. Bajo propiedad del obispado de Tortosa, se llega a un acuerdo con el Ayuntamiento de la localidad para dedicarlo a equipamiento sociocultural.

Respecto a la iglesia, el ábside actual y la torre-campanario es lo único que se salva de la quema de 1835 (Eixarch Frasno, 1994: 94)

1835 (Eixarch Frasno, 1994: 94). cial en el camino hacia Monroyo, porque la intención táctica es "inducir al enemigo a avanzar por dicho camino para reducirlo en las espléndidas posiciones de la Muela de la Garumba" (Von Rahden, 2013: 448). Dicho de otro modo, los escarpes rocosos de la muela hacen las funciones de fortificación.

Fig. 454. Esquema en planta de Forcall con los puntos de interés defensivos 01. Exconvento de Dominicos

02. Iglesia Parroquia de la Asunción de María

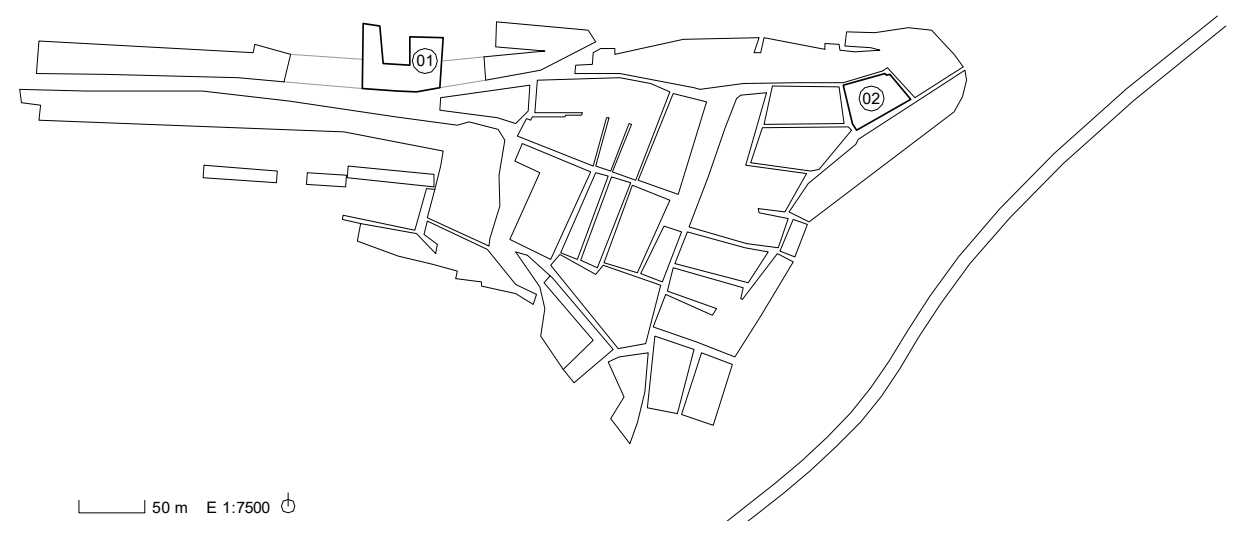


36 GaRBRALA/ Tejeda la Vieja

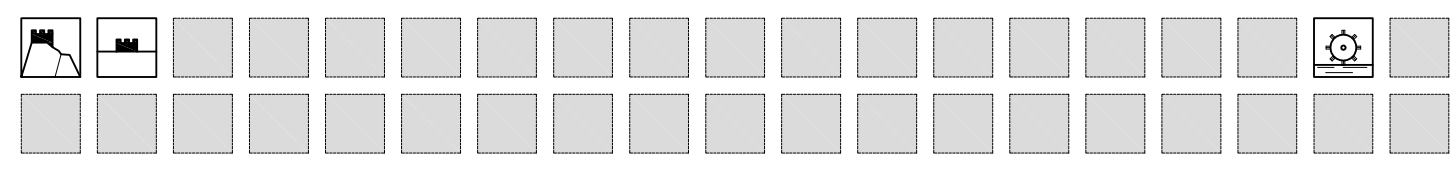




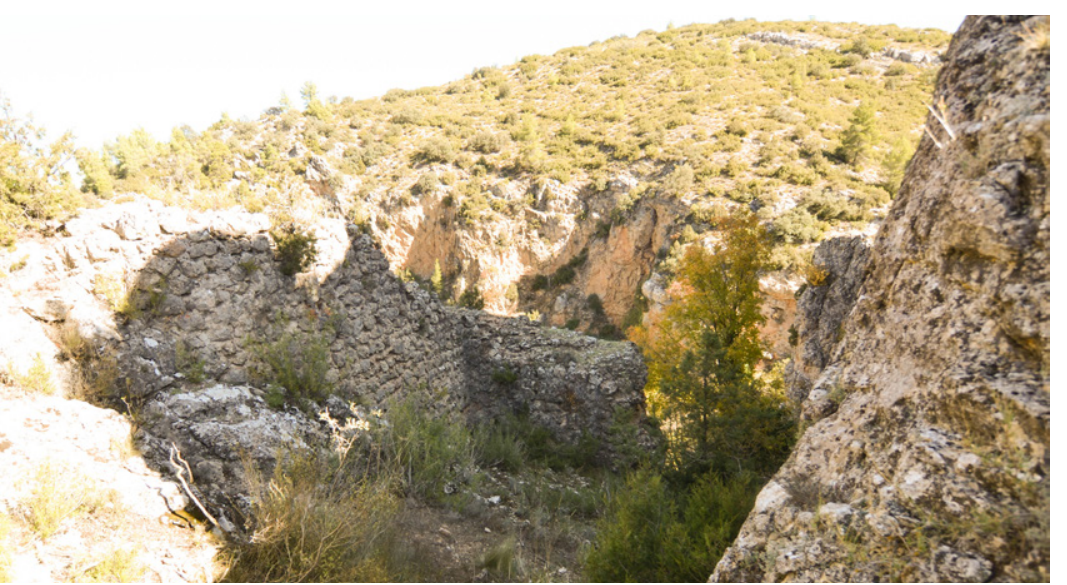

Fig. 458. Cuerpo de acceso al fuerte, orientado a norte. Se observa que la colina de la derecha

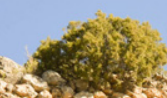

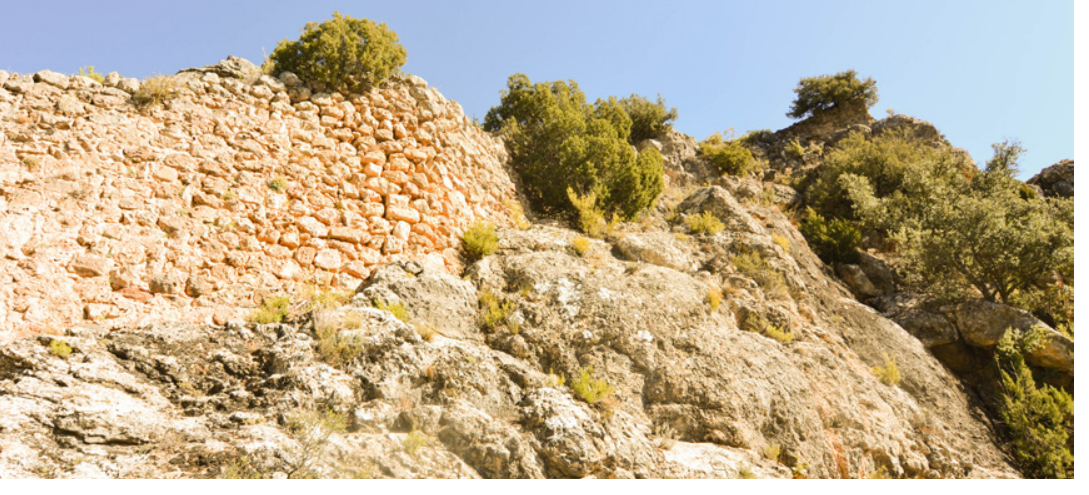

Fig. 459. Frente suroeste del fuerte.

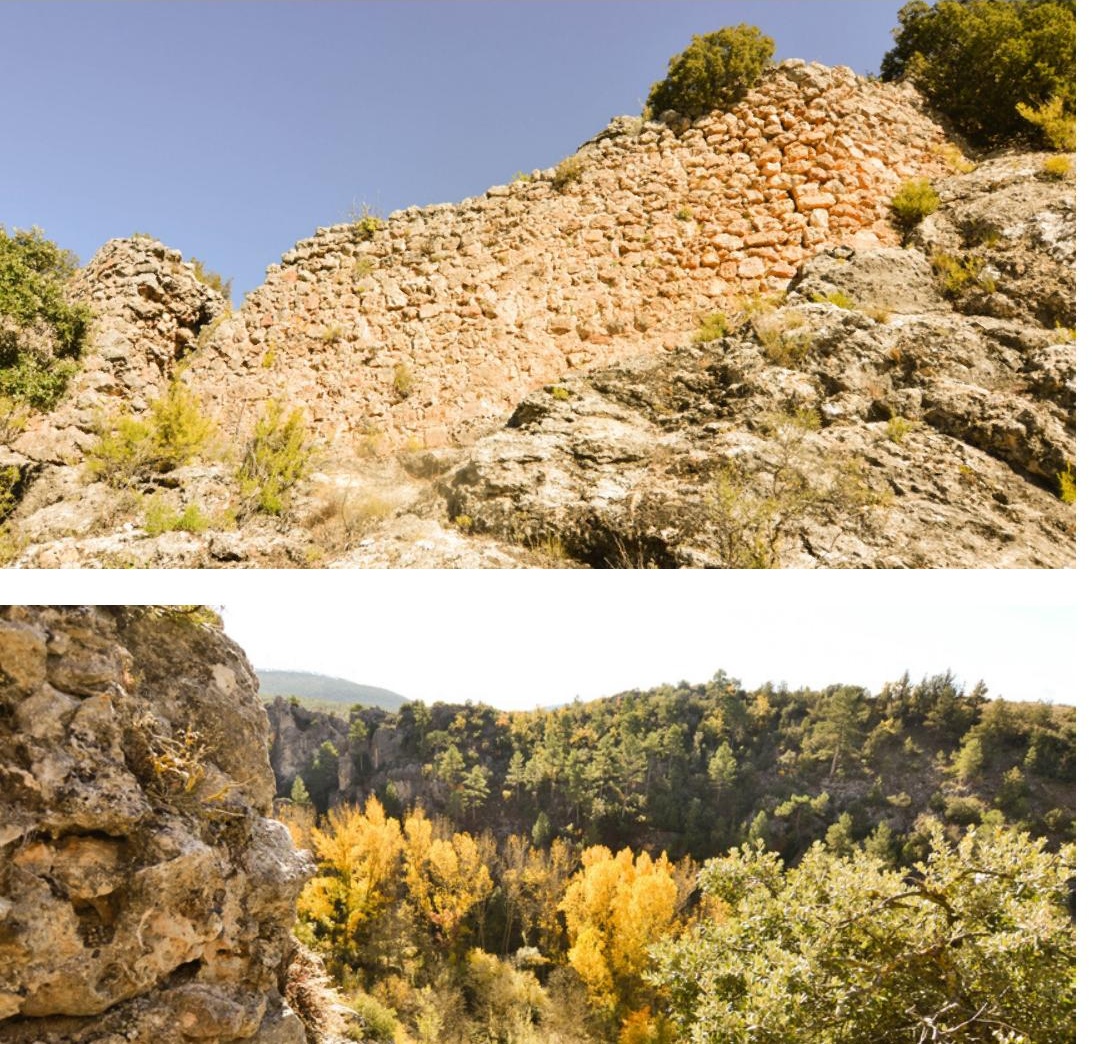

Fig. 460. Frente suroeste del fuerte.

Fig. 461. Vistas desde el fuerte. Se aprecia que se sitúa en un punto elevado, pero no en el más elevado del contorno.
El gran equipamiento histórico en la misma Garaballa es el Monasterio de Tejeda o Tejeda la Nueva, en un extremo de la población, que pudo concluirse en 1581 y, por tanto, está presente en los acontecimientos. El monasterio sufre avatares en la Guerra de Independencia, pero también durante el trienio liberal o las Guerras Carlistas, actuando de hospital tanto durante la Guerra de Independencia como durante la Guerra Civil. Es posible, dado que es habitual el uso de estructuras monásticas como punto de alojamiento de tropas, que el monasterio nuevo fuera tenido en cuenta por los efectivos carlistas, aunque no se han encontrado fuentes que corroboren esta hipótesis. En la actualidad se ha adaptado a uso hotelero.

Fig. 462. Planta esquemática del conjunto de Tejeda la Vieja en Garaballa.

01. Río Ojos de Moya

02. Molino de Papel y antiguo

convento

03. Cueva del Risco

04. Restos del castillo (refugio

carlista)

5. Cueva de la Virgen

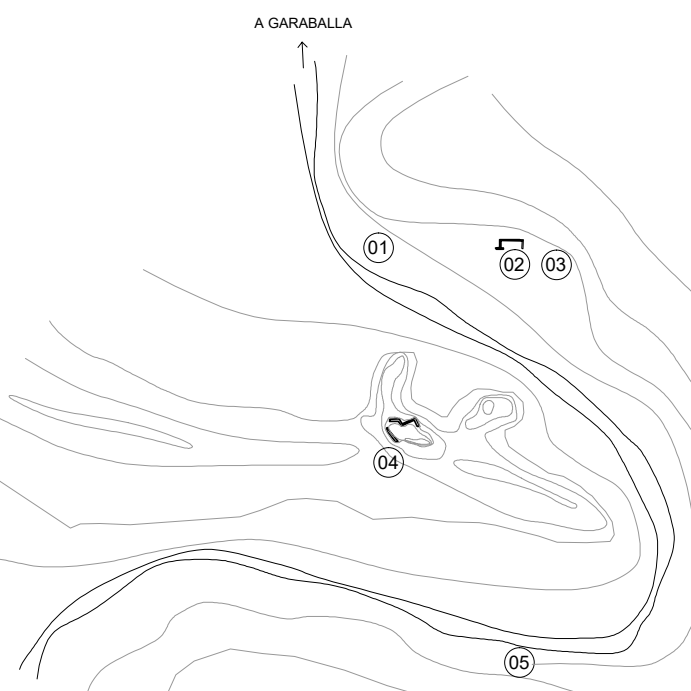


37 LA FrEsNDEA 


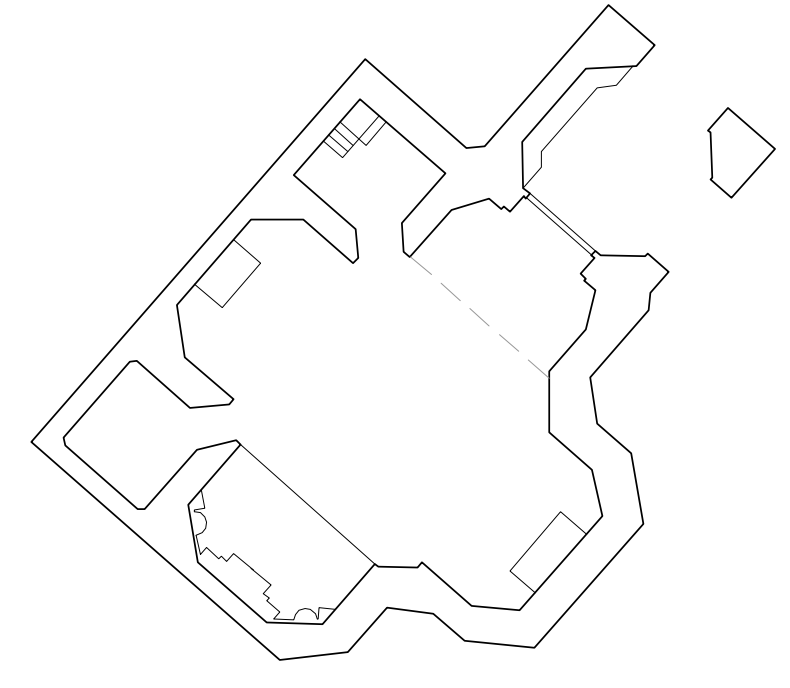

2m E1:300
Fig. 475. Esquema en planta de la Ermita del Calvario de La fresneda. la torre del fuerte. $38_{\text {La Galera }}$ 17) . 


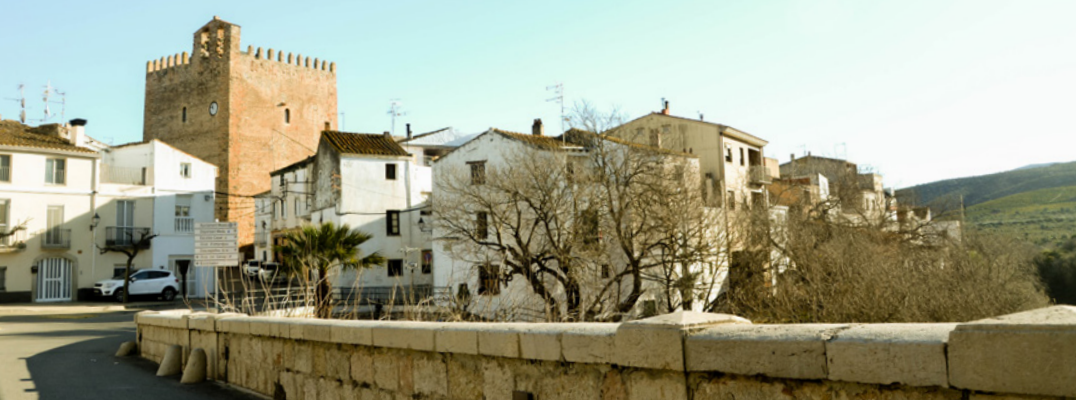

Fig. 477. Torre medieval de Galera fotografiada desde el puente sobre el barranco que conecta Tortosa y Ulldecona.

Fig. 478. Esquina oeste de la

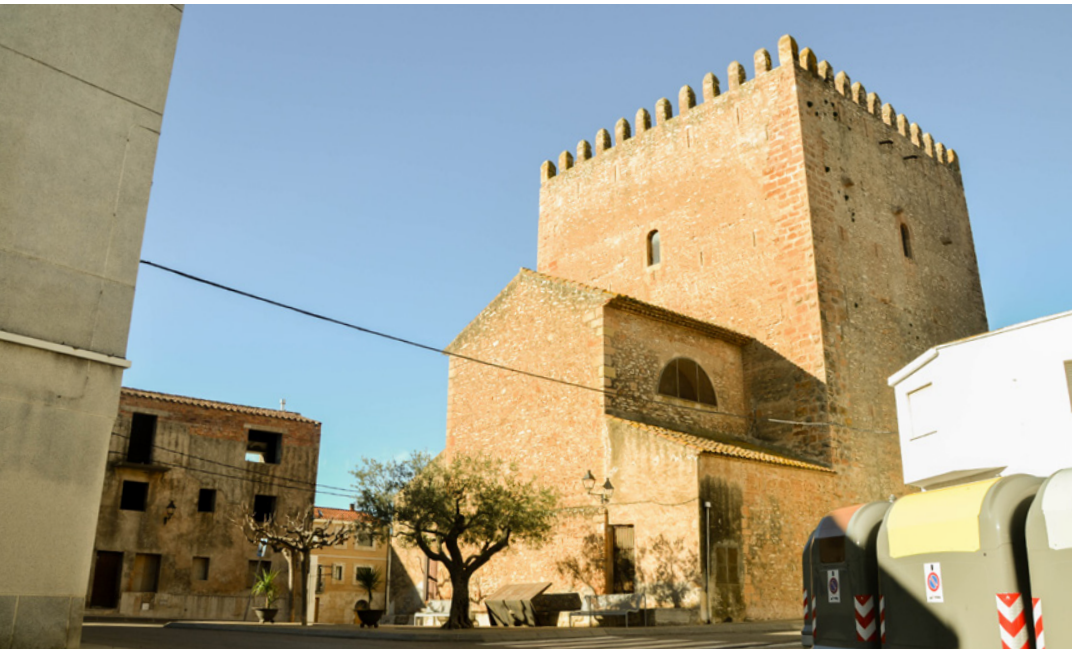

Fig. 479. Fachadas traseras de la torre, orientadas a noreste

Fig. 480. Detalle de las aspilleras ubicadas en el frente sureste de la torre.

\section{La Galera}

Localidad en castellano / catalán: La Galera

Provincia actual: Tarragona

Comarca: Montsiá

Coordenadas geográficas: 40.681050931666846, 0.4628536533862473

Tipos defensivos: torre.

Acciones y fortificación:

Se sabe que el cabecilla carlista Antonio Vallés Vallés, con grado de coronel, participa en un combate en La Galera, donde es capturado para ser trasladado a Tortosa y fusilado el 29 de diciembre de 1834 (Caridad, 2014: 526).

Tras el saqueo de Benicarló, los carlistas merodean por las orillas del Ebro y a finales de la primavera de 1836 Forcadell parece proveerse en La Galera, desde donde se dirige a Amposta para atacar la casa-fuerte y castillo. Tras dos horas de ataque regresa a los territorios de Rosell y la Sénia (Pirala, 1869: III, 73).

La Galera y Santa Bárbara constituyen lugares de paso frecuentes de las tropas carlistas por entonces (Córdoba, 1844: I, 257, 260, 364; II, 58, 317).

En enero del año 1837 Joaquín Andreu "Rufo", que integra la escolta de Cabrera en la Sénia, marcha hacia la Galera para conseguir víveres, pero es sorprendido y salva la vida en la fuga (Caridad, 2014: 253; Córdoba, 1844: II, 174, 185).

A finales de mayo de 1839 podrían haberse emprendido obras defensivas tratando de fortificar el territorio del río Sénia en la Galera, además de en Santa Bárbara y Xerta (Caridad, 2013: 262).

El mes de mayo de 1840 supone el desplome de la línea defensiva carlista, pues caen Alpuente, Alcalá de la Selva y Bejís, siendo abandonados Linares de Mora, Villahermosa del Río, Montán, Benicarló y también La Galera (Córdoba, 1844-1846: v.4, 330), Ulldecona, Sant Mateu y Cantavieja (Caridad, 2013: 266)

Con toda probabilidad, la torre medieval de 1340 en La Galera se activa para funciones de vigilancia, pues responde bastante bien a las tipologías reutilizadas por los carlistas. Se eleva dominando la población y el denominado Pla de la Galera, y presenta sus merlones y espadañas para guarecerse, controlando el paso del puente por encima del barranco que conecta Tortosa y Ulldecona. Permite además la comunicación visual con la sierra de Godall y los Puertos de Tortosa y Beceite. La torre parece ser reconstruida en 1684 y sufre desperfectos durante la Guerra Civil. Una rehabilitación reciente ha acondicionado la planta superior, la cubierta y el acceso a la misma. 


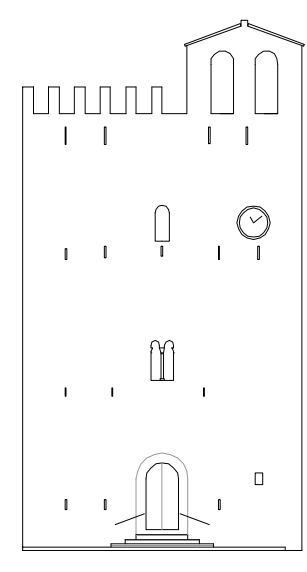

2m E1:500

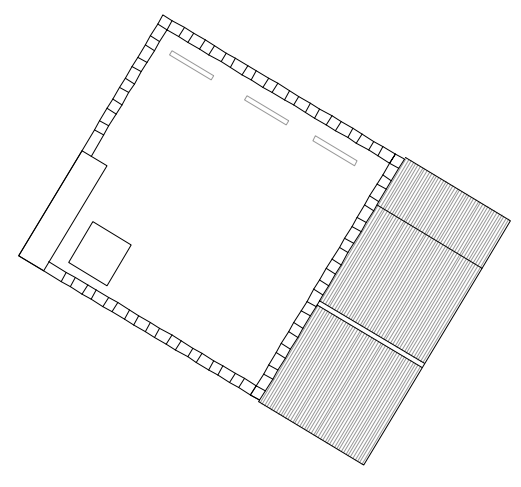

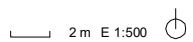

Fig. 481. Alzado nororeste de la torre medieval de La Galera.

Fig. 482. Planta de la torre medieval de La Galera.

39 ᄂA HOZ DE LA VЕЕА

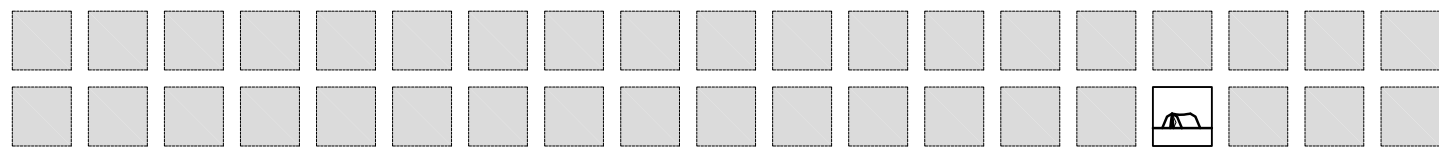




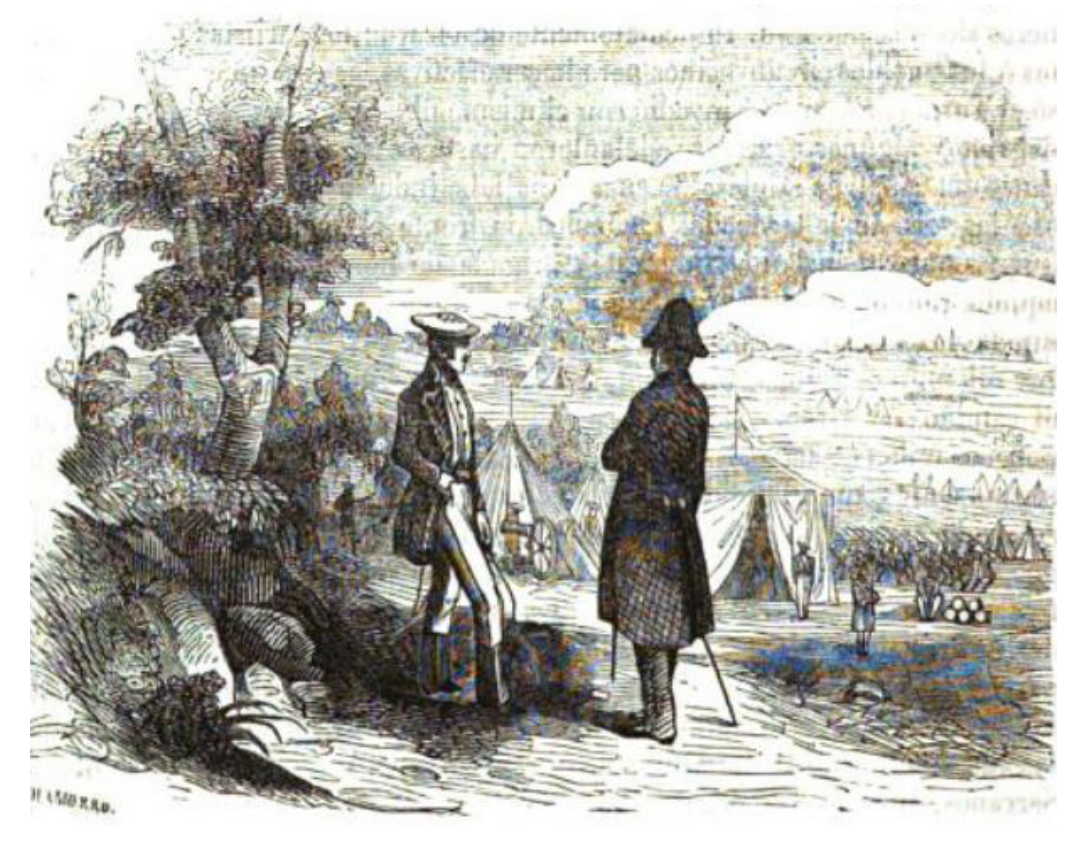

Fig. 483. Ilustración de un campamento carlista. La imagen campamento carlista. La imagente pertenece al campanento de 1845: 326)

\section{La Hoz de la Vieja}

Provincia actual: Teruel

Comarca: Cuencas Mineras

Coordenadas geográficas: $40.924131578752565,-0.8432797494627664$

Tipos defensivos: campamento.

\section{Acciones y fortificación:}

Entre la Hoz y Segura hay constancia de que el ejército carlista instala un campamento, según el testimonio de Von Rahden (Von Rahden, 2013: 335). Con toda probabilidad, se hace referencia a la Hoz de la Vieja. Von Rahden construye "atrincheramientos sencillos, de piedra o tierra" con sus zapadores. No se ha podido detectar ningún vestigio. El 12 de junio de 1839 se produce en la Hoz un enfrentamiento entre carlistas y liberales donde destacan las caballerías de ambos ejércitos, al mando de los comandantes Balmaseda y Serrano respectivamente. 
40 Landete 


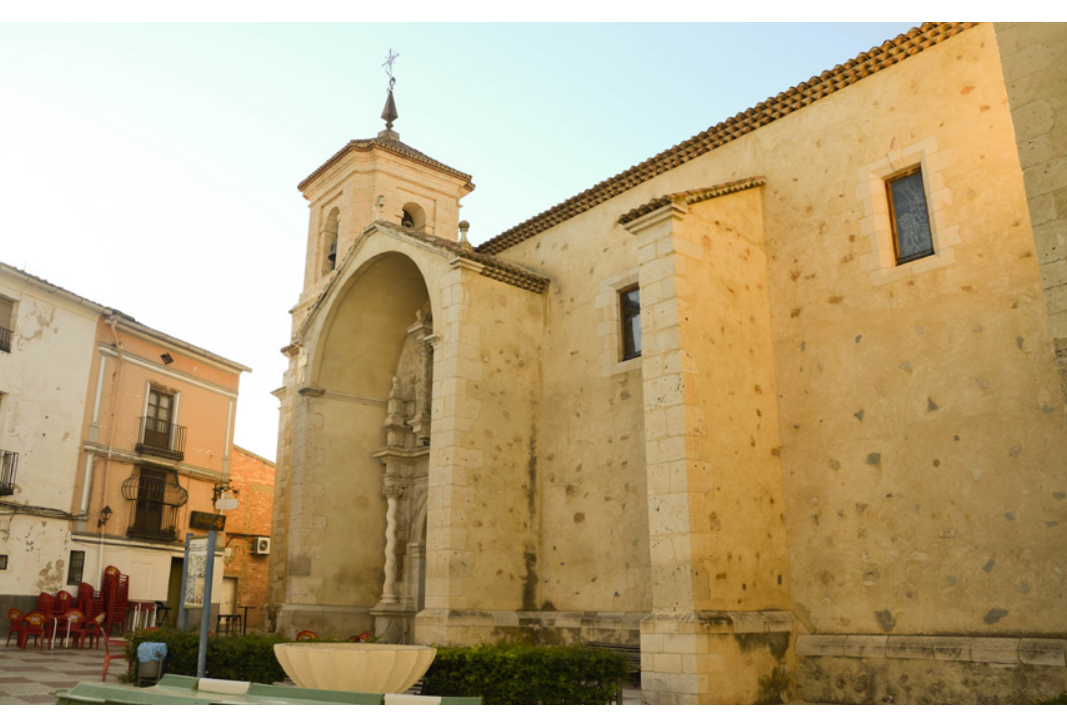

Fig. 484. Iglesia de Landete, llamada Parroquia Nuestra Señora de la Asunción. No está especialmente elevada, pero sí enclavada en el perímetro norte de la población (punto 01 en fig. 488).

Fig. 485. Torre de la iglesia. Fig. 486. Portada de la iglesia. Fig. 487. Fachadas traseras de la manzana más septentrional de la población, cuyas fachadas principales vuelcan a la calle Castillo (punto 02 en fig. 488).
Landete

Provincia actual: Cuenca

Comarca: Serranía de Cuenca

Coordenadas geográficas: $39.908205801951084,-1.3667604701039124$.

Tipos defensivos: fortificación de iglesias.

Acciones y fortificación:

El pueblo domina el curso del río Algarra, u Ojos de Moya, que pasa por su perímetro y condiciona su fisonomía. La iglesia, reedificada en el siglo XVIII, se sitúa en el centro del pueblo y domina la población.

Se sabe que a principios de septiembre de 1836 la Expedición de Gómez pasa por Landete y se hacen algunos alistamientos por la zona (El Eco del comercio, 1836, n 868: p,4). El 16 de agosto de ese mismo año, su iglesia es incendiada por los carlistas. La guarnición, integrada por voluntarios del batallón ligero de Extremadura, es sitiada en la torre por Miguel Sancho, conocido como el Fraile de la Esperanza (El Español, Madrid, 2 de julio de 1836). Otras fuentes sostienen que la acción es acometida por Llagostera (Ferrer et altr. 1941). El objetivo es el saqueo del pueblo. Se constata que en la población no hay más defensa que "unos vallados inmediatos" a la iglesia. El procedimiento defensivo es rústico. Las familias de los afectados se encierran en la iglesia, con cántaros de agua. Desde la es rústico. Las familias de los afectados se encierran en la iglesia, con cántaros de agua. Desde la
torre se dispara a los que se asoman. Se sabe que el capitán Silva "aspilleró la puerta de la iglesia para torre se dispara a los que se asoman. Se sabe que el capitán Silva "aspilleró la puerta de la iglesia para
defenderla de un incendio" y para prevenir el ataque sobre la puerta, "hizo levantar con bayonetas parte del pavimento de la iglesia y formó un parapeto detrás de aquella". Dicho de otra forma, acaba tapiando la puerta con el pavimento de la iglesia. Para huir del fuego proyectado desde la torre, los carlistas se protegen con un "carro lleno de colchones" (El Español, Madrid, 2 de julio de 1836). Los carlistas consiguen prender fuego a la iglesia a través de un boquete y los 160 ocupantes se refugian en la torre, pero no caben y deben romper el "cuarto del reloj y pasar a ocupar la cina de la bóvechi pero el humo los iba nofocary ses a caldearse a punto de no poder sufrir su ardor en los pies, y se vieron obligados a apoyarse sobre las vigas y maderos en que descansaba el tejado, los que también principiaban a arder, u cuyo fuego consiguieron apagar con los escombros" (ibíd.).

Landete es un punto de paso tanto para carlistas como para liberales. El general San Miguel, tras entrevistarse con Narváez, marcha en busca de los carlistas en la zona de Cuenca y se sabe que el 25 de septiembre de 1836 pernocta en Santa Cruz de Moya, trasladándose después a Landete, donde se entera de que las tropas carlistas están muy próximas, en la fortaleza de la Magdalena, en Salinas del Manzano (López Marín, 2014: 371).

También Arnau, años más tarde, pasa por Landete, el 22 de enero de 1839, en dirección a Chelva: “El comandante militar de Liria en oficio de esta mañana dice con referencia a avisos confidenciales que Arnau pernoctó anteayer en Landete con toda su facción y el llamado batallón de Mora, y que anoche se la aguardaba de regreso en Chelva" (El Eco del comercio, $\mathrm{n}^{\circ} 1729,1839$, p. 2).

En la actualidad, la iglesia de Landete se conserva en perfecto estado, pues recientemente ha sido objeto de una restauración. La puerta en la que se abrió una aspillera ya no existe y no queda ningún vestigio del enfrentamiento de 1836 ni de ninguna obra de fortificación posterior. 


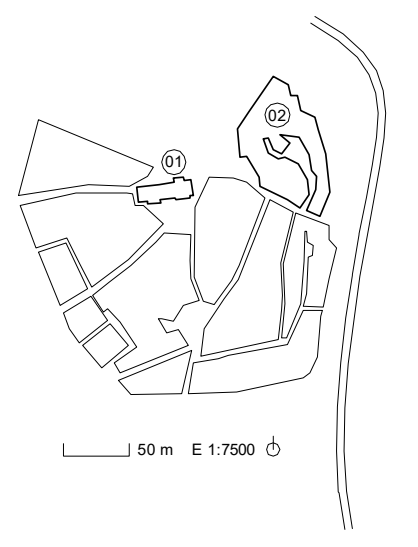

Fig. 488. Esquema en planta de Landete con los puntos de interés defensivo

01. Iglesia

02. Calle Castillo

41 La Pobla de BenIfassà

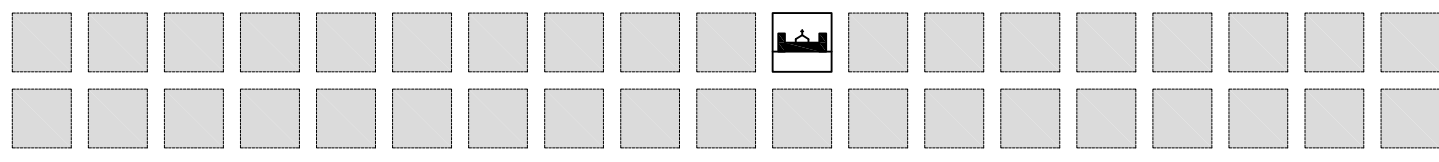


la abadía indica Pérez Galdós que se trata de un "edificio devastado sucesivamente por tres guerras: la de las Germanías, la de Sucesión y la que ahora se relata. Daba pena ver su noble arquitectura mutilada por bárbaras manos: aquí señales de incendios, allá desplomados muros, la iglesia con medio techo de menos, la torre melancólica y sin campanas con sus espadañas ciegas y mudas, las junturas pobladas de jaramagos y ortigas y el claustro, en fin, con sólo tres costados, más triste que todo lo demás, y más poético y ensoñador" (Pérez Galdós, 1993: 2473). En un momento determinado de la novela se habla de trabajos defensivos, cortando árboles para "proteger el camino cubierto entre la casa del abad y un mas situado a tiro de vos, cortando árboles para "proteger el camino cubierto entre la casa del abad y un mas situado a tiro de
fusil, dominando el río y el sendero" (Pérez Galdós, 1993:2474). Después se produce un ataque de Oráa fusil, dominando el rí y el sendero" (Pérez Galdós, 1993:2474). Después se produce un ataque de Oráa
desde Vinaròs hacia la Sénia y Rosell. Tienen que acudir las fuerzas del Serrador desde "Benifazá" y Cabrera y el Serrador se refugian en la sierra de Bel. Cuando Oráa, falto de municiones, debe regresar a Vinaròs, los carlistas ocupan de nuevo la Sénia y Rosell.

El conjunto de localidades que componen la antigua tenencia de Benifassà, como Ballestar, Bel, El Boixar, Castell de Cabres, Corachar y Fredes, se ve también afectado por el conflicto. A pesar de no existir referencias, es preciso destacar las estructuras escalonadas de El Boixar, con el supuesto castillo aspillerado. También el caso de Fredes, donde no es descartable el uso de su campanario castillo aspillerado. También el caso de Fredes, donde
como puesto de observación del abrupto territorio.

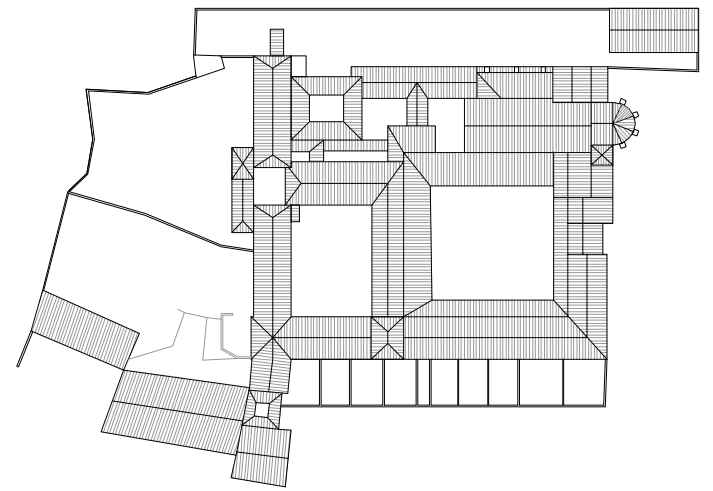


42 las Cuevas de Cañart

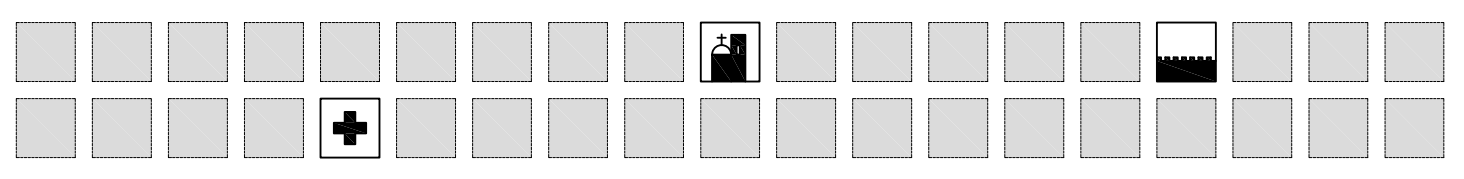




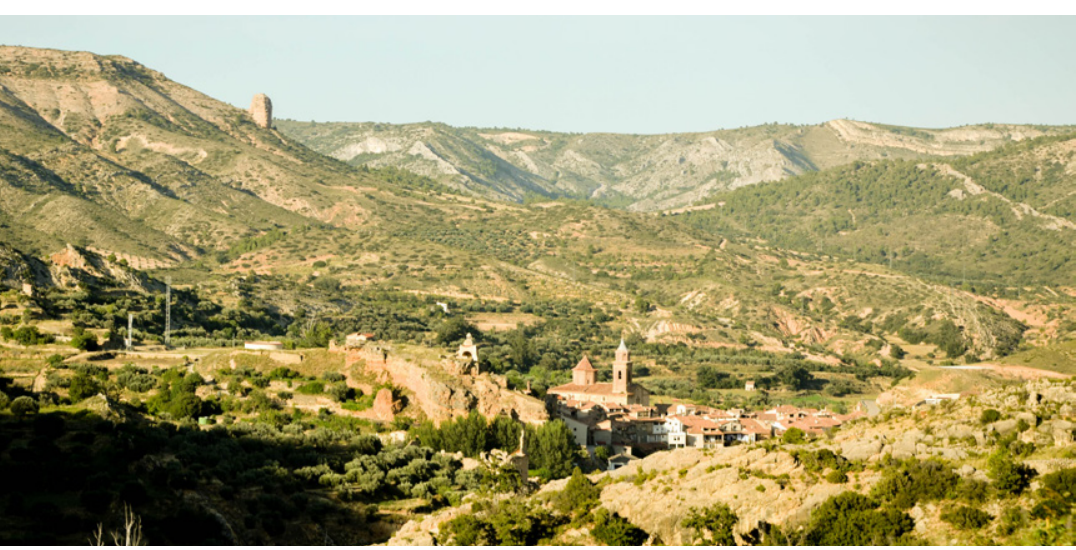

Fig. 494. Las Cuevas de Cañart en el territorio.

Fig. 495. Ruinas del castillo en su frente este.
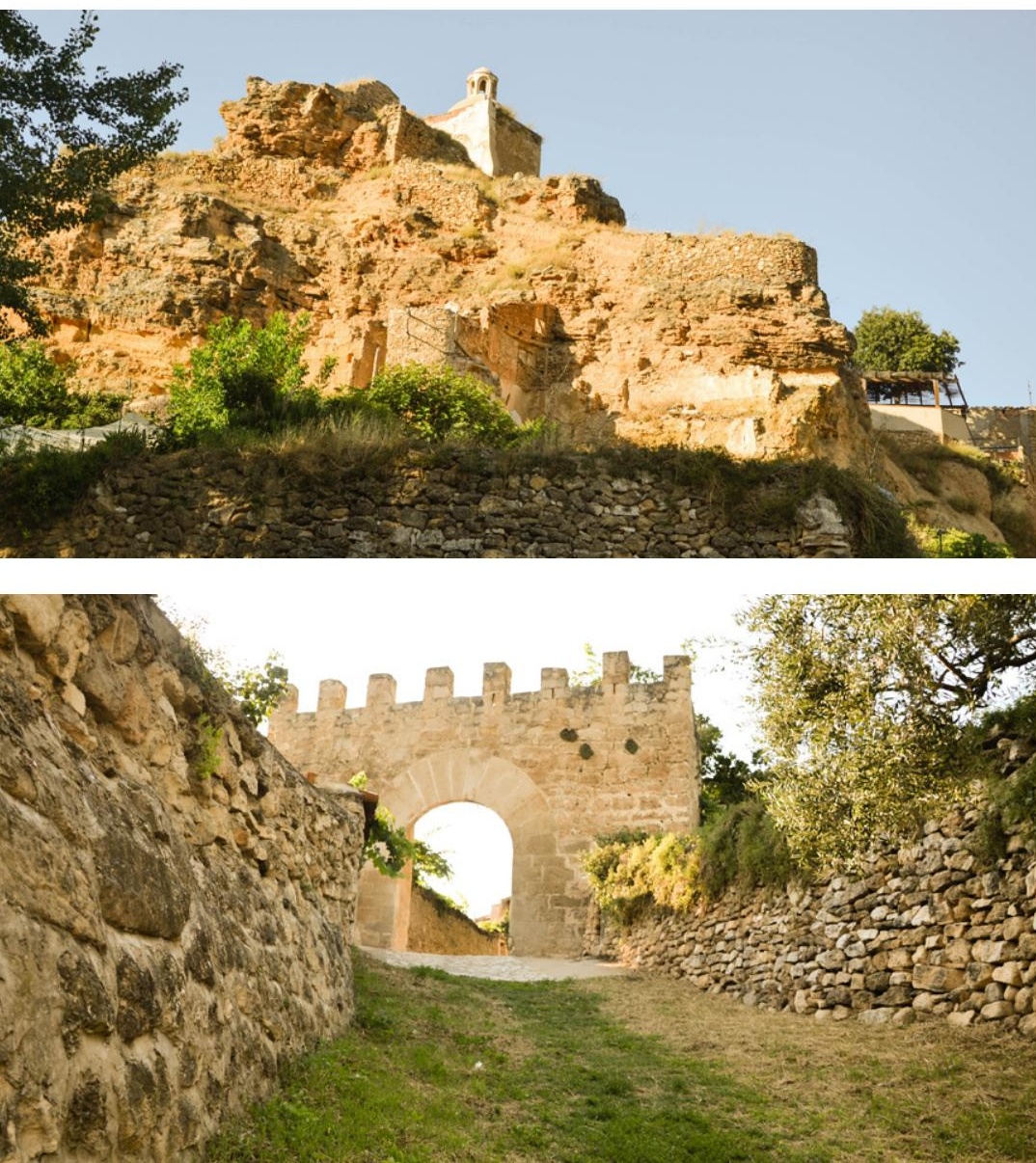

Fig. 496. Ruinas del castillo en su frente sur.

Fig. 497. Portal de Marzo.

\section{Las Cuevas de Cañart}

Provincia actual: Terue

Comarca: Maestrazgo

Coordenadas geográficas: $40.761621417359294,-0.43177985791044193$.

Tipos defensivos: fortificación de conventos, muralla urbana, hospitales.

Acciones y fortificación:

Pirala, en su Historia de la Guerra Civil, y de los Partidos Liberal y Carlista cita Las cuevas de Castellote (hoy Las Cuevas de Cañart) cuando hace una relación de hospitales. "En el ex-convento de religiosos servitas y una casa grande en la plaza del mismo pueblo, capaces ambos edificios de 230 camas. En el primero estaban los enfermos de medicina y en la casa del pueblo los de cirugía. A este eran conducidos los que operaban de Aragón entre Teruel y Montalbán" (Pirala, 1869: tomo V, 573).

También Von Rahden cita "Las Cuevas" cuando nombra las plazas aseguradas en la cuenca del Guadalope (Von Rahden, 2013: 477).

En la actualidad, se hallan unas valiosas ruinas del Convento de los Monjes Servitas, intervenidas en enero de 2020 con voluntad de conservación, aunque con escaso respeto al valor estético de la ruina. Por otra parte, todo hace pensar que, tras la restauración, no se ha vuelto a tener interés en los restos, pues una fachada se halla cubierta completamente de hiedra, y el interior, de todo tipo de vegetación.

En la población se conserva una puerta almenada llamada Portal de Marzo y un arco ojival. En el cerro que domina la misma, se encuentran trazas de muralla, restos de un muro saliente curvo y la pequeña Ermita de los Pueyos. Este emplazamiento sin duda sería ocupado por los carlistas, al menos como punto de observación, al ser una posición elevada bien situada para la vigilancia. 


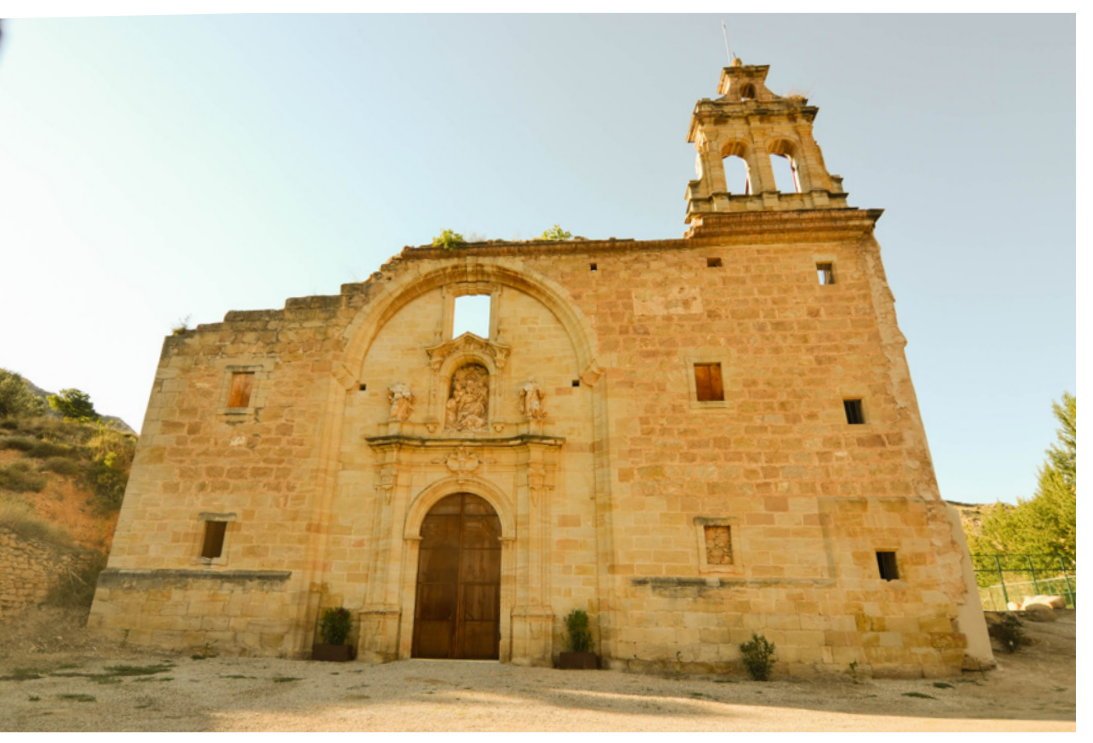

Fig. 498. Portada del Convento de los Monjes Servitas, utilizado como hospital durante la Primera Guerra Carlista.
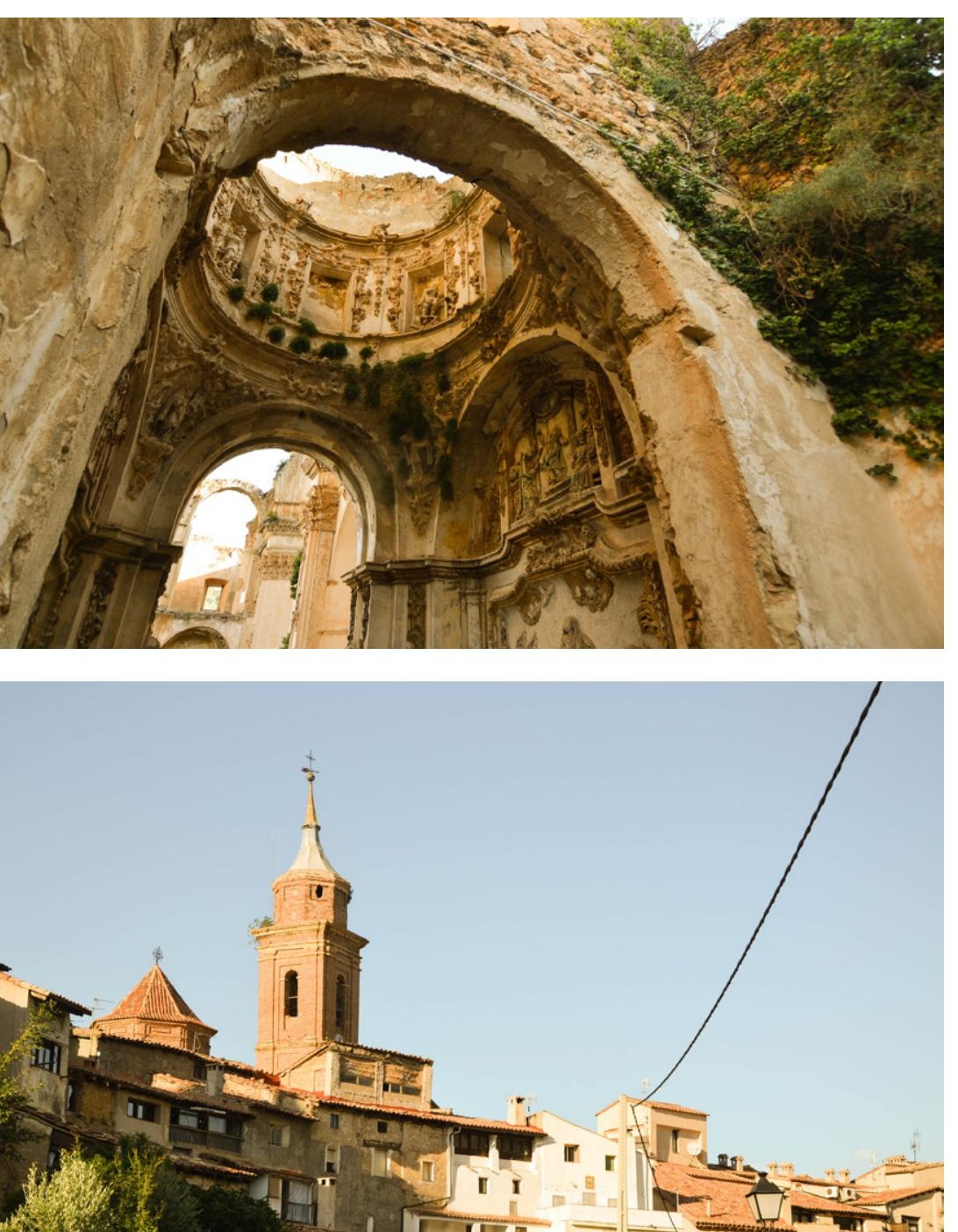

Fig. 499. Interior del convento.

Fig. 500. Torre campanario de la Iglesia de San Pedro.
Fig. 501. Planta urbana de

Las Cuevas de Cañart en la

actualidad.

01. Convento de los Monjes

Servitas

02. Portal de marzo

03. Ermita de San Blas

04. Arco ojival

05. Molino harinero

06. Ermita de la Virgen de los

Pueyos

07. Ermita de San Juan

08. Iglesia de San Pedro, del S.

XVIII

09. Ruinas del castillo

10. Lavadero

11. Casa Moliner

12. Horno

13. Never 
$43_{\text {LA SENIA }}$ *

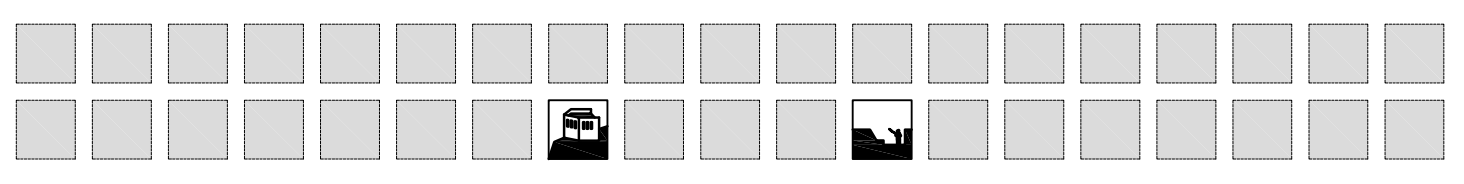



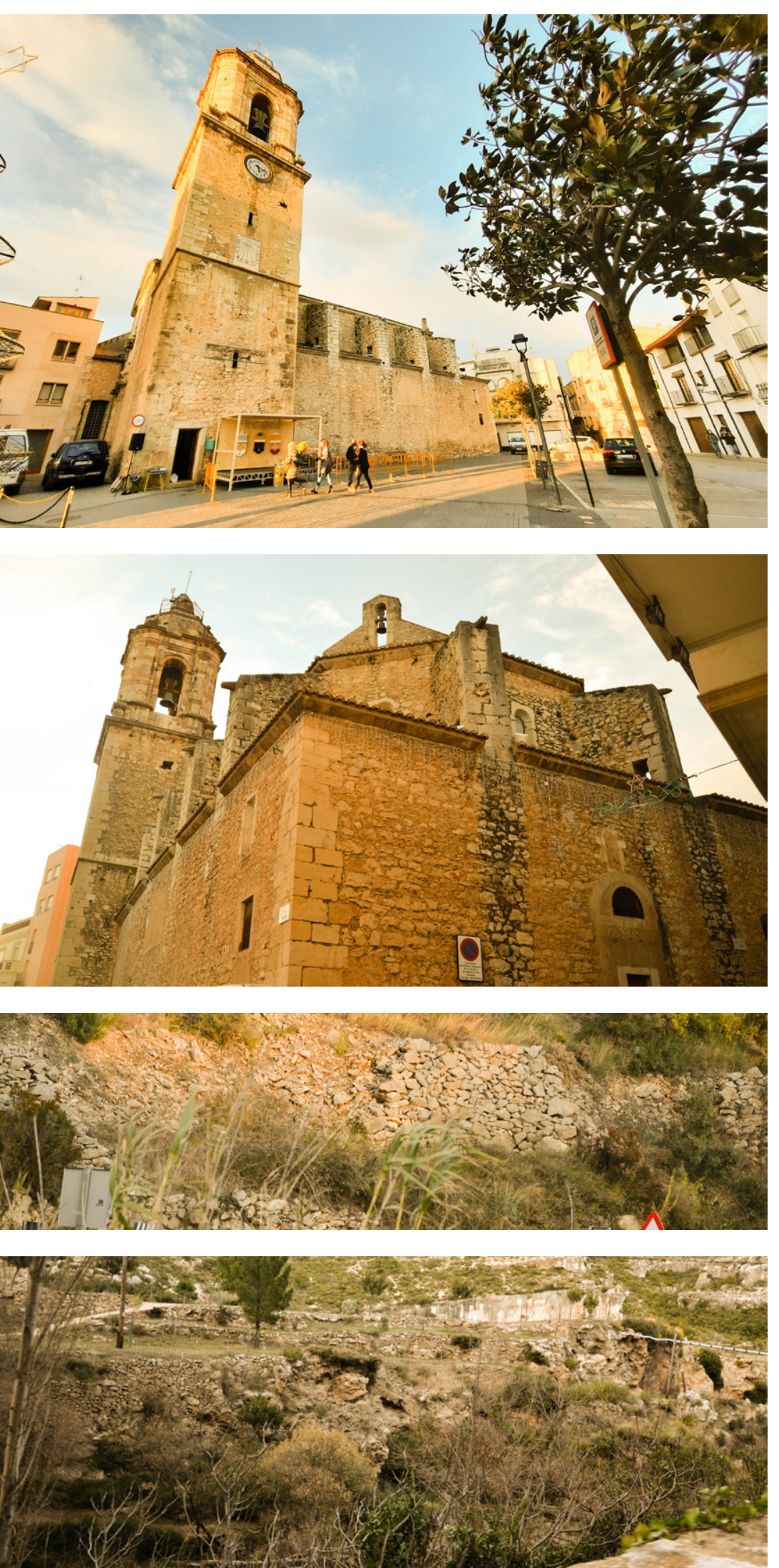

Fig. 503. Fachada trasera de la iglesia.

Fig. 502. Iglesia Parroquia de San Bartolomé de la Sénia y su torre. Esta última muestra aspìlleras en su frente sureste.

Fig. 504. Restos de muros de piedra en la zona norte de la Sénia, siguiendo el cauce del río Sénia y por el camino de Benifassà.

Fig. 505. Otros restos de muros en la misma zona de la figura 3 .
La Sénia

Localidad en castellano / catalán: La Cenia / La Sénia Provincia actual: Castellón

Comarca: Montsiá

Coordenadas geográficas: 40.63524417328895, 0.28108490716786605

Tipos defensivos: reducto, trinchera de campaña.

Acciones y fortificación:

La Sénia, además de aportar hombres, se convierte en un importante centro de operaciones, estableciéndose en su término una de las principales casernas de Cabrera. En la Sénia Cabrera se recupera de sus heridas y se produce aquí el último gran enfrentamiento en tierras del Ebro. A principios del conflicto, tras diversos intentos de apoderarse de la villa por parte de Carnicer, este es rechazado por la milicia. Con el control de las poblaciones de la zona en 1835 y tras varios intentos frustrados, en octubre de 1835 se evacúa a los familiares de los Nacionales. En el invierno y primavera de 1836 están construyendo obras de fortificación. Se sabe que Cabrera se refugia en la Sénia después de intentar tomar Peñíscola, convirtiéndola en punto de reunión de sus tropas dispersadas (Córdoba, 255-257, Caridad, 2014: 63). En la Sénia se tiene constancia de que los carlistas, en la primavera de 1836 construyen una serie de reductos y trincheras concretamente en dirección norte, desde la población al emplazamiento denominado Martinete (El Martinet), que se localiza precisamente siguiendo el cauce del río Sénia y por el camino de Benifassà (Diario Mercantil de Valencia, 4 de junio de 1836, Pirala, 1984: v.3, 72; Caridad, 2013:246). Parte de la infraestructura implementada en la Sénia son almacenes de avituallamiento, que hacen que la población se convierta en punto estratégico en el momento. Pero, dado que las posiciones tomadas por los carlistas son deficientes desde el punto de vista defensivo, en mayo de 1836 las fuerzas liberales dirigidas por Martín José registran enrentamientos sin que haya testimonios de obras de fortificación (S Barcelona, 2 de junio de 1836, pp. 1242-1243). En 1837 Cabrera se enfrenta con Oráa en la Sénia con un resultado incierto, pues ambos se atribuyen la victoria. En el tránsito de 1838 a 1839 hay propósitos de fortificar Ulldecona, la Sénia o Alcanar a fin de establecer una línea defensiva en el rio Sénia, una línea que coincide con el propósito ofensivo del general liberal Valdés, que llega a exclamar: "Bravo, bravisimo, así los tendremos encerraditos en un corral" (Diario Mercantil y Político, reproducido por el Diario de Barcelona, 31 de mayo de 1839, p. 2294 en Sauch Cruz, 2007: 131). A finales de mayo de 1839 tan solo se han realizado obras en la torre de la Iglesia de Ulldecona. Vergara y la concentración de las furzas liberales en el Maestrazgo llegan mientras Cabrera se plantea fortificar plantea fortificar Móra d'Ere do nicia en la Sénia la úlima batalla entre Centro (Gaceta e Madrid, 7 de junio de 1840, p. 1. Diario de Barcelona, 31 de mayo de 1840, p. 2164, Sauch Cruz, 2007: 134)

Ilustraciones de la época:

Ilustración 1

Título a pie: Acción de la Cenia.

Fuente: Calbo y Rochina, 1845: 518 


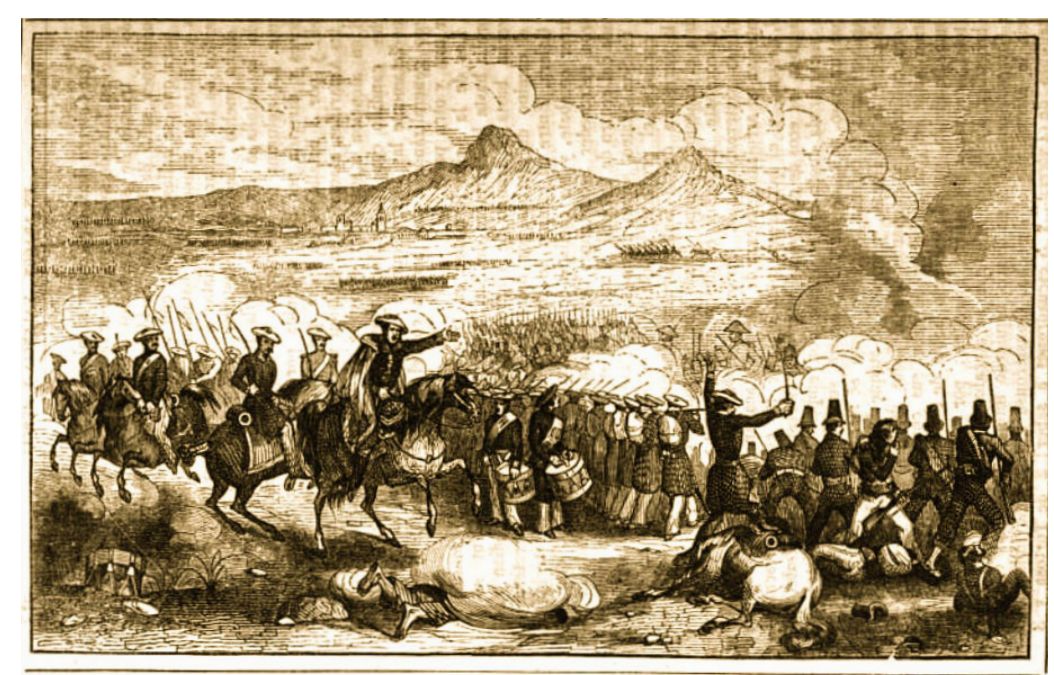

Fig. 506. Ilustración 1. Acció de la Cenia, 1845

Fig. 507. Plano de posible emplazamiento de la línea defensiva de La Sénia.

01. Martinete carlista (posible emplazamiento)

02. Posible emplazamiento de

reductos y trincheras en 1 camino norte de La Sénia.

03. Monasterio de Santa María de Benifassà.
44 LINARES DE MorA *

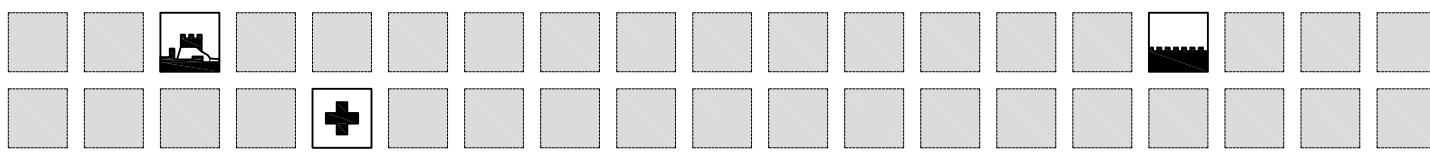


Fig. 508 Casco urbano de

inares de Mora, visto desde el sureste, donde destaca la iglesia su torre campanario y el castillo.

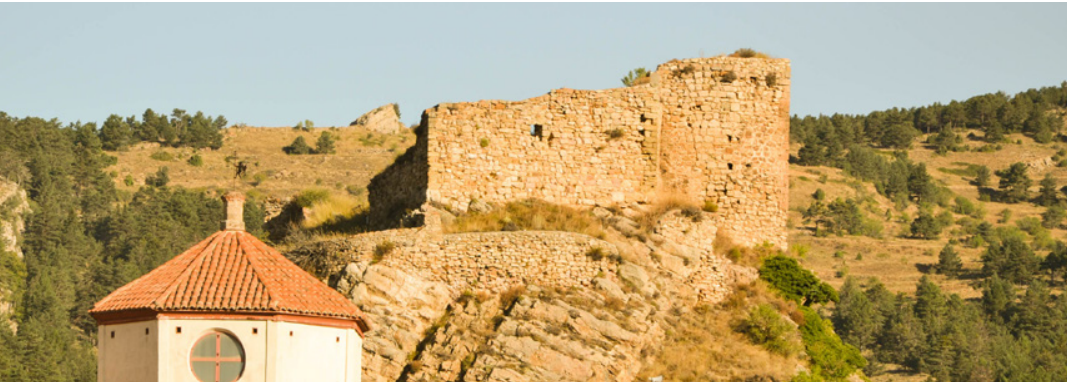

este del castillo de Linares de Mora. Fotografía realizada desde el monte del Calvario.

Fig. 510. Frente noreste del castillo. Destaca la torre de traza poliédrica.

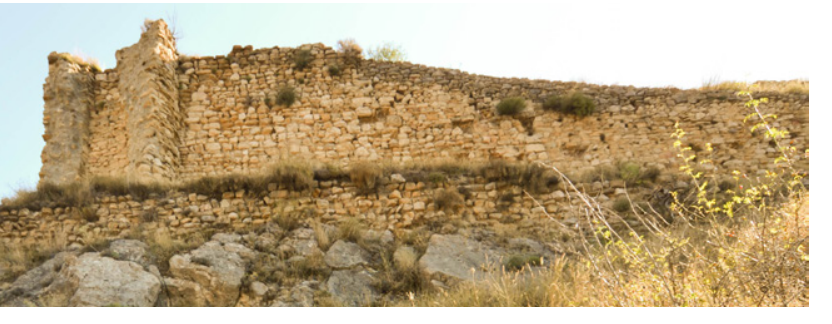

ig. 511. Frente occidental del castillo.

Fig. 512. Frente noroeste del castillo.

\section{Linares de Mora}

Provincia actual: Teruel

Comarca: Gúdar-Javalambre

Coordenadas geográficas: $40.32197966366812,-0.5753879518843803$

Tipos defensivos: castillo reforzado que domina la población, muralla urbana, hospitales.

Acciones y fortificación:

El 15 de diciembre de 1839 el Diario Mercantil de Valencia recoge la noticia de que Arnau ha demolido dos conventos y la cárcel de Rubielos, utilizando el material para fortificar Linares de Mora (Caridad, 2013:264)

El mes de mayo de 1840 supone el desmoronamiento de la línea defensiva carlista, cayendo Alpuente, Alcalá de la Selva y Bejís, y siendo abandonados Linares de Mora, que está incompleto (Diario Mercantil de Valencia, 9 de mayo de 1840; Calbo y Rochina, 1945:505), Villahermosa del Río, Montán, Benicarló, La Galera, Ulldecona, Sant Mateu y Cantavieja (Caridad, 2013: 266).

Sobre esta plaza sabemos que es considerada una villa fortificada que domina el valle del río Linape de Gúdar. En un mapa de 1839 observamos que conecta Olva y Nogueruelas con Fortanete, vía de tercer nivel que dificulta las comunicaciones del ejército liberal y permite que los carlistas puedan controlar el territorio con más facilidad.

Hoy, sobre la peña que domina la población, sobreviven las ruinas del castillo de origen musulmán. La población fue confiada a la Orden del Temple hasta el año 1202. Existen datos de una restauración del castillo en 1532 encargada por el arzobispo de Zaragoza a Juan de Galí y Juan de la Mira. De forma aproximadamente triangular y con unos $30 \mathrm{~m}$ de eje mayor, cuenta con una torre cilíndrica en un extremo y una torre del homenaje de planta pentagonal cuya altura parece rebajada. Las fichas históricas, tanto del castillo como de las murallas de la villa, no recogen información acerca de a edad media hasta el siglo XIX. Con la ocupación carlista de la villa, se sabe que se efectúan esfuerzos de fortificación, que la guarnición permanece hasta abril de 1840 y que abren una carretera que atraviesa el término municipal que no se conserva. Es conveniente incidir en que los caminos que unían las masías, el municipio y los pueblos vecinos eran caminos de herradura. En la actualidad existe un edificio en la Calle Hospital, conocido como "el antiguo hospital", transformado en hostal, que pude ser usado como hospital durante la ocupación carlista de Linares de Mora, pero no se tiene constancia de ello. De las murallas urbanas medievales se conservan fragmentos en buen estado junto al portal Alto. Sobreviven también el portal Bajo o de la Fuente y el portal de Enmedio. 
Fig. 513. Restos del castillo desde el interior

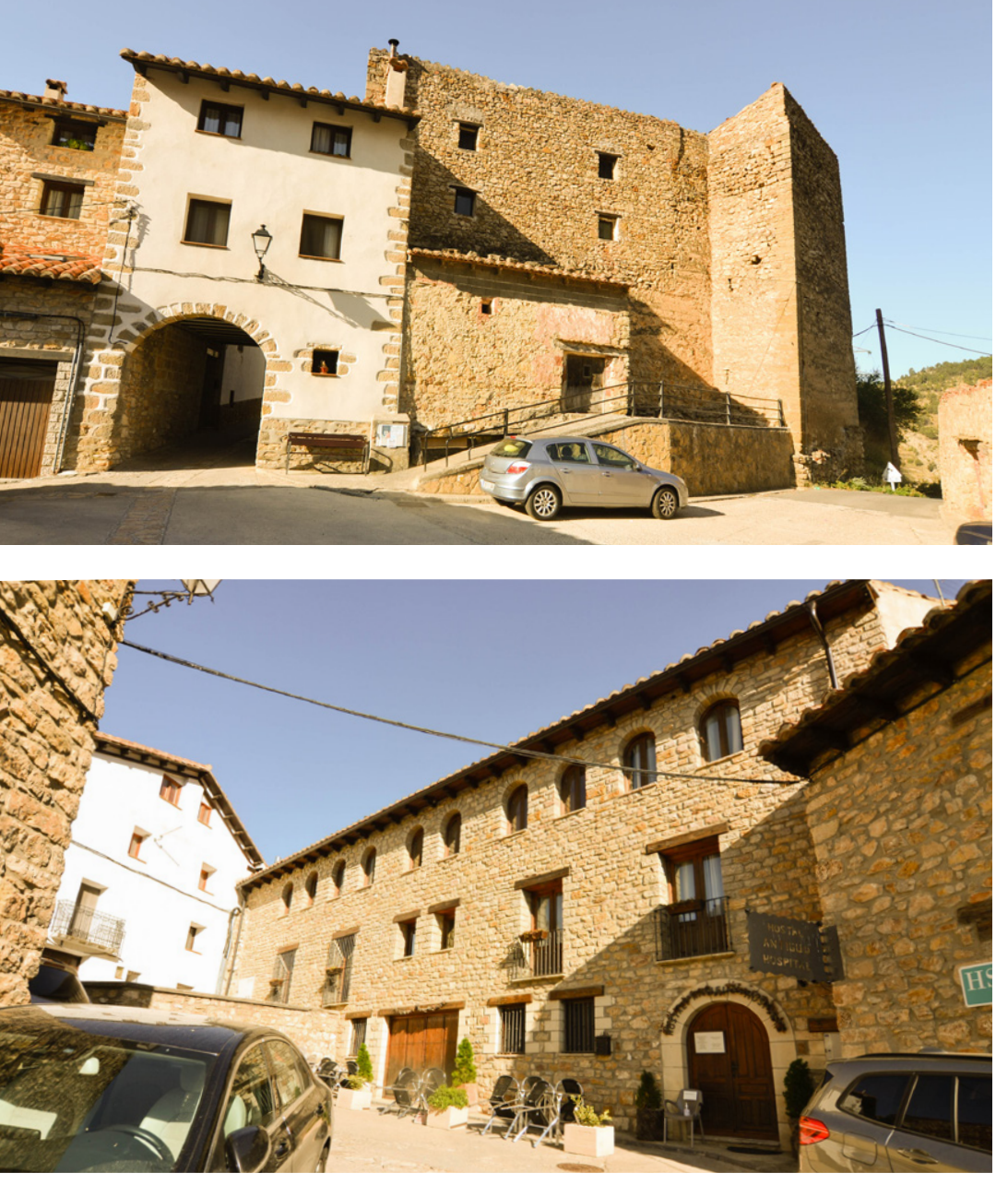

Fig. 514. Portal Alto, muralla urbana, torre de traza cuadrangular adosada a muralla y aspilleras. Foto realizada desde el exterior del casco urbano
Fig. 515. Antiguo hospital.

Fig. 516. Panorámica de $360^{\circ}$ desde la cima del castillo. Se observa, de izquierda a derecha un valle, el casco urbano, la Ermita de Santa Ana, el calvario que conduce a ella, la techumbre de la iglesia y la torre campanario.
Fig. 517. Alzado occidental del castillo.

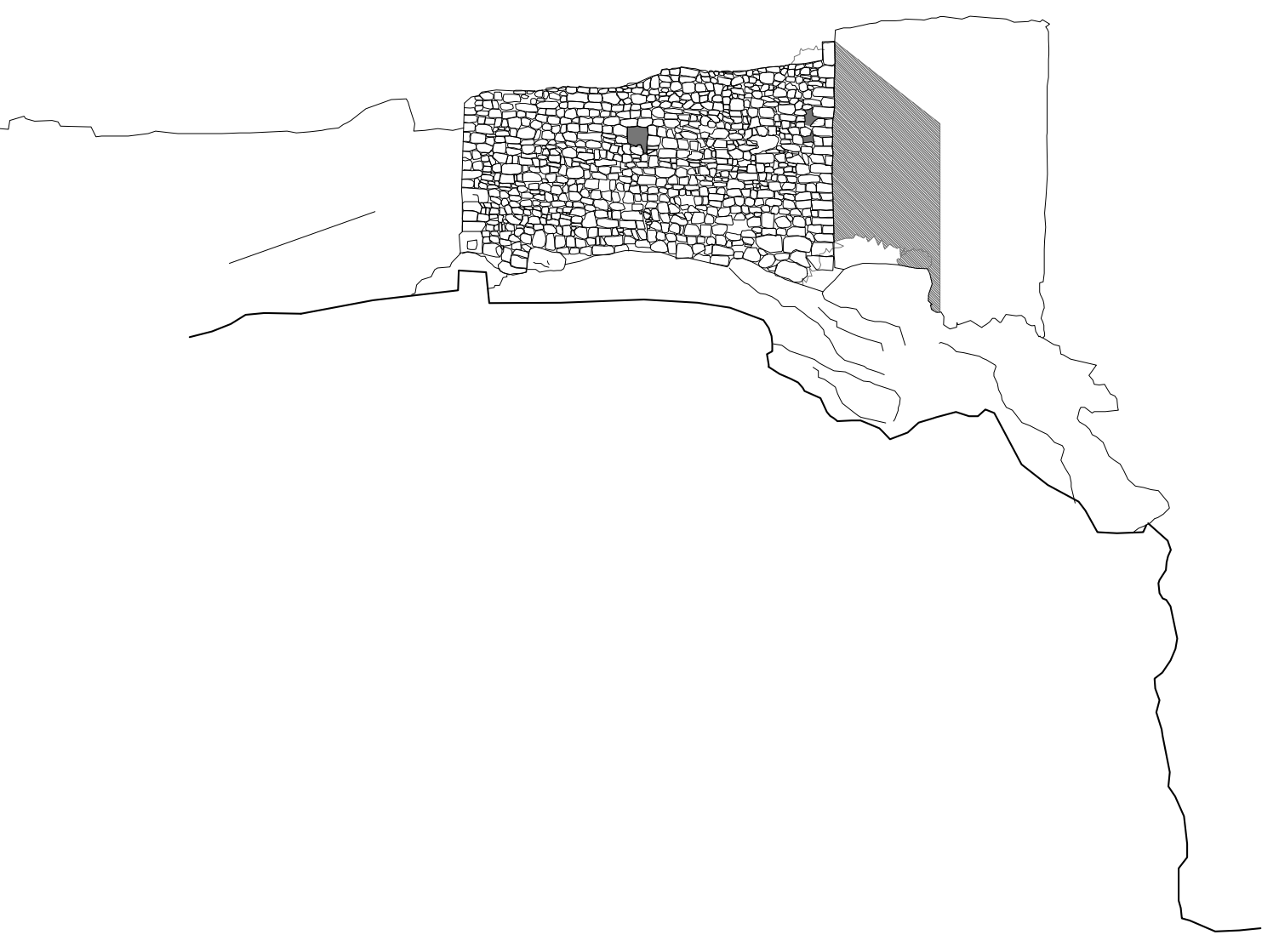

$10 \mathrm{~m}$ 
Fig. 518. Planta urbana del Linares de Mora y puntos de interés defensivo.

01. Portal Alto

02. Portal Bajo o de la Fuente

$$
\text { 03. Portalico }
$$

04. Iglesia de la Inmaculada

05. Torre dampana

05. Torre campanio exenta

06. Castillo

07. Ermita de Santa Ana y

Calvario

08. Ermita del Loreto

09. Ermita de Santa Bárbara

10. Puente medieval sobre el río

Linares

11. Antiguo hospital

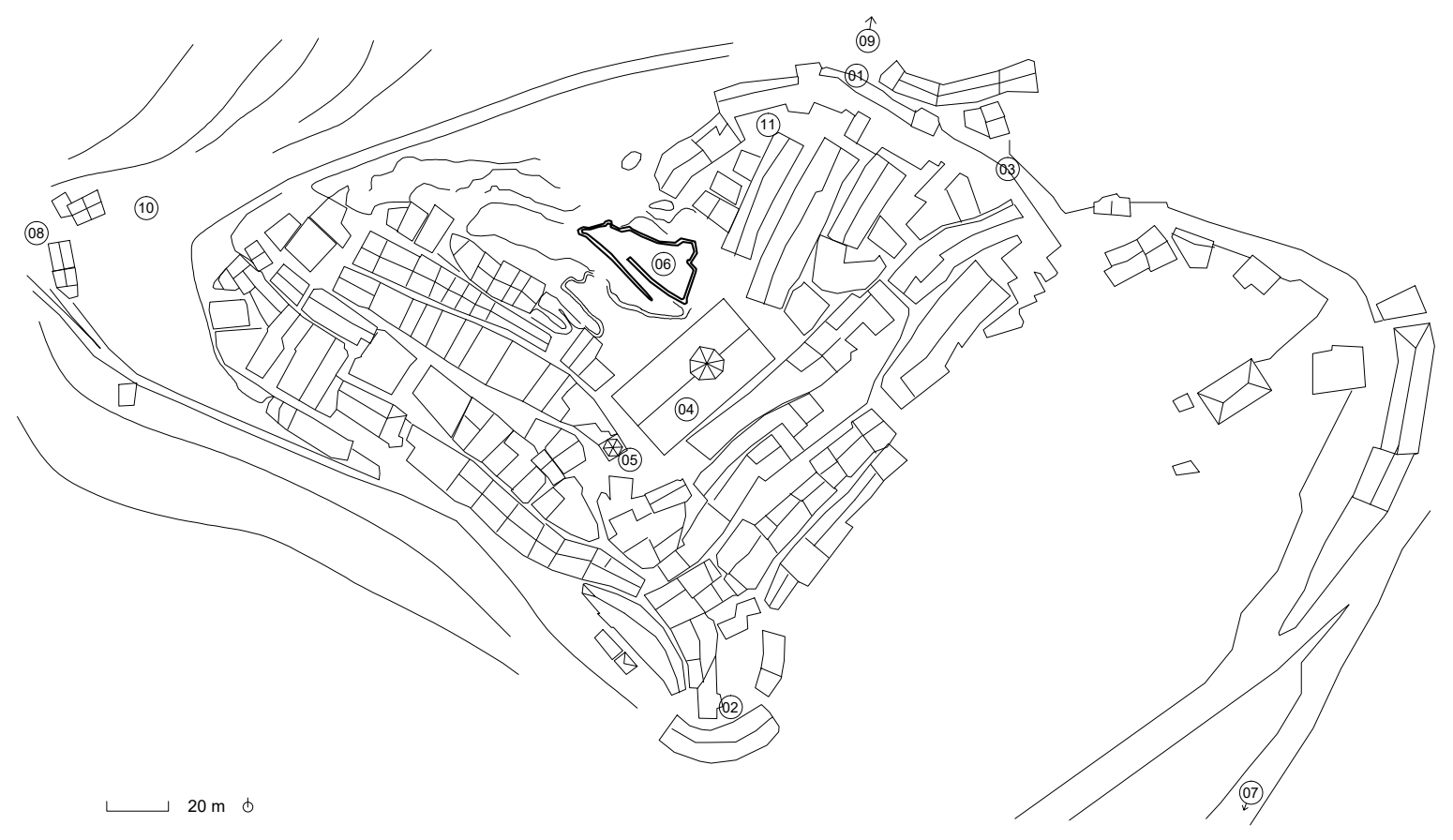

45 Manzanera $*$ 

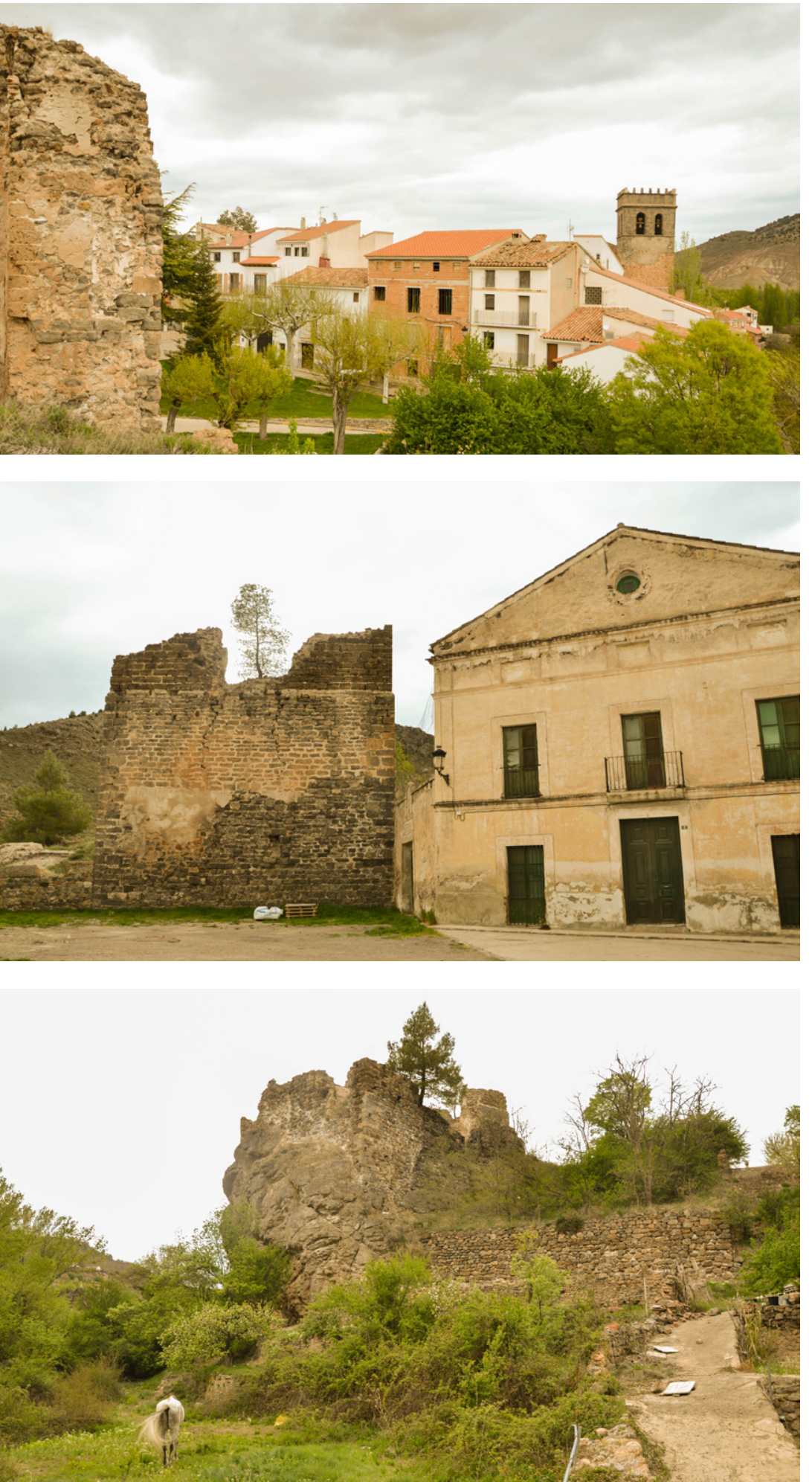

\section{Manzanera}

Provincia actual: Terue

Comarca: Gúdar-Javalambre

Coordenadas geográficas: $40.056091330585986,-0.8305313364259916$

Datos históricos:

Guarnición 1839-1840: 45 (Caridad, 2013:263)

Inicio bombardeo liberal: 14-12-1839

Rendición o abandono: 14-12-1839

Días de resistencia: 0

Fuente: Diario Mercantil de Valencia, Boletín Oficial de la Provincia de Castellón de la Plana, Córdoba (1844), Calbo y Rochina (1845), Caridad (2013:297)
Fig. 519. Fotografía realizada desde el castillo de Manzanera. Se percibe la relación visual entre el castillo y la torre campanario.

Fig. 520. Restos del castillo vistos desde la plaza del Castillo, intramuros

Fig. 521. Restos del castillo vistos desde extramuros, desde el sureste. Torrijas, estas últimas como puntos de comunicación con la altiplanicie" (Von Rahden, 2013: 406).

\section{muralla urbana.}

\section{Acciones y fortificación:}

En octubre de 1834 se produce un enfrentamiento entre los carlistas de Cabrera y las tropas liberales de Amor y Buil en las inmediaciones del convento de San Francisco, que se encuentra extramuros (Calbo y Rochina, 1845: 116). En verano de 1837 recala en Manzanera la Expedición Real. Con el fracaso de la expedición, la villa es ocupada por las tropas liberales de O'Donnell, pero se vuelve a ocupar en el verano de 1838 por Cabrera, que la sostiene bajo dominio carlista hasta el final del conflicto

Von Rahden indica que tras recorrer la zona desde Alcora y Montán hasta Torrijas, visitando Chelva, Alpuente y Castielfabib, y regresando por Alcalá de la Selva y Cantavieja hasta Morella, se más del conjunto de fortificaciones que se han decidido fortificar, "serían fortificadas también las poblaciones de Manzanera y

El Diario Mercantil de Valencia (18 de mayo de 1839) recoge que se inicia en el mes de mayo la construcción de un fuerte en Manzanera al tiempo que en Ayódar y Bejís, tratando de crear la línea defensiva que une Chelva con Cantavieja. La localidad ya cuenta con murallas y el palacio de los duques de Calabria, que dominaba la población, de traza rectangular y almenado, que bien podría considerarse la ciudadela de la plaza. La nueva fortificación planteada por los carlistas recurre tanto a la muralla histórica como al palacio para integrar la unidad fortificada. Para ello les añade fosos, aspilleras y un tambor cubriendo la puerta. La parte posterior de la población cuenta con los escarpost pes rocoss y el bar Azpiroz conquista Chelva y sus fortificaciones a finales de 1839 , habiendo sido abandonadas por sus defensores (Diario Mercantil de Valencia, 15 de noviembre de 1839; Córdoba, 1844-1845: v. 4, 168; Caridad, 2013:265). Más adelante caen Torre de Castro (Archivo de la Diputación Provincial de Castellón, colección de actas de 1839, folio 232; Caridad, 2013: 265), Manzanera (Diario Mercantil de Valencia, 17 y 18 de noviembre de 1839; Caridad, 2013:265) y Chulilla (Diario Mercantil de Valencia, 31 de diciembre de 1839; Caridad, 2013:265), pero las fortificaciones carlistas crecen, pues se siguen construyendo otras. Manzanera, concretamente, es cañoneada por las fuerzas del general Hoyos desde el amanecer del 14 de diciembre de 1839 hasta conseguir la rendición de los 40 hombres que la defienden (Calbo y Rochina, 1845: 454).

A finales del siglo XIX se conservan gran parte de las murallas y las torres perimetrales. Sin embargo, la estabilización de un frente durante la guerra civil daña sobremanera la población. Con el 
Fig. 525. Esquema en planta del casco urbano de Manzanera con

los puntos de interés.

01. Portal de Abajo

02. Portal de Arriba

03. Torre del castillo (los restos

del castillo se extienden alrede-

dor hacia el sureste de la torre)

04. Iglesia de Manzanera

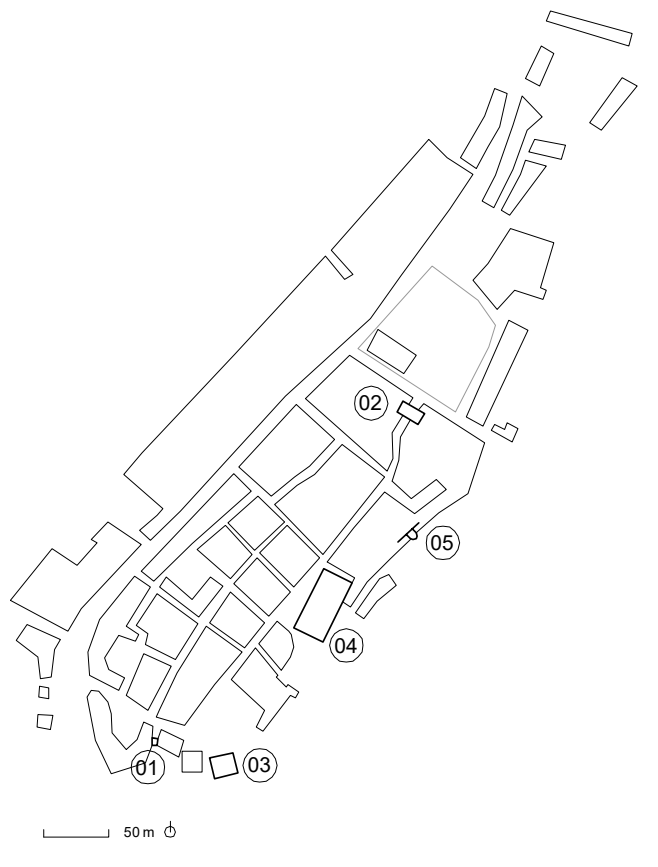

05. Torreón y murallas

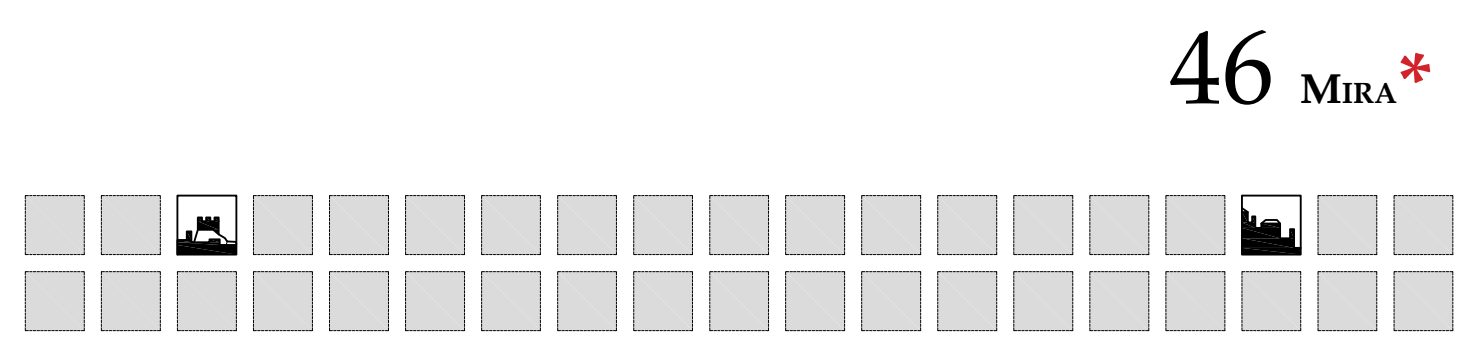


Fig. 530. Esquema en planta de Mira con los puntos de interés

01. Mirador de las Tres Cruces, emplazamiento del castillo

02. Iglesia de Mira

03. Río Ojos de Moya
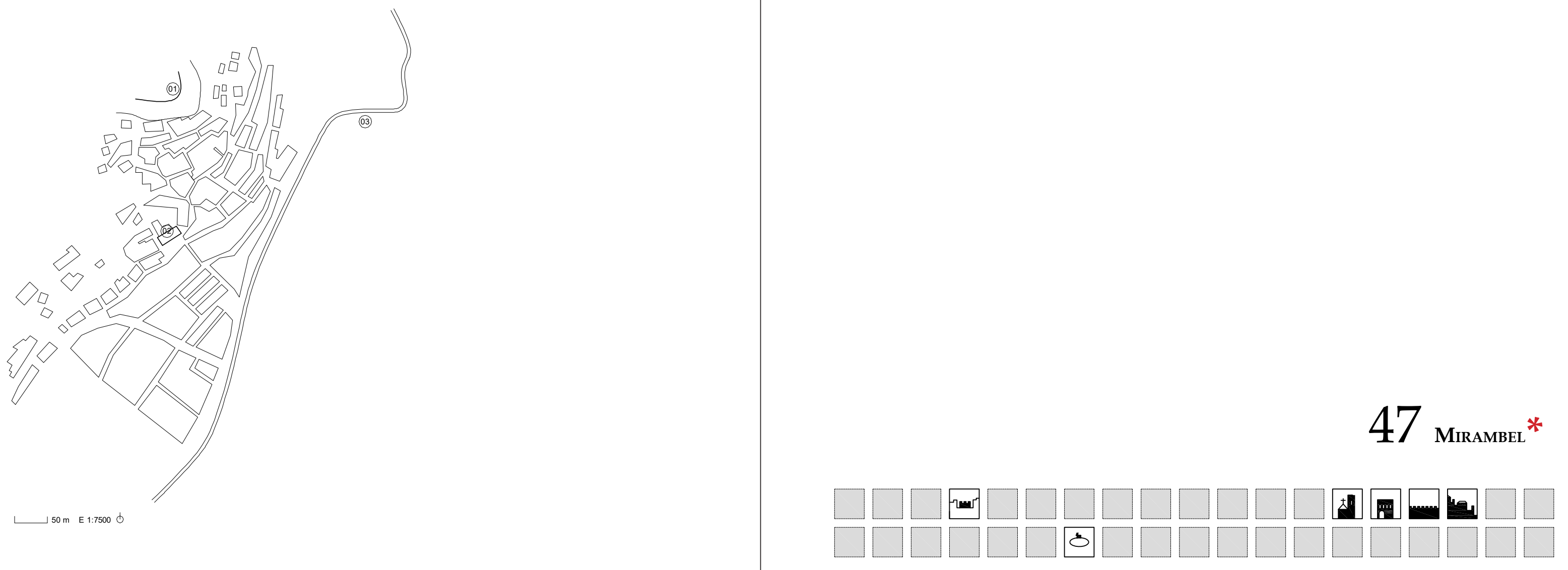


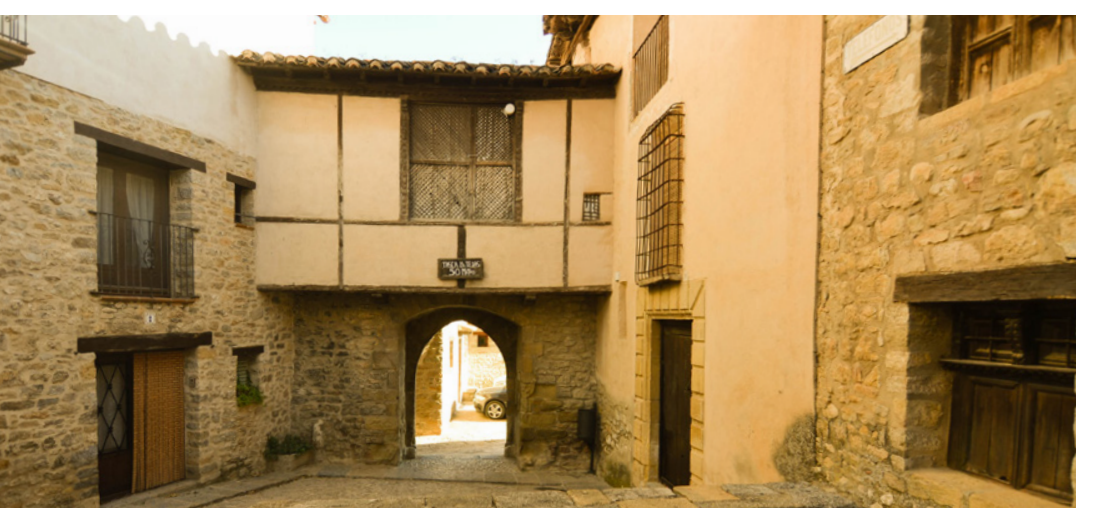

Fig. 534. Portal del Estudio,

orientado a sur, visto desde interior

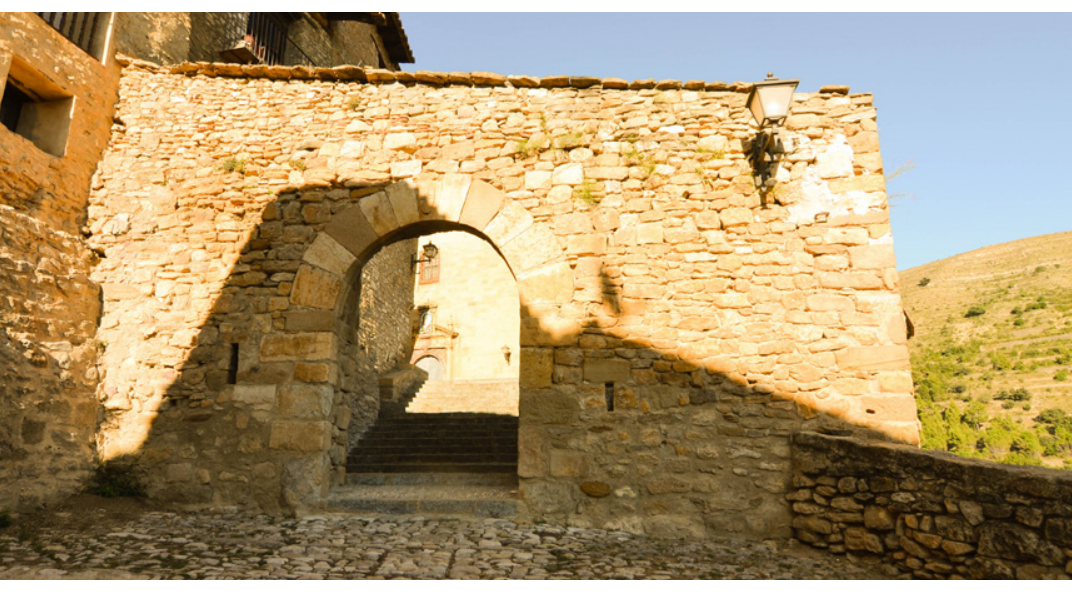

Fig. 535. Portal de la Fuente, orientado a sur. Se observan aspilleras a cada lado del arco de acceso

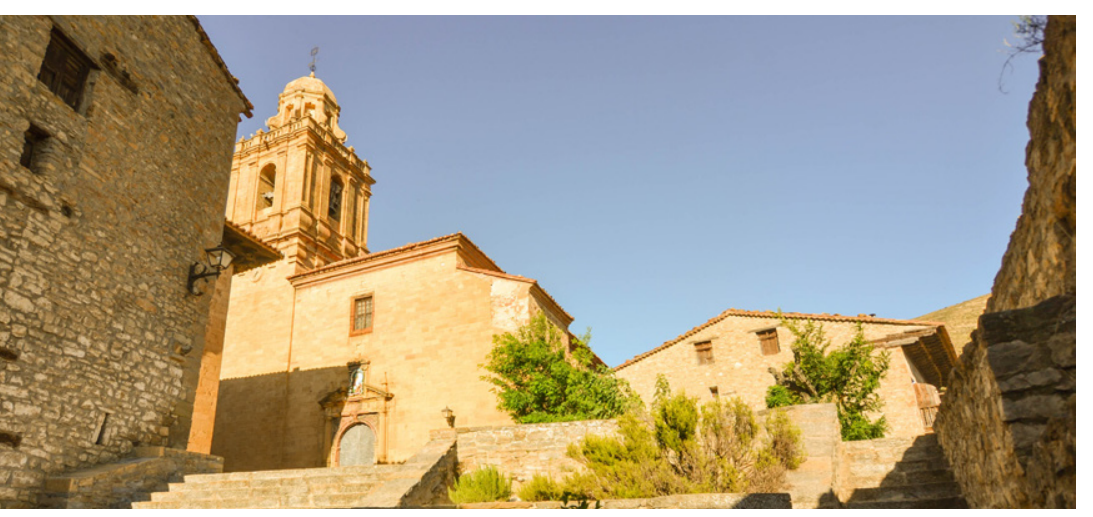

Fig. 536. Iglesia de Santa Margarita, a la izquierda, y casa Pastor a la derecha.

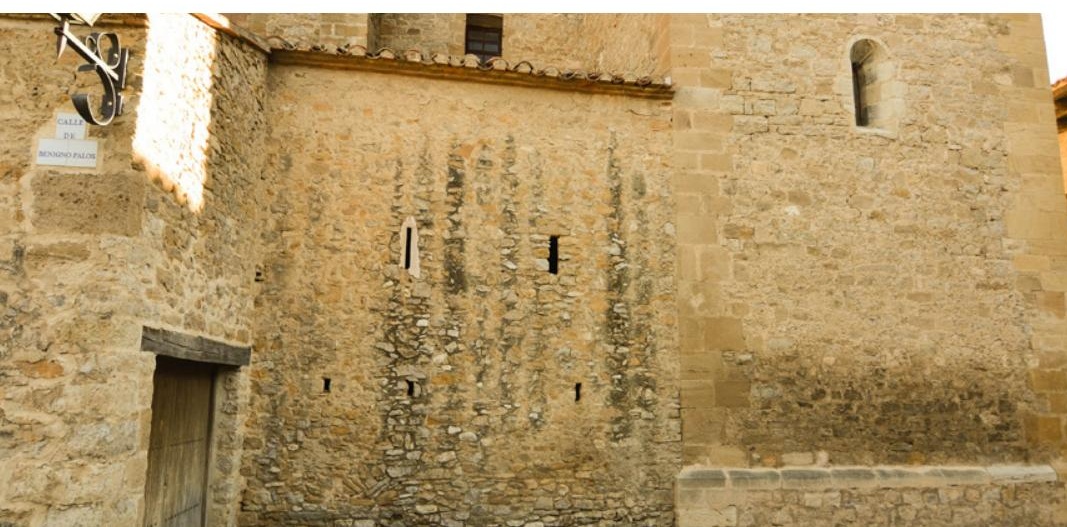

siglo XIII que fue reformado en el siglo XIX y finalmente demolido durante las Guerras Carlistas. Se mantienen muros de mampostería, arcos apuntados y un antiguo horno.

Aparte de los numerosos elementos constructivos propios de la fortificación carlista hallados en la

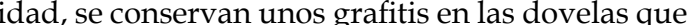
que podrían datar de las guerras carlistas, aunque no se dispone de datos que lo confirmen. Los grafitis hallados hacen referencia con toda probabilidad al grado del habitante del palacio y al número de caballos, suponemos que también de acompañantes, que se alojan en él. Están bien conservados, así como toda la localidad, gracias a la restauración que se llevó a cabo en el conjunto y que recibió el Premio Europa Nostra en 1981

Fig. 538. Esquema en planta de

casco urbano de Mirambel con

los puntos de interés.

01. Portal de las Monjas

02. Bastión

03. Portal de valero

04. Portal de San Roque

05. Portal de la Fuente

06. Portal del Estudio

07. Convento de las Agustinas

08. Casa Aliaga

9. Casa Castellot

10. Casa Barceló

11. Castillo

12. Iglesia de Santa Margarita

13. Ayuntamiento

15. Casa de los Julianes

16. Ermita de San Roque

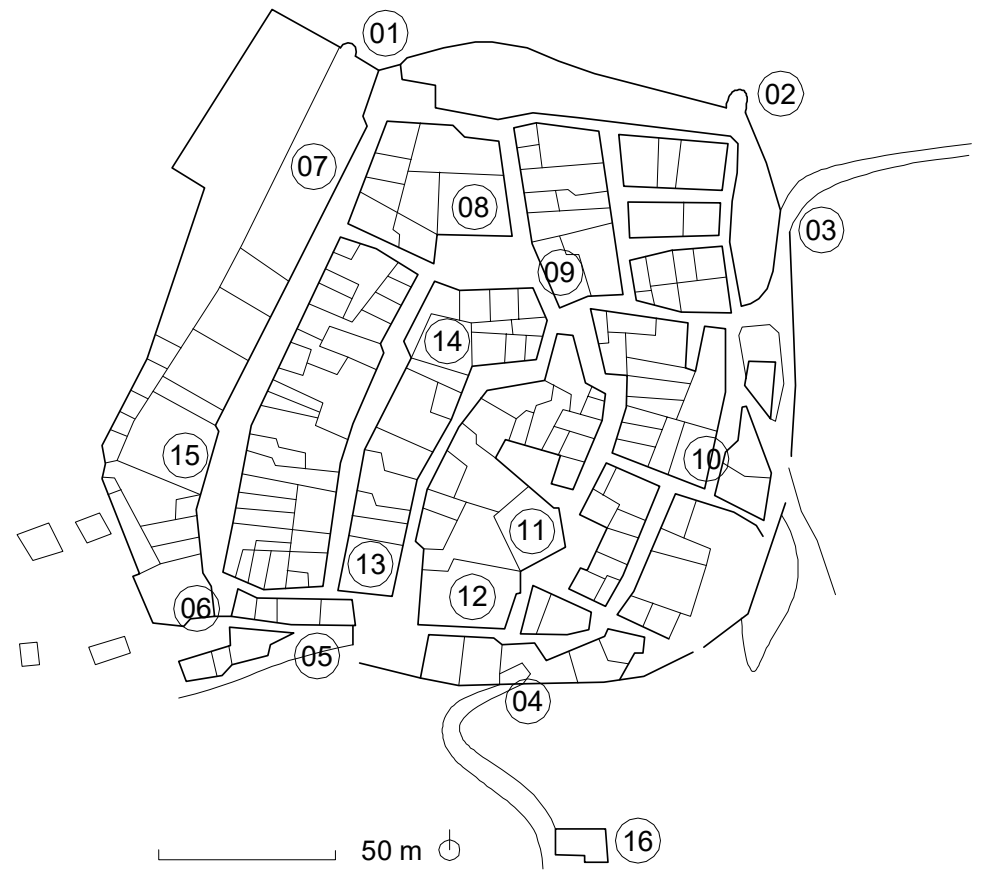




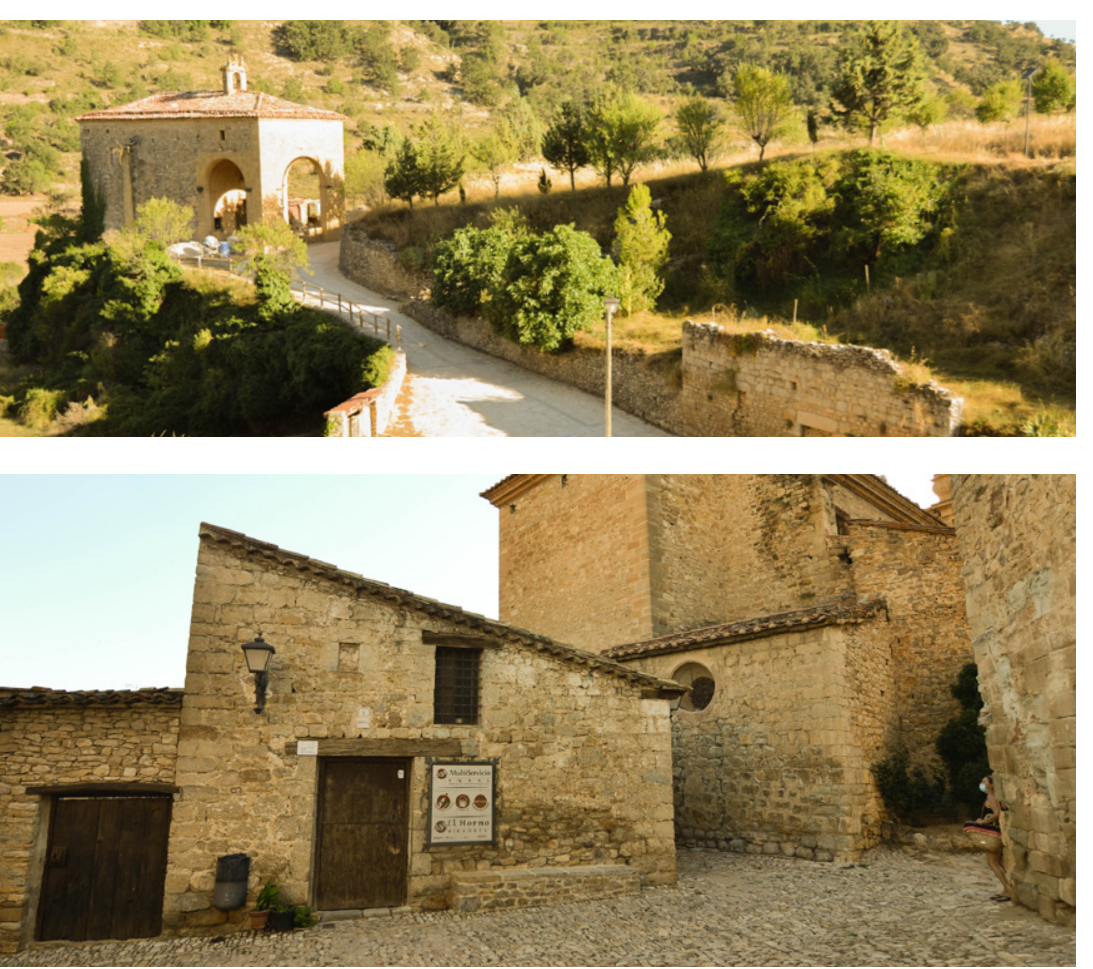

Fig. 539. Ermita de San Roque.

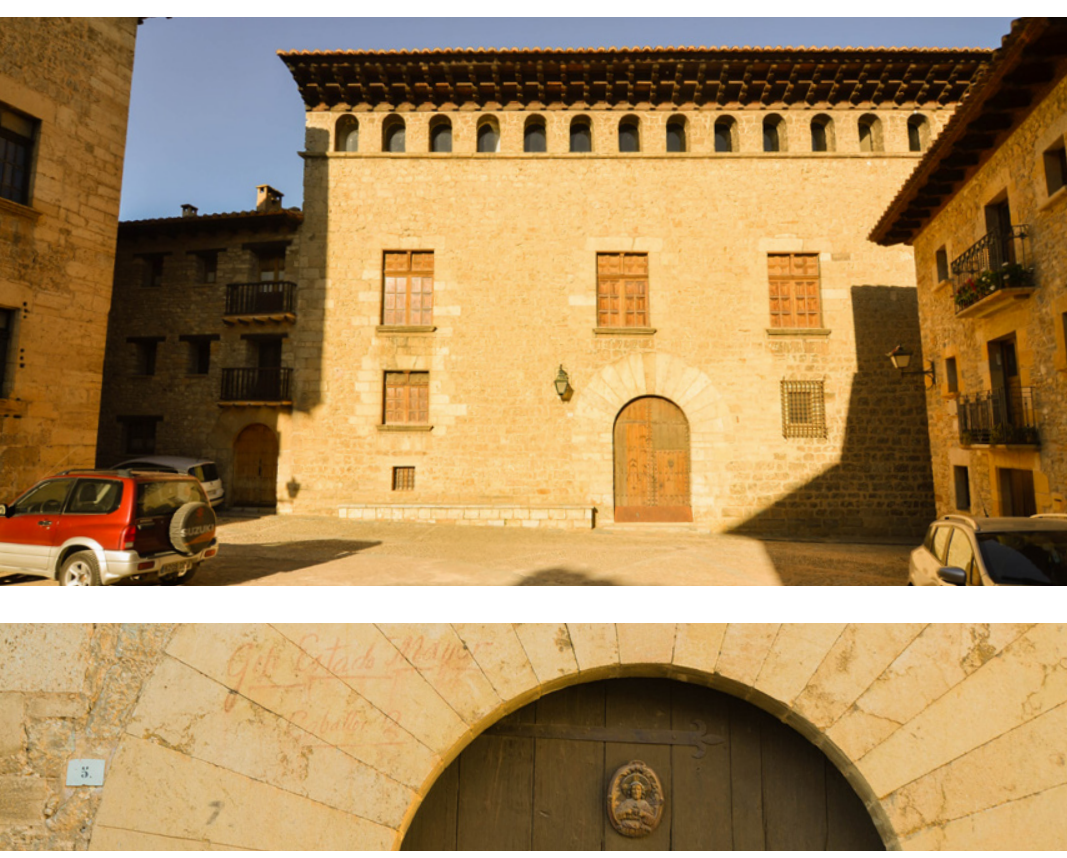

Fig. 541. Ejemplo de casa señorial. En este caso, casa Castellot.

Fig. 542. Grafitos encontrados en el arco de acceso a la cas Aliaga. Se lee "Gefe Estado Mayor Caballos 2".

48 Miravet $^{*}$

Fig. 543. Aspilleras encontradas en una de las casas señoriales de la calle Mayor, intramuros. 
Fig. 554. Plantas del castillo de

Miravet con añadidos carlistas.

01. Recinto inferior

02. Caballeriza

03. Terraza inferior

04. Torre

05. Terraza sur

06. Recinto principal, soberano

07. Cuerpo de guardia

08. Cisterna

09. Patio de armas

10. Cocina

11. Refectorio

12. Granero

13. Almacén

14. Bodega

15. Galería

16. Iglesia

17. Terraza

18. Cisterna

19. Barbacana

20. Muralla

\section{Monasterio de Santa María del Olviar}
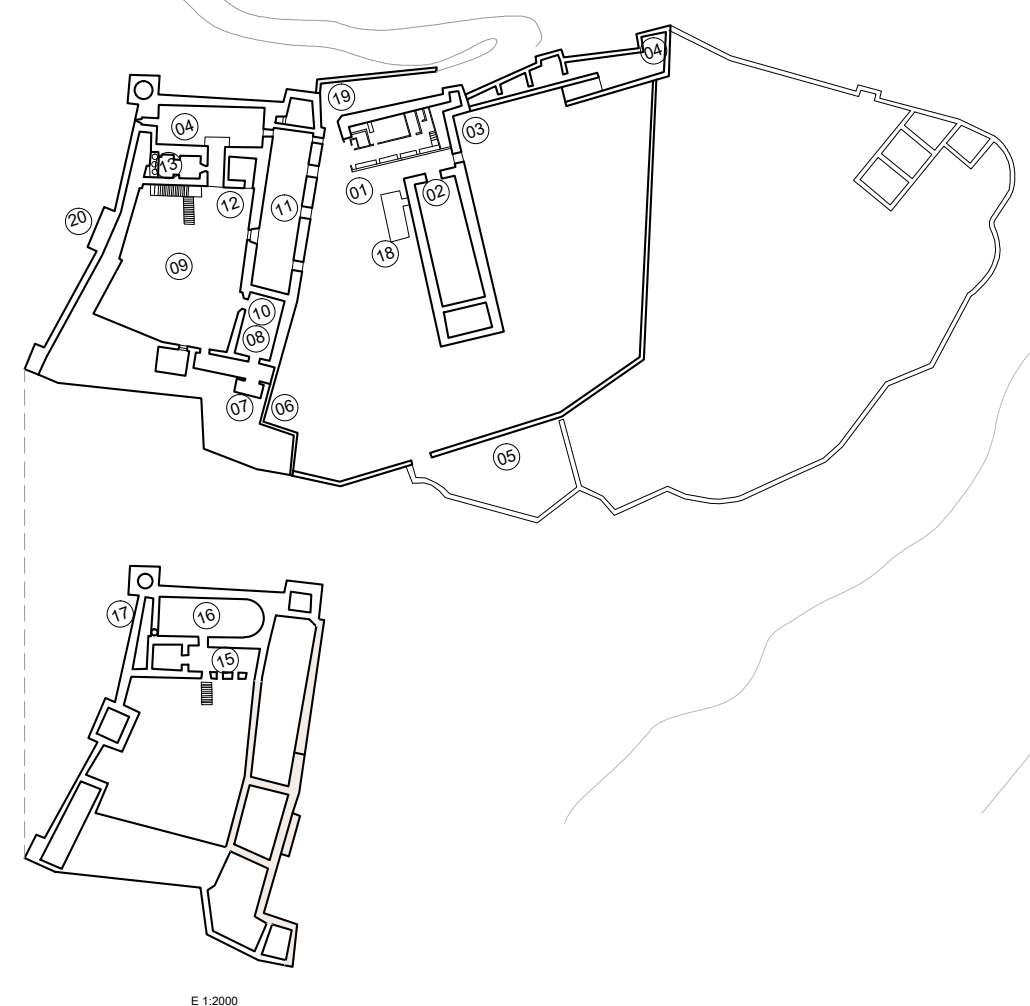

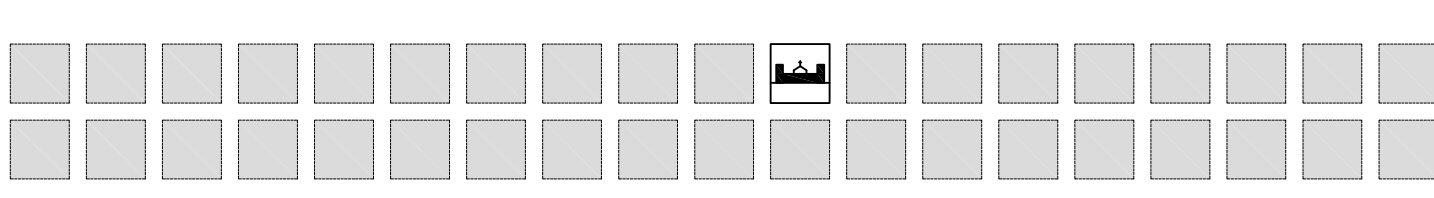


50 моквого 
[...] El enemigo se vio reducido a su posición en la fortaleza. Ya en la tercera noche fueron tomados los últimos edificios, que se hallaban a solo 30 pasos de la iglesia. En la entrada de esta última había construido el enemigo dos grandes tambores cuyo fuego dominaba toda la plaza del mercado. Yo me había hecho acondicionar como puesto de observación una casa en una esquina que permitía observar sin obstáculos toda la plaza y las citadas obras de defensa del enemigo. Las ventanas fueron tabicadas con piedras y ladrillos y solo una pequeña abertura en el piso superior me facilitaba una visión completa. Desde aquí incluso podía oír las conversaciones del tura en el piso superior me facilitaba una vision
enemigo en las obras de defensa adelantadas.

[...] visité un lugar elevado en medio de la población donde según costumbre del país se trillaba el cereal. Las Heras es la denominación que reciben estas plazas, generalmente redondas y pavimentadas con piedras grandes y anchas. Aquí se construyó, según mis indicaciones, la batería de brecha, ya que al atardecer debían llegar

Fig. 569. Ruinas del castillo vistas desde el oeste. Relació con la torre de la iglesia.

Fig. 570. Iglesia de Montalbán, protagonista de la defensa liberal en la primavera de 1839

Fig. 571. Portal de Zaragoza

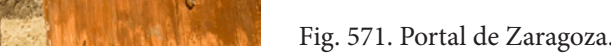

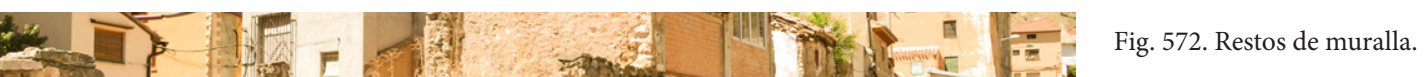

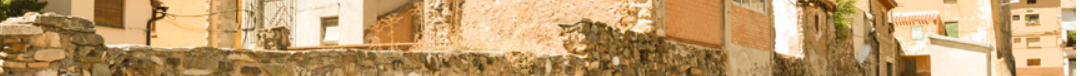

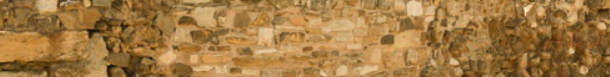
198.
Fig. 573. Esquema en planta de Montalbán con los puntos de interés defensivo.

01. Castillo

02. Iglesia

03. Plaza de la iglesia

04. Arco del Postigo

05. Portal de Daroca

06. Portal de Zaragoza

07. Portal de Santa Engracia

08. Murallas

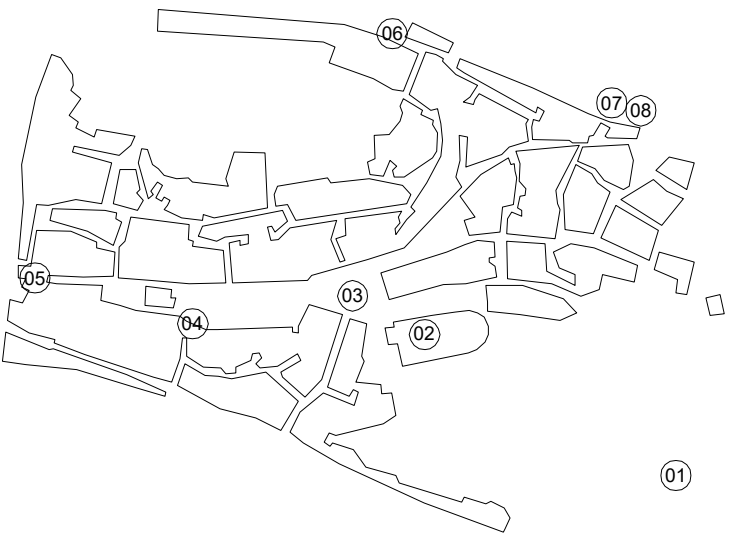

$\longleftarrow 50 \mathrm{~m} \mathrm{E1:5000}$ 
52 Montá* 
según el plano, con un patio central amplio, siendo la iglesia el lado norte del mismo. En el plano aparece denominado como monasterio y en su lado este se identifica un tambor junto a la puerta principal. También aparecen señalados otros puntos, como la plaza, el cementerio, el monte del calvario, el monte de las heras, arroyos, y los caminos de Caudiel, Onda, Montanejos y Villanueva.

\section{Planos históricos:}

Plano 1

Título uniforme: Montán (Castellón). Mapas generales (1810-1840?)

Título: Croquis de la villa de Montan / levantado y dibujado por el Ayudante de la Guardia Real de Infanteria que subcrive Antonio Pelaez

Publicación: 1810-1840?

Descripción física: 1 mapa: ms., montado sobre tela; 17 x $18 \mathrm{~cm}$, en h. de 23,5 × 30,6 cm

Notas: Manuscrito firmado y rubricado por el autor. A plumilla en tinta negra Orientado con flecha. Relieve representado por normales. Indica cultivos. Relación de los principales accidentes geográficos, caminos y edificios indicada por clave numérica.

Ejemplares: Archivo Cartográfico de Estudios Geográficos del Centro Geográfico del Ejército - Colección: SG - Signatura: Ar.G-T.2-C.2-100

Fig. 577. Frente occidental del fuerte y su relación con la colina donde se ubicaba el castillo árabe.

Fig. 578. Restos del castillo árabe.

Fig. 579. (Izquierda) Aspiller en el frente occidental, cubriendo el camino que llega a la población desde el oeste.

Fig. 580. (Derecha) Portada de la iglesia y su torre aspillerada.
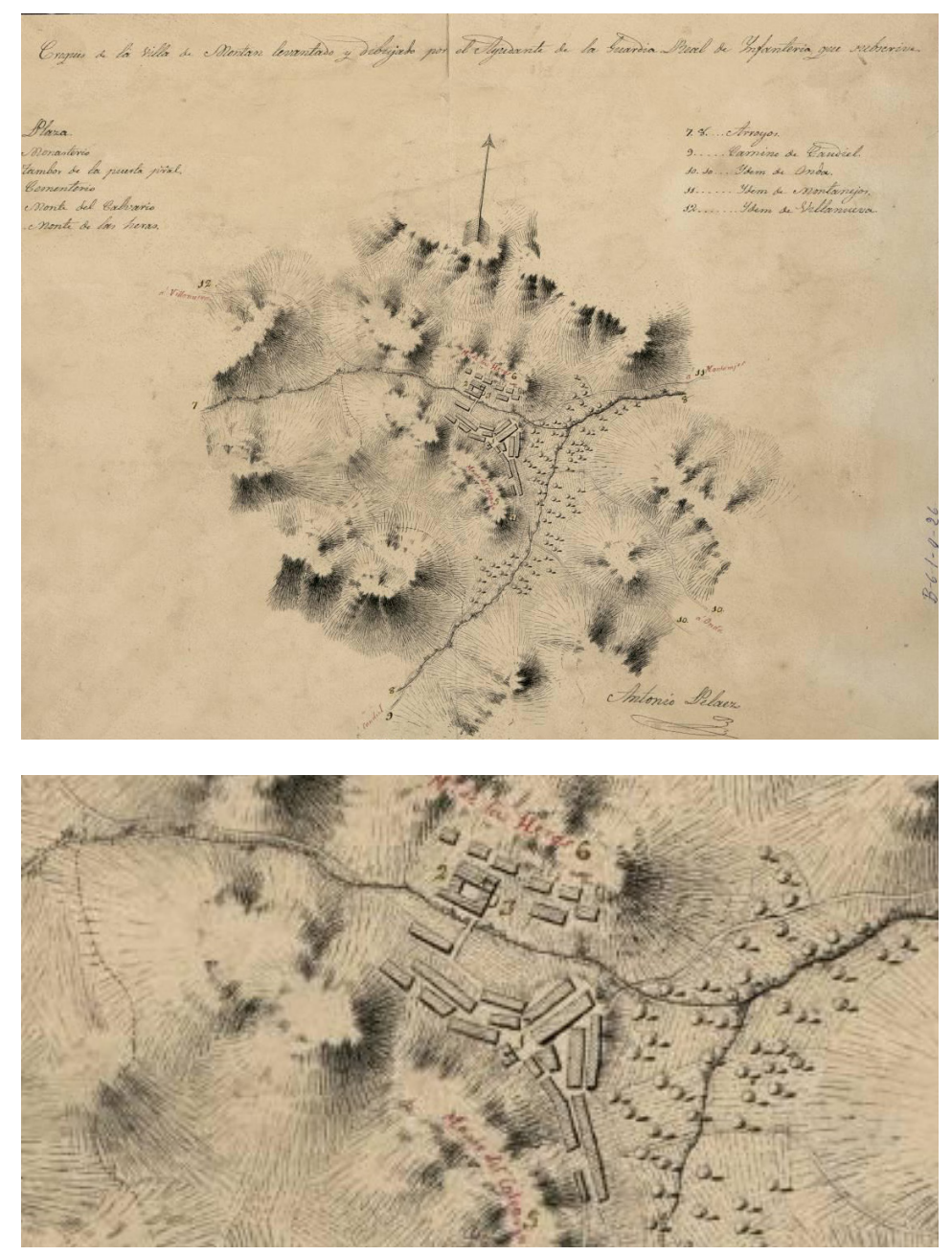

Fig. 582. Detalle del Plano donde se observa la morfologí urbana y la planta y posición del fuerte.

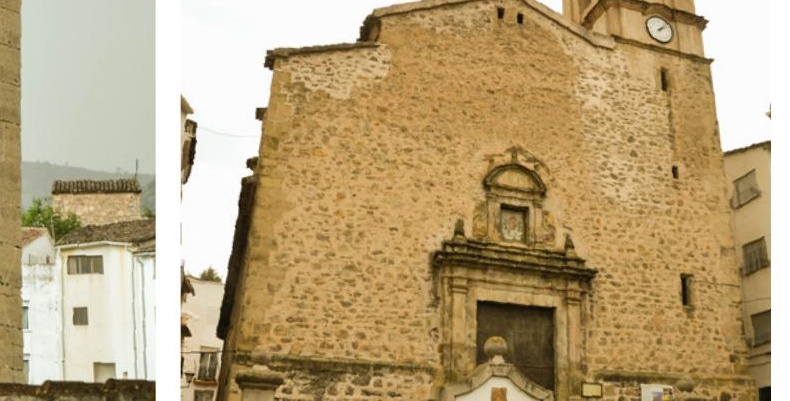




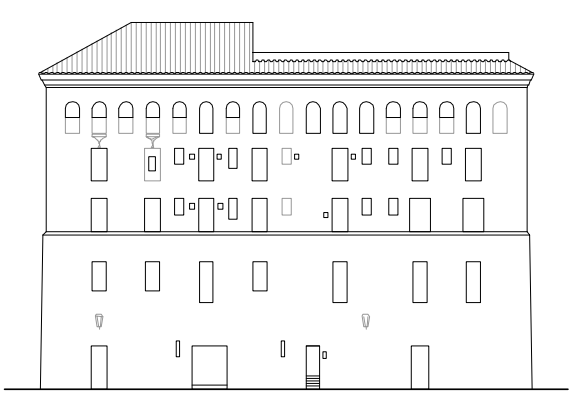

$\sqcup 2 \mathrm{~m}$ E 1:750

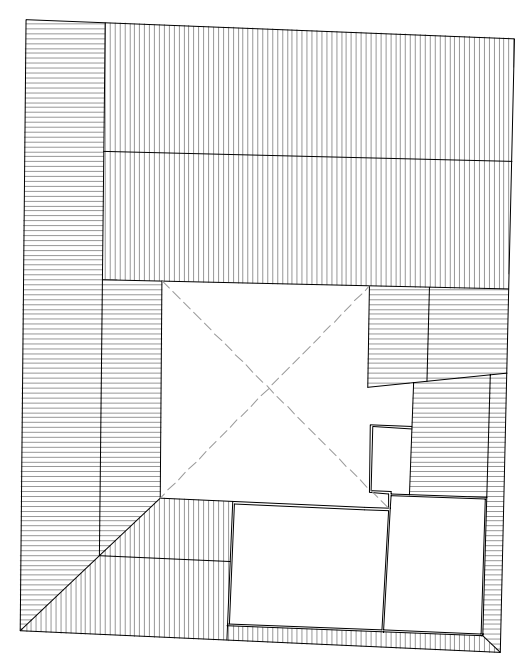

$\sqcup 2 \mathrm{~m} E 1: 750 \quad$ ᄋ
Fig. 583. Alzado sur del fuerte de Montán en la actualidad.

Fig. 584. Planta del fuerte de Montán en la actualidad. $533_{\text {MORA } D^{\prime} \text { EBRE }} *$

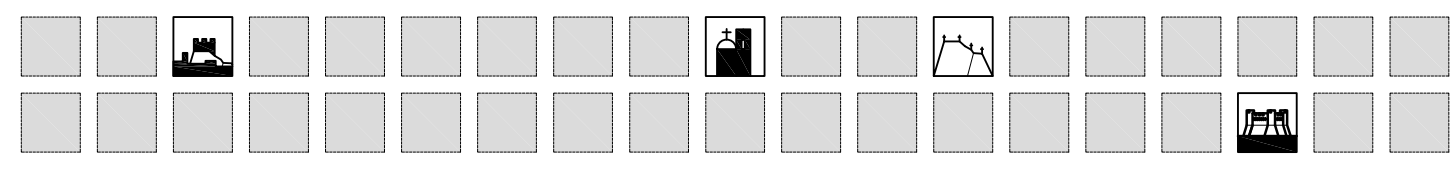


Morella

Localidad en castellano / valenciano: Morella

Provincia actual: Castellón

Comarca: Los Puertos de Morella

Coordenadas geográficas: $40.61998736658498,-0.10208802883241219$

Datos históricos:

Guarnición 1839-1840: 3000. Incluye guarnición del Fuerte de San Pedro Mártir, donde los liberales hicieron 274 prisioneros (Caridad, 2013:263)

Inicio bombardeo liberal: 26-5-1840

Rendición o abandono: 30-5-1840

Días de resistencia: 4

Fuente: Diario Mercantil de Valencia, Boletín Oficial de la Provincia de Castellón de la Plana, Córdoba (1844), Calbo y Rochina (1845), Caridad (2013:297)

Tipos defensivos: castillo reforzado que domina la población, castillo en casco urbano reforzado, muela fortificada, torre, torre artillada adosada a muralla o tambor, torres exentas, fortificación de ermitas, fortificación de conventos, fortificación de monasterios, fortificación de iglesias, muralla urbana, frente escalonado, fortificación de mesones, fortificación de masías, hospitales, cárceles, urbana, frente escalonado, fortificación de mesones, fortific
reducto, línea de reductos, batería o plataforma artillera.

\section{Acciones y fortificación:}

El papel de la plaza fuerte de Morella resulta clave en la guerra del Maestrazgo, fundamental en el estallido de la sublevación, y una pieza codiciada en todo momento por los efectivos carlistas, en especial por Cabrera. Sin embargo, no se convierte en capital del maestrazgo carlista hasta su recuperación gracias a un golpe de fortuna o audacia en 1838. Su conquista catapulta internacionalmente a Cabrera como caudillo y la causa carlista en general. Su sostenimiento es el referente de la resistencia carlista. La heroica resistencia al primer asedio liberal de 1838 engrandece su leyenda y, resistencia carlista. La heroica resistencia al primer asedio liber
con su caída en el asedio de 1840 se asume el fin del conflicto.

con su caída en el asedio de 1840 se asume el fin del conflicto.
Von Rahden describe con nitidez su emplazamiento estratégico, en "una sierra que se extiende desde Von Rahden describe con nitidez su emplazamiento estratégico, en "una sierra que se extiende desde
la divisoria del Ebro con el río Bergantes en dirección sudoeste, hasta las proximidades de dicho río (uno de los afluentes de la margen derecha del Ebro y que confluye a una hora al norte de Calanda con el Guadalope), concluye en una elevación cuya base tiene una dimensión de alrededor de una hora. En el cerro superior y en la ladera sur de este monte rocoso, muy escarpado y de al menos 200 pies de altura, se halla situada Morella, rodeada al modo morisco por murallas y torreones, casi inexpugnable ya que solo on el lado norte, donde este para abrir una brecha en la muralla. En la cima más alta del cerro de Morella, situada en el oeste, en la proximidad de las murallas que circundan la ciudad, ha sido capricho de la naturaleza emplazar un cono de granito que, con una altura vertical de 150 pies, tiene una base de unos 200 a 300 pies de diámetro. Este cono rocoso lo ha transformado el arte en ciudadela, la cual, bien aprovisionada, con una guarnición de 300 hombres y bien dotada de artillería como ahora, era completamente imposible de tomar por la fuerza de las armas" (Von Rahden, 2013: 63-64).

En realidad, Morella constituye la primera fortificación carlista del territorio, aunque de ocupación inicialmente efímera. Sublevada como tal el 13 de noviembre de 1833, es ocupada en diciembre del mismo año. Ante el inminente ataque liberal y la desorganización interna en relación con el mando de la plaza, el ejército carlista la abandona más adelante sin resistencia (El Turia, 11 de enero de 1834; Anónimo, 1839-1840:111, 129; Córdoba, 1844-1846: 36 en Caridad, 2013:245). 


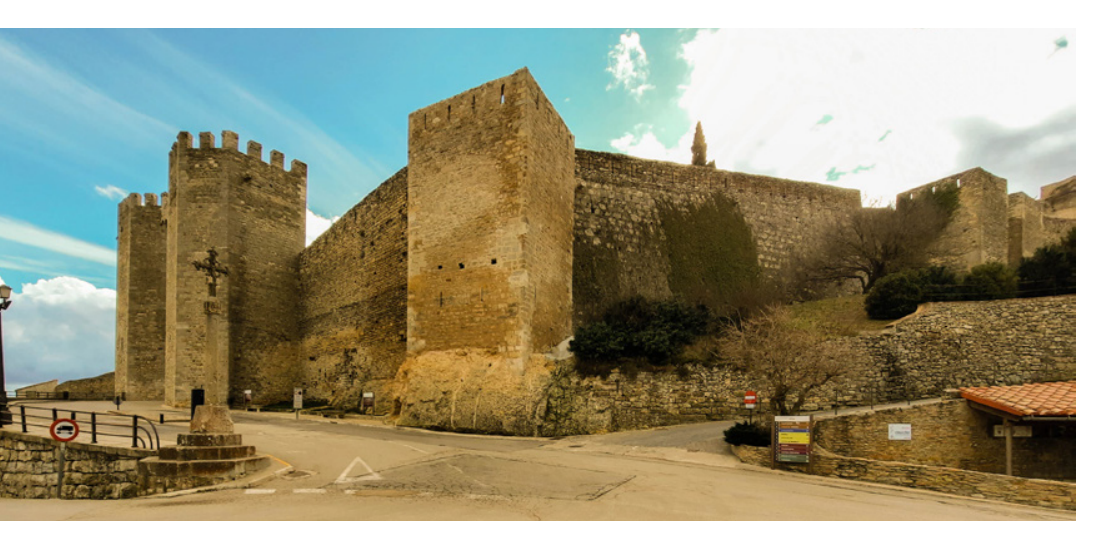

Fig. 606. Primer recinto de Morella visto desde el sur. Portal de San Miguel (izq.), Torre del Racó (centro) y Portal de la Nevera.

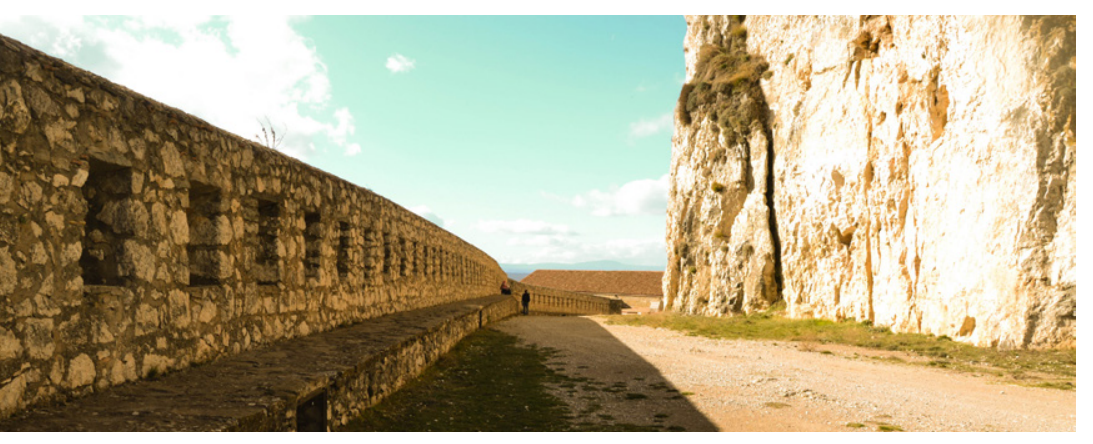

Fig. 607. Camino cubierto aspillerado, comenzado en 1835 y finalizado por Von Rahden en 1840. Protege el camino de acceso al castillo de la artillería.

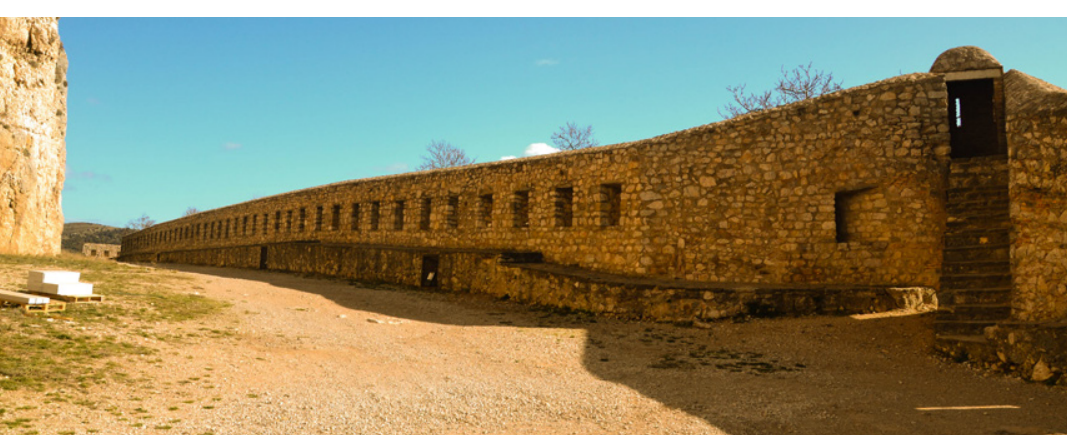

Fig. 608. Camino cubierto aspillerado.

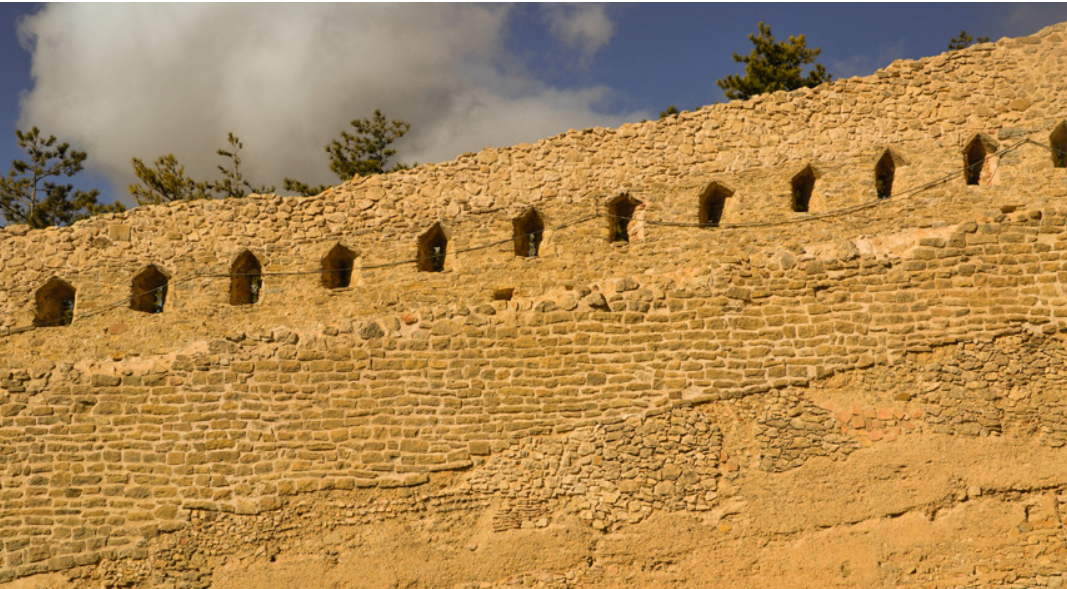

insalvable", pues como insiste Von Rahden, las tropas regulares no estaban preparadas para este tipo de guerra, adiestradas más bien según el "modelo europeo para tácticas de líneas y masas cerradas" (Von Rahden, 2013: 104).

Tras avanzar por un terreno accidentado donde les acechan las escaramuzas, los liberales asientan su posicion en "nudo montañoso al norte de Morella, en cuyo punto más elevado se hallaba la ermita de San Pedro Mártir", donde pueden establecer conexión con Alcañiz, su principal plaza fuerte y base de abastecimiento. Esta ermita, que se ocupa el 2 de agosto de 1838, se convierte en la base de operaciones del asedio de Oraá. Cabrera, consciente de la trascendencia de esta posición, centra sus esfuerzos en desalojar a los liberales de ella sin éxito

Parece que finalizadas las escaramuzas y combates exteriores que pretenden impedir que el enemigo fije el sitio, y una vez asentado este, los esfuerzos se centran en disponer a la ciudad para la defensa. En la actividad frenética que se desata se observa que se centra en la disposición de tropas, en la adaptación de la artillería recurriendo a las fortificaciones existentes. Según Von Rahden "la ras se situaron en los torreones para proteger con fuego de flanco la muralla exterior y los profundos fosos que discurren a los pies de la parte occidental de la fortaleza. Para ello, algunos de los numerosos torreones que, como era habitual antiguamente, se elevaban sobre la muralla fueron rebajados y preparados para la colocación de las baterías, entre las que prestaba un servicio ejemplar en la llamada Torre Redonda un cañón de 12 libras" (Von Rahden, 2013: 108). Esta torre es transformada, rebajándose para adaptar la artillería, como recoge el ingeniero también más adelante (Von Rahden, 2013: 115).

La defensa planteada por Cabrera en Morella ejemplifica la teoría sostenida en esta tesis del característico frente escalonado aspillerado, donde la fortificación en esta guerra de mínimos se basa en una rquitectura preexistente adaptada al armamento propio de la época. Se aprovecha la arquitectura previa, se aprovechan sus escalonamientos debidos a la adaptación topográfica en enclaves topográficos elevados y se adecua al fuego fusilero para concentrar la mayor potencia de disparo en las direcciones convenientes. Las aspilleras o fusileras priorizan la precisión del fusil y en los emplazamientos oportunos se habilitan baterías artilleras. Esta idea la recoge el propio Von Rahden cuando indica que "la ciudad había sido dividida en distritos, cada uno de los cuales, gracias a la posición en forma de anfiteatro de los edificios, construidos de forma escalonada, y a las calles que recorrían la población de este a oeste, estaba cubierto por el fuego de líneas defensivas escalonadas, para lo cual se habían practicado aspilleras en las fachadas posteriores de las casas" (Von Rahden, 2013:109). Cada distrito está al mando de un oficial, cuatro en total, que delimitan el mismo a partir de las estrechas calles transversales que un oficial, cur tro en total, que delimitan (Von Rahen se inicia en lo alto a los pies del castillo y acaba en el encuentro con la muralla de la ciudad. se inicia en lo alto a los pies del castillo y acaba en el encuentro con la muralla de la ciudad.
Parece que en el momento del asedio la plaza está bien abastecida con munición y víveres, entre los Parece que en el momento del asedio la plaza está bien abastecida con munición y viveres, entre los
que destaca el pan, la carne y el vino (ibíd., 110). Pero clave en la resistencia es el mantenimiento de la línea de comunicación con Cantavieja, que le suministra continuamente munición.

Se sabe que varias casas "amplias" son reconvertidas en hospital de campaña, del mismo modo que los liberales hacen de la ermita de San Pedro Mártir un fuerte inexpugnable protegiendo con parapetos las ventanas y accesos (ibíd. 112). Es fundamental destacar las labores previas de obstaculización y destrucción Alcañiz con rocas, encinas taladas o, incluso, socavándola. Sin embargo, los liberales se aprestaron a efectuar las reparaciones oportunas para mantener una comunicación fluida con su base durante el asedio de 1838. Algo parecido sucede con el camino de La Pobleta a Morella, por donde los liberales pretenden aproximar su artillería. Se sabe que los liberales fortifican el día 11 de agosto de 1838 varias masías, que Von Rahden define como "casas de labradores de piedra" en la ladera de la Querola, ladera que se extiende "desde la ermita de San Pedro Mártir hasta las proximidades de la fortaleza" (Von Rahden, 2013: 114).

Es fundamental en esta guerra el papel que juegan en las defensas de Morella el conjunto de edificaciones exteriores que actúan como fuertes avanzados. Von Rahden hace referencia por ejemplo al "Mesón Beltrán, situado a una distancia de apenas unos centenares de pasos del pie de la abrupta ladera al oeste de Morella" al que atribuye un destacado protagonismo en el asedio. Este mesón, hallado en la carretera de Forcall, es tomado por los liberales, "fortificado y provisto de artillería ligera". Bien defendido, se mantiene en poder de los sitiadores durante todo el asedio y dificulta sobremanera la 


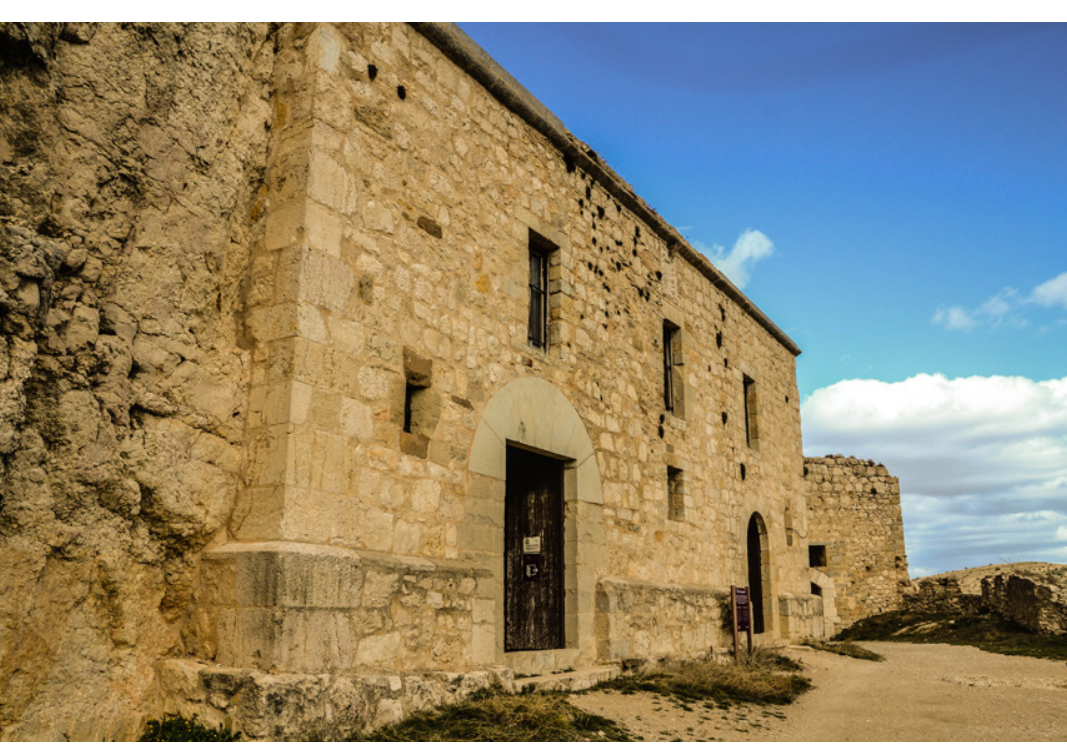

Fig. 623. Palacio del Gobern dor, construido en 1713 por barón de Ytre tras concluir la Guerra de Sucesión.

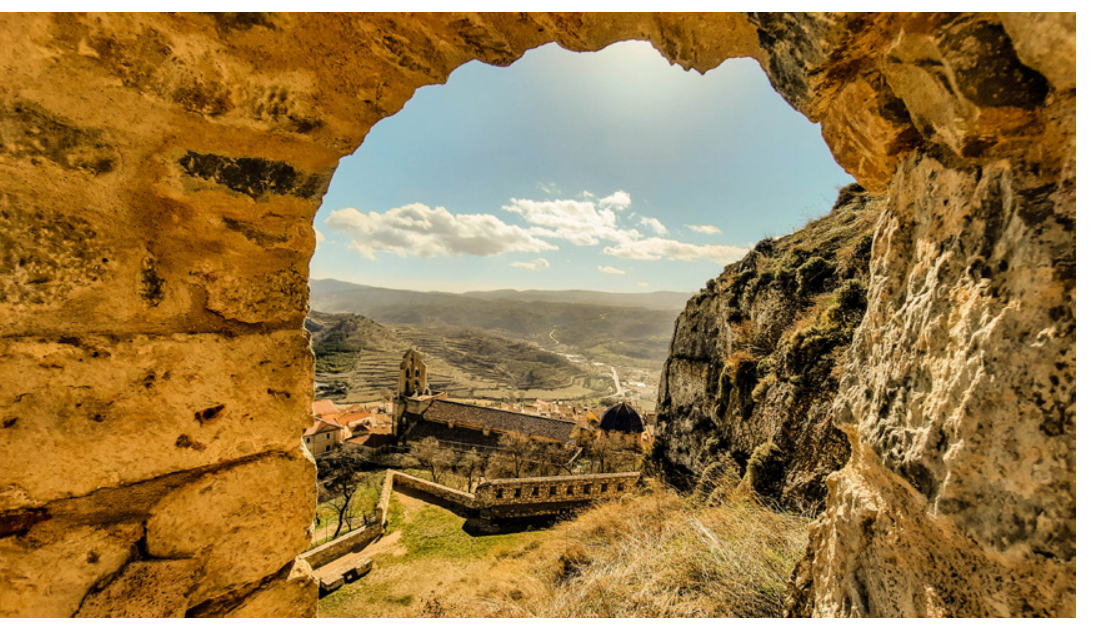

Fig. 624. Vistas hacia el sur desde el Cuerpo de Guardia. Este protege la Puerta Barbacana a la vez que sirve como punto de vide San Francisco y el acceso a Morella desde el sur.

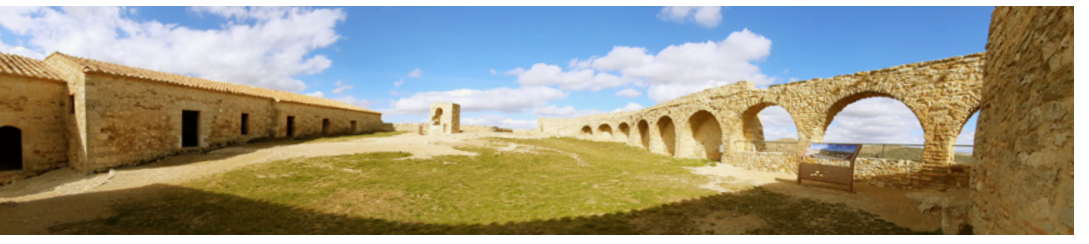

Fig. 625. Plaza de armas, de 60×30m. Es el punto más elevado del castillo hasta 1840 , a 1070 ms.n.m.

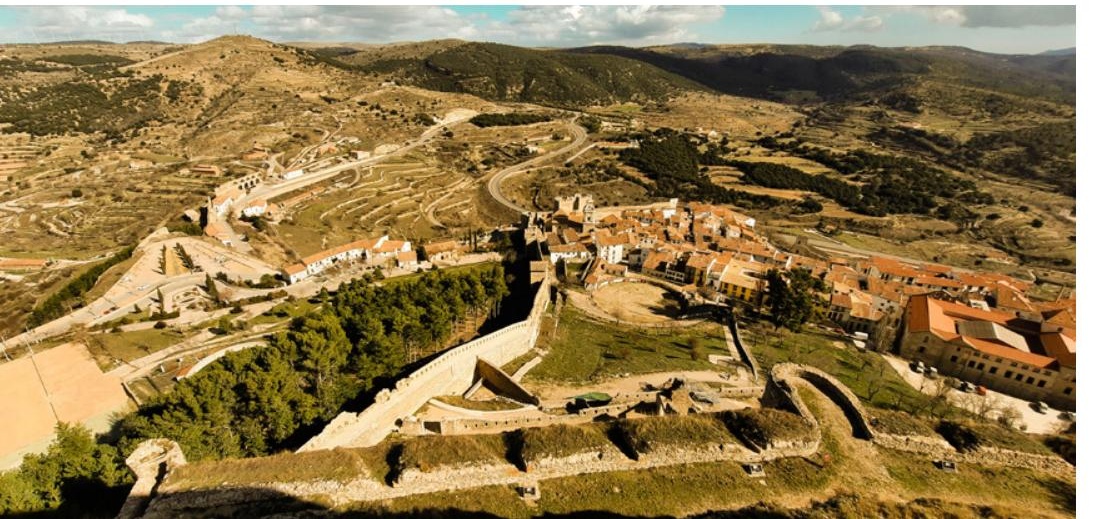

Ye. 626. Vistas de la población armas. de Vent, domina el terreno que se halla detrás de la gran conducción de agua, detrás de la cual el enemigo, protegido por sus elevados y fuertes muros, había establecido sus depósitos en asedios anteriores. El acueducto llevaba agua fresca de manantial desde San Pedro Mártir, en las proximidades de la pedrera (o cantera), a la ciudad con lo que el suministro podía ser interrumpido por el enemigo todas las veces. Dominar a citada elevación lo impedía aunque ciudad y castillo se hallaban totalmente abastecidos mediante dos cisternas y un pozo respectivamente" (Von Rahden 2013:329).

Las alturas del Collet del Vent y Carraixet [Caraiset] se incorporan a la defensa construyendo en ambas reductos de tierra, que se minan para el caso de que sean ocupados. A pesar de que se encuentran bajo el dominio del castillo, Von Rahden considera ambas posiciones susceptibles de ser ocupadas por el enemigo, donde puede emplazar morteros y obuses para destruir la ciudad (ibíd. 329).

En el sector oeste, se construyen "torres amuralladas redondas con dos a tres niveles de fuego de fusilería" en las alturas de Cruz de Beneito y de Morella la Vieja. El objetivo es poder desplegar allí tropas defensivas, pero, una vez producido el asedio, dado que no se despliega ninguna tropa defensiva, las torres no acaban cumpliendo ninguna misión.

Llama la atención la justificación que da Von Rahden a este tipo de construcción permanente, como una especie de preferencia en el contexto bélico español. Así indica que "el soldado español prefiere estos reductos elevados y cerrados a los construidos con tierra, que solo proporcionan una protección parcial del cuerpo. Su utilización en esta guerra montañosa ha alcanzado tal predicamento que con frecuencia han tenido que sustituir a las trincheras de campaña más sencillas. Esto se explica por el carácter de la dirección de la guerra y por el terreno, donde el resultado de los combates depende a menudo del dominio de un punto totalmente aislado. Estas torres de unos 12 a 15 pies de altura y grosor reducido - ya que habitualmente se hallan tan elevadas que la artillería no puede dañarlas - se construyen también con escaso coste y en poco tiempo, ya que casi siempre están disponibles piedras pizarrosas ya partidas, que simplemente se superponen en seco para cumplir su función" (Von Rahden, 2013:330)

Estas dos posiciones, Cruz de Beneito y Morella la Vieja, por su ubicación, protegen la conexión de Estas dos posiciones, Cruz de Beneito y Morella la Vieja, por su ubicación, protegen la conexión de la ciudad con la Muela de la Garumba, desde cuyas crestas montañosas se puede acceder a Cantavieja, aunque, como sucede en el asedio de 1838, la conexión directa entre la Muela y Morella se que hizo que los liberales se posicionaran en el mesón y controlasen ese punto induce la fortificación del mismo.

Al noroeste de Morella se emplaza un torreón redondo que debe defender el camino de Vallivana y hace frente a la sierra de Beltrol.

En relación con las mejoras en las fortificaciones de la ciudad el ingeniero indica que "en las murallas de la ciudad y en el castillo se han blindado los edificios más importantes, dotándolos de aspilleras, y se han construido dos trincheras de tierra y piedras en la punta oriental y entre el castillo y la zona de casas de la población, que permiten un fuego escalonado múltiple en toda la fortaleza" (Von Rahden, 2013: 330).

Cuando Von Rahden abandona Morella a finales de 1839, en su testimonio confirma el estado de las fortificaciones tal y como se han descrito. Es muy ilustrativo el "plano de morella, incluidos los alrededores del dominio de la fortaleza", elaborado por el mismo Von Rahden a partir de bocetos originales en 1840, donde se pueden identificar los elementos descritos. Atendiendo a la boyenda del inales de 1839:

Obras preexistentes: muralla circular con sus 16 torres y la ciudadela.

Nuevas construcciones en la ciudad:

-Dos grandes parapetos de tierra (A y B) como protección hacia el este.

espaldón ejecutado a raíz del asedio de 1838

-Basílica arciprestal (a), que se trata como una posición más.

-Puerta y plaza del Estudio (b).

-Hospital (c).

-Viviendas de Cabrera (d, e)

-Parque y Academia de ingeniería (f). 


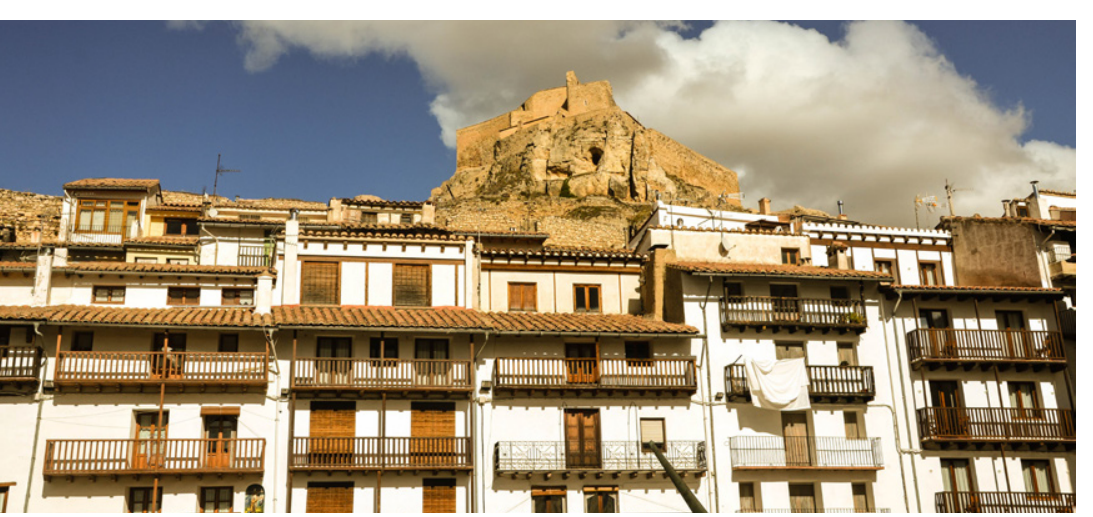

Fig. 627. Castillo de Morella visto desde la plaza del Estudio.

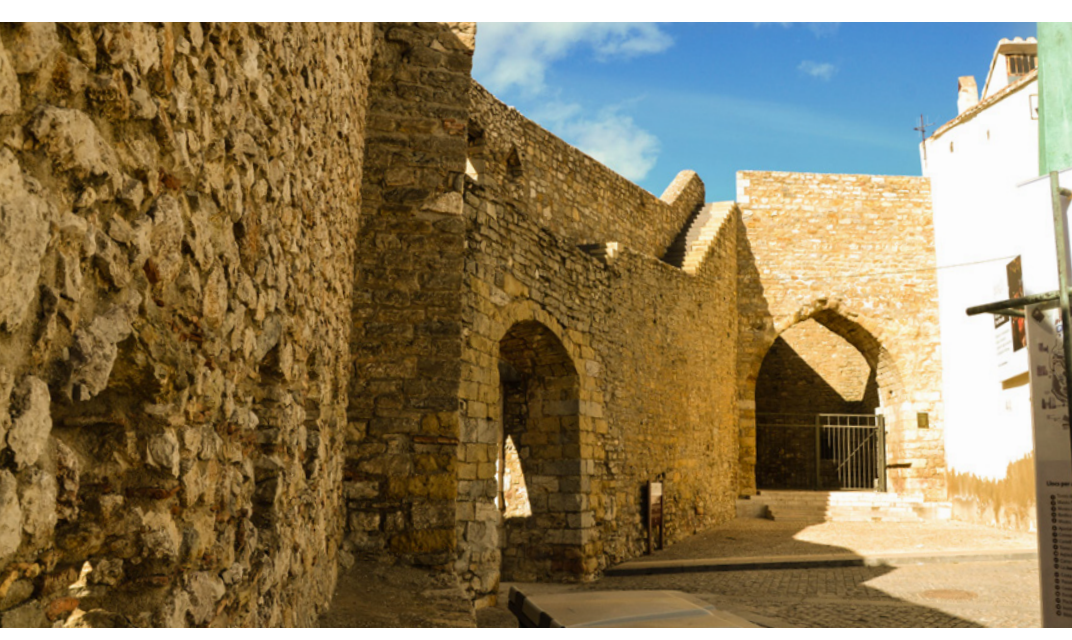

Fig. 628. Portal del Estudio, intervenido por Von Rahden, y único acceso a la población en 1838.

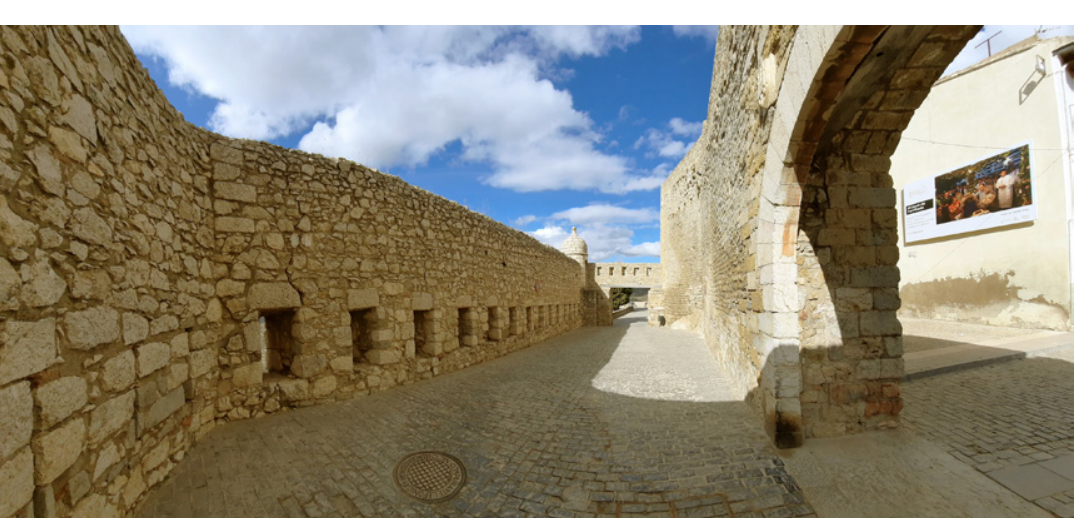

Fig. 629. Acceso en recodo al recinto de Morella a través de Portal del Estudio.

Fig. 630. Acceso exterior del Portal del Estudio.
-Iglesia de San Juan (g)

-Iglesia de San Miguel (h).

-Brecha de agosto de 1838 (i).

-Convento fortificado con la entrada subterránea a la ciudadela (k).

-Escuela de artillería (1).

Obras de fortificación exteriores:

Al norte de la fortaleza:

-El fuerte de San Pedro Mártir (1)

-El parapeto de tierra de la Querola (2)

-Trinchera para flanquear el acueducto (3).

Al oeste de la fortaleza:

-Dos torreones redondos de piedra en la elevación de la Cruz de Beneito y el Moral.

- Al sur de la fortaleza:

-Reducto del Collet del Vent (1).

-Gran trinchera de Carraixet (2).

-Pequeñas marcas y parapetos de tierra $(\mathrm{E})$

No se sabe con exactitud el desarrollo de las obras a partir del testimonio de Von Rahden. Según Calbo y Rochina, Von Rahden recibe una herida en el sitio de Montalbán. Bien por ello o porque intuye el desenlace de la contienda, solicita a Cabrera permiso para marchar al extranjero a reponerse de sus heridas justo después de la muerte del Conde de España y ya no regresa. Por ello las obras son continuadas por el teniente coronel comandante de zapadores carlistas D. Juan José Alzaga (a) "spartero, la ermita de San Pedro Mártir es destruida, trasladando altares e imágenes a la ciudad, "sin dejar más en pie del edificio que el recinto que ocupaba el presbiterio y retablo principal del Santo, pues dicho sitio era en el que se guarecian la tropa y trabajadores". Sostiene Calbo y Rochina que los trabajos avanzaban y aquella posición hubiese sido eficaz si "hubiera estado bien guarnecida y artillerada" (ibíd. 524). Parece que a primeros de mayo Cabrera visita esas obras y en el glacis del fuerte de San Pedro indica a Alzaga que en aquella misma posición se emplazaría Espartero. Pero finalmente el fuerte queda artillado únicamente con un cañón de a 6 de hierro y un obús de "á lomo", además de que no puede ser concluida la fortificación como se esperaba, "arreglando precipitadamente la defensa". El 19 inician los liberales su avance sobre Morella posicionándose en la masada de las Matas, la Ermita de San Marcos, Chiva y Forcall. Una nevada el día 20 lleva a alojar las caballerías de los sitiadores en Peñarroya y la Pobleta. El enemigo avanza desde esas posiciones el día 23, con la mejoría del clima, y ocupa los cerros del Mas del Pou y la Pedrera, y los ingenieros liberales verifican el reducto avanzado de San Pedro Mártir y el de la Querola, el cual se eleva en un punto intermedio entre el anterior y la plaza, en una loma que controla el camino a Aragón. Según se indica, ambas posiciones están sin concluir y los liberales se aprestan a impedir las obras para su conclusión cañoneándolas desde el cerro de la Pedrera. El bombardeo se efectúa con granadas y proyectiles de 12 y 16. Como ya predice Von Rahden, la clave del asedio se centra en esta posición avanzada. Los sitiados efectúan salidas desde el reducto para repeler el avance fusilero liberal, recuperan la comunicación con la plaza y la Querola. Inicialmente parece que los defensores del reducto se sienten especialmente amenazados por los "fuegos curvos" (Calbo y Rochina, 1845:527). Parece que el fuerte cumple su misión y resiste al acoso "fuegos curvos" (Calbo y Rochina, 1845:527). Parece que el fuerte cumple su misión y resiste al acoso de dos piezas al oeste del Mas de la Pedrera, a distancia de "medio tiro de fusil del fuerte". Cuando los liberales alcanzan una posición del foso que permite un posible asalto en la madrugada del día 25 , instan a la rendición. Los carlistas carecen de bombas de mano para repeler el asalto, con las fuerzas fatigadas y pocas esperanzas de socorro desde la plaza, por lo que, tras varias negociaciones, acaban rindiendo la posición, ocupada en ese momento por el gobernador, 264 soldados, 13 oficiales y un capellán (Calbo y Rochina, 1845: 528).

La toma de San Pedro facilita la conquista de la Querola, cuya guarnición se retira a la plaza incendiando la obra y los repuestos. A partir de este momento se producen deserciones que desestabilizan la defensa, pues facilitan datos de la misma a Espartero, especialmente de los puntos más de- 
ante las cargas liberales, son confundidos por las tropas carlistas que permanecen en Morella y se enfrentan a un fuego cruzado mientras se dirigen unos hacia la Puerta del Rey y otros a la de los Estudios. Muchos quedan aprisionados en la oscuridad sobre el puente levadizo de la puerta de (a) que la luz de una fogata permite a los defensores darse cuenta de su error. Al amanecer del día siguiente, los sitiados solicitan la capitulación. Se hacen 2731 prisioneros y en el foso se hallan 141 cadáveres en la puerta de los Estudios. Del bombardeo quedan numerosas casas destruidas. Ortí Miralles registra que la Casa Capitular "fue alcanzada diferentes veces por las bombas y la llamada Casa del Pósito, sita al lado de la Casa Capitular - dice el acuerdo de $1^{\circ}$ de marzo de 1845 - fue destruida [...]". De entonces data el salón de sesiones y su artesonado, como el que sería el teatro convertido más adelante en cine de la casa del Pósito (Ortí, 1979:145)

Cabo y Rochina es explícito ante el panorama desolador en que queda la ciudad tras el asedio de Espartero, "lúgubre y espantoso [..] unn ciudad desierta, llena de escombros é inmundicins y en la cual apenas habia una casa donde albergarse sin temor de que se desplomase el taladrado y mal seguro techo. El castillo no era otra cosa sino un montón de ruinas sobre una elevada roca: apenas habia quedado en pie un solo reparo ó murallon. La batería real (sitio de que tantas muertes habian salido) yacia á su vez por tierra, y en vez de hacer alarde de su poderío, cubrian sus escombros mil desmembrados esqueletos. Toda la parte de muralla que serpenteando por la roca concluye en el elevado pico del principal baluarte (donde tanto los carlistas como los de la Reina tenian colocada el asta de bandera) estaba taladrada de la artilleria que habia abierto muchos y grandes boquetes como tambien desmoronado completamente toda la parte superior ó coronamiento de dicho reparo, cortado ademas en muchos puntos hasta el caso de tener varias brechas casi practicables respecto á la muralla aunque no, atediendo al cimiento de ella en peñascos inaccesibles" (Calbo y Rochina, 1845: 544).

Fig. 635. Acceso al convento de San Francisco.

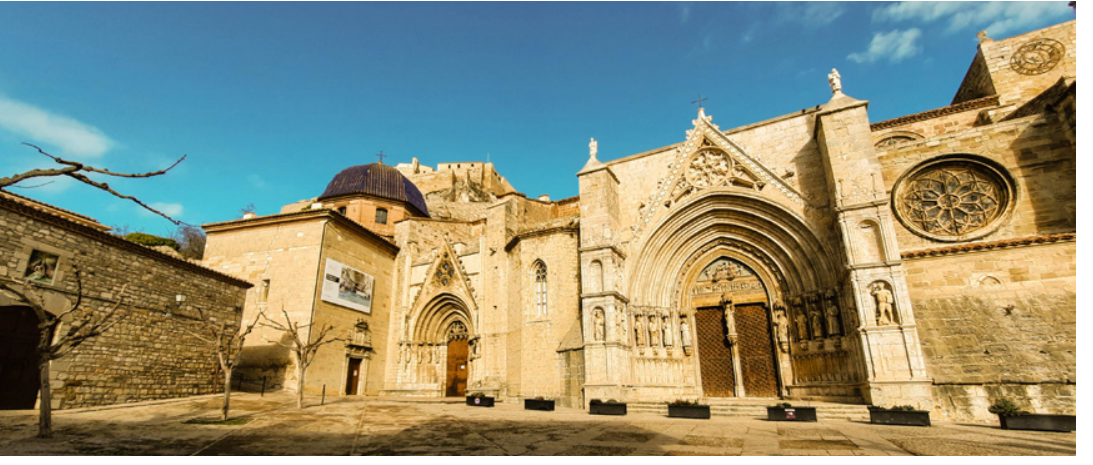

Fig. 636. Iglesia de Santa María.

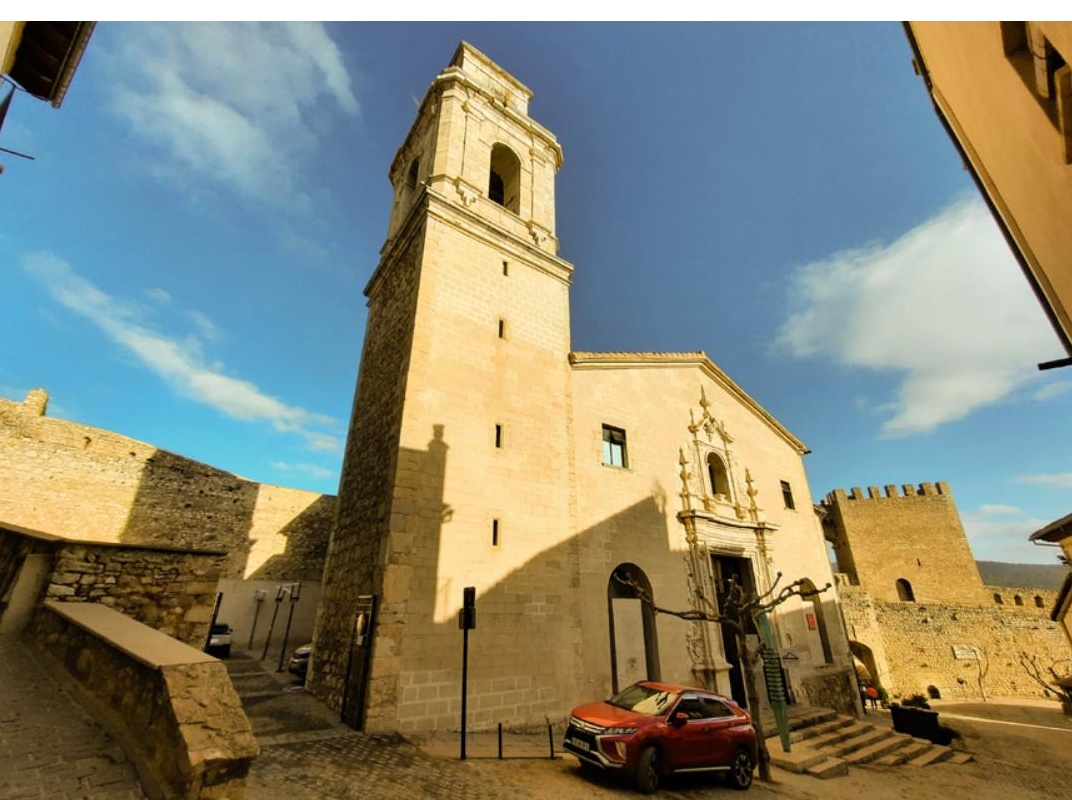

Fig. 637. Antigua Iglesia de San Miguel, contigua al Portal de San Miguel.
Además de estas informaciones extraídas de las fuentes de la época, los diferentes hallazgos arqueológicos desvelan información complementaria, como que, hacia 1834, el ejército isabelino, desconfiado de las inclinaciones políticas de la población, podría haber construido el muro con troneras de sardinel que se extendería desde la muralla (muy próximo a la denominada puerta Ferrisa) hasta el límite existente entre el convento de San Francisco y el de las Agustinas. En este límite se emplaza el acceso a la estructura avanzada del castillo mediante una rampa empedrada que es descubierta en las excavaciones arqueológicas realizadas en la zona (Medina, 2005: 45) Hisun, revista del castillo de Morella, $\mathrm{n}^{0}$. 1, 2005, p. 45). El acceso al castillo se efectuaría por la placita de San Francesc. Es preciso recordar de la Comandancia General del Maestrazgo, construida en 1869, y cuya demolición da una idea de la perspectiva de este acceso. La ocupación carlista a partir de 1838 es la que va a conducir a una mayor metamorfosis de estos espacios. Las estructuras no destruidas acaban siendo ocupadas por la tropa. Existen en estudios contemporáneos contradicciones acerca del uso del Convento de San Francisco. Algunos sostienen que mantiene su comunidad hasta 1840, otros que precisamente en 1838 es cuando los franciscanos abandonan el convento para establecerse en Castellón. Existen datos acerca del refuerzo efectuado en la fachada del convento en 1839. El plano del sitio de Espartero de 1840 nos muestra el estado de la plaza tras el bombardeo liberal, y en él se observa un muro que se extiende desde el atrio de la iglesia a lo largo de toda la calle del Hospital hasta alcanzar la muralla oeste, que se conserva en la actualidad y que traza un espacio cerrado al norte por el refectorio y cocinas del convento, y al oeste con un tramo de muro que se une al anterior que sigue la calle del Hospital. La reforma se efectúa en el convento a partir de los restos de los edificios derruidos, que se utilizan como cimentación de los muros que constituyen el gran patio sin pavimentar, con suelo de tierra, destinado al uso militar de las tropas. Segura y Barreda, que confirma la ocupación del convento por parte de los carlistas, indica que "aprovecharon una tercera parte para la maestranza, talleres y hornos de fundición" (Medina, 2005: 46). La ocupación como cuartel de tropa del convento se confirma en 1843, al considerar las autoridades militares que el alojamiento de la tropa en casas de vecinos puede conducir a equívocos. Las excavaciones arqueológicas parecen haber probado la ocupación de los conventos de Morella por contingentes militares desde 1840 hasta inicios del la ocupación de los conventos de Morella por contingentes militares desde 1840 hasta inicios del
siglo XX, cuando éstos abandonan las instalaciones. En la consolidación de este uso resulta clave la creación en Morella en 1850 de la "Comandancia General del Maestrazgo" (ibíd.). 


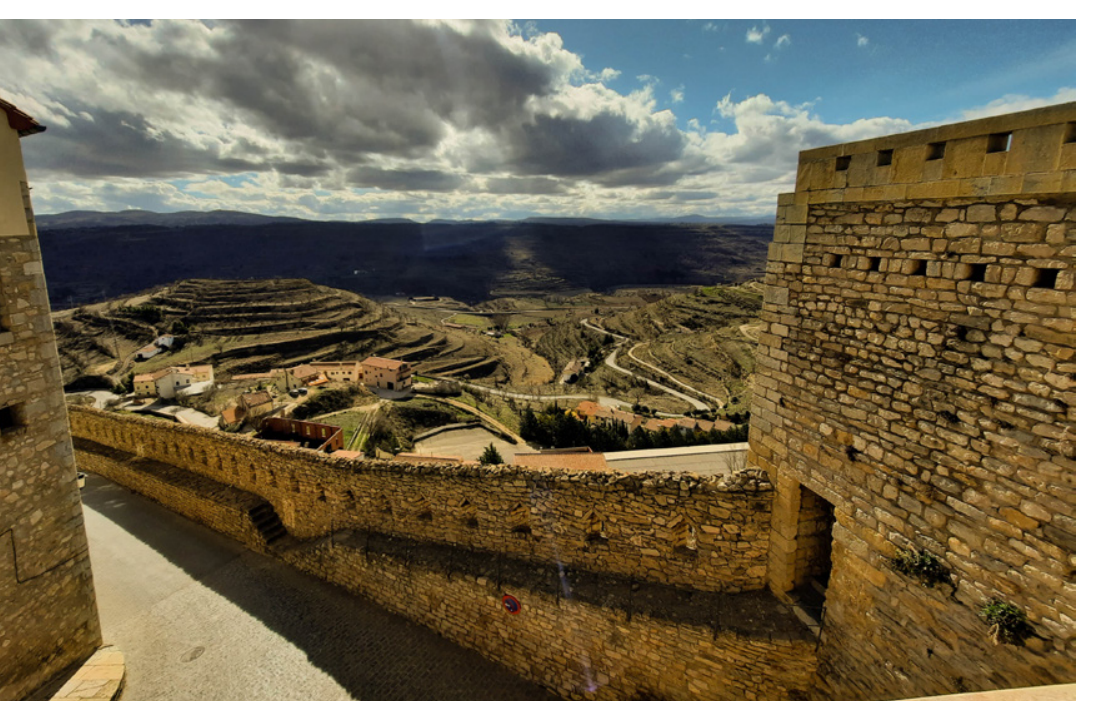

Fig. 644. Carraixet en relación con el castillo de Morella.
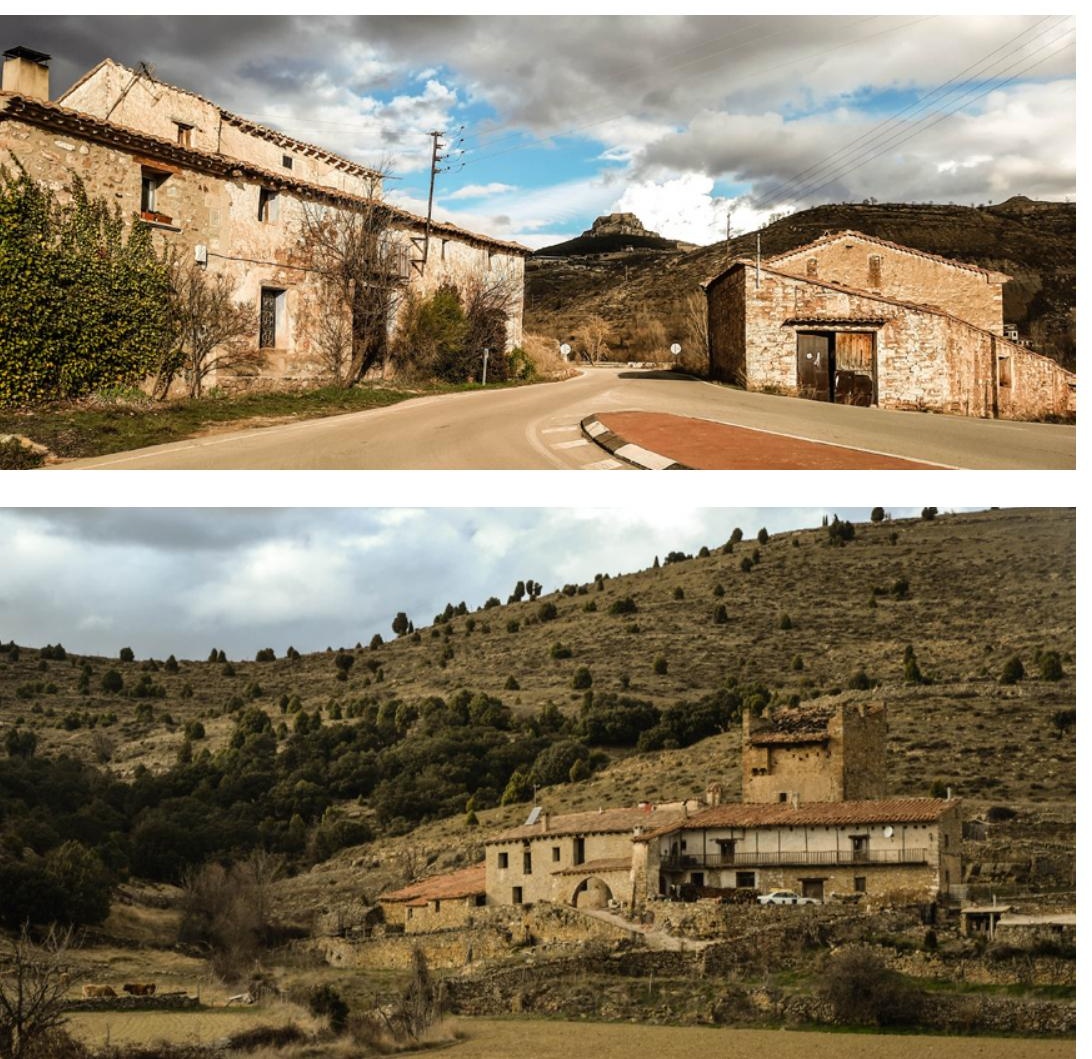

Plano 3

Título uniforme: Morella (Castellón). Mapas generales (1840). 1:6.000

Título: Plano de la Plaza y Castillo de Morella con el croquis de sus inmediaciones Publicación: 1840 ?

Descripción física: 1 plano: ms., col., montado sobre papel; 39,5x47 cm, en h. de 42,5x49 cm

Notas: Manuscrito iluminado a la acuarela en carmín, amarillo y gris. Orientado con flecha. Relieve representado por sombreado

Ejemplares: Archivo Cartográfico de Estudios Geográficos del Centro Geográfico del Ejército Ubicación: AR - Signatura: Ar.G-T.2-C.2-65 - Código de barras: 2210325.

Plano 4

Título uniforme: Morella (Castellón). Planos de población (1840). 1:2.000

Título: Plano de la ciudad de Morella y perspectiva de su Castillo

Publicación: 1840?

Descripción física: 1 plano: ms., montado sobre tela; 80,5x88,5 cm, pleg. en 52×88,5

Notas: Título propio tomado del que figura manuscrito con posterioridad a tinta. Manuscrito a lápiz. Relieve representado por sombreado. Relación de los principales edificios de la ciudad indicados por clave numérica. Dibujo en alzado del castillo y de las casas existentes fuera de la fortificación.

Ejemplares: Archivo Cartográfico de Estudios Geográficos del Centro Geográfico del Ejército Ubicación: AR - Signatura: Ar.G-T.2-C.2-66 - Código de barras: 2210326.

Plano 5

Título uniforme: Morella (Castellón). Planos de población (1840). 1:1.900

Título: Plano topográfico de la plaza de Morella y su castillo en el estado que se hallaba el día 30 de mayo de 1840 de su rendición / Pedro de Eguia, Eusebio de Unzaga.

Publicación: 1840 junio 5

Descripción física: 1 plano: ms., col., montado sobre tela ; 40,5x43,2 cm, en h. de 44,6x64 cm

Notas: Manuscrito firmado, rubricado y fechado en Morella. A plumilla en tinta roja e iluminado. Relación de las dependencias del castillo y puntos principales del plano indicados por clave alfanumérica. Inserta: Plano del Fuerte de San Pedro Martir.

Autores secundarios: Eguía, Pedro de; Unzaga, Eusebio de.

Ejemplares: Archivo Cartográfico de Estudios Geográficos del Centro Geográfico del Ejército Ubicación: AR - Signatura: Ar.G-T.2-C.2-63 - Código de barras: 2210323.

Plano 6

Título uniforme: Morella (Castellón). Asedios (1840). 1:7300

Título: Plano topográfico: lebantado con la brújula, de Morella y sus alrededores, con la posición de las baterias que se construyeron en el sitio del mes de Mayo de 1840 / Pedro de Eguia, Eusebio de Unzaga.

Publicación: 1840 junio 12

Descripción física: 1 plano: ms., col., montado sobre tela ; 40,5×36 cm, en h. de 44,8×57,4 cm.

Notas: Firmado, rubricado y fechado en Morella. Iluminado a la acuarela en verde, carmin, siena y azul. Orientado con flecha. Relieve representado por sombreado. Relación de las principales posiciones militares indicadas por clave alfanumérica.

Autores secundarios: Eguía, Pedro de; Unzaga, Eusebio de.

Ejemplares: Archivo Cartográfico de Estudios Geográficos del Centro Geográfico del Ejército Ubicación: AR - Signatura: Ar.G-T.2-C.2-64 - Código de barras: 2210324 
Fig. 651. (Arriba) Plano 1, de 1838. Vista del pueblo de Morella y de su castillo. Aparecen numerados, y explicados en la leyenda, los elementos importantes de la ciudad.

Fig. 652. (Abajo) Plano 2 de 1838. Plano y vista de la plaza de Morella y sus cercanías.

Fig. 647. Ilustración 3. Vista de Morella. Tomada de la carretera de Aragón.

Fig. 648. Ilustración 1. Sorpresa y toma del castillo de Morella por los carlistas (y vista del mismo castillo por la parte

Fig. 649. Iustración 2. Asalto dado en la brecha de Morella.

Fig. 650. Ilustración 4. Vista del castillo de Morella después del bombardeo.
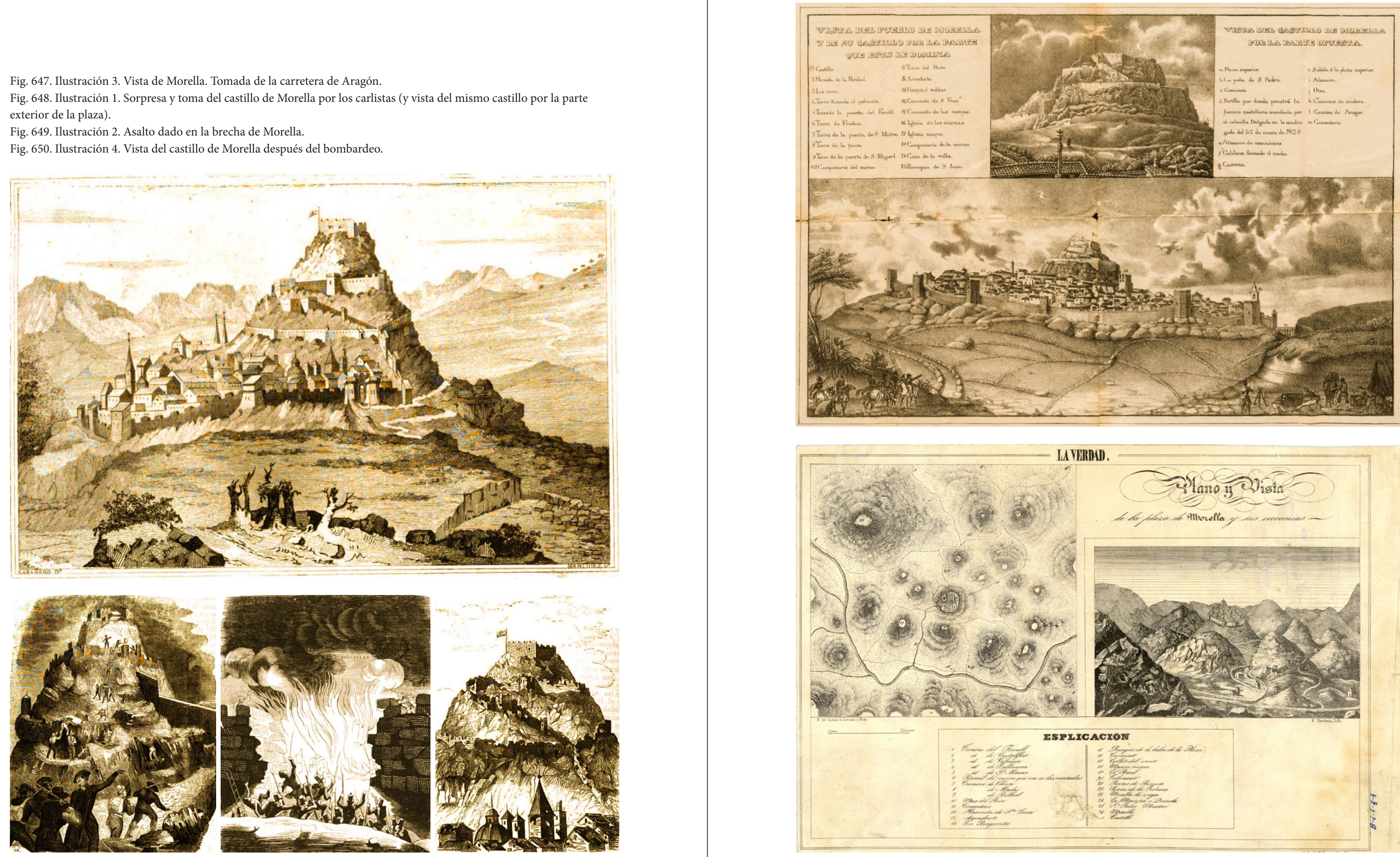

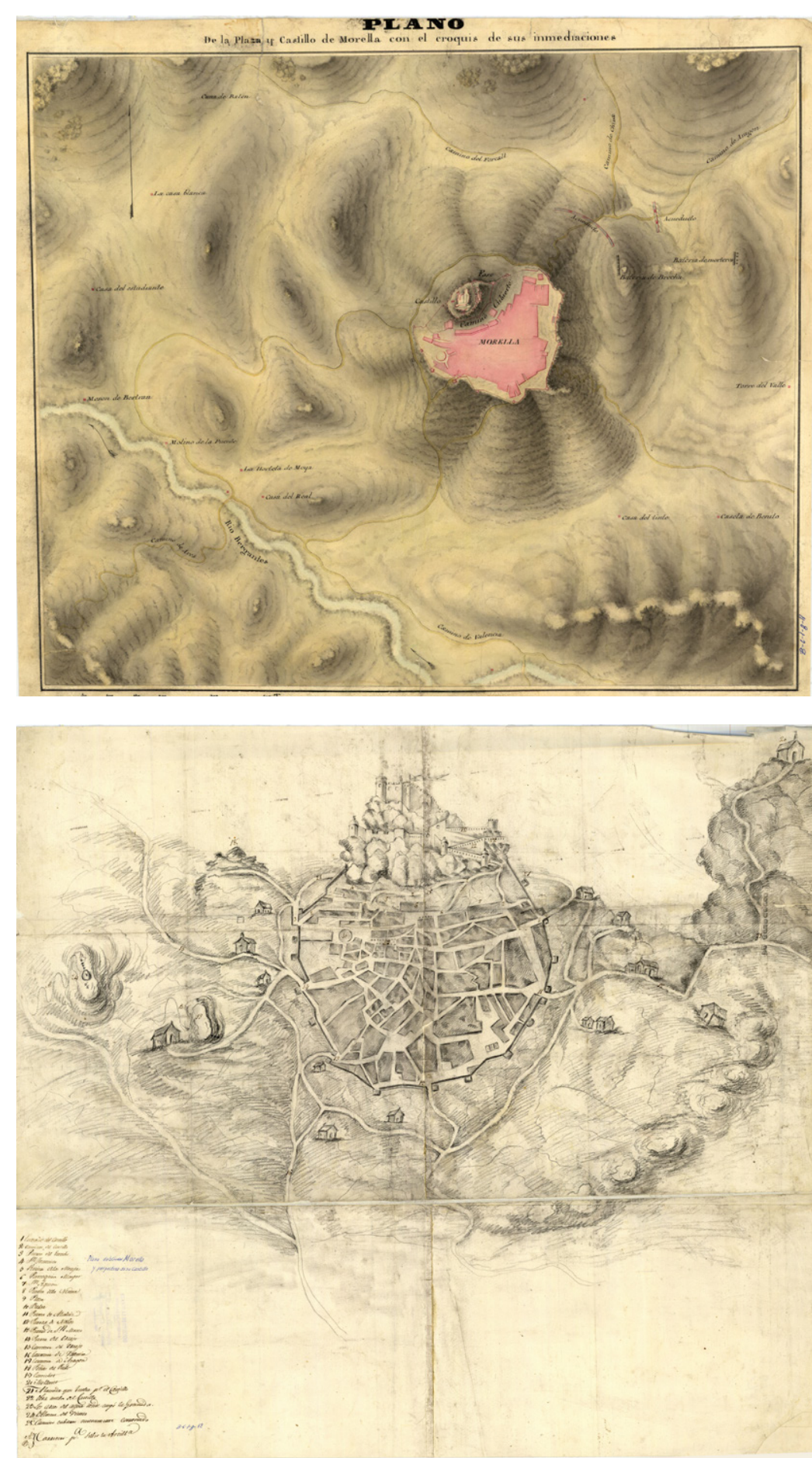

Fig. 653. Plano 3, de 1840 posiblemente. Plano de la Plaza y Castillo de Morella con el croquis de sus inmediaciones.

Fig. 654. Plano 4, de 1840 posiblemente. Plano de la ciudad de Morella y perspectiva de su Castillo.

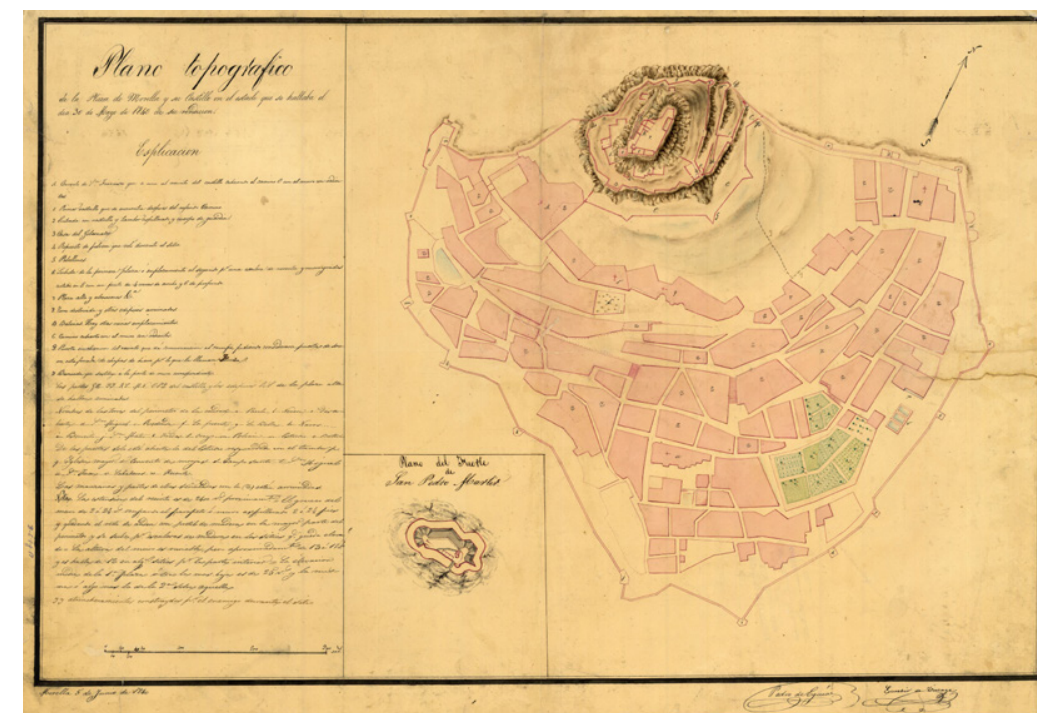
Plano topográfico de la plaza stado en el que se hallaba el dí 30 de mayo de 1840, día de rendición.

Fig 656. Plano 6, de 1840. topográfico de Morella y sus alrededores, con la posición de las baterías que se construyeron e el sitio del mes de mayo de 1840

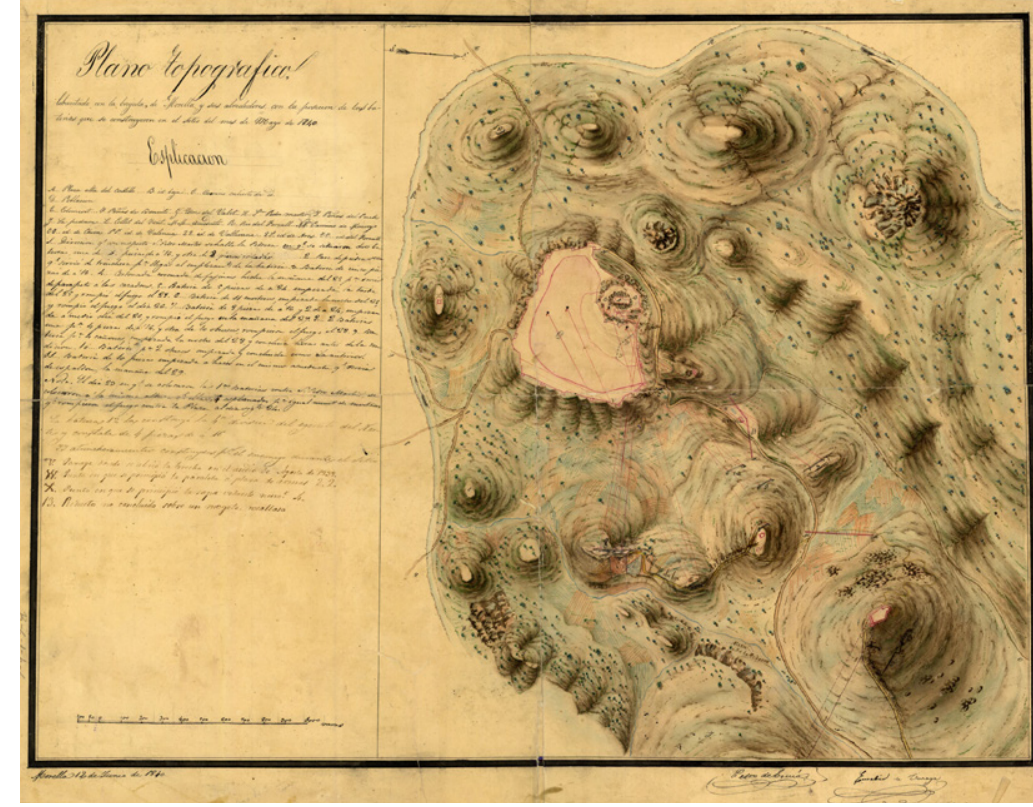




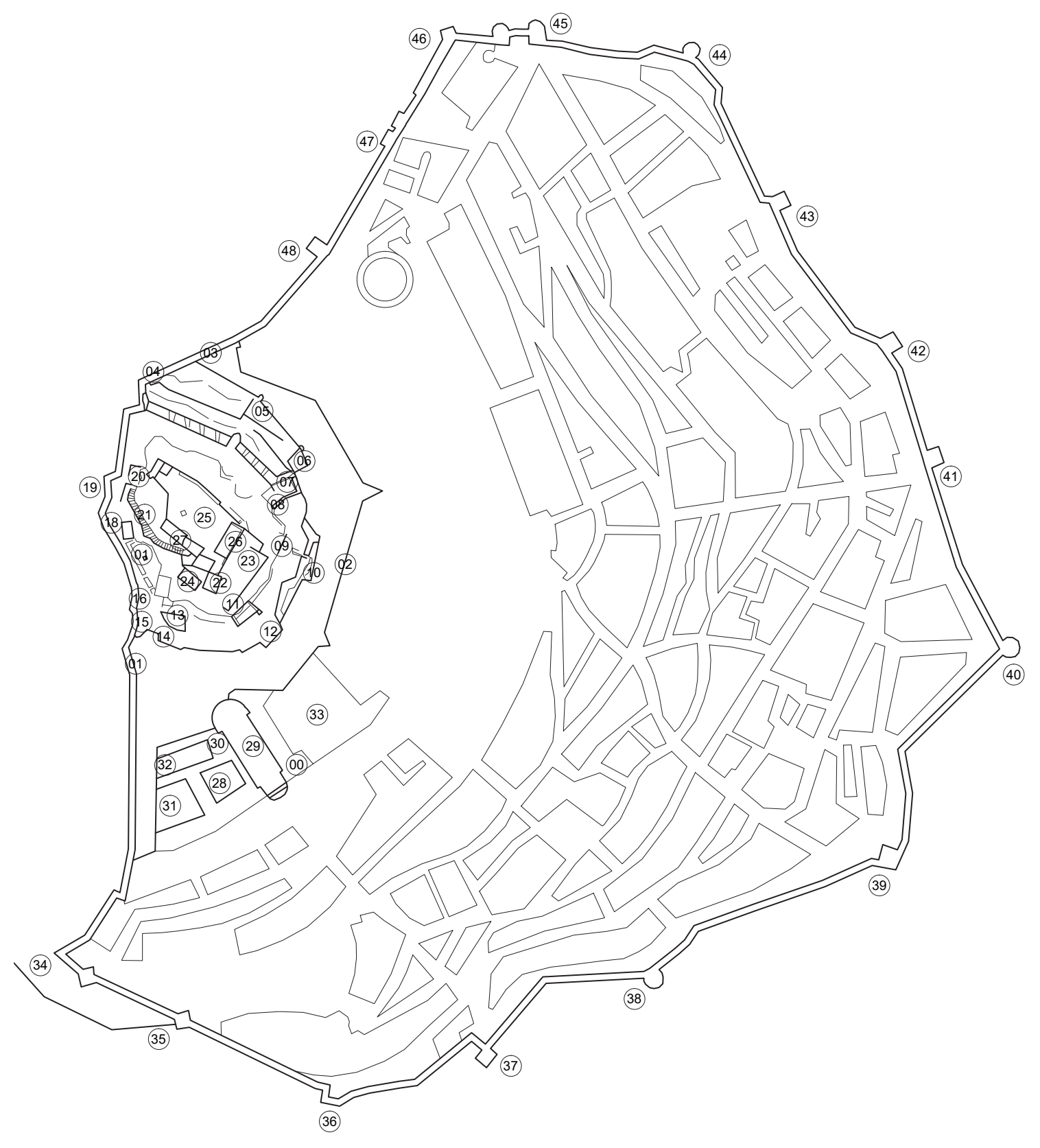

$50 \mathrm{~m} \quad \mathrm{E} 1: 5000$
4

Fig. 657. Esquema en planta de Mo-

rella y los puntos de interés.

PRIMER NIVEL

00. Gobierno Militar

01. Torre de San Francesc

02. Camino cubierto aspillerado

(1835-1840)

03. Primera puerta

04. Puerta Ferrissa

05. Segunda puerta / Barbacana

06. Cuerpo de Guardia

SEGUNDO NIVEL

07. Puerta Principal (S. XV-XIX)

08. Aljibe (S. XIII-XIX)

09. Palacio del Gobernador (1713)

10. Muro atrincherado

11. Horno o tahona

12. Puesto artillero $\mathrm{A}$

13. Alojamiento de tropa

\section{Cañó}

15. Torre de la Pardala (XIII-XV)

16. Letrinas en voladizo

17. Prisión del Cacho

18. Guardia del Cadró

19. Cantal de San Pedro

20. Polvorín

\section{TERCER NIVEL}

21. Escala

22. Torre celoquia

23. Cementerio

24. Alojamiento de tropa

25. Plaza de armas

26. Alojamiento de tropa

27. Pabellón de oficiales

Fig. 658. Alzado de la Puerta Principal, reconfigurada po orden de Von Rahden.
CONVENTO DE SAN FRANCISCO

28. Claustro

29. Iglesia

30. Sala De Profundis

31. Segundo claustro

32. Refectorio

33. Ruinas del Convento de las Agustinas Calzadas

\section{PERÍMETRO EXTERIOR}

34. Portal de los Estudios

35. Portal del Rey

36. Torre del Carraixet

37. Portal de Forcall

38. Torre de Fredes

39. Portal de San Mateo

40. Torre Beneito

41. Torre de Alós

3. Tore de horó

44. Torre Redonda

45. Portal de San Miguel

46. Torre del Rincón

47. Portal de la Never

48. Torre del Pantó

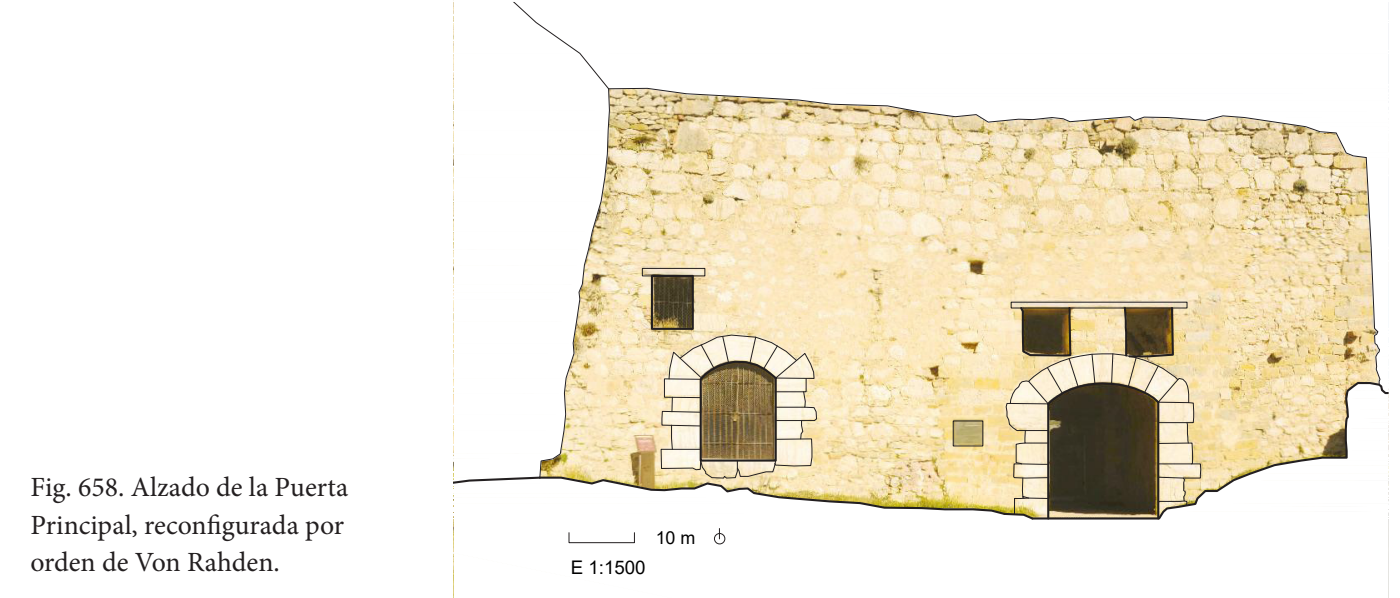


55 Peñarroya de Tastavins $*$ 


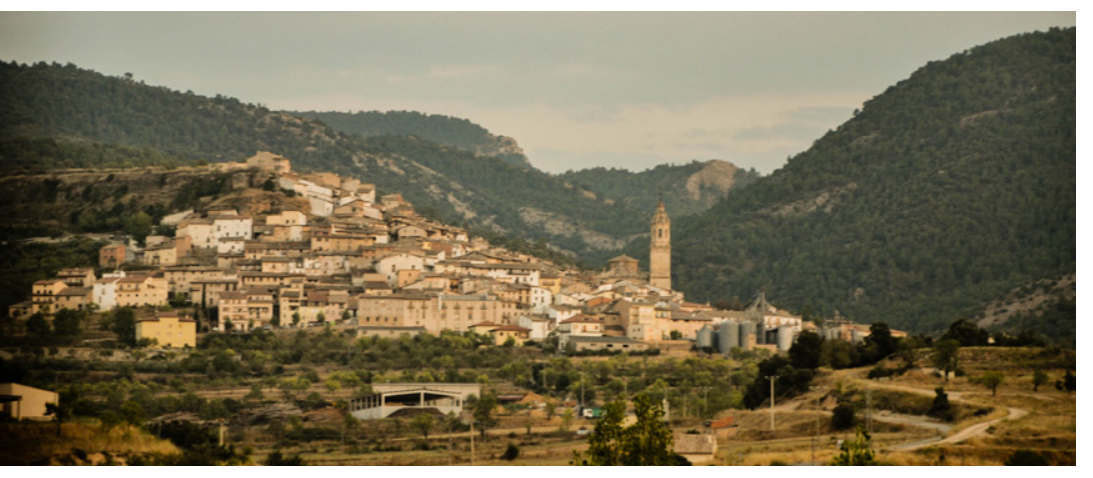

Fig. 659. Peñarroya de Tastavins en el territorio. A la izquierda, elevado, el fuerte.
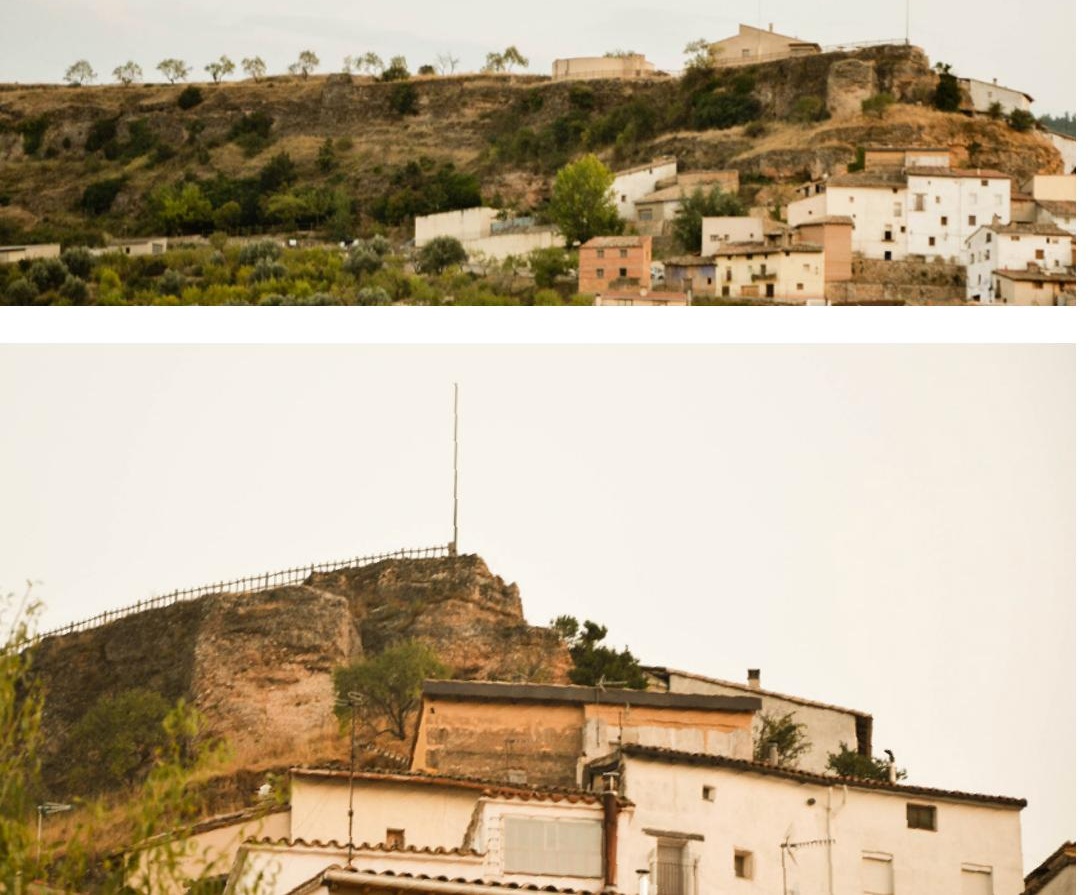

Fig. 660. Frente norte del castillo de Peñarroya de Tastavins.

Fig. 661. Restos del castillo.

\section{Peñarroya de Tastavins}

Localidad en castellano / valenciano: Peñarroya de Tastavins / Pena-roja de Tastavins Provincia actual: Terue

Comarca: Matarraña

Coordenadas geográficas: 40.7561954130978, 0.04073908724515718

Datos históricos:

Guarnición 1839-1840: 40 y pico (Caridad, 2013:263)

Inicio bombardeo liberal: $9-4-1840$

Rendición o abandono: 9-4-1840

Días de resistencia: 0

Fuente: Diario Mercantil de Valencia, Boletín Oficial de la Provincia de Castellón de la Plana, Córdoba (1844), Calbo y Rochina (1845), Caridad (2013:297)

Tipos defensivos: castillo reforzado que domina la población

Acciones y fortificación:

En octubre de 1839 los carlistas están reforzando Peñarroya y Ares del Maestre (Caridad, 2013: 264, Von Rahden, 2013: 478). Según Von Goeben, se le encomienda a él la dirección de los trabajos en San Pedro Mártir (Morella), así como terminar la fortificación de Villarluengo, alternando con el capitán Verdeja la supervisión de Cantavieja. A este le asignan los fuertes de Ares del Maestre y de Culla, y al capitán Jiménez los de Castellote y Peñarroya. Manuel Brusco, según Von Goeben “dirigía los trabajos en las fortalezas situadas al otro lado de la carretera de Teruel a Segorbe". Cuentan bajo su mando con oficiales subalternos, maestros de obras y compañías del batallón de zapadores que se distribuyen en función de las necesidades (Von Goeben, 1841:390). Más adelante, en sus memorias, Von 作 uego cabalgar hacia Aguaviva, pasando por Mo el enemigo" (Von Goeben, 1841:393)

En 1840, Peñarroya es ocupada por los liberales junto a otras muchas plazas (Boletín Oficial de la Provincia de Castellón de la Plana, 16 de abril de 1840; Diario Constitucional de Zaragoza, 20 de abril de 1840; Córdoba, 1844-1845: 277, 279; Calbo y Rochina, 1845: 498, 499; Caridad, 2013:265).

Las obras de Peñarroya con toda probabilidad suponen una adaptación del castillo existente en el cerro de la Mola, de origen musulmán. El castillo ocupa la totalidad de la cumbre y a día de hoy se aprecian algunos lienzos de mampostería de la muralla perimetral, en uno de cuyos lados menores e destaca la base de un toreon circula En el interior se localiza el arranque de otro recinto de planta redondeada y un muro de tapia. No podemos asegurar que algunos de los restos conservados sean obra carlista.

Calbo y Rochina recoge la toma de Peñarroya, a la que se dirigen los liberales tras tomar Villarluengo. Testimonia que, caído este último, los carlistas aún trabajan en la fortificación de Peñarroya. Los liberales toman primero Monroyo, donde sorprenden a los carlistas que se disponen a prender fuego a la fortificación. Tras tomar Monroyo y disponer una guarnición, el general León se encamina a Peñarroya, donde le recibe el fuego de artillería carlista. Mientras responde con su artillería a los defensores, rodea la posición con sus hombres, "ocupando el pueblo a la carrera" (Calbo y Rochina, 1845: 499). Se entiende que los carlistas resisten en la loma del castillo. Los defensores evacúan la posición descolgándose por los muros, aunque son apresados poco después (Calbo y Rochina, 1845: 499). 
Fig. 662. Esquema en planta de

Peñarroya de Tastavins con los

puntos de interés defensivo.

01. Restos del castillo

02. Iglesia

56 Pinos* $^{*}$

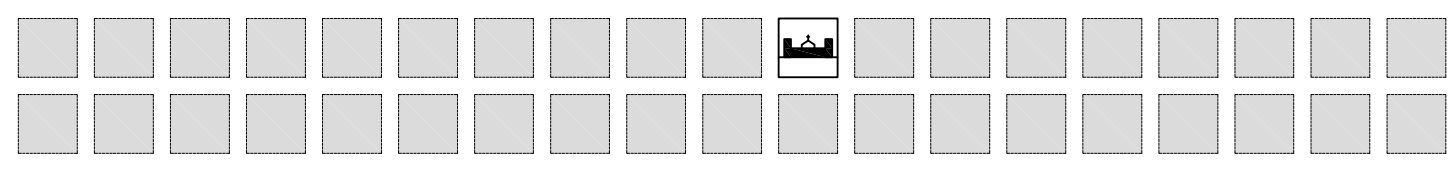


57 salinas del Manzano

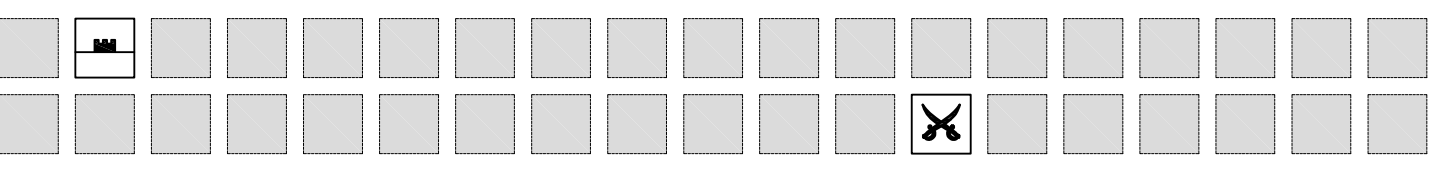




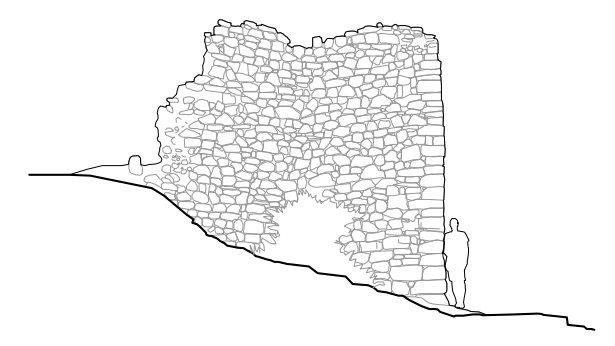

$\stackrel{\text { E1:200 }}{1} 1 \mathrm{~m}$
Fig. 670. Salinas del Manzano, castillo de las Malenas y campo

$$
\text { de batalla. }
$$

01. Río Henarrubia

02. Carretera $\mathrm{N}-410$ en la

actualidad

03. Castillo de las Malenas

04. Campo de batalla en 1839 a

los pies del castillo.

06. Ermita de San Roque

07. Localidad de Salinas del

Manzano

08. Antiguas salinas romanas
58

Castillo de Torrefuerte de las Veguillas

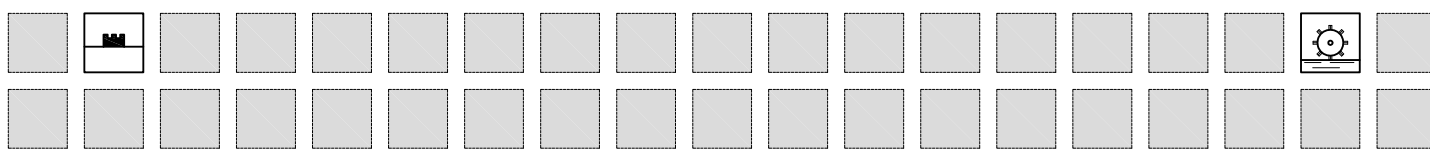



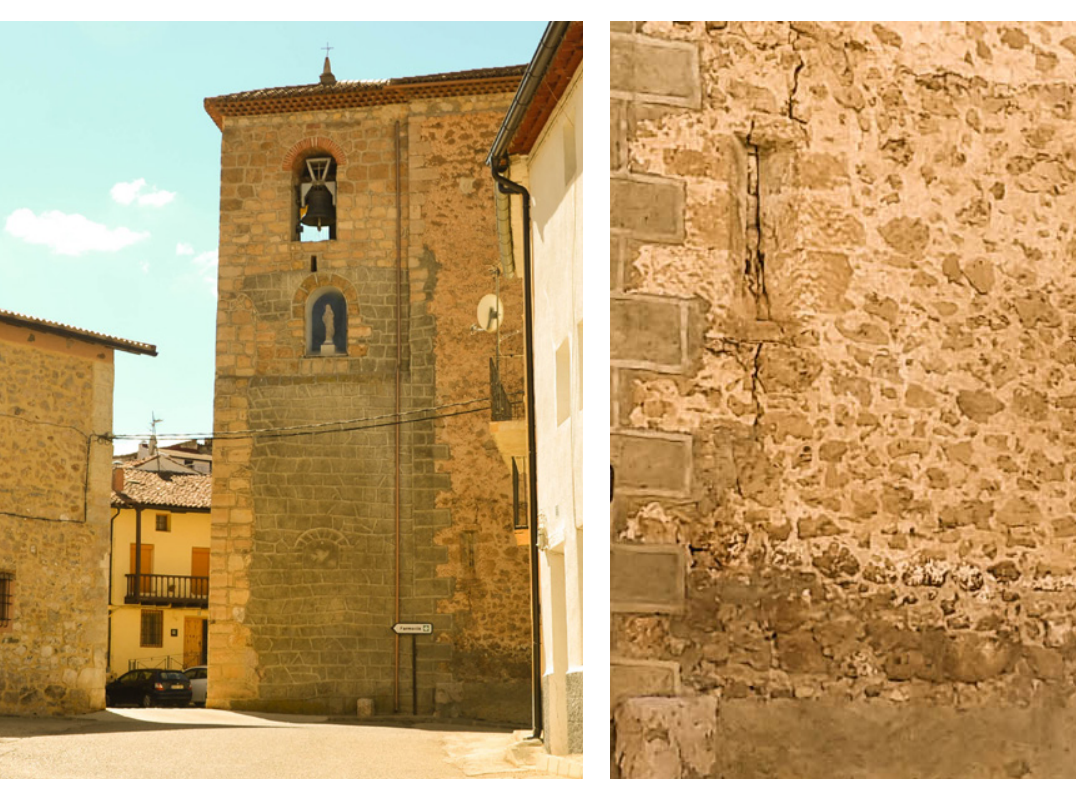

Fig. 674. (Izq.) Alzado oriental del campanario de la iglesia. Se observa una aspillera en la torre y otra, cegada, en el cuerpo derecho, en planta baja.

Fig. 675. (Dcha.) Detalle de la aspillera cegada situada junto a campanario, en el frente este.
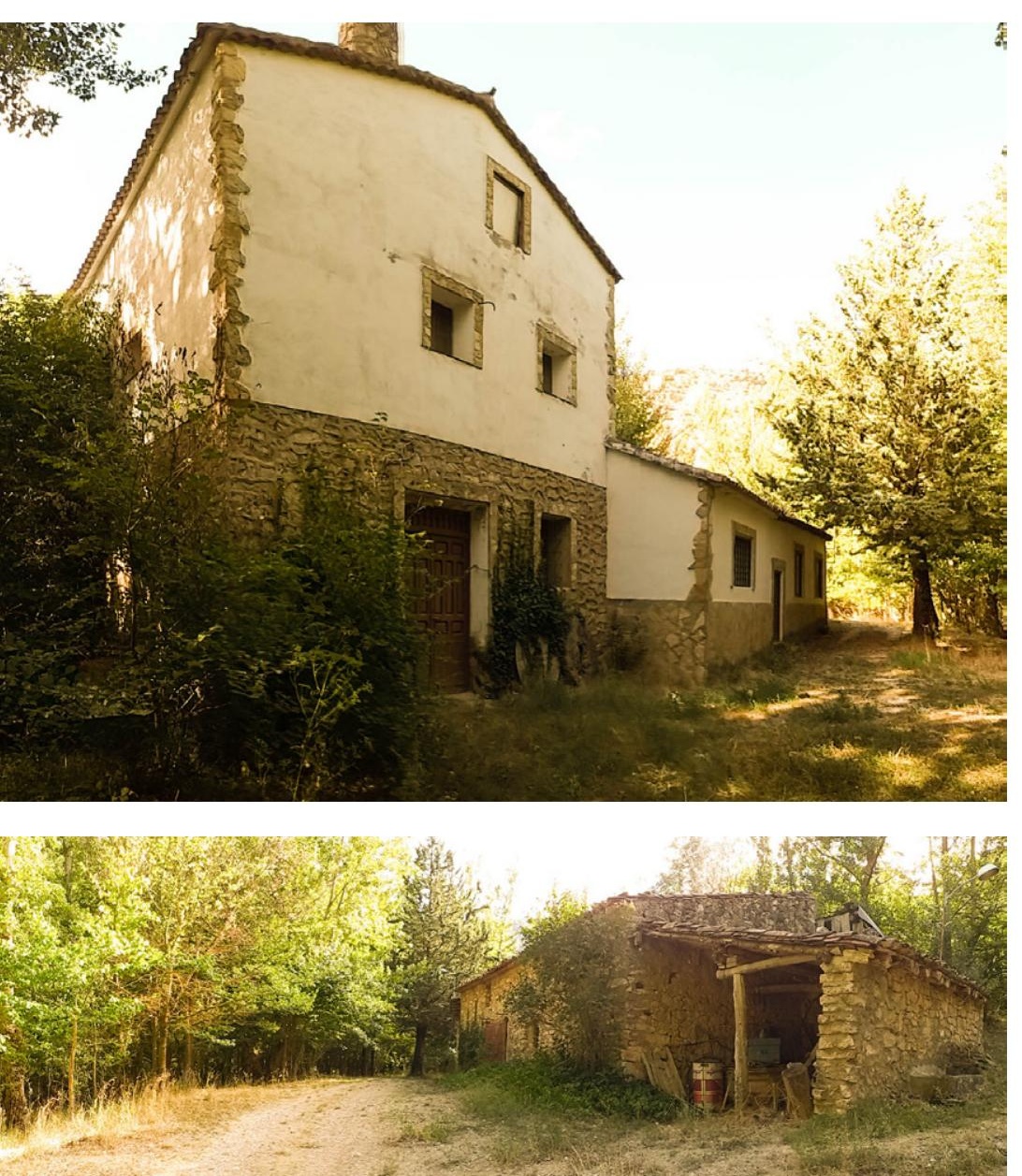

un arrojo extraordinario matándoles bastantes, cogiéndoles 50 prisioneros y obligándoles a huir..." Se observa el papel de la topografía como elemento de acción en la defensa y el papel que juegan las iglesias como elementos básicos de la defensa de los pueblos en la época.

En septiembre de 1836 los carlistas se introducen en Salvacañete y queman varias casas. La expedición de Gómez pasa por Salvacañete, pero sus habitantes dejan abandonado el pueblo (El Eco del Comercio, 14 de octubre de 1836, n.868, p.4). La Expedición Real, y también Cabrera ya de regreso de la misma, pasan por Salvacañete. El día 5 de septiembre el pretendiente D. Carlos se aloja en la de la misma, pasan por Salvacañete. El día 5 de septiembre el pretendiente D. Carlos se aloja en la
casa del cura, donde estudiaría los planes de marcha (Romero Saiz, 1993: 45). El campamento se emplaza en un lugar próximo a la plaza. En octubre de 1837 el cabecilla carlista Sancho se refugia en la localidad antes de dirigirse a sitiar Moya, baluarte liberal. En el año 38 el dominio de la zona es predominantemente carlista.

El 7 de febrero de 1838 se produce una nueva acción en el Castillo de las Veguillas, fuerte así denominado en la crónica del Eco del Comercio (15 de febrero de 1838, nº 1387 , p.1), que hace referencia al castillo de Torrefuerte, también conocido como Castillo de Torrefuerte de las Veguillas.

Se trata de la posición defensiva más relevante en las proximidades de Salvacañete. De hecho, durante las acciones, en sus alrededores se detectan correrías de partidas carlistas como las de Jiménez (López Marín, 2014: 362). Sin embargo, la posición del castillo se encuentra bastante alejada de la localidad, aproximadamente alrededor de 8 kilómetros, accediendo a través de una pista de tierra, en el interior de una propiedad privada, la finca denominada Los Cortijos, en la Sierra del Escornadero, por lo que podría considerarse una posición defensiva independiente. Se conjetura que en ocasiones la equidistancia del castillo respecto a Salvacañete o Zafrilla podría generar el equívoco en diversas fuentes que hablan de las posiciones de uno u otra confundiéndolas con el castillo de Torrefuerte.

La crónica citada recogida en El Eco del Comercio indica que: “después de mi arribo a Salvacañete, supe que la facción capitaneada por don Francisco del Olmo en número de 40 infantes y 30 caballos estaba en el castillo o Torre de las Veguillas, cuatro horas de aquella villa en el instante, y como por encanto reuní mi fuerza compuesta de 200 hombres, inclusa la compañía franca, y me dirigí a dicho castillo. Al llegar a él hice salir tres guerrillas para que hostilizasen al enemigo, como en efecto a los primeros disparos de nuestra parte comenzó el enemigo un vivo fuego sobre nuestra tropa: habiéndose pronunciado en dispersión a la hora de un vivo fuego de una y otra parte. Son veinte y tres los cadáveres vistos sobre el campo, y unos doce que se refugiaron en el referido castillo después de una tenaz resistencia han sucumbido y sido hechos prisioneros; pues para ello dispuse escalar el edificio, y estos valientes entraron por una ventan han cogito porción de fusiles, lanzas, mantas y otros efectos; también hay sobre el campo muchos caballos muertos". El informe revela lo rudimentario de las acciones. El papel jugado por la fortificación es el de un mero obstáculo que domina las alturas y sobre el que posicionarse. Pero ni los defensores ni la fortificación están a la altura de una acción básica.

Entre los días 19 y 21 de marzo de 1838, de nuevo Salvacañete está en manos del coronel carlista denominado Fernando (La estafeta de Madrid, 29 de marzo de 1838, p. 1).

Entre febrero y julio de 1840 se suceden varias acciones de la partida de Salvacañete, que vuelve a estar bajo control liberal (El Eco del Comercio, 28 de febrero de 1840, nº 2129, p. 3; El Guardia Nacional, 15 de mayo de 1840, p. 4).

Se colige así que cuando se hace referencia al fuerte de Salvacañete se está haciendo referencia al denominado Torrefuerte de las Veguillas, que se alza sobre una elevación que domina el valle. De origen medieval, está dominado por una torre del homenaje en planta semicircular, rodeada por ocho cubos circulares y las correspondientes cortinas. El castillo ha sido objeto de numerosas reformas. Una intervención reciente en el castillo se centró en la restauración de las fábricas de mampostería con lavado y rejuntado del mortero coloreado, resistente a las heladas e hidrofugado. Se intervino en la plaza de acceso levantando las solerías a fin de impermeabilizar el conjunto con espuma de poliuretano, reconstruyendo la fuente preexistente con sus bancos periféricos. Se repasaron también las almens picando las zonas de El uso del edificio y las continuas operaciones de diluido el rastro de cualquier intervención de época carlista que pudo, posiblemente, localizarse en los muros del recinto exterior. 


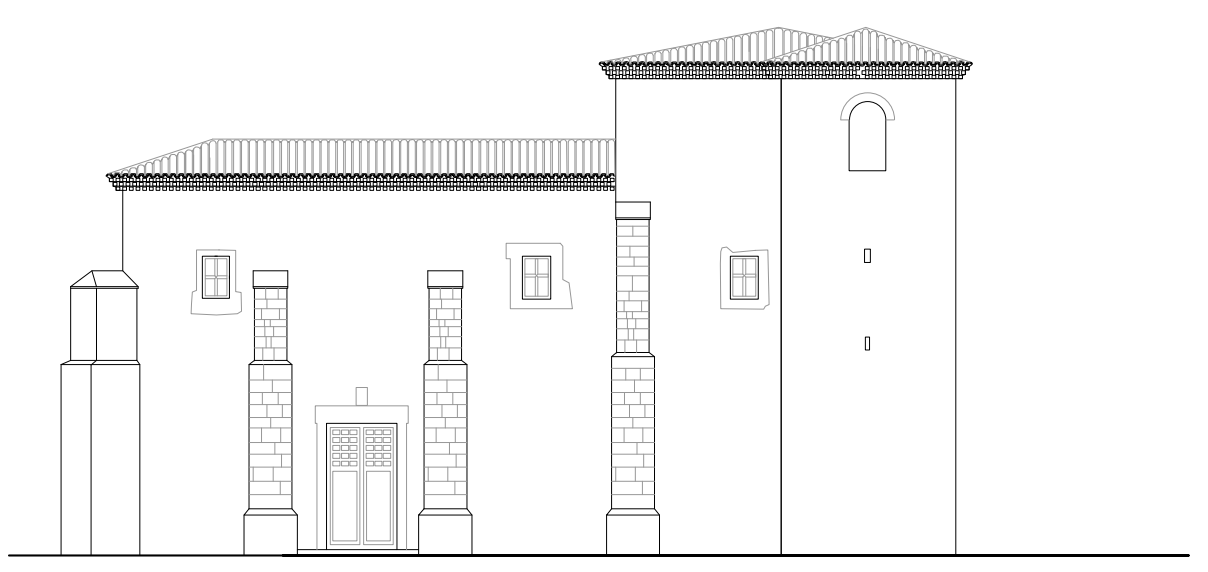

E 1:300

59 SAMper de CALANDA $*$ 

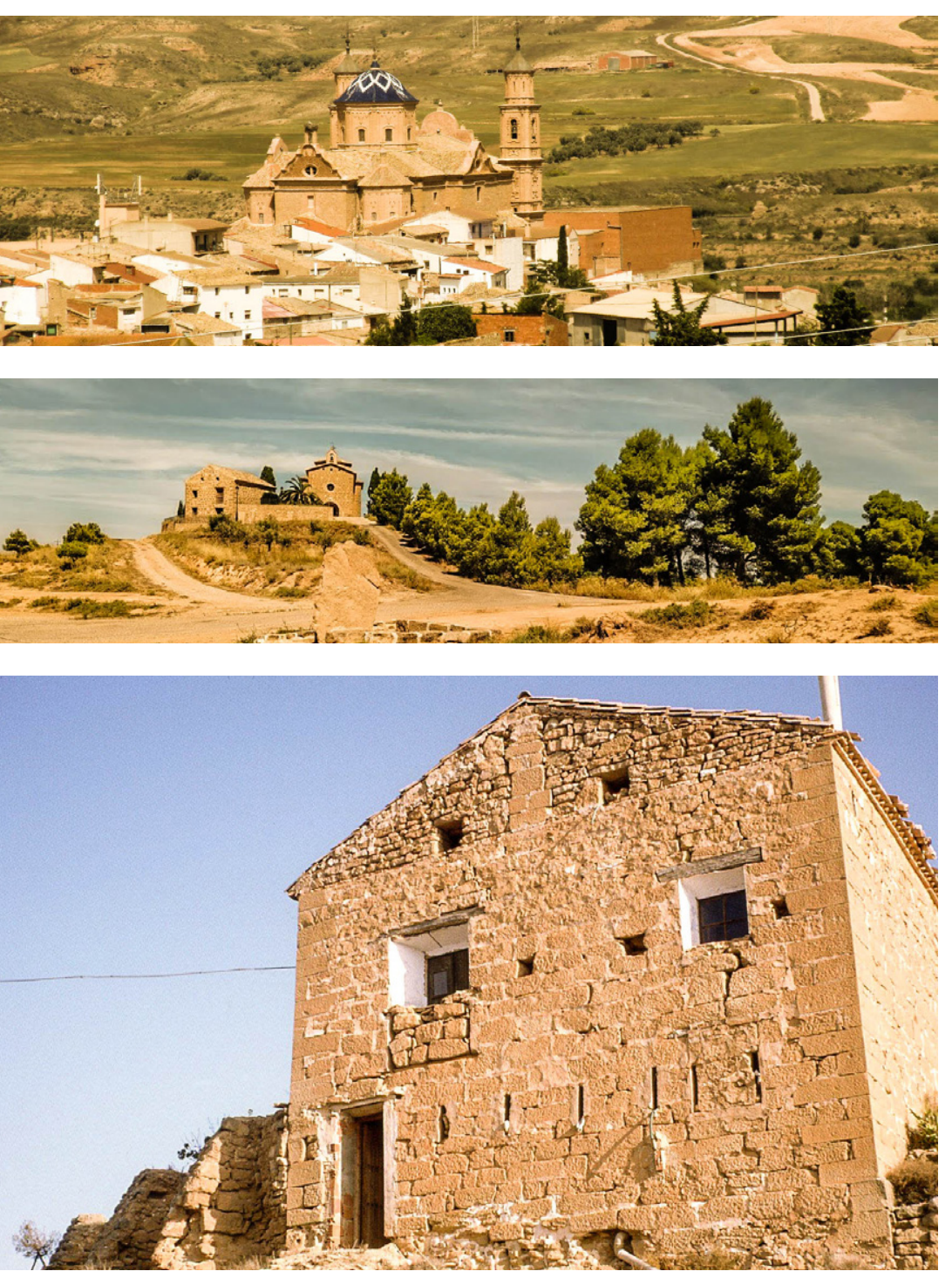

Fig. 681. Aspilleras en el calvario fortificado de Samper de Calanda.

Fig. 682. Fortín cerca de Samper de Calanda, posiblemente de la Tercera Guerra Carlista.

Fig. 683, 684. Fortín cerca de Samper de Calanda, posiblemente de la Tercera Guerra Carlista, recientemente restaurado.

\section{Samper de Calanda}

Provincia actual: Teruel

Comarca: Bajo Martín

Coordenadas geográficas: $41.19009350070007,-0.3900551439379285$

Tipos defensivos: castillo reforzado que domina la población, fortificación de calvarios, fortificación de iglesias.

\section{Acciones y fortificación:}

Esta población de la comarca Bajo Martín se fortifica en 1838 según el Diario Mercantil de Valencia (5 y 28 de mayo de 1838). Domina el río Martín en el camino que comunica Hijar y Escatrón. Presidida por el gran volumen de la iglesia parroquial del Salvador, del siglo XVIII, sus dos torres que flanquean la fachada deben de apoyar la misión de vigilancia.

Córdoba verifica también la fortificación de Samper. Según Córdoba, Samper y Albalate son puntos fortificados por "el enemigo" en torno al 8 de junio de 1837. El 22 de junio, indica, cuando los carlistas se aproximan para obligar a Samper a proporcionar víveres, la localidad, como punto fortificado, se resiste. "El alcalde y regidores de Samper se encerraron en el fuerte, y la orden de Cabrera quedó cumplida. Según la Gaceta de 22 de junio fueron incendiadas 16 casas. Los diarios carlistas dicen: 'Tan pronto como salieron de Samper nuestras tropas, acudieron los paisanos y lograron apagar el fuego de las casas, y según se dijo solo una ó dos quedaron destruidas por las llamas" (Córdoba, 1844: II, 241).

dijo solo una ó dos quedaron destruidas por las llamas" (Córdoba, 1844: II, 241). El castillo de Samper es destruido durante la Primera Guerra Carlista, en 1838. El castillo ya existía antes de 1194, en que se registra la donación del castillo a la orden de San Juan de Jerusalén en el fotografías de Luis Laín Nicolau permiten entrever vestigios de las intervenciones en la barbacana del antiguo castillo que se harían por parte de León Cappa en 1862 para conectar la calle de la Cárcel con la de los Marqueses, percibiéndose en primer plano los últimos paños de la muralla del lado sur del castillo antiguo. En ella se observa que se ensancha el foso del fuerte para descender a la actual carretera, levantando un muro de piedra que acompaña la escalera. La denominada barbacana del antiguo castillo se convierte en un lugar escogido para efectuar fotografías panorámicas de la del antiguo castillo se convierte en un lugar escogido para efectuar fotografías panorámicas de la
localidad en los años 50 del siglo XX. Se sabe también que la casa del calvario era un fuerte fusilero
y, dadas las características de los muros y las aspilleras, nos encontramos con un nuevo calvario y, dadas las características de los muros y las aspilleras, nos encontramos con un nuevo calvario que probablemente date de la Tercera Guerra Carlista, al conectar con los fortines de Escatrón y Chiprana en una dirección y con Hijar y Alcañiz. Esta "torre óptica", "mocatero" o "fortín" basa su funcionamiento en el uso de mensajes formales detectables con catalejo. Deben dominar, obviamente, las alturas, y se caracterizan por su encalado, que les permite destacar en la distancia. Contaba con un sótano y dos pisos de altura. En 1913 un informe del Ayuntamiento acuerda su desalojo por "inminente ruina", pero en la actualidad se encuentra restaurado y en buen estado. 
60 Sant Mateu 


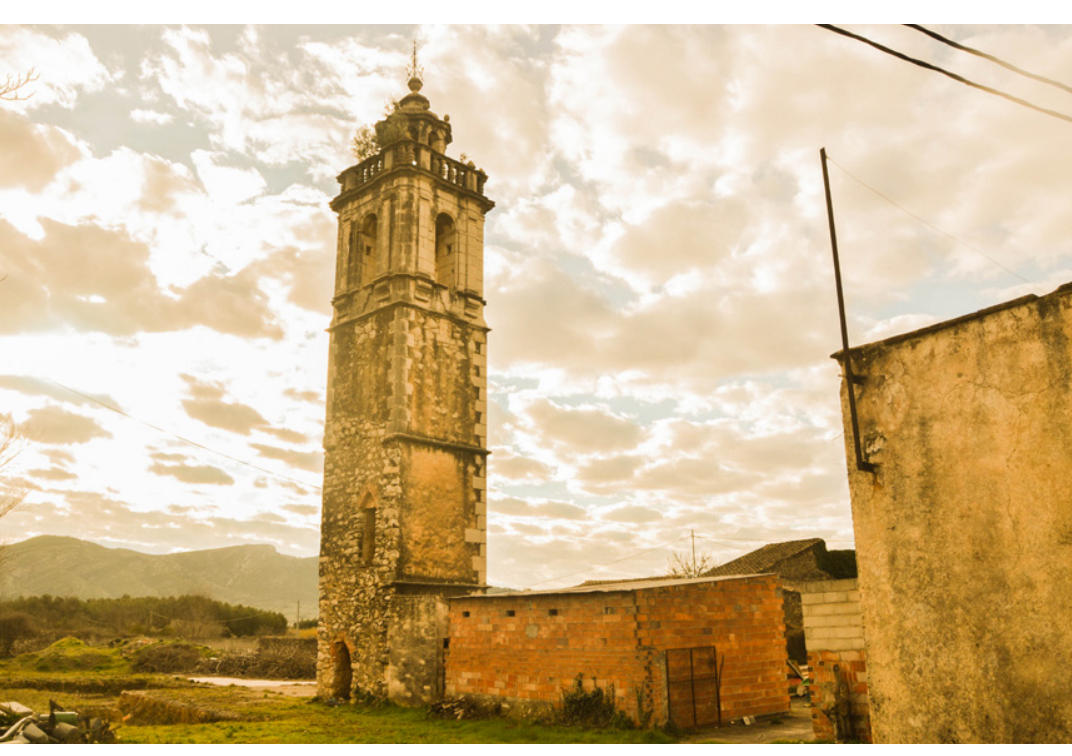

Fig. 690. Torre de les Llàsti-

mes, campanario del antiguo

Convento de los Dominicos fortificado por los carlistas.

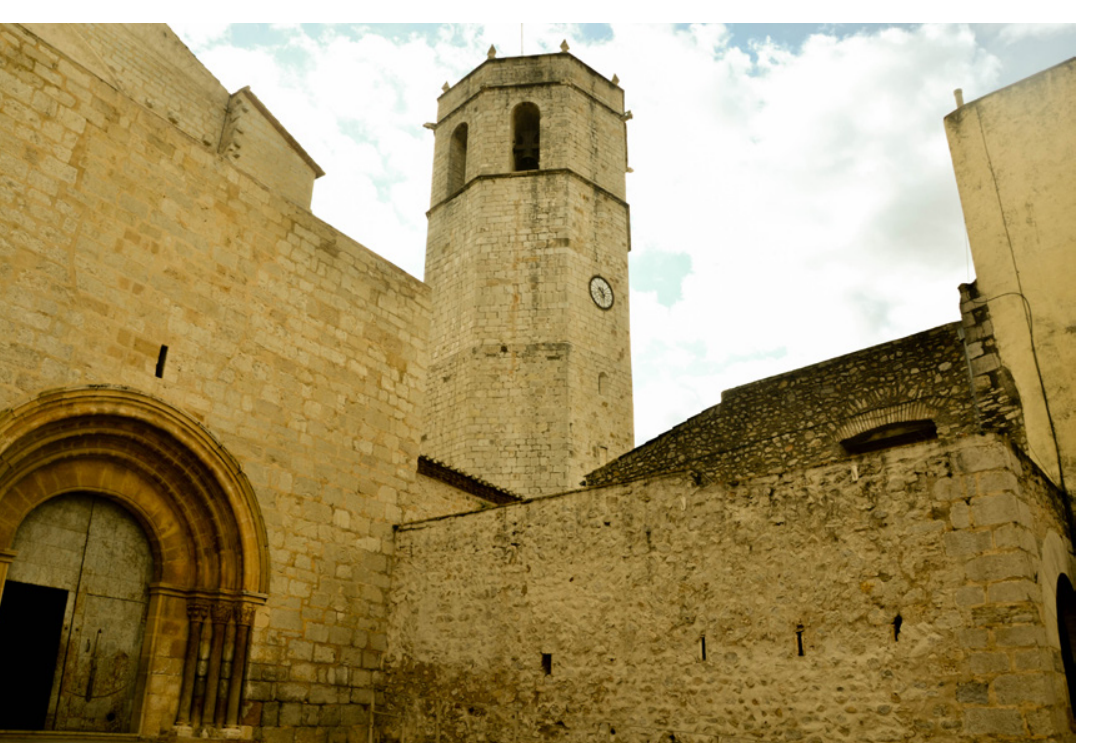

Fig. 691. Acceso a la Iglesia

Arciprestal de Sant Mateu y

torre campanario. Se aprecia

numerosas aspilleras.

Fig. 693. Ilustración 1. Vista de San Mateo por el Portal de Morella.

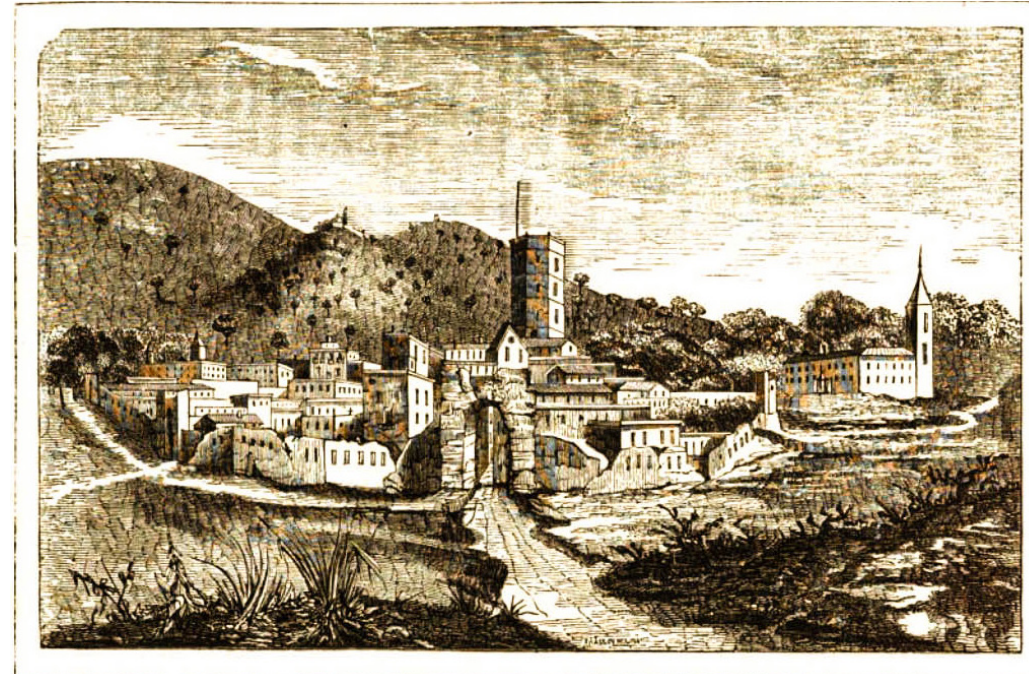

Fig. 694. Campanario del antiguo Convento de los Dominicos fortificado por los carlistas.

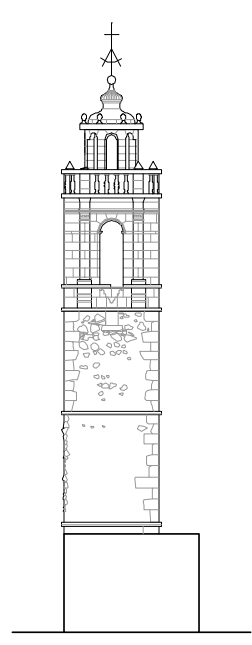

Fig. 692. Murallas de la pobla-

ción en el frente norte de la misma. 
Fig. 695. Esquema en planta de Sant Mateu con los puntos de interés defensivo.

01. Campanario del antiguo

Convento de los Dominicos

02. Murallas

03. Iglesia Arciprestal

04. Calvario

05. Murallas aspilleradas - Con-

vento de las Monjas Agustinas

06. Torre Contacorps - Portal de

Morella

07. Iglesia de San Pedro

08. Les presons

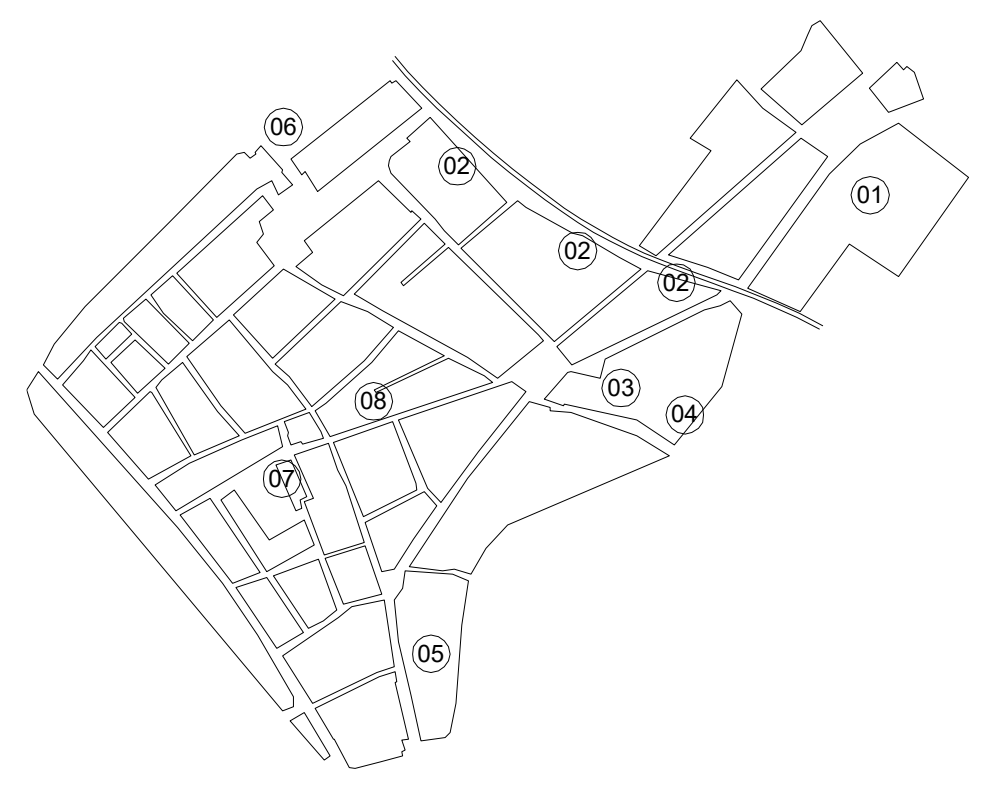

$611_{\text {ANTA BAвBRAA }}$

$\longleftarrow 50 \mathrm{~m} \quad \mathrm{E} 1: 7500$

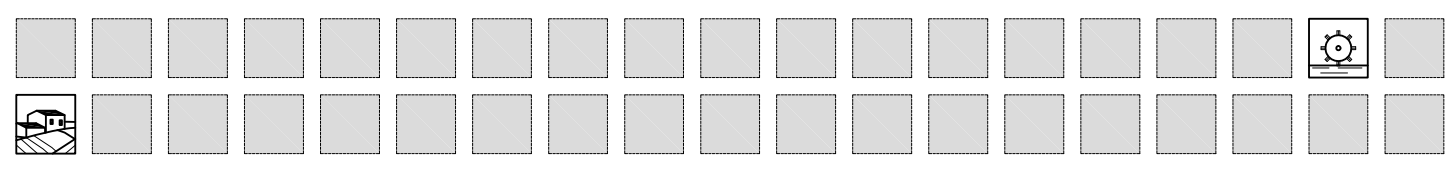




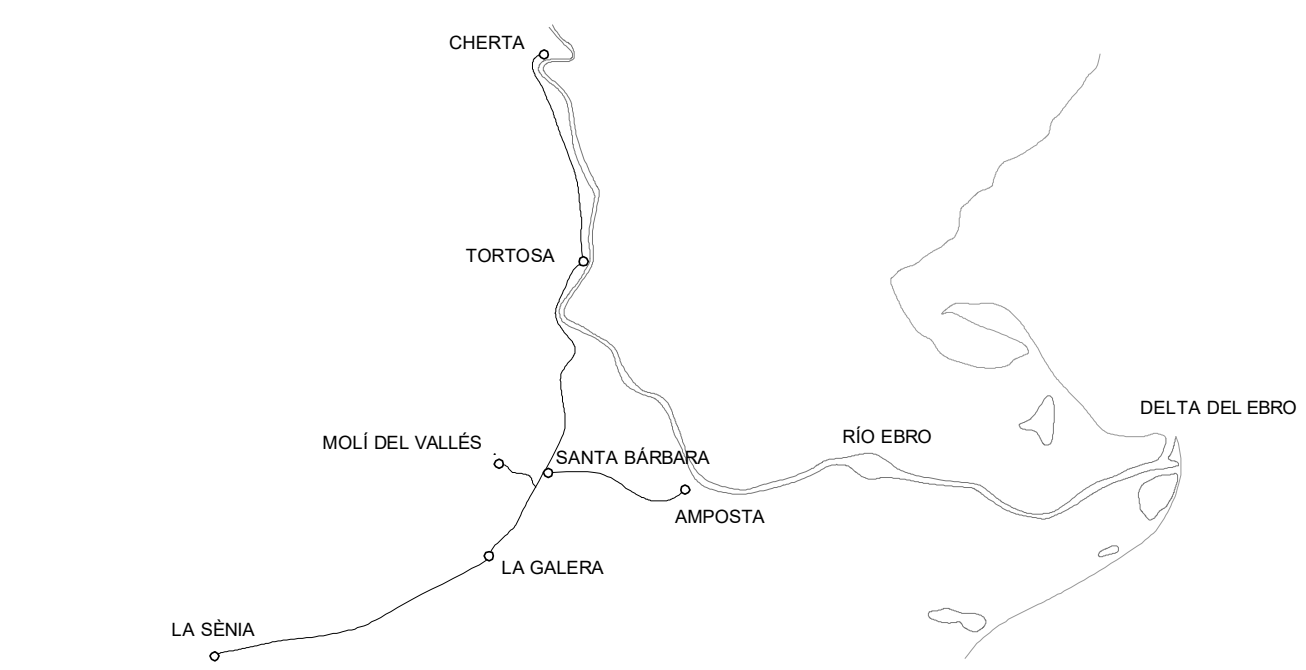

E 1:500.000

$5000 \mathrm{~m} \mathrm{~d}$
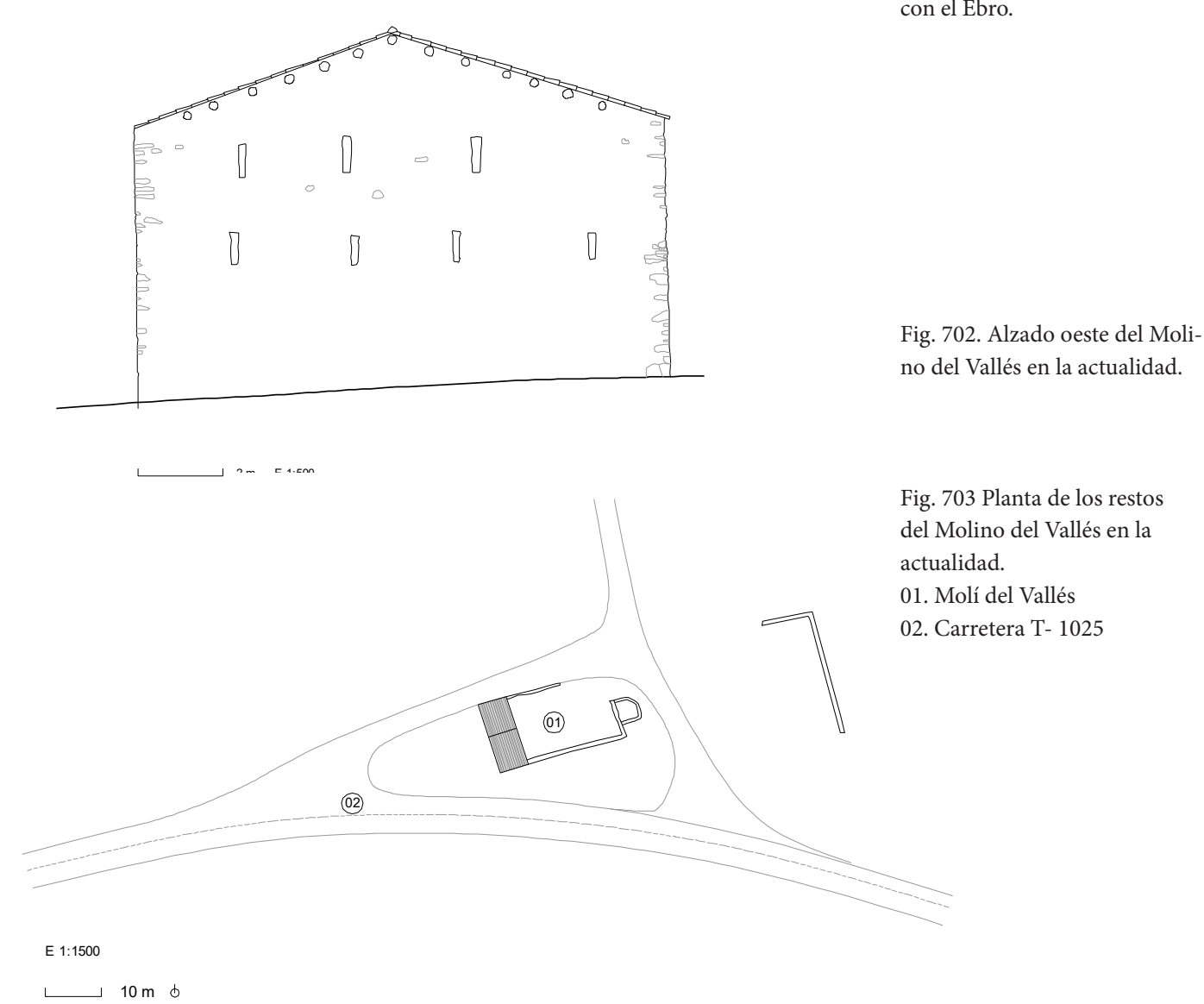

Fig. 701. Planta de localización del Molino del Vallés en relación con el Ebro.

Fig. 702. Alzado oeste del Molino del Vallés en la actualidad.

\section{SANT CariLS DE LA RAPTtA $^{*}$}

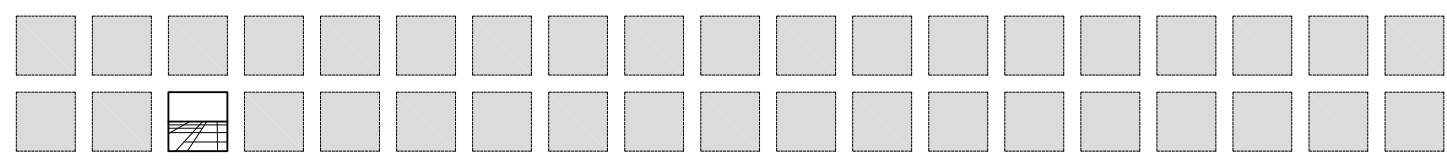




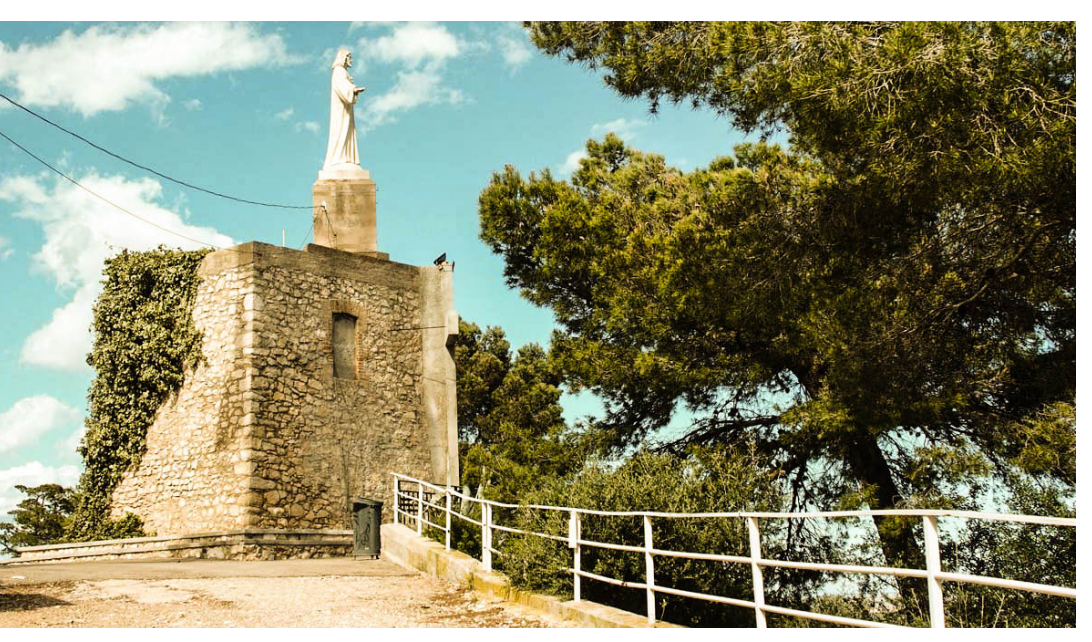
ins
Fig 704. Torre de vigilancia ubicada en el Mirador de la Guardiola, posiblemente utilizada por los carlistas.

Fig. 705. Plano de relación territorial entre la línea defensiva del Riu Sénia Y Sant Carles de del Riu Sénia y Sant Carles de

01. Torre de la Guardiola (s. XV) 02. Castillo de Ulldecona 03. Salinas de la Trinidad (ubicación actual)

\section{Sant Carles de la Ràpita}

Localidad en castellano / catalán: San Carlos de la Rápita / Sant Carles de la Ràpita Provincia actual: Tarragona

Comarca: Montsiá

Coordenadas geográficas: 40.613876841103576, 0.5927058366603148.

Tipos defensivos: fortificación de salinas.

Acciones y fortificación:

Córdoba recoge un avance realista de Alcanar hacia Sant Carles tras la toma de Alcanar en octubre de 1835 y la victoria sobre la milicia urbana de Vinaròs (1844: I, 222). En el puerto de Sant Carles se encuentran anclados buques de guerra ingleses y españoles, que los cañonean (Córdoba, 1844: 222). Tras el ataque a Benicarló del año 1836, los carlistas llegan a Sant Carles de la Ràpita y se produce un encuentro con tropas liberales (Pirala, 1869: III, 73).

Con ocasión de la Expedición Real se sabe que Cabrera se apodera de lanchas del puerto de Sant Carles, las monta en carretones y rodillos y las desplaza a Cherta para facilitar el paso del Ebro de la Expedición. Se deduce que las tropas no controlan la desembocadura ni el río, de ahí la necesidad de transportar las barcas por tierra (Córdoba, 1844: II, 249).

Algunas fuentes sostienen que a finales de mayo de 1839 se fortifica algún castillejo entre Tortosa y Amposta, así como las salinas de Sant Carles de la Ràpita (Diario Mercantil de Valencia, 29 y 30 de mayo de 1839; Caridad, 2013: 262).

Pero, ¿en qué puede consistir esta fortificación? ¿Dónde se ubican entonces las salinas?

Las poblaciones costeras son de difícil sostenimiento por parte de los efectivos carlistas ante la presencia de la marina liberal. Sorprende que se pueda hacer referencia a una fortificación carlista en la zona.

Las actuales salinas de la Trinidad se emplazan en la Punta de la Banya, en el extremo del Delta del Ebro. Es poco probable que se trate de este emplazamiento. Las antiguas salinas, denominadas Salines Velles, se emplazaban en el otro extremo del puerto de los Alfaques, de las que pervive un muelle de piedra que fue engullido por el mar. Sin embargo, no se ha podido constatar ningún testimonio escrito ni construido de esta posición.

Se puede efectuar alguna conjetura sobre el denominado mirador de la Guardiola, que domina desde la sierra del Montsià la plaza de Sant Carles, la bahía de los Alfaques, incluso la totalidad del Delta del Ebro. En este mirador se identifica una antigua torre de vigilancia costera, que podría datar del siglo $\mathrm{XV}$, aunque podría haberse apoyado en alguna preexistencia islámica. La primera documentación de la que se dispone data de 1483 , siendo reforzada y reparada en el siglo XVI a partir de la política de defensa costera que pretende asegurar la costa de los ataques berberiscos. Se rehace a mediados del siglo XIX como torre $\mathrm{n}^{\circ} 45$ de la red de telegrafía óptica de la línea ValenSe rehace a mediados del siglo XIX como torre $\mathrm{n}^{\circ} 45$ de la red de telegrafía óptica de la línea Valen-
cia-Barcelona. Su posición privilegiada, y la presencia constatada de una estructura en tiempo del conflicto carlista, hacen muy probable su utilización para control del territorio, teniendo en cuenta que su posición ocupa las estribaciones de la sierra del Montsià y tras esta se extiende la línea del Sénia a Xerta bajo control carlista. 
63 SgGura de los Baños * 
Fig. 706. Segura vista desde el camino de Montalbán, es decir, desde el sur. Se aprecian los tres cerros principales. Fig. 707. Segura desde el sureste.

Fig. 708. Panorámica desde el resalte rocoso oriental.

Fig. 709. Vistas desde la colina secundaria más oriental. Se aprecian las tres colinas principales y la población.

Provincia actual: Teruel

Comarca: Cuencas Mineras

Coordenadas geográficas: $40.93919971981643,-0.950171769739967$

Datos históricos:

Guarnición 1839-1840: 374 (Caridad, 2013:263)

Inicio bombardeo liberal: 23-2-1840

Rendición o abandono: $27-2-1840$

Días de resistencia: 4

Fuente: Diario Mercantil de Valencia, Boletín Oficial de la Provincia de Castellón de la Plana, Córdoba (1844), Calbo y Rochina (1845), Caridad (2013:297)

Tipos defensivos: castillo reforzado que domina la población, torre, fortificación de iglesias, eras.

Acciones y fortificación:

De la importancia de esta plaza da idea la consigna que, según numerosas fuentes, está grabada en las murallas de Segura: "Segura siempre será Segura, o de Ramón Cabrera la sepultura" (Pirala: 1869, V, 260). Von Rahden, jefe de ingenieros, hace una descripción de la ciudad: "Sobre el peñasco central se levanta Von Rahden, jefe de ingenieros, hace una descripción de la ciudad: "Sobre el peñasco central se levanta
el antiguo castillo musulmán, mientras que a derecha e izquierda se encuentran a tiro de fusil los otros dos
resaltes rocosos, de los que solo son accesibles, aun siendo muy empinadas, sus laderas orientales. El castillo resaltes rocosos, de los que solo son accesibles, aun siendo muy empinadas, sus laderas orientales. El castillo y las otras dos elevaciones secundarias, que forman hacia el sur un arco de aproximadamente 1000 pasos, coronan y dominan completamente el cerro y constituyen el terreno sobre el cual, a comienzos del año anterior y en el espacio de unos pocos meses, fue levantado como por arte de magia un fuerte casi inexpugnable. La propia población se halla en la depresión formada por estas tres cimas, pegada a los pies del castillo, de forma que la iglesia, emplazada como es costumbre en la parte alta de la población, no solo permite con su elevada torre la vista al interior del castillo, sino que se halla separada del mismo por apenas 50 pasos en línea recta" (Von Rahden, 2013: 280).

El jefe de ingenieros llega a Segura cuando ya habían comenzado las obras de fortificación, dejando constancia de que casi 3000 hombres estaban quitando escombros y acarreando piedras, madera y ladrillos. Se había derrumbado parte de la muralla del recinto exterior, posiblemente a causa de una brecha abierta en un asedio previo, y se encontraban rellenándola 30 albañiles (Von Rahden, 2013: 291). "En otro lugar se levantaban impresionantes andamiajes de madera para acceder al segundo y tercer piso de este coloso de piedra, cuyas torres [...] se hallaban en ruinas. [...] Casi 3000 quintos trabajaban en la construcción del castillo, cuyo estilo constructivo era tan grandioso, con su amplio perimetro y su notable xtensión en todas las direcciones, que permitía emplazar la artillería en tres nivel de fuego de fusilería. En cambio, dado el carácter mayoritariamente rectilíneo de la planta, no había lugar apenas para variaciones ni fuego de flanqueo. Aproximadamente 4000 infantes y 400 caballos estaban a cargo de la protección de la construcción. Pasamos [...] los tres o cuatro primeros días en permanente espera de un ataque y [Cabrera] [...] acrecentaba con su ejemplo personal de tal manera la capacidad de trabajo de sus subordinados que la actividad incesante, día y noche, produjo realmente resultados extraordinarios" (Von Rahden, 2013: 294).

Cabrera ordena derribar las viviendas y cercados de las inmediaciones del castillo y que pueden servir de abrigo al enemigo (Diario Mercantil de Valencia, 14 de abril de 1839; Caridad, 2013:259). (n) concluidas y se puede hacer frente a la ofensiva, a pesar de que bombardean el fuerte. Con un ataque nocturno, Cabrera consigue que los liberales de Ayerbe se retiren. Después hace quemar el pueblo, acusando a los habitantes de colaborar con el enemigo. Dos días más tarde llega a Segura Van Halen con su

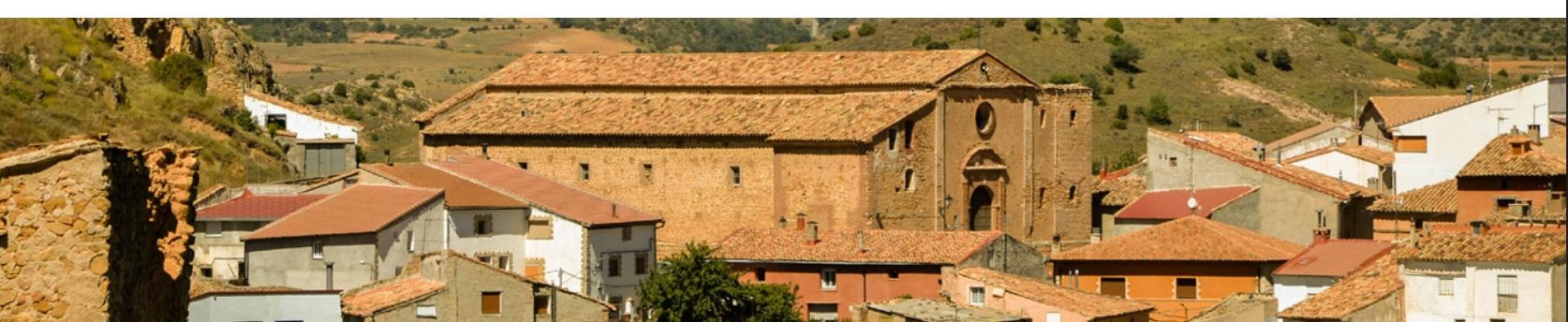




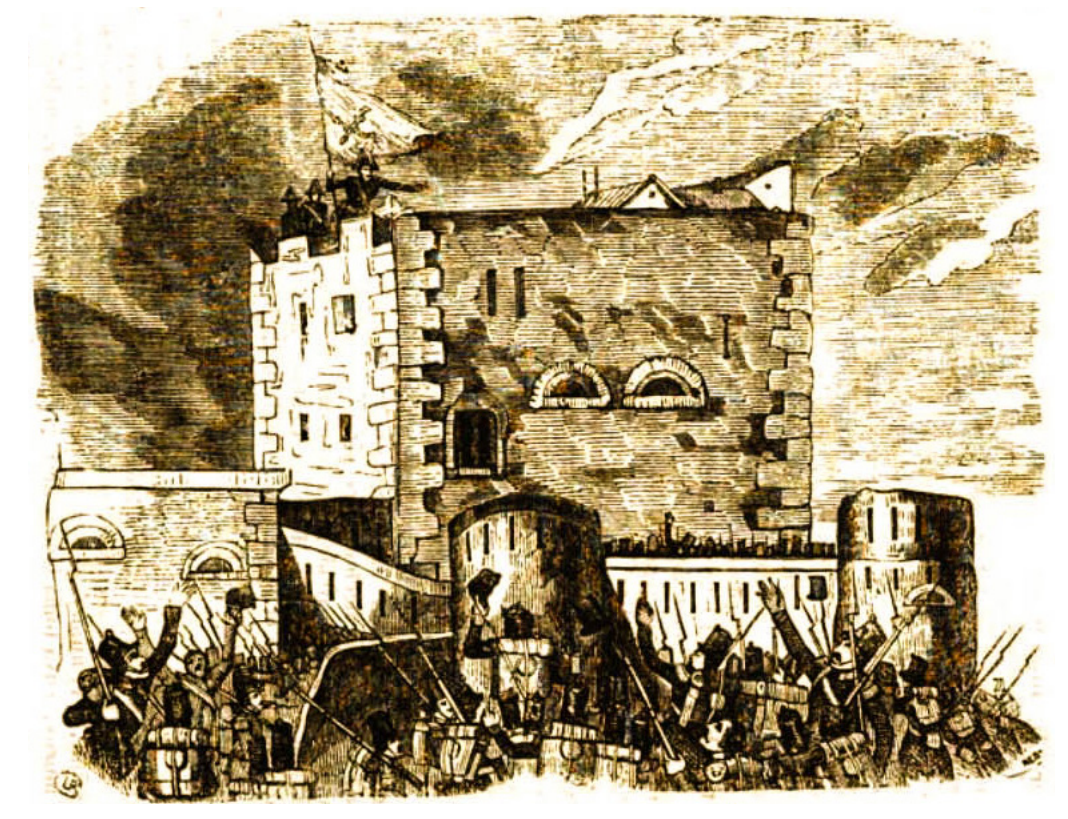

Fig. 718. Ilustración 3. Toma de Segura.

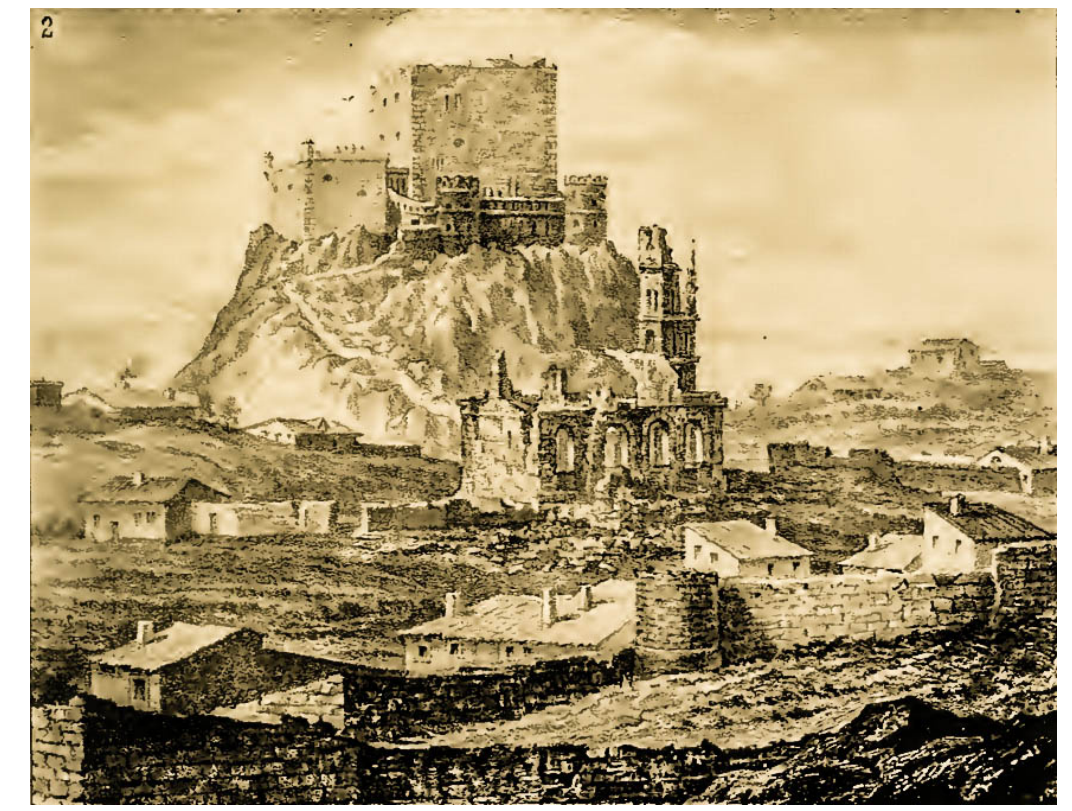

Fig. 720. Ilustración 5. Toma de

Segura.

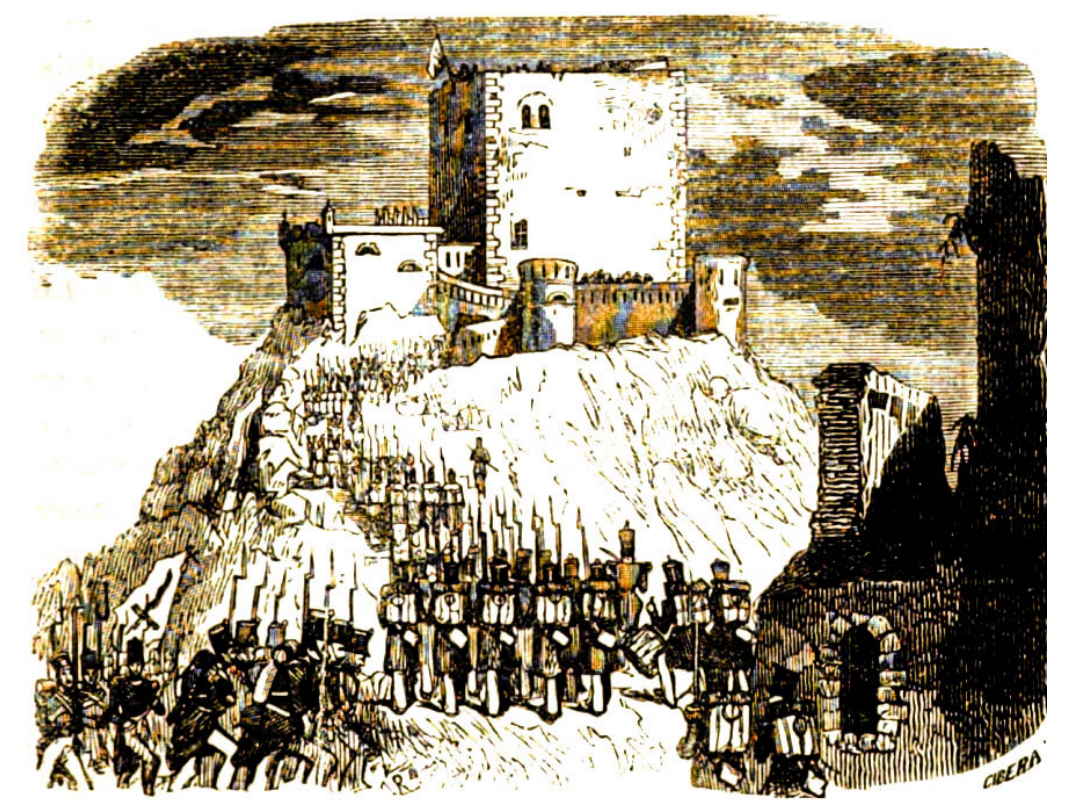

Fig. 721. Alzado sureste de las ruinas del castillo de Segura y alzado sur de un reducto en la meseta oriental de Segura.

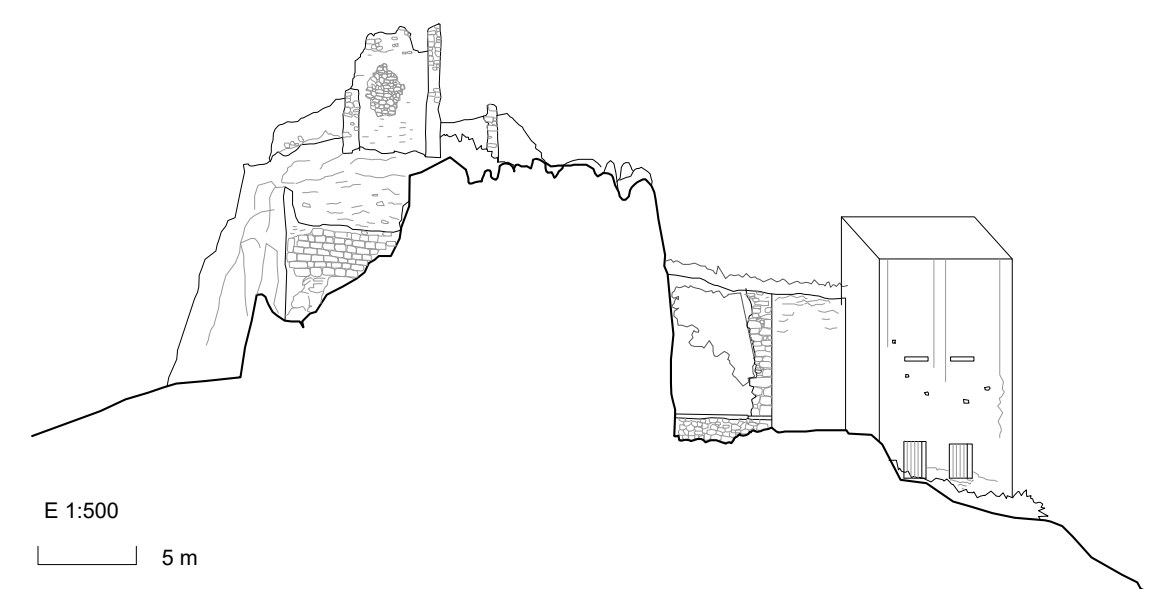

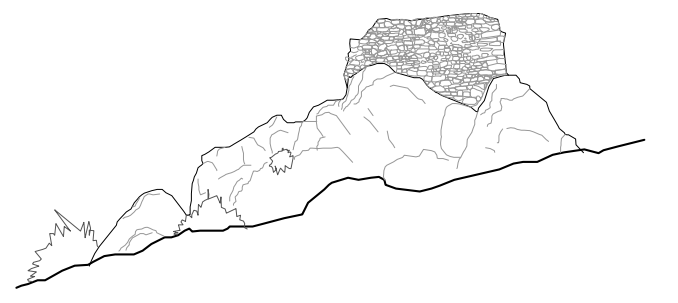


Fig. 722. Planta general de Segura con los puntos de interés en la actualidad.

01. Ruinas de la fortificación

02. Ayuntamiento

03. Iglesia de San Juan Bautista

04. Castillo de Segura

05. Lavadero

06. Nevera

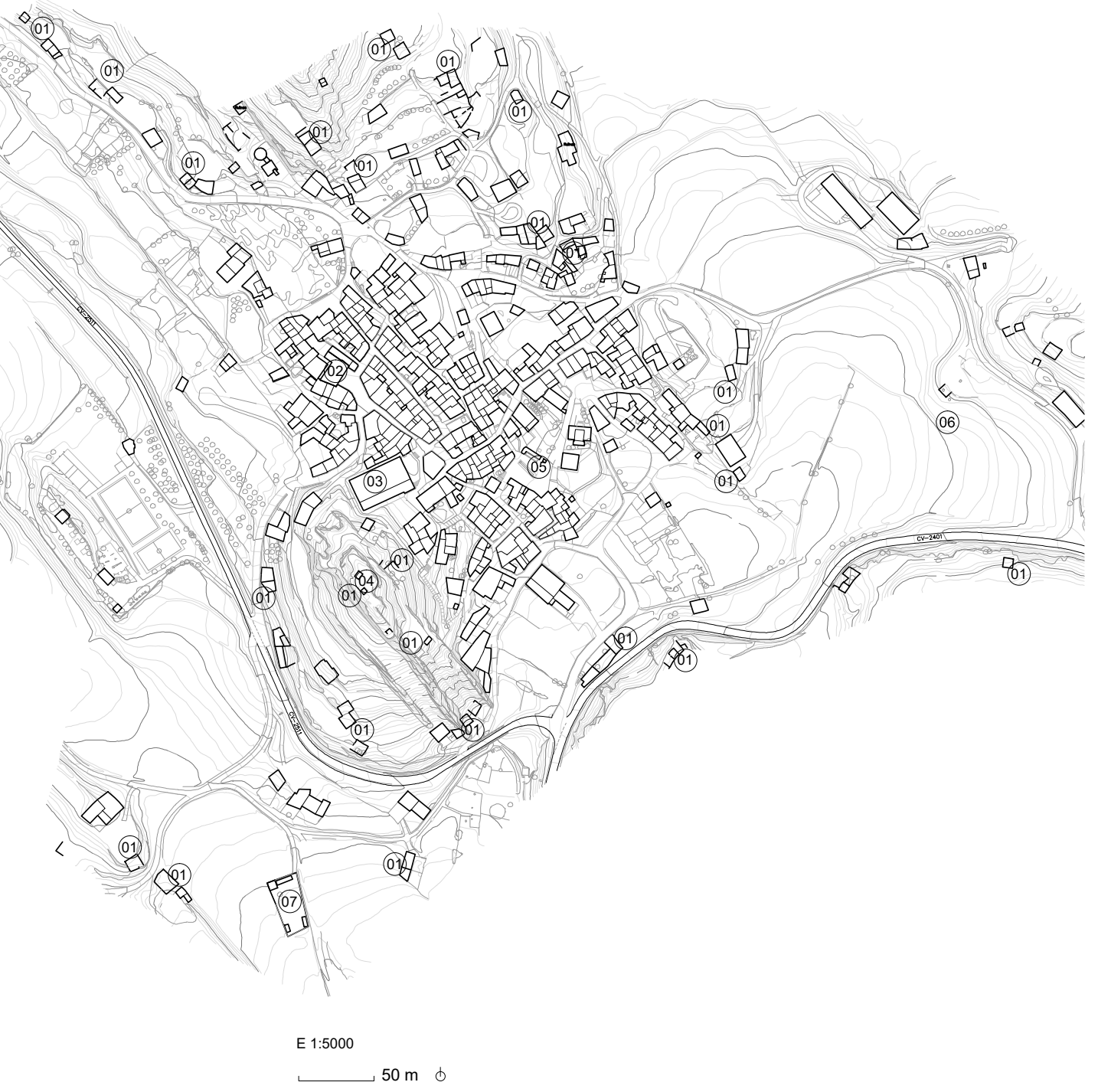

64 Tales $^{*}$

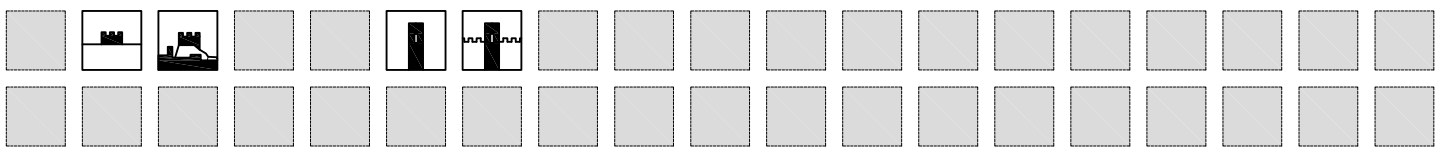




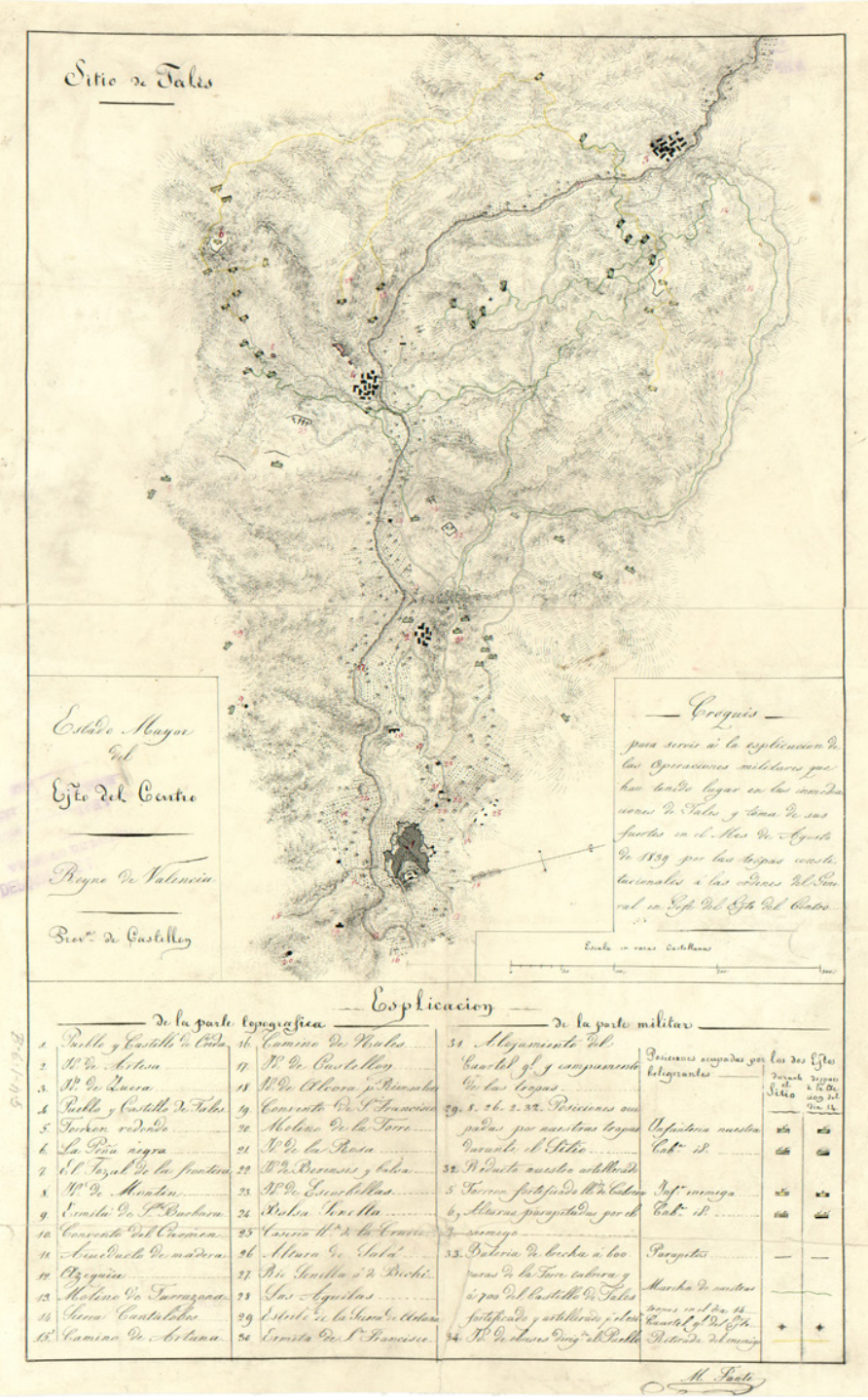

Fig. 727. Plano 1. Sitio de Tales y toma de sus fuertes en el mes de agosto de 1839 .
Hoy en día, a pesar del proceso destructivo que vive en este periodo, que queda testimoniado en el escudo de la ciudad, sobreviven restos de la construcción carlista que se apoyan sobre los estratos de la primera y segunda fases medievales. Consisten en una porción de lienzo y el torreón semicircular central, el lienzo y el torreón semicircular oriental, la habilitación del aljibe y la pared de lo que podría ser el refugio de la guarnición. En estas obras, especialmente en los torreones, se identifica con claridad el modo general de actuar: acumulación de fábrica de piedra en seco aprovechando ca con claridad el modo general de actuar:
la base de las fortificaciones preexistentes.

\section{Planos históricos:}

Plano 1

Título uniforme: Tales (Castellón). Asedios (1839). 1:45000

Título: Sitio de Tales, pueblo de la prova. de Castellón en el reino de Valencia: croquis para servir á la esplicación de las operaciones militares... y toma de sus fuertes en el mes de agosto de 1839 Publicación: 184-?

Descripción física: 1 mapa: montado sobre tela; $15 \times 19,5 \mathrm{~cm}$, en $\mathrm{h}$. de 30,5×20, $7 \mathrm{~cm}$

Notas: Relieve representado por normales. Relación de la topografía y baterias indicadas por clave numérica. Tabla de signos convencionales para indicar las posiciones de ambos ejércitos. Inserta: vista de Tales desde Artesa

Ejemplares: Archivo Cartográfico de Estudios Geográficos del Centro Geográfico del Ejército Ubicación: AR - Signatura: Ar.G-T.2-C.2-103 - Código de barras: 2210371

\section{Plano 2}

Título uniforme: Tales (Castellón). Asedios (1839). 1:26000

Título: Sitio de Tales: croquis para servir a la esplicación de las Operaciones militares... en el Mes de Agosto de 1839 por las tropas constitucionales a las órdenes del General en Gefe del Ejto. del Centro / M. Fanti

Publicación: 184-?

Descripción física: 1 mapa: ms., col., montado sobre tela ; 31,7×25,8 cm, en h. de 46,5×28 cm

Notas: Manuscrito firmado y rubricado. A plumilla en tinta negra, verde, carmín y amarillo. Orientado con flecha. Relieve representado por normales. Relación de la topografía y baterias indicadas por clave numérica. Tabla de signos convencionales y cromáticos para indicar las posiciones de ambos ejércitos. En el ángulo inferior izquierdo, 'Estado Mayor del Ejto. del Centro, Reyno de Valencia, Prova. de Castellón'

Ejemplares: Archivo Cartográfico de Estudios Geográficos del Centro Geográfico del Ejército Ubicación: AR - Signatura: Ar.G-T.2-C.2-102 - Código de barras: 2210370

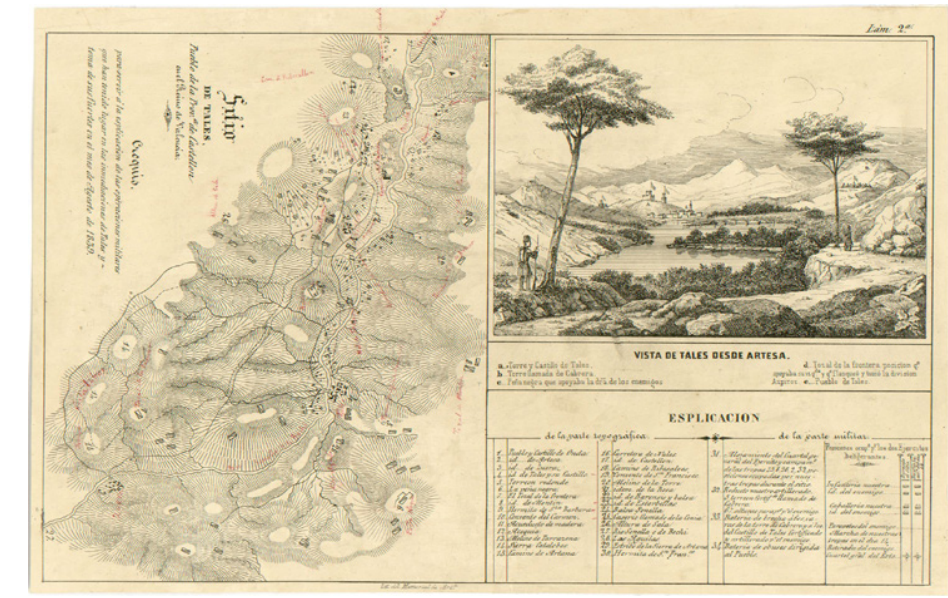




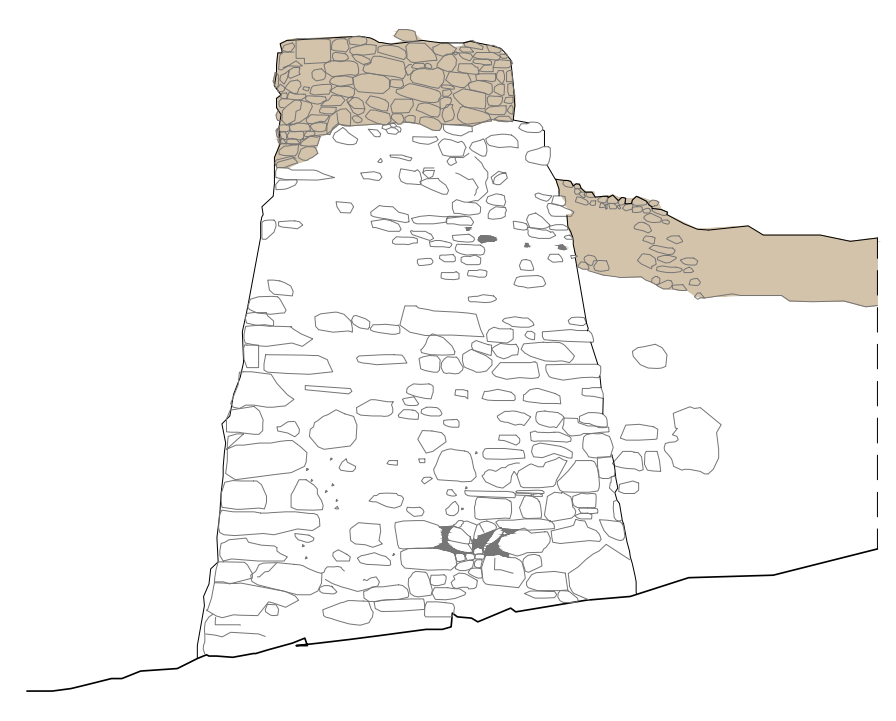

Fig. 729. Alzado occidental del tambor carlista meridional del castillo de Tales.

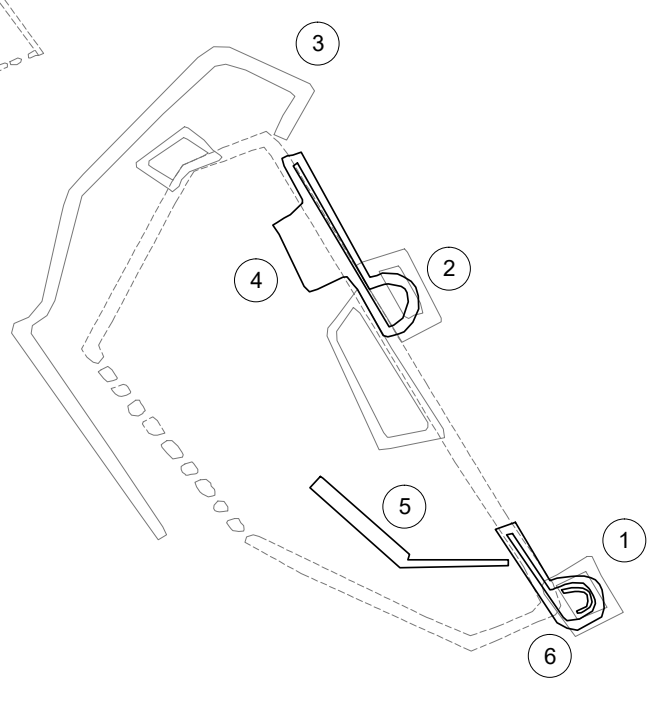

65 torre de Castro (Calles) *

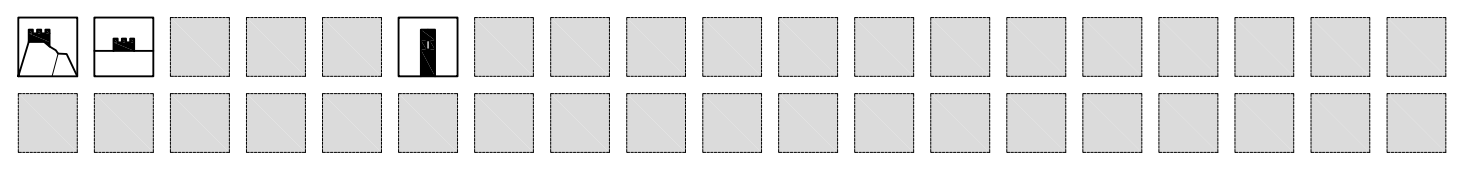


Fig. 731. Panorámica desde las ruinas de unos posibles corrales que dan acceso a la cumbre de Torre de Castro. Fig. 732. Panorámica hacia la cumbre, que queda a la derecha de la imagen.

Fig. 733. Cumbre. Se aprecia que no quedan vestigios de la torre.
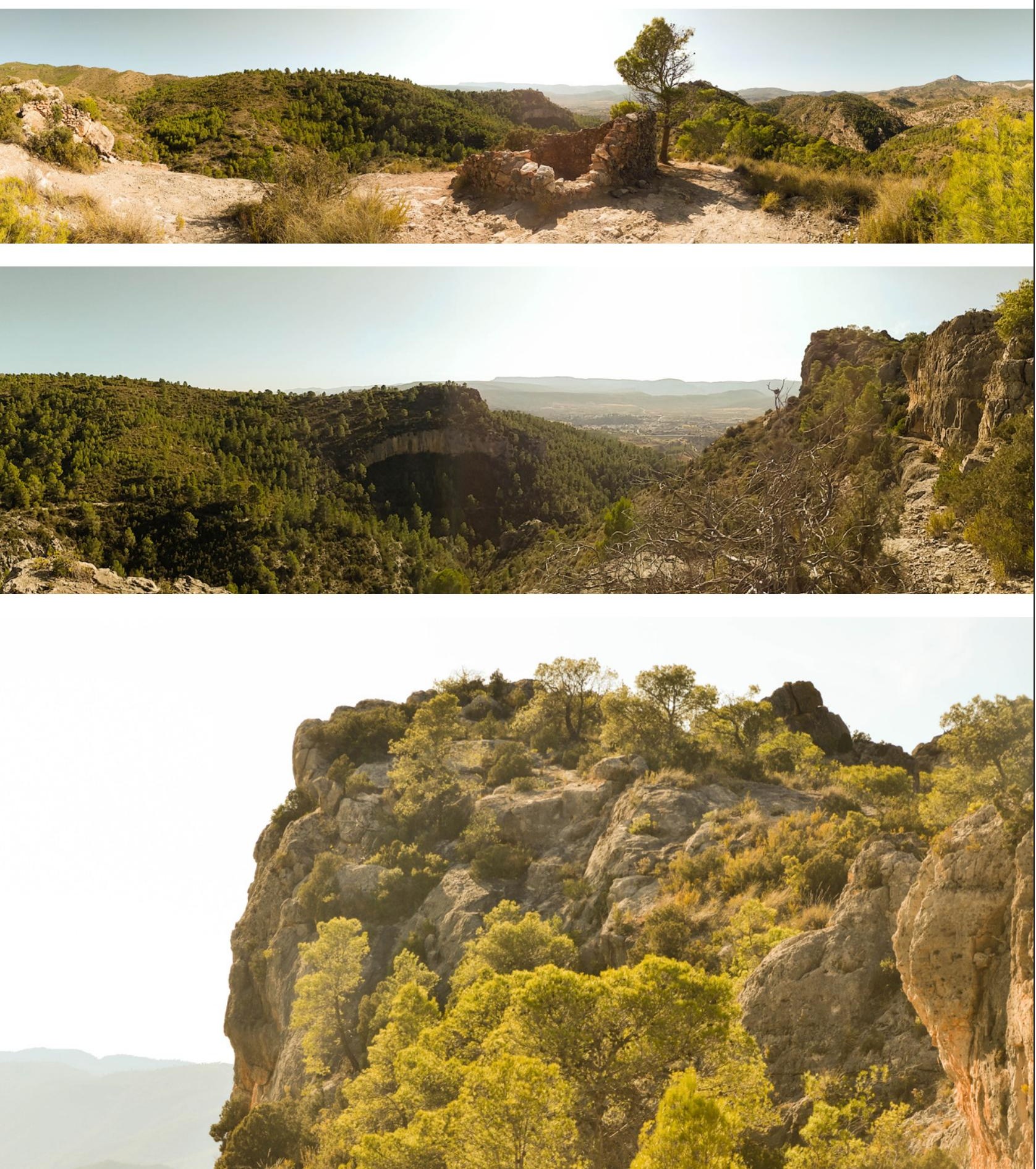

Torre de Castro en Calles

Localidad en castellano / valenciano: Torre de Castro en Calles

Provincia actual: Valencia

Comarca: Los Serranos

Coordenadas geográficas: $39.744077000184944,-0.9595740455275745$.

Tipos defensivos: fuerte roquero, fuerte aislado, torre.

Acciones y fortificación:

En julio de 1839 los carlistas refuerzan fortificaciones, entre las que se encuentran la Torre de Castro (Calles), Domeño, Chulilla, Villarluengo, Ares del Maestre, La Fresneda y Beteta (Caridad, 2013: 262). El origen de la construcción es una torre medieval de mediados del siglo XIV. Parece datar de la Guerra de los Dos Pedros.

El enclave constituye un mirador privilegiado para dominar el Pico Ropé (Chelva), Calles, el acueducto de Peña Cortada y el castillo de Domeño, también fortificado por los carlistas. Llama la atención que en sus proximidades se hallan caleras y corrales.

Según Calbo y Rochina el fuerte de Castro "consistía en un fuerte y antiguo torreon situado en un monte prócsimo al pueblo de Calles, desde el cual ponian los carlistas en contribucion los inmediatos, hostilizando infinito con interceptar las comunicaciones entre Chelva y Domeño". Los liberales solo pueden acceder desde un lado, pues el resto es inaccesible y los carlistas se defienden con un nutrido fuego de fusilería y lanzando piedras (Calbo y Rochina, 1845: 453). Los liberales tienen que recurrir a una mina para tomarlo. Antes de que esta estalle, los carlistas se rinden. Tras la rendición, los liberales destruyen la posición en 1839 mediante voladura para evitar que sea ocupada de nuevo por carlistas o bandoleros. No hay restos de la misma en la actualidad, aunque sí unos corrales cercanos.

Azpiroz conquista Chelva y sus fortificaciones a finales de 1839, habiendo sido abandonadas por sus defensores (Diario Mercantil de Valencia, 15 de noviembre de 1839; Córdoba, 1844-1845: v. 4, 168; Caridad, 2013:265). Más adelante caen Torre de Castro (Archivo de la Diputación Provincial de Castellón, colección de actas de 1839, folio 232; Caridad, 2013: 265), Manzanera (Diario Mercantil de Valencia, 17 y 18 de noviembre de 1839; Caridad, 2013:265) y Chulilla (Diario Mercantil de Valencia, 31 de diciembre de 1839; Caridad, 2013:265), pero el número de fortificaciones carlistas aumenta. Esta fortificación se eleva sobre un peñasco en las estribaciones del Remedio, justo en su ladera este. Contaba con un muro perimetral de poca altura y una torre almenada, cuyas porciones este y sur eran de tapia. En la parte septentrional aparecían unos espacios abovedados. Dominaba a 611 m la rambla de Alcotas. Parece que el asentamiento original data de 1390. La torre contaba con dos niveles, en el segundo se observaban espacios de bóveda apuntada. Con toda probabilidad la plataforma aspillerada superior fuera obra de los carlistas. Bajo la misma se encontraba un aljibe (Sebastián Fabuel, 2001:994). Un plano en tinta negra y acuarela del Archivo Cartográfico de Estudios Geográficos del Centro Geográfico del Ejército (Sign. Ar.G-T.3-C.2-265) que indica que la “Torre está situada a media hora de Calles, y a la derecha del Camino de Domeño y Chelva... Fué defendida por ochenta hombres de la facción del Cabecilla Arevalo y Tomada por las tropas de la Legitimidad que componen la primera División del Ejército del Centro el 22 de Noviembre. de 1839".

Hoy en día no pervive nada, salvo el asentamiento de esta posición. La dificultad del acceso a través de la ladera y sus limitadas posibilidades visuales, especialmente en dirección al pico del Remedio, y abriéndose hacia la localidad de Calles, con escasa posibilidad de hostilizar vías significativas de comunicación, hacen sospechar que la posición simplemente sirviera para vigilar el tránsito a través de esta zona inmediata y su misión fundamental fuera la de servir de reducto, cobijo y escondrijo de aquellos que, desde el lugar, efectuaban razias por la zona. Así parece interpretarse del comentario de Calbo y Rochina recogido con anterioridad, en el que afirma que "desde el cual ponían en contribude Calbo y Rochina recogido con anterioridad, en el que afirma que "desde el cual ponian en contribu-
ción lodiatos, hostilizando infinito con interceptar la comunicaciones entre Chelva y Domeño" (Calbo y Rochina, 1845: 453). 


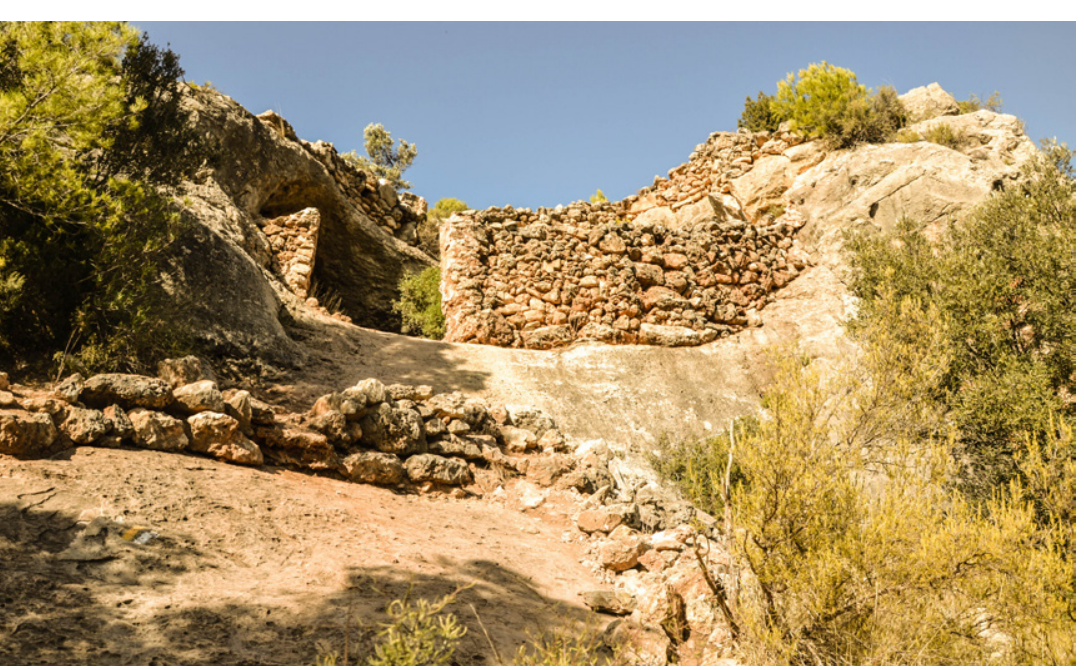

Fig. 734. Acceso a la cumbre a través de una cueva usada posteriori como corral

Fig. 735. Restos de la salida de la cueva que da acceso a la cumbre.

Fig. 736. Restos de la salida de la cueva que da acceso a la cumbre.
Planos históricos:

Plano 1

Título uniforme CALLES (Valencia). Torre de Castro. Torres (1839). 1:240

Título: Plano perfil y vista de la Torre de Castro / [Oficiales de E.M. de la 1 Division del Ejto. del Centro]

Publicación: 184-

Descripción física: 1 plano: ms., col., montado sobre tela : $22,5 \times 16,2 \mathrm{~cm}$, en h. de $24,1 \times 37 \mathrm{~cm}$

Notas: Presenta el plano de la planta, perfil y alzado de la torre. Mención de responsabilidad tomada del Catálogo del SG: 'Región Valenciana, Provincias de Castellón y Valencia. Siglos XVI a XIX, 1790, p. 265. Manuscrito a plumilla en tinta negra e iluminado a la acuarela en siena y gris. Orientado con flecha. Nota indicando que 'Esta Torre está situada a media hora de Calles, y a la derecha del Camino de Domeño y Chelva... Fué defendida por ochenta hombres de la faccion del Cabecilla primera División del Ejercito cumento E00461) entelado junto con la copia.

Ejemplares: Archivo Cartográfico de Estudios Geográficos del Centro Geográfico del Ejército Ubicación: AR - Signatura: Ar.G-T.3-C.2-265 - Código de barras: 2210622. sección de la Torre de Castro, fechado el 22 de noviembre de

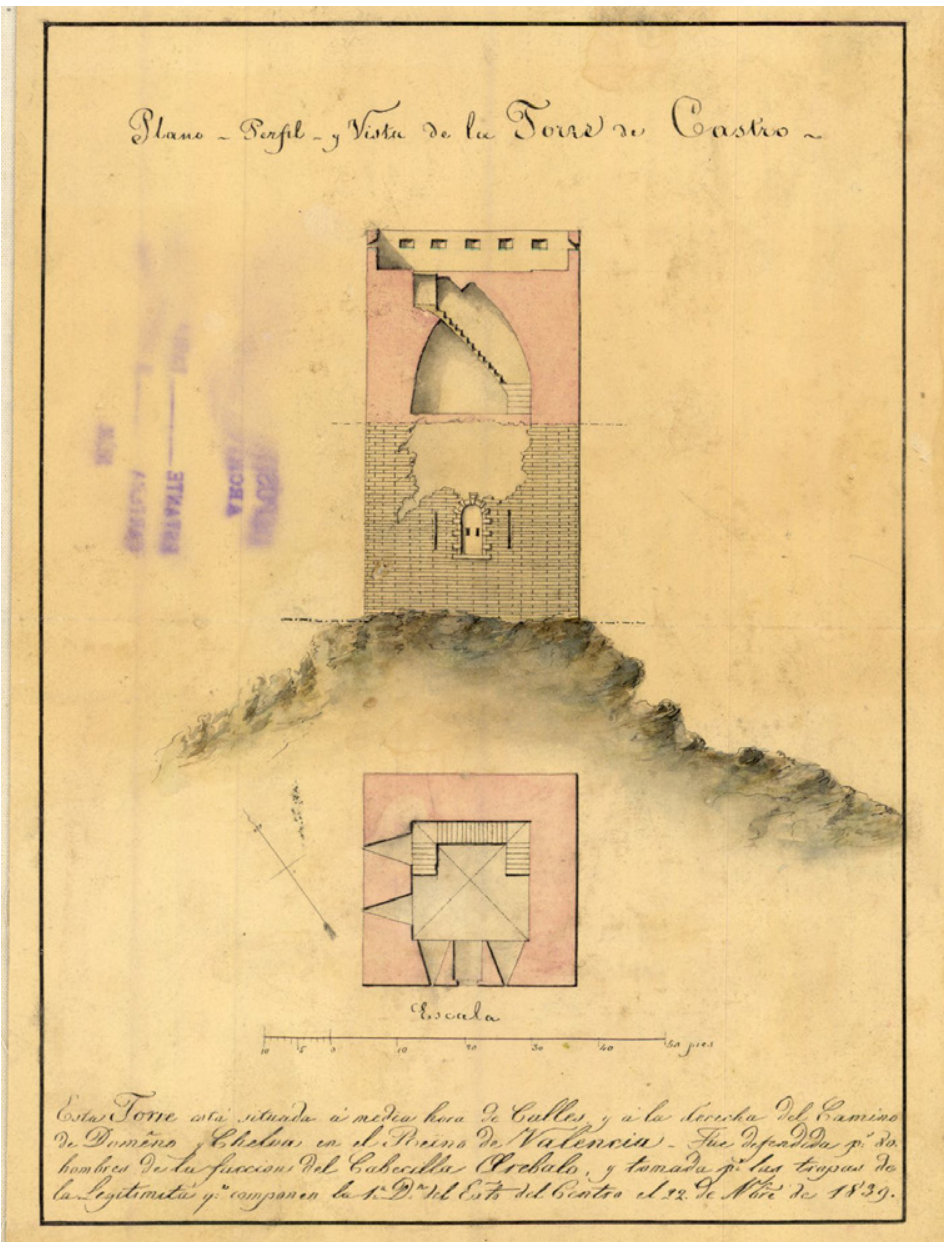



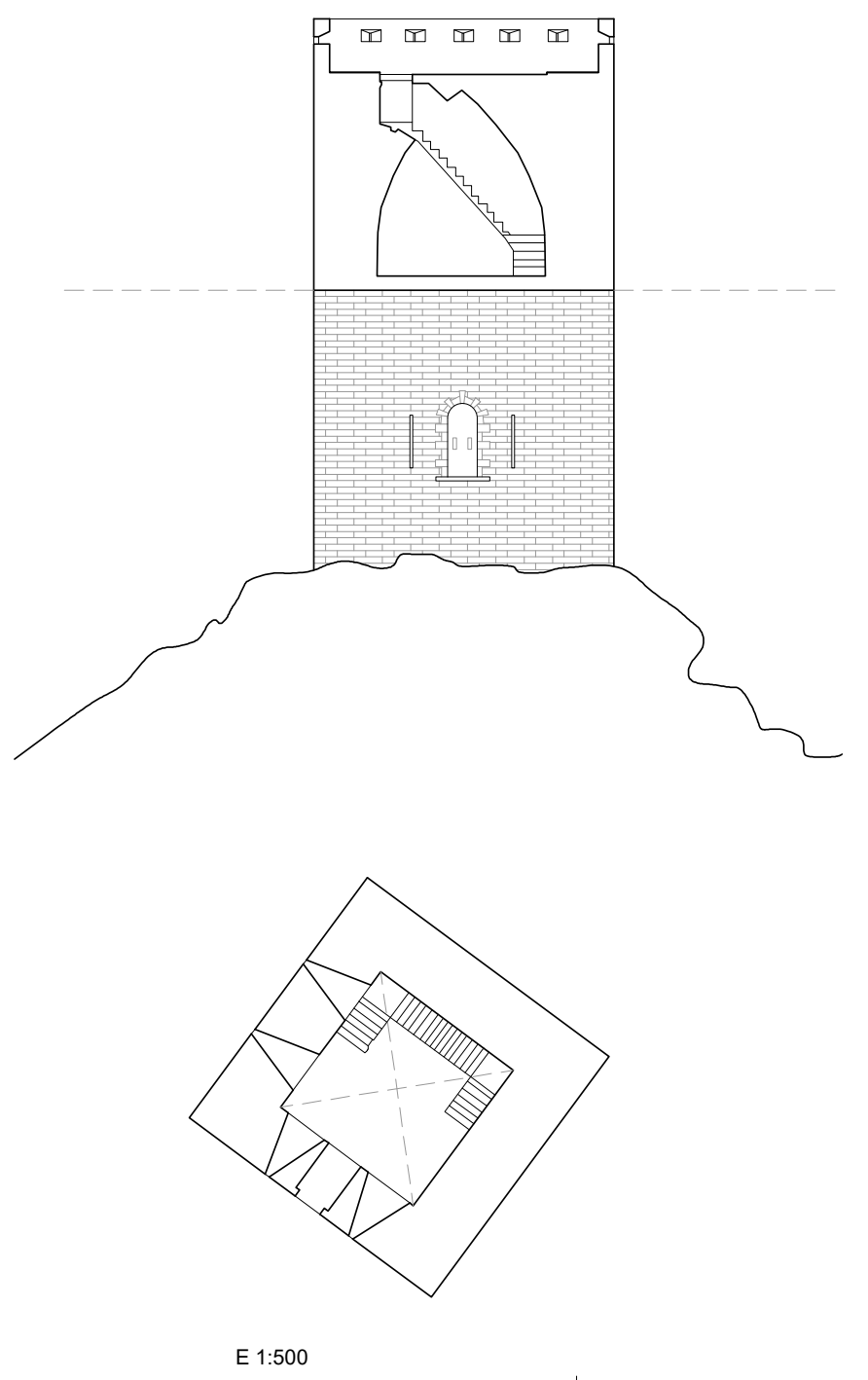

66 Torrebaja $*$

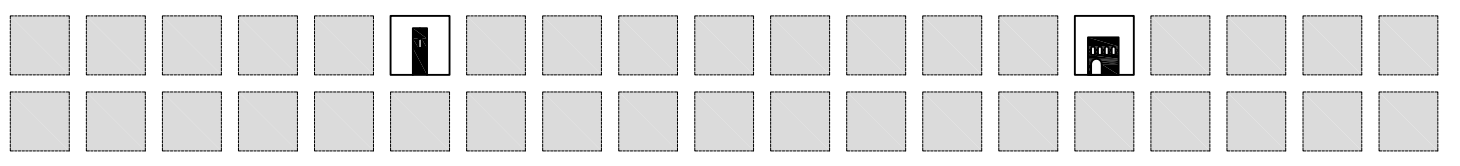




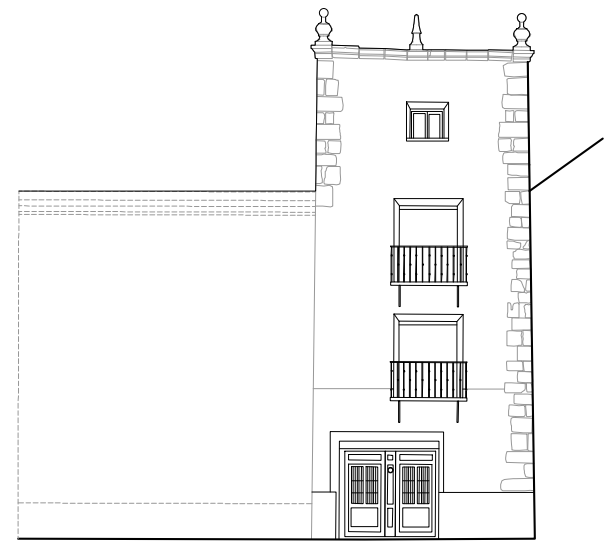

$\stackrel{\text { E1:200 }}{\underbrace{}_{1 m}} \quad 0$

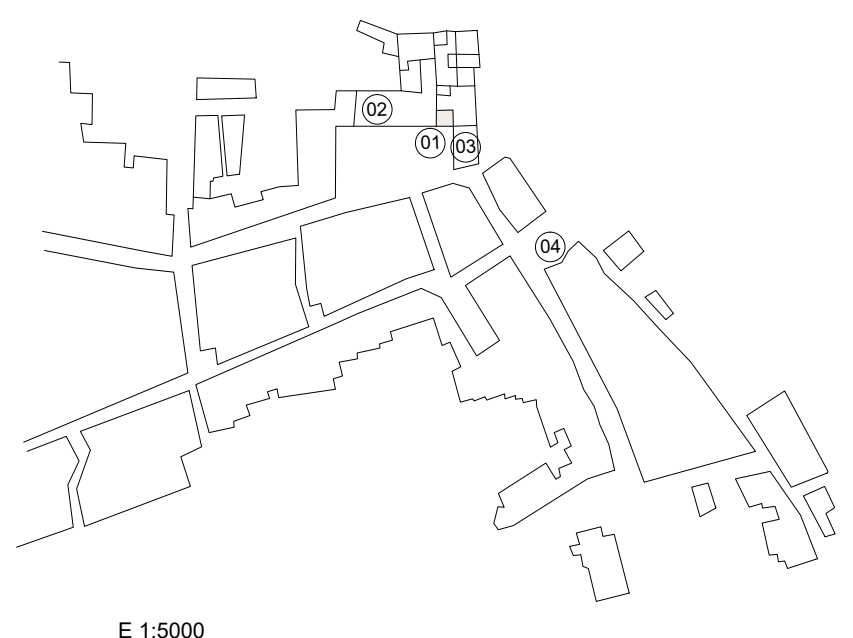

E 1:5000
Fig. 741. Alzado de la Torre de los Picos.

67 Torrectila del Reboltar

Gigaliza-

ción de la torre de los Picos en Torrebaja.

02. Antigua Casa Grande del

Mayorazgo de Torrebaja

03. Emplazamiento de laantigua casa consistorial (actual ayuntamiento)

04. Iglesia Parroquial de Santa Marina 


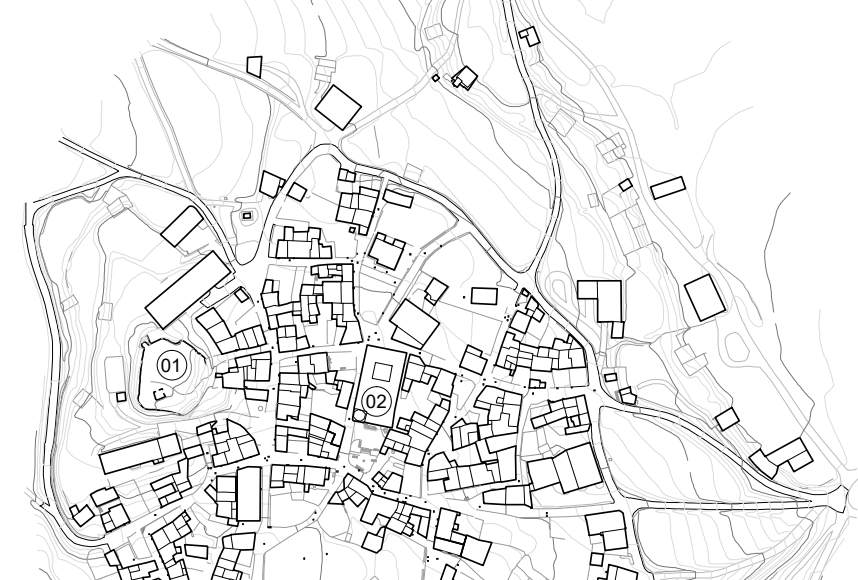

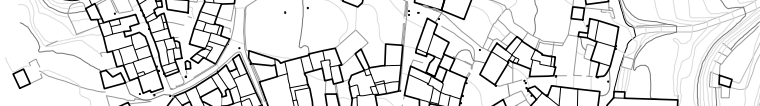

8 asen a

08 espor 03

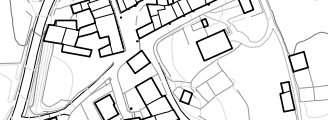

- 5 a

E 1:5000

Fig. 749. Planta general de Torrecilla del Rebollar en la actualidad.

01. Ruinas de la fortificación

02. Iglesia de San Cristóbal

03. Casa fortificada. Muro

aspillerado.

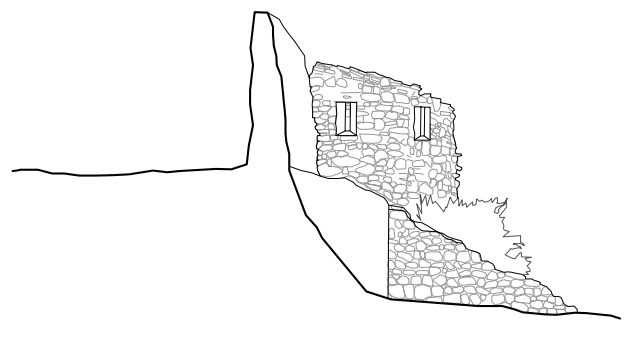


Torrijas

Provincia actual: Teruel

Comarca: Gúdar-Javalambre

Coordenadas geográficas: $40.0235593655444,-0.9573770359189666$.

Tipos defensivos: frente escalonado, punto estratégico de paso y abastecimiento.

Acciones y fortificación:

En Torrijas se registra actividad de liberales y carlistas, pues es un paso frecuente en las rutas carlistas y así lo reconoce, por ejemplo, Von Rahden, cuando indica que en el mes de abril 1839, "Yo avancé por Alcora y Montán hacia Torrijas, visité Chelva, Alpuente y Castielfabib y regresé por Alcalá de la Selva a Cantavieja y Morella" (Von Rahden, 2013: 406).

La División del Turia informa haber pernoctado en Torrijas, con el $1^{\circ}$ de Mora y granaderos del Cid. Alertados de la presencia de una columna enemiga, con 3 batallones y "bastante caballería" en Manzanera, redoblan la vigilancia del pueblo. "Serían las doce y media cuando los puntos avanzados me avisaron de la próxima llegada del enemigo, siéndome preciso dirijirme sobre el barranco que hay al medio de dicho pueblo, para atravesar á la parte del Villar. Con efecto el enemigo llegó, y hallándome en posiciones ventajosas le convidé al combate, que despreció, quedando campado junto al pueblo, y ya bien entrada la tarde emprendi la marcha para Canales, donde llegué a las doce de la noche" (Córdoba, 1844: 299). Por lo que se emprendi la marcha para Canales, donde llegué a las doce de la noche" (Córdoba, 1844: 299). Por lo que se
aprecia en las fuentes, Torrijas, además de ser punto de paso de los ejércitos, sirve de apoyo, pero aprecia en las fuentes, Torrijas, además de ser punto de paso de los ejércitos, sirve de apoyo, pero ciones, salvo las que proporciona la naturaleza o el frente de la localidad. En el interior, la iglesia de San Cosme y San Damián, compacta, del siglo XVIII, dispone de un elevado campanario que haría las funciones de torre de vigilancia. El ayuntamiento, con sus porches, albergaba unos antiguos calabozos a los que no se hace mención en las fuentes.

Fig. 751. Torrijas desde la carretera que se dirige a Arcos de las Salinas. Se observa su presencia en lo alto de una loma y la iglesia de San Cosme y San Damián.

Fig. 752. Acceso oeste a la población, con sucesivos muros y posición predominante de la iglesia y su torre campanario.
Fig. 753. Esquema en planta de Torrijas con los puntos $\mathrm{d}$ interés.

01. Iglesia de San Cosme y San Damián

02. Carretera A-1514, de Arcos de las Salinas (oeste) a Manzanera (este)

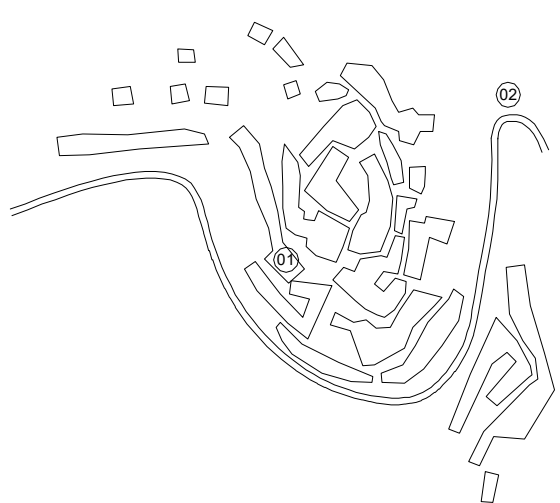

$\longleftarrow 50 \mathrm{~m} \mathrm{E}$ 1:7500 d 
$69_{\text {TracACrte }}$

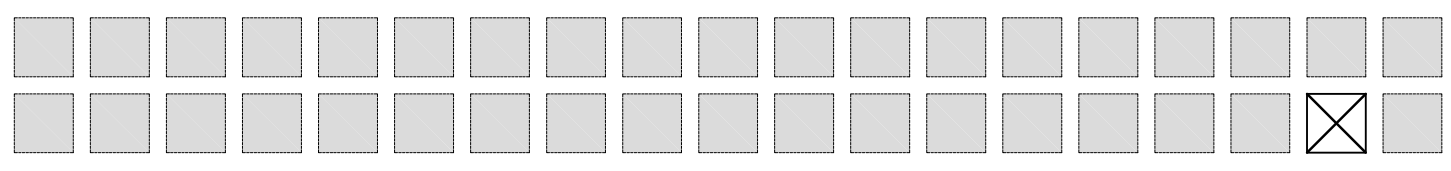


70 ULbecona 
Fig. 762. Esquema en planta del castillo de Ulldecona.

71 Чтек
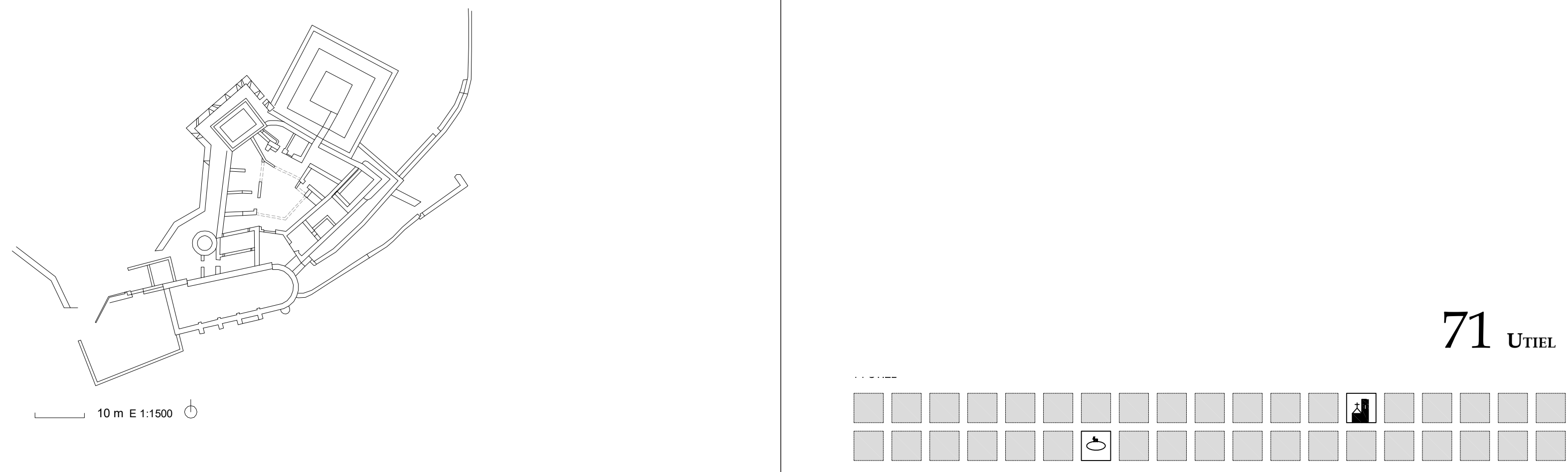


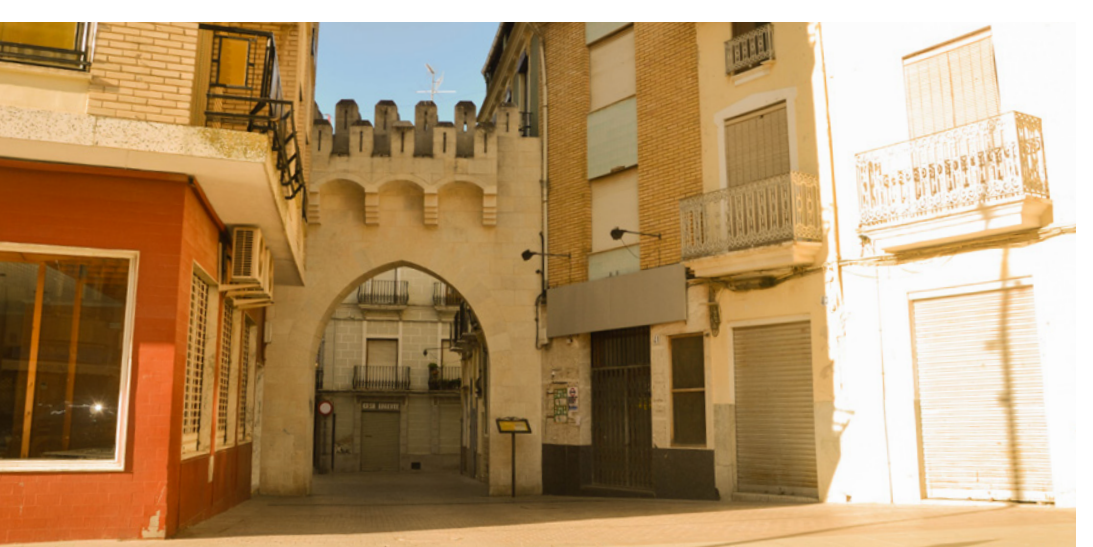

Fig. 763. Reconstrucción de la Puerta de las Eras (02 en fig. 5).

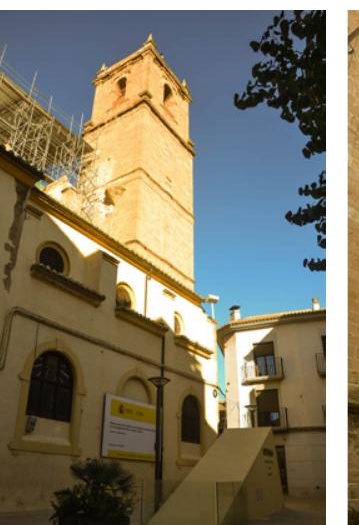

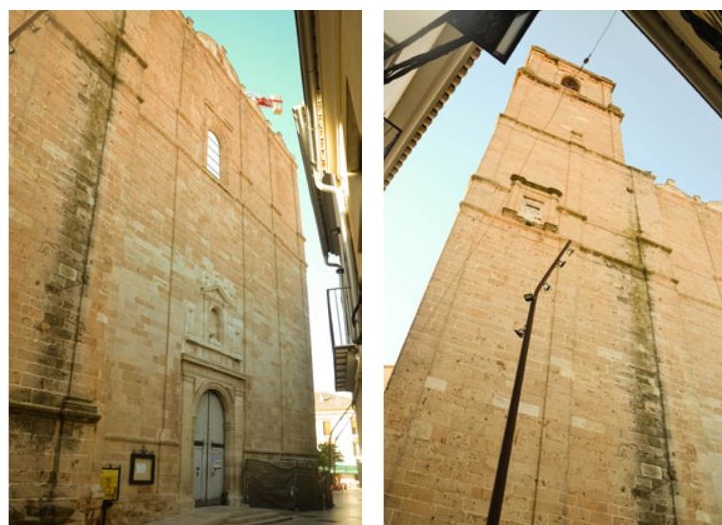

Figs. 764, 765, 766. Iglesia y torre campanario de Utiel, refugio de las tropas defensoras de la plaza durante los asedios.
Utiel

Localidad en castellano / valenciano: Utiel

Provincia actual: Valenci

Comarca: Requena-Utiel

Coordenadas geográficas: 39.56706800056568, -1.2054492397324452.

Tipos defensivos: fortificación de iglesias, eras.

Acciones y fortificación:

A finales de septiembre de 1835 los carlistas ocupan Utiel con 1200 hombres y 50 caballos, y al día siguiente intentan tomar Requena sin éxito, siendo expulsados de la zona y perseguidos por los cristinos (Diario Mercantil de Valencia, 8 de octubre de 1835; Córdoba, 1815: v. 1, 204, 205; Calbo y Rochina, 1845: 115 y 116).

En el verano de 1836, José Millán, conocido como el Arcipreste de Moya, levanta con el consentimiento de Cabrera una partida en la provincia de Cuenca de 25 a 30 infantes y 6 caballos, con los que en agosto empieza a operar cerca de Utiel y en septiembre ataca la población. Los liberales se quentan en campanaro de la iglesia cuand listas tienen que retirarse (Caridad, 2014: 432; Ballesteros, 1999: 625-627; Diario de Avisos de la Ciudad
de Valencia, 13 de septiembre de 1836).

Poco después, el 12 de septiembre de 1836, se unen en Utiel los hombres de la expedición de Gómez, Cabrera con su estado mayor y una pequeña escolta, las fuerzas de Quílez y las del Serrador. Intentan la toma de Requena con el máximo número de fuerzas, pero, al no poder conquistarla, la expedición continúa su camino dirigiéndose a Albacete con las nuevas fuerzas incorporadas, dejando las calles con tantos despojos de reses que hubo que despejarlas apresuradamente para evitar una epidemia (Caridad, 2014: 67, 137; Delgado, 1943: 46; Córdoba, 1815: v. 2, 92, 93). En julio de 1837, las tropas de Tallada y de Llagostera hacen incursiones por la zona y entran en la que están construyendo (Caridad, 2014: 512; Diario Mercantil de Valencia, 10 de julio de 1837. Ballesque están construyen 1999: 633, 637)

teros, 1999: 633, 637).
Miguel Sancho, "el Fraile de la Esperanza", ocupa Utiel en octubre de 1837, retirándose después a Alpuente (Caridad, 2014: 504; Ballesteros, 1999: 639).

En enero de 1838 vuelven a entrar en Utiel los carlistas y parece que permanecen en la zona unos meses (Caridad, 2014: 535; Ballesteros, 1999: 645, 646).

La población va pasando de manos durante la guerra, pues el 5 de febrero de 1839 Arnau es derrotado en Utiel por Iriarte, que en inicio finge la retirada y acaba haciendo 143 prisioneros. (Caridad, 2014: 237; Diario Mercantil de Valencia, 8 y 10 de febrero de 1839. Pirala, 1869: v. 5, 289).

En abril de 1839 Arévalo llega a Utiel exigiendo una abultada contribución de guerra y, al no poder En abril de 1839 Arévalo llega a Utiel exigiendo una abultada contribución de guerra y, al no poder
ser pagada, se lleva a numerosos rehenes, entre ellos muchas mujeres (Caridad, 2014: 222; Ballesteros, 1999: 661; Diario Mercantil de Valencia, 5 de abril de 1839). En otoño vuelve a pasar por Utiel y se hace allí con un convoy de víveres, paños y calzado que iba destinado a su ejército (Caridad, 2014: 222; Von Goeben, 1966: 313).

En diciembre de ese mismo año, Arnau ocupa Utiel con varios batallones y es atacado por los liberales. Llagostera acude para socorrerle, pero deben abandonar la población (Córdoba, 1815: v. 3, 481).

Pérez Galdós en La campaña del Maestrazgo narra el recorrido de un personaje, don Beltrán de Urdanera, y en cuanto al paso de este por Utiel indica que "determinó Cabrera fotificar a Utiel, y lo primero que puso mano fue el Convento o Colegio de Escolapios y la iglesia parroquial, gótica, de buena y sólida. Para despejar las inmediaciones del primero de aquellos edificios, mandó demoler varias casas y cortar 
todos los árboles de una alameda que al camino salía. Empleáronse en tales obras, noche y día, multitud de hombres..." (Pérez Galdós, 1993: 2452).

Cuando Pérez Galdós escribe la novela, el citado Convento o Colegio de Escolapios no pertenece a la misma orden religiosa que durante la Primera Guerra Carlista, pues anteriormente había pertenecido a la de los franciscanos, según afirma la noticia publicada el 10 de agosto de 1869 en el diario Las Provincias. "El ayuntamiento de Utiel, entre otras mejoras que introduce en la población, ... ha dievado a cabo una de grande importancia para la enseñanza, la fundación de un colegio de padres escolapios, llevado a cabo una de grande importancia para la enseñanza, la fundación de un colegio de padres escolapios, de padres franciscanos, que por las grandes obras que se han hecho, queda completamente renovado, reuniendo a la vez por su capacidad y posición las mejores condiciones para la enseñanza. Situado en lo más alto de la población, domina un hermoso horizonte y hace más agradable su situación la circunstancia de hallarse rodeado por todas partes menos por la fachada principal, de una gran viña cercada de pared. Esta viña, sustituida por arboleda, ofrecerá a los alumnos internos un local espacioso para recreo y para los ejercicios de gimnasia y equitación. Tan buenos alrededores no desdicen de lo grandioso del establecimiento. La planta baja, la ocupan las escuelas que por lo espaciosas y bien ventiladas pueden competir con las primeras de la provincia. El piso $1^{\circ}$ estará ocupado por la comunidad y oficinas propias del establecimiento. El $2^{\circ}$ piso destinado para los El piso $1^{\circ}$ estará ocupado por la comunidad y oficinas propias del establecimiento. El $2^{\circ}$ piso destinado para los
colegiales, llama la atención por sus magníficos salones dormitorios, salas de estudio, de aseo, de música, de dibujo, oratorio y demás departamentos indispensables en tales establecimientos" (Las Provincias. Valencia, martes 10 agosto de 1869). Según esta narración, el edificio domina la población y el territorio, lo que lo convierte en sospechoso de ser ocupado, si no también fortificado, por los carlistas. Por tanto, podría ser cierto el dato que aporta Galdós sobre la fortificación del mismo. En la actualidad, el complejo se encuentra muy transformado, siendo su uso actual el de centro de salud.

Un personaje clave, y real, en la zona es Timoteo Andrés, "Pimentero", nacido en Utiel. Durante toda la guerra hace de guía para el ejército carlista en la comarca y no la abandona, sino que se queda en ella como guerrillero con algunos acompañantes. Sus correrías le llevan a ser arrestado por sus superiores por robar para sí y no para la facción, aunque no tarda en ser liberado (Caridad, 2014: 251; Diario Constitucional de Zaragoza, 27 de enero y 24 de febrero de 1840). En abril de 1840 ocupa Utiel, pero las tropas isabelinas apostadas en Requena salen a perseguirlo y lo hacen hasta Villar de Olmos, donde son heridos varios de sus hombres y él escapa (Caridad, 2014: 252; Ballesteros, 1999: $664,665)$. Acabada la guerra, se refugia en Francia, hasta que vuelve a las andadas en 1848 y acaba siendo pasado por las armas en marzo de 1849 (Caridad, 2014: 252; Diario Mercantil de Valencia, 14 y 19 de marzo de 1849. Ballesteros, 1999: 689).

En cuanto a la fortificación de Utiel, al tratarse de una población poco elevada, es difícilmente defendible y los diversos ejércitos la toman con facilidad. Sabemos que en ocasiones la iglesia sirve de refugio para las tropas defensoras de la plaza, gracias a que la torre del campanario es el punto más elevado de la población. Si tomamos por cierta la ficción de Galdós, lo cual no es descabellado, estaríamos hablando de que se fortifican dos puntos: el hospicio de los padres franciscanos, más adelante Convento o Colegio de Escolapios, y la iglesia. Pocos datos más se tienen de obras acomeidas por los efectivos carlistas en la localidad. Hoy existe un elemento que pretende reconstruir la morfología de la antigua Puerta de las Eras, con arco apuntado y matacán aspillerado, pero desconocemos si existía durante la Primera Guerra Carlista.

Fig. 767. Plano 1. Plano de la acción dada en Utiel el 6 de febrero de 1839 contra Arna por parte del ejército liberal. 
Planos históricos:

Plano 1

Título uniforme: Utiel (Valencia). Operaciones bélicas (1839). 1:34.000

Título: Plano de la acción dada en Utiel el 6 de Febrero de 1839 al Cabecilla Arnau, mandada por el Sor. Brigadier Comandte. Gral. de la prova. de Cuenca Dn. Martin Jose Yriarte / D. y D. por Caseres. Publicación: 184-?

Fig. 768. Esquema en planta del casco histórico de Utiel con los puntos de interés defensivo. 01. Iglesia

02. Puerta de las Eras reconstruida

03. Emplazamiento antigua Puerta del Sol

04. Restos de antigua Puerta Real o de Requena

Real o de Requena
05. Restos de antigua puerta 05. Restos de antiga Castillo 06. Calle Castillo
07. Restos de la antigua Puerta 07. Restos de la antigua Puerta Nueva

08. Restos de Puerta de Ximén Pérez

09. Restos en el Callejón de las Almenas

10. Restos de antigua puerta 11. Actual centro de salud $y$ antiguo hospicio franciscano posiblemente fortificado (más tarde Convento y Colegio de Escolapios)

12. Cuartel de la Guardia Civil, con torre cilíndrica adosada al cuerpo principal.

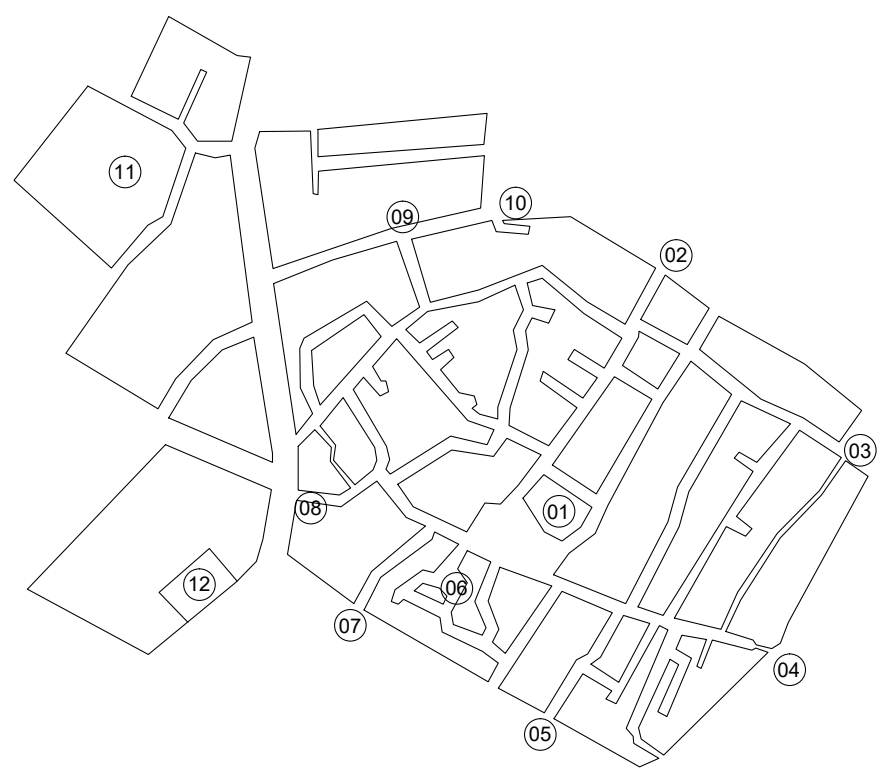

$\longleftarrow 50 \mathrm{~m} \quad \mathrm{E} 1: 7500$ d
Descripción física: 1 mapa: ms., col., montado sobre tela ; $31,2 \times 26,1 \mathrm{~cm}$, en h. de $40,3 \times 29 \mathrm{~cm}$

Notas: Comprende la población de Utiel y sus alrededores. Manuscrito firmado y rubricado. A plumilla en tinta negra e iluminado a la acuarela en verde, carmín y azul. Orientado con flecha. Relieve representado por sombreado. Indica las posiciones de ambos ejércitos por clave cromática. Señala cultivos y masas forestales.

Ejemplares: Archivo Cartográfico de Estudios Geográficos del Centro Geográfico del Ejército Ubicación: AR - Signatura: Ar.G-T.3-C.2-269 - Código de barras: 2210623. 
72 VILLAнRrMosa deL Rio 
Fig.687. Esquema en planta de

Villahermosa del Río con los

puntos de interés defensivo.

01. Mirador de la Muela

02. Ermita del Calvario

03. Base de una torre

04. Castillo medieval

05. Iglesia

06. Ermita de San Antonio Abad

\section{3 villar del Humo}

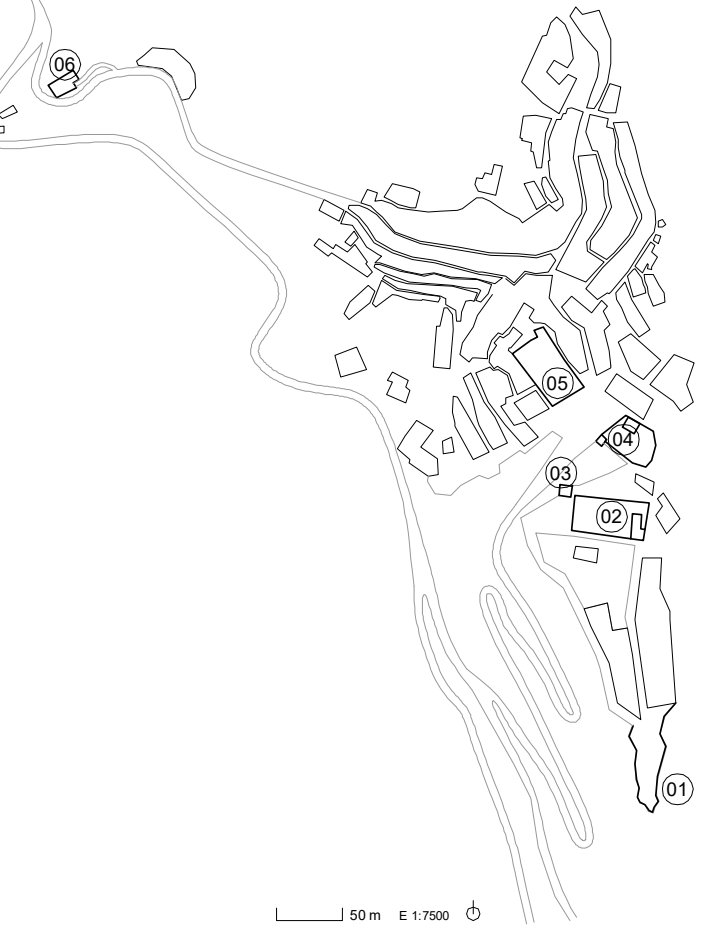



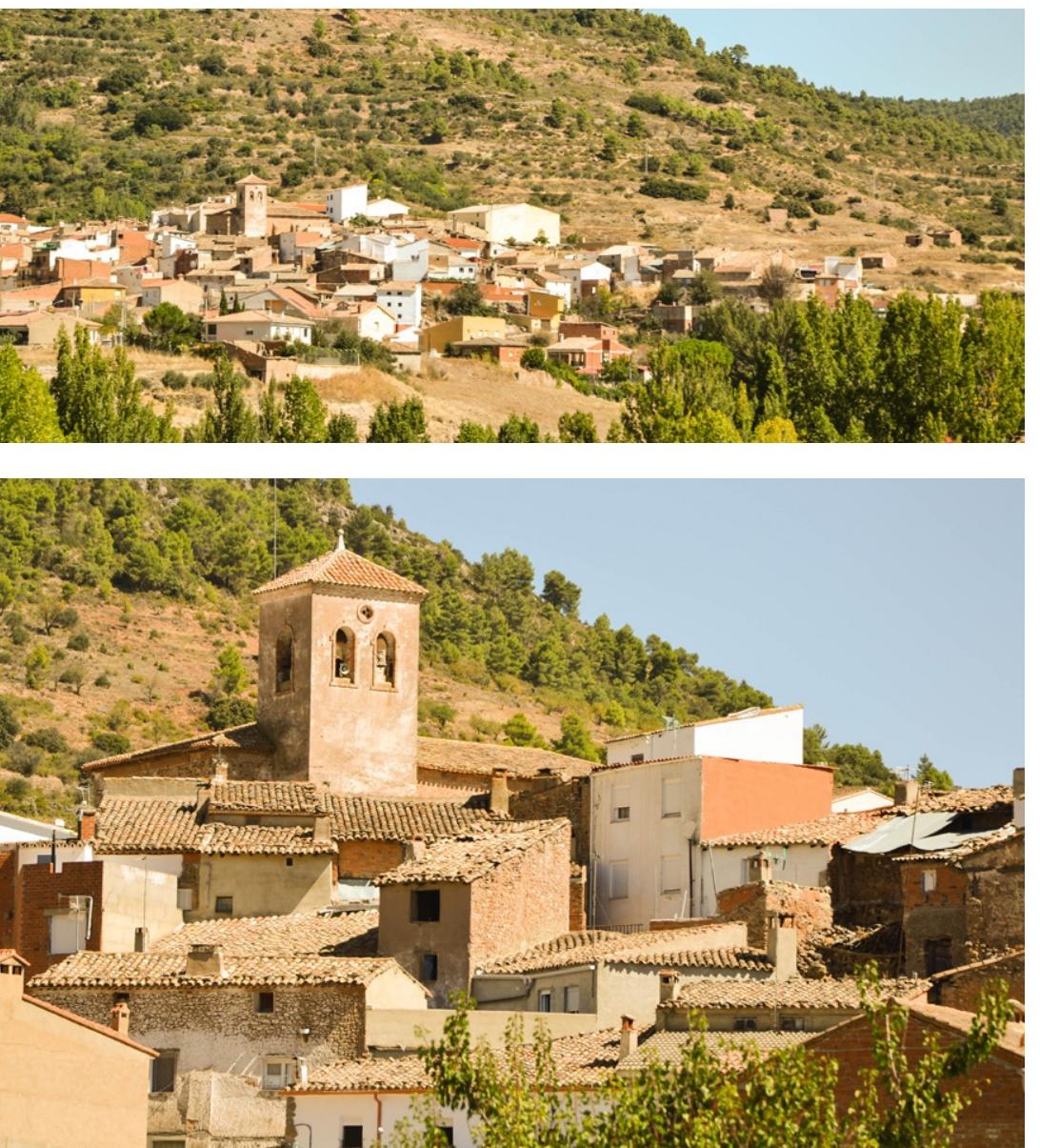

\section{Villar del Humo}

Provincia actual: Cuenca

Comarca: Serranía de Cuenca

Coordenadas geográficas: 39.87068663550335, -1.6274307626817404

Tipos defensivos: torre, eras.

\section{Acciones y fortificación:}

Por Villar del Humo pasa la Expedición Real, desde Salvacañete y pasando por Alcalá de la Vega. La expedición alcanza la población tras "siete horas de marcha por terreno quebrado entre riachuelos". Entran el 6 de septiembre de 1837 y se producen disturbios "causados por un grupo de leales al gobierno isabelino que se enfrentaron verbalmente a las tropas carlistas a su paso por las calles de la población. Desde Villar del Humo las tropas carlistas se dirigieron a Cardenete. En la salida del pueblo hubo algunos altercados y varios vecinos capitaneados por un miembro de la familia Ferrer intentaron provocar un atentado en un lugar próximo a un molino, en el cruce del puente de la carretera en dirección a Cardenete" (López Marín, 2013: 373).

Llama la atención la descripción que hace Pérez Galdós en La Estafeta Romántica, al hablar de este acontecimiento: "Desde la fácil victoria de Villar de los Navarros hasta que se nos unió Cabrera en Buenache de Alarcón, en mi memoria se marcan principalmente los días por los Te Deum que cantaban algunos pueblos al ver entrar al Rey, por las misas que éste mandaba celebrar, por la continua matanza de prisioneros. Las fragosidades de Albarracín por la parte de Teruel y por la de Cuenca nos vieron correr de misa en misa, de ración en ración, de susto en susto. ;Qué horribles pueblos! Me resisto a inscribir en las lápidas de la Historia los nombres de Villar del Humo, Trama Castilla, Calomarde, Salvacañete, Campillo de Alto Buey ... No puedo asociar a tales nombres más que la miseria y la barbarie ..." (Pérez Galdós, 1993h: XXXV, 2607).

En las proximidades se emplaza la Torre Barrachina, torre almorávide del siglo XI, que pasó a manos de la orden del Hospital. De traza rectangular, se emplaza en un valle solitario, sobre un promontorio junto al río Mesto.

El 17 de enero de 2019 se recoge en la prensa (La cerca.com) el reciente acondicionamiento de la pista de acceso a la Torre y el resultado final de la intervención, financiada por la Diputación Provincial de Cuenca. El estudio realizado por Ruiz Checa y Cristini sobre la torre permite identificar una secuencia de añadidos y reparaciones que se corresponde con diferentes periodos (Ruiz Checa et altr., 2012: 476), aunque no existe constancia de intervención ni uso de la torre en el transcurso de la primera Guerra Carlista.

La visita a la torre, así como a la localidad, no permite identificar intervenciones con claridad.
Fig. 689. Torre de la iglesia de Villar del Humo 


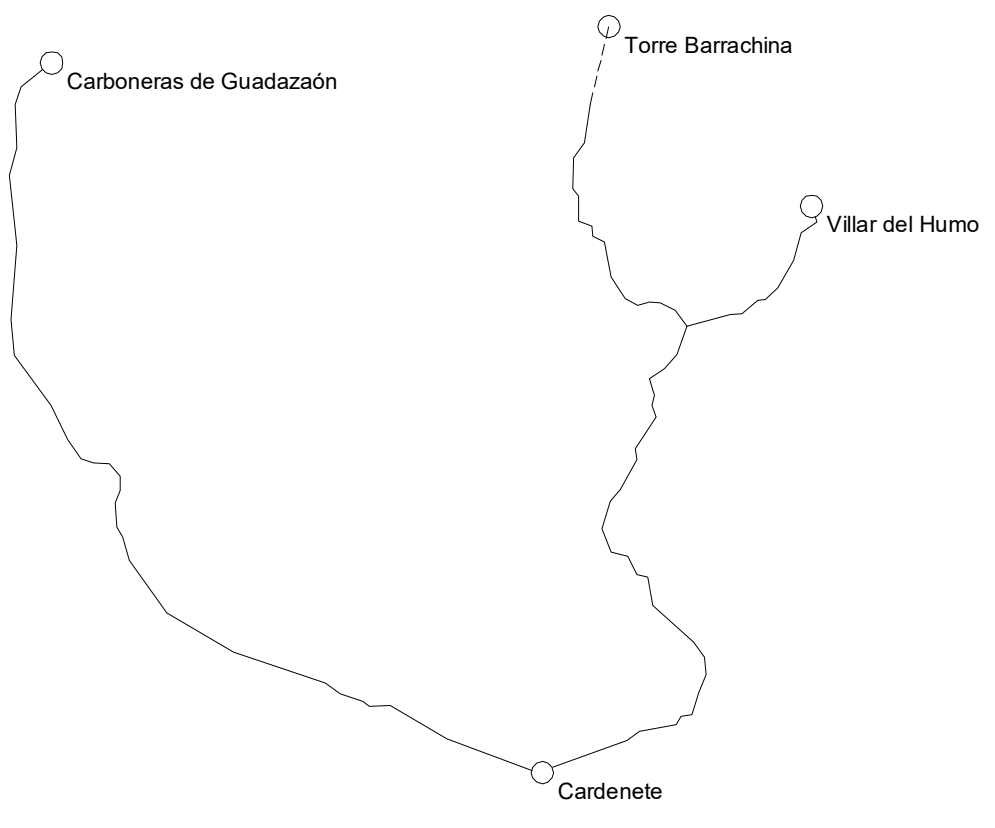

$1000 \mathrm{~m} \mathrm{E1:200000}$

Fig. 690. Esquema territorial de la posición relativa de la Torre Barrachina, Vllar del Humo, Cardenete y Carboneras de Guadazaón.

\section{Fig. 691. Esquema en plan-} ta de Villar del Humo con la posición de la iglesia.

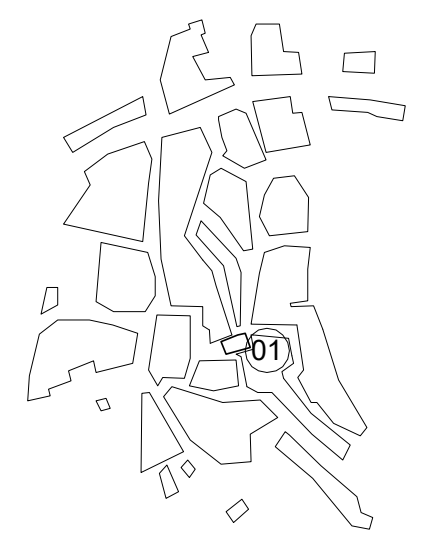

74 villarluengo/ Convento de Monte Santo 


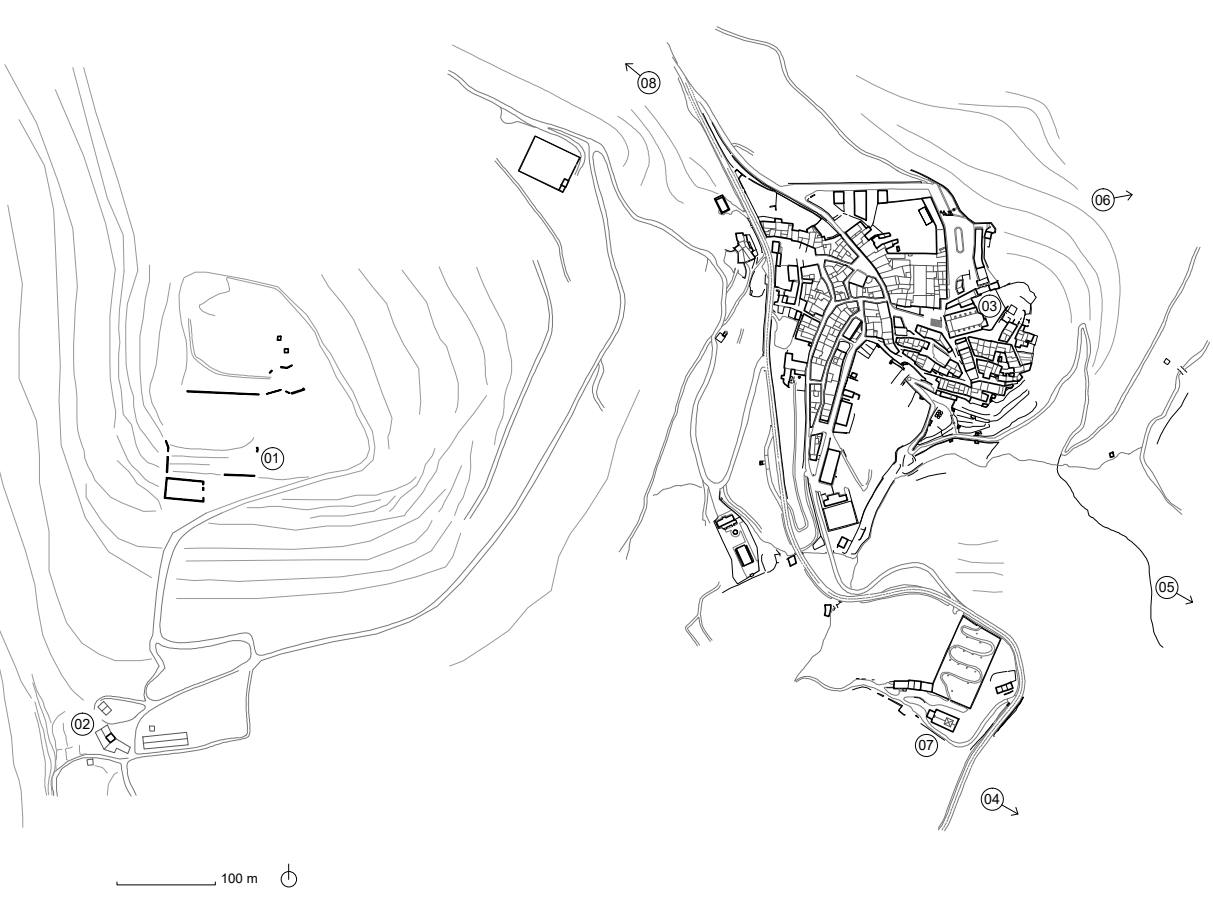

Fig. 702. Planta general de emplazamiento de Villarluengo y los restos del convento de Monte Santo. Fig. 702. Planta general de emplazamiento de Villarluengo y 02. Torre de Montesanto.

03. Iglesia Parroquial de la Asunción de Nuestra Señora (reconstruida en 1859)

04. Masía fortificada Torre Gorgue

05. Masía fortificada Torre Sancho

06. Masía fortificada Torre Soriano

07. Ermita de San Bartolomé

08. Ermita de San Cristóbal

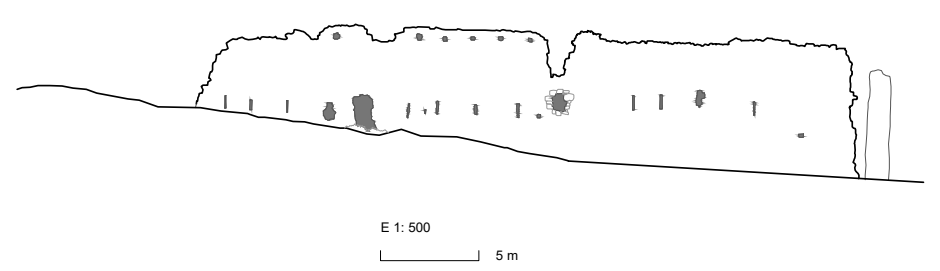


Fig. 708. Alzado este y esquema

en planta de los restos del casti-

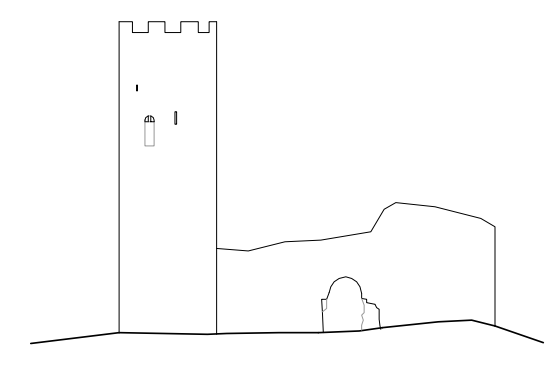

llo de Víllora en la actualidad.

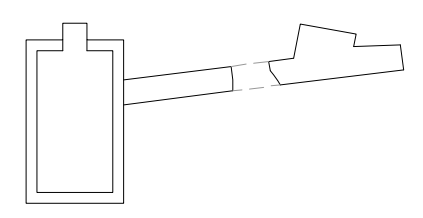

76 xerr $*^{*}$ 


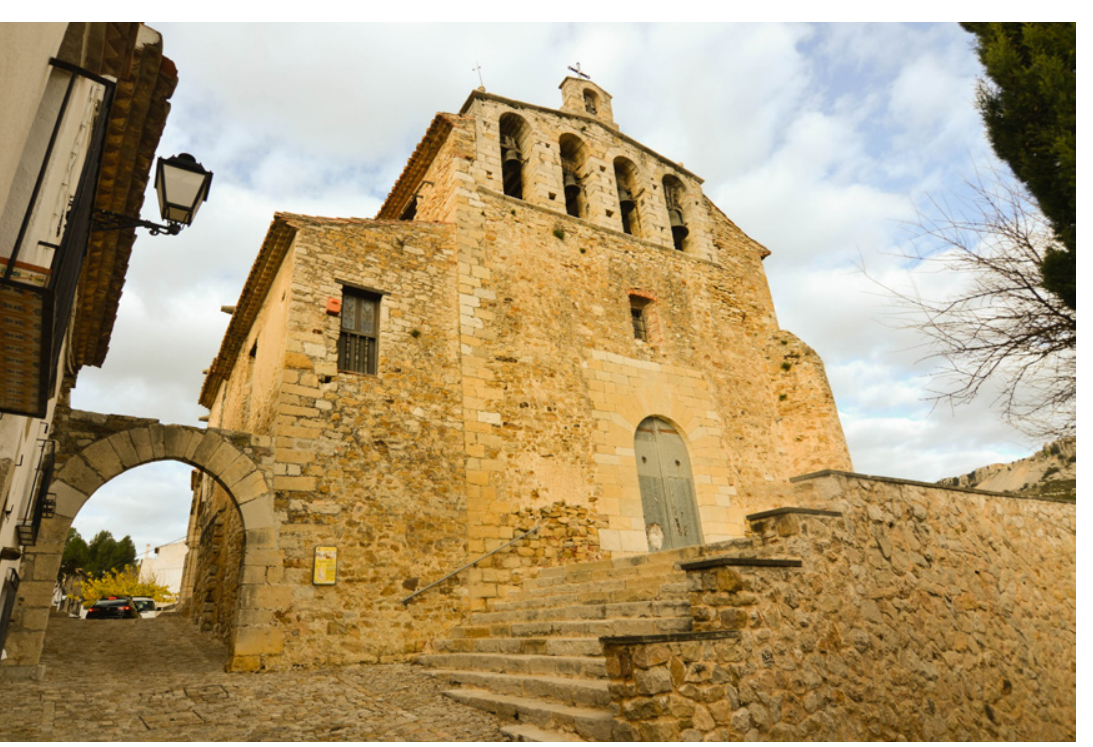

Fig. 709. Fachada principal de la antigua iglesia parroquial de Xert, orientada a este.

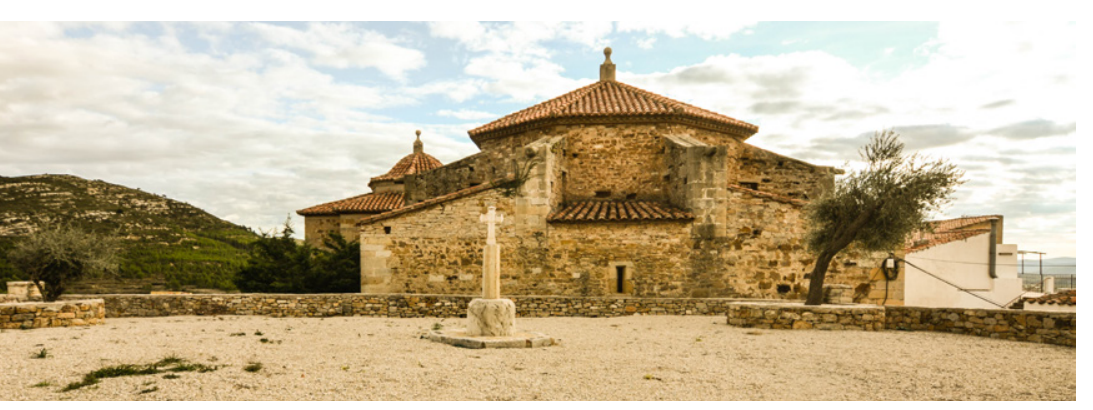

Fig. 710. Fachada posterior de la antigua iglesia parroquial centerio.

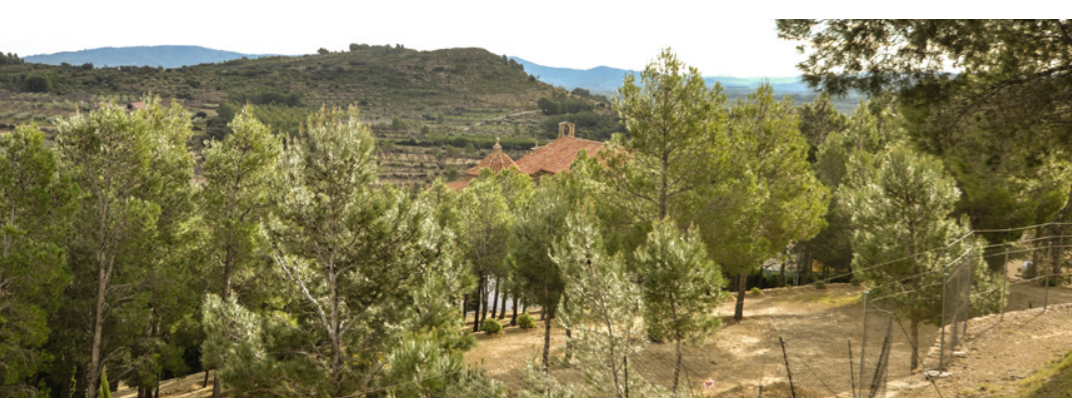

Fig. 711. Iglesia y muelas cercanas. Se aprecia la relación de alturas. La fotografía se realiza desde la elevación donde se cree que un día estuvo el castillo.

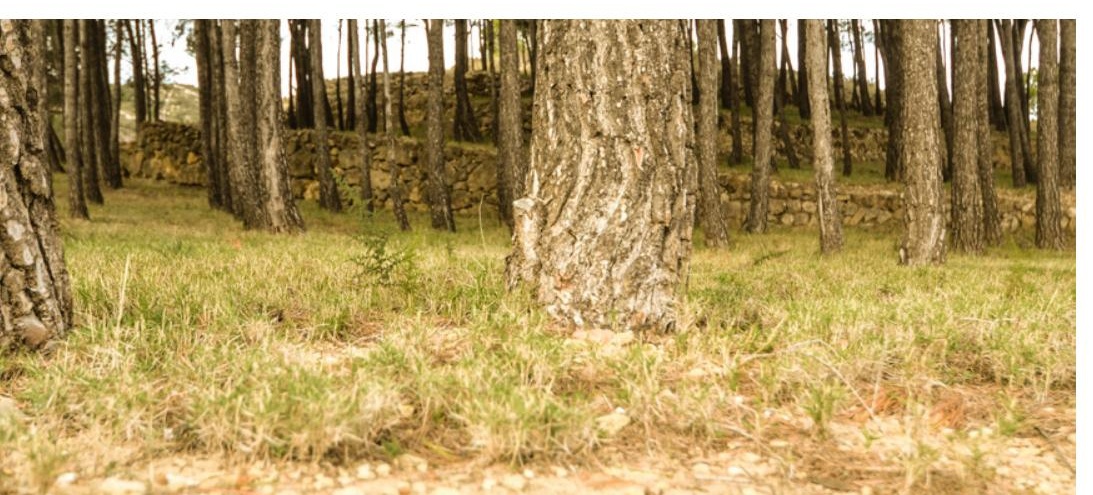

g. 712. Muros de contención de tierras encontrados en el emplazamiento del castillo.
Xert

Localidad en castellano / valenciano: Chert / Xert

Provincia actual: Castellón

Comarca: Bajo Maestrazgo

Coordenadas geográficas: 40.52120794382003, 0.15610535997683428

Tipos defensivos: castillo reforzado que domina la población, torre, torres exentas, fortificación de iglesias, muralla urbana, frente escalonado.

Acciones y fortificación:

La localidad de Xert es dominada por la formación montañosa conocida como "moles de Xert", cuyo punto más alto es denominado precisamente La Muela, con $807 \mathrm{msnm}$. Junto a ella, la muela Llarga, la Redona y la Murada. Precisamente esta última albergó un asentamiento de la Edad del Bronce. No hay constancia de ocupación carlista sobre estas muelas. Sí en el castillo, emplazado en las alturas de la localidad, que ve cómo se levantan parapetos. Caridad recoge que "levantaron parapetos en las alturas de Chert (Castellón), así como una pared aspillerada alrededor del peñasco de La Muela" (Diario Mercantil de Valencia 4 de julio de 1836; Caridad, 2013: 246). El castillo ocupa el asentamiento de la antigua Iglesia Parroquial de la Asunción de María, y la población está contenida por un recinto amurallado que queda integrado en muchas de las viviendas actuales. En el término se localizan diversas torres de época medieval utilizadas para la defensa de la población, como la Torre d'En Molinar, la Torre de San Marcos, la Torre d'En Roig y la Torre dels Pepos. El 4 de enero de 1836, el Serrador sostiene contra el coronel Villapadierna la acción de Xert y, ese mismo año, Forcadell obtiene una victoria en las proximidades ante el brigadier liberal Borso.

\section{Fig. 713. La Muela, a la izquier- da, $\mathrm{y}$ las otras muelas de Xert, vistas desde la elevación del} castillo.

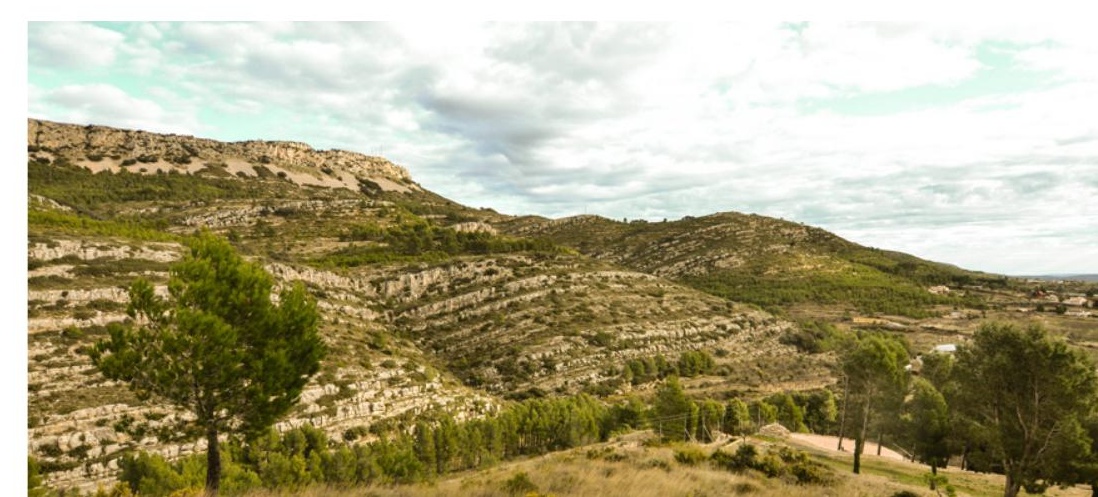


(02)

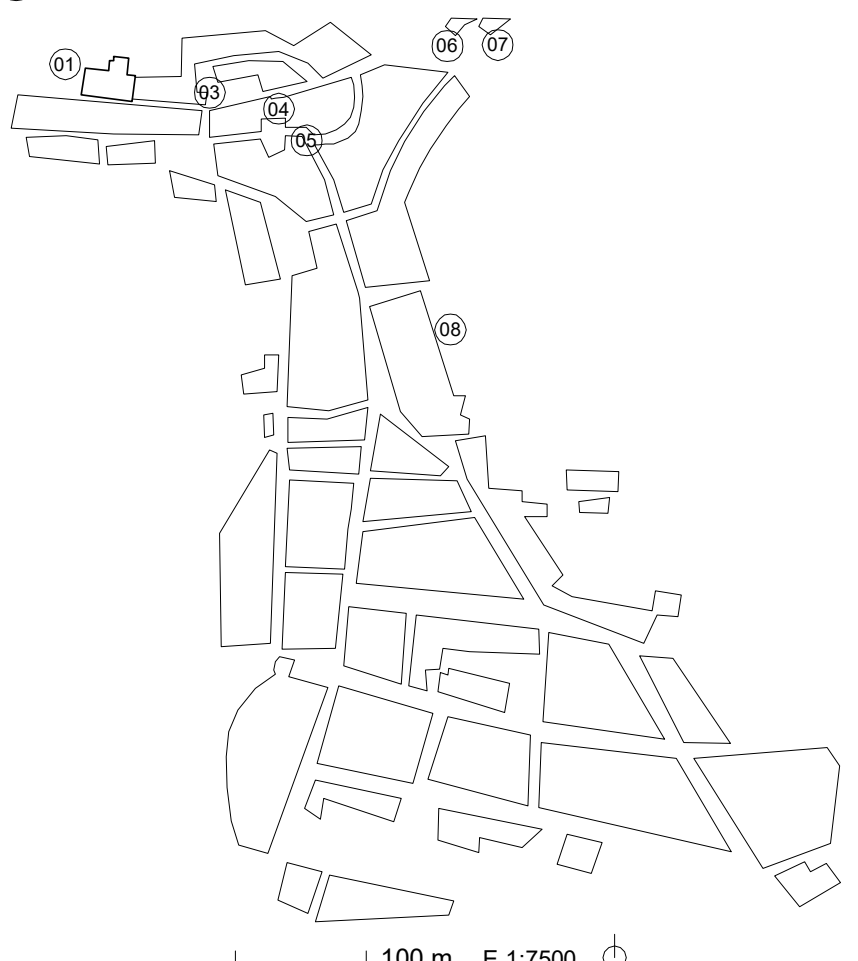

Fig. 714. Esquema en planta de la población de Xert y ubicación de puntos de interés. 01. Antigua iglesia

02. Ascenso al castillo

03 . Antiguo horno

04. Placa vella - perre

05. Ayuntamiento viejo

06. Puente medieval

07. Lavadero

08. Iglesia nueva, de 1962

\section{7 ХевтА}

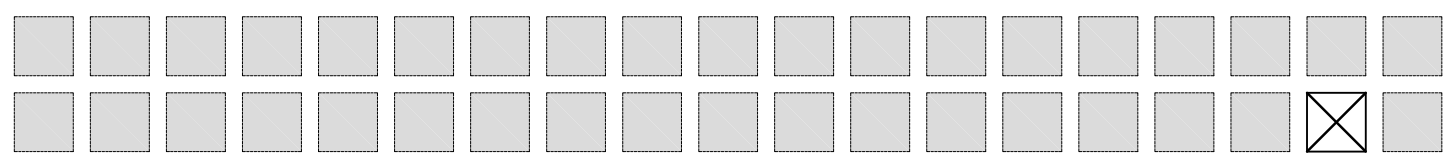




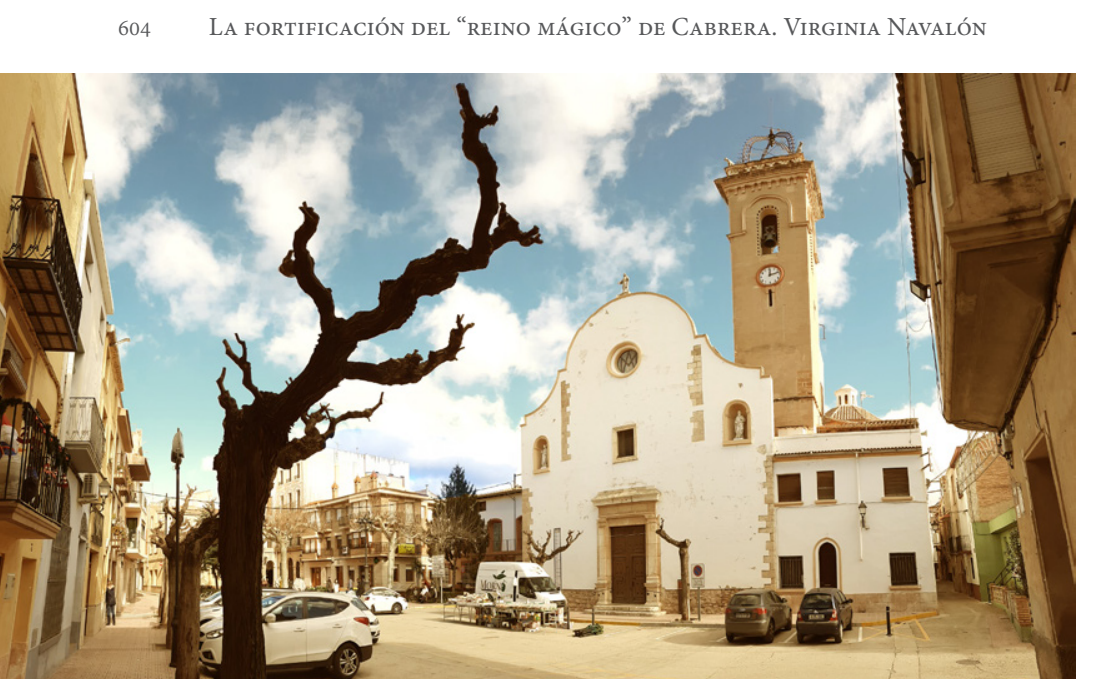

Fig. 720. Iglesia parroquial de Xerta.

Fig. 721. Esquema en planta de Xerta con los puntos de interés

$$
\text { carlista. }
$$

01. Iglesia parroquia

02. Posible casa de Cabrera 03. Puerta Capella del Pilar 


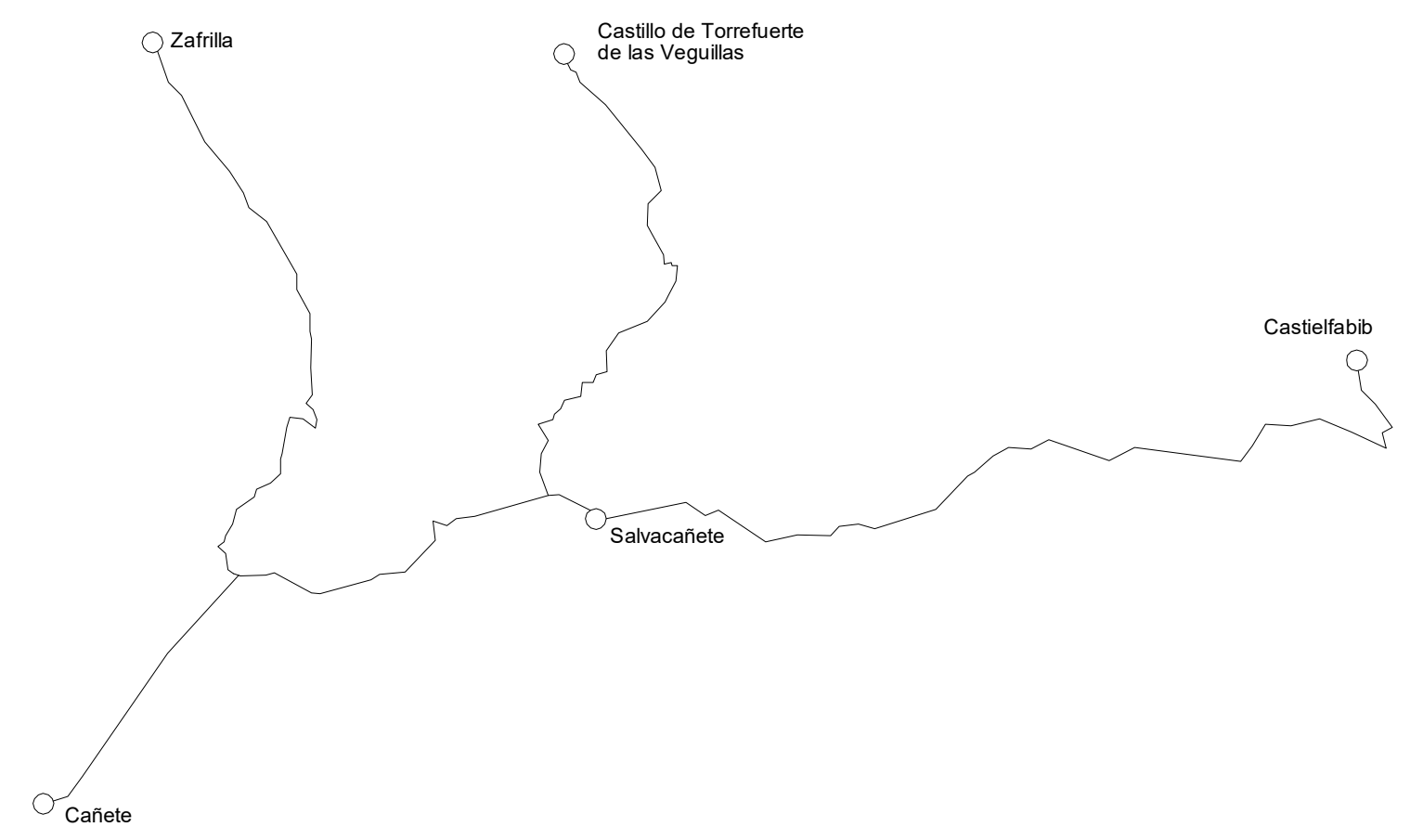

\section{Zafrilla}

Provincia actual: Cuenca

Comarca: Serranía Alta

Coordenadas geográficas: 40.19426144156651, -1.6163015535350098.

Tipos defensivos: iglesia fortificada.

\section{Acciones y fortificación:}

Según Von Rahden, Zafrilla integra la defensa de Castilla la Nueva en el Cabriel, junto a Cañete y Salvacañete (Von Rahden, 2013: 477) en 1839.

Una de las primeras acciones de las guerras carlistas sucede en unos pinares en las proximidades de Zafrilla, cuando el mariscal Bessiers es derrotado por las tropas liberales de Saturnino Albuin. Algunos carlistas huyen a refugiarse a las casas de la población, pero allí son apresados (López Marín, 2014: 365)

Sin embargo, no se encuentra más referencia a fortificaciones defensivas en el municipio, salvo la tradicional posición fortificada de la iglesia. Con toda probabilidad, Von Rahden pretende referirse al castillo de Torrefuerte. De este modo, es posible que el destacamento de Torrefuerte se confunda en ocasiones con la posición de Zafrilla o de Salvacañete. Para más datos al respecto, se puede consultar el apartado de Salvacañete.

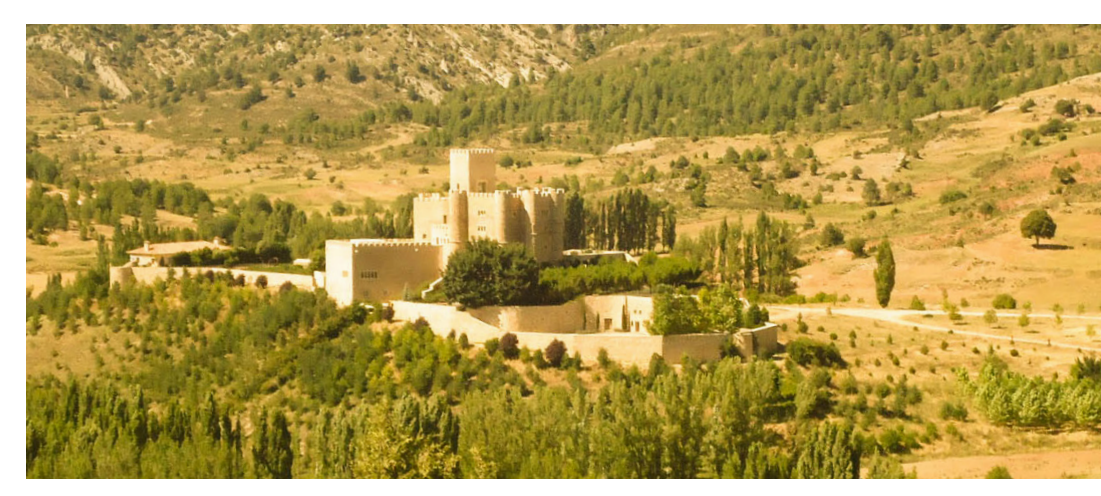


9 Estudio de caso: la Fortificación LibERAL De Requena 
Para entender el papel de la ciudad de Requena en la Primera Guerra Carlista se debe efectuar un análisis a partir del entendimiento que en la época se tenía de la posición de la entonces villa, así como de sus valores geoestratégicos, entendiendo como tales los vínculos existentes entre los factores geográficos y los problemas militares, que condicionan la elección de los emplazamientos, los

elementos y los trazados fortificatorios.

En este sentido resulta curioso cómo un autor contemporáneo a la contienda como W. Ayguals de Izco analiza los valores de la ciudad en 1843, indicando:

"La ciudad de Requena es cabeza de partido en la provincia de Cuenca. Tiene cerca de tres mil vecinos y unos once mil habitantes. Está situada en los confines de Castilla con Valencia, en la carretera de las Cabrillas á corta distancia de las montañas del mismo nombre, sobre el riachuelo de Oliana. Es vastísimo su término y se vé salpicado de aldeas, ventas y otros caseríos. Es riquísima en sus productos de lino, seda, azafrán, vino, hortalizas, frutas y granos, no menos que en su industria de lienzos, tejidos de seda, tintes y batanes; pero su principal lucro estriba en sus relaciones mercantiles con Valencia y otros mercados que consumen sus productos. [.. ] Sabia Cabrera que no habí en Requena un solo sold do de guarnición y si bien por el lado de Villa, que es la parte antigua de la población, podía ser esta defendible por su situacion elevada, no sucedia así respecto de la parte moderna que se dilata por el collado de las Peñas, dominado por las inmediatas colinas y montes (Ayguals, 1849: 180-182).

En 1784, Cavanilles valoraba la presencia de un territorio de suelo quebrado o montes elevados en la frontera occidental del Reino de Valencia. Cavanilles resalta la presencia de abundante agua, especialmente en el término de Siete Aguas y destaca que la cosecha principal "son los granos, como cebada, avena y mucho trigo" (Cavanilles,: 40). Pero es cierto que las observaciones de Cavanilles sobre Requena son marginales, al abordar exclusivamente los territorios del Reino de Valencia, y precisamente Requena en aquel momento quedaba fuera de sus límites. Lo más resaltable geoestratégicamente es la ubicación de las cadenas montañosas que encierran el altiplano. Cavanilles hace tégicamente es la ubicación de las cadenas montañosas que encierran el altiplano. Cavanilles hace
referencia a los montes orientales del altiplano, indicando que "hallánse los mayores y los mas fragosos en el término de Sieteaguas, los quales unidos á los de Chiva forman las Cabrillas, sitio peligroso por los malhechores que abriga" (Cavanilles, 1797:38). Exactamente las Cabrillas es la denominación que recibe el puerto de montaña existente entre Buñol y Siete Aguas y que salva el desnivel entre la Hoya de Buñol y el Altiplano de Requena. Este puerto, que dificultaba la conexión Requena-Valencia, junto al de Contreras, en la conexión Requena-Madrid, complicaba la comunicación entre la capital y la costa. En 1816 se trazarían los planos de la carretera que debía mejorar el viejo camino de herradura, las obras se iniciarían hacia 1825 y se extenderían hasta 1847 , cuando sería reconocida como "la mejor carretera de España" (Piqueras, 1978:50).

Observamos que, en el transcurso de la Primera Guerra Carlista, las ciudades de Requena y Utiel, en el altiplano, se convierten en hitos clave por los que trazar una de las principales vías de comunicación peninsulares, facilitando la conexión con Valencia y planteando la superación de la histórica barrera topográfica que, dada la intensificación de los vínculos comerciales con la costa, propician la adscripción de la zona al Reino de Valencia en el año 1851.

Es fundamental recalcar la existencia de otra comunicación entre Valencia y Madrid, posiblemente menos accidentada pero más larga, a través del Valle de Montesa, que históricamente estuvo controlada por Xátiva y Almansa. Mientras existieron las aduanas entre los reinos de Castilla y Valencia, esta última ciudad rivalizó con Requena por el control de los pasos. Requena precisamente 
se benefició de la brevedad del trayecto (a pesar de su peligrosidad) y del control de las comunicaciones hacia Almansa y Alicante a través de los valles de Ayora y el Vinalopó; hacia Albacete y Córdoba, por el Cabriel; hacia Cuenca y Madrid, por el Pajazo o Camporrobles; hacia Aragón, por Moya y hacia Llíria y Segorbe, por la fosa tectónica del Reatillo (Piqueras, 1978: 29-30).

Esta ubicación privilegiada en el altiplano y la abundancia de agua hicieron de Requena un hito clave para el control de las comunicaciones entre la costa y la capital, especialmente cuando la clave para el control de las comunicaciones entre la costa y la capital, especialmente cuando la
guerra se desata en el interior peninsular. Esta guerra, que tiene su origen en la guerra de guerriguerra se desata en el interior peninsular. Esta guerra, que tiene su origen en la guerra de guerri-
llas planteada ante la invasión francesa de 1808, encuentra en los montes el refugio adecuado para llas planteada ante la invasión francesa de 1808, encuentra en los montes el refugio adecuado para
los guerrilleros. Desde entonces, y especialmente en el transcurso de la Primera Guerra Carlista, los guerrilleros. Desde entonces, y especialmente en el transcurso de la Primera Guerra Carlista,
concretamente en la Campaña del Maestrazgo, las partidas carlistas se apoyan en los conceptos de movilidad y sorpresa para mantener en jaque a las tropas liberales entre 1833 y 1840.

Desde Morella, los carlistas pueden desembocar en cualquier punto del altiplano, del mismo modo que en el litoral, y retirarse a su nido de águilas sin que el grueso del ejército liberal pueda neutralizar sus ataques.

Si pormenorizamos los diferentes elementos geográficos, se puede decir que el altiplano de Requena, orientado de noroeste a sureste, está delimitado en el noreste por las sierras de Utiel, Juan Navarro y el Tejo (con el pico que da nombre a la sierra, que constituye la principal elevación de la zona con $1250 \mathrm{~m}$ ) y en el este por las sierras de Malacara y Martés. Un arco hidrológico definido por el río Cabriel confina el altiplano por el sur y el oeste, con profundas gargantas. El corazón del altiplano está atravesado por el río Magro, que contornea la ciudad de Requena por el límite suroeste. Ambos, Cabriel y Magro, son afluentes del Júcar (Bernabeu, 1982: 30).

La ciudad, originariamente, se emplazó exactamente sobre una plataforma de roca caliza, elevada unos 6 o 12 metros sobre el resto del altiplano, condición trascendental para el dominio visual y los requerimientos defensivos. Esta elevación se corresponde con la ocupada por el actual barrio de la Villa. La erosión de las aguas favoreció la aparición de dos escarpes, uno por el lado oriental (regajo de Reinas y fuente de Bernate), y otro por el lado occidental (fuentes del Peral, Pino y Pilas) (Piqueras, 1978:1)

La situación privilegiada y la dominación de las alturas debieron de constituir la base de los primeros asentamientos poblacionales de la ciudad, que, según las excavaciones arqueológicas realizadas en la fortaleza y en la Plaza del Castillo, podrían remontarse al siglo VII a. C., en la primera Edad del Hierro-Ibérico Antiguo. Con toda probabilidad, la existencia del asentamiento y su prosperidad faHierro-lbérico Antiguo. Con toda probabilidad, la existencia del asentamiento y su prosperidad fa-
vorecieron su consolidación en periodo íbero, romano y visigótico hasta la ocupación musulmana. Dominando el Magro y la altiplanicie, la elevación acabó siendo consolidada con las fortificaciones islámicas que fueron reforzadas tras la conquista cristiana (ha. 1238-1239) a raíz de los sucesivos conflictos medievales. Estos acontecimientos, que se desglosan en el apartado histórico, consolidan la típica estructura de "mota y liza", donde un caballero se erige en máxima dominación del territorio y último reducto defensivo, circundado por una extensión amurallada que constituirá el recinto de la medina. Exactamente encontramos consolidada en Requena la estructura convencional de asentamiento hispano-musulmán, con una alcazaba, una medina y un arrabal. Parte del perímetro amurallado de la medina pervive en la actualidad. Por su parte, la alcazaba se emplazaba en el amurallado de la medina pervive en la actualidad. Por su parte, la alcazaba se emplazaba en el
extremo más elevado de la mota, aislada de la medina. El acceso empinado que se producía hasta la alcazaba por la denominada Cuesta del Castillo, propició la elevación de la denominada Torre Mayor, destinada a batir este acceso estratégico. Los cubos de la alcazaba se orientaban hacia el norte cubriendo la medina, que se extendía en la parte norte de la elevación. Precisamente en la antigua muralla musulmana se fijan los emplazamientos de las principales puertas que comunicaban con las ciudades más relevantes: la Puerta de Alcalá (en dirección a Alicante), la Puerta del Cristo (conexión con el interior castellano) y la Puerta de Fargalla (camino viejo a Valencia).

A partir de la conquista cristiana, la ciudad supera el límite islámico y se extiende por el Arrabal (siglos XIII y XIV), con estructuras relevantes como el Convento del Carmen. También, probablemente desde la segunda mitad del siglo XIII, se coloniza el conocido como barrio de las Peñas, 
Observamos pues una configuración histórica característica que se apoya en dos elevaciones, la elevación fortificada de la Villa y el barrio de las Peñas, con una zona en depresión conocida como el Arrabal entre ambas, sectores claramente referenciados en los informes de los ataques producidos en el siglo XIX.

Cuando en 1835 Cabrera acomete el ataque de Requena, lo hace desde la ciudad de Utiel. Como atestigua Ayguals, sabia Cabrera que no habia en Requena un solo soldado de guarnición, y si bien por el lado de la Villa, que es la parte antigua de la población, podía estar defendible por su situación elevada, no sucedía así respecto de la parte moderna que se dilata por el collado de las Peñas, dominado por las inmediatas colinas y montes. Los nacionales habían colocado una avanzada fuera de la ciudad por esta parte débil que fue

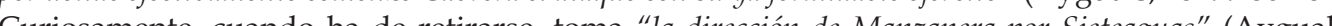
1849:182). 1849:182).

\subsection{Una historia relativa. Los asedios carlistas de Requena}

Abordar el caso de los diferentes ataques a Requena por parte de las partidas o ejército carlista permite entender las necesidades defensivas que requiere la ciudad y justifica de algún modo las obras de fortalecimiento de las defensas que se plantearán entre 1833 y 1839. No obstante, a pesar de la existencia de documentos históricos que contienen los informes oficiales sobre el resultado de los ataques, a pesar de la corroboración de los hechos por parte de algún historiador local, existen desavenencias entre lo narrado oficialmente y unos testimonios que aseguran haber presenciado alguno de los sucesos. En algún caso, la exageración oficial, tanto de la magnitud del ataque como de la leal defensa de los ciudadanos, parece más destinada a regalar el oído de los gobernantes que a ser fiel a lo realmente sucedido. Los objetivos son diversos, bien se pretende engrandecer los hechos históricos de la ciudad, o bien, desde un punto de vista más pragmático, se pretende obtener algún tipo de rédito, como será la elevación de Requena de villa a ciudad, o justificar la necesidad de unas obras de defensa que puedan tranquilizar a los ciudadanos.

Requena, desde el comienzo del conflicto, se declaró partidaria de Isabel II y cerró sus puertas a los carlistas. Inmediatamente se convirtió en una plaza desde la que movilizar a las milicias para disuadir las acciones en la zona de las partidas enemigas. Así recoge Bernabeu (1982: 413) que "como la Milicia Urbana era insuficiente, con los varones de 18 a 50 años de edad que pagasen 'más de treinta reales de Milicia Urbana era insuficiente, con los varones de 18 a 50 años de edad que pagasen 'más de treinta reales de Sobrerribas. Estas fuerzas alejaron de Siete Aguas a la partida de Roger, mereciendo por este y otros servicios las siguientes felicitaciones"

La milicia se reforzó más adelante con una Sección de Caballería y otras dos compañías, que serían provistas de armas, municiones y pertrechos desde Valencia por orden de la Capitanía General del Reino de Valencia.

Se observa que, desde el comienzo de la guerra, la base de la defensa humana de la ciudad reside en el peso de la milicia, en el caso de Requena, a diferencia de otros municipios, bastante implicada. Posiblemente el cómputo numérico de las milicias era superior al del ejército en el caso de la Capitanía de Valencia. La milicia urbana fue creada en 1834, pasaría a denominarse guardia nacional y acabaría con el nombre de milicia nacional. La clara implicación liberal de la milicia llevó al gobierno a exigir su constitución por "personas respetables", asociadas a un determinado poder adquisitivo, exigiéndose una renta mínima y que los integrantes se pagasen el uniforme. Ello dificultaba de algún modo el acceso a la milicia pero, dado que empezó a requerirse un mayor número de efectivos, la regla se subvirtió y, en poco tiempo, muchas milicias urbanas acabaron recurriendo al reclutamiento forzoso. Es fundamental recalcar la identificación ideológica de unos cuerpos ciudadanos, militarizados, que campaban a sus anchas por las localidades correspondientes. Estos pseudo-ejércitos, acabaron convirtiéndose en muchos casos en instrumentos de presión para los gobiernos moderados e incluso trataron de imponer su propia justicia, exigiendo el fusilamiento de prisioneros (Caridad, 2013:32)

unto a la milicia nacional hay que destacar a los denominados cuerpos francos, llamados 'peseteros', por su sueldo de peseta al día. Se trató de un cuerpo regulado en 1834 que operaba a modo de guerrilla liberal oponiéndose a los grupos carlistas. En este caso los cuerpos francos eran integrados por voluntarios seducidos por la paga, generalmente de origen humilde, como jornaleros. El pago de su soldada corría a cargo de los ayuntamientos, y solía estar integrada por vecinos de la zona, como debió de suceder en el caso de Requena, dispuesta a repeler a los grupos carlistas que se aventuraran a actuar en la zona (Caridad, 2013:32)

La estrategia liberal fue la de cohesionar diferentes ejércitos, como el Ejército del Centro, dividido La estrategia liberal fue la de cohesionar diferentes ejércitos, como el Ejército del Centro, dividido
en columnas, que perseguía a los ejércitos carlistas o acudía en socorro de las poblaciones. Estas, de 
algún modo, estaban obligadas a resistir el tiempo necesario para que la información llegara a los ejércitos que operaban en las proximidades y pudieran acudir en su socorro. Por ello, los carlistas, sin un ejército que pudiera enfrentarse con solvencia en campo abierto al ejército liberal, acabaron basanliberal se vio obligado a dejar destacamentos pequeños en poblaciones estratégicas o puntos frecuentemente atacados. Pero hacia 1835 esta estrategia demostró que los destacamentos nunca constituían una fuerza suficiente como para repeler los ataques carlistas, por lo que las autoridades optaron por reducir el número de localidades defendidas, concentrando un mayor número de efectivos. As estas localidades aseguradas se convertían en puntos clave de una red orbital que ponía en práctica la teoría de campos volantes a gran escala (Caridad, 2013:33). Muchas localidades, como Requena debieron apelar al espíritu de la milicia para su defensa. Dada la resistencia volátil de sus integrantes, voluntarios, la defensa de Requena demostró la implicación de la ciudad con la causa liberal.

Hay que distinguir el papel de esta milicia nacional, apostada en la localidad, con los citados cuer(a) oficial, partidas que no estaban destinadas a la defensa de las localidades, sino a explorar, atacar a partidas enemigas o convoyes del ejército carlista. En ocasiones, estos cuerpos actuaron como simples cuadrillas de bandoleros. Amparados en el caos de la guerra, recorrían los campos y los pueblos y se aprovechaban de su indefensión (Caridad, 2013:34).

En el verano del 34 se desatará en Requena una epidemia de cólera. Un séptimo de la población perece, según Bernabeu, y se observa, tal y como solía ser habitual, cómo se desata una extraña combinación de fervor religioso que se simultanea con un momento de efervescencia política nacional posiblemente fruto del descontento. El decantamiento del gobierno hacia el radicalismo liberal, como se ha indicado en apartados anteriores, produce que muchos simpatizantes del carlismo acaben abrazando la causa y tomen las armas. Es el momento de auge del carlismo, sus fuerzas se incrementan y esta situación se nota en Requena, pues el incremento de las facciones acerca la guerra más que nunca al altiplano. En este momento, registra Bernabeu, "los más calificados defensore del Carlismo eran don José Medrano y el canónigo don Isidoro Salazar, refugiado en Los Corrales de Utie y 'retenido' luego en nuestro Castillo [de Requena] por el capitán de urbanos de Utiel, don Miguel Sáez (El Gitano); don Antonio Ruiz Perejil y don Francisco Guillén, este último, franciscano exclaustrado, se instalo en Fuenterrobles y, con José A. López y otros, formó luego una partida Carlista" (Bernabeu, 1982:416).

\section{El ataque de Cabrera de 1835}

Sobre el primer ataque a Requena dirigido por el mismo Cabrera existen diversas versiones. Bernabeu (1982: 416-417), por ejemplo, se basa en los testimonios de F. Cabello, F. Santacruz y M. Temprado (Cabello, 1845) y Calvo y Rochina (1846). El primero de ellos describe del siguiente modo e primer ataque de Requena.
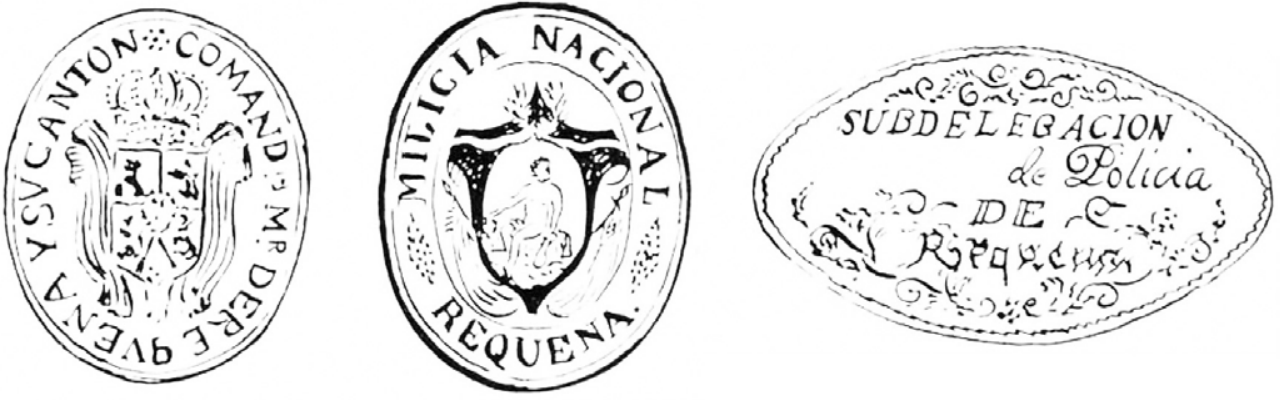

Fig. 726. Sellos del Cantón Militar, de la Milicia Nacional y de la Subdelegación de Policía (Bernabeu, 1982:415).
"Cabrera pudo entregarse a sus sueños más dorados. Cruzando el día 14 por Sarrión, Manzanera y Ademuz, fue a pernoctar a Utiel el 19. Quiso al siguiente probar fortuna contra Requena seguro de que su conquista le proporcionaba víctimas, recursos y dinero, pero los requenenses le conocían, y se contentó con ofrecerles una ocasión para probar al mundo que eran los mismos que defendieron la libertad el año 23 y los que por ella

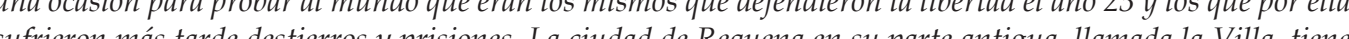
una posición elevada y defendible, pero la nueva, situada en un llano y que se corre por un collado llamado de las Peñas, está dominada por las alturas inmediatas. Por esta comenzó Cabrera el ataque llamando la atención su caballería con correrías y excursiones por los flancos. Su guerrilla y columna de infantería se dirigían con cierta serenidad y arrojo hacia el barrio de las Peñas. Fuera de esta calle había una compañía de nacionales extendida en guerrilla que, con sus acertados fuegos, contenía el ataque faccioso. Apenas se atrevía a avanzar, pero, provocado por los nacionales, acometió con más empeño, y aquellos se replegaron en el mayor orden al abrigo de las casas. Cuando los facciosos estuvieron a tiro de la población, las torres, ventanas y tejados aparecieron coronados de gente armada, mientras las mujeres y niños abrían zanjas en las calles o cruzaban carros y maderas. No puede derse mins decision, una actitur el ejército y sin embargo, no había un solo soldado. Los nacionales habían causado sesenta bajas en la facción y habian hecho conocer a Cabrera que las calles de Requena le estaban vedadas.

A la medianoche cargó sus heridos y marchó por Siete Aguas hacia Manzanera. Antes de llegar a este pueblo le encontró el general Amor, pero como el terreno es quebradísimo y sembrado de bosques, el bravo y entendido coronel de caballería del Rey don Francisco González no pudo hacer uso de su arma, por lo cual el encuentro se redujo a una escaramuza y a trepar cerros y posiciones que abandonaba Cabrera al acercarse nuestros soldados.

Al día siguiente le volvió a alcanzar Amor cerca de Mora, y alli perdió la facción bastante gente y casi todos los equipajes." (Rújula, 2006:60-61).

La llegada de Cabrera a Requena según Bernabeu se produce exactamente el 17 de septiembre de 1835. El objetivo no era otro que la "conquista de un punto altamente militar, junto con las circunstancias de riqueza y abundancia". Para atacarla, Cabrera tiene en cuenta la estructura territorial defensiva del ejército liberal, por ello "calculó el tiempo que podrían tardar los socorros de nuestras columnas y quiso aventurar un ataque violento" (Bernabeu, 1982:416). Dicho de otro modo, el primer ataque a Requena se plantea a contrarreloj. Cabrera sabe que si la resistencia de la ciudad es consistente, no podrá sostener el ataque ante la llegada de refuerzos, y por ello se retira.

La llegada de Cabrera a Utiel obliga a que el coronel don José Ruiz de Albornoz, jefe del Cantón Militar, deba precipitar la defensa basada en la estructura vecinal, "que cada vecino asegurase la de su casa" (Bernabeu, 1982:416). Recogiendo un testimonio anónimo, Bernabeu recalca que cuentan con "150 fusiles y muchas escopetas". La defensa de Requena pues, depende exclusivamente de la precisión de las armas cortas a partir de la defensa cercana.

La síntesis que hace Bernabeu de los diferentes testimonios coincide con la de Cabello: "A mediodía cruzáronse los primeros disparos. Dos horas después, la caballería de Cubells evolucionaba por los flancos de las Peñas, mientras que las huestes de Quilez se lanzaban sobre el Portal de las Reinas, siendo contenidas por el fuego de los urbanos al amparo de tapias y ribazos. Simultáneamente, los ataques se repitieron por tres puntos, resultando infructuosos" (Bernabeu, 1982:416).

Cabrera parece lanzar un ataque al asalto y cuenta, como vemos, con efectivos de caballería que parecen destinados a flanquear dada su mayor velocidad de movimiento, lo cual nos clarifica la existencia de un objetivo de ataque y un intento envolvente, al lanzar huestes por retaguardia del ataque a través del Portal de las Reinas.

¿Por dónde está tratando de golpear Cabrera? Las descripciones con las que contamos parecen poco explícitas. Es seguro que el objetivo de Cabrera es tomar el barrio de la Peñas, desguarnecido y, por tanto, su gran sorpresa es encontrar tamaña resistencia en las calles. Si recurrimos al testimonio de ( abuelo y demás personas de juicio y entendimiento claro" (Herrero, 1891: 48) - Cabrera se presenta a la vista de Requena el 20 de septiembre de 1835 y lo hace "por la parte Norte, ó sea por la fuente y camino de las Reinas". Coincide en la cifra de 1200 hombres del bando carlista que parecen concentrar pues 
el ataque en este sector norte. "Pero encontró una tenaz resistencia en los vecinos alistados en las banderas de la milicia urbana, que ocupaban sus entradas, á saber la puerta de Reinas, cerrada con unos palos y aportaderas de vendimiar" (Herrero, 1891:48).

Parece que en su avance desde el Norte, Cabrera ocupa el convento de San Francisco, donde alguien debió informarle falsamente magnificando las fuerzas con las que contaba Requena (Herrero, guien 1891:48). En este punto se produce una nueva contradicción entre las fuentes. Una vez Cabrer observa la tenaz resistencia que ofrece la ciudad (en el barrio de las Peñas), teniendo en cuenta que él, con la mera exhibición de su presencia en las proximidades de Requena, estaba "seguro de atraerla a su causa" (Bernabeu, 1982:416), se retira a Utiel (Herrero, 1891:48) o marcha hacia Chelva (Bernabeu, 1982:418)

Esta aparente falta de coincidencia de las fuentes podría justificarse si entre el retiro puntual a Utie y la marcha a Chelva, se incorporan nuevos sucesos, tal y como deducimos si interpretamos los datos ofrecidos por Bernabeu.

Cabrera avanza con sus efectivos desde el Norte. El objetivo parece ser invadir el barrio de las Peñas, desguarnecido. La base del ataque es el Portal de las Reinas. Pero no se trata de un ataque directo. Sus fuerzas se dividen para dividir la resistencia, "por tres puntos", y la caballería rodea las Peñas. La resistencia de los ciudadanos sorprende el primer avance de los carlistas que deben retroceder. Pero se efectúan diferentes asaltos. Es fundamental recalcar, como indica Bernabeu, que "simultáneamente, los ataques se repitieron por tres puntos, resultando infructuosos". Es decir, se intent el asalto en más de una ocasión y, ante la resistencia, los carlistas se retiran disparando y con " tos desesperads, retirando siete muertos y uarios herido". Los requenese, solo tuvieron una baja, en la que coinciden las diversas fuentes: Fausto Gimilio o Ginulio (Bernab 418). ¿Hacia dónde se retiran las huestes carlistas? Realmente es un repliegue, pues se insiste en un nuevo ataque que en esta ocasión obliga a que los defensores se resguarden dentro de las casas (Bernabeu, 1982:416), lo cual indica que en los ataques anteriores los ciudadanos de Requena se defendían apostados en las mismas calles, en esas zanjas y barricadas que han improvisado con la ayuda de niños y mujeres (Bernabeu, 1982:416).

Con los carlistas acometiendo de nuevo sobre las Peñas y los defensores recluidos en las casas, se produce un gesto defensivo de manual: los efectivos de la Villa, concretamente, el batallón de do Mauro Térez, simulan una salida por e Pota de Reinas. Esta simulación hace que los efectivos carlistas concentren su atención sobre dicho portal, "pero las torres, ventanas y tejados se hallaban coronados de gentes que abrieron un fuego vivísimo, forzando la retirada de los atacantes hacia San Francisco" (Bernabeu, 1889:417)

No se puede concluir dónde se apostan las armas defensoras, si intramuros o en las alturas de las casas extramuros de las Peñas. Sea como fuere, especialmente en la segunda interpretación, es difícil que los carlistas puedan sostener ese fuego concentrado que llega desde las alturas. Llama la atención que en este momento el convento de San Francisco es un punto al que retirarse, lo cual demuestra que ha sido tomado por los carlistas en su avance. Posiblemente en este momento es brera ha tenido sesenta bajas, según Bernabeu, y le han sido sustraídos tres carros de víveres. Podrí en este momento retirarse el ejército hacia Utiel, o sostenerse en las proximidades. Lo cierto es que al atardecer, Domingo Forcadell exige la rendición a Ruiz de Albornoz, un intento parlamentari para forzar in extremis la caída de la ciudad. Pero todos saben que se aproximan las columnas de refuerzo, según Bernabeu mandadas por el coronel Eguaguirre, desde "Turís, Buñol, Chiva, Cofrentes, Utiel y Jalance" (Bernabeu, 1982:418). Es curioso observar que se cita Utiel, cuando era el punto de concentración de las huestes de Cabrera, pero se entiende desde la guerra de movilidad emprendida por Cabrera, que avanza de un puesto a otro y, siempre, acaba retirándose a sus posiciones inge que "Cabrera marchó hacia Chelva" (Bernabeu, 1982:418), aunque parece más precisa la descripción del movimiento de evasion citado por Cabello, al indicar que se encaninaba Manzanera por Siete Aguas (Rújula, 2006.61). Es decir, Cabrera avanzó en dirección Este desde Requena, posiblemente por el único punto que le quedaba libre a través de las montañas, para luego tomar dirección Norte.
El ataque de Requena de 1835 es una muestra de la táctica de Cabrera, el ataque sorpresa y la evasión, descomponiendo el ejército en partidas que se dispersan en el momento de retirarse si existe una amenaza. Al mismo tiempo, es una muestra de la eficacia parcial de la teoría de campos volantes aplicada a escala territorial a la que se vio abocado el ejército liberal.

Una anécdota que incita a la reflexión a partir de la descripción histórica es la mención que se hace a la sustracción por parte de la ciudad de tres carros de víveres (Bernabeu, 1982:418). Esta sustracción podría ser el resultado de su abandono por parte del ejército de Cabrera, cuando tiene que plantearse su huida veloz por los montes. Pero, curiosamente, dicha sustracción se efectúa, según la crónica de Bernabeu, antes de que Forcadell parlamente con Ruiz de Albornoz, por tanto, los carlistas han perdido dichos carros en el asalto a la ciudad. No hay ejército que acometa un asalto militar haciéndose acompañar de carros de víveres, por lo que este dato permite insistir en una idea coherente con el modo de actuar de Cabrera. Habitualmente, la presencia de las partidas carlistas provocaba que los ciudadanos abandonaran sus propiedades buscando refugio en los centros fortificados o en l monte. De este modo, la partidas podían campar a sus anchas aqueando las propiedade donadas. Parece que los carlistas esperaban esta reacción en las Peñas, y el ataque podría tratarse más de un ataque de saqueo que de un verdadero ataque a la plaza. Es cierto que si la plaza, atemorizada, se rendía, la intentona merecía la pena. Cabrera sabía que tendría que retirarse si el centro fortificado planteaba resistencia, lo que no esperó es una defensa inusitada en el barrio desguarnecido. Sus tropas avanzan por las Peñas dispuestas a saquear lo que encuentran a su paso, de ahí la presencia de carros de víveres. Cuando la resistencia se encona y tienen que retroceder, deberán abandonarlos, de ahí que caigan en poder de los ciudadanos de Requena. La interpretación es bien diferente: si se trata de carros utilizados para el saqueo, los requenenses recuperan lo que es suyo; si se trata de carros de la retaguardia carlista abandonados en la retirada final, sí que puede tratarse del botín y el equipamiento del propio ejército. Queda esta laguna en la interpretación, pero podría ayudar a entender y confirmar el cariz del ataque carlista de 1835 sostenido en esta investigación.

\section{El ataque de Gómez de 1836}

La mayor amenaza para Requena en el conflicto carlista se plantea cuando la Expedición del general Gómez transita por el altiplano. Bernabeu registra con precisión la llegada del grueso del ejército a Utiel a la una de la tarde del 7 de septiembre del año siguiente, 1836 (Bernabeu, 1982:418; Herrero y Moral, 1849:49). Como se ha contado en el apartado de historia general, nos encontramos en un momento de auge del ejército carlista. Si bien Zumalacárregui ha fallecido un año antes y en el frente norte se ha tenido que levantar el primer sitio de Bilbao, existe el convencimiento en las huestes te norte se ha tenido que levantar el primer sitio de Bilbao, existe el convencimiento en las huestes
de don Carlos de que un conjunto de expediciones por el territorio español pueden convertir las simpatías por el bando carlista en activismo. Pero no parece que los métodos vayan a funcionar visto lo sucedido en Requena.

Gómez había convertido Utiel en centro comarcal para la concentración de todas las tropas que operaban desde el Maestrazgo hasta la huerta murciana. A su llamada acuden las fuerzas de Cabrera, Quílez, Forcadell, el Serrador, Arnau y otros jefes menores (Herrero y Moral, 1849:50).

“La opinión más generalizada nos dice que el ejército carlista lo integraban 8000 combatientes. Ortiz de la Vega señala 15000; Ballesteros, 11000; Madoz, Cabello y Calvo, 7000; Herrero y Moral, en un lugar indica de 6 a 7000 y en otro 13000 ... Sabemos que la división de Gómez, constituida por 'gente aguerrida, dura y feroz', según escribió Pío Baroja, al penetrar en Utiel no bajaba de 3000 hombres; Quilez y Miralles aportaron 3500; Cabrera, 2500, además las partidas de Arnau, Arévalo, Cala, Millán, Font, Sancho y Durán que se incorporaron a la vecina población" (Bernabeu, 1982:419).

Desde Requena se observa con temor tamaña concentración de tropas y no auguran nada bueno para el futuro, dada la implicación liberal de la ciudad. Se desconoce el objetivo del ejército, pero se confía en que su destino sea la capital. 
Requena, según el testimonio de Bernabeu, cuenta en ese momento con el batallón de Nacionales (Milicia Nacional), una compañía provisional integrada por "enfermos y cansados" y grupos armado procedentes de Utiel y otros pueblos (Bernabeu, 1982:418-419). Se observa cómo se cita una derrama que se aplica a las admintraciones y hacendados ausentes para obtener fondos económicos, cuyo objetivo, posiblemente, sería pagar suministros y especialmente todo tipo de contribución para la objetivo,
defensa.

Desde el mismo día 9, Requena se podía considerar prácticamente sitiada. Bernabeu testimonia tanteos sin consecuencias por parte de José Miralles (El Serrador)

No queda clara la voluntad general de atacar Requena. Según Bernabeu, Cabrera, a su llegada a Utiel el día 11 de septiembre, propone una acción contra la ciudad, a la que Gómez se opone. La intervención del arcipreste de Moya, don José Millán, lo convence para que se efectúe un tanteo. A pesar de que utilizan el término "excursión", los carlistas estaban convencidos de poder rendir la ciudad y, de hecho, "prepararon cincuenta acémilas para cargar el botín y gran cantidad de picos para la ciudad y, de hecho, "prepararon cincuenta acémilas para cargar el botin y gran cantidad de picos para
demoler nuestras defensas" (Bernabeu, 1982:419). Es necesario precisar que el papel de Cabrera no es demoler nuestras defensas" (Bernabeu, 1982:419). Es necesario precisar que el papel de Cabrera no es
especialmente tenido en cuenta por Gómez. Según atestiguan Cabello, Santa Cruz y Templado, “a pesar de ser Cabrera el jefe de todas las fuerzas de Aragón y Valencia, Gómez llamó a Quilez y el Serrador, estos fueron a Utiel con sus divisiones sin contar con aquél. También es muy reparable el desprecio con que Gómez trató a Cabrera, no dándole colocación militar en la división. Así, se ignora el punto que ocupaba en la derrota de Villarrobledo y se le ve llegar a Córdoba con los exploradores de Villalobos. En Baena mandaba una guerrilla de caballerín, y en Trujillo ni aun noticia tenía del paradero de los aragoneses. Era un sobresaliente en la corrida o un aficionado" (Rújula, 2006: 100).

También es conveniente preguntarse qué representaba un ejército de la magnitud del de Gómez a efectos de intendencia. Según Ballesteros y Caridad, durante la ocupación de Utiel la calle de la ciudad parecía un matadero y, al marcharse los carlistas, dejaron el pueblo con tantos despojo de reses que hubo que retirarlos rápidamente para evitar una epidemia (Ballesteros, 1999:629-630 Caridad, 2013:137)

Si abordamos el proceso de aproximación y el modo de plantear definitivamente el ataque, encontramos en las fuentes, tanto en Pirala, Herrero y Moral, como en Bernabeu, recogiendo parte de las descripciones del anterior, un modo de conocer la ciudad y los recursos defensivos en aquel entonces. Incorporamos la narración de Herrero para después efectuar una comparación crítica con el resto:

“El 13 de Septiembre por la mañana se divulgó por Utiel la noticia de que los carlistas iban a bajar a Requena a atacarla y asaltarla, cuya nueva la confirmó el toque de generala que dejaban oír por las calles sus clarines y tambores. Formadas las fuerzas que defendían la causa de D. Carlos, salieron de aquella villa con dirección a esta. A la sazón, el convento de San Francisco se había convertido en fuerte avanzado de Requena y su comunidad religiosa, que ya no existía en él por haberse secularizado, en voluntarios urbanos defensores de

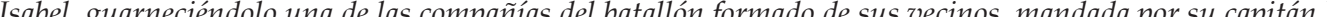
Gregorio Cañete, quien á cosa del medio día y previo aviso del vigía de la torre que le dijo que por las casas de Agedrea se veían inmensas polvaredas producidas por el paso y tránsito de los carlistas que venían camino abajo, mando izar la bandera de alarma y de inmediato peligro, dando el correspondiente parte al comandante militar de la población coronel D. José Albornoz. Este señor mandó que se disparara el cañón de la batería del Cristo, aviso de la aproximación del enemigo á las gentes que trabajaban en la huerta, que no veían la seña que les comunicaba la bandera del fuerte, y se situó en el conocido con el nombre de 'Cerrito de Isabel II', que lo guarnecían fuerzas de la Milicia urbana y un cañón de á cuatro, desde donde podía ver al enemigo y aprecior sus maniobras. A la sazón y en la casa de campo y recreo llamada de la Fuen Caliente, vivía su dueño el Sr. D. verion Requena, salio a su trcuentro, y presentrndose a jefe de aquellas fuerzas general Cómez, con su

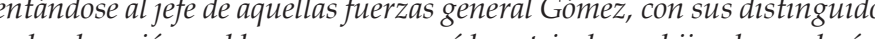
modales, fruto inequivoco de su esmerada educacion, noble sangre y amor á la patria de sus hijos, le ponderó de tal modo las fuerzas, armas y municiones con que contaba Requena, que aunque dicho jefe llevara intención de asaltarla, de cierto que hubiera desistido de su empeño. Gómez creyó en la honrada palabra del caballero que le hablaba, y aún más la creyó cuando le dijo que le estaba hablando el que no hacía mucho era el comandante del cuerpo de voluntarios realistas de toda la jurisdicción. Prendado Gómez del trato noble y caballeroso del Sr. Medrano, se despidió de él hasta más tarde ó pocas horas después, y bajó á la huerta de Requena.

Después ya no se llegaron a ver más. Serían las dos de la tarde cuando se presentó la cabeza del ejército carlista en el punto llamado el Rollo, eras y corral de las Mudas (sitio que hoy ocupa el comienzo de la Plaza de Toros), y entonces D. Joaquín Herrero tocó a rebato la campana salvadora. Conforme iban llegando á dicho sitio las brigadas, batallones y caballería carlista, que cubrían todo el camino que hay desde Agedrea al Rollo, estos se iban distribuyendo en varios puntos. Las muchas gentes que del pueblo de Utiel les venían acompañando (tal vez á presenciar satisfactoriamente el asalto y toma de Requena, y quizá á participar de su saqueo y botín, como muchos creían, aunque yo no lo he creido nunca) se quedaron en dicho camino y sitio extenso llamado fuente de los Regidores. En el antes dicho corral de las Mudas, se situó el general Gómez con todo su estado mayor y en las eras inmediatas o lindantes un batallón navarro con una pequeña pieza de artillería, lo cual advertido por el teniente de esta arma de la Milicia Sr. D. Enrique Zanón que mandaba la pieza emplazada en tocando á rebato; las cureñas y armones haciendo con su rodaje el ruido consiguiente, cuando por solo las mujeres eran conducidos por las calles á los fortines que defendían los sitios que, al parecer, ofrecían mayor peligro; el cañón del Cristo disparando contra el corral de las Mudas; el escuadrón de Nacionales, que lo componían D. Bartolomé Cobo, D. Pedro de Vera, D. José Viana, D. Luis Gil (que aún vive), D. Juan Suárez, el Maltés, D. Gregorio Valero, D. Roque Carretero y otros 50 ó 60 patricios más al mando de su comandante el caballero D. José Fernández Albarruiz, situado en la plazuela y debajo de la torre del Salvador, en continuo movimiento, llevando dichos individuos á la carrera al fuerte del Cerrito los partes verbales que les comunicaban los vigías sacerdotes Sres. D. Epifanio Moya y Monsalve D. Basilio y D. Fermín Sáez de Cepeda que sobre 13000 enemigos, daban á Requena un aspecto majestuoso, imponente y aterrador. Con mi abuelo y mi padre, que no pertenecían á cuerpo alguno reglado de la Milicia, y que, como todos los vecinos de la población, estaban armados, me encontraba yo, que contaba doce años de edad, en la galería de la casa del Sr. Conde de Montenegro, sita encima del fortín y puerta del Santo Angel de la Guardia, y por consiguiente, enfrente del corral que ocupaba el general Gómez, y en este supuesto, veía y presenciaba todos los movimientos de los carlistas por aquella parte, como también á la persona que salió de su cuartel general portadora del oficio que este dirigia al jefe de la plaza intimándole la rendición, que por cierto, y aunque traía la señal blanca anunciando parlamento, fue recibida á tiros por los voluntarios que defendían el fuerte avanzado de la puerta camino de vecino de Requena, que por fin penetró en la población y fue al cerrito de Isabel II á entregarlo al Sr. Albornoz. Las pretensiones del general Gómez, apoyadas en sus inmensas fuerzas, de que hizo una ponderativa exibición, colocadas en diferentes puntos y á la vista de Requena, no fueron atendidas, y sí despreciadas por le Jefe de la plaza y su Estado Mayor, cuya contestación negativa la llevó el mismo mensajero al antedicho general, dando á la vez la orden, que fue comunicada á todo el recinto con la mayor prontitud, 'de que seria pasado por las armas aquel que disparara la suya contra el enemigo hasta que este no estuviera á la distancia de seis pasos, y se pudieran contar los botones que abrochaban sus capotes'. Como el enemigo no se acercó ni aun á los seiscientos, nadie disparó contra ellos.

$Y$ así las cosas, y sin que se percibiera el más pequeño movimiento de ataque ni mucho menos de asalto en ningún ángulo de la población, porque los carlistas no se salieron dos pasos siquiera de las posiciones que ocuparon desde que á nuestra vista se colocaron, se puso el sol y cerró la noche, y los carlistas volvieron á Utiel con todos sus acompañantes, y los hijos de Requena dieron la prueba más insigne de ser los dignos sucesores de aquellos nobles varones ilustres, por cuyos hechos de armas y amor á la realeza castellana constituída, tenían los honorificos títulos de Caballeros, Muy Nobles, Muy Leales y Fidelísimos; pues no se amedrentaron, ni desmayaron, ni decayeron sus viriles fuerzas á la vista de aquellas enormes masas de enemigos que á la vista tenían. Es verdad que estas, como acabo de decir, no acometieron las débiles tapias que cerraban y fortificaban á Requena; pero estemos seguros que si hubieran intentado tan temeraria empresa, habrían recibido una sangrienta y mortífera lección á las puertas mismas de la población que querían conquistar. A los pocos días después de llegadas á Utiel las fuerzas carlistas de regreso del paseo militar que dieron por la huerta de Requena, se diseminaron y marcharon en diferentes direcciones" (Herrero y Moral, 1889: 51-54).

La narración de Herrero, testigo presencial de los hechos con doce años y en contacto directo con muchos de los participantes, difiere sobremanera de otras narraciones, como la de Pirala, así como 
se contrapone al informe oficial que el coronel D. José Albornoz expide a la Capitanía General de Castilla la Nueva y que fue transmitida inmediatamente al Secretario de Estado y del despacho de la Guerra, Antonio Seoane, para regocijo del gobierno.

Antonio Pirala, en su versión escrita hacia 1858, sostiene que "conformes los jefes carlistas en embestir á Requena, - y no tendría en este propósito la menor parte el deseo en Cabrera de vengar el revés que un año hacia había sufrido ante los desmoronados muros de la citada villa, - y después de completado el armamento, de haber construido boinas, cartuchos y otros efectos, de haber provisto al arcipreste de Moya, jefe de los car listas en la provincia de Cuenca, de setecientos fusiles, diez y ocho acémilas y ventídos caballos cansados, después, finalmente, de haber formado con los mozos que sacaban y los presentados el $70^{\circ}$ batallón de Castilla que prestó á los demás un servicio importante guardando los prisioneros de Córdoba, Almadén y otros puntos, los batallones valencianos salieron todos el 13 de Utiel, confiados en ocupar la población á que se dirigían. Contaría Requena once mil habitantes. Situada en Castilla, al Norte, confinaba con el reino de Valencia. Circúndanla dos series de montes, y eran antiguas sus murallas y castillo [ ] y siete meses nada más hab́r trascurrido desde que rechazó con éxito al caudillo de Tortosa, que poco acostumbrado al malogro de empresas de este género, anhelaba dominar á Requena.

Dos leguas distante, llegó descansada la espedícion. Defendía la villa el coronel don José Albornoz, comandante militar del cantón, sin más fuerza que los milicianos y una compañía improvisada, titulada provisional, compuesta de los enfermos y cansados de varios cuerpos del ejército. Al divisar á los carlistas cubrió en lo posible algunos puntos, y se aprestó á la resistencia, sin intimidarse por el número de su implacable enemigo. El buen espiritu de la población, y el justo temor de todos los que tenían algo que perder, indujo á la mayorí de sus habitantes á comprometerse en la defensa, sin distinción de clase, sexo, ni aun edad, acordándose del carácter de Cabrera. Acercóse con Cómez y reconociendo ambos el esterior de la villa hicieron avanzar una cor compañís de preferencia, cuyo movimiento seguía en reserva el resto de las fuerzas, y situaron las dos piezas que llevaban, rompiendo sin demora el fuego de cañón y fusilería. Contestado vigorosamente, vanas fueron las multiplicadas tentativas para escalar el muro apenas guarnecido. Rechazados en todas partes cuantas veces embistieron, por más que variaban estratégicamente y con velocidad de dirección, porque al punto también acudían hasta las mujeres, mudando las piezas, y desmontada una de las de Gómez, apeló al uso de la persuasión, ya que no era fructuoso el de la fuerza.

Invitó la rendición, ofreciendo respetarlo todo, amenazando, de lo contrario, con el asalto y sus consecuencias. Rechazada y devuelta la invitación, que recibió simuladamente á causa de haber saludado á balazos al parlamentario que la conducía, redoblaron Gómez y Cabrera sus esfuerzos, sin conseguir más que menguar proximidad de San Miguel y Alaix, y llevando, Cabrera especialmente, el despecho de este nuevo desaire. No imitó Requena el ejemplo de otros pueblos y capitales, que con medios de defensa se apresuraron á franquear sus puertas á Gómez. Sostúvose, por el contrario, heroicamente, y acreció su nombradía conquistando el título de ciudad, con que las Cortes premiaron la bizarría de sus moradores, y presentando á la fuerza ciudadan otro de sus gloriosos timbres.

Descansaron en Utiel los carlistas todo el día 14, y con intento, nada menos, que de amenazar á Madrid salieron tercera vez el 15, dejando á la derecha el camino de Cuenca y marchando hacia Albacete, por ocultar sin duda su verdadera dirección y no llamar fuerzas á la desouarnecida residencia del oobierno" (Pirala 1869:223-224)

Observamos que esta versión no se aleja tanto como la de Herrero y Moral de la oficial. En el comunicado de la Capitanía general de Castilla la Nueva a la Secretaría del Estado, se escribía: "Excmo. Señor: El coronel D. José Albornoz, comandante militar de Requena y su cantón, me dice desde la citada villa, con fecha 15 del actual, en oficio que acabo de recibir, lo que sigue: Excmo. Señor: El dia 7 del actual llegó a la inmediata villa de Utiel, a la una del dia, el rebelde Gómez con toda su facción, y ha permanecido hasta hoy al amanecer, que ha salido en unión de Cabrera, Quiles y el Serrador con dirección a Casas Ibánez distante de esta ocho leguas. En estos nueve días puede decirse que este pueblo ha estado bloqueado por toda su circunferencia, menos por la parte de saliente y mediodía, teniendo de continuo á la vista las avanzadas enemigas, cuyas guerrillas se han aproximado algunos días á tiro de fusil de mis puestos fortificados - Pero el 13 se puso ya en marcha toda la facción con la fuerza, según las noticias más aproximadas, de seis á siete mil hombres, resueltos á atacar á todo trance á esta liberal y decidida población que tengo el honor de mandar y que cada vez se halla mas firme en cumplir sus juramentos de morir antes que sucumbir á los enemigos de nuestra libertad y trono constitucional; y sin otra fuerza para la defensa que esta benemérita Guardia Nacional y una compañía con el título de provisional, formada por los enfermos y cansados de varios cuerpos del ejército, y dadas mis disposiciones, los esperamos tranquilos y seguros de la victoria. En efecto, á la una mprendió sus ataques, dirigién dose una de ellas cacia la puerta de Cantarranas, otra á la de Alcalá, y la tercera á la de Valencia, colocando al mismo tiempo en batería los dos pedreros, únicas piezas que traía - En esta disposición, mi artillería, que solo esperaba mi voz, principió á hacer un fuego vivo y certero que les hizo por todas partes, obligándolos a retirar una de sus piezas desmontada, haciendo después lo mismo con la otra, sin duda por igual contratiempo. Se vieron en sus columnas grandes claros causados por los fuegos de nuestra artillería, así como contribuyeron eficazmente los de la infantería á que fuesen rechazados. Visto que sus ataques eran infructuosos, mandó, como lo tiene de costumbre el cabecilla Gómez, un parlamentario que fue recibido a tiros, y valiéndose de la estratagema de un paisano, le entregó el pliego para que lo hiciese llegar á mis manos, el que contenía las asechanzas de esta canalla reducido á que nos entregásemos, reconociésemos á Carlos $V$, que serian respetadas las personas y propiedades, y que nal con la respuesta verbal de que Requena no conocía más que á Isabel II constitucional y el código sacrosanto que ha jurado sostener. Los ataques se volvieron a repetir; pero nuestros valientes, llenos de entusiasmo, le hicieron conocer su loca temeridad, porque por cualquiera parte que dirigía sus masas, encontraba artillería é infantería que las hacía retroceder, hasta que llegada la noche, y cubierto no solo de oscuridad sino también de ignominia, emprendió su retirada y llegó á Utiel, morada y cuartel general de sus iniquidades, por la decidida protección que le dispensa la escandalosa y marcada desafección de aquel vecindario - No me es posible detallar la pérdida del enemigo, porque como $V$. E. sabe, tiene sí se vio caer á unos y montar á otros en caballerías, sin haber experimentado por la nuestra ni un solo herido [...]" (Herrero y Moral, 1889: 55:56).

Dada la distorsión de los hechos que se producen, observamos que la versión de Antonio Pirala (1824-1903) coincide con la versión oficial, exaltando las glorias de Requena y el arrojo del espíritu liberal. Es preciso recalcar la identidad progresista liberal del autor. Observamos que la versión de Pirala de la Historia de la Guerra Civil se nutre de documentos de toda procedencia dada su amistad con muchos de los protagonistas de la guerra, documentos que él coleccionó y archivó. No obstante, su tratamiento de los datos ha sido muy cuestionado en la medida que se limitó a copiar aquella información de que disponía, incluyendo versiones contrapuestas. Si bien la historia de Pirala es imprescindible para los historiadores de la guerra y parece existir unanimidad de criterio a la hora de cias, nos preguntamos hasta qué punto Pirala narró la verdad del asedio. ¿Podría Pirala haber recurrido al mismo informe del Coronel Albornoz para testimoniar los hechos? La historia del asedio del general Gómez se perpetúa del modo más glorioso porque a nadie perjudica. Los ciudadanos de Requena y todos los mandos defensores se benefician de la exaltación de su heroicidad. Los mandos intermedios y el gobierno de Madrid pueden recurrir al hecho heroico de un modo ejemplarizante. Es cierto que Requena es premiada siendo elevada al rango de ciudad, y ello implica un regalo por parte del gobierno central si en realidad no hay motivo para ello. Aún siendo así, el premio debía justificarse con hazañas que lo mereciesen. Finalmente queda la versión del enemigo, cuyo fracaso en el asedio, se ve minorado si la acción defensiva es heroica, como queda narrado. La Historia, pues se consolida porque el engrandecimiento de la hazaña no perjudica a nadie, sino que más bien beneficia a todos. Esta interpretación, no obstante, solo puede dejarse aquí patente y sostenerse a modo de reflexión. ¿Qué interés podía tener Herrero y Moral en su narración descafeinada de los hechos? ¿Quizás la mera exposición de la verdad de unos hechos que él mismo había presenciado?

Respecto a las diferentes versiones, se observan diferencias en el modo de atacar. El coronel Albornoz habla de un ataque en tres columnas por tres de las puertas. Herrero habla del desmontaje casual de una de las piezas enemigas, pero el resto de versiones hablan de la inutilización de los dos pedreros enemigos. Pero si una diferencia es sustancial son los acontecimientos tras el parlamento. Según Herrero no sucede nada y el enemigo se retira, algo coherente dado que no podía arriesgarse a asediar la ciudad conociendo la estructura defensiva de columnas militares de apoyo. Si la ciudad resistía y se producían bajas, la ambiciosa expedición de Gómez habría quedado retenida en Reque- 
na. Sin embargo las versiones oficiales nos hablan de un asalto final, que dura hasta el anochecer finalmente rechazado y que sirve para glosar la gloria de la defensa; el mismo Pirala hace referencia a intentos de escalada, para añadir dramatismo a la escena. Según Herrero y Moral, en ningún momento los atacantes se pondrán a tiro.

El conjunto de testimonios de los historiadores viene a ser complementado con una curiosidad documental como es el viaje que Pío Baroja realiza a Requena, siguiendo la ruta del General Gómez a fin de redactar una crónica por entregas para la revista Estampa, en 1935 (Baroja, 1935). De especial interés para esta investigación es el artículo "sobre la ruta del General Gómez por los camino de España. Utiel, Requena y la Mancha", publicado en el número 377 de Estampa (Baroja, 1935: 37-39), donde Baroja no aborda un reportaje no solo descriptivo del acontecimiento militar, sino también de carácter sociológico, efectuando entrevistas a las gentes de Requena completando un estudio impresiones de carácter local.

De entrada Baroja sostiene que cuando llega a Utiel apenas encuentra información sobre Gómez. Según Baroja "Gómez llegó a Utiel el 11 de septiembre de 1836. Alaix había marchado con su columna a Cuenca, donde pudo pertrecharse. Gómez escribió a los cabecillas Quilez y el Serrador desde Jadraque. Les explicaba que tenía un número excesivo de prisioneros, que convendría internar en Cantavieja, y que si los dos jefes se le incorporaban podrían preparar operaciones para entrar en Madrid". Para Baroja parece claro el objetivo de Gómez. "Propuso también a Cabrera una conferencia temeroso de que Alaix le atacara en Utiel, salió para Cantazieja por Chelva pero a la mitad de la jornada recibió aviso de que Quilez y el Serrador llegan a Utiel. Entonces retrocedió. Quilez vino con tres batallones y el Serrador con dos. En conjunto dos mil quinientos hombres de infantería y ochocientos sesenta caballos" (Baroja, 1935: 37). Se observa pues que Gómez tiene siempre presente su debilidad ante la llegada de las columnas del ejército liberal. $\mathrm{Ni}$ tan siquiera se siente seguro en Utiel hasta la llegada de más efectivos. No tardó en llegar Cabrera que "venía acompañado de Arnau, Arévalo, el cura Cala y otros". "Con las fuerzas carlistas del Maestrazgo llegó poco después don Domingo Forcadell". Según Baroja, "el primer propósito de los jefes carlistas fué embestir contra Requena. Cabrera le tenia ganas a este pueblo, donde había fracasado el año anterior" (Baroja, 1935: 37). Tras presentar las intenciones de los carlistas y sus componentes, Baroja aborda el bando liberal: "A Requena la defendía un viejo militar, el coronel Albornoz, y no tenía más fuerzas que los milicirnos y una comprini formada por enfermos y cansados de varios cuerpos del ejercito" (Baroja, 1935.37). En esta composición de las fuerzas defensoras coincide con todas las fuentes. "En el pueblo había armas y se repartieron en el vecindario, y hombres, mujeres y niños fueron a la muralla, dispuestos a impedir la entrada de los carlistas, porque sabian cómo las gastaba Cabrera. Gómez y sus compañeros mandaron com-

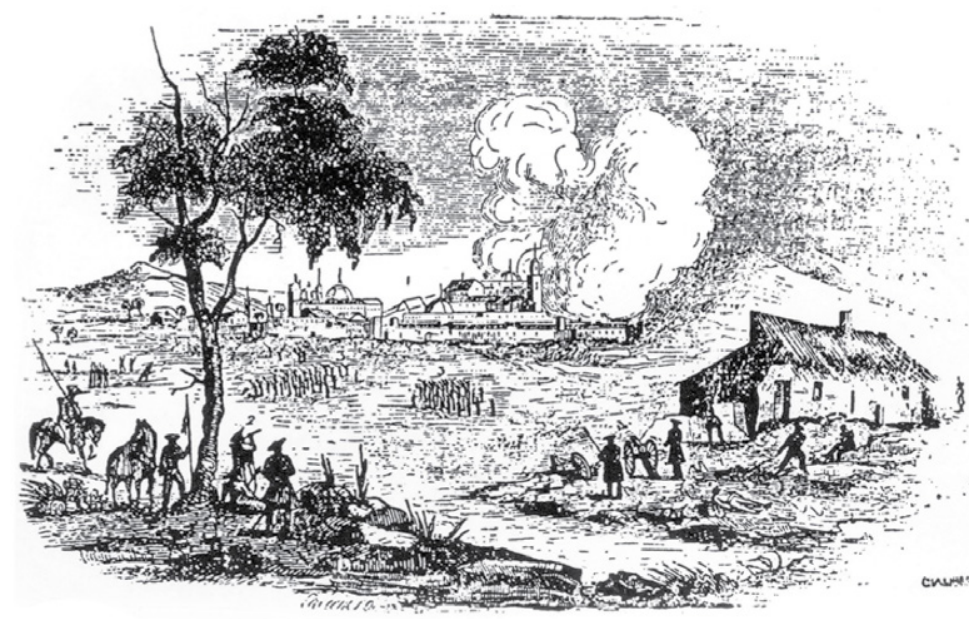

Fig. 727. Ataque a Requena en 1836. Se observa la posición de Rollo y el frente fortificado de Requena con la torre del SalvaCo y Rochina, 1845) pañias de asalto a combatir contra los muros y comenzaron el fuego con dos piezas de artilleria. Fue inutil: no pudieron escalar la muralla. Algún oficial que tenía un cañón en una ventana del Palacio del Cid, disparó y logró desmontar uno de los cañones carlistas. Gómez mandó un parlamentario con bandera blanca y los de decir a los requenenses que si se rendían respetarían a la población: que si no, entrarían al saqueo. Los nenses contestaron: 'Que vengan'. Gómez y Cabrera, por la noche se retiraron a Utiel'. Observamos que Baroja mezcla versiones, habla de dos cañones atacantes y del intento de escalada, coincidiendo con la versión oficial, frente al uso de una pequeña pieza artillera por los atacantes y la ausencia de asalto final sostenida por Herrero. No encuentra el nombre para el artillero y atribuye el parlamento a otra persona, el antiguo prior, pero, a pesar de la falta de correspondencia en la identificación de los protagonistas, lo hechos siguen coincidiendo. Ubica el disparo artillero en el Palacio del Cid, a diferencia de Herrero y Moral que los ubica en la batería del Cristo. Y si el testimonio de Albornoz desmonta las dos piezas artilleras, Baroja desmonta una y Herrero y Moral la única que cita.

Quizás lo más valioso del documento de Baroja sea la interpretación de los hechos que hacen algunos requenenses, a los que localiza gracias al fondista. Uno de los encuestados, según Baroja con simpatías carlistas, "dice que si Gómez no entró en Requena fue porque temía que los generales liberales estuvieran cerca y porque el prior de los franciscanos le aseguró que el asalto costaría mucha sangre. También afirma que el cañón de los nacionales no valía nada y que no consiguió más que incendiar un pequeño batán, por lo que le llamaban en broma el cañón del batanejo." (Baroja, 1935: 39). El testimonio liberal "dice que hombres, mujeres y chicos se defendieron heroicamente, que los carlistas fusilaban a todos los que encontraban en el campo y que esto acentuó la furia y el valor de los sitiados. Hasta hace poco, veíanse cruces de muerto, entre ellas la del Gallo. A un molinero a quien fueron a prender, disparó por la gatera del trabuco, perniquehacer comentarios, Baroja deja un breve cuadro de cómo la historia de aquella primera guerra civil sigue definiendo una clara polaridad casi un siglo después. Estamos hablando de 1935, cuando las dos Españas están, si no más presentes que nunca, tan presentes como siempre. Baroja, eso sí, deja un comentario bastante explícito cuando alcanza Alborea: "los de Gómez encontraron por el Campo los cuerpos muertos de voluntarios carlistas de la expedición de Batanero, y como en esta clase de guerra, cuando se mata a la gente enemiga se la mata correctamente, y cuando matan a los del propio bando se considera que se les asesina, pensaron que estaba muy legitimado el incendiar el pueblo" (Baroja, 1935:39).

Al margen de comentarios y desavenencias, sorprende en las diversas fuentes la absoluta unanimidad en la descripción de los elementos arquitectónicos o localizaciones por aquel entonces de la ciudad, ya que en otros aspectos hay grandes divergencias. En este sentido, para dar verosimilitud a sus respectivos relatos, parece que todos coinciden, y dicha coincidencia puede servir de ayuda a este trabajo en la medida que fija posiciones para conocer algunas referencias de la ciudad.

Entre ellas podríamos enumerar:

1.- El Convento de San Francisco es considerado fuerte avanzado de Requena. Secularizado, se localiza en él un batallón de la milicia.

2.-Una de las torres de la ciudad actúa de vigía, posiblemente se trata de la Torre del Salvador. Sobre ella se iza una bandera blanca, como advertencia de peligro. En los sistemas de alerta, prima la comunicación visual. Los observadores son los propios sacerdotes del pueblo, que envían los comunicados por medio de mensajeros a la carrera hasta el puesto de mando.

3.-En el camino a Utiel existe un conjunto de casas, las casas de 'Agedrea', primer punto visible desde la torre. Y el camino es de tierra, por las polvaredas que levanta. La Ajedrea en la actualidad podría ubicarse próxima a la Rambla de Estenas.

4.-Casi como en periodo feudal, los alrededores de la ciudad constituyen el campo productivo, y se extiende hasta posiciones desde las que es imposible percibir las señales visuales de la torre del Salvador.

5.-La batería del Cristo consta de artillería. Es precisamente el cañón en ella emplazado el encargado de asumir las funciones de comunicación alternativas al telégrafo sin hilos o visual. Un cañonazo sirve para alertar a los hortelanos que no pueden percibir las señales. 
T. 651. Аก̃ก อB 4856.

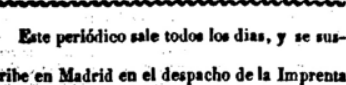
give én Madrid en el despecho de la Impres Nacioasal, en les provin

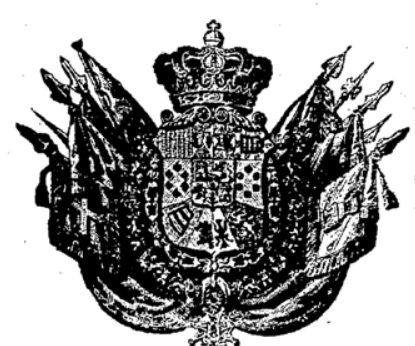

VIERTES 25 DE SETEMIRRE.

MAECTOS DE Strschipctoos.

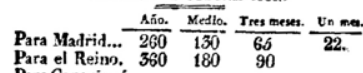

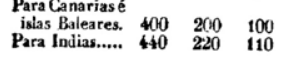

\section{GACETA DE MADRID.}
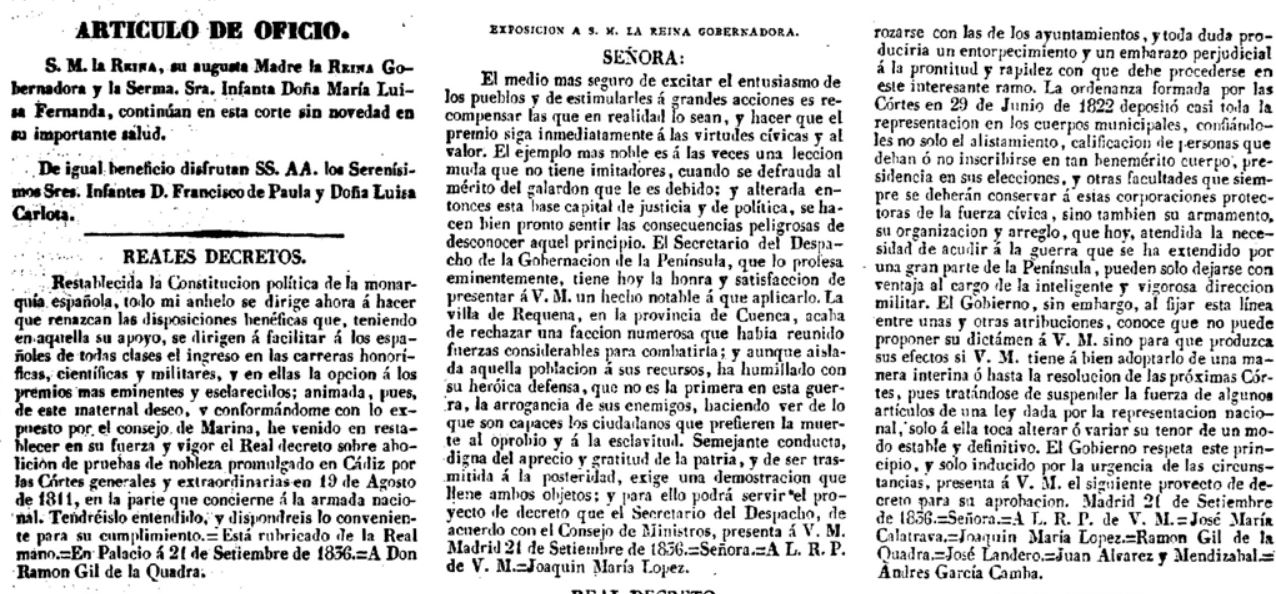

REAL DECRETO.

Conninienlo a la cassa píllica que el nombra
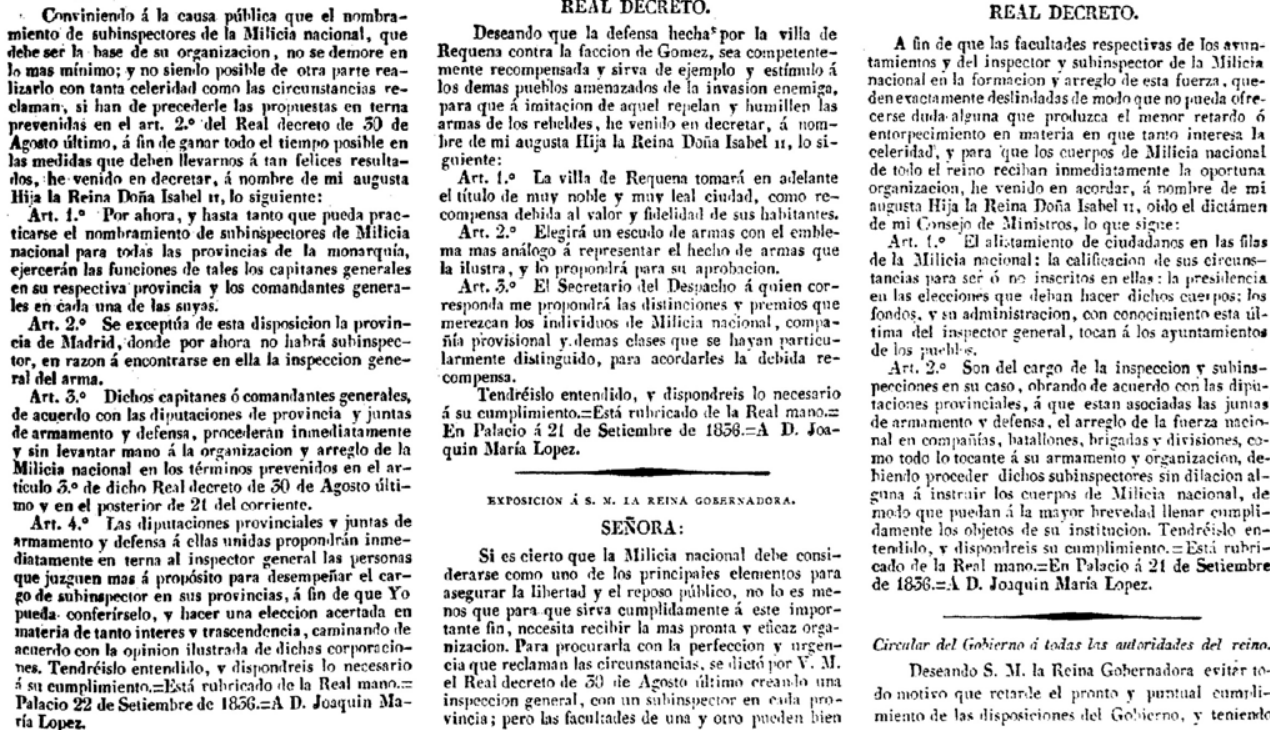

Fig. 728. Publicación del Real Decreto recompensando a la Villa de Requena por la defensa que hizo ante la facción de Gómez (Gaceta de Madrid, el 23 de septiembre de 1836).
6.-Existe en Requena un cerro de escasa envergadura, de ahí lo de "cerrito", denominado de Isabel II. Desde el mismo se aposta el Estado Mayor para divisar las maniobras del atacante. En dicho cerro se ubica parte de la milicia y cuenta con un cañón de a cuatro (cuatro libras). Desde el cerro se dominan todas las operaciones, recibiéndose los mensajes que llegan desde la torre de vigía. El Cerrito de Isabel II es identificado por Bernabeu como Pozo de la nieve (Bernabeu, 1982: 419), un dato contradictorio dado que se trata de dos posiciones aledañas pero diferentes.

7.- En la casa de campo y recreo llamada de la Fuen Caliente vivía su dueño el Sr. D. José de Medrano con toda su familia. Se encuentra en el camino de Utiel, dado que es el Sr. Medrano el primero en salir al encuentro de Gómez. Tras despedirse de Medrano, Gómez alcanzará la Huerta de Requena. Ello no quiere decir que Fuen Caliente se encuentre antes de alcanzar la huerta desde Utiel, podría emplazarse en el ámbito de la misma huerta requenense dado que Medrano sale al encuentro de Gómez. 8.-El Rollo, eras y corral de las Mudas es un emplazamiento que coincide con la actual plaza de toros. Parece tratarse de unas construcciones en las que los carlistas pueden apostar el Estado Mayor, concretamente en el Corral de las Mudas. En la eras contiguas se emplaza una pieza de artillería que será alcanzada por la pieza de a cuatro desde el cerro de Isabel II. Con estos datos se puede colegir que el corral de las Mudas se encuentra al alcance de la artillería de este calibre. Es preciso tener en cuenta que el alcance máximo de un cañón en tiro parabólico podía alcanzar los $4000 \mathrm{~m}$. Sin embargo, el disparo eficaz se producía en un ámbito de $300 \mathrm{~m}$. No se puede pues estimar una distancia exacta, pero podría rondar entre los 600 y los $700 \mathrm{~m}$ la distancia entre el corral de las Mudas y la batería del Cristo.

9.-Sabemos también que el camino entre el Rollo y las casas de 'Agedrea' es cubierto por el ejército carlista en su avance (brigadas, batallones y caballería).

10.- También sabemos que gentes de Utiel se posicionan a resguardo en este camino, en una extensión denominada Fuente de los Regidores, que existe en la actualidad.

11.-Existe un escuadrón de la milicia con 50 o 60 hombres apostado en la plazuela a los pies de la Iglesia del Salvador.

12.-Existe un fortín en la puerta del Santo Ángel de la Guardia. Dicha puerta parece dar al frente de Utiel, donde se aposta el enemigo, pues se visualiza el corral del general Gómez y la llegada de mensajeros. Junto a la puerta, se ubica la casa del Sr. Conde de Montenegro, que cuenta con una galería desde la que se observa la campaña. Tanto la puerta como la casa de Montenegro existen en la actualidad.

13.-Los carlistas parecen no cerrar el cerco de la ciudad en "naciente y mediodía", es decir, ni por el sector este, ni sur, lo cual tiene lógica pues parece corresponder más que con una orientación precisa de los puntos cardinales y el recorrido solar, con el curso del río Magro, que supone un obstáculo natural que dificulta las maniobras de un ejército atacante, sin contar lo escarpado del terreno en esa posición.

14.-Cuando se procede atacar, si es que dicho ataque se produce, lógicamente este se hace buscando las puertas, reconociéndose la existencia de la Puerta de Cantarranas, la Puerta de Alcalá y la Puerta de Valencia. Esta identificación podría corresponderse con las puertas originarias de la ciudad medieval, las denominadas del Cristo (conexión con el interior castellano), la Puerta de Alcalá (conexión con Alicante) y la Puerta de Fargalla o Valencia (camino viejo a Valencia). La puerta de Valencia (Ollerías) en el año 1840 parece contar ya con un foso y un puente levadizo, según el testimonio de Bernabeu a raíz de los conatos subversivos tras el golpe de Espartero (Bernabeu, 1982: 436).

15.-Finalmente queda la cita que Baroja hace del Palacio del Cid, presencia edilicia indudable en la ciudad. Más dudosa es la disposición en él de la batería que desarme las posiciones del Rollo tal y como atestigua el escritor.

El ataque de Cabrera de 1837

Con el fracaso del nuevo asedio a Bilbao, la guerra prosigue en los entornos de Requena en la misma tónica. Los pueblos y los caminos son objeto de las idas y venidas de las innumerables partidas y sufren los desmanes de unos y otros, ya sean los carlistas, como las tropas francas que campan ibremente. 
Son numerosos los sucesos en el campo de Requena, pero nos interesa recalcar, dado el objeto de nuestro trabajo, el último intento de Cabrera por atacar Requena, que se produce con el apoyo de Forcadell y Sancho en la mañana del 19 de marzo de 1837. Una vez más, el ataque se fragua desde Utiel. En aquel momento, en Requena se apostaba la compañía provisional, 300 soldados dispersos de la columna de Crehuet y milicianos de Cofrentes, aunque seguía también contando con el ímpetu defensivo del vecindario.

Los soldados de Crehuet procedían de la desbandada del ejército liberal que había sido sorprendida en el "valle rodeado de los montes conocidos por la Cabrera". Fue una debacle militar cuyos jirones ha-

bían acabado buscando refugio en Requena, Játiva y Alcira. ${ }^{1}$ (Rújula, 2006:112-113)

Hay pocos datos sobre este ataque, pero algún testimonio recuerda las ganas que Cabrera tenía a la ciudad: "Cabrera mientras tanto quiso vengar los reveses que por dos veces había sufrido en Requena. Bloqueada la población, se entretenía en quemar y devastar sus alrededores. No pudiendo vencer a sus habitantes, queada la población, se entretenía en quemar y devastar sus alrededores. No,

quería arruinarlos dejándolos pobres y miserables" (Rújula, 2006: 114). El ataque, una vez más, se emprendió a través del barrio de las Peñas, pero sería rechazado, Requena estaba bloqueada y así lo testimonia Bernabeu con un periódico de la época que indicaba cómo "esta desgraciada población... sigue bloqueada por las facciones reunidas a las órdenes de Cabrera, que tiene establecido su cuartel general en Utiel; llevamos seis días de bloqueo. Estos valientes y comprometido ciudadanos no se acobardan ni por la excesiva nieve ni continuas lluvias; pero se conoce van resintiéndose de abandono en que se nos deja... El comercio de Requena yace en total abandono; estamos dejados a nosotros

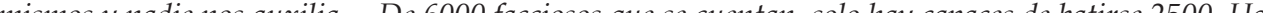
sado y destruido todos los caseríos de estas inmediaciones. Si solo tubiéramos 500 hombres con 100 caballos, no tendrían su cuartel general tan inmediato..." (Bernabeu, 1982:426)

Requena sostuvo un bloqueo de cinco días, justo hasta el 25 de marzo. Se podría interpretar que el bloqueo de Requena fue una estratagema de Cabrera para movilizar al ejército liberal en defensa de la ciudad, pues cuando los generales Álvarez y Nogueras, con ocho batallones y seis escuadrones llegaron para levantar el sitio el día 3 de abril, Cabrera se precipitó sobre la huerta valenciana. Por su parte, Forcadell, que se dirigía hacia Utiel con el botín saqueado en tierras murcianas, consiguió eludir al ejército y alcanzar los Pedrones.

La presencia del ejército o de las columnas volantes tampoco resultará cómoda en la zona, pues si por un lado las partidas carlistas saquean las propiedades, el ejército exige sus propias exacciones para su sostenimiento, lo cual hace que muchos habitantes se planteen emigrar para eludir los abusos (Bernabeu, 1982: 427). Con una Real Orden de 6 de junio de 1837, la ciudad se ve obligada pagar las armas y municiones que ha recibido para su defensa, así como sufragar los 80.000 reales que supone el Hospital Militar (Bernabeu, 1982: 427).

Este periodo de 1837 es un periodo clave en la mejora de las fortificaciones de la ciudad, que abordaremos a continuación.

Cuando Cabrera se presente de nuevo en Utiel el 2 de septiembre de 1837, será ahuyentado por la presencia del ejército de Oráa. Como recoge Cabello, "El general Oraá sería o no afortunado, pero con su venida había hecho ya un señalado servicio a los pueblos, estableciendo orden y economía en las exacciones, y 1 "Crehuet, que con sus tres batallones y dos excelentes escuadrones podía haberse defendido en el llano, quiso ir a buscar la facción en
la sierra y por lo menos evitar que cruzara el Jucar. No conociendo el terreno, fue a pernoctar en un valle rodeado de los montes conocidos

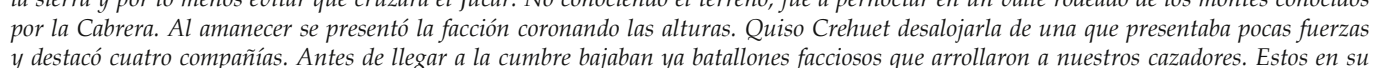
retirada arrastraron la brigada de municiones y equipajes que estaban al pie del cerro y hasta desordenaron el batallón que formaba punto la brigada. Los otros dos que mandaba Crehuet se movieron por la izquierda a ganar las alturas mientras salía la caballería de un desfiladero. Mucho rato se defendieron estos batallones, pero, cediendo por fin al mayor numero, hubieron de retirarse. Por desgracia, al fin de la cuest había grandes cortaduras y un río de muy profundo cauce. La mayor parte se precipitaron en él para salvarse y se salvaron, pero Crehuet,
con veinticinco oficiales y cuatrocientos soldados, se hallaron cercados en un gran peñasco del que no pudieron salir. Algunos oficialles se precipitaron, prefiriendo morir a caer prisioneros; la mayor parte se rindieron. La división, hecha pelotones, acudió a Requena, Játiva y Alcira" (Rújula, 2006: 112-113). lo habia hecho mayor a la libertad creando un ejército. Tan pronto como arregló las oficinas de hacienda militar y las divisiones de Valencia, salió de esta ciudad para Chelva. En esta población y sus alrededores estaban Tallada y el fraile Esperanza con unos mil quinientos facciosos, menos aguerridos y peor armados y uniformados que los otros pero que tenían en alarma a Requena y toda la provincia de Cuenca, que servían de apoyo para las incursiones que Cabrera intentara por Las Cabrillas, y que, a retaguardia del terreno en que debía vivir y operar nuestro ejército contra las fuerzas principales, podían ponerle alguna vez en grandes compromisos. El general Oraá debía empezar por ahuyentarla, y, aprovechando la ocasión de estar en los confines de su distrito el capitán general de Castilla con una división de la Guardia Real, la persiguieron en combinación. Las facciones abandonaron Chelva antes de llegar nuestras columnas y dejaron algunos enfermos y efectos de guerra, pero se corrieron por Ademuz y Arcos y no fueron seguidas. En Chelva se presentaron unos cuarenta soldados y fueron rescatados otros prisioneros" (Rújula, 2006: 120).

La tónica general desde este momento hasta el fin de la guerra depende sobremanera de la toma de Morella. Desde este bastión Cabrera sostiene el último reducto carlista, que sirve de base para las numerosas acciones de las partidas. Las anécdotas son innumerables y afectan a Requena, pero las numerosas acciones de las partidas. Las anécdotas son innumerables y afectan a Requena, pero
resultan menos trascendentes para la historia de sus fortificaciones. Por recoger algunas, la gran resultan menos trascendentes para la historia de sus fortificaciones. Por recoger algunas, la gran
mayoría narradas en el Diario Mercantil de Valencia, nos basamos en el trabajo de Caridad que, por mayoría narradas en el Diario Mercantil de Valencia, nos basamos en el trabajo de Caridad que, por
ejemplo, cita cómo ante la necesidad de poder producir su propia artillería, "en julio de 1839 los carlistas confiscaron las campanas de Gestalgar y de Utiel. De este último punto se llevaron incluso las calderas de la fábrica de aguardiente" (Diario Mercantil de Valencia, 20 de julio de 1839; Caridad, 2013:165). También las partidas trataban de suministrar alimento, que obtenían del propio terreno de innumerables formas, en algunos casos, incluso recolectándolo: "En el campo de Requena, a finales de junio de 1839, una partida de 100 infantes y alounos caballos, acompañada de muchas caballería y paisanos del río Blanco (que llevaban hoces) se dedicó a segar las espigas para llevarlas a sus guaridas" (Diario Mercantil de Valencia, 3 de julio de 1839; Caridad, 2013:131). "Muchas de estas tierras habian sido confiscadas a emigrados liberales y los carlistas recogían el fruto de sus cosechas" (Diario Mercantil de Valencia, 18 de agosto de 1839; Caridad, 2013:131). También era importante el salitre, utilizado en la fabricación de pólvora. Así "en diciembre robaron 40 arrobas $(511,2 \mathrm{~kg})$ de salitre a los carreteros de Requena. Todo este material se llevaba a las fábricas de Cantavieja (fundada en 1837), Miravet, Mirambel..." (Caridad, 2013:164). El saqueo y el robo es sistemático, por ejemplo para apropiarse de un elemento clave para el conflicto armado, para el transporte de materiales y el trabajo en el campo: los caballos. Así, el Mercantil Mercantil de Valencia, 19 de agosto de 1837), lo que fue seguido por muchos robos de carros a los mercaderes que transitaban por la zona" (Diario Mercantil de Valencia, 16 de diciembre de 1838; Caridad, 2013:200). Los elementos de transporte resultaban claves, y los carlistas, dada su necesidad de movilidad, se veían obligados a abandonarlos cuando se veían acosados por las columnas regulares. Por ejemplo "Forcadell tuvo que esconder muchas piezas de paño cerca de Requena por falta de medios de transporte" (Calbo y Rochina, 1845:276; Caridad, 2013:207).

Se detecta una especial preocupación en el bando carlista por la escasez de apoyos en la zona de Requena: "un año después el caudillo carlista envió al subteniente Manuel Gutiérrez para organizar una partida en el distrito de Requena, donde la facción contaba con escasos apoyos" (Caridad, 2013: 45). Cuando den comienzo las primeras deserciones con la aproximación del fin del conflicto, Requena se convertirá en un centro donde desemboquen algunos facciosos: "en marzo de 1840 se presentó un cabecilla con cinco hombres en Requena, mientras que otro se ofreció a entregarse con su partida si se le perdonaba" (Diario Mercantil de Valencia, 3 de abril de 1840; Caridad, 2013:118).

Quizá, de las últimas acciones hostiles que afectan a la ciudad de Requena y que prueba la impunidad con la que campaban las partidas, destacan las acciones de las partidas de Merino, Vizcarro, La Diosa que hostilizó a la ciudad el 3 de enero de 1838, el paso impune de un convoy carlista, a la vista de las Peñas, conducido por Orejita (Bernabeu, 1982:428), o cuando la caballería de Domingo Arnau campó a sus anchas por la Vega intentando un golpe de mano contra las Peñas. Pero en Requena se encontraba la brigada del Turia, lo cual desconocía, y acabó siendo "aparatosamente derrotado en el Barranco del Diablo (Utiel) por don Martín Iriarte, quien horas después entraba triunfalmente en 
Requena a la cabeza de la brigada de Cuenca y con numerosos prisioneros (Bernabeu, 1982:428) Esta victoria, que se producía el 6 de febrero de 1839, servía a Iriarte para escribir a Cabrera a fin de potenciar el trato humanitario a los prisioneros, explicando en la misiva cómo trasladó a "los heridos al hospital militar de Requena" (Rubio, 1869:132).

Recalcaremos en la fase final de la guerra la tirantez que se produce entre militares y paisanos, especialmente debido a las presiones fiscales a las que son sometidos los últimos para sostene la guerra. Cuando el general Aznar llega a la ciudad para combatir a Cabrera y Forcadell, se ve obligado a regresar a Valencia, dado que no obtiene de la ciudad más que raciones para tres días, acusando a Requena de no prestar ayuda alguna. Requena se veía extorsionada desde los dos frentes, si no apoyaba las exigencias de la administración, perdía la protección y quedaba a merced de las correrías carlistas. El papel de los alcaldes resulta clave para relanzar la situación y exponer las quejas al gobierno por encima de las autoridades provinciales. En el caso del alcalde José Matrés, Bejabeu indica cómo efectúa una “ depuración administration, apretó a los propietarios ausentes, resolvio Bernabe ind cosolvión el trágico abandono de los presos y consiguio una sección de caballeria para asegurar la recolección. También reorganizó el cuerpo de serenos y dispuso para el alumbrado público pequeñas lámparas de aceite" (Bernabeu, 1982: 429).

9.3. La fortificación liberal de Requena de la Primera Guerra Carlista a través de los documentos históricos: proyecto y construcción

En el Archivo Municipal de Requena se ha podido localizar una serie de documentos trascendentales para entender el proyecto y construcción de la muralla liberal de Requena. Se trata de documentos fechados en 1833, 1834, 1835, 1836, 1837, 1838 y 1839, precisamente el periodo que dura el primer conflicto carlista, cuando Requena se ve especialmente amenazada por las partidas que operan en el Maestrazgo y por la expedición de Gómez (1836), observándose la preocupación por poner la ciudad en estado de defensa.

El primer documento, fechado en Requena el 12 de noviembre de 1833, resulta menos trascendente que el resto para esta investigación, en la medida que constituye un desglose del conjunto de "Armamento, Correage, municiones y demás efectos de vestuario procedente de las extinguidas compañías de voluntarios realistas de la jurisdicción" (AMR, 1818/16). En la jurisdicción de Requena se hace referencia a la villa de Requena, Caudete, Fuenterrobles, Venta del Moro, Villa de Moya, y respecto a los materiales militares, la tabla distingue entre la partida de armamento y correaje: "fusiles, portafusiles, bayonetas, vaynas, cinturones, cartucheras, sables"; partida de municiones: "caxas de guerra, paquetes de cartuchos"; y la de efectos de vestuario: "casacas, morriones, Fundas de... gorras de cuartel, pares de dragonas, charreteras de sargentos, caponas de ..., pompones". Las partidas resultan irrisorias, pues de dragonas, charreteras de sargentos, caponas de ..., pompones". Las partidas resultan irrisorias, pues
observamos que se cuenta con un total de 92 fusiles, otras tantas bayonetas y 2 sables. Unicamente 2 cajas de municiones y 20 de cartuchos. En principio se trataría de la herencia que recibe la milicia urbana y podemos hacernos una idea de los efectos defensivos con que cuenta esta en 1833.
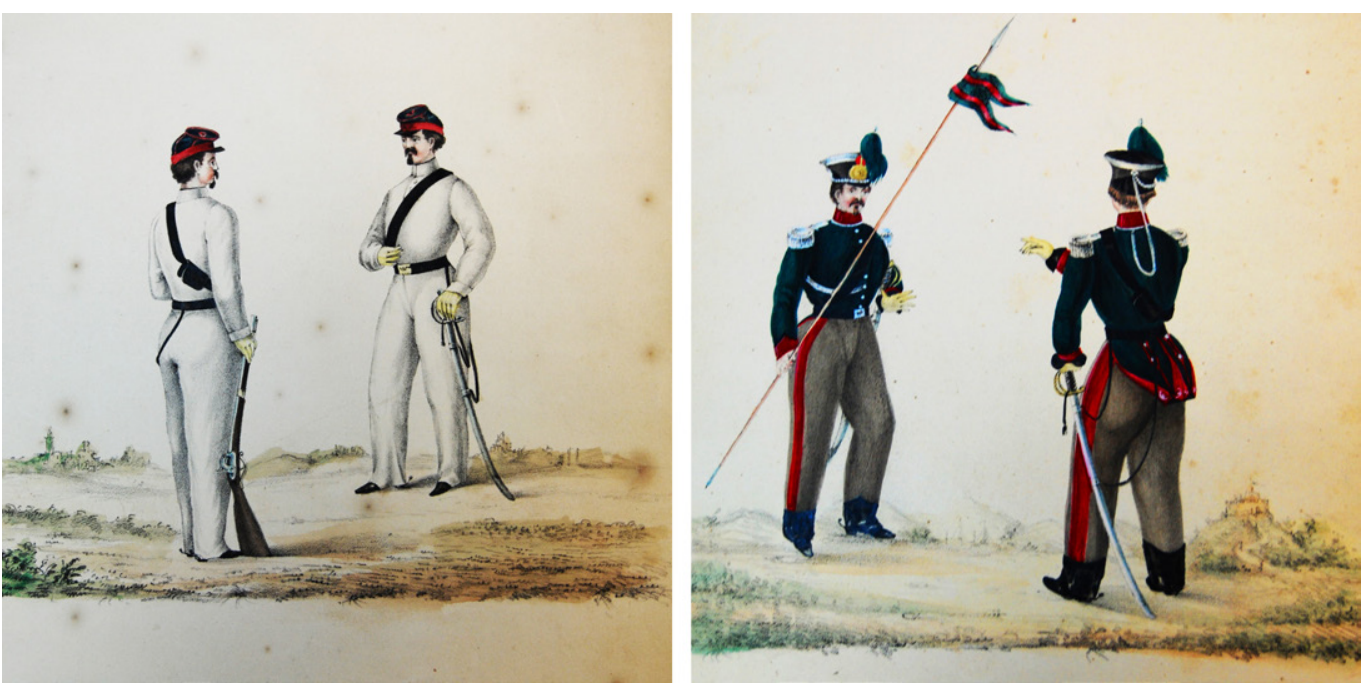

Fig. 729. Uniformes para la milicia nacional de Valencia. Litografía de Estellés y la Compañía Calabazas 8, aprobado por la Subinspección (1836. AMR, 1818-16) 
La primera etapa de la fortificación liberal. Las obras de urgencia para prevenir un posible ataque carlista entre 1834 y el verano de 1835

Se trata de un conjunto de obras de carácter provisional que se emprenden en la ciudad ante la inminencia de un ataque de Cabrera, que definitivamente se produciría en el verano de 1835 (Vera, 1993: 60). Para testimoniar dichas acciones previas se ha localizado el Acuerdo, adoptado por el 1993: 60). Para testimoniar dichas acciones previas se ha localizado el Acuerdo, adoptado por el
Ayuntamiento de Requena, con fecha del 27 de julio de 1835 , en el que se toman medidas para la deAyuntamiento de Requena, con fecha del 27 de julio de 1835, en el que se toman medidas para la defensa de la población ante la amenaza de la facción de Cabrera (AMR, 1818/48). En él se observa lo
desasistido que se encuentra el municipio, que debe tomar las medidas de supervivencia apelando desasistido que se encuentra el municipio, que debe tomar las medidas de supervivencia apelando a sus propios recursos. Como se ha comentado, las tropas de Cabrera y el Serrador se hallaban en Chelva y las tropas liberales del Teniente coronel mayor de caballería D. Adrián Jacome habian sido derrotadas y se habían tenido que refugiar en Requena (AMR, 1818/48). La prioridad es acopia armamento y municiones. Para ello los ciudadanos deben presentar sus escopetas y se debe acopiar plomo y pólvora para fabricar cartuchos. Se deben almacenar víveres y concentrar caballos. También se pide al Capitán General el aprovisionamiento de veinte mil cartuchos de fusil. En el aspecto defensivo, las prioridades se centran en consolidar los frentes amurallados y habilitar aspilleras: "Sería preciso formar aspilleras, cerrar las entradas del pueblo con maderas y ponerlo en estado de defensa contando para ello con el Sr. Comandante de Armas y el de los beneméritos Urbanos y con la inteligencia en este punto de los SS. Militares Retirados en esta Villa" (AMR, 1818/48).

¿Cómo se materializan estas iniciativas? Al respecto tenemos el testimonio de Herrero y Moral, ya citado, en el que se detalla cómo Cabrera, al atacar en septiembre de ese mismo año, se sorprende ante la resistencia de los vecinos. Pero solo se hace referencia concreta a una puerta, la de Reinas, cerrada con palos y aportaderas de vendimiar, así como alounas calles, sin especificar, cerradas, se supone, con algún tipo de atrincheramiento (Herrero, 1891:48).

A pesar de las afirmaciones que se repiten fechando el comienzo de las obras de la fortificación de Requena con las obras de urgencia del verano de 1835, se ha localizado también una relación presupuestaria del maestro de obras Guillermo Sáez del 9 de septiembre de 1834, "para la seguridad" de Requena. Se trata de una "relación jurada" de los gastos originados en los cerramientos de calles y caminos de la villa que identifica puntos de intervención asignándoles un coste. En este caso se trata de una indicación de la obra pendiente de ejecutar y el coste, que asciende a un total de 1.323 tos puntos pendientes se indican: el Camino de los Asnos, la Puerta del Ángel, la Calle de la Cortina, "bajo de los güertos", El batanejo, Las piezas, El tirador, la Calle de las Eras, Calle de los Álamos, Calle de Juan Penén, Calle de Gil, Calle de San Fernando y calle de Poniente (AMR, 1818/48).

Con la misma fecha, el maestro de obras desglosa el estado de las cantidades recibidas hasta el momento por el trabajo en cerramientos, calles y caminos de la población, sin precisar nada específico, salvo un conjunto de fechas en las que se formularon diversos pagos. El estadillo nos permite afirmar que, dado que se han efectuado pagos desde el 29 de julio de 1834 hasta el 16 de agosto, aque verano de 1834 la villa de Requena ya estaba invirtiendo en su fortificación. Gracias a esta documenhasta el momento, no se inicia con las obras de urgencia de 1835, sino que cuenta con precedentes constructivos en el verano de 1834, ejecutadas por el mismo maestro de obras: Guillermo Sáez.

El 24 de noviembre de 1834, el maestro de obras presenta una nueva relación jurada en la que, por primera vez se hace referencia, además de a los precios, a la sociología constructiva y a algú material. Se habla de "piedra recibida", el consumo de diez carros para el Sr. don Francisco "errero" o, en el caso del "Frente de las Monjas" (frente del desaparecido convento en el portal de Madrid), veintidós carros, conducidos por el "carretero Rubio". Por lo que se observa, el principal trabajo en la muralla consiste en los aportes de piedra (sin especificar características) mediante carretadas.

Esta relación nos permite además sostener que parece que las obras no solo no comenzarían antes, sino que también se prolongarían durante el año 1834 y, posiblemente, enlazarían con aquellas de verano de 1835
La segunda etapa de la fortificación liberal, de 1835 a 1836. La fortificación de Requena a partir del informe del maestro de obras Guillermo Sáez (5 de diciembre de 1835, AMR, 1818/50), indicando las obras a realizar

El documento, fechado el 5 de diciembre de 1835 y firmado por el maestro de obras Guillermo Sáez, informa de los puntos de fortificación de la villa de Requena (AMR, 1818/50), indicando el tipo de operaciones a realizar y el posible presupuesto: realización de garitas, apertura de aspilleras ya sea en muros, parapetos de balcones, colocación de puertas, tapiado de balcones y huecos, cierre de calles y recercado de huertos, habilitar un pequeño cuerpo de guardia y construir un tambor y acabar un foso ya iniciado en San Francisco. El conjunto de obras se presupuesta en 11.920 reales de vellón. Al margen de las operaciones a realizar, que se desglosan en el documento transcrito al final de este trabajo (apartado anexos), se observa que lo que se pretende es cerrar el recinto defensivo enlazando una serie de puntos de la ciudad con muros fusileros de no mucha consistencia, especialmente calles abiertas o huertos traseros de las casas, así como garantizar líneas aspilleradas en la totalidad del conjunto.

A fin de poder reconstruir la línea en la que se prefiguraría el límite de la ciudad, que desde extramuros se percibiría nítidamente en el paisaje, se destacan, partiendo de la puerta de Madrid, y siguiendo el recorrido amurallado en sentido levógiro:

1.-Portal de Madrid: en las inmediaciones de la plaza del Portal 2.-Fuente del Pera

3.-Cantarranas

4.-Puerta del Cristo

5.-Puerta del Ángel: junto a ella se ubica la casa de Montenegro y la de don Domingo Laguna. 6.-La Cortina: en el arrabal de San Nicolás. Así denominada porque estará flanqueada de algún modo por las defensas. En ella se ha abierto una puerta que conecta con el callejón de Paniagua. 7.-Calle de Cantero: entre la calle de Cantero y la calle de Paniagua hay una casa que hay que aspillerar. En la calle del Cantero se ubica un corral, de la "torre Onda" (no confundir en la transcripción con la "torre Oria", actuales bodegas de 1903).

8.-Torre "Onda", o Torre Montijana: único resto de la muralla del arrabal de San Nicolás. Es la única cilíndrica del recinto. Restos de una reconstrucción de mampuesto llevada a cabo en el siglo XV.

9.-Puerta de Alcalá: la salida a Alicante. Donde se ubica el matadero y los huertos. Uno de ellos es el de don Rafael López.

10.-"Bajo de los huertos": es un espacio de huertos ubicado desde la puerta de Alcalá hasta la actual zona del Batanejo. Se cita la necesidad de cerrar el callejón denominado de Pavón.

11.-Callejón de Pavón: el callejón de Pavón constituye uno de los cuatro (Pavón, Cava, Picazo y Botica) que integraron la judería a partir del momento en que la judería fue emplazada en el siglo XV a los pies de la torre Redonda o de En medio desde la Horra (Jorra). Dicho callejón estuvo junto a la demolida mansión de los Enríquez de Navarra.

12.-El Batanejo: se extendía una huerta que nos habla de la importancia del sector de la seda, por encima de la producción del vino. El huerto que ocupaba el Batanejo (donde hoy se desarrolla un proyecto de actuación integrada residencial), propiedad de "don Josef la Carzel", estaba ocupado por moreras principalmente y otros árboles de huerta. Es importante asociar el Batanejo con los contornos del batán medieval, donde se trabajaba el cuero "con el martilleo de los batanes". En las cercanías, se ubicaría la mansión solariega de "uno de los títulos de más rancio abolengo de Requena, el de los Cárcel, cuyo escudo campea sobre el dintel que corona neoclásico frontón, como remate de la noble portada a la casa de los alfareros" (Martínez, 1975).

13.-Las Ollerías o Puerta de Valencia: se correspondería con el antiguo camino de Valencia, que pasa precisamente por el puente de las Ollerías. Esta zona, en periodo medieval punto de trabajo de los alfareros, estaba delimitada por la "pared de Antonio Ponze" y la denominada "Casa-Cuerta" o "Cara-Cuesta" (actual calle Caracuesta), con puertas falsas que debían cerrarse. Se accedía al barrio de las Ollerías, como se observa en el plano de Ortiz de Pinedo (AGMM, Ar. G-T.3-C.2.262), una vez sorteada la Puerta de Valencia y atravesado el puente de las Ollerías, en dirección a la campaña. 
14.-Calle Caracuesta: la actual calle Caracuesta de Requena, de trazado curvo, conformaría el límite construido

15.-El "tirador": se asocia con un sector de huertos con parapetos a los que vuelcan un conjunto de casas. En este sector se hace referencia a la casa del tinte, que debe ser aspillerada. Observamos que gracias a estas indicaciones y a la evidente y próspera industria textil de Requena, en este sector se ubicaría una de las estructuras más importantes de esta industria. Fijémonos que al mismo tiempo ubicaría una de las estucturas a se habla de una casa del tinte. Según Llibrer, haciendo referencia a la industria de Cocentaina, e tirador consistiría en una barra de madera donde colgarían los paños después del bataneado para su cardado, a fin de "igualar la superficie y darle un aspecto externo más brillante que lo hiciera más atractivo al comprador" (Llibrer, 2014:138). Se requería de amplias instalaciones a fin de poder trabajar con varios paños a la vez, de ahí que el tirador sea una estructura considerable a tener en cuenta en Requena. El equipamiento consistía en bastidores de madera a los que se sujetaba el paño con garfios o escarpias. Los tiradores han contribuido a toponimias locales, como sucede en Cocentaina $S$ perchas...) que solia estar controlado por los pelaires más poderosos. Suele suceder que los pelaire se ubiquen en áreas suburbanas, cerca de la villa, en espacio de regadío, posiblemente donde se localicen huertos. Así sucede en Cocentaina (Llibrer, 2014:139), pero también, por lo que vemos, en Requena.

16.-El tinte: debía tratarse de una construcción para el teñido del tejido. Se habla de unos huertos parapetados que terminan en la salida de las Eras. Llama la atencion que en el plano de Ortiz de Pinedo, se identifica en la misma posición el que denomina "tinte de Navarro". En 1740 se testimonia en Requena la presencia de cinco tintes de sedas y lanas ejercidos por Pedro García, Francisco Marco, Joseph de Cros, Juan Gómez, y, precisamente, Bartolomé Navarro (Laruga, 1792.292). H cuenta que era una profesión hereditaria, podría tratarse de su casa de tinte. Cerca, se emplazará más adelante (en el proyecto de Ortiz de Pinedo) una batería, la "batería de Onrrubia", siendo Onrrubia (u Honrubia) un apellido, que podría hacer referencia al propietario de la casa en la que se emplazará la batería. Entre el tinte y la batería de Onrrubia, se configura la línea de las dos casas estudiadas en la calle Antonio Pérez.

17.-Calle de las eras: se habla de una calle, pero también se menciona una salida en la que se emplazaban las eras para el trillo. Se identifica una línea de casas. Curiosamente, en una ubicación parecida se encuentra, en el plano de Ortiz de Pinedo, la denominada "Puerta del Trillero". Podrí de Trillos. Fue alcalde de Requena durante la última Guerra Carlista. Hoy, la calle próxima a dicha puerta y que transcurre perimetralmente a la Glorieta se denomina C/ de Antonio Pérez, la antigua Calle de las Eras.

18.-Calle de los Álamos: en ella se ubica la casa de Pedro López y un huerto, el denominado Huerto de Narbón. La presencia de álamos podría indicar la abundancia de agua en la zona. Podría coincidir con la actual Calle Constitución.

19.-Calle de Juan Penén: existe una calle con el mismo nombre actualmente.

20.-La Calle de Gil: la calle del mismo nombre casi podría entenderse como una prolongación de la anterior. Se identifica una casa pajar y un porche de Francisco Fernández y un huerto de Nicolás Gallego.

21.- "Ygerillas" (Higuerillas): con toda probabilidad una zona que recibe su nombre por la presencia de higueras. Se caracteriza por un nuevo sector de huertas asociadas a puertas. En la actualidad la calle Higuerillas transcurre paralela hacia el norte de la Avenida Reinas, y da nombre al Colegio Público.

22.-Huerto de don Pedro Martínez: donde existía una puerta que comunica con corrales.

23.-Calle Reinas: la calle Reinas discurre hoy al sureste de la de Higuerillas. Su posición debía configurar el límite de la ciudad por medio de la hoya de Reinas, por donde discurría el arroyo (regajo) del mismo nombre según los planos de Ortiz de Pinedo.

24.-Camino de San Sebastián (Carrera de San Sebastián): el nombre procede de la Ermita o iglesia de San Sebastián, emplazada en el barrio de las Peñas. Entre la calle de San Sebastián y el denominado "pedazo de los muertos", parece existir una casa.

25.-“Bajada a los bolos": haría referencia a alguna comunicación entre el "Pedazo de los muertos" y el "cerrito de los bolos", llamado más adelante "Cerrito de Isabel II".

26.-"Pedazo de los muertos": en este espacio se habla de prolongar tapias hasta alcanzar al "cerrito de

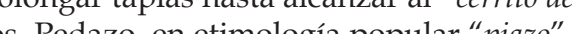
"El pedazo de los muertos se ubica en el plano de Ortiz de Pinedo justo en el norte de las peñas. Por tanto se trataba de una porción llana de terreno confinada por el límite norte del barrio de las Peñas y la depresión sur configurada por la Hoya de Martinete.

27.-“Cerrito de los bolos y paso A el pozo de la niebe”: si bien algunas fuentes identifican el cerrito con el pozo de la nieve, no se trata de lo mismo. El cerrito sería el lugar en el que se instalaría el fortín que sería el punto de observación en el asedio de 1836, conocido como cerrito de Isabel II.

28.-El pozo de la nieve: debía tratarse de un nevero o el emplazamiento de un nevero en la antigua Requena. En los estudios toponímicos de Cruz Orozco se recoge la referencia toponímica en Reurbano tratado como plaza en el barrio de las Peñas (Cruz Orozco, 1986:109). Según el plano de Ortiz de Pinedo, el pozo de la nieve es un entrante al oeste del cerrito de Isabel II, en el límite septentrional de las Peñas.

29.-Calle de Poniente: su nombre indica claramente su orientación oeste.

30.-"Bajo de las bodegas": debía localizarse en relación a algunas bodegas, o corresponder con una zona donde se concentraban diversas bodegas. Es preciso recordar la profusión de cuevas en Requena y su uso como bodegas particulares. Hoy en día existe la calle Bodegas en un emplazamiento similar.

31.-“Calle de las Cruzes": se hace referencia así al antiguo vía crucis o subida a San Francisco, denominada más adelante calle de Teatro (1820) y de Pi y Margall (1900). Precisamente el Vía Crucis fue minada más adelante calle de Teatro (1820) y de Pi y Margall (1900).

derribado durante la Primera Guerra Carlista (Bernabeu, 1982:78).
32.-"Pedazo de la [Rayuela]" (¿o "rejuela"?): si el nombre definitivo que se interpreta fuera rayuela, ¿podría tratarse de un espacio plano comúnmente utilizado por los niños?, de ahí la denominación del juego de la rayuela.

33.-Convento de San Francisco: el actual convento desamortizado. Se convierte en una especie de reducto avanzado al norte de la hoya de Martinete.

34.-Cuesta del Castillo: sigue hoy denominándose igual.

35.-Las Carnicerías: en la actualidad existe la denominada Calle de la Cuesta de Carnicerías. Se debían ubicar en ese punto la entrada y salida de la carne, si tenemos en cuenta que la cuesta servía de conexión con el matadero.

Se adjunta una tabla donde se indica el conjunto de obras propuesto por el maestro de obras Guillermo Sáez que, como se puede comprobar, aspiran a generar un recinto continuo que, aprovechando los muros de la villa, se extienda por el barrio del Arrabal y las Peñas. Para ello se aprovechan los frentes de edificación y se construyen tapias aspilleradas recercando huertos. Se trata de una relación que identifica puntos de la ciudad y propone el modo de actuar sin hacer referencia a materiales ni técnicas constructivas. Por lo general se elevan tapias, se consolidan muros, se tapian huecos y se abren aspilleras.

Tabla 1. Intervenciones propuestas por Guillermo Sáez el 5 de diciembre de 1835 (AMR, 1818/50).

\section{Localización}

Portal de Madrid

Fuente del Peral

Cantarranas

Puerta del Cristo

Puerta del Ángel

La Cortina

\section{Intervención}

Una garita y aspilleras

Aspillerado de las huertas y refuerzo de la puerta

Aspillerado y "doblado" de puertas

Aspillerado y cierre de balcones de la Casa de Montenegro y la Casa de la Lagun Se cierran balcones. Aspillerado del pretil de Sánchez, cierre de la puerta del Cällejón de Paniagua 
Calle de Cantero

Torre "Onda", o Torre Montijana

Puerta de Alcalá

Se aspillera el corral de la torre con su ventana y "puerta firme por si tomasen el barriete"

Bajo de los huertos

Callejón de Pavón

El Batanejo

Las Ollerías o Puerta de

Valencia

Calle Caracuesta

"El "tirador"

El tinte

Calle de las eras

Calle de los álamos

Calle de Juan Penén

La Calle de Gil

Ygerillas (Higuerillas)

Huerto de don Pedro

Martínez

Calle Reinas Rafael López Se aseguraba la línea de huertos "y en los parapetos poner ylo de tapia y cerrar el callejón de Pabón"

Se cierra el acceso al callejón desde el exterior

Se derriban las moreras de la huerta de D. Josế la Cárce

Se cierran las puertas y ventanas baja y se aspillera la pared de Juan Antonio Ponce. Se sobreentiende que se hace referencia a fortificar la puerta de Valencia o "de las Ollerías" y no el barrio que quedaba en las afueras.

Se cierran las puertas falsas de la calle

Se construye una tapia en lugar de un parapeto que termina en el "tirador"

Se aspillera el tinte, "asegurando o cerrando la puerta pequeña y tapiando en forma todos los güertos parapetados que terminan en la salid En Entrel las obras a reälizar se comunica la casa de Pedro López con la casa contigua y

No se indican obras a realizar

En ella se aseguraban paredes y puertas de la alineación, y se aspilleraba la casa paja y porche de Francisco Fernández y "batir" (derribar) la pared del huerto de Nicolás Gallego, que actuaría posiblemente de obstáculo visual

Se aseguran las puertas de los huertos y se tapia el parapeto

Se tapian los parapetos y se aseguran las puertas

Según el plano de Ortiz de Pinedo se observa que cerrando los huertos, al sureste del muro aspillerado que constituye el frente de edificación de las Higuerillas, se plantea un segundo muro que confina la amplia superificie de huertas que quedan entre el límite de las peñas y el desnivel de la hoya. Sin embargo en la propuesta de 1835 solo se cita la calle. Sin hablar de intervención.

Se refuerza la pared de la casa intermedia entre la carrera y el " pedazo de los muertos"

Camino de San Sëbastián (Carrera de San Sebastian)

"Bajada a los bolos"

Pedazo de los muertos

En el pedazo de los muertos se continúan las tapias, delimitando el frente escarpado de la hoya del Martinete, y dejando el pedazo confinado intramuros. Se terraplena el piso y se aspilleran las tapias construidas en el frente de la era.

Cerrito de los bolos y paso A el pozo de la niebe"

El pozo de la nieve

Calle de Poniente

"Bajo de las bodegas"

"Calle de las Cruzes"

"Pedazo de la Rayuela"

Convento de San Francisco

Cuesta del Castillo

Se propone parapetar desde el Cerrito a la puerta del pozo de la nieve

Se concluyen aspilleras y se refuerzan paredes

No se mencionan obras

No se mencionan obra

Dado que hay riesgo de que pasen por encima de la pared, se propone levantar un costado y aspillerar una casa vecina

"Cojer la pared". Con esta expresiôn puede hacer referencia a un rejuntado o a ü revoco.

Rematar el tambor de la puerta y concluir un foso que parece avanzado en su construcción Se propone tapar la puerta y colocarla en la entrada de la fortaleza, habilitando el acceso

Las Carnicerías
En la relación de "los puntos de fortificación que comprende en esta Billa de Requena con espresion de reponer los que se notaran y sus intermedios", se plantea un presupuesto de 11.920 reales de vellón. Esta cifra parece una estimación de lo que podría costar el tipo de intervención propuesto, pues se desglosan las partidas únicamente por localización urbana, indicando la descripción de la intervención, sin precisar, como decíamos, técnicas ni materiales y asignando un precio en reales de vellón a cada partida. (AMR, 1818/50)

Se observa que en la inmediata relación de gastos pendientes hasta la fecha del maestro de obras Guillermo Sáez, que acompaña al documento anterior (AMR, 1818/50), se incorporan algunas nuevas referencias, como "La Posada de Afuera", "la Puerta de San Julián" o "las ceraduras". En dicha relación, el autor indica el "costo que falta en dia de la Fecha, para su completa Seguridad", es decir, el cinco de diciembre de 1835. En la relación tan solo se ofrece una asociación entre localizaciones y costes, cuya suma asciende a 1.822 reales de vellón. Llama la atención que se matiza que en algunas

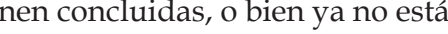
previsto realizar obra: la "Posada de Afuera" "La Cortina", "El batanejo", "Calle de las eras", "Calle de Reynas", "Carrera de San Sebastian", "Bajada a los Bolos" y "Calle de Poniente". Resulta curiosa la consideración de un costo "elástico" para el pozo de la nieve o el foso, que posiblemente hace referencia a un coste pendiente difícil de fijar.

De ambos documentos esta relación es la única que aborda brevemente alguna descripción material y de mano de obra, cuando hace referencia a "madera comprada", "gastos de brazeros y caballerías", que deben contratarse debido a la sustracción de caballerías por parte de las partidas. Se hace referencia también a "yeseros", a los propios honorarios del maestro de obras y a "raciones de pan, de carne y demás liquidado". Por ello que se deduce que el municipio sufragaba no solo materiales y mano de obra, sino también la alimentación de los operarios (AMR, 1818/50).

La verificación del estado de las obras y las medidas de fortificación de la comisión municipal del 26 de febrero de 1836 integrada por el maestro de obras Guillermo Sáez (AMR, 1818/53)

Si anteriormente comentábamos que el informe de Sáez clarifica el proyecto de obras pero no sirve para identificar las obras realmente ejecutadas, un informe de una Comisión Municipal fechado el 26 de febrero de 1836, tras los ataques de Cabrera y Gómez, puede servirnos para determinar qué obras fueron definitivamente ejecutadas. En dicho informe, a raíz de la inspección visual del propio maestro de obras Guillermo Sáez, un grupo de vecinos, y los representantes del Ayuntamiento don Martín Clavijo y don José Cañizares, detectan no solo que algunas obras han sido "descompuestas por los vecinos", principalmente para abrir puertas al campo, sino que algunas se encuentran en mal estado y en algunos casos se detectan carencias u obras pendientes. La comisión distingue entre aquellas obras que deberá sufragar la villa y aquellas otras que deben ser sufragadas por los propietarios, posiblemente responsables de su deterioro. Se aprovecha la comisión para promover un "bando" a fin de que todos los propietarios se respono se apicen de limpiar los parapetos de "los pedazos y huertos", detectándose esa distinción etimológica, donde el principal matiz estará asociado con el carácter productivo del terreno.

Observamos en la tabla adjunta cómo las obras principales consisten en obras del mismo calado que en los casos precedentes: se trata de asegurar un recinto para evitar el golpe de mano, poniendo alguna dificultad al acceso. Así se levantan muros, se reparan tapias, se reconstituyen portillos y se aspilleran aquellos puntos no suficientemente aspillerados.

Observamos que el principal conflicto lo plantean los corrales y huertas en el límite de las defensas que han derribado sus tapias o deben constituirlas.

Una vez más se detectan pocas indicaciones tácticas propias de la fortificación, salvo la referencia a la apertura de fosos en el caso del Convento de San Francisco, que ya aparecía en el informe de 1835, y en el huerto de Fernández, mirando hacia el regajo de Reinas. Estos fosos consisten en excavar una zanja en la piedra "a pico". También llama la atención la construcción de un camino cubierto en la conexión entre el Cerro de Isabel II, que se menciona así por primera vez en los informes de Sáez, 
anteriormente denominado el "cerrito" o "cerrito de los bolos". Dicho camino cubierto, terminológicamente, hace referencia a una comunicación resguardada por un parapeto, que discurre exteriormente, mirando a la campaña, y que conectará el Cerrito con el pozo de la Nieve, dos eminencias que actúan de caballeros defensivos en el frente noroeste, mirando a la Vega. En principio, un camino cubierto propiamente dicho, de acuerdo con la terminología de la fortificación, constituía la primera línea de la defensa y servía para apostar la fusilería en sus banquetas además de para comunicar puntos del perímetro.

Desde el punto de vista constructivo, las indicaciones son limitadas. Parece distinguirse entre tapias y muros de piedra y ripio. Existen puertas de madera y, para evitar el deterioro de muros y tapias, se recomienda el "bardado" de los mismos, es decir, rematarlos con sarmientos, paja, espinos o broza, que se pone, asegurada con tierra o piedras, sobre las tapias para evitar su deterioro por la acción del agua principalmente. Observamos que nada se plantea para la acción propia de la artillería de la época. El único matiz para dar consistencia a muros y tapias es "hacerlas de tirante", así se propone para los muros de las casas Se trata de una solucion an muro de una cierta elasticidad, conveniente para atenuar las vibraciones, pero, por supuesto, no suficientes para atenuar el impacto artillero de la época.

Tabla 2. Intervenciones pendientes a partir del informe de la Comisión Municipal integrada por Guillermo Sáez del 26 de febrero de 1836 (AMR, 1818/16).

\begin{tabular}{|c|c|c|c|}
\hline LOCALIZACIÓN & DESCRIPCIÓN & OBRAS & $\begin{array}{l}\text { RESPONSABILI- } \\
\text { DAD DE LA OBRA }\end{array}$ \\
\hline & $\begin{array}{l}\text { Comisión del } 26 \text { de febrero de } \\
1836 \text { (Guillermo Sáez) estado y } \\
\text { por concluir }\end{array}$ & & \\
\hline Cantarranas & $\begin{array}{l}\text { Se hace referencia a una puerta } \\
\text { de Cantarranas }\end{array}$ & $\begin{array}{l}\text { Se propone hacer seis aspilleras en } \\
\text { la pared inmediata. }\end{array}$ & La Villa \\
\hline El Batanejo & & $\begin{array}{l}\text { En el batanejo, mirando a las Olle- } \\
\text { rías hay que construir "un poco" } \\
\text { de parapeto que falta. }\end{array}$ & La Villa \\
\hline $\begin{array}{l}\text { Huerta de Jose } \\
\text { Carcel }\end{array}$ & $\begin{array}{l}\text { Una huerta "de abajo del } \\
\text { Batanejo". Al indicar inmediata } \\
\text { "a las Piezas" se sobreentiende } \\
\text { que delimitaría con un } \\
\text { emplazamiento artillero. }\end{array}$ & $\begin{array}{l}\text { Hay que componer un portillo en } \\
\text { "la de arriba", se entiende que será } \\
\text { la pared superior. Indica, inmediato } \\
\text { "a las Piezas". En la pared inferior } \\
\text { también tiene que fortalecer la puer- } \\
\text { ta de la huerta bajo los huertos. }\end{array}$ & Particulares \\
\hline Las piezas & $\begin{array}{l}\text { Emplazamiento artillero } \\
\text { existente en el Batanejo }\end{array}$ & & \\
\hline $\begin{array}{l}\text { Ygerillas } \\
\text { (Higuerillas) }\end{array}$ & $\begin{array}{l}\text { Se hace referencia a una "puerta } \\
\text { de Higuerillas" }\end{array}$ & $\begin{array}{l}\text { Se propone cortar } 3 \text { varas de la } \\
\text { pared }(2,51 \mathrm{~m}) \text { que hay entre el } \\
\text { camino y los huertos y se une con } \\
\text { la puerta. Recomponer tres porti- } \\
\text { llos que comunican con los huertos } \\
\text { inmediatos. }\end{array}$ & La Villa \\
\hline \multicolumn{4}{|l|}{$\begin{array}{l}\text { Huerto de don } \\
\text { Pedro Martínez }\end{array}$} \\
\hline Calle Reinas & $\begin{array}{l}\text { Existe un conjunto de casas que } \\
\text { miran a Reinas y que tienen } \\
\text { puerta al campo: la de don } \\
\text { Nicolás Pérez, la de Las Bobas, } \\
\text { la de Anselmo Biana, la de Juan } \\
\text { Antonio Monsalve }\end{array}$ & $\begin{array}{l}\text { Tienen que tapiarlas con ripio y } \\
\text { piedra o "hazerlas de tirante" }\end{array}$ & Particulares \\
\hline
\end{tabular}

\begin{tabular}{|c|c|c|c|}
\hline $\begin{array}{l}\text { Huerto de } \\
\text { Fernández }\end{array}$ & $\begin{array}{l}\text { Un huerto que mira hacia el } \\
\text { regajo de Reinas }\end{array}$ & $\begin{array}{l}\text { En la pared del huerto que mira } \\
\text { a Reina se propone la ejecución } \\
\text { de un foso que corre a cargo de la } \\
\text { villa. No así sucede con el levanta- } \\
\text { miento de la pared del huerto que } \\
\text { mira a Reinas, que debe sufragarlo } \\
\text { el propietario }\end{array}$ & $\begin{array}{l}\text { La Villa / } \\
\text { particulares }\end{array}$ \\
\hline Huerto de Parra & $\begin{array}{l}\text { Un huerto que mira hacia el } \\
\text { regajo de Reinas y una de cuyas } \\
\text { paredes queda a la derecha de la } \\
\text { Puerta de Reinas }\end{array}$ & $\begin{array}{l}\text { Levantar la pared que mira a } \\
\text { Reinas }\end{array}$ & La Villa \\
\hline $\begin{array}{l}\text { Pedazo de los } \\
\text { muertos }\end{array}$ & $\begin{array}{l}\text { En este documento se hace } \\
\text { referencia a una diferencia entre } \\
\text { "pedazo" y "huerto" }\end{array}$ & $\begin{array}{l}\text { Todos los dueños deben limpiar } \\
\text { sus parapetos de huertos y peda- } \\
\text { zos. En el caso del pedazo de los } \\
\text { muertos se deben levantar dos } \\
\text { espaldones de } 8 \text { varas de largo } \\
(6,69 \mathrm{~m}) \text { y } 3 \text { varas de altura }(2,51 \\
\text { m), recomponiendo la pared que } \\
\text { mira a Reinas, aspillerándola y } \\
\text { bardándola. La acción de bardar } \\
\text { hace referencia a poner bardas en } \\
\text { los vallados, paredes y tapias. Las } \\
\text { bardas son según la Real Acade- } \\
\text { mia de la lengua, una cubierta de } \\
\text { sarmientos, paja, espinos o broza, } \\
\text { que se pone, asegurada con tierra o } \\
\text { piedras, sobre las tapias. }\end{array}$ & La Villa \\
\hline $\begin{array}{l}\text { “Cerrito de los bolos } \\
\text { y paso A el pozo de la } \\
\text { niebe" }\end{array}$ & $\begin{array}{l}\text { Ya se denomina en este } \\
\text { documento el cerrito de los } \\
\text { bolos como Fortín de Isabel II }\end{array}$ & $\begin{array}{l}\text { El conocido como paso al pozo de } \\
\text { la nieve consiste en la ejecución } \\
\text { de una comunicación a modo de } \\
\text { camino cubierto entre el fortín y el } \\
\text { pozo de la nieve }\end{array}$ & \\
\hline $\begin{array}{l}\text { Camino de San } \\
\text { Agustín. Casa del } \\
\text { tinte }\end{array}$ & $\begin{array}{l}\text { En el camino de San Agustín se } \\
\text { localiza otra casa del tinte }\end{array}$ & $\begin{array}{l}\text { Aspillerar y fortificar la casa del } \\
\text { tinte }\end{array}$ & La Villa \\
\hline $\begin{array}{l}\text { "Bajo de las } \\
\text { bodegas" }\end{array}$ & $\begin{array}{l}\text { Se ubica el huerto de Martín } \\
\text { García }\end{array}$ & $\begin{array}{l}\text { Tiene que levantar la pared del } \\
\text { huerto que tiene bajo las Bodegas }\end{array}$ & Particulares \\
\hline $\begin{array}{l}\text { Convento de San } \\
\text { Francisco }\end{array}$ & & $\begin{array}{l}\text { Se indica que solo resta tapiar la } \\
\text { ventana de la sacristía y cortar "un } \\
\text { poco de Piedra á pico en el Foso" }\end{array}$ & Particulares \\
\hline Camino de los asnos & & $\begin{array}{l}\text { Se propone hacer más aspilleras } \\
\text { en la pared que mira al camino de } \\
\text { los asnos }\end{array}$ & La Villa \\
\hline \multicolumn{4}{|l|}{ La Posada } \\
\hline $\begin{array}{l}\text { El huerto de las } \\
\text { monjas }\end{array}$ & $\begin{array}{l}\text { Las monjas hace referencia con } \\
\text { toda probabilidad al antiguo } \\
\text { convento del Carmen hoy } \\
\text { ocupado por el Ayuntamiento y } \\
\text { que volcaba hacia el sureste. }\end{array}$ & & La Villa \\
\hline $\begin{array}{l}\text { Pared de don Diego } \\
\text { Montes }\end{array}$ & $\begin{array}{l}\text { Delimitaría el huerto de las } \\
\text { Monjas y miraría hacia los } \\
\text { molinos. Lo cual testimonia en } \\
\text { aquella dirección la presencia de } \\
\text { molinos harineros. }\end{array}$ & Aspillerar la pared & La Villa \\
\hline Fuente del Peral & & $\begin{array}{l}\text { Se propone hacer una puerta fuer- } \\
\text { te que solo se dispondrá en caso } \\
\text { necesario }\end{array}$ & La Villa \\
\hline $\begin{array}{l}\text { Corral de Eugenio } \\
\text { Mas }\end{array}$ & & $\begin{array}{l}\text { Hay que levantar las paredes del } \\
\text { corral }\end{array}$ & Particulares \\
\hline $\begin{array}{l}\text { Corral de Gabriel } \\
\text { Justo }\end{array}$ & & $\begin{array}{l}\text { Hay que levantar las paredes del } \\
\text { corral }\end{array}$ & Particulares \\
\hline
\end{tabular}


La tercera etapa de la fortificación liberal: el perfeccionamiento a partir de los informes del capitán del Cuerpo nacional de ingenieros, D. Pedro Ortiz de Pinedo (1837) y del Comandante Militar de la Plaza D. José García de Orozco (1838)

Señala Bernabeu que entre 1837 y 1839 "las fortificaciones fueron notablemente mejoradas bajo la dirección de don Pedro Ortiz de Pinedo y de don Juan Ramón de Carbonell se construyeron paredones de cal y canto, tapias, fosos, reductos y baterías (los 'tambores de Alcalá, Tirador, Cecina, Reinas, Garrota, Honrubia, canto, tapias, fosos, reductos y baterías (los 'tambores de Alcalá, Tirador, Cecin
Valencia y Cristo, aspillando paredes y edificios')" (Bernabeu, 1982:428).

Bernabeu también cita el plano del ingeniero y comenta que "en el Croquis del cerramiento aspillado de Requena por don Pedro Ortiz de Pinedo, citado por V. Gascón Pelegrí, se da la fecha de 1812 en vez de 1837. Tampoco se señala que dicho recinto tenía unas seis mil varas. También conocemos la Memoria presentada por el Comandante Militar don José María de Orozco para la total defensa de Requena y decisión del Ayunlas que se apoyaban 850 nacionales y un corto número de soldados" (Bernabeu, 1982:428).

La comisión de servicios del Ingeniero Pedro Ortiz de Pinezo del 11 de marzo de 1837 y las instrucciones para el comisario de guerra del Ayuntamiento de Requena del 12 de marzo de 1837 (AMR, 1818-16)

A través de los documentos localizados en al Archivo Municipal de Requena se ha podido testimoniar cómo se comisiona al ingeniero Pedro Ortiz de Pinedo el 11 marzo de 1837, por orden del capitán General de la provincia de Valencia, para reconocer y calcular las nuevas obras indispensables en la fortificación de Requena. (AMR, 1818-16). El ingeniero debe trabajar de acuerdo con el Ayuntamiento "a quien toca proveer los fondos" y deberá "proceder a la ejecución, levantando el croquis, y estendiendo la memoria de defensa" que debe ser remitida al capitán general para su aprobación "a la mayor brevedad" (AMR, 1818-16).

Se observa una cierta urgencia en clarificar la situación defensiva de la ciudad, y es que cuando el capitán Ortiz de Pinedo alcance la ciudad, "el ocho del mes actual" [abril], han transcurrido solo diez días desde el desastre liberal del Plá del Pou en Paterna (29 de marzo de 1837), tras el cual las tropas carlistas habían fusilado a los oficiales prisioneros en Burjassot.

El trabajo de Ortiz de Pinedo en Requena se traduce en una interesante memoria (AMR, 4733-25) y el "croquis del cerramiento aspillerado de Requena" localizado en la Cartoteca del Archivo General Militar de Madrid (AGMM, 1838, Ar. G-T.3-C.2.262).

A su llegada a Requena, el ingeniero presenta una instrucción del Director subinspector del Cuerpo en la Provincia, fechada el 12 de marzo de 1837, y que dirige al "comisionario" del Ayuntamiento de Requena, que, como se indica más adelante en el mismo documento, se trata de un "comisario de Guerra" designado por el Ayuntamiento. En el documento se sintetiza lo "más esencial" de sus obligaciones según la Ordenanza de Ingenieros.

Según el artículo 1, "como comisario estará a su cargo proporcionar los trabajadores y materiales y será un fiscal económico en la calidad, precios y sueldos".

"Artículo $2^{\circ}$, inspeccionará el número de trabajadores, pasándoles lista cuando le pareciese y despedirá los que fuesen desechados por el ingeniero".

"3". Recibirá del sobrestante un parte diario del número de trabajadores que hayan comenzado las obras con espacios de sus jornales, materiales recibidos y sus valores". "4 $4^{\circ}$. Estará a su cargo el pago de trabajadores y materiales que certificará en publico con asistencia del inge-

"niero y demás empleados los domingos a la hora oportuna".

" 5 . Formará relación semanal del importe de jornales y materiales, a cuyo pie certificará el ingeniero en virtud de la cual se librará el pago correspondido en el artículo $4^{\circ \prime \prime}$ (AMR, 1818-16).
Observamos que esta síntesis nos permite entender cuál es la organización y la estructura de la obra, donde un ingeniero militar, destinado en comisión de servicios por el gobierno militar, es el responsable de establecer el proyecto y luego supervisarlo, dando el visto bueno a operarios, sueldos, materiales, calidades... a través de certificaciones.

elección de los materiales a supervisar, es el "Comisario de Guerra" por parte del Ayuntamiento dado que es al Ayuntamiento de Requena a quien le corro dado que es al Ayuntamiento de Requena a quien le corresponde el pago de la obra de fortificación “dotaciones que estimasen oportunas" (AMR, 1818-16).

¿Cuál es el cometido del ingeniero comisionado? Según el citado comunicado del Capitán General a través del Director Sub Inspector del Cuerpo de ingenieros, fechado el 12 de marzo de 1837 (AMR 1818/16), el ingeniero debe desplazarse para reconocer la fortificación "que ha construido"

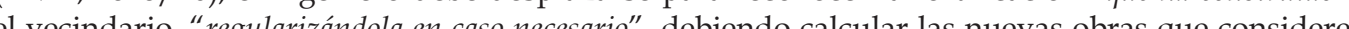
"indispensables" o aquellas que requieren ser reformadas. Como indicábamos, deberá hacerlo en coordinación con el Ayuntamiento, que es el responsable de proveer los fondos. Su trabajo concreto consiste en redactar una "memoria de defensa" y levantar "un croquis" que debe remitir urgentemente a la capitanía general (AMR, 1818/16)

\section{La memoria militar del ingeniero Pedro Ortiz de Pinedo de marzo o abril de 1837 (AMR, 1818-52E)}

El ingeniero Ortiz de Pinedo deberá redactar diligentemente esa memoria, localizada en el Archivo Municipal de Requena e identificada como "memoria militar de Requena del cuerpo nacional de ingenieros" (AMR, 1818/52E). El croquis, localizado en la cartoteca del Archivo General Militar de Madrid (AGMM, Ar. G-T.3.C.2.262), con el título "Croquis del cerramiento aspillerado de Requena", firmado por Pedro Ortiz de Pinedo, sin embargo, podría no haber sido incluido en la primera documentación remitida a la Capitanía General. Como el mismo Ortiz de Pinedo afirma, dado que el capitán general había estado en la ciudad recientemente y había podido visitar las fortificaciones, se limita a enviarle unas observaciones ya que ejecutar el croquis "exige unos tiempos" (AMR, 1818-52). El ingeniero estructura su informe en varios apartados. Primero evalúa cuestiones demográficas y económicas. Juego aborda la historia de los ataques 1835, 1836 y 1837. Analiza las obras de fortificación construidas por los ciudadanos, las fuerzas con que cuenta la ciudad y sus carencias. Finalmente, procede a enumerar las necesidades militares de la plaza.

Se detecta en todo el escrito una cierta admiración por el carácter de la población, resaltando su implicación con la defensa y su lealtad, una admiración que resulta clave para sostener sus argumentos tácticos. Interesa el análisis del número de vecinos y la renta de los mismos en la medida que de ello va a depender el sostenimiento de los costes de la fortificación. Entre otros datos que se consideran relevantes se indica el número de casas fuertes de propietarios (doce), y otras tantas de casas de comerciantes. Tambien núm campo y manufacturas. Las cantidades se desglosan por quinquenios y se destaca la producción de trigo, cebada, avena, maíz, judías, patatas ("criadillas"); líquidos como vino, aguardiente y aceite; y trigo, cebada, avena, maíz, judías, patatas ("criadillas"); líquidos como vino, aguardiente y aceite; y
manufacturas centradas en la producción de seda. Resalta la caída de producción debido al estado de guerra de 40.000 libras castellanas $(18.400 \mathrm{~kg}$ ) a 12.000 libras castellanas $(5.520 \mathrm{~kg})$.

Cuando Ortiz de Pinedo glosa la historia de Requena y su participación en la defensa ante los ataques carlistas, coincide con la historia oficial, posiblemente informado por las propias autoridades requenenses. En el momento de su visita, se muestra impresionado por la capacidad de la ciudad para poner en marcha unas medidas de defensa que pueden exceder de los "30.000 duros" cir, unos 600.000 reales de vellón. Para entonces, según el testimonio del ingeniero, parece que la

1 Una libra castellana era equivalente a 16 onzas, 460,0093 gramos.

2 Un peso fuerte o peso duro, equivalía a 20 reales de vellón (aleación de plata y cobre) 
ciudad ha llegado incluso a "comprar cañones", los mismos con los que se enfrentó a la artillería de Gómez el 13 de septiembre de1836, que más adelante en el informe identifica como dos cañones de hierro de a ocho, y cuatro cañones de hierro de a cuatro, es decir, de ocho libras y de cuatro libras.

A partir de este momento el ingeniero insiste en la absoluta soledad defensiva de la ciudad, abandonada por las fuerzas tanto de Cuenca, Valencia y Madrid, que no solo no pueden garantizar unos refuerzos a tiempo, sino que en ocasiones van a requerir las fuerzas para sí u otros destinos. La meteorización de los ataques de las partidas carlistas no ayuda, y la velocidad de los batallone volantes nunca es suficiente. A criterio del ingeniero, garantizar la seguridad de Requena es garantizar el camino de Madrid. Cuando hace referencia a las defensas insiste en su poca consistencia: paredes de tapias de tierra aspillerada y paredes de piedra revocadas con yeso. Son efectivas, sostiene, al tiro del fusil, y pueden sostener el ataque habitual de las reducidas partidas procedentes de Aragón. Por ello, el ingeniero recalca que "las obras construidas por esta ciudad exigen poca modificación seguido, tras describir las características topográficas de la ciudad y su entorno, propone un mejor uso táctico de la ciudad.

Según el ingeniero: "Las inmediaciones de la Ciudad son despejadas pues no hay a distancia inmediata altura de dominación capital, pero tiene contra si el que desde la linea de defensa y por todo su perímetro se presenta el terreno en anfiteatro, al Este en descenso y al Oeste en ascenso, cuyos anfiteatros los forman ormas ó cejas mas ó menos altas de las heredades, corriendo al noreste el arroyo que llaman de las Ollerias, bastante profundo en su [Madre]." (AMR, 1818-52). Por todo ello, es consciente de que el fusil solo garantiza la defensa de proximidad, pero para garantizar la defensa lejana, que podría hostilizar a las partidas que circulan impunemente a la vista de las murallas, requiere la adquisición de obuses para recurrir al tiro "curvo" que no solo pueda repeler "zapas o masas descubiertas", sino a aquellas que puedan agazaparse, poniendo como ejemplo lo sucedido durante el asedio de Gómez. Ruiz de Pinedo glosa las ventajas del obús por su mayor efecto a igualdad de carga que el cañón convencional, la trayec toria curva, su alcance y el efecto de su metralla.

Dicho de otro modo, para el ingeniero, la clave de la defensa de la ciudad requiere de la adaptación de nueva artillería, tres piezas concretamente, cuya ubicación propone en el Pozo de la Nieve, en la casa de "Nuebalos" y en el Molino de Valero, a fin de batir todo el perímetro de la ciudad.

El ingeniero sabe las reticencias a dotar de artillería a ciudades que podrían caer en manos del enemigo, pero defiende la ciudad de Requena por sus virtudes y su historia reciente. Según el ingeniero, armando suficientemente Requena no solo se evita acudir en su socorro, pudiendo destinar esos efectivos a otros menesteres, sino que además se convierte la propia ciudad en un punto clave que podría apoyar a las columnas liberales de Moya, garantizando la seguridad de Cuenca.

El ingeniero incluso enumera los efectivos de la ciudad en la fecha: 800 guardias nacionales de infantería, de 30 a 40 de caballería y dos compañías de movilizados con 200 hombres, es decir un total de 1000 infantes y 30 caballos. Es una guarnición insuficiente para un recinto amurallado

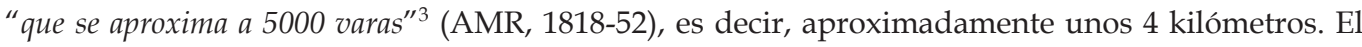
ingeniero sostiene una carencia de 200 fusiles y hace una propuesta de distribución de hombres que adjuntamos en la tabla siguiente, en la que se localizan los puntos tradicionales tal y como ya lo había hecho Guillermo Sáez:
Tramo defensivo

De Reinas a la Batería de Isabel $2^{\mathrm{a}}$

De esta a la de la Nieve

De esta a la Puerta de S. Francisco

De esta a la de Madrid

Casa del Tinte

De la Puerta de Madrid a la de Cantarranas $\quad \ldots$

$\begin{array}{ll}\text { El Angel } & 10 \\ \text { Casa de Carcel } & 10\end{array}$

Torreón de la Montejana

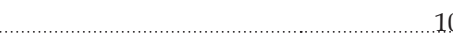

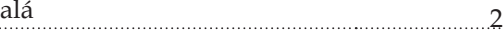

De esta al Batanejo $\ldots$

De esta a la Puerta de Valencia
De Reynas al Balson

De este a las Higuerillas

De este a la Puerta del Trillero

(1)

De este a la Pueta de Valencia -

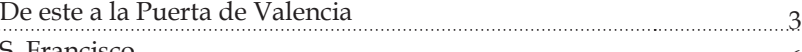

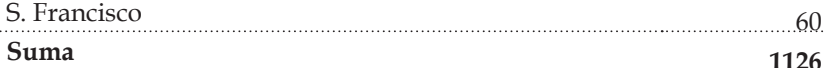

1126

100

Paza de la Constitución $\quad 100$

S. Sebastián $\quad 100$

Total Reservas $\quad 300$

Total de efectivos $\quad 142$

Fuerza existente $\quad 100$

Faltan para el estado de buena defensa

A la hora de definir qué tipo de soldados incorporar, insiste en la necesidad de especialistas en artillería, haciendo hincapié en la necesidad del mantenimiento profesional de los cañones. Llama la atención sobre el mal estado de conservación de los seis cañones de hierro existentes en la plaza y destaca las ventajas de adquirir nueva artillería de bronce, concretamente los tres obuses para los emplazamientos citados, así como la incorporación a la guarnición de la ciudad de un oficial y veinte hombres del cuerpo de artilleros.

El ingeniero acaba la memoria existente en el archivo histórico (AMR, 1818- 52) haciendo mención y cuestionándose el papel defensivo del Convento de San Francisco. Su análisis es ambiguo, donde 列 de la población sirve de Hospital militar, y este punto... si bien lo es sobrado contra la arma del fusil, tiene el defecto de estar fuera de la población, convirtiéndose por ello el efecto de reducto de seguridad en el de fuerte destacado; aunque también impide la quieta ocupación de la loma y produce algun fuego de espalda a los asaltantes de algunos defensores" (AMR, 1818-52).

Ruiz de Pinedo insiste en la necesidad de proveer defensivamente a la ciudad, sin dejar de socorrerla con columnas volantes, destacando los inconvenientes de su trazado urbano "accesible, de calles anchas y piso fácil", descripción que interpretamos hace referencia al arrabal, que debe de integrar el primer recinto defensivo, cuya defensa deja al buen criterio del "jefe militar" que deberá disponer
"obstáculos con cortaduras en ellas, de toneles, portaderas, palizadas y otros", pues el segundo recinto, "obstáculos con cortaduras en ellas, de toneles, portaderas, palizadas y otros", pues el segundo recinto, y suficiente alimento (frutas) para resistir un asedio (AMRE, 1818-52). 
El croquis del cerramiento aspillerado de la ciudad de Requena trazado por el ingeniero Pedro Ortiz de Pinedo en el año 1837 (AGMM, Ar. G-T.3.C.2.262)

Este plano, localizado en el Archivo General Militar de Madrid, de fecha incierta, podría corresponderse con el croquis demandado por el Capitán General en su comisión de servicios. Se trata del croquis que supuestamente el ingeniero no envió en primera instancia acompañando a su memoria croquis que supuestamente el ingeniero no envió en primera instancia acompañando a su memoria
militar de abril de 1837 , al indicar que la elaboración del croquis requería su tiempo. Lo más probable militar de abril de 1837, al indicar que la elaboración del croquis requería su tiempo. Lo más probable es que fuera remitido más adelante en ese mismo año 1837, aunque se desconoce la fecha de partida
del ingeniero.

Trazado a plumilla en tinta negra y pintado a la acuarela en siena, verde y carmín, responde a las técnicas de representación de muchos planos militares de la época. Aparece la flecha orientando el Norte y el relieve del terreno clarificado con el sombreado, con escala de 200 varas castellanas. El plano describe únicamente el perímetro aspillerado relacionando los puntos significativos, fortificaciones, puertas, pozos o molinos con una leyenda y, en todo caso, describiendo textualmente otros: a os diferentes caminos: A Madrid por Utiel, "Al Reyno de Murcia", A Tarazona (de la Mancha), camino de herraduras a Valencia, camino de carros a Valencia y un camino de difícil transcripción que podría dirigirse a "las fuentes". Entre los puntos relacionados, que se corresponden con los citados en informes anteriores:

Fig. 730. Croquis del cerramiento aspillerado de la ciudad de Requena trazado por el ingeniero Pedro Ortiz de Pinedo el año 1837 (AGMM, Ar. G-T.3.C.2.262).

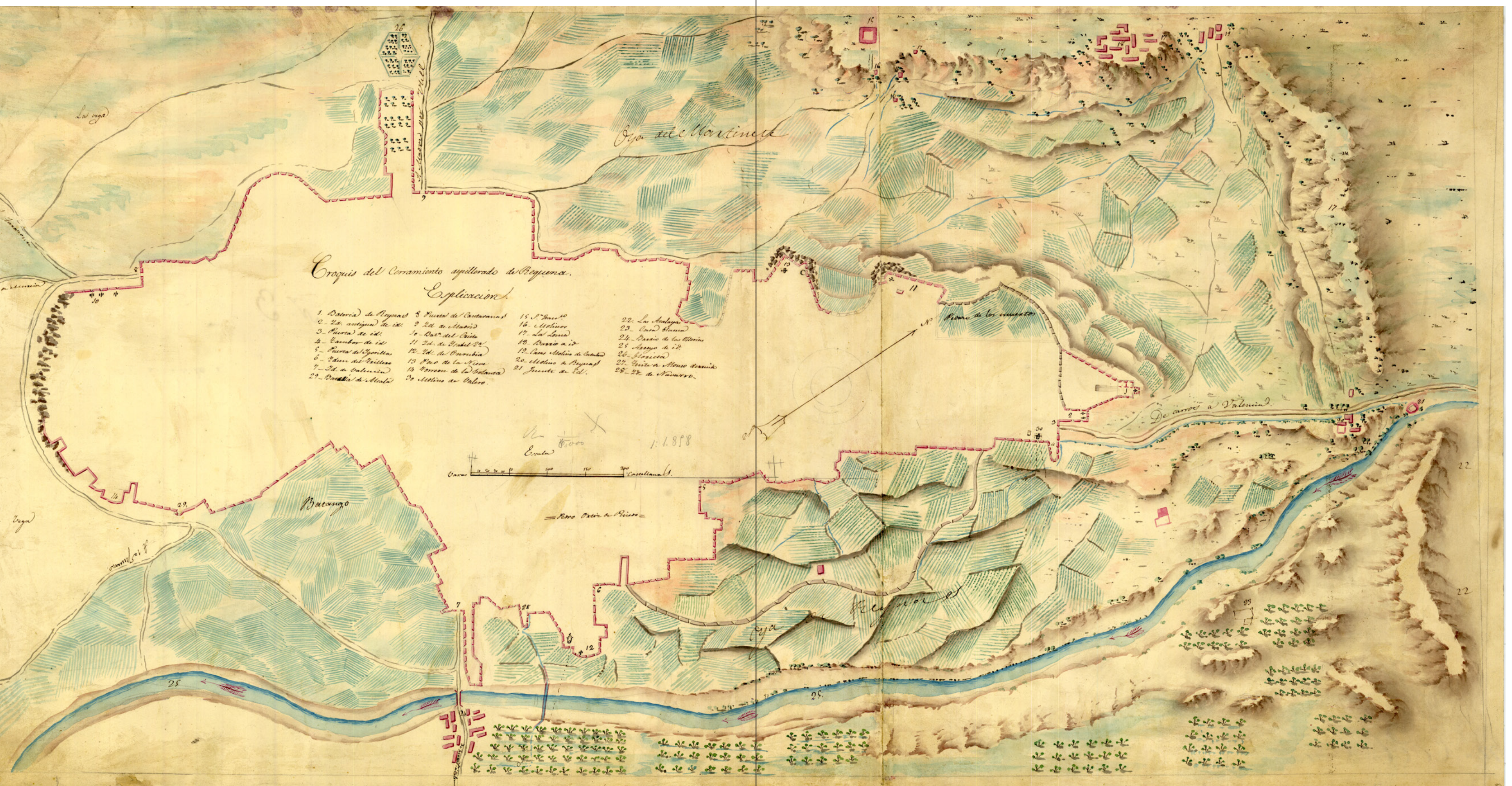


- 1 cañón en la batería de Isabel II, frente a San Francisco y batiendo la Hoya del Martinete, que cruza sus fuegos con el siguiente.

- 1 cañón en el Pozo de la Nieve, que actúa conjuntamente con el anterior, pero que se supone también está destinado a batir la Vega y el camino a Madrid desde Utiel.

El plano de Ortiz de Pinedo ayuda a entender la ubicación también de determinados barrios extramuros que él, se supone, considera necesario expresar dada su interacción en la defensa, así como el conjunto de construcciones exteriores que podrían entorpecerla, desde el Barrio de la Loma, las Ollerías, el Molino y fuente de Reinas, Casa Blanca. .

Aunque carente de todo tipo de detalle topográfico, llama la atención el intento por plasmar las cejas orográficas que contornean la ciudad, así como el dibujo de algo de vegetación, especialmente al Este del Regajo de Reinas, entre las Ollerías y Casa Blanca, como si fuera una zona de concentración de cultivos o arbolada.

Otro elemento característico del plano es la peculiar muralla aspillerada paralela que se aleja de la población en la puerta de Madrid y acaba en una glorieta de planta hexagonal, alejada de la población y que se identifica como tal, Glorieta, que no hay que confundir con el actual parque de la glorieta, en otro punto de la ciudad.

Intervenciones registradas en la estancia del ingeniero Ortiz de Pinedo a través de las comisiones de tasación del 23 de abril de 1837 (AMR, 1818-16) y las certificaciones sobre las varas, jornales, materiales y precios de las obras de reedificación de la fortificación de Requena del $\mathbf{3 0}$ de mayo de $1837(1818-34 \mathrm{E})$

Pocos datos se encuentran sobre las intervenciones realizadas por el ingeniero Pedro Ortiz de Pinedo. Se sabe que integra dos comisiones municipales, de acuerdo con las instrucciones recibidas de la superioridad con el objeto de validar las tasaciones de inmuebles para algunas de las expropiaciones que se consideran necesarias.

ig. 736. Detalle del barrio de las Ollerías, a la salida de camino de herraduras (orie tado a norte) en el Croquis del cerramiento aspillerado de la ciudad de Requena trazado ciudad de Requena trazado por el ingeniero Pedro Ortiz de Pinedo en el año 1837 (AGMM Ar. G-T.3.C.2.262).

Fig. 737. Detalle de la glorieta y el doble muro paralelo aspillerado en el camino de Madrid por Utiel (orientando orte). Croquis del cerramiento aspillerado de la ciudad de Requena trazado por el ingeniero Pedro Ortiz de Pinedo en el año 1837 (AGMM, Ar. G-T.3.C.2.262).
En un primer escrito sin fecha (AMR, 1818-16), el ingeniero parece adjuntar un presupuesto del gasto al que podrían ascender las obras, contemplando aquello a reformar y aquello a construir de

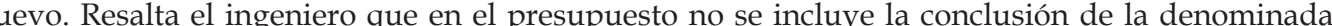
Batería de Reinas que, por lo visto, debía ser costeada por la Comandancia Militar, así como tampoco se incluye el presupuesto del cerramiento de determinados emplazamientos ubicados entre el Molino de Valero y el identificado como "balsón", dado que corre a cargo de particulares. Son datos que, como se observa, no aparecen en la memoria militar anteriormente expuesta. El ingeniero indica que en otro presupuesto se especificarán los fondos, los trabajadores y los materiales "de que se pueden disponer para proceder a la ejecución de estas obras", se supone que hace referencia al documento hallado en el Archivo Municipal de Requena, del 30 de mayo de 1837, que analizaremos más adelante (1818-34E).

Junto con comisionados del Ayuntamiento, el ingeniero participará en la tasación de una "casa ruinosa y parte de su huerto contiguo situado en la Glorieta (que no hay que confundir con el actual parque de la Glorieta, sino identificarlo con la Glorieta extramuros que Ortiz de Pinedo sitúa en el camino de Madrid). Los terrenos debían ser ocupados por la fortificación por acuerdo del Ayuntamiento y previo dictamen del ingeniero comisionado. Tras acudir el 23 de abril de 1837 al lugar, acompañados de un perito representando al propietario, "Alonso Gavaldón", se fijó la tasación de la propiedad en 6.150 reales de vellón.

El mismo 23 de abril de 1837 (AMR, 1818-16), el ingeniero participará en otra comisión con el objeto de tasar una parte de huerto a "las espaldas de la Calle de San Agustín extramuros de esta ciudad", que debía ser ocupada por la fortificación. La medición, efectuada en presencia del perito que representa al propietario, identifica un octavo de [taula] de tierra regadía, con un valor de 525 reales de senta al propietario, identifica un octavo de [taula] de tierra regadía, con un valor de 525 reales de
vellón. Parece que el terreno debía estar destinado a la construcción del denominado tambor de 
la puerta de Madrid, en las inmediaciones de la actual plaza del Portal (según Vera, 1993:68). Se trataría de una obra de planta circular adosada a la puerta de Madrid con un cuerpo cilíndrico de mampostería con aspilleras, que podría emplazar una batería en el terraplén superior. Dicha obra, en la que participarían 312 braceros, "por citación vecinal y sin jornal", con 156 caballos mic taba previsto que finalizara el 30 de mayo de 1837 y debió concluirse después del tinte de Gabaldón (Vera, 1993:68, AMR, 1818-34)

El día 30 de mayo de 1837 el ingeniero firma las certificaciones sobre las varas, jornales, materiales y precios de las obras de reedificación de la fortificación de Requena (1818-34E). Se trata de un documento de interés constructivo en la medida que permite conocer el número de operarios que intervienen en las obras realizadas, por ejemplo en el tinte de Gabaldón, la duración de la obra y los materiales empleados.

Entre los operarios se distinguen un maestro mayor, Alonso Martínez, cinco albañiles, otros cinco peones, un conjunto de braceros sin identificar, aunque se indica que se utilizan doce braceros diarios y un conjunto de seis caballerías diarias. Se deduce que la paga se efectúa a jornales. El jorna del maestro mayor es de 11 reales de vellón, el de los albañiles de 9, el de los peones de 5, aunque alguno cobra 6 reales de vellón, como los braceros. Los caballos también se pagan a 6 reales el jornal. Las obras del tinte de Gabaldón se extienden del 21 de abril al 24 de mayo, y ocupan un total de 26 jornales (hay que descontar pues que se toman 8 días festivos o $\sin$ trabajo)

Se observa que los materiales empleados en la obra son 312 cahíces de yeso a 4368 reales de vellón 19 cahíces de cal a 304 reales de vellón, 98 tablas de madera para banquetas a 98 reales de vellón, 47 cuartones para banquetas y suelos a 235 reales de vellón, 7 vigas tercias a 350 reales de vellón, 32 docenas de clavos de tres pulgadas a 65 reales de vellón y tres puertas para el cuerpo de guardia y cuarto del oficial, a 270 reales de vellón y, finalmente, ocho clavos a 40 reales de vellón.

Estamos hablando de una construcción relativamente modesta que asciende, contemplando jornales y materiales a 7662 reales de vellón. Se trata de una obra de reutilización en la que se está aprovechando la fábrica del antiguo tinte abandonado para habilitar un forjado y cerrar compartimentos; un forjado constituido por vigas y tablas de madera claveteadas. Parece que el yeso se utilizará para revocar los muros, dada su proporción, y la cal, dado que hablamos de un volumen aproximado de 12 metros cúbicos, es poco probable que se utilice para el rejuntado. Por tanto se debe suponer otro uso de la cal, constitución de tapias o forjados de mayor consistencia que podrín asegurar un terraplén a pryeba, para albergar la a la obra del tinte de Gabaldón parece destinada a alojamiento y cuerpo de guardia. En su cubierta sí parecen habilitarse banquetas para los fusileros. Recordemos que Ortiz de Pinedo preveía una guarnición para este punto de 30 hombres. Su emplazamiento, dado que se hace referencia a terrenos ubicados en la glorieta, entendida como el pequeño parque poligonal extramuros en la puerta de Madrid, parece que correspondería con las obras emprendidas en sus proximidades.

El 20 de mayo de 1837, Ortiz de Pinedo certificaba una serie de jornales y materiales correspondientes a la construcción del tambor alzado en la puerta de Madrid. Según Vera, este se emplazaría en la actual plaza del Portal (Vera, 1993:68). En la certificación no se contemplaba la mano de obra de 312 braceros y 156 caballos menores por "citación vecinal y sin jornal" (AMR, 1818-34). En dichas obras solo se hace referencia a 4368 cahíces de yeso, 304 cahíces de cal junto a maderas, puertas y clavos, computando un total de 26 jornales. El total de las obras del tambor ascendió a 10.396 reale de vellón. Llama la atención de nuevo que estamos hablando de una obra en la que no se recurre piedra, sino a cal y yeso, por lo que se estima que en caso de utilizarse piedra esta no se computaba o ya se encontraba en obra.

El 6 de junio de 1837 el ingeniero certificaba al ayuntamiento de la ciudad que el "cerramiento aspillerado de la misma formado en parte de tapiales á tierra, aprovechado en otras las paredes de Casas, y en otras cuerda" de cinco mil cuerda" de cinco mil doscientos cincuenta y siete varas castellanas $(4,4 \mathrm{~km})$, con una altura media de cuatro varas $(3,3 \mathrm{~m})$. El recinto se presupuestaba en 5000 reales de vellón. A su vez se sumaban 500 varas de tapia de tierra (418 m), con un coste de 3600 reales de vellón. El trabajo de aspilleramiento de casas se computaba en 600 varas aspilleradas $(501 \mathrm{~m})$, con un coste de 107.900 reales de vellón. Finalmente se citaba la obra de nueva planta a piedra, barro y yeso, 4150 varas $(3,469 \mathrm{~km})$. El total del cerramiento aspillerado ascendía a 116.500 reales de vellón, a lo que había que sumar la "obra muera del Tinte de Cavaldón", con 7.662 reales de vellón, lo que hacía que el presupuesto total de las obras alcanzase los 124.162 reales de vellón. Una cuantía considerable si tenemos en cuenta que el jornal de un peón de la época era de 5 reales de vellón (AMR, 1818-34). ${ }^{4}$

A partir de esta certificación no se localiza ninguna nueva información sobre las obras o la participación del ingeniero en el Archivo Municipal de Requena hasta la Real orden del 2 de julio de 1837, en que se autoriza a la ciudad para echar mano de todos los recursos a fin de que sea abastecida durante 30 días ante la amenaza de las facciones del Bajo Aragón (AMR, 1818-36).

Ante el informe de la comandancia, el ayuntamiento responderá el 10 de julio manifestando su dificultad para garantizar el suministro a tropas así como el sostén del hospital, lo cual implica que el con retirar las tropas por falta de "raciones diuns", algo a lo que se resiste el alto a la comandancia (AMR, 1818-36). Pero el informe se centra en cuestiones de suministro de raciones, aprovisionamientos, pero no hace ninguna referencia a la fortificación. Debemos recordar que en el mes de mayo se había emprendido la Expedición Real, que llegaba a Arganda, las puertas de Madrid, el 12 de septiembre de 1837. Anulada la amenaza con el retroceso de las tropas carlistas hasta atravesar el Ebro el 24 de octubre, no parece preocupar la fortificación de la ciudad.

La activación de la alarma en 1838. Primeros informes para poner la ciudad en estado de defensa

La toma de Morella el 26 de enero de 1838 por parte del ejército de Cabrera parece ser el detonante para que se active de nuevo la inquietud por la defensa de la plaza. De hecho, el 5 de febrero de 1838 se tramita un expediente para el alistamiento de todos los habitantes de la ciudad no pertenecientes a la Milicia Nacional a fin de que entren en servicio en caso de alarma (AMR, 1818-26).

Estas fuerzas, entre cuyos componentes más capacitados se repartirán los fusiles disponibles, se organizan en secciones, una con armas, otra con "chuzos" (una especie de lanza rudimentaria) y otra desarmada, que deben responder a un protocolo de actuación. "Al Toque de alarma, las secciones armadas con las de fuego se reunirán en la Plaza de la Villa para cubrir y defender los puntos de ésta, estableciendo un retén si resultare fuerza sobrante despues de cubiertos aquellos en dicha Plaza para atender á la mayor necesidad de cualquiera de ellos". Además "las dos secciones de Chuzos se reunirán una en la Carrera de los Frailes y otra en el Portal de Madrid, dispuestas a prestar el servicio que se les mande". Por su parte "los cuatro Pelotones de desarmados, tendrán por punto de reunión San Sebastián, Portal de Madrid, Carrera de los Frailes y Plaza de la Villa, para desempeñar el servicio que la necesidad exija en las diferentes atenciones de los puntos atacados y otras de la poblacion mandadas por sus autoridades" (AMR, 1818-26).

Más interesante para esta investigación es el resultado de la comisión expuesto el 9 de febrero que propone cómo mejorar la seguridad de la ciudad. La base consiste en la vigilancia, con el nombra(La Loma, Ollerías..). También se recomiendan rondas interiores. Llama la atención que en el tercer punto la comisión aprovecha para censurar la actividad de "mujeres licenciosas" en la casa de [Francisco] Pérez, en las casas del Barriete. Solo por el mero hecho de su actividad se las considera sospechosas y se las conmina a habitar en el interior de la población. El argumento militar para justificar el abandono de la casa es la debilidad de sus paredes. Parece que el conjunto de casas colindantes, a las que denominan del Collado, presenta particularidades parecidas, por lo que se propone una inspección técnica por parte del maestro de obras para decidir si es preciso independizarlas de la ciudad ("cortar y separarlas de la comunicación con la ciudad"). (AMR, 1818-8). Se hace referencia a una operación similar con una casa emplazada bajo la batería de Sánchez. Resulta curioso el orden de prioridad en la enumeración, primero la presencia de las mujeres "licenciosas", luego las 
características constructivas. Parece que la comisión municipal aprovecha la situación militar para restablecer su orden social.

La comisión resalta haber reconocido toda la fortificación y no haber encontrado "ninguna rotura" en ella. Sin embargo se detectan unos defectos de "alta monta" que exigen, según la comisión, un remedio urgente. Estos defectos hacen referencia a:

- Posada de José Puebla, que mira a la fuente del Peral: dos paredes (poniente y mediodía), que conforman esquina, parecen fácilmente perforables, lo cual facilitaría el acceso a través de dicho punto. No solo debido a la consistencia de las paredes, sino también porque el vecino más próximo, Manuel Ponce, no es de confianza y es considerado altamente sospecho, se supone que de connivencia con el carlismo. Es precisamente en dicha esquina donde se propone la construcción de un pequeño tambor que pueda alojar a cuatro hombres y desde el que se pueda abrir fuego. Desde dicho punto se pretende batir el huerto de las monjas, pero también el conjunto de huertos que "miran a mediodía", que se extienden hasta la fortificación "de la Glorieta", es decir, de la Puerta de Madrid. Se indica que las dos "citadas tapias se harán de pared maestra". Distinguiendo entre la materialidad de la tapia, tierra, y la materialidad de la pared maestra, que se supone de cal y canto.

- Tapia que va desde la Casa del Puente de las Ollerías hasta el Tinte de Zorrongo, que mira al Norte: se trata de una tapia, de tierra, "tan bagita [que] los niños de ocho años la saltan sin dificultad". Se plantea elevarla y fortificarla. Llama la atención el concepto "fortificar", que hace referencia a un tipo de operación que se supone tendrá que ver con los accesorios de la pared: aspillerar, parapetar, abanquetar.. Pero el texto no es preciso. (AMR, 1818-8).

En fecha 13 de febrero de 1838, el ayuntamiento aprobará las medidas de la Comisión (AMR, 1818 8): establecimiento de los barrios extramuros, las Ollerías y la Loma de San Francisco, un celador secreto en cada uno, encargado de la seguridad pública. Se establecen rondas por las noches. Se insta al maestro de obras Guillermo Sáez, que reaparece de nuevo en los documentos, que, junto con el ta al maestro de obras Guillermo Sáez, que reaparece de nuevo en los documentos, que, junto con el Síndico, D. Pedro Antonio Monsalve, reconozcan las casas señaladas a fin de acometer la ejecución de las obras necesarias "aunque con la posible economía para la ciudad". Se insta a todos los habitantes que viven en las casas denominadas de "Francisco Pérez Duque, el pucherero" y las contiguas de Collado, que se "internen a habitar en otras de la población, sin perjuicio de que los dueños puedan poner al interior de esta ciudad, exigen estas medidas en beneficio del bien publico" (AMR, 1818-8).

También se reconocerán las casas del "sitio titulado del barriete y los demás", con el fin de asegurar el interior de la ciudad. Se obliga al inquilino que habita la posada a ocupar otra habitación y que dicha habitación sea ocupada por alguien de más garantía, exigiendo la identificación de todo "forastero" que llegue y se aloje en la ciudad (AMR, 1818-8).

Se observa que en el mes de febrero de 1838 la situación en Requena es de calma tensa y de máxima desconfianza. Sin embargo, no parecen mostrarse muy preocupados por el estado de defensa principal de la fortificación, dadas las medidas que plantean y aprueban.

\section{La memoria del Coronel Comandante Militar de la Plaza, José García de Orozco y las decisiones} adoptadas por el ayuntamiento para asegurar la total defensa de la ciudad de Requena el 25 de marzo de 1838 (AMR, 1818-24)

El comandante militar de la plaza, José García de Orozco, demuestra en su memoria del 25 de marzo de 1838, una total gratitud a la ciudad, así como su sintonía con los ciudadanos. Al igual que sucedía en el informe de Ortiz de Pinedo, esta sintonía se delata cuando ensalza las gestas pasadas y el carácter de los requenenses. Sin embargo, no se muestra muy confiado con la seguridad de la ciudad dado que considera la necesidad de unas mejoras en la fortificación pues sostiene que " $p r$ mero, el que para no ser vencido no basta ser valiente, sino es precavido, y segundo, que los descuidos en la Guerra, se purgan, ó con la perdida de la vida o con la del honor" (AMR, 1818-24).

Conforme enumera las mejoras, van apareciendo en el informe citas de lugares comunes ya mencionados que nos permiten entender y reconstruir el perímetro amurallado de la ciudad, éstos y las obras propuestas son:

Tabla 5. Identificación y propuesta de obras según la Memoria del Coronel Comandante Militar de la Plaza José García de Orozco (25 de marzo de 1838).

LOCALIZACIÓN DESCRIPCIÓN

Sobre la Villa y el

Castillo

Tambor de la Puerta de Madrid

Se habla de un tambor ya construido (por Ortiz de Pinedo), en la Puerta de Madrid, frente a la Glorieta.

Batería del Cristo La pieza artillera alojada en la batería "alcance la "Casa de la Garróta" y "Tinte de Cecina", considerados puntos débiles de la defensa.

Se ubica contiguo a la Puerta de Valencia y puede ser batido por el enemigo desde el Barrio de las Ollerías. Tiene poca concentración

La casa y fuerte de de fuego en el frente desde el Huerto de la Casa de don Juan Antonio Ponce hasta el camino de las casas de Amorós. La casa de Manuel Ponce, contigua al puente de las Ollerías, tiene poca solidez y defensa.

No se establece ninguna asociación entre este tinte, de nueva denominación, y alguno de los tintes citados en informes anteriores (Navarro o Gabaldón). Este nuevo tinte se encuentra al alcance de la bateria de Honrubia, por tanto, en el frente este y pretende convertirse en fuerte que batiría desde la casa de Garrota hasta la puerta del Trillero.
OBRAS

Es la primera vez que se trata la Villa y e Castillo en una memoria. Para García de Orozco constituyen un "alcázar inexpugnable" que hay que considerar como pieza activa de la defensa, como ultimo reducto defensivo. Se concibe como inconquistable la ciudad. Según el comandante no serán necesarios grandes gastos dado que la "posición natural de la Villa y Castillo, la hacen por sí inćccesible y de consiguiente facil á suplir lo que el arte ni pueda aplicarle" (AMR 1818-24). Se considera que el tambor existente es suficiente, recomienda construir parán batir la zona. Solo se la Puerta de Madrid hasta las baterías de Isabel II y el Pozo de la Nieve, para reforzar las cortinas ya y el Pozo de

Se considera suficiente

Se pretende darle más capacidad para que la pieza alojada en ella pueda "obrar con desahogo" batiendo puntos débiles como la "Casa de la Garróta" y el inte de Cecina

Se propone dar más amplitud y consistencia a la casa de Amoròs, dotándola de más fuegos construyendo un tambor en su frente.

No tiene fuegos, ni protección, así como no no "presta seguridad al carecer de cuerpo de guardia que vigile los ángulos entrantes que tiene a derecha y a izquierda. Se propone hacer un fortín que arranque del ángulo que configura dicho tinte con el que hace pared con la calle de la Plaza. El fuerte deberá alojar una Compañía con un Cuerpo de Guardia. Desde el ángulo del tinte deberá construirse una tapia aspillerada con foso, con trazado oblicuo, buscando el encuentro con las antiguas tapias construidas por Albornoz, dando así potencia a la cortina de Fernández. Esta tapia oblicua permite con pocos hombres batir en todas las direcciones desde el arranque de la cortina hasta el rincón "que forma la tapia que cierra la calle de la Plaza". Permite cubrir así todos los rincones y ángulos entrantes que quedan a la izquierda del tinte de Cecina, asi la Puerta del Trillero. 
Es considerado el punto más débil de toda la fortificación. Tiene pocos fuegos y su solidez ningún otro fuego. Se propone reforzar su frente Alcance de la batería de Honrubia. Parece ubicarse en relación con la Puerta del Trillero, dado que las desde ella hasta dicha puerta.

Casa de la Garróta con un tambor aspillerado. Dicho tambor, así como todos los ángulos de la casa, serán antecedidos po un foso y una estacada hasta alcanzar la puerta del Trillero. Se pretende que esta zona sea cubierta desde otros puntos.

La cortina se considera endeble. Se le construira un foso y se convierte asi en un retrincheramiento

Parece que constituiría el flanco de Cortina de la Huerta defensa para la casa de la Garrota y de don Baltasar Pérezla Puerta del Trillero, que carecen otro fuego de flanco.

Esta batería, ya especificada en el proyecto de Ortiz de Pinedo, se emplaza en el espolón que acompan el camino de carros de Valencia. Por tanto, por el lado este delimita con la Hoya de Reinas, y por el oeste delimita con la Loma y San Francisco (Hoya de Martinete)

Huerto de Parra construidas por Albornoz. Estas últimas deben conservarse y robustecerse para que puedan cubri la huerta citada y, a su vez, flanquear la casa de la Garrota y la Puerta del Trillero.

Es considerada la obra menos afortunada y considerada inútil. Fue planteada para un fuego de frente, batiendo el camino de Valencia, pero la mala disposición de las caras y la explanada la hacen inservible para las piezas. Solo son útiles Por sus aspilleras. Se espera darle provecho artillero Para ello bay que conformar dos explan Lomas. Parar ex lugar donde se emplazan los actuales cuerpos de guardia. Se debe procurar que los fuegos de las piezas purir la tom pero no desater de barrio noreste hasta cl camino der En én angulo saliente del huerto se propone "formar bien y firme" la banqueta, do se propone "form pue disponerse para hacer fuego. disponerse para hacer fuego. lo que tiene que habilitarse un depósito a prueb para municiones que actúe de cuerpo de guardia o cuartel para sus sirvientes. Se considera que el punto artillado está al alcance del enemigo, distancia de "punto en blanco" (es decir, disparo artillero preciso).

Se propone emplazar un obús, y, si ello no pudiera ser, dar al punto capacidad para una pieza de ocho. Se pretende entre a bas baterias impedir avance en la Loma.

Es la primera vez que se habla de plantear la defensa de Requena para un ataque en regla (u sitio formal). Por ello se plantea la necesidad de que en caso de que así suceda, el barrio de la Loma el Fuerte de San Francisco deberían destruirse. Pero la situación habitual es un ataque de facciones sin artilleria, por lo que basta con garantizar la cubrición artillera de estos puntos (se hará desde la Batería de Isabel II y el Pozo de la Nieve), que como no está en disposición de hacerlo, deben ser reforzadas.
El día 18 de abril de 1838 García de Orozco se dirige al ayuntamiento de la ciudad de Requena con el objeto de reclamar una mayor atención a la memoria redactada días antes. Para ello menciona los acontecimientos de la guerra a nivel nacional, las expediciones enemigas y cómo las principales ciudades como Madrid, Valencia o Teruel han hecho esfuerzos para reforzar sus defensas. Conmina a la ciudad con las siguientes palabras: "¿á que espéra Requéna? ¿Será por ventúra posible hacer cuando tengámos a nuestro frente esas ordas, lo que no hemos hecho cuando reinába la tranquilidad?" (AMR, 181824, fol. 12), de cuyas palabras se deduce que hasta el momento ninguna de sus propuestas ha sido emprendida. Sí que se hace mención a la llegada de tres piezas de artillería, entre las que se cuenta un obús. Pero no considera a la ciudad capacitada para su manejo. Critica la organización de la Compañía de Artillería existente y considera que, en la fecha del escrito, las nueve piezas de artillería existentes en la plaza pueden constituir un estorbo. Propone crear una compañía de "bomberos o zapadores", destinada a, "con acierto y sin confusión y desorden", acometer los trabajos de defensa, demolicion de edificios y obstruccion o atrincheramiento de las calles. Los integrantes de dichas No deben ser "sujetos extraños a la profesión" (AMR, 1818-24, fol. 12). El comandante espera una respuesta del ayuntamiento a fin de poder dirigirse con ella a las autoridades superiores (Gobierno Militar y Subinspección General) para eximirse de responsabilidades, dado el caso omiso que se hace a sus recomendaciones.

El 18 de abril de 1838 el ayuntamiento de Requena responderá al escrito del Comandante Militar del Cantón, dándose por enterado y accediendo a sus propuestas, a fin de emprender no solo las obras de fortificación, sino "aún otras mayores" (AMR, 1818-24, fol. 18). Pero hace matizaciones:

1.- No accede a la destrucción del Convento de San Francisco, por su utilidad en caso de destinarse a Hospital de Caridad y casa de Beneficencia.

2.-Tampoco accede a la destrucción de edificios de particulares sin que se acredite su perjuicio a la defensa de la población ni se indemnice a los particulares.

3.-Respecto al resto de obras, se alega la falta de fondos para realizarlas,

4.-Se suministran cuatro mil reales de vellón, adelantados de su bolsillo por los ciudadanos, a fin de abordar las obras del Tinte de Cecina.

5.-Se invita al Comandante y a los ciudadanos a una reunión a las tres de la tarde del día 19 de abril de 1838, en la sala capitular, a fin de informarles de la memoria militar, del tipo de obras a efectuar, para que libremente decidan lo que la mayoría considere oportuno, en un claro ejemplo de democracia en una decisión que afecta a la seguridad, pero también al bolsillo de los ciudadanos.

6.-Se accede a la formación de una compañía de artillería, intentando aportar ciudadanos acordes a la instrucción exigida. Pero respecto a la compañía de bomberos y zapadores, queda pendiente el ayuntamiento de "acordar lo que se estime oportuno", se supone en la citada asamblea popular.

El 19 de abril de 1838 los ciudadanos, con cierto buen criterio, acordaron que no podían opinar al respecto de las decisiones que afectaban a la idoneidad o no del plan de defensa, en relación con el "Fuerte de San Francisco" o las "casas de particulares". Acordaron la necesidad de que un ingeniero reconociese la fortificación, pagado por el vecindario, y que, a partir de dicho estudio, los vecinos no opondrían resistencia a prestarse a las obras necesarias, cubriendo el coste, prestando voluntarios, "pagando jornales y conduciendo yeso". Se produce una respuesta popular de sentido común, en la que se reparten las tasas, la mano de obra (eximiendo a aquellos que prestan ya servicio en la milicia) y formando una comisión para supervisar el buen desarrollo y correcto manejo de los fondos. Curiosamente esta comisión está encabezada por el Alcalde Segundo, el Médico de la ciudad (don Pedro de Vera) y el arcipreste de la iglesia del Salvador, que, junto a otros cinco ciudadanos, están obligados a presentar un informe de obras y gastos semanal. 
La memoria sobre obras de reparación y obras nuevas efectuada por el Comandante de Infantería y Capitán de Ingenieros Juan Ramón de Carbonell el 4 de julio de 1838 (AMR, 1818-17)

El 4 de julio de 1838 llegará la memoria realizada por un especialista en fortificación, Comandante de Infantería y Capitán de Ingenieros, Juan Ramón de Carbonell, comisionado por el General del Ejército del Centro. Como sucedió en el caso del ingeniero Ortiz de Pinedo, al ingeniero comisionado parecen encomendársele dos misiones: redactar una memoria y confeccionar un croquis. Del nado parecen encomendársele dos misiones: redactar una memoria y confeccionar un croquis. Del
mismo modo que sucedió con su predecesor, no se adjunta croquis a la memoria con las mismas mismo modo que sucedió con su predecesor, no se adjunta croquis a la memoria con las mismas
argumentaciones: "hubiéra deseádo tener el tiempo suficiente para levantar el plano de las priméras, y argumentaciones: "hubiéra deseádo tener el tiempo suficiente para levantar el plano de las priméras, y proyéctar en el las segundas. Mas ya que mi corta permanéncia en este punto y la atención que debo á otros encárgos, no me permíte un trabájo tan esténso, me limitare á esprésar en esta memória las observaciónes producídas por el reconocimiénto que hé practicádo; la descripcion de las obras que juzgo conveniente se verifiquen, y las mejoras que en mi opinion deben hacérse en las que ecsisten. Afortunadamente basta una ligéra esplicacion" (AMR, 1818-17).

Una vez más se habla de unas obras que "no tienen la perfección indispensable para asegurar completamente la población". Si bien se reconoce el arrojo en la defensa de los habitantes, es preciso el "auxilio de obras de fortificación suficientemente resistentes".

El ingeniero distingue entre:

1.-Obras que no exigen la menor innovación, "por su buen trazado y arregladas dimensiones".

2.-Obras que requieren alteraciones de poca entidad.

3.-Obras que reclaman "imperiosamente" un cambio de configuración debido a los cambios en el

"distinto carácter que ha tornada la guerra desde la época en que se construyeron" (AMR, 1818-17, fol. 4).

Carbonell distingue diferentes clases de obras a realizar:

1.-Primera clase: obras de reparación de los desperfectos originados por la intemperie u otras causas. Normalmente hace referencia a reparaciones urgentes como trozos de tapias o paredes a reponer, puertas y ventanas que hay que cerrar y aspillerar, banquetas y explanadas que rehacer y otras recomposiciones

2.-Segunda clase: obras de nueva planta, ampliaciones o adaptación útil para la defensa de edificios próximos al recinto, como podría ser la excavación de fosos, derribo de casas mal ubicadas que entorpecen la defensa.

3.-Tercera clase: se trata de aquellas obras interiores a la plaza, como la habilitación del castillo 3.-Tercera clase: se trata de aquellas obras interiores a la plaza, como la habilitación del castillo
antiguo emplazado en la Villa. Se trata de definir un segundo recinto defensivo entendido como antiguo em
ciudadela.

Observamos que desde la memoria de García de Orozco se han incorporado en el debate defensivo dos aspectos relevantes y que debieron estar presentes con anterioridad, aunque se supone que, por evidentes, se daban por supuestos:

1.-El debate en torno a la existencia de dos perímetros defensivos. El primer perímetro, el que abarcaba la totalidad de la ciudad utilizando el límite de la Hoya de Reinas y la del Martinete, es decir incluyendo la Villa, el Arrabal y las Peñas, fue siempre el objeto de todos los estudios. El segundo perímetro, interior, siempre se dio por supuesto, y es el que configura el barrio histórico de la Villa y el Castillo. Ahora se insiste en la posibilidad de adecuarlo para que cumpla efectivamente el papel de ciudadela.

2.-El segundo debate afecta a las obras exteriores, donde resultan claves las presencias del Convento de San Francisco y el barrio de la Loma, que dominan un punto crucial para plantear un sitio en regla efectivo a la plaza.

Una vez más, nos encontramos con un ingeniero que localiza punto por punto posiciones clave de la defensa, plantea sus características y propone el tipo de intervención. Si bien el ingeniero trata de evitar la elaboración de un documento gráfico, es bastante pormenorizado en sus descripciones, especialmente las de aquellos cuerpos de mayor importancia del nuevo perímetro defensivo, como son los fortines. Careciendo aún de documentación gráfica, se podrían representar si se dispusiese de la preexistencia construida a fin de apoyarse en las alineaciones y direcciones a las que hace referencia el ingeniero. Resulta preciso a la hora de especificar las dimensiones y ángulos de caras de la línea magistral, define la altura del terraplén base, así como de los correspondientes niveles, especifica los espesores relativos de los diferentes muros, su materialidad, e incluso la dimensión y separación de las aspilleras, ubicación de banquetas y dimensiones de parapetos. Por lo general es bastante reiterativo en el tipo de intervención: parapetar, aspillerar, trazar líneas, tapiar...

La propuesta del ingeniero Juan Ramón de Carbonell podría desglosarse en la siguiente tabla:

Tabla 6. Propuesta de intervención del ingeniero Juan Ramón de Carbonell. Requena, 4 de julio de 1838 (AMR, 1818-17).

IDENTIFICACIÓN

INTERVENCIÓN

REF.

Desde la Puerta de

cia a la de

Alcalá

Casa de D. Juan

Antonio Ponce

"En la pared que mira al barrio de las Ollerias se abriran aspilleras en todos los cuerpos, y se tabicará el balcón hasta la altura de 4 1/2 pies. Asi mismo se aspillerarán las demás parédes de esta clase y las inmediátas hasta las del Batanejo,
en los frentes y pisos que descubran el campo"

Esta Batería se crea para actuar conjuntamente con las baterías existente de la Puerta de Alcalá, Honrubia y la del Molino de Herrero. El objetivo es impedir que el enemigo ocupe el Barrio de las Ollerías y oponerse a una batería enemiga instalada en él. Descubre el camino a la Puerta de Valencia y las avenidas a las casas del Batanejo y al Matadero. Cruza sus fuegos con el cañón de la Puerta de Alcalá. Defiende las inmediaciones de recinto Intermedio. Se propone dar al lado exterior de la Batería el trazado siguiente: una cara parte desde la garita del fortín hacia el campo en dirección perpendicular á las [caras] que lindan con el Camino de Valencia. La cara tendra nueve varas de largo $(7,5 \mathrm{~m})$. La otra cara forma con esta un y su longitud será de once varas $(9,2 \mathrm{~m})$. La tercera cara formá con y su longitud sera de 115 rados y termin . Lá é las casas de cora con la dando frente a las del Batanejo. La elevación de esta batería desde el nivel Bateria que se del terreno a un piso superior será de seis pies $(1,67 \mathrm{~m})$ pero el revestimiento proyecta contigua del terraplén, que se hará de mampostería tendrá 9 pies de altura $(2.5 \mathrm{~m})$, pos Ponce construirá de tapia, dándole dos varas de espesor en las dos primeras caras $(1,67 \mathrm{~m})$, una vara en la tercera $(0,83 \mathrm{~m})$ y 8 pies de altura en todas $(2,22 \mathrm{~m})$ En cada una de las caras se dejará una cañonera, estableciendo el centro de la tercera a 3,5 varas $(0,97 \mathrm{~m})$ del ángulo saliente interior. Desde esta mism cañonera hasta las caras de cara-cuesta, se aspillerará el parapeto hasta la altura de 4,5 pies $(1,25 \mathrm{~m})$. Para que en el resto de emplazamientos pueda usarse la fusilería por encima de los merlones, se construirán banquetas que no perjudiquen al uso de la pieza. Se hará una explanada de madera para las tres cañoneras, con tablones de 4 a 5 pulgadas de espesor (aprox. de $93 \mathrm{~mm}$ a $116 \mathrm{~mm}$ ). Se emplazarán los durmientes y batientes que corresponden en las embrasuras, con recias portezuelas de dos hojas que puedan separarse fácilmente de sus marcos para preservarlas de la intemperie en tanto que no sea preciso usarlas. La entrada a la batería se dará por los corrales de la Casa de Ponce, y en los mismos debe hacerse un pequeño refuerzo para municiones. Desde la Bateria Además de aspillerarse las paredes de las casas y corrales, se cerrarán y a las casas de paredes débiles, elevanas situadas en el recinto. Se reforzaran las tapias 
Se cerrará con tapia aspillerada de 4 varas de alto el descubierto de la Casa de "Omtin", construyendo una banqueta. Por lo general las aspilleras arrancan a una altura de 6,5 o 7 pies $(1,9 \mathrm{~m})$ del piso (sin contar el foso). En la paredes con orientación a Levante se refuerzan las puertas, recalzándolas y revocando las paredes donde sea necesario. Se tapiarán las ventanas que se hallen a menos de 8 varas de altura $(6,7 \mathrm{~m})$ y se harán aspilleras en todos los cuerpos. La pared del mediodía se reforzará por la parte interior hasta el piso principal, y en tanto en este piso como en los demás se abrirán aspilleras. Se darán 2 varas $(1,7 \mathrm{~m})$ más de altura a la tapia que atraviesa el camino formando parte de este frente de mediodía, se macizará su puerta y continuarán las aspilleras hasta el ribazo. Delante de dicha tapia se abrirá un foso por el cual pueden dirigirse las aguas del arbellon contiguo. Como por el lado de poniente hay un parapeto que cubre las casas, solo deben

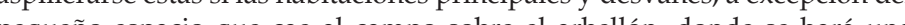
pequeno espcio que cae al flopo Patanejo, poco defendido a hora de otras partes del recinto, y para flanquear Batanejo, poco defendido ahora de otras partes del recinto, y para flanquear Herrero y las inmediatas, se construirá un fortín que tendrá la ventaja de descubrir las avenidas en el entrante de fortificación que ma ventaja de descubir las ave y se propone el siguiente trazado de su polígono exterior: desde el ángulo que forma la tapia ya citada que cruza el camino con las de D. Marcelino Herrero, se tomarán 7 varas $(5,85 \mathrm{~m})$ sobre la horma, y se obtendrá así AMR, la primera cara. Partiendo de su extremo avanzado se marcará otra con 1818-17, dirección a los edificios contiguos a la Parroquia de Santa María, dándole la fol. 6-8 misma longitud. La tercera cara será paralela a las tapias de D. Marcelino de 9 varas de largo $(7,5 \mathrm{~m})$. La cuarta cara, que es la que flanquea la línea parapetada de poniente, hará con esta un ángulo de 110 grados. Cerca de dicho ángulo estará la subida desde el camino o calle al fortín. Este se compondrá de dos cuerpos: en el cuerpo bajo las paredes tendrán 3 pies de espesor $(0,84 \mathrm{~m})$, excepto la del norte, la cual, así como las del segundo cuerpo serán de 1,5 pies $(0,42 \mathrm{~m})$. Las aspilleras distarán 3 pies de centro a centro $(0,84 \mathrm{~m})$. Las aspilleras del piso bajo se elevarán 7 pies desde el terreno $(1,95 \mathrm{~m})$, salvo aquellas que estén sobre el ribazo que arrancarán a los 4 pies, sin necesitar banqueta $(1,11 \mathrm{~m})$. La altura total de la obra descrita queda determinada por la que componen sus dos cuerpos. Estará cubierta con tejado. De este modo el piso bajo servirá de cuerpo de guardia y en el piso de arriba se emplazara el centinela, sin necesidad de garitas, que en esta obra serian más perjudiciales que útiles. En las tapias que hay desde el fortín proyectado hasta el granero de don Francisco Antonio Herrero se elevaran hasta que tengan 3,5 varas sobre el terreno exterior $(2,92 \mathrm{~m})$, haciendo aspilleras a la altura de 6,5 pies del mismo $(1,81 \mathrm{~m}), \mathrm{y}$ estableciendo la correspondiente banqueta de madera. Se macizarán todas las puertas con el mismo espesor de la tapia.

Para dar comunicación con la ciudad á las casas del Batanejo, que quedan ahora dentro del recinto, se abrirá un estrecho portal en el cerramiento que se halla en la esquina de la Casa de Cárcel, colocando en él una puerta

Se renuevan las aspilleras de la trascocina y se levantará un tabique AMR, aspillerado en la galería contigua.

Se reforzarán sus paredes y tabiques, se tapiarán las ventanas y se harán

$\begin{array}{ll}\text { aspilleras en los dos pisos, puesto que la poca altura de las del bajo no } & \text { AMR, } \\ \text { parecen perjudiciales debido a la horma que existe en frente (se entiende } & 1818-17\end{array}$

Granero de don Francisco Antonio Herrero por horma a una pared de piedra seca)
Tapias aspilleradas y edificios

el Granero de

de Alcalá intermedios desde

Esta línea configura un reentrante, lo cuall favorecee su posición por la protección que
recibe de las mismas obras (frente atenazado), por el fuego que puede hacerse desde recibe de las mismas obras (frente atenazado), por el fuego que puede hacerse desde
las casas de la espalda y por los obstáculos que presentan los ribazos que la anteceden. Sin embargo en el estado en que actualmente se halla no ofrece la indispensable seguridad ante un ataque sorpresa. Los defectos de que adolece y sus remedios son: procurar que toda esta finca tenga por lo menos 5 varas $(4,18 \mathrm{~m})$ de altura sobre e terreno exterior o 6 varas $(5,01 \mathrm{~m}$ ) sobre el fondo del foso en los "parajes" donde hormas o ribazos sobre los que asientan las tapias, es preciso ser precavido para escarparla (dotarlas de cierto talud) y arrancar las matas y arbustos existente para impedir la subida. No basta que el parapeto tenga el relieve citado si no cubre bien a los defensores de los tiros de frente, de revés y de enfilada. Este inconveniente que se da en varios frentes se evitará ya levantando la tapia, ya rebajando al piso interior, o bien empleando ambas soluciones. Hay algunos angulos donde será indispensable emplearán también traviesas (traveses) donde convenga. Las comunicaciones entre todas las partes de esta línea estarán expeditas y a cubierto. En diversos sitios deben recomponerse las tapias, y en aquellos donde ha habido puerta se macizará el hueco con mampostería, en vez del debil cerramiento que tienen. Casi todas las aspilleras son defectuosas, tanto por su colocación, como por su figura y dimensiones; es necesario pues reforzarlas en términos que queden más desahogadas, que sus caras estén mejor
dirigidas, y que disten 4 pies de centro a centro $(1,11 \mathrm{~m})$. Se revocarán para mayor dirigidas, y que distencia 4 pies de cada una pero también del conjunto de la obra Se abrirán par los luagre donde se han dejado a modo de almenas. Su altura se graduará de modo que por la parte del campo no pueda introducirse en ellos un fusil, y que por el lado interio estén a 4 ó 4,5 pies $(1,11 \mathrm{mo} \mathrm{o} 1,25 \mathrm{~m})$ sobre el piso, o sobre la banqueta. Se establecerán banquetas de tierra de 3,5 pies de ancho $(0,97 \mathrm{~m})$ donde sea preciso para satisfacer las ellas y el parapeto. Para que la extensa cortina del mediodía quede mejor defontid se levantará una plataforma, apoyada en el Pajar de Ignacio Moya, por donde se le dará comunicación. Sus planos apoyarán en las esquinas del Pajar: el de la derech formará un ángulo de 100 grados con la cortina, y tendrá 6 varas $(5,01 \mathrm{~m})$ de lado exterior: la cara tendrá el mismo largo y su dirección será perpendicular a las tapias
de la huerta de [Domingo] Vives: el otro flanco queda determinado por este trazado. de la huerta de [Domingo] Vives. el oro yanco queda deterninado por este trazado. Esta plataforma tendrá dos cuerpos, sus paredes serán de dos pies de espesor en cara habrá un tejado de 1.5 varas de vuelo interior que sirva de abrigo al centinela Enfrente de las dos paredes de la casa de Maluenda que caen a la campaña, y a varas de distancia, se construirá un parapeto aspillerado de 4 varas de alto $(3,34 \mathrm{~m})$, formando una garita en su ángulo saliente. En los pisos altos de dicha casa se abrirán todas las aspilleras posibles. Es de absoluta necesidad proporcionar algún flanqueo a A este fin se levantará una de plataforma en la curva que abolutamente de esta protección. casa de $\mathrm{D}^{\mathrm{a}}$ María Herrero. La cara de esta plataforma insistirá en el revestimiento del camino contiguo, sacando un flanqueo de la casa de Maluenda, y tendrá 9 varas de lado exterior (7,52 m): los dos flancos formarán con las tapias ángulos de 110 grados. Esta obra tendra dos cuerpos, el espesor de sus muros en el bajo será de 3 pies $(0,83$ $\mathrm{m})$, en la cara y en el fanco de la derecha, $\mathrm{y}$ en el superior $\mathrm{y}$ todo el flanco de zquierda sera de 1,5 pies $(0,42 \mathrm{~m})$. Las aspilleras bajas estaran a 4 pies del piso $(1$, "bajo de los huertos" se guarnecerá con foso, cuyo obstáculo correrá por delante de la plataforma que se acaba de describir, y parapetos de la casa de Maluenda hasta e ribazo. Se aspillerarán en todos los pisos las paredes de las casas de la Villa que caen al bajo de los huertos, y se cerrarán en ellas con un recio muro de mampostería las puertas que hay abiertas o mal tapiadas. No obstante, se dejara la comunicacion alta escalera de piedra, y en su lugar se usará una escala móvil de madera. Para que esta no sea vista desde el campo se harán los tabiques necesarios. Se allanará el piso de modo que las aspilleras queden a la altura de 4 pies: se levantará el parapeto donde es necesario para cubrir a los defensores de los tiros de frente y de Corrales altos de la enfilada, y se dará comunicación a los dos corrales entre sí. Se cerrarán con piedra AMR, y batería contiguas.
AMR,

A 


\section{Desde la Puerta}

de Alcalá a la
Cantarranas

"En el parapéto que está encima de la puerta se realzarán y ensancharán los huecos de las aspilléras, dejándolas de modo [que] un soldádo en su posicion natural descubra bien toda la campaña: además se cubrirán estas aspilléras por su parte superior, y se dará mas elebacion al parapéto. Las aspilléras bajas que hay en el flanco de la derécha se reformarán, dejándolas todas á cuatro pies sobre el piso, y cerrándo por consiguiénte las que se hallan á mayor altúra. Conviniendo aumentar los obstaculos que presenta esta entráda, se hara un cerramiénto de dos lados por

Puerta de Alcalá y la parte interior dejándo en el una puerta paraléla á la priméra. La nueba puerta estará defendida por las aspilleras de [dichol cerramiento, y por el fuego que puede 1818-17, hacérse por la espálda á los enemigos desde la banquéta alta que viene á quedar á su frente. En la Batería se aumentará la alturá de las rodilléras, y se harán otras pequeñas reformas que necesitan las cañonéras, y en sus dimensiones, ya en la diréccion de sus caras: las cuales no se especifican en este lugar ni en los sucesibos porque las percibe facilmente una mediana inteligéncia, y sería prolijo describirlas. Se pondrán portezuélas de madéra en las cañonéras. Se compondrá y allanará bien "la esplanáda de piedra."
"Se aspilleraran las casas que se hallan en el recinto, y aun las inmediátas, en todos los parájes y pisos que descubren el campo; no olvidándose de verificárlo en las

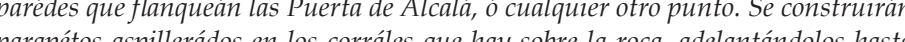

Desde la Puerta de Alcalá al brrio debajo de la misma a orilla de esta. Por regla general se cerráńn las bocas de las curbs [quel ecsibten debájo de la misma roca de la Puerta de Alcalá á la de Cantarránas. Se derribarán las tapias de la huerta del Rojo del Pino"

"Las pocas y misérables casas que hay en este Barrio deben derribärse, pues perjudican notablemente a la defensa, entorpeciéndo los fuegos de la fortificacion y facilitando al enemigo un ascénso [para] introducirse por sitios, que sin este [padrásto] serán inaccesibles. Desde este punto hasta la Puerta de Cantarránas conviéne realizar las indicaciones que se apüntan en seguida, sin periuicio de repetirlas en algun caso particular en que intérese llamar la aténcion. Se destruirán las tapias de las huertas procsimas y paralelas al recinto. Se barrenaran las peñas inmediátas, se escarpara la roca en varios puntos, en que, aunque no sin dificúltad, permite la subida. Se abriran aspilleras en todos los [cpos.] de las casas en que no lo impída el grueso de las parédes, y se aprovecharán las garitas y balcónes para establecer parapétos aspillerádos con cuyo [motibo] se recomienda de nuébo el que estas no solo se verifiquen en las parédes del frente, sino tambien en las de los costádos que proporcionan fuegos de flanco. Las puertas y ventánas que no se eleben mas de [ocho] baras de los sitios del despeñádero á donde un hombre pueda subir, se cerraran y aspillerarán. Se construirán cerramiéntos aspillerádos sobre los despeñadéros en las bocas calles que no los tienen, y se dará mas altúra á los que ecsisten. En los parájes donde la roca sobresale dejándo algún espácio superior, se levantarán tapias aspilleradas, y como hay algunos corrales altos ya cortádos, pero sin aspilleras, se procurará hacerselas. No se [omitirá] el dar las debidas dimensiones á las aspilléras abiértas hasta [aquí], y á las que se abran de nuebo, disponiéndolas con sujecion á los principios [que] se hán espuésto al [hablar] de otras lineas."

Desde Torregord

a la casa de [catorce]

Estas tres casas, la galeria de la de Catorce, y la obra que hay debajo de estas, deben [demolerse] totalmente, ya porque interrúmpen la vista y la accion de los fuegos de Torregorda y otros fortines sobre la inmediacion del recinto, ya porque AMR,

Casas llamadas de debajo de la Peña que proporcionen ellas mismas la defénsa que ahóra impíden, pero prescindiéndo de que esto ocasionaria gastos aprocsimádos al valor de las casas, y de que estas no podrian havitárse, seria preciso auméntar el servicio de la Guarnicion para evitar el segúndo inconveniente"

Casas de Antonio

Herrero y Blas
Perez
"Se construirá una esplanáda y se elebará el suelo á la inmediacion de las aspilléras, hasta que estas queden á 4. pies. Se abrirá un portádo para que pueda entrár el AMR, Bateria de Nuebalos cañon por la Calle de la Cortina. En la desembocadúra de esta calle al despeñadero, 1818-17, se reformarán las aspilléras según las reglas dadas, se levantará el parapéto y se fol. 12

Casa de don $\quad$ "Se guarnecerá con parapéto aspillerádo el pequeño corral que hay sobre la Roca" AMR,

Montenegro

Casa de Estebana

"Se levantará un parapéto aspillerado en el corral que está encima de la Peña. fons fol. 12 tapias que hay enfrente de la misma se derribarán: y se cerrará la cueba [que] queda AMR, descubiérta; según se há dicho ya por [puntol general"

Carcel

"Se cerrarán con recia pared el balcón, las ventánas y la puerta; y se abrirán

$\begin{array}{clll} & \text { aspilléras en todos los [Cpos.] por el frente y costádos. La escalerá por donde se baja AMR, } \\ \text { Casa del Ángel } & \text { desde el Recinto, debe ser de madéra y amovible. Se escarpará bien la Peña que hay } & \text { 1818-17, }\end{array}$ á la derecha de esta Casa, y se dispondrán los corráles superióres con arreglo á las fol. 12 indicaciónes espuestas

Se realzarán las rodilléras y la cresta del parapéto. Deben hacérse tres esplanádas de madéra; asi como tambien portezuelas para las canoneras. El parapeto aspillerádo AMR,

Batería del Cristo contiguo se reformará con sujecion á los pincipios tantas veces referidos: se hará que 1818-17, algunas aspilleras se dirijan á la Puerta de Cantarranas, y en todas se ensancharán fol. 13 las bocas."

Desde la Puerta de

Cantarranas a la de

"La pared fronteriza de la garita al cuchillo del angulo entránte se elebará lo necesario para que un [caballeté] pare á 3. pies sobre la entrádas. En el pequéño con mas firméz h banuéta de los altas y se abrión un fosó́ un frente. Se pondra gruesas puertas nuebas en lugar de las debiles [que] ahóra hay: cuyas puertas tendran su postigo de tres pies de alto en una de sus hojas. Para auméntar la seguridad de esta entródr, se efectuará por la parte interior lo obra que sigue. Se levantará un parapéto aspillerádo sobre el rebestimiénto de la rampa por donde se sube á la Villa con lo cual se consigue tambien la ventépi de resgurdar esta

Puerta de Cantarranas rampa de los tiros de la cumpaña, se elebará tres pies mas, y se aspillerará lar esta 列 unirán por medio de otro paralélo á dicha facháda: en cuyo tercer parapéto se dejarán una segúnda entráda, donde pueden colocarse las puertas [que] se desechan en la una segunda entráda, donde pueden colocarse las puertas [que] se desechan en la priméra. En el pequeño huerto que acaba de citárse se desenflará la escalerá de la aspillerará la tapia que flanquéa la cortina contigua, realzándola lo que sea preciso para que su altúra sobre el terréno no baje de cuatro baras. Se desharán los restos de una tapia paraléla á la que se acaba de citar, porque perjudícan á la defénsa". "Se dará á todo el parapéto de esta cima una misma altúra, que será la del trozo que ahóra se eléba mas. Se recalzará, compondrán y rebocarán las parédes y tapias en divérsas partes en que lo recláma su actual estado, y se masisarán las puertas que se hallan debilmente tapiádas. Se destruirán dos pasadizos de piedra que ecsisten sobre la acequia contigua, y se cortarán los arboles y arbústos [que] facilitan la escaláda de la cortina. Las casas de la Calle de Cantarranas se aspillerarán en todos los cuerpos que descubran el campo. Se tendrá cuidádo de que las aspilléras que se hagan o reformen queden desahogadas: que en el paraménto esterior tengan de 16. A 18. pulgádas de alto, y de $31 / 2$ á 4 de ancho: que las direcciónes de sus á las condiciónes mas conveniéntes; $y$ que su elebacion sobre el terreno se sujete fol.13 centro á centro cuatro pies en las lineas esténsas, y solo tres en las [reducidas], donde interése multipliocar los fuegos: sin embárgo en los edificios no siempre se puede obsérvar esta regla, pero se procurará aprocsimárse á ella todo lo posible. Siendo generáles estas advertencias, no solo se aplicarán á la parte del recinto [que] ahóra se considera, sino á todos los demas: por lo cual se evitará su repeticion en lo subcesibo. Y por la misma razon se omitirá tambien el repetir otras indicaciones que son igualmente generáles" 

$\begin{aligned} & \text { Postigo de la fuente } \\ & \text { del Peral }\end{aligned}$
cerrádo y a cualillerádo el frente. Delánte de esta nueba puerta se escabará un foso en 1818-17, del Peral comunicacion con la acequia, y para su paso se empleará un puente amovible de fol. 14 madéra. A este tambor se dará la elebacion que se há dicho para la cortina"

Casa de don Andrés "Se hará el mayor numero de aspilléras posibles en todos los pisos, en la pared que AMR, Casa de don Andres
Ferrer pora sobre el camíno, y se abrirán algunas en las que descúbren las inmediaciónes 1818-17 por encima de las tapias."

"Las tapias se elebarán lo suficiente [para] que en ningún punto baje un reliéve de cinco baras, y en cuanto á las aspilléras se sujetarán á las reglas dadas. En frente de la Fuente del Peral, se hará aun mas considerable el relieve dicho; puesto que don Andrés Ferrer debe establecérse un orden superior de aspilléras en la banquéta correspondiênte AMR, hasta la posada de para dominár el terréno de lascercanias. Este segundo orden de fuegos se estenderá 1818-17 afuera

catorcé baras desde la derécha de la garita, á la que tambien se dará mas altúra. Todas las tapias de huertas procsimas a la fortificacion, y a la fuente se hán de demóler.

"Se aspillerará en todos sus cuerpos, cerrándo y aspillerándo las ventanas bajas. Se AMR, dará cinco pies mas de altura á la tapia de su izquierda".

Posada de afuera

Se repararán con esméro las parédes debiles ó deteriorádas, aumentándo hasta cinco baras la alturra de toda esta linea. Se dara mas longitud al tambor contiguo a La Casa de Ponce: al efecto en el pilar de la tercia se levantará perperdicularmente

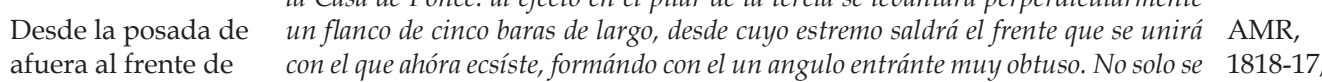

$\begin{array}{ll}\text { afuera al frente de con el que ahóra ecsíste, formándo con el un angulo entránte muy obtuso. No solo se } & 1818-17 \\ \text { la Glorieta } & \text { hará en el recinto el mayor numero de aspilléras que sea doble, sino que tambien se fol. } 14\end{array}$ aspillerarán [la] casas interiores por los sitios donde descúbran la campána, y esto aspillerarán [la] casas interiores por los sitios donde descubran la campána, y esto se verificará muy particularmente en todas las parédes que dominan el fre

"Despues de aspillerárse todos los pisos se renobarán con mas solidéz los

Desde el frente de la Glorieta a la Puerta de Madrid

cerramientos de las puertas. Se tapiarán las ventánas, cuya elebación sob los a

\section{Desde la Puerta de}

Madrid a la de las

Cruces

Puerta de Madrid

mino no exceda de ocho baras, y se arrancarán las rejas y balcónes que facilitan 1818-17 a escaláda. Se daran seis baras de altúra á las tapias que forman el angulo entránte fol. 14 de la Puerta de Madrid."

"Se dará mas alturá á los tabíques del tambor volado. Se mejorará el mecanísmo AMR, 18 substituyendo á las actuales cadénas, otras mas adecuadas, 1818-17, cuerdas de cañamo"

Palomar de D. Jose

[Cros] descúbren las cercanias."

Desde la Garita del huerto de D. Diego Montés a la Pues
de las Cruces

"Se procurará que en ningún punto de las tapias baje su elebacion de $21 / 2$ baras, y

de las Cruces

.....

Desde la Puerta de

Reinas dadas."

"Se cubrirá con tambor rectángular que ocupe el ancho del camino, y tenga doce
baras de largo desde la puerta. La altura de su parapéto será de cuatro baras, y el AMR,

Puerta de las Cruces espésor de dos pies. Se construirá una banquéta para el uso de las aspilléras. La 1818-17, puerta de este tambor se situará en el flanco de su izquiérda, donde se hará un fol. 15 pequéño puente para el paso de la acequia."

"Las tapias de Don Andrés Ferrer deben levantárse para [que] cubran bien a una persona: al mismo tiempo se reformarán las aspilléras, dándoles mas desahógo y AMR,

Bajo de las Bodegas mejor bajas, y se abrirán otras mas arriba. Se abrirá un foso en frente del lienzo que hay fol. 15 desde la garita al despeñadéro."

"Esta Bateria se halla en la posicion mas ventajosá para defendér las inmediaciónes de la poblacion, desde la Gloriéta, Fuerte de San Francisco, Loma, olla del martinéte, y Cerro del mísmo, pero para que correspónda á su objéto hay que mejorárla según se propóne á continuacion. En la cara del norte se abrirán dos cañoneras, así como la que ecsiste al poniente, se sujetarán á las dimensiones que el arte prescriba. En todo este espácio se reforzará el parapéto con obra de tapia; hasta que tenga bara y media de espésor, y se levantarán banquétas detrás de los merlones, para que por del parapéto dandole la conveniénte para que los artilléros queden á cubiérto y bien

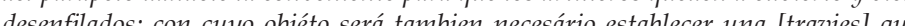
cubre la ultima piez del frente del norte. Por la parte de poriénte termin

Batería del Pozo de espaldón de la Bateria á una bara á la izquierda de la cañonéra: desde cuyo punto y aspillescléra al paráéto constituirá lo paréd que ahóra ecsíste, realzíndol 1818-17, y aspilleríndola. Dicha escalór por donde se baja al ahobl y calles nuebse, se fol. 15 desenfilará por medio de tabiques. Se nivelará el [techo] del [pozo] de la misma, y sobre el se levantará un parapéto aspillerído: De este modo quedará formádo un pequéño torreon al que se subirá por dentro del actual cuerpo de Guardin que debe destinárse [esclusivamente] á la defénsa. Se pondrán portalónes en las cañonéras, así como tambien las correspondiéntes esplanadas de tablónes. Se construiré un pequeño refuérzo en el paráje mas resguardádo. Tambien se construirá un nuebo cuerpo de [Guardia] hacia el centro de la obra que se considéra, estableciéndolo de modo que sirva de espáldon [para] cubrir las comunicaciónes con otros puestos. Todas las aspilléras del parapéto [quel hay desde la derécha de la Bateria hasta las casas, deben reformarse y en algúnas, se correiirán las dirécciones."

"Se adelantará el frente del norte girándo sobre vertice del angúlo saliénte hasta que su lado esterior quede á la orilla del desfiladéro, [y] se terminará á la distáncia de trece haras: Desde el estrémo de esta linea se dirijirá una cara oblicua de siete hares de lado esterior, de modo que vaya á morir en el lienzo aspillerádo de la derécha. Al parapéto de estas caras se dará bara y media de espésor. El lado interior del frente de poniente no se ignobará, pero si el esterior, pues se aumentará el grueso de su parapeto todo lo que permita la peña que le sirve de base. La garita se situará en AMR,

Batería de Isabel II parapeto todo lo que permita la peñalo saliente que résulte por este trazádo. La cara de poniénte se unirá con la 1818-17, el angulo saliente que résulte por este trazádo. La cara de poniente se unirá con la fol 16 de los parapetos se graduará por la condicion de que el interior quede cubiérto y desenfiládo. La cara [oblicua] de levánte tendrá una cañonéra, la del norte dos, y la de poniénte otras dos, todas con portezuelas y esplanádas de tablónes. El repuésto de polvora se colocará al abrigo de las quiebras del terreno, ó mas bien en una cueba abiérta debájo del mismo con las precauciónes oportúnas."

"Se conserbará la linea abanzáda que es de suma utilidad; pero siendo como debe ser

Sitio denominado Pedazo de lo
Muertos dos baras de ancho por la parte interior. A la linea del recinto principal se aplicarán AMR, los principios establecidos: además se reforzará la puerta de comunicación con la 1818-17, priméra, y delante se hará un trozo de foso con puente amovible." 


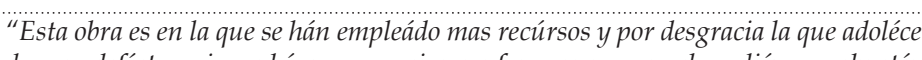
de mas deféctos: sin embárgo es preciso confesar que su mucho reliéve y robustéz le dan alguna importancia, y que a fabor de las indispensables correcciónes será de utilidad, En la parte mas saliénte que es la mas elebäa deben reformarse las cañonéras dandoles la configuracion ordinária. Se pondrán en ellas gruesas portezuélas y ademas guarda-cabézas de biga en la cresta del parapeto. Este pequeño espácio donde solo con [estrechez] cabe una pieza, tiene descubiérta á los tiros de rebés la cara de la izquiérda: para remediar este inconveniénte y desénfilar baja debe hovilitárse para el emplazamién to de artillerin: al efécto se destruirán

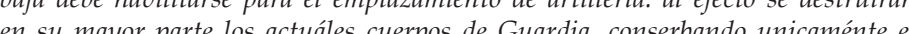

Batería nueva de $\quad$ en su mayor pário lara cinco hombres á la inmediacion de la gola Sobre la mise el AMR,

chá en la cara de la deréch otro cuerpo de Guaroin [para] igual fuerza el cual fol. 16 servirá de espáldon contra los fuegos de la campaña. En cada cara se abrirán dos ceñonéras, proveýéndolas de las portezuélas y esplenédas correspóndientes. Se dejarón las aspillérns intermedias y se dejań el parapéto don le sea preciso para

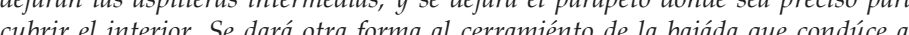
repuésto de polbora: pues en lugar de la compuerta que hay ahóra se abrirá la escaléra con un [gariton] de albañileria, que la presérbe mejor de las aguas: cuyo garitón tendrá puerta con cerradúra. En el espácio cerrado donde [ecsiste] la subida ála obra que se acába de ecsaminar, se abrirá una comunicacion con la Ba teria vieja de Reinas, y se levántarán los espaldónes indispénsables para ocúltar al enemigo esta comunicacion, y la cara interior de los parapétos." $\begin{array}{lll}\text { Batería vieja de } & \text { "Se dará mayor elebacion á sus parapétos, se reformarán las aspilleras y se dará á AMR, } \\ \text { Reinas } & \text { estas mejor diréccion. Deben rehacerse las esplanádas." } & 1818-17,\end{array}$

Reinas

"Para proporciónar mayor flanquééo á la puerta de Reinas, se dará mas altúra á la modo se podrá hacer un segúndo orden de aspilléras para cuyo uso se dispondrá la 1818-17, andamiada. Sobre el caballete del tejado se levantará un trozo de tabicón á fin de fol. 17 evitar la enfiláda."

Desde la puerta

Valencia

Desde la Puerta de

Se realzarán las parédes de modo que partiéndo desde la parte superior de la garita a puerta, no bajen en ningun punto de 4 . baras de altura. Sobre el nibel del AMR,

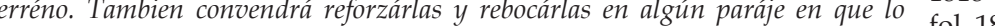
necesiten."

"Deben cortárse unos olmos contiguos al recinto [que] facilitan sobre manéra la AMR, escaláda."

"Se hán de levántar las tapias del corral, siendo indispénsáble que así estas como AMR, las de la casa se aspilléren. En el huerto se abrirá una cañonéra á la derécha de la 1818-17 „

Molino de Herrero

"En este lienzo del recinto se encuéntran algúnos trozos de rebestimiénto de piedra seca que deben rebocarse para su mayor firméza, y que no formen escalónes. Se cortarán las higuéras y matas arraigadas en las parédes. El escurridor de Erancisco Ramón se há de cerrar en prolongacion de las tapias de su izquiérda Desde el huerto de dejándo un arbellón bajo para la salida de aguas. Conviene no descuidar el pronto AMR, Herrero al Molino aspilleramiénto de las tapias del molino de Valéro en el angúlo entránte, donde $1818-17$ sirven de flanco á la parte contigua. Enel tendederó de este molino se construirá un fol parapéto con una cañonéra á fin de que sirva de Bateria. Todas las casas interióres deben aspillerárse en las paredes que descúbren las inmediaciónes ó flanquéan el recinto."

"Deben elebárse una bara mas las tapias fronterizas al [cas] del molino, achicándo AMR,

Huerto de Valero el arbellón que hay á su pie, y ensanchándo el mismo [cas] para que sirva de foso. La 1818-17 puerta debe cerrárse con buena obra de Albañileria."

"Se abrirán algúnas aspilléras, y se reparará la pared.

Desde la Casa de Gregoria Moral de Antonio Monsalve

Desde el torreón casa de Francisco Narbón

esde la casa de Narbón a las de la Garrota

Casas de la Garrota

Cancus
"Se variará su posicion y trazado del modo que va á indicárse. Se adelantará hasta
las tapias del huerto sobre las cuales se marcará un frente de nuebe baras de lado
esterior en linea recta. Esta será la cara de levánte: la de medio dia formará con ella un an en linea recta. Esta será la cara de levánte: la de medio dia formará con ella un angulo de 140. grados, y tendrá otras nuebe baras: la del norte formará con la misma un angulo de 100. grados, y terminará en el rebestimiento de la rampa de que va á hablarse. La rampa [para] subir á la Bateria partirá desde la inmediacion de las tapias que cierran el huerto por la parte del norte, y apoyándose en las parédes de las casas, terminará en el piso de la obra. Tendrá cuatro baras de ancho, y su guardaládo será un parapéto aspillerádo. Al [frente] de esta rampa se abrirá una comunicacion para la conducion de estas piezas por la Casa de Roque. Desde el

Batería del huerto de Agustín Monsalve

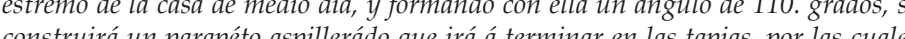
construirá un parapéto aspillerádo que irá á terminar en las tapias, por las cuales seguirá el recinto hasta la Casa de Onrrubia, en cuyo paráje se hará una entráda para comunicarse con los huértos procsimos. Todas las tapias que quedan fuera del recinto que se ha trazado deben demolerse. La altara de la Bateria será de dos baras y media sin contar el parapeto, ni la profundidad del foso que debe rodearla por $l a$

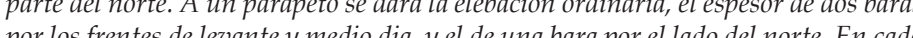

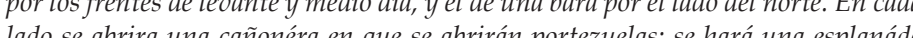
de madéra que oculte el piso de la Bateria, pero tanto para eso como para gradí el espesor de los espaldónes, solo se graduaré por tal el sitio en que há de revolvérse la piesa. El parapéto que cubre los demás puntos, solo tendrá dos pies de esṕ́ estará aspillerádo."

Huerta de "Se elebarán las tapias de este huerto y de los de la derecha hasta que cubran bien á los defensores, aspillerándolas á la conveniente altúra. La cañonera se conserbará, pero dandole mejor forma. En las parédes de la izquierda de esta se reformarán las pero dandole

"Sus tapias están muy mal cimentadas, por lo que deben reparárse. Se abrirá un

Huerto de Tirador aspilléra mas frente del tinte y se procurará [que] de todas pueda hacérse buen uso. Las parédes del tinte se aspillerarán en todos los pisos por los parájes que descúbran
el campo."

$\mathrm{AMR}$

1818-17, la AMR,
$1818-17$ fol. 20 de se de AMR, (1) AMR, 1818-17, fol. 20 
“Se reforzarán las parédes de la casa................................................................ camino, dandoles tres pies mas de espésor por su parte interior. En las mismas se abrirán aspilléras en todos los pisos. La puerta de comunicacion con las casas del AMR,

Fortín de Cara- $\quad$ puente se trasladará al angulo de la derécha; y como en este frente debe abrirse 1818-17, un foso se empleará un puente de madéra para su paso. Las dos lineas que ciérran fol. 22 la comunicacion desde el fortin dicho á las casas del puente, se hán de realzar y aspillerar en debida forma".

"Estas casas se hallan en tan mal estado que seria necesario derribárlas, si el enemigo atacáse á la Poblacion con recúrsos imponéntes: pero como no hay inconveniente AMR, Casas del Puente en conserbárlas, mientras no llegue este caso, debe aspillerárse en todos sus pisos, y 1818-17 sujetárse á las prevénciónes que se hán hecho para todos los edificios que se hallan fol. 22 en el perimetro de la Ciudad."

Desde la Casa $\quad$ "Se aspillerarán las parédes en todos los cuerpos, se masisarán las puertas con AMR, de "Amoroz" a la _ buena albañileria, se arrancarán los balcónes que no se elében mas de ocho 1818-17 Puerta de Valencia baras sobre el terréno, y se tapiarán las ventanas que se hallen en igual caso." fol. 22

La Villa

La Villa "Se aspillerarán en todos sus pisos que miran á la parte interior, y forman parte del $\mathrm{AMR}$

Se aspillerarán igualménte. Se levantará en forma de parapéto el guardaládo del blanquéador; tanto donde es de tabique como de pared. Las puertas que ahóra están AMR, cerradas con obra, se cerrarán con mas perféccion, abriéndo aspilléras: La tapia 1818-17 Manuel Gonzáles que sigue la misma linea. La comunicacion de este corral con la fol. 23 Manuel Gonzáles que sigue la misma linea. La comunican

"Se abrirán aspilléras en la tapia que mira á la calle de Cantarránas, y en la que "Se abrirán aspilléras en la tapia que mira á la calle de Cantarranas, y en la que Cantarránas se tapiarán en caso de riesgo. Las vocas calles que caen á la Plaza de Casáres se cerrarán con cortadúras barricádas [signo ilegible] en caso de riesgo. AMR,

Corral de don José
La puerta grande del corral de Don [Cantos] será la comunicacion unica para la 1818-17,

$\begin{array}{ll}\text { Cantos } & \text { La puerta grande del corral de Don [Cantos] será la comunicacion unica para la 1818-17 } \\ & \text { retiráda de los defensóres de la Plaza de Casáres, pero para esto solo se dejará una fol. } 23\end{array}$ hoja, y otra se podrá masisar por detrás en caso critico. Las tapias inmediatas á esta puerta se aspillerarán. Todas las casas que se hallan en el recinto se aspillerarán por su frente y flancos."

"Despues de espillerárse como se há dicho se harán parapétos aspillerádos de tabicón en la galeria que cae al corral. Todas las casas desde la de [Cantos] hasta el callejón del pozo del astillo sufrirán el mismo [aspilleramiento] y obras que por regla general se hán establecído. La boca calle del callejón citádo se cerrará en su salida con pared aspilleráda desde la puerta del corral de Victor Comas hasta la de AMR,

Casa de don José $\quad$ su frente, quedándo ambas interióres. La puerta de la casa [que] hay en frente se 1818-17, masisará, y se derribarán las parédes de los costádos de esta casa que están sobre fol. 23 el desfiladéro. Desde el callejón del Pozo del Castillo hasta la casa de [Picapórte], cuyas caras están sobre el desfiládero se observarán las reglas generales. Desde la izquierda de la puerta de casa de Picapórte á la esquína de la casa del Castillo se hará un cerramiento aspillerádo con puerta á la inmediacion de [dicho] Castillo.

Castillo y Fortaleza

"Su plaza alta se rodeará de un parapéto aspillerado. En cada uno de sus cuatro angulos se establecerá una garita, haciéndo algúnos ahujéros en su baseá manera de natacanes para descubrir el pie. En la pequena plaza baja se rodeará de un parapéto Torres, por una galeria voláda que se dirija oblicuamente á la múla de las [tres] encima de ella recomponiéndola, parándo por la que sirve de pared á aloúnas casas AMR, por la primér Torre Las parédes de las havitaciónes nuebss incorporílas al Castillo 1818-17, se aspillerarán, cerrándo las ven tónas que no sean necesarias y aspillerándolas. La fol. 23 puerta principal que está ahóra inmediáta ála [Cuesta] se masisará y aspillerará

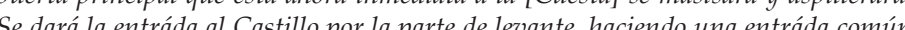
Castillo y la Fortaleza. Los torreones se rodearán en sus plazas altas con my aspillerádo."
“No se dejará á la Plaza llamáda así mas comunicacion que la que tiene al callejón por donde se debe dejar la unica entráda para el torreon del Castillo. Todas las paredes que estan sobre el desflidero se repararan y aspilleraran. En los parájes donde sobre sálen las casas del arrabál se estableceran banquétas para descubrir AMR, por encima de los tejádos. En frente de la unica puerta que se deja se hará un gran 1818-17, tambor. Su lado izquiérdo será parte del mismo en todo el recinto, la diréccion fol. 24 del frente será la conveniénte para que sea flanquéado por los torreónes y camino

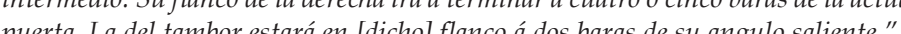
puerta. La del tambor estará en [dicho] flanco á dos baras de su angulo saliente."
Pasado el recinto

Casa de Calaforra

"Se levantará un parapéto aspillerádo en el corral."

Casa del Arte

"En todo el corral parapéto aspillerádo; por supuesto, parédes, casas [signo ilegible] AMR, se aspillerarán. En todas las demás casas y corráles hasta la de D. Andrés Carcia se hará lo mísmo, y se dará comunicacion en las casas y corráles simpre que se pueda." fol. 24 "Las aspilléras y cerramiéntos prevenidos por regla general, las puertas se

Desde la casa de don Andrés García hasta el cerramient de la Cuesta de las Carnicería

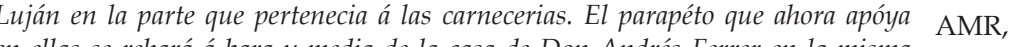
diréccion que áŕ tiene, pero dirijiéndo un flunco sobre el despeñ déro que por lo 1818-17, demolicion 24 aspillerádos, y la puerta donde ab́ra se halla pero mas fuerte y con cerrójo y llabe."

\section{Los documentos asociados con las obras de la Puerta de Alcalá en el año 1838 localizados en el} Archivo Municipal de Requena (AMR, 1818-15)

En el archivo Municipal de Requena se han encontrado una serie de documentos sin fechar que relacionan los materiales suministrados y los costes parciales de la denominada puerta de Alcalá, acompañados de un plano con el siguiente encabezado: "planta, perfil y corte para la puerta de Alcalá de esta ciudad cortado por la linia marcada BA. Dicha obra reza marcada por la escala proporcional y pliego de condiciones"

Se trata de una propuesta sencilla con una puerta moldurada dispuesta asimétricamente, con un parapeto superior aspillerado y tres aspilleras al nivel del espacio bajo que flanquea la puerta. La puerta se eleva sobre una escarpa inclinada, por lo que se deduce la existencia de un foso o zanja que la antecede. Tiene derrame hacia el exterior y un parapeto estrecho en la parte superior de apenas dos pies castellanos. El terraplén superior o remate de la puerta está constituido únicamente por un conjunto de listones de madera que conforman el dintel y base para dicho terraplén, que tiene un paso inferior a 5 pies $(1,3 \mathrm{~m})$, y con un mínimo parapeto que protege de la caída.

La puerta, según las partidas, se ejecutó recurriendo a numerosos suministradores, a los que se pagan carretadas de piedra, cubos de agua, cal, cargas de madera, dos vigas, cahíces de yeso, cerradura, llaves, clavos, vino y aguardiente, un revoltón, forraje... Y entre los operarios se cita carreteros, carpinteros y operarios sin especificar.

No se puede efectuar una estimación del coste total ante la falta de documentos, pero se puede extraer de los mismos el fraccionamiento de los pagos por partidas que se efectúan a diferentes suministradores, el seguimiento minucioso de dichos pagos y el modo de efectuar las mediciones: jornales, carros, cahíces, unidades... Y, todos los pagos, en reales de vellón. 
El expediente final sobre la fortificación de la ciudad emitido por el Coronel Comandante Militar de la Plaza de Requena, José García de Orozco, el 9 de marzo de 1839 (AMR, 1818-35)

Aproximadamente un año después del proyecto planteado por el ingeniero Juan Ramón Carbonell el Coronel Comandante Militar de la Plaza escribe al alcalde de Requena (se interpreta más adeel Corme Comenta (se inter lante en la medida que hace referencia a él como "autoridad tutelar de esta ciudad"), para advertir de que la fortificación sigue incompleta. Por aquel entonces Cabrera ha fortificado Chelva y se teme un golpe de mano. Se informa de que a pesar de los fondos recibidos, la obra no ha podido llevarse cabo, quedando mucho por hacer, aunque se matiza que las obras restantes no serán del costo de lo construido en el verano de 1838.

Las principales carencias pendientes de construir son los fosos, que por lo visto ya están marcados, y de "uno ó dos puntos céntricos de defensa cosa tan substancial en el arte militar como que sin ellos no puede ecsistir fortificacion al gúna que deba contemplárse como tal" (AMR, 1818-35). No se explica exactamente de qué puntos se trata, pero con toda probabilidad hará referencia a alguno de los fortines precisados en el proyecto de Carbonell.

García de Orozco solo pide fondos, ya que entiende que la ciudad no puede ser sangrada financieramente más de lo que ha sido, por ello "toca remober los obstáculos y hacer oir [su] voz á los habitantes" (AMR, 1818-35)

Una vez más el consistorio acordará reunir a los vecinos para tomar una decisión, y lo hace en escrito fechado el 10 de marzo, donde se incorpora una lista de los principales contribuyentes.

En el mes de marzo se localiza una serie de documentos, mezclados con los anteriormente citados (AMR, 1818-35) que hacen referencia al proceso de expropiación de determinadas casas del Barriete, para su demolición, dado que afectan, según el informe del ingeniero Carbonell, a la seguridad. Los propietarios reaccionan satisfactoriamente, no oponiéndose, pero pidiendo que la tasación sea Los propietarios reaccionan satisfactoriamente, no oponiéndose, pero pidiendo que la tasación sea
efectuada por un perito competente. Los peritos alarifes nombrados por el ayuntamiento son conminados a efectuar la tasación el 1 de abril de 1839, "teniendo presente que en el caso de demolición se tenga en consideración el valor principal de los edificios y lo que de ellos pueden aprovecharse los dueños en sus maderas y despojos útiles" (AMR, 1818-35).

El 4 de abril de 1839 García de Orozco informa de unas obras de reparación en el Convento de San Francisco, pidiendo al municipio el pago de las mismas. Uno de los tramos del convento se veía amenazado de ruina, especialmente una de las vigas maestras que sostenían la techumbre. También se recomendaba descargar la parte del noviciado del peso del tejado, casi derruido, que amenazaba se recomendaba descargar la pa
arrastrar todo con su caída.

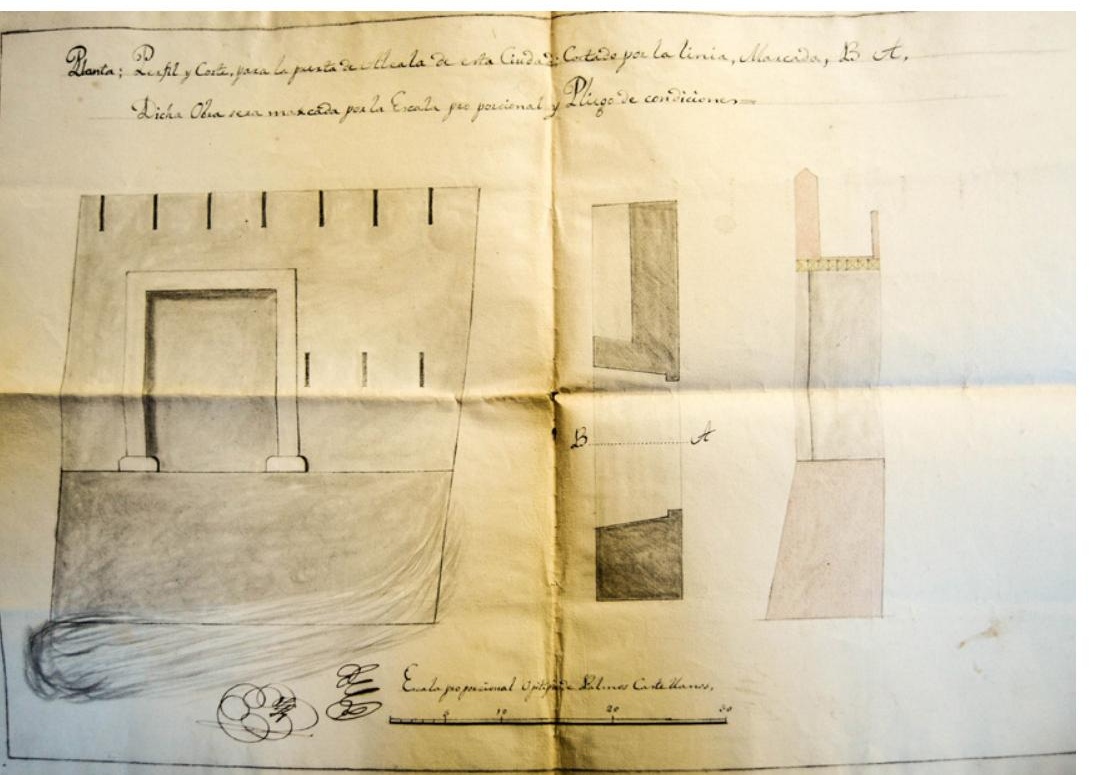

Fig. 738. Plano de la Puerta de Alcalá en el año 1838 localizado en el Archivo Municipal de Requena (AMR, 1818-15)
Como último documento, perteneciente al conjunto archivado como AMR, 1818-35, destaca el escrito dirigido por un ciudadano al ayuntamiento, fechado el 5 de abril, en el que se trata de encontrar una alternativa a la demolición de las casas del Barriete. No satisfechos con las posibles indemnizaciones, "se atreven a proponer un medio capaz de conciliar los intereses de los propietarios con la seguridad de la población" y lo hacen con las siguientes palabras:

"Efectivamente rebajados los techos de las casa del Barriete a la altura o nivel de los cimientos de aquellas que forman ya la población y levantando una muralla en línea paralela a la que se mira ya construida; tendremos que el objeto principal cual es la seguridad y defensa de la Plaza, queda conseguido: puesto que entonces queda aislado el Barriete sin comunicación con la ciudad y sin que los enemigos puedan ofender desde él a los defensores de ésta" (AMR, 1818-35).

Es en este punto cuando se interrumpe la documentación escrita acerca de las obras de fortificación y quedan en el aire infinidad de dudas acerca de qué debió construirse y qué quedó pendiente de aquel amplio y complejo proyecto propuesto por el ingeniero Juan Ramón Carbonell y respaldado por el comandante de la Plaza, José García de Orozco.

\section{La descripción que hace Jorge Vera en 1993 del circuito fortificado de Requena construido hasta} 1839 (Vera, 1993:72)

Muchos autores hacen referencia a los informes citados para suponer los elementos construidos de la fortificación. Así, por ejemplo, Vera describe pormenorizadamente en su artículo sobre la fortificación de Requena (Vera, 1993:72) el circuito defensivo acabado de construir o interrumpido en el año 1839, casi a la conclusión de la Primera Guerra Carlista, con las siguientes características: "Partiendo del Portal de Madrid se dirigía en dirección suroeste atravesando Cantarranas hasta el pie de la cuesta del Cristo, desde donde se plegaba al antiguo contorno noroeste-sur de la Villa hasta la torre Montijana y Puerta de Alcalá, nuevamente tapial frente a los Huertos hasta las casas de Pabón, tapial hasta la Casa Grande de Cárcel y de alli a la Puerta de Valencia y puente de Santa Cruz, con aprovechamiento de muros de casas y aspilleramiento de algunas de ellas, que defendían en saliente el flanco sureste de la ciudad. Desde allí con diferencia cambios de dirección por el Tirador. Tinte de Navarro, Batería de Honrubia, Puerta del Trillero formando el flanco este de la ciudad. Nuevo plegamiento a las antiguas murallas de las Peñas y quiebro en la Puerta de Reinas formando tapial y apoyándose en muros de casas aspilleradas hasta el Pedazo de los Muertos y Cerrito de Isabel II, el Pozo de la Nieve, a las inmediaciones del actual Teatro Principal, con bruscos cambios de dirección hasta la Puerta de Madrid, y por Cantarranas, hasta el tambor del pie de la Cuesta del Cristo o puerta de Cantarranas, defendian los flancos norte y noroeste.

Los tambores que jalonaban este circuito, reforzándolo, de los que hay constancia fehaciente eran los siguientes: Puertas de Madrid y de Cantarranas, de la Puerta de Valencia y de Reinas. Fortines con cuerpos de guardia: Puerta de Alcalá, Tirador, Tinte de Gabaldón, de la calle de la Plata (junto Puerta del Trillero) y casa de la Garrota. Baterías: del Cristo, de Honrubia, de Reinas, del Cerrito de Isabel II (posiblemente convertido en revellín o media luna por su valor estratégico), del Pozo de la Nieve.

Las puertas: Madrid, Cantarranas, Alcalá, Valencia, Trillero, Higuerillas, Reinas y San Francisco. Fuerte avanzado: San Francisco" (Vera, 1993: 72-73).

El testimonio de Vera resulta trascendental en la medida que pudo presenciar la existencia de determinados restos que hoy en día han desaparecido, a pesar de la insistencia del autor por salvaguardar un patrimonio de indudable valor en la historia requenense.

Amparado en los informes de los ingenieros, dio por sentada la ejecución de las obras dictadas en los informes y, si bien el perímetro de la ciudad y los restos podían validar sus afirmaciones, desconocemos hasta qué punto se puede sostener la ejecución total, especialmente de la última propuesta de Carbonell. 

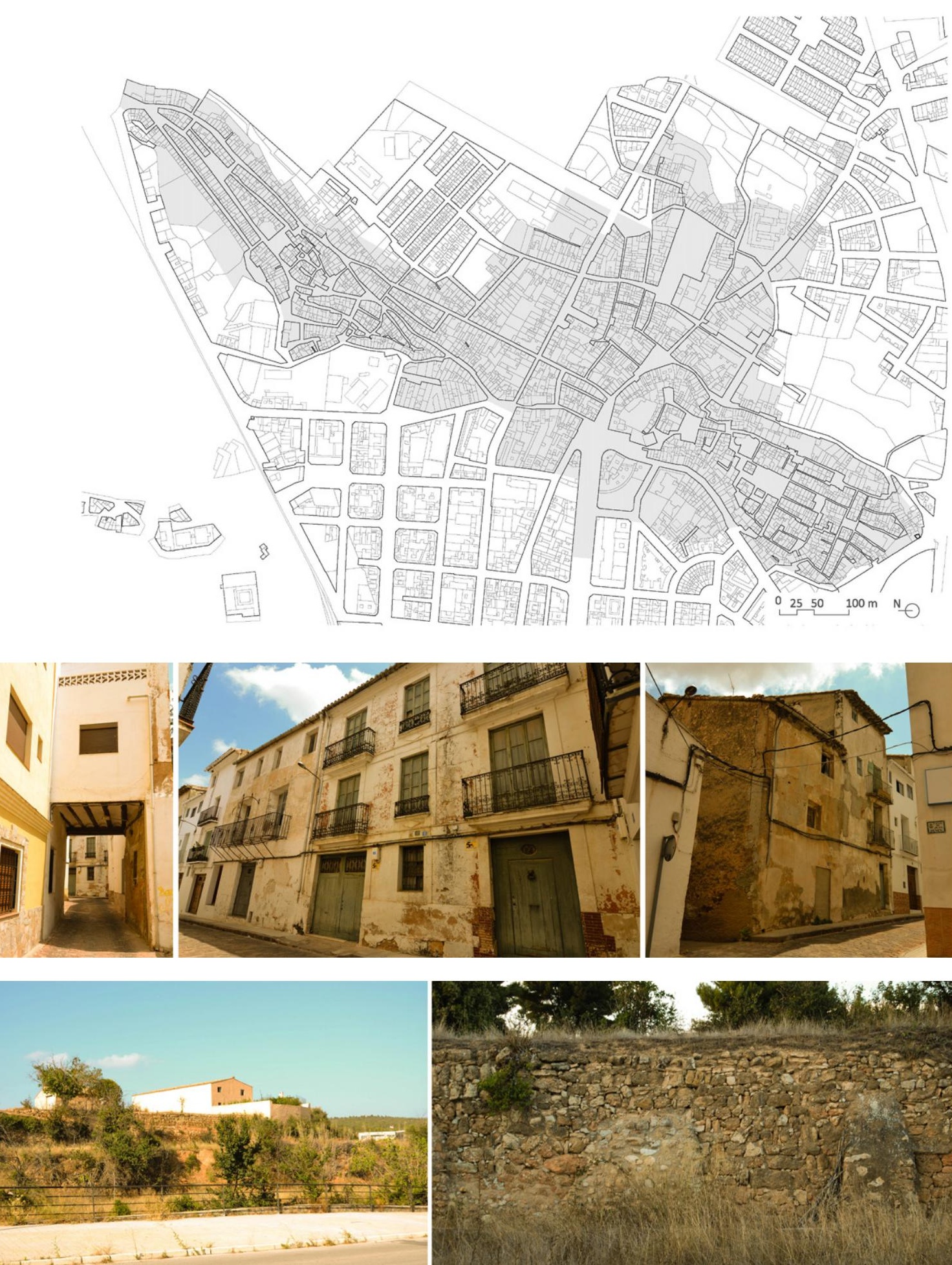

**Observación inicial: para efectuar el estudio se ha confeccionado una base de datos a fin de introducir los puntos arquitectónicos existentes y desaparecidos cuyos contenidos se adjuntan en el anexo 1. Esta base de datos numera las diferentes posiciones en base al criterio aportado por Juan Ramón de Carbonell en el informe AMR, 1818-17, del 4 de julio de 1838, posiblemente el más detallado y que aborda las últimas propuestas antes del fin de la guerra. A partir de este orden numérico, se han ido incorporando hitos que se localizan en otros informes y en la investigación in situ, por lo que, a partir de un momento, la numeración no es correlativa.

Esta numeración es la que aparece en el plano que se acompaña, que debe tomarse como una propuesta hipotética donde se distinguen en color verde las posiciones descritas por los ingenieros que existen en la actualidad, en color rojo aquellas posiciones descritas por los ingenieros, no probada su existencia y estimada su posición. Finalmente se señalan en color azul aquellas posiciones que revelan su existencia en el lugar, no descritas en los informes militares. El trazado del posible perímetro amurallado se grafía a trazos cuando no se dispone de ningún tipo de validación in situ de la posición.

Analizados los proyectos e informes históricos que se suceden entre 1833 y 1840, quedan muchas dudas en relación con el trazado fortificado liberal debidas a los siguientes motivos:

1.-Muchas de las indicaciones toponímicas o identificación de propiedades a partir del nombre del propietario han caído en el olvido y no se establece una asociación directa con el patrimonio existente, salvo determinados hitos de la ciudad: Castillo, Convento de San Francisco, tambor de Cantarranas, Carrera de San Sebastián... La cultura popular ha desterrado del recuerdo cualquier referencia, y, si sobrevive alguna referencia toponímica directa como "las troneras", se ha anulado de la memoria la conexión significante-significado.

2-La alteración profunda que ha experimentado la ciudad en sus bordes especialmente con el desarrollo del arrabal, el trazado del ferrocarril, la Nacional III y las obras de urbanización de los sucesivos planes, especialmente los últimos planes de Honrubia y el Batanejo, han diluido la posibilidad de percibir y disfrutar con claridad de este patrimonio. La percepción es clave para la valoración. El hecho de que la fortificación ocupe en determinados puntos áreas marginales, escondidas de la vista de los recorridos más frecuentes, no contribuye a su identificación y, por tanto, tampoco a su puesta en valor, más bien al contrario, dado que camufla la destrucción sistemática de los vestigios.

3.-La desaparición o inexistencia de muchos documentos históricos que podrían ayudar a clarificar las características del trazado, donde llama poderosamente la atención la ausencia de planos, dificulta la investigación. Solo se cuenta con el sencillo croquis de Ortiz de Pinedo, que se limita a definir el límite, sin detallar las edificaciones intramuros. Ninguno de los ingenieros comisonados, tanto Ortiz como Carbonell, disponen de tiempo para elaborar un plano en condiciones y así lo comunican a sus respectivas autoridades como hemos visto en el apartado precedente.

Por ello es preciso recalcar de nuevo que nos encontramos ante una investigación que parte de la nada. Es decir, de la conciencia asumida por parte de los ciudadanos, e incluso los especialistas sensibilizados con el patrimonio requenense, de que la fortificación liberal ha desaparecido salvo el derruido "tambor de Cantarranas". 
Fig. 742. Izquierda: muro de mampuesto definiendo la base de las huertas de la Hoya de Reinas, coincidiendo con la prolongación de la muralla. Centro: Tableta sobre un muro de mampostería recrecido con bloque de hormigón donde 1837 y 1838 que se recogen en el informe de Carbonell. Derecha: el encuentro de dos muros de Higuerillas conform do una arista con pendiente (VN, 2013).

Fig. 743. Fragmento de muralla junto a la puerta de Higuerillas con una aspillera. Se observa que la muralla se interrumpe con la interposición de casas nuevas pero aparece y reaparece continuamente pues conforma el pretil de los huertos de higuerillas. A la derecha, casa aspillerada en el denominado Pedazo de los muertos (VN, 2013).

Fig. 744. Fotografía histórica (Salinas \& Pardo, 2014:129) de una postal de Requena (s. f.). Se entiende que es anterior al Plan Borso de 1941 y al incendio del 23 de marzo de 1936 del convento de las Agustinas Recoletas. Este fachada urbana de Requena ha desparecido por completo, pero la foto resulta sumamente ilustrativa de la estructura defensiva que se reitera en otros frentes. En la línea posterior de defensa, el antiguo frente amurallado medieval con las casas correspondientes. En un escalón inferior, el nuevo frente de casas que define la calle García Montes (Cantarranas) y en
un tercer escalón las huertas correspondientes. Al fondo de la fotografía se observa el macho del castillo de Requena por delante la desaparecida casa del marqués de Caro. A su espalda queda la fuente del Peral y, al final de la perspectiva, el convento de las Monjas, también desaparecido y donde se ubicará el arranque de la Avenida Arrabal.
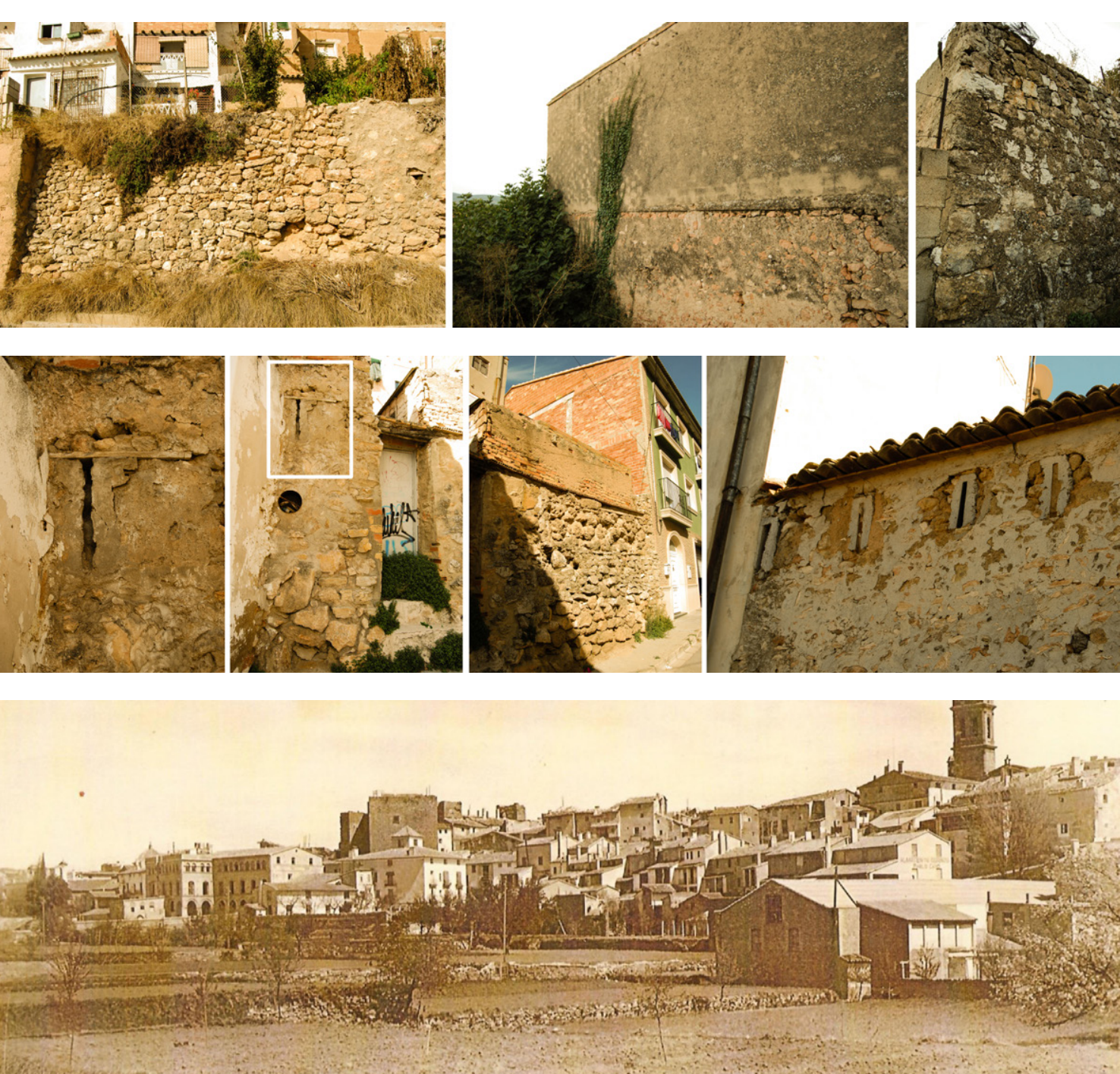

En esta investigación se demuestra cuan equivocada está dicha interpretación y se saca a la luz un patrimonio "aparentemente" inexistente, cuya puesta en valor se abordará en el apartado siguiente.

¿Cómo se reconstruye el trazado?

1.-A partir de los informes militares, y dado que la exposición de los puntos a fortificar se efectúa siempre por orden, ya sea levógiro o dextrógiro, se identifican aquellos puntos que se conservan en la actualidad. Es conveniente indicar que la referencia a los tramos fortificados se fija en los informes militares a partir de las puertas de diversa índole del recinto decimonónico: Puerta de Valencia (Localización 001 en el plano y en las fichas), Puerta de Alcalá (014), Puerta del Ángel (026), Puerta del Cristo o de Cantarranas (027), Puerta de Madrid (036), Puerta de las Cruces (040), Puerta de Reinas (053), Puerta de Higuerillas (120) y Puerta del Trillero (072). De ellas tan solo se identifican las antiguas salidas del recinto medieval como la Puerta del Angel, la Puerta del Cristo y la Puerta puntos de referencia y orientación aproximada. El recorrido se fija a partir del complemento de aquellos hitos existentes: Puente de las Ollerías (004), Casa de Cárcel (008), Convento del Carmen (116), Iglesia de Santa María (095), Torre Montijana (017), Iglesia de San Nicolás (115), Cuesta de la Cortina (019), tambor de Cantarranas (028)...

Fijados los puntos, y a pesar de extensas áreas sin identificar, como los tramos Puerta de Madrid-Puerta de las Cruces, Puerta de las Cruces-Puerta de Reinas, Puerta de Reinas-Puerta de Higuerillas, Puerta de Higuerillas-Puerta del Trillero, Puerta del Trillero-Puerta de Valencia, se pueden ir ajustando todas las localizaciones.

Por ejemplo, sabemos que entre San Nicolás y la Cuesta del Ángel se encuentran por orden las " $c a$ sas llamadas de debajo de la Peña" (020), las "Casas de Antonio Herrero y Blas Pérez" (021) y la "Batería de Nuevalos" (022), pues la casa de "Don Antonio Montenegro" (023) ya se ubica en la misma Cuesta del Ángel y está localizada en la actualidad.

2.-El estudio de la morfología urbana de la ciudad, que se ha mantenido inalterada, especialmente en el área de los barrios de la Villa y las Peñas, permite a través de la planta urbana determinar aproximadamente la superficie que debió comprenderse en el interior de las murallas. Evidentemente no se pueden considerar los límites que definen las áreas de morfología urbana característica como la misma línea definitiva del trazado, pero sí que nos sirve para considerar que a partir de esos límites en dirección intramuros no se localizó la muralla liberal dado que su objeto era dar seguridad a estas edificaciones. Existen testimonios de edificaciones de la época extramuros, como seguridad a estas edificaciones. Existen testimonios de edifica
las casas del Barriete (016), pero se identifican con claridad.

3.-Complementa la valoración que aporta la morfología la identificación de las construcciones anónimas que se emplazan en la proximidad del perímetro, como podría ser la estudiada Casa del retablo en la calle de Antonio Pérez, antiguo Camino de las eras (072), que responden a la tipología y características constructivas de la época. Esta aportación resulta clave por ejemplo en la expansión del arrabal efectuada en 1783 por Bartolomé Ribelles, en tiempos de Carlos III y que dio origen a las entonces denominadas calles de San Luis, San Fernando y San Carlos. La calle de San Fernando (100), paralela a la antigua avenida de los Álamos (actual calle constitución) (070) delimitaba claramente con la muralla, y se aprecia por el cambio de características arquitectónicas en la zona.

4.-En el proceso de investigación se ha detectado que la toponimia requenense ha conservado referencias a elementos ya desaparecidos, ignorados por gran parte de la población actual y que han sido de suma ayuda para recomponer las posiciones de las que no se tenía referencia física. Precisamente gracias a la toponimia se han podido fijar muchos puntos, Calle Higuerillas, Calle Bodegas (043), Calle San Agustín (101), Calle Asnos (099), Calle del Pozo (044)... Se adjunta al final del trabajo un anexo toponímico con las asociaciones al plano. No todas la referencias toponímicas responden exactamente a una posición idéntica: Calle Telégrafo, Calle Pinos de Florillo... pero la superposición entre documentos y la identificación en el lugar ha sido determinante. 
Fig. 748. En esta imagen de los arrabales hacia Albacete (Bernabeu, 1982:393) se observa la embocadura de Cantarranas, la muralla a la derecha y, afinando la vista, se enmarca la presencia del desahuciado tambor de Contarranas. rranas, la muralla a la derecha y, afinando la vista, se enmarca la presencia dee dester

Fig. 749. El análisis del frente de Santa María a partir de las fotografías históricas permite entender las características de los frentes anteriores. Se pueden distinguir las alteraciones producidas en los últimos años en el conjunto patrimonial de Santa María y en las torres del recinto islámico que alteran la percepción de este paisaje urbano (Jordá, 2000: fig. 13). Fig. 750. Esta fotografía de la denominada avenida de los Álamos en los años treinta (Jordá, 2000: fig. 9) permite visualizar las construcciones existentes en este sector de la ciudad. A la izquierda se pueden observar los terraplenes escalonados de las huertas y el frente de casas respondiendo a la misma sección urbana descrita en fotografías anteriores.
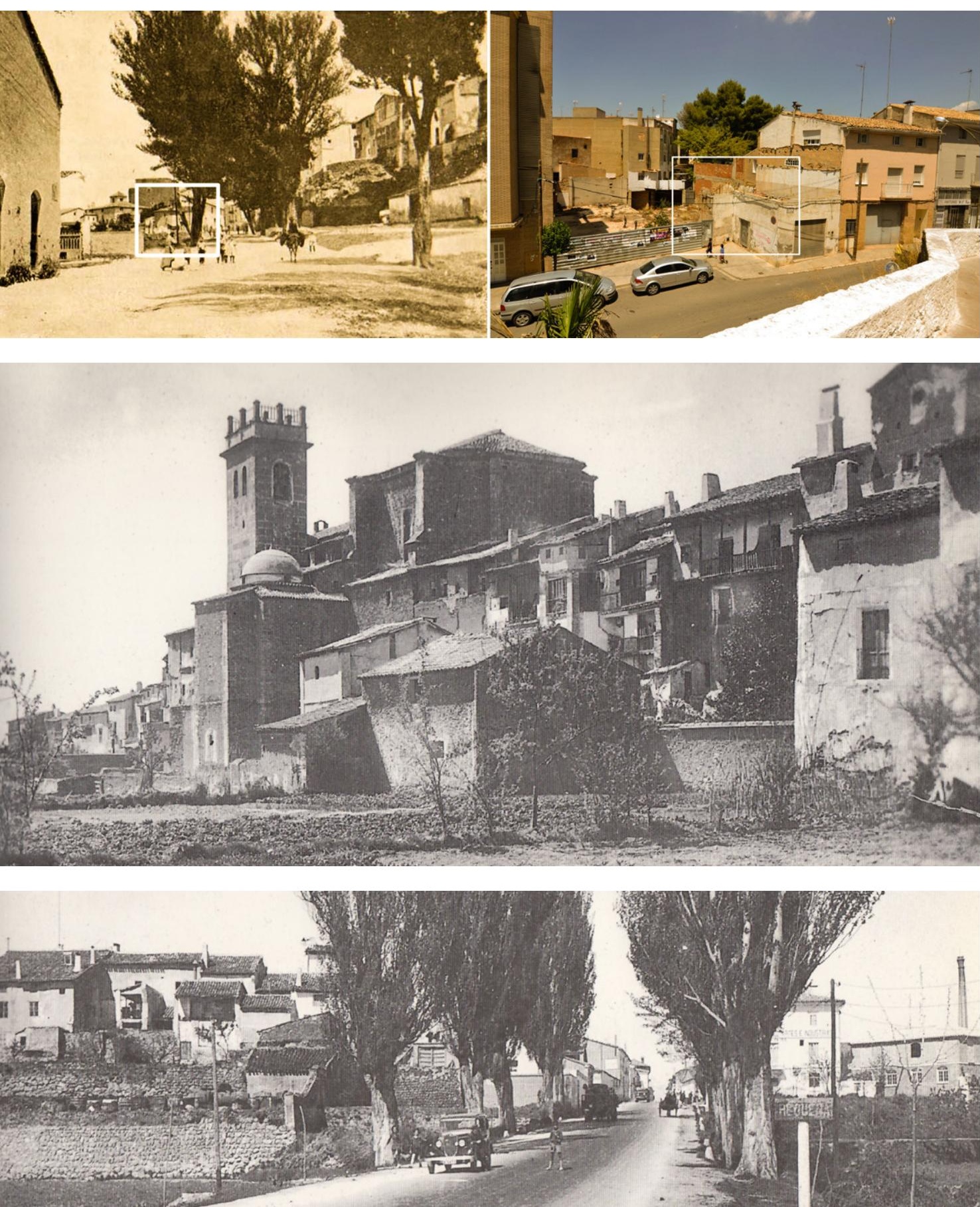

8.-La superposición de trazados. El croquis aspillerado de Ortiz de Pinedo, realizado entre finales de 1837 y 1838 (AGMM, Ar. G-T.3.C.2.262) es el único localizado que testimonia la ubicación de los puntos clave de la fortificación y parece carecer de una cierta imprecisión en el levantamiento (véase apartado correspondiente). A pesar de ello, la confianza en la formación y el rigor de los ingenios militar y el conc turico que el ingeniero levanta en su comisión de servicios, como así hace constar por escrito para informar a la superioridad, nos hace presuponer una cierta voluntad de precisión. De hecho el ingeniero omite detallar el interior de la ciudad y se centra en el perímetro fortificado. Sabemos también que tuvo que lanzar sus medidas y que estas se realizaron a cuerda. Cuando superponemos el plano actual con el croquis a escala nos sorprenden unas coincidencias muy precisas. Por ejemplo, el denominado pedazo de los muertos coincide en forma y superficie. También sucede así con la morfología de salientes muy característicos como el que corresponde a la Batería de Isabel II y al Pozo de la Nieve. También resultan muy coincidentes el sector correspondiente a los huertos de Santa María. Sin embargo, el interior de la villa se desroporciona sobremanera, así como algunos tramos correspondientes a Tiene sentido. La coincidencia exacta se produce en aquellos lugares donde el ingeniero contó con planos horizontales y pocos obstáculos para efectuar sus mediciones. Los callejones y pendientes de la Villa no le ayudaron. La superposición de planos, como vemos, resulta clave a la hora de posicionar claramente y definir puntos que no estaban del todo claros en la planimetría: el Pedazo de los muertos (047), el Pozo de la nieve (044) o la batería de Isabel II (046)

9.-Como observamos en el ejemplo, mucha información oculta por la abstracción de la planimetría tampoco revelada por la observación in situ debido a los desniveles topográficos, es aportada por in (1945-1946 y des (1973-1986. Otro como los americanos de 1945-1946 y de 1956-1957 o el vulo internatida en la actualidad es una herramienta como google maps habilitada en opción satélite. Es una lástima que no exista información fotográfica anterior al plan Borso de 1941, o anterior de 1936, pues facilitaría la comprensión planimétrica del sector de la plaza del Portal o la Puerta de Madrid. Las fotos aéreas ayudan a demostrar cómo la morfología de la ciudad definida por la muralla liberal apenas se ha visto modificada y ha permitido validar muchos supuestos del trazado.

10.- Se han podido complementar las informaciones principales extraídas de los documentos histórico militares de todo el conjunto documental asociado al patrimonio civil. Es preciso recordar que el conjunto fortificado está constituido por las propias edificaciones, no solo viviendas, también otros usos, principalmente molinos, tintes o batanes, que abren un campo de investigación interesante en la ciudad de Requena a partir de la industria sedera. Se produce una asociación simultánea pues con el patrimonio hidráulico, pues las acequias que proceden de las fuentes van a alimentar a este conjunto de molinos, tintes y batanes que se citan en los mismos informes militares. Documentos catastrales como el Real interrogatorio de 1749 y el conjunto de Respuestas Generales del catastro de Marqués de la Ensenada para

Fig. 751. Comparación del área del Pedazo de los Muertos. Izq.: detalle del plano de Ortiz de Pinedo (AGMM, Ar

G-T.3.C.2.262). Centro: plano esquemático de estado actual (VN, 2015). Derecha: fotografía aérea extraída de google maps
(2015).
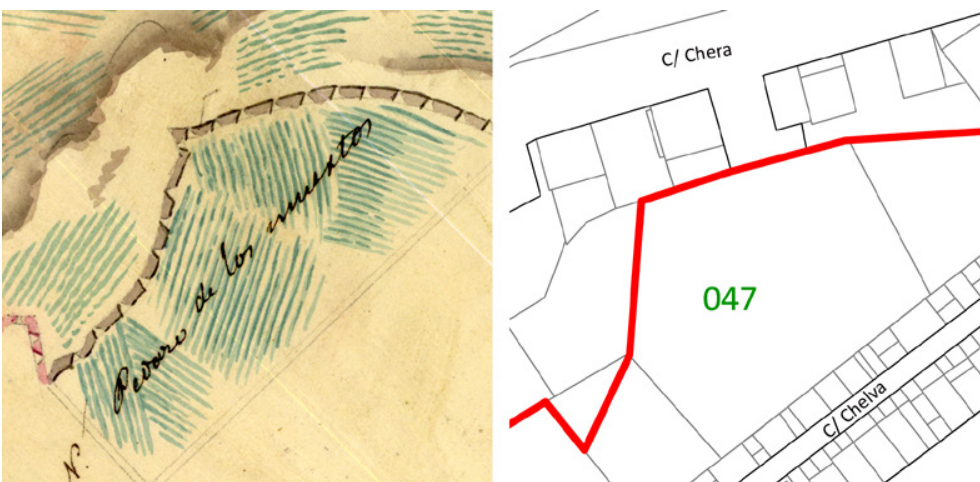

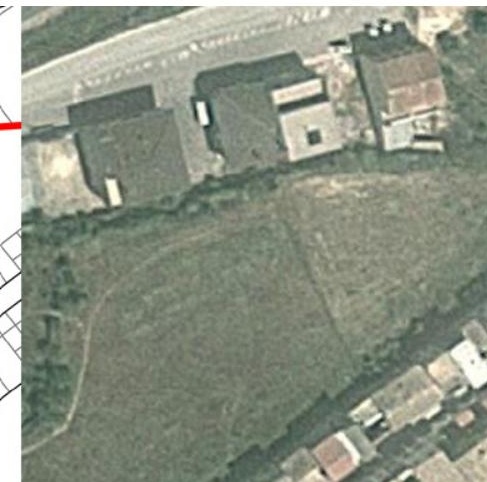




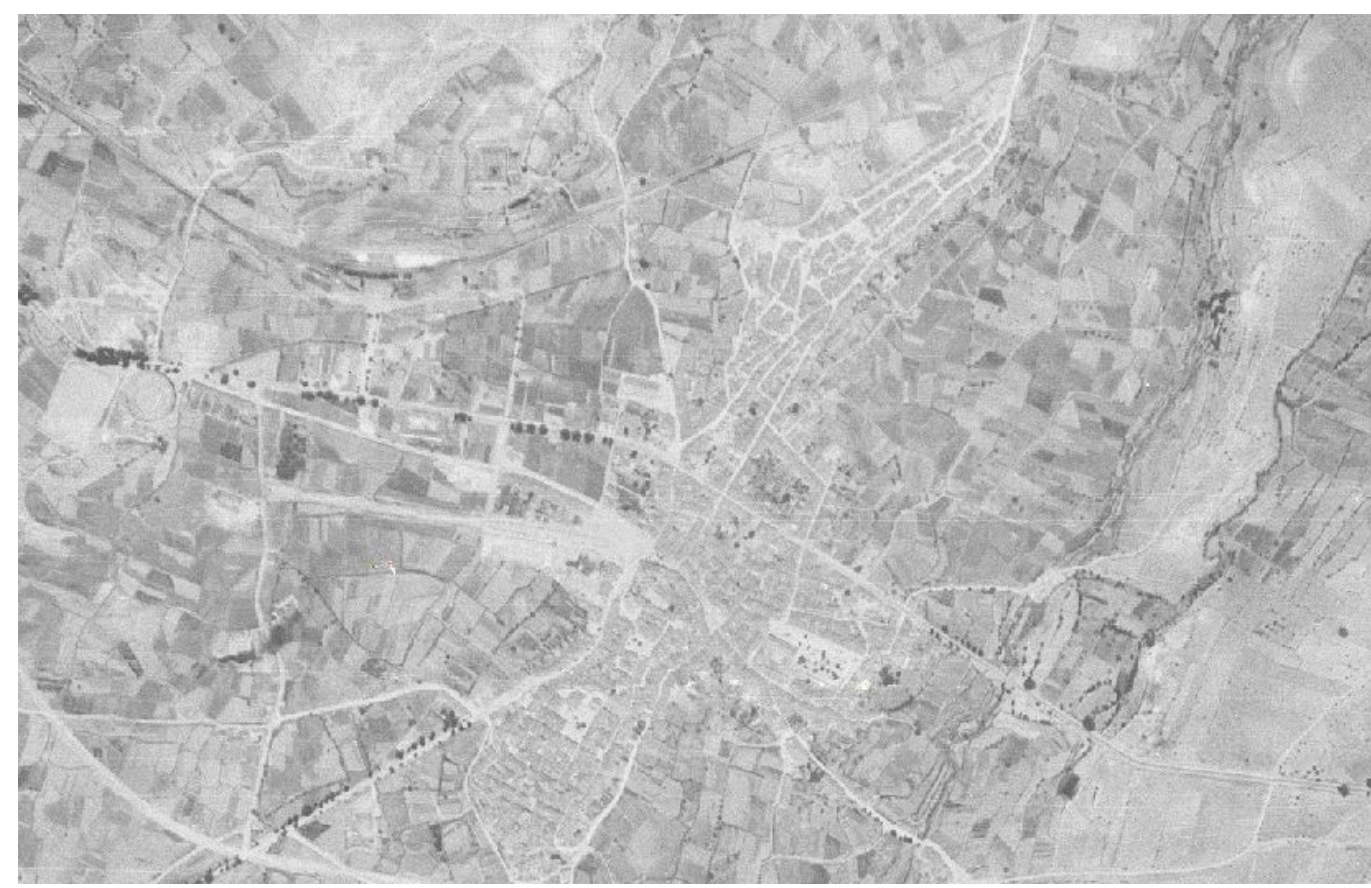

Fig. 755. Vuelo fotogramétrico realizado en los años 1945-46 por el Army Map Service de EE.UU. (Información cedida po el Ministerio de Defensa (CECAF), con la colaboración del ejército del aire). Fotogramas en blanco y negro con escala aproximada de la fotografía original 1:43.000 (IGN, 2015).

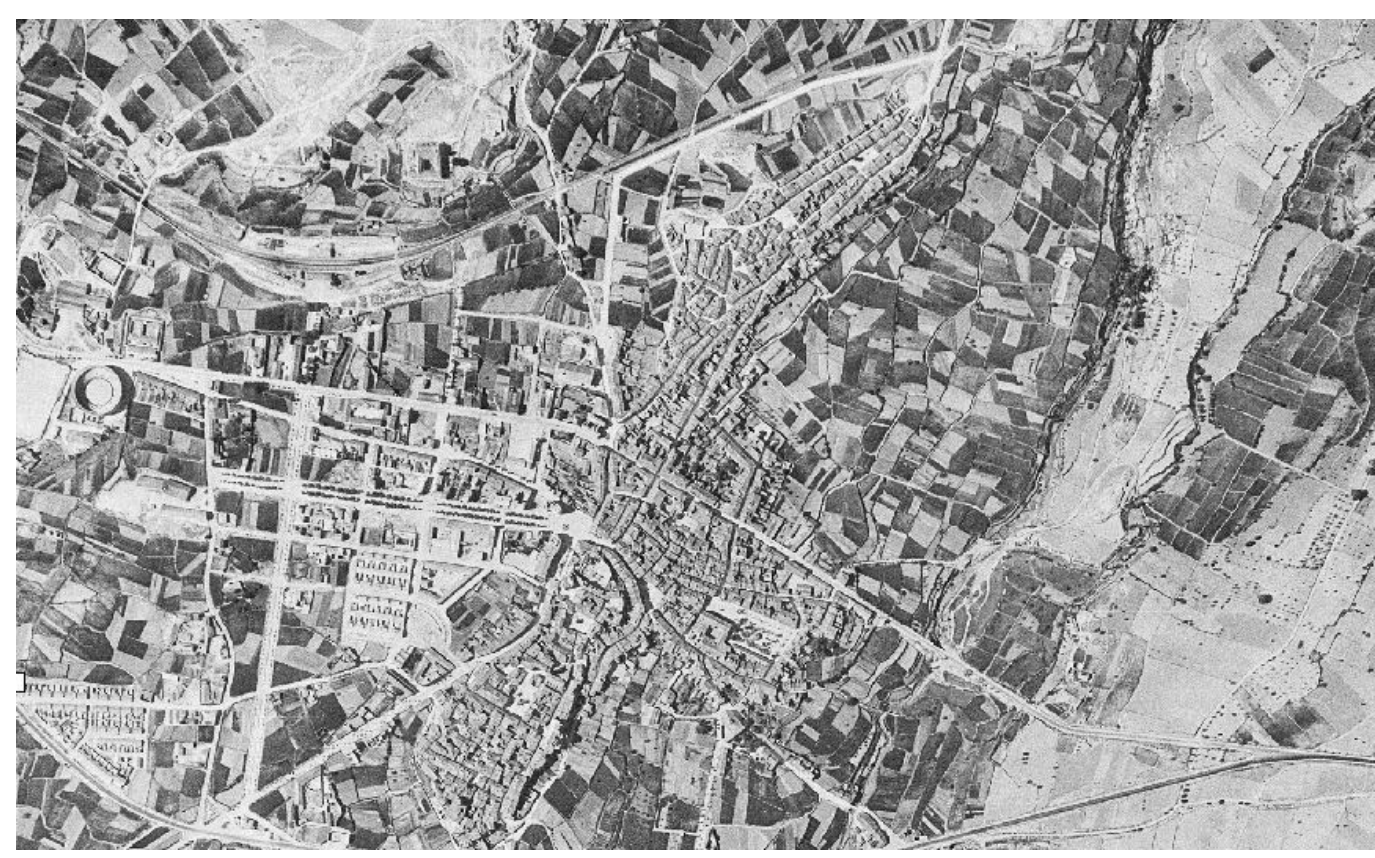

Fig. 756. Vuelo fotogramétrico realizado en los años 1956-57 por el Army Map Service de EE.UU. (Información cedida por el Ministerio de Defensa (CECAF), con la colaboración del ejército del aire. Fotogramas en blanco y negro con escala aproximada del original de 1:32.000 (IGN, 2015).

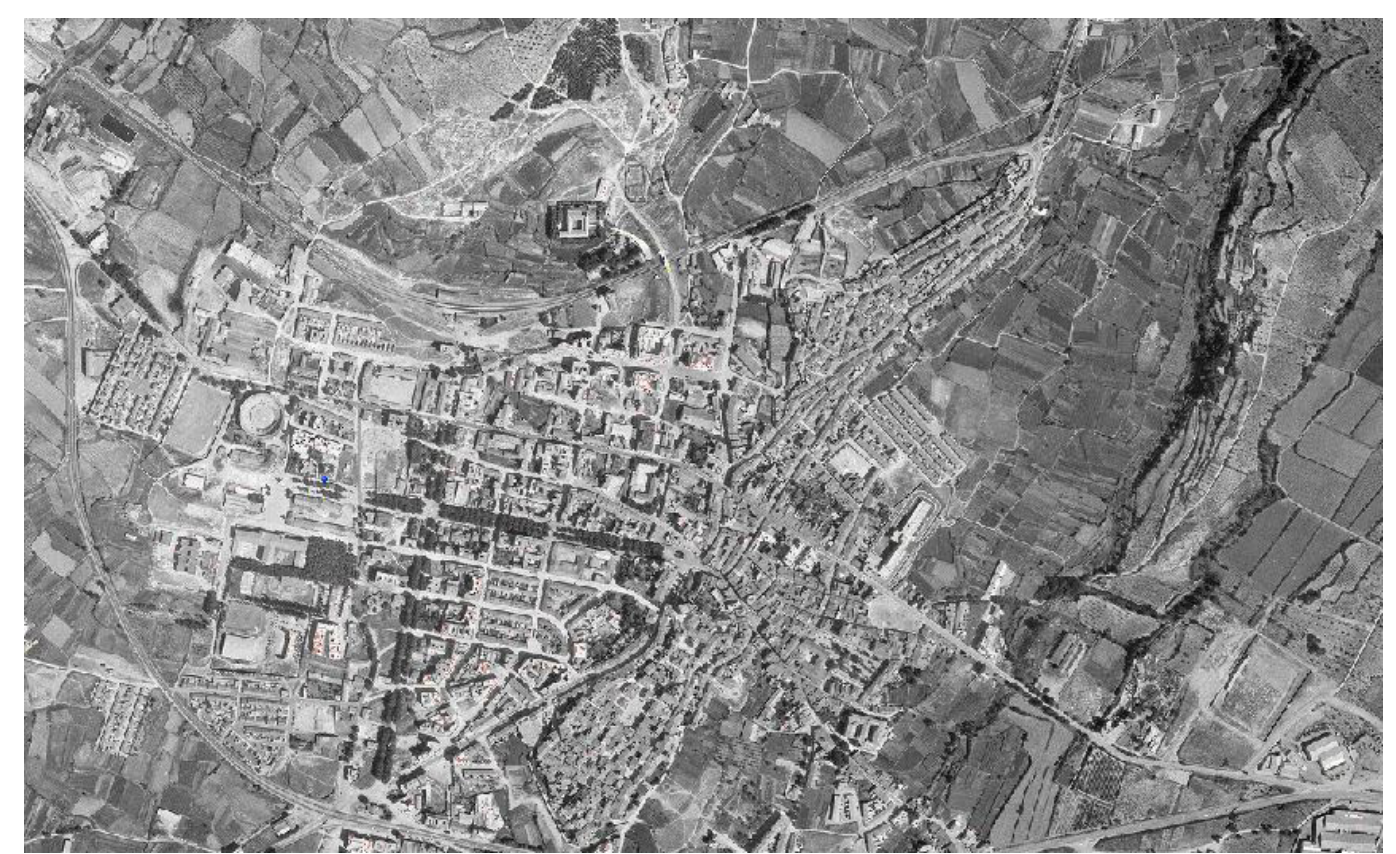

Fig. 757. Vuelo fotogramétrico interministerial entre los años 1973-1986 por encargo de los Ministerios de Agricultura, Defensa, Hacienda y del Instituto Geográfico y Catastral (IGN). Fotogramas en blanco y negro con escala aproximada del original de 1:18.000 (IGN, 2015).

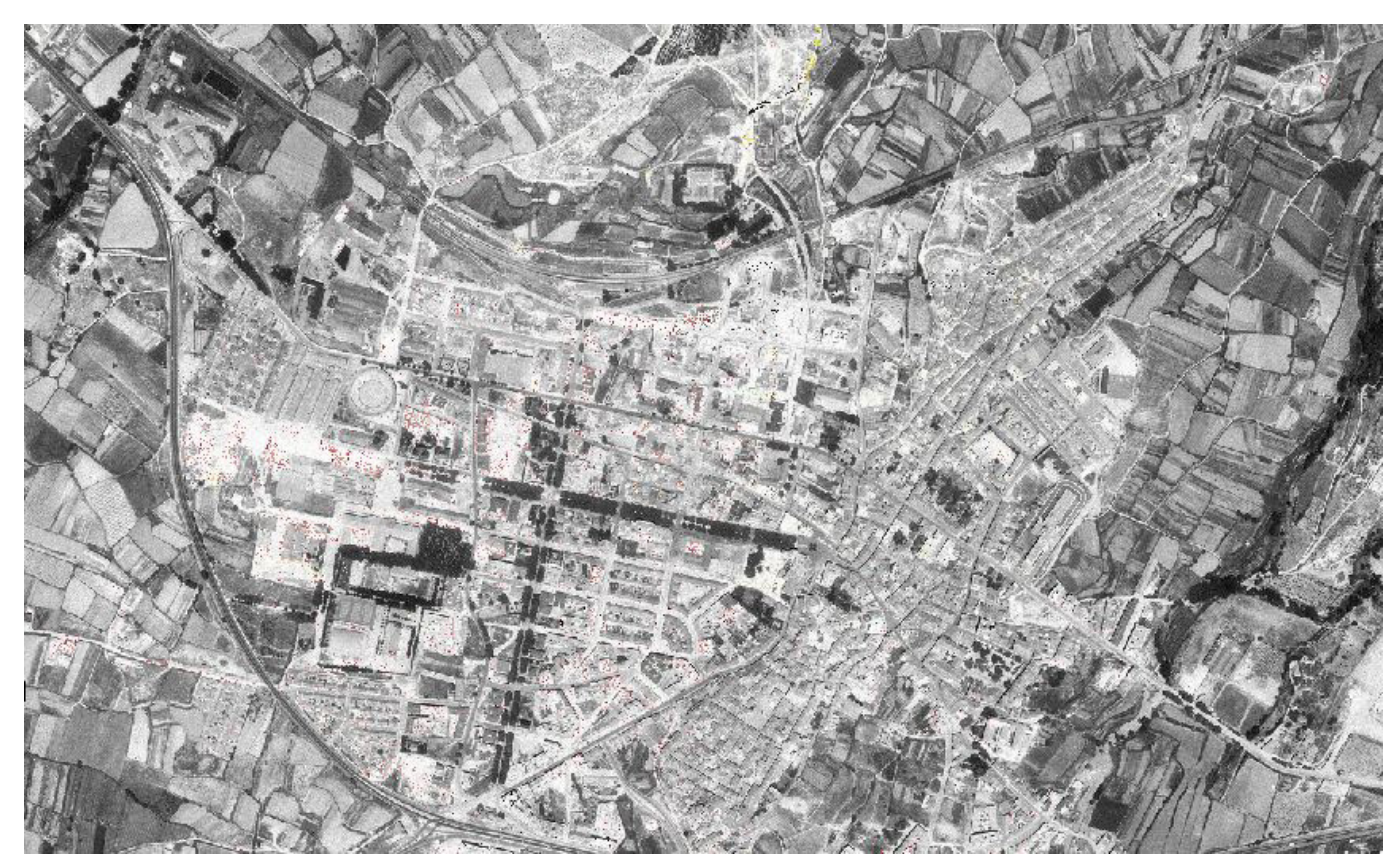
Fig. 758. Vuelo fotogramétrico nacional entre los años 1980-1986 por encargo del Instituto Geográfico y Catastral (IGN).
Fechas de vuelo de 1980, 1986. Fotogramas en blanco y negro con escala aproximada del original de 1:30.000 (IGN, 2015). 


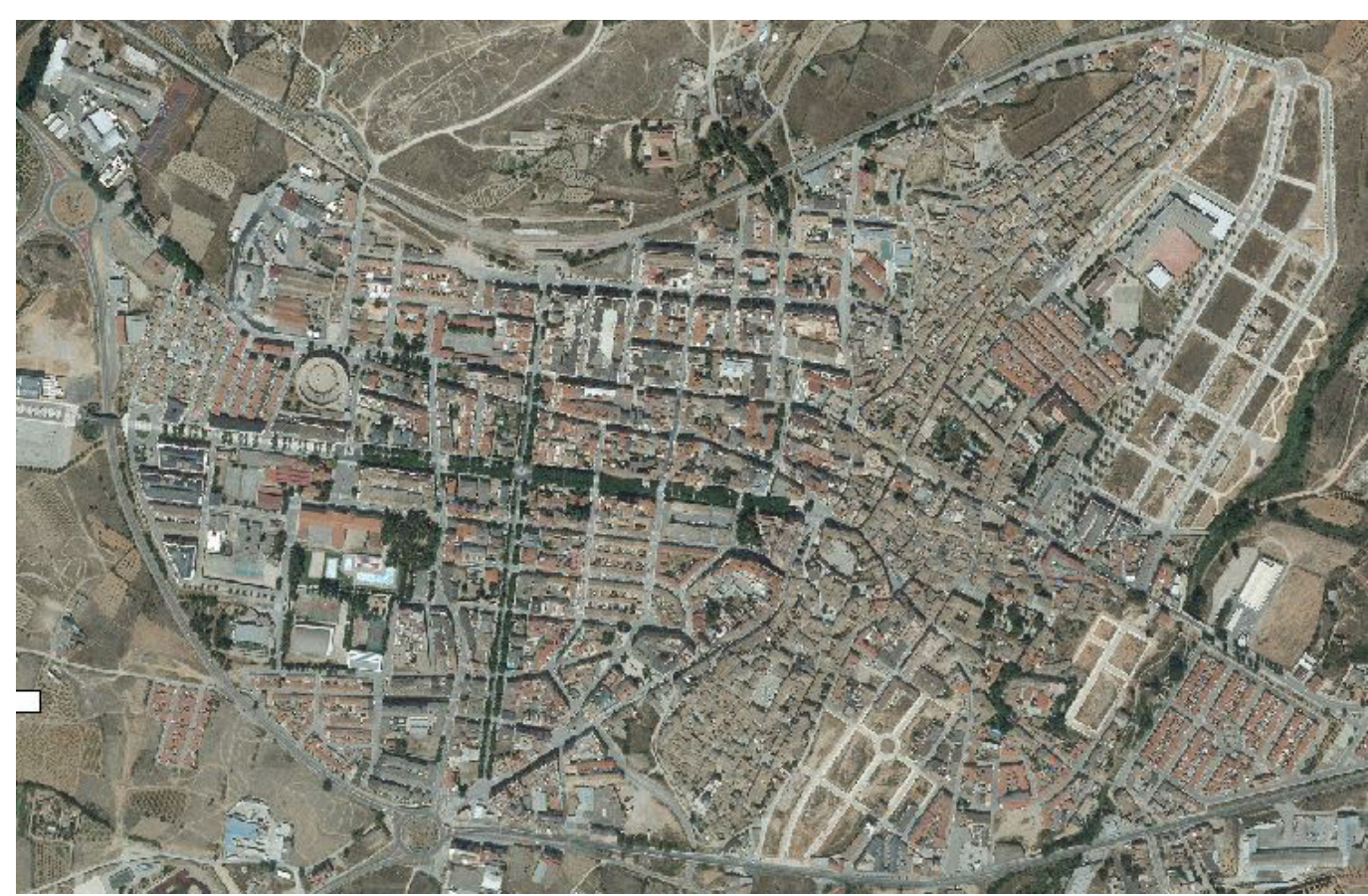

Fig. 759. Vuelo fotogramétrico del Plan Nacional de Ortofotogrametría Aérea (PNOA) de año 2012, con tamaño de pixe Fig. 759. escala de vuelo de 1:30.000 en el caso de Requena (IGN, 2015).

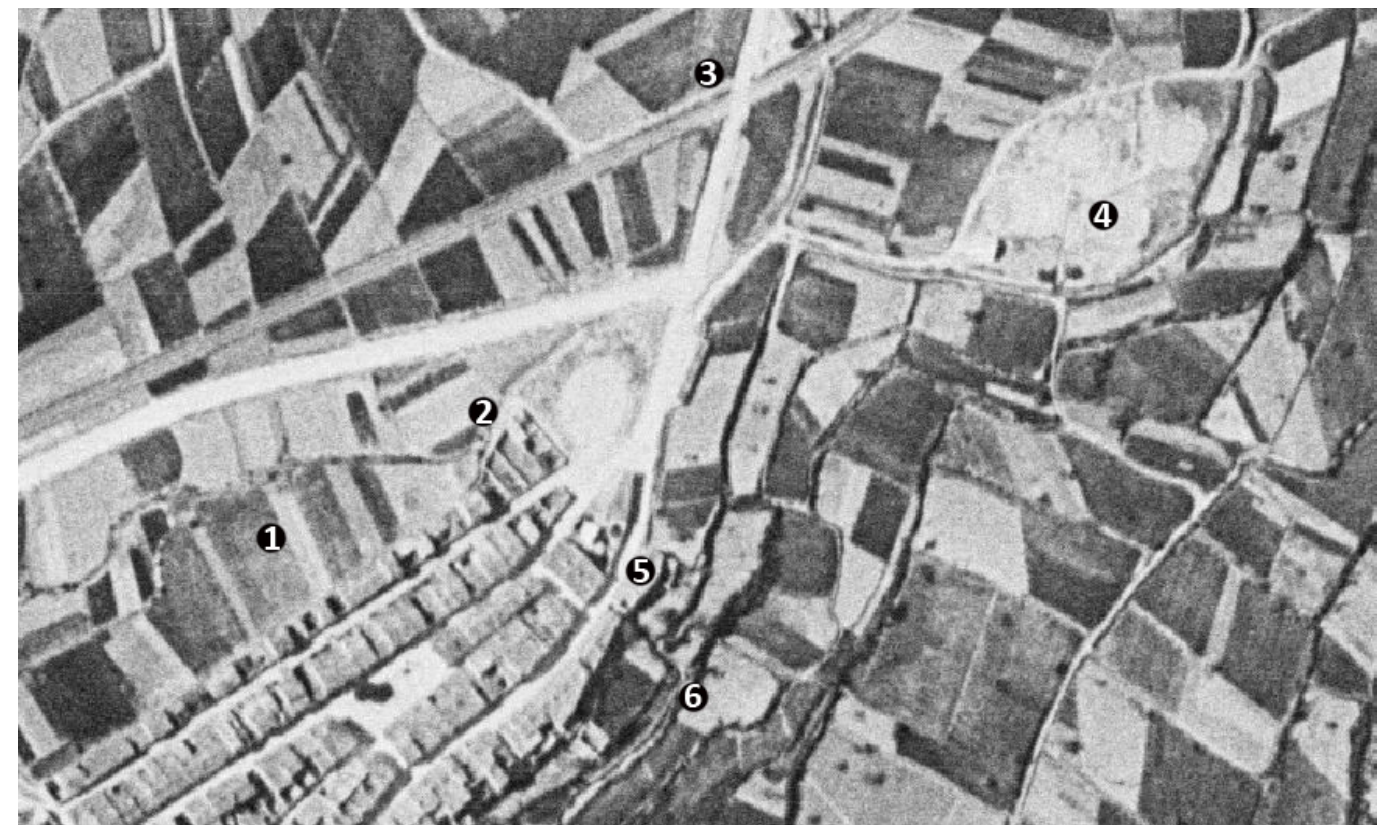

Fig. 760. Detalle del vuelo fotogramétrico 1956-57 realizado por el Army Map Service de EE.UU (IGN, 2015). Se puede clarificar dudas sobre el extremo noreste de la fortificación. Se detecta el pedazo de los muertos (1), sin las construcciones que han alterado su frente (2). La salida a Chera y el ferrocarril (3) ya habían alterado ese extremo de la ciudad. Se confirma la ausencia de construcciones en el promontorio noreste (4) que prácticamente se mantiene igual y despeja dudas sobre el posicionamiento de una batería permanente en esta posición. Los huertos del extremo inferior a la muralla presentan formas que recuerdan a la batería antigua de Reinas (5) y al tambor de Reinas del croquis de Ortiz de Pinedo (6).
8.-Extramuros:

Pared de D. Diego Montes (105), La Posada o posada de afuera (103).

La gran mayoría de apellidos aparecen ya recogidos en el catastro de Ensenada. Con toda probabilidad, los propietarios de 1834 a 1840 sean descendientes de las familias citadas: Ponce, Herrero, Cárcel, Moya, Vives, Pérez, Montenegro, Laguna, Ferrer, Cros, Montés, Mas, Justo, Cepeda, Fernández, Valero, Moral, Monsalve, Amoraga [Amorós], Alonso.

Más efectivo en la identificación de algunas viviendas es el documento sin referencia localizado en el Archivo municipal de Requena (AMR), en lo que parece ser un intento de padrón que se presenta como "Edificios. Estadística urbana". A pesar de que la fecha de la portada parece indicar $1634 \mathrm{o}$ 1734, en función de la interpretación de la caligrafía, dados los nombres incluidos y la identificación de las calles a las que hemos tenido acceso, Calle de los Álamos y Calle de las Eras, podrían hacer referencia al año 1834

Así en la calle de los Álamos se identifican: $1^{\circ}$ Vicente Segura, Ana Flores; $2^{\circ}$, Alonso Sánchez, Manuel López; $3^{\circ}$, Alonso Sánchez; $4^{\circ}$, Nicolás Pérez Duque, Juan Suarez; $5^{\circ}$, $\mathrm{M}^{\mathrm{a}}$ Antonia García; $6^{\circ}$, Juan Antonio Escamilla; $7^{\circ}$, Mariano Pérez; $8^{\circ}$, Estanislao Moral; $9^{\circ}$, Víctor López; $10^{\circ}$, Teresa Serrano, Juan José Pérez; $11^{\circ}$, Nicolas Pérez Duque; $12^{\circ}$, Vicente Teruel, $D^{a}$ Andrea Penén, $13^{\circ}$, Bruno Celda; $14^{\circ}$, Guillermo Sáez, $15^{\circ}$, Felipe Pérez; $16^{\circ}$, Martín Alba, Rufino Segura; $17^{\circ}$, Alonso Ferrer, Antonio Ramirez; 18ㅇ, Silvestre Raval, Catalina [Z]anón; 19, Guillermo Sáez, Diego Yranzo; 20, Vicente Pérez; 21, Austero Yagüe, Agustín Sabater; 22, Salvador Romero, Salvador Carrero; 23ㅇ, José Ferrer.

En la calle de las Eras se identifican: $1^{\circ}$, Juan Pérez Mendoza, Lucio Montés; $2^{\circ}$, Joaquín Alcaide; $3^{\circ}$, Baltasar Montes; $4^{\circ}$ Sandalio Honrubia, Josefa Gil; $5^{\circ}$, Antonio Honrubia, Luis Molini; $6^{\circ}$, Juan José Perez, [E.]García (interrumpido).

Llama por ejemplo la atención cómo el maestro de obras Guillermo Sáez aparece referenciado en varias ocasiones, como propietario múltiple en Requena. El acceso a esta documentación y su análisis más exhaustivo permitiría validar algunas hipótesis. Con la documentación obtenida, se podría incluso fijar la numeración del parcelario y, a partir de ella, su posición exacta. Pero el objetivo del presente trabajo no es ahondar en el conocimiento de las cuentas municipales, o identificación exacta de propiedades sino definir el trazado de la fortificación.

También resultan interesantes los expedientes de subasta, como por ejemplo el Expediente para subasta y 1829 remates de las fincas y derechos de propios y arbitrios de la villa: almotazanía, herbaje de Montes Blancos, borras, portazgo, asadura, Pozo de la Nieve, juego de pelota, arbitrio para el armamento y equipo de los Voluntarios Realistas y abasto de carnes y aceite, para 1830, (AMR, 2432/10PL), que permite constatar en 1830 la existencia y funcionamiento del Pozo de la Nieve, así como de un espacio para el juego de pelota.

Los documentos que más información han aportado son los ya tratados sobre comisiones de tasación y expropiaciones, abordados en el apartado de historia de la fortificación de Requena, y que Gabaldón, o el huerto de las Monjas a la espalda de la calle San Agustín (AMR, 1818-16). 


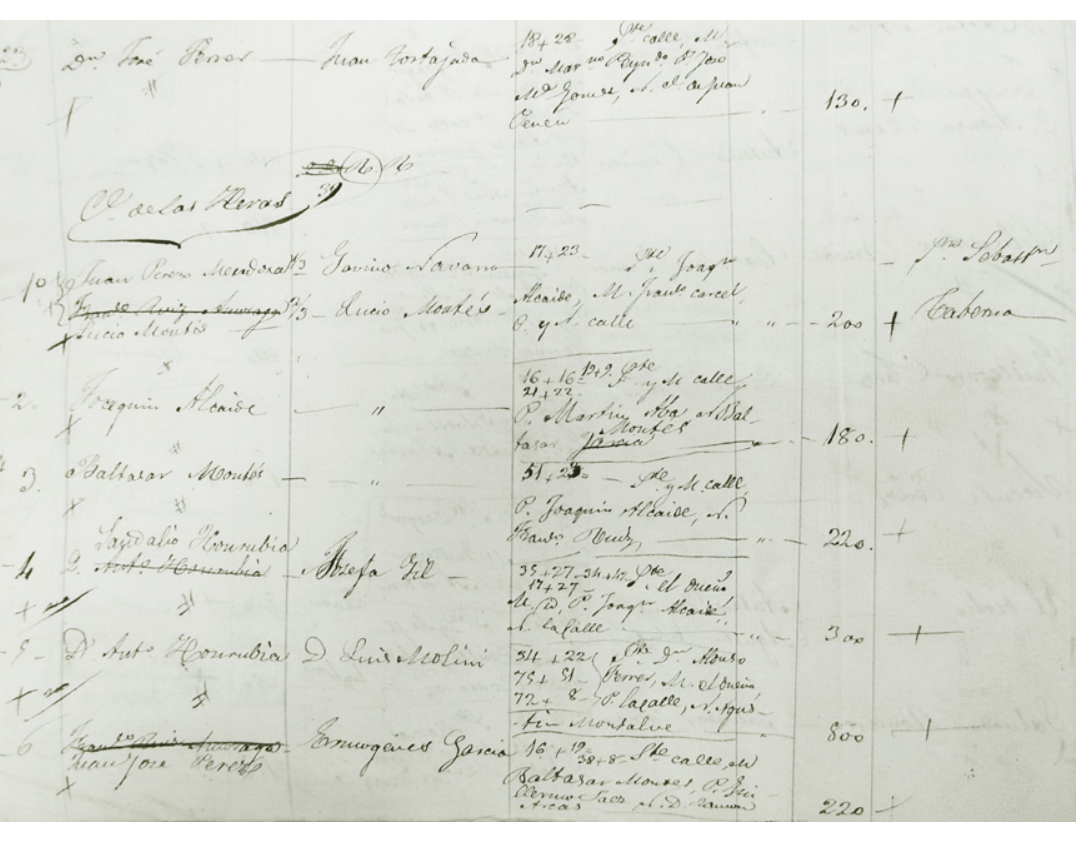

Fig. 761. Extracto del Padrón de Requena (AMR, sin ref.) de los números correspondientes a la calle de las Eras.

\subsection{Puesta en valor: criterios aplicables a la fortificación liberal de Requen}

El caso del recinto de la fortificación liberal de Requena es un caso paradigmático en la medida que no le son aplicables los criterios utilizados en los más conocidos recintos defensivos promocionados turísticamente. Generalmente los recintos defensivos de las eras moderna y contemporánea se caracterizan por contar con patrimonio militar de diversas características, que se acumulan por procesos de incrustación, yuxtaposición o transformación de las formas preexistentes, necesarias para la adaptación a los nuevos requisitos defensivos. A estos procesos evolutivos se sumarían todas las transformaciones similares propias de la caída en desuso y de los intentos de reutilización. Pero el denominador común es que suelen acabar sobreviviendo potentes lienzos amurallados o fosos, y especialmente variadas formas contenedoras de espacio. Podría valernos el ejemplo ya citado de la plaza de Cartagena, u otros igual de exitosos como los de Melilla, Ibiza, Menorca o Pamplona. Suelen ser escasos los ejemplos puros de un modelo defensivo, que si se pueden localizar es por la rápida obsolescencia tanto del sistema defensivo escogido como del emplazamiento, como podría ser el Real fuerte de la Concepción en Aldea del Obispo (Salamanca).

Requena, como hemos visto, no es el caso de lo uno ni de lo otro.

Plaza defensiva clave desde su fundación, podría haber sido un ejemplo de la evolución de las tácticas defensivas a través de sus formas: fortificación neurobalística y pirobalística. En este último caso, con adaptaciones del recinto militar medieval a la defensa pirobalística con el uso de fuegos de flanqueo, presencia de galerías de mina, y, especialmente, implantación de baterías, líneas aspilleradas, fosos, puertas y torres de comunicación sin hilos... Sin embargo, como hemos indicado, el crecimiento de la ciudad y el escaso aprecio al patrimonio militar, bien por su valor simbólico, bien porque constriñe las posibilidades de expansión urbana, han acabado fagocitando los pocos restos que quedaban. Desaparecen puertas, determinados muros aspillerados, fosos... Tan solo pervive parte del recinto neurobalístico, coincidente prácticamente con lo que sería el antiguo barrio de la parte del recinto neurobalistico, coincidente
villa, dominado por el castillo de la ciudad.

La política protectora del patrimonio nacional declaró en su momento Bien de Interés Cultural la Villa y el Castillo con sus murallas, así como a las más relevantes iglesias intramuros, como Santa María y el Salvador (véanse datos de protección en las fichas correspondientes). Las intervenciones y las principales inyecciones económicas priorizaron y siguen priorizando así la recuperación de estos hitos arquitectónicos de la ciudad. La Villa, a pesar de seguir desahuciada, puede ser objeto de un plan especial de protección, mientras que el resto del patrimonio de la ciudad intenta ser protegido desde el reciente Plan General de Ordenación Urbana, a partir del catálogo de elementos patrimoniales, que identifican el conjunto de piezas con su nivel de protección y la afección patrimonial correspondiente. Según esta estrategia de identificación del hito, y de acuerdo con el patrimonial correspondiente. Según esta estrategia de identificación del hito, y de acuerdo con el
testimonio de muchos historiadores, podemos confirmar que el único patrimonio protegido asotestimonio de muchos historiadores, podemos confirmar que el único patrimonio protegido aso-
ciado con el recinto liberal de Requena es el pequeño tambor de Cantarranas, y, en todo caso, el ran contenedor de San Francisco, aunque este se cifra como estructura eclesiástica u hospitalaria. Con este razonamiento queremos llegar a enunciar el error que se plantea a la hora de definir la estrategia de defensa de determinado patrimonio, como sería en el caso de la fortificación liberal de Requena, que, en el fondo, es decir lo mismo que la defensa patrimonial de la ciudad de Requena. Para poder afrontar el reto es preciso incorporar otros conceptos ya utilizados en el estudio del patrimonio y vincularlos íntimamente con el pasado militar. Podría ser la morfología urbana, incluso hacer uso de los nuevos instrumentos que nos ofrece el patrimonio no solo para la salvaguarda hacer uso de los nuevos instrumentos que nos ofrece el patrimonio no solo para la salvaguarda
del mismo, sino para su dinamización. Podría ser también el concepto de paisaje cultural o el de del mismo, sino para su dinamización. Podría ser también el concepto de paisaje cultural o el de
itinerario cultural, eludiendo la aplicación directa de recomendaciones patrimoniales formuladas 
para un caso genérico inexistente, sino aplicando una cierta creatividad en la interpretación de las recomendaciones de los expertos en patrimonio.

El caso que nos ocupa, en el que estamos abordando un patrimonio supuestamente inexistente, invisible, pero que según sostenemos resulta trascendental para preservar la identidad urbana de Requena, no puede ser abordado siguiendo las prescripciones habituales.

Analicemos qué sucede cuando acometemos las recomendaciones de los principales organismos internacionales. Precisamente ICOFORT, el Comité Científico Internacional de ICOMOS sobre Fortificaciones y Patrimonio Militar, valoraba recientemente en el Congreso Fortified Heritage: Management and Sustainable Development (Pamplona, 15-17 de octubre de 2014) la situación de este patrimonio. Los documentos doctrinales existentes de aplicación en el momento que se recogían en el congreso eran la Carta de Venecin (1964), el Documento de Nara sobre la Autenticidad (1994) junto a otros (1987) para la Conservación de las Ciudades Históricas y Áreas Urbanas y la Carta de Itinerarios Culturales (2008). Sin embargo se reconocía la necesidad de un documento específico para enfrentarse a la singularidad de las fortificaciones y el patrimonio militar (Flores, 2014:64).

Por una parte se hacía referencia a la necesidad de identificar aquellos nuevos usos que no atenten contra la autenticidad, la integridad y la protección.

Se suman todo el conjunto de polémicas habituales en la arquitectura patrimonial, agravadas por la extensión, envergadura y complejidad de las piezas militares. Por ejemplo todo lo que tiene que ver con "la protección legal, la gestión del plan de la propiedad y la gestión orientada al impacto de las zonas de amortiguamiento, asi como los efectos del turismo sobre la propiedad" (Flores, 2014:65).

ICOFORT reconocía entonces el gran desafío a nivel mundial que ofrece la conservación y utilización del patrimonio fortificado, y especialmente el desafío económico. Su principal enemigo, enumeraba: "estar fuera de contexto histórico, la agresión del hombre, su tecnología, el exceso de visitación falta de interpretación adecuada, usos no apropiados, malas prácticas de conservación o, por el contrario, total abandono" (Flores, 2014:66)

ICOFORT insiste en la necesidad prioritaria de interpretar correctamente este patrimonio, interpretación que debe condicionar la intervención futura, que debe a su vez ser acorde a la interpretación. Tanto la inacción como la acción pueden ser la causa del deterioro de cualquier legado patrimonial. el error de tomar como base el planteamiento de ICOFORT se observa cuando se formula la gran pregunta: "¿cuáles creemos que son los principales desafios para la conservación y gestión de sitios del Patrimonio Fortificado Mundo?", a la que se respondía con un sencillo "mantener los mismos atributos únicos en base a los cuales su Valor Universal fue reconocido por la UNESCO". Las metas son grandes dado que se apunta a los grandes sitios fortificados. Incluso éstos se encuentran en peligro. ¿Qué debate cabe plantearse entonces sobre aquellos lugares patrimoniales donde la relevancia n tan siquiera se entiende como de nivel local? Como sostienen muchos: inexistente. Las armas con las que combatir no pueden ser las mismas.

Coincidimos en la premisa formulada por la que "una declaratoria de Patrimonio de la Humanidad nunca debe convertirse en el final del proceso de reconocimiento; debe convertirse en el principio del compromiso de por vida para la protección y conservación del sitio como legado para el disfrute, inspiración y beneficio de las generaciones futuras" (Flores, 2014:67). Las claves sin embargo se cifran en la reutilización, planteando la "visita agradable", la "interpretación del sitio", "la apertura al público"... Parece que el gran sitio, Patrimonio de la Humanidad, dialoga muy bien con el turismo. Un primer paso unánime consiste en el estudio concienzudo, la interpretación y la divulgación. No vamos a negar que son pasos imprescindibles, pero, difícilmente se conservará el patrimonio si el proceso se detiene aquí. Llama la atención que la correcta interpretación, al final, depende de la provisión de medios de información que se traducen literalmente en la incorporación de "centros interpretativos formales, o de activida(Flores, 2014:67). Podemos observar que al final los procesos de intervención sugeridos se orientan hacia una tematización, hacia una conversión del icono patrimonial en centro de diversión, observando cómo allá donde posamos la vista no conseguimos eludir la cultura de "parque temático". Como se ha observado en unas décadas aplicando esta estrategia, la proliferación de los iconos turísticos, los centros de diversión, han generado monopolios que se han visto favorecidos por ser especialmente atrayentes, mientras el resto resultaba insostenible al no existir demanda del producto. Esta visión del patrimonio desde el consumo, desde el mercado, esta mezcla de cultura y mercado, no han producido el resultado deseado. Unos y otros han vivido la degradación del patrimonio, los grandes atrayentes, por exceso; los desheredados, por defecto.

Si bien se esgrimen críticas hacia esta particular visión de la dinamización del patrimonio, estas se acentúan cuando hablamos de un patrimonio como el que nos ocupa, donde la opción turística es inconcebible.

La opción de optar por "la buena práctica de salvaguardar la integridad y autenticidad del sitio: por ejemplo mediante el apoyo de los nuevos re-usos de mínimo impacto para la integridad y la autenticidad de la propiedad o en el sitio" (Flores, 2014:67) se plantea imposible al no identificarse un contenedor al que aplicar dicha reutilización. La buena práctica sugerida de "reforzar el establecimiento de zonas de amortiguamiento para preservar la configuración del sitio" (Flores, 2014:67) sería de aplicación si tenemos en cuenta qué sucede con el sitio amortiguado. No podemos generar una isla, rodeada de un foso, que consista en la nada. Curiosamente, de nuevo se plantea una planificación y desarrollo en asociación con las comunidades vecinales de "un Plan de Gestión de Turismo eficaz" (Flores, 2014:67). Se trata de una orientación errónea si, una vez más, el único horizonte es el turístico. Aunque sí resulta de interés la idea de coordinar un plan de acción con las comunidades vecinales en la línea de las últimas propuestas de participación ciudadana.

Parecen asumidos la "planificación y fomento de la investigación" para la interpretación del sitio, recurriendo a estudios multidisciplinares donde concurra tanto la investigación arqueológica, etnográfica e histórica no solo desde el objeto arquitectónico, sino también desde su integración en un conjunto más complejo y su contribución a la definición de un paisaje.

Será precisa también la investigación constructiva a fin no solo de estudiar la capacidad mecánica, la durabilidad, sino también cómo contribuyen a los factores anteriormente citados: identificación del espíritu de una época, caracterización de atmósferas arquitectónicas y paisajísticas..

En lo que hace referencia al modo de plantear las investigaciones para asegurar el correcto conocimiento del patrimonio objeto de estudio, la experiencia adquirida a través de las investigaciones precedentes acometidas por Noguera y Guimaraens (2005) han permitido implementar, en ocasiones de modo prioritario, determinados apartados que es preciso exigir en el estudio de la fortificación, especialmente la moderna, lo cual sería extensible a la fortificación contemporánea que nos ción, especio.
ocupa.

1.-Se trata de implementar estudios compositivos en relación con la tratadística militar histórica, dado que el trazado de estas fortificaciones depende en gran medida de ciertas medidas y recomendaciones que son recogidas en las fuentes escritas (Noguera \& Guimaraens, 2005: 4-5). Una alteración incorrecta de esos trazados desvirtuaría el sentido de la intervención y la interpretación posterior, así como el conocimiento del trazado puede ayudar a entender las huellas borradas por el tiempo y el deterioro.

2.-Por otra parte se plantea el estudio e identificación de los elementos característicos del tipo de 2.-Por otra parte se plantea el estudio e identificación de los elementos característicos del tipo de
fortificación objeto de estudio a partir de sus trazas geométricas, pero también de su construcción: revellines, hornabeques, cortinas, baluartes, tenazones... La existencia, el trazado o la morfología de cada uno de ellos podría ubicarnos temporalmente, identificar autores o escuelas, significar el interés de la fortificación por su mera presencia y, por tanto, de nuevo contribuir al sentido de la restauración, apoyando la interpretación o la lectura antes y después de la intervención.

3.-Se plantea la necesidad del estudio de los procesos de ideación y su relación con la formación militar de sus proyectistas, normalmente con una formación académica específica, lo cual contribuiría positivamente en la misma dirección que los apartados anteriores.

4.-El estudio del proceso constructivo, dada la singularidad constructiva de estas construcciones. 5.-La identificación de elementos constructivos y técnicas, que pueden también contribuir a las tareas de identificación 
6.-El análisis de la funcionalidad. La vocación utilitaria de esta arquitectura, donde incluso la búsqueda de la belleza ornamental tiene su cometido y se restringe a áreas muy concretas, es fundamental en la vía de la correcta interpretación y el diseño de un programa de reutilización. También ayudaría a entender la complejidad táctica y estratégica del conjunto, que, con toda probabilidad, se extiende a una amplia escala territorial.

7.-La identificación de aquellos operarios, incluso más allá del ramo militar, responsables del pro7.-La identificación de aquellos operarios, incluso más allá del ramo militar, responsables del pro-
yecto, como pudieran ser artesanos que trabajan en la fortificación. La investigación biográfica, en yecto, como pudieran ser artesanos que trabajan en la fortificación. La investigación biográfica, en
base a intervenciones precedentes y posteriores, tipo de formación o procedencia pueden contribuir a entender los propósitos.

8.-Estudio de los elementos ornamentales. Dado que siempre tienen su razón de ser, pueden facilitar vías de interconexión con otros apartados: ubicación cronológica, identificación de autores cometidos comunicativos.

9.-Análisis de las unidades de medida empleadas. El proceso de alteración de unidades de medida que se produce desde el siglo XVII hasta mediados del siglo XIX, con la implantación en España del sistema métrico decimal, puede resultar clave para los apartados precedentes. A su vez, las unidasistema métrico decimal, puede resultar clave para los apartados precedentes.
des de medida, normalmente enteras, contribuirán a los estudios geométricos.

Muchos de estos aspectos se han desarrollado en el presente trabajo, pero a partir de las particularidades de unas construcciones que se erigen en un periodo muy concreto, 1833-1840, con una dificultad de medios y con unos propósitos muy específicos. Si algo se puede destacar de las intervenciones llevadas a cabo sería su carácter de urgencia con vocación de permanencia. Al menos desde la óptica militar, y por tanto gubernamental, pero también desde el ramo civil en la medida que los desde la Corona, los diferentes ministerios, gobiernos militares pero también desde el municipio aunque, en este último caso, como veremos, con ciertos matices. Estas intervenciones, como ya hemos estudiado en los apartados precedentes, cifran su base de actuación en la preexistencia, po lo que de algún modo son el testimonio de un estado de partida. Pero, a diferencia de otro tipo de actuaciones arquitectónicas, y especialmente en el siglo XIX, las actuaciones de fortificación vienen caracterizadas por un grado de tensión y en su código genético se asume una característica clave que es preciso contemplar en todo estudio que se haga cargo: los intereses de la arquitectura milita son polares y distan mucho de un contexto de paz a un contexto de guerra. El primero exige la permeabilidad; el segundo, el hemetismo. Esta tensión se dirime en el elemento arquitectónico, pues estamos hablando no de un legado fijo, sino de un legado que desde el primer momento estuvo en permanente metamorfosis. La tapias y muros se reducen, se desmontan, se recrecen, se superponen, se anteceden, se perforan, se convierten en base de edificaciones... De este complejo proceso de transformación, ¿qué cabe conservar? Son tan relevantes los procesos de apertura de aspilleras en tiempos de guerra, de levantamiento de tapias en los huertos, como de cegado de muros aspillerados en tiempos de paz o de apertura de boquetes para facilitar el acceso a las huertas. La realidad es que el legado final es un amasijo de elementos confundido entre la arquitectura presente, casi diríamos diluido, invisible, pero que sin embargo sigue ahí, al menos en determinadas porciones de experimentó su crecimiento más agresivo: Portal de Madrid, Avenida de la Constitución, Frente de Cantarranas (donde sobrevive el citado tambor entre las nuevas edificaciones)... Pero, sorprendentemente, gran parte de la imagen de aquella Requena de aspecto sutilmente cambiante, pero definiendo un constante perfil en el paisaje, se mantiene viva esperando a que alguien quiera verlo así y entienda que, precisamente los límites desahuciados de la ciudad son los que aún conservan parte del código genético de lo que fue la ciudad de Requena. Poco a poco, estos límites se desvirtúan, por las mismas intervenciones parciales en el mismo, por el abandono, o por la interposición de obstáculos visuales nada sensibles con el concepto del paisaje. En este último caso, al hablar de (1975:25). "El concepto de paisaje ocupa uno de los escalafones en los diferentes niveles de percepción del espacio existencial. No deja de constituir ese ambiente... que en ocasiones nos rodea. Como bien define el teórico del espacio existencial, el paisaje nos envuelve, es un fondo, incomprensible sin la presencia de un espectador que lo disfrute y lo utilice como tal" (Guimaraens \& Navalón, 2013: 13). Pero frente a esta idea de paisaje como fondo, clave para entender uno de los valores que ofrecen los tramos defensivos que vamos a analizar y recuperar, es preciso no olvidar la definición de paisaje como vino a ser definida en el año 2000 por el Consejo de Europa en el Convenio Europeo del Paisaje, haciendo referencia a un área, tal como la percibe la gente, el carácter de la cual es el resultado de la acción e interacción (ando, sino de un área en la que el perceptor actúa. Nuestra intención es precisamente demostrar que la inexistente fortificación de Requena, supuesto del que hemos partido, no solo constituye un fondo, sino que constituye un área habitable y perceptible desde la habitación.

Gracias a la implementación de los habituales estudios históricos sobre patrimonio fortificado de la historia militar, la táctica y el empleo de las herramientas gráficas de la arquitectura, se descubre que las presuntamente desaparecidas defensas liberales de Requena, no es que hayan desaparecido, sino que siguen parcialmente presentes, en algunos casos definiendo las estampas paisaiísticas más reseñables de la ciudad, quizá no valoradas suficientemente por muchos requenenses.

Procederemos a efectuar un razonamiento discursivo para descubrir lo que estamos afirmando.

Si nos detenemos a analizar la historia de la Primera Guerra Carlista, especialmente tal y como se desarrolla en los alrededores de Requena, se puede concluir que resulta determinante para definir, o más bien consolidar, una interesante silueta urbana, desde la campaña, propia de toda ciudad fortificada, o, dicho más sencillamente, propia de toda ciudad desde que la historia genera el concepto. El concepto de ciudad es un estatus que adquiere todo asentamiento humano dotado de un recinto amurallado. Este recinto no solo garantiza su defensa, sino, y especialmente, los controles arancelarios, símbolo del comercio que garantiza la prosperidad de los núcleos humanos. Es precisamente el comercio el que impulsa las primeras aglomeraciones urbanas mesopotámicas, como es el comercio el que impulsa el poder de las ciudades en la baja Edad Media y la consolidación de los grandes estados, como será también el comercio, y por tanto las ciudades, quienes, en parte, de los grandes estados, como será también el comercio, y por tanto las ciucades, quienes, en parte, impulsen el liberalismo. Sin lismo-liberalismo respectivamente, es muy dudosa y se puede enriquecer con infinidad de variantes de índole geográfica e ideológica.

Desde la primigenia visión formal que aporta la ciudad desde los orígenes de la humanidad, el conglomerado urbano se recorta en el paisaje natural dejando una marcada huella y, en muchos casos, característica hasta el punto de singularizar el lugar. Contribuyen a ello axiomas clave de los principios defensivos como la dominación de las alturas, desde un centro no necesariamente geométrico, hasta el perímetro exterior. También la definición de recintos compactos, impermeables. Aquí es preciso remarcar que estos recintos pueden ser definidos por un elemento amurallado ex-novo, pero también, sin que ello nos induzca a error, dado que es el caso que nos ocupa, por los propios lienzos de la construcciones domésticas. No es preciso olvidar que la impermeabilidad de estos recintos no es total, debe garantizarse el paso, especialmente pensando en tiempos de paz. Para ello resulta trascendental el control de las puertas de la ciudad que garantizan el tránsito de viajeros. Se trata de perforaciones en el muro, puntos débiles de la defensa que deben ser suficientemente protegidos, y, dada su ubicación en el punto de mayor tránsito, habitualmente se convierten en los puntos de mayor poder comunicativo, donde suele concentrarse la carga ornamental de la austera y utilitaria arquitectura militar. Por meras cuestiones de táctica defensiva se puede recurrir a otro tipo de accesos y salidas, pero que, en este caso, requieren de su ocultación, por tratarse de salidas secretas o de socorro a fin de favorecer evacuaciones, retiradas o ataques sorpresa a los campos enemigos. Este conjunto de principios básicos, que se sostienen incluso en la fortificación contemporánea, se irán completando con otros principios en función del desarrollo de las tácticas de guerra o de la resistencia estructural. Por lo general el límite fortificado se dota de elementos salientes, que refuerzan la consistencia de los muros y, a su vez, fortalecen la eficacia defensiva con el fuego de flanco. Puede tratarse de los primitivos torreones o cubos, pero también de los característicos baluartes que dan nombre a la fortificación moderna, o de las cortinas abaluartadas o murallas en forma de tenazas, configurando entrantes y salientes. En el caso de Requena, la propia ocupación del terreno irá definiendo esta condición de abaluartamiento de las piezas, garantizando los flanqueos. Precisa- 
mente se intervendrá incorporando baterías salientes en aquellos puntos donde sea preciso anular los ángulos muertos.

Otra característica que supone una constante en la historia de la fortificación es la de la interposición Or obstáculos. Puede ser avanzandounas muralas a otas, antemurallas, pero tambiénjugandocon la disposición de fosos, o incluso contando con la presencia de elementos naturales que puedan contribuir a la defensa, lo más sensato y, por tanto, lo más habitual. Es fácil considerar el papel que puede jugar el regajo de Reinas o de Martinete, la roca de las peñas o de la villa en Requena. Pero, a nivel territorial, incluso sería preciso apoyarse en el Magro o las Atalayas que permiten adivinar cuáles pueden ser los supuestos tácticos de la defensa de la ciudad de Requena. Si se trata de un gran ejército que aspira a un asedio en regla, la ciudad se precaverá precisamente desde la Vega. Si hablamos de pequeñas partidas que buscan la sorpresa, será más predecible el descenso desde el monte, posiblemente desde Chelva o Siete Aguas.

De todo este razonamiento lo que concluimos es que ciudades como Requena ofrecieron en el siglo donde se conserva, sería preciso salvaguardarla. Es fundamental recalcar que es una estampa no solo identitaria de la ciudad de Requena, sino del espíritu de un época, pues se extiende por gran parte del territorio afectado por el conflicto, sobre todo el Maestrazgo, pero también en Cataluña y las vascongadas. Podríamos exceptuar las grandes plazas que, en tiempos de las guerras carlistas, serán objeto de asedio por parte de grandes ejércitos regulares. Principalmente se produce en ciudades clave convertidas en símbolo y objetivo para los intereses de guerra, como pueden ser las ciudades de Bilbao y San Sebastián, ubicadas en las zonas calientes del conflicto, donde encontramos las intervenciones fortificadas de mayor envergadura en la época, pero que no responden al caso que nos ocupa.

Una fuente de interés para entender y justificar el enfoque que adquiere este trabajo de investigación lo ofrecen, junto a la abundante documentación histórica, la gran cantidad de ilustraciones recogidas en libros de la época que tratan el conflicto y que reflejan el papel que juega la arquitectura en el conjunto de escaramuzas de guerra de gran singularidad táctica, como es el caso del Maestrazgo.

El resultado se podría sintetizar en el límite difuso que existe entre un patrimonio propio de los estudios acerca de la tradición vernácula y el patrimonio militar. No importa hablar de un pozo, un abrevadero, un molino, una iglesia o una modesta vivienda, pues constituyen el conjunto de efensivos provisionales. Quizá sea muy ilustrativo de la idea atmosférica que pretendemos poner en valor y recuperar el texto escrito por Pío Baroja en 1919, haciendo referencia a la imaginaria localidad de Urbía. El texto "cómo era la villa de Urbía en el último tercio del siglo XIX", del prólogo a la novela Zalacaín el Aventurero, se acompaña íntegramente dado que consideramos que ningún apartado tiene desperdicio, junto a las primeras líneas del capítulo primero. Si bien es cierto que el paisaje de Urbía y las aventuras de Zalacaín se desarrollan en el contexto geográfico vasco-navarro, en el transcurso de la Tercera Guerra Carlista, las estampas no difieren mucho de las descripciones que se sugieren en el contexto requenense de la época, y se entiende cómo el paisaje arquitectónico debe ligarse con el paisaje cultural y el paisaje natural. Es preciso recalcar, como ya se ha indicado en este trabajo, que el propio Baroja visitó Requena tras las huellas del General Gómez, y se convierte en un fiel cronista de los paisajes visuales y sociales de España en la década de los treinta del siglo XX. Evidentemente, Requena no es Urbía, pero algo de la atmósfera de Urbía se puede detectar y preservar en ciudades como Requena.

"Una muralla de piedra, negruzca y alta rodea a Urbía. Esta muralla sigue a lo largo del camino real, limita el pueblo por el Norte y al llegar al río se tuerce, tropieza con la iglesia, a la que coge, dejando parte del ábside fuera de su recinto, y después escala una altura y envuelve la ciudad por el Sur.

Hay todavía, en los fosos, terrenos encharcados con hierbajos y espadañas, poternas llenas de hierros, garitas desmochadas, escalerillas musgosas, y alrededor, en los glacis, altas y románticas arboledas, malezas y boscajes y verdes praderas salpicadas de florecillas. Cerca, en la aguda colina a cuyo pie se sienta el pueblo, un castillo sombrío se oculta entre gigantescos olmos. 
Desde el camino real, Urbía aparece como una agrupación de casas decrépitas, leprosas, inclinadas, con balcones corridos de madera y miradores que asoman por encima de la negra pared de piedra que las circunda. Tiene Urbía una barriada vieja y otra nueva. La barriada vieja, la 'calle', como se le llama por antonomasia en vascuence, está formada, principalmente, por dos callejuelas estrechas, sinuosas y en cuesta que se unen en la plaza.

El pueblo viejo, desde la carretera, traza una línea quebrada de tejados torcidos y mugrientos, que va descendiendo desde el Castillo hasta el río. Las casas, encaramadas en la cintura de piedra de la ciudad, parece a cendiendo desde el Castillo hasta el río. Las casas, encaramadas en la cintura de piedra de la ciudad, parece porque, entre el pie de las casas y los muros fortificados, existe un gran espacio ocupado por una serie de magnificas huertas. Tales huertas, protegidas de los vientos fríos, son excelentes. En ellas se pueden cultivar plantas de zona cálida como naranjos y limoneros.

La muralla, por la parte interior que da a las huertas, tiene un camino formado por grandes losas, especie de acera de un metro de ancho con su barandado de hierro.

En los intersticios de estas losas viejas, y desgastadas por las lluvias, crecen la venenosa cicuta y el beleño junto a las paredes brillan, en la primavera, las flores amarillentas del diente del león y del verbasco, los glajunto a las paredes brillan, en la primavera, las flores amarillentas del diente del leon y del verbasco, los glaamapolas, se extienden por la muralla y adornan con su verdura y con sus constelaciones de flores pequeña y simples las almenas, las aspilleras y los matacanes.

Durante el invierno, en las horas de sol, algunos viejos de la vecindad, con traje de casa y zapatillas, pasean por la cornisa, y al llegar marzo o abril contemplan los progresos de los hermosos perales y melocotoneros de las huertas.

Observan también, disimuladamente, por las aspilleras, si viene algún coche o carro al pueblo, si hay novedades en las casas de la barriada nueva, no sin cierta hostilidad, porque todos los habitantes del interior sienten una obscura y mal explicada antipatía por sus convecinos de extramuros.

La cintura de piedra del pueblo viejo se abre en unos sitios por puertas ojivales; en otros se rompe irregularmente, dejando un boquete que por días se ve agrandarse.

En algunas de las puertas, debajo, de la ojiva primitiva, se hizo posteriormente, no se sabe con qué objeto, un arco de medio punto.

En las piedras de las jambas quedan empotrados hierros que sirvieron para las poternas. Los puentes levadizos están substituidos por montones de tierra que rellenan el foso hasta la necesaria altura.

Urbía ofrece aspectos varios según el sitio de donde se le contemple; desde lejos y viniendo desde la carretera,

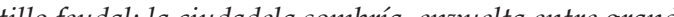
to grave y guerrero, en cambio, desde el puente y un dia de sol, Urbia no da ninguna impresión fosca, por el contrario, parece una diminuta Florencia, asentada en las orillas de un riachuelo claro, pedregoso, murmurado y de rápida corriente.

Las dos filas de casas bañadas por el río son casas viejas con galerías y miradores negruzcos, en los cuales cuelgan ropas puestas a secar, ristras de ajos y de pimientos.

Estas galerías tienen en un extremo una polea y un cubo para subir agua. Al finalizar las casas, siguiendo las orillas del río, hay algunos huertos, por cuyas tapias verdosas surgen cipreses altos, delgados y espirituales, lo que da a este rincón un mayor aspecto florentino.

Urbía intramuros se acaba pronto; fuera de las dos calles largas, solo tiene callejones húmedos y estrechos y la plaza. Esta es una encrucijada lóbrega, constituida por una pared de la iglesia con varias rejas tapiadas, por la Casa del Ayuntamiento con sus balcones volados y su gran portón coronado por el escudo de la villa, y por un caserón enorme en cuyo bajo se halla instalado el almacén de Azpillaga.

El almacén de Azpillaga, donde se encuentra de todo, debe dar a los aldeanos la impresión de una caja de Pandora, de un mundo inexplorado y lleno de maravillas. A la puerta de casa de Azpillaga, colgando de las negras paredes, suelen verse chisteras para jugar a la pelota, albardas, jáquimas, monturas de estilo andaluz; y en las ventanas, que hacen de escaparate frascos con caramelos de color, aparejos complicados de pesca, con su corcho rojo y sus cañs, redes sujetas a un mango, marcos de hojadelata, santos de yeso y de laton y estampas viejas, sucias por las moscas. En el interior hay ropas, mantas, lanas, jamón, botellas de Chartreuse falsificado, loz fina... El Museo Británico no es nada, en variedad, al lado de este almacén.

A la puerta suele pasearse Azpillaga, grueso, majestuoso, con su aire clerical, unas mangas azules y su boina. Las dos calles principales de Urbía son estrechas, tortuosas y en cuesta. La mayoría de los vecinos de esas do calles son labradores, alpargateros y carpinteros de carros. Los labradores, por la mañana, salen al campo con sus yuntas. Al despertar el pueblo, al amanecer, se oyen los mugidos de los bueyes; luego, los alpargateros sacan su banco a la acera, y los carpinteros trabajan en medio de la calle en compañía de los chiquillos, de las gallinas y de los perros.

Algunas de las casas de las dos calles principales muestran su escudo, otras, sentencias escritas en latín, y la generalidad, un número, la fecha en que se hicieron y el nombre del matrimonio que las mandó construir... Hoy, el pueblo lo forma casi exclusivamente la parte nueva, limpia, coquetona, un poco presuntuosa. El verano cruzan la carretera un sin fin de automóviles y casi todos se paran un momento en la casa de Ohando, convertido en Gran Hotel de Urbía. Algunas señoritas, apasionadas por lo pintoresco, mientras el grueso papá escribe postales en el hotel, suben las escaleras del portal de la Antigua, recorren las dos calles principales de la ciudad y sacan fotografías de los rincones que les parecen románticos y de los grupos de alpargateros que se dejan retratar sonriendo burlonamente.

Hace cuarenta años la vida en Urbía era pacífica y sencilla; los domingos había el acontecimiento de la misa mayor y por la tarde és, en un prado anejo a la Ciud había apoderado la villa, iba el tamborilero y la gente bailaba alegremente, al son del pito y del tamboril, hasta que el toque del Ángelus terminaba con la zambra y los campesinos volvían a sus casas después de hacer una estación en la taberna." (Baroja, 1985: 9-12).

El relato prosigue en el capítulo primero del libro con la siguiente presentación, que es igual de reveladora:

"Un camino en cuesta baja de la Ciudadela, pasa por encima del cementerio y atraviesa el portal de Francia. Este camino, en la parte alta, tiene a los lados varias cruces de piedra, que terminan en una ermita y por la parte baja, después de entrar en la ciudad, se convierte en calle. A la izquierda del camino, antes de la muralla, había hace años un caserío viejo, medio derruido, con el tejado terrero lleno de pedruscos y la piedra arenisca de sus paredes desgastada por la acción de la humedad y del aire. En el frente de la decrépita y pobre casa, un agujero indicaba dónde estuvo en otro tiempo el escudo, y debajo de él se adivinaban, más bien que se leian, varias letras que componían una frase latina: 'Post funera virtus vivit'"'1 (Baroja, 1985:13).

Las coincidencias no son casuales. Nos encontramos con una descripción ficticia de un patrón, el patrón de una pequeña localidad de provincias en la época, que retiene todos los invariantes que le son propios: la muralla de piedra, la presencia de un Camino real, la iglesia con su campanario recortado sobre el cielo y su ábside integrando el recinto defensivo, la presencia de un río y, cómo no, de alguna prominencia rocosa, peñas, que sirven de asiento a la ciudad, que con toda probabilidad domina el entorno. Se habla de fosos, que en el fondo son los propios terrenos encharcados, quizás ríos, con poca o mucha agua, donde crecen las hierbas. Existe un castillo, pero tan importante como el castillo, para conformar la imagen de conjunto, son esas casas "decrépitas", con sus balcones de madera o reja. Como toda ciudad histórica, cuenta con sus barrios característicos, se contrapone lo nuevo con lo viejo, y precisamente lo viejo se caracteriza por una morfología concreta y frecuente. Llama la atención el hecho de la presencia del elemento huerta, a los pies de las casas, integradas en ellas, y resguardadas con sus tapias.

También destacan las características de un factor tan relevante como el constructivo. Sin la relación vacío-lleno, sin la presencia del terreno rural productivo y sin el matiz distintivo de los grandes terrenos de producción en campo abierto y esos pequeños huertos integrados en el recinto, la potencia de la imagen se diluye. Es fundamental la descripción de la vegetación autóctona, pero también de las indumentarias, los hábitos de vida, las conductas, para entender mejor el sentido de aquel contexto vital específico. Resulta crucial en la descripción la plasmación de la tensión ejercida sobre el elemento fortificado. Se habla de las perforaciones abiertas, sin cronología específica, de los restos de puertas e incluso de los puentes inexistentes que sortean el foso, sustituidos por montones de tierra. La descripción sugiere pues dos imágenes simultáneas, la idealizada que puede recomponerse en la mente del lector, de aquel recinto en todo su esplendor defensivo, y la existente, esa imagen de ruina, de pasado metamorfoseado. Es preciso recalcar que la primera no existe, y, posiblemente, nunca existió porque, como sucede en Requena, los procesos de transformación nunca ofrecen una 


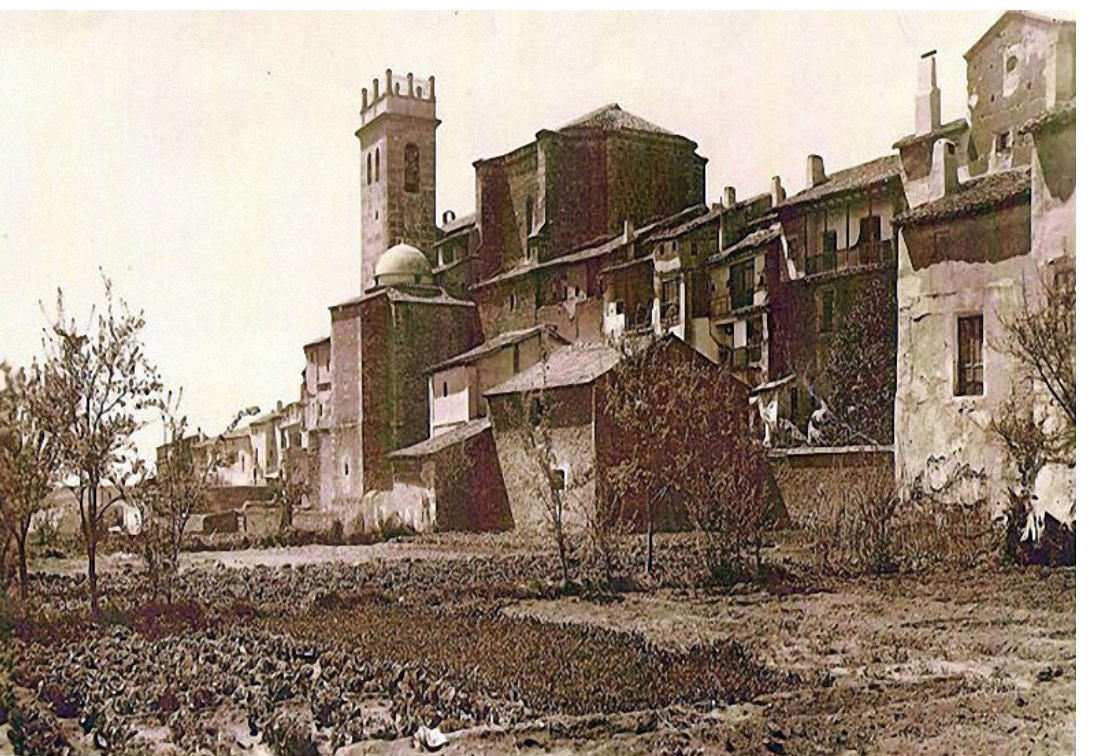

Fig. 764. Imagen histórica del Huerto de Santa Maria o "bajo los huertos" (J. M de Dios,

Fig. 765. Frente de la hoya de Reinas (dibujo de F. Morencos) imagen total acabada, una imagen de crecimiento constructivo progresivo, de avance imparable. La fortificación, como sucede en Requena, crece en una dirección, se refuerza en la opuesta, se deshace para luego rehacerse en otra. La palabra que define este proceso suponemos que es metamorfosis, y esa idea es a que preciso congelar en la mente. Pero hay que prestar especial atención al concepto que queremos subrayar, el concepto como representación de un legado. La metamorfosis del recinto es la realidad del pasado. Desde la óptica presente se trata de preservar aquel pasado para preservar la identidad de la ciudad. Pero es preciso no asumir desde la contemporaneidad la lógica de que la metamorfosis pasada legitima la fagocitación del pasado por las nuevas formas del presente. No es necesario que recalquemos el resto de elementos contenidos en el pasaje de Baroja pues, si nos percatamos, al desglosarlos, prácticamente estamos copiando el pasaje del escritor: escudos heráldicos en viejos caserones, caminos tortuosos, la presencia del progreso reconvirtiendo usos en otros de igual valor histórico local, ermitas, caminos de cruces (vía crucis), etc. Todo, absolutamente

Si a partir de esta idea nos centramos en el área objeto de estudio, podemos contraponer los puntos analizados y aquellos registrados por la fotografía histórica que, de algún modo, podría ayudarnos a entender qué puntos de la ciudad fueron considerados retratables por un daguerrotipo, como suele suceder con toda foto turística. Es decir, qué puntos resultan memorables, identificativos de la imagen de la ciudad. Observaremos que junto con las tradicionales escenas del castillo e iglesias de la ciudad, se encuentran los entrañables rincones de la villa, cuestas, recodos, pasajes... Todos ellos, posiblemente, unánimemente valorados. Pero junto a ellos, sorprendentemente, aparece una voluntad de testimoniar rincones del patrimonio vernáculo, donde se retiene no solo el valor del patrimonio arquitectónico en sí, sino el valor de lo que dichos espacios propiciaron para la vida local. Es el caso de las fuentes, lavaderos, molinos de Requena, donde se concentran celebraciones, lecturas en la intimidad, paseos amorosos... Llama poderosamente la atención que con el mismo interés que los grandes hitos turísticos de la ciudad, que los pequeños y entrañables espacios de vida popular, se retraten frentes panorámicos que hoy en día aún existen, casi diríamos intactos, aparentemente, carentes del aprecio que despertaron entonces, dado el estado de abandono y el interés por anular su presencia. Se trata sin duda de frentes urbanos como el frente de la hoya de Reinas, el frente denominado bajo los huertos... Son frentes continuamente mencionados en los informes militares, frentes que formaron parte de la cultura popular pero que se han diluido en la memoria, conservando intacta parte de su función, salvo en aquellos puntos dejados al abandono... Se trata de los verdaderos frentes militares que sobreviven de aquella Requena, y que, posiblemente, sean los únicos que preserven la huella en el paisaje más emotiva de la ciudad, progresivamente devorado por las construcciones modernas que siguen acometiéndose sin apenas sensibilidad por el patrimonio más impactante, más visible, a pesar de su invisibilidad aparente, de la ciudad de Requena. Al frente de la hoya de Reinas y del de bajo los Huertos, se podría sumar el frente del pedazo de los muertos, en el Noroeste, que se prolonga en el que se vino a denominar frente de bajo las cuevas, que, en este caso, mantiene su idiosincrasia pero ha perdido su percepción distante por la intromisión histórica del Arrabal. Sobrevive en parte el que se denominaría frente del Barriete, con el conjunto de siempre conflictivo desde el punto de vista militar, pero considerado un superviviente de la pugna entre intereses militares e intereses de los propietarios que contaron con el consejo municipal para interponer sus sugerencias ante las autoridades militares, como hemos observado en el apartado de historia de las fortificaciones.

Cada frente tiene sus características morfológicas, sus singularidades estratégicas, y un cierto denominador común, que es la pervivencia del uso. Por tanto nos encontramos con una situación sencilla de intervención y preservación de la identidad patrimonial, pues ni tan siquiera se está hablando del planteamiento de una reutilización, ni se está hablando de una inversión de adecuación turística con los inconvenientes que genera la interacción de dichas adecuaciones con el patrimonio histórico. Muchas edificaciones requerirían simplemente su adecuación a la habitabilidad sin necesidad de aditamentos atractivos, pues el valor patrimonial, y el valor añadido del complemento vida urbana y rural que ofrecen estos tramos, podrían constituir la mejor intervención de acupuntura 
ta María. Nos encontraríamos con una situación similar al frente de Reinas, con la particularidad de que los accesos principales al frente de viviendas que integran el recinto antiguo se producen desde la Calle Santa María, en la Villa. Pero los huertos y las viviendas adosadas que han crecido pegadas a la muralla y la roca, antiguos corrales en algunos casos, tienen acceso desde la calle inferior, extraColegio. Este frente se encuentra muy amenazado por el desarrollo PAI del Batanejo, que, con toda probabilidad, anulará uno de los principales patrimonios paisajísticos del recinto amurallado de Requena, que aún puede apreciarse desde la antigua Nacional III.

\section{Tramo 8. Frente del antiguo camino de las Eras}

Hemos denominado así al frente más desconcertante en la planificación defensiva decimonónica de Requena, y que se extendería desde el puente de las Ollerías hasta la antigua Avenida de los Álamos. Los informes militares resultan confusos a la hora de definir con exactitud el trazado, y el croquis de Ortiz de Pinedo describe unos entrantes y salientes que sorprenden por su incoherencia, croquis de Ortiz de Pinedo describe unos entrantes y salientes que sorprenden por su incoherencia,
especialmente en el tramo comprendido entre los denominados molino de Navarro y la puerta del Trillero. Este frente también se encuentra sumamente afectado por el PAI del Batanejo, cuyas obras interrumpidas han generado un espacio fantasma entre el regajo de Reinas y las alineaciones de casas con huerto, que se retraen tras diversos bancales. La yuxtaposición en el extremo sureste de tramo de la residencia de ancianos ha alterado la percepción de lo que pudo ser. Precisamente por todo ello se han escogido dos viviendas de este tramo para hacer un estudio en más profundidad, que abordamos a continuación.

Fig. 773. Frente del camino de las Eras en su confluencia con la Avenida de los Álamos (actual C/ Constitución), que se encontraría en el extremo derecho. Se observa la sucesión de bancales de cultivo y un frente edificado final. Los ejemplo de cómo la tradición vernácula de la piedra en seco cohabita y se complementa con la tradición patrimonial militar (VN, 2015).

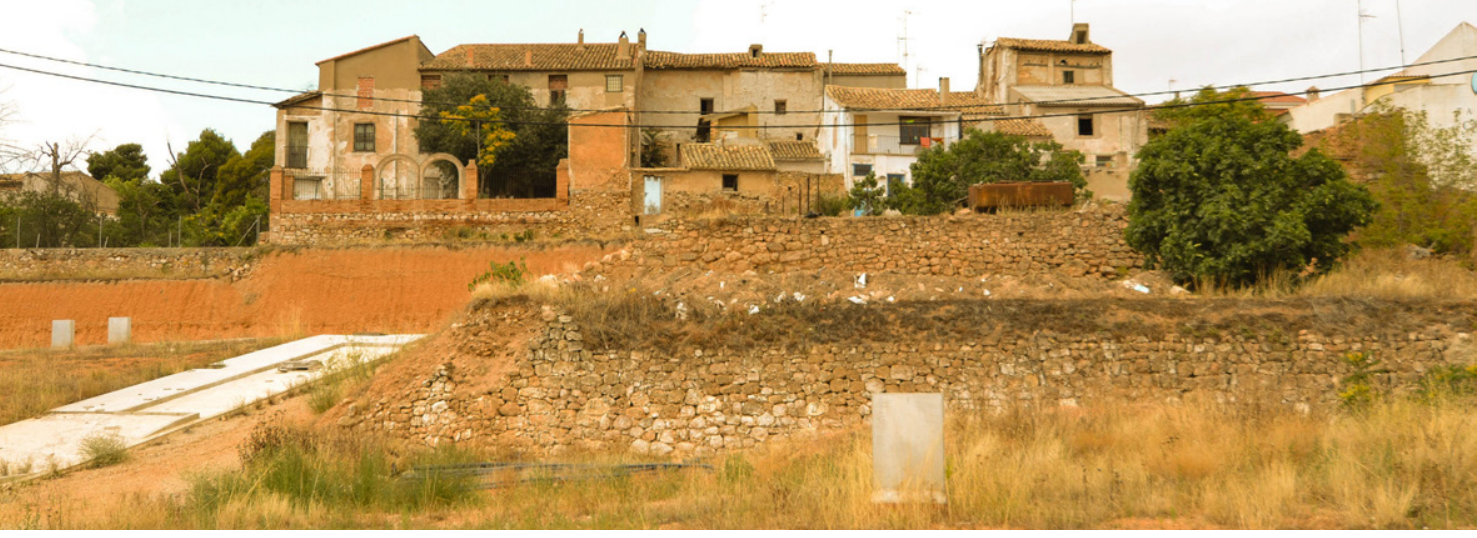

9.6. Estudio particularizado: el caso de la Casa del retablo

Como hemos observado a partir del apartado anterior, existen numerosas lagunas acerca del trazado del perímetro fortificado de época carlista de la ciudad de Requena. Si algunas partes del mismo parecen quedar claras gracias a los límites definidos por la morfología urbana, otros, disueltos por el crecimiento de la ciudad, han generado un área de discusión que resulta imposible de esclarecer en este trabajo. Podría servir como ejemplo el área que se extiende frente a la plaza del Portal y que (límite occidental), el área del Batanejo (límite suroriental) o la zona de la puerta de Reinas (extremo nororiental). Con el fin de profundizar en el conocimiento de estas áreas oscuras y de poner a prueba la metodología planteada en el trabajo, se propone ahondar en uno de los sectores más contradictorios a la hora de efectuar el seguimiento de los informes militares, altamente afectado por el reciente Plan de actuación integrada del Batanejo y susceptible de inminente desaparición. Se trataría del tramo comprendido entre la puerta de Valencia y la Puerta del Trillero. Este sector, que cubriría los terrenos que se extienden entre el actual parque de la Glorieta y el arroyo de las Ollerías, resulta sumamente desconcertante dado que el conjunto debería haber permanecido relativamente inalterado, si exceptuamos las demoliciones que se han acometido en los últimos años, alounas asociadas a las obras de urbanización paralizadas del citado PAI. Precisamente de este tramo nos llamó la atención el trazado recogido en el plano de Ortiz de Pinedo de finales de 1837 o principios de 1838 (AGMM, núm. 262, sign.: Ar. G-T.3-C.2.262), que comprende desde el saliente configurado por el denominado "tinte de Navarro" y la denominada "Batería de desde el saliente configurado por el denominado "tinte de Navarro" y la denominada "Batería de
Honrubia". ¿A qué es debido este trazado tan singular? La realidad es que se genera una especie de cortina flanqueada por ambos salientes que, al visitar el lugar, se entienden condicionados claramente por la topografía.

Nos proponíamos determinar exactamente la localización de esa línea fortificada, aparentemente inexistente, y para ello solo teníamos la convicción de unos datos confirmados a partir de la investigación precedente: la nueva Glorieta se había edificado en parte sobre los huertos del Carmen y las denominadas eras de José María Penén. También sabíamos que, curiosamente, la actual calle de Antonio Pérez, el alcalde de Requena en tiempos de la Tercera Guerra Carlista, apodado El trillero, podría coincidir con el camino que en los informes militares se viene a denominar camino de las Eras y que confluye en la denominada Puerta del Trillero. El nombre de esta puerta no debería confundirnos pretendiendo asociarlo con el citado alcalde, dado que la puerta es denominada así ya en los años treinta del siglo XIX. Esta puerta, de dimensiones poco precisas, podría recaer a la altura de la actual Plaza de Isabel II, y también sería conocida en su tiempo como Puerta de las eras, a la que convergía el denominado camino de los álamos, actual Calle Constitución.

Con esta base era preciso aplicar la lógica defensiva. El área de estudio, sobreelevada sobre las Ollerías, no parece plantearse como el frente más trascendente del perímetro amurallado, aunque en sus proximidades parecen concentrarse diversos puntos artillados. Tiene su lógica. En el flanco occidental el terreno desciende acompañado por la calle Desamparados en busca del cruce del arroyo a través del puente de Santa Cruz, donde se posicionaban las casas que definían la puerta de Valencia, punto defensivo clave. Llama la atención que dominando el ascenso desde el puente de Santa Cruz, se posicione la actual residencia de ancianos, una construcción contemporánea que domina el sector. Al inspeccionar con detenimiento la zona, se percibe con claridad que la residenva sobre un terraplén con camisas de mampostería, recubierta de hiedra, que debió constituir un emplazamiento artillero ideal, posiblemente el enclave de lo que en muchos informes militares se viene a denominar "Las piezas". Pero sostengamos que todas estas reflexiones se tratan de meras hipótesis. 


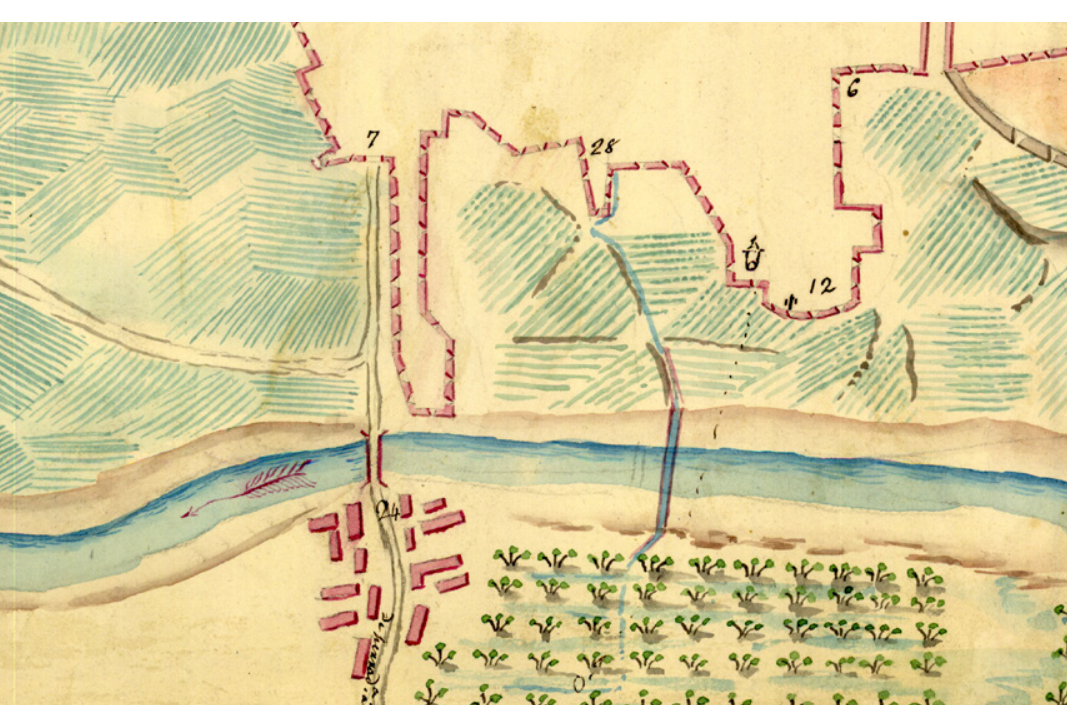

Fig. 774. Fragmento del Plano de Ortiz de Pinedo. Se enmar corresponde con el tinte de Navarro, y el $n^{\circ} 12$ con la batería de Honrubia. A la izquierd se observa en el $n^{\circ} 7$ la puerta de Valencia y el camino que conduce al puente de Santa Cruz y el barrio de las Ollerías extramuros.

Fig. 775. Vista aérea de la ciudad de Requena. Se remarca el área que preserva la morfología urbana existente en 183

Fig. 776. Vista aérea señalando el área de localización del inmueble.

En el flanco oriental, el saliente donde se emplazaba la batería de Honrubia, según el plano de Ortiz de Pinedo, batiría las Ollerías hacia el Este, dominando el camino de los Álamos y, en su flanco norte, dominando lo que serían las huertas de Honrubia y todo el desarrollo del Regajo de Reinas. No tenemos certeza ni de un emplazamiento artillero, ni del otro, sino una simple suposición de que ambos podrían haberse ubicado entre las actuales C/ Desamparados, al Sur, y la C/ Constitución, al Norte. El límite este lo constituiría el barranco de las Ollerías, y el límite oeste el denominado camino de las Eras, o actual C/ Antonio Pérez, por fijar una referencia.

Tras esta definición del área, queda remitirse a los restos existentes. Para ello se analiza la edificación existente en la actualidad que, por sus características, podría haber existido en el momento en que se plantea la construcción de la defensa liberal. Nos centramos pues en las casas de la C/ Antonio Pérez y, concretamente, en la que vamos a denominar a partir de este momento la Casa del Retablo, correspondiente a los números 20, 22 y 24

\section{Elección de la edificación}

El motivo de la elección de la edificación es una suma de características detectadas en el momento de su visita. Por una parte, existe en la fachada un retablo cerámico de la Virgen del Carmen y Ánimas, catalogado por el PGOU de Requena como Bien de Relevancia Local, con un nivel de protección integral afectando al entorno específico, es decir, la "totalidad de la fachada en la que se encuentra, de donde no podrá ser trasladado" (PGOU, 2013: T.CAS.BRL.2). En la misma ficha del plan se describe el elemento del siguiente modo:

"La Virgen del Carmen. Sentada entre nubes, con el hábito carmelitano y con corona cubierta, la Virgen tiene en su regazo a Jesús Niño que enseña en la mano derecha el escapulario a las ánimas -hombres y mujeres desnudos- que emergen abajo entre las llamas del purgatorio. La orla tiene bocel entre filetes amarillo y naranja. Realizado con pintura cerámica polícroma vidriada sobre fondo estamnífero liso. Perfilado con manganeso. No posee inscripciones. El retablo tiene un formato rectangular vertical, cuyas dimensiones son 0,8 $\times 0,6 \mathrm{~m}$. Tiene un total de 12 piezas. No presenta fornicula. Hay repisa arriba y debajo de mamperlanes blancos" (ibíd).

Si comparamos el plano del Plan General con el plano catastral observamos la alteración y falta de coincidencia con los límites de propiedad. La primera realidad a la que nos enfrentamos es la histórica fragmentación de propiedades, cuyo rastro se ha perdido ante la falta de documentación registral, donde se detecta un mercadeo frecuente de espacios que pasan de unas manos a otras diluyendo los límites estructurales de las edificaciones.

Fig. 777. Plano de situación según el PGOU

Fig. 778. Plano de situación con ficación (en rojo). En amarillo se indican el conjunto de casas demolidas recientemente $\mathrm{y}$, en verde, se trata de señalizar el acceso a la vivienda objeto de estudio, que ha quedado con su medianera desnuda a un solar que, actualmonte, se utilizacomo aparcamiento.
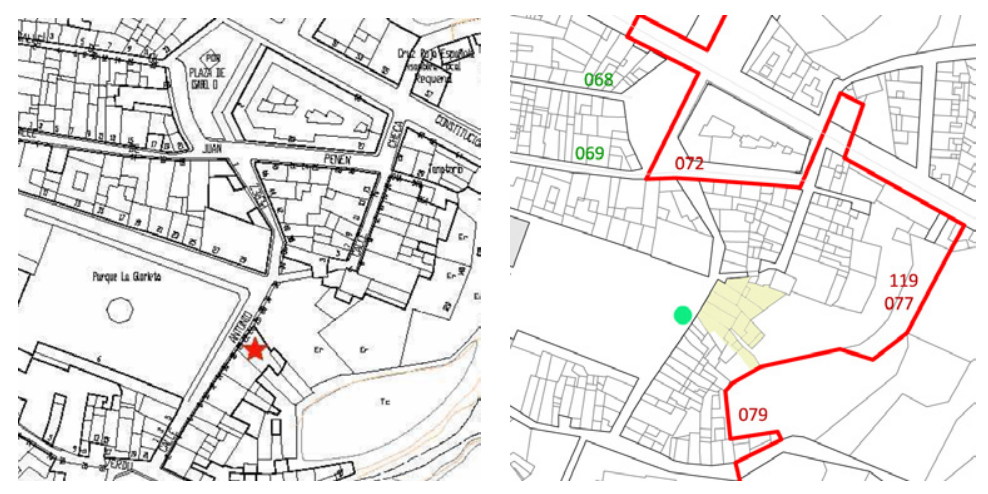


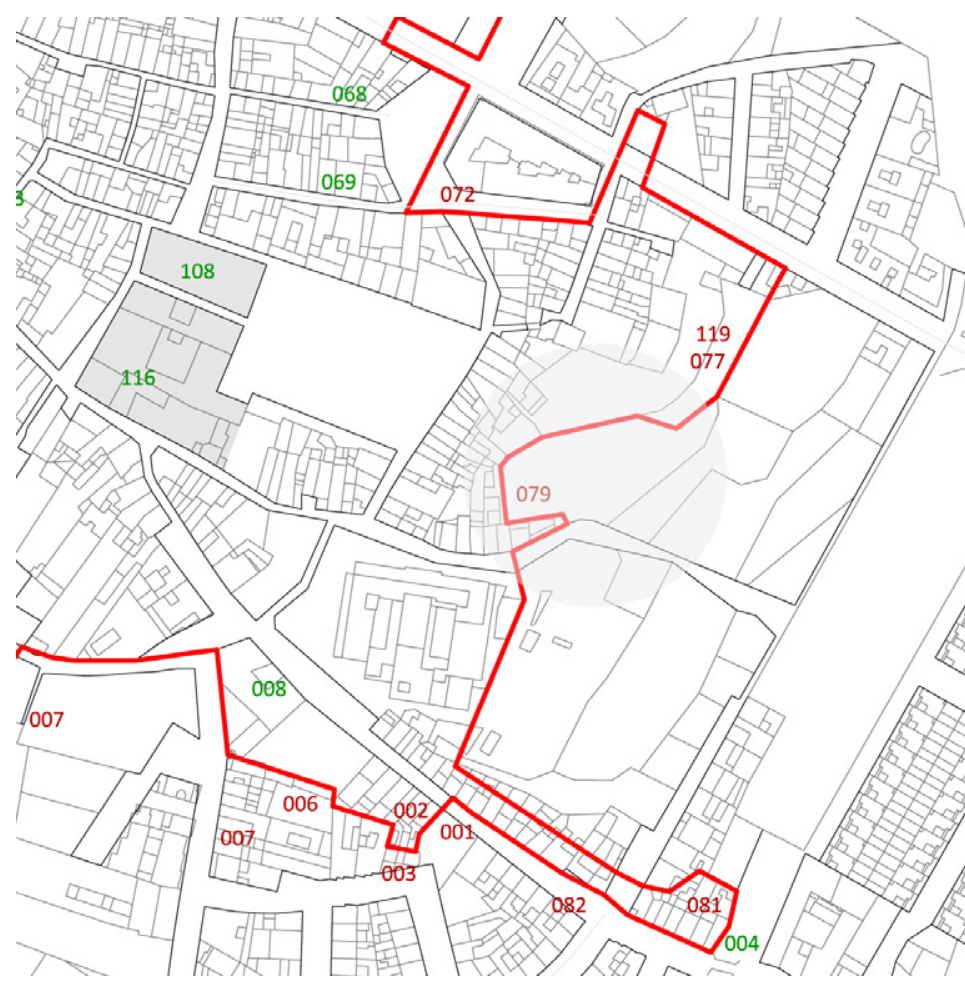

Fig. 779. En este plano de la rona de actuación en referencia posible trazado de la murall (a partir de la ultima hipotesis de esta investigación). Observamos que la referencia 079 podría corresponderse con el denominado tinte de Navarro del plano de Ortiz de Pinedo. . ciudad. Con el no 116 el convento del Carmen. En su ángulo noreste se ubica el espacio abierto de la actual Glorieta. Bordeando la misma por el Este tenemos la calle Antonio Pérez que ascendería buscando la el n 072. En el extremo inferio del plano, con el número 004, Cruz Ollerías. Podemos observar cómo, desde el Carmen (116) desciende la Calle Desamparados buscando la salida a Valencia. En el no 008 tenemos la casa de Cárcel y, frente a ella, la estructura de la actual Residencia de Ancianos.

Fig. 780. Detalle del retablo cerámico (VN, 2014).

Fig. 781. Vista de la medianer desnuda desde el encuentro de la C/ Antonio Pérez y la C/ Martínez Checa. Tras acceder a las diferentes propiedades, se detectó que en el momento de realización de esta estudio la casa estaba distribuida para un uso de cuatro viviendas de muy diversas características, que a tres propietarios diferentes. Se detectaban pues a simple vista un conjunto de obras superpuestas en el tiempo destinadas a facilitar dicha segmentación. Más adelante abordaremos esta apreciación.

\section{Datos catastrales}

En la sede electrónica del Catastro se localizaron las siguientes descripciones del inmueble y sus propiedades correspondientes a los números 20, 22 y 24, donde solo en el número 20 se distinguen dos propiedades; una ocupa la planta baja y otra, las restantes. La realidad catastral, como sucede en muchos casos similares, no coincide con el estado actual. Del mismo modo que el número de expedientes de legalización no clarifica el número de obras realizadas en el inmueble, dada la proliferación de obras ejecutadas sin licencia en el pasado siglo XX. Adjuntamos las fichas de las propiedades catastrales.

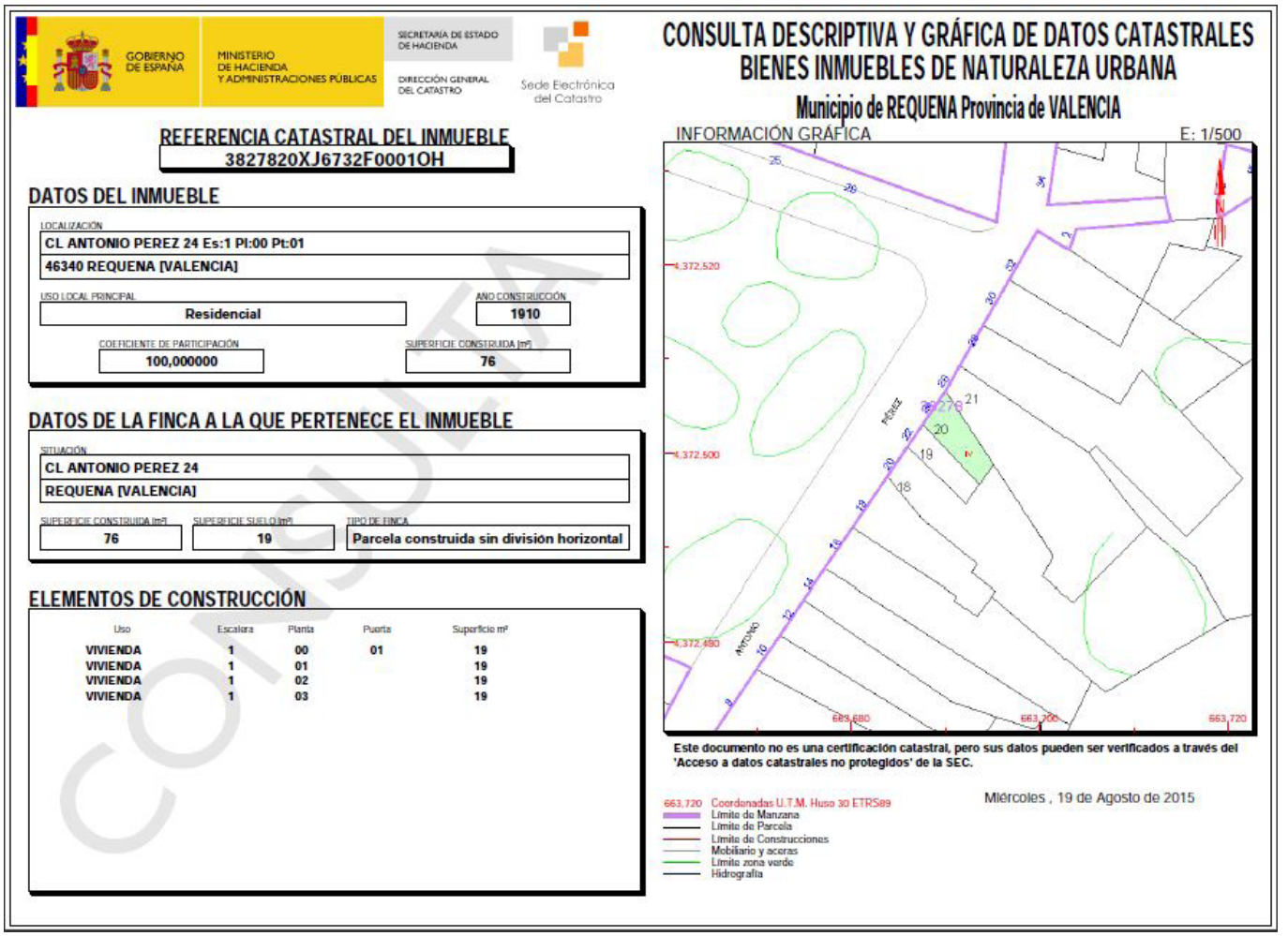

Fig. 782. Ficha catastral del núm. 24 de la C/ Antonio Pérez 


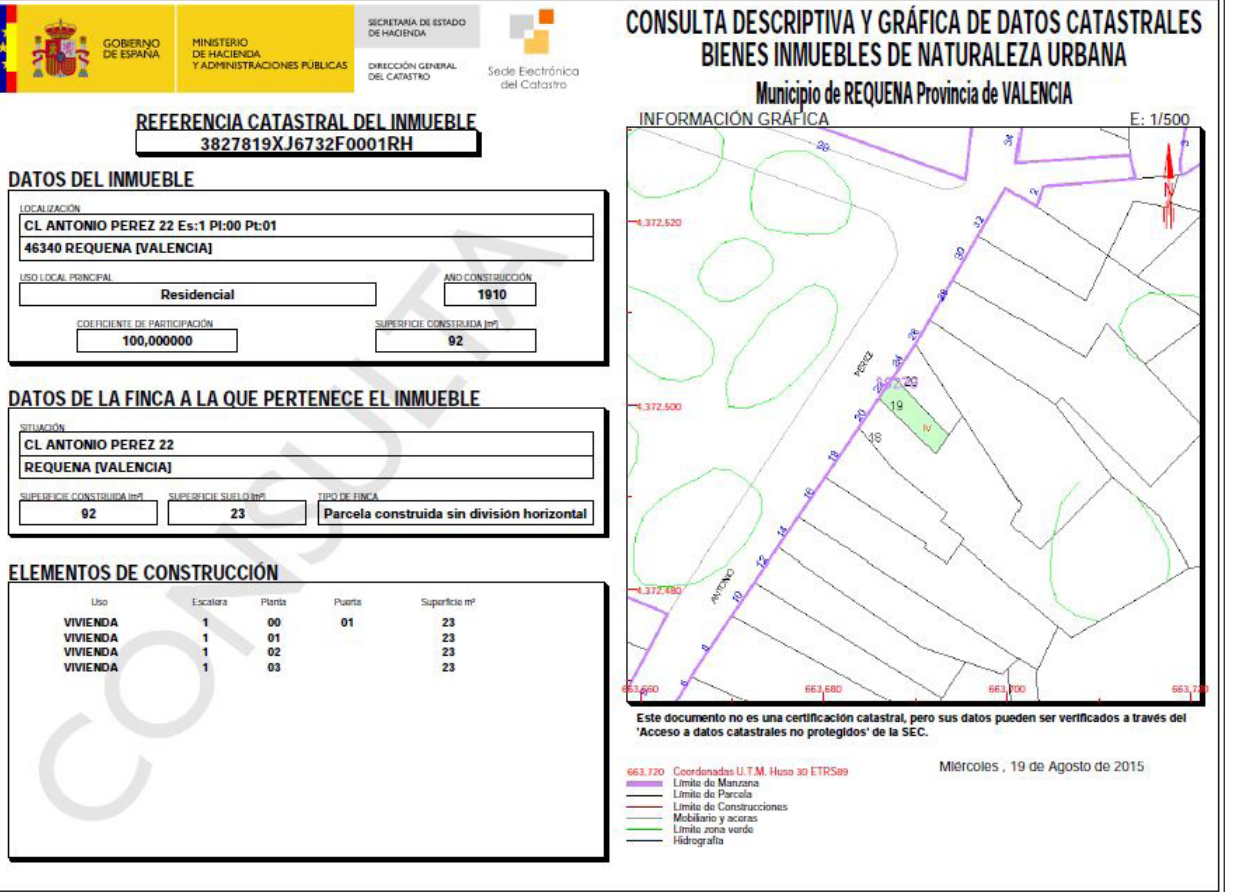

Fig. 783. Ficha catastral del núm. 22 de la C/ Antonio Pérez (19 de agosto de 2015).

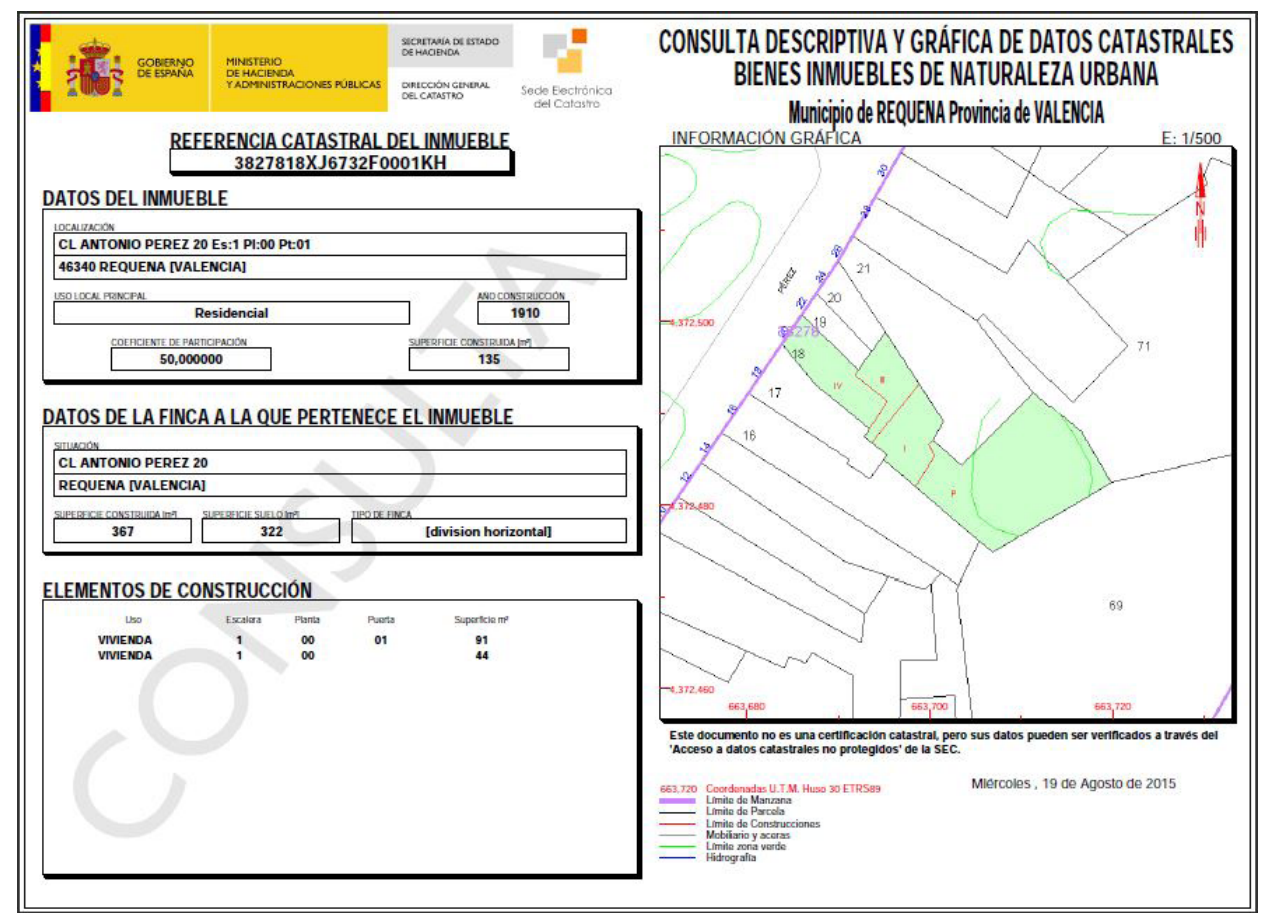

Fig. 784. Ficha catastral del núm. 20 de la C/ Antonio Pérez. Propiedad ocupando la planta baja. Se observa que segun catastro dicha propiedad contiene la huerta o jardín que se extiende por la parte posterior afectando al resto propiedades (19 de agosto de 2015).

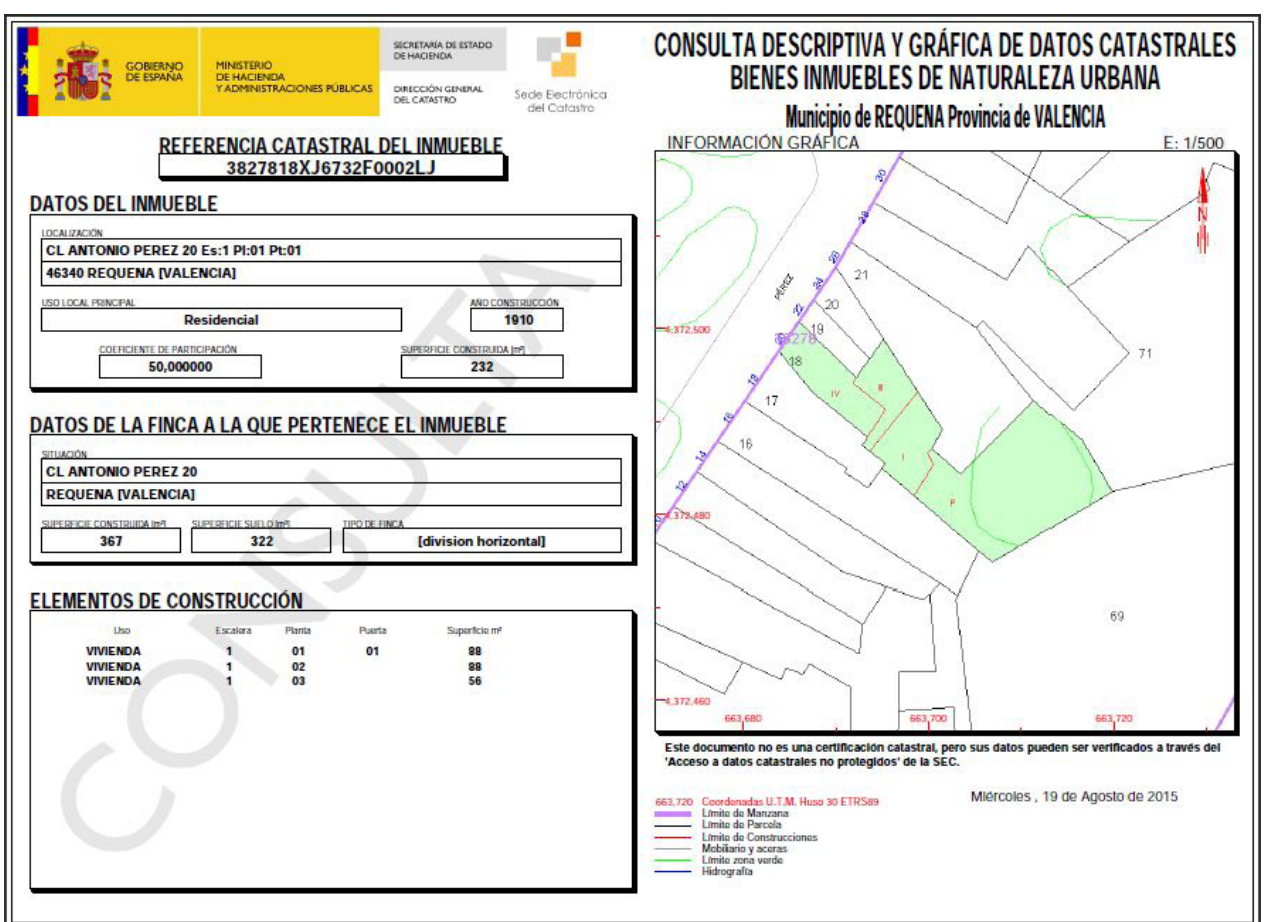

Fig. 785. Ficha catastral del núm. 20 de la C/ Antonio Pérez. Propiedad ocupando las plantas primera, segunda y tercera (19 de agosto de 2015).

\section{Datos del Archivo Municipal}

La consulta en los archivos locales no clarificó nada respecto al inmueble. Para identificar los informes de obra localizados en el Archivo Histórico Municipal de Requena (AMR) era preciso consultar en el ayuntamiento de la ciudad acerca de las signaturas correspondientes a los documentos. En este tan solo se encuentran informatizadas las obras de licencias posteriores a 1980, y, concretamente sobre la edificación estudiada no se recoge ninguna información a partir de dicha fecha. En este sentido se puede afirmar que no se han efectuado reformas (legales) en el inmueble desde el año 1980. La información relativa a licencias anteriores a 1980 se localiza de forma manual a partir de fichas, pero dichas fichas se organizan en función del nombre del propietario inicial. A partir del nombre de los propietarios identificados no se ha podido localizar ningún tipo de información. Con la ayuda del archivero municipal, Ignacio Latorre, se pudieron localizar varios informes asociados con obras en casas de la C/ Antonio Pérez.

1.-Solicitud de licencia de obras de María Jesús Camps Teruel, con domicilio en la C/ Antonio Pérez, [26], y registro de entrada 000981 de 26 de mayo de 1973. En él se plantea "construir una terraza" sin más especificaciones y "enlucir la fachada" (AMR, 2105/26). La solicitud se acompaña del informe en el que se identifica al constructor, Manuel Paterna Ruiz, el coste, 18.000 ptas., y la descripción de las obras a realizar donde se indica: "consisten en hacer una terracita de $4 m$ en alto y echar en la fachada tirolesa como si fuese pintada. La fachada tiene 350x3 planta nada de Reforma. Sólo rascarla y pintar a la tiroless" (AMR, 2105/26). La licencia es concedida el 7 de junio de 1973 (AMR, 2105/26). (2)encia del acabado de fachada actual. En el interior se detecta la supuesta obra de la "terracita", consistente en un forjado de viguetas autorresistentes de hormigón por concluir que cubre parcialmente el patio de la segunda propiedad (vid. documentación gráfica). No obstante, la obra hace referencia al nú- 

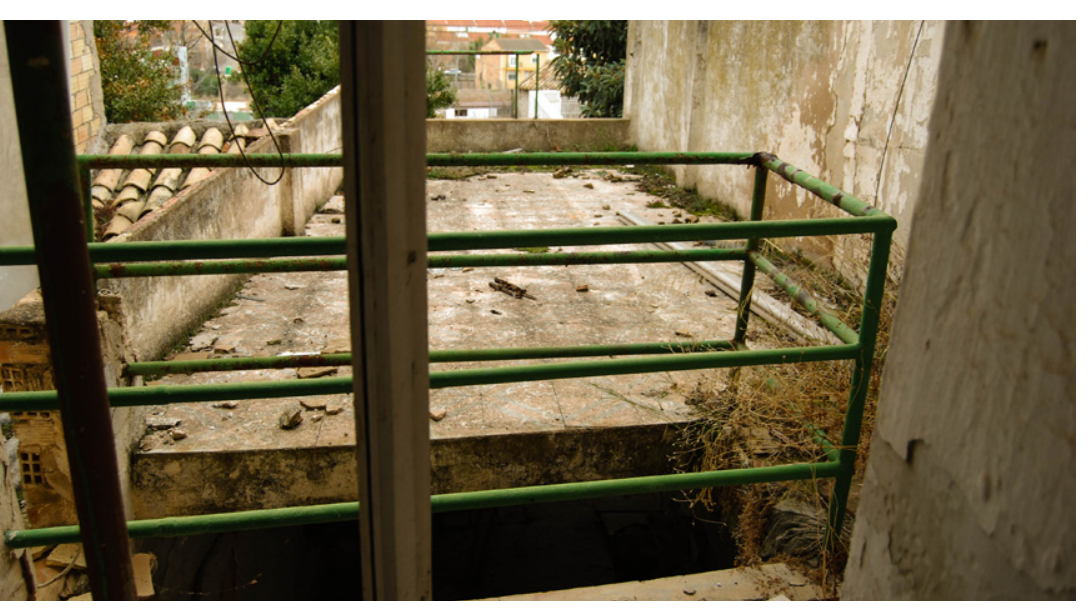

M. I. Ayuntamiento de Requena vias y Obras

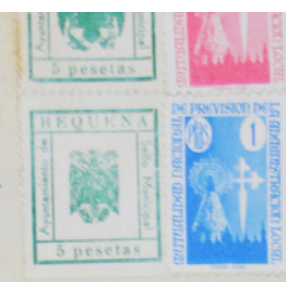

$00095+44296-73$

Don MARTA JESUS CAMPS TERUEL

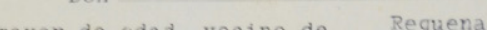
en la calle de Antonio Férez, 26 provisto de D. N. I. num.

S O L I C I T A respetuosamente de esa Ilustre Corporación municipal que, previos los trámites correspondientes, se digne acordar la concesión de licencia al compareciente para la realización de las obras que se indican a continuación, comprometiéndose al cumplimiento de lo establecido en las ordenanzas vigentes y a las instrucciones que le sean dictadas por la Corporación y los técnicos municjpales.

CLASE DE OBRA: Construir una terraza de y enlucir la fachada.

RMPLAZAMIENTO: Antonio Pérez 26

DOCUMENTOS QUE ACOMPANA :

Dios guarde a esa Ilustre Corporación muchos años.

$$
\text { Requena, } 26 \text { de mayo de } 1973
$$

$$
\text { Mana Jesm Camps }
$$

Fig. 786. Posible terraza asociada al expediente de obras AMR 2105/26 del 7 de junio de 1973.

Fig. 787. Primera hoja del expediente de obras de reforma de 1973 localizado en el Archivo Municipal de Requena. mero 26 de la calle, dato que hace dudar sobre la correspondencia de la documentación con la casa objeto de estudio. Podría haberse producido un cambio en la numeración, o un error de referencia. En estos momentos el número 26 no existe al haber sido demolido, por lo que resulta imposible verificar estas obras. Esta documentación no debería pues considerarse.

2.-Expediente de licencia de obras particulares de "Don Saturnino Sánchez Solano para construir acometida y reforma en el interior de la casa de su propiedad en la calle de Antonio Pérez" (AMRM 2032/62). El expediente está fechado el 18 de junio de 1948. La obra exactamente consiste en "construir una acometida o encaño a la alcantarilla general próxima inmediata así como también obras de reforma en el interior consistente en construcción de tabique división patio y nuevo cerramiento fachada de $5 \mathrm{~m}$.)".

Sobre esta obra no se puede concluir nada, al no poderse asociar a la casa objeto de estudio, pero sí que se puede afirmar la existencia del alcantarillado en el año 1948. Constatándose al mismo tiempo la constante alteracion de particiones interiores asi como de los muros de fachada posterior. licencia se concedería el 13 de julio de 1948.

Como podemos deducir, apenas se ha podido localizar información procedente del Archivo Municipal. Ello no ha impedido estimar la datación de la posible fecha de construcción del conjunto original de viviendas del frente a partir del estudio de Juan Piqueras Haba sobre el desarrollo urbano de Requena (Piqueras, 1978: 17).

Piqueras afirma que "tras la primera etapa de reconstrucción, el reinado de Carlos III (1759-1788) coincide con una etapa de prosperidad económica y urbanística de Requena. La Sociedad Económica de Amigos del País encargó hacia 1783 al arquitecto Bartolomé Ribelles unos planes de urbanización que, si bien no sabemos exactamente en qué consistieron, debieron afectar a las manzanas construidas entre el Arrabal y las Peñas, cubriendo el campo abierto que quedaba entre los dos. [...] El Arrabal se extendía entonces por el E hasta la cubriendo el campo abierto que quedaba entre los dos. [...] El Arra
calle de Antonio Pérez y por el Whasta la calle de las Monjas."

Los informes militares que se originan durante el conflicto carlista de 1833 a 1840 permiten considerar el frente de la calle Antonio Pérez consolidado. Así pues, el conjunto de edificaciones, entre las que se encuentra la edificación estudiada, podría haberse edificado en las postrimerías del siglo XVIII, a partir de 1783, y como muy tarde estaría construido en el año 1833.

Una serie de detalles, como determinados pavimentos, herrajes y técnicas constructivas que analizaremos posteriormente permiten confirmar el origen de la edificación a finales del siglo XVIII. No sucede así con algunos cuerpos añadidos. 
Datos del levantamiento in situ y consultas de escrituras de propiedad de los actuales propietarios

A partir del levantamiento in situ de las diferentes propiedades en el estado actual, y de acuerdo con las escrituras de propiedad de los actuales propietarios, nos encontramos con la siguiente distribución.

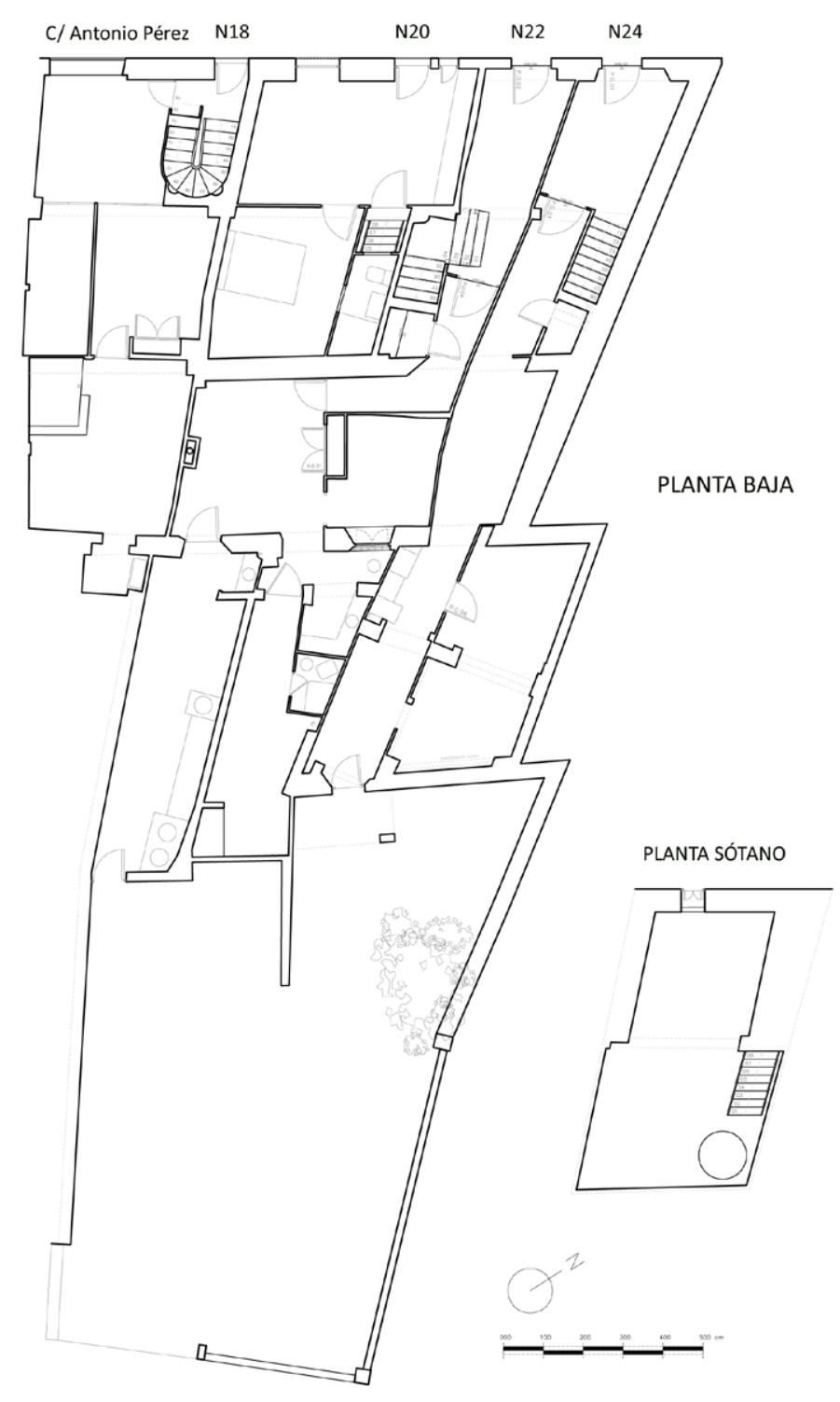

Fig. 788. Levantamiento de la planta baja de los números 18, 20,22 y 24 de la C/ Antonio Pérez y pequeño sótano del número 20. Este sótano se habilitó en torno a los años 40, según testimonio del propietario.

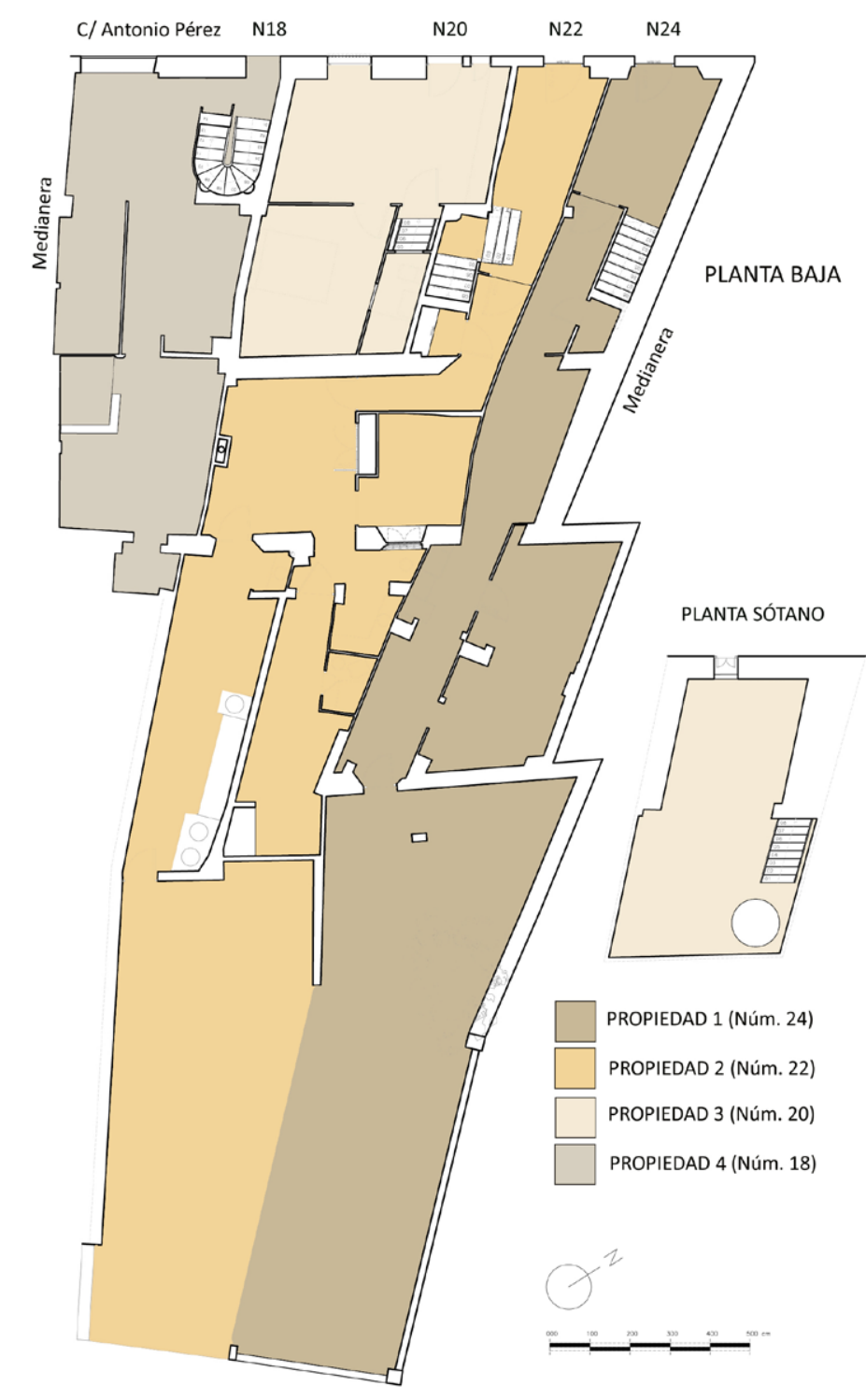

Fig. 789. Levantamiento de la planta baja de los números 18, 20, 22 y 24 de la c/ Antonio Pérez y pequeño sótano del número 20. En color se identifican las propiedades. 

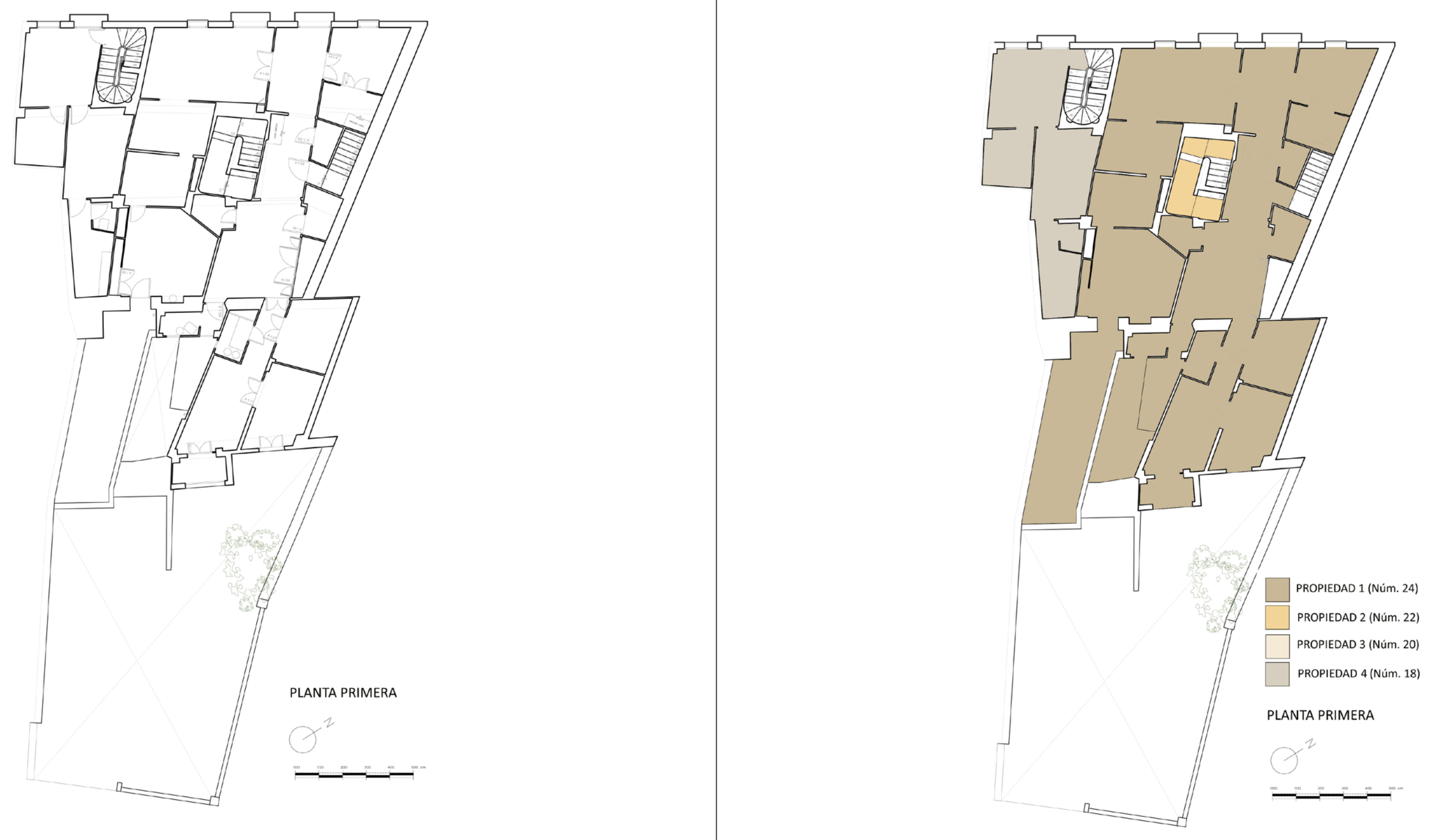

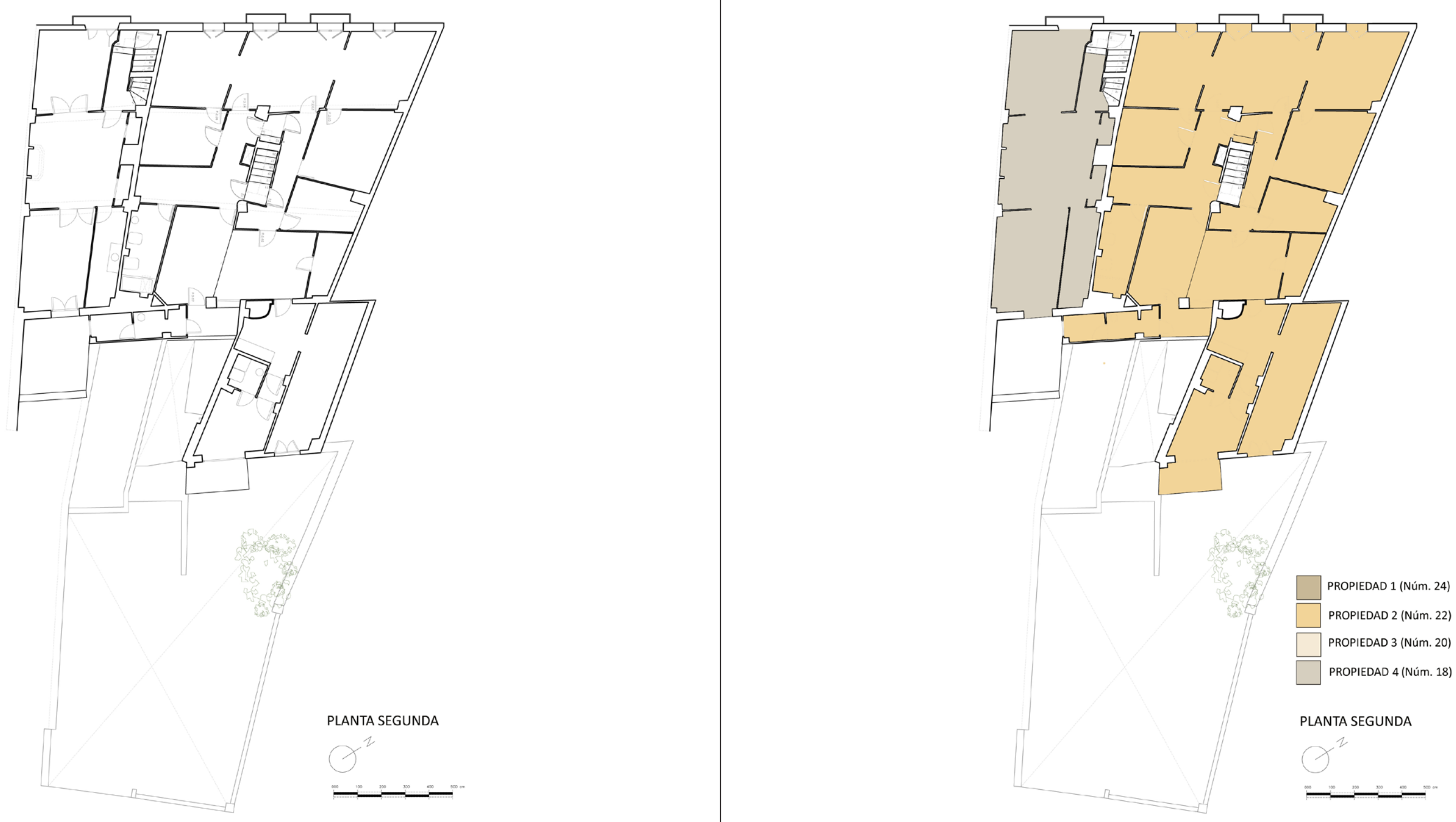

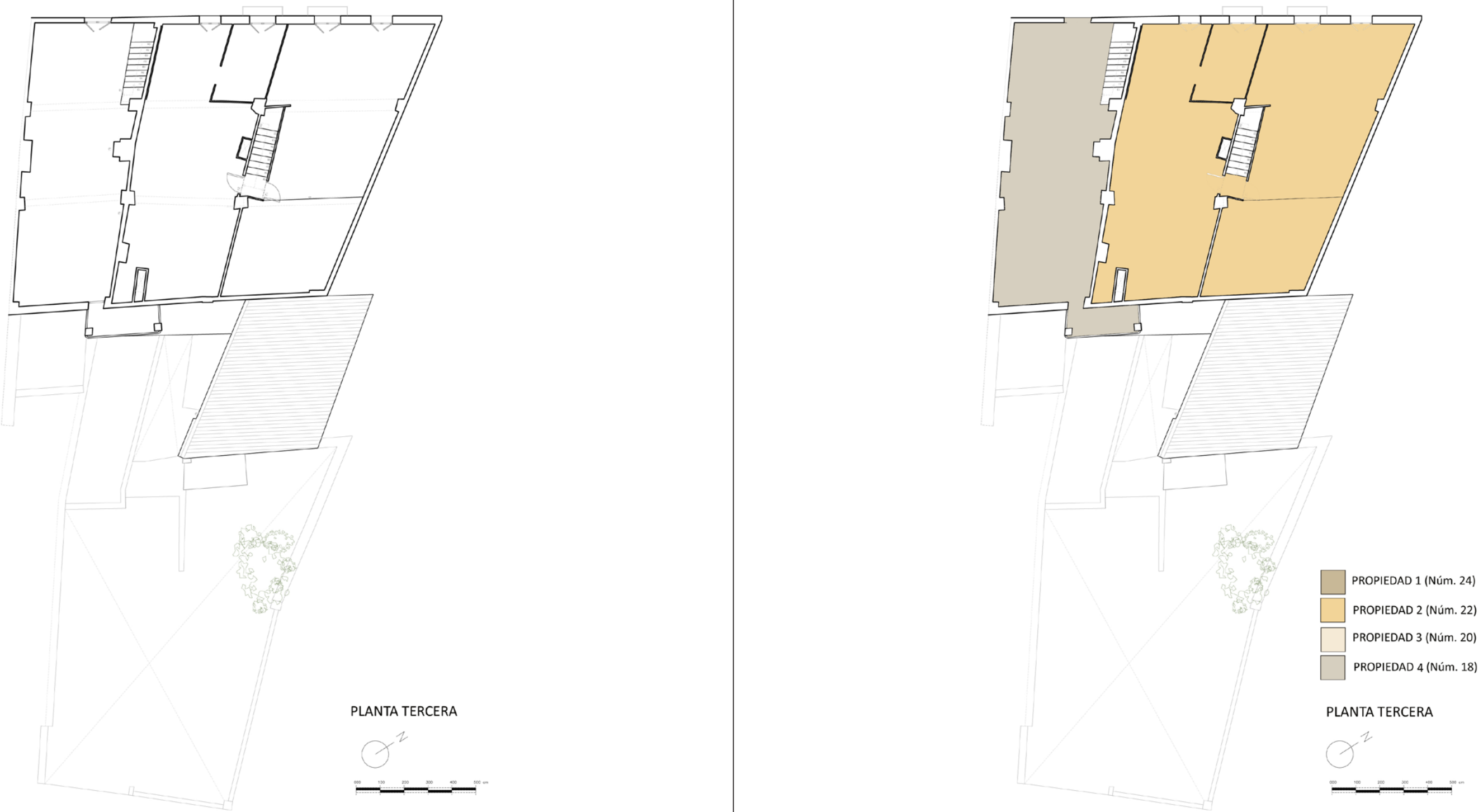


\section{Etapas de construcción}

Es preciso recordar que el presente apartado del trabajo de investigación tiene por objeto la detección del trazado de la muralla. La hipótesis que lanzamos a la hora de seleccionar la denominada "casa del retablo" se basaba en la posible coincidencia del trazado de Ortiz de Pinedo por sus inmediaciones. Al acceder a la vivienda, se barajan pues varias hipótesis.

1.- La construcción podría esconder parte del elemento fortificado. Bien porque se construye aprovechando las tapias, bien porque los elementos que se anexan con el tiempo aprovechan los lienzos de la fortificación.

2.-La construcción constituiría de por sí el elemento fortificado, por lo que su fachada posterior integraría uno de aquellos muros que se aspilleran y tapian.

3.-Las tapias aspilleradas y parapetos se corresponderían con los límites del huerto anexo perteneciente a la propiedad.

4.-El trazado de la fortificación no discurriría por la propiedad, pudiendo haber sido destruido en el proyecto de urbanización del Batanejo.

A partir de estas hipótesis, lo primero que se descubre al analizar la construcción es que todas las hipótesis son factibles.

La construcción ha sido objeto de numerosas reformas, pudiéndose distinguir diferentes etapas vitales gracias a las características estructurales, constructivas y formales, que no solo distinguen el carácter de unas y otras intervenciones, sino que también caracterizan el grado de deterioro de las mismas.

1.-La tipología inicial consistiría en una construcción relativamente regular en planta de traza trapezoidal. Fiel a las tipologías urbanas vernáculas, se construye entre medianeras, con una fachad principal que vuelca a la calle Antonio Pérez, que asume la carga representativa y que también posee un papel estructural. Sólida en planta baja, con muros de mampostería, pierde consistencia por las múltiples alteraciones en las plantas superiores. La fachada posterior, hoy absorbida por los espacios añadidos, volcaba a los tradicionales huertos posteriores, que se escalonan descendentemente A principios de siglo XIX este escalonamiento de bancales podria alcanzar et bar 列 las Ollerías.

Se ha detectado en esta fachada posterior el desprendimiento en planta primera del calicastrado, que permite identificar una pared de tapia. Por ello estaríamos hablando de una estructura de muros de distinta constitución: mampostería de cal y canto para la fachada principal, tapia para la posterior.

La estructura interior es completada con pilares estructurales de ladrillo de traza cuadrangular. Posiblemente una escalera central conectaba los dos niveles superiores por encima de la planta baja. Al tercer nivel, ya sin pavimentar, se accedería por la escalera existente de un tramo. Este tercer nivel, o bajo cubierta, debió de cubrir las misiones tradicionales de almacén. De hecho, el suelo sigue sin pavimentar. La cubierta, a dos aguas, dirigidas hacia la fachada principal y el huerto, aún conserva su aspecto tradicional: vigas y rollizos de madera, cañizo y teja árabe. Esta construcción ha sufrido diferentes alteraciones en el transcurso del tiempo a fin de acondicionar los usos que expondremos en las plantas de la página siguiente.

2.-Al volumen de la edificación se fueron añadiendo cuerpos por la fachada posterior, generando la fachada irregular que encontramos en la actualidad. El número de operaciones de añadido es difuso, pero la fachada posterior del huerto, como sucede en el conjunto de tipologías similares de la ciudad, se acaba conformando como un aglutinado de crecimiento orgánico. Normalmente se ejecuta esta construcción con menor destreza y peor calidad técnica y material que en épocas anteriores, lo que condiciona el mal estado de conservación con el que ha llegado a nuestros días. Por lo general la voluntad es colonizar la huerta en toda la altura posible, siempre condicionados por la altura de cornisa que impone la prolongación de la cubierta inclinada. El crecimiento progresivo se inicia quizás con modestas estructuras de corrales o tapias de huertas que se cubren y colonizan en los niveles superiores. Los añadidos en la edificación estudiada se habrían producido en el transcurso del siglo XIX, con numerosas reparaciones puntuales en el siglo XX en forma de sustitución zan por su irregularidad y falta de criterio compositivo. Precisamente los intentos de conexión de los espacios históricos con los añadidos indujeron a un horadamiento excesivo del antiguo muro de fachada posterior, aminorando su capacidad portante.
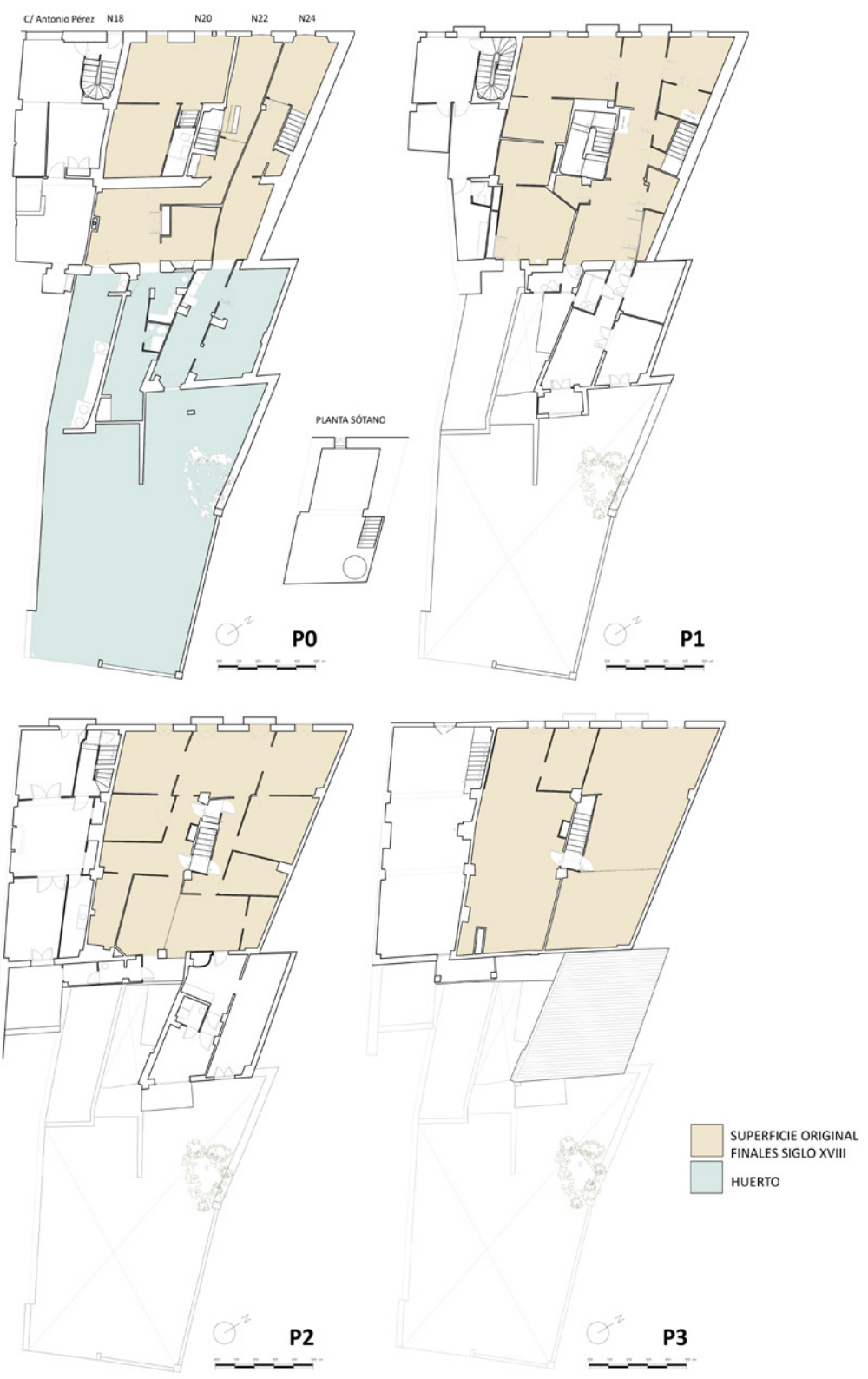

Fig. 796. Esquema coloreado de superficies habitables y de huerto de la construcción original. 

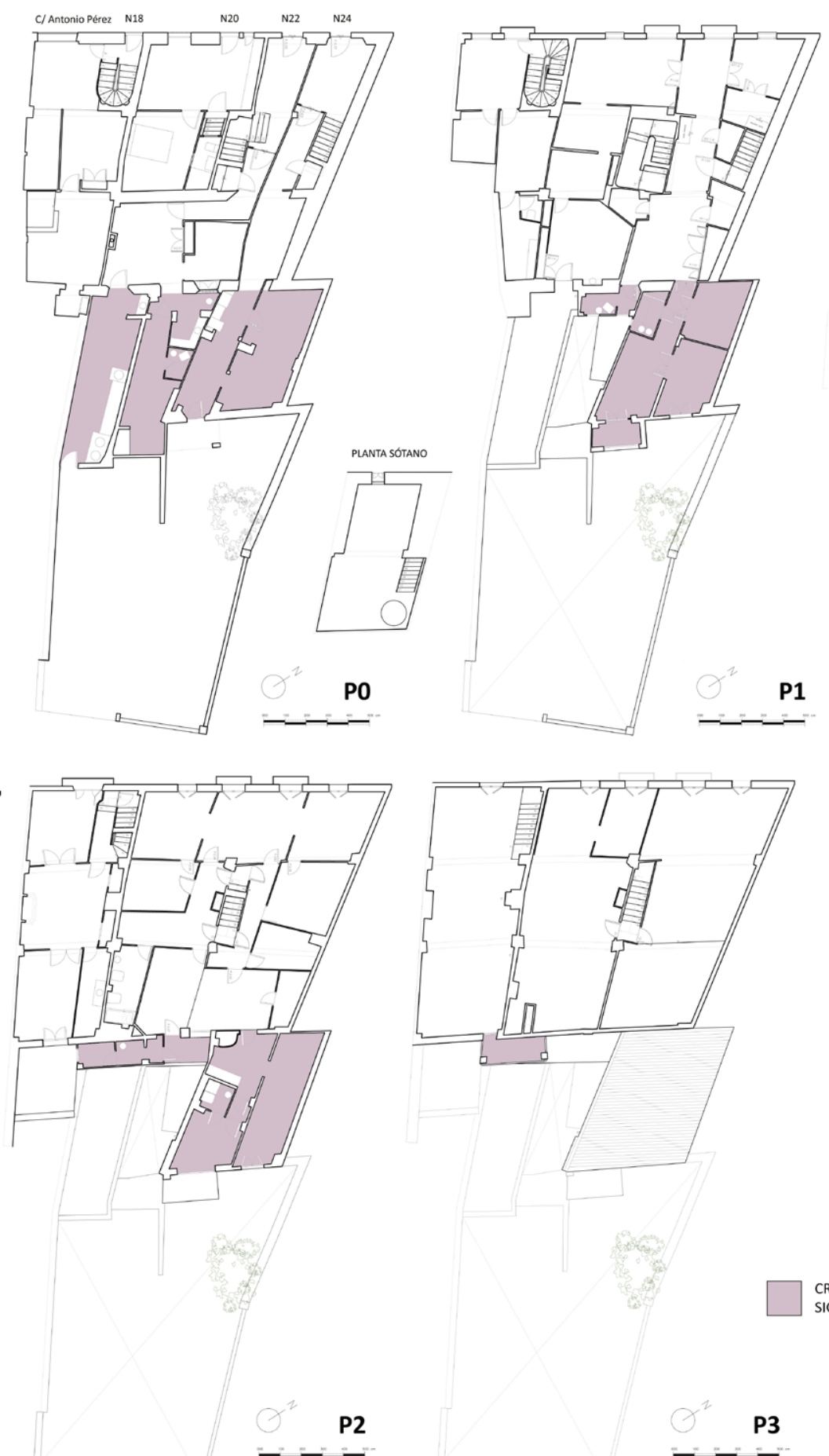

CRECIMIENTO ORGÁNICO
SIGLOS XIXYXX siglo XIX.
3.-Paralelamente al crecimiento horizontal posterior de la edificación, se fue produciendo una adaptación a las diversas condiciones de vida interior. Herencias, división de propiedades, adquisición de espacios al vecino colindante... Quizás el testimonio más claro de estas operaciones es la creación de una segunda escalera adosada a la medianera este para proporcionar un acceso independiente. El grado de deterioro y el diferente formato del pavimento de barro de la misma permite fechar esta intervención bastantes décadas después. Simultáneamente se debió acondicionar la escalera central, impidiendo su comunicación con la primera planta y conduciendo con un añadido directamente hasta la segunda. La reorientación de las escaleras, y la ejecución de una nueva escalera, implica la generación de huecos en los forjados superiores para evitar cabezadas, generando unos cajeados en las plantas superiores (ver esquema). En otros puntos, las escaleras generan conflictos con la cabezada (tránsito de planta primera a planta segunda en la escalera central). Son las características de la distribución de propiedad que encontramos en la edificación actual. De acuerdo con testimonios orales de los propietarios, se sabe que la vivienda ubicada en la planta baja del número 20 se independiza del edificio y la legaría a sus descendientes como una propiedad independiente (ya en el siglo XX).
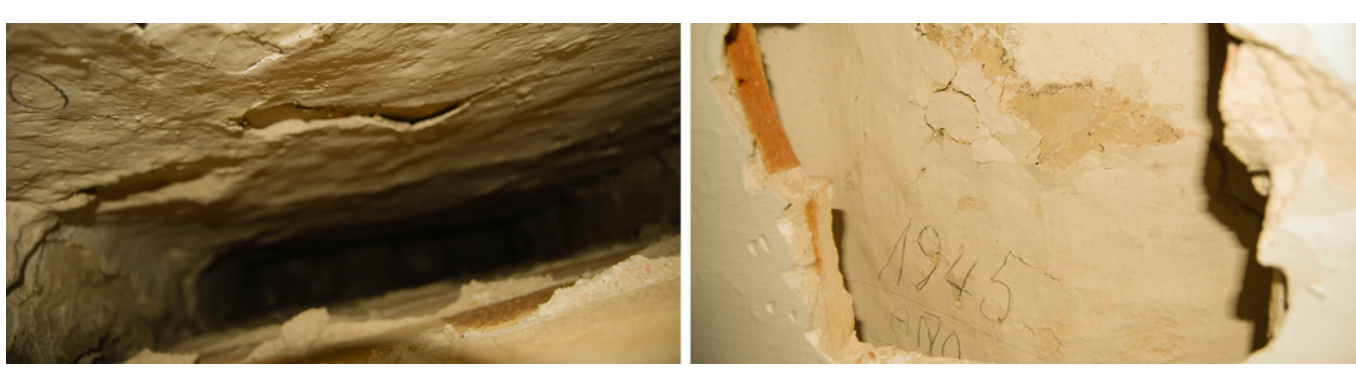

Fig. 798. Foto de detalles del trasdosado del muro de la escalera principal generando una cámara y la inscripción del año en el trasdós descubierta al efectuar una cata.

4.-Las intervenciones del siglo XX se caracterizan por un conjunto de obras impropias de adecuación de cuartos de baño, interposición de bajantes de PVC que perforan los forjados y refuerzos estructurales. El refuerzo más llamativo está asociado con el muro de la escalera principal, que se dobla tal y como se ha podido observar en las catas efectuadas, encontrándose el testimonio de la fecha de intervención en 1945 gracias a una anotación en grafito descubierta en el intradós del muro. Es preciso destacar que el conjunto de catas se realizaron a raíz del levantamiento gráfico al comprobar la falta de coincidencia de determinados paramentos. Se pudo descubrir así una serie de espacios huecos residuales fruto de las sucesivas intervenciones.

5.-La demolición de los edificios colindantes en el siglo XXI ha ocasionado un grave perjuicio a la edificación que, por momentos, ve cómo vence el muro medianero y se abren los forjados de las plantas superiores en su conexión con la medianera. El deterioro de la medianera en la parte superior, especialmente en las zonas añadidas en el siglo XIX han conducido a tapiar las partes desmoronadas con fábrica de ladrillo cerámico. Aún así, el agua, filtra por las grietas, augurando el rápido deterioro de la construcción.

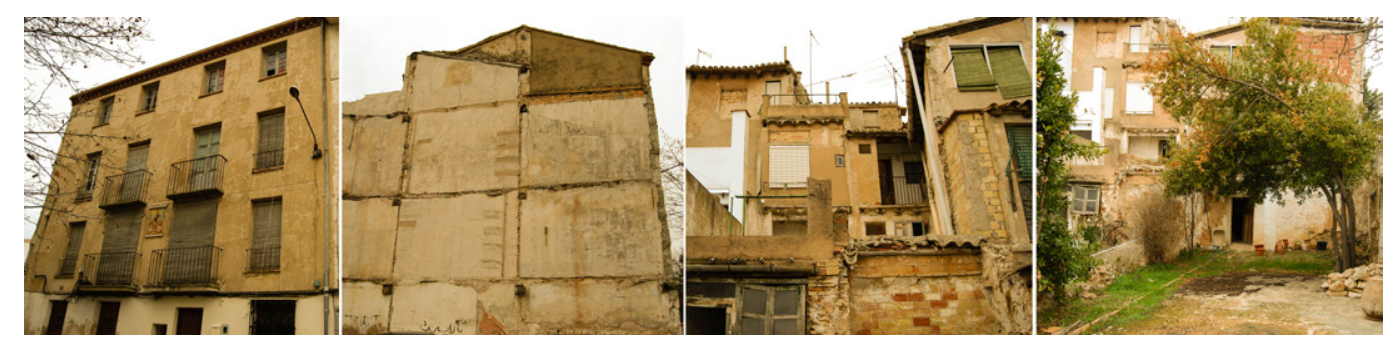

Fig. 799. Se observa el diferente caracter de las fachadas. En primer lugar, la fachada septentrional a la C/ Antonio Pérez, con un criterio compositivo de huecos y ciertas alteraciones. En segundo lugar, la medianera desnuda occidental. En tercer lugar, la fachada de crecimiento organico que vuelca al huerto tradicional, que se observa en ultimo lugar. 

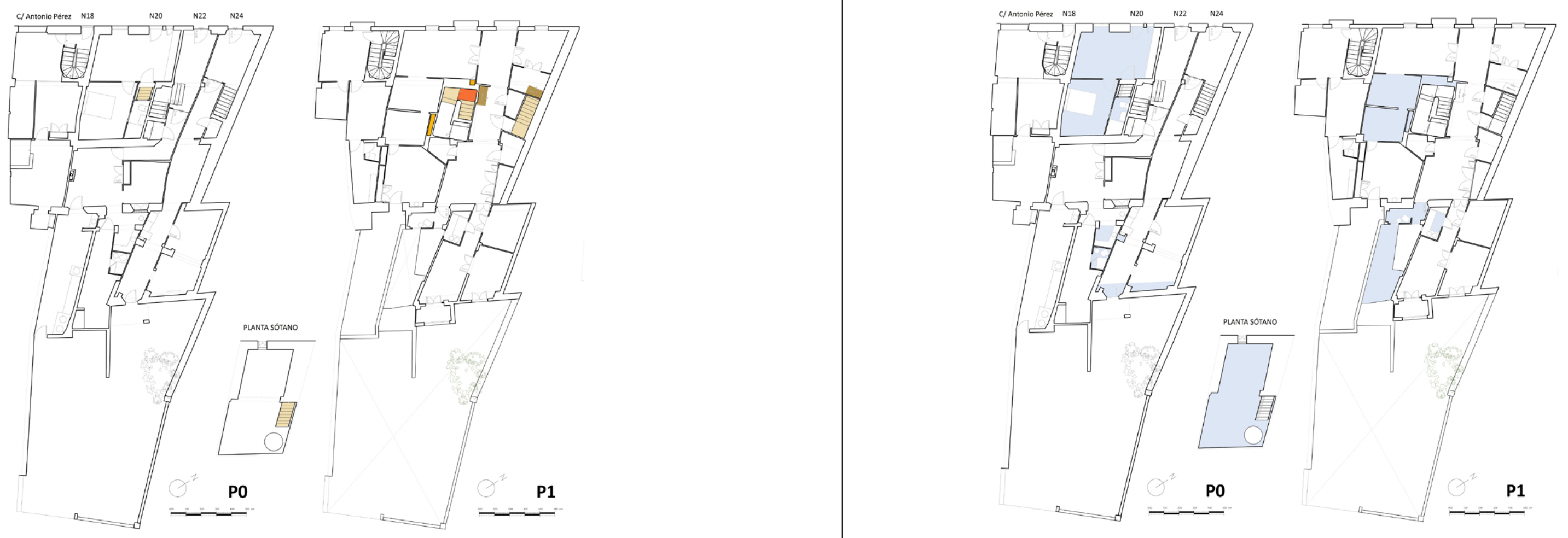
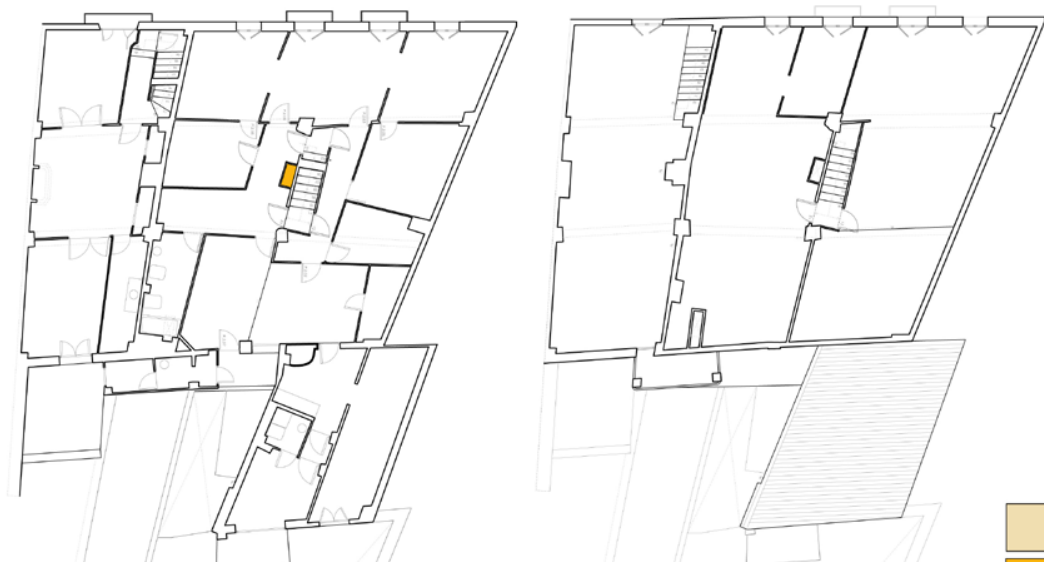

ESCALRAS ALTERADA

ESPACIOS CEGADOS
OCAMARAS DESCUBIERTAS

PUNTO DE CABEZADA

P3

Fig. 800. Esquema de alteraciones producidas en las escaleras para facilitar la segmentación de la propiedad, cabezadas y espacios inservibles ocultos conformando cámaras detectados gracias a la investigación gráfica.

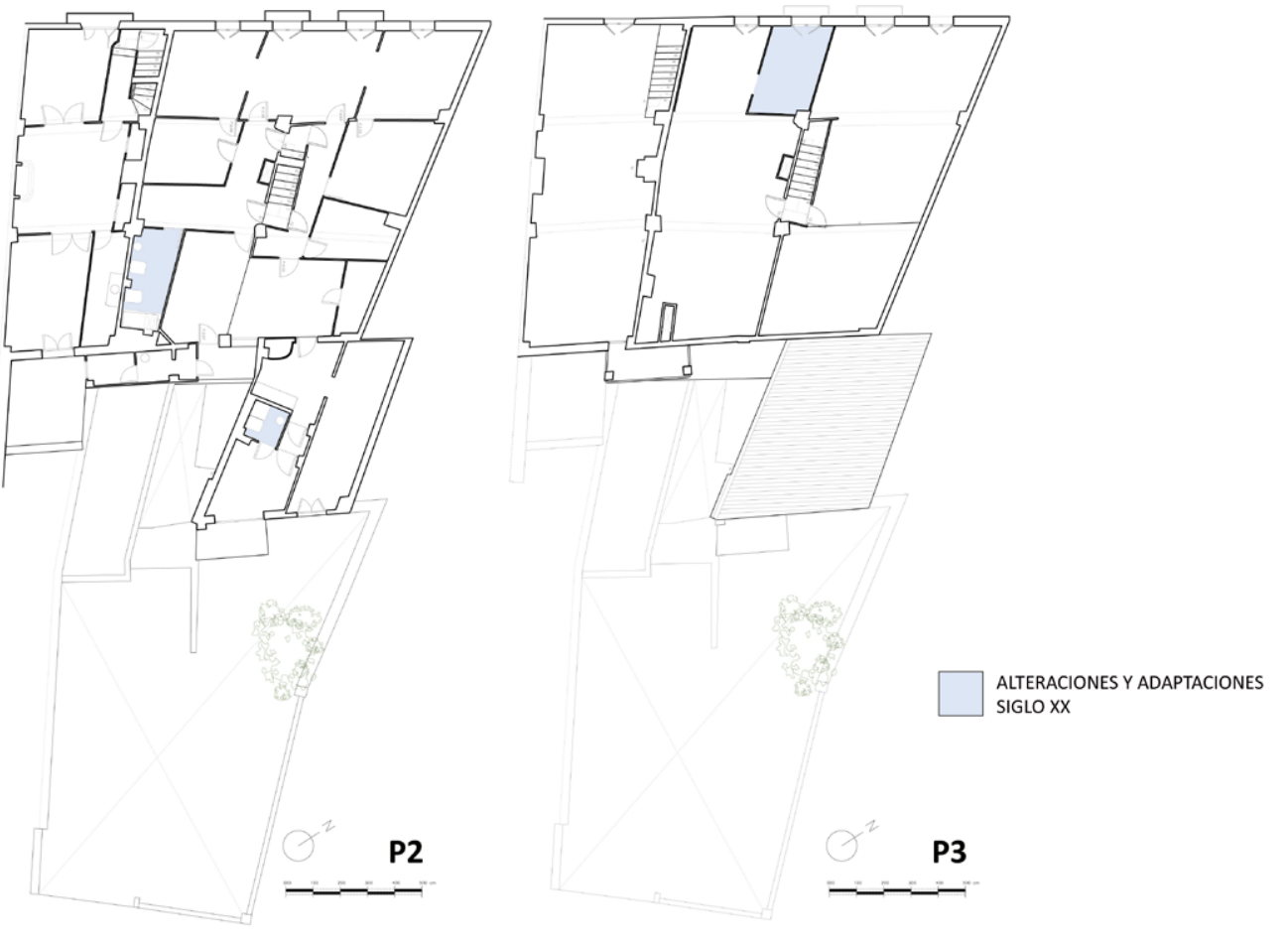

Fig. 801. Esquema de alteraciones puntuales en el transcurso del siglo XX. 
Técnicas y elementos constructivos

Las técnicas constructivas han ayudado a la identificación de las etapas, pero básicamente han servido para detectar amplios márgenes cronológicos de intervención. La prolongada tradición de las técnicas vernáculas de la zona diluyen sobremanera las posibilidades de acotar con concreción un ámbito cronológico, salvo cuando existe la certeza de que el material o la técnica no existe o no es frecuente en una fecha concreta como suele suceder con algún tipo de pavimento, o, especialmente con determinados materiales propios del siglo XX

El sistema de cimentación parece basarse en la tradicional cimentación corrida bajo los muros, o puntual bajo pilares, con masas de cal y canto. Se efectúan soleras posiblemente con encachado de piedra, cal y pavimento de diversa índole. Curiosamente los pavimentos de planta baja no se corresponden con los pavimentos históricos de plantas superiores. Ello permite deducir que se experimenta un proso de repavimento posiblemente asociado también a los escalonamientos que rimentantos que se producen en el suelo de planta baja y a algun problema de humedades. Se detectan áreas re-pavimentadas con pavimento hidráulico en gamas de crema con marcas de agua, solo característico a finales del siglo XIX. En otros sectores hallamos un cemento continuo coloreado en rojo (cemento con almagra). En el exterior se detectan áreas pavimentadas con canto rodado y cal.

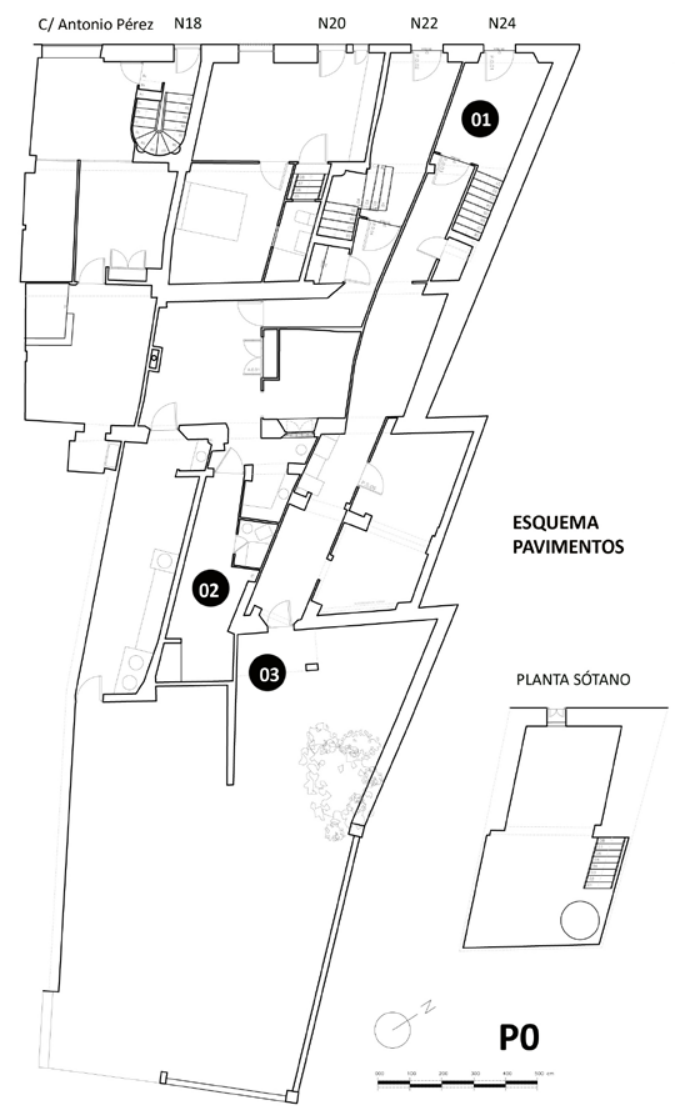

Fig. 802. Planta baja con localización de los diferentes pavimentos.

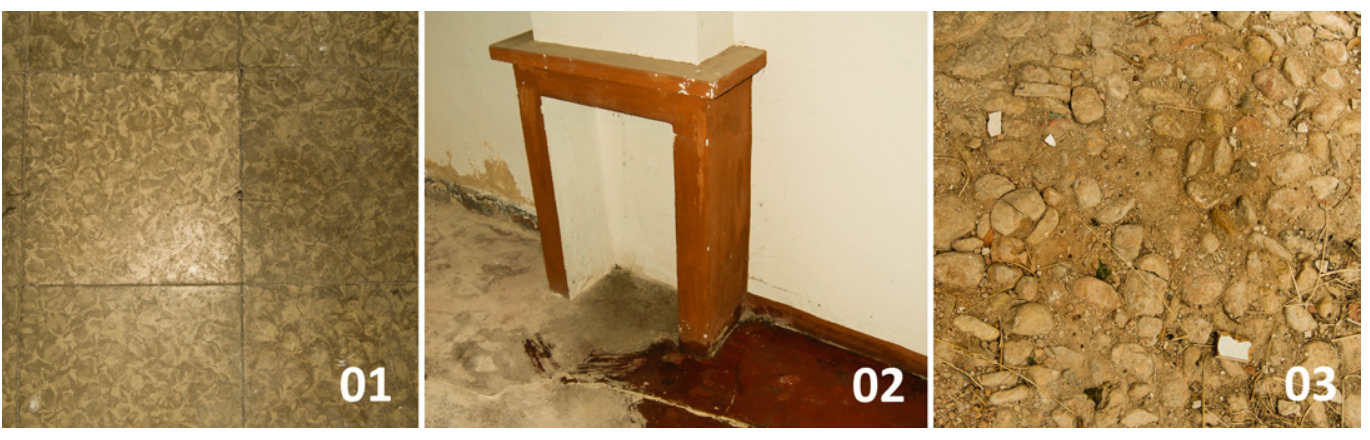

trada (1), cemento con almagra de la habitación suroeste (2), cantos rodados del exterior, bajo el pequeño porche (3).

Como hemos indicado, el sistema estructural básico se centra en la presencia de dos muros estructurales de fachada, principal y posterior. El muro de la fachada principal ejecutado con sillería de cal y canto presentaría en su día un revoco y estaría pintado de blanco, de acuerdo con la tradición establecida en Requena a raíz de las sucesivas epidemias (como la de cólera de 1834) y respondiendo a las recomendaciones sanitarias que se impusieron en el siglo XVIII bajo el reinado de Carlos III (Gárate Rojas, 2002). El muro de la fachada principal pierde espesor en las plantas superiores. En el caso de la fachada posterior (hacemos referencia a la antigua fachada original, hoy embebida en el interior), se han detectado partes de tapia, donde, en zonas horadadas para favorecer el act nuevas instancias, el calicastrado se ha fracturado dejando entrever la tierra.

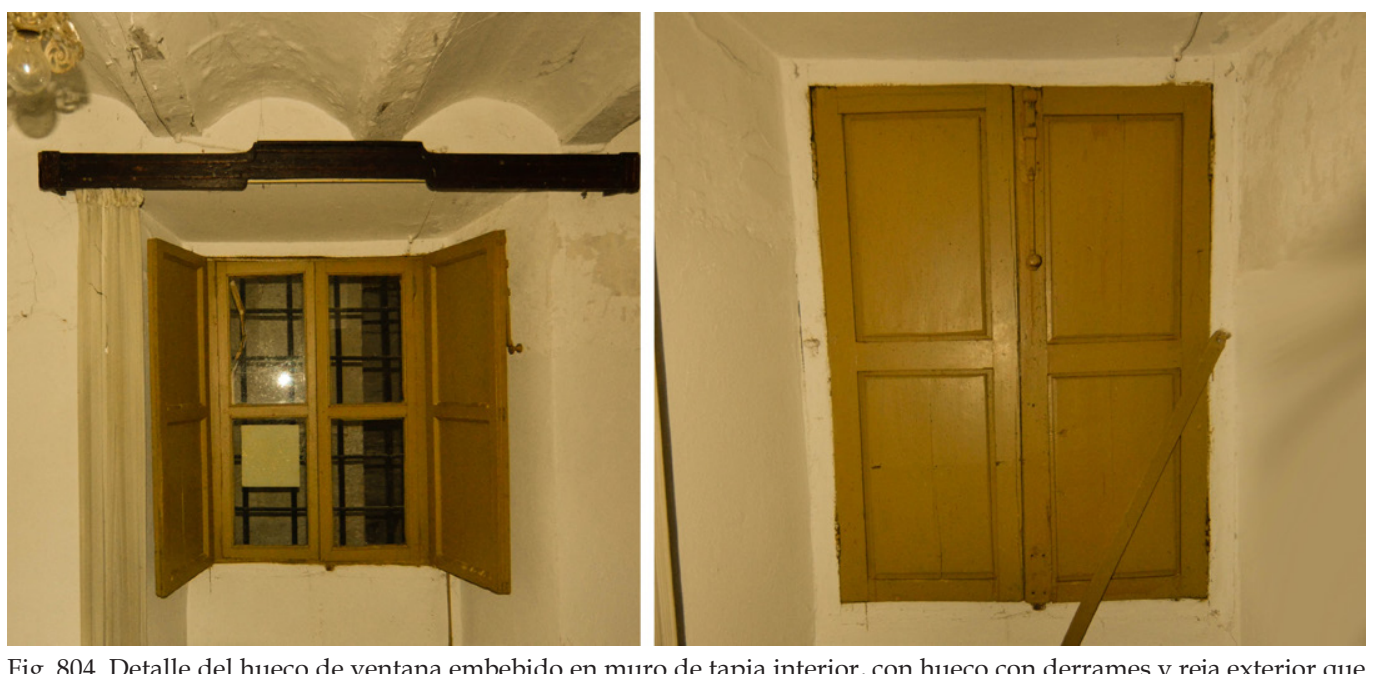

ig. 804. Detalle del hueco de ventana embebido en muro de tapia interior, con hueco con derrames y ref

Los sistemas estructurales horizontales alternan los forjados de viguetas de madera y revoltones de 1780 con forjados de igual técnica constructiva pero más recientes, correspondientes a las ampliaciones del siglo XIX y principios del siglo XX. Los primeros se distinguen por la mejor calidad de la madera (dado su estado de conservación) y una mayor separación intereje de viguetas, con revoltones de yeso.

Estos forjados se apoyan directamente en los muros o bien en grandes vigas de madera que conectan pilares. La dirección de las viguetas difiere sin un criterio claro. Por ello no podemos hablar de una estructura unidireccional (véanse planos de arquitectura). En algunos casos el forjado ha sido reemplazado por una losa, especialmente en las zonas afectadas por la alteración de la escalera. 
726
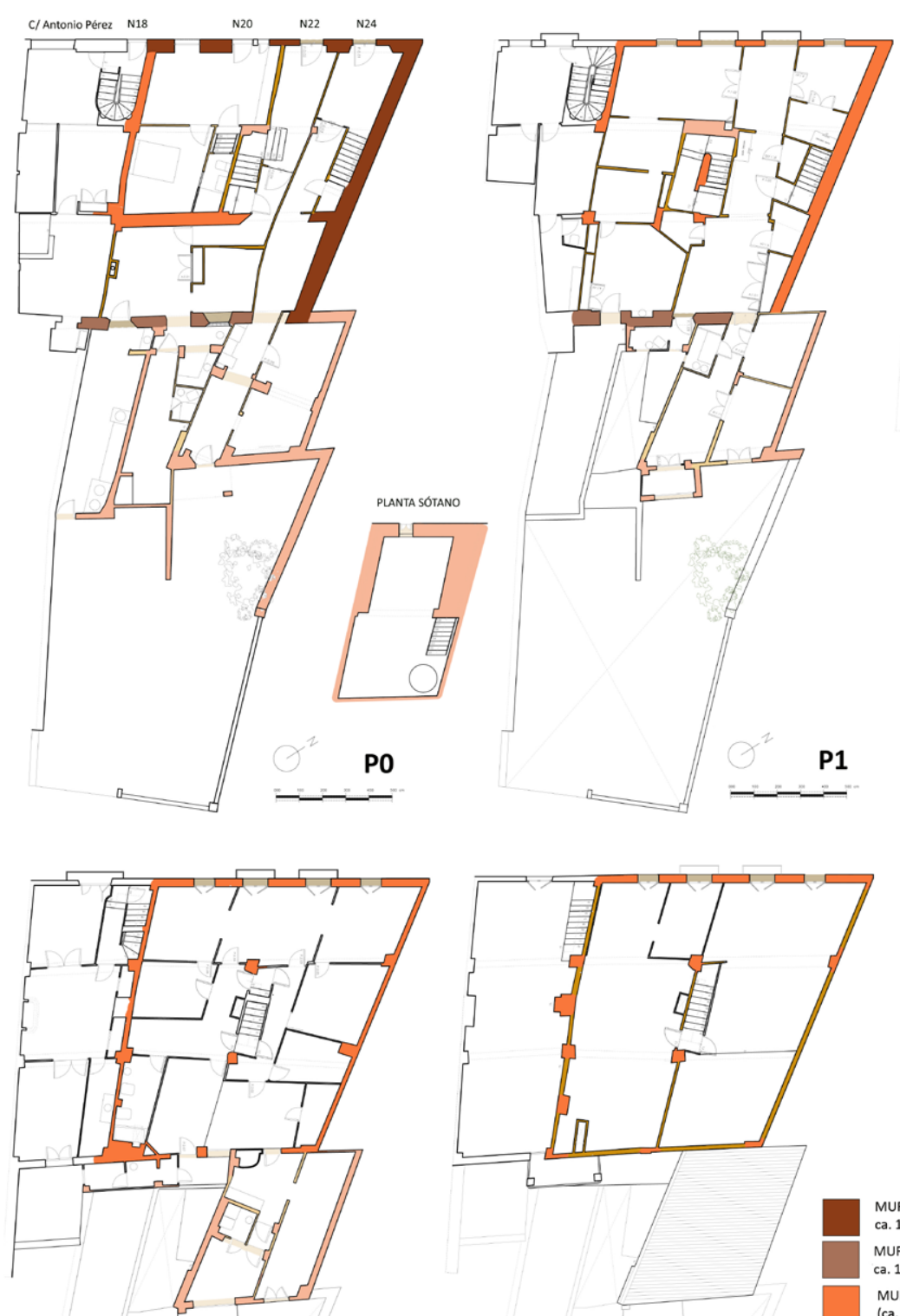

P2
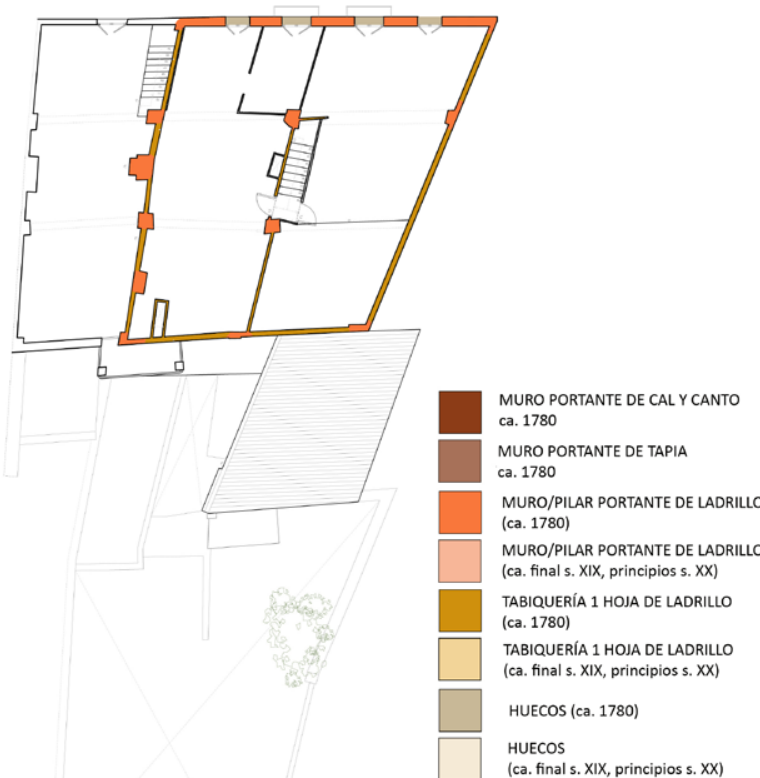

P3
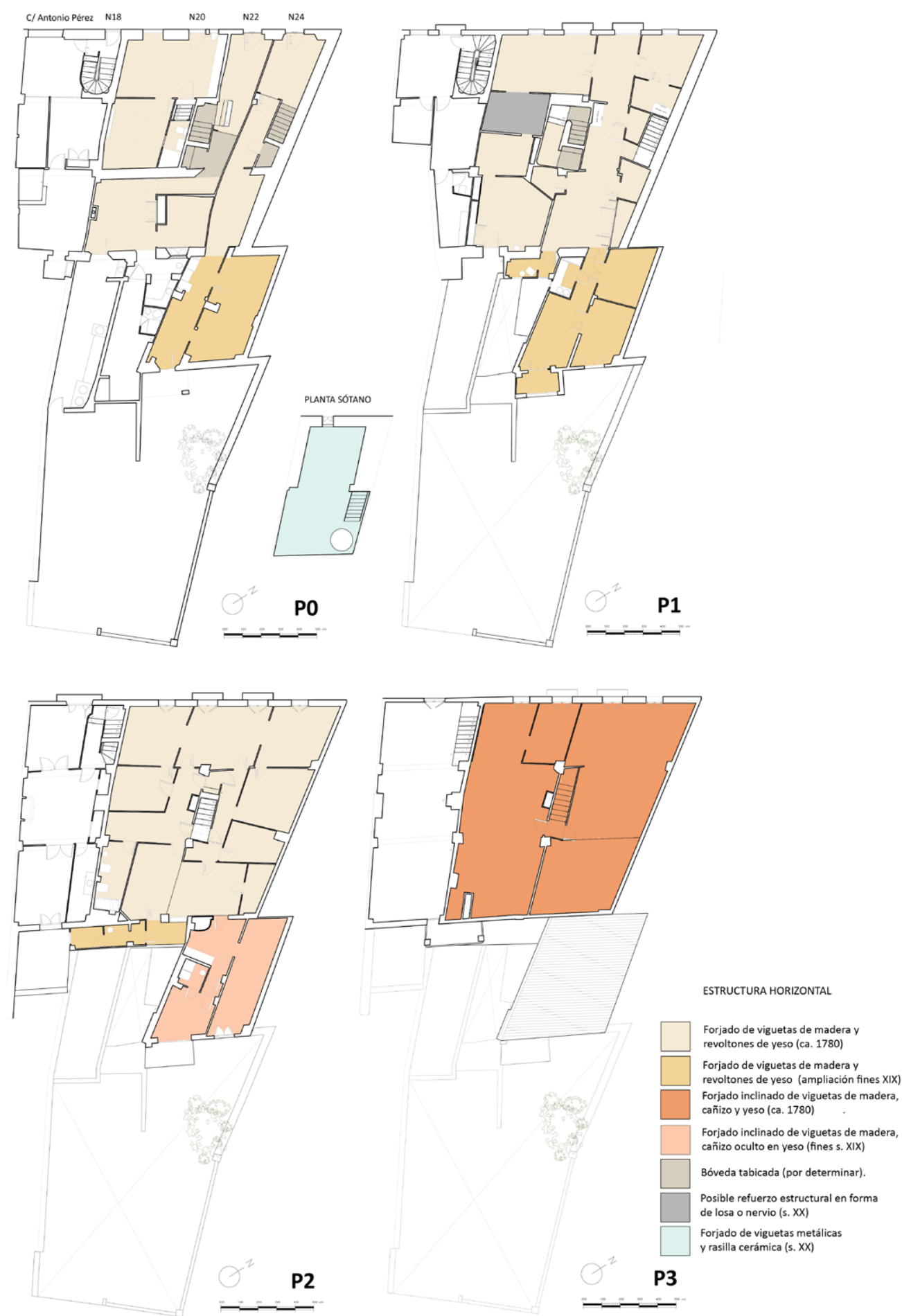

Fig. 806. Plantas de forjados. 
Los elementos integrantes de forjado se encuentran aparentemente en buen estado, no así el conjunto estructural, afectado en determinados puntos por el vencimiento de la medianera. Los elemento de madera, pintados, ocultan las posibles lesiones existentes. Aún no se ha procedido a hacer las oportunas catas, en zonas húmedas, cabezas de viga o caras superiores, para clarificar exactamente

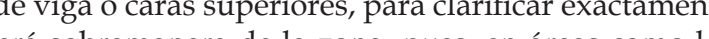
como la próximas a la medianera oeste, la que actualmente se encuentra expuesta a la intemperie, el agua de lluvia está siendo absorbida por las cabezas de viga. A su vez, filtra por los intersticios y se detectan muestras claras de presencia de hongos, no solo microscópicos, sino macroscópicos, como se observa en la fotografía de la alacena del primer piso.

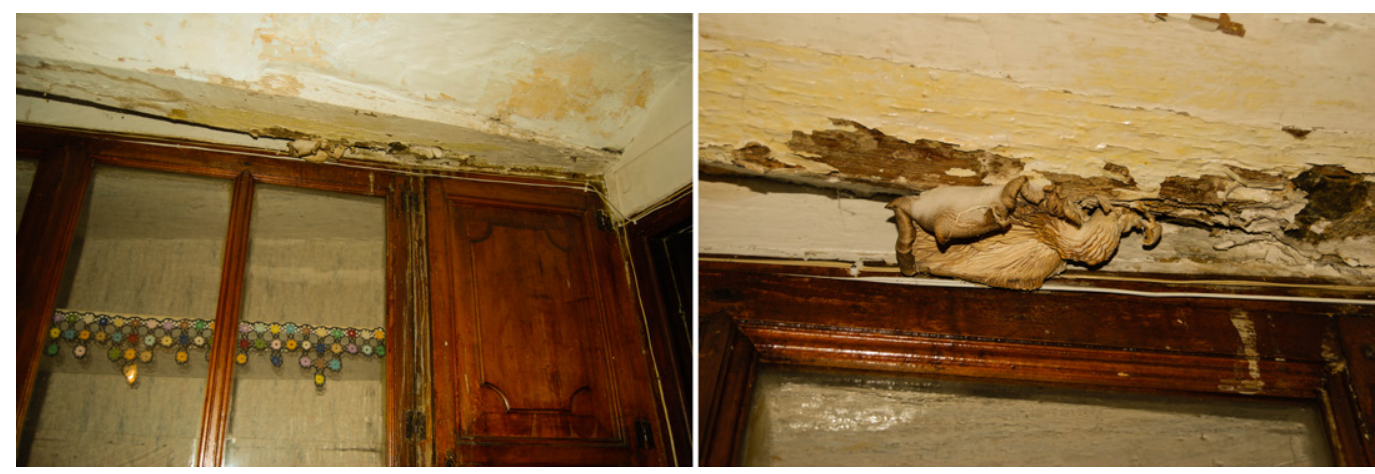

Fig. 807. Fotografía de afección de humedad sobre la alacena de la primera planta.

En la vivienda encontramos dos escaleras con mamperlán de madera, baldosas de barro cocido en la huella y pavimento cerámico blanco en la contrahuella, típicas en estas construcciones de finales del XVIII. Ambas están construidas con bóveda tabicada y enfoscadas con mortero de yeso por su intradós. Además, las dos escaleras incorporan un pasamanos continuo de madera curvada.

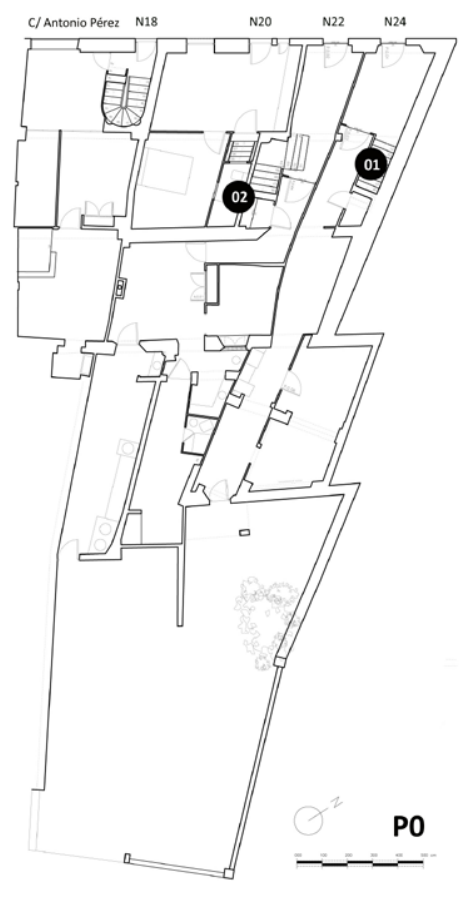

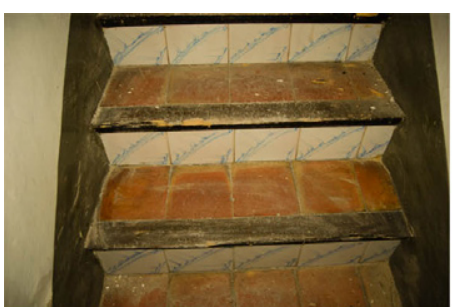
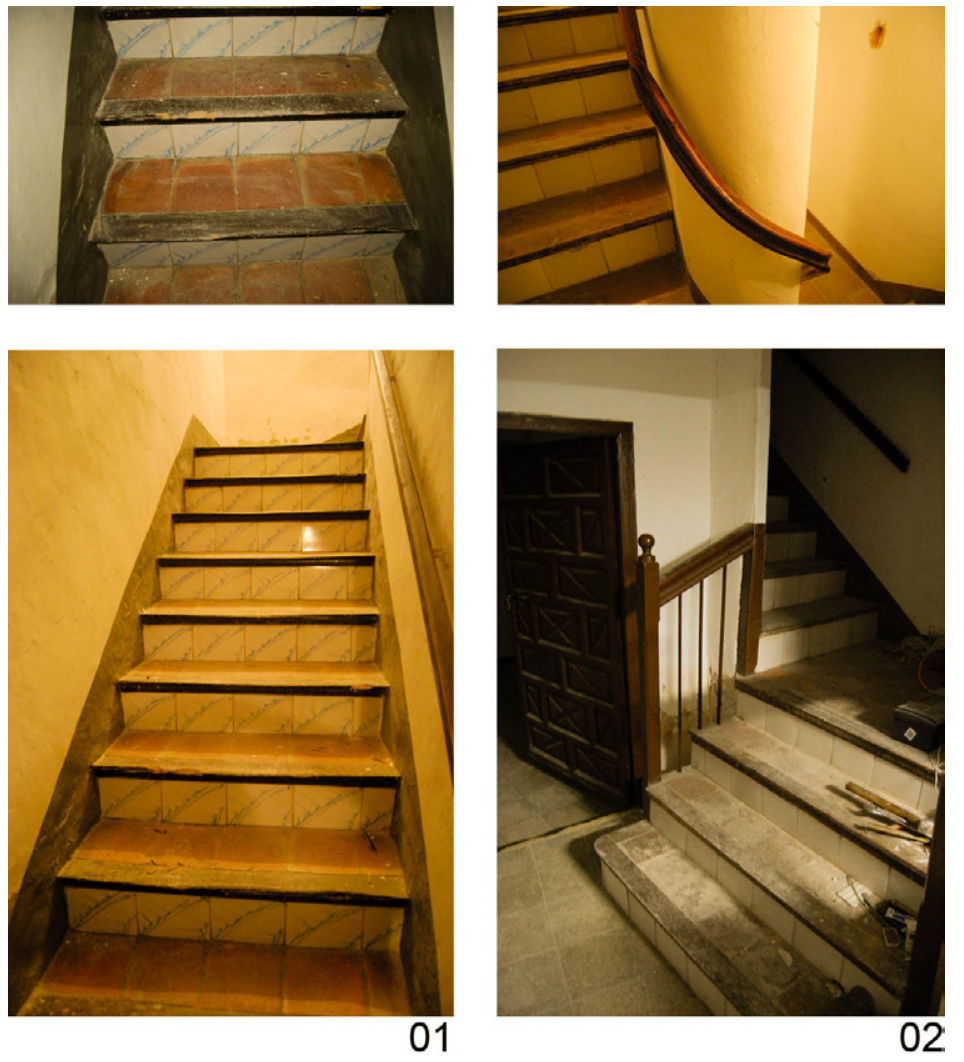

Fig. 809. Fotografías de las escaleras con los detalles del mamperlán de madera y la barandilla de madera curvada. La escalera 01 se corresponde con la escalera adosada a la medianera. La escalera 02 corresponde con la escalera central. Todas las fotos se toman en la conexión de planta baja a planta primera.

La cubierta se presenta en su estado original, con vigas y viguetas de madera, cañizo y capa de comprensión de yeso con teja árabe. Se encuentran en buen estado pese a las modificaciones y añadidos efectuados en la coronación de los muros donde apoyan las vigas.

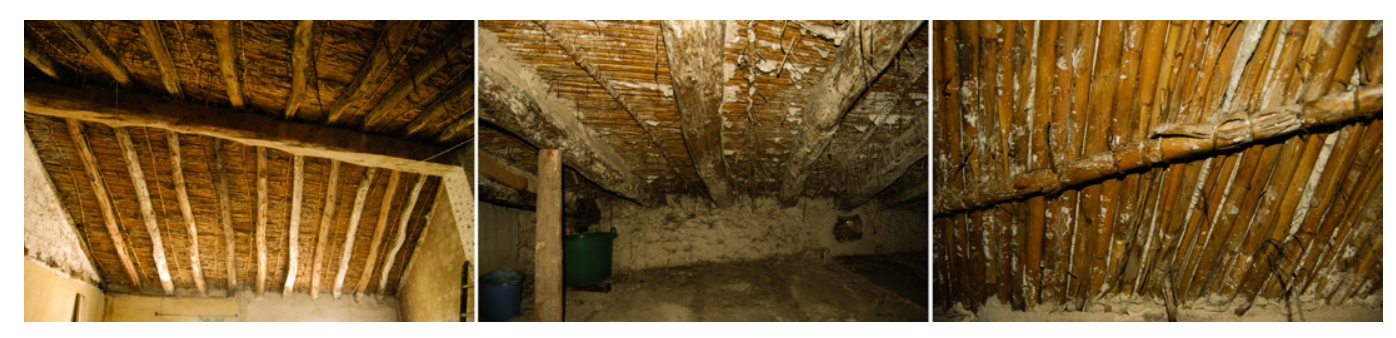

Fig. 810. Fotografías del espacio bajo-cubierta.

En una prueba de rascado de las paredes se han podido descubrir numerosos motivos decorativos polícromos bajo la actual de capa de color blanco. En ocasiones aparecen unos encintados en la zona del rodapié y bajo las vigas. En la primera planta existen numerosas capas polícromas superpuestas; al menos hemos identificado tres de interés. 
Fig. 811. Las imágenes 1 y 2 se corresponden con la misma zona de un mismo paramento (sala de estar de la alacena en la planta primera). La imagen número 1 refleja la capa original. La imagen número 2, la capa inmediatamente anterior al último revestimiento blanco. Entre ambas se detecto la presencia de un pigmento azulado que correspondería a una decoración intermedia imposible de rescatar al estar adherida a la penúltima capa.
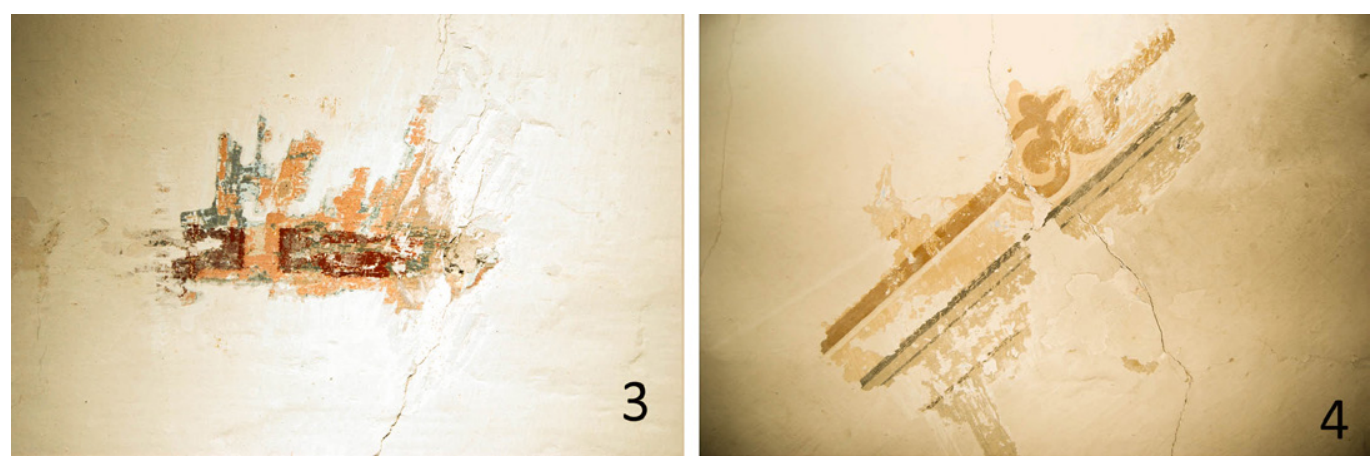

Fig. 812. Las imágenes 3 y 4 corresponden a paramentos diferentes. La 3 coincide con el paramento de las 1 y 2 con otra localización. La 4 corresponde con la decoración de la escalera lateral adosada a la medianera denominada anteriormente como 01 .

\section{Pavimentos}

Los pavimentos son de diversa índole. Hemos hecho referencia con antelación a los pavimentos que se encuentran en la planta baja, sin embargo los pavimentos más destacables los encontramos en las habitaciones septentrionales de la planta primera. Se trata de un pavimento de barro, con motivos (olambrillas vidriadas de terracota), que podría tratarse del pavimento de la casa original, ya que podría datar, por sus características, de finales del siglo XVIII según sostiene Pérez Guillén en su estudio sobre cerámica arquitectónica valenciana, aproximadamente hacia 1780 (Pérez Guillén, 1996). El motivo decorativo, en azulejo de $11 \times 11 \mathrm{~cm}$, verde azulado, verde oliva amarillo, naranja y morado. Representa un ramo de tallos cruzados con una naranja, una ciruela una palmeta trímera. Según Pérez Guillen es un pavimento localizado por la geografía valencian en la casa de Andrés Ochando en Requena, "pavimento del piso principal, en el antiguo convento de San Sebastián (Rocafort), en el zócalo del presbiterio de la iglesia parroquial de Villar del Arzobispo, en el Museo Nacional de Cerámica de Valencia, en el Museo Municipal de Xátiza" (Pérez Guillén, 1996:87). También la encont parroquial de San Nicolás de Valencia, así como en la iglesia parroquial de Onda. Sostiene Pérez que "sin ningún fundamento histórico documental se la denomina 'pometa'" (Pérez Guillén, 1996:87). En la obra La pintura ceràmica a Carcaixent (Guerola i Blay, 2002:362), se asocia este pavimento (taulells)

con el rococó, concretamente a mediados del siglo XVIII, en una disposición idéntica al que nos encontramos: combinados con barro cocido, disponiéndose en el lateral de los vértices. En este caso se sostiene que los dos frutos, "pometes", podrían ser realmente granadas, una pintada de amarillo y naranja en primer término y otra en segundo plano de manganeso violáceo.
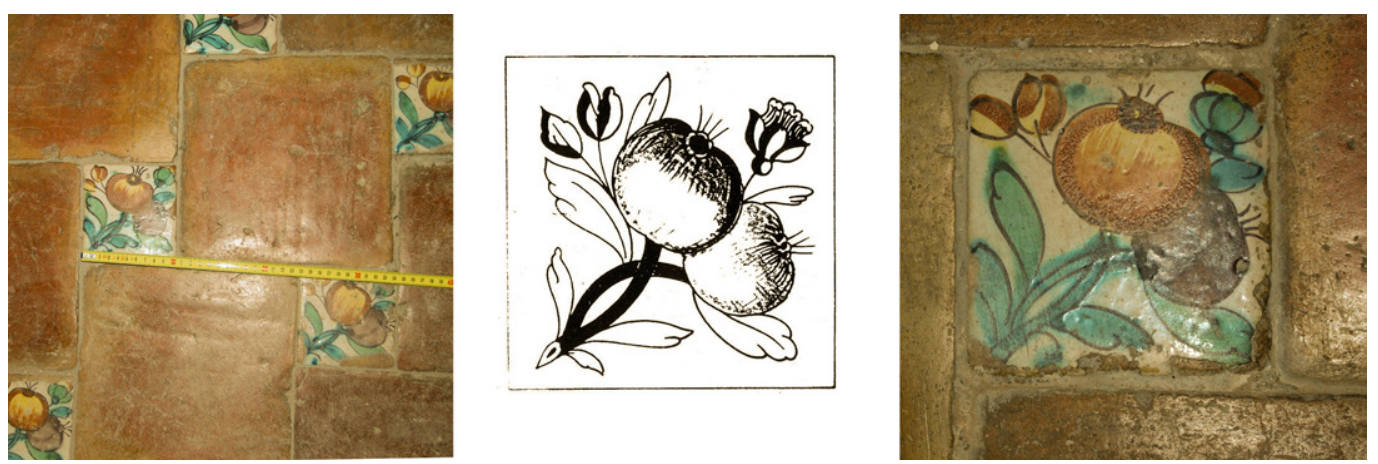

Fig. 813. Pavimento "de pometa" de finales del siglo XVIII localizado en la planta primera.

Este pavimento, solo localizado en la planta primera, permitiría sostener alguna conjetura relacionada con posibles ampliaciones del edificio, o de una edificación que solo alcanzara la primera planta, dado que esta hipótesis coincide con la hipótesis de alteración de la escalera principal. Un pavimento de barro de las mismas dimensiones y estado de deterioro, se localiza en el primer tramo de la escalera central, desde planta baja a planta primera.

El sector central de la planta primera, hasta la antigua fachada, mantiene solo el pavimento de barro con idéntico formato. Sin embargo, en las supuestas ampliaciones meridionales, el pavimento cambia a un pavimento hidráulico propio del siglo XIX.
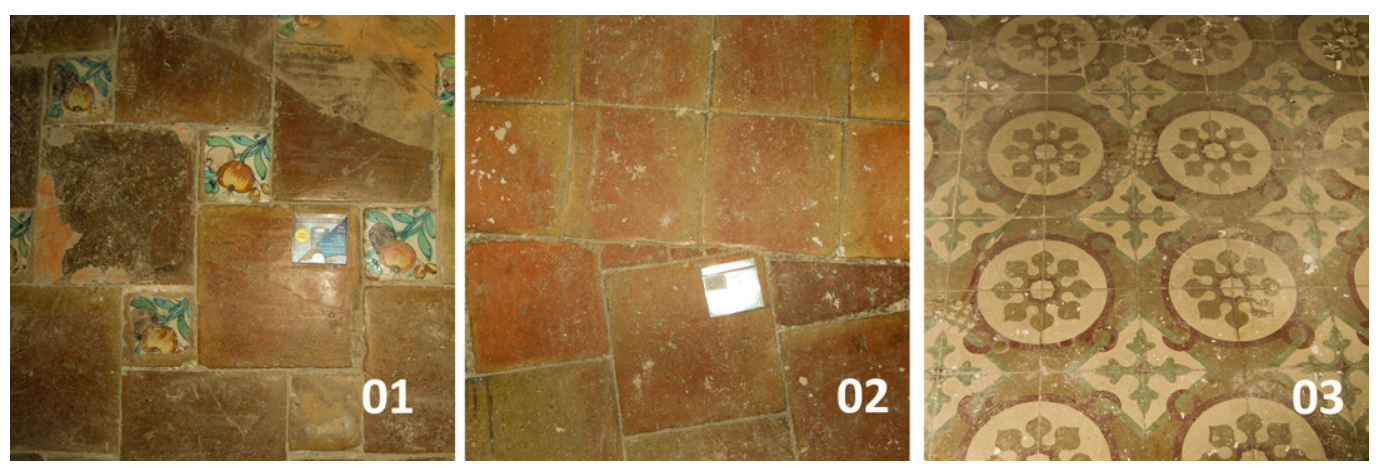

Fig. 814. Pavimentos de planta primera. 01, pavimento de "pometa" (siglo XVIII). 02, pavimento de barro (siglo XVIII) por idénticas características de formato y desgaste. 03 , pavimento hidráulico (siglo XIX).

En la planta segunda los pavimentos son todos hidráulicos, propios del siglo XIX, con tres motivos diferentes. Se sostiene que este tipo de pavimento, fabricado con cemento con una delgada capa final con dibujos de colores, se inició a finales del siglo XIX (Vegas \& Mileto, 2011:148). 

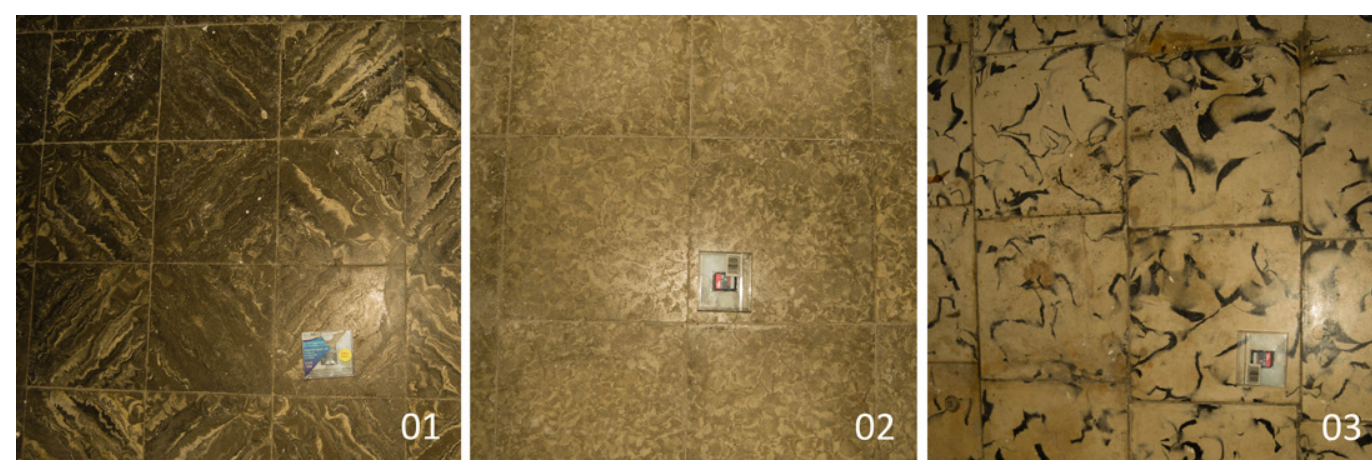

Fig. 815. Pavimentos localizados en la planta segunda. Pavimentos hidráulicos 01, 02 , 03 (siglo XIX o XX). Encontramo en un area el mismo pavimento de baldosa hidraulica bícroma, 02 , con marcas de agua que se localiza en planta baja posiblemente correspondiendo a la reforma de 1945
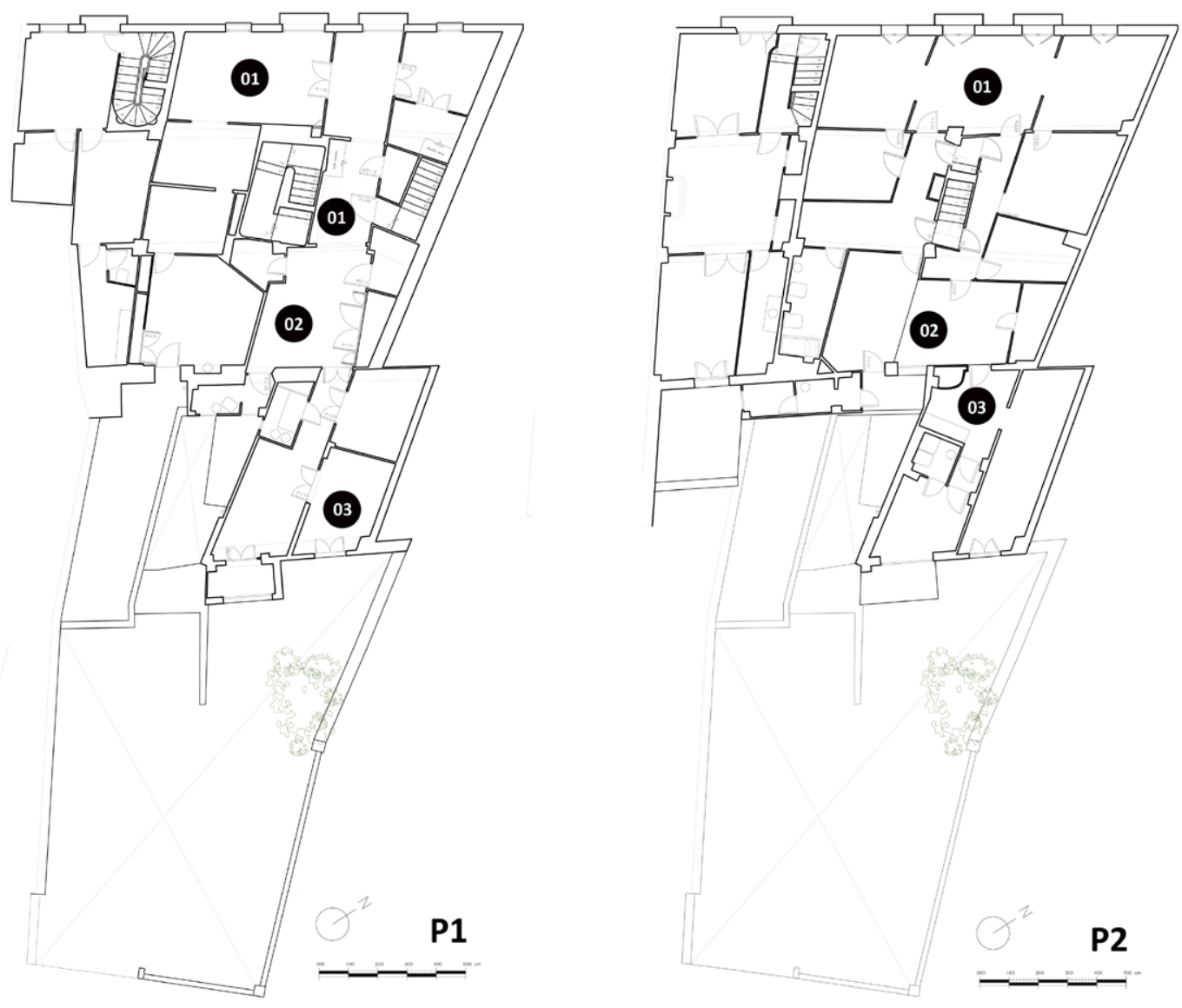

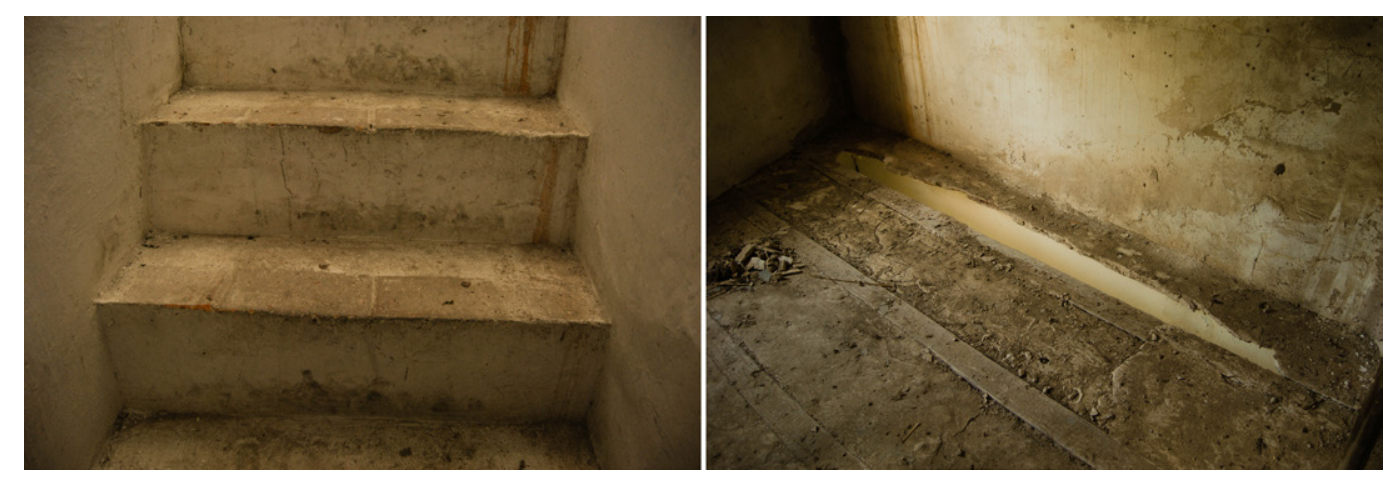

Fig. 818. Pavimento de barro de la estrecha escalera de un tramo que comunica la planta segunda y el espacio bajo cubierta o planta tercera. A la derecha se observa que este se encuentra si pavimentar, con las viguetas de madera vistas y el revoltón de yeso. En el detalle se observa el desprendimiento del revoltón ante el cedimiento de la pared medianera.

Carpinterías

El contraste entre unas carpinterías y otras, localizándose las de características comunes en áreas concretas, permite sostener la hipótesis de las fases de construcción, especialmente cuando se comprueba la correspondencia entre pavimentos, carpinterías, estructuras y secuencia de espacios (véase plano de carpinterías interiores que se adjunta con la docusecuencia de
mentación).

Las carpinterías interiores permiten distinguir, por su formato y por su componente ornamental, grupos que se distribuirían a finales del siglo XVIII, mientras que otros son más propios de finales del siglo XIX y principios del siglo XX.

En el primer caso, puertas más bajas y anchas, aunque no existen unas dimensiones fijas (véase plano de carpinterías) de apertura simple o doble, con una decoración predominante en forma de e vertical o apaisado, con grabados ganelado cuadrangula uniforme. Las puertas más primitivas no cuentan con bisagras, sino con cáncamos.

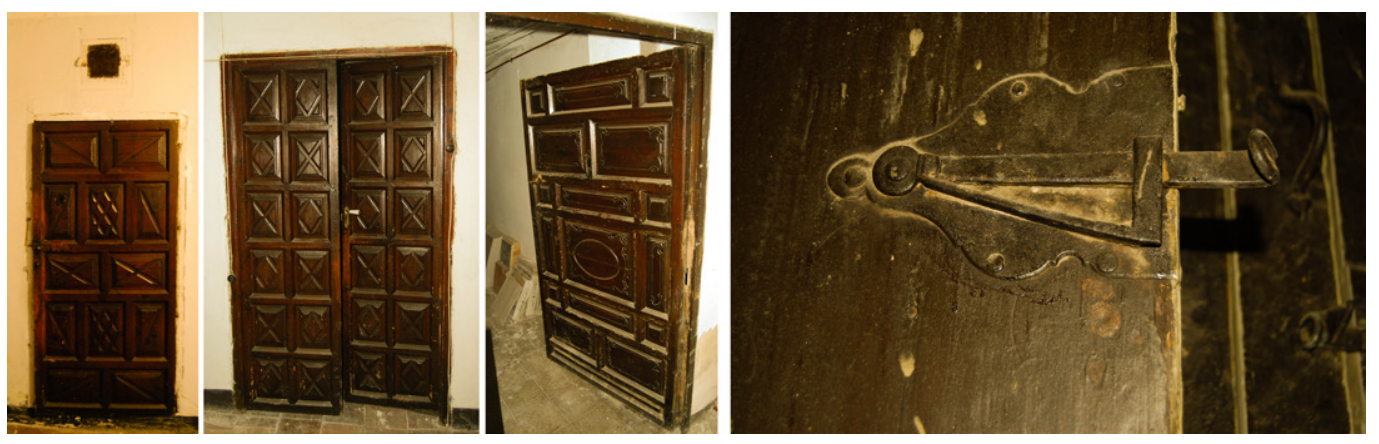

Fig. 819. Carpinterías interiores que posiblemente se encuentran en la primera construcción, por sus caseptentrional). 


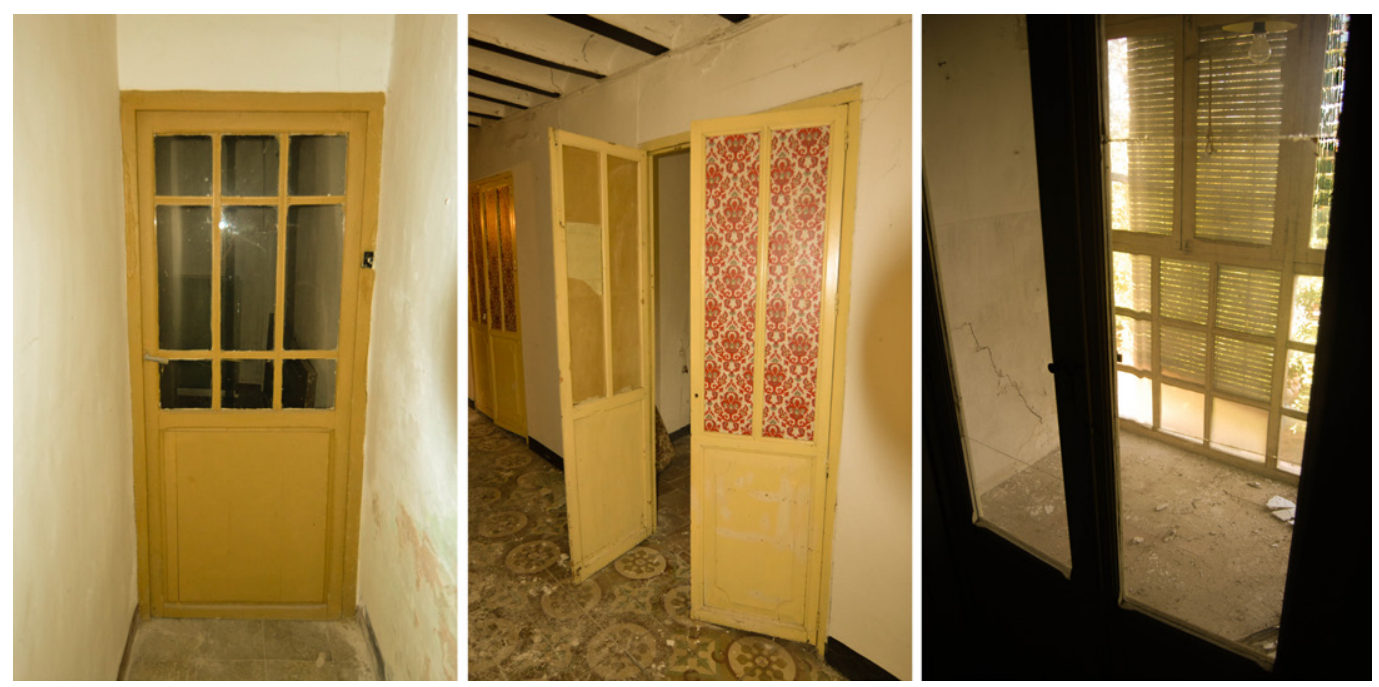

Fig. 820. Puertas localizadas en los anexos que se adosan en la fachada posterior al cuerpo original de finales del siglo XVIII. El formato de las puertas hace pensar en carpinterías de finales del siglo XIX o principios del siglo XX.

Una ayuda en la datación de las carpinterías interiores la pueden aportar las manillas de las puertas. Por lo general hablamos de herrajes de fundición con pomos de porcelana blancos sin decoración que podrían datar de finales del siglo XIX y principios del siglo XX, coincidiendo con las ampliaciones o reforma de la vivienda.
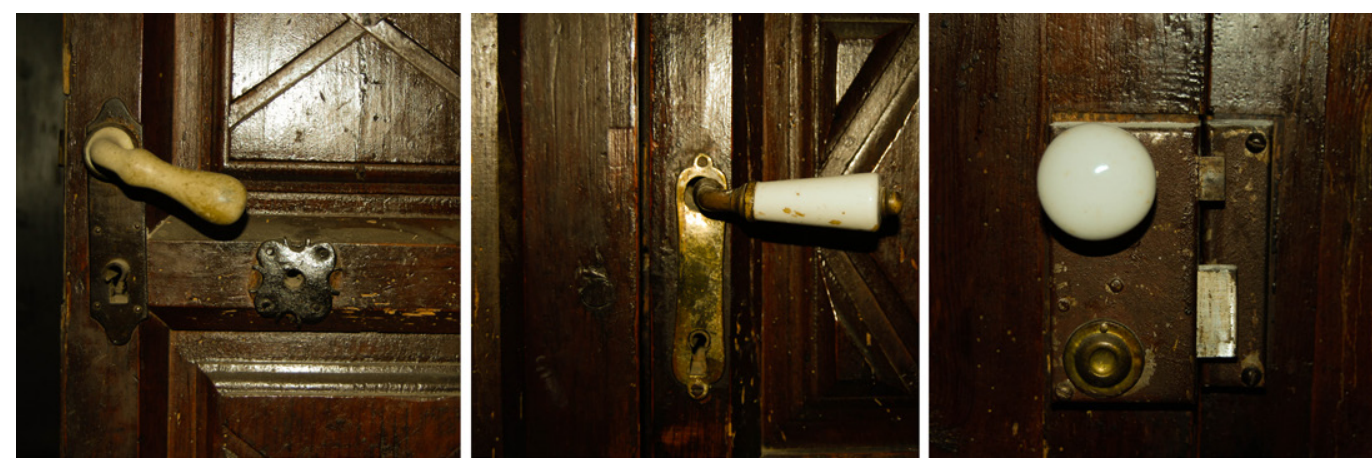

Fig. 821. Manijas y pomos de porcelana implementados en las puertas históricas.

Las puertas exteriores de planta baja recayentes a la C/ Antonio Pérez presentan diversas características. Llamaremos la atención sobre las dos puertas de la esquina noreste (núm. 24 y 22), idénticas. Difieren de la puerta y los huecos abiertos ex novo en el núm. 20, suponiendo una composición cas. Difieren de la puerta y los huecos abiertos ex novo en el núm. 20, suponiendo una composición
simétrica de fachada. Precisamente, el núm. 20, se correspondió con la porción de fachada ocupada por el personal de servicio, que habilitó en ese sector de la casa una pequeña vivienda.
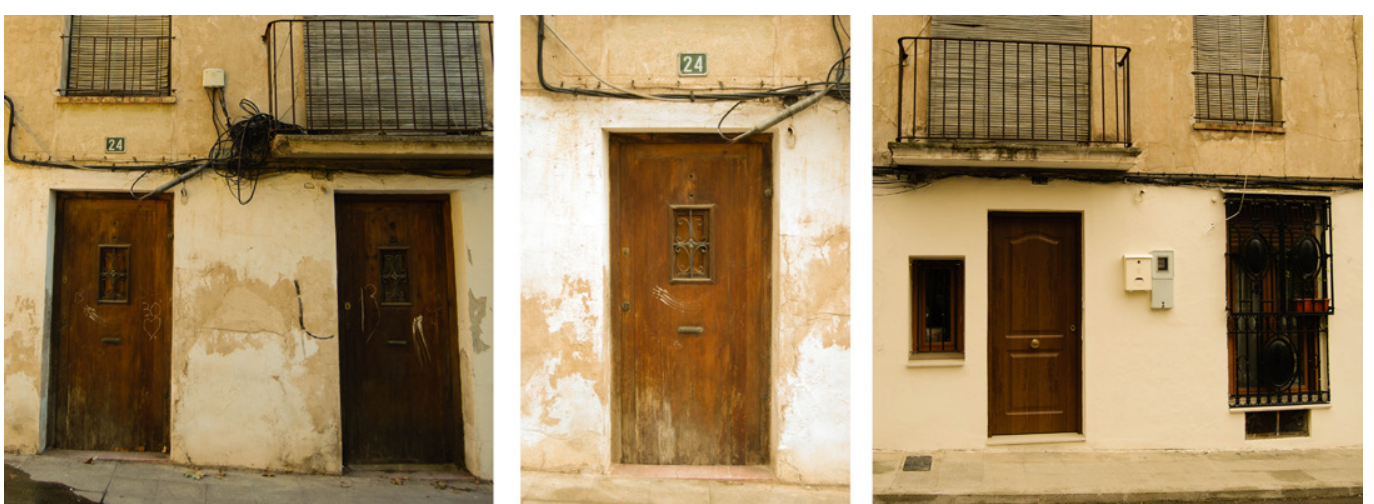

Fig. 822. Puertas exteriores de la fachada principal. En el el propietario del número 20 .

Las carpinterías exteriores en los niveles superiores de la fachada podrían tratarse de las carpinterías originales. Con doble hoja batiente con carpintería de madera y vidrio simple y fraileros, o contraventanas interiores colgadas de la propia hoja. Parece que las ventanas originales no incluían los paños de vidrio y éstos debieron de ser añadidos posteriormente con la ayuda de un junquillo superpuesto en la parte exterior de la sección. La forma y el tamaño de los herrajes de esta ventana nos confirman la fecha de su construcción a finales del siglo XVIII.

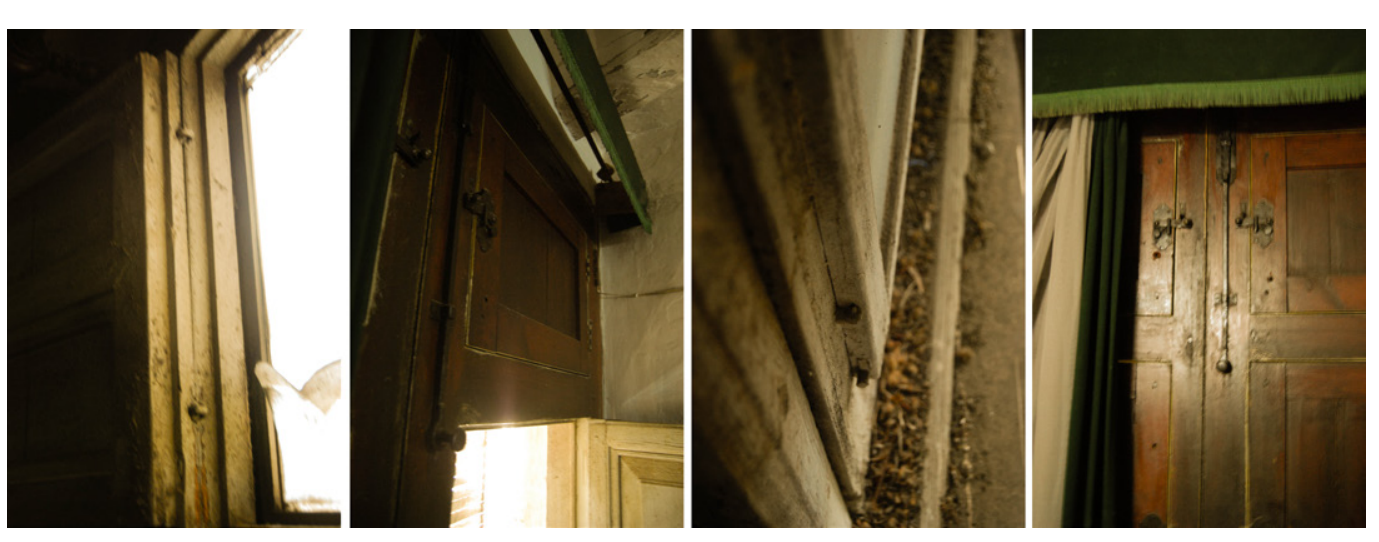

Fig. 823. Detalles de las carpinterías exteriores de la fachada principal. Se pueden observar los fraileros, también el vidrio adosado por el exterior con marco de madera y los herrajes.

En la fachada posterior nos encontramos carpinterías de madera con vidrio instaladas a hueso que delatan una fecha más reciente, finales del siglo XIX o principios del XX, acorde con esta fase de ampliación. 


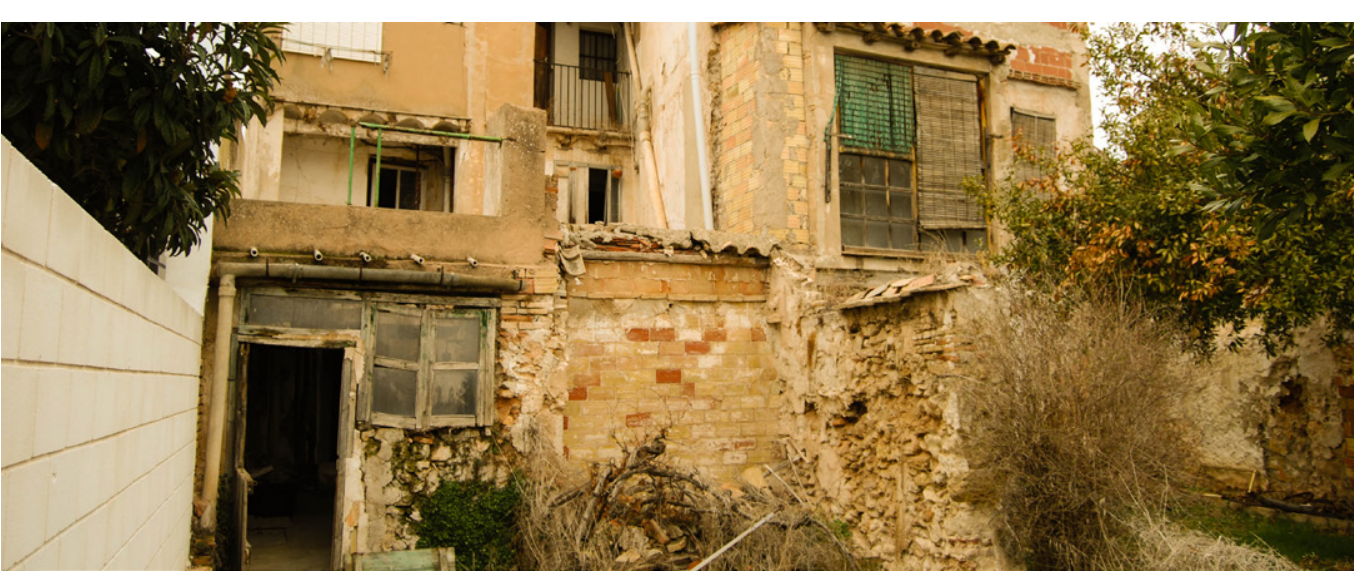

Fig. 824. Detalle del conglomerado de añadidos de la fachada posterior. Se observa en primer plano carpinterías de madera y vidrio, muy deterioradas, enrasadas a la fachada.

Rejería

Resulta interesante la presencia de un elemento de rejería interior. Se trata de una rejería metálica tradicional enrasada que cierra el hueco con derrame del muro estructural de la primera construcción del siglo XVIII, que ayuda a asociar dicho límite con un límite entre exterior e interior en sus ción del
orígenes.

Respecto a los balcones, los únicos que encontramos en el edificio se localizan en la fachada principal, en los pisos primero y segundo. Hay que distinguir los balcones salientes de forja de los cuatro huecos centrales, de los antepechos de forja de los huecos laterales. El sistema de protección a la caída está constituido por barras verticales ancladas a las pletinas horizontales, superior e inferio mediante martillado en caliente. La separación entre montantes es de aproximadamente un palmo $(21 \mathrm{~cm})$ lo que nos indica que su fecha de construcción es con toda probabilidad posterior a mediados del siglo XVIII. Solo los dos balcones centrales de la planta segunda presentan una decoración en hierro floral integrada en el centro de los barrotes verticales. Dicha ornamentación coincide con la del hueco-mirilla de las puertas principales de planta baja, lo cual permite asociar al artesano productor de los herrajes de estas puertas y de la forja de los balcones. La pletina inferior se remach con otras perpendiculares que se empotran en el muro de fachada conformando la bandeja del balcón. La base responde al tipo tradicional con sota-balcón de baldosas, en este caso hidráulicas, apoyadas sobre un enrejado metálico inferior. Por encima se encuentra una capa de mortero de cal sin piezas de borde sobre la que se dispone el pavimento de los balcones (Vegas \& Mileto, 2011: 175).
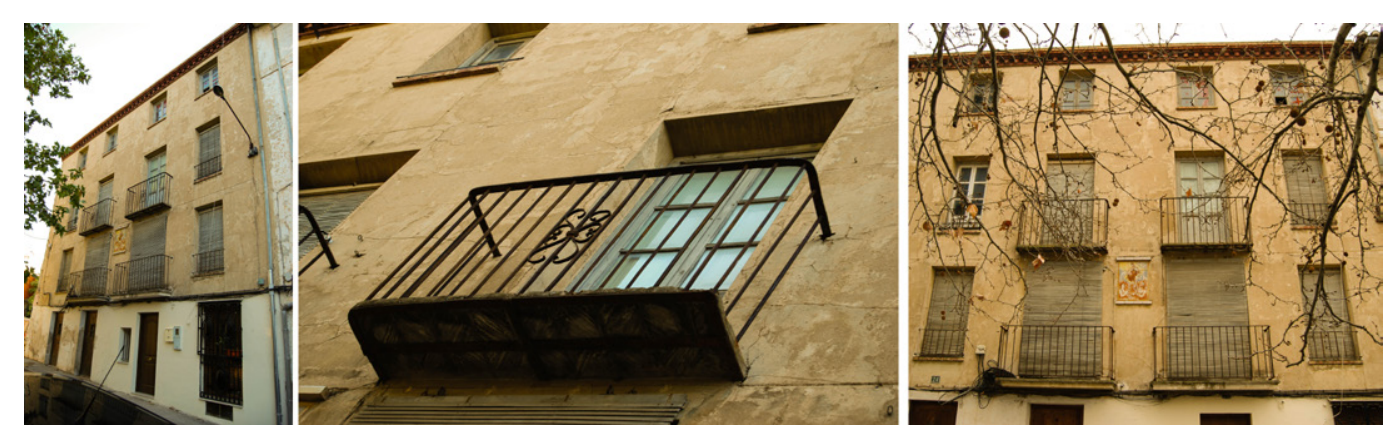

Fig. 825. Fachada principal a la C/ Antonio Pérez. Detalle de balcón y composición de huecos.
Entre otros elementos ornamentales significativos de la fachada es resaltable el remate pétreo en forma de canecillos de la cubierta. Este remate podría estar asociado a una intervención más reciente debido a su estado de conservación respecto a la totalidad del edificio. Posiblemente alguna reparación de los elementos salientes de cubierta, por desprendimientos, no registrada, que debió quizás efectuarse paralelamente a la intervención de 1973, cuando se revocó la fachada con un acabado a la tirolesa. Este revoco consistiría en la proyección de un mortero de cal de granulometría gruesa que aporta un acabado satinado pero inferior en finura al revoco tendido. Se supone que se escogió por su facilidad en la puesta en obra. Consistía en aplicar una primera capa de enfoscado con el fratás y dos más salpicando el paramento con una escobilla untada en mortero. El resultado final se cepilló a fin de eliminar los granos sueltos.

El remate por el que se optó no parece corresponder con el tradicional en edificios de la época que podemos localizar en Requena. Tal y como sucede en la fachada posterior, lo más probable es que nos encontráramos con una prolongación de la estructura de cubierta, por tanto, un sistema de alero de cañizo y correas de madera. Dado el mal estado de conservación, como se verifica en el alero similar de la fachada posterior, y la necesidad de reconducir las aguas, se debió de optar por la incorporación de esta cornisa con el canal de desagüe integrado.
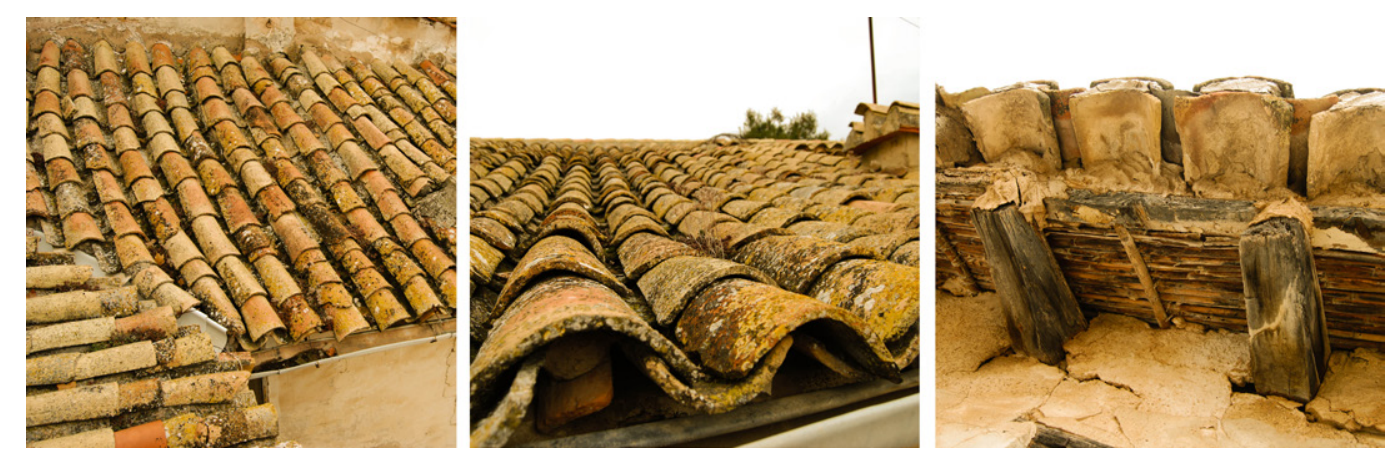

Fig. 826. Solución de remate en diferentes sectores de la cubierta en la fachada posterior.

Sobre la posible integración de la casa en la estructura fortificada

Es preciso no perder de vista que el análisis de los números 18, 20, 22 y 24 de la C/ Antonio Pérez tenía por objeto dirimir la posible presencia de algún vestigio concluyente del trazado fortificado liberal. Lo que nos hemos encontrado al visitar las viviendas no difiere mucho de lo intuido en otros sectores del frente que, a fin de cuentas, constituyó la realidad de la gran mayoría de perímetros urbanos rurales: la edificación define un límite claro de la ciudad, normalmente continuo, dado que hablamos de un coniunto de viviendas urbanas ente medianeras. Este límite de sólido arquitectónico destinado a la vivienda define una fachada hacia el interior de la ciudad nítida y compuesta para satisfacer su carácter urbano. No sucede así con el límite extramuros. La habitual tendencia de habilitar huertos particulares extramuros convierte el límite exterior en un límite realmente difuso, en la medida que el espacio de los huertos tienta a los propietarios a incorporar nuevos elementos cubiertos. Primero serán corrales, o tapias bajas para habilitar cobertizos, quizá para el ganado o los aperos, pero más adelante esos cobertizos se convertirán en prolongación de la vivienda y surgirán nuevos añadidos. Progresivamente no solo se avanza extramuros, sino que también se coloniza en altura. Por tanto hablamos de un área de crecimiento orgánico, en continua transformación, una banda superficial de terreno de ocupación imprecisa, unos espacios exteriores, convertidos en interiores o espacios de transición.

$\mathrm{Al}$ mismo tiempo, el elemento murario original, la masa, se contamina de ese carácter difuso en una pugna continua por la necesidad de cierre en tiempos de guerra, y por la necesidad de permeabilidad en tiempos de paz. Esta es la esencia, el símbolo perpetuo de la muralla decimonónica, que se ilustra con la imagen escogida para la portada de este trabajo: la pared que quiere ser muro, aspillera, ventana.. 


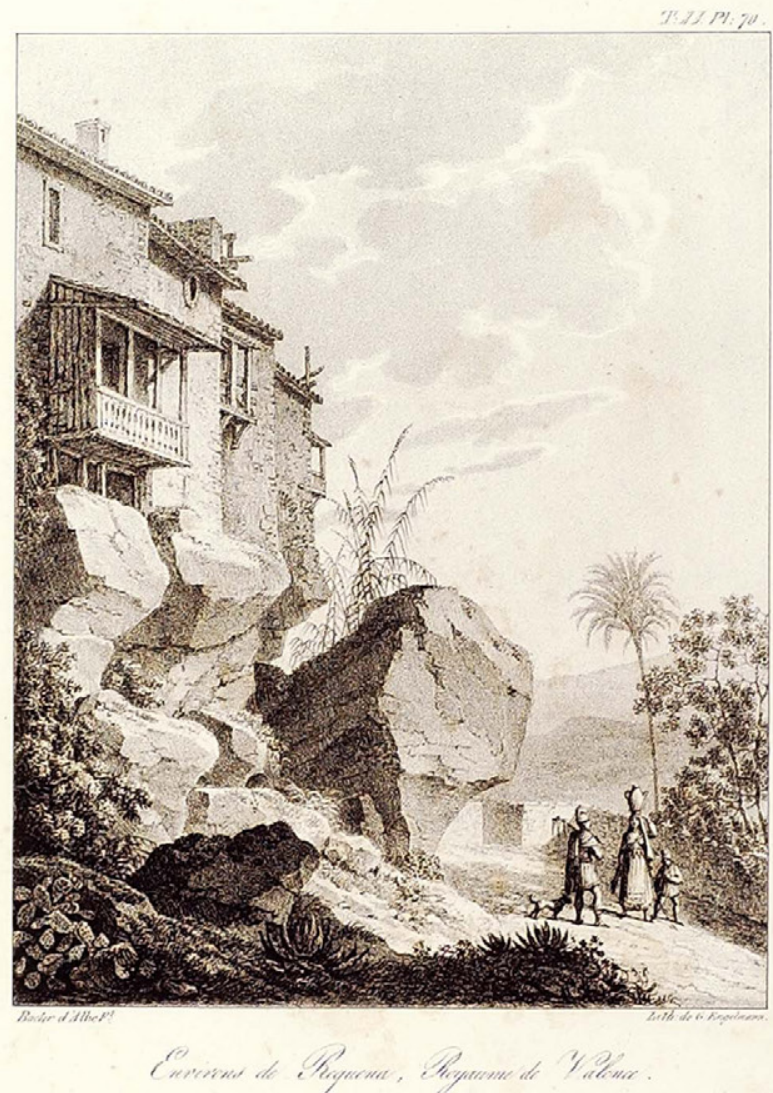

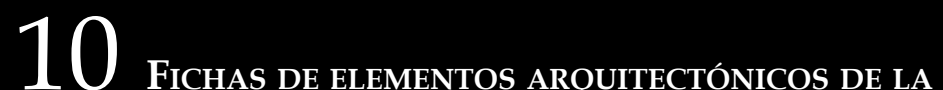
FORTIFICACIÓN DE REQUENA 
001 Puerta de Valencia

\section{- Identificación}

Tramo de estudio: Otras denominacion

rramo 1: Puerta de Valencia-Puerta de Alcalà

Ref. catastral:

Localización: C/ Desamparad
Desamparados

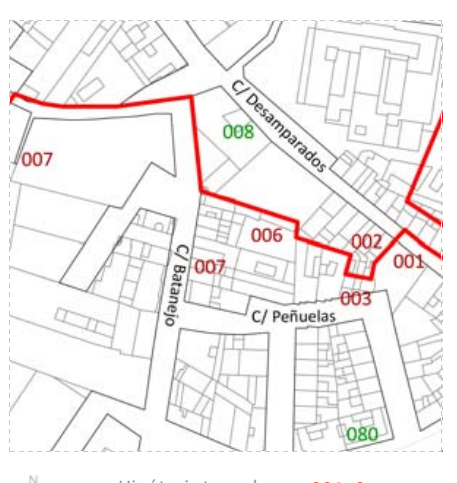

..... Dudas de trazado

O0A Supuesto
OOA Existente

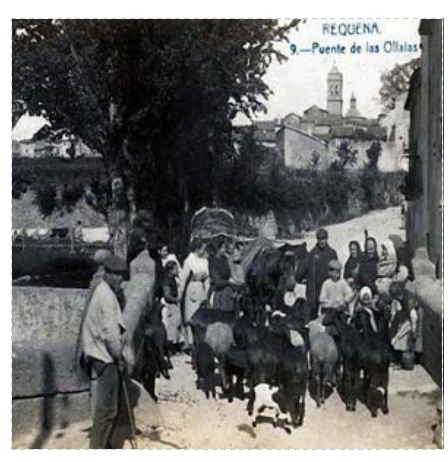

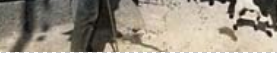

- Referencias en documentación histórica

\section{Referencias numéricas en cartografía sobre fortificación}

-Ref. en el croquis de Ortiz de Pinedo (1837-38, AGM, núm. 262): 007

-Ref. en plano de Vera Aparici (1993): Sin ref.

Referencias en memorias técnicas militares

-Ref. Guillermo Sáez (9/9/1834-5/12/1835): Requena, 5/12/1835 AMR, 1818-50

Se cierran las puertas y ventanas baja y se aspillera la pared de Juan Antonio Ponce. Se sobreentiende que se hace referencia a fortificar la puerta de Valencia o "de las Ollerías" y no el barrio que quedaba en las afueras.

-Ref. Guillermo Sáez (26/02/1836):Sin ref.

-Ref. P. Ortiz de Pinedo (12/03/1837-30/05/1837): Requena, abril de 1837, AMR, 1818-52

-Ref Jose María de Orozco (25/03/1838): Requena, 25/03/1838, AMR 1818-24

-Ref. Carbonell (4/7/1838): AMR, 1818-17, fol. 4

- Observaciones a partir de los informes militares

La Puerta de Valencia, o de las Ollerías, constituía el acceso a la ciudad desde el antiguo camino de Valencia que transita por el puente de Santa Cruz o de las Ollerias.

$\square \frac{\text { Rellenar en caso de que el elemento sea }}{\text { contemplado con datos del PGOU, } 2013}$
PROTECCIÓN Nivel de protección

Entorno:

$\square$ Inmueble

$\square$ Inmueble

$\square$ Recinto arquitectónico

$\square$ Entorno específico
AFECCIÓN PATRIMONIAL

$\square$ Bien de interés cultural (BIC)

$\square$ Bien de relevancia local (BRL)

$\square$ Afectado entorno BIC

$\square$ Afectado Plan especial
Incluido en fichas PGOU 2013 Dien de intés cultural

cód. postal: 46340

Autonomia: Comunidad Valencian 
- Descripción histórico-arquitectónica

\section{Tipología:}

Cronologia:

Observaciones a la cronologia

\section{Descripción}

- Entorno urbano

Descripción entorno urbano:

Uso actual:

Estado de conservación:

Intervenciones:

Régimen Urbanístico:

Titularidad:

Nivel protección s/catálogo 1996:

Bibliografía: AMR, 1818-17, 1818-24; 1818-50; 1818-52; 1818-53.

observaciones generales:

$\begin{array}{lll}\text { OBJETIVACIÓN DE INTERÉS } & \text { Soluciones constructivas } & \text { Soluciones ornamentales } \\ \square \text { Interés tipológico } & \square \text { Estructura } & \square \text { Carpintería } \\ \square \text { Valor ambiental } & \square \text { Aleros } & \square \text { Rejería } \\ \square \text { Vigencia de la trama } & \square \text { Coronación } & \square \text { Cubrepersianas } \\ \square \text { Composición de la fachada } & \square \text { Jambas } & \square \text { Alicatados } \\ \square \text { Materiales, color, textura } & \square \text { Dinteles } & \square \text { Recercos } \\ & & \square \text { Dinteles } \\ & & \square \text { Otros ornamentos }\end{array}$

Interés paisajistico
$\square$ Incidencia visual
$\square$ Carácter articulador
$\square$ Organización
$\square$ Interés cultural
$\square$ Carácter representativo

\section{- Datos específicos catalogación BIC $\square$ Rellenar sólo si está catalogado BIC}

\section{Datos Jurídicos:}

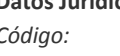

Estado:

Categoria:

Fecha Disposición:

Tipo delimitación:

Anotación $M$

Plan:

Fecha informe:

Fecha Publicación BOP:

Fecha Publicación DOCV:
002 Casas de Manuel Ponce. Casa D. Juan Antonio Ponce. Casas de Amorós

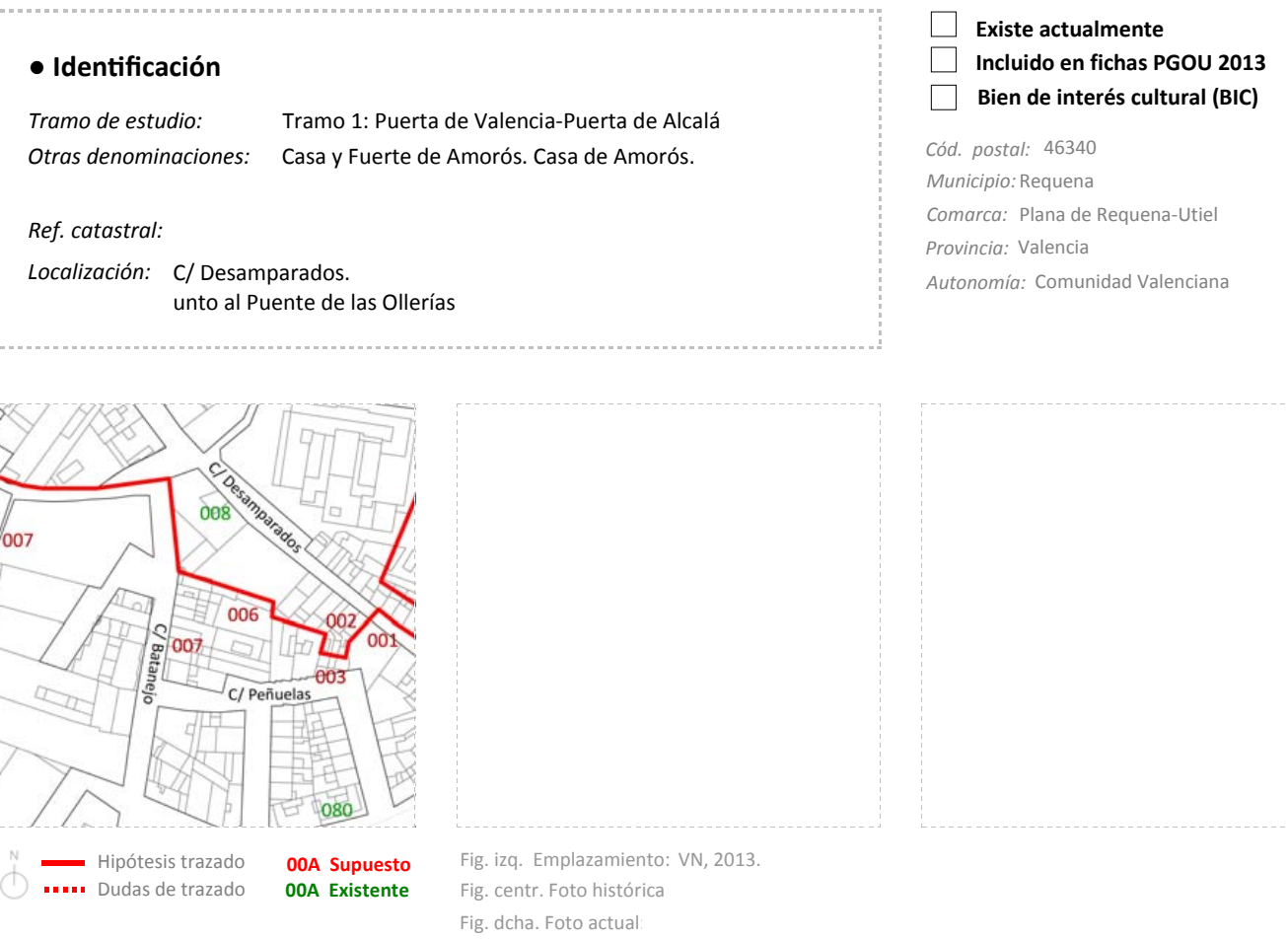

- Referencias en documentación histórica

\section{Referencias numéricas en cartografía sobre fortificación}

-Ref. en el croquis de Ortiz de Pinedo (1837-38, AGM, núm. 262): Sin ref.

-Ref. en plano de Vera Aparici (1993): Sin ref.

Referencias en memorias técnicas militare

-Ref. Guillermo Sáez (9/9/1834-5/12/1835): Sin ref.

-Ref. Guillermo Sáez (26/02/1836): Sin ref.

-Ref. P. Ortiz de Pinedo (12/03/1837-30/05/1837): Sin ref.

-Ref Jose María de Orozco (25/03/1838): Sin ref.

-Ref. Carbonell (4/7/1838): AMR, 1818-17, fol. 4

"En la pared que mira al barrio de las Ollerias se abriran aspilleras en todos los cuerpos, y se tabicará el balcón hasta la altura de 4 1/2 pies. Asi mismo se aspillerarán las demás parédes de esta clase y las inmediátas hasta las del Batanejo, en los frentes y pisos que

descubran el campo" (Carbonell, Requena, 4 de julio de 1838, AMR, 1818-17, fo. 4).

\section{- Observaciones a partir de los informes militares}

El único dato que tenemos es la descripción de su ubicación, que no queda del todo clara. Parece que se ubica en el entorno del Puente de las Ollerías. No forman parte del Barrio de las Ollerías y, puesto que sí lo hacen de la defensa, debe tratarse del conjunto de casas que, por las fotos historicas, se concentran en el lado septentrional de la C/ Desamparados.

La Casa de Manuel Ponce se ubica contigua a la Puetla de Valencia y puede ser batido por el enemigo desde el Barrio de las Ollerías. Tien poca concentración de fuego en el frente desde el Huerto de la Casa de Don Juan Antonio Ponce hasta el camino de las casas de Amorós. 
$\square \frac{\text { Rellenar en caso de que el elemento sea }}{\text { contemplado con datos }}$

\section{PROTECCIÓN}

Nivel de protección:

Entorno:

$\square$ Inmueble

$\square$ Parcela catastral

$\square$ Recinto arquitectónico
AFECCIÓN PATRIMONIAL

$\square$ Bien de interés cultural (BIC)

$\square$ Afectado entorno BIC

$\square$ Afectado Plan especia

\section{- Descripción histórico-arquitectónica}

\section{Tipología:}

Cronología:

Observaciones a la cronología

Descripción:

\section{- Entorno urbano}

Descripción entorno urbano:

Uso actual:

Estado de conservación:

Intervenciones:

Régimen Urbanístico:

Titularidad:

Nivel protección s/catálogo 1996:

Bibliografía: AMR, 1818-17, 1818-24; 1818-50; 1818-52; 1818-53.

Observaciones generales:

\section{OBJETIVACIÓN DE INTERÉS}

$\square$ Interés tipológico

$\square$ Valor ambiental

Vigencia de la trama

$\square$ Materiales, color, textura

Soluciones constructiv
$\square$ Estructura
$\square$ Aleros
$\square$ coronación
$\square$ Jambas
$\square$ Dinteles

Soluciones ornamentales
$\square$ Carpintería
$\square$ Rejería
$\square$ Cubrepersianas
$\square$ Alicatados
$\square$ Recercos
$\square$ Dinteles
$\square$ Otros ornamentos

Interés paisajistico

$\square$ Incidencia visual

$\square$ Carácter articulador

$\square$ Organización

$\square$ Interés cultural

Carácter representativo

\section{Barrio de las Ollerías}

- Identificación

Tramo de estudio: Tramo 1: Puerta de Valencia-Puerta de Alcalá

Otras denominaciones:

Ref. catastral:

Localización: C/ Ollerías. Entorno de la calle Ollerías, pasado el puente de Sta. Cruz o de las Ollerías, hasta el actual cementerio.

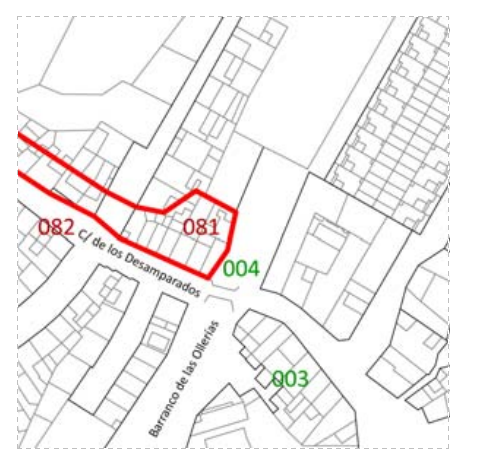

-.... Dupótesis trazado de trazado

O0A Supuesto
OOA Existente

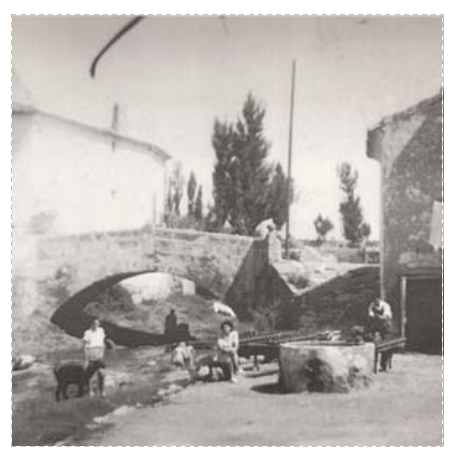

Fig. izq. Emplazamiento: VN, 2013.

$$
\begin{aligned}
& \text { Fig. centr. Foto histórica Jordá, 2000: fig. } 29 \\
& \text { Fig. dcha. Foto actual:VN, } 2013
\end{aligned}
$$

$\nabla$ Existe actualmente

$\square$ Incluido en fichas PGOU 2013

Bien de interés cultural (BIC)

cód. postal: 46340

Municipio: Requena

Comarca: Plana de Requena-Utie

Provincia: Valencia

Autonomia: Comunidad Valencian

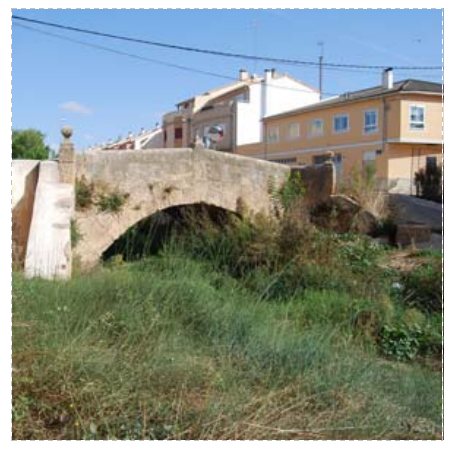

- Referencias en documentación histórica

\section{Referencias numéricas en cartografía sobre fortificación}

-Ref. en el croquis de Ortiz de Pinedo (1837-38, AGM, núm. 262): 024

-Ref. en plano de Vera Aparici (1993): 011

Referencias en memorias técnicas militare

-Ref. Guillermo Sáez (9/9/1834-5/12/1835): Requena, 5/12/1835 AMR, 1818-50

Se cierran las puertas y ventanas baja y se aspillera la pared de Juan Antonio Ponce. Se sobreentiende que se hace referencia a fortificar ta puerta de Valencia o "de las Ollerías" y no el barrio que quedaba en las afueras.

-Ref. Guillermo Sáez (26/02/1836): Sin ref.

-Ref. P. Ortiz de Pinedo (12/03/1837-30/05/1837): Sin ref.

-Ref Jose María de Orozco (25/03/1838): Sin ref.

-Ref. Carbonell (4/7/1838): Sin ref.

\section{- Observaciones a partir de los informes militares}

Se correspondería con el antiguo camino de Valencia, que pasa precisamente por el puente de las Ollerías. Esta zona, en periodo medieval punto de trabajo de los alfareros, estaba delimitada por la "pared de Antonio Ponze" $\gamma$ la denominada "Casa-Cuerta" (calle Caracuesta) con puertas falsas que debían cerrarse. Se accedía al barrio de las Ollerías, como se observa en el plano de Ortíz de Pinedo (AGM, Ar. GT.3-C.2.262), una vez sorteada la Puerta de Valencia y atravesado el puente de las Ollerías, en dirección a la campaña. 
$\square$ Rellenar en caso de que el elemento sea
contemplado con datos del PGoU, 2013

PROTECCIÓN

Nivel de protección:

Entorno:

$\square$ Inmueble

$\square$ Parcela catastral

$\square$ Recinto arquitectónico

AFECCIÓN PATRIMONIAL

$\square$ Bien de interés cultural (BIC)

$\square$ Afectado entorno BIC

$\square$ Afectado Plan especial

- Descripción histórico-arquitectónica

Tipología:

Cronología:

Observaciones a la cronología

Descripción

- Entorno urbano

Descripción entorno urbano:

Uso actual:

Estado de conservación:

Intervenciones:

Régimen Urbanistico:

Titularidad:

Nivel protección s/catálogo 1996:

Bibliografía: AMR, 1818-17, 1818-24; 1818-50; 1818-52; 1818-53,

Observaciones generales:

\section{OBJETIVACIÓN DE INTERÉS}

$\square$ Interés tipológico

Valor ambiental

Vigencia de la trama

Materiales, color, textura

Soluciones construct
$\square$ Estructura
$\square$ Aleros
$\square$ coronación
$\square$ Jambas
$\square$ Dinteles

Soluciones ornamentales
$\square$ Carpintería
$\square$ Rejería
$\square$ Cubrepersianas
$\square$ Alicatados
$\square$ Recercos
$\square$ Dinteles

Interés paisajistico

$\square$ Incidencia visual

$\square$ Carácter articulador

$\square$ Organización

$\square$ Interés cultural

Dinteles

$\square$ otros ornamentos
004 Arroyo de las Ollerías, Regajo de Reinas

\section{- Identificación}

Tramo de estudio: Tramo 1: Puerta de Valencia-Puerta de Alcalá

Otras denominaciones: Regajo de Reinas, Arroyo de las Ollerías

Ref. catastral:

Localización: Arroyo de Reinas o de las Ollerías.

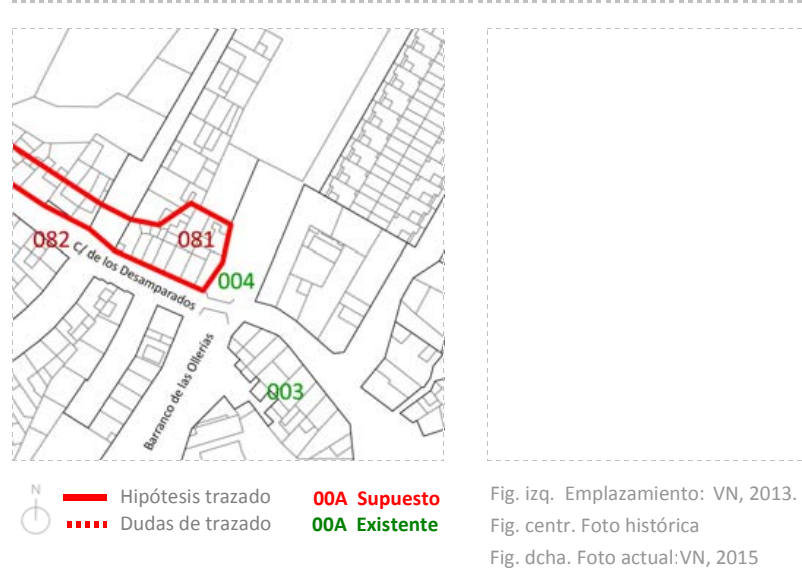

- Referencias en documentación histórica

Referencias numéricas en cartografía sobre fortificación

-Ref. en el croquis de Ortiz de Pinedo (1837-38, AGM, núm. 262): 025

-Ref. en plano de Vera Aparici (1993): Sin ref.

Referencias en memorias técnicas militares

-Ref. Guillermo Sáez (9/9/1834-5/12/1835): Sin ref.

-Ref. Guillermo Sáez (26/02/1836): Sin ref.

-Ref. P. Ortiz de Pinedo (12/03/1837-30/05/1837): Sin ref.

-Ref Jose Maria de Orozco (25/03/1838): Sin ref.

-Ref. Carbonell (4/7/1838): Sin ref.

\section{- Observaciones a partir de los informes militares}

Identificado como el arroyo de las Ollerías, por Ortiz de Pinedo (SHM, núm. 262), se corresponde con la denominación de Regajo de Reinas. Discurre definiendo el foso suroeste de la ciudad, sorteable a través del puente de Santa Cruz o de las Ollerías.

$\begin{array}{lll}\square \frac{\text { Rellenar en caso de que el elemento sea }}{\text { contemplado con datos del PGOU, 2013 }} & \text { PROTECCIÓN } & \text { AFECCIÓN PATRIMONIAL } \\ & \text { Nivel de protección: } & \square \text { Bien de interés cultural (BIC) } \\ & \text { Entorno: } & \square \text { Bien de relevancia local (BRL) } \\ & \square \text { Inmueble } & \square \text { Afectado entorno BIC } \\ & \square \text { Parcela catastral } & \square \text { Afectado Plan especial } \\ & \square \text { Recinto arquitectónico } & \\ & \square \text { Entorno específico } & \end{array}$

$\checkmark$ Existe actualmente

Incluido en fichas PGOU 2013

Bien de interés cultural (BIC)

cód. postal: 4634

comarca: Plana de Requena-Utiel

Provincia: Valencia

Autonomía: Comunidad Valenciana

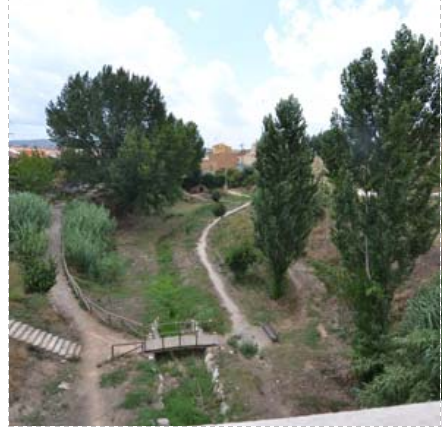

\section{Datos Jurídicos:}

Código:
Estado:

Categoria:

Anotación M

Plan:

Informe:

Fecha Publicación BOP:

Fecha Publicación DOCV 
- Descripción histórico-arquitectónica

Tipología:

Cronología:

Observaciones a la cronología

\section{Descripción:}

\section{- Entorno urbano}

Descripción entorno urbano:

Uso actual:

Estado de conservación:

Intervenciones:

Régimen Urbanístico:

Titularidad:

Nivel protección s/catálogo 1996:

Bibliografía: AMR, 1818-17, 1818-24; 1818-50; 1818-52; 1818-53.

Observaciones generales:

$\begin{array}{lll}\text { OBJETIVACIÓN DE INTERÉS } & \text { Soluciones constructivas } & \text { Soluciones ornamentales } \\ \square \text { Interés tipológico } & \square \text { Estructura } & \square \text { Carpintería } \\ \square \text { valor ambiental } & \square \text { Aleros } & \square \text { Rejería } \\ \square \text { Vigencia de la trama } & \square \text { Coronación } & \square \text { Cubrepersianas } \\ \square \text { Composición de la fachada } & \square \text { Jambas } & \square \text { Alicatados } \\ \square \text { Materiales, color, textura } & \square \text { Dinteles } & \square \text { Recercos } \\ & & \square \text { Dinteles } \\ & & \square \text { Otros ornamentos }\end{array}$

- Datos específicos catalogación BIC $\square$ Rellenar sólo si está catalogado BIC

Datos Jurídicos:

$\begin{array}{lll}\text { Código: } & \text { Fecha Disposición: } & \text { Fecha informe: } \\ \text { Estado: } & \text { Tipo delimitación: } & \text { Fecha Publicación BOP: } \\ \text { Categoría: } & \text { Plan: } & \text { Fecha Publicación DOCV: } \\ \text { Anotación Mo: } & \text { Informe: } & \text { Fecha Publicación BOE: }\end{array}$

Interés paisajístico

$\square$ Incidencia visual

$\square$ Carácter articulador

$\square$ Organización

Carácter representativo

\section{Puente de Santa Cruz}

- Identificación

Tramo de estudio: Tramo 1: Puerta de Valencia-Puerta de Alcalá

Otras denominaciones: Puente de las Ollerías

Ref. catastral:

sin ref. cat.

Localización: C/ Desamparados sobre el barranco de Reinas

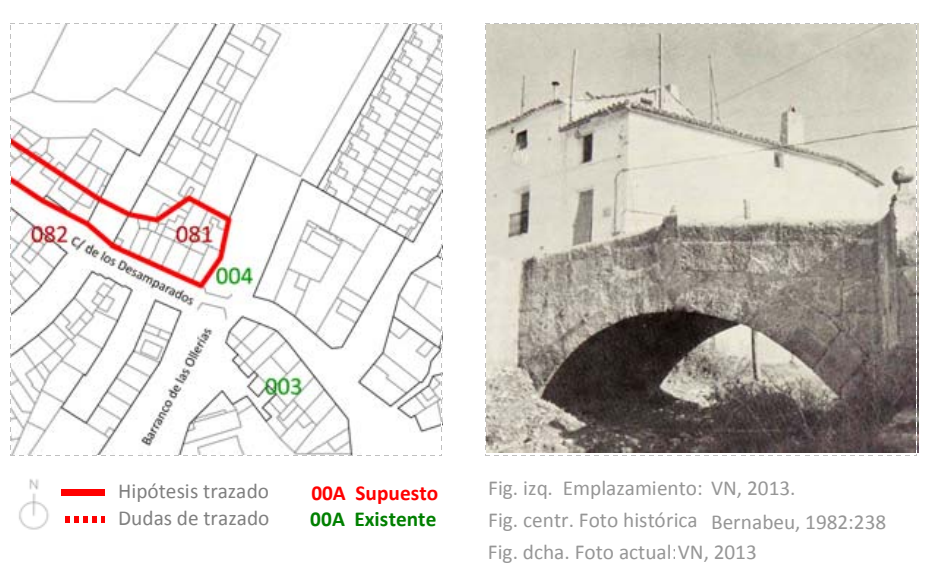

\section{- Referencias en documentación histórica}

Referencias numéricas en cartografía sobre fortificación

-Ref. en el croquis de Ortiz de Pinedo (1837-38, AGM, núm. 262): Sin ref.

-Ref. en plano de Vera Aparici (1993): Sin ref.

Referencias en memorias técnicas militares

-Ref. Guillermo Sáez (9/9/1834-5/12/1835): Sin ref.

-Ref. Guillermo Sáez (26/02/1836): Sin ref.

-Ref. P. Ortiz de Pinedo (12/03/1837-30/05/1837): Sin ref.

-Ref Jose María de Orozco (25/03/1838): Sin ref.

-Ref. Carbonell (4/7/1838): Sin ref.

\section{- Observaciones a partir de los informes militares}

Se trata del puente que desde la puerta de Valencia, conectaba, ya extramuros, con el barrio de las Ollerías y el camino antiguo de Valencia, sorteando e resajo de Reinas o arroyo de las Ollerías.

$\begin{array}{lll}\square \text { Rellenar en caso de que el elemento sea } \\ \frac{\text { contemplado con datos del PGOU, 2013 }}{} & \begin{array}{ll}\text { PROTECCIÓN } \\ \text { Nivel de protección: Integral }\end{array} & \square \text { BFECCIÓN PATRIMONIAL } \\ & \text { Entorno: } & \square \text { Bien de releverancia cultural (BIC) } \\ & \square \text { Inmueble (BRL) } \\ & \square \text { Parcela catastral } & \square \text { Afectado entorno BIC } \\ & \square \text { Recinto arquitectónico } & \square \text { Afectado Plan especial } \\ \square \text { Entorno específico } & \end{array}$

$\checkmark$ Incluido en fichas PGOU 2013

$\square$ Bien de interés cultural (BIC)

cód. postal: 46340

Comarca: Plana de Requena-Utiel

Provincia: Valencia

Autonomía: Comunidad Valencian

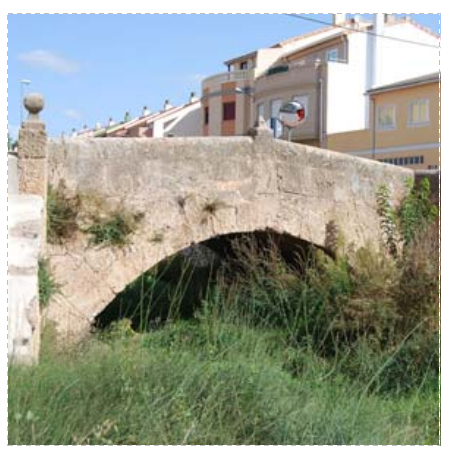

(1) $\checkmark$ Existe actualmente 
- Descripción histórico-arquitectónica

\section{Tipología: Infraestructuras}

Cronologia: s. XII

Observaciones a la cronología:

Descripción: "Puente de un solo vano, con arco de medio punto, construido con piedras de sillería sin revestimiento alguno. Está construido sobre el barranco de Reinas y se halla en un estado magnífico (circulan vehiculos sobre él); sirvió de aduana en
época foral, tras la cual pasó unicamente a registrar los ganados que pasaban hacia Valencia. Su construcción data de tiempo muy antiguo, aunque no está del todo claro. Sin embargo, se sabe con exactitud que tras la riada de 1728, el puente quedó totalmente destrozado, y tuvo que ser restaurado, construyéndolo practicamente de nuevo en 1733. Es un puente que mide tres metros de ancho por unos siete de largo. Ha sido sometido a procesos de restauración, consolidación y conservación" (PGOU, 2013: E.CAS.CAT.80).

\section{- Entorno urbano}

Descripción entorno urbano:

"El puente se localiza hacia el sureste del barrio de la Villa, conformando parte del antiguo Camino Real. Las edificaciones a su alrededor datan igualmente de la época medieval. Recientemente la zona se ha ido consolidando hacia el noreste del puente con urbanizaciones residenciales de baja densidad" (PGOU, 2013: E.CAS.CAT.80).

Uso actual: Puente

Estado de conservación: Bueno

Intervenciones: Consolidación, conservación y restauración

Régimen Urbanístico: S. U

Titularidad: Pública

Nivel protección s/catálogo 1996:

Bibliografía: AMR, 1818-17, 1818-24; 1818-50; 1818-52; 1818-53.

Observaciones generales:

\begin{tabular}{|c|c|c|}
\hline OBJETIVACIÓN DE INTERÉS & Soluciones constructivas & Soluciones ornamentales \\
\hline 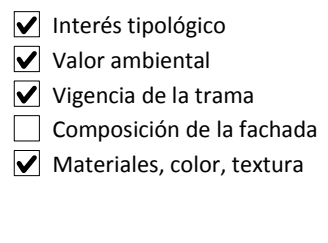 & $\begin{array}{l}\boldsymbol{V} \text { Estructura } \\
\square \text { Aleros } \\
\square \text { Coronación } \\
\square \text { Jambas } \\
\square \text { Dinteles }\end{array}$ & $\begin{array}{l}\square \text { Carpintería } \\
\square \text { Rejería } \\
\square \text { Cubrepersianas } \\
\square \text { Alicatados } \\
\square \text { Recercos } \\
\square \text { Dinteles } \\
\square \text { otros ornamentos }\end{array}$ \\
\hline
\end{tabular}

- Datos específicos catalogación BIC $\square$ Rellenar sólo si está catalogado BIC

$\begin{array}{lll}\text { Datos Jurídicos: } & & \\ \text { Código: } & \text { Fecha Disposición: } & \text { Fecha informe: } \\ \text { Estado: } & \text { Tipo delimitación: } & \text { Fecha Publicación BOP: } \\ \text { Categoría: } & \text { Plan: } & \text { Fecha Publicación DOCV: } \\ \text { Anotación Mo: } & \text { Informe: } & \text { Fecha Publicación BOE: }\end{array}$

005 Batería que se proyecta contigua al fortín de la casa de D. Juan Antonio Ponce

\section{- Identificación}

Tramo de estudio:

Tramo 1: Puerta de Valencia-Puerta de Alcalá

Otras denominaciones: Las Piezas

Ref. catastral:

Localización: Entorno del Puente de las Ollerías-C/ Desamparados

Existe actualmente

Incluido en fichas PGOU 2013

Bien de interés cultural (BIC)

cód. postal: 46340

Comarca: Plana de Requena-Utiel

Provincia: Valencia

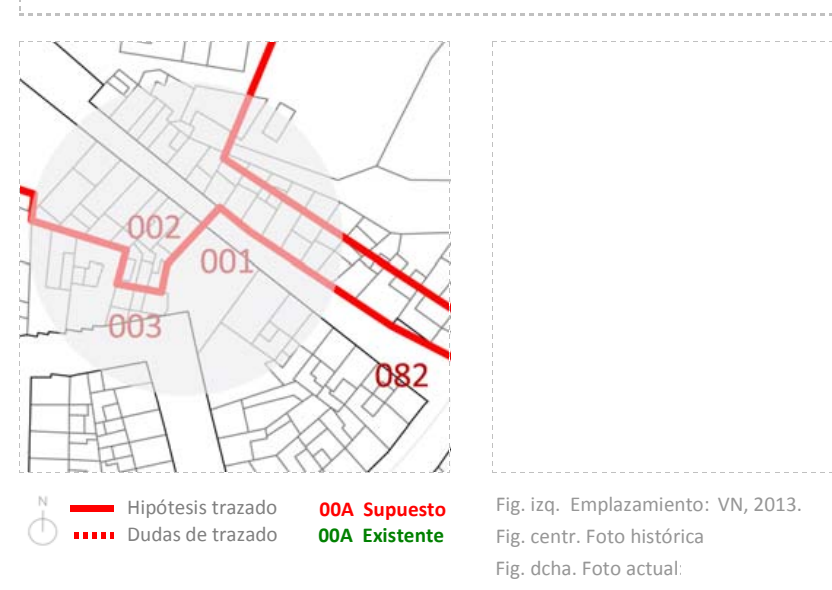

- Referencias en documentación histórica

Referencias numéricas en cartografía sobre fortificación

-Ref. en el croquis de Ortiz de Pinedo (1837-38, AGM, núm. 262): Sin ref.

-Ref. en plano de Vera Aparici (1993): Sin ref.

Referencias en memorias técnicas militares

-Ref. Guillermo Sáez (9/9/1834-5/12/1835): Sin ref.

-Ref. Guillermo Sáez (26/02/1836): Sin ref.

-Ref. P. Ortiz de Pinedo (12/03/1837-30/05/1837): Sin ref.

-Ref Jose María de Orozco (25/03/1838): Sin ref.

-Ref. Carbonell (4/7/1838): AMR, 1818-17, fol. 5

Esta Bateria se crea para actuar conjuntamente con las baterías existentes de la Puerta de Alcalá, Honrrubia y la del Molino de Herrero. El objetivo es impedir que el enemigo ocupe el Barrio de las Ollerías y oponerse a una batería enemiga instalada en él. Descubre el camino la Puerta de Valencia y las avenidas a las casas del Batanejo y al Matadero. Cruza sus fuegos con el cañon de la Puerta de Alcalá. Defiende las inmediaciones del recinto Intermedio. Se propone dar al lado exterior de la Bateria el trazado siguiente: una cara parte desde la garit del fortin hacia el campo en direccion perpendicular á las [caras] que lindan con el Camino de Valencia. La cara tendrá nuebe varas de largo $(7,5 \mathrm{~m})$. La otra cara forma con ésta un angulo de cien grados, mirando por Consiguiente al Camino de Cofrentes, $y$ su longtud será frente a lasas $(2,2 \mathrm{~m})$. La tercera cara fomará con la segunda un ángulo de 115 grados $y$. revestimiento del de un terraplén, que se hará de mampostería, tendrá 9 pies de altura $(2,5 \mathrm{~m})$, puesto que el referido terreno debe rebajarse una vara por la parte exterior $(0,83 \mathrm{~m})$, en forma de foso, á fin de aumentar el relieve. El parapeto se construirá de tapia, dandole dos varas de espesor en las dos priméras caras $(1,67 \mathrm{~m})$, una vara en la tercera $(0,83 \mathrm{~m})$ y 8 pies de altura en todas $(2,22 \mathrm{~m})$. En cada una de las caras se dejará una cañonera, estableciendo el centro de la tercera á $3,5 \mathrm{varas}(0,97 \mathrm{~m})$ del angulo saliente interior. Desde esta misma cañonera hasta las caras de cara-cuesta, se aspilierará el parapeto hastá la altura de 4,5 pies $(1,25 \mathrm{~m})$. Para que en el resto de hará unamientos pueda usarse la fusslefia por encima de los merlones, se construirán banque das que no perjudiquen al uso de la pieza. Se hara una explanada de madera para las tres cañoneras, con tablones de 4 a 5 pulgadasde espesor (aprox. de $93 \mathrm{~mm}$. a $116 \mathrm{~mm}$ ). Se facilmente de sus marcos para preservarlas de la interperie en tanto que no sea preciso usarlas. La entrada a la Bateria se dará por los corrales de la Casa de Ponce, y en los mismos debe hacerse un pequeño refuerzo para municiones (Carbonell, Requena, 4 de julio de 1838 AMR, 1818-17, fo. 5). 


\section{- Observaciones a partir de los informes militares}

Actúa conjuntamente con las baterías existentes de la Puerta de Alcalá, Honrubia y la del Molino de Herrero. El objetivo es impedir que el enemigo ocupe el Barrio de las Ollerías y oponerse a una batería enemiga instalada en él. Descubre el camino a la Puerta de Valencia y las plano de Ortiz de Pinedo las medidas definidas por Carbonell la batería tiene las dimensiones idénticas al saliente trapezoidal que se emplaza al suroeste de la puerta de Valencia, y permite cubrir todo el entrante del Batanejo.

\begin{tabular}{|lll}
$\square \frac{\text { Rellenar en caso de que el elemento sea }}{\text { contemplado con datos del PGOU, 2013 }}$ & PROTECCIÓN & AFECCIÓN PATRIMONIAL \\
& Nivel de protección: & $\square$ Bien de interés cultural (BIC) \\
& Entorno: & $\square$ Bien de relevancia local (BRL) \\
& $\square$ Inmueble & $\square$ Afectado entorno BIC \\
& $\square$ Parcela catastral & $\square$ Afectado Plan especial \\
& $\square$ Recinto arquitectónico & \\
\hline & Entorno espećfico &
\end{tabular}

\section{- Descripción histórico-arquitectónica}

Tipología:

Observaciones a la cronología:

\section{Descripción:}

\section{- Entorno urbano}

Descripción entorno urbano:

Uso actual:

Estado de conservación

Intervenciones:

Régimen Urbanístico:

Titularidad:

Nivel protección s/catálogo 1996:

Bibliografía: AMR, 1818-17, 1818-24; 1818-50; 1818-52; 1818-53.

Observaciones generales:

\begin{tabular}{llll} 
OBJETIVACIÓN DE INTERÉS & Soluciones constructivas & Soluciones ornamentales & Interés paisajistico \\
$\square$ Interés tipológico & $\square$ Estructura & $\square$ Carpintería & $\square$ Incidencia visual \\
$\square$ valor ambiental & $\square$ Aleros & $\square$ Rejería & $\square$ Carácter articulador \\
$\square$ vigencia de la trama & $\square$ coronación & $\square$ cubrepersianas & $\square$ Organización \\
\hline$\square$ composición de la fachada & $\square$ Jambas & $\square$ Alicatados & $\square$ Interés cultural \\
$\square$ Materiales, color, textura & $\square$ Dinteles & $\square$ Recercos & $\square$ Carácter representativo \\
& & $\square$ Dinteles & \\
& & $\square$ otros ornamentos &
\end{tabular}

\section{- Datos específicos catalogación BIC $\square$ Rellenar sólo si está catalogado BIC}

Datos Jurídicos:

$\begin{array}{lll}\text { Datos Juridicos: } & \text { Fecha Disposición: } & \text { Fecha informe: } \\ \text { Código: } & \text { Tipo delimitación: } & \text { Fecha Publicación BOP: } \\ \text { Estado: } & \text { Plan: } & \text { Fecha Publicación DOCV: } \\ \text { Categoría: } & \text { Informe: } & \text { Fecha Publicación BOE: } \\ \text { Anotación Mo: } & \end{array}$

\section{Desde la Batería a las casas del Batanejo}

\section{- Identificación}

Tramo de estudio:

Tramo 1: Puerta de Valencia-Puerta de Alcalá

Otras denominaciones:

Ref. catastral:

Localización: Entorno de la C/ Batanejo.

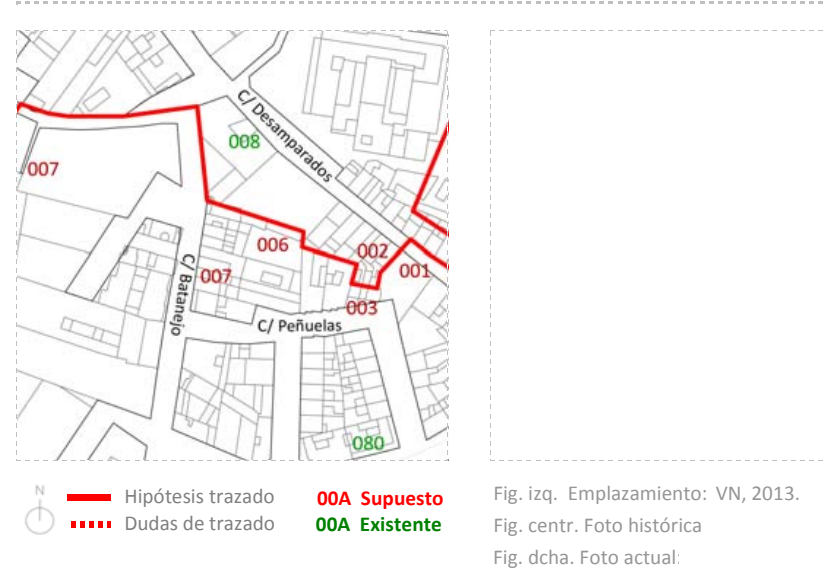

- Referencias en documentación histórica

Referencias numéricas en cartografía sobre fortificación

-Ref. en el croquis de Ortiz de Pinedo (1837-38, AGM, núm. 262): Sin ref.

-Ref. en plano de Vera Aparici (1993): 010

Referencias en memorias técnicas militares

-Ref. Guillermo Sáez (9/9/1834-5/12/1835): Sin ref.

-Ref. Guillermo Sáez (26/02/1836): Sin ref.

-Ref. P. Ortiz de Pinedo (12/03/1837-30/05/1837): Sin ref.

-Ref Jose Maria de Orozco (25/03/1838): Sin ref.

-Ref. Carbonell (4/7/1838): AMR, 1818-17, fol. 5

Además de aspillerarse las paredes de las casas y corrales, se cerrarán y aspillerarán las ventanas situadas en el recinto. Se reforzarán las tapias y paredes debiles, elevando las mas bajas hasta la altura de 4 varas $(3,34 \mathrm{~m}$ ) (Carbonell, Requena, 4 de julio de 1838, AMR, 1818-17,

\section{- Observaciones a partir de los informes militares}

Consiste en el tramo defensivo que la batería proyectada junto al fortín de la casa de Antonio Ponce, que avanzaría en dirección Este buscando un conjunto de casas denominadas del Batanejo. Que se emplazarían en el actual área afectada por el PAl. Se trata de fragmentos de muros. 
$\square \frac{\text { Rellenar en caso de que el elemento sea }}{\text { contemplado con datos del PGOU, 2013 }}$

\section{PROTECCIÓN}

Nivel de protección:

Entorno:

$\square$ Inmueble

$\square$ Parcela catastral

$\square$ Recinto arquitectónico

AFECCIÓN PATRIMONIAL

$\square$ Bien de interés cultural (BIC)

$\square$ Afectado entorno BIC

$\square$ Afectado Plan especial

\section{Casas del Batanejo}

- Identificación

Tramo de estudio: Tramo 1: Puerta de Valencia-Puerta de Alcalá

Otras denominaciones: El Batanejo

Ref. catastral:

Localización: Área del Batanejo.

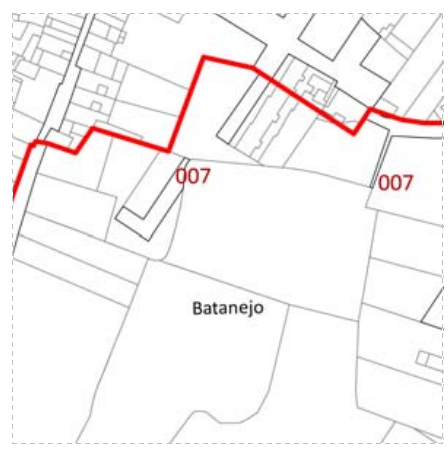

\section{- Hipótesis trazado O0A Supuesto}

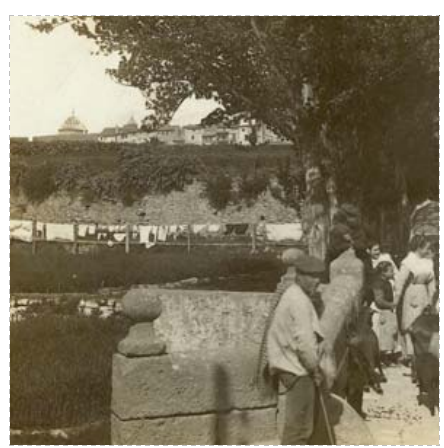

Existe actualmente

Incluido en fichas PGOU 2013

$\square$ Bien de inteŕs culvo 2013

cód. postal: 46340

Municipio: Requena

Comarca: Plana de Requena-Utiel

Provincia: Valencia

Autonomia: Comunidad Valencian

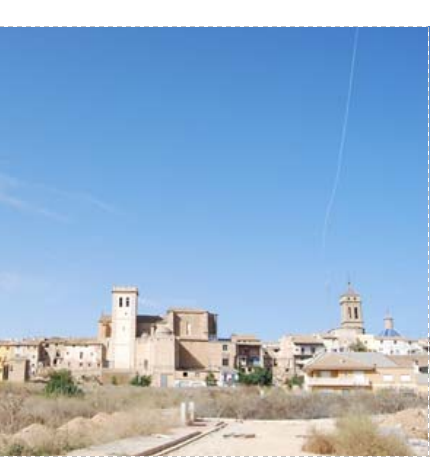

el protección s/catálogo 1996 :

Bibliografía: AMR, 1818-17, 1818-24; 1818-50; 1818-52; 1818-53.

Observaciones generales:

\section{OBJETIVACIÓN DE INTERÉS}

$\square$ Interés tipológico

$\square$ Valor ambiental

$\square$ Composición de la fachada

Soluciones constructivas

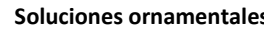

Interés paisajistico

$\square$ Estructura

$\square$ Aleros

$\square$ Coronación

Jambas

$\square$ Carpintería

Rejería

$\square$ Cubrepersian

Alicatados

7 Dinteles

$\square$ otros ornamentos
Vigencia de la trama $\square$ Incidencia visual

Carácter articulador

Organización

Interés cultural arán
- Datos específicos catalogación BIC

$\square$ Rellenar sólo si está catalogado BIC

Datos Jurídicos:

Código:

Estado:

Disposición:

Plan:

Anotación M

Informe:

Fecha informe:

Fecha Publicación BOP:

Fecha Publicación DOCV:

Fecha Publicación BOE:

Referencias en memorias técnicas militare

\section{- Referencias en documentación histórica}

\section{Referencias numéricas en cartografía sobre fortificación}

-Ref. en el croquis de Ortiz de Pinedo (1837-38, AGM, núm. 262): Sin ref.

-Ref. en plano de Vera Aparici (1993): 010

-Ref. Guillermo Sáez (9/9/1834-5/12/1835): Requena, 5/12/1835 AMR, 1818-50

Se derriban las moreras de la huerta de D. José la Cárcel.

-Ref. Guillermo Sáez (26/02/1836): Requena, 26/02/1836 AMR, 1818-53

En el batanejo, mirando a la Ollería hay construir "un poco" de parapeto que falta. La responsabilidad de la obra depende de la Villa.

-Ref. P. Ortiz de Pinedo (12/03/1837-30/05/1837): Sin ref.

-Ref Jose Maria de Orozco (25/03/1838): Sin ref.

-Ref. Carbonell (4/7/1838): AMR, 1818-17, fol. 6-8

Se cerrará con tapia aspilierada de 4 varas de alto el descubierto de la Casa de $[0 \mathrm{mtin}]$, construyendo una banqueta. Por lo general las aspilleras arrancan a una altura de 6,507 pies $(1,9 \mathrm{~m}$ ) del piso (sin contar el foso). En la paredes con orientación a Levante se refuerzan las puertas, recalzándolas y revocando las paredes donde sea necesario. Se tapiarán las ventananas que se hallen a menos de 8 varas de altura $(6,7 \mathrm{~m})$ y se harán aspilleras en todos los cuerpos. La pared del mediodia se reforzará por la parte interior hasta el piso principal, y en
tanto en este piso como en los demás se abrián aspilleras. Se darán 2 varas $(1,7 \mathrm{~m}$ más de altura a la tapia que atraviesa el camino formando parte de este frente de mediodia, se macizará su puerta y continuarán las aspilleras hasta el ribazo. Delante de dicha tapia se abrirá un foso por el cual pueden dirijirse las aguas del arbellón contiguo. Como por el lado de poniente hay un parapeto que cubre las casas, sólo deben aspillerarse estas si las habitaciónes principales y desvanes, a excepcion del pequeño espacio que cae al campo sobre e arbellón, donde se hará una aspillera en cada piso. [...] En las tapias que hay desde el fortín proyectado hasta el granero de Don Francisco Antonio Herrero se elevarán hasta que tengan 3,5 varas sobre el terreno exterior $(2,92 \mathrm{~m})$, hacienndo aspilleras a la altura de 6,5 pies del mismo $(1,81 \mathrm{~m})$, y estableciendo la correspondiente banqueta de madera. Se macizaran todas las puertas con el mismo espesor de la tap cerramiento que se halla en la esquina de la Casa de Carcel, colocando en él una Puerta (Carbonell, Requena, 4 de julio de 1838, AMR, 


\section{- Observaciones a partir de los informes militares}

Se extendía una huerta que nos habla de la importancia del sector de la seda propiedad de "don Josef la Carzel". Ocupado por moreras principalmente y otros árboles de huerta. El término provendrá de la presencia de un batán. Habituales en Requena, donde se trabajaba el insignificante batán en 1836: "el cañón de los nacionales no valía nada y no consiguió más que incendiar un pequeño batán, por lo que le llamaban en broma el cañón del batanejo." (Baroja, 1935: 39). En la actualidad el Batanejo es afectado por la Unidad de Ejecución no 1 del PAl del sector del Batanejo, que tras años abandonada, está pendiente de la adjudicación de un nuevo agente urbanizador.El emplazamiento genera un grave conflicto paisajistico no denunciado que afecta al perfil histórico de Requena.

$\begin{array}{lll}\square \text { Rellenar en caso de que el elemento sea } \\ \text { contemplada con datos del PGOU, 2013 } & \text { PROTECCIÓN } & \text { AFECCIÓN PATRIMONIAL } \\ & \text { Nivel de protección: } & \square \text { Bien de interés cultural (BIC) } \\ & \square \text { Bien de relevancia local (BRL) } \\ & \square \text { Inmueble } & \square \text { Afectado entorno BIC } \\ & \square \text { Parcela catastral } & \square \text { Afectado Plan especial } \\ & \square \text { Recinto arquitectónico } & \end{array}$

\section{- Descripción histórico-arquitectónica}

Tipología:

Observaciones a la cronología:

\section{Descripción:}

- Entorno urbano

Descripción entorno urbano:

Uso actual:

Estado de conservación:

Intervenciones:

Régimen Urbanístico:

Titularidad:

Nivel protección s/catálogo 1996:

Bibliografía: AMR, 1818-17, 1818-24; 1818-50; 1818-52; 1818-53.

Observaciones generales:

$\begin{array}{lll}\text { OBJETIVACIÓN DE INTERÉS } & \text { Soluciones constructivas } & \text { Soluciones ornamentales } \\ \square \text { Interés tipológico } & \square \text { Estructura } & \square \text { Carpintería } \\ \square \text { Valor ambiental } & \square \text { Aleros } & \square \text { Rejería } \\ \square \text { vigencia de la trama } & \square \text { coronación } & \square \text { Cubrepersianas } \\ \square \text { Composición de la fachada } & \square \text { Jambas } & \square \text { Alicatados } \\ \square \text { Materiales, color, textura } & \square \text { Dinteles } & \square \text { Recercos } \\ & & \square \text { Dinteles } \\ & \square \text { Otros ornamentos }\end{array}$

\section{- Datos específicos catalogación BIC $\square$ Rellenar sólo si está catalogado BIC}

\section{Datos Jurídicos:}

Código:
Estado:

Estado:
Categoría:

Anotación Mo:

\section{7b Fortín del Batanejo}

\section{- Identificación}

Tramo de estudio:

Tramo 1: Puerta de Valencia-Puerta de Alcalá

Otras denominaciones: El Batanejo

Ref. catastral:

Localización: Área del Batanejo.

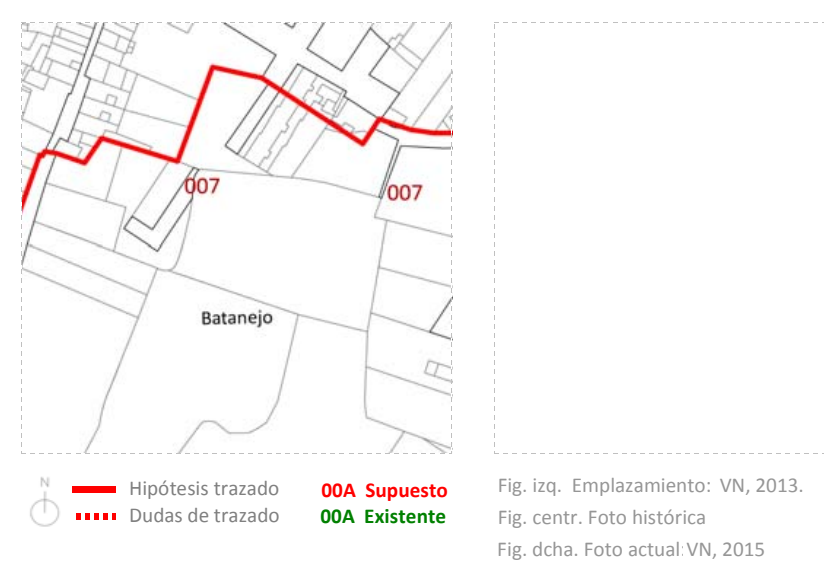

Existe actualmente

Incluido en fichas PGOU 2013

Bien de interés cultural (BIC)

cód. postal: 46340

Municipio: Requena

Comarca: Plana de Requena-Utie

Provincia: Valencia

Autonomia: Comunidad Valencian

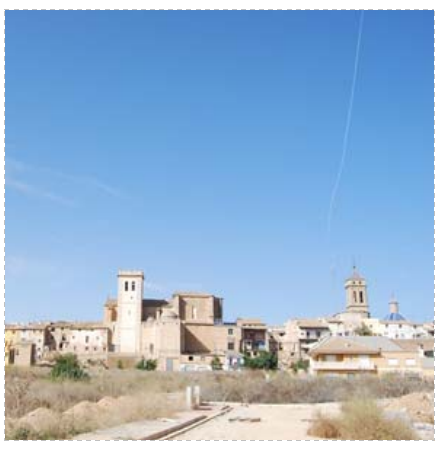

- Referencias en documentación histórica

\section{Referencias numéricas en cartografía sobre fortificación}

-Ref. en el croquis de Ortiz de Pinedo (1837-38, AGM, núm. 262): Sin ref. -Ref. en plano de Vera Aparici (1993): 010

Referencias en memorias técnicas militares

-Ref. Guillermo Sáez (9/9/1834-5/12/1835): Requena, 5/12/1835 AMR, 1818-50

-Ref. Guillermo Sáez (26/02/1836): Requena, 26/02/1836 AMR, 1818-53

-Ref. P. Ortiz de Pinedo (12/03/1837-30/05/1837): Sin ref.

-Ref Jose María de Orozco (25/03/1838): Sin ref.

-Ref. Carbonell (4/7/1838): AMR, 1818-17, fol. 6-8

"Para flanquear el frente avanzado de las casas del Batanejo, poco defendido ahora de otras partes del recinto, y para flanquear tambien el parapeto de poniente que forman las tapias de Don Marcelino Herrero y las inmediatas, se construirá un fortin que tendrá la ventaja de ribazo y se propone el siguiente trazado de su poligono exterior: desde el ángulo que forma la tapia ya citada, que cruza el camino con las de D. Marcelino Herrero, se tomarán 7 baras $(5,85 \mathrm{~m})$ sobre la horma y se obtendrá aś la priméra cara. Partiendo de su extremo avanzado se marcará otra con direccion a los edificicios contiguos a la Parroquia de Santa María, dándole la misma longitud. La tercera cara será paralela a las tapias de D. Marcelino, de 9 varas de largo $(7,5 \mathrm{~m})$. La cuarta cara que es la que flanquea la línea parapetada de poniente; hará con esta un ángulo de 110 grados. Cerca de dicho angulo estara la subida desde el camino o calle al fortin. Este se compondra de dos cuerpos: en el cuerpo bajo las paredes tendrán 3 pies de espesor $(0,84 \mathrm{~m})$, excepto la del norte, la cual, así como las de segundo cuerpo serán de 1,5 pies $(0,42 \mathrm{~m})$. Las aspilleras distarañn 3 pies de centro a centro $(0,84 \mathrm{~m})$. Las aspilleras del piso bajo se
elevaran 7 pies desde el terreno $(1,95 \mathrm{~m})$ salvo aquellas que estén sobre el ribazo que arrancarán a los 4 pies, sin necesitar banque (1,11 $\mathrm{m}$ ) ta altura total de la obra decrita queda determinada por a que componen sus dos cuerpos. Estará cubiérta con tejajdo. De este modo el piso bajo servirá de cuerpo de Guardia y en el piso de arriba se emplazará el centinela, sin necesidad de garitas, que en esta obra serían más periudiciales que útiles. (Carbonell, Requena, 4 de julio de 1838, AMR, 1818-17, fo. 6-8). 


\section{- Observaciones a partir de los informes militares}

Proyectado para flanquear el frente avanzado de las casas del Batanejo,y para flanquear tambien el parapeto de poniente que forman las dicho punto y la Puerta de Alcal.

$\frac{\text { Rellenar en caso de que el elemento sea }}{\text { contemplado con datos del PGou, } 2013}$ ontemplado con datos del PGOU, 2013

\section{PROTECCIÓN}

Nivel de protección:

Entorno:

$\square$ Inmueble

$\square$ Parcela catastral

$\square$ Recinto arquitectón

\section{- Descripción histórico-arquitectónica}

Tipología:

Cronologia:
Observaciones a la cronología:

Descripción:

\section{- Entorno urbano}

\section{Descripción entorno urbano:}

Uso actual:

Estado de conservación:

Intervenciones:

Régimen Urba

Nivel protección s/catálogo 1996:

Bibliografía: AMR, 1818-17, 1818-24; 1818-50; 1818-52; 1818-53.

Observaciones generales:

$\begin{array}{lll}\text { OBJETIVACIÓN DE INTERÉS } & \text { Soluciones constructivas } & \text { Soluciones ornamentales } \\ \square \text { Interés tipológico } & \square \text { sstructura } & \square \text { Carpintería } \\ \square \text { Valor ambiental } & \square \text { Aleros } & \square \text { Rejería } \\ \square \text { vigencia de la trama } & \square \text { coronación } & \square \text { Cubrepersianas } \\ \square \text { Composición de la fachada } & \square \text { Jambas } & \square \text { Alicatados } \\ \square \text { Materiales, color, textura } & \square \text { Dinteles } & \square \text { Recercos } \\ & & \square \text { Dinteles } \\ & \square \text { Otros ornamentos }\end{array}$

\section{- Datos específicos catalogación BIC $\square$ Rellenar sólo si está catalogado BIC}

$\begin{array}{lll}\text { Datos Jurídicos: } & & \\ \text { Código: } & \text { Fecha Disposición: } & \text { Fecha informe: } \\ \text { Estado: } & \text { Tipo delimitación: } & \text { Fecha Publicación BOP: } \\ \text { Categoría: } & \text { Plan: } & \text { Fecha Publicación DOCV: } \\ \text { Anotación Mo: } & \text { Informe: } & \text { Fecha Publicación BOE: }\end{array}$

\section{Casa de Cárcel. Huerta de José Cárcel}

\begin{tabular}{|c|c|}
\hline \multicolumn{2}{|l|}{ - Identificación } \\
\hline Tramo de estudio: & Tramo 1: Puerta de Valencia-Puerta de Alcalá \\
\hline Otras denominaciones: & Huerta de José Cárcel \\
\hline Ref. catastral: & $37259-01$ \\
\hline $\begin{aligned} \text { Localización: } & \text { C/ Desam } \\
& \text { Grande). }\end{aligned}$ & $\begin{array}{l}\text { C/ Desamparados, o 20. Actual casa de los Cárcel-Marcilla (Case } \\
\text { Grande). }\end{array}$ \\
\hline
\end{tabular}

$\checkmark$ Existe actualmente

$\checkmark$ Incluido en fichas PGOU 2013

$\square$ Bien de interés cultural (BIC)

cód. postal: 46340

Comarca. Plana de Requena-Utie

Provincia: Valencia Autonomia: Comunidad Valencian

Afectado entorno BIC

$\square$ Afectado Plan especial

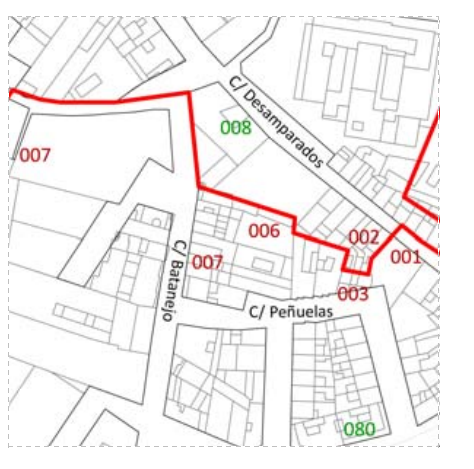

- Hipótesis trazado

OOA Supuesto

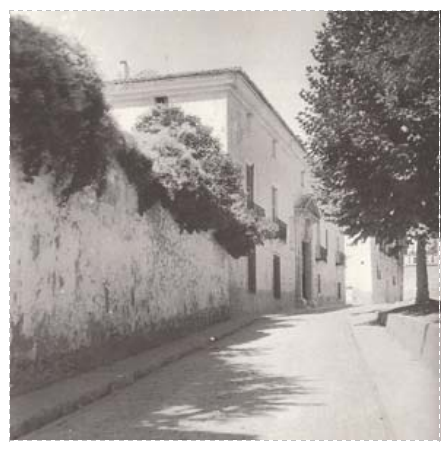

Fig. izq. Emplazamiento: VN, 2013

Fig. centr. Foto histórica Jordá, 2000: fig. 52.
Fig. dcha. Foto actual: VN, 2015

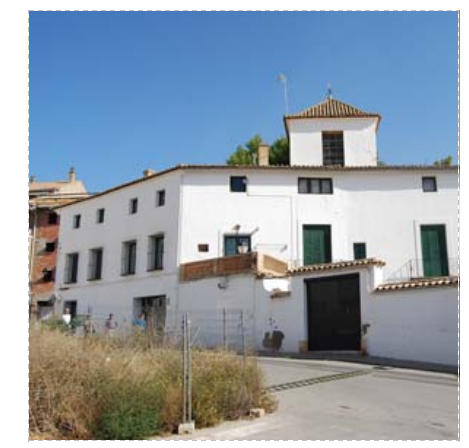

- Referencias en documentación histórica

\section{Referencias numéricas en cartografía sobre fortificación}

-Ref. en el croquis de Ortiz de Pinedo (1837-38, AGM, núm. 262): Sin ref.

-Ref. en plano de Vera Aparici (1993): Sin ref.

Referencias en memorias técnicas militares

-Ref. Guillermo Sáez (9/9/1834-5/12/1835): Requena, 5/12/1835 AMR, 1818-50

Se derriban las moreras de lan huerta de D. José la Cárcel.

-Ref. Guillermo Sáez (26/02/1836): Requena, 26/02/1836 AMR, 1818-53

Hay que componer un portillo en "la de arriba", se entiende que será la pared superior. Indica, inmediato "a las Piezas". En la pared

inferior también tiene que fortalecer la puerta de la huerta bajo los huertos. La obra depende de particulares.

-Ref. P. Ortiz de Pinedo (12/03/1837-30/05/1837): Sin ref.

-Ref Jose María de Orozco (25/03/1838): Sin ref.

-Ref. Carbonell (4/7/1838): AMR, 1818-17, fol. 8

Se renuevan las aspilleras de la trascocina, y se levantará un tabique aspillerado en la galería contigua (Carbonell, Requena, 4 de julio de 1838, AMR, 1818-17, fol. 8).

\section{- Observaciones a partir de los informes militares}

La huerta consiste en una huerta "de abajo del Batanejo". Al indicar inmediata "a las Piezas" se sobreentiende que delimitaría con un la actual cassa de los Có. Se trata de la batería construida junto al fortín de la casa de Antonio Ponce. La casa de Cárcel se corresponde con sobre el dintel que correl-Marcilla, mansión solariega de "uno de los titulos de más rancio abolengo de Requena cuyo escudo campea descripción de la casa en el apartado de la ficha del catálogo del PGOU. 
$\nabla \frac{\text { Rellenar en caso de que el elemento sea }}{\text { contempladado con datas del PCOOU, } 2013}$

PROTECCIÓN

Nivel de protección: E.CAS.BRL.05.01-Int Entorno:

AFECCIÓN PATRIMONIAL

Bien de interés cultural (BIC)

Monumento

$\square$ Inmueble

Recinto arquitectónico

Monumento
Afectado entorno

$\square$ Afectado Plan especia

$\checkmark$ Entorno específico

\section{- Descripción histórico-arquitectónica}

\section{Tipología: Arquitectura civil}

Cronología: ss. XVII-XVIII

Observaciones a la cronologia:

Descripción: "Conjunto formado por la Mansión de los Cárcel y los escudos heráldicos ubicados en el inmueble" (PGOU, 2013: C.CAS.BIC.O5). Edificio de esitlo neoclassico del S. XVIII, de planta rectangular irregular, constrindo en mampostería y sillerí cuenta con planta baja, planta principal y altillo. La fachada alberga un pórtico de estilo neoclásico, que inclua casa que de los Cárcel en el testero. En una fachada lateral se encuentra otro escudo de los Cárcel y en un patio interior un tercer escudo, de los Enríquez. En el interior tiene interés el amplio vestibulo de la entrada con la escalera de subida a la primera planta. La ornamentación tiene azulejos valencianos del S. XVIII en las paredes del vestibulo. Desde su construcción, esta casa ha sido sometida a procesos de consolidación, conservación y restauración" (PGOU, 2013: C.CAS.BRL.05.01)

\section{- Entorno urbano}

\section{Descripción entorno urbano:}

"La vivienda se localiza sobre el antiguo Camino Real, muy cerca de la plaza Consistorial. Aunque su construcción data de tiempo muy antiguo, el entorno que la rodea es de formación más reciente, en su mayoría de carácter residencial, exceptuando la residencia de ancianos contigua a la vivienda" (PGOU, 2013: C.CAS.BIC.05)

Uso actual: Vivienda particular

Estado de conservación: Bueno

Intervenciones: Consolidació, conservación y restauración

Régimen Urbanístico: S. U.

Titularidad: Privada

Nivel protección s/catálogo 1996: 2/3/4 tipológico-fachada-ambiental

Bibliografía: AMR, 1818-17, 1818-24; 1818-50; 1818-52; 1818-53.

Observaciones generales:

Forma parte del conjunto C.CAS.BIC.05"

\begin{tabular}{|c|c|c|c|}
\hline OBJETIVACIÓN DE INTERÉS & Soluciones constructivas & Soluciones ornamentales & Interés paisajistico \\
\hline $\begin{array}{ll}\nabla & \text { Interés tipológico } \\
\square & \text { Valor ambiental } \\
\square & \text { Vigencia de la trama } \\
\square & \text { Composición de la fachada } \\
\square & \text { Materiales, color, textura }\end{array}$ & $\begin{array}{l}\nabla \text { Estructura } \\
\square \text { Aleros } \\
\square \text { Coronación } \\
\square \text { Jambas } \\
\square \text { Dinteles }\end{array}$ & $\begin{array}{l}\boldsymbol{\nabla} \text { Carpintería } \\
\boldsymbol{\nabla} \text { Rejería } \\
\square \text { Cubrepersianas } \\
\square \text { Alicatados } \\
\square \text { Recercos } \\
\square \text { Dinteles } \\
\boldsymbol{\nabla} \text { Otros ornamentos }\end{array}$ & $\begin{array}{l}\nabla \text { Incidencia visual } \\
\nabla \text { Carácter articulador } \\
\square \text { Organización } \\
\square \text { Interés cultural } \\
\nabla \text { Carácter representativo }\end{array}$ \\
\hline
\end{tabular}

- Datos específicos catalogación BIC $\square$ Rellenar sólo si está catalogado BIC

$\begin{array}{lll}\text { Datos Jurídicos: } & & \\ \text { Código: } & \text { Fecha Disposición: } & \text { Fecha informe: } \\ \text { Estado: } & \text { Tipo delimitación: } & \text { Fecha Publicación BOP: } \\ \text { Categorí: } & \text { Plan: } & \text { Fecha Publicación DOCV: } \\ \text { Anotación Mo: } & \text { Informe: } & \text { Fecha Publicación BOE: }\end{array}$

\section{Callejón de Pavón}

\section{- Identificación}

Tramo de estudio:

Otras denominacio

Tramo 1: Puerta de Valencia-Puerta de Alcalá

Ref. catastral:

Localización: C/Colegio / C/Santa María.

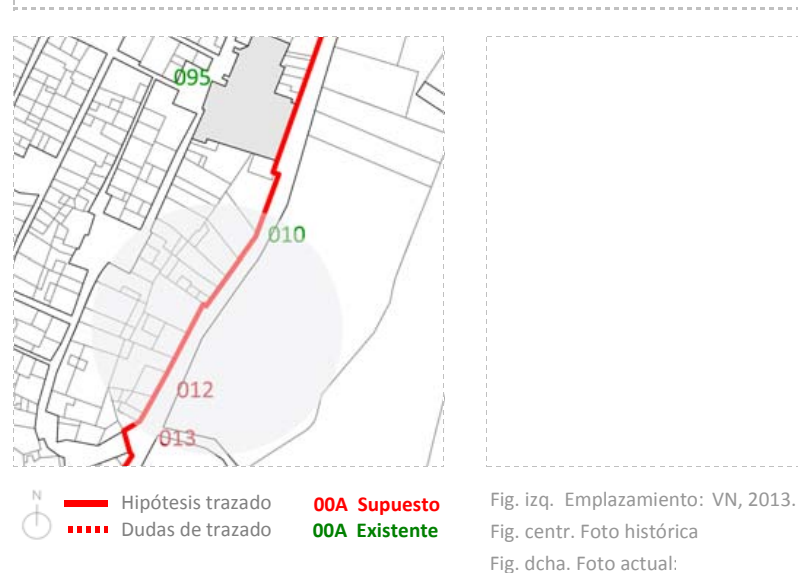

- Referencias en documentación histórica

\section{Referencias numéricas en cartografía sobre fortificación}

-Ref. en el croquis de Ortiz de Pinedo (1837-38, AGM, núm. 262): Sin ref. -Ref. en plano de Vera Aparici (1993): Sin ref.

Referencias en memorias técnicas militares

-Ref. Guillermo Sáez (9/9/1834-5/12/1835): Requena, 5/12/1835 AMR, 1818-50

Se cierra el acceso al callejón desde el exterior.

-Ref. Guillermo Sáez (26/02/1836): Sin ref.

-Ref. P. Ortiz de Pinedo (12/03/1837-30/05/1837): Sin ref.

-Ref Jose Maria de Orozco (25/03/1838): Sin ref.

-Ref. Carbonell (4/7/1838): Sin ref.

\section{- Observaciones a partir de los informes militares}

El callejón del Médico Pavón constituye uno de los cuatro (Médico Pavón, La Cava, Picazo de Narrica y Botica) que integraron la judería a partir del momento en que la judería fue emplazada en el siglo XV a los pies de la torre Redonda (torre Montijana) o de En medio desde su 1986:71). Dado que el callajo Horra (Jorra). Dicho callejón estuvo junto a la demolida mansión de los Enríquez de Navarra (Piqueras,

$\begin{array}{|lll|}\square \frac{\text { Rellenar en caso de que el elemento sea }}{\text { contemplado con datos del PGOU, 2013 }} & \text { PROTECCIÓN } & \text { AFECCIÓN PATRIMONIAL } \\ & \text { Nivel de protección: } & \square \text { Bien de interés cultural (BIC) } \\ & \text { Entorno: } & \square \text { Bien de relevancia local (BRL) } \\ & \square \text { Inmueble } & \square \text { Afectado entorno BIC } \\ & \square \text { Parcela catastral } & \square \text { Afectado Plan especial } \\ & \square \text { Recinto arquitectónico } & \end{array}$

Existe actualmente

Bien do in

Cód. postal: 4634

Municipio: Requena

quena-Utiel 


\section{- Descripción histórico-arquitectónica}

Tipología

Observaciones a la cronologi

Descripción:

\section{- Entorno urbano}

Descripción entorno urbano:

Uso actual:

Estado de conservación:

Intervenciones:

Régimen Urbanístico:

Titularidad:

Nivel protección s/catálogo 1996:

Bibliografía: AMR, 1818-17, 1818-24; 1818-50; 1818-52; 1818-53.

Observaciones generales:

\begin{tabular}{|c|c|c|}
\hline \multirow{2}{*}{$\begin{array}{l}\text { OBJETIVACIÓN DE INTERÉS } \\
\square \text { Interés tipológico }\end{array}$} & Soluciones constructivas & Soluciones ornamentales \\
\hline & $\square$ Estructura & $\square$ Carpintería \\
\hline$\square$ Valor ambiental & $\square$ Aleros & $\square$ Rejería \\
\hline Vigencia de la trama & Coronación & $\square$ Cubrepersianas \\
\hline Composición de la fachada & $\square$ Jambas & $\square$ Alicatados \\
\hline & $\square$ Dinteles & $\square$ Recercos \\
\hline & & $\square$ Dinteles \\
\hline & & $\square$ otros ornamentos \\
\hline
\end{tabular}

- Datos específicos catalogación BIC $\square$ Rellenar sólo si está catalogado BIC

$\begin{array}{lll}\text { Datos Juridicos: } & & \\ \text { Código: } & \text { Fecha Disposición: } & \text { Fecha informe: } \\ \text { Estado: } & \text { Tipo delimitación: } & \text { Fecha Publicación BOP: } \\ \text { Categoría: } & \text { Plan: } & \text { Fecha Publicación DOCV: } \\ \text { Anotación Mo: } & \text { Informe: } & \text { Fecha Publicación BOE: }\end{array}$

\section{Interés paisajistico}

$\square$ Incidencia visual

$\square$ Carácter articulador

$\square$ Organización

$\square$ Caŕcter representativo
010 Bajo de los Huertos

- Identificación

Tramo de estudio:

Tramo 1: Puerta de Valencia-Puerta de Alcalá

Otras denominacions

C/Bajo los Huertos. C/ Colegio

Ref. catastral:

Localización: c/ Colegio.
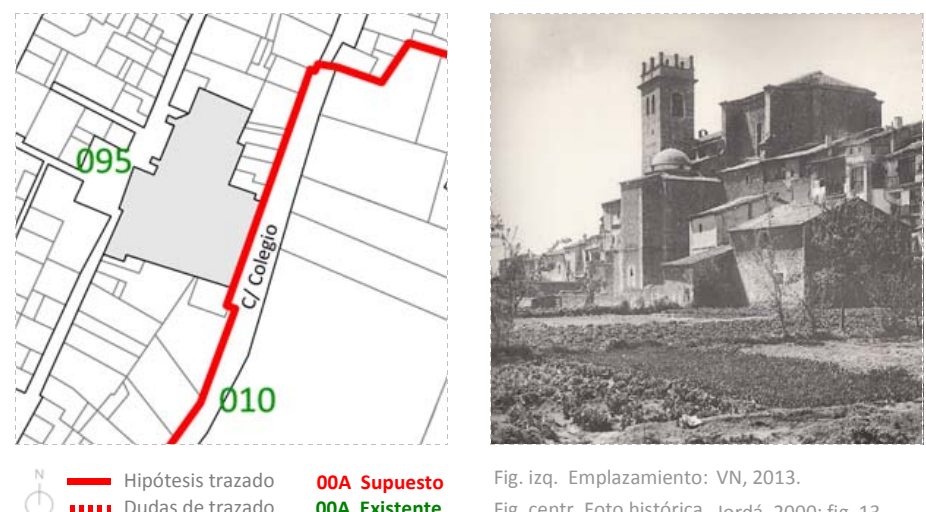

Fig. izq. Emplazamiento: VN, 2013

Fig. centr. Foto histórica Jordá, 2000: fig. 13 Fig. dcha. Foto actual: VN, 2015

-Ref. en plano de Vera Aparici (1993): Sin ref.

Referencias en memorias técnicas militare

-Ref. Guillermo Sáez (26/02/1836): Sin ref.

-Ref Jose María de Orozco (25/03/1838): Sin ref.

-Ref. Carbonell (4/7/1838): Sin ref.

\section{- Referencias en documentación histórica}

Referencias numéricas en cartografía sobre fortificación

-Ref. en el croquis de Ortiz de Pinedo (1837-38, AGM, núm. 262): Sin ref.

-Ref. Guillermo Sáez (9/9/1834-5/12/1835): Requena, 5/12/1835 AMR, 1818-50

Se aseguraba la línea de huertos "y en los parapetos poner ylo de tapia y cerrar el callejón de Pabón".

-Ref. P. Ortiz de Pinedo (12/03/1837-30/05/1837): Sin ref.

\section{- Observaciones a partir de los informes militares}

Es un espacio de Huertos ubicado desde la puerta de Alcalá hasta la actual zona del Batanejo. Se cita la necesidad de cerrar el callejón denominado de Pavón. Se cuenta que en torno a 1089 el Cid, que acude a Requena a descansar, acostumbraba a practicar una de sus 1990:37) Más adelante este lugr fue utilizado para los mismo lances (1300, con motivo de las nupcias de Don luan de Castilla, hijo do

Alfonso X). A partir de la remodelación renacentista de la Villa, los festejos se trasladan a la Plaza de la Villa (ibíd. 38).

$\square$ Existe actualmente

Incluido en fichas PGOU 2013

$\square$ Bien de interés cultural (BIC)

cod. postal: 46340

Comarca: Plana de

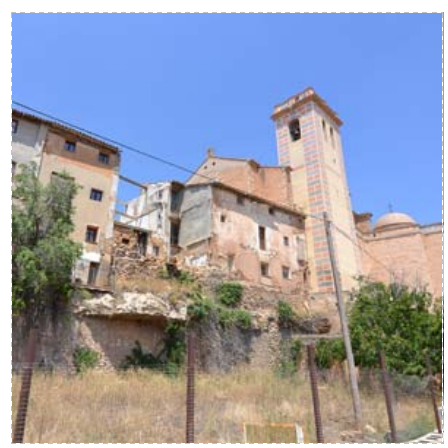


$\square \frac{\text { Rellenar en caso de que el elemento sea }}{\text { Gontermblato }}$

\section{PROTECCIÓN}

Nivel de protección:

AFECCIÓN PATRIMONIAL

Entorno:

$\square$ Inmueble

Parcela catastral

$\square$ Recinto arquitectónico

Bien de interés cultural (BIC)

$\square$ Bien de relevancia local (BRL)

$\square$ Afectado entorno BIC

\section{- Descripción histórico-arquitectónica}

\section{Tipología:}

Cronología:

Observaciones a la cronología

Descripción:

- Entorno urbano

Descripción entorno urbano:

Uso actual:

Estado de conservación:

Intervenciones:

Régimen Urbanistico

Regimen Urb:

Nivel protección s/catálogo 1996:

Bibliografía: AMR, 1818-17, 1818-24; 1818-50; 1818-52; 1818-53.

Observaciones generales:

\begin{tabular}{lll} 
OBJETIVACIÓN DE INTERÉS & Soluciones constructivas & Soluciones ornamentales \\
$\square$ Interés tipológico & $\square$ Estructura & $\square$ carpintería \\
\hline$\square$ Valor ambiental & $\square$ Aleros & $\square$ Rejería \\
\hline$\square$ vigencia de la trama & $\square$ coronación & $\square$ cubrepersianas \\
$\square$ composición de la fachada & $\square$ Jambas & $\square$ Alicatados \\
$\square$ Materiales, color, textura & $\square$ Dinteles & $\square$ Recercos \\
& & $\square$ Dinteles \\
& $\square$ otros ornamentos
\end{tabular}

- Datos específicos catalogación BIC $\square$ Rellenar sólo si está catalogado BIC Datos Jurídicos:

$\begin{array}{lll}\text { Datos Juridicos: } & \text { Fecha Disposición: } & \text { Fecha informe: } \\ \text { Código: } & \text { Tipo delimitación: } & \text { Fecha Publicación BOP: } \\ \text { Estado: } & \text { Plan: } & \text { Fecha Publicación DOCV: } \\ \text { Categoría: } & \text { Informe: } & \text { Fecha Publicación BOE: }\end{array}$

\section{Granero de Don Francisco Antonio Herrero}

- Identificación

Tramo de estudio:

Tramo 1: Puerta de Valencia-Puerta de Alcalá

Otras denominaciones:

Ref. catastral:

Localización: c/ Colegio.

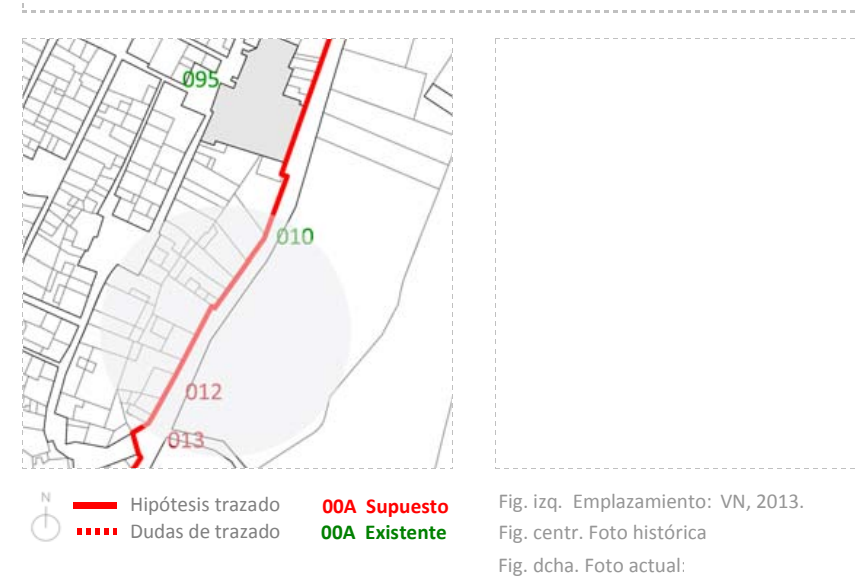

- Referencias en documentación histórica

\section{Referencias numéricas en cartografía sobre fortificación}

-Ref. en el croquis de Ortiz de Pinedo (1837-38, AGM, núm. 262): Sin ref.

-Ref. en plano de Vera Aparici (1993): Sin ref.

Referencias en memorias técnicas militares

-Ref. Guillermo Sáez (9/9/1834-5/12/1835): Sin ref.

-Ref. Guillermo Sáez (26/02/1836): Sin ref.

-Ref. P. Ortiz de Pinedo (12/03/1837-30/05/1837): Sin ref.

-Ref Jose María de Orozco (25/03/1838): Sin ref.

-Ref. Carbonell (4/7/1838): AMR, 1818-17, fol. 8

Se reforzarán sus paredes y tabiques, se tapiarán las ventanas y se harán aspilleras en los dos pisos, puesto que la poca altura de las del bajo no parecen perjudiciales debido a la horma que existe en frente (se entiende por horma a una pared de piedra seca) (Carbonell, Requena, 4 de julio de 1838, AMR, 1818-17, fo. 8).

\section{- Observaciones a partir de los informes militares}

Este granero parece volcar una de sus tapias hacia el exterior, por lo que integra la defensa. Precisamente el granero se conecta con las tapias que vienen del fortín del Batanejo (007b), como se explica en ese apartado acometen al granero con $2,92 \mathrm{~m}$ de altura, con aspilleras
a $1,81 \mathrm{~m}$ y banqueta de madera en la parte posterior. Las aspillera se elevan a 1,8 del suelo. Se habla de tapia y de macizado de puerta. La estrategia es la misma, generar un muro aspillerado. El granero tiene dos pisos con puertas y ventanas. Se propone aspillerar ambos. Existe un muro de piedra seca frente al granero que no parece generar inconveniente. 
$\square$ Rellenar en caso de que el elemento sea $\quad$ PROTECCIÓN

Nivel de protección

$\square$ Bien de interés cultural (BIC)

$\square$ Bien de relevancia local (BRL)

$\square$ Inmueble

$\square$ Parcela catastral

$\square$ Recinto arquitectónico

$\square$ Afectado entorno BIC
$\square$ Afectado Plan especial

\section{- Descripción histórico-arquitectónica}

Tipología:

Cronología:

Observaciones a la cronología

Descripción:

- Entorno urbano

Descripción entorno urbano

Uso actual:

Estado de conservación:

Intervenciones:

\section{Régimen Urbanístico:}

Titularidad:

Nivel protección s/catálogo 1996:

Bibliografía: AMR, 1818-17, 1818-24; 1818-50; 1818-52; 1818-53.

Observaciones generales:

$\begin{array}{lll}\text { OBJETIVACIÓN DE INTERÉS } & \text { Soluciones constructivas } & \text { Soluciones ornamentales } \\ \square \text { Interés tipológico } & \square \text { Estructura } & \square \text { carpintería } \\ \square \text { Valor ambiental } & \square \text { Aleros } & \square \text { Rejería } \\ \square \text { vigencia de la trama } & \square \text { coronación } & \square \text { Cubrepersianas } \\ \square \text { Composición de la fachada } & \square \text { Jambas } & \square \text { Alicatados } \\ \square \text { Materiales, color, textura } & \square \text { Dinteles } & \square \text { Recercos } \\ & & \square \text { Diteles } \\ & & \square \text { otros ornamentos }\end{array}$

\section{- Datos específicos catalogación BIC $\square$ Rellenar sólo si está catalogado BIC}

$\begin{array}{lll}\text { Datos Juridicos: } & & \\ \text { Código: } & \text { Fecha Disposición: } & \text { Fecha informe: } \\ \text { Estado: } & \text { Tipo delimitación: } & \text { Fecha Publicación BOP: } \\ \text { Categoría: } & \text { Plan: } & \text { Fecha Publicación DOCV: } \\ \text { Anotación Mo: } & \text { Informe: } & \text { Fecha Publicación BOE: }\end{array}$

\section{Interés paisajístico}

$\square$ Incidencia visual

$\square$ Carácter articulado

$\square$ Organización

Carácter representativo

\section{Tapias aspilleradas y edificios intermedios desde el Granero de Herrero a la Puerta} de Alcalá

\section{- Identificació}

Tramo de estudio:

Tramo 1: Puerta de Valencia-Puerta de Alcalá

Otras denominaciones: Afecta al Pajar de Ignacio Moya, huerta de [Domingo] Vive

Ref. catastral:

Localización: c/ Colegio.

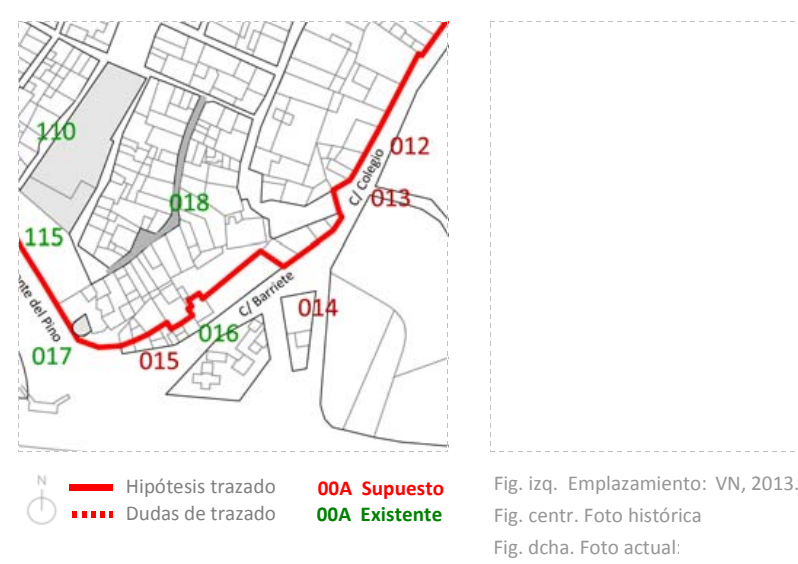

- Referencias en documentación histórica

Referencias numéricas en cartografía sobre fortificación

-Ref. en el croquis de Ortiz de Pinedo (1837-38, AGM, núm. 262): Sin ref.

-Ref. en plano de Vera Aparici (1993): 008

Referencias en memorias técnicas militares

-Ref. Guillermo Sáez (9/9/1834-5/12/1835): Sin ref.

-Ref. Guillermo Sáez (26/02/1836): Sin ref.

-Ref. P. Ortiz de Pinedo (12/03/1837-30/05/1837): Sin ref.

-Ref Jose María de Orozco (25/03/1838): Sin ref.

-Ref. Carbonell (4/7/1838): AMR, 1818-17, fol. 8-10

Esta linea configura un reentrante, lo cual favorece su posición por la protección que recibe de las mismas obras (frente atenazado), por el fueg espalda y por los obstaculos que presentan los ribazos que la anteceden. Sin embargo en spensable seguridad ante un ataque sorpresa. Los defectos de que adolece y sus el fondo del foso en los [parajes] donde éste se ejecute. Como parte de la altura en muchos fragmentos es aportada por las hormas o ribazos sobre los que asientan las tapias, es preciso ser precavido para escarparla (dotarlas de cierto talud) y arrancar las matas y arbustos existente para impedir la subida. No basta que el parapeto tenga el relieve citado, sino cubre bien a los defensores de los tiros de frente, de rieses ye entlada. Este desenfilada de las caras a cuyo fin se empleán también traviesas (traveses) donde converga Las comunicaciones entre todas las par de esta línea estarán expeditas y a cubierto. En diversos sitios deben recomponerse las tapias, y en aquellos donde ha habido Puerta se macizará el hueco con buena mamposteria, en vez del debil cerramiento que tienen. Casi todas las aspilleras son defectuosas, tanto por su colocación, como por su figura y dimensiones; es necesario pues reforzarlas en terminos que queden mas desahogadas, que sus caras estén mejor dirijidas, $y$ que disten 4 pies de centro a centro $(1,11 \mathrm{~m})$. Se revocaran [para] mayor resistencia de cada una, pero tambien de del campo no pueda introducirse en ellos un fusil, y que por el lado interior estén a 4 ó 4,5 pies $(1,11 \mathrm{~m} 01.25 \mathrm{~m})$ sobre el piso, 0 sobre banqueta Se establecrén banquetas de tierra de 3.5 pies de ancho $(0,97 \mathrm{~m})$ donde sea preciso para satiffacer las condiciones exprestas en cuyo caso no se dejarán acequias, ni espacio alguno entre ellas $y$ el parapeto- 


\section{- Observaciones a partir de los informes militares}

Se trata de una amplia línea defensiva que se extendería a los pies de la muralla de la Villa hasta la puerta de Alcalá (012-017). Se suceden en ella una serie de propiedades. Se define como reentrante, ya que entre la linea del Batanejo y esta linea se definen las dos caras

\section{$\square \frac{\text { Rellenar en caso de que el elemento sea }}{\text { Contempen }}$}

\section{PROTECCIÓN}

Nivel de protección:

AFECCIÓN PATRIMONIAL

Entorno:

$\square$ Inmueble

Parcela catastral

Entorno espećifico $\square$ Bien de interés cultural (BIC)

$\square$ Bien de relevancia local (BRL)

$\square$ Afectado entorno BIC

$\square$ Afectado Plan especial

\section{- Descripción histórico-arquitectónica}

Tipología:

Observaciones a la cronología

Descripción:

\section{- Entorno urbano}

Descripción entorno urbano:

Uso actual:

Estado de conservación:

Intervenciones:

Régimen Urbanistico:

Titularidad:

Nivel protección s/catálogo 1996:

Bibliografía: AMR, 1818-17, 1818-24; 1818-50; 1818-52; 1818-53.

Observaciones generales:

$\begin{array}{llll}\text { OBJETIVACIÓN DE INTERÉS } & \text { Soluciones constructivas } & \text { Soluciones ornamentales } & \text { Interés paisajistico } \\ \square \text { Interés tipológico } & \square \text { Estructura } & \square \text { Carpintería } & \square \text { Incidencia visual } \\ \square \text { Valor ambiental } & \square \text { Aleros } & \square \text { Rejería } & \square \text { Carácter articulador } \\ \square \text { vigencia de la trama } & \square \text { Coronación } & \square \text { cubrepersianas } & \square \text { Organización } \\ \square \text { Composición de la fachada } & \square \text { Jambas } & \square \text { Alicatados } & \square \text { Interés cultural } \\ \square \text { Materiales, color, textura } & \square \text { Dinteles } & \square \text { Recercos } & \square \text { Carácter representativo } \\ & & \square \text { Dinteles } & \\ & & \square \text { otros ornamentos } & \end{array}$

- Datos específicos catalogación BIC $\square$ Rellenar sólo si está catalogado BIC

Datos Jurídicos:

$\begin{array}{lll}\text { Datos Juridicos: } & \text { Fecha Disposición: } & \text { Fecha informe: } \\ \text { Código: } & \text { Tipo delimitación: } & \text { Fecha Publicación BOP: } \\ \text { Estado: } & \text { Plan: } & \text { Fecha Publicación DOCV: } \\ \text { Categoría: } & \text { Informe: } & \text { Fecha Publicación BOE: }\end{array}$

\section{2b Plataforma del pajar de Ignacio Moya}

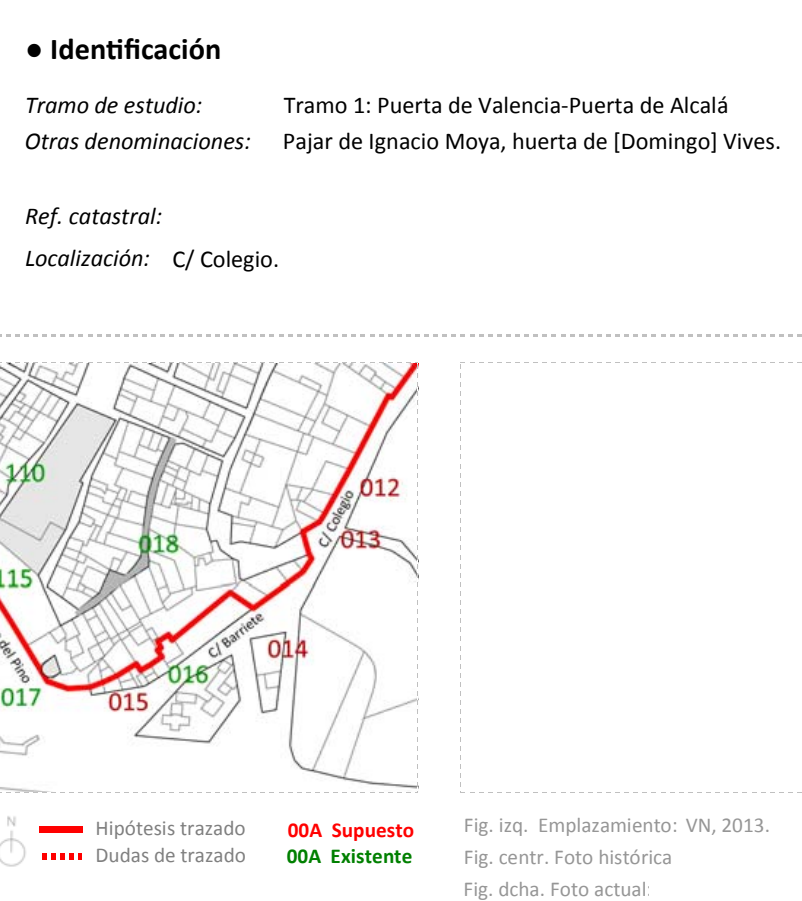

Existe actualmente

Incluido en fichas PGOU 2013

Bien de interés cultural (BIC)

cód. postal: 46340

Municipio: Requena

Comarca: Plana de Requena-Utie

Provincia: Valencia

Autonomía: Comunidad Valenciar

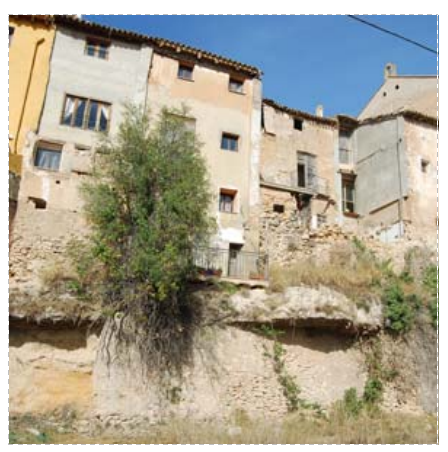

- Referencias en documentación histórica

Referencias numéricas en cartografía sobre fortificación

-Ref. en el croquis de Ortiz de Pinedo (1837-38, AGM, núm. 262): Sin ref.

-Ref. en plano de Vera Aparici (1993): 008

Referencias en memorias técnicas militares

-Ref. Guillermo Sáez (9/9/1834-5/12/1835): Sin ref.

-Ref. Guillermo Sáez (26/02/1836): Sin ref.

-Ref. P. Ortiz de Pinedo (12/03/1837-30/05/1837): Sin ref.

-Ref Jose María de Orozco (25/03/1838): Sin ref.

-Ref. Carbonell (4/7/1838): AMR, 1818-17, fol. 8-10

Para que la extensa cortina del mediodia quede mejor defendida se levantará una plataforma, apoyada en el Pajar de Ignacio Moya, por donde se le dará comunicacion. Sus planos apoyarán en las esquinas del Pajar: el de la derecha formará un angulo de 100 grados con la de [Domingo] Vives: el otro fron pies de espesor en el bajo y de uno y medio en el superior, aspillerándolas de vara en vara. Sobre la cara habrá un tejado de 1,5 varas de .

- Observaciones a partir de los informes militares

Integra la línea $012-0,17$, la cara de la tenaza definida por el frente amurallado Sureste de la Villa. Su objetivo es incrementar la defensa de este frente con un punto elevado (Ver descripción de Juan Ramón de Carbonell) (Ver 012) 


\section{Rellenar en caso de que el elemento sea
contemplado con datos del PGOU, 2013}

\section{PROTECCIÓN}

Nivel de protección:

Entorno:

$\square$ Inmueble

$\square$ Parcela catastral

$\square$ Entorno específico

- Descripción histórico-arquitectónica

\section{Tipología:}

Cronología:

Observaciones a la cronologia

Descripción:

- Entorno urbano

Descripción entorno urbano

Uso actual:

Estado de conservación:

Intervenciones:

Régimen Urbanistico:

Titularidad:

Nivel protección s/catálogo 1996:

Bibliografía: AMR, 1818-17, 1818-24; 1818-50; 1818-52; 1818-53.

Observaciones generales:

\begin{tabular}{|c|c|c|}
\hline OBJETIVACIÓN DE INTERÉS & Soluciones constructivas & Soluciones ornamentales \\
\hline Interés tipológico & $\square$ Estructura & $\square$ Carpintería \\
\hline Valor ambiental & Aleros & $\square$ Rejería \\
\hline Vigencia de la trama & $\square$ Coronación & $\square$ Cubrepersianas \\
\hline Composición de la fachada & $\square$ Jambas & $\square$ Alicatados \\
\hline Materiales, color, textura & Dinteles & $\square$ Recercos \\
\hline & & $\square$ Dinteles \\
\hline & & $\square$ Otros ornamentos \\
\hline
\end{tabular}

- Datos específicos catalogación BIC $\square$ Rellenar sólo si está catalogado BIC

Datos Jurídicos:

$\begin{array}{lll}\text { Código: } & \text { Fecha Disposición: } & \text { Fecha informe: } \\ \text { Estado: } & \text { Tipo delimitación: } & \text { Fecha Publicación BOP: } \\ \text { Categoria: } & \text { Plan: } & \text { Fecha Publicación DOCV: } \\ \text { Anotación Mo: } & \text { Informe: } & \text { Fecha Publicación BOE: }\end{array}$

AFECCIÓN PATRIMONIAL

$\square$ Bien de interés cultural (BIC)

$\square$ Afectado entorno BIC

Afectado Plan especial

\section{2c Parapeto aspillerado de la casa de Maluenda}

\section{- Identificación}

Tramo de estudio:

Tramo 1: Puerta de Valencia-Puerta de Alcala

Otras denominaciones: Casa de Maluenda

Ref. catastral:

Localización: c/ Colegio.

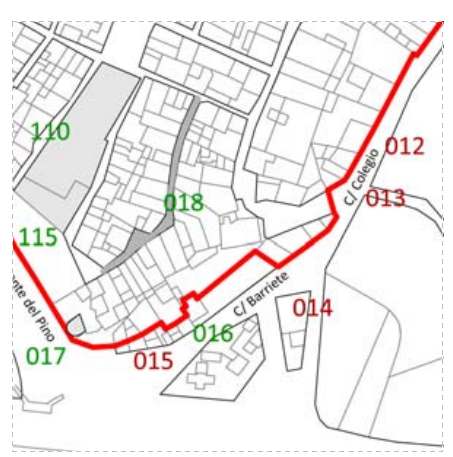

-... Hipótesis trazado 00A Supuesto

\section{Interés paisajistico}

$\square$ Incidencia visual

$\square$ Craranización

Interés cultural

Carácter representativo

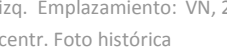

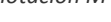
Fecha Publicación BOE:

\section{- Referencias en documentación histórica}

\section{Referencias numéricas en cartografía sobre fortificación}

-Ref. en el croquis de Ortiz de Pinedo (1837-38, AGM, núm. 262): Sin ref. -Ref. en plano de Vera Aparici (1993): 008

Referencias en memorias técnicas militares

-Ref. Guillermo Sáez (9/9/1834-5/12/1835): Sin ref.

-Ref. Guillermo Sáez (26/02/1836): Sin ref.

-Ref. P. Ortiz de Pinedo (12/03/1837-30/05/1837): Sin ref.

-Ref Jose Maria de Orozco (25/03/1838): Sin ref.

-Ref. Carbonell (4/7/1838): AMR, 1818-17, fol. 8-10

En frente de las dos paredes de la casa de Maluenda que caen a la campaña, y [a] 5 baras de distancia, se construirá un parapeto aspillerado de 4 varas de alto $(3,34 \mathrm{~m})$, formando una garita en su angulo saliente. En los pisos altos de [dicha] casa se abrirán todas

- Observaciones a partir de los informes militares

Integra la línea 012-0,17, la cara de la tenaza definida por el frente amurallado Sureste de la Villa. Su objetivo es incrementar la defensa de este frente con un punto elevado (Ver descripción de Juan Ramón de Carbonell). Para ello se aprovecha esta casa, adosada a la muralla y con dos caras expuestas para aspillerarla. Frente a ella se antepone un parapeto con garita (Ver 012).
Existe actualmente

2013

$\square$ Bien de interés cultural (BIC)

Cód. postal: 46340

uena-Utie

Provincia: Valencia

Autonomia: Comunidad Valenciar

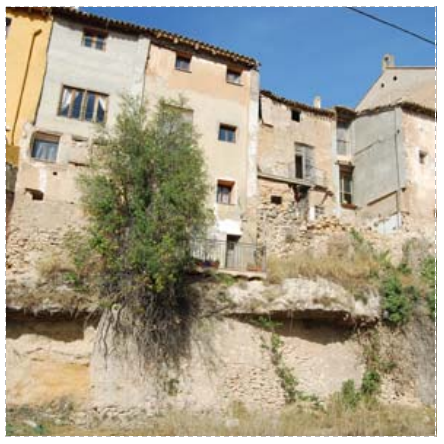




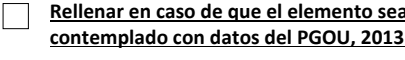

\section{PROTECCIÓN}

Nivel de protección:

AFECCIÓN PATRIMONIAL

$\square$ Inmueble
$\square$ Parcela catastra

$\square$ Recinto arquitectónico

$\square$ Entorno específico $\square$ Bien de interés cultural (BIC)

$\square$ Afectado entorno BIC

$\square$ Afectado Plan especial

- Descripción histórico-arquitectónica

Tipología:

Cronología:

Observaciones a la cronología:

Descripción

- Entorno urbano

Descripción entorno urbano:

Uso actual:

Estado de conservación:

Intervenciones:

Régimen Urbanistico:

Régimen Urb

Nivel protección s/catálogo 1996:

Bibliografía: AMR, 1818-17, 1818-24; 1818-50; 1818-52; 1818-53.

Observaciones generales:

\begin{tabular}{|c|c|c|}
\hline OBJETIVACIÓN DE INTERÉS & Soluciones constructivas & Soluciones ornamentales \\
\hline Interés tipológico & $\square$ Estructura & $\square$ Carpintería \\
\hline Valor ambiental & Aleros & Rejería \\
\hline Vigencia de la trama & Coronación & $\square$ Cubrepersianas \\
\hline Composición de la fachada & $\square$ Jambas & $\square$ Alicatados \\
\hline Materiales, color, textura & $\square$ Dinteles & $\square$ Recercos \\
\hline & & Dinteles \\
\hline & & \\
\hline
\end{tabular}

Interés paisajistico
$\square$ Incidencia visual
$\square$ Carácter articulador
$\square$ Organización
$\square$ Interés cultural
$\square$ Carácter representativo

- Datos específicos catalogación BIC

$\square$ Rellenar sólo si está catalogado BIC

Datos Jurídicos:

Código:

Estado:

Fecha Disposición:

Anotación $M$

Tipo delimitación:

Plan:

Informe:

Fecha informe:

Fecha Publicación BOP:

Fecha Publicación DOCV:

Fecha Publicación BOE:

\section{2d Plataforma de la casa de Dạ Ma Herrero}

\section{- Identificación}

Tramo de estudio:

Otras denominacio

Tramo 1: Puerta de Valencia-Puerta de Alcalá

Ref. catastral:

Localización: c/ Colegio.

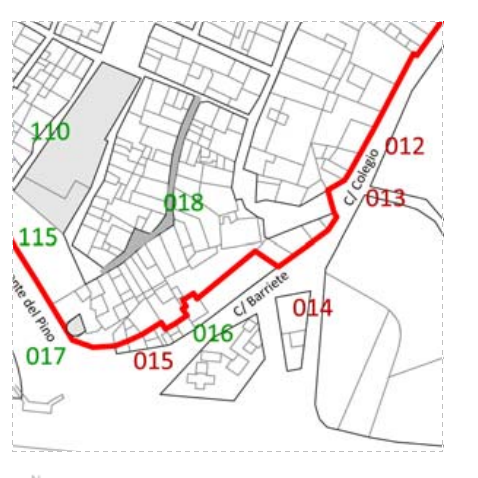

-... Hipótesis trazado ${ }^{\text {OOA Supuesto }}$

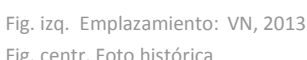

Fig. centr. Foto histórica
Fig. dcha. Foto actual.

\section{- Referencias en documentación histórica}

\section{Referencias numéricas en cartografía sobre fortificación}

-Ref. en el croquis de Ortiz de Pinedo (1837-38, AGM, núm. 262): Sin ref.

-Ref. en plano de Vera Aparici (1993): 008

Referencias en memorias técnicas militares

-Ref. Guillermo Sáez (9/9/1834-5/12/1835): Sin ref.

-Ref. Guillermo Sáez (26/02/1836): Sin ref.

-Ref. P. Ortiz de Pinedo (12/03/1837-30/05/1837): Sin ref.

-Ref Jose María de Orozco (25/03/1838): Sin ref.

-Ref. Carbonell (4/7/1838): AMR, 1818-17, fol. 8-10

"Es de absoluta necesidad proporcionar algún flanqueo al extremo de la [extensa] línea de levante, que carece absolutamente de esta proteccion. A este fin se levantará [una] plataforma en la curva que forman las tapias enfrente de la casa de Dả María Herrero. La cara de esta plataforma insistirá en el revestimiento del camino contiguo, sacando un flanqueo de la casa de [Maluenda], y tendrá 9 varas de lado exterior $(7,52 \mathrm{~m}$ ): los dos flancos formarán con las tapias anngulos de 110 grados. Esta obra tendră dos cuerpos, el espesor de sus muros en el bajo sera de 3 pies $(0,28 \mathrm{~m})$, en la cara, $y$ en el flanco de la derecha, y en el superior $y$ todo el flanco de la izquierda será de 1,5 pies $(0,42$

\section{- Observaciones a partir de los informes militares}

Integra la linea $012-0,17$, la cara de la tenaza definida por el frente amurallado Sureste de la Villa. Se trata de una plataforma destinada a flanquear toda esta linea defensiva. Parece que su ubicación coincidiría con la curva comprendida entre los puntos 015 y 017 del plano.
Incluido en fichas PGOU 2013

Bien de interés cultural (BIC)

postal: 46340

Comarca: Plana de Requena-Utie

Provincia: Valencia

Autonomia: Comunidad Valenciar

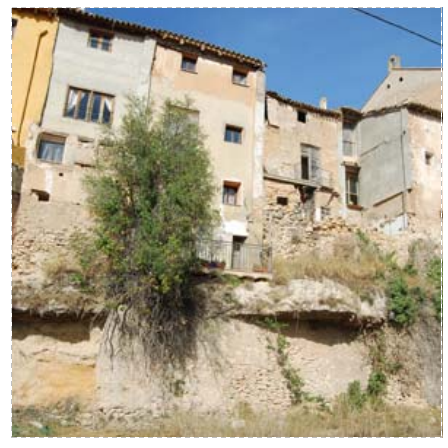


$\frac{\text { Rellenar en caso de que el elemento sea }}{\text { contemplado }}$

\section{PROTECCIÓN}

Nivel de protección:

Entorno:

$\square$ Inmueble

$\square$ Parcela catastral

$\square$ Recinto arquitectónico
AFECCIÓN PATRIMONIAL

$\square$ Bien de interés cultural (BIC)

$\square$ Afectado entorno BIC

$\square$ Afectado Plan especia
- Descripción histórico-arquitectónica

Tipología:

Cronología:

Observaciones a la cronologia:

Descripción

- Entorno urbano

Descripción entorno urbano:

Uso actual:

Estado de conservación:

Intervenciones:

Régimen Urbanistico:

Titularidad:

Nivel protección s/catálogo 1996:

Bibliografía: AMR, 1818-17, 1818-24; 1818-50; 1818-52; 1818-53.

Observaciones generales:

\section{OBJETIVACIÓN DE INTERÉS}

$\square$ Interés tipológico

Valor ambiental

Vigencia de la trama

Materiales, color, textura

Soluciones constru
$\square$ Estructura
$\square$ Aleros
$\square$ Coronación
$\square$ Jambas
$\square$ Dinteles

Soluciones ornamentales
$\square$ Carpintería
$\square$ Rejería
$\square$ Cubrepersianas
$\square$ Alicatados
$\square$ Recercos
$\square$ Dinteles

Interés paisajístico

$\square$ Incidencia visual

$\square$ Carácter articulador

$\square$ Organización

$\square$ Interés cultural

Otros ornamentos

\section{- Datos específicos catalogación BIC $\square$ Rellenar sólo si está catalogado BIC}

\section{Datos Jurídicos:}

Estado:

Categoría:

Anotación $M$

Fecha Disposición:
Tipo delimitación:

Plan:

Informe:
Fecha informe

Fecha Publicación BOP:

Fecha Publicación DOCV:

Fecha Publicación BOE:

\section{2e Línea de tapias aspilleradas de bajo los Huertos}

\section{- Identificación}

Tramo de estudio:

Tramo 1: Puerta de Valencia-Puerta de Alcalá

Otras denominaciones: Casa de Maluenda, Casa de Don Eusebio Chorrea

Ref. catastra:

Localización: c/ Colegio

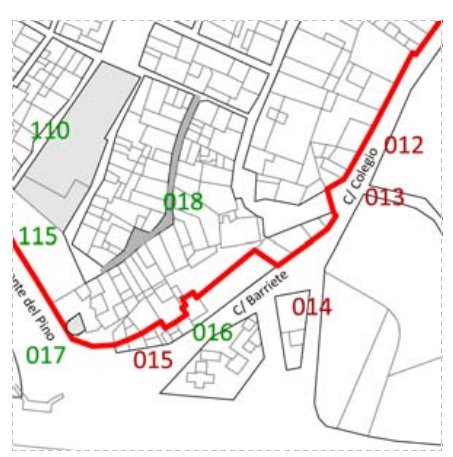

-... Hipótesis trazado OoA Supuesto
Existe actualmente

Incluido en fichas PGOU 2013

Bien de interés cultural (BIC)

cód. postal: 46340

Municipio: Requen

Comarca: Plana de Requena-Utie

Prvincia: Valencia

Autonomia: Comunidad Valencian

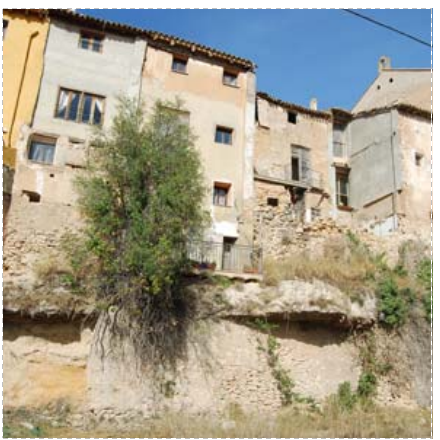

\section{- Referencias en documentación histórica}

\section{Referencias numéricas en cartografía sobre fortificación}

-Ref. en el croquis de Ortiz de Pinedo (1837-38, AGM, núm. 262): Sin ref.

-Ref. en plano de Vera Aparici (1993): 008

Referencias en memorias técnicas militares

-Ref. Guillermo Sáez (9/9/1834-5/12/1835): Sin ref.

-Ref. Guillermo Sáez (26/02/1836): Sin ref.

-Ref. P. Ortiz de Pinedo (12/03/1837-30/05/1837): Sin ref.

-Ref Jose Maria de Orozco (25/03/1838): Sin ref.

-Ref. Carbonell (4/7/1838): AMR, 1818-17, fol. 8-10

Toda la línea de tapia del sitio llamado "Bajo de los huertos", se guarnecerá con foso, cuyo obstaculo correrá por delante de la plataforma que se acaba de describir, $y$ parapetos de la casa de Maluenda hasta el ribazo.

Se aspillerarán en todos los pisos las paredes de las casas de la Villa que caen al bajo de los huertos, y se cerrarán en ellas con un recio muro de mamposterla las puertas que hay abiertas o mal tapiadas. No obstante, se dejara la comunicacion alta [que) existe en la casa que habita Don Eusebio Chorea, pero se acabará de destruir la escalera de piedra, y en su lugar se usara una escala movil de madera. Para

\section{- Observaciones a partir de los informes militares}

Integra la linea 012-0,17, la cara de la tenaza definida por el frente amurallado Sureste de la Villa. Constituye el cerramiento exterior de esta linea. Dicho de otro modo, el muro que cierra los huertos a los pies de Santa María. (Ver descripción de Juan Ramón de Carbonell). S 


\section{Rellenar en caso de que ele lemento sea
contemplado o con datos del 1 PGOU, 2013}

PROTECCIÓN

Nivel de protección:

Entorno:

$\square$ Inmueble

$\square$ Parcela catastral

Recinto arquitectónico

$\square$ Entorno específico

AFECCIÓN PATRIMONIAL

$\square$ Bien de interés cultural (BIC)

$\square$ Afectado entorno BIC

$\square$ Afectado Plan especia

\section{- Descripción histórico-arquitectónica}

Tipología:

Cronología:

Observaciones a la cronologia:

Descripción

- Entorno urbano

Descripción entorno urbano:

Uso actual:

Estado de conservación:

Intervenciones:

Régimen Urbanístico:

Titularidad:

Nivel protección s/catálogo 1996:

Bibliografía: AMR, 1818-17, 1818-24; 1818-50; 1818-52; 1818-53.

Observaciones generales:

\section{OBJETIVACIÓN DE INTERÉS}

$\square$ Interés tipológico

$\square$ Valor ambiental

Vigencia de la trama

Materiales, color, textura

Soluciones construc
$\square$ Estructura
$\square$ Aleros
$\square$ Coronación
$\square$ Jambas
$\square$ Dinteles

Soluciones ornamentales
$\square$ Carpintería
$\square$ Rejería
$\square$ Cubrepersianas
$\square$ Alicatados
$\square$ Recercos
$\square$ Dinteles
$\square$ Otros ornamentos

Interés paisajistico
$\square$ Incidencia visual
$\square$ Carácter articulador
$\square$ Organización
$\square$ Interés cultural
$\square$ Carácter representativo

$\square$ Interés cultural

$\square$ Otros ornamentos

\section{- Datos específicos catalogación BIC $\square$ Rellenar sólo si está catalogado BIC}

\section{Datos Jurídicos:}

Datos Juridicos:
Código:

Estado:

Categoría:

Anotación Mo
Fecha Disposición:
Tipo delimitación:

Plan:

Informe:
Fecha informe:

Fecha Publicación BOP:
Fecha Publicación BOE:

\section{Corrales altos de la Villa}

\section{- Identificación}

Tramo de estudio:

Tramo 1: Puerta de Valencia-Puerta de Alcalà

Otras denominaciones: Cuevas debajo de la peña (que actúan de suelo de los corr

Ref. catastral:

Localización: C/ Colegio / C/ Santa María.

Bien de interés cultural (BIC)

cód. postal: 46340

Municipio: Requen

Comarca: Plana de Requena-Utie

Provincia: Valencia

Autonomía: Comunidad Valencian

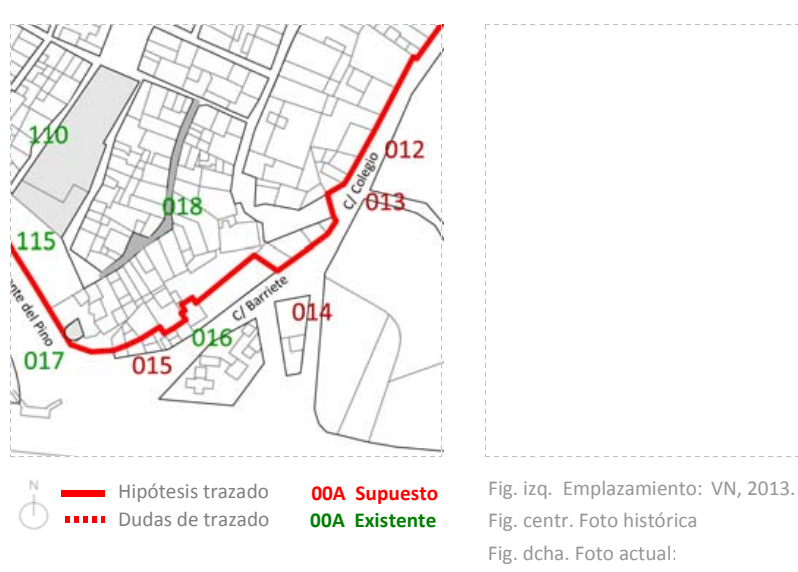

- Referencias en documentación histórica

Referencias numéricas en cartografía sobre fortificación

-Ref. en el croquis de Ortiz de Pinedo (1837-38, AGM, núm. 262): Sin ref.

-Ref. en plano de Vera Aparici (1993): Sin ref.

Referencias en memorias técnicas militares

-Ref. Guillermo Sáez (9/9/1834-5/12/1835): Sin ref.

-Ref. Guillermo Sáez (26/02/1836): Sin ref.

-Ref. P. Ortiz de Pinedo (12/03/1837-30/05/1837): Sin ref.

-Ref Jose María de Orozco (25/03/1838): Sin ref.

-Ref. Carbonell (4/7/1838): AMR, 1818-17, fol. 11

Se allanará el piso de modo que las aspilleras queden a la altura de 4 pies: se levantará el parapeto donde es necesario para cubrir a los defensores de los tiros de frente y de lenfiladal, y se dará comunicacion a los dos corrales entre sí. Se cerrarán con piedra seca revocada 1818-17, fo. 11)

\section{- Observaciones a partir de los informes militares}

En el frente de Levante de la Villa, existían corrales altos correspondientes a las viviendas que volcaban a la Calle Santa María. Las tapias de estos corrales pueden resguardar a defensores aspillerándolas. Aportarían una nueva línea de fuego desde las alturas. 
$\square$ Rellenar en caso de que ele elemento sea

\section{PROTECCIÓN}

Nivel de protección:

AFECCIÓN PATRIMONIAL

$\square$ Bien de interés cultural (BIC)

$\square$ Inmueble

$\square$ Parcela catastral

$\square$ Recinto arquitectónico

$\square$ Afectado entorno BIC

$\square$ Afectado Plan especia

\section{- Descripción histórico-arquitectónica}

Tipología:

Cronologia:

Observaciones a la cronologia:

\section{Descripción}

- Entorno urbano

Uso actual:

Estado de conservación:

Intervenciones:

\section{Régimen Urbanistico:}

Titularidad:

Nivel protección s/catálogo 1996:

Bibliografía: AMR, 1818-17, 1818-24; 1818-50; 1818-52; 1818-53.

Observaciones generales:

$\begin{array}{lll}\text { OBJETIVACIÓN DE INTERÉS } & \text { Soluciones constructivas } & \text { Soluciones ornamentales } \\ \square \text { Interés tipológico } & \square \text { Estructura } & \square \text { Carpintería } \\ \square \text { Valor ambiental } & \square \text { Aleros } & \square \text { Rejería } \\ \square \text { vigencia de la trama } & \square \text { Coronación } & \square \text { cubrepersianas } \\ \square \text { Composición de la fachada } & \square \text { Jambas } & \square \text { Alicatados } \\ \square \text { Materiales, color, textura } & \square \text { Dinteles } & \square \text { Recercos } \\ & & \square \text { Dinteles } \\ & \square \text { otros ornamentos }\end{array}$

Interés paisajístico
$\square$ Incidencia visual
$\square$ Carácter articulador
$\square$ organización
$\square$ Interés cultural
$\square$ Carácter representativo

- Datos específicos catalogación BIC

$\square$ Rellenar sólo si está catalogado BIC Datos Jurídicos:

$\begin{array}{lll}\text { Código: } & \text { Fecha Disposición: } & \text { Fecha informe: } \\ \text { Estado: } & \text { Tipo delimitación: } & \text { Fecha Publicación BOP: } \\ \text { Categoria: } & \text { Plan: } & \text { Fecha Publicación DOCV: } \\ \text { Anotación } M \text { Mo: } & \text { Informe: } & \text { Fecha Publicación BOE: }\end{array}$

\section{Puerta de Alcalá y su batería}

- Identificación

Tramo de estudio:

Otras denominaciones:

Tramo 2: Puerta de Alcalá-Puerta de Cantarranas

Ref. catastral:

Localización: C/ Colegio. En la confluencia con la C/ Barriete

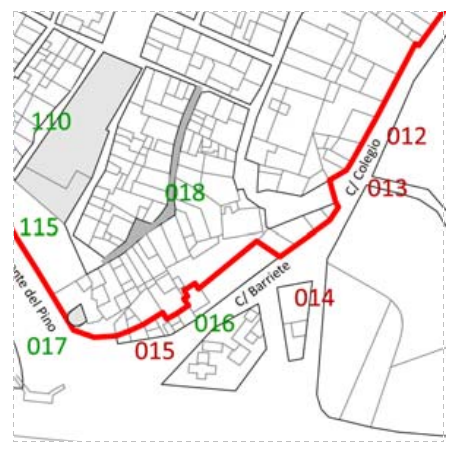

- Hipótesis trazado OOA Supuesto $\square$ Existe actualmente

$\square$ Bien de interés cultural (BIC)

cód. postal: 46340

Municipio: Requena

Comarca: Plana de Requena-Utiel

Provincia: Valencia

Autonomia: Comunidad Valenciar

\section{- Referencias en documentación histórica}
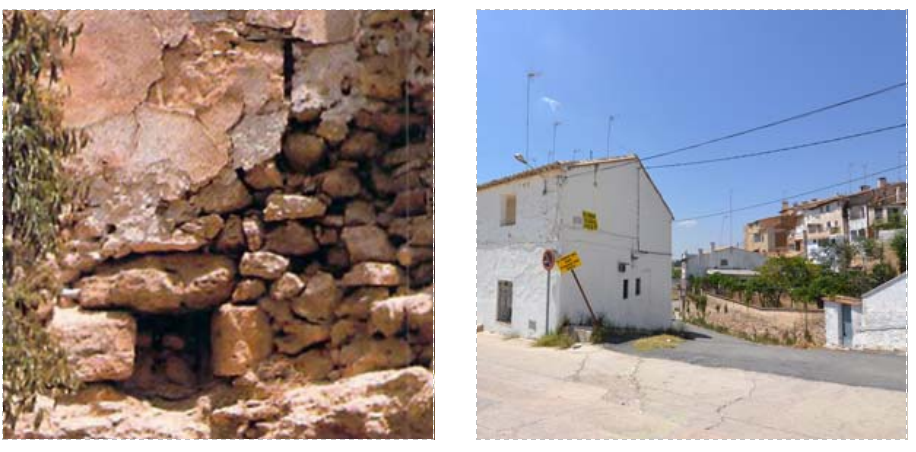

\section{Referencias numéricas en cartografía sobre fortificación}

-Ref. en el croquis de Ortiz de Pinedo (1837-38, AGM, núm. 262): 029

-Ref. en plano de Vera Aparici (1993): Sin ref.

Referencias en memorias técnicas militares

-Ref. Guillermo Sáez (9/9/1834-5/12/1835): Requena, 5/12/1835 AMR, 1818-50

Se aspillera el "Matadero", levantándose una pared en un huerto inmediato de D. Rafael López.

-Ref. Guillermo Sáez (26/02/1836): Sin ref.

-Ref. P. Ortiz de Pinedo (12/03/1837-30/05/1837): Sin ref.

-Ref Jose María de Orozco (25/03/1838): Sin ref.

-Ref. Carbonell (4/7/1838): AMR, 1818-17, fol. 11

"En el parapéto que está encima de la puerta se realzarán y ensancharán los huecos de las aspilléras, dejándolas de modo [que] un soldádo en su posicion natural descubra bien toda la campaña: además se cubrirán estas aspilléras por su parte superior, y se dará mas cerrándo por consiguiente las que se hallan á mayor altúra Conviniendo aumentar los obstaculus que presenta asta entráda, se hará un cerramiénto de dos lados por la parte interior dejándo en el una puerta paraléla á la priméra. La nueba puerta estará deféndida por las aspilléras de [dicho] cerramiénto, y por el fuego que puede hacérse por la espálda á los enemigos desde la banquéta alta que viene a En la Batería se aument

tará la alturá de las rodilléras, y se harán otras pequeñas refórmas que necesitan las cañonéras, y en sus una mediana inteligéniréccion de sus caras: las cuales no se especifican en este lugar ni en los sucesibos porque las percibe facilmente esplanáda de piedra."

\section{- Observaciones a partir de los informes militares}

La salida a Alicante. Donde se ubica el matadero y los huertos. Uno de ellos es del de don Rafael López. En el año 1838, unos documentos del Archivo Municipal de Requena (AMR, 1818-15) testimonian la ejecución de una sencilla puerta moldurada, aspillerada y con foso. No emplazaba una Batería, empecisamente en una posición privilegiada que proyectaría sus disparos prácicamente en más a de la Puerta se $200^{\circ}$ para batir Batanejo, el camino de Alicante e incluso el frente de San Nicolás (al Sureste). 


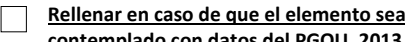

\section{PROTECCIÓN}

Nivel de protección:

Entorno:

$\square$ Inmueble

$\square$ Parcela catastral

$\checkmark$ Entorno específico
AFECCIÓN PATRIMONIAL

$\square$ Bien de interés cultural (BIC)

$\square$ Afectado entorno BIC

$\square$ Afectado Plan especial

\section{- Descripción histórico-arquitectónica}

Tipologia

Observaciones a la cronologia

Descripción:

- Entorno urbano

Descripción entorno urbano

Uso actual:

Estado de conservación:

Intervenciones:

Régimen Urbanístico:

Titularidad:

Nivel protección s/catálogo 1996:

Bibliografia: AMR, 1818-17, 1818-24; 1818-50; 1818-52; 1818-53.

Observaciones generales:

\begin{tabular}{|c|c|c|}
\hline OBJETIVACIÓN DE INTERÉS & Soluciones constructivas & Soluciones ornamentales \\
\hline Interés tipológico & $\square$ Estructura & $\square$ Carpintería \\
\hline Valor ambiental & $\square$ Aleros & Rejería \\
\hline Vigencia de la trama & $\square$ Coronación & $\square$ Cubrepersianas \\
\hline Composición de la fachada & $\square$ Jambas & $\square$ Alicatados \\
\hline Materiales, color, textura & $\square$ Dinteles & $\square$ Recercos \\
\hline & & $\square$ Dinteles \\
\hline & & \\
\hline
\end{tabular}

\section{- Datos específicos catalogación BIC $\square$ Rellenar sólo siestá catalogado BIC}

Datos Jurídicos:

$\begin{array}{lll}\text { Código: } & \text { Fecha Disposición: } & \text { Fecha informe: } \\ \text { Estado: } & \text { Tipo delimitación: } & \text { Fecha Publicación BOP: } \\ \text { Categoría: } & \text { Plan: } & \text { Fecha Publicación DOCV: } \\ \text { Anotación Mo: } & \text { Informe: } & \text { Fecha Publicación BOE: }\end{array}$

\section{Interés paisajistico}

$\square$ Incidencia visual

$\square$ Carácter articulador

$\square$ Organización

$\square$ Carácter rep

\section{Desde la Puerta de Alcalá al barrio debajo de la misma}

- Identificación

Tramo de estudio:

Tramo 2: Puerta de Alcaĺ-Puerta de Cantarranas

Otras denominaciones: Huerta del Rojo del Pino

Ref. catastral:

Localización: C/Barriete.

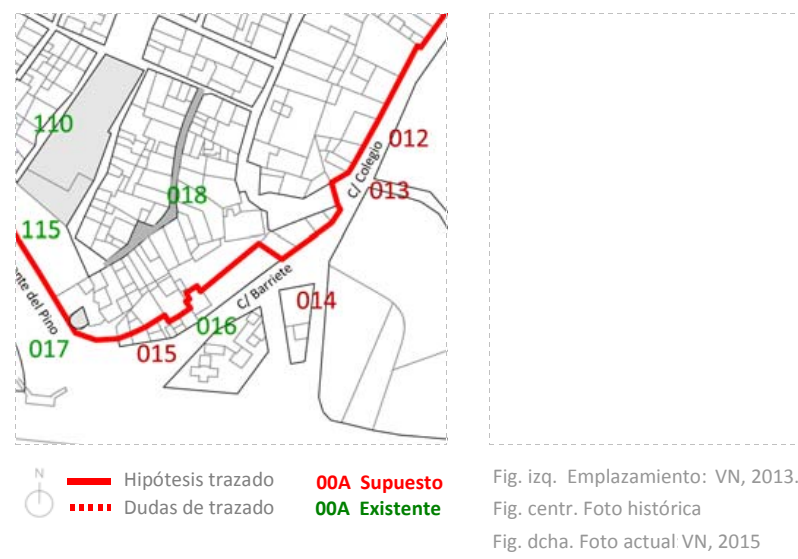

$\square$ Existe actualmente

Incluido en fichas PGOU 2013

Bien de interés cultural (BIC)

cód. postal: 46340

Municipio: Requena

Autonomia: Comunidad Valenciana

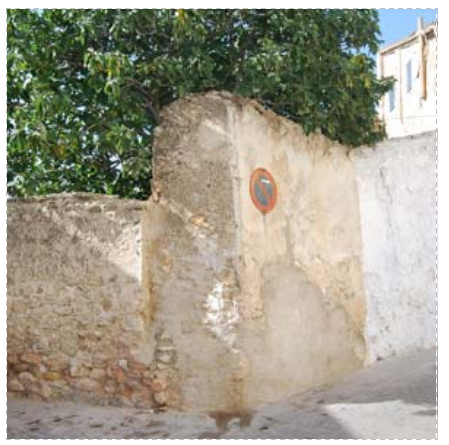

- Referencias en documentación histórica

Referencias numéricas en cartografía sobre fortificación

-Ref. en el croquis de Ortiz de Pinedo (1837-38, AGM, núm. 262): Sin ref.

-Ref. en plano de Vera Aparici (1993): Sin ref.

Referencias en memorias técnicas militares

-Ref. Guillermo Sáez (9/9/1834-5/12/1835): Sin ref.

-Ref. Guillermo Sáez (26/02/1836): Sin ref.

-Ref. P. Ortiz de Pinedo (12/03/1837-30/05/1837): Sin ref.

-Ref Jose María de Orozco (25/03/1838): Sin ref.

-Ref. Carbonell (4/7/1838): AMR, 1818-17, fol. 11

"Se aspillerarán las casas que se hallan en el recinto, y aun las inmediátas, en todos los parájes y pisos que descubren el campo; no

olvidándose de verificárlo en las parédes que flanqueán las Puerta de Alcalá, ó cualquier otro punto. Se construirán parapétos aspillerádos en los corráles que hay sobre la roca, adelantándolos hasta la orilla de esta.Por regla general se cerrarán las bocas de las cuebas [que] ecsisten debájo de la misma roca de la Puerta de Alcalá á la de Cantarránas. Se derribarán las tapias de la huerta del Rojo del Pino"

(Carbonell, Requena, 4 de julio de 1838, AMR, 1818-17, fo. 11).

\section{- Observaciones a partir de los informes militares}

En este frente, aparece una zona de casas y huertas elevadas asociadas a la puerta de Alcalá. Por la descripción parecen compartir tapia con la puerta y se ubican desde ésta hasta el Barriete. Este balcón sobre las casas del Barriete sería un lugar privilegiado para la defensa del frente Sur. En dirección a San Nicolás, este frente configura cuevas a sus pies que se propone tapiar. Y con toda probabilidad la Huerta del Rojo del Pino se encuentra a los pies del conjunto, en la campaña, por lo que es accesible y sus tapias constituyen un obstáculo visual 
$\square \frac{\text { Rellenar en caso de que el elemento sea }}{\text { contemplado con datos del pcovi } 203}$

\section{PROTECCIÓN}

Nivel de protección:

Entorno:

$\square$ Inmueble
$\square$ Parcela catastral
$\square$ Recinto arquitectónico
$\square$ Entorno espećífico

AFECCIÓN PATRIMONIAL

$\square$ Bien de interés cultural (BIC)

$\square$ Afectado entorno BIC
016 Barrio bajo de la Puerta de Alcalá

\section{- Identificación}

Tramo de estudio:

Tramo 2: Puerta de Alcalá-Puerta de Cantarranas

Otras denominaciones: Barriete

Ref. catastra:

Localización: C/ Barriete.

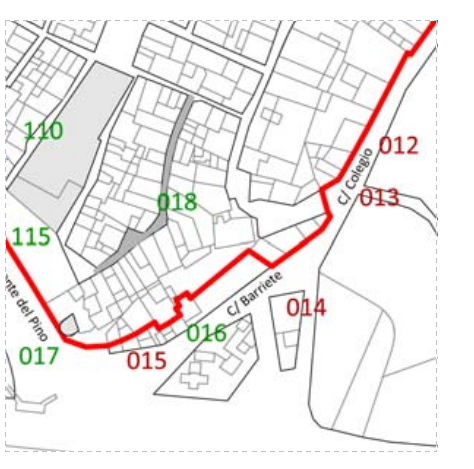

$\begin{array}{ll}\text {-.... Hipótesis trazado } & \text { OOA Supuesto } \\ \text { OOA Existente }\end{array}$

ig. izq. Emplazamiento: VN, 2013

Fig. dcha. Foto actual VN, 2015

- Referencias en documentación histórica

Referencias numéricas en cartografía sobre fortificación

-Ref. en el croquis de Ortiz de Pinedo (1837-38, AGM, núm. 262): Sin ref.

-Ref. en plano de Vera Aparici (1993): Sin ref.

Referencias en memorias técnicas militare

-Ref. Guillermo Sáez (9/9/1834-5/12/1835): Sin ref.

-Ref. Guillermo Sáez (26/02/1836): Sin ref.

-Ref. P. Ortiz de Pinedo (12/03/1837-30/05/1837): Sin ref.

-Ref Jose Maria de Orozco (25/03/1838): Sin ref.

-Ref. Carbonell (4/7/1838): AMR, 1818-17, fol. 11

"Las pocas y misérables casas que hay en este Barrio deben derribárse, pues perjudican notablemente á la defénsa, entorpeciéndo los . Desde este punto hasta la Puerta de Cantarránas conviéne realizar las indicaciónes que se apúntan en seguida, sin perjuicio de repetirlas en algun caso particular en que interese llamar la aténcion. Se destruirán las tapias de las huertas procsimas y paralelas al recinto. Se barrenarán las peñas inmediátas, se escarpará la roca en varios puntos, en que, aunque no sin dificúltad, permite la subida. Se abrirán aspilléras en todos los [cpos.] de las casas en que no lo impida el grueso de las parédes, y se aprovecharán las garitias y balcónes para establecer parapetos aspillerados con cuyo (motibo) se recomienda de nuebo el que estas no solo se ven hauen en las paredes del frente, los sitios del despeñádero á donde un hombre pueda subir, se cerraŕn y a spillerarán Se construirán cerramiéntos aspillerádos sobre los despeñadéros en las bocas calles que no los tienen, y se dará mas altúra á los que ecsisten. En los parájes donde la roca sobresale dejándo algún espácio superior, se levantarán tapias aspilleradas, y como hay algunos corrales altos ya cortádos, pero sin aspilleras, se procurará hacerselas. No se [omitirá] el dar las debidas dimensiones á las aspilléras abiértas hasta [aquí], yá las que se abran de nuebo, disponiéndolas con sujecion á los principios [que] se hán espuésto al [hablar] de otras lineas."

\section{- Observaciones a partir de los informes militares}

Barrio de casas miserables susceptibles de demolerse por entorpecer la defensa. En los expedientes de expropiación, a poco de acabar la siempre se eleve por encima de estas y se garantice una defensa escalonada. No se conoce el desenlace. Pero debieron sobrevivir. 


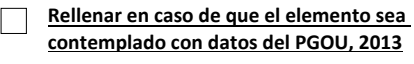

\section{PROTECCIÓN \\ Nivel de protección:}

AFECCIÓN PATRIMONIAL

$\square$ Bien de interés cultural (BIC)

$\square$ Inmueble

$\square$ Parcela catastral

$\square$ Recinto arquitectónico

$\square$ Afectado entorno BIC

$\square$ Afectado Plon especial

\section{- Descripción histórico-arquitectónica}

Tipología:

Cronología:

Observaciones a la cronologia:

\section{Descripción}

- Entorno urbano

Descripción entorno urbano:

Uso actual:

Estado de conservación:

Intervenciones:

Régimen Urbanístico

Titularidad:

Nivel protección s/catálogo 1996:

Bibliografia: AMR, 1818-17, 1818-24; 1818-50; 1818-52; 1818-53.

observaciones generales:

$\begin{array}{lll}\text { OBJETIVACIÓN DE INTERÉS } & \text { Soluciones constructivas } & \text { Soluciones ornamentales } \\ \square \text { Interés tipológico } & \square \text { Estructura } & \square \text { Carpintería } \\ \square \text { Valor ambiental } & \square \text { Aleros } & \square \text { Rejería } \\ \square \text { Vigencia de la trama } & \square \text { coronación } & \square \text { cubrepersianas } \\ \square \text { Composición de la fachada } & \square \text { Jambas } & \square \text { Alicatados } \\ \square \text { Materiales, color, textura } & \square \text { Dinteles } & \square \text { Recercos } \\ & & \square \text { Dinteles } \\ & \square \text { otros ornamentos }\end{array}$

Interés paisajístico
$\square$ Incidencia visual
$\square$ carácter articulador
$\square$ Organización
$\square$ Interés cultural
$\square$ Carácter representativo

\section{- Datos específicos catalogación BIC $\quad \square$ Rellenar sólo si está catalogado BIC} Datos Jurídicos:

$\begin{array}{lll}\text { Código: } & \text { Fecha Disposición: } & \text { Fecha informe: } \\ \text { Estado: } & \text { Tipo delimitación: } & \text { Fecha Publicación BOP: } \\ \text { Categoría: } & \text { Plan: } & \text { Fecha Publicación DOCV: } \\ \text { Anotación Mo: } & \text { Informe: } & \text { Fecha Publicación BOE: }\end{array}$

\section{Torreón de la [Balanza]}

\section{- Identificación}

Tramo de estudio:

Tramo 2: Puerta de Alcalá-Puerta de Cantarranas

Otras denominaciones: Torre Montijana (Vid. Torre Montijana)

Ref. catastra:

Localización: Encuentro de C/ Barriete con C/ Fuente del Pino

$\checkmark$ Existe actualmente

Incluido en fichas PGOU 2013

Bien de interés cultural (BIC)

cód. postal: 46340

Municipio: Requena

Comarca: Plana de Requena-Utiel

Provincia: Requena

Autonomía: Comunidad Valencian

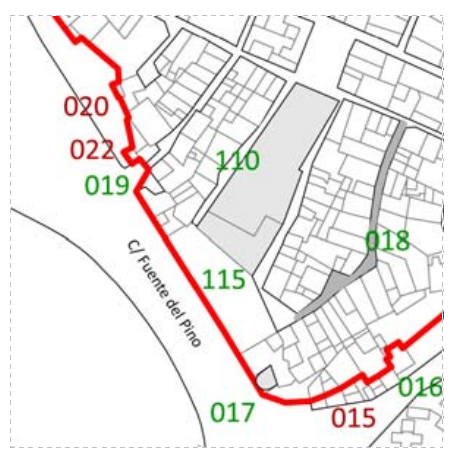

.... Hipótesis trazado

OOA Supuesto
OOA Existente
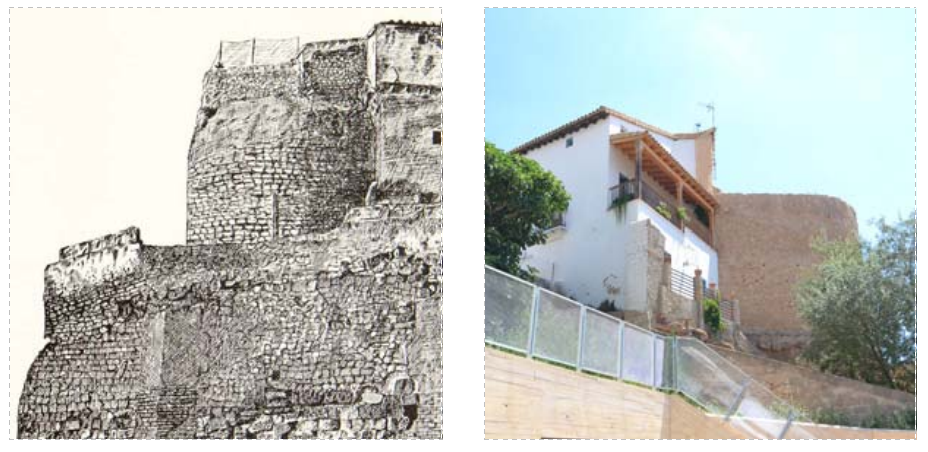

- Referencias en documentación histórica

Referencias numéricas en cartografía sobre fortificación

-Ref. en el croquis de Ortiz de Pinedo (1837-38, AGM, núm. 262): 014

-Ref. en plano de Vera Aparici (1993): Sin ref.

Referencias en memorias técnicas militares

-Ref. Guillermo Sáez (9/9/1834-5/12/1835): Sin ref.

-Ref. Guillermo Sáez (26/02/1836): Sin ref.

-Ref. P. Ortiz de Pinedo (12/03/1837-30/05/1837): Sin ref.

-Ref Jose María de Orozco (25/03/1838): Sin ref.

-Ref. Carbonell (4/7/1838): Sin ref.

\section{- Observaciones a partir de los informes militares}

Así denominado en el plano de Ortiz de Pinedo (SHM, núm. 262) sobre el cerramiento aspillerado de Requena. Emplazado junto a la Puerta de Alcaĺ, podría corresponderse con la aún existente torre Montijana. (Vid. Torre Montijana).

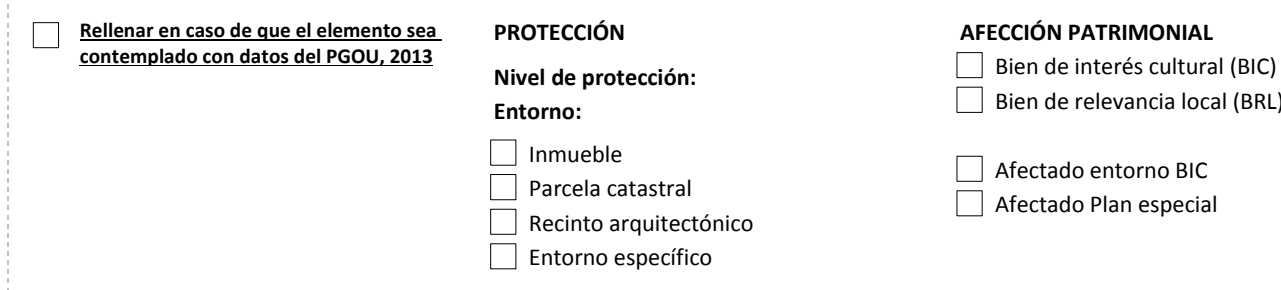




\section{- Descripción histórico-arquitectónica}

Tipología:

Cronología:

Observaciones a la cronologia

\section{Descripción:}

\section{- Entorno urbano}

Descripción entorno urbano:

Uso actual:

Estado de conservación:

Intervenciones:

Régimen Urbanistico:

Titularidad:

Nivel protección s/catálogo 1996:

Bibliografía: AMR, 1818-17, 1818-24; 1818-50; 1818-52; 1818-53.

Observaciones generales:

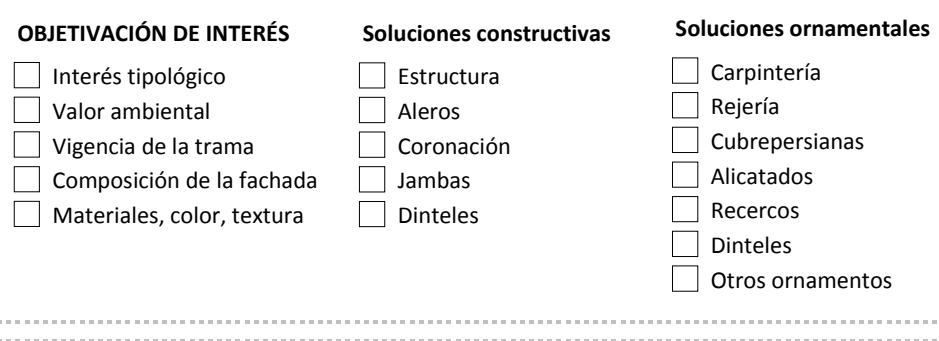

\section{- Datos específicos catalogación BIC $\square$ Rellenar sólo si está catalogado BIC}

$\begin{array}{lll}\text { Datos Jurídicos: } & & \\ \text { Código: } & \text { Fecha Disposición: } & \text { Fecha informe: } \\ \text { Estado: } & \text { Tipo delimitación: } & \text { Fecha Publicación BOP: } \\ \text { Categoría: } & \text { Plan: } & \text { Fecha Publicación DOCV } \\ \text { Anotación Mo: } & \text { Informe: } & \text { Fecha Publicación BOE: }\end{array}$

\section{Interés paisajistico}

$\square$ Incidencia visual

$\square$ Carácter articulador

$\square$ Organización

$\square$ Carácter representativo

\section{Desde Torregorda a la casa de [catorce]}

\section{- Identificación}

Tramo de estudio:

Tramo 2: Puerta de Alcalá-Puerta de Cantarranas

Otras denominaciones: Torre Onda o Torre Montijana, Torreón de la Montejana

Ref. catastral:

Localización: C/ Cantero. Desde la Avenida de Valencia se toma la calle del Pintor Uan Masiá. Desde la Villa por la C/ Fuente del Pino.

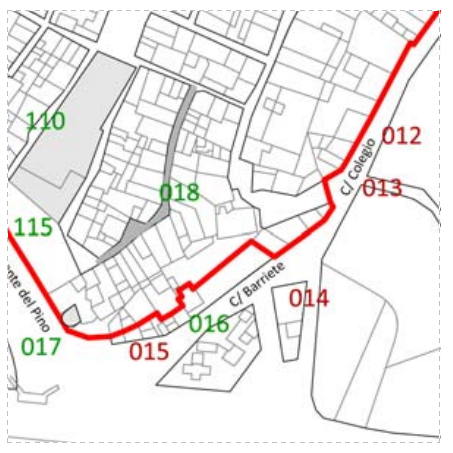

- Hipótesis trazado O0A Supuesto

$\checkmark$ Existe actualmente

Incluido en fichas PGOU 2013

cód. postal: 46340

Municipio: Requena

Comarca: Plana de Requena-Utiel

Provincia: Valencia

Autonomía: Comunidad Valenciana

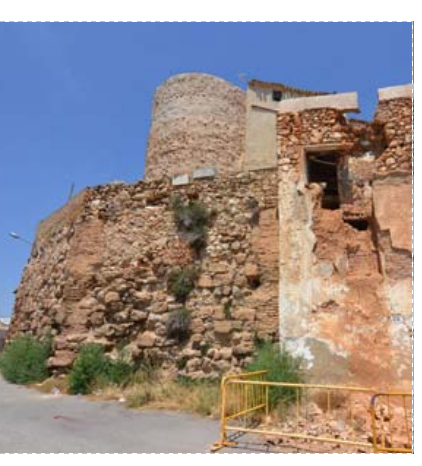

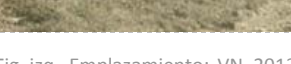

$$
\begin{aligned}
& \text { Fig. centr. Foto histórica Torre Montijana en una postal de } 1930 \text { (M. de Dios, J.) } \\
& \text { Fig. dcha. Foto actual:VN, } 2015
\end{aligned}
$$

\section{- Referencias en documentación histórica}

\section{Referencias numéricas en cartografía sobre fortificación}

-Ref. en el croquis de Ortiz de Pinedo (1837-38, AGM, núm. 262): Sin ref.

-Ref. en plano de Vera Aparici (1993): 007

Referencias en memorias técnicas militares

-Ref. Guillermo Sáez (9/9/1834-5/12/1835): Requena, 5/12/1835 AMR, 1818-50

Se aspillera el corral de la torre con su ventana y "puerta firme por si tomasen el barriete". Vid. Calle Cantero.

-Ref. Guillermo Sáez (26/02/1836): Sin ref.

-Ref. P. Ortiz de Pinedo (12/03/1837-30/05/1837): Sin ref.

-Ref Jose Maria de Orozco (25/03/1838): Sin ref.

-Ref. Carbonell (4/7/1838): AMR, 1818-17, fol. 12

"Se cortará verticalmente la roca, en el paráje donde es accesible se cerrarán y aspillerarán las ventánas bajas" (Carbonell, Requena, 4 de julio de 1838, AMR, 1818-17, fo. 12).

\section{- Observaciones a partir de los informes militares}

Único resto de la muralla del arrabal de San Nicolás. Es la única cilíndrica que queda del recinto. Restos de una reconstrucción de mampuesto llevada a cabo en el siglo XV. 
$\square \frac{\text { Rellenar en caso de que el elemento sea }}{\text { contemplado con datos del PGOU, 2013 }}$

PROTECCIÓN
Nivel de protección:
Entorno:
$\square$ Inmueble
$\square$ Parcela catastral
$\square$ Recinto arquitectónico
$\square$ Entorno espećifico

AFECCIÓN PATRIMONIAL

$\square$ Bien de interés cultural (BIC)

$\square$ Bien de relevancia local (BRL)

$\square$ Afectado entorno BIC

$\square$ Afectado Plan especial

\section{- Descripción histórico-arquitectónica}

Tipología:

Cronología:

Observaciones a la cronología

Descripción

- Entorno urbano

Descripción entorno urbano

Uso actual:

Estado de conservación:

Intervenciones:

Régimen Urbanistico:

Titularidad:

Nivel protección s/catálogo 1996

Bibliografía: AMR, 1818-17, 1818-24; 1818-50; 1818-52; 1818-53.

Observaciones generales:

$\begin{array}{ll}\text { OBJETIVACIÓN DE INTERÉS } & \text { Soluciones constructivas } \\ \square \text { Interés tipológico } & \square \text { Estructura } \\ \square \text { Valor ambiental } & \square \text { Aleros } \\ \square \text { Vigencia de la trama } & \square \text { coronación } \\ \square \text { Composición de la fachada } & \square \text { Jambas } \\ \square \text { Materiales, color, textura } & \square \text { Dinteles }\end{array}$

$\begin{array}{ll}\text { Soluciones ornamentales } & \text { Interés paisajistico } \\ \square \text { Carpintería } & \square \text { Incidencia visual } \\ \square \text { Rejería } & \square \text { Carácter articulador } \\ \square \text { Cubrepersianas } & \square \text { organización } \\ \square \text { Alicatados } & \square \text { Interés cultural } \\ \square \text { Recercos } & \square \text { Carácter representativo } \\ \square \text { Dinteles } & \\ \square \text { Otros ornamentos } & \end{array}$

\section{- Datos específicos catalogación BIC $\square$ Rellenar sólo si está catalogado BIC}

\section{Datos Jurídicos:}

$\begin{array}{lll}\text { Código: } & \text { Fecha Disposición: } & \text { Fecha informe: } \\ \text { Estado: } & \text { Tipo delimitación: } & \text { Fecha Publicación BOP: } \\ \text { Categoría: } & \text { Plan: } & \text { Fecha Publicación DOCV: } \\ \text { Anotación Mo: } & \text { Informe: } & \text { Fecha Publicación BOE: }\end{array}$

\section{Calle de Cantero}

- Identificación

Tramo de estudio: Tramo 2: Puerta de Alcalá-Puerta de Cantarranas

Otras denominaciones:

Incluido en fichas PGOU 2013

Bien de interés cultural (BIC)

cód. postal: 46340

Municipio: Requen

Ref. catastral:

Localización: c/Cantero.

\section{rovincia: Valencis}

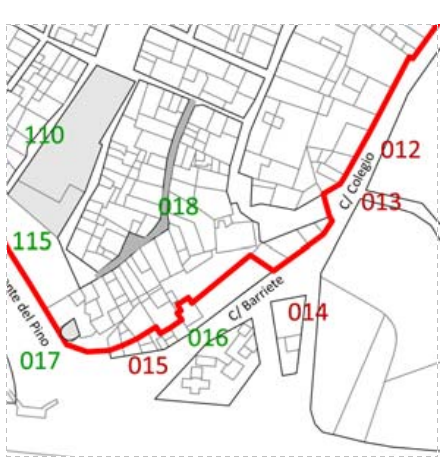

- Hipótesis trazado

OOA S

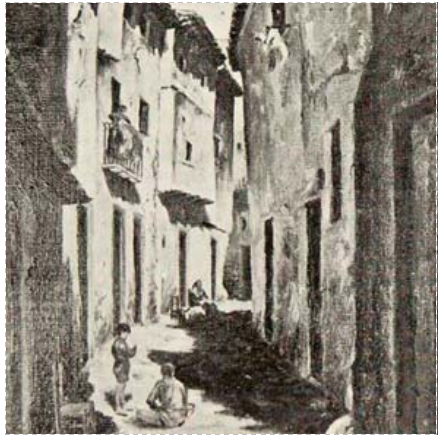

$$
\begin{aligned}
& \text { Fig. centr. Foto históric } \\
& \text { Fig. dcha. Foto actual: }
\end{aligned}
$$

- Referencias en documentación histórica

Referencias numéricas en cartografía sobre fortificación

-Ref. en el croquis de Ortiz de Pinedo (1837-38, AGM, núm. 262): Sin ref.

-Ref. en plano de Vera Aparici (1993): 006

Referencias en memorias técnicas militares

-Ref. Guillermo Sáez (9/9/1834-5/12/1835): Requena, 5/12/1835 AMR, 1818-50

Aspillerado del corral de la "torre onda" (Torre Montijana)

-Ref. Guillermo Sáez (26/02/1836): Sin ref.

-Ref. P. Ortiz de Pinedo (12/03/1837-30/05/1837): Sin ref.

-Ref Jose María de Orozco (25/03/1838): Sin ref.

-Ref. Carbonell (4/7/1838): Sin ref.

\section{- Observaciones a partir de los informes militares}

Entre la calle de Cantero y la calle de Paniagua hay una casa que hay que aspillerar. En la calle del Cantero se ubica un corral, de la "torre Onda (no confundir en la transcripción con la "torre Oria", actuales bodegas de 1903)

\begin{tabular}{|c|c|c|}
\hline \multirow[t]{2}{*}{$\begin{array}{l}\square \text { Rellenar en caso de que el elemento sea } \\
\text { contemplado con datos del PGOU, 2013 }\end{array}$} & $\begin{array}{l}\text { PROTECCIÓN } \\
\text { Nivel de protección: } \\
\text { Entorno: }\end{array}$ & $\begin{array}{l}\text { AFECCIÓN PATRIMONIAL } \\
\begin{array}{|l}\square \text { Bien de interés cultural (BIC) } \\
\square \text { Bien de relevancia local (BRL) }\end{array}\end{array}$ \\
\hline & $\begin{array}{l}\square \text { Inmueble } \\
\square \text { Parcela catastral } \\
\square \text { Recinto arquitectónico } \\
\square \text { Entorno específico }\end{array}$ & $\begin{array}{l}\square \text { Afectado entorno BIC } \\
\square \text { Afectado Plan especial }\end{array}$ \\
\hline
\end{tabular}




\section{- Descripción histórico-arquitectónica}

\section{Tipologia:}

Observaciones a la cronologí

Descripción:

\section{- Entorno urban。}

Descripción entorno urbano:

Uso actual:

Estado de conservación:

Intervenciones:

Régimen Urbanístico:

Titularidad:

Nivel protección s/catálogo 1996:

Bibliografía: AMR, 1818-17, 1818-24; 1818-50; 1818-52; 1818-53.

Observaciones generales:

\section{OBJETIVACIÓN DE INTERÉS}

$\square$ Interés tipológico

$\square$ Valor ambiental

Vomposición de la fach

$\square$ Materiales, color, textura

Soluciones constructiva
$\square$ Estructura
$\square$ Aleros
$\square$ Coronación
$\square$ Jambas
$\square$ Dinteles

Soluciones ornamentales
$\square$ Carpintería
$\square$ Rejería
$\square$ Cubrepersianas
$\square$ Alicatados
$\square$ Recercos
$\square$ Dinteles
$\square$ Otros ornamentos

Interés paisajistico

$\square$ Incidencia visual

$\square$ Carácter articulador

$\square$ Organización

$\square$ Carácter representativo

$\square$ Otros ornamentos

\section{- Datos específicos catalogación BIC $\square$ Rellenar sólo si está catalogado BIC}

$\begin{array}{lll}\text { Datos Juridicos: } & & \\ \text { Código: } & \text { Fecha Disposición: } & \text { Fecha informe: } \\ \text { Estado: } & \text { Tipo delimitación: } & \text { Fecha Publicación BOP: } \\ \text { Categoría: } & \text { Plan: } & \text { Fecha Publicación DOCV: } \\ \text { Anotación Mo: } & \text { Informe: } & \text { Fecha Publicación BOE: }\end{array}$

019 La Cortina

- Identificación

Tramo de estudio: Tramo 2: Puerta de Alcalá-Puerta de Cantarranas

Otras denominaciones: Cuesta de la cortina

Ref. catastral:

Localización: C/ Cortina, C/ Fuente del Pino.
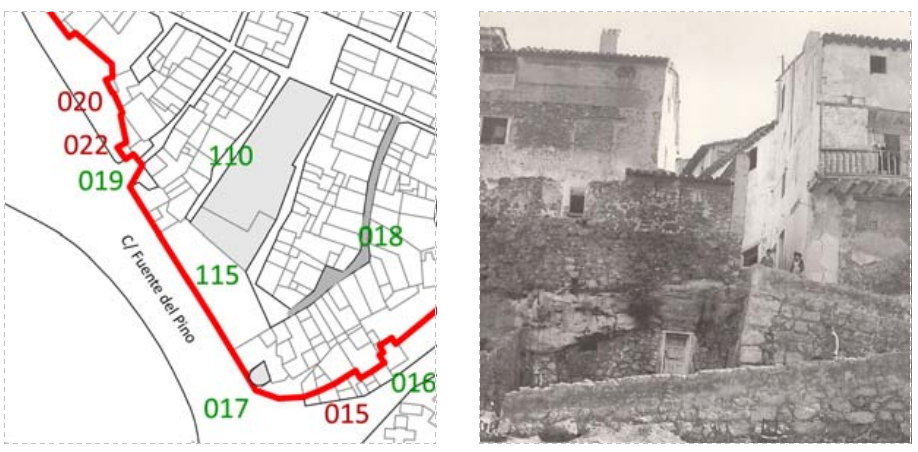

-.... Hipótesis Dusazeado te trazado

OOA Supuesto

\section{Fig. izq. Emplazamiento: VN, 2013}

Fig. centr. Foto histórica Jordá, 2000: fig. 28

\section{$\checkmark$ Existe actualmente}

Incluido en fichas PGOU 2013

Bien de interés cultural (BIC)

cód. postal: 46340

Municipio: Requena

Comarca: Plana de Requena-Utie

Provincia: Valencia

Autonomía: Comunidad Valencian

\section{- Referencias en documentación histórica}

Referencias numéricas en cartografía sobre fortificación

-Ref. en el croquis de Ortiz de Pinedo (1837-38, AGM, núm. 262): Sin ref.

-Ref. en plano de Vera Aparici (1993): 005

Referencias en memorias técnicas militares

-Ref. Guillermo Sáez (9/9/1834-5/12/1835): Requena, 5/12/1835 AMR, 1818-50

Se cierran balcones, Aspillerado del pretil de Sánchez, cierre de la puerta del Callejón de Paniagua.

-Ref. Guillermo Sáez (26/02/1836): Sin ref.

-Ref. P. Ortiz de Pinedo (12/03/1837-30/05/1837): Sin ref.

-Ref Jose María de Orozco (25/03/1838): Sin ref.

-Ref. Carbonell (4/7/1838): Sin ref.

\section{- Observaciones a partir de los informes militares}

En el arrabal de San Nicolás. Así denominada porque ascás funceada de algún modo por las defensas. En ella se ha abierto una puerta

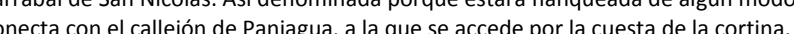

$\begin{array}{lll}\square \frac{\text { Rellenar en caso de que el elemento sea }}{\text { contemplado con datos del PGOU, 2013 }} & \text { PROTECCIÓN } & \text { AFECCIÓN PATRIMONIAL } \\ & \text { Nivel de protección: } & \square \text { Bien de interés cultural (BIC) } \\ & \text { Entorno: } & \square \text { Bien de relevancia local (BRL) } \\ & \square \text { Inmueble } & \square \text { Afectado entorno BIC } \\ \square \text { Parcela catastral } & \square \text { Afectado Plan especial } \\ \square \text { Recinto arquitectónico } & \\ & \square \text { Entorno específico } & \end{array}$

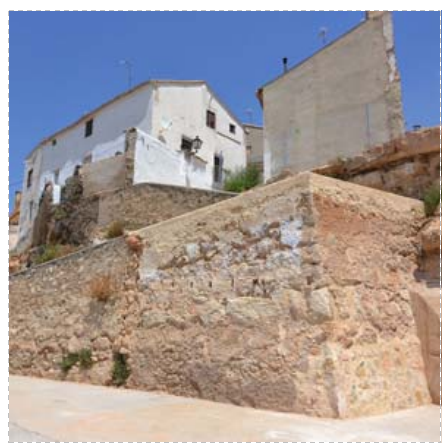




\section{- Descripción histórico-arquitectónica}

\section{Tipología}

Onología:

Observaciones a la cronolog

Descripción:

\section{- Entorno urbano}

Descripción entorno urbano:

Uso actual:

Estado de conservación:

Intervenciones:

Régimen Urbanistico:

Titularidad:

Nivel protección s/catálogo 1996:

Bibliografía: AMR, 1818-17, 1818-24; 1818-50; 1818-52; 1818-53.

Observaciones generales:

$\begin{array}{lll}\text { OBJETIVACIÓN DE INTERÉS } & \text { Soluciones constructivas } & \text { Soluciones ornamentales } \\ \square \text { Interés tipológico } & \square \text { Estructura } & \square \text { Carpintería } \\ \square \text { valor ambiental } & \square \text { Aleros } & \square \text { Rejería } \\ \square \text { Vigencia de la trama } & \square \text { Coronación } & \square \text { Cubrepersianas } \\ \square \text { composición de la fachada } & \square \text { Jambas } & \square \text { Alicatados } \\ \square \text { Materiales, color, textura } & \square \text { Dinteles } & \square \text { Recercos } \\ & & \square \text { Dinteles } \\ & & \square \text { Otros ornamentos }\end{array}$

\section{- Datos específicos catalogación BIC $\square$ Rellenar sólo si está catalogado BIC}

$\begin{array}{lll}\text { Datos Juridicos: } & & \\ \text { Código: } & \text { Fecha Disposición: } & \text { Fecha informe: } \\ \text { Estado: } & \text { Tipo delimitación: } & \text { Fecha Publicación BOP: } \\ \text { Categoría: } & \text { Plan: } & \text { Fecha Publicación DOCV: } \\ \text { Anotación Mo: } & \text { Informe: } & \text { Fecha Publicación BOE: }\end{array}$

\section{Interés paisajistico}

$\square$ Incidencia visual

$\square$ Carácter articulador

$\square$ Organización

$\square$ Carácter representativo

\section{Casas llamadas de debajo de la Peña}

- Identificación

Tramo de estudio: Tramo 2: Puerta de Alcalá-Puerta de Cantarranas

Otras denominaciones: Tres casas y Galeria de la de Catorce

Ref. catastral:

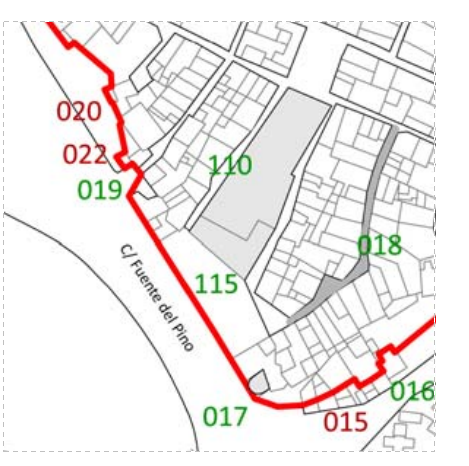

-... Hipótesis trazado Dudas de trazado Supuesto

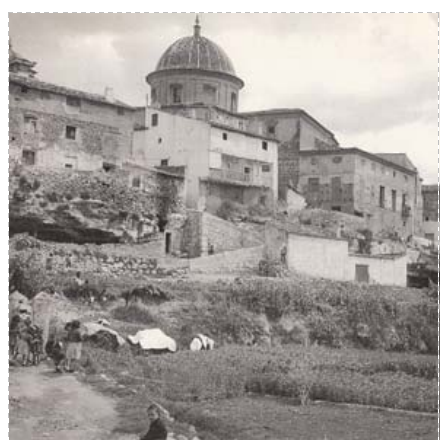

Fig. izq. Emplazamiento: VN, 2013.

Fig. centr. Foto histórica Jordá, 2000:fig. 2
Localización: C/ Fuente del Pino.

$\square$ Existe actualmente

Incluido en fichas PGOU 2013

Bien de interés cultural (BIC)

cód. postal: 46340

Municipio: Requena

Comarca: Plana de Requena-Utiel

Provincia: Valencia

Autonomía: Comunidad Valencian

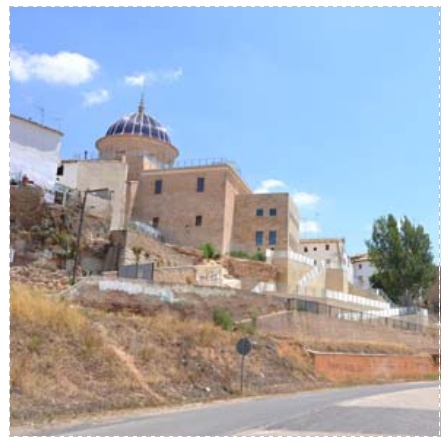

- Referencias en documentación histórica

\section{Referencias numéricas en cartografía sobre fortificación}

-Ref. en el croquis de Ortiz de Pinedo (1837-38, AGM, núm. 262): Sin ref.

-Ref. en plano de Vera Aparici (1993): Sin ref.

Referencias en memorias técnicas militares

-Ref. Guillermo Sáez (9/9/1834-5/12/1835): Sin ref.

-Ref. Guillermo Sáez (26/02/1836): Sin ref.

-Ref. P. Ortiz de Pinedo (12/03/1837-30/05/1837): Sin ref.

-Ref Jose Maria de Orozco (25/03/1838): Sin ref.

-Ref. Carbonell (4/7/1838): AMR, 1818-17, fol. 12

"Estas tres casas, la galeria de la de Catórce, y la obra que hay debájo de estas, deben [demolerse] totalmente, ya porque interrúmpen la vista y la accion de los fuegos de Torregorda y otros fortines sobre la inmediacion del recinto, ya porque esponen la ciudad á una sorprésa. Verdad es que pueden havilitárse en terminos que proporcionen ellas mismas la defénsa que ahóra impíden, pero prescindiéndo de que esto ocasionaria gastos aprocsimádos al valor de las casas, y de que estas no podrian havitárse, seria preciso auméntar el servicio de la

Guarnicion para evitar el segúndo inconveniente" (Carbonell, Requena, 4 de julio de 1838, AMR, 1818-17, fo. 12).

- Observaciones a partir de los informes militares

Se podrian asociar con las desaparecidas cuevas de San Nicolás (o Albaicín) 
$\square \frac{\text { Rellenar en caso de que el elemento sea }}{\text { contemblato }}$

PROTECCIÓN

AFECCIÓN PATRIMONIAL

Nivel de protección:

Entorno:

$\square$ Inmueble

$\square$ Parcela catastral

$\square$ Recinto arquitectónico

$\square$ Bien de relevancia local (BRL)

$\square$ Afectado entorno BIC

$\square$ Afectado Plan especial

- Descripción histórico-arquitectónica

Tipología:

Cronología:

Observaciones a la cronología:

Descripción:

- Entorno urbano

Descripción entorno urbano:

Uso actual:

Estado de conservación:

Intervenciones:

Régimen Urbanístico:

Titularidad:

Nivel protección s/catálogo 1996:

Bibliografía: AMR, 1818-17, 1818-24; 1818-50; 1818-52; 1818-53.

Observaciones generales:

\section{OBJETIVACIÓN DE INTERÉS}

$\begin{array}{ll}\square \text { Interés tipológico } & \square \text { Estructura } \\ \square \text { valor ambiental } & \square \text { Aleros } \\ \square \text { Vigencia de la trama } & \square \text { coronación } \\ \square \text { composición de la fachada } & \square \text { Jambas } \\ \square \text { Materiales, color, textura } & \square \text { Dinteles }\end{array}$
$\square$ Dinteles

Soluciones ornamentales
$\square$ Carpintería
$\square$ Rejería
$\square$ Cubrepersianas
$\square$ Alicatados
$\square$ Recercos
$\square$ Dinteles
$\square$ Otros ornamentos

Interés paisajístico

$\square$ Incidencia visual

$\square$ Carácter articulador

$\square$ Organización

$\square$ Interés cultural

Carácter representativo

\begin{tabular}{|lll} 
- Datos específicos catalogación BIC & $\square$ Rellenar sólo si está catalogado BIC \\
\hline Datos Jurídicos: & & \\
Código: & Fecha Disposición: & Fecha informe: \\
Estado: & Tipo delimitación: & Fecha Publicación BOP: \\
Categoría: & Plan: & Fecha Publicación DOCV: \\
Anotación $M^{\circ}:$ & Informe: & Fecha Publicación BOE:
\end{tabular}

021 Casas de Antonio Herrero y Blas Perez

\section{- Identificación}

Tramo de estudio:

otras denominacion

Tramo 2: Puerta de Alcalá-Puerta de Cantarranas

ef. catastral:

Localización: C/ Fuente del Pino.

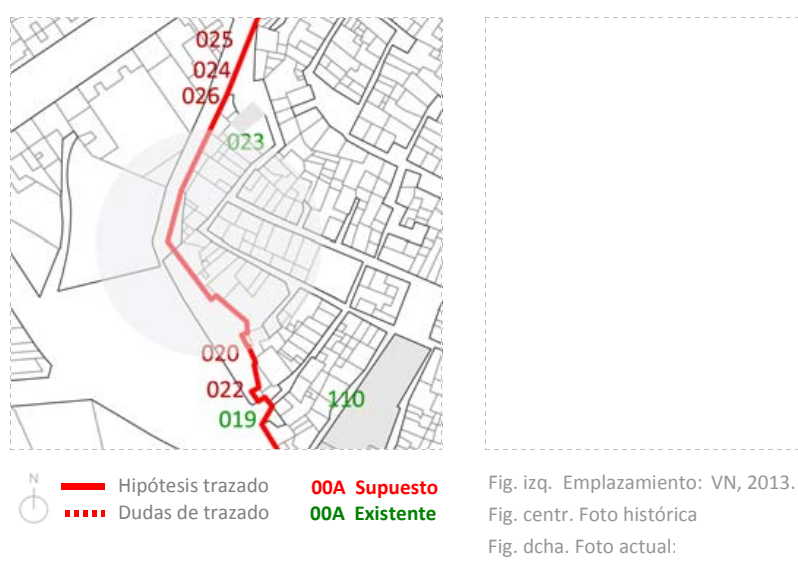

- Referencias en documentación histórica

Referencias numéricas en cartografía sobre fortificación

-Ref. en el croquis de Ortiz de Pinedo (1837-38, AGM, núm. 262): Sin ref.

-Ref. en plano de Vera Aparici (1993): Sin ref.

Referencias en memorias técnicas militares

-Ref. Guillermo Sáez (9/9/1834-5/12/1835): Sin ref.

-Ref. Guillermo Sáez (26/02/1836): Sin ref.

-Ref. P. Ortiz de Pinedo (12/03/1837-30/05/1837): Sin ref.

-Ref Jose María de Orozco (25/03/1838): Sin ref.

-Ref. Carbonell (4/7/1838): AMR, 1818-17, fol. 12

"Se tapiarán las ventánas bajas dejándo en ellas aspilléras" (Carbonell, Requena, 4 de julio de 1838, AMR, 1818-17, fo. 12).

\section{- Observaciones a partir de los informes militares}

Se trata de dos casas que se emplazarían a partir de San Nicolás y que integrarían el frente de la Villa. Una prueba mas de que este frente sureste está integrado principalmente por el frente rocoso de la Villa y las casas que lo coronan o se adosan a él. La estrategia es siempre

\begin{tabular}{|lll}
$\square$ Rellenar en caso de que el elemento sea \\
contemplado con datos del PGOU, 2013 & $\begin{array}{ll}\text { PROTECCIÓN } \\
\text { Nivel de protección: }\end{array}$ & AFECCIÓN PATRIMONIAL \\
Entorno: & $\square$ Bien de interés cultural (BIC) \\
& $\square$ inmueble & $\square$ Bien de relevancia local (BRL) \\
& $\square$ Parcela catastral & $\square$ Afectado entorno BIC \\
& $\square$ Recinto arquitectónico & $\square$ Afectado Plan especial \\
$\square$ Entorno específico &
\end{tabular}

\begin{tabular}{|lll}
$\square$ Rellenar en caso de que el elemento sea \\
contemplado con datos del PGOU, 2013 & $\begin{array}{ll}\text { PROTECCIÓN } \\
\text { Nivel de protección: }\end{array}$ & AFECCIÓN PATRIMONIAL \\
Entorno: & $\square$ Bien de interés cultural (BIC) \\
& $\square$ inmueble & $\square$ Bien de relevancia local (BRL) \\
& $\square$ Parcela catastral & $\square$ Afectado entorno BIC \\
& $\square$ Recinto arquitectónico & $\square$ Afectado Plan especial \\
$\square$ Entorno específico &
\end{tabular}

Existe actualmente

Incluido en fichas PGOU 2013

Bien de interés cultural (BIC)

cod. postal: 46340

comarca: Plana de

Provincia: Valenci 


\section{- Descripción histórico-arquitectónica}

Tipología

cronologia:

Observaciones a la cronología

Descripción:

\section{- Entorno urbano}

Descripción entorno urbano:

Uso actual:

Estado de conservación:

Intervenciones:

Régimen Urbanístico:

Titularidad:

Nivel protección s/catálogo 1996:

Bibliografía: AMR, 1818-17, 1818-24; 1818-50; 1818-52; 1818-53.

Observaciones generales:

$\begin{array}{lll}\text { OBJETIVACIÓN DE INTERÉS } & \text { Soluciones constructivas } & \text { Soluciones ornamentales } \\ \square \text { Interés tipológico } & \square \text { Estructura } & \square \text { Carpintería } \\ \square \text { Valor ambiental } & \square \text { Aleros } & \square \text { Rejería } \\ \square \text { Vigencia de la trama } & \square \text { Coronación } & \square \text { Cubrepersianas } \\ \square \text { Composición de la fachada } & \square \text { Jambas } & \square \text { Alicatados } \\ \square \text { Materiales, color, textura } & \square \text { Dinteles } & \square \text { Recercos } \\ & & \square \text { Dinteles } \\ & \square \text { Otros ornamentos }\end{array}$

\section{- Datos específicos catalogación BIC $\square$ Rellenar sólo si está catalogado BIC}

$\begin{array}{lll}\text { Datos Juridicos: } & & \\ \text { Código: } & \text { Fecha Disposición: } & \text { Fecha informe: } \\ \text { Estado: } & \text { Tipo delimitación: } & \text { Fecha Publicación BOP: } \\ \text { Categoría: } & \text { Plan: } & \text { Fecha Publicación DOCV: } \\ \text { Anotación Mo: } & \text { Informe: } & \text { Fecha Publicación BOE: }\end{array}$

\section{Bateria de Nuévalos}

\section{- Identificación}

Tramo de estudio:

Tramo 2: Puerta de Alcalá-Puerta de Cantarranas

Otras denominaciones: de Nuebalos, de Nuébalos

Ref. catastral:

Localización: C/ Fuente del Pino.

\section{Interés paisajistico}

$\square$ Incidencia visual

$\square$ Carácter articulador

$\square$ Organización

$\square$ Carácter representativo

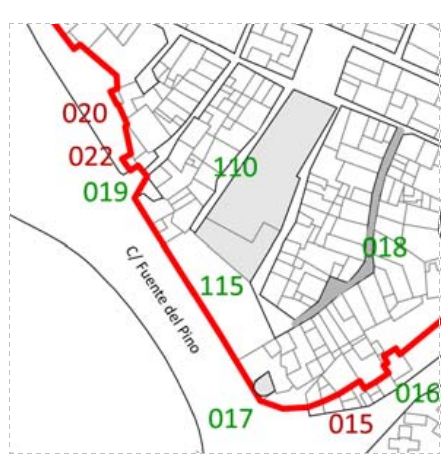

$\square$ Existe actualmente

Incluido en fichas PGOU 2013 $\square$ Bien de interés cultural (BIC) cód. postal: 4634 Municipio: Requena Comarca: Plana de Requena-Utiel Provincia: Valencia Autonomia: Comunidad Valencian

$$
\begin{array}{lll}
\text {.... Hipótesis trazado } & \text { OOA Supuesto } & \text { Fig. izq. Emplazamiento: VN, 2013 } \\
& \text { O0A Existente } & \text { Fig. centr. Foto histórica } \\
& \text { Fig. dcha. Foto actual: }
\end{array}
$$

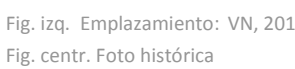

- Referencias en documentación histórica

\section{Referencias numéricas en cartografía sobre fortificación}

-Ref. en el croquis de Ortiz de Pinedo (1837-38, AGM, núm. 262): Sin ref.

-Ref. en plano de Vera Aparici (1993): Sin ref.

Referencias en memorias técnicas militares

-Ref. Guillermo Sáez (9/9/1834-5/12/1835): Sin ref.

-Ref. Guillermo Sáez (26/02/1836): Sin ref.

-Ref. P. Ortiz de Pinedo (12/03/1837-30/05/1837): Sin ref.

-Ref Jose Maria de Orozco (25/03/1838): Sin ref.

-Ref. Carbonell (4/7/1838): AMR, 1818-17, fol. 12

"Se construirá una esplanáda y se elebará e suelo á la inmediacion de las aspilléras, hasta que estas queden á 4. pies. Se abrirá un portádo para que pueda entrár el cañon por la Calle de la Cortina. En la desembocadúra de esta calle al despeñadero, se reformarán las aspilléras
según las reglas dadas, se levantará el parapéto y se rellenará el piso". (Carbonell, Requena, 4 de julio de 1838, AMR, 1818-17, fo. 12).

\section{- Observaciones a partir de los informes militares}

Se trata de una explanada artillera habilitada en el extremo de la C/ Cortina. Su emplazamiento no está claro y, tácticamente, lo suyo sería que un emplazamiento artillero tan nombrado en los informes, ocupe los ángulos salientes de la fortificación. Hacia el punto 019 , o hacia el extremo Noroeste del plano de situación que se adjunta, actualmente ocupado por viviendas arracimadas en un saliente rocoso. Este elemento, conocido como el "viejo baluarte", constituiria el lugar ideal. De no ser así, si la batería se emplaza hacia el punto 022 o 020 , debía configurarse como elemento saliente y su ángulo de visión estaría muy reducido, destinado sólo a la defensa frontal. 
$\square \frac{\text { Rellenar en caso de que el elemento sea }}{\text { contemplado con daes del PGovt, } 2013}$

\section{PROTECCIÓN}

Nivel de protección:

Entorno:

$\square$ Inmueble

$\square$ Parcela catastral

$\square$ Recinto arquitectónico

AFECCIÓN PATRIMONIAL

$\square$ Bien de interés cultural (BIC)

$\square$ Afectado entorno BIC

$\square$ Afectado Plan especia

- Descripción histórico-arquitectónica

Tipología:

Cronología:

Observaciones a la cronologia:

Descripción

- Entorno urbano

Descripción entorno urbano:

Uso actual:

Estado de conservación:

Intervenciones:

Régimen Urbanístico:

Titularidad:

Nivel protección s/catálogo 1996:

Bibliografía: AMR, 1818-17, 1818-24; 1818-50; 1818-52; 1818-53.

Observaciones generales:

\section{OBJETIVACIÓN DE INTERÉS}

$\square$ Interés tipológico

$\square$ Valor ambiental

Vigencia de la trama

$\square$ Mamposición de la fachada

Soluciones constructiva
$\square$ Estructura
$\square$ Aleros
$\square$ Coronación
$\square$ Jambas
$\square$ Dinteles

Soluciones ornamentales
$\square$ Carpintería
$\square$ Rejería
$\square$ Cubrepersianas
$\square$ Alicatados
$\square$ Recercos
$\square$ Dinteles

$\square$ Incidencia visual

$\square$ Carácter articulador

$\square$ Organización

$\square$ Carácter representativo
023 Casa de Don Antonio Montenegro

\section{- Identificación}

Tramo de estudio:

Otras denominaciones:

Tramo 2: Puerta de Alcalá-Puerta de Cantarranas

Ref. catastral:

Localización: Cuesta del Ángel.

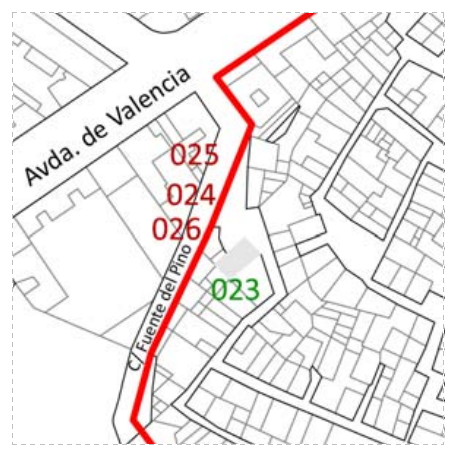

- Hipótessis trazado

\section{O0A Supuesto
$00 A$ Existente}

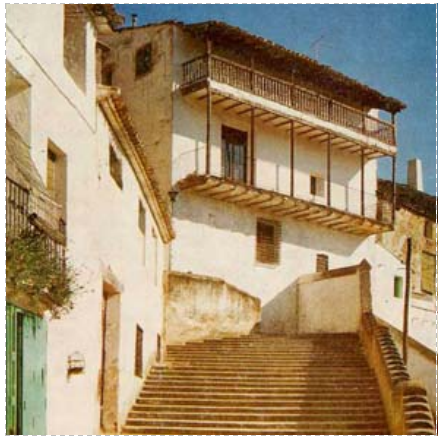

Fig. izq. Emplazamiento: VN, 2013

if. centr. Foto histórica Bernabeu, 1982:168

- Referencias en documentación histórica

Referencias numéricas en cartografía sobre fortificación

-Ref. en el croquis de Ortiz de Pinedo (1837-38, AGM, núm. 262): Sin ref.

-Ref. en plano de Vera Aparici (1993): Sin ref.

Referencias en memorias técnicas militares

-Ref. Guillermo Sáez (9/9/1834-5/12/1835): Sin ref.

-Ref. Guillermo Sáez (26/02/1836): Sin ref.

-Ref. P. Ortiz de Pinedo (12/03/1837-30/05/1837): Sin ref.

-Ref Jose María de Orozco (25/03/1838): Sin ref.

-Ref. Carbonell (4/7/1838): AMR, 1818-17, fol. 12

"Se guarnecerá con parapéto aspillerádo el pequeño corral que hay sobre la Roca" (Carbonell, Requena, 4 de julio de 1838, AMR, 1818-17,

\section{- Observaciones a partir de los informes militares}

Al fondo de la escalinata de la Cuesta del Ángel se ubica la solana de los Condes de Montenegro con sus balcones colgados. Desde las alturas de esta casa, Herrero y Moral presenció el ataque de Gómez de niño. Ello permite conjeturar que el frente de casas que se eleva campo de Batalla desde la muralla hasta la actual Plaza de Toros.

$\checkmark$ Existe actualmente

Incluido en fichas PGOU 2013

Bien de interés cultural (BIC)

cód. postal: 46340

Comarca: Plana de Requ

Provincia: Valenci

Autonomía: Comunidad Valenciar

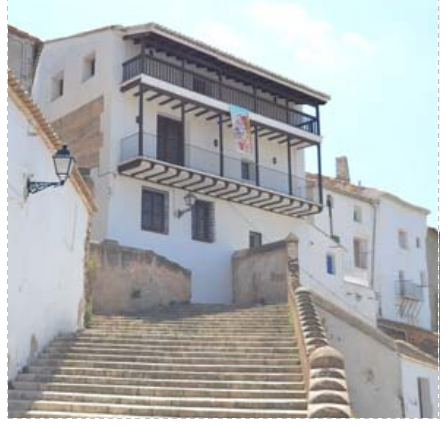

echa Publicación BOP:

Fecha Publicación BOE: 


\section{$\square \frac{\text { Rellenar en caso de que ele lemento sea }}{\text { contemplado o con datos del }}$}

PROTECCIÓN

Nivel de protección:

Entorno:

$\square$ Inmueble

$\square$ Parcela catastral

$\square$ Recinto arquitectónico

AFECCIÓN PATRIMONIAL

$\square$ Bien de interés cultural (BIC)

$\square$ Bien de relevancia local(BRL)

$\square$ Afectado entorno BIC

$\square$ Afectado Plan especia

\section{- Descripción histórico-arquitectónica}

Tipología:

Cronología:

Observaciones a la cronología:

Descripción

- Entorno urbano

Descripción entorno urbano:

Uso actual:

Estado de conservación:

Intervenciones:

Régimen Urbanístico:

Titularidad:

Nivel protección s/catálogo 1996:

Bibliografía: AMR, 1818-17, 1818-24; 1818-50; 1818-52; 1818-53.

observaciones generales:

\section{OBJETIVACIÓN DE INTERÉS}

$\square$ Interés tipológico

$\square$ Valor ambiental

Vigencia de la trama

Materiales, color, textura

Soluciones constru
$\square$ Estructura
$\square$ Aleros
$\square$ Coronación
$\square$ Jambas
$\square$ Dinteles

Soluciones ornamentales
$\square$ carpintería
$\square$ Rejería
$\square$ Cubrepersianas
$\square$ Alicatados
$\square$ Recercos
$\square$ Dinteles
$\square$ Otros ornamentos

Interés paisajistico

$\square$ Incidencia visual

$\square$ Carácter articulador

$\square$ Organización

Interés cultural

cter representativo

$\square$ otros ornamentos

\section{- Datos específicos catalogación BIC $\square$ Rellenar sólo si está catalogado BIC}

\section{Datos Jurídicos:}

Código:

Estado:

Categoria:

Fecha Disposicion:

Anotación $M \stackrel{-}{0}$

Tipo delimitación:

Plan:

Fecha informe:

Fecha Publicación DOCV:

\section{Casa de Don Domingo Laguna}

\section{- Identificación}

Tramo de estudio: $\quad$ Tramo 2: Puerta de Alcalá-Puerta de Cantarranas

Otras denominaciones:

Ref. catastral:

Localización: Cuesta del Ángel.

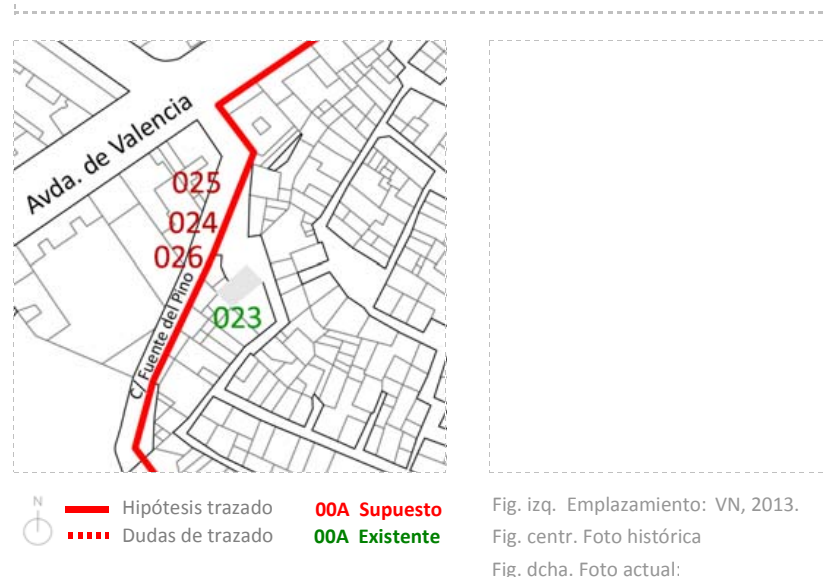

\section{- Referencias en documentación histórica}

Referencias numéricas en cartografía sobre fortificación

-Ref. en el croquis de Ortiz de Pinedo (1837-38, AGM, núm. 262): Sin ref.

-Ref. en plano de Vera Aparici (1993): Sin ref.

Referencias en memorias técnicas militares

-Ref. Guillermo Sáez (9/9/1834-5/12/1835): Sin ref.

-Ref. Guillermo Sáez (26/02/1836): Sin ref.

-Ref. P. Ortiz de Pinedo (12/03/1837-30/05/1837): Sin ref.

-Ref Jose María de Orozco (25/03/1838): Sin ref.

-Ref. Carbonell (4/7/1838): Sin ref.

\section{- Observaciones a partir de los informes militares}

Junto a la Puerta del Ángel. Constituiría el conjunto de casas que se arraciman en la Villa en torno a la cuesto del Ángel.

$\begin{array}{lll}\square \frac{\text { Rellenar en caso de que el elemento sea }}{\text { contemplado con datos del PGOU, 2013 }} & \text { PROTECCIÓN } & \text { AFECCIÓN PATRIMONIAL } \\ & \text { Nivel de protección: } & \square \text { Bien de interés cultural (BIC) } \\ & \text { Entorno: } & \square \text { Bien de relevancia local (BRL) } \\ & \square \text { Inmueble } & \square \text { Afectado entorno BIC } \\ & \square \text { Parcela catastral } & \square \text { Afectado Plan especial } \\ & \square \text { Recinto arquitectónico } & \\ \square \text { Entorno específico } & \end{array}$

Existe actualmente

Incluido en fichas PGOU 2013

Bien de interés cultural (BIC)

cód. postal: 46340

Provincia: Valencia

Autonomia: Comunidad Valencian 
- Descripción histórico-arquitectónica

\section{Tipología:}

Cronología:

Observaciones a la cronología:

\section{Descripción:}

\section{- Entorno urbano}

Descripción entorno urbano

Uso actual:

Estado de conservación:

Intervenciones:

Régimen Urbanistico:

Titularidad:

Nivel protección s/catálogo 1996:

Bibliografía: AMR, 1818-17, 1818-24; 1818-50; 1818-52; 1818-53.

Observaciones generales:

\begin{tabular}{|c|c|c|}
\hline OBJETIVACIÓN DE INTERÉS & Soluciones constructivas & Soluciones ornamentales \\
\hline $\begin{array}{l}\square \text { Interés tipológico } \\
\square \text { valor ambiental } \\
\square \text { vigencia de la trama } \\
\square \text { Composición de la fachada } \\
\square \text { Materiales, color, textura }\end{array}$ & $\begin{array}{l}\square \text { Estructura } \\
\square \text { Aleros } \\
\square \text { Coronación } \\
\square \text { Jambas } \\
\square \text { Dinteles }\end{array}$ & $\begin{array}{l}\square \text { Carpintería } \\
\square \text { Rejería } \\
\square \text { Cubrepersianas } \\
\square \text { Alicatados } \\
\square \text { Recercos } \\
\square \text { Dinteles } \\
\square \text { Otros ornamentos }\end{array}$ \\
\hline
\end{tabular}

- Datos específicos catalogación BIC $\square$ Rellenar sólo si está catalogado BIC

$\begin{array}{lll}\text { Datos Juridicos: } & & \\ \text { Código: } & \text { Fecha Disposición: } & \text { Fecha informe: } \\ \text { Estado: } & \text { Tipo delimitación: } & \text { Fecha Publicación BOP: } \\ \text { Categoría: } & \text { Plan: } & \text { Fecha Publicación DOCV: } \\ \text { Anotación Mo: } & \text { Informe: } & \text { Fecha Publicación BOE: }\end{array}$

\section{Interés paisajistico}

$\square$ Incidencia visual

$\square$ Carácter articulador

$\square$ Organización

$\square$ Carácter representativo
025 Casa de Estebana Cárcel

\section{- Identificación}

Tramo de estudio:

Tramo 2: Puerta de Alcalá-Puerta de Cantarranas

Otras denominaciones: Casa de Cárcel

Ref. catastral:

Localización: Cuesta del Ángel.

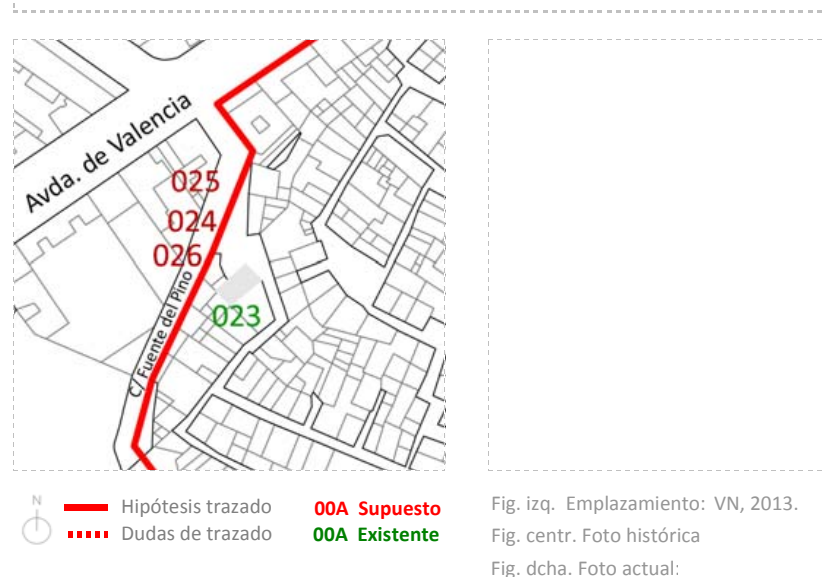

\section{- Referencias en documentación histórica}

Referencias numéricas en cartografía sobre fortificación

-Ref. en el croquis de Ortiz de Pinedo (1837-38, AGM, núm. 262): Sin ref.

-Ref. en plano de Vera Aparici (1993): Sin ref.

Referencias en memorias técnicas militares

-Ref. Guillermo Sáez (9/9/1834-5/12/1835): Sin ref.

-Ref. Guillermo Sáez (26/02/1836): Sin ref.

-Ref. P. Ortiz de Pinedo (12/03/1837-30/05/1837): Sin ref.

-Ref Jose María de Orozco (25/03/1838): Sin ref.

-Ref. Carbonell (4/7/1838): AMR, 1818-17, fol. 12

"Se levantará un parapéto aspillerado en el corral que está encima de la Peña. Las tapias que hay enfrente de la misma se derribarán; y se cerrará la cueba [que] queda descubiérta; según se há dicho ya por [punto] general" (Carbonell, Requena, 4 de julio de 1838, AMR, 181817, fol. 12).

\section{- Observaciones a partir de los informes militares}

Próxima a la Puerta del Ángel. Constituiría el conjunto de casas que se arraciman en la Villa en torno a la cuesta del Ángel. No obstante podría integrar algunas de las casas del otro sector de la calle Cantarranas, dado que en su momento este frente de casas, que definía la obstante, nos posicionamos en la primera hipótesis.
Existe actualmente

Incluido en fichas PGOU 2013

Bien de interés cultural (BIC)

cód. postal: 46340

Provincia: Valenci

Autonomia: Comunidad Valenciara 
$\square \frac{\text { Rellenar en caso de que e elemento sea }}{\text { contempladodo con datotos del PCOOU, } 2013}$

PROTECCIÓN

Nivel de protección:

Entorno:

$\square$ Inmueble

Parcela catastral

Recinto arquitectónico

$\square$ Entorno específico

$\square$ Bien de interés cultural (BIC)

$\square$ Afectado entorno BIC

Afectado Plan especial

- Descripción histórico-arquitectónica

Tipología:

Cronología:

Observaciones a la cronologia:

Descripción:

- Entorno urbano

Descripción entorno urbano:

Uso actual:

Estado de conservación:

Intervenciones:

Régimen Urbanístico:

Titularidad:

Nivel protección s/catálogo 1996

Bibliografí: AMR, 1818-17, 1818-24: 1818-50; 1818-52; 1818-53.

Observaciones generales:

OBJETIVACIÓN DE INTERÉS

$\square$ Interés tipológico

$\square$ Valor ambiental

$\square$ Vigencia de la trama

$\square$ Materiales, color, textura

Soluciones constructivas
$\square$ Estructura
$\square$ Aleros
$\square$ Coronación
$\square$ Jambas
$\square$ Dinteles

\section{Soluciones ornamentales}

$\square$ Carpintería
$\square$ Rejería
$\square$ Cubrepersianas
$\square$ Alicatados
$\square$ Recercos

Interés paisajistico

$\square$ Incidencia visual

$\square$ Carácter articulador

$\square$ Organización

$\square$ Interés cultural

$\square$ Recercos

$\square$ Otros ornamentos

\section{- Datos específicos catalogación BIC $\square$ Rellenar sólo si está catalogado BIC}

\section{Datos Jurídicos:}

Código:

Estado:
Categoría:

Categoría:

Fecha Disposición:
Tipo delimitación:

Plan:

Informe:
Fecha informe:

Fecha Publicación BOP:

Fecha Publicación DOCV:

Fecha Publicación BOE:

\section{Casa del Ángel}

\section{- Identificación}

Tramo de estudio: $\quad$ Tramo 2: Puerta de Alcalá-Puerta de Cantarranas

Otras denaminaciones: El Angel. Puerta del Ángel. Cuesta del Ángel

Ref. catastral:

Localización: Cuesta del Ángel.
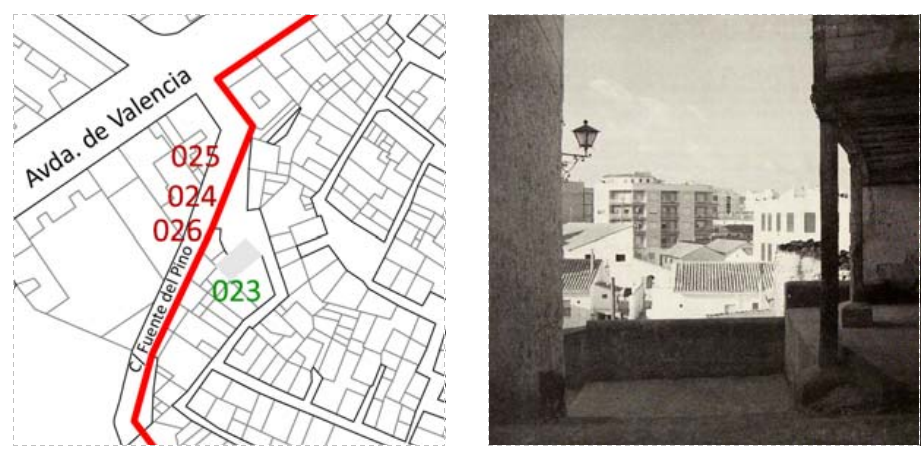

-.... Hipótesis trazado

O0A Supuesto
OOA Existente

ig. izq. Emplazamiento: VN, 2013

G. centr. Foto histórica Bernabeu, 1982:518

$\checkmark$ Existe actualmente

Incluido en fichas PGOU 2013

Bien de interés cultural (BIC)

cód. postal: 46340

Municipio: Requen

Comarca: Plana de Requena-Utie

Provincia: Valencia

Autonomia: Comunidad Valencian

\section{- Referencias en documentación histórica}

Referencias numéricas en cartografía sobre fortificación

-Ref. en el croquis de Ortiz de Pinedo (1837-38, AGM, núm. 262): Sin ref.

-Ref. en plano de Vera Aparici (1993): 004

Referencias en memorias técnicas militares

-Ref. Guillermo Sáez (9/9/1834-5/12/1835): Requena, 5/12/1835 AMR, 1818-50

Aspillerado y cierre de balcones de la Casa de Montenegro y la Casa de la Laguna

-Ref. Guillermo Sáez (26/02/1836): Sin ref.

-Ref. P. Ortiz de Pinedo (12/03/1837-30/05/1837): Sin ref.

-Ref Jose María de Orozco (25/03/1838): Sin ref.

-Ref. Carbonell (4/7/1838): AMR, 1818-17, fol. 12

"Se cerrarán con recia pared el balcón, las ventánas y la puerta; y se abrirán aspilléras en todos los [Cpos.] por el frente y costádos. La y se dispondrán los corráles superióres con arreglo á las indicaciónes espuestas". (Carbonelll, Requena, 4 de julio de 1838, AMR, 1818-17, fo. 12).

\section{- Observaciones a partir de los informes militares}

Junto a ella se ubica la Casa de Montenegro y la de Don Domingo Laguna. La actual Cuesta del Ángel consituía una salida del recinto amurallado hacia Albacete y Almansa. Destaca hoy llama la atención por su escalinata. Estaba flanqueada por torres. En ella las mujeres rezaban al Santo Ángel de la Guarda pidiendo su protección con candiles y fanales.
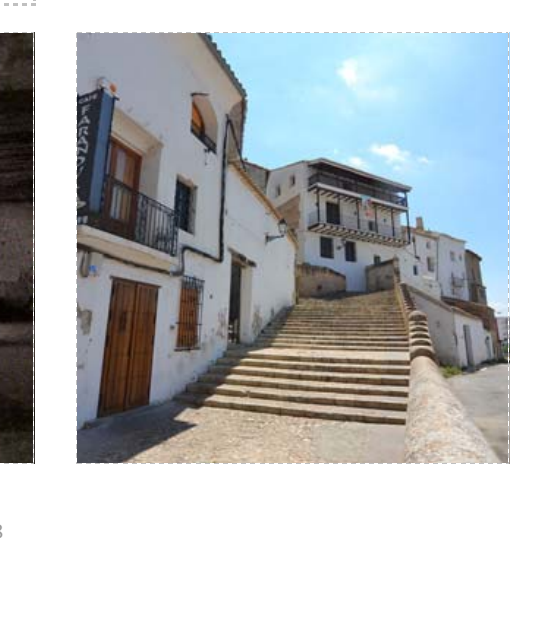

(1)

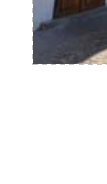




\section{$\frac{\text { Rellenar en caso de que e elemento se }}{\text { contemplado con datos del } P \text { PCOU, } 2013}$}

PROTECCIÓN

Nivel de protección:

$\square$ Inmueble

Parcela catastral

$\square$ Recinto arquitectónico

$\square$ Bien de interés cultural (BC)

$\square$ Afectado entorno BIC

$\square$ Afectado Plan especia

- Descripción histórico-arquitectónica

Tipología:

Cronología:

Observaciones a la cronología

Descripción

- Entorno urbano

Descripción entorno urbano:

Uso actual:

Estado de conservación:

Intervenciones:

Regimen Urbanist
Titularidad:

Nivel protección s/catálogo 1996

Bibliografía: AMR, 1818-17, 1818-24; 1818-50; 1818-52; 1818-53.

Observaciones generales:

\section{OBJETIVACIÓN DE INTERÉS}

$\square$ Interés tipológico

Valor ambiental

Vigencia de la trama

$\square$ Materiales, color, textura

Soluciones construc
$\square$ Estructura
$\square$ Aleros
$\square$ Coronación
$\square$ Jambas
$\square$ Dinteles

Soluciones ornamentales
$\square$ Carpintería
$\square$ Rejería
$\square$ Cubrepersianas
$\square$ Alicatados
$\square$ Recercos
$\square$ Dinteles
$\square$ Otros ornamentos

Interés paisajistico

$\square$ Incidencia visual

$\square$ Carácter articulador

$\square$ Organización

$\square$ Carácter representativo

\section{- Datos específicos catalogación BIC $\square$ Rellenar sólo si está catalogado BIC}

\section{Datos Juridicos:}

Código:

Estado:

Categorí:

Fecha Disposición:
Tipo delimitación:

Plan:

Informe:
Fecha informe:

Fecha Publicación BOP:

Fecha Publicación DOCV:

Fecha Publicación BOE:

\section{Batería del Cristo}

\section{- Identificación}

Tramo de estudio

Tramo 2: Puerta de Alcalá-Puerta de Cantarranas

Otras denominaciones: Puerta del Cristo, Puerta del Cristo del amparo. Puerta, cu

Ref. catastral

Localización: Desde la calle García Montes en dirección a la Villa.
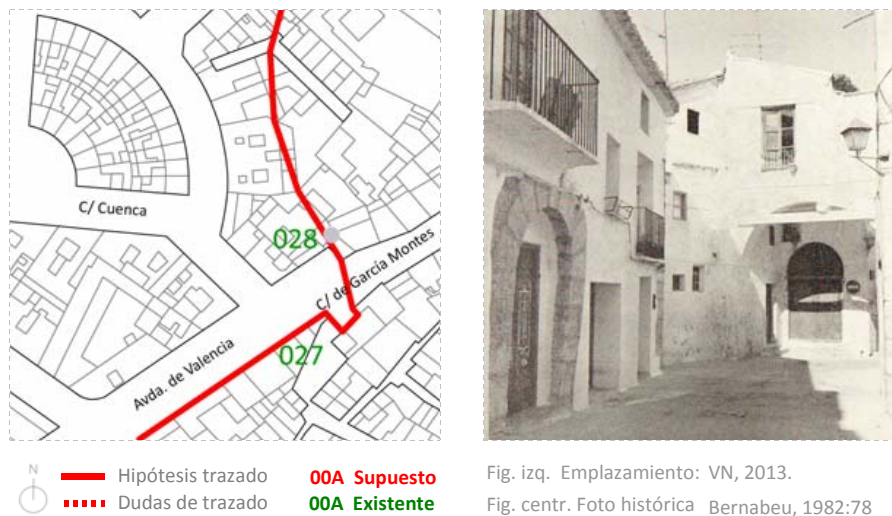

Fig. izq. Emplazamiento: VN, 2013$$
\begin{aligned}
& \text { oto histórica Bernabeu, } 1982 \text {. } \\
& \text { pto actual:VN, } 2015
\end{aligned}
$$

- Referencias en documentación histórica

Referencias numéricas en cartografía sobre fortificación

-Ref. en el croquis de Ortiz de Pinedo (1837-38, AGM, núm. 262): 010

-Ref. en plano de Vera Aparici (1993): Sin ref.

Referencias en memorias técnicas militares

-Ref. Guillermo Sáez (9/9/1834-5/12/1835):Sin ref.

-Ref. Guillermo Sáez (26/02/1836): Sin ref.

-Ref. P. Ortiz de Pinedo (12/03/1837-30/05/1837): Sin ref.

-Ref Jose María de Orozco (25/03/1838): Requena, 25/03/1838, AMR 1818-24

Se considera suficiente la batería existente.

-Ref. Carbonell (4/7/1838): AMR, 1818-17, fol. 13

"Se realzarán las rodilléras y la cresta del parapéto. Deben hacérse tres esplanádas de madéra; asi como tambien portezuelas para las cañoneras. El parapéto aspillerádo contiguo se reformará con sujecion á los pincipios tantas veces referidos: se hará que algúnas aspilléras

\section{- Observaciones a partir de los informes militares}

La puerta del Cristo (o Cantarranas) marcaba el camino hacia Castilla. Se configura como puerta en recodo. Su torre se habilita para vivienda y cuenta con un nicho con una popular imagen denominada Capilla del Cristo (Cristo del Ámparo). La capilla fue instalada en una de las antiguas torres. Tanto la capilla como la puerta fueron reconstruidas en el siglo XVIII, y han recibido una cuestionada intervención recientemente.

\section{$\checkmark$ Existe actualmente}

Incluido en fichas PGOU 2013

Bien de interés cultural (BIC)

cód. postal: 46340

Comarca: Plana de Requen

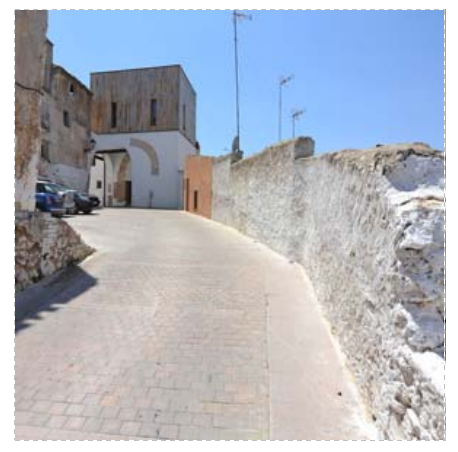


$\square$ Rellenar en caso de que el elemento sea
contemplado con datos del PGOU, 2013

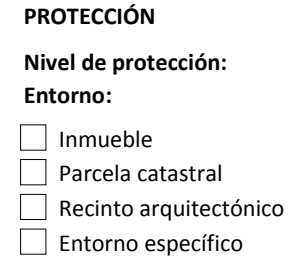

AFECCIÓN PATRIMONIAL

$\square$ Bien de interés cultural (BIC)

$\square$ Afectado entorno BIC

$\square$ Afectado Plan especia

\section{- Descripción histórico-arquitectónica}

Tipología:

Cronología:

Observaciones a la cronología

\section{Descripción:}

- Entorno urbano

Descripción entorno urbano:

Uso actual:

Estado de conservación:

Intervenciones:

Régimen Urb:
Titularidad:

Nivel protección s/catálogo 1996

Bibliografia: AMR, 1818-17, 1818-24; 1818-50; 1818-52; 1818-53.

Observaciones generales:

$\begin{array}{lll}\text { OBJETIVACIÓN DE INTERÉS } & \text { Soluciones constructivas } & \text { Soluciones ornamentales } \\ \square \text { Interés tipológico } & \square \text { Estructura } & \square \text { Carpintería } \\ \square \text { valor ambiental } & \square \text { Aleros } & \square \text { Rejería } \\ \square \text { vigencia de la trama } & \square \text { Coronación } & \square \text { Cubrepersianas } \\ \square \text { Composición de la fachada } & \square \text { Jambas } & \square \text { Alicatados } \\ \square \text { Materiales, color, textura } & \square \text { Dinteles } & \square \text { Recercos } \\ & & \square \text { Dinteles } \\ & \square \text { Otros ornamentos }\end{array}$

Interés paisajistico
$\square$ Incidencia visual
$\square$ Carácter articulador
$\square$ Organización
$\square$ Interés cultural
$\square$ Carácter representativo

\section{- Datos específicos catalogación BIC $\square$ Rellenar sólo si está catalogado BIC}

Datos Jurídicos:

$\begin{array}{lll}\text { Código: } & \text { Fecha Disposición: } & \text { Fecha informe: } \\ \text { Estado: } & \text { Tipo delimitación: } & \text { Fecha Publicación BOP: } \\ \text { Categoría: } & \text { Plan: } & \text { Fecha Publicación DOCV: } \\ \text { Anotación Mo: } & \text { Informe: } & \text { Fecha Publicación BOE: }\end{array}$

\section{Puerta de Cantarranas}

\section{- Identificación}

Tramo de estudio:

Tramo 3: Puerta de Cantarranas-Puerta de Madrid

Otras denominaciones: Tambor de la Puerta de Cantarranas, Fortín de la Guerra C

Ref. catastral:

3276-39

Localización: C/ De García Montes, nํ36. Desde la C/ García Montes (Cantarranas). Se encuentra vallado el paso con una chapa metálica grecada.
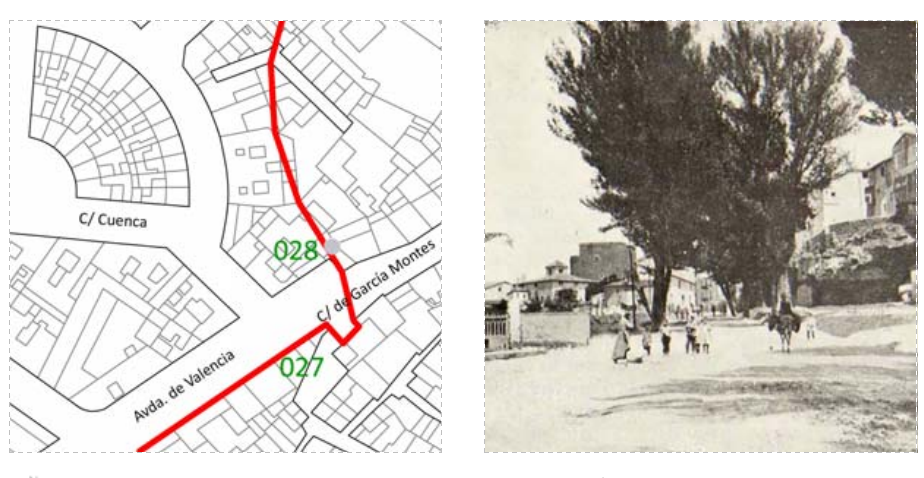

..... Dudas des de trazado

O0A Supuesto

$$
\begin{aligned}
& \text { Fig. izq. Emplazamiento: VN, 2013, } \\
& \text { Fig. centr. Foto histórica Bernabeu, 1982:393 } \\
& \text { Fig. dcha. Foto actual:VN, } 2015
\end{aligned}
$$

$\checkmark$ Existe actualmente

$\checkmark$ Incluido en fichas PGOU 2013

$\square$ Bien de interés cultural (BIC)

cód. postal: 46340

Municipio: Requena

Comarca: Plana de Requena-Utiel

Provincia: Valencia

Autonomía: Comunidad Valencian

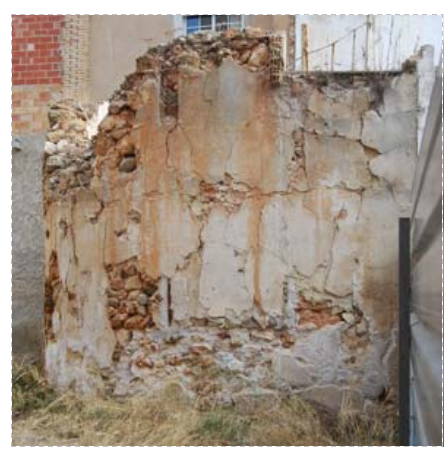

\section{- Referencias en documentación histórica}

\section{Referencias numéricas en cartografía sobre fortificación}

-Ref. en el croquis de Ortiz de Pinedo (1837-38, AGM, núm. 262): 008

-Ref. en plano de Vera Aparici (1993): 003

Referencias en memorias técnicas militares

-Ref. Guillermo Sáez (9/9/1834-5/12/1835): Requena, 5/12/1835 AMR, 1818-50

Aspillerado y "doblado" de puertas

-Ref. Guillermo Sáez (26/02/1836): Requena, 26/02/1836 AMR, 1818-53

Se propone hacer seis aspilleras en la pared inmediata. La responsabilidad de la obra depende de la Villa.

-Ref. P. Ortiz de Pinedo (12/03/1837-30/05/1837): Sin ref.

-Ref Jose Maria de Orozco (25/03/1838): Sin ref.

-Ref. Carbonell (4/7/1838): AMR, 1818-17, fol.13

"En el pequéño lienzo de la izquierda de esta se dará mas desahogo á las aspilléras, se establecerá con mas firméza la banquéta de las altas y se abrirá un foso á un frente. Se pondran gruesas puertas nuebas en lugar de las debiles [que] ahóra hay: cuyas puertas tendran su postigo de tres pies de alto en una de sus hojas. Para auméntar la seguridad de esta entráda, se efectuará por la parte interior la obra que sigue. Se levantará un parapéto aspillerádo sobre el rebestimiénto de la rampa por donde se sube á la Villa, con lo cual se consigue tambien la ventaja de resguardar esta rampa de los tiros de la campana, se elebará tres pies mas, y se aspilleraráa la tapia interior del huertecillo de la derecha, formanndo un cuchillo en su proximidad con la facháda, à fin de desenfillar la banquéta alta de la misma: estos pueden colocarse las puertas [quel se desechan en la priméra. En el pequeño huerto que acába de citárse se desenfilaráa la escallerá de garita, cubriendo hasta la linea que convénga las dos aspilléras de la derécha. Se aspillerará la tapia que flanquéa la cortina contigua realzándola lo que sea preciso para que su altúra sobre el terréno no baje de cuatro baras. Se desharán los restos de una tapia paraléla á la que se acaba de citar, porque perjudican á la defénsa"

\section{- Observaciones a partir de los informes militares}

En la puerta de Cantarranas se localiza uno de los pocos restos existentes de la fortificación liberal el denominado tambor de Cantarranas. 


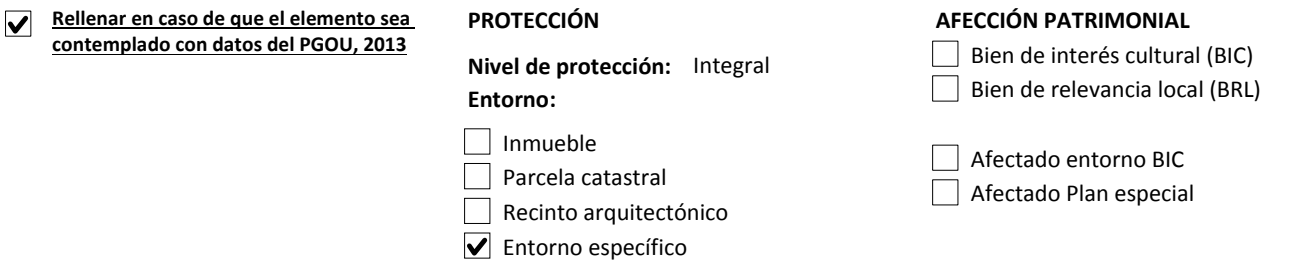

- Descripción histórico-arquitectónica

Tipología: Infraestructura militar

Cronología: s. XIX

Observaciones a la cronología:

Descripción: "Ubicado al oeste del barrio de la Villa, en la parte baja de uno de los antiguos accesos al barrio. Se trata de una pequeñ de colindante, y tan sólo se conservan los muros de la primera planta" (PGOU, 2013: E.CAS.CAT.75).

\section{- Entorno urbano}

Descripción entorno urbano:

del barrio de la Villa. Junto a la vía que constituye el límite oeste de este barrio. Actualmente inserto en una de las manzanas del ensanche, de la zona residencial. Desde la vía pública pasa desapercibido por las construcciones que lo rodean

Estado de conservación: Malo

tervenciones: Recientemente se vio afectado por una explosión en un edificio adyacente

Rérimentions

Titularidad: Pública:

Nivel protección s/catálogo 1996:

ibliografía: AMR, 1818-17, 1818-24; 1818-50; 1818-52; 1818-53.

Observaciones generales:

\begin{tabular}{llll} 
OBJETIVACIÓN DE INTERÉS & Soluciones constructivas & Soluciones ornamentales & Interés paisajístico \\
$\nabla$ Interés tipológico & $\boldsymbol{\nabla}$ Estructura & $\square$ Carpintería & $\square$ Incidencia visual \\
$\square$ Valor ambiental & $\square$ Aleros & $\square$ Rejería & $\square$ Carácter articulador \\
$\square$ Vigencia de la trama & $\square$ Coronación & $\square$ Cubrepersianas & $\square$ Organización \\
$\square$ Composición de la fachada & $\square$ Jambas & $\square$ Alicatados & $\nabla$ Interés cultural \\
\hline$\nabla$ Materiales, color, textura & $\square$ Dinteles & $\square$ Recercos & $\square$ Carácter representativo \\
& & $\square$ Dinteles & \\
& & $\square$ Otros ornamentos &
\end{tabular}

\section{- Datos específicos catalogación BIC $\square$ Rellenar sólo si está catalogado BIC} Datos Jurídicos:

$\begin{array}{lll} & \text { Fecha Disposición: } & \text { Fecha informe: } \\ \text { Código: } & \text { Tipo delimitación: } & \text { Fecha Publicación BOP: } \\ \text { Estado: } & \text { Plan: } & \text { Fecha Publicación DOCV: } \\ \text { Categoría: } & \text { Informe: } & \text { Fecha Publicación BOE: } \\ \text { Anotación Mo: } & \end{array}$

\section{Cortina de la Calle de Cantarranas}

- Identificación

Tramo de estudio:

Otras denominaciones:

Tramo 3: Puerta de Cantarranas-Puerta de Madrid

Ref. catastral:

Localización: c/ García Montes

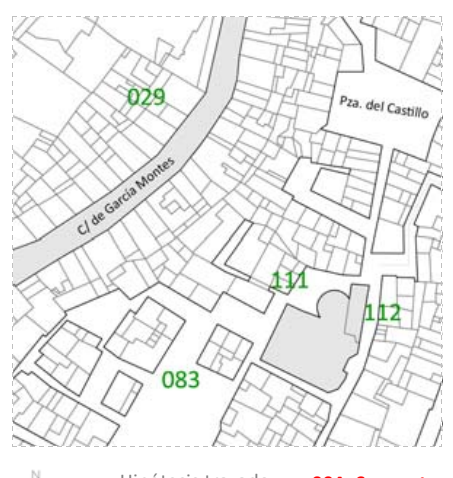

- Hipótesis trazado $00 \mathrm{~A}$ Supuesto

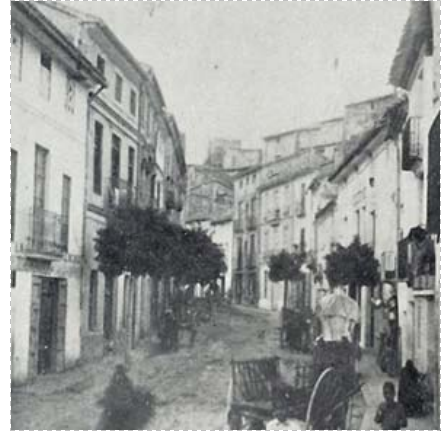

Fig. izq. Emplazamiento: VN, 2013

Fig. centr. Foto historica Canta $\checkmark$ Existe actualmente

$\square$ Incluido en fichas PGOU 2013

$\square$ Bien de interés cultural (BIC)

cód. postal: 46340

Municipio: Requena

Comarca: Plana de Requena-Utiel

Provincia: Valencia

Autonomia: Comunidad ValencianaComunida

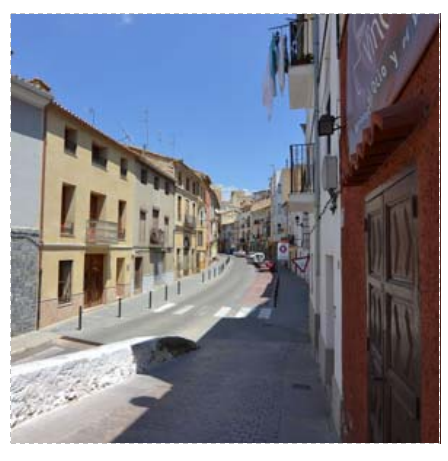

- Referencias en documentación histórica

\section{Referencias numéricas en cartografía sobre fortificación}

-Ref. en el croquis de Ortiz de Pinedo (1837-38, AGM, núm. 262): Sin ref.

-Ref. en plano de Vera Aparici (1993): 005

Referencias en memorias técnicas militare

-Ref. Guillermo Sáez (9/9/1834-5/12/1835): Sin ref.

-Ref. Guillermo Sáez (26/02/1836): Sin ref.

-Ref. P. Ortiz de Pinedo (12/03/1837-30/05/1837): Sin ref.

-Ref Jose Maria de Orozco (25/03/1838): Sin ref.

-Ref. Carbonell (4/7/1838): AMR, 1818-17, fol.13

"Se dará á todo el parapéto de esta cima una misma altúra, que será la del trozo que ahóra se eléba mas. Se recalzará, compondrán y rebocarán las parédes y tapias en divérsas partes en que lo recláma su actual estado, y se masisarán las puertas que se hallan debilmente tapiádas. Se destruirán dos pasadizos de piedra que ecsisten sobre la acequia contigua, y se cortarán los arboles y arbústos [que] facilitan la escaláda de la cortina. Las casas de la Calle de Cantarránas se aspillerarán en todos los cuerpos que descubran el campo.

Se tendrá cuidado de que las aspilleras que se hagan o reformen queden desahogadas: que en el paramentto esterior tengan de 16. A 18. pulgádas de alto, $y$ de $31 / 2$ a 4 de ancho: que las direcciónes de sus costádos sean las mas conveniéntes; $y$ que su elebacion sobre el
terreno se sujéte á las condiciónes que anteriórmente se hán establecido. Las aspilléras distarán de centro á centro cuatro pies en las

lineas esténsas, y solo tres en las [reducidas], ó donde interése multipliocar los fuegos: sin embárgo en los edificios no siempre se puede obsérvar esta regla, pero se procurará aprocsimárse á ella todo lo posible. Siendo generáles estas advertencias, no solo se aplicarán á la parte del recinto lque] ahora se considera, sino a todos los demas: por lo cual se evitará su repeticion en lo subcesibo. Y por la misma razon se omitirá tambien el repetir otras indicaciones que son igualmente generáles"

\section{- Observaciones a partir de los informes militares}

Constituiría todo el frente defensivo que transcurre coincidiendo con la calle de Diego Montes. De hecho se habla de aspillerar las casas de Cantarranas. Por la zona discurría una acequía que parece limitaba con una cresta rocosa, donde estaría ubicado el conjunto de casas acompañaba la orientación de la calle. 


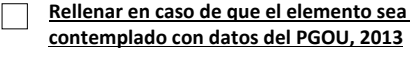

\section{PROTECCIÓN}

Nivel de protección:

AFECCIÓN PATRIMONIAL

$\square$ Bien de interés cultural (BIC)

$\square$ Inmueble

$\square$ Parcela catastral

$\square$ Recinto arquitectónico

$\square$ Afectado entorno BIC

$\square$ Afectado Plan especial

\section{- Descripción histórico-arquitectónica}

Tipología:

Cronología:

Observaciones a la cronología:

Descripción

- Entorno urbano

Descripción entorno urbano:

Uso actual:

Estado de conservación:

Intervenciones:

Régimen Urbanístico:

Titularidad:

Nivel protección s/catálogo 1996

Bibliografí: AMR, 1818-17, 1818-24: 1818-50; 1818-52: 1818-53.

observaciones generales:

$\begin{array}{llll}\text { OBJETIVACIÓN DE INTERÉS } & \text { Soluciones constructivas } & \text { Soluciones ornamentales } & \text { Interés paisajistico } \\ \square \text { Interés tipológico } & \square \text { Estructura } & \square \text { carpintería } & \square \text { Incidencia visual } \\ \square \text { Valor ambiental } & \square \text { Aleros } & \square \text { Rejería } & \square \text { Carácter articulador } \\ \square \text { Vigencia de la trama } & \square \text { coronación } & \square \text { cubrepersianas } & \square \text { Organización } \\ \square \text { Composición de la fachada } & \square \text { Jambas } & \square \text { Alicatados } & \square \text { Interés cultural } \\ \square \text { Materiales, color, textura } & \square \text { Dinteles } & \square \text { Recercos } & \square \text { Carácter representativo } \\ & & \square \text { Dinteles } & \\ & \square \text { otros ornamentos } & \end{array}$

\begin{tabular}{|c|c|c|}
\hline \multirow{2}{*}{\multicolumn{3}{|c|}{$\begin{array}{l}\text { - Datos específicos catalogación BIC } \\
\text { Datos Jurídicos: }\end{array}$}} \\
\hline & & \\
\hline Código: & Fecha Disposición: & Fecha informe: \\
\hline Estado: & Tipo delimitación: & Fecha Publicación BOP: \\
\hline Categoría: & Plan: & Fecha Publicación DOCV \\
\hline Anotación Mo: & Informe: & Fecha Publicación BOE: \\
\hline
\end{tabular}




\begin{tabular}{lll}
$\square \frac{\text { Rellenar en caso de que ele elemento sea }}{\text { contemplado con datos del PGOU, 2013 }}$ & PROTECCIÓN & AFECCIÓN PATRIMONIAL \\
& Nivel de protección: & $\square$ Bien de interés cultural (BIC) \\
& Entorno: & $\square$ Bien de relevancia local (BRL) \\
& $\square$ Inmueble & $\square$ Afectado entorno BIC \\
& $\square$ Parcela catastral & $\square$ Afectado Plan especial \\
& $\square$ Recinto arquitectónico & \\
\hline Entorno específico &
\end{tabular}

- Descripción histórico-arquitectónica

Tipología:

Cronología:

Observaciones a la cronología:

Descripción:

- Entorno urbano

Descripción entorno urbano:

Uso actual:

Estado de conservación:

Intervenciones:

Régimen Urbanístico:

Titularidad:

Nivel protección s/catálogo 1996:

Bibliografía: AMR, 1818-17, 1818-24; 1818-50; 1818-52; 1818-53.

Observaciones generales:

$\begin{array}{llll}\text { OBJETIVACIÓN DE INTERÉS } & \text { Soluciones constructivas } & \text { Soluciones ornamentales } & \text { Interés paisajistico } \\ \square \text { Interés tipológico } & \square \text { Estructura } & \square \text { carpintería } & \square \text { Incidencia visual } \\ \square \text { valor ambiental } & \square \text { Aleros } & \square \text { Rejería } & \square \text { carácter articulador } \\ \square \text { vigencia de la trama } & \square \text { coronación } & \square \text { cubrepersianas } & \square \text { organización } \\ \square \text { composición de la fachada } & \square \text { Jambas } & \square \text { Alicatados } & \square \text { Interés cultural } \\ \square \text { Materiales, color, textura } & \square \text { Dinteles } & \square \text { Recercos } & \square \text { carácter representativo } \\ & & \square \text { Dinteles } & \\ & \square \text { otros ornamentos } & \end{array}$

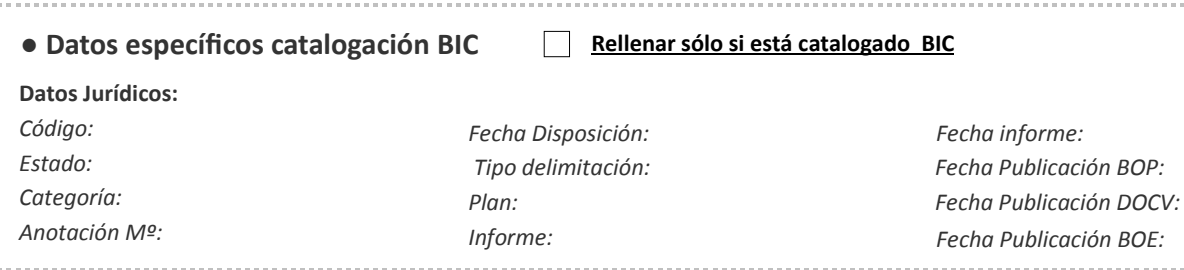

\section{Casa de Don Andrés Ferrer}

\section{- Identificación}

Tramo de estudio:

Otras denominaciones:

Tramo 3: Puerta de Cantarranas-Puerta de Madrid

Ref. catastral:

Localización: Área entre el mercado y la plaza del Portal.

Existe actualmente

Incluido en fichas PGOU 2013

Bien de interés cultural (BIC)

cód. postal: 4634

Municipio: Requena

Comarca: Plana de Requena-Utiel

Provincia: Valencia

Autonomiá: Comunidad Valencian

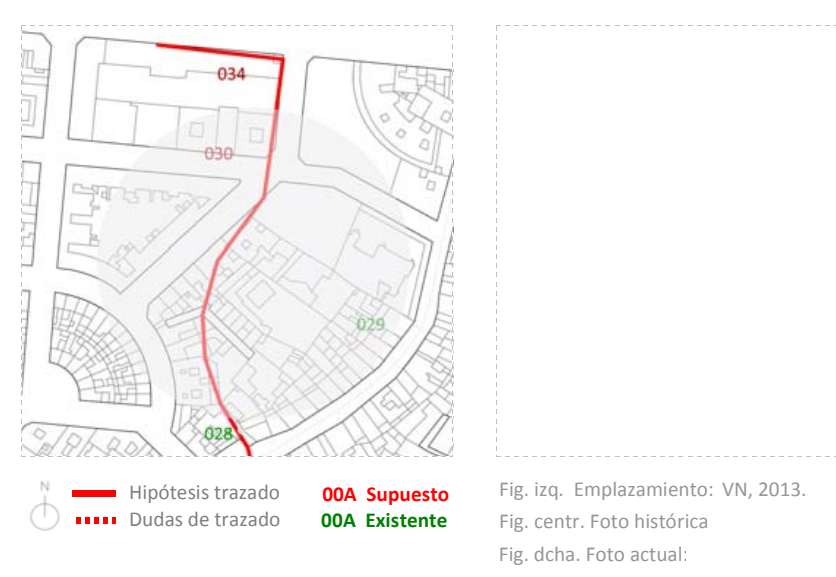

\section{- Referencias en documentación histórica}

Referencias numéricas en cartografía sobre fortificación

-Ref. en el croquis de Ortiz de Pinedo (1837-38, AGM, núm. 262): Sin ref.

-Ref. en plano de Vera Aparici (1993): Sin ref.

Referencias en memorias técnicas militares

-Ref. Guillermo Sáez (9/9/1834-5/12/1835): Sin ref.

-Ref. Guillermo Sáez (26/02/1836): Sin ref.

-Ref. P. Ortiz de Pinedo (12/03/1837-30/05/1837): Sin ref.

-Ref Jose María de Orozco (25/03/1838): Sin ref.

-Ref. Carbonell (4/7/1838): AMR, 1818-17, fol. 14

"Se hará el mayor numero de aspilléras posibles en todos los pisos, en la pared que está sobre el camíno, y se abrirán algunas en las que

descúbren las inmediaciónes por encima de las tapias" (Carbonell, Requena, 4 de julio de 1838, AMR, 1818-17, fol. 14).

- Observaciones a partir de los informes militares

Se trata de una casa que se emplazaría en los alrededores de la Fuente del Peral. Podría definir el frente de Cantarranas. Se hace flanco de San Aqustin o se refiere al propio cal col 
$\square \frac{\text { Rellenar en caso de que el elemento sea }}{\text { contemplado con datos del PGOU, } 2013}$

\section{PROTECCIÓN}

Nivel de protección:

$\square$ Inmueble

$\square$ Parcela catastral

Recinto arquitectónico

Entorno especifico

AFECCIÓN PATRIMONIAL

$\square$ Bien de interés cultural (BIC)

$\square$ Afectado entorno BIC

$\square$ Afectado Plan especial

\section{- Descripción histórico-arquitectónica}

\section{Tipología:}

Observaciones a la cronología:

\section{Descripción:}

- Entorno urbano

Descripción entorno urbano:

Uso actual:

Estado de conservación:

Intervenciones:

Régimen Urbanístico:

Titularidad:

Nivel protección s/catálogo 1996

Bibliografia: AMR, 1818-17, 1818-24; 1818-50; 1818-52; 1818-53.

Observaciones generales:

$\begin{array}{lll}\text { OBJETIVACIÓN DE INTERÉS } & \text { Soluciones constructivas } & \text { Soluciones ornamentales } \\ \square \text { Interés tipológico } & \square \text { Estructura } & \square \text { Carpintería } \\ \square \text { valor ambiental } & \square \text { Aleros } & \square \text { Rejería } \\ \square \text { vigencia de la trama } & \square \text { Coronación } & \square \text { Cubrepersianas } \\ \square \text { Composición de la fachada } & \square \text { Jambas } & \square \text { Alicatados } \\ \square \text { Materiales, color, textura } & \square \text { Dinteles } & \square \text { Recercos } \\ & & \square \text { Dinteles } \\ & \square \text { Otros ornamentos }\end{array}$

Interés paisajístico

$\square$ Incidencia visual

$\square$ Carácter articulado

$\square$ Organización

$\square$ Carácter representativo
Otros ornamentos

\section{- Datos específicos catalogación BIC $\square$ Rellenar sólo si está catalogado BIC}

\section{Datos Jurídicos:}

Código:

Estado:
Categoría:

Fecha Disposición:

Tipo delimitación:

Plan:

Anotación $M$

Informe

Fecha informe:

Fecha Publicación DOCV
032 Desde la Casa de Don Andrés Ferrer hasta la posada de afuera

\section{- Identificación}

Tramo de estudio:

Tramo 3: Puerta de Cantarranas-Puerta de Madrid

Otras denominaciones:

Ref. catastral:

Localización: Área entre el mercado y la plaza del Portal.

\section{Existe actualmente}

Incluido en fichas PGOU 2013

Bien de interés cultural (BIC)

cód. postal: 46340

Municipio: Requena

Comarca: Plana de Requena-Utiel

Provincia: Valencia

Autonomía: Comunidad Valencian

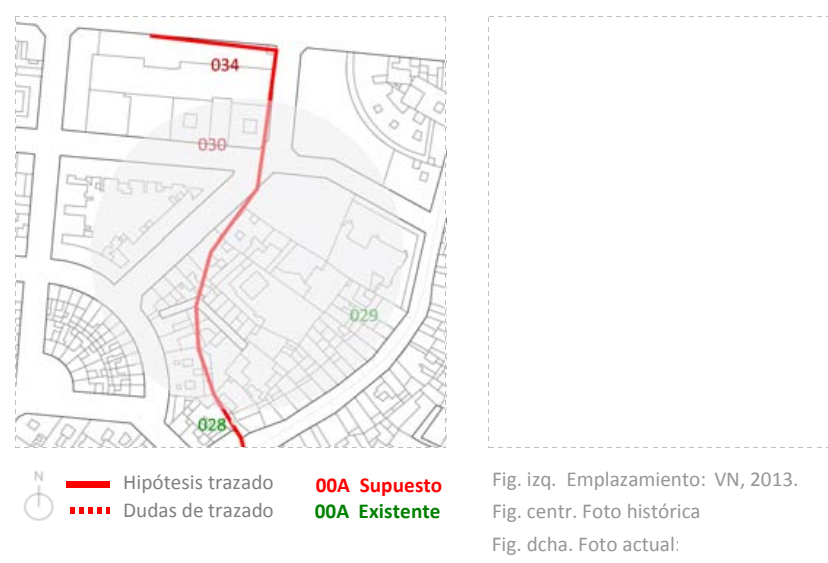

- Referencias en documentación histórica

\section{Referencias numéricas en cartografía sobre fortificación}

-Ref. en el croquis de Ortiz de Pinedo (1837-38, AGM, núm. 262): Sin ref.

-Ref. en plano de Vera Aparici (1993): Sin ref.

Referencias en memorias técnicas militares

-Ref. Guillermo Sáez (9/9/1834-5/12/1835): Sin ref.

-Ref. Guillermo Sáez (26/02/1836): Sin ref.

-Ref. P. Ortiz de Pinedo (12/03/1837-30/05/1837): Sin ref.

-Ref Jose María de Orozco (25/03/1838): Sin ref.

-Ref. Carbonell (4/7/1838): AMR, 1818-17, fol. 14

"Las tapias se elebarán lo suficiente [para] que en ningún punto baje un reliéve de cinco baras, y en cuanto á las aspilléras se sujetarán á las reglas dadas. En frente de la Fuente del Perál, se hará aun mas consideráble el relieve dicho; puesto que debe establecérse un orden superior de aspilléras en la banquéta correspondiénte para dominár el terréno de lascercanias. Este segundo orden de fuegos se estenderá catorcé baras desde la derécha de la garita, a la que tambien se dará mas altúra. Todas las tapias de huertas procsimas á la fortificacion, yá la fuente se hán de demóler" (Carbonell, Requena, 4 de julio de 1838, AMR, 1818-17, fol. 14).

- Observaciones a partir de los informes militares

Se supone que la Casa de Andrés Ferrer marca un cambio de dirección en la muralla, posiblemente buscando la fuente del Peral, en cuyas inmediaciones se emplazaba una posada. El que ésta se identifique como "de afuera", la localiza extramuros. Por ello la nueva defensa integraria con un muro aspillerado la posada. Es el punto clave para entender que la murall, en un punto de Cantarranas se orienta hacia poniente, justricando la aparición de restos detras del actual Teatro Principal. Este sector, estaria lleno de huertas, con sus tapias, que por 
$\square \frac{\text { Rellenar en caso de que e elemento sea }}{\text { contempladodo con datotos del PCOOU, } 2013}$

PROTECCIÓN

Nivel de protección:

AFECCIÓN PATRIMONIAL

$\square$ Inmueble

Parcela catastral

Recinto arquitectónico

$\square$ Entorno específico

$\square$ Bien de interés cultural (BC)

$\square$ Bien de relevancia local (BR

$\square$ Afectado entorno BIC

$\square$ Afectado Plan especia

\section{- Descripción histórico-arquitectónica}

Tipología:

Cronología:

Observaciones a la cronologia:

\section{Descripción}

- Entorno urbano

Descripción entorno urbano:

Uso actual:

Estado de conservación:

Intervenciones:

Régimen Urbanístico:

Titularidad:

Nivel protección s/catálogo 1996:

Bibliografía: AMR, 1818-17, 1818-24; 1818-50; 1818-52; 1818-53.

observaciones generales:

\section{OBJETIVACIÓN DE INTERÉS}

$\square$ Interés tipológico

$\square$ Valor ambiental

Vigencia de la trama

Materiales, color, textura

Soluciones constructiva
$\square$ Estructura
$\square$ Aleros
$\square$ Coronación
$\square$ Jambas
$\square$ Dinteles

Soluciones ornamentales
$\square$ Carpintería
$\square$ Rejería
$\square$ Cubrepersianas
$\square$ Alicatados
$\square$ Recercos
$\square$ Dinteles
$\square$ Otros ornamentos

Interés paisajistico
$\square$ Incidencia visual
$\square$ Carácter articulador
$\square$ Organización
$\square$ Interés cultural
$\square$ Carácter representativo

$\square$ Carácter representativo

$\square$ Otros ornamentos

\section{- Datos específicos catalogación BIC $\square$ Rellenar sólo si está catalogado BIC}

\section{Datos Jurídicos:}

Código:

Estado:

Categoria:
Fecha Disposición:
Tipo delimitación:

Plan:

Informe:
Fecha informe:

Fecha Publicación BOP:

Fecha Publicación DOCV:

Fecha Publicación BOE:

\section{Posada de afuera}

\section{- Identificación}

Tramo de estudio: Tramo 3: Puerta de Cantarranas-Puerta de Madrid

Otras denominaciones:

Ref. catastral:

Localización: Área entre el mercado y la plaza del Portal.

$\square$ Existe actualmente

Incluido en fichas PGOU 2013

Bien de interés cultural (BIC)

cód. postal: 46340

Municipio: Requena

Comarca: Plana de Requena-Utie

Provincia: Valencia

Autonomia: Comunidad Valenciarn

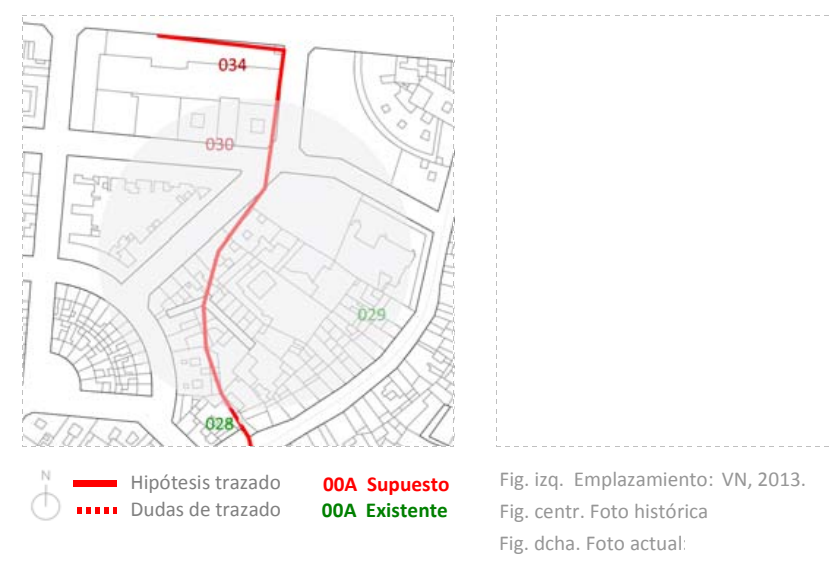

- Referencias en documentación histórica

Referencias numéricas en cartografía sobre fortificación

-Ref. en el croquis de Ortiz de Pinedo (1837-38, AGM, núm. 262): Sin ref.

-Ref. en plano de Vera Aparici (1993): Sin ref.

Referencias en memorias técnicas militares

-Ref. Guillermo Sáez (9/9/1834-5/12/1835): Sin ref.

-Ref. Guillermo Sáez (26/02/1836): Sin ref.

-Ref. P. Ortiz de Pinedo (12/03/1837-30/05/1837): Sin ref.

-Ref Jose María de Orozco (25/03/1838): Sin ref.

-Ref. Carbonell (4/7/1838): AMR, 1818-17, fol. 14

"Se aspillerará en todos sus cuerpos, cerrándo y aspillerándo las ventanas bajas. Se dará cinco pies mas de altura á la tapia de su

izquierda" (Carbonell, Requena, 4 de julio de 1838, AMR, 1818-17, fol. 14).

- Observaciones a partir de los informes militares

En Requena existín varias posadas. Una de ellas se emplazaba en el camino de Madrid se encontraba extramuros. El proyecto de 1838 la integra en el perímetro amurallado. El objetivo es prolongar las defensa apoyando una de las principales entradas a la ciudad: la Puerta de integra en $\square \frac{\text { Rellenar en caso de que el elemento sea }}{\text { contemplado con datos del PGOU, } 2013}$

PROTECCIÓN
Nivel de protección:
Entorno:
$\square$ Inmueble
$\square$ Parcela catastral
$\square$ Recinto arquitectónico
$\square$ Entorno específico

\section{AFECCIÓN PATRIMONIAL}

$\square$ Bien de interés cultural (BIC)

$\square$ Bien de relevancia local (BRL)

$\square$ Afectado entorno BIC

Afectado Plan especial 
- Descripción histórico-arquitectónica

\section{Tipología:}

Cronologí:

Observaciones a la cronología:

\section{Descripción:}

\section{- Entorno urbano}

Descripción entorno urbano:

Uso actual:

Estado de conservación:

Intervenciones:

Régimen Urbanístico:

Titularidad:

Nivel protección s/catálogo 1996:

Bibliografia: AMR, 1818-17, 1818-24; 1818-50; 1818-52; 1818-53.

Observaciones generales:

$\begin{array}{llll}\text { OBJETIVACIÓN DE INTERÉs } & \text { Soluciones constructivas } & \text { Soluciones ornamentales } & \text { Interés paisajistico } \\ \square \text { Interés tipológico } & \square \text { Estructura } & \square \text { carpintería } & \square \text { Incidencia visual } \\ \square \text { Valor ambiental } & \square \text { Aleros } & \square \text { Rejería } & \square \text { Carácter articulador } \\ \square \text { vigencia de la trama } & \square \text { Coronación } & \square \text { cubrepersianas } & \square \text { Organización } \\ \square \text { Composición de la fachada } & \square \text { Jambas } & \square \text { Alicatados } & \square \text { Interés cultural } \\ \square \text { Materiales, color, textura } & \square \text { Dinteles } & \square \text { Recercos } & \square \text { Carácter representativo } \\ & & \square \text { Dinteles } & \\ & & & \end{array}$

\section{- Datos específicos catalogación BIC $\square$ Rellenar sólo si está catalogado BIC}

\section{Datos Jurídicos:}

$\begin{array}{lll}\text { Datos Juridicos: } & \text { Fecha Disposición: } & \text { Fecha informe: } \\ \text { Código: } & \text { Tipo delimitación: } & \text { Fecha Publicación BOP: } \\ \text { Estado: } & \text { Plan: } & \text { Fecha Publicación DOCV: } \\ \text { Categoría: } & \text { Informe: } & \text { Fecha Publicación BOE: }\end{array}$

\section{Desde la posada de afuera al frente de la Glorieta}

\section{- Identificación}

Tramo de estudio:

Otras denominaciones:

Tramo 3: Puerta de Cantarranas-Puerta de Madrid

Ref. catastral:

Localización: En torno a la Avenida.

Existe actualmente

Incluido en fichas PGOU 2013

Bien de interés cultural (BIC)

cód. postal: 46340

Municipio: Requena

Comarca: Plana de Requena-Utie

Provincia: Valencia

Autonomía: Comunidad Valencian
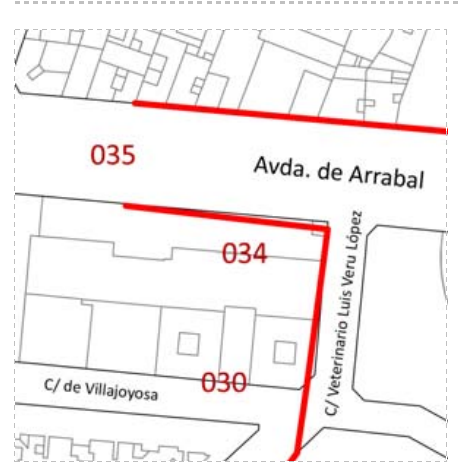

$$
\begin{array}{lll}
\text {..... Hipótesis trazado } & \text { O0A Supuesto de trazado } & \text { Fig, izq. Emplazamiento: VN, 2013. } \\
\text { O0A Existente } & \text { Fig, centr. Foto histórica } \\
\text { Fig, dcha. Foto actual: }
\end{array}
$$

\section{- Referencias en documentación histórica}

Referencias numéricas en cartografia sobre fortificación

-Ref. en el croquis de Ortiz de Pinedo (1837-38, AGM, núm. 262): Sin ref.

-Ref. en plano de Vera Aparici (1993): Sin ref.

Referencias en memorias técnicas militares

-Ref. Guillermo Sáez (9/9/1834-5/12/1835): Sin ref.

-Ref. Guillermo Sáez (26/02/1836): Sin ref.

-Ref. P. Ortiz de Pinedo (12/03/1837-30/05/1837): Sin ref.

-Ref Jose María de Orozco (25/03/1838): Sin ref.

-Ref. Carbonell (4/7/1838): AMR, 1818-17, fol. 14

"Se repararán con esméro las parédes debiles ó deteriorádas, aumentándo hasta cinco baras la altúra de toda esta linea. Se dará mas

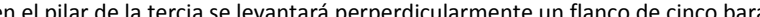
de largo, desde cuyo estremo saldrá el frente que se unirá con el que ahóra ecsíste, formándo con el un angulo entránte muy obtuso. No solo se hará en el recinto el mayor numero de aspilléras que sea doble, sino que tambien se aspillerarán [la] casas interiores por los sitios donde descúbran la campáña, y esto se verificará muy particularmente en todas las parédes que dominan el frente de la Glorieta. Se

darán mayóres dimensiónes al foso que rodéa este frente" (Carbonell, Requena, 4 de julio de 1838, AMR, 1818-17, fol. 14).

- Observaciones a partir de los informes militares

La Glorieta, como se explica en la ficha correspondiente y se observa en el plano de Ortiz de Pinedo, constituía un paseo extramuros en dirección a Poniente. La nueva defensa incorpora esta área para dar potencia a la Puerta de Madrid. 


\section{Rellenar en caso de aue ele lemento sea
contempladado con datos del 1 PGOO, 2013}

\section{PROTECCIÓN}

Nivel de protección:

\section{$\square$ Inmueble}

\section{$\square$ Parcela catastral}

$\square$ Entorno espećífico
AFECCIÓN PATRIMONIAL

$\checkmark$ Bien de interés cultural (BIC)

$\checkmark$ Bien de relevancia local (BRL)

$\square$ Afectado entorno BIC

$\square$ Afectado Plan especial

\section{- Descripción histórico-arquitectónica}

\section{Tipología:}

Observaciones a la cronología

\section{Descripción}

\section{- Entorno urbano}

Descripción entorno urbano:

Uso actual:

Estado de conservación:

Intervenciones:

\section{Régimen Urbanístico}

\section{Titularidad}

\section{/catálogo 1996:}

Bibliografía: AMR, 1818-17, 1818-24; 1818-50; 1818-52; 1818-53. Observaciones generales:

$\begin{array}{lll}\text { OBJETIVACIÓN DE INTERÉS } & \text { Soluciones constructivas } & \text { Soluciones ornamentales } \\ \square \text { Interés tipológico } & \square \text { Estructura } & \square \text { carpintería } \\ \square \text { Valor ambiental } & \square \text { Aleros } & \square \text { Rejería } \\ \square \text { vigencia de la trama } & \square \text { coronación } & \square \text { cubrepersianas } \\ \square \text { Composición de la fachada } & \square \text { Jambas } & \square \text { Alicatados } \\ \square \text { Materiales, color, textura } & \square \text { Dinteles } & \square \text { Recercos } \\ & & \square \text { Dinteles } \\ & \square \text { otros ornamentos }\end{array}$

Interés paisajistico
$\square$ Incidencia visual
$\square$ Carácter articulador
$\square$ Organización
$\square$ Interés cultural
$\square$ Carácter representativo

\section{- Datos específicos catalogación BIC $\square$ Rellenar sólo si está catalogado BIC} Datos Jurídicos:

$\begin{array}{ll}\text { Código: } & \text { Fecha Disposición: } \\ \text { Estado: } & \text { Tipo delimitación: } \\ \text { Categoría: } & \text { Plan: } \\ \text { Anotación } M \text { Mo: } & \text { Informe: }\end{array}$

Fecha informe:

Anotación $M$

\section{Glorieta}

- Identificación

Tramo de estudio:

Tramo 3: Puerta de Cantarranas-Puerta de Madrid

Otras denominaciones: Antigua Glorieta. Emplazamiento de la antigua ermita de S

Ref. catastral:

Localización: En torno a la Avenida.

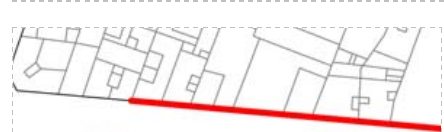

035

Avda. de Arrabal

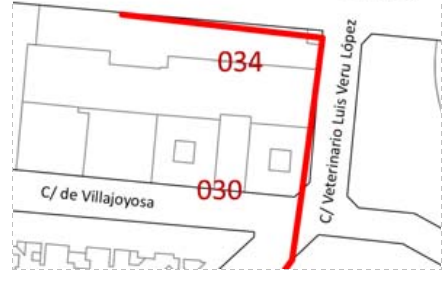

$$
\begin{aligned}
& \begin{array}{ll}
\text {-.... Hipótesis trazado Dudas de trazado } & \text { O0A Supuesto } \\
\text { O0A Existente }
\end{array} \\
& \text { Fig. izq. Emplazamiento: VN, 2013. } \\
& \text { Fig. dcha. Foto actual: }
\end{aligned}
$$

\section{- Referencias en documentación histórica}

\section{cartografía sobre fortificación}

-Ref. en el croquis de Ortiz de Pinedo (1837-38, AGM, núm. 262): 026

-Ref. en plano de Vera Aparici (1993): Sin ref.

Referencias en memorias técnicas militare

-Ref. Guillermo Sáez (9/9/1834-5/12/1835): Sin ref.

-Ref. Guillermo Sáez (26/02/1836): Sin ref.

-Ref. P. Ortiz de Pinedo (12/03/1837-30/05/1837): Sin ref.

-Ref Jose Maria de Orozco (25/03/1838): Sin ref.

-Ref. Carbonell (4/7/1838): AMR, 1818-17, fol. 16

\section{- Observaciones a partir de los informes militares}

Con seis tahúllas que donó don José de Cantos en la huerta de San Agustín se abrió en 1834 el denominado Paseo de María Cristina,

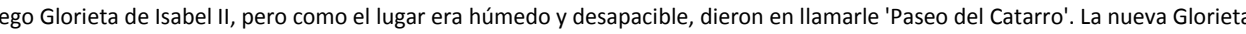
se trasladaría a otro emplazamiento de la ciudad: en el huerto de los Carmelitas y eras de D. José María Penén. En las proximidades,
lindante con el camino viejo de Madrid, y entre éste y el que conduce a las era de María, llamado de los Alguaciles, muy inmediato y extramuros de esta ciudad, y en el mismo sitio en que Gregorio Iranzo acaba de construir una casa habitación y para la fábrica de aguardiente, también existió una ermita (Herrero, 1890:139). El edificio decayó por falta de mantenimiento y se convino su demolición, quedando el terreno en propiedad del Ayuntamiento. En 1829, sobre el construyo un pilar, que sostenia, colgada de una escarpia de hierso ejecución. el verdugo le cortó la mano derech, que en la plaza de la Fortaleza fue frita en una caldera llena de aceite. Dicho pilar. escarpia y mano estuvieron en el sitio indicado hasta que la nación varió de instituciones y sistema político, cuyas autoridades locales mandaron su demolición y desaparición (Herrero, 1890:140-141).
Existe actualmente

Bien de interés cultural (BIC)

cód. postal: 46340

Comarca: Plana de Requena-Utiel

Provincia: Valencia Autonomia: Comunidad Valencian
Fecha Publicación DOCV: Fecha Publicación BOE: 
$\square \frac{\text { Rellenar en caso de que el elemento sea }}{\text { contemplado con datos del PGOU, 2013 }}$

\section{PROTECCIÓN}

Nivel de protección:

Entorno:

$\square$ Inmueble

Parcela catastral

$\square$ Recinto arquitectónico

AFECCIÓN PATRIMONIAL

$\square$ Bien de interés cultural (BIC)

$\square$ Bien de relevancia local (BRL)

$\square$ Afectado entorno BIC

- Descripción histórico-arquitectónica

Tipología:

Cronologia:

Observaciones a la cronologia

\section{Descripció}

- Entorno urbano

Descripción entorno urbano:

Uso actual:

Estado de conservación:

Intervenciones:

Régimen Urbanístico:

Titularidad:

Nivel protección s/catálogo 1996

Bibliografia: AMR, 1818-17, 1818-24; 1818-50; 1818-52; 1818-53.

Observaciones generales:

$\begin{array}{llll}\text { OBJETIVACIÓN DE INTERÉS } & \text { Soluciones constructivas } & \text { Soluciones ornamentales } & \text { Interés paisajistico } \\ \square \text { Interés tipológico } & \square \text { Estructura } & \square \text { carpintería } & \square \text { Incidencia visual } \\ \square \text { valor ambiental } & \square \text { Aleros } & \square \text { Rejería } & \square \text { carácter articulador } \\ \square \text { vigencia de la trama } & \square \text { coronación } & \square \text { cubrepersianas } & \square \text { Organización } \\ \square \text { composición de la fachada } & \square \text { Jambas } & \square \text { Alicatados } & \square \text { Interés cultural } \\ \square \text { Materiales, color, textura } & \square \text { Dinteles } & \square \text { Recercos } & \square \text { carácter representativo } \\ & & \square \text { Dinteles } & \\ & \square \text { otros ornamentos } & \end{array}$

\section{- Datos específicos catalogación BIC $\square$ Rellenar sólo si está catalogado BIC}

\section{Datos Jurídicos:}

Código:

Estado:
Categoría:

Fecha Disposición:

Tipo delimitación:

Plan:
Informe:

Anotación $M$

Fecha informe:

Fecha Publicación BOP:

Fecha Publicación DOCV:

Fecha Publicación BOE:

\section{Desde el frente de la Glorieta a la Puerta de Madrid}

\section{- Identificación}

Tramo de estudio:

Tramo 3: Puerta de Cantarranas-Puerta de Madrid

Otras denominaciones: Puerta de Madrid, el Portal, Plaza del Abrevadero o del ant

$\checkmark$ Existe actualmente

$\square$ Incluido en fichas PGOU 2013

Bien de interés cultural (BIC)

cód. postal: 46340

Ref. catastra:

Localización: Entorno de la Plaza del Portal.

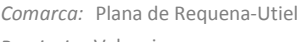

Autonomia: Comunidad Valencian
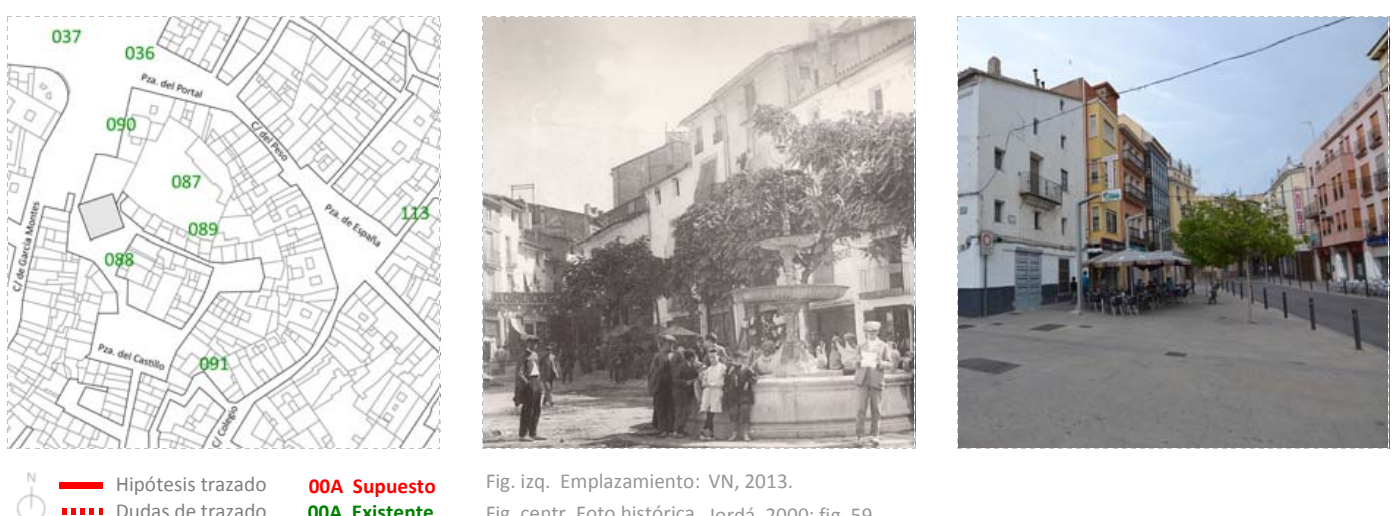

-.... Hipótesis trazaz de traz do

lazamiento: VN, 2013

Fig. centr. Foto histórica Jordá, 2000: fig. 59

- Referencias en documentación histórica

Referencias numéricas en cartografía sobre fortificación

-Ref. en el croquis de Ortiz de Pinedo (1837-38, AGM, núm. 262): Sin ref.

-Ref. en plano de Vera Aparici (1993): 001

Referencias en memorias técnicas militare

-Ref. Guillermo Sáez (9/9/1834-5/12/1835): Sin ref.

-Ref. Guillermo Sáez (26/02/1836): Sin ref.

-Ref. P. Ortiz de Pinedo (12/03/1837-30/05/1837): Sin ref.

-Ref Jose María de Orozco (25/03/1838): Sin ref.

-Ref. Carbonell (4/7/1838): AMR, 1818-17, fol. 14

"Despues de aspillerárse todos los pisos se renobarán con mas solidéz los cerramientos de las puertas. Se tapiarán las ventánas, cuya altúra á las tapias que forman el angulo entránte de la Puerta de Madrid" (Carbonell, Requena, 4 de julio de 1838, AMR, 1818-17, fol. 14).

\section{- Observaciones a partir de los informes militares}

La Plaza del Portal, también conocida como la Plaza de los Patos por la fuente instalada en 1883 sustituyendo al antiguo Pilón o abrevadero. En 1913 se denominaba Plaza de Canalejas, y en 1939, del General Sanjurjo (Jordá, 2000: fig. 41)

\begin{tabular}{|c|c|c|}
\hline \multirow[t]{2}{*}{$\begin{array}{l}\text { Rellenar en caso de que el elemento sea } \\
\text { contemplado con datos del PGOU, 2013 }\end{array}$} & $\begin{array}{l}\text { PROTECCIÓN } \\
\text { Nivel de protección: } \\
\text { Entorno: }\end{array}$ & $\begin{array}{l}\text { AFECCIÓN PATRIMONIAL } \\
\begin{aligned} \square \text { Bien de interés cultural (BIC) } \\
\square \text { Bien de relevancia local (BRL) }\end{aligned}\end{array}$ \\
\hline & $\begin{array}{l}\square \text { Inmueble } \\
\square \text { Parcela catastral } \\
\square \text { Recinto arquitectónico } \\
\square \text { Entorno específico }\end{array}$ & $\begin{array}{l}\square \text { Afectado entorno BIC } \\
\square \text { Afectado Plan especial }\end{array}$ \\
\hline
\end{tabular}


- Descripción histórico-arquitectónica

Tipología

Cronología:

Observaciones a la cronología:

Descripción:

\section{- Entorno urbano}

Descripción entorno urbano:

Uso actual:

Estado de conservación:

Intervenciones:

Régimen Urbanístico:

Titularidad:

Nivel protección s/catálogo 1996:

Bibliografía: AMR, 1818-17, 1818-24; 1818-50; 1818-52; 1818-53.

Observaciones generales:

\begin{tabular}{|c|c|c|}
\hline \multirow{8}{*}{$\begin{array}{l}\text { OBJETIVACIÓN DE INTERÉS } \\
\begin{array}{l}\square \text { Interés tipológico } \\
\square \text { Valor ambiental } \\
\square \text { Vigencia de la trama } \\
\square \text { Composición de la fachada } \\
\square \text { Materiales, color, textura }\end{array}\end{array}$} & Soluciones constructivas & Soluciones ornamentales \\
\hline & $\square$ Estructura & $\square$ Carpintería \\
\hline & $\square$ Aleros & \\
\hline & $\square$ Coronación & $\square$ Cubrepersianas \\
\hline & $\square$ Jambas & $\square$ Alicatados \\
\hline & & $\square$ Recercos \\
\hline & & \\
\hline & & Otros ornamentos \\
\hline
\end{tabular}

- Datos específicos catalogación BIC $\square$ Rellenar sólo si está catalogado BIC

$\begin{array}{lll}\text { Datos Jurídicos: } & & \\ \text { Código: } & \text { Fecha Disposición: } & \text { Fecha informe: } \\ \text { Estado: } & \text { Tipo delimitación: } & \text { Fecha Publicación BOP: } \\ \text { Categoría: } & \text { Plan: } & \text { Fecha Publicación DOCV: } \\ \text { Anotación Mo: } & \text { Informe: } & \text { Fecha Publicación BOE: }\end{array}$

$\square$ Organización

\section{Puerta de Madrid. Huerto de las Monjas. Tambor de la Puerta de Madrid}

\section{- Identificación}

Tramo de estudio:

Tramo 4: Puerta de Madrid-Puerta de las Cruces

Otras denominaciones: Tambor de la Puerta de Madrid. Huerto de las Monjas, Las

$\square$ Existe actualmente

Incluido en fichas PGOU 2013

Bien de interés cultural (BIC)

cód. postal: 46340

Ref. catastral:

Localización: Sector Occidental de la Plaza del Portal.
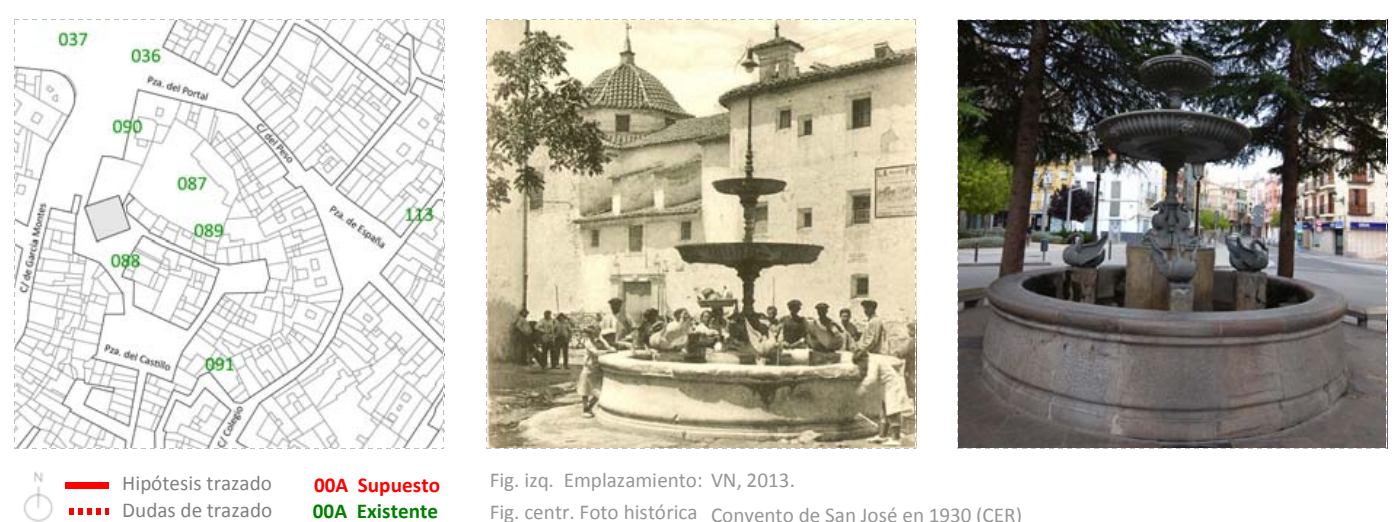

$\square$ Carácter representativo

Fig. izq. Emplazamiento: VN, 201

$$
\begin{aligned}
& \text { Fig. centr. Foto histórica Convento de San José en } 1930 \text { (CER) } \\
& \text { Fig., dcha. Foto actual:VN, } 2015
\end{aligned}
$$

- Referencias en documentación histórica

\section{Referencias numéricas en cartografía sobre fortificación}

-Ref. en el croquis de Ortiz de Pinedo (1837-38, AGM, núm. 262): 009

-Ref. en plano de Vera Aparici (1993): 001

Referencias en memorias técnicas militare

-Ref. Guillermo Sáez (9/9/1834-5/12/1835): Requena, 5/12/1835 AMR, 1818-50

Una garita y aspilleras

-Ref. Guillermo Sáez (26/02/1836): Sin ref.

-Ref. P. Ortiz de Pinedo (12/03/1837-30/05/1837): Sin ref.

-Ref Jose María de Orozco (25/03/1838): Requena, 25/03/1838, AMR 1818-24

En la memoria militar se hace referencia a un tambor de la Puerta de Madrid. Se considera que el tambor existente es suficiente, junto el

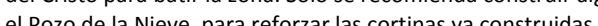
-Ref. Carbonell (4/7/1838): AMR, 1818-17, fol. 15

"Se dará mas alturá à los tabiques del tambor volado. cadénas, otras mas adecuadas, ó cuerdas de cañámo" (Carbonell, Requena, 4 de julio de 1838, AMR, 1818-17, fol. 15).

\section{- Observaciones a partir de los informes militares}

En las inmediaciones de la plaza del Portal. Las monjas, o el portal. Desaparecida I Iglesia y convento de San Jose, en la salida a Madrid. Próxima a la fuente de los Patos. Por "las monjas", se conoce al antiguo Convento de las agustinas recoletas, que se incendiaría en 1936. La desaparición del convento resulta clave en la expansión del ensanche hacia el oeste, configurando la avenida del Arrabal. 
$\square \frac{\text { Rellenar en caso de que el elemento sea }}{\text { contemplado con datos del PGOU, } 2013}$

\section{PROTECCIÓN}

Nivel de protección:

$\square$ Inmueble

$\square$ Parcela catastral

$\square$ Recinto arquitectónico

$\square$ Entorno específico

\section{- Descripción histórico-arquitectónica}

Tipología:

Cronología:

Observaciones a la cronología:

\section{Descripción:}

- Entorno urbano

Descripción entorno urbano:

Uso actual:

Estado de conservación:

Intervenciones:

Régimen Urbanístico:

Titularidad:

Nivel protección s/catálogo 1996

Bibliografía: AMR, 1818-17, 1818-24; 1818-50; 1818-52; 1818-53.

Observaciones generales:

\section{OBJETIVACIÓN DE INTERÉS}

$\square$ Interés tipológico

$\square$ valor ambiental

Vigencia de la trama

$\square$ Composición de la fachada

Soluciones constru
$\square$ Estructura
$\square$ Aleros
$\square$ Coronación
$\square$ Jambas
$\square$ Dinteles

Soluciones ornamentales
$\square$ Carpintería
$\square$ Rejería
$\square$ Cubrepersianas
$\square$ Alicatados
$\square$ Recercos
$\square$ Dinteles
$\square$ otros ornamentos

Interés paisajistico
$\square$ Incidencia visual
$\square$ Carácter articulador
$\square$ Organización
$\square$ Interés cultural
$\square$ Carácter representativo

AFECCIÓN PATRIMONIAL

$\square$ Bien de interés cultural (BIC)

Bien de relevancia local (BRL)

$\square$ Afectado entorno BIC

Afectado Plan especia

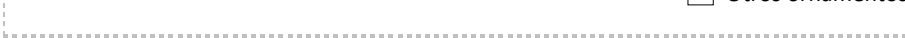

\section{- Datos específicos catalogación BIC $\square$ Rellenar sólo si está catalogado BIC}

\section{Datos Jurídicos:}

Código:

Estado:
Categoría:

Categoría:
Anotación $M$

Fecha Disposición:
Tipo delimitación:

Plan:

Fecha informe:

Fecha Publicación BOP:

Fecha Publicación BOE:

\section{Palomar de D. Jose [Cros]}

\section{- Identificación}

Tramo de estudio:

Tramo 4: Puerta de Madrid-Puerta de las Cruces

Otras denominaciones:

Incluido en fictas $P G O{ }^{2} 2013$

Bien de inteŕs culturat (BD)

cód. postal: 46340

Municipio: Requena

Comarca: Plana de Requena-Utiel

Ref. catastral:

Localización: En torno a la C/ Asnos.

Autonomia: Comunidad Valencian

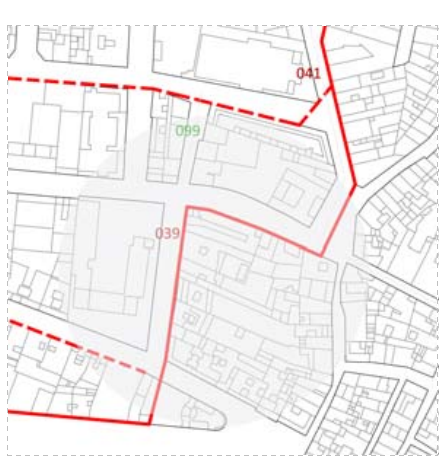

-... Hipótesis trazado Dudas de trazado Supuesto

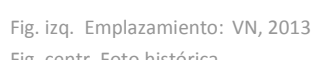

Fig. centr. Foto histórica
Fig. dcha. Foto actual

- Referencias en documentación histórica

\section{Referencias numéricas en cartografía sobre fortificación}

-Ref. en el croquis de Ortiz de Pinedo (1837-38, AGM, núm. 262): Sin ref.

-Ref. en plano de Vera Aparici (1993): Sin ref.

Referencias en memorias técnicas militares

-Ref. Guillermo Sáez (9/9/1834-5/12/1835): Sin ref.

-Ref. Guillermo Sáez (26/02/1836): Sin ref.

-Ref. P. Ortiz de Pinedo (12/03/1837-30/05/1837): Sin ref.

-Ref Jose María de Orozco (25/03/1838): Sin ref.

-Ref. Carbonell (4/7/1838): AMR, 1818-17, fol. 15

"Se aspillerará en sus dos pisos, no solo por el frente sino por los costados, que descúbren las cercanias" (Carbonell, Requena, 4 de julio de (3) 38 , AMR, 1818-17, fol. 15).

\section{- Observaciones a partir de los informes militares}

Este palomar integaría el frente de casas que se extienden desde la Puerta de Madrid buscando las de las Cruces, en una zona altamente atterada por la expansion del Arrabal. Parece que en este tramo la fortificacion genera redientes, entrantes y salientes, que dificultan el para fortificar. 
$\square$ Rellenar en caso de que el elemento sea

\section{PROTECCIÓN}

Nivel de protección:

Entorno:

$\square$ Inmueble

$\square$ Parcela catastral

$\square$ Recinto arquitectónico

AFECCIÓN PATRIMONIAL

$\square$ Bien de interés cultural (BIC)

$\square$ Afectado entorno BIC

$\square$ Afectado Plan especial

\section{- Descripción histórico-arquitectónica}

Tipología:

Cronología:

Observaciones a la cronologia:

Descripción:

- Entorno urbano

Descripción entorno urbano:

Uso actual:

Estado de conservación:

Intervenciones:

Régimen Urbanístico:

Titularidad:

Nivel protección s/catálogo 1996:

Bibliografía: AMR, 1818-17, 1818-24; 1818-50; 1818-52; 1818-53.

Observaciones generales:

\section{OBJETIVACIÓN DE INTERÉS}

$\square$ Interés tipológico

Valor ambiental

Vigencia de la trama

Materiales, color, textura

Soluciones construc
$\square$ Estructura
$\square$ Aleros
$\square$ Coronación
$\square$ Jambas
$\square$ Dinteles

Soluciones ornamentales
$\square$ Carpintería
$\square$ Rejería
$\square$ Cubrepersianas
$\square$ Alicatados
$\square$ Recercos
$\square$ Dinteles

Interés paisajistico

$\square$ Incidencia visual

$\square$ Carácter articulador

$\square$ Organización

$\square$ Carácter representativo

Dinteles

Otros ornamento

\section{- Datos específicos catalogación BIC $\square$ Rellenar sólo si está catalogado BIC}

\section{Datos Juridicos:}

Código:

Estado:

Categoria:

Anotación M

Fecha Disposición:
Tipo delimitación:
Plan:

Fecha informe:

Fecha Publicación BOP:

Fecha Publicación DOCV:

Informe:
039 Desde la Garita del huerto de D. Diego Montés a la Puerta de las Cruces

\section{- Identificación}

Tramo de estudio:

Tramo 4: Puerta de Madrid-Puerta de las Cruces

Otras denominaciones:

Ref. catastral:

Localización: Entorno de la C/ Asnos hacia C/ de las Cruces.

$\square$ Existe actualmente

Incluido en fichas PGOU 2013

Bien de interés cultural (BIC)

cód. postal: 46340

Municipio: Requena

Comarca: Plana

Provincia: Valencia

Autonomia: Comunidad Valencian

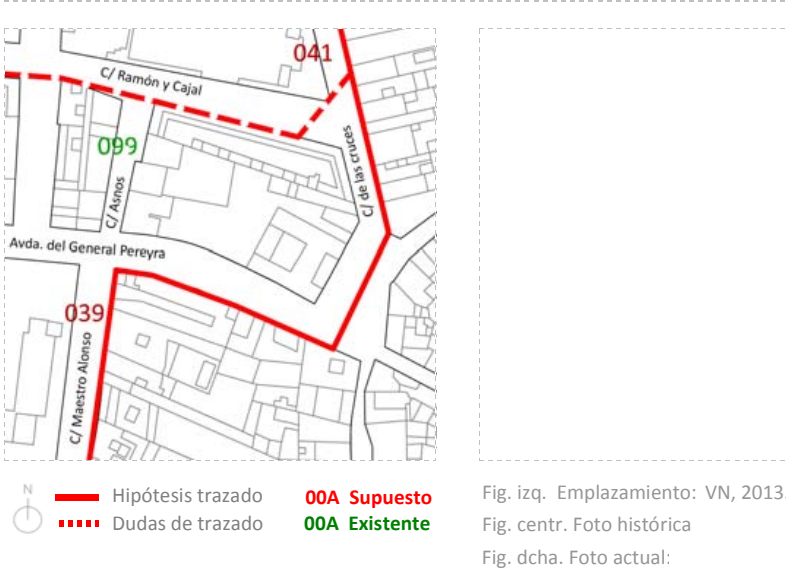

- Referencias en documentación histórica

Referencias numéricas en cartografía sobre fortificación

-Ref. en el croquis de Ortiz de Pinedo (1837-38, AGM, núm. 262): Sin ref.

-Ref. en plano de Vera Aparici (1993): Sin ref.

Referencias en memorias técnicas militares

-Ref. Guillermo Sáez (9/9/1834-5/12/1835): Sin ref.

-Ref. Guillermo Sáez (26/02/1836): Sin ref.

-Ref. P. Ortiz de Pinedo (12/03/1837-30/05/1837): Sin ref.

-Ref Jose María de Orozco (25/03/1838): Sin ref.

-Ref. Carbonell (4/7/1838):AMR, 1818-17, fol. 15

"Se procurará que en ningún punto de las tapias baje su elebacion de $21 / 2$ baras, y además se las guarnecerá con un foso. En la Calle de las Cruzes conviene reforzar las tapias que ahóra son muy debiles. Respécto á aspilléras se observarán las reglas dadas" (Carbonell, las Cruzes conviene reforzar las tapias que ahóra son
Requena, 4 de julio de 1838, AMR, 1818-17, fol. 15).

- Observaciones a partir de los informes militares

El tramo desde la Puerta de Madrid hasta la Calle de las Cruces, comentado en el punto 038, estaría caracterizado por la presencia de huertos cuyas tapias configurarían la primera línea defensiva a la que se propone anteponer un foso.

$\frac{\text { Rellenar en caso de que el elemento sea }}{\text { contemplado con datos del PGOU, } 2013}$

PROTECCIÓN
Nivel de protección:
Entorno:
$\square$ Inmueble
$\square$ Parcela catastral
$\square$ Recinto arquitectónico
$\square$ Entorno espećifico

AFECCIÓN PATRIMONIAL

Bien de interés cultural (BC)

Bien de relevancia local (BRL)

$\square$ Afectado entorno BIC

$\square$ Afectado Plan especial 
- Descripción histórico-arquitectónica

\section{Tipología:}

Cronología:

Observaciones a la cronología:

Descripción:

\section{- Entorno urbano}

Descripción entorno urbano

Uso actual:

Estado de conservación:

Intervenciones:

Régimen Urbanístico:

Titularidad:

Nivel protección s/catálogo 1996:

Bibliografia: AMR, 1818-17, 1818-24; 1818-50; 1818-52; 1818-53.

Observaciones generales:

$\begin{array}{ll}\text { OBJETIVACIÓN DE INTERÉS } & \text { Soluciones construc } \\ \begin{array}{ll}\square \text { Interés tipológico } & \square \text { Estructura } \\ \square \text { valor ambiental } & \square \text { Aleros } \\ \square \text { vigencia de la trama } & \square \text { coronación } \\ \square \text { composición de la fachada } & \square \text { Jambas } \\ \square \text { Materiales, color, textura } & \square \text { Dinteles }\end{array}\end{array}$

Soluciones ornamentales
$\square$ Carpintería
$\square$ Rejería
$\square$ Cubrepersianas
$\square$ Alicatados
$\square$ Recercos
$\square$ Dinteles
$\square$ Otros ornamentos

\section{Interés paisajistico}

$\square$ Incidencia visual

$\square$ Carácter articulador

$\square$ Organización

$\square$ Carácter representativo

\section{Calle de las Cruces}

\section{Calle de las Cruces}

\section{- Identificación \\ Tramo de estudio:}

Otras denominaciones:

Ref. catastral:

Localización: c/ de las Cruces.

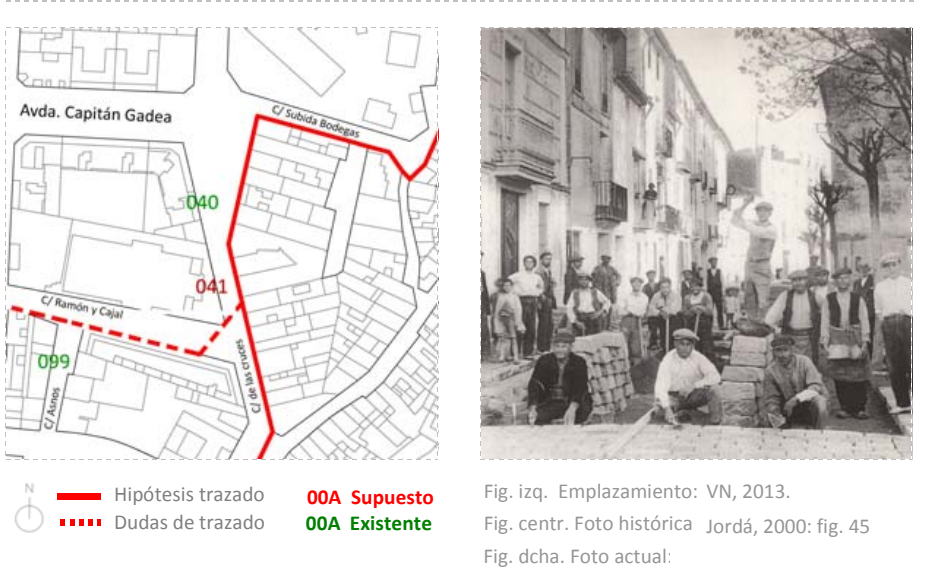

- Referencias en documentación histórica

\section{Referencias numéricas en cartografía sobre fortificación}

-Ref. en el croquis de Ortiz de Pinedo (1837-38, AGM, núm. 262): Sin ref.

-Ref. en plano de Vera Aparici (1993): Sin ref.

Referencias en memorias técnicas militares

-Ref. Guillermo Sáez (9/9/1834-5/12/1835): Sin ref.

-Ref. Guillermo Sáez (26/02/1836): Sin ref.

-Ref. P. Ortiz de Pinedo (12/03/1837-30/05/1837): Sin ref.

-Ref Jose Maria de Orozco (25/03/1838): Sin ref.

-Ref. Carbonell (4/7/1838): Sin ref.

\section{- Observaciones a partir de los informes militares}

Ya en 1835 se testimonia la presencia de una calle de las cruces. Ésta aún hoy existe partiendo de la plaza de Valentín García buscando la Subida Bodegas, y permite entender el emplazamiento del trazado defensivo del recinto exterior en este sector. En principio se asocia con el antiguo via crucis que ascendía a San Francisco. $\checkmark$ Existe actualmente

$\square$ Bien de interés cultural (BIC)

cód. postal: 46340

Municipio: Requena $\square$ Incluido en fichas PGOU 2013 


\section{Rellenar en caso de que el elemento sea
contemplado con datos del PGOU, 2013}

\section{PROTECCIÓN}

Nivel de protección:

$\square$ Inmueble

\section{$\square$ Parcela catastral}

$\square$ Entorno específico
AFECCIÓN PATRIMONIAL

$\square$ Bien de interés cultural (BIC)

$\square$ Bien de relevancia local (BRL)

$\square$ Afectado entorno BIC

$\square$ Afectado Plan especia

\section{- Descripción histórico-arquitectónica}

\section{Tipología:}

Cronología:

Observaciones a la cronología

\section{Descripción}

- Entorno urbano

Descripción entorno urbano:

Uso actual:

Estado de conservación:

Intervenciones:

\section{Régimen Urbanístico:}

Titularidad:

Nivel protección s/catálogo 1996:

Bibliografía: AMR, 1818-17, 1818-24; 1818-50; 1818-52; 1818-53.

Observaciones generales:

$\begin{array}{lll}\text { OBJETIVACIÓN DE INTERÉS } & \text { Soluciones constructivas } & \text { Soluciones ornamentales } \\ \square \text { Interés tipológico } & \square \text { Estructura } & \square \text { Carpintería } \\ \square \text { valor ambiental } & \square \text { Aleros } & \square \text { Rejería } \\ \square \text { vigencia de la trama } & \square \text { coronación } & \square \text { cubrepersianas } \\ \square \text { Composición de la fachada } & \square \text { Jambas } & \square \text { Alicatados } \\ \square \text { Materiales, color, textura } & \square \text { Dinteles } & \square \text { Recercos } \\ & & \square \text { Dinteles } \\ & \square \text { Otros ornamentos }\end{array}$

Interés paisajístico

$\square$ Incidencia visual

$\square$ Carácter articulador

$\square$ Organización

$\square$ Interés cultural

esentativo

\section{- Datos específicos catalogación BIC $\square$ Rellenar sólo si está catalogado BIC}

\section{Datos Jurídicos:}

Código:

Estado:

Categoría:

Fecha Disposición:

Tipo delimitacion:

Anotación $M$

Plan:

Fecha informe:
Fecha Publicación BOP:

Fecha Publicación DOCV:

\section{Via Crucis, Calle de las Cruces}

\section{- Identificación}

Tramo de estudio:

Tramo 4: Puerta de Madrid-Puerta de las Cruces

Otras denominaciones: Via Crucis, subida a San Francisco, calle de las Cruces

Ref. catastral:

Localización: c/ de las Cruces

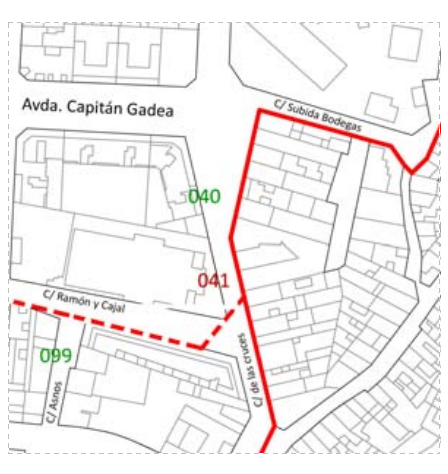

$$
\begin{array}{lll}
\text {-.... Hioutesis trazado de trazado } & \text { O0A Supuesto } & \text { Fig. izq. Emplazamiento: VN, 2013 } \\
\text { O0A Existente } & \text { Fig. centr. Foto histórica } \\
& \text { Fig. dcha. Foto actual: }
\end{array}
$$

\section{- Referencias en documentación histórica}

Referencias numéricas en cartografía sobre fortificación

-Ref. en el croquis de Ortiz de Pinedo (1837-38, AGM, núm. 262): Sin ref.

-Ref. en plano de Vera Aparici (1993): 021

Referencias en memorias técnicas militare

-Ref. Guillermo Sáez (9/9/1834-5/12/1835): Requena, 5/12/1835 AMR, 1818-50

Dado que hay riesgo de que pasen por encima de la pared, se propone levantar un costado y aspillerar una casa vecina. -Ref. Guillermo Sáez (26/02/1836): Sin ref.

-Ref. P. Ortiz de Pinedo (12/03/1837-30/05/1837): Sin ref.

-Ref Jose María de Orozco (25/03/1838): Sin ref.

-Ref. Carbonell (4/7/1838): Sin ref.

\section{- Observaciones a partir de los informes militares}

Se hace referencia así al antiguo via crucis o subida a San Francisco, denominada más adelante calle de Teatro (1820) y de Pi y Margall (1900) y, actualmente, Calle de las Cruces. Precisamente el Via Crucis fue derribado durante la primera Guerra Carlista (Bernabeu,
1982:78). Ya en 1835 se testimonia la presencia de una calle de las Cruces. śsta aún hoy existe partiendo de la plaza de Valentín Garcia buscando la calle de Chera y, curiosamente, la calle saliente que conduce a la Loma. Esta calle, intramuros conecta con la que se conoce como la Calle Subida Bodegas, y permite entender el emplazamiento del trazado defensivo del recinto exterior en este sector. En principio

se asocia con el antiguo via crucis que ascendía a San Francisco.
Existe actualmente

Incluido en fichas PGOU 2013

Bien de interés cultural (BIC)

cód. postal: 46340

Comarca: Plana de Requena-Utie

Provincia: Valencia

Autonomía: Comunidad Valencian 
$\square$ Rellenar en caso de que ele elemento sea

PROTECCIÓN

Nivel de protección:

AFECCIÓN PATRIMONIAL

$\square$ Inmueble

$\square$ Parcela catastral

$\square$ Recinto arquitectónico

$\square$ Bien de relevancia local (BR)

$\square$ Afectado entorno BIC

- Descripción histórico-arquitectónica

Tipología:

Cronología:

Observaciones a la cronología:

\section{Descripción:}

\section{- Entorno urbano}

Descripción entorno urbano:

Uso actual:

Intervenciones:

Régimen Urbanístico:

Titularidad:

Nivel protección s/catálogo 1996:

Bibliografía: AMR, 1818-17, 1818-24; 1818-50; 1818-52; 1818-53.

observaciones generales:

\section{OBJETIVACIÓN DE INTERÉS}

$\square$ Interés tipológico

$\square$ Valor ambiental

Vigencia de la trama

$\square$ Materiales, color, textura

\section{Soluciones constructivas}

\section{$\square$ Estructura}

$\square$ Aleros

$\square$ Coronación

$\square$ Jambas
Soluciones ornamentales

$\square$ Carpintería
$\square$ Rejería
$\square$ Cubrepersianas
$\square$ Alicatados
$\square$ Recercos

Interés paisajistico

$\square$ Incidencia visual

$\square$ Carácter articulador

$\square$ Organización $\square$ Carácter representativo

$\square$ Otros ornamentos

\section{- Datos específicos catalogación BIC \\ $\square$ Rellenar sólo si está catalogado BIC}

\section{Datos Jurídicos:}

Código:

Estado:
Categoría:

Fecha Disposicion:

Anotación Mo

Plan:

Fecha informe:

Fecha Publicación DOCV:

\section{Puerta de las Cruces}

- Identificación

Tramo de estudio:

Otras denominacio

Tramo 5: Puerta de las Cruces-Puerta de Reinas

Ref. catastral:

Localización: En torno de la C/ de las Cruces.

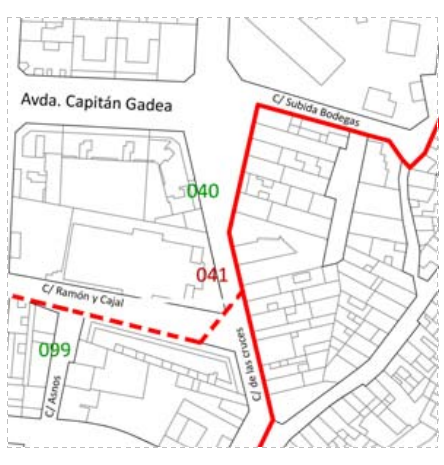

-... Hivótesis trazado Dudas de trazado Supuesto

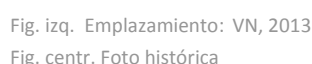

Fig. centr. Foto históric
Fig, dcha. Foto actual

- Referencias en documentación histórica

Referencias numéricas en cartografía sobre fortificación

-Ref. en el croquis de Ortiz de Pinedo (1837-38, AGM, núm. 262): Sin ref.

-Ref. en plano de Vera Aparici (1993): Sin ref.

Referencias en memorias técnicas militares

-Ref. Guillermo Sáez (9/9/1834-5/12/1835): Sin ref.

-Ref. Guillermo Sáez (26/02/1836): Sin ref.

-Ref. P. Ortiz de Pinedo (12/03/1837-30/05/1837): Sin ref.

-Ref Jose María de Orozco (25/03/1838): Sin ref.

-Ref. Carbonell (4/7/1838): AMR, 1818-17, fol. 15

"Se cubrirá con tambor rectángular que ocúpe el ancho del camino, y tenga doce baras de largo desde la puerta. La altura de su parapéto sera de cuatro baras, y el espésor de dos pies. Se construirá una banquéta para el uso de las aspilléras. La puerta de este tambor se situard en el flanco de su izquiérda, donde se hará un pequéño puente para el paso de la acequia" (Carbonell, Requena, 4 de julio de 1838, AMR, 1818-17, fol. 15).

\section{- Observaciones a partir de los informes militares}

La puerta de las Cruces se asocia con una salida que conecta la ciudad con San Francisco. Como sucede en todas las puertas, se habilita un asimila con el foso. Parece ser acoger a la guarnición que hace la guardia. Frente a la puerta discurre una acequia, que es la que se en el flanco izquierdo.
Existe actualmente

cluido en fichas PGOU 2013

Bien de interés cultural (BIC)

cod. postal: 46340

quena-Utie

Autonomia: Comunidad Valencian 
$\square \frac{\text { Rellenar en caso de que el elemento sea }}{\text { contemplado con datos del PGOU, 2013 }}$

PROTECCIÓN

AFECCIÓN PATRIMONIAL

Nivel de protección:

Entorno:

$\square$ Inmueble

Parcela catastral

$\square$ Recinto arquitectónico

$\square$ Bien de relevancia local (BRL)

$\square$ Afectado entorno BIC

$\square$ Afectado Plan especia

\section{- Descripción histórico-arquitectónica}

\section{Tipología: \\ Cronologia:}

Observaciones a la cronología:

Descripción:

- Entorno urbano

Descripción entorno urbano:

Uso actual:

Estado de conservación:

Intervenciones:

Régimen Urbanístico:

Titularidad:

Nivel protección s/catálogo 1996:

Bibliografía: AMR, 1818-17, 1818-24; 1818-50; 1818-52; 1818-53.

observaciones generales:

\section{OBJETIVACIÓN DE INTERÉS}

$\begin{array}{ll}\square \text { Interés tipológico } & \square \text { Estructura } \\ \square \text { valor ambiental } & \square \text { Aleros } \\ \square \text { vigencia de la trama } & \square \text { coronación } \\ \square \text { composición de la fachada } & \square \text { Jambas } \\ \square \text { Materiales, color, textura } & \square \text { Dinteles }\end{array}$

$\square$ Materiates, color lexhada

$\square$ Dinteles

Soluciones ornamentales
$\square$ Carpintería
$\square$ Rejería
$\square$ Cubrepersianas
$\square$ Alicatados
$\square$ Recercos
$\square$ Dinteles

$\square$ Incidencia visual

$\square$ Carácter articulador

Organización

Interés cultural

$\square$ Dinteles

Otros ornamentos

\section{- Datos específicos catalogación BIC $\square$ Rellenar sólo si está catalogado BIC}

Datos Jurídicos:
Código:

Estado:
Categoría:

Fecha Disposición:

Anotación M

Plan:

Fecha informe:

Fecha Publicación DOCV:

Fecha Publicación BOE:

\section{Pedazo de la Rayuela}

\section{- Identificación}

Tramo de estudio: Tramo 5: Puerta de las Cruces-Puerta de Reinas

Otras denominaciones:

Ref. catastral:

Localización: Entre la C/ de las Cruces y la C/ Bodegas.

Existe actualmente

Incluido en fichas PGOU 2013

Bien de interés cultural (BIC)

cód. postal: 46340

Municipio: Requena

Comarca: Plana de Requena-Utie

Provincia: Valencia

Autonomia: Comunidad Valencian

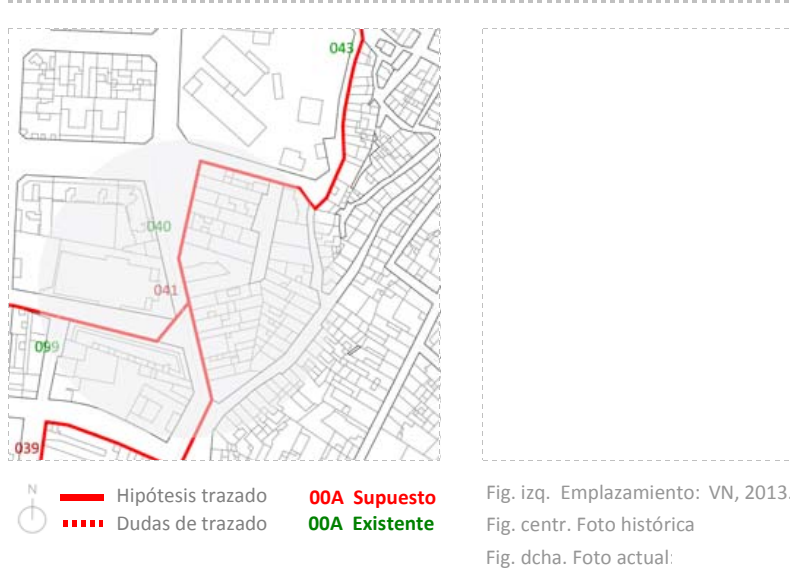

- Referencias en documentación histórica

Referencias numéricas en cartografía sobre fortificación

-Ref. en el croquis de Ortiz de Pinedo (1837-38, AGM, núm. 262): Sin ref.

-Ref. en plano de Vera Aparici (1993): Sin ref.

Referencias en memorias técnicas militares

-Ref. Guillermo Sáez (9/9/1834-5/12/1835): Requena, 5/12/1835 AMR, 1818-50

"Cojer la pared". Con esta expresión puede hacer referencia a un rejuntado o a un revoco.

-Ref. Guillermo Sáez (26/02/1836): Sin ref.

-Ref. P. Ortiz de Pinedo (12/03/1837-30/05/1837): Sin ref.

-Ref Jose María de Orozco (25/03/1838): Sin ref.

-Ref. Carbonell (4/7/1838): Sin re.

\section{- Observaciones a partir de los informes militares}

Como se define en el apartado del Pedazo de los muertos, este pedazo constituiría una superficie plana sin cultivar. El término "Rayuela" deriva de una interpretación de la denominación escrita por Guillermo Sáez en 1835. Este pedazo no se cita en años posteriores. ¿Sería un término podría quizás leerse como "rejuela" (ipor la presencia de una reja?) o cual quier nombre propio correspondiente al propietario, que era la forma habitual de hacer referencia a las localizaciones en los informes militares. 
$\square \frac{\text { Rellenar en caso de que el elemento sea }}{\text { contemplado con datos del PGOU, 2013 }}$

\section{PROTECCIÓN}

Nivel de protección:

Entorno:

$\square$ Inmueble

$\square$ Parcela catastral

Recinto arquitectón

Entorno específico
AFECCIÓN PATRIMONIAL

Bien de interés cultural (BIC)

Bien de relevancia local (BRL)

$\square$ Afectado entorno BIC

$\square$ Afectado Plan especial

\section{- Descripción histórico-arquitectónica}

\section{Tipología:}

Cronologia:

Observaciones a la cronología

\section{Descripción:}

\section{- Entorno urbano}

Descripción entorno urbano:

Uso actual:

Estado de conservación

Intervenciones:

égimen Urbanístico:

itularidad:

ivel protección s/catálogo 1996:

Bibliografía: AMR, 1818-17, 1818-24; 1818-50; 1818-52; 1818-53.

observaciones generales:

$\begin{array}{lll}\text { OBJETIVACIÓN DE INTERÉS } & \text { Soluciones constructivas } & \text { Soluciones ornamentales } \\ \square \text { Interés tipológico } & \square \text { Estructura } & \square \text { Carpintería } \\ \square \text { Valor ambiental } & \square \text { Aleros } & \square \text { Rejería } \\ \square \text { Vigencia de la trama } & \square \text { Coronación } & \square \text { Cubrepersianas } \\ \square \text { Composición de la fachada } & \square \text { Jambas } & \square \text { Alicatados } \\ \square \text { Materiales, color, textura } & \square \text { Dinteles } & \square \text { Recercos } \\ & & \square \text { Dinteles } \\ & \square \text { Otros ornamentos }\end{array}$

Interés paisajístico

$\square$ Incidencia visual

$\square$ Carácter articulador

$\square$ Organización

$\square$ Caŕcter representativo

\section{- Datos específicos catalogación BIC}

$\square$ Rellenar sólo si está catalogado BIC

\section{Datos Jurídicos:}

$\begin{array}{lll}\text { Código: } & \text { Fecha Disposición: } & \text { Fecha informe: } \\ \text { Estado: } & \text { Tipo delimitación: } & \text { Fecha Publicación BOP: } \\ \text { Categoría: } & \text { Plan: } & \text { Fecha Publicación DOCV: } \\ \text { Anotación Mo: } & \text { Informe: } & \text { Fecha Publicación BOE: }\end{array}$

\section{Bajo de las Bodegas}

\section{- Identificación}

Tramo de estudio:

Tramo 5: Puerta de las Cruces-Puerta de Reinas

Otras denominaciones: Tapias de Don Andrés Ferrer y tapias de Don Manuel Nueb

Ref. catastral:

Localización: C/ Bodegas.

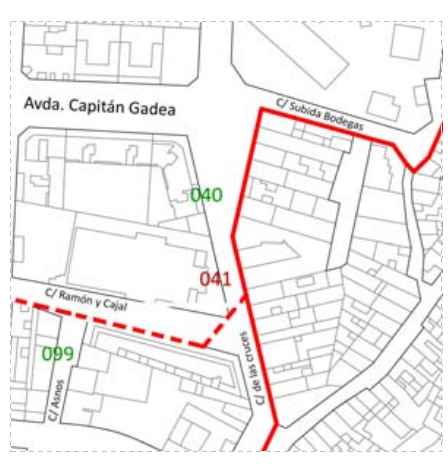

$$
\begin{aligned}
& \text { - Hipótesis trazado O0A Supuesto } \\
& \text { Fig. izq. Emplazamiento: VN, } 2013 \\
& \text { Fig, dcha, Foto actual: VN, } 2015
\end{aligned}
$$

$\checkmark$ Existe actualmente

Incluido en fichas PGOU 2013

Bien de interés cultural (BIC)

cód. postal: 46340

Municipio: Requena

Comarca: Plana de Requena-Utie

Provincia: Valencia

Autonomía: Comunidad Valencian

\section{- Referencias en documentación histórica}

\section{Referencias numéricas en cartografía sobre fortificación}

-Ref. en el croquis de Ortiz de Pinedo (1837-38, AGM, núm. 262): Sin ref.

-Ref. en plano de Vera Aparici (1993): Sin ref.

Referencias en memorias técnicas militare

-Ref. Guillermo Sáez (9/9/1834-5/12/1835): Sin ref.

-Ref. Guillermo Sáez (26/02/1836): Requena, 26/02/1836 AMR, 1818-53

En el huerto de Martín García se tiene que "levantar la pared del huerto que tiene bajo las Bodegas". La obra depende del particular.

-Ref. P. Ortiz de Pinedo (12/03/1837-30/05/1837): Sin ref.

-Ref Jose Maria de Orozco (25/03/1838): Sin ref.

-Ref. Carbonell (4/7/1838): AMR, 1818-17, fol. 15 "Las tapias de Don Andrés Ferrer deben levantárse para [que] cubran bien á una persona: al mismo tiempo se reformarán las aspilléras,
dándoles mas desahógo y mejor diréccion. En las tapias de Don Manuel Nuebalos se masizarán las aspilléras bajas, y se abrirán otras mas arriba. Se abrirá un foso en frente del lienzo que hay desde la garita al despeñadéro" (Carbonell, Requena, 4 de julio de 1838, AMR, 181817 , fol. 15).

\section{- Observaciones a partir de los informes militares}

En el terreno denominado bajo de las Bodegas, según Sáez (AMR, 1818-50), se ubica en 1835 el huerto de Martín García. En principio se interpreta como un huerto que se emplaza por delante de la pared de las bodegas o cuevas. Podemos observar en el actual plano de Requena la pervivencia de la denominada "Calle Bodegas" que transcurre contorneando el cerro de lsabel II y el pozo de la Nieve, hasta la Escuela de Viticultura y Enologia. A la altura del pozo de la nieve, desde la calle, sobrevive en la actualidad una cueva, que pudo ser una de tantas bodegas, que, con toda probabilidad, aprovecharon el conjunto de casas que acompañan la calle. La muralla debio acompañar a la Desde ella transcurriría hasta la pared oeste (posterior) del Teatro Prinicipal, bajindos, or la actual calle asnos, en donde se localizer, 
$\square \frac{\text { Rellenar en caso de que el elemento sea }}{\text { contemplado con datos del PGOU, 2013 }}$

\section{PROTECCIÓN}

Nivel de protección:

$\square$ Inmueble

$\square$ Parcela catastral

$\square$ Recinto arquitectóni

$\square$ Entorno específico

- Descripción histórico-arquitectónica

Tipología:

Cronologia:

Observaciones a la cronologia

Descripción

- Entorno urbano

Descripción entorno urbano:

Uso actual:

Estado de conservación:

Intervenciones:

Régimen Urbanístico:

Titularidad:

Nivel protección s/catálogo 1996:

Bibliografía: AMR, 1818-17, 1818-24; 1818-50; 1818-52; 1818-53.

Observaciones generales:

$\begin{array}{lll}\text { OBJETIVACIÓN DE INTERÉS } & \text { Soluciones constructivas } & \text { Soluciones ornamentales } \\ \square \text { Interés tipológico } & \square \text { sstructura } & \square \text { Carpintería } \\ \square \text { valor ambiental } & \square \text { Aleros } & \square \text { Rejería } \\ \square \text { vigencia de la trama } & \square \text { coronación } & \square \text { Cubrepersianas } \\ \square \text { Composición de la fachada } & \square \text { Jambas } & \square \text { Alicatados } \\ \square \text { Materiales, color, textura } & \square \text { Dinteles } & \square \text { Recercos } \\ & & \square \text { Dinteles } \\ & \square \text { Otros ornamentos }\end{array}$

\section{- Datos específicos catalogación BIC $\square$ Rellenar sólo si está catalogado BIC}

Datos Jurídicos:

$\begin{array}{lll}\text { Código: } & \text { Fecha Disposición: } & \text { Fecha informe: } \\ \text { Estado: } & \text { Tipo delimitación: } & \text { Fecha Publicación BOP: } \\ \text { Categoría: } & \text { Plan: } & \text { Fecha Publicación DOCV } \\ \text { Anotación Mo: } & \text { Informe: } & \text { Fecha Publicación BOE: }\end{array}$

\section{Bateria del Pozo de la Nieve}

AFECCIÓN PATRIMONIAL

$\square$ Afectado entorno BIC

$\square$ Afectado Plan especia $\square$ Bien de relevancia local (BRI)

\section{- Identificación}

$\begin{array}{ll}\text { Tramo de estudio: } & \text { Tramo 5: Puerta de las Cruces-P } \\ \text { Otras denominaciones: } & \text { Pozo de la Nieve. Escuela Zorita }\end{array}$

Ref. catastral:

36323-01

C/ del Pozo, o 23. Cuando la Calle San Sebatián, en dirección $\checkmark$ Existe actualmente

$\checkmark$ Incluido en fichas PGOU 2013

$\square$ Bien de interés cultural (BIC)

Cód. postal: 46340

Municipio: Requen

Comarca: Plana de Requena-Utie

Provincia: Valencia

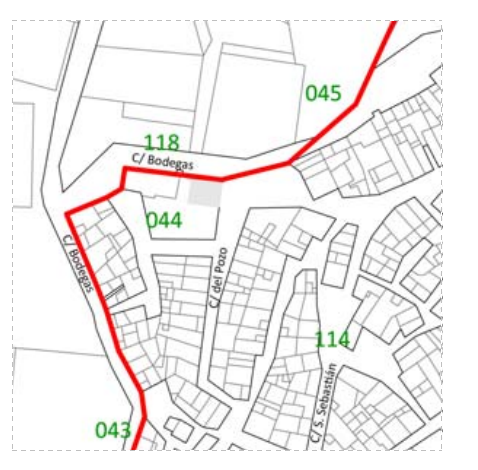

..... Hipótesis trazado de trazado

OOA Supuesto
OOA Existente

\section{Interés paisajistico}

$\square$ Incidencia visual

$\square$ Carácter articulador

$\square$ Organización

Carácter representativo

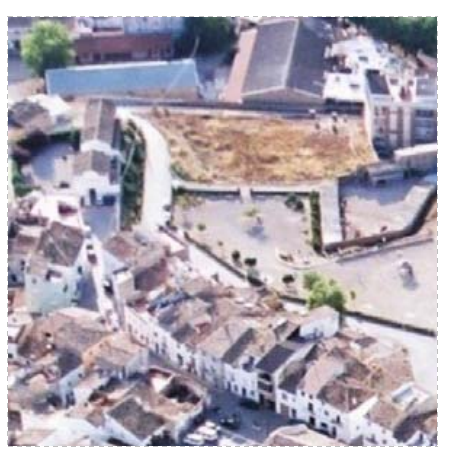

Fig. izq. Emplazamiento: VN, 2013. Fig. dcha. Foto actual:VN, 2015

- Referencias en documentación histórica

Referencias numéricas en cartografía sobre fortificación

-Ref. en el croquis de Ortiz de Pinedo (1837-38, AGM, núm. 262): 013 -Ref. en plano de Vera Aparici (1993): Sin ref.

Referencias en memorias técnicas militares

-Ref. Guillermo Sáez (9/9/1834-5/12/1835): Requena, 5/12/1835 AMR, 1818-50

Se concluyen aspilleras y se refuerzan paredes.

-Ref. Guillermo Sáez (26/02/1836): Sin ref.

-Ref. P. Ortiz de Pinedo (12/03/1837-30/05/1837): Sin ref.

-Ref Jose María de Orozco (25/03/1838): Requena, 25/03/1838, AMR 1818-24

Se propone emplazar un obús, $y$, si ello no pudiera ser, dar al punto capacidad para una pieza de a ocho. Se pretende entre ambas baterías impedir el sostenimiento de las posiciones enemigas $y$ su avance en ta Loma.

-Ref. Carbonell (4/7/1838): AMR, 1818-17, fol. 15

"Esta Bateria se halla en la posicion mas ventajosá para defendér las inmediaciónes de la poblacion, desde la Gloriéta, Fuerte de San Francisco, Loma, olla del martinete, y Cerro del mismo, pero para que correspónda á su objéto hay que mejorárla según se propóne á prescriba. En todo este espácio se reforzará el parááto con obra de tapia; hasta que tenga bara y media de espésor, y se levan que el arte banquétas detrás de los merlones, para que por encima de ellos se pueda hacer uso de la fusilería. Tambien se aumentará la altúra de parapéto dandole la conveniénte para que los artilléros queden á cubiérto y bien desenfilados: con cuyo objéto será tambien necesário establecer una [travies] que cubre la ultima pieza del frente del norte. Por la parte de poniénte terminará el espaldón de la Bateria á una bara à la izquierda de la cañonéra: desde cuyo punto hasta la escaléra, al parapéto lo constituirá la paréd que ahora ecsiste, realzándola y aspillerándola. Dicha escaléra, por donde se baja al arrabal y calles nuebas, se desenfilará por medio de tabiques. Se nivelará el [techo] de por dentro del actual cuerpo de Guardia que debe destińrse [esclusivamentol á la defénsa. Se pondrán portáónes en las cañ sé subirá como tambien las correspondiéntes esplanadas de tablónes. Se construirá un pequeño refuérzo en el paráje mas resguardá́do. Tumbien sen construirá un nuebo cuerpo de [Guardia] hacia el centro de la obra que se considéra, estableciéndolo de modo que sirva de espáldon [para] cubrir las comunicaciónes con otros puestos. Todas las aspilléras del parapéto [que] hay desde la derécha de la Bateria hasta las casas, deben reformarse y en algúnas, se correjirán las dirécciones" (Carbonell, Requena, 4 de julio de 1838, AMR, 1818-17, fol. 15). 


\section{- Observaciones a partir de los informes militares}

Debía tratarse de un nevero o el emplazamiento de un nevero en la antigua Requena. En los estudios toponímicos de Cruz Orozco se recoge la referencia toponímica en Requena de dos enclaves urbanos, "Los Pozos de la Nieve" en La Loma, y "el Pozo de la Nieve", enclave entrante al oeste del cerrito de Isabel II, en el límite septentrional de las Peñas. Hoy en día parece que se correspondería con el emplazamiento de la escuela Zorita, donde curiosamente se finaliza la actual Calle del Pozo. En su actual emplazamiento se localiza otro edificio de valor patrimonial, la Escuela Zorita, de principios del siglo XX, que debió aprovechar parte de las estructuras preexistentes.

\section{$\checkmark \frac{\text { Rellenar en caso de que el elemento sea }}{\text { contemplado con datos del PGOU, 2013 }}$}

PROTECCIÓN
Nivel de protección:
Entorno:
$\square$ Inmueble
$\square$ Parcela catastral
$\square$ Recinto arquitectónico
$\square$ Entorno específico

\section{AFECCIÓN PATRIMONIAL}

$\square$ Bien de interés cultural (BIC)

$\square$ Afectado entorno BIC

$\square$ Afectado Plan especial

\section{- Descripción histórico-arquitectónica}

Tipología:

Observaciones a la cronología:

\section{Descripción:}

\section{- Entorno urbano}

Descripción entorno urbano:

Uso actual:

Estado de conservación

Intervenciones:

\section{Titularidad:}

Nivel protección s/catálogo 1996 :

Bibliografia: AMR, 1818-17, 1818-24; 1818-50; 1818-52; 1818-53.

Observaciones generales:

\begin{tabular}{|c|c|c|c|}
\hline OBJETIVACIÓN DE INTERÉS & Soluciones constructivas & Soluciones ornamentales & Interés paisajistico \\
\hline $\begin{array}{l}\boldsymbol{V} \\
\boldsymbol{V} \text { Interés tipológico } \\
\boldsymbol{v} \text { Valor ambiental } \\
\square \text { Vigencia de la trama } \\
\square \text { Composición de la fachada } \\
\square \text { Materiales, color, textura }\end{array}$ & $\begin{array}{l}\square \text { Estructura } \\
\square \text { Aleros } \\
\square \text { Coronación } \\
\square \text { Jambas } \\
\square \text { Dinteles }\end{array}$ & $\begin{array}{l}\square \text { Carpintería } \\
\square \text { Rejería } \\
\square \text { Cubrepersianas } \\
\square \text { Alicatados } \\
\square \text { Recercos } \\
\square \text { Dinteles } \\
\square \text { Otros ornamentos }\end{array}$ & $\begin{array}{ll}\nabla & \text { Incidencia visual } \\
\nabla & \text { Carácter articulador } \\
\nabla & \text { Organización } \\
\nabla & \text { Interés cultural } \\
\square & \text { Carácter representativo }\end{array}$ \\
\hline
\end{tabular}

- Datos específicos catalogación BIC $\square$ Rellenar sólo si está catalogado BIC Datos Jurídicos:

$\begin{array}{lll}\text { Código: } & \text { Fecha Disposición: } & \text { Fecha informe: } \\ \text { Estado: } & \text { Tipo delimitación: } & \text { Fecha Publicación BOP: } \\ \text { Categoria: } & \text { Plan: } & \text { Fecha Publicación DOCV: } \\ \text { Anotación Mo: } & \text { Informe: } & \text { Fecha Publicación BOE: }\end{array}$

\section{4b Escuela Zorita}

\section{- Identificación}

Tramo de estudio:

Tramo 5: Puerta de las Cruces-Puerta de Reinas

Otras denominaciones: Pozo de la Nieve. Escuela Zorita

Ref. catastral:

\section{3-01}

Localización: C/ del Pozo, no 23. Cuando la Calle San Sebatián, en dirección suroeste, se bifurca hacia la calle Bodegas, descendiendo, tambié

$\checkmark$ Existe actualmente

$\checkmark$ Incluido en fichas PGOU 2013

$\square$ Bien de interés cultural (BIC)

cód. postal: 46340

Municipio: Requena

Comarca: Plana de Requena-Utiel

Provincia: Valencia

Autonomia: Comunidad Valenciana

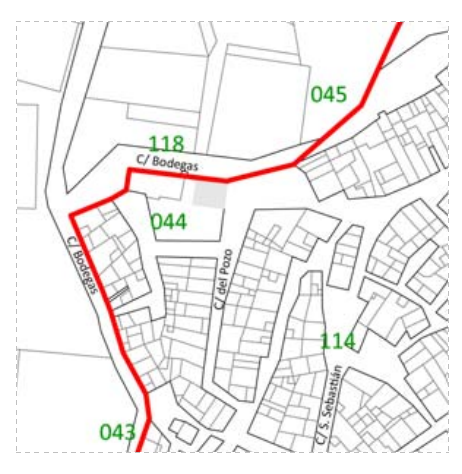

.... Hipótesis trazado

OOA Supuesto
OOA Existente
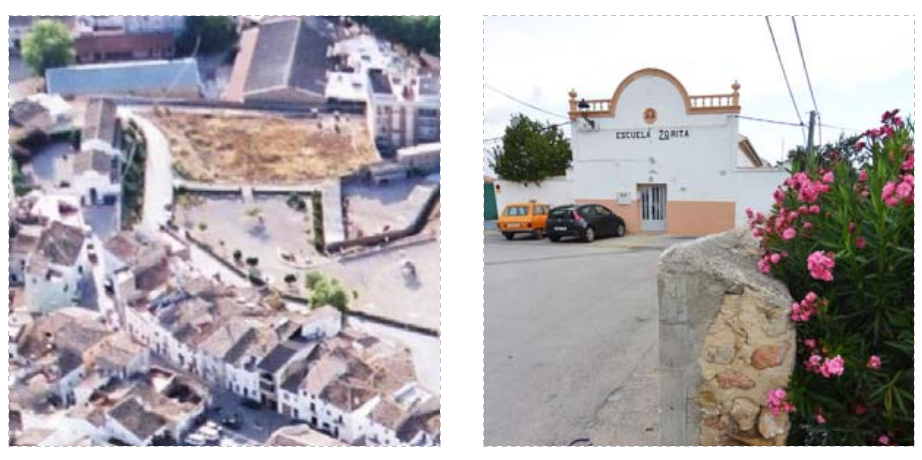

Fig. izq. Emplazamiento: VN, 201

Fig. chentr. Foto histótrica actual:VN, 2015

- Referencias en documentación histórica

Referencias numéricas en cartografía sobre fortificación

-Ref. en el croquis de Ortiz de Pinedo (1837-38, AGM, núm. 262): 013

-Ref. en plano de Vera Aparici (1993): Sin ref.

Referencias en memorias técnicas militares

-Ref. Guillermo Sáez (9/9/1834-5/12/1835): Sin ref.

-Ref. Guillermo Sáez (26/02/1836): Sin ref.

-Ref. P. Ortiz de Pinedo (12/03/1837-30/05/1837): Sin ref.

-Ref Jose Maria de Orozco (25/03/1838): Sin ref.

-Ref. Carbonell (4/7/1838): Sin ref.

\section{- Observaciones a partir de los informes militares}

La escuela Zorita es una construcción de principios del siglo XX, que como su nombre indica estaba destinada a acoger un colegio. Enclavada en el hipotético emplazamiento de la batería del Pozo de la Nieve, Debió aprovechar parte de las estructuras preexistentes (ver ficha PGOU).

$\begin{array}{lll}\square \frac{\text { Rellenar en caso de que el elemento sea }}{\text { contemplado con datos del PGoU, 2013 }} & \text { PROTECCIÓN } & \text { AFECCIÓN PATRIMONIAL } \\ & \text { Nivel de protección: Parcial } & \square \text { Bien de interés cultural (BIC) } \\ & \text { Entorno: } & \square \text { Bien de relevancia local (BRL) } \\ & \square \text { Inmueble } & \square \text { Afectado entorno BIC } \\ & \square \text { Parcela catastral } & \square \text { Afectado Plan especial } \\ & \square \text { Recinto arquitectónico } & \\ \square \text { Entorno espećfico } & \end{array}$




\section{- Descripción histórico-arquitectónica}

Tipología: Arquitectura civil

Cronología: Principios s. XX

Observaciones a la cronología: La cronología hace referencia a la Escuela Zorita. No se tiene referencia cronológica del pozo de la

Descripción: "Conjunto de dos grandes edificios de cubierta a dos aguas, uno situado delante del otro y uniéndose ambos por un jardín o patio vallado. El primer edificio de planta rectangular aparece sobre una base de ladrillos, está horadado por distintos con baranda con balaustres a cada lado y decoración de jarrones. En el centro hay un óculo con decoración floral y debajo se lee "Escuela Zorita". El segundo edificio presenta estructura idéntica al anterior, solo diferenciándose la fachada, que es curvilínea, sin ninguna inscripción. Tipos de fábrica: Ladrillo cerámico y mampostería enfoscada" (PGOU, 2013:
E.CAS.CAT.62).

\section{- Entorno urbano}

Descripción entorno urbano:

"Se trata de un entorno que tradicionalmente ha funcionado como borde urbano, ubicado en el extremo oeste del barrio primigenio de las Peñas. El desarrollo urbanístico de esta zona hacia el norte se ha visto limitado por la proximidad del ferrocarril. Las Normas Subsidiarias vigentes tienen proyectada una gran zona verde en los solares vacantes, la cual aún

no se ha ejecutado' (PGOU, 2013: E.CAS.CAT.62).

Uso actual: Escuela en desuso

Estado de conservación: Buen

Intervenciones:

Régimen Urbanístico: S. U.

Titularidad: Pública

Nivel protección s/catálogo 1996:

Bibliografía: AMR, 1818-17, 1818-24; 1818-50; 1818-52; 1818-53.

Observaciones generales:

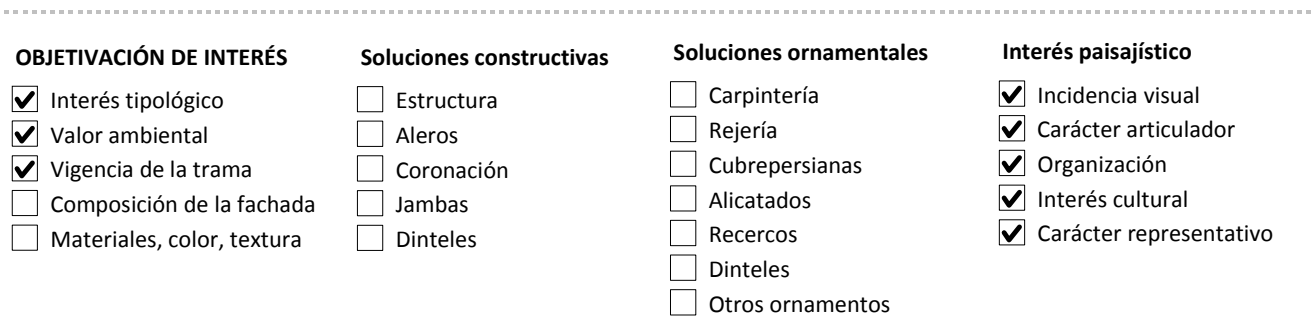

\section{- Datos específicos catalogación BIC $\square$ Rellenar sólo si está catalogado BIC}

$\begin{array}{lll}\text { Datos Jurídicos: } & & \\ \text { Código: } & \text { Fecha Disposición: } & \text { Fecha informe: } \\ \text { Estado: } & \text { Tipo delimitación: } & \text { Fecha Publicación BOP: } \\ \text { Categoría: } & \text { Plan: } & \text { Fecha Publicación DOCV: } \\ \text { Anotación Mo: } & \text { Informe: } & \text { Fecha Publicación BOE: }\end{array}$

\section{Bajada a los bolos}

\section{- Identificación}

Tramo de estudio:

Tramo 5: Puerta de las Cruces-Puerta de Reinas

Otras denominaciones: Camino cubierto entre el Pozo de la nieve y el Fortín de ls

Ref. catastral:

Localización: Carrera de San Sebastián.

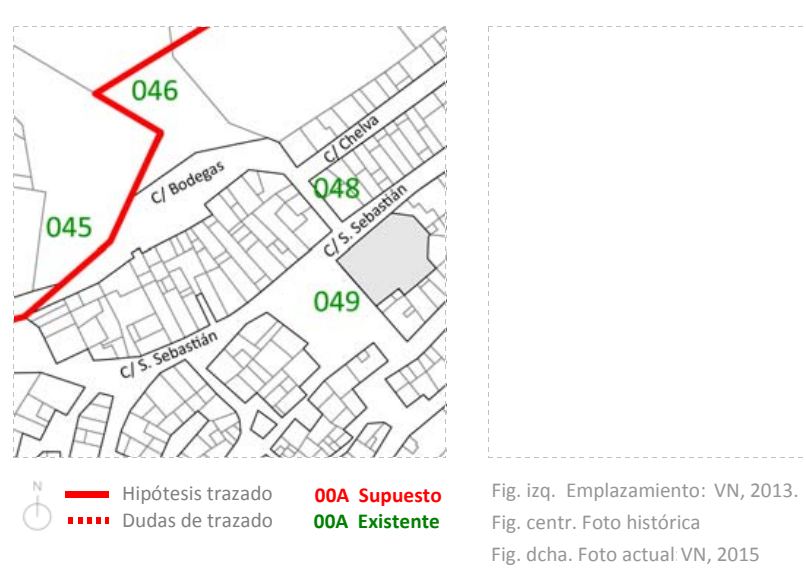

- Referencias en documentación histórica

Referencias numéricas en cartografía sobre fortificación

-Ref. en el croquis de Ortiz de Pinedo (1837-38, AGM, núm. 262): Sin ref.

-Ref. en plano de Vera Aparici (1993): Sin ref.

Referencias en memorias técnicas militares

-Ref. Guillermo Sáez (9/9/1834-5/12/1835): Sin ref.

-Ref. Guillermo Sáez (26/02/1836): Sin ref.

-Ref. P. Ortiz de Pinedo (12/03/1837-30/05/1837): Sin ref.

-Ref Jose María de Orozco (25/03/1838): Sin ref.

-Ref. Carbonell (4/7/1838): Sin ref.

\section{- Observaciones a partir de los informes militares}

Hará referencia alguna comunicación entre el "Pedazo de los muertos" y el "cerrito de los bolos", llamado más adelante "Cerrito de Isabel ll". Hoy en dí esta zona está ocapada por solares abancalados Como se observa en la fotografía, muchas de estas cejas de piedra en seco pudieron existir y el camino cubierto, con toda probabilidad, se apoyó en las mismas.

\section{Rellenar en caso de que el elemento sea
contemplado con datos del PGOU, 2013}

PROTECCIÓN
Nivel de protección:
Entorno:
$\square$ Inmueble
$\square$ Parcela catastral
$\square$ Recinto arquitectónico
$\square$ Entorno específico

$\checkmark$ Existe actualmente

Incluido en fichas PGOU 2013

Bien de interés cultural (BIC)

cód. postal: 46340

Comarca: Plana de Requena-Utie

Provincia: Valenci

Autonomia: Comunidad Valencian

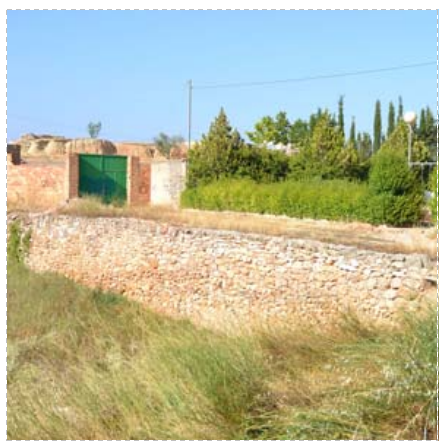

\section{AFECCION PATRMONIAL}

Bien de interés cultural (BIC)

$\square$ Afectado entorno BlC

Afectado Plan especial $\square$ Bien de relevancia local (BRL) 


\section{- Descripción histórico-arquitectónica}

Tipología

Cronología:

\section{Observaciones a la cronología:}

Descripción:

\section{- Entorno urbano}

Descripción entorno urbano:

Uso actual:

Estado de conservación:

Intervenciones:

Régimen Urbanístico:

Titularidad:

Nivel protección s/catálogo 1996:

Bibliografía: AMR, 1818-17, 1818-24; 1818-50; 1818-52; 1818-53.

Observaciones generales:

$\begin{array}{lll}\text { OBJETIVACIÓN DE INTERÉS } & \text { Soluciones constructivas } & \text { Soluciones ornamentales } \\ \square \text { Interés tipológico } & \square \text { Estructura } & \square \text { Carpintería } \\ \square \text { Valor ambiental } & \square \text { Aleros } & \square \text { Rejería } \\ \square \text { Vigencia de la trama } & \square \text { Coronación } & \square \text { Cubrepersianas } \\ \square \text { Composición de la fachada } & \square \text { Jambas } & \square \text { Alicatados } \\ \square \text { Materiales, color, textura } & \square \text { Dinteles } & \square \text { Recercos } \\ & & \square \text { Dinteles } \\ & \square \text { Otros ornamentos }\end{array}$

\section{- Datos específicos catalogación BIC $\square$ Rellenar sólo si está catalogado BIC}

$\begin{array}{lll}\text { Datos Juridicos: } & & \\ \text { Código: } & \text { Fecha Disposición: } & \text { Fecha informe: } \\ \text { Estado: } & \text { Tipo delimitación: } & \text { Fecha Publicación BOP: } \\ \text { Categoría: } & \text { Plan: } & \text { Fecha Publicación DOCV: } \\ \text { Anotación Mo: } & \text { Informe: } & \text { Fecha Publicación BOE: }\end{array}$

$\square$ Organización

\section{Batería de Isabel II}

\section{- Identificación}

Tramo de estudio:

Tramo 5: Puerta de las Cruces-Puerta de Reinas

otras denominaciones: Cerrito, Cerrito de los bolos, las troneras

$\checkmark$ Existe actualmente

$\square$ Incluido en fichas PGOU 2013

$\square$ Bien de interés cultural (BIC

cód. postal: 46340

Municipio: Requena

Comarca: Plana de Requena-Utie

Ref. catastral:

Localización: Área septentrional del encuentro de la C/ Bodegas con la C/ Chelva.

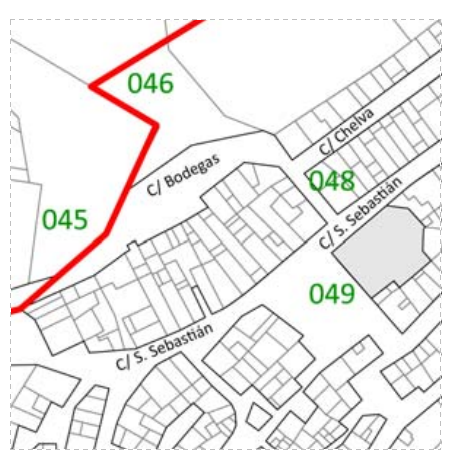

$\square$ Incidencia visual

$\square$ Carácter articulador

$\square$ Carácter representativo

-.... Hiṕtesis trazado O0A Supuesto

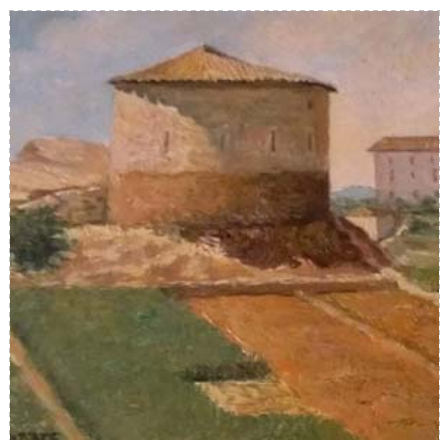

Fig. izq. Emplazamiento: VN, 201

Fig. chena. Foto actual: $:$ N, 2015

\section{- Referencias en documentación histórica}

\section{Referencias numéricas en cartografía sobre fortificación}

-Ref. en el croquis de Ortiz de Pinedo (1837-38, AGM, núm. 262): 011

-Ref. en plano de Vera Aparici (1993): Sin ref.

Referencias en memorias técnicas militares

-Ref. Guillermo Sáez (9/9/1834-5/12/1835): Requena, 5/12/1835 AMR, 1818-50

Se propone parapetar desde el Cerrito a la puerta del pozo de la nieve.

-Ref. Guillermo Sáez (26/02/1836): Requena, 26/02/1836 AMR, 1818-53

El conocido como paso al pozo de la nieve consiste en la ejecución de una comunicación a modo de camino cubierto entre el el fortín del bolos" y el pozo de la nieve.

-Ref. P. Ortiz de Pinedo (12/03/1837-30/05/1837): Sin ref.

-Ref Jose Maria de Orozco (25/03/1838): Requena, 25/03/1838, AMR 1818-24

Deben batir convenientemente el Convento de San Francisco. Debe albergar dos piezas de a ocho, por lo que debe habilitarse un depósito delenemiro, a distancia de "punto en banco" (es decir, disparo artillero preciso). -Ref. Carbonell (4/7/1838): AMR, 1818-17, fol. 16

"Se adelantará el frente del norte girándo sobre vertice del angúlo saliénte hasta que su lado esterior quede á la orilla del desfiladéro, [y] se terminará a la distancia de trece baras: Desde el estrémo de esta linea se dirijiirá una cara oblicua de siete baras de lado esterior, de modo que vaya a morir en el henzo aspillerádo de la derécha. Al parapeto de estas caras se dará baray sirve de base. La garita se situará en el angulo saliente que résulte por este trazádo La cara de poniénte se unirá con la tapia baja de la izquiérda por medio de un parapéto de dos pies de grueso. El reliéve de los parapetos se graduará por la condicion de que el interior quede cubiérto y desenfiláado. La cara [oblicua] de levánte tendrá una cañonéra, la del norte dos, y la de poniénte otras dos, todas con portezuelas y esplanádas de tablónes. El repuésto de polvora se colocará al abrigo de las quiebras del terreno, ó mas bien en una cueba abiérta debájo del mismo con las precauciónes oportúnas (Carbonell, Requena, 4 de julio de 1838, AMR, 1818-17, fol. 13).

- Observaciones a partir de los informes militares 
Si bien algunas fuentes identifican el cerrito con el pozo de la nieve, no se trata de lo mismo. El cerrito sería el lugar en el que se instalaría el fortín que sería el punto de observación en el asedio de 1836, conocido como cerrito de Isabel II. Herrero y Moral, haciendo referencia a la hermandad de San Cayetano, una de las tres hermandades de San sebastín, indica que era propietaria de un "terreno sito en el llamado cerrito de Isabel II, conocido por el Juego de los Bolos, indante con un bancal que cultiva Pedro Gadea, donde se edificó el edificio desde 1833 á esta parte" (Herrero, 1890: 138). Hoy en dí persisten grandes bloques de piedra que pudieron constitur las escarpas de batería.

\begin{tabular}{lll}
$\square \frac{\text { Rellenar en caso de que el elemento sea }}{\text { contemplado con datos del PGoU, 2013 }}$ & PROTECCIÓN & AFECCIÓN PATRIMONIAL \\
& Nivel de protección: & $\square$ Bien de interés cultural (BIC) \\
& Entorno: & $\square$ Bien de relevancia local (BRL) \\
& $\square$ Inmueble & $\square$ Afectado entorno BIC \\
& $\square$ Parcela catastral & $\square$ Afectado Plan especial \\
& $\square$ Recinto arquitectónico & \\
\hline Entorno específico &
\end{tabular}

\section{- Descripción histórico-arquitectónica}

Tipología:

Observaciones a la cronología:

Descripción:

\section{- Entorno urbano}

Descripción entorno urbano:

Uso actual:

Estado de conservación

Intervenciones:

Régimen Urbanístico:

Titularidad:

Nivel protección s/catálogo 1996:

Bibliografía: AMR, 1818-17, 1818-24; 1818-50; 1818-52; 1818-53.

Observaciones generales:

$\begin{array}{llll}\text { OBJETIVACIÓN DE INTERÉS } & \text { Soluciones constructivas } & \text { Soluciones ornamentales } & \text { Interés paisajistico } \\ \square \text { Interés tipológico } & \square \text { sstructura } & \square \text { Carpintería } & \square \text { Incidencia visual } \\ \square \text { Valor ambiental } & \square \text { Aleros } & \square \text { Rejería } & \square \text { carácter articulador } \\ \square \text { Vigencia de la trama } & \square \text { coronación } & \square \text { cubrepersianas } & \square \text { Organización } \\ \square \text { Composición de la fachada } & \square \text { Jambas } & \square \text { Alicatados } & \square \text { Interés cultural } \\ \square \text { Materiales, color, textura } & \square \text { Dinteles } & \square \text { Recercos } & \square \text { carácter representativo } \\ & & \square \text { Dinteles } & \\ & \square \text { Otros ornamentos } & \end{array}$

- Datos específicos catalogación BIC $\square$ Rellenar sólo si está catalogado BIC

Datos Jurídicos:

$\begin{array}{lll}\text { Datos Juridicos: } & \text { Fecha Disposición: } & \text { Fecha informe: } \\ \text { Código: } & \text { Tipo delimitación: } & \text { Fecha Publicación BOP: } \\ \text { Estado: } & \text { Plan: } & \text { Fecha Publicación DOCV: } \\ \text { Categoría: } & \text { Informe: } & \text { Fecha Publicación BOE: }\end{array}$

\section{Sitio denominado Pedazo de los Muertos}

\section{- Identificación}

Tramo de estudio:

Tramo 5: Puerta de las Cruces-Puerta de Reinas

Otras denominaciones: Pedazo de los Muertos

Ref. catastral:

Localización: Acceso desde casas de la C/ Chelva. Huerto abancalado al Noroeste.

$\checkmark$ Existe actualmente

$\square$ Incluido en fichas PGOU 2013

Bien de interés cultural (BIC)

cód. postal: 46340

Municipio: Requen

Comarca: Plana de Requena-Utiel

Provincia: Valencia

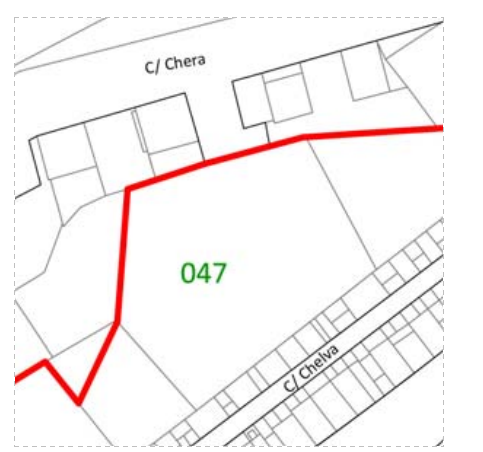

$\begin{array}{ll}\text {-... Hipótesis trazado } & \text { O0A Supuesto } \\ \text { OOA Existente }\end{array}$

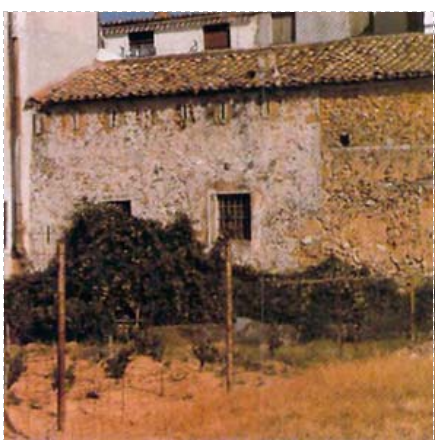

$$
\begin{aligned}
& \text { Fig. Izq. Emplazamiento: VN, 2013. } \\
& \text { Fig. centr. Foto histórica Vera, 1993: } 78 \\
& \text { Fig. dcha. Foto actual:VN, } 2015
\end{aligned}
$$

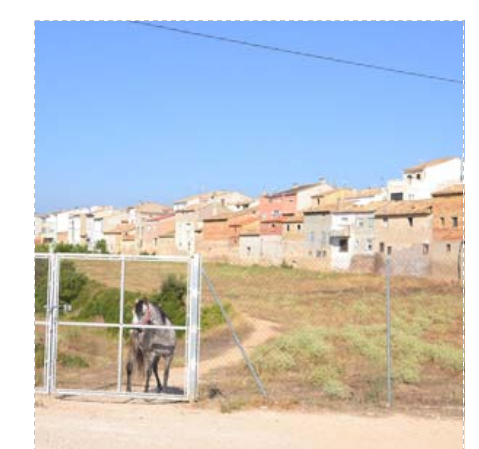

- Referencias en documentación histórica

\section{Referencias numéricas en cartografía sobre fortificación}

-Ref. en el croquis de Ortiz de Pinedo (1837-38, AGM, núm. 262): Sin ref.

-Ref. en plano de Vera Aparici (1993): 020

\section{Referencias en memorias técnicas militares}

-Ref. Guillermo Sáez (9/9/1834-5/12/1835): Requena, 5/12/1835 AMR, 1818-50

En el pedazo de los muertos se continuan las tapias, delimitando el frente escarpado de la hoya del Martinete, $y$ dejando el pedazo confinado intramuros. Se terraplena el piso y se aspilleran las construidas en el frente de la era.

-Ref. Guillermo Sáez (26/02/1836): Requena, 26/02/1836 AMR, 1818-53

En este documento se hace referencia a una diferencia entre "pedazo" y "huerto". Todos los dueños deben limpiar sus parapetos de huertos y pedazos. En el caso del pedazo de los muertos se deben levantar dos espaldones de 8 varas de largo $(6,69 \mathrm{~m})$ y 3 varas de altura $(2,51 \mathrm{~m})$, recomponiendo la pared que mira a Reinas, aspillerándola y bardándola (la acción de bardar, hace referencia a poner bardas en los vallados, paredes y tapias. Las bardas son segun la Real Academia de la lengua, una cubierta de sarmientos, paja, espinos o broza, que se pone, asegurada con tierra o piedras sobre las tapias. Las obras dependen de la Villa.

-Ref. P. Ortiz de Pinedo (12/03/1837-30/05/1837): Sin ref.

-Ref Jose María de Orozco (25/03/1838): Sin ref.

-Ref. Carbonell (4/7/1838): AMR, 1818-17, fin

"Se conserbará la linea abanzáda que es de suma utilidad; pero siendo como debe ser baja, es necesario que para que puedan cubrirse los defénsores, se abra una zanja de dos baras de ancho por la parte interior. A la linea del recinto principal se aplicarán los principios (Carbonell, Requena, 4 de julio de 1838, AMR, 1818-17, fol. 16).

\section{- Observaciones a partir de los informes militares}

En este espacio se habla de prolongar tapias hasta alcanzar al "cerrito de los bolos", terraplenando el suelo y aspillerando los muros. Pedazo, en etimología popular "piazo", suele hacer referencia a un extensión de terreno plana. El pedazo de los muertos se ubica en el del barrio de las Peñas y la depresión sur configurada por la Hoya de Martinete. Según atestigua Herrero y Moral (1890:136), el edificio fue utilizado como hospital, desde "tiempos remotisimos", "cuyos cadáveres de los alli fallecidos se enterraban en un bancal que hay 
inmediato a la calle de la Carrera de San Sebastián y al camino de los Chelvanos, que desde entonces es conocido con el nombre de "Pedazo de los muertos" (Herrero, 1890:136).

\section{Rellenar en caso de que el elemento se}

PROTECCIÓN
Nivel de protección:
Entorno:
$\square$ Inmueble
$\square$ Parcela catastral
$\square$ Recinto arquitectónico
$\square$ Entorno específico

\section{AFECCIÓN PATRIMONIAL}

$\square$ Bien de interés cultural (BIC)

$\square$ Bien de relevancia local (BRL)

$\square$ Afectado entorno BIC

$\square$ Afectado Plan especia

\section{- Descripción histórico-arquitectónica}

Tipología:

Observaciones a la cronología:

\section{Descripción}

\section{- Entorno urbano}

Descripción entorno urbano:

\section{Uso actual:}

\section{stado de conservación}

Intervenciones:

Régimen Urb:

作

Bibliografía: AMR, 1818-17, 1818-24; 1818-50; 1818-52; 1818-53.

Observaciones generales:

$\begin{array}{llll}\text { OBJETIVACIÓN DE INTERÉS } & \text { Soluciones constructivas } & \text { Soluciones ornamentales } & \text { Interés paisajistico } \\ \square \text { Interés tipológico } & \square \text { Estructura } & \square \text { carpintería } & \square \text { Incidencia visual } \\ \square \text { valor ambiental } & \square \text { Aleros } & \square \text { Rejería } & \square \text { carácter articulador } \\ \square \text { vigencia de la trama } & \square \text { coronación } & \square \text { cubrepersianas } & \square \text { Organización } \\ \square \text { Composición de la fachada } & \square \text { Jambas } & \square \text { Alicatados } & \square \text { Interés cultural } \\ \square \text { Materiales, color, textura } & \square \text { Dinteles } & \square \text { Recercos } & \square \text { carácter representativo } \\ & & \square \text { Dinteles } & \\ & \square \text { otros ornamentos } & \end{array}$

- Datos específicos catalogación BIC $\square$ Rellenar sólo si está catalogado BIC Datos Jurídicos:

$\begin{array}{lll} & \text { Fecha Disposición: } & \text { Fecha informe: } \\ \text { Código: } & \text { Tipo delimitación: } & \text { Fecha Publicación BOP: } \\ \text { Estado: } & \text { Plan: } & \text { Fecha Publicación DOCV: } \\ \text { Categoría: } & \text { Informe: } & \text { Fecha Publicación BOE: } \\ \text { Anotación Mo: } & \end{array}$

\section{Carrera de San Sebastián}

\section{- Identificación}

Tramo de estudio:

Otras denominaciones:

Tramo 5: Puerta de las Cruces-Puerta de Reinas

Ref. catastral:

Localización: Carrera de San Sebastián. Conecta la c/ Chelva con la Calle San

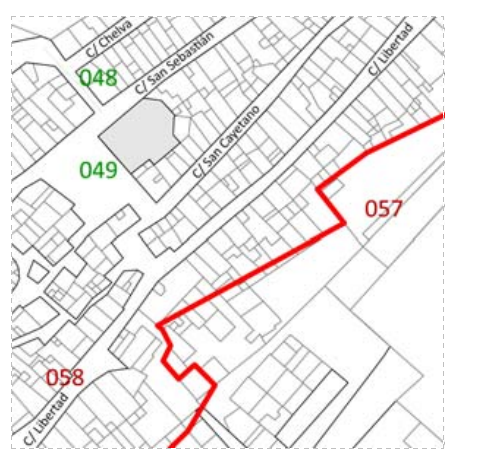

$\begin{array}{ll}\text {..... Hipótesis trazado Dudas de trazado } & \text { OOA Supuesto } \\ \text { OOA Existente }\end{array}$ $\checkmark$ Existe actualmente

Incluido en fichas PGOU 2013

Bien de interés cultural (BIC)

cód. postal: 46340

Municipio: Requena

Comarca: Plana de Requena-Utiel

Provincia: Valencia

Autonomía: Comunidad Valenciana

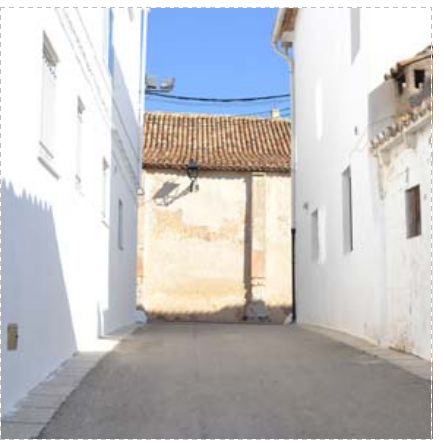

\section{- Referencias en documentación histórica}

\section{Referencias numéricas en cartografía sobre fortificación}

-Ref. en el croquis de Ortiz de Pinedo (1837-38, AGM, núm. 262): Sin ref.

-Ref. en plano de Vera Aparici (1993): 013

Referencias en memorias técnicas militare

-Ref. Guillermo Sáez (9/9/1834-5/12/1835): Requena, 5/12/1835 AMR, 1818-50

Se refuerza la pared de la casa intermedia entre la carrera y el "pedazo de los muertos".

-Ref. Guillermo Sáez (26/02/1836): Sin ref.

-Ref. P. Ortiz de Pinedo (12/03/1837-30/05/1837): Sin ref.

-Ref Jose María de Orozco (25/03/1838): Sin ref.

-Ref. Carbonell (4/7/1838): Sin ref.

\section{- Observaciones a partir de los informes militares}

El nombre procede de la Ermita o iglesia de San Sebastián, emplazada en el barrio de las Peñas. No hay que confundir la Carrera de Sa

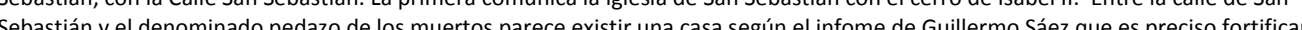

\begin{tabular}{|c|c|c|}
\hline \multirow{3}{*}{$\begin{array}{l}\text { Rellenar en caso de que el elemento sea } \\
\text { contemplado con datos del PGOU, } 2013\end{array}$} & PROTECCIÓN & AFECCIÓN PATRIMONIAL \\
\hline & Nivel de protección: & $\begin{array}{l}\square \text { Bien de interés cultural (BIC) } \\
\text { Bien de relevancia local (BRL) }\end{array}$ \\
\hline & $\begin{array}{l}\square \text { Inmueble } \\
\square \text { Parcela catastral } \\
\square \text { Recinto arquitectónico } \\
\square \text { Entorno específico }\end{array}$ & $\begin{array}{l}\square \text { Afectado entorno BIC } \\
\square \text { Afectado Plan especial }\end{array}$ \\
\hline
\end{tabular}


- Descripción histórico-arquitectónica

Tipología

Cronología:

Observaciones a la cronología:

Descripción:

\section{- Entorno urbano}

Descripción entorno urbano:

Uso actual:

Estado de conservación:

Intervenciones:

Régimen Urbanistico:

Titularidad:

Nivel protección s/catálogo 1996:

Bibliografia: AMR, 1818-17, 1818-24; 1818-50; 1818-52; 1818-53.

Observaciones generales:

\section{OBJETIVACIÓN DE INTERÉS}

$\square$ Interés tipológico

$\square$ Valor ambiental

Vigencia de la trama

$\square$ Materiales, color, textura

Soluciones construc
$\square$ Estructura
$\square$ Aleros
$\square$ Coronación
$\square$ Jambas
$\square$ Dinteles

Soluciones ornamentales
$\square$ Carpintería
$\square$ Rejería
$\square$ Cubrepersianas
$\square$ Alicatados
$\square$ Recercos
$\square$ Dinteles
$\square$ Otros ornamentos

Interés paisajístico

$\square$ Incidencia visual

$\square$ Carácter articulado

$\square$ Organización

$\square$ Carácter representativo

$\square$ Otros ornamento

\section{- Datos específicos catalogación BIC $\square$ Rellenar sólo si está catalogado BIC}

\section{Datos Jurídicos:}

Código:

Estado:

Categoría:

Anotación M

\section{Iglesia de San Sebastián}

\section{- Identificación}

Tramo de estudio:

Otras denominaciones:

Ref. catastral:

38332-01

Localización: Plaza de San Sebastián, № 36

$\checkmark$ Existe actualmente

$\checkmark$ Incluido en fichas PGOU 2013

$\square$ Bien de interés cultural (BIC)

cód. postal: 46340

Comarca: Plana de Requena-Utie

Provincia: Valencia

Autonomía: Comunidad Valencian
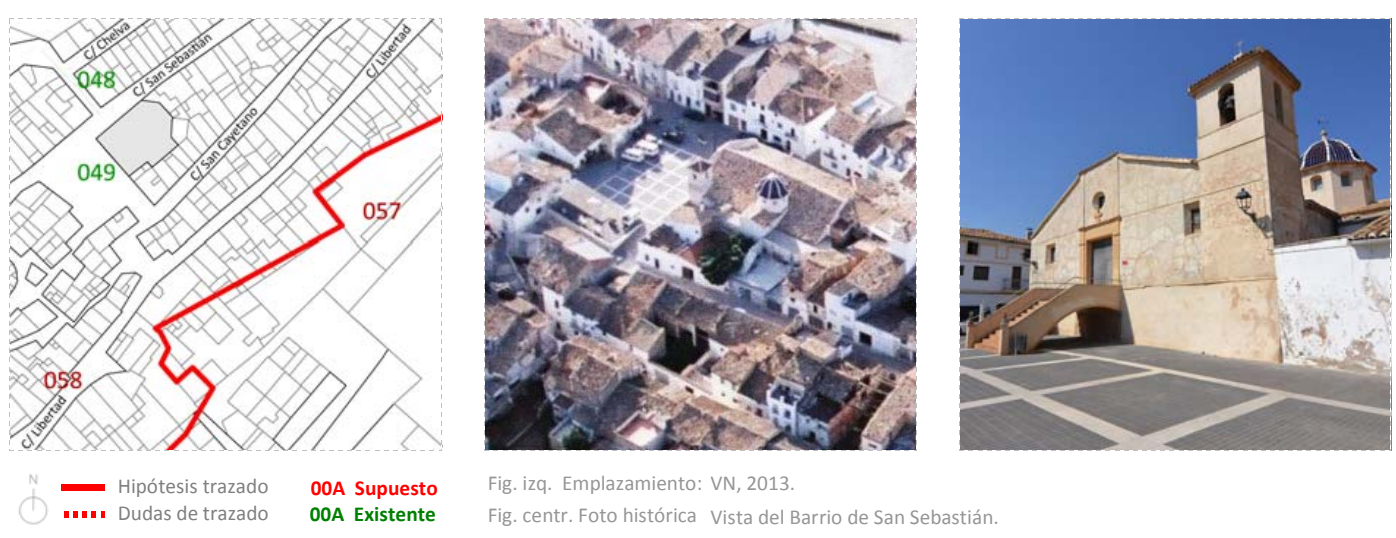

\section{Fig. iza. Emplazamiento: VN, 2013,}

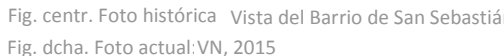

- Referencias en documentación histórica

Referencias numéricas en cartografía sobre fortificación

-Ref. en el croquis de Ortiz de Pinedo (1837-38, AGM, núm. 262): Sin ref.

-Ref. en plano de Vera Aparici (1993): Sin ref.

Referencias en memorias técnicas militare

-Ref. Guillermo Sáez (9/9/1834-5/12/1835): Sin ref.

-Ref. Guillermo Sáez (26/02/1836): Sin ref.

-Ref. P. Ortiz de Pinedo (12/03/1837-30/05/1837): Sin ref.

-Ref Jose María de Orozco (25/03/1838): Sin ref.

-Ref. Carbonell (4/7/1838): Sin ref.

\section{- Observaciones a partir de los informes militares}

Data del siglo XV, cuando se construyó para los mudéjares (conversos) expulsados de la villa en el siglo XIII y que se habían alojado en las Peñas. La denominada en 1833 ermita de San Sebastián, sirvió para albergar las imágenes provenientes del convento de San Francisco, deteriorado poricuid los vecinos (Herrero, 1890:135-136). Ve fich PGOU.

\begin{tabular}{|c|c|}
\hline \multirow[t]{2}{*}{$\begin{array}{l}\nabla \frac{\text { Rellenar en caso de que el elemento sea }}{\text { contemplado con datos del PGOU, } 2013} \\
\text { con col }\end{array}$} & $\begin{array}{l}\text { PROTECCIÓN } \\
\text { Nivel de protección: } \\
\text { Entorno: }\end{array}$ \\
\hline & $\begin{array}{l}\square \text { Inmueble } \\
\square \text { Parcela catastral } \\
\square \text { Recinto arquitectónico } \\
\square \text { Entorno específico }\end{array}$ \\
\hline
\end{tabular}

$\square$ Bien de interés cultural (BIC)

$\checkmark$ Bien de relevancia local (BRL)

Monumento

Afectado entorno BIC
Afectado Plan especial 


\section{- Descripción histórico-arquitectónica}

\section{Tipología: Arquitectura religiosa}

Cronología: s. XIV

\section{Observaciones a la cronologia}

Descripción: "Edificio de tres naves con cubierta a dos aguas, presbiterio con bóveda de cascarón y torre campanario en fachada principal. De las tres naves, la central más ancha y larga que las laterales está separada de éstas por unas pilastras unidas columnas. En la nave lateral iz.l. El presbiterio está construido con bóveda de cascarón y altar de piedra sostenido por do campanario, más adelante una capilla que se cubre con cúpula y por último, cerca de la cabecera, aparece la Sacristía. Estas dos naves laterales tienen distinto techo, la más próxima a los pies de la iglesia es de forma de tejadillo y en el último tramo hay dos arcos completos, entre ellos un artesonado de madera. La fachada principal es de forma triangular y presenta una escalinata en abanico, en su lado derecho se adosa la torre campanario, horadada por cuatro vanos con dos graderios por sus costados laterales En 1786 hubo altares 5 y 6 y la nueva escalinata que sustituye a la anterior de piedra. Recientemente está en proceso de restauración al descubrirse en 1999, un precioso artesonado mudéjar de madera, sustentado por columnas de piedra embutidas en los citados pilares, único en la Comunidad Valenciana. Tipos de fábrica: Mampostería y ladrillo" (PGOU, 2013:E.CAS.BRL.64).

Entorno urbano

Descripción entorno urbano: por la austeridad en la decoración y la uniformidad tipológica" (PGOU, 2013:E.CAS.BRL.64).

Uso actual: Dedicado al culto

Estado de conservación: Bueno

tervenciones: Consolidción, conservación, restauración Rehabilitación en el año 2002.

Régimen Urbanístico: S. U.

Titularidad: Privada

Nivel protección s/catálogo 1996: 2/3/4 tipológico-fachada-ambiental

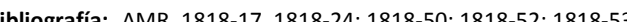

observaciones generales:

"Las intervenciones en el entorno de protección del bien se atendrán a lo dispuesto en el art. 25.3 de las normas de presente Catálogo" (PGOU, 2013:E.CAS.BRL.64).

\section{OBJETIVACIÓN DE INTERÉS}

$\checkmark$ Interés tipológico

$\checkmark$ Valor ambiental

$\checkmark$ Vigencia de la trama

Materiales, color, textura

\section{Soluciones constructivas}

Soluciones ornamentales

$\nabla$ Estructura

$\checkmark$ Coronación

$\square$ cormos

$\square$ Dinteles $\checkmark$ Composición de la fachada
- Datos específicos catalogación BIC

$\square$ Rellenar sólo si está catalogado BIC

\section{Datos Jurídicos:}

Código:

Estado:

Anotación $M$ o:
Fecha Disposición:

Tipo delimitación:

Inform $\checkmark$ Carpintería

$\square$ Rejería

Interés paisajístico

$\checkmark$ Incidencia visual

$\checkmark$ Carácter articulador

$\checkmark$ Organización

$\checkmark$ Interés cultural

$\square$ Alicatados

Recercos

$\checkmark$ Otros ornamentos

\section{Bateria nueva de Reinas}

- Identificación

Tramo de estudio: Tramo 5: Puerta de las Cruces-Puerta de Reinas

Otras denominaciones: Batería de Reynas (según Ortiz de Pinedo)

$\square$ Existe actualmente

Incluido en fichas PGOU 2013

Bien de interés cultural (BIC)

cód. postal: 46340

comarca: Plana de

Provincia: Valencia

Ref. catastral

Localización: Extremo Norte de la C/Libertad/ C/Chelva

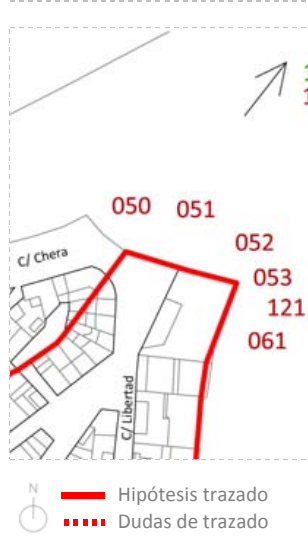

$\bigwedge_{127}^{126}(\mathrm{a} 1 \mathrm{~km})$

051

052

12

-... Hipótesis trazas de trazato

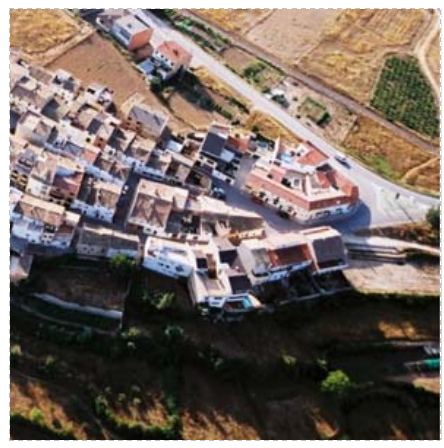

Fig. izq. Emplazamiento: VN, 201

Fig. centr. Foto histórica Foto

- Referencias en documentación histórica

Referencias numéricas en cartografia sobre fortificación

-Ref. en el croquis de Ortiz de Pinedo (1837-38, AGM, núm. 262): 001

-Ref. en plano de Vera Aparici (1993): Sin ref.

Referencias en memorias técnicas militares

-Ref. Guillermo Sáez (9/9/1834-5/12/1835): Sin ref.

-Ref. Guillermo Sáez (26/02/1836): Sin ref.

-Ref. P. Ortiz de Pinedo (12/03/1837-30/05/1837): Sin ref.

-Ref Jose Maria de Orozco (25/03/1838): Requena, 25/03/1838, AMR 1818-24

[La batería vieja de Reinas] Es considerada la obra menos afortunada y considerada inútil por Orozco en 1838. Fue planteada para un fuego de frente, batiendo el camino de Valencia, pero la mala disposición de las caras y la explanada la hacen inservible para las piezas. conformar dos explanadas en el lugar donde se emplazan los actuales cuerpos de guardia. Se debe procurar que los fuegos hey que puedan también fugar hacia la derecha Es decir, cubrir las lomas pero no desatender el sector de barrio noreste hasta el camino de Valencia.

-Ref. Carbonell (4/7/1838): AMR, 1818-17, fol. 16

"Esta obra es en la que se hán empleádo mas recúrsos y por desgracia la que adoléce de mas deféctos: sin embárgo es preciso confesar que su mucho relieve y robusteźz le dán algúna importancia, y que a fabor de las indispensabables correcciónes será de utilidad, En la parte portezuélas y ademas guarda-cabézas de biga en la cresta del parapeto. Este pequeño espácio donde solo con [estrechez] cabe una pieza tiene descubiérta á los tiros de rebés la cara de la izquiérda: para remediar este inconveniénte y desénfilar la rampa de madéra se levantarán tabicónes opórtunamente establecidos. La plaza baja debe havilitárse para el emplazamiénto de artilleria: al efécto se destruirán en su mayor parte los actuáles cuerpos de Guardia, conserbando unicaménte el espacio necesário para cinco hombres, á la inmediacion de la gola. Sobre la misma se hara en la cara de la dereccha otro cuerpo de Guargia [para] igual fuerza, el cual servirá de espáldon contra los fuegos de la campaña. En cada cara se abrirán dos cañoneras, proveyenndolas de las portezuélas y esplanádas correspondientes. Se dejarán las aspilleras intermedias, y se dejará el parapeto donde sea preciso para cubiri el interior. Se dará otra
forma al cerramiénto de la bajáda que condúce al repuésto de polbora; pues en lugar de la compuerta que hay ahóra, se abríá la escalora con un [gariton] de albañileria, que la presérbe mejor de las aguas: cuyo garitón tendrá puerta con cerradúra. En el espácio cerrado donde [ecsiste] la subida á la obra que se acába de ecsaminar, se abrirá una comunicacion con la Bateria vieja de Reinas, y se levántarán los espaldones indispensables para ocultar al enemigo esta comunicacion, y la cara interior de los parapetos." 


\section{- Observaciones a partir de los informes militares}

Esta batería, especificada en el proyecto de Ortiz de Pinedo, se emplaza en el espolón que acompaña el camino de carros de Valencia. Por lo tanto por el lado Este delimita con la Hoya de Reinas, y por el Oeste delimita con la Loma y San Francisco (Hoya de Martinete). Los con un conjunto de baterías se justifica en la medida que se convierte el punto preferido para atacar la ciudad por parte de las partidas. Existe poco desnivel, tiene pocos flanqueos del resto del perímetro amurallado, y se alcanza bien si se desciende desde el Norte, principal punto de llegada y huida de las partidas carlistas.

\section{$\square \frac{\text { Rellenar en caso de que ele lemento sea }}{\text { contempladodo con datoso del PGOU, } 2013}$}

\section{PROTECCIÓN}

Nivel de protección:

Entorno:

\section{$\square$ Inmueble}

Recinto arquitectón

\section{- Descripción histórico-arquitectónica}

Tipología:

Observaciones a la cronología:

\section{Descripción:}

\section{- Entorno urbano}

Descripción entorno urbano:

Uso actual:

Estado de conservación:

Intervenciones:

Regimen Urb:

Nivel protección s/catálogo 1996:

Bibliografía: AMR, 1818-17, 1818-24; 1818-50; 1818-52; 1818-53.

Observaciones generales:

\section{OBJETIVACIÓN DE INTERÉS}

$\square$ Interés

$\square$ Interés tipológico

Composición de la fachada

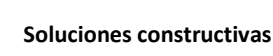

\section{$\square$ Estructura}

$\square$ Aleros

$\square$ Coronación

$\square$ Materiales, color, textura

$\square$ Dinteles
Vigencia de la tram

$\begin{array}{ll}\text { Soluciones ornamentales } & \text { Interés paisajistico } \\ \square \text { Carpintería } & \square \text { Incidencia visual } \\ \square \text { Rejería } & \square \text { Carácter articulador } \\ \square \text { Cubrepersianas } & \square \text { Organización } \\ \square \text { Alicatados } & \square \text { Interés cultural } \\ \square \text { Recercos } & \square \text { Carácter representativo } \\ \square \text { Dinteles } & \\ \square \text { Otros ornamentos } & \end{array}$

AFECCIÓN PATRIMONIAL

Bien de interés cultural (BIC)

$\square$ Afectado entorno BIC

$\square$ Afectado Plan especial
- Datos específicos catalogación BIC $\square$ Rellenar sólo si está catalogado BIC Datos Jurídicos:

Código:

Estado:
Categoria:

Anotación Mo

Fecha Disposición:

Tipo delimitación:

Plan:
Fecha informe:

Fecha Publicación BOP: Fecha Publicación DOCV:

\section{Bateria vieja de Reinas}

\section{- Identificación}

Tramo de estudio:

Tramo 5: Puerta de las Cruces-Puerta de Reinas

Otras denominaciones: Batería Antigua de Reynas

Ref. catastral:

Localización: Extremo Norte de la C/Libertad/ C/Chelva.

\section{$\square$ Existe actualmente}

Incluido en fichas PGOU 2013

$\square$ Bien de interés cultural (BIC)

cód. postal: 4634

comarca: Plana de Requena-Utie

Provincia: Valencia

Autonomía: Comunidad Valencian

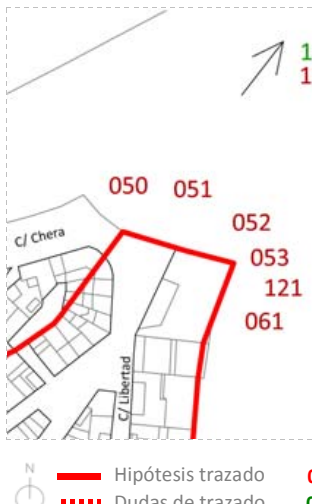

$\bigwedge_{127}^{126}(\mathrm{a} 1 \mathrm{Km})$

..... Dudas de trazado

OOA Supuesto
OOA Existente

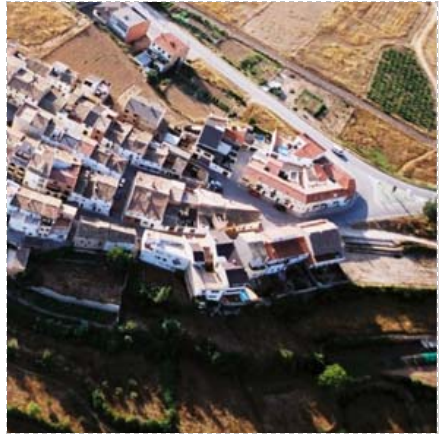

Fig. iza. Emplazamiento: VN, 2013

Fig. centr. Foto histórica Vista
- Referencias en documentación histórica

Referencias numéricas en cartografía sobre fortificación

-Ref. en el croquis de Ortiz de Pinedo (1837-38, AGM, núm. 262): 002

-Ref. en plano de Vera Aparici (1993): Sin ref.

Referencias en memorias técnicas militares

-Ref. Guillermo Sáez (9/9/1834-5/12/1835): Sin ref.

-Ref. Guillermo Sáez (26/02/1836): Sin ref.

-Ref. P. Ortiz de Pinedo (12/03/1837-30/05/1837): Sin ref.

-Ref Jose María de Orozco (25/03/1838): Sin ref.

-Ref. Carbonell (4/7/1838): AMR, 1818-17, fol. 17

"Se dará mayor elebacion á sus parapétos, se reformarán las aspilleras y se dará á estas mejor diréccion. Deben rehacerse las esplanádas"

(Carbonell, Requena, 4 de julio de 1838, AMR, 1818-17, fol. 17).

\section{- Observaciones a partir de los informes militares}

Se trata de una batería cuyo emplazamiento es confuso. Como sucede con todo el conjunto de Reinas. La conexión del Barrio de San Parece que las casas del extremo noreste de la C/ libertad podrían constituir en sus taludes el conjiunto de estructuras que defendieron

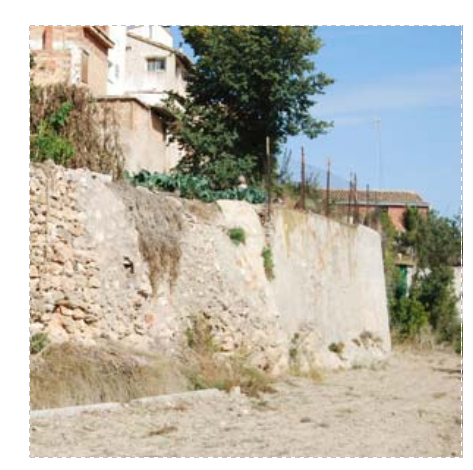




\section{$\square \frac{\text { Rellenar en caso de que ele lemento sea }}{\text { contemplado o con datos del } 1 \text { PGOU, } 2013}$}

PROTECCIÓN

Nivel de protección:

$\square$ Inmueble

Recinto arquitectónico

$\square$ Entorno específico $\square$ Bien de interés cultural (BIC)

$\square$ Afectado entorno BIC

$\square$ Afectado Plan especia

\section{- Descripción histórico-arquitectónica}

\section{Tipología:}

Cronología:

Observaciones a la cronología:

Descripción

- Entorno urbano

Descripción entorno urbano:

Uso actual:

Estado de conservación:

Intervenciones:

Régimen Urbanístico:

Titularidad:

Nivel protección s/catálogo 1996:

Bibliografía: AMR, 1818-17, 1818-24; 1818-50; 1818-52; 1818-53.

Observaciones generales:

\section{OBJETIVACIÓN DE INTERÉS}

$\square$ Interés tipológico

$\square$ Valor ambiental

Vigencia de la trama

Materiales, color, textura

Soluciones constru
$\square$ Estructura
$\square$ Aleros
$\square$ Coronación
$\square$ Jambas
$\square$ Dinteles

Soluciones ornamentales
$\square$ Carpintería
$\square$ Rejería
$\square$ Cubrepersianas
$\square$ Alicatados
$\square$ Recercos
$\square$ Dinteles
$\square$ otros ornamentos

Interés paisajistico

$\square$ Incidencia visual

$\square$ Carácter articulador

$\square$ Organización

Interés cultural

er representativo

$\square$ otros ornamentos

\section{- Datos específicos catalogación BIC $\square$ Rellenar sólo si está catalogado BIC}

\section{Datos Jurídicos:}

Código:

Estado:

Categoría:

Anotación M

Fecha Disposición:
Tipo delimitación:

Plan:

Informe:
Fecha informe:

Fecha Publicación BOP:

Fecha Publicación DOCV:

Fecha Publicación BOE:

\section{Corral de Cepeda}

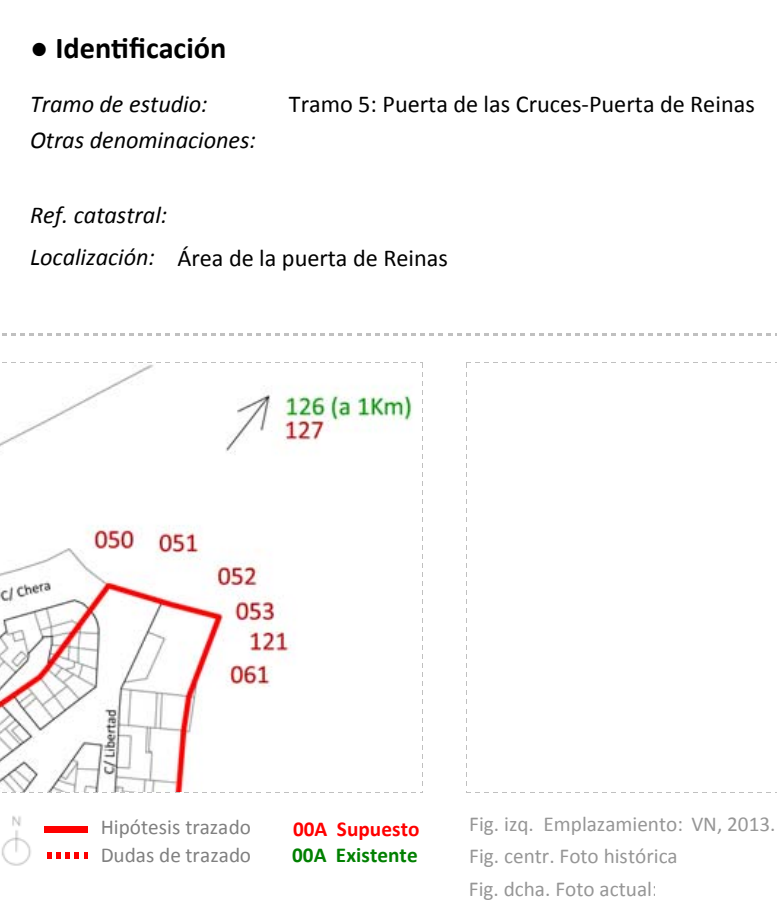

- Referencias en documentación histórica

\section{Referencias numéricas en cartografía sobre fortificación}

-Ref. en el croquis de Ortiz de Pinedo (1837-38, AGM, núm. 262): Sin ref.

-Ref. en plano de Vera Aparici (1993): Sin ref.

Referencias en memorias técnicas militares

-Ref. Guillermo Sáez (9/9/1834-5/12/1835): Sin ref.

-Ref. Guillermo Sáez (26/02/1836): Sin ref.

-Ref. P. Ortiz de Pinedo (12/03/1837-30/05/1837): Sin ref.

-Ref Jose María de Orozco (25/03/1838): Sin ref.

-Ref. Carbonell (4/7/1838): AMR, 1818-17, fol. 17

"Para proporciónar mayor flanquéo á la puerta de Reinas, se dará mas altúra á la tapia que hav á la izquiérda, estendiéndolo por encima caballete del tejado se levantará un trozo de tabicón á fin de evitar la enfiláda" (Carbonell, Requena, 4 de julio de 1838, AMR, 1818-17, fol. 17).

\section{- Observaciones a partir de los informes militares}

Se trata de un corral emplazado en la Puerta de Reinas. Parece ubicarse en el sector Noreste del espolón que configura la ciudad en este de Reinas.
Existe actualmente

Incluido en fichas PGOU 2013

Bien de interés cultural (BIC)

cód. postal: 46340

Comarca: Plana de Requena-Utie

Autonomia: Comunidad Valencian 


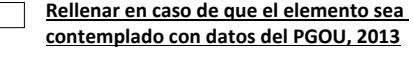

\section{PROTECCIÓN}

Nivel de protección:

$\square$ Bien de interés cultural (BIC)

$\square$ Inmueble

$\square$ Parcela catastral

Recinto arquitectónico

$\square$ Entorno específic

$\square$ Afectado entorno BIC

$\square$ Afectado Plan especial

\section{- Descripción histórico-arquitectónica}

Tipología:

Cronología:

Observaciones a la cronología:

Descripción

- Entorno urbano

Descripción entorno urbano:

Uso actual:

Estado de conservación:

Intervenciones:

Régimen Urbanistico:

Titularidad:

Nivel protección s/catálogo 1996:

Bibliografía: AMR, 1818-17, 1818-24; 1818-50; 1818-52; 1818-53.

Observaciones generales:

\section{OBJETIVACIÓN DE INTERÉS}

$\square$ Interés tipológico

$\square$ Valor ambiental

$\square$ Vigencia de la trama

$\square$ Materiales, color, textura

Soluciones constructivas
$\square$ Estructura
$\square$ Aleros
$\square$ Coronación
$\square$ Jambas
$\square$ Dinteles

\section{Soluciones ornamentales}

\section{$\square$ Carpintería}

Rejería

$\square$ Cubrepersianas

Alicatados

$\square$ Dinteles

Otros ornamentos

\section{Interés paisajistico}

$\square$ Incidencia visual

Carácter articu do

Organización

$\square$ Carácter representativo

\section{- Datos específicos catalogación BIC}

$\square$ Rellenar sólo si está catalogado BIC

Datos Jurídicos:

Código:

Estado:
Categoria:

Anotación Mo:

Fecha Disposición:

Plan:

Informe:

Fecha informe:

Fecha Publicación BOP:

Fecha Publicación DOCV:

Fecha Publicación BOE:

\section{Puerta de Reinas}

\section{- Identificación}

Tramo de estudio:

Tramo 6: Puerta de Reinas-Puerta de Valencia

Otras denominaciones:

Existe actualmente

Incluido en fichas PGOU 2013

Bien de interés cultural (BIC)

cód. postal: 46340

Municipio: Requena

Comarca: Plana de Requena-Utiel

Provincia: Valencia

Localización: Extremo Norte de la C/Libertad/ C/Chelva.

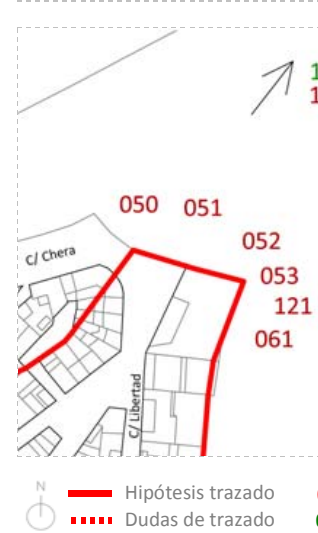

- Referencias en documentación histórica

\section{Referencias numéricas en cartografía sobre fortificación}

-Ref. en el croquis de Ortiz de Pinedo (1837-38, AGM, núm. 262): 003

-Ref. en plano de Vera Aparici (1993): Sin ref.

Referencias en memorias técnicas militares

-Ref. Guillermo Sáez (9/9/1834-5/12/1835): Sin ref.

-Ref. Guillermo Sáez (26/02/1836): Sin ref.

-Ref. P. Ortiz de Pinedo (12/03/1837-30/05/1837): Sin ref.

-Ref Jose María de Orozco (25/03/1838): Sin ref.

-Ref. Carbonell (4/7/1838): Sin ref.

\section{- Observaciones a partir de los informes militares}

Lo único que se conoce de esta Puerta es que constituiría el punto de salida de la ciudad en dirección a Chera, que constituía el camino de Carros a Valencia según el plano de Ortiz y Pinedo. Se denomina así porque la carretera conduce a la fuente del mismo nombre. El ser el principal punto de ataque para tomar las Peñas por parte de Cabrera en 1835 , y dada la consolidación de la guerra de partidas, esta puerta requiere ser defendida por diversas baterías que se adosarán a las casas o huertos preexistentes. La Batería Vieja, por lo visto, quedaba escorada al Noreste y no llegaba a batir San Francisco, por lo que hubo de incorporarse una nueva batería para sostener el duelo artillero con la Loma y San Francisco en caso de que fueran tomadas por el enemigo. 
$\square$ Rellenar en casso de que ele elemento sea

\section{PROTECCIÓN}

AFECCIÓN PATRIMONIAL

Nivel de protección: $\quad \square$ Bien de interés cultural (BIC)

$\square$ Bien de relevancia local (BRL)

$\square$ Inmueble

$\square$ Afectado entorno BIC

Pecinto arquitectónico

$\square$ Entorno específico

$\square$ Afectado Plan especial

\section{- Descripción histórico-arquitectónica}

Tipología:

Cronología:

Observaciones a la cronología:

\section{Descripción}

- Entorno urbano

Descripción entorno urbano:

Uso actual:

Estado de conservación:

Intervenciones:

Régimen Urbanistico:

Titularidad:

Nivel protección s/catálogo 1996:

Bibliografía: AMR, 1818-17, 1818-24; 1818-50; 1818-52; 1818-53.

Observaciones generales:

\section{OBJeTIVACIÓN DE INTERÉS}

$\square$ Interés tipológico

$\square$ valor ambiental

$\square$ Vigencia de la trama

$\square$ Materiales, color, textura

Soluciones constructivas
$\square$ Estructura
$\square$ Aleros
$\square$ Coronación
$\square$ Jambas
$\square$ Dinteles

\section{Soluciones ornamentales}

$\square$ Carpintería

Rejería

$\square$ Cubrepersianas

$\square$ Alicatados

Recercos

Otros ornamentos

Interés paisajístico

$\square$ Incidencia visual

Carácter articul

Organización

Carácter representativo

\section{- Datos específicos catalogación BIC $\square$ Rellenar sólo si está catalogado BIC}

Datos Jurídicos:

$\begin{array}{lll}\text { Datos Juridicos: } & \text { Fecha Disposición: } & \text { Fecha informe: } \\ \text { Código: } & \text { Tipo delimitación: } & \text { Fecha Publicación BOP: } \\ \text { Estado: } & \text { Plan: } & \text { Fecha Publicación DOCV: } \\ \text { Categoría: } & \text { Informe: } & \text { Fecha Publicación BOE: }\end{array}$

\section{Desde la Puerta de Reinas al fortín del huerto de Parra}

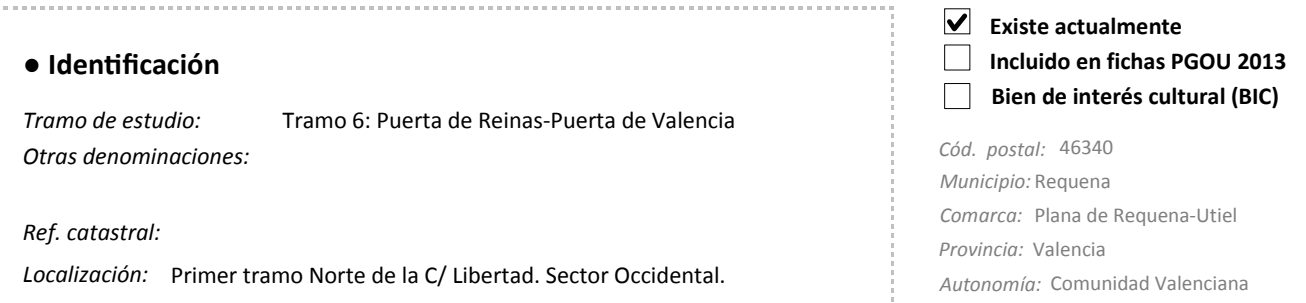

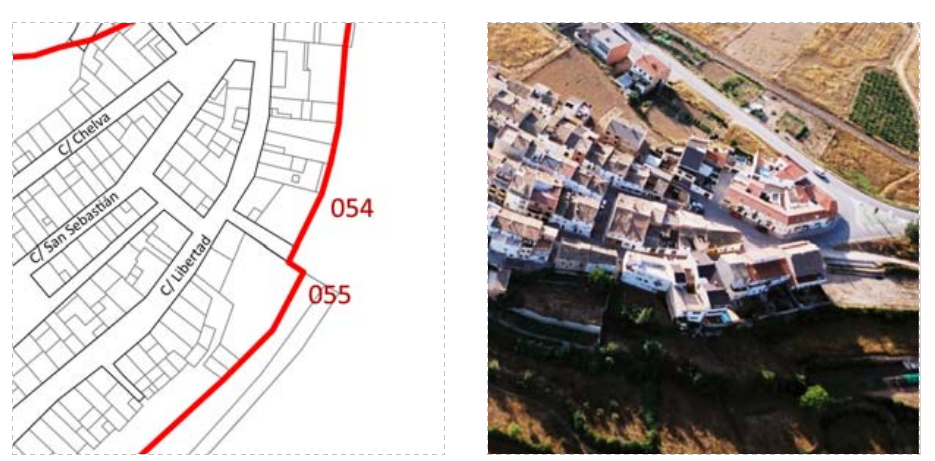

-.... Hipótesis trazado

DoA Supuesto Fig. izq. Emplazamiento: VN, 2013

Fig. centr. Foto histórica Posibl

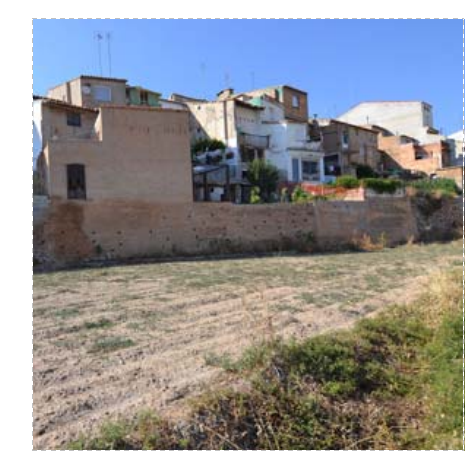

- Referencias en documentación histórica

Referencias numéricas en cartografía sobre fortificación

-Ref. en el croquis de Ortiz de Pinedo (1837-38, AGM, núm. 262): Sin ref.

-Ref. en plano de Vera Aparici (1993): Sin ref.

Referencias en memorias técnicas militares

-Ref. Guillermo Sáez (9/9/1834-5/12/1835): Sin ref.

-Ref. Guillermo Sáez (26/02/1836): Sin ref.

-Ref. P. Ortiz de Pinedo (12/03/1837-30/05/1837): Sin ref.

-Ref Jose María de Orozco (25/03/1838): Sin ref.

-Ref. Carbonell (4/7/1838): AMR, 1818-17, fol. 18

"Se realzarán las parédes de modo que partiéndo desde la parte superior de la garita de la puerta, no bajen en ningún punto de 4 . baras de altúra. Sobre el nibel del terréno. Tambien convendrá reforzárlas y rebocárlas en algún paráje en que lo necesíten" (Carbonell,

Requena, 4 de julio de 1838, AMR, 1818-17, fol. 18).

\section{- Observaciones a partir de los informes militares}

Existen muchas dudas sobre el sector Septentrional de Barrio de las Peñas. El espolón triangular Norte hasta el primer saliente 055 podría constituir el emplazamiento del complejo fortificado constituido por las baterias y la puerta de Reinas. Sobre el que se construyen las
edificaciones de los extremos septentrionales de las calles Libertad, San Sebastián o Chelva. Por lo que este tramo del recinto podría iniciarse en el punto 055 . 
$\square \frac{\text { Rellenar en caso de que el elemento sea }}{\text { contempladoco dea }}$

PROTECCIÓN

AFECCIÓN PATRIMONIAL

$\begin{array}{ll}\text { Nivel de protección: } & \square \text { Bien de interés cultural (BIC) } \\ & \square \text { Bien de relevancia local (BRL) }\end{array}$

Entorno:

$\square$ Inmueble

$\square$ Parcela catastral

$\square$ Recinto arquitectónico

$\square$ Afectado entorno BIC

$\square$ Afectado Plan especial

\section{- Descripción histórico-arquitectónica}

\section{Tipología:}

Cronología:

Observaciones a la cronología:

Descripción:

- Entorno urbano

Descripción entorno urbano:

Uso actual:

Estado de conservación:

Intervenciones:

Régimen Urbanístico:

Régimen Urb

Nivel protección s/catálogo 1996:

Bibliografía: AMR, 1818-17, 1818-24; 1818-50; 1818-52; 1818-53.

Observaciones generales:

\section{OBJETIVACIÓN DE INTERÉS}

$\square$ Interés tipológico

$\square$ Valor ambiental

Vigencia de la trama

Composición de la fachada

Soluciones constructivas
$\square$ Estructura
$\square$ Aleros
$\square$ Coronación
$\square$ Jambas
$\square$ Dinteles

\section{Soluciones ornamentales}

$\square$ Carpintería

Rejería

$\square$ Cubrepersianas

Alicatados

Dinteles

$\square$ Otros ornamentos

\section{Interés paisajístico \\ $\square$ Incidencia visual \\ $\square$ Carácter articulador \\ Organización \\ Interés cultural \\ $\square$ Carácter representativo}

Datos especificos catalogación BIC

$\square$ Rellenar sólo si está catalogado BIC

Datos Jurídicos:

Código:

Estado:

a Disposición:

Anotación $M$

Tipo delimitacion:

Plan:

Informe:

Fecha informe:

Fecha Publicación BOP:

Fecha Publicación DOCV:

Fecha Publicación BOE:

\section{Huerto de Parra}

\section{- Identificación}

Tramo de estudio: Tramo 6: Puerta de Reinas-Puerta de Valencia

Otras denominaciones:

Ref. catastral:

Localización: C/ Libertad. Sector Occidental.

$\square$ Existe actualmente

Incluido en fichas PGOU 2013

Bien de interés cultural (BIC)

cód. postal: 46340

Municipio: Requena

Comarca: Plana de Requena-Utie

Provincia: Valencia

Autonomia: Comunidad Valenciana

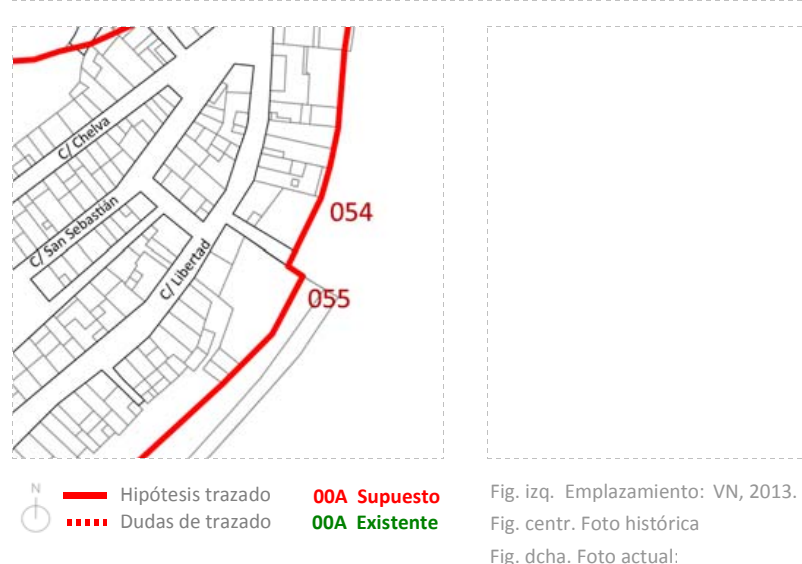

- Referencias en documentación histórica

Referencias numéricas en cartografía sobre fortificación

-Ref. en el croquis de Ortiz de Pinedo (1837-38, AGM, núm. 262): Sin ref.

-Ref. en plano de Vera Aparici (1993): Sin ref.

Referencias en memorias técnicas militares

-Ref. Guillermo Sáez (9/9/1834-5/12/1835): Requena, 5/12/1835 AMR, 1818-50

Levantar la pared que mira a Reinas. La obra depende de la villa.

-Ref. Guillermo Sáez (26/02/1836): Sin ref.

-Ref. P. Ortiz de Pinedo (12/03/1837-30/05/1837): Sin ref.

-Ref Jose María de Orozco (25/03/1838): Requena, 25/03/1838, AMR 1818-24

En el ángulo saliente del huerto se propone "formar bien y firme" la Banqueta, dado que en este momento sólo existen unos "palos" por los que no pueden transitar los hombres en caso de tener que disponerse para hacer fuego.

-Ref. Carbonell (4/7/1838): AMR, 1818-17, fol. 18

"Deben cortárse unos olmos contiguos al recinto [que] facilitan sobre manéra la escaláda" (Carbonell, Requena, 4 de julio de 1838, AMR, 1818-17, fol. 18).

- Observaciones a partir de los informes militares

Un huerto que mira hacia el regajo de Reinas y una de cuyas paredes queda a la derecha de la Puerta de Reinas 
$\square$ Rellenar en caso de que el elemento sea

PROTECCIÓN

Nivel de protección:

AFECCIÓN PATRIMONIAL

$\square$ Inmueble

Parcela catastral

$\square$ Recinto arquitectó

$\square$ Bien de interés cultural (BIC)

$\square$ Afectado entorno BIC

\section{- Descripción histórico-arquitectónica}

\section{Tipología:}

Cronología:

Observaciones a la cronologia:

Descripción:

- Entorno urbano

Descripción entorno urbano:

Uso actual:

Estado de conservación:

Intervenciones:

Régimen Urbanístico

Titularidad:

Nivel protección s/catálogo 1996:

Bibliografía: AMR, 1818-17, 1818-24; 1818-50; 1818-52; 1818-53.

Observaciones generales:

\begin{tabular}{|c|c|c|}
\hline BJETIVACIÓN DE INTERÉS & Soluciones constructivas & Soluciones ornamentales \\
\hline Interés tipológico & $\square$ Estructura & $\square$ Carpintería \\
\hline Valor ambiental & $\square$ Aleros & \\
\hline Vigencia de la trama & Coronación & cubrepersianas \\
\hline Composición de la fachada & $\square$ Jambas & $\square$ Alicatados \\
\hline Materiales, color, textura & $\square$ Dinteles & $\square$ Recercos \\
\hline & & $\begin{array}{l}\square \text { Dinteles } \\
\square \text { Otros ornamentos }\end{array}$ \\
\hline
\end{tabular}

- Datos específicos catalogación BIC $\square$ Rellenar sólo si está catalogado BIC

Datos Jurídicos:

Estado:

Categoría:

Anotación $M$

Fecha Disposicion:

Plan:

Fecha informe:

Fecha Publicación BOP:

Fecha Publicación DOCV:

Fecha Publicación BOE:
Interés paisajistico

$\square$ Incidencia visual

Carácter artic

Interés cultural

Carácter representativo

\section{Huerto de Fernández}

\section{- Identificación}

Tramo de estudio:

Otras denominaciones:

Tramo 6: Puerta de Reinas-Puerta de Valencia

Ref. catastral:

Localización: C/ Libertad. Sector Occidental.

$\square$ Existe actualmente

Incluido en fichas PGOU 2013

Bien de interés cultural (BIC)

Cód. postal: 4634

Municipio: Requena

Comarca: Plana de Requena-Utie

Provincia: Valenci

Autonomía: Comunidad Valencian
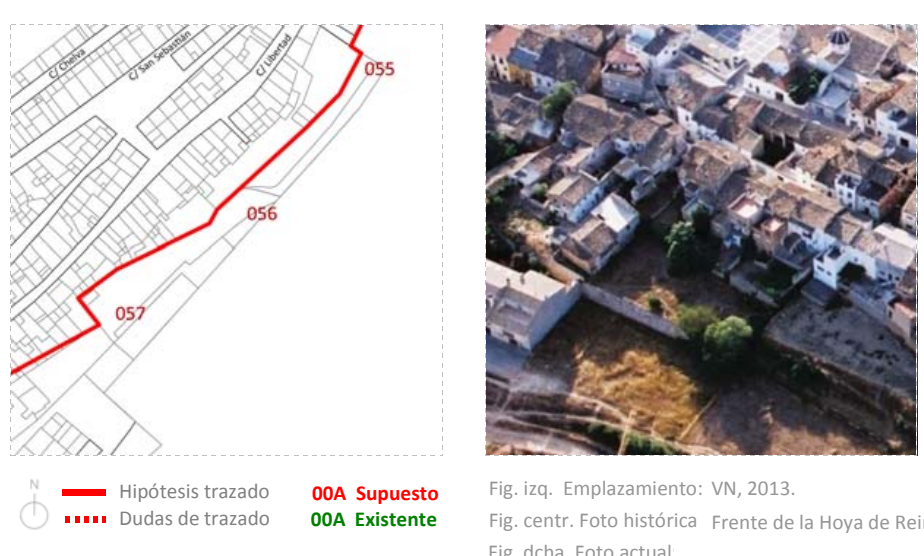

Referencias en documentación histórica

\section{Referencias numéricas en cartografía sobre fortificación}

-Ref. en el croquis de Ortiz de Pinedo (1837-38, AGM, núm. 262): Sin ref.

-Ref. en plano de Vera Aparici (1993): Sin ref.

Referencias en memorias técnicas militares

-Ref. Guillermo Sáez (9/9/1834-5/12/1835): Requena, 5/12/1835 AMR, 1818-50

En la pared del huerto que mira a Reinas se propone la ejecución de un foso que corre a cargo de la villa. No así sucede con el

levantamiento de la pared del huerto que mira a Reinas, que debe sufragarlo el propietario.

-Ref. Guillermo Sáez (26/02/1836): Sin ref.

-Ref. P. Ortiz de Pinedo (12/03/1837-30/05/1837): Sin ref.

-Ref Jose María de Orozco (25/03/1838): Sin ref.

-Ref. Carbonell (4/7/1838): Sin ref.

\section{- Observaciones a partir de los informes militares}

Un huerto que mira hacia el regajo de Reinas. Las ubicaciones son aproximadas y habría que identificar el emplazamiento exacto de estos huertos. Pero podria ocupar el sector que discurre entre el punto 056 y 057 . Parecen constituir el conjunto de huertos abancalados que $s$ habla de diversas paredes pero sólo de una que mira hacia Reinas con misión defensiva, lo cual corroboraría la hipótesis de 
$\square$ Rellenar en caso de que el elemento sea
contemplado con datos del PGoU, 2013

\section{PROTECCIÓN}

Nivel de protección

Entorno:

$\square$ Inmueble

Parcela catastral
Recinto arquitectón

$\square$ Recinto arquitectónico

AFECCIÓN PATRIMONIAL

$\square$ Bien de interés cultural (BIC)

$\square$ Afectado entorno BIC

\section{Frente de la Hoya de Reinas}

- Identificación

Tramo de estudio: Tramo 6: Puerta de Reinas-Puerta de Valencia

Otras denominaciones: Casas de Don Nicolás Pérez, Casa de las Bobas, casa de Ans

Ref. catastral:

Localización: C/ Libertad. Sector Occidental.

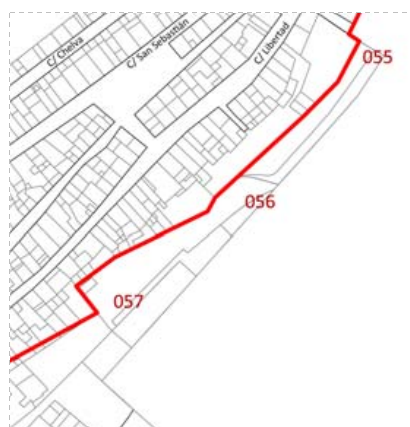

— Hipótesis trazado

OOA Supuesto

$\begin{array}{ll}\text { Soluciones ornamentales } & \text { Interés paisajistico } \\ \square \text { Carpintería } & \square \text { Incidencia visual } \\ \square \text { Rejería } & \square \text { carácter articulador } \\ \square \text { cubrepersianas } & \square \text { Organización } \\ \square \text { Alicatados } & \square \text { Interés cultural } \\ \square \text { Recercos } & \square \text { Carácter representativo }\end{array}$

$\square$ Interés cultural

Recercos

$\square$ Otros ornamento

\section{- Referencias en documentación histórica}

\section{Referencias numéricas en cartografía sobre fortificación}

-Ref. en el croquis de Ortiz de Pinedo (1837-38, AGM, núm. 262): Sin ref.

-Ref. en plano de Vera Aparici (1993): Sin ref.

Referencias en memorias técnicas militares

-Ref. Guillermo Sáez (9/9/1834-5/12/1835): Requena, 5/12/1835 AMR, 1818-50

Tienen que tapiar con ripio y piedra o "hazerlas de tirante" las puerta de las casas de Don Nicolás Pérez, la de Las Bobas, la de Anselmo Biana, la de Juan Antonio Monsalve que miran a las huertas de Reinas). Las obras dependen de los particulares.

-Ref. Guillermo Sáez (26/02/1836): Sin ref.

-Ref. P. Ortiz de Pinedo (12/03/1837-30/05/1837): Sin ref.

Según el plano de Ortíz de Pinedo se observa que cerrando los huertos, al sureste del muro aspillerado que constituye el frente de

edificación de las Higuerillas, se plantea un segundo muro que confina la amplia superficie de huertas que quedan entre el límite de tas peñas y el desnivel de la hoya. Sin embargo en la propuesta de 1835 sólo se cita la calle. Sin hablar de intervención.

-Ref Jose María de Orozco (25/03/1838): Sin ref.

-Ref. Carbonell (4/7/1838): Sin ref.

\section{- Observaciones a partir de los informes militares}

La calle Reinas, discurre hoy al sureste de la de Higuerillas, acompañando al Regajo de Reina. Debia configurar el limite de la ciudad con la hoya de Reinas, por donde discurria el arroyo regajo del mismo nombre según los planos de Ortiz de Pinedo. Existian un conjunto de casas que miran a Reinas y que tienen puerta al campo: la de Don Nicolás Perrez, la de Las Bobas, la de Anselmo Biana, la de Juan Antonio Monsalve. Non debe con $\mathrm{l}$ a

$\checkmark$ Existe actualmente

has PGOU 2013

cód. postal: 46340

equena-Utiel

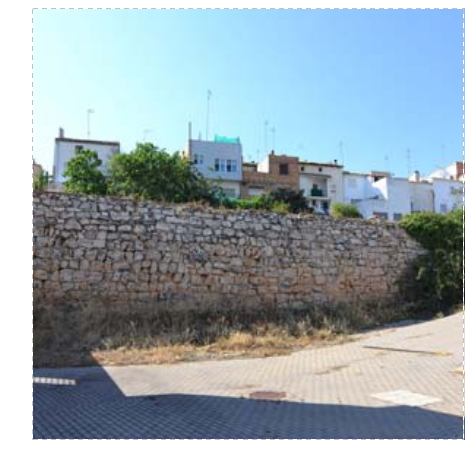

Fecha Publicación DOCV:

Plan:
Informe:
Fecha Publicación BOE:




\section{Rellenar en caso de que el elemento sea $\quad$ PROTECCIÓN}

\section{Nivel de protección:}

Entorno:

$\square$ Inmueble

$\square$ Parcela catastral

$\square$ Recinto arquitectónico

$\square$ Bien de interés cultural (BIC)

$\square$ Afectado entorno BIC

$\square$ Afectado Plan especia

\section{- Descripción histórico-arquitectónica}

Tipología:

Cronología:

Observaciones a la cronología:

Descripción:

- Entorno urbano

Descripción entorno urbano:

Uso actual:

Estado de conservación:

Intervenciones:

Régimen Urbanistico:

Titularidad:

Nivel protección s/catálogo 1996:

Bibliografía: AMR, 1818-17, 1818-24; 1818-50; 1818-52; 1818-53.

Observaciones generales:

$\begin{array}{ll}\text { OBJETIVACIÓN DE INTERÉS } & \text { Soluciones construc } \\ \square \text { Interés tipológico } & \square \text { Estructura } \\ \square \text { Valor ambiental } & \square \text { Aleros } \\ \square \text { Vigencia de la trama } & \square \text { Coronación } \\ \square \text { Composición de la fachada } & \square \text { Jambas } \\ \square \text { Materiales, color, textura } & \square \text { Dinteles }\end{array}$

Soluciones ornamentales
$\square$ Carpintería
$\square$ Rejería
$\square$ Cubrepersianas
$\square$ Alicatados
$\square$ Recercos
$\square$ Dinteles
$\square$ Otros ornamentos

Interés paisajistico
$\square$ Incidencia visual
$\square$ Carácter articulador
$\square$ Organización
$\square$ Interés cultural
$\square$ Carácter representativo

$\square$ Carácter representativo

- Datos específicos catalogación BIC $\square$ Rellenar sólo si está catalogado BIC

Datos Jurídicos:

Estado:

Categoria:

Anotación $M$

Fecha Disposición:
Tipo delimitación:
Plan:

Fecha informe:

Fecha Publicación BOP:

Fecha Publicación DOCV:

Informe:

\section{El Balsón}

\section{- Identificación}

Tramo de estudio:

Tramo 6: Puerta de Reinas-Puerta de Valencia

Otras denominaciones:

\section{Ref. catastral:}

Localización: C/ Libertad. Sector Occidental.

$\square$ Existe actualmente

Incluido en fichas PGOU 2013

Bien de interés cultural (BIC)

cód. postal: 46340

Municipio: Requena

equena-Utiel

Provincia: Valencia

Autonomía: Comunidad Valencian

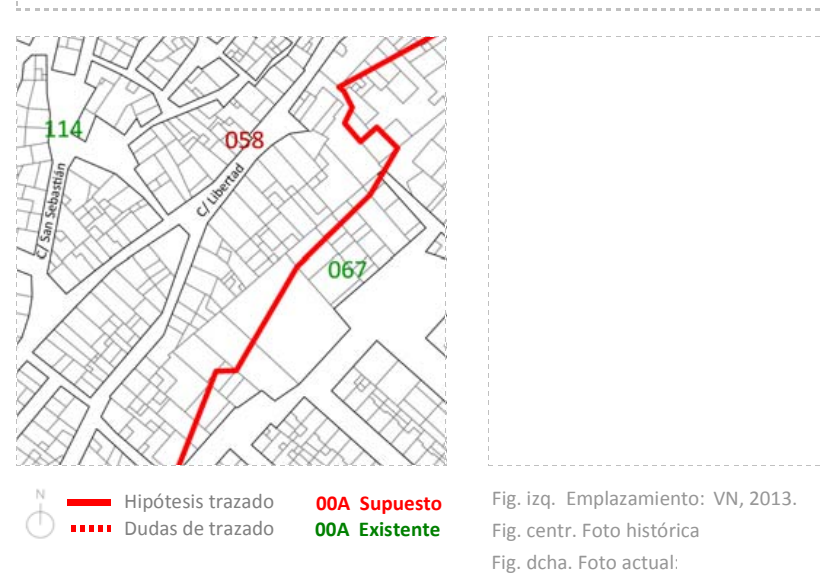

\section{- Referencias en documentación histórica}

\section{Referencias numéricas en cartografía sobre fortificación}

-Ref. en el croquis de Ortiz de Pinedo (1837-38, AGM, núm. 262): Sin ref.

-Ref. en plano de Vera Aparici (1993): Sin ref.

Referencias en memorias técnicas militare

-Ref. Guillermo Sáez (9/9/1834-5/12/1835): Sin ref.

-Ref. Guillermo Sáez (26/02/1836): Sin ref.

-Ref. P. Ortiz de Pinedo (12/03/1837-30/05/1837): Sin ref.

-Ref Jose María de Orozco (25/03/1838): Sin ref.

-Ref. Carbonell (4/7/1838): Sin ref.

\section{- Observaciones a partir de los informes militares}

En los informes militares se hace referencia a un balsón. Pero a la hora de fijar la significación del citado balsón, es conveniente recordar la definición que la Real Academia hace del término como un terreno fangoso. Existe constancia de un Molino del Balsón o de las Peñas, se encontraba "en la Calle Libertad 44, siendo su propietaria Carmen Teruel, nacida en 1918, lo heredó de su padre José Antonio Teruel Pérez, el cuál lo adquirió hacia 1922, Carmen vive desde hace 75 años en dicho molino, fue el primer molino situado en el Barrio de las Peñas de Requena, tenia derecho a toda el agua los miércoles, jueves, viernes y sábado; domingo y lunes nada; martes unas seis horas, procedente del Manantial de Reinas. Molía cebada, trigo y maíz (arazá). Posee un solo juego de piedras. Molian de dia y de noche excepto cuando se regaba. Tralan grano de Valencia a moler siguiendo el régimen de maquila se quedaban un porcentaje de la molienda (AMR, circula en la base del conjunto de edificaciones del frente denominado de la Hoya de Reinas. Pero el balsón también podria acequia referencia al terreno cenagoso que constituía la denominada Balsa de Moros. Terreno ocupado por una urbanización a la salida a Valenci. Existe antes de llegar a la aldea de Campo Arcís una pista denominada Camino del Balsón que conduce a un yacimiento del mismo nombre (PGOU,2013, Ficha de catálogo de yacimientos arqueológicos, 106). Los límites del yacimiento precisamente los definen dos ramblas, la del Balsón y la de los Pozos. 
$\square$ Rellenar en caso de que el elemento sea

\section{ROTECCIÓN}

AFECCIÓN PATRIMONIAL

Nivel de protección

$\square$ Bien de interés cultural (BIC)

Entorno:

$\square$ Inmueble

$\square$ Parcela catastral

$\square$ Recinto arquitectónic

$\square$ Afectado entorno BIC

\section{- Descripción histórico-arquitectónica}

\section{Tipología:}

Cronologia:

Observaciones a la cronologia

Descripción:

- Entorno urbano

Descripción entorno urbano:

Uso actual:

Estado de conservación:

Intervenciones:

Régimen Urbanistico:

Titularidad:

Nivel protección s/catálogo 1996:

Bibliografia: AMR, 1818-17, 1818-24; 1818-50; 1818-52; 1818-53.

Observaciones generales:

$\begin{array}{lll}\text { OBJETIVACIÓN DE INTERÉS } & \text { Soluciones constructivas } & \text { Soluciones ornamentales } \\ \begin{array}{|lll}\square \text { Interés tipológico } & \square \text { Estructura } & \square \text { Carpintería } \\ \square \text { Valor ambiental } & \square \text { Aleros } & \square \text { Rejería } \\ \square \text { Vigencia de la trama } & \square \text { coronación } & \square \text { Cubrepersianas } \\ \square \text { Composición de la fachada } & \square \text { Jambas } & \square \text { Alicatados } \\ \square \text { Materiales, color, textura } & \square \text { Dinteles } & \square \text { Recercos } \\ & & \square \text { Dinteles } \\ & \square \text { otros ornamentos }\end{array}\end{array}$

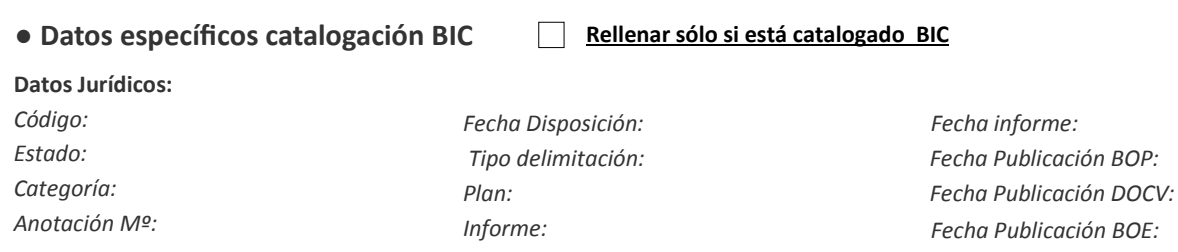

059 Molino de Herrero

\section{- Identificación}

Tramo de estudio:

Otras denominaciones:

Tramo 6: Puerta de Reinas-Puerta de Valencia

Ref. catastral:

Localización: C/ Libertad. Sector Occidenta.

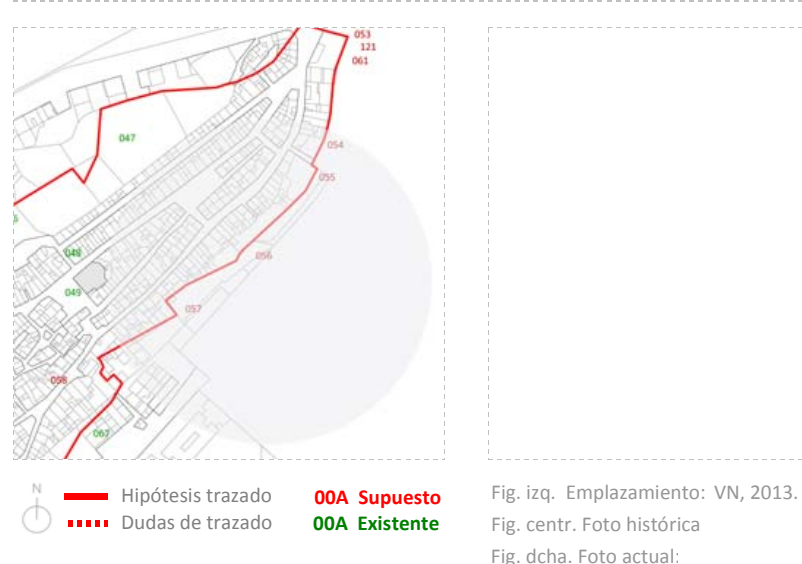

\section{- Referencias en documentación histórica}

Referencias numéricas en cartografía sobre fortificación

-Ref. en el croquis de Ortiz de Pinedo (1837-38, AGM, núm. 262): Sin ref.

-Ref. en plano de Vera Aparici (1993): Sin ref.

Referencias en memorias técnicas militares

-Ref. Guillermo Sáez (9/9/1834-5/12/1835): Sin ref.

-Ref. Guillermo Sáez (26/02/1836): Sin ref.

-Ref. P. Ortiz de Pinedo (12/03/1837-30/05/1837): Sin ref.

-Ref Jose María de Orozco (25/03/1838): Sin ref.

-Ref. Carbonell (4/7/1838):AMR, 1818-17, fol. 18

"Se hán de levántar las tapias del corral, siendo indispénsáble que asi estas como las de la casa se aspilléren. En el huerto se abrirá una cañonéra á la derécha de la garíta" (Carbonell, Requena, 4 de julio de 1838, AMR, 1818-17, fol. 18).

- Observaciones a partir de los informes militares

Molino que volcaba hacia el exterior con un huerto y un corral.

$\begin{array}{|lll|}\square \text { Rellenar en caso de que el elemento sea } & \text { PROTECCIÓN } & \text { AFECCIÓN PATRIMONIAL } \\ \text { contemplado con datos del PGOU, 2013 } & \text { Nivel de protección: } & \square \text { Bien de interés cultural (BIC) } \\ & \text { Entorno: } & \square \text { Bien de relevancia local (BRL) } \\ & \square \text { Inmueble } & \square \text { Afectado entorno BIC } \\ & \square \text { Parcela catastral } & \square \text { Afectado Plan especial } \\ & \square \text { Recinto arquitectónico } & \end{array}$

Existe actualmente

Incluido en fichas PGOU 2013

Bien de interés cultural (BIC)

cód. postal: 46340

Comarca: Plana de Requena-Utie

Provincia: Valencia

Autonomía: Comunidad Valencian 
- Descripción histórico-arquitectónica

Tipología:

Cronología:

Descripción:

\section{- Entorno urbano}

Descripción entorno urbano:

Uso actual:

Estado de conservación:

Intervenciones:

Régimen Urbanistico:

Titularidad:

Nivel protección s/catálogo 1996:

Bibliografía: AMR, 1818-17, 1818-24; 1818-50; 1818-52; 1818-53.

Observaciones generales:

\section{OBJETIVACIÓN DE INTERÉS}

$\square$ Interés tipológico

$\square$ Valor ambiental

Vigencia de la trama

Soluciones constructiva
$\square$ Estructura
$\square$ Aleros
$\square$ coronación
$\square$ Jambas
$\square$ Dinteles

Soluciones ornamentales
$\square$ Carpintería
$\square$ Rejería
$\square$ Cubrepersianas
$\square$ Alicatados
$\square$ Recercos
$\square$ Dinteles
$\square$ Otros ornamentos

Interés paisajistico

$\square$ Incidencia visual

$\square$ Carácter articulador

$\square$ Organización

$\square$ Carácter representativo
Observaciones a la cronologi

Composición de la fachada

\section{Desde el huerto de Herrero al Molino de Valero}

- Identificación

Tramo de estudio:

Tramo 6: Puerta de Reinas-Puerta de Valencia

Otras denominaciones:

Ref. catastral:

Localización: C/ Libertad. Sector Occidental.

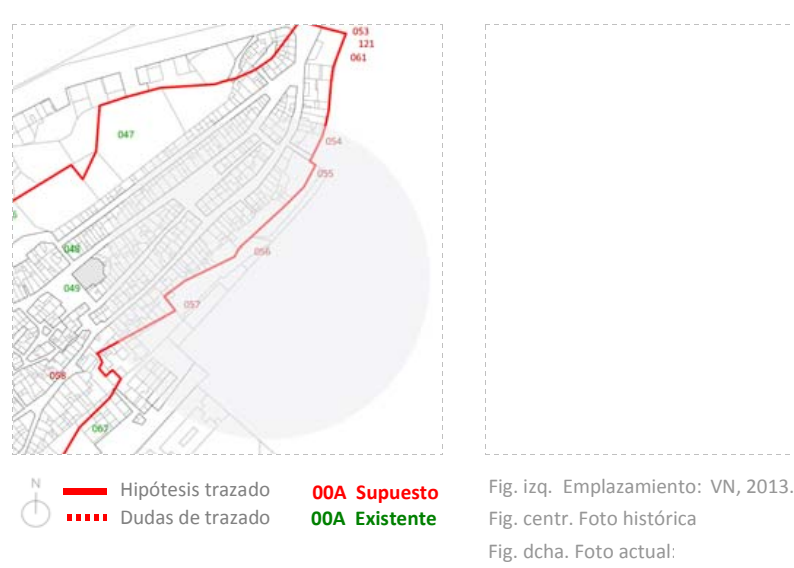

- Referencias en documentación histórica

\begin{tabular}{|c|c|c|}
\hline \multicolumn{3}{|c|}{$\square$ Rellenar sólo si está catalogado BIC } \\
\hline \multicolumn{3}{|l|}{ Datos Jurídicos: } \\
\hline Código: & Fecha Disposición: & Fecha informe: \\
\hline Estado: & Tipo delimitación: & Fecha Publicación BOP: \\
\hline Categoría: & Plan: & Fecha Publicación DOCV: \\
\hline Anotación $M \stackrel{\text { : }}{ }$ & Informe: & Fecha Publicación BOE \\
\hline
\end{tabular}

\section{Referencias numéricas en cartografía sobre fortificación}

-Ref. en el croquis de Ortiz de Pinedo (1837-38, AGM, núm. 262): Sin ref.

-Ref. en plano de Vera Aparici (1993): Sin ref.

Referencias en memorias técnicas militares

-Ref. Guillermo Sáez (9/9/1834-5/12/1835): Sin ref.

-Ref. Guillermo Sáez (26/02/1836): Sin ref.

-Ref. P. Ortiz de Pinedo (12/03/1837-30/05/1837): Sin ref.

-Ref Jose María de Orozco (25/03/1838): Sin ref.

-Ref. Carbonell (4/7/1838): AMR, 1818-17, fol. 19

"En este lienzo del recinto se encuéntran algúnos trozos de rebestimiénto de piedra seca que deben rebocarse para su mayor firméza, y que no formen escalones. Se cortarán las higuéras y matas arraigadas en las parédes. El escurridor de Francisco Ramón se há de cerrar prolongacion de las tapias de su izquiérda, dejándo un arbellón bajo para la salida de aguas. Conviene no descuidar el pronto

aspilleramiénto de las tapias del molino de Valéro en el angülo entrante, donde sirven de flanco à la parte contigua. En el tendederó de este molino se constrina un parapeto con una cañonera a fin de que siva de Bateria. Todas las casas ineriores deben aspiliterárse en las

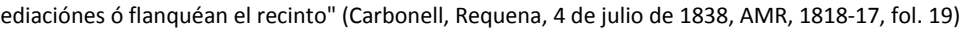

\section{- Observaciones a partir de los informes militares}

Se entiende que la distancia comprendida entre el Huerto de Herrero y el Molino de Valero constituye un nuevo frente. Exactamente un nuevo tramo de la prolongada linea fortificada que desciende en dirección Suroeste desde la puerta de Reinas. Del mismo modo que su emplazamiento actual, apoyado en la C/ Higuer las, el frente estaba integrado por huertos escalonados y un potente frente edficado flanqueo de este extenso frente. Se observa que se habla de un escurridor, una salida de aguas que se produciría desde los huertos y casas. 


\section{Rellenar en caso de aue ele lemento sea
contemplado on datos del 1 PGOU, 2013}

\section{PROTECCIÓN}

Nivel de protección:

$\square$ Inmueble

$\square$ Parcela catastral

Recinto arquitectónico

$\square$ Entorno especifico $\square$ Bien de interés cultural (BIC)

$\square$ Afectado entorno BIC

$\square$ Afectado Plan especia

\section{- Descripción histórico-arquitectónica}

Tipología:

Cronologia:

Observaciones a la cronología:

\section{Descripción}

- Entorno urbano

Descripción entorno urbano:

Uso actual:

Estado de conservación:

Intervenciones:

\section{Régimen Urbanístico:}

Titularidad:

Nivel protección s/catálogo 1996:

Bibliografía: AMR, 1818-17, 1818-24; 1818-50; 1818-52; 1818-53.

Observaciones generales:

\section{OBJETIVACIÓN DE INTERÉS}

$\square$ Interés tipológico

$\square$ Valor ambiental

Vigencia de la trama

$\square$ Materiales, color, textura

Soluciones construc
$\square$ Estructura
$\square$ Aleros
$\square$ coronación
$\square$ Jambas
$\square$ Dinteles

\section{Soluciones ornamentales}

$\square$ Carpintería

Rejería

$\square$ Cubrepersianas

$\square$ Alicatados

Recercos

$\square$ Otros ornamentos

\section{Interés paisajistico}

$\square$ Incidencia visual

Carácter articulador

Organización

Interés cultural

\section{- Datos específicos catalogación BIC $\square$ Rellenar sólo si está catalogado BIC}

Datos Jurídicos:

Código:

Estado:
Categoría:

Fecha Disposición:

Tlipo

Anotación $M$

Inform

Fecha informe:

Fecha Publicación BOP:

Fecha Publicación DOCV:

Fecha Publicación BOE:

\section{Molino de Valero}

\section{- Identificación}

Tramo de estudio:

Tramo 6: Puerta de Reinas-Puerta de Valencia

Otras denominaciones:

Existe actualmente

Incluido en fichas PGOU 2013

Bien de interés cultural (BIC)

cód. postal: 46340

Municipio: Requen

Ref. catastra:

Localización: C/ Libertad. Sector Occidental.

\section{rovincia: Valencis}

Autonomia: Comunidad Valencian

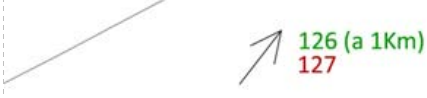

$050 \quad 051$

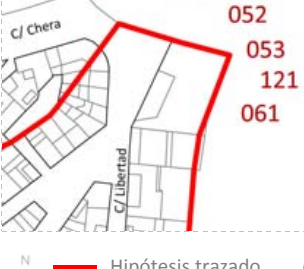

$$
\begin{array}{lll}
\text {..... Hipótesis trazado } & \text { O0A Supuesto } & \text { Fig. izq. Emplazamiento: VN, 2013 } \\
\text { O0A Existente } & \text { Fig. centr. Foto historica }
\end{array}
$$

Fig. dcha. Foto actual:

\section{- Referencias en documentación histórica}

Referencias numéricas en cartografía sobre fortificación

-Ref. en el croquis de Ortiz de Pinedo (1837-38, AGM, núm. 262): 030

-Ref. en plano de Vera Aparici (1993): Sin ref.

Referencias en memorias técnicas militares

-Ref. Guillermo Sáez (9/9/1834-5/12/1835): Sin ref.

-Ref. Guillermo Sáez (26/02/1836): Sin ref.

-Ref. P. Ortiz de Pinedo (12/03/1837-30/05/1837): Sin ref.

En el plano de Ortiz de Pinedo el Molino constituye el asentamiento para un mortero, $y$ conforma una cortina entrante flanqueada desd el noreste por el tambor de Reinas, y por el extremo suroeste con la cortina flanqueante que conforma sucesivamente todo el frente de

-Ref Jose María de Orozco (25/03/1838): Sin ref.

-Ref. Carbonell (4/7/1838): AMR, 1818-17, fol. 19

"Conviene no descuidar el pronto aspilleramiénto de las tapias del molino de Valéro en el angúlo entránte, donde sirven de flanco á la parte contigua. En el tendederó de este molino se construirá un parapéto con una cañonéra á fin de que sirva de Bateria. Todas las casas interióres deben aspillerárse en las paredes que descúbren las inmediaciónes ó flanquéan el recinto" (Carbonell, Requena, 4 de julio de 1838, AMR, 1818-17, fol. 19).

\section{- Observaciones a partir de los informes militares}

El molino de Valero se ubica contiguo al tambor de Reinas, en su esquina meridional, de acuerdo con el croquis aspillerado de Ortiz de Pinedo. Esta hipótesis desmiente la hipótesis del punto 060. Lo cual permitiría corroborar la idea de que el actual extremo Noreste de las Peñas era el actual emplazmiento del complejo constituido por la Puerta de Reinas y sus baterias. Habria que descender hacia el sur por e frente de Levante, más allá del punto 061 , para encontrar (fuera de la imagen que se acompaña) la otra posibilidad de emplazamiento de fortificación hacia el Norte y hacia el Sur. Esto llevaría a suponer que el tramo constituido por el Molino de Valero y el Huerto de o tiene una orientación diferente al frente, o tiene invertidos los términos. Es decir, que el Molino de Valero se emplazara al Norte, yel. huerto de Herrero se emplazara al sur de Este. De esto se deduce la imprecisión en todo este frente para localizar los puntos a pesar de tener claramente identificada la totalidad de su trazado. 


\section{Rellenar en caso de que el elemento sea
contemplado con datos del PGOU, 2013}

PROTECCIÓN

\section{PROTECCIÓN}

Nivel de $\mathrm{p}$

$\square$ Inmueble

$\square$ Parcela catastral

$\square$ Recinto arquitectónico
AFECCIÓN PATRIMONIAL

$\square$ Bien de interés cultural (BIC)

$\square$ Afectado entorno BIC

$\square$ Afectado Plan especial

\section{- Descripción histórico-arquitectónica}

\section{Tipología:}

Cronología:

Observaciones a la cronología:

\section{Descripción:}

\section{- Entorno urbano}

Descripción entorno urbano:

Uso actual:

Estado de conservación:

Intervenciones:

Régimen Urbanístico:

Titularidad:

Nivel protección s/catálogo 1996:

Bibliografía: AMR, 1818-17, 1818-24; 1818-50; 1818-52; 1818-53.

Observaciones generales:

\section{OBJETIVACIÓN DE INTERÉS}

$\square$ Interés tipológico

$\checkmark$ Valor ambiental

Composición de la fachada

Soluciones constructivas
$\square$ Estructura
$\square$ Aleros
$\square$ Coronación
$\square$ Jambas
$\square$ Dinteles

Soluciones ornamentales
$\square$ Carpintería
$\square$ Rejería
$\square$ cubrepersianas
$\square$ Alicatados
$\square$ Recercos
$\square$ Dinteles

Interés paisajistico

$\square$ Carácter articulado

$\square$ Organización

$\square$ Interés cultural

$\square$ Otros ornamentos

\section{- Datos específicos catalogación BIC $\square$ Rellenar sólo si está catalogado BIC}

\section{Datos Jurídicos:}

Datos Juridicos:
Código:

Estado:

Categoría:

Anotación Mo

Fecha Disposición:
Tipo delimitación:
Plan:

Fecha informe:

Fecha Publicación BOP:

Fecha Publicación DOCV:

Informe:

Fecha Publicación BOE:
Vigencia de la trama

$\square$ Incidencia visual

\section{Huerto de Valero}

\section{- Identificación}

Tramo de estudio:

Otras denominaciones:

Tramo 6: Puerta de Reinas-Puerta de Valencia

\section{Ref. catastral:}

Localización: C/ Libertad. Sector Occidental.

Existe actualmente

Incluido en fichas PGOU 2013

Bien de interés cultural (BIC)

cód. postal: 46340

Municipio: Requena

Comarca: Plana de

Provincia: Valencia
Autonomia: Comunidad Valenciana

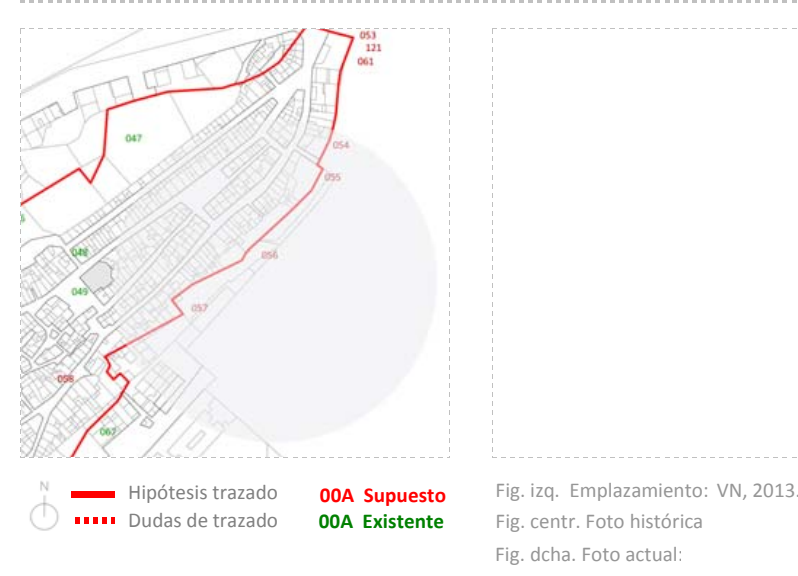

\section{- Referencias en documentación histórica}

\section{Referencias numéricas en cartografía sobre fortificación}

-Ref. en el croquis de Ortiz de Pinedo (1837-38, AGM, núm. 262): Sin ref.

-Ref. en plano de Vera Aparici (1993): Sin ref.

Referencias en memorias técnicas militares

-Ref. Guillermo Sáez (9/9/1834-5/12/1835): Sin ref.

-Ref. Guillermo Sáez (26/02/1836): Sin ref.

-Ref. P. Ortiz de Pinedo (12/03/1837-30/05/1837): Sin ref.

-Ref Jose María de Orozco (25/03/1838): Sin ref.

-Ref. Carbonell (4/7/1838): AMR, 1818-17, fol. 19

"Deben elebárse una bara mas las tapias fronterizas al [cas] del molíno, achicándo el arbellón que hay á su pie, y ensanchándo el mismo [cas] para que sirva de foso. La puerta debe cerrárse con buena obra de Albañileria" (Carbonell, Requena, 4 de julio de 1838, AMR, 181817, fol. 19).

\section{- Observaciones a partir de los informes militares}

Se entiende que se trata de un Huerto asociado al molino de Valero. Tiene sentido por ser el mismo propietario y porque comparten tapias "fronterizas". Dado que el molino lleva implicito algún canal de agua para su funcionamiento, éste, haría la funciones de foso. Parece que hay un arbellón (desaguadero de corrales y patios...) que discurre por el huerto, pegado a la pared del Molino, que se propone ensanchar para que haga las funciones de foso. 


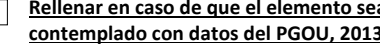

PROTECCIÓN

AFECCIÓN PATRIMONIAL

Entorno:

$\square$ Bien de interés cultural (BIC)

$\square$ Inmueble

$\square$ Parcela catastral

Recinto arquitectónico

Entorno especifico

$\square$ Afectado entorno BIC

$\square$ Afectado Plan especia

\section{- Descripción histórico-arquitectónica}

Tipología:

Cronología:

Observaciones a la cronologia:

Descripción:

- Entorno urbano

Descripción entorno urbano:

Uso actual:

Estado de conservación:

Intervenciones:

Régimen Urbanistico:

Titularidad:

Nivel protección s/catálogo 1996:

Bibliografía: AMR, 1818-17, 1818-24; 1818-50; 1818-52; 1818-53.

Observaciones generales:

\section{OBJETIVACIÓN DE INTERÉS}

$\square$ Interés tipológico

$\square$ Valor ambiental

$\checkmark$ Vigencia de la trama

$\square$ Materiales, color, textura

Soluciones constructivas
$\square$ Estructura
$\square$ Aleros
$\square$ Coronación
$\square$ Jambas
$\square$ Dinteles

\section{Soluciones ornamentales}

$\square$ Carpintería

Rejería

$\square$ Cubrepersianas

Alicatados

Recercos

$\square$ Otros ornamentos

Interés paisajistico
$\square$ Incidencia visual
$\square$ carácter articulador
$\square$ organización
$\square$ Interés cultural
$\square$ carácter representativo

- Datos especificos catalomacion $\square$ Rellenar sólo si está catalogado BIC Datos Juridicos:

Código:

Estado:

ha Disposición:

Tipo delimitacion:

Plan:

Anotación Mo

Informe:

Fecha informe:

Fecha Publicación BOP:

Fecha Publicación DOCV:

Fecha Publicación BOE:

\section{Casa de Gregoria Moral}

\section{- Identificación}

Tramo de estudio: Tramo 6: Puerta de Reinas-Puerta de Valencia

Otras denominacions:

Ref. catastral:

Localización: Área comprendida entre la Plaza de Isabel II y el extremo sur de la C/ Libertad.

Existe actualmente

Incluido en fichas PGOU 2013

Bien de interés cultural (BIC)

cód. postal: 46340

Municipio: Requena

Comarca: Plana de Requena-Utie

Provincia: Valencia

Autonomía: Comunidad Valencian

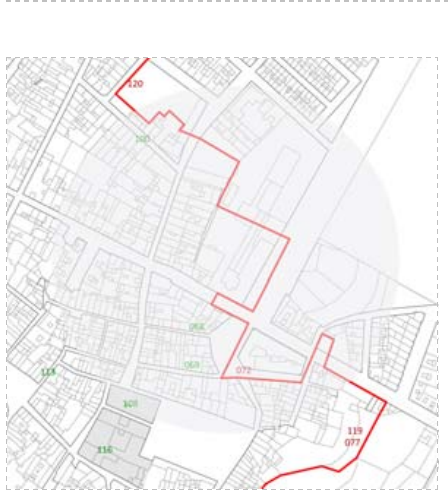

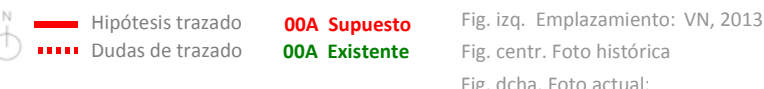

- Referencias en documentación histórica

Referencias numéricas en cartografía sobre fortificación

-Ref. en el croquis de Ortiz de Pinedo (1837-38, AGM, núm. 262): Sin ref.

-Ref. en plano de Vera Aparici (1993): Sin ref.

Referencias en memorias técnicas militares

-Ref. Guillermo Sáez (9/9/1834-5/12/1835): Sin ref.

-Ref. Guillermo Sáez (26/02/1836): Sin ref.

-Ref. P. Ortiz de Pinedo (12/03/1837-30/05/1837): Sin ref.

-Ref Jose María de Orozco (25/03/1838): Sin ref.

-Ref. Carbonell (4/7/1838): AMR, 1818-17, fol. 19

"Se abrirán algúnas aspilléras, y se reparará la pared" (Carbonell, Requena, 4 de julio de 1838, AMR, 1818-17, fol. 19).

- Observaciones a partir de los informes militares

No se sabe con exactitud su emplazamiento. Podría seguir acompañando la línea de Higuerillas o formar parte del conjunto de casas de la

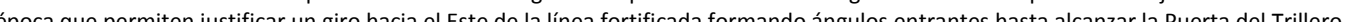

\begin{tabular}{lll}
$\square \frac{\text { Rellenar en caso de que el elemento sea }}{\text { contemplado con datos del PGoU, 2013 }}$ & PROTECCIÓN & AFECIÓN PATRIMONIAL \\
& Nivel de protección: & $\square$ Bien de interés cultural (BIC) \\
& Entorno: & $\square$ Bien de relevancia local (BRL) \\
& $\square$ Inmueble & $\square$ Afectado entorno BIC \\
$\square$ Parcela catastral & $\square$ Afectado Plan especial \\
$\square$ Recinto arquitectónico & \\
\hline$\square$ Entorno espećfico &
\end{tabular}


- Descripción histórico-arquitectónica

Tipología:

Cronología:

Observaciones a la cronología

Descripción:

\section{- Entorno urbano}

Descripción entorno urbano:

Uso actual:

Estado de conservación:

Intervenciones:

Régimen Urbanistico:

Titularidad:

Nivel protección s/catálogo 1996:

Bibliografía: AMR, 1818-17, 1818-24; 1818-50; 1818-52; 1818-53.

Observaciones generales:

$\begin{array}{llll}\text { OBJETIVACIÓN DE INTERÉS } & \text { Soluciones constructivas } & \text { Soluciones ornamentales } & \text { Interés paisajistico } \\ \square \text { Interés tipológico } & \square \text { Estructura } & \square \text { Carpintería } & \square \text { Incidencia visual } \\ \square \text { valor ambiental } & \square \text { Aleros } & \square \text { Rejería } & \square \text { carácter articulador } \\ \square \text { vigencia de la trama } & \square \text { coronación } & \square \text { Cubrepersianas } & \square \text { organización } \\ \square \text { composición de la fachada } & \square \text { Jambas } & \square \text { Alicatados } & \square \text { Interés cultural } \\ \square \text { Materiales, color, textura } & \square \text { Dinteles } & \square \text { Recercos } & \square \text { carácter representativo } \\ & & \square \text { Dinteles } & \\ & \square \text { Otros ornamentos } & \end{array}$

- Datos específicos catalogación BIC $\square$ Rellenar sólo si está catalogado BIC

$\begin{array}{lll}\text { Datos Jurídicos: } & & \\ \text { Código: } & \text { Fecha Disposición: } & \text { Fecha informe: } \\ \text { Estado: } & \text { Tipo delimitación: } & \text { Fecha Publicación BOP: } \\ \text { Categoría: } & \text { Plan: } & \text { Fecha Publicación DOCV: } \\ \text { Anotación Mo: } & \text { Informe: } & \text { Fecha Publicación BOE: }\end{array}$

Informe:

Fecha Publicación BOE:

\section{Desde la Casa de Gregoria Moral al tinte de Antonio Monsalve}

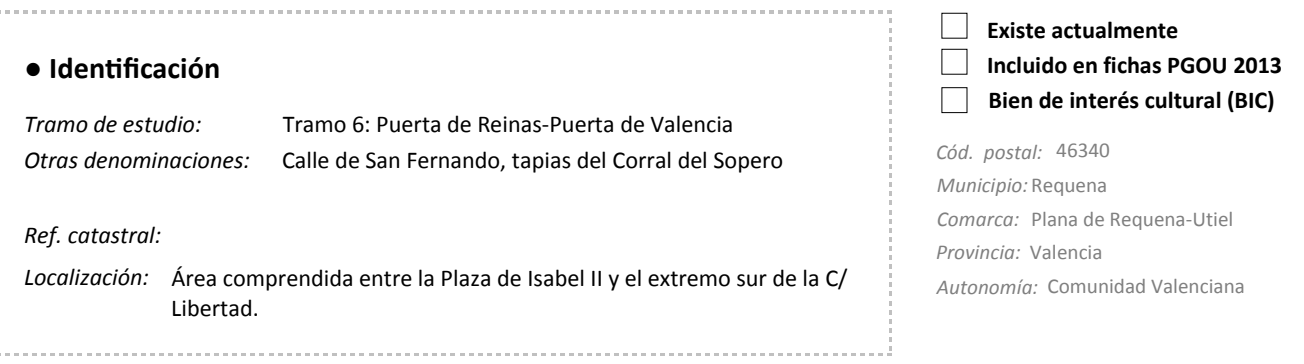

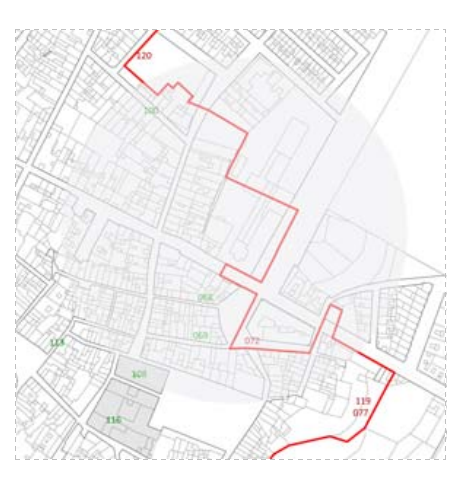

$\begin{array}{lll}\text {-.... Hipótesis trazado Dudas de trazado } & \text { 00A Supuesto } & \text { Fig. izq. Emplazamiento: VN, } 2013 . \\ & \text { O0A Existente } & \begin{array}{l}\text { Fig. centr. Foto histórica } \\ \text { Fig. dcha. Foto actual: }\end{array}\end{array}$

- Referencias en documentación histórica

Referencias numéricas en cartografía sobre fortificación

-Ref. en el croquis de Ortiz de Pinedo (1837-38, AGM, núm. 262): Sin ref.

-Ref. en plano de Vera Aparici (1993): Sin ref.

Referencias en memorias técnicas militares

-Ref. Guillermo Sáez (9/9/1834-5/12/1835): Sin ref.

-Ref. Guillermo Sáez (26/02/1836): Sin ref.

-Ref. P. Ortiz de Pinedo (12/03/1837-30/05/1837): Sin ref.

-Ref Jose Maria de Orozco (25/03/1838): Sin ref.

-Ref. Carbonell (4/7/1838): AMR, 1818-17, fol. 19

"Se guarnecerán con foso las parédes de la Calle de San Fernándo, se harán de nuebo con mayor elebacion, y las aspilléras [correspondientes], las tapias del corral del [Sopéro]. Las casas de este y demás que forman el contórno del recinto, se hán de aspillerar en todos sus pisos" (Carbonell, Requena, 4 de julio de 1838, AMR, 1818-17, fol. 19).

- Observaciones a partir de los informes militares

Al hacer referencia a este tramo, Carbonell cita las paredes de la Calle San Fernando. Dicho de otro modo, la casa de Gregoria Moral podría constituir la referencia para el giro de la fortificación a la altura de la Calle San Fernando. Sabemos que consituye el límite Noreste de la intervención urbana del siglo XVIII integrada por las Calles San Luis y San Carlos. El limite noreste de la calle estaria constituido por edificaciones que podrían ser las que se citan. Su fachada Noreste volcaría a las huertas, por lo que el objetivo sería aspillerarlas. 


\section{Rellenar en caso de que ele lemento sea
contemplado o con datos del}

\section{PROTECCIÓN}

Nivel de protección:

Entorno:

$\square$ Inmueble

$\square$ Parcela catastral

Recinto arquitectónico

$\square$ Entorno específico

- Descripción histórico-arquitectónica

Tipología:

Cronologia:

Observaciones a la cronología:

\section{Descripción}

- Entorno urbano

Descripción entorno urbano:

Uso actual:

Estado de conservación:

Intervenciones:

Régimen Urbanístico:

Titularidad:

Nivel protección s/catálogo 1996:

Bibliografía: AMR, 1818-17, 1818-24; 1818-50; 1818-52; 1818-53.

Observaciones generales:

\section{OBJETIVACIÓN DE INTERÉS}

$\square$ Interés tipológico

Valor ambiental

Vigencia de la trama

Materiales, color, textura

\section{Soluciones constructivas}

$\square$ Estructura

$\square$ Estructura
$\square$ Aleros

$\square$ Aleros

Jambas

$\square$ Dinteles
AFECCIÓN PATRIMONIAL

$\square$ Bien de interés cultural (BIC)

$\square$ Bien de relevancia local (BRL)

$\square$ Afectado entorno BIC

$\square$ Afectado Plan especia

Soluciones ornamentales
$\square$ Carpintería
$\square$ Rejería
$\square$ Cubrepersianas
$\square$ Alicatados
$\square$ Recercos
$\square$ Dinteles
$\square$ Otros ornamentos

Interés paisajistico

$\square$ Incidencia visual

$\square$ Carácter articulador

$\square$ Organización

Interés cultural

presentativo
065 Desde el torreón de Monsalve a la casa de Francisco Narbón

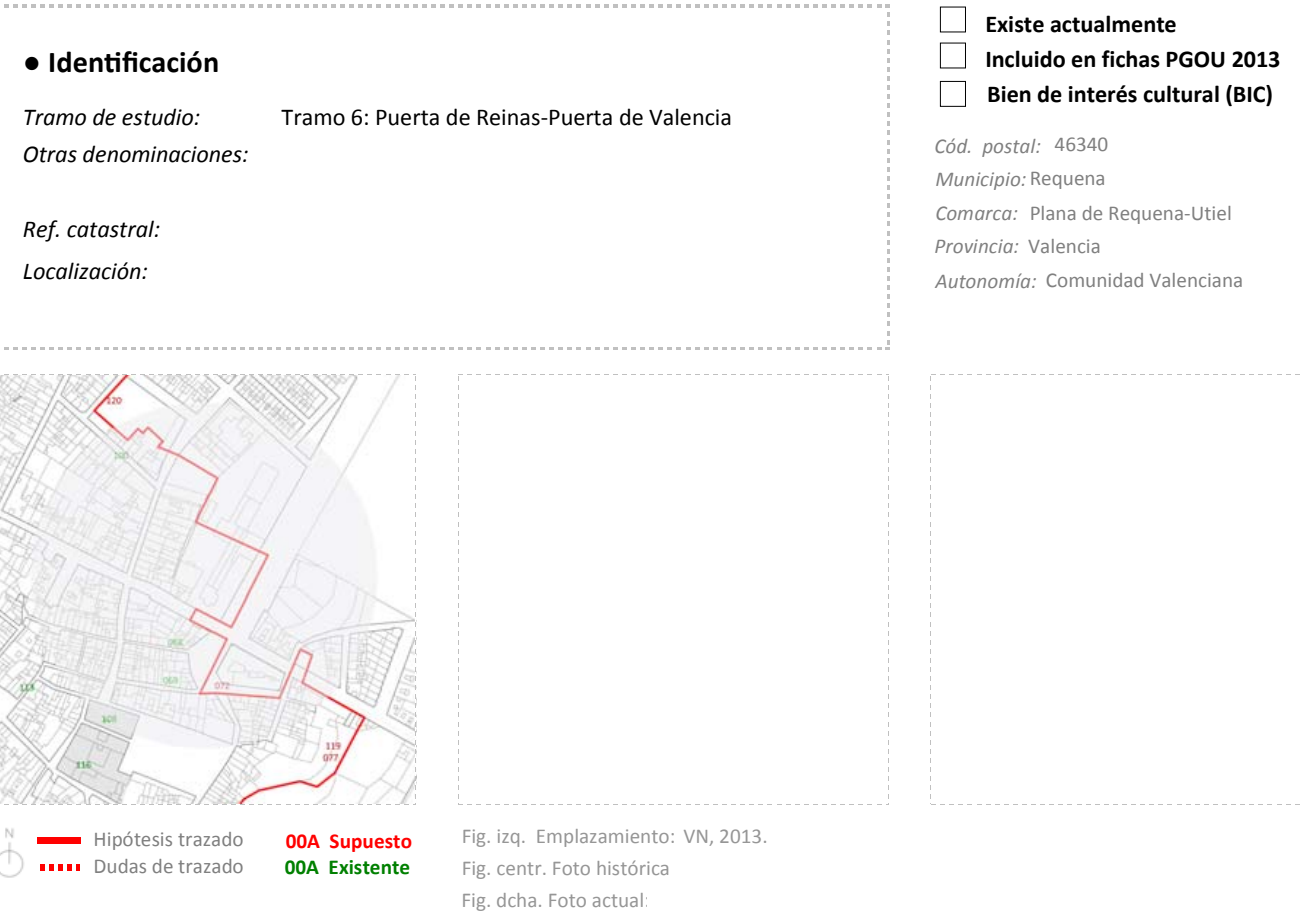

- Referencias en documentación histórica

\section{en cartografía sobre fortificación}

-Ref. en el croquis de Ortiz de Pinedo (1837-38, AGM, núm. 262): Sin ref.

-Ref. en plano de Vera Aparici (1993): Sin ref.

Referencias en memorias técnicas militares

-Ref. Guillermo Sáez (9/9/1834-5/12/1835): Sin ref.

-Ref. Guillermo Sáez (26/02/1836): Sin ref.

-Ref. P. Ortiz de Pinedo (12/03/1837-30/05/1837): Sin ref.

-Ref Jose Maria de Orozco (25/03/1838): Sin ref.

-Ref. Carbonell (4/7/1838): AMR, 1818-17, fol. 20

"En este frente se hará de nuebo la linea [perimetral] de fortificacion, abanzandola hasta las tapias que mandó construir el Señor Coronel Albornóz, lo cual se verificará segun va á indicárse. Desde el angúlo entránte del Torreón se dirijirá una linea que encuéntre á [dichas] tapias dos baras á la izquiérda del estrémo del pedázo del [Contador]: la otra linea dará frente á las casas de la Garróta, seguirá la

configuracion del ribázo que le serviráa de base, y terminará cerrándo la calle de Gil, en la esquina de la casa de [Francisco] Narbón. De este modo quedara trazáda esta parte de fortificacion, cuya altura sobre el terréno será por lo menos de cuatro baras, teniéndo además foso fortificacion interior que ahora ecsiste se conserbará, y para su comunicacion con la nueba se abrirá una puerta inmediáta al Torreón. comunicacion resúlta por la Calle de Gill por cuya causa debe colocárse una puerta en su salida" (Carbonell, Requena 4 de julio de 1838, AMR, 1818-17, fol. 20).

\section{- Observaciones a partir de los informes militares}

En relación con el Pedazo del Contador y las casas de la Garrota, C/ de Gil y casa de Francisco Narbón. Se produce un solape con las tapias construidas por el coronel Albornoz. La única referencia que tenemos clara es que el tramo cierra la muralla en la calle Gil y que

muy pronunciado entre superficies a distinto nivel. No todo el frente se apoya en el ribazo y, por ello, en esos puntos se deberá realizar un foso. Este sector también resulta confuso la hablarse de una doble línea fortificada: una primera trazada en tiempo de Albornoz (18351836) y la nueva propuesta de 1838. 
$\square \frac{\text { Rellenar en caso de que el elemento sea }}{\text { contemplado con datas del } P \text { PCoO, } 2013}$

PROTECCIÓN
Nivel de protección:
Entorno:
$\square$ Inmueble
$\square$ Parcela catastral
$\square$ Recinto arquitectónico
$\square$ Entorno específico

AFECCIÓN PATRIMONIAL

$\square$ Bien de interés cultural (BIC)

$\square$ Bien de relevancia local (BR

$\square$ Afectado entorno BIC

$\square$ Afectado Plan especia

- Descripción histórico-arquitectónica

Tipología:

Cronología:

Observaciones a la cronologia:

\section{Descripción:}

- Entorno urbano

Descripción entorno urbano:

Uso actual:

Estado de conservación:

Intervenciones:

Régimen Urbanístico:

Titularidad:

Nivel protección s/catálogo 1996

Bibliografia: AMR, 1818-17, 1818-24; 1818-50; 1818-52; 1818-53.

Observaciones generales:

$\begin{array}{llll}\text { OBJETIVACIÓN DE INTERÉS } & \text { Soluciones constructivas } & \text { Soluciones ornamentales } & \text { Interés paisajistico } \\ \square \text { Interés tipológico } & \square \text { Estructura } & \square \text { carpintería } & \square \text { Incidencia visual } \\ \square \text { valor ambiental } & \square \text { Aleros } & \square \text { Rejería } & \square \text { carácter articulador } \\ \square \text { vigencia de la trama } & \square \text { coronación } & \square \text { cubrepersianas } & \square \text { Organización } \\ \square \text { composición de la fachada } & \square \text { Jambas } & \square \text { Alicatados } & \square \text { Interés cultural } \\ \square \text { Materiales, color, textura } & \square \text { Dinteles } & \square \text { Recercos } & \square \text { carácter representativo } \\ & & \square \text { Dinteles } & \\ & \square \text { otros ornamentos } & \end{array}$

$\begin{array}{lll}\text { - Datos específicos catalogación BIC } & \square \text { Rellenar sólo si está catalogado BIC } \\ \begin{array}{lll}\text { Datos Jurídicos: } & \\ \text { Código: } & \text { Fecha Disposición: } & \text { Fecha informe: } \\ \text { Estado: } & \text { Tipo delimitación: } & \text { Fecha Publicación BOP: } \\ \text { Categoría: } & \text { Plan: } & \text { Fecha Publicación DOCV: } \\ \text { Anotación Mo: } & \text { Informe: } & \text { Fecha Publicación BOE: }\end{array}\end{array}$

066 Huerto de Don Pedro Martínez

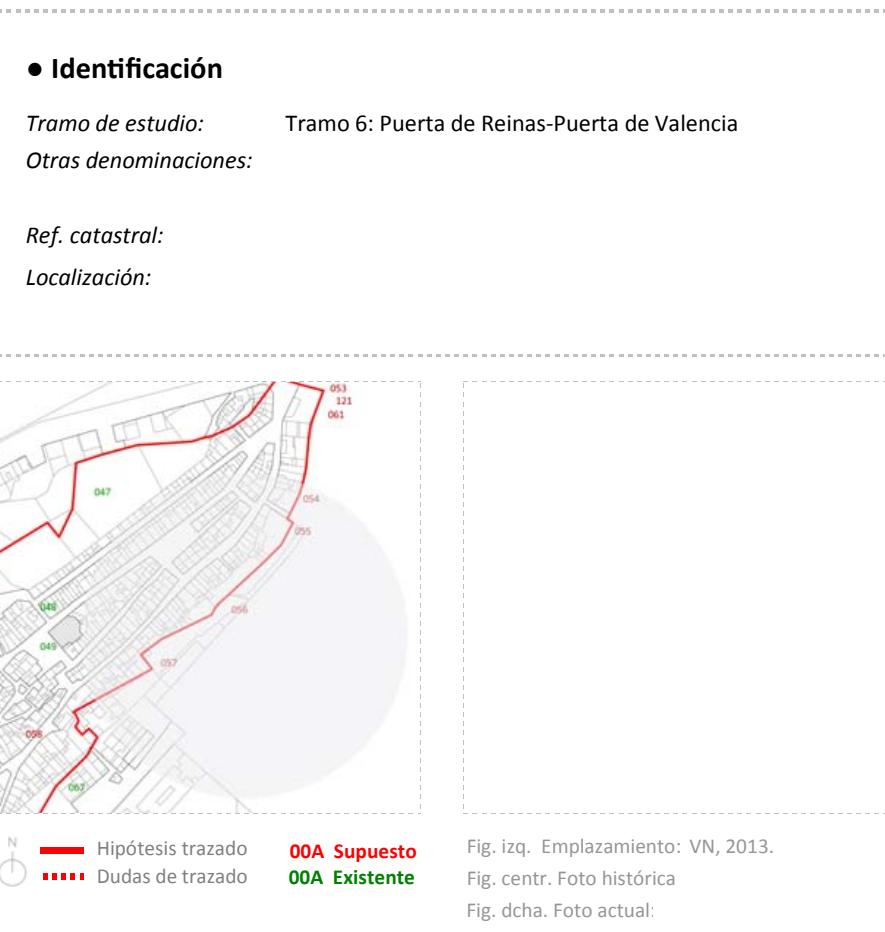

Existe actualmente

Incluido en fichas PGOU 2013

Bien de interés cultural (BIC)

Cód. postal: 46340

Municipio: Requena

Comarca: Plana de Requena-Utiel

Provincia: Valencia

Autonomia: Comunidad Valenciana

\section{- Referencias en documentación histórica}

Referencias numéricas en cartografía sobre fortificación

-Ref. en el croquis de Ortiz de Pinedo (1837-38, AGM, núm. 262): Sin ref.

-Ref. en plano de Vera Aparici (1993): 018

Referencias en memorias técnicas militares

-Ref. Guillermo Sáez (9/9/1834-5/12/1835): Requena, 5/12/1835 AMR, 1818-50

Se tapian los parapetos y se aseguran las puertas.

-Ref. Guillermo Sáez (26/02/1836): Sin ref.

-Ref. P. Ortiz de Pinedo (12/03/1837-30/05/1837): Sin ref.

-Ref Jose Maria de Orozco (25/03/1838): Sin ref.

-Ref. Carbonell (4/7/1838): Sin ref.

- Observaciones a partir de los informes militares

Existe una puerta que comunica con corrales.

$\begin{array}{|lll|}\square \text { Rellenar en caso de que el elemento sea } & \text { PROTECCIÓN } & \text { AFECCIÓN PATRIMONIAL } \\ \text { contemplado con datos del PGOU, 2013 } & \text { Nivel de protección: } & \square \text { Bien de interés cultural (BIC) } \\ & \text { Entorno: } & \square \text { Bien de relevancia local (BRL) } \\ & \square \text { Inmueble } & \square \text { Afectado entorno BIC } \\ & \square \text { Parcela catastral } & \square \text { Afectado Plan especial } \\ & \square \text { Recinto arquitectónico } & \\ \square \text { Entorno específico } & \end{array}$




\section{- Descripción histórico-arquitectónica}

Tipología:

Cronologí:

Observaciones a la cronología

\section{Descripción:}

\section{- Entorno urbano}

Descripción entorno urbano:

Uso actual:

Estado de conservación:
Intervenciones:

Régimen Urbanístico:

Titularidad:

Nivel protección s/catálogo 1996:

Bibliografía: AMR, 1818-17, 1818-24; 1818-50; 1818-52; 1818-53.

Observaciones generales:

$\begin{array}{lll}\text { OBJETIVACIÓN DE INTERÉS } & \text { Soluciones constructivas } & \text { Soluciones ornamentales } \\ \square \text { Interés tipológico } & \square \text { Estructura } & \square \text { Carpintería } \\ \square \text { Valor ambiental } & \square \text { Aleros } & \square \text { Rejería } \\ \square \text { Vigencia de la trama } & \square \text { coronación } & \square \text { cubrepersianas } \\ \square \text { composición de la fachada } & \square \text { Jambas } & \square \text { Alicatados } \\ \square \text { Materiales, color, textura } & \square \text { Dinteles } & \square \text { Recercos } \\ & & \square \text { Dinteles } \\ & & \square \text { otros ornamentos }\end{array}$

- Datos específicos catalogación BIC $\square$ Rellenar sólo si está catalogado BIC

$\begin{array}{lll}\text { Datos Jurídicos: } & & \\ \text { Código: } & \text { Fecha Disposición: } & \text { Fecha informe: } \\ \text { Estado: } & \text { Tipo delimitación: } & \text { Fecha Publicación BOP: } \\ \text { Categoría: } & \text { Plan: } & \text { Fecha Publicación DOCV: } \\ \text { Anotación Mo: } & \text { Informe: } & \text { Fecha Publicación BOE: }\end{array}$

$\square$ Organización
067 Higuerillas

\section{- Identificación}

Tramo de estudio:

Tramo 6: Puerta de Reinas-Puerta de Valencia

Otras denominaciones: Ygerillas. Frente de Higuerillas. Frente de la Hoya de Reina

Ref. catastral:

Localización: Entre la C/ Libertad y la C/ Higuerillas.

$\checkmark$ Existe actualmente

$\square$ Incluido en fichas PGOU 2013

$\square$ Bien de interés cultural (BIC)

cód. postal: 46340

Municipio: Requen

Comarca: Plana de Requena-Utiel

Provincia: Valencia

utonomia: Comunidad Valenciana
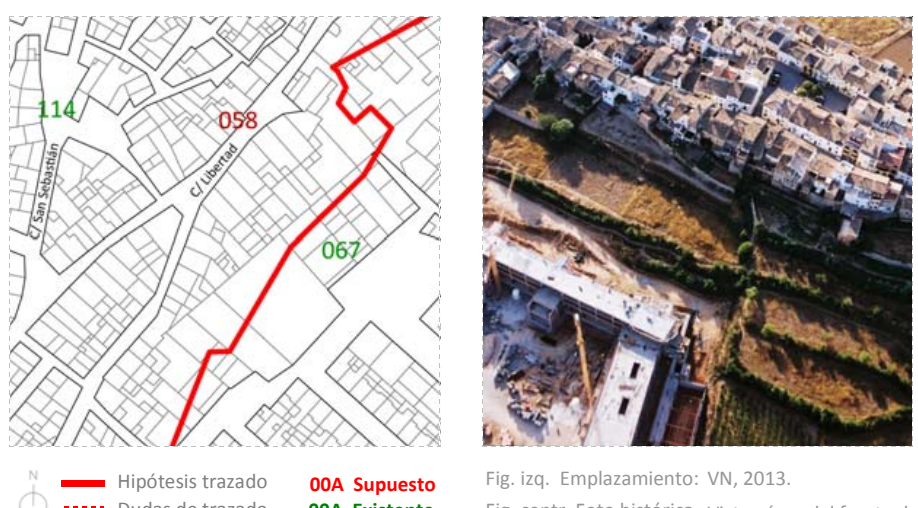

$\square$ Incidencia visual

$\square$ Carácter articulador

$\square$ Carácter representativo

\section{- Hipótesis trazado}

O0A Supuesto

Fig. izq. Emplazamiento. VN, 2013

Fig. centr. Foto histórica Vista

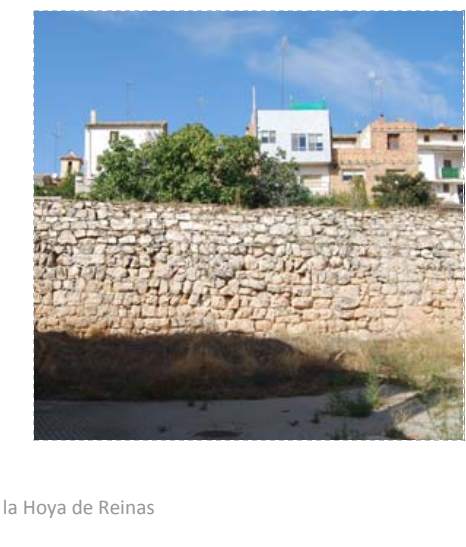

\section{- Referencias en documentación histórica}

\section{Referencias numéricas en cartografía sobre fortificación}

-Ref. en el croquis de Ortiz de Pinedo (1837-38, AGM, núm. 262): Sin ref.

-Ref. en plano de Vera Aparici (1993): 017

Referencias en memorias técnicas militare

-Ref. Guillermo Sáez (9/9/1834-5/12/1835): Requena, 5/12/1835 AMR, 1818-50

Se aseguran las puertas de los huertos y se tapia el parapeto.

-Ref. Guillermo Sáez (26/02/1836): Requena, 26/02/1836 AMR, 1818-53

Se propone cortar 3 varas de la pared $(2,51 \mathrm{~m})$ que hay entre el camino y los huertos y se une con la puerta. Recomponer tres portillos que comunican con los huertos inmediatos. Las obras dependen de la villa.

-Ref. P. Ortiz de Pinedo (12/03/1837-30/05/1837): Sin ref.

-Ref Jose María de Orozco (25/03/1838): Sin ref.

-Ref. Carbonell (4/7/1838): Sin ref.

\section{- Observaciones a partir de los informes militares}

Se hace referencia a una "puerta de Higuerillas". Con toda probabilidad una zona que recibe su nombre por la presencia de higueras. Se caracteriza por un nuevo sector de huertas asociadas a puertas. En la actualidad la calle Higuerillas transcurre paralela hacia el norte de la Avenida Reinas, y da nombre al Colegio Público. 
$\square$ Rellenar en caso de que el elemento sea

PROTECCIÓN

Nivel de protección:

AFECCIÓN PATRIMONIAL

$\square$ Inmueble

$\square$ Parcela catastral

$\square$ Recinto arquitectón

$\square$ Bien de interés cultural (BIC)

$\square$ Bien de relevancia local (BRL)

$\square$ Afectado entorno BIC

\section{- Descripción histórico-arquitectónica}

\section{Tipología:}

Cronología:

Observaciones a la cronología

Descripción:

- Entorno urbano

Descripción entorno urbano:

Uso actual:

Estado de conservación:

Intervenciones:

Régimen Urbanístico

Titularidad:

Nivel protección s/catálogo 1996:

Bibliografía: AMR, 1818-17, 1818-24; 1818-50; 1818-52; 1818-53.

Observaciones generales:

\begin{tabular}{lll} 
OBJETIVACIÓN DE INTERÉS & Soluciones constructivas & Soluciones ornamentales \\
$\square$ Interés tipológico & $\square$ Estructura & $\square$ Carpintería \\
$\square$ Valor ambiental & $\square$ Aleros & $\square$ Rejería \\
\hline$\square$ vigencia de la trama & $\square$ coronación & $\square$ Cubrepersianas \\
$\square$ Composición de la fachada & $\square$ Jambas & $\square$ Alicatados \\
$\square$ Materiales, color, textura & $\square$ Dinteles & $\square$ Recercos \\
& & $\square$ Dinteles \\
& $\square$ Otros ornamentos
\end{tabular}

- Datos específicos catalogación BIC $\square$ Rellenar sólo si está catalogado BIC

Datos Jurídicos:

Estado:

Categoría:

Anotación $M$

Fecha Disposición:

Plan:

Fecha informe:

Fecha Publicación BOP:

Fecha Publicación DOCV

Fecha Publicación BOE:
068 Calle de Gil (actual)

- Identificación

Tramo de estudio: Tramo 6: Puerta de Reinas-Puerta de Valencia

Otras denominaciones: Casa Pajar y porche de Francisco Fernández, Huerto de Nic

Ref. catastral:

Localización: C/ De Gi

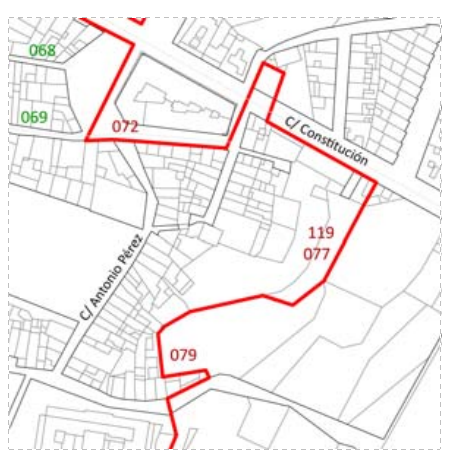

$\begin{array}{lll}\text {-.... Hipótesis trazado } & \text { 00A Supuesto } & \text { Fig. izq. Emplazamiento: VN, } 2013 \\ \text { O0A Existente } & \text { Fig. centr. Foto histórica } & \end{array}$

$\checkmark$ Existe actualmente

$\square$ Incluido en fichas PGOU 2013

$\square$ Bien de interés cultural (BIC)

cód. postal: 46340

Autonomia: Comunidad Valencia

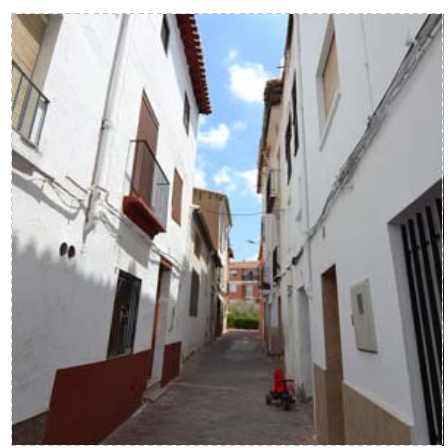

- Referencias en documentación histórica

Referencias numéricas en cartografía sobre fortificación

-Ref. en el croquis de Ortiz de Pinedo (1837-38, AGM, núm. 262): Sin ref.

-Ref. en plano de Vera Aparici (1993): 016

Referencias en memorias técnicas militares

-Ref. Guillermo Sáez (9/9/1834-5/12/1835): Requena, 5/12/1835 AMR, 1818-50

En ella se aseguraban paredes y puertas de la alineación, y se aspilleraba la casa pajar y porche de Francisco Fernández y "batir" (derribar) la pared del huerto de Nicolás Gallego, que actuaría, posiblemente, de obstáculo visual.

-Ref. Guillermo Sáez (26/02/1836): Sin ref.

-Ref. P. Ortiz de Pinedo (12/03/1837-30/05/1837): Sin ref.

-Ref Jose María de Orozco (25/03/1838): Sin ref.

-Ref. Carbonell (4/7/1838): Sin ref.

\section{- Observaciones a partir de los informes militares}

Se trata de la denominación de una calle actual de Requena. Se identifica una casa pajar y un porche de Francisco Fernandez y un huerto de Nicolás Gallego. El exteno de la calle ur constituye un punto de referencia claro por donde pasa la muralla, coincidiendo con la casa obras en tiempo de Albornoz (1835 y 1836) y otras, con un trazado diferente, a las de Orozco (1838). 


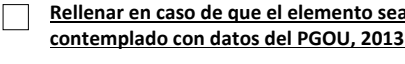

\section{PROTECCIÓN}

Nivel de protección:

AFECCIÓN PATRIMONIAL

$\square$ Bien de interés cultural (BIC)

$\square$ Inmueble

$\square$ Parcela catastral

$\square$ Recinto arquitectónico

$\square$ Afectado entorno BIC

$\square$ Afectado Plan especial

\section{- Descripción histórico-arquitectónica}

Tipología:

Cronología:

Observaciones a la cronología

\section{Descripción}

- Entorno urbano

Descripción entorno urbano:

Uso actual:

Estado de conservación:

Intervenciones:

Régimen Urbanistico:

ón s/catálogo 1996:

Bibliografía: AMR, 1818-17, 1818-24; 1818-50; 1818-52; 1818-53.

observaciones generales:

\section{OBJETIVACIÓN DE INTERÉS}

$\square$ Interés tipológico

$\square$ Valor ambiental

$\square$ Vigencia de la trama

Composición de la facha

\section{Soluciones constructivas}

\section{Soluciones ornamentales}

Interés paisajístico

$\square$ Materiales, color, textura

\section{$\square$ Estructura}

$\square$ Aleros

$\square$ Coronación

$\square$ Dinteles

$\square$ Carpintería

Rejería

Cubrepersianas

Alicatados

Recercos

$\square$ Otros ornamentos

\section{- Datos específicos catalogación BIC}

$\square$ Rellenar sólo si está catalogado BIC

Datos Jurídicos:

Código:

Categoria:

Anotación Mo

Fecha Disposición:
Tipo delimitación:

Plan:

Informe:

Fecha informe:

Fecha Publicación DOCV:
069 Calle de Juan Penén (actual)

\section{- Identificación}

Tramo de estudio:

Tramo 6: Puerta de Reinas-Puerta de Valencia

Otras denom

Ref. catastra:

Localización: C/ de Juan Penen

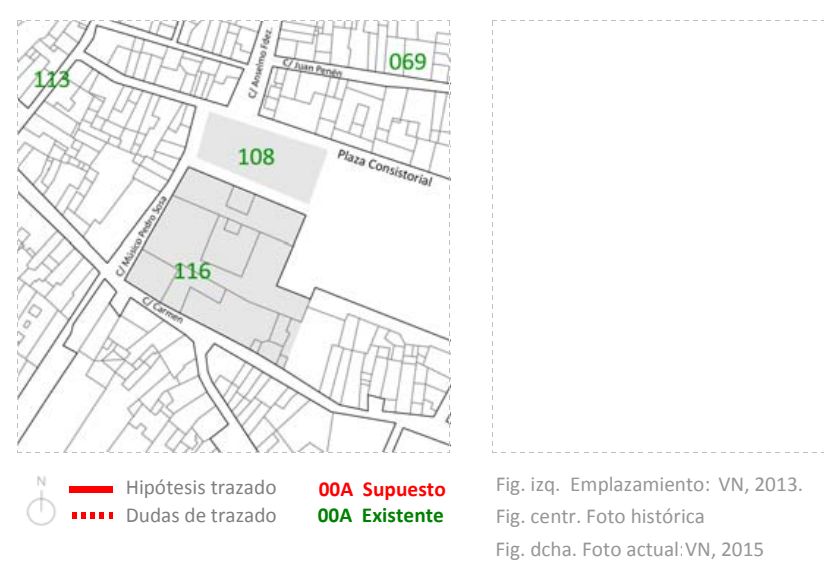

$\checkmark$ Existe actualmente

Incluido en fichas PGOU 2013

Bien de interés cultural (BIC)

Cód. postal: 46340

Municipio: Requena

Comarca: Plana de Requena-Utiel

Provincia: Valencia

Autonomía: Comunidad Valencian

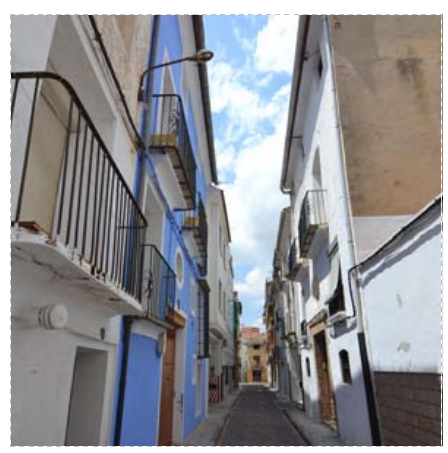

- Referencias en documentación histórica

Referencias numéricas en cartografía sobre fortificación

-Ref. en el croquis de Ortiz de Pinedo (1837-38, AGM, núm. 262): Sin ref.

-Ref. en plano de Vera Aparici (1993): Sin ref.

Referencias en memorias técnicas militare

-Ref. Guillermo Sáez (9/9/1834-5/12/1835): Requena, 5/12/1835 AMR, 1818-50 No se indican obras a realizar

-Ref. Guillermo Sáez (26/02/1836): Sin ref.

-Ref. P. Ortiz de Pinedo (12/03/1837-30/05/1837): Sin ref.

-Ref Jose María de Orozco (25/03/1838): Sin ref.

-Ref. Carbonell (4/7/1838): Sin ref.

\section{- Observaciones a partir de los informes militares}

La casas que dan frente a la actual calle de Juan Penén, configurarian parte del recinto exterior noreste, el cual proseguiría acompañando

\begin{tabular}{|lll}
$\square \frac{\text { Rellenar en caso de que el elemento sea }}{\text { contemplado con datos del PGOU, 2013 }}$ & PROTECCIÓN & AFECCIÓN PATRIMONIAL \\
& Nivel de protección: & $\square$ Bien de interés cultural (BIC) \\
& Entorno: & $\square$ Bien de relevancia local (BRL) \\
& $\square$ Inmueble & $\square$ Afectado entorno BIC \\
& $\square$ Parcela catastral & $\square$ Afectado Plan especial \\
& $\square$ Recinto arquitectónico & \\
& $\square$ Entorno específico &
\end{tabular}


- Descripción histórico-arquitectónica

\section{Tipología:}

Cronología:

Observaciones a la cronología:

Descripción:

\section{- Entorno urbano}

Descripción entorno urbano:

Uso actual:

Estado de conservación:

Intervenciones:

Régimen Urbanístico:

Titularidad:

Nivel protección s/catálogo 1996:

Bibliografia: AMR, 1818-17, 1818-24; 1818-50; 1818-52; 1818-53.

Observaciones generales:

$\begin{array}{lll}\text { OBJETIVACIÓN DE INTERÉS } & \text { Soluciones constructivas } & \text { Soluciones ornamentales } \\ \square \text { Interés tipológico } & \square \text { Estructura } & \square \text { carpintería } \\ \square \text { valor ambiental } & \square \text { Aleros } & \square \text { Rejería } \\ \square \text { Vigencia de la trama } & \square \text { coronación } & \square \text { cubrepersianas } \\ \square \text { composición de la fachada } & \square \text { Jambas } & \square \text { Alicatados } \\ \square \text { Materiales, color, textura } & \square \text { Dinteles } & \square \text { Recercos } \\ & & \square \text { Dinteles } \\ & \square \text { otros ornamentos }\end{array}$

- Datos específicos catalogación BIC $\square$ Rellenar sólo si está catalogado BIC

Datos Jurídicos:

$\begin{array}{lll}\text { Datos Juridicos: } & \text { Fecha Disposición: } & \text { Fecha informe: } \\ \text { Código: } & \text { Tipo delimitación: } & \text { Fecha Publicación BOP: } \\ \text { Estado: } & \text { Plan: } & \text { Fecha Publicación DOCV: } \\ \text { Categoria: } & \text { Informe: } & \text { Fecha Publicación BOE: }\end{array}$

Interés paisajistico

$\square$ Incidencia visual

$\square$ Carácter articulador

$\square$ Organización

$\square$ Carácter representativo

\section{Calle de los Álamos}

\section{- Identificación}

Tramo de estudio:

Tramo 6: Puerta de Reinas-Puerta de Valencia

Otras denominaciones: Avenida de los Alamos. Camino de Valencia. Casa de Pedro

\section{Ref. catastral:}

Localización: c/ Constitución.

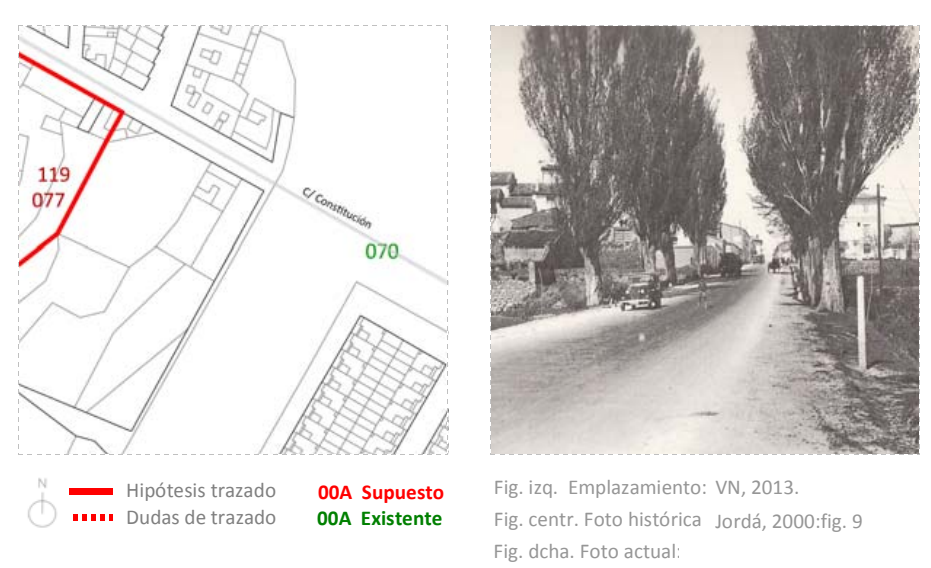

\section{- Referencias en documentación histórica}

\section{Referencias numéricas en cartografía sobre fortificación}

-Ref. en el croquis de Ortiz de Pinedo (1837-38, AGM, núm. 262): Sin ref.

-Ref. en plano de Vera Aparici (1993): 015

Referencias en memorias técnicas militares

-Ref. Guillermo Sáez (9/9/1834-5/12/1835): Requena, 5/12/1835 AMR, 1818-50

Entre las obras a realizar se comunica la casa de Pedro López con la casa contigua y se aspillera el huerto de Narbón.

-Ref. Guillermo Sáez (26/02/1836): Sin ref.

-Ref. P. Ortiz de Pinedo (12/03/1837-30/05/1837): Sin ref.

-Ref Jose María de Orozco (25/03/1838): Sin ref.

-Ref. Carbonell (4/7/1838): Sin ref.

\section{- Observaciones a partir de los informes militares}

En ella se ubica la casa de Pedro López y un huerto, el denominado Huerto de Narbón. La presencia de álamos podría indicar la abundancia de agua en la zona. Podría coincidir con la actual Calle Constitución. Definiendo una porción de perímetro amurallado del recinto exterior, de agua en la zona. Podria coincidir con la actual Calle Constitución. Definiendo una porción de perimetro amurallado de
constituyendo un baluarte que batiría las Ollerías y el entrante que configuran las casas de la actual C/ Antonio Pérez.

$\begin{array}{|lll|}\square \frac{\text { Rellenar en caso de que ele elemento sea }}{\text { contemplado con datos del PGOU, 2013 }} & \text { PROTECCIÓN } & \text { AFECIÓN PATRIMONIAL } \\ & \text { Nivel de protección: } & \square \text { Bien de interés cultural (BIC) } \\ & \text { Entorno: } & \square \text { Bien de relevancia local (BRL) } \\ \square \text { Inmueble } & \square \text { Afectado entorno BIC } \\ \square \text { Parcela catastral } & \square \text { Afectado Plan especial } \\ \square \text { Recinto arquitectónico } & \\ & \square \text { Entorno especifico }\end{array}$

$\nabla$ Existe actualmente

Incluido en fichas PGOU 2013

$\square$ Bien de interés cultural (BIC)

Cód. postal: 46340

Comarca: Plana de Requena-Utiel

Provincia: Valenci

Autonomía: Comunidad Valenciar 


\section{- Descripción histórico-arquitectónica}

Tipología:

Observaciones a la cronología

\section{Descripción:}

\section{- Entorno urbano}

Descripción entorno urbano:

Uso actual:

Estado de conservación:
Intervenciones:

Régimen Urbanístico:

Titularidad:

Nivel protección s/catálogo 1996:

Bibliografía: AMR, 1818-17, 1818-24; 1818-50; 1818-52; 1818-53.

Observaciones generales:

$\begin{array}{lll}\text { OBJETIVACIÓN DE INTERÉS } & \text { Soluciones constructivas } & \text { Soluciones ornamentales } \\ \square \text { Interés tipológico } & \square \text { Estructura } & \square \text { carpintería } \\ \square \text { valor ambiental } & \square \text { Aleros } & \square \text { Rejería } \\ \square \text { Vigencia de lá trama } & \square \text { coronación } & \square \text { cubrepersianas } \\ \square \text { composición de la fachada } & \square \text { Jambas } & \square \text { Alicatados } \\ \square \text { Materiales, color, textura } & \square \text { Dinteles } & \square \text { Recercos } \\ & & \square \text { Dinteles } \\ & \square \text { otros ornamentos }\end{array}$

\section{- Datos específicos catalogación BIC $\square$ Rellenar sólo si está catalogado BIC}

$\begin{array}{lll}\text { Datos Juridicos: } & & \\ \text { Código: } & \text { Fecha Disposición: } & \text { Fecha informe: } \\ \text { Estado: } & \text { Tipo delimitación: } & \text { Fecha Publicación BOP: } \\ \text { Categoría: } & \text { Plan: } & \text { Fecha Publicación DOCV: } \\ \text { Anotación Mo: } & \text { Informe: } & \text { Fecha Publicación BOE: }\end{array}$

\section{Desde la casa de Narbón a las de la Garrota}

\section{- Identificación}

Tramo de estudio:

Tramo 6: Puerta de Reinas-Puerta de Valencia

Otras denominaciones:

Ref. catastral:

Localización: Área de la plaza de Isabel II. Extremo Norte de la C/ Antonio Pérez.

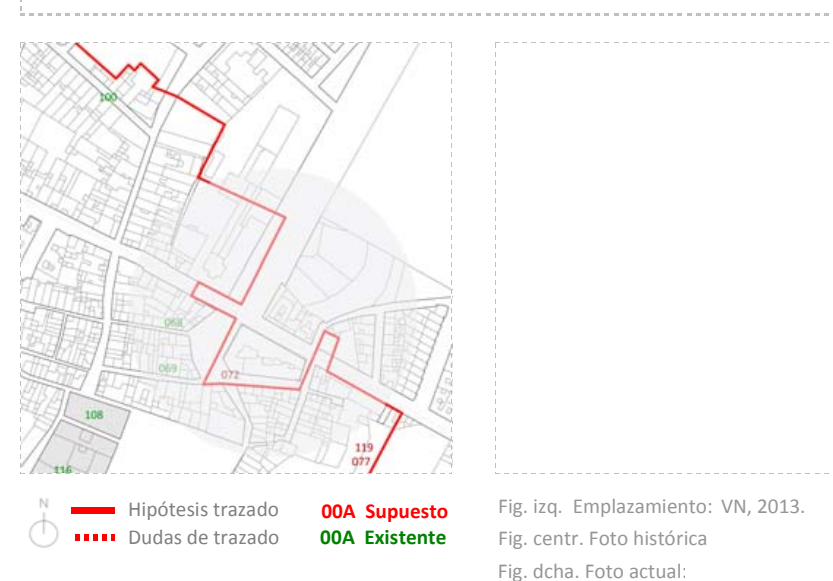

- Referencias en documentación histórica

Referencias numéricas en cartografía sobre fortificación

-Ref. en el croquis de Ortiz de Pinedo (1837-38, AGM, núm. 262): Sin ref.

-Ref. en plano de Vera Aparici (1993): Sin ref.

Referencias en memorias técnicas militares

-Ref. Guillermo Sáez (9/9/1834-5/12/1835): Sin ref.

-Ref. Guillermo Sáez (26/02/1836): Sin ref.

-Ref. P. Ortiz de Pinedo (12/03/1837-30/05/1837): Sin ref.

-Ref Jose María de Orozco (25/03/1838): Sin ref.

-Ref. Carbonell (4/7/1838): AMR, 1818-17, fol. 20

"Las parédes de las casas se aspillerarán en todos los cuerpos, cerrándo y aspillerándo las ventanas y balcónes cuya altúra no escéda de ocho baras: se masisarán bien las puertas. A las tapias de la derécha que van á unirse con las casas de la Garróta debe darseles una bara baras de largo: los otros dos se unirán con el recinto en forma de flancos. En el lado del poniénte se establecerá la puerta del tambor, y delante de ella un pequeño y profúndo foso, empleándo para su paso un puente amovible de madéra" (Carbonell, Requena, 4 de julio de 1838, AMR, 1818-17, fol. 20).

\section{- Observaciones a partir de los informes militares}

Este tramo que se inicia con la casa de Narbón, arrancaría pues a la altura del extremo Este de la C/ Gil. Parece estar constituido por casas que con ventanas y balcones. Hacia el Este (hacia la derecha), la tapias se prolonga y se encuentran con un conjunto de casas denominadas de la Garrota. Es en este, en su extremo Oeste, donde se emplaza el denominado postigo del [trillero]. Se interpreta que se trata de dicho postigo, aunque no se matiza en el informe. 


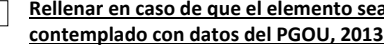

PROTECCIÓN

Nivel de protección

$\square$ Inmueble

$\square$ Parcela catastral

$\square$ Recinto arquitectónico

AFECCIÓN PATRIMONIAL

$\square$ Bien de interés cultural (BIC)

$\square$ Afectado entorno BIC

$\square$ Afectado Plan especial

- Descripción histórico-arquitectónica

Tipología:

Cronología:

Observaciones a la cronología:

Descripción:

- Entorno urbano

Descripción entorno urbano:

Uso actual:

Estado de conservación:

Intervenciones:

Régimen Urbanístico:

Titularidad:

Nivel protección s/catálogo 1996:

Bibliografía: AMR, 1818-17, 1818-24; 1818-50; 1818-52; 1818-53.

observaciones generales:

\section{OBJETIVACIÓN DE INTERÉS}

$\square$ Interés tipológico

Valor ambiental

Vigencia de la trama

Materiales, color, textura

Soluciones constructiva
$\square$ Estructura
$\square$ Aleros
$\square$ Coronación
$\square$ Jambas
$\square$ Dinteles

Soluciones ornamentales
$\square$ Carpintería
$\square$ Rejería
$\square$ Cubrepersianas
$\square$ Alicatados
$\square$ Recercos
$\square$ Dinteles

$\square$ Incidencia visual

$\square$ Carácter articulador

Organización

$\square$ Interes cultural

Otros ornamento

\section{Puerta del Trillero, Calle de las Eras}

- Identificación

Tramo de estudio:

Tramo 6: Puerta de Reinas-Puerta de Valencia

Otras denominaciones: Postigo del Trillero, Calle de las Eras, Puerta de las Eras.

Ref. catastral:

Localización: C/Antonio Pérez.

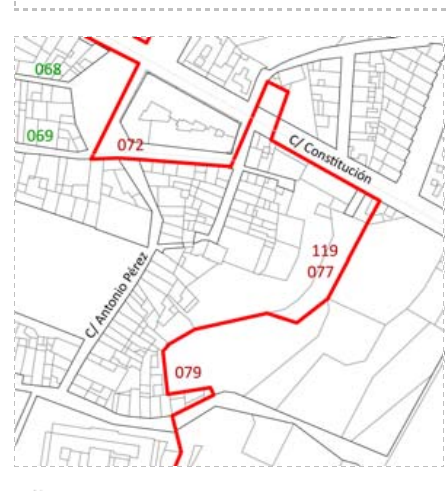

$$
\begin{array}{lll}
\text {..... Hipótesis trazado } & \text { DoA Supueste trazado } & \text { Fig. izq. Emplazamiento: VN, 2013 } \\
\text { O0A Existente } & \text { Fig. centr. Foto histórica } \\
& \text { Fig. dcha. Foto actual: }
\end{array}
$$

\section{- Referencias en documentación histórica}

\section{Referencias numéricas en cartografía sobre fortificación}

-Ref. en el croquis de Ortiz de Pinedo (1837-38, AGM, núm. 262): 006

-Ref. en plano de Vera Aparici (1993): Sin ref.

Referencias en memorias técnicas militares

-Ref. Guillermo Sáez (9/9/1834-5/12/1835): Requena, 5/12/1835 AMR, 1818-50

En la línea de casas hay que asegurar puertas y aspillerar pisos bajos.

-Ref. Guillermo Sáez (26/02/1836): Sin ref.

-Ref. P. Ortiz de Pinedo (12/03/1837-30/05/1837): Sin ref.

-Ref Jose Maria de Orozco (25/03/1838): Sin ref.

-Ref. Carbonell (4/7/1838): Sin ref.

El postigo del [trilléro] se subirá con un tambor de tres lados: el del frente seguirá la orilla del camino, y tendrá ocho baras de largo: los otros dos se unirán con el recinto en forma de flancos. En el lado del poniénte se establecerá la puerta del tambor, y delante de ella un
pequeño y profúndo foso, empleándo para su paso un puente amovible de madéra" (Carbonell, Requena, 4 de julio de 1838, AMR, 181817 , fol. 20).

\section{- Observaciones a partir de los informes militares}

Se habla de una calle, pero también se menciona una salida en la que se emplazaban las eras para el trillo. Se identifica una línea de casas Curiosamente, en una ubicación parecida se encuentra, en el plano de Ortíz de Pinedo, la denominada "Puerta del Trillero". Podría hacer referencia a Don Antonio Perez Sanchez (1819-1900), apodado "el Trillero", por ser fabricante de Trillos. Fue alcalde de Requena durante la ultima guerra carlista. Hoy, la calle proxima a dicha puerta y que transcurre perimetralmente a la Glorieta se denomina C/ de Antonio Pérez, la anligua calle de las eras. Precisamente el Parque de la Gloneta actual (Parque Infant Gómez Fenrer) se instalo en parte sobre e intramuros. Posiblemente en el emplazamiento de la actual plaza de Isabel II, donde desemboca la calle de Antonio Pérez, debía Iocalizarse esta puerta, conocida como Puerta del Trillero o de las Eras. El postigo se emplazaba a poniente del tramo entre la Casa de Narbón y las Casas de la Garrota. A el se accedía por medio de un tambor saliente de tres caras: una cara frontal y dos flancos. En el flanco oeste se ubica la puerta al tambor $y$, frente a ella un foso con un puente móvil de madera. 


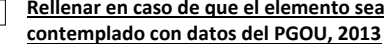

\section{PROTECCIÓN}

Nivel de protección:

AFECCIÓN PATRIMONIAL

$\square$ Bien de interés cultural (BIC)

$\square$ Inmueble

$\square$ Parcela catastral

Recinto arquitectónico

$\square$ Entorno específico

$\square$ Afectado entorno BIC

$\square$ Afectado Plan especia

\section{- Descripción histórico-arquitectónica}

Tipología:

Cronología:

Observaciones a la cronologia:

Descripción:

- Entorno urbano

Descripción entorno urbano:

Uso actual:

Estado de conservación:

Intervenciones:

Régimen Urbanistico:

Titularidad:

Nivel protección s/catálogo 1996:

Bibliografía: AMR, 1818-17, 1818-24; 1818-50; 1818-52; 1818-53.

Observaciones generales:

$\begin{array}{lll}\text { OBJETIVACIÓN DE INTERÉS } & \text { Soluciones constructivas } & \text { Soluciones ornamentales } \\ \square \text { Interés tipológico } & \square \text { Estructura } & \square \text { Carpintería } \\ \square \text { Valor ambiental } & \square \text { Aleros } & \square \text { Rejería } \\ \square \text { Vigencia de la trama } & \square \text { coronación } & \square \text { Cubrepersianas } \\ \square \text { Composición de la fachada } & \square \text { Jambas } & \square \text { Alicatados } \\ \square \text { Materiales, color, textura } & \square \text { Dinteles } & \square \text { Recercos } \\ & & \square \text { Dinteles } \\ & \square \text { Otros ornamentos }\end{array}$

Interés paisajistico
$\square$ Incidencia visual
$\square$ Carácter articulador
$\square$ Organización
$\square$ Interés cultural
$\square$ Carácter representativo

\section{- Datos específicos catalogación BIC}

$\square$ Rellenar sólo si está catalogado BIC

\section{Datos Jurídicos:}

Código:
Estado:

Estado:
Categoría:

Fecha Disposición:

Anotación Mo

Plan:

Fecha informe:

Fecha Publicación BOP:

Fecha Publicación DOCV

Fecha Publicación BOE:

\section{Casas de la Garrota}

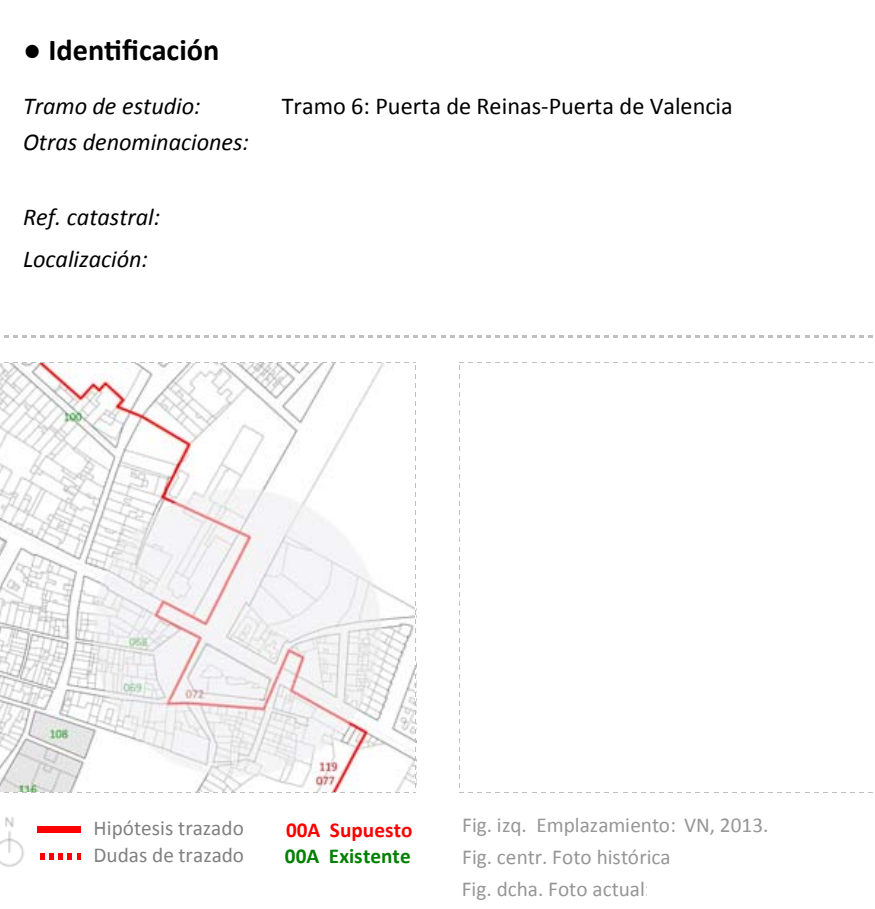

Existe actualmente

Incluido en fichas PGOU 2013

Bien de interés cultural (BIC)

cód. postal: 46340

Municipio: Requena

Comarca: Plana de Requena-Utie

Provincia: Valencia

Autonomía: Comunidad Valencian

\section{- Referencias en documentación histórica}

\section{(a)}

-Ref. en el croquis de Ortiz de Pinedo (1837-38, AGM, núm. 262): Sin ref.

-Ref. en plano de Vera Aparici (1993): Sin ref.

Referencias en memorias técnicas militares

-Ref. Guillermo Sáez (9/9/1834-5/12/1835): Sin ref.

-Ref. Guillermo Sáez (26/02/1836): Sin ref.

-Ref. P. Ortiz de Pinedo (12/03/1837-30/05/1837): Sin ref.

-Ref Jose Maria de Orozco (25/03/1838): Requena, 25/03/1838, AMR 1818-24

Es considerado el punto más débil de toda la fortificación. Tiene pocos fuegos y su solidez es escasa. Así como no se encuentra cubiert porán aun or tro fo. Se propone reforzar su frente con un tambor aspillerado. Dicho tambor, asi como todos los angulos de la casa,

-Ref. Carbonell (4/7/1838): AMR, 1818-17, fol. 20

"Se dará mas espésor á la pared del primer piso reforzandolo interiormente, y asi en este piso como en los demás se abrirán todas las aspilléras posibles" (Carbonell, Requena, 4 de julio de 1838, AMR, 1818-17, fol. 20 ).

\section{- Observaciones a partir de los informes militares}

Al alcance de la bateria de Honrubia. Parece ubicarse en relación con la Puerta del Trillero, dado que las estacadas y el foso se prolongarán desde ella hasta dicha puerta. Tácticamente es considerado un punt débil de la fortificación por lo que hay que considerar que este conjunto de casas constituian un ángulo saliente de la fortificación. En estas casas sepropone anteponer en el frente un tambor fortificación, que es el que sigue la descripción de Carbonell, antes de alcanzar la puerta del Trillero. Podrín constituir el vértice saliente superior del plano que enmarcamos en el plano con un círculo gris. 
$\square$ Rellenar en caso de que el elemento sea

PROTECCIÓN

Nivel de protección:

AFECCIÓN PATRIMONIAL

Entorno:

$\square$ Inmueble

$\square$ Parcela catastral

$\square$ Recinto arquitectónico

$\square$ Bien de relevancia local (BRL)

$\square$ Afectado entorno BIC

$\square$ Afectado Plan especia

\section{- Descripción histórico-arquitectónica}

Tipología:

Cronología:

Observaciones a la cronología:

Descripción

- Entorno urbano

Descripción entorno urbano:

Uso actual:

Estado de conservación:

Intervenciones:

Régimen Urbanístico:

Titularidad:

Nivel protección s/catálogo 1996:

Bibliografía: AMR, 1818-17, 1818-24; 1818-50; 1818-52; 1818-53.

Observaciones generales:

\section{OBJETIVACIÓN DE INTERÉS}

$\square$ Interés tipológico

$\checkmark$ Valor ambiental

Vigencia de la trama

Materiales, color, textura

Soluciones construc
$\square$ Estructura
$\square$ Aleros
$\square$ Coronación
$\square$ Jambas
$\square$ Dinteles

Soluciones ornamentales
$\square$ Carpintería
$\square$ Rejería
$\square$ Cubrepersianas
$\square$ Alicatados
$\square$ Recercos
$\square$ Dinteles

Interés paisajistico
$\square$ Incidencia visual
$\square$ Carácter articulador
$\square$ Organización
$\square$ Interés cultural
$\square$ Carácter representativo

$\square$ Interés cultural

Dinteles

$\square$ Otros ornamentos

\section{- Datos específicos catalogación BIC $\square$ Rellenar sólo si está catalogado BIC}

\section{Datos Jurídicos:}

Código:

Estado:

Categoría:

Anotación $M$

Fecha Disposición:
Tipo delimitación:
Plan:
Informe.

Fecha informe:

Fecha Publicación BOP:

Fecha Publicación DOCV:

Fecha Publicación BOE:

\section{Cortina de la Huerta de Don Baltasar Pérez}

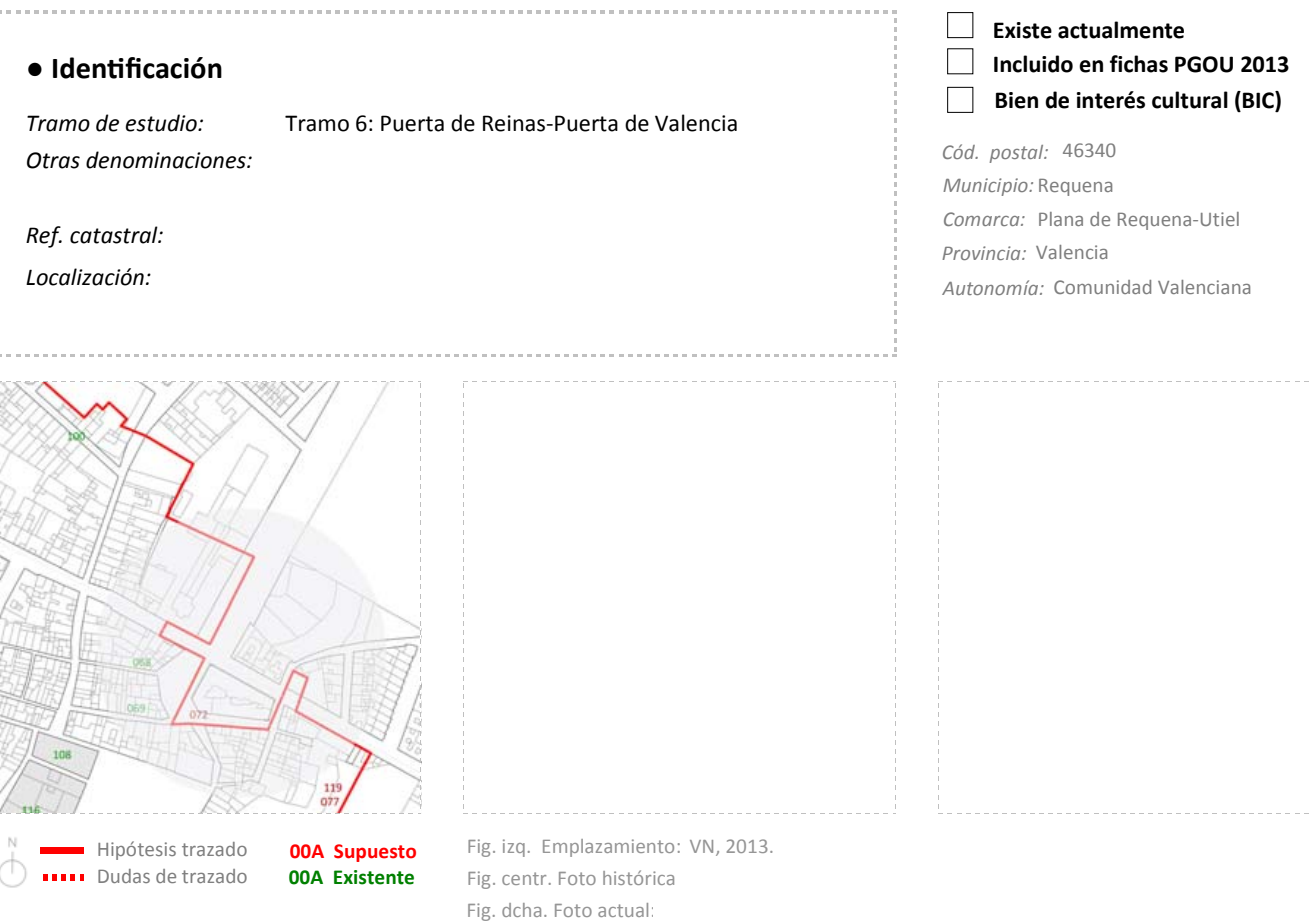

- Referencias en documentación histórica

Referencias numéricas en cartografía sobre fortificación

-Ref. en el croquis de Ortiz de Pinedo (1837-38, AGM, núm. 262): Sin ref.

-Ref. en plano de Vera Aparici (1993): Sin ref.

Referencias en memorias técnicas militares

-Ref. Guillermo Sáez (9/9/1834-5/12/1835): Sin ref.

-Ref. Guillermo Sáez (26/02/1836): Sin ref.

-Ref. P. Ortiz de Pinedo (12/03/1837-30/05/1837): Sin ref.

-Ref Jose María de Orozco (25/03/1838): Requena, 25/03/1838, AMR 1818-24

La cortina se considera endeble. Se le construira un foso y se convierte asi en un retrincheramiento o segunda línea de las tapias avanzadas ya construidas por Albornoz. Estas ultimas deben conservarse y robustecerse para que puedan cubrir la huerta citada y, a su

-Ref. Carbonell (4/7/1838): Sin ref.

\section{- Observaciones a partir de los informes militares}

Parece que constituiría el flanco de defensa para la casa de la Garrota y la Puerta del Trillero, que carecen de otro fuego de flanco.

\begin{tabular}{|c|c|c|}
\hline \multirow[t]{2}{*}{$\begin{array}{l}\text { Rellenar en caso de que el elemento sea } \\
\text { contemplado con datos del PGOU, } 2013\end{array}$} & $\begin{array}{l}\text { PROTECCIÓN } \\
\text { Nivel de protección: } \\
\text { Entorno: }\end{array}$ & $\begin{array}{l}\text { AFECCIÓN PATRIMONIAL } \\
\begin{array}{|l}\square \text { Bien de interés cultural (BIC) } \\
\square \text { Bien de relevancia local (BRL) }\end{array}\end{array}$ \\
\hline & $\begin{array}{l}\square \text { Inmueble } \\
\square \text { Parcela catastral } \\
\square \text { Recinto arquitectónico } \\
\square \text { Entorno específico }\end{array}$ & $\begin{array}{l}\square \text { Afectado entorno BIC } \\
\square \text { Afectado Plan especial }\end{array}$ \\
\hline
\end{tabular}




\section{- Descripción histórico-arquitectónica}

Tipología:

Observaciones a la cronología:

\section{Descripción:}

\section{- Entorno urbano}

Descripción entorno urbano:

Uso actual:

Estado de conservación:

Intervenciones:

Régimen Urbanístico:

Titularidad:

Nivel protección s/catálogo 1996:

Bibliografia: AMR, 1818-17, 1818-24; 1818-50; 1818-52; 1818-53.

Observaciones generales:

$\begin{array}{llll}\text { OBJETIVACIÓN DE INTERÉS } & \text { Soluciones constructivas } & \text { Soluciones ornamentales } & \text { Interés paisajistico } \\ \square \text { Interés tipológico } & \square \text { Estructura } & \square \text { carpintería } & \square \text { Incidencia visual } \\ \square \text { Valor ambiental } & \square \text { Aleros } & \square \text { Rejería } & \square \text { carácter articulador } \\ \square \text { Vigencia de la trama } & \square \text { coronación } & \square \text { cubrepersianas } & \square \text { Organización } \\ \square \text { Composición de la fachada } & \square \text { Jambas } & \square \text { Alicatados } & \square \text { Interés cultural } \\ \square \text { Materiales, color, textura } & \square \text { Dinteles } & \square \text { Recercos } & \square \text { carácter representativo } \\ & & \square \text { Dinteles } & \\ & \square \text { otros ornamentos } & \end{array}$

- Datos específicos catalogación BIC $\square$ Rellenar sólo si está catalogado BIC

$\begin{array}{lll}\text { Datos Juridicos: } & & \\ \text { Código: } & \text { Fecha Disposición: } & \text { Fecha informe: } \\ \text { Estado: } & \text { Tipo delimitación: } & \text { Fecha Publicación BOP: } \\ \text { Categoría: } & \text { Plan: } & \text { Fecha Publicación DOCV: } \\ \text { Anotación Mo: } & \text { Informe: } & \text { Fecha Publicación BOE: }\end{array}$

Plan:

echa Publicación BOE:

\section{Batería del huerto de Agustín Monsalve}

\section{- Identificación}

Tramo de estudio:

Tramo 6: Puerta de Reinas-Puerta de Valencia

Otras denominaciones: Huerto de Monsalve, Casa de Roque, Casa de Onrrubia

Ref. catastral:

Localización:

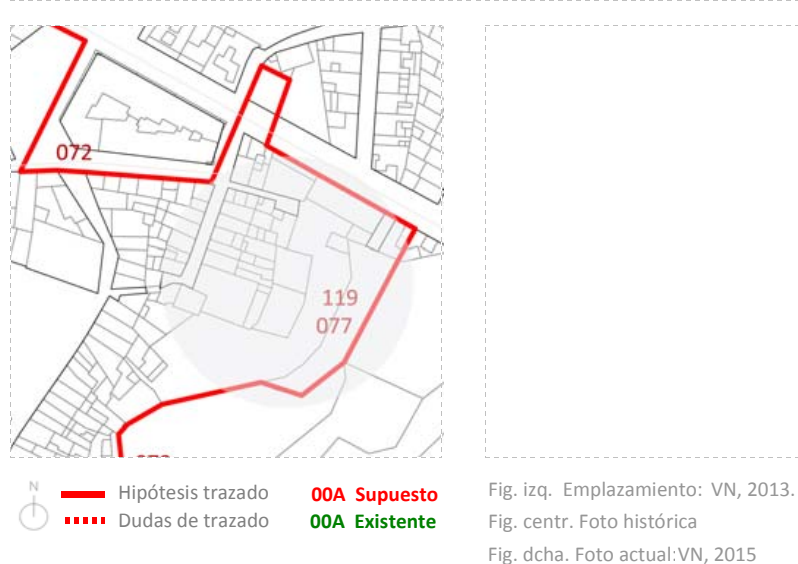

$\square$ Existe actualmente Bien de interés cultural (BIC)

cód. postal: 46340

Municipio: Requena

Comarca: Plana de Requena-Utie

Provincia: Valencia

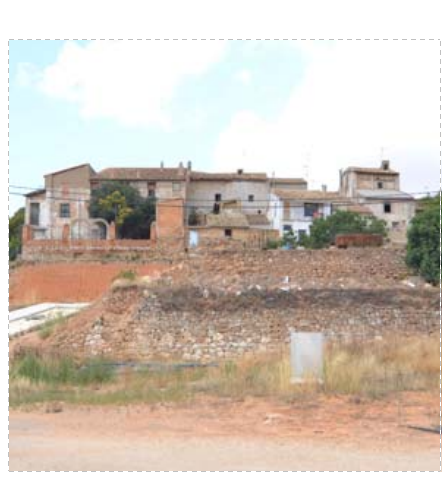

\section{- Referencias en documentación histórica}

Referencias numéricas en cartografía sobre fortificación

- Ref. en el croquis de Ortiz de Pinedo (1837-38, AGM, núm. 262): Sin ref.

-Ref. en plano de Vera Aparici (1993): Sin ref.

Referencias en memorias técnicas militares

-Ref. Guillermo Sáez (9/9/1834-5/12/1835): Sin ref.

-Ref. Guillermo Sáez (26/02/1836): Sin ref.

-Ref. P. Ortiz de Pinedo (12/03/1837-30/05/1837): Sin ref.

-Ref Jose Maria de Orozco (25/03/1838): Sin ref.

-Ref. Carbonell (4/7/1838): AMR, 1818-17, fol. 20

"Se variará su posicion y trazado del modo que va á indicárse. Se adelantará hasta las tapias del huerto sobre las cuales se marcará un frente de nuebe baras de lado esterior en linea recta. Esta será la cara de levánte: la de medio dia formará con ella un angulo de 140. grados, y tendrá otras nuebe baras: la del norte formará con la misma un angulo de 100 . grados, y terminará en el rebestimiento de la
rampa de que va á hablarse La rampa [paral subirá la Bateria partirá desde la inmediacion de las tapias que cierran el huerto por la parte del norte, y apoyándose en las parédes de las casas, terminará en el piso de la obra. Tendrá cuatro baras de ancho, y su guardaládo será un parapéto aspillerádo. Al [frente] de esta rampa se abrira una comunicacion para la conducion de estas piezas por la Casa de Roque. Desde el estremo de la casa de medio daa, ýo mañdo con ella un angulo de 110. grados, se construirá un parapeto aspilierádo que irá à con los huértos procsimos. Todas las tapias que quedan fuera del recinto que se ha trazado deben demolerse. La altúra de la Bateria será de dos baras y media sin contar el parapéto, ni la profundidad del foso que debe rodearla por la parte del norte. A un parapeto se dará la elebacion ordinária, el espésor de dos baras por los frentes de levante y medio dia, y el de una bara por el lado del norte. En cada lado se abrira una cañonéra en que se abrirán portezuelas; se hará una esplanáda de madéra que oculte el piso de la Bateria, pero tanto para eso como para gradúar el espesor de los espaldónes, solo se graduará por tal el sitio en que há de revolverse la piesa. El parapeto que cubre .

- Observaciones a partir de los informes militares 
Se está haciendo referencia a un conjunto de casas (Roque, Onrubia) y huerto (Agustin Monsalve), en los que se va a emplazar la denominada Bateria de Honrubia (Onrubia). Parece una posición clave de la fortificación de Requena. Se sabe que la batería tiene un frente de Norte, de Levante y de Mediodia, lo cual, y con el apoyo además del plano de Ortiz de Pinedo, nos permite ijijar relativa exactitud paredes de las casas ta posición es privilegiada pues bate desde las Ollerís hasta la Puerta del Trillero e Higuerillas.

$\begin{array}{lll}\square \frac{\text { Rellenar en caso de que el elemento sea }}{\text { contemplado con datos del PGOU, 2013 }} & \begin{array}{l}\text { PROTECCIÓN } \\ \text { Nivel de protección: }\end{array} & \square \text { AFECCIÓN PATRIMONIAL } \\ & \text { Entorno: } & \square \text { Bien de interés culturancia local (BRC) } \\ & \square \text { Inmueble } & \square \text { Afectado entorno BIC } \\ & \square \text { Parcela catastral } & \square \text { Afectado Plan especial } \\ & \square \text { Recinto arquitectónico } & \\ & \square \text { Entorno específico } & \end{array}$

\section{- Descripción histórico-arquitectónica}

Tipología:

Cronología:

iones a la cronologí:

\section{Descripción:}

\section{- Entorno urbano}

\section{Descripción entorno urbano:}

Uso actual:

Estado de conservación:

Intervenciones:

\section{Régimen Urbanístico:}

Titularidad:

Nivel protección s/catálogo 1996:

Bibliografía: AMR, 1818-17, 1818-24; 1818-50; 1818-52; 1818-53.

Observaciones generales:

$\begin{array}{llll}\text { OBJETIVACIÓN DE INTERÉS } & \text { Soluciones constructivas } & \text { Soluciones ornamentales } & \text { Interés paisajistico } \\ \square \text { Interés tipológico } & \square \text { Estructura } & \square \text { Carpintería } & \square \text { Incidencia visual } \\ \square \text { Valor ambiental } & \square \text { Aleros } & \square \text { Rejería } & \square \text { carácter articulador } \\ \square \text { vigencia de la trama } & \square \text { coronación } & \square \text { cubrepersianas } & \square \text { Organización } \\ \square \text { composición de la fachada } & \square \text { Jambas } & \square \text { Alicatados } & \square \text { Interés cultural } \\ \square \text { Materiales, color, textura } & \square \text { Dinteles } & \square \text { Recercos } & \square \text { carácter representativo } \\ & & \square \text { Dinteles } & \\ & & \square \text { otros ornamentos } & \end{array}$

\section{- Datos específicos catalogación BIC $\square$ Rellenar sólo si está catalogado BIC}

$\begin{array}{lll}\text { Datos Jurídicos: } & & \\ \text { Código: } & \text { Fecha Disposición: } & \text { Fecha informe: } \\ \text { Estado: } & \text { Tipo delimitación: } & \text { Fecha Publicación BOP: } \\ \text { Categoría: } & \text { Plan: } & \text { Fecha Publicación DOCV: } \\ \text { Anotación Mo: } & \text { Informe: } & \text { Fecha Publicación BOE: }\end{array}$

\section{El tinte de Navarro}

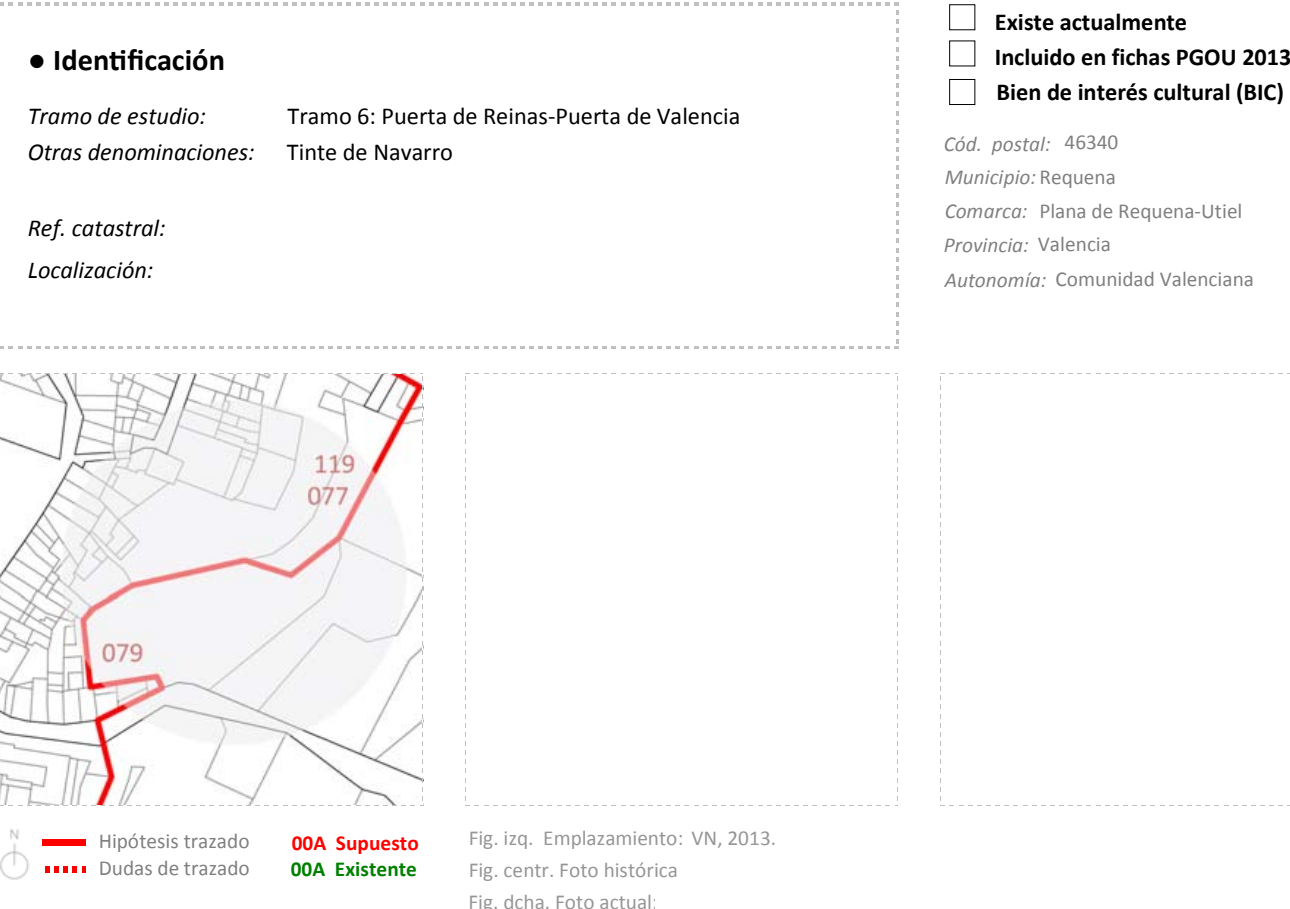

\section{- Referencias en documentación histórica}

Referencias numéricas en cartografía sobre fortificación

-Ref. en el croquis de Ortiz de Pinedo (1837-38, AGM, núm. 262): 028

-Ref. en plano de Vera Aparici (1993): 013

Referencias en memorias técnicas militare

-Ref. Guillermo Sáez (9/9/1834-5/12/1835): Requena, 5/12/1835 AMR, 1818-50

Se aspillera el tinte, "asegurando o cerrando la puerta pequeña y tapiando en forma todos los güertos parapetados que terminan en la salida de las Eras". Es decir, se contruye una tapia cerrando la línea que conecta la casa del tinte con la salida de las eras.

-Ref. Guillermo Sáez (26/02/1836): Sin ref.

-Ref. P. Ortiz de Pinedo (12/03/1837-30/05/1837): Sin ref.

-Ref Jose María de Orozco (25/03/1838): Sin ref.

-Ref. Carbonell (4/7/1838): Sin ref.

\section{- Observaciones a partir de los informes militares}

Debía tratarse de una construcción para el teñido del tejido. Se habla de unos huertos parapetados que terminan en la salida de las Eras. Llama la atención que en el plano de Ortiz de Pinedo, se identifica en la misma posición el que denomina "tinte de Navarro". En 1740, se Gómez, y, precisamente, Bartolomé Navarro. Habida cuenta que era una profesión hereditaria, podría tratarse de su casa de tinte (Larruga, 1792:292). Cerca, se emplazará más adelante una batería, la "batería de Onrubia", siendo Onrubia un apellido, que podría hacer referencia al propietario de la casa o de las huertas en la que se emplazará la batería. Entre el tinte y la batería de Onrubia, se configura la línea de las dos casas estudiadas en la calle Antonio Pérez, apodado el Trillero. Este tinte podría ocupar el saliente edificado junto a la 
$\square \frac{\text { Rellenar en caso de que el elemento sea }}{\text { contemplado con datos del PGOU, 2013 }}$

PROTECCIÓN

Nivel de protección

Entorno:

$\square$ Inmueble

$\square$ Parcela catastral

$\square$ Recinto arquitectónico

AFECCIÓN PATRIMONIAL

$\square$ Bien de interés cultural (BIC)

$\square$ Afectado entorno BIC

$\square$ Afectado Plan especial

- Descripción histórico-arquitectónica

Tipología:

Cronologí:

Observaciones a la cronología:

\section{Descripción:}

- Entorno urbano

Descripción entorno urbano:

Uso actual:

Estado de conservación:

Intervenciones:

Régimen Urbanístico:

Titularidad:

Nivel protección s/catálogo 1996:

Bibliografía: AMR, 1818-17, 1818-24; 1818-50; 1818-52; 1818-53.

Observaciones generales:

\section{OBJETIVACIÓN DE INTERÉS}

$\square$ Interés tipológico

Valor ambiental

Vigencia de la trama

$\square$ Materiales, color, textura

Soluciones constructiva
$\square$ Estructura
$\square$ Aleros
$\square$ Coronación
$\square$ Jambas
$\square$ Dinteles

$\begin{array}{ll}\text { Soluciones ornamentales } & \text { Interés paisajistico } \\ \square \text { Carpintería } & \square \text { Incidencia visual } \\ \square \text { Rejería } & \square \text { Carácter articulador } \\ \square \text { cubrepersianas } & \square \text { organización } \\ \square \text { Alicatados } & \square \text { Interés cultural } \\ \square \text { Recercos } & \square \text { carácter representativo } \\ \square \text { Dinteles } & \\ \square \text { otros ornamentos } & \end{array}$

\section{- Datos específicos catalogación BIC $\square$ Rellenar sólo si está catalogado BIC}

Datos Jurídicos:

Código:

Estado:

Categoria:

Anotación M

Fecha Disposición:
Tipo delimitación:
Plan:

Fecha informe:

Fecha Publicación BOP:

Fecha Publicación DOCV:

Informe:

\section{Batería de Onrubia (Honrubia), Huerta de Onrubia (Honrubia)}

\section{- Identificación}

Tramo de estudio:

Tramo 6: Puerta de Reinas-Puerta de Valencia

Otras denominaciones: Batería de Onrubia, Onrrubia (Honrrubia), "Huerta de Hon

$\square$ Existe actualmente

Incluido en fichas PGOU 2013

Bien de interés cultural (BIC)

cód. postal: 46340

Ref. catastral:

Localización: Área meridional entre la c/ Antonio Pérez y la c/ Constitución
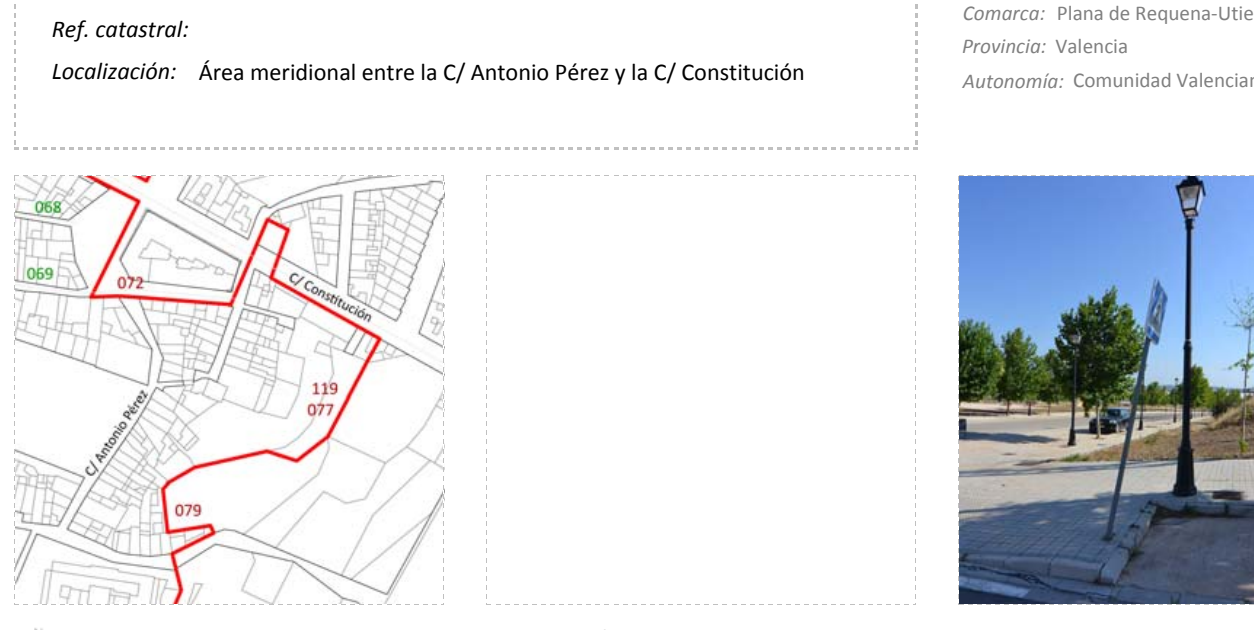

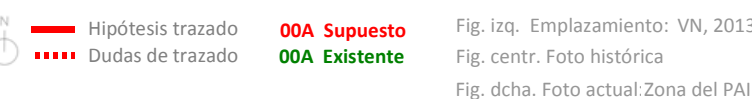

Fig. dcha. Foto actual:Zona del PAl de Honrubia (VN, 2015)

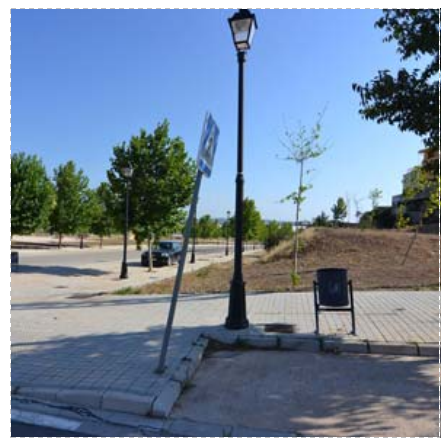

\section{- Referencias en documentación histórica}

\section{Referencias numéricas en cartografía sobre fortificación}

-Ref. en el croquis de Ortiz de Pinedo (1837-38, AGM, núm. 262): 012

-Ref. en plano de Vera Aparici (1993): Sin ref.

Referencias en memorias técnicas militares

-Ref. Guillermo Sáez (9/9/1834-5/12/1835): Sin ref.

-Ref. Guillermo Sáez (26/02/1836): Sin ref.

-Ref. P. Ortiz de Pinedo (12/03/1837-30/05/1837): Sin ref.

Ortiz de Pinedo interviene el 23 de abril de 1837 en la tasación de una propiedad de "Alonso Gavaldón", ruinosa, citada como tinte de

- Ref Jose Maric de Orozco (25/03/1838): Requena, 25/03/1838, AMR $1818-24$

-Ref Jose María de Orozco (25/03//1838) Requea, 25/03/1838, AMR 1818-24

"Casa re Garróta" $y$ el "Tinte de Cecin", considerados puntos débilera alojada en la batería (el 25 de marzo de 1838), tiene al alcance la

作 "Casa de la Garróta" y el "Tinte de Cecina".

-Ref. Carbonell (4/7/1838): AMR, 1818-17, fol. 21

"Se elebarán las tapias de este huerto y de los de la derecha hasta que cubran bien á los defensores, aspillerándolas á la conveniente altúra. La cañonera se conserbará, pero dandole mejor forma. En las parédes de la izquierda de esta se reformarán las aspilléŕs"

\section{- Observaciones a partir de los informes militares}

Sobre la batería de Honrubia, ver 075 . Se supone que la denominada batería de Honrubia, estaba destinada a batir la huerta de Honrubia. En la actualidad la "Huerta de Honrubia" existe. Fue afectada por un PAl (Programa de actuación integrada), el PAl de la Huerta de

Honrubia, que tenía por objeto generar 980 viviendas afectando a 160000 metros de suelo, en una mala decision que pretendía generar
suelo urbanizable para evitar la fuga de constructoras (Abietar Zahonero, 1 . Requena crea suelo urbanizable para construir viviendas $y$ evitar la fuga de empresas constructoras. Las provincias, 10/07/2007). En la actualidad el terreno se encuentra abandonado y con las obras de urbanización a medio terminar. Generando numerosos conflictos con el vecindario. El emplazamiento genera un grave conflicto paisajistico no denunciado que afecta al perfil histórico de Requena. 


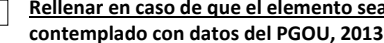

\section{PROTECCIÓN}

Nivel de protección:

Entorno:

$\square$ Inmueble

$\square$ Parcela catastral

$\square$ Recinto arquitectónico

AFECCIÓN PATRIMONIAL

Bien de interés cultural (BIC)

$\square$ Afectado entorno BIC

$\square$ Afectado Plan especia

- Descripción histórico-arquitectónica

Tipología:

Cronología:

Observaciones a la cronología:

Descripción

\section{- Entorno urbano}

Descripción entorno urbano:

Uso actual:

Estado de conservación:

Intervenciones:

Régimen Urbanístico:

Titularidad:

Nivel protección s/catálogo 1996:

Bibliografía: AMR, 1818-17, 1818-24; 1818-50; 1818-52; 1818-53.

observaciones generales:

\section{OBJETIVACIÓN DE INTERÉS}

$\square$ Interés tipológico

Valor ambiental

Vigencia de la trama

Materiales, color, textura

Soluciones construc
$\square$ Estructura
$\square$ Aleros
$\square$ Coronación
$\square$ Jambas
$\square$ Dinteles

$\begin{array}{ll}\text { Soluciones ornamentales } & \text { Interés paisajistico } \\ \square \text { Carpintería } & \square \text { Incidencia visual } \\ \square \text { Rejería } & \square \text { Carácter articulador } \\ \square \text { Cubrepersianas } & \square \text { Organización } \\ \square \text { Alicatados } & \square \text { Interés cultural } \\ \square \text { Recercos } & \square \text { Carácter representativo } \\ \square \text { Dinteles } & \\ \square \text { Otros ornamentos } & \end{array}$

\section{- Datos específicos catalogación BIC $\square$ Rellenar sólo si está catalogado BIC}

\section{Datos Jurídicos:}

Código:

Estado:

Categoría:

Anotación Mo
Fecha informe:

Fecha Publicación BOP:

Fecha Publicación DOCV:

Fecha Publicación BOE:

\section{Tinte de Cecina}

\section{- Identificación}

Tramo de estudio:

Otras denominaciones:

Tramo 6: Puerta de Reinas-Puerta de Valencia

Ref. catastral:

Localización:

Existe actualmente

Incluido en fichas PGOU 2013

Bien de interés cultural (BIC)

cód. postal: 46340

Municipio: Requena

Comarca: Plana de Requena-Utiel

Provincia: Valencia

Autonomia: Comunidad Valencian

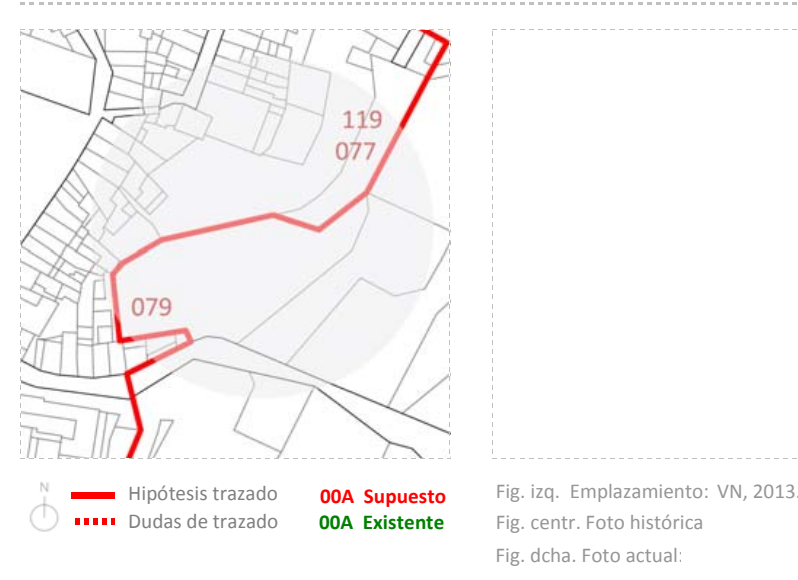

\section{- Referencias en documentación histórica}

\section{Referencias numéricas en cartografía sobre fortificación}

-Ref. en el croquis de Ortiz de Pinedo (1837-38, AGM, núm. 262): Sin ref.

-Ref. en plano de Vera Aparici (1993): Sin ref.

Referencias en memorias técnicas militares

-Ref. Guillermo Sáez (9/9/1834-5/12/1835): Sin ref.

-Ref. Guillermo Sáez (26/02/1836): Sin ref.

-Ref. P. Ortiz de Pinedo (12/03/1837-30/05/1837): Sin ref.

-Ref Jose María de Orozco (25/03/1838): Requena, 25/03/1838, AMR 1818-24

Éste tinte se encuentra al alcance de la bateria de Honrubia, por tanto, en el frente Este y pretende convertirse en fuerte que batiría desde guardia que vigile los ángulos entrantes que tiene a derecha y a izquierda. Se propone hacer un fortín que arranque del ángulo que

configura dicho tinte con el que hace pared con la calle de la Plaza. El fuerte deberá alojar una Compañía con un Cuerpo de Guardia. Desde el ángulo del tinte deberá construirse una tapia aspillerada con foso, con trazado oblicuo, buscando el encuentro con las antiguas tapias construidas por Albornoz, dando así potencia a la cortina de Fernández. Esta tapia oblicua, permite con pocos hombres batir en todas las direcciones desde el arranque de la cortina hasta el rincón "que forma la tapia que cierra la calle de la Plaza". Permite cubrir así todos los thines yangulos entrantes que quedan a la izquierda del tinte de Cecina, asi como todo el frente de la casa de la Garrota hasta la Puer

-Ref. Carbonell (4/7/1838): Sin ref.

\section{- Observaciones a partir de los informes militares}

En el informe de Orozco de 1838 no se establece ninguna asociación entre este tinte, de nueva denominación, y alguno de los tintes des anteriores (Navarro, o Gabaldón). Éste nuevo tinte se encuentra al alcance de la bateria de Honrubia, por tanto, en e frente Este y pretende convertirse en fuerte que batiría desde la casa de la Garrota hasta la puerta del Trillero. 


\section{Rellenar en caso de que el elemento sea
contemplado con datos del PGOU, 2013}

\section{PROTECCIÓN}

Nivel de protección:

AFECCIÓN PATRIMONIAL

ntorno:

$\square$ Inmueble

$\square$ Parcela catastral

Recinto arquitectónico
Entorno específico

Bien de interés cultural (BIC)

$\square$ Afectado entorno BIC

\section{- Descripción histórico-arquitectónica}

Tipología:

Cronologí:

Observaciones a la cronología

Descripción:

- Entorno urbano

Descripción entorno urbano:

Uso actual:

Estado de conservación:

Intervenciones:

Régimen Urbanístico:

Régimen Urb:
Titularidad:

Nivel protección s/catálogo 1996:

Bibliografía: AMR, 1818-17, 1818-24; 1818-50; 1818-52; 1818-53.

Observaciones generales: $\square$ Interés tipológico

$\checkmark$ Valor ambiental

Vigencia de la trama

$\checkmark$ Composición de la fachada

Soluciones constructivas

\section{$\square$ Estructura}

$\square$ Aleros

Coronación

Jambas

\section{OBJETIVACIÓN DE INTERÉS}

\section{Soluciones ornamentales}

$\square$ Carpintería

Rejería

$\square$ Cubrepersianas

Alicatados

Dinteles

Otros ornamentos
Interés paisajístico

$\square$ Incidencia visual

$\square$ Carácter articulado

Organización

Carácter representativo

\section{Huerto de Tirador}

- Identificación

Tramo de estudio:

Tramo 6: Puerta de Reinas-Puerta de Valencia

Otras denominaciones: $\quad \mathrm{El}$ Tirador

Ref. catastra:

Localización: Al Este de la C/ Antonio Pérez

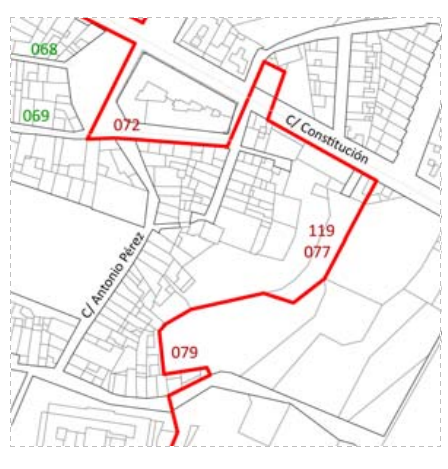

$$
\begin{aligned}
& \text {.... Hipótesis trazado OoA Supuesto } \\
& \text { fig. izq. Emplazamiento: VN, } 2013 \\
& \text { Fig, centr. Foto hoto hotóric actual: }
\end{aligned}
$$

\section{- Referencias en documentación histórica}

\section{Referencias numéricas en cartografía sobre fortificación}

-Ref. en el croquis de Ortiz de Pinedo (1837-38, AGM, núm. 262): Sin ref.

-Ref. en plano de Vera Aparici (1993): Sin ref.

Referencias en memorias técnicas militare

-Ref. Guillermo Sáez (9/9/1834-5/12/1835): Sin ref.

-Ref. Guillermo Sáez (26/02/1836): Sin ref.

-Ref. P. Ortiz de Pinedo (12/03/1837-30/05/1837): Sin ref.

-Ref Jose María de Orozco (25/03/1838): Sin ref.

-Ref. Carbonell (4/7/1838): AMR, 1818-17, fol. 21

"Sus tapias están muy mal cimentadas, por lo que deben reparárse. Se abrirá una aspilléra mas frente del tinte, y se procurará [que] de todas pueda hacerse buen uso. Las parédes del tinte

Fecha informe:

Datos Juridicos:

Código:

Fecha Disposición:

Categoría:

Fecha Publicación BOP:

Anotación Mo

Fecha Publicación BOE: $\square$ Existe actualmente

Incluido en fichas PGOU 2013

Bien de interés cultural (BIC)

cód. postal: 46340

Municipio: Requena

Comarca: Plana de Requena-Utiel

Provincia: Valencis

tonomia: Comunidad Valenciar

\section{- Observaciones a partir de los informes militares}

Se asocia con un sector de huertos con parapetos a los que vuelcan un conjunto de casas. En este sector se hace referencia a la casa del tinte, que debe ser aspillerado. Observamos que gracias a estas indicaciones y a la evidente y próspera industria textil de Requena, en este sector se ubicaría una de las estructuras más importantes de esta industria. Fijémonos que al mismo tiempo se habla de una casa del tinte. Según Llibrer, haciendo referencia a la industria de Cocentaina, el tirador consistiría en una barra de madera donde colgarían los paños después del bataneado para su cardado, a fin de "gualar la superficie y darle un aspecto externo más brillante que lo hicera mas atractivo al comprador" (Lintrer, 2014.138). Se requerta de amplias instalaciones a fin de poder trabajar con varios paños a lavez, de ahi que el sujetaba el paño con garfios o escarpias. Los tiradores han contribuido a toponimias locales, como sucede en Cocentaina. Se suele tratar de un gran complejo productivo, debido a las instalaciones e instrumental (bastidores, perchas...) que solía estar controlado por los pelaires más poderosos. Suele suceder que los pelaires se ubiquen en áreas suburbanas, cerca de la villa, en espacio de regadío, posiblemente donde se localicen huertos. Asi sucede en Cocentaina (Llibrer, 2014:139), pero también, por lo que vemos, en Requena. 
$\square \frac{\text { Rellenar en caso de que el elemento sea }}{\text { contemplado con datos del PGOU, 2013 }}$

\section{PROTECCIÓN}

Nivel de protección:

Entorno:

$\square$ Inmueble

$\square$ Recinto arquitectón

$\square$ Entorno especifico

- Descripción histórico-arquitectónica

Tipología:

Cronologia:

Observaciones a la cronología

Descripción

- Entorno urbano

Descripción entorno urbano:

Uso actual:

Estado de conservación:

Intervenciones:

Régimen Urbanístico:

Titularidad:

Nivel protección s/catálogo 1996:

Bibliografía: AMR, 1818-17, 1818-24; 1818-50; 1818-52; 1818-53.

Observaciones generales:

$\begin{array}{ll}\text { OBJETIVACIÓN DE INTERÉS } & \text { Soluciones constructivas } \\ \square \text { Interés tipológico } & \square \text { Estructura } \\ \square \text { Valor ambiental } & \square \text { Aleros } \\ \square \text { Vigencia de la trama } & \square \text { Coronación } \\ \square \text { Composición de la fachada } & \square \text { Jambas } \\ \square \text { Materiales, color, textura } & \square \text { Dinteles }\end{array}$

$\begin{array}{ll}\text { Soluciones ornamentales } & \text { Interés paisajistico } \\ \square \text { Carpintería } & \square \text { Incidencia visual } \\ \square \text { Rejería } & \square \text { Carácter articulador } \\ \square \text { Cubrepersianas } & \square \text { Organización } \\ \square \text { Alicatados } & \square \text { Interés cultural } \\ \square \text { Recercos } & \square \text { Carácter representativo } \\ \square \text { Dinteles } & \\ \square \text { Otros ornamentos } & \end{array}$

$\square$ Bien de interés cultural (BIC)

$\square$ Afectado entorno BIC

$\square$ Afectado Plan especia

\section{Fortín de Cara-Cuesta, Caracuesta}

\section{- Identificación}

Tramo de estudio:

Otras denominaciones:

Tramo 6: Puerta de Reinas-Puerta de Valencia

\section{Ref. catastral:}

Localización: c/ de Caracuesta
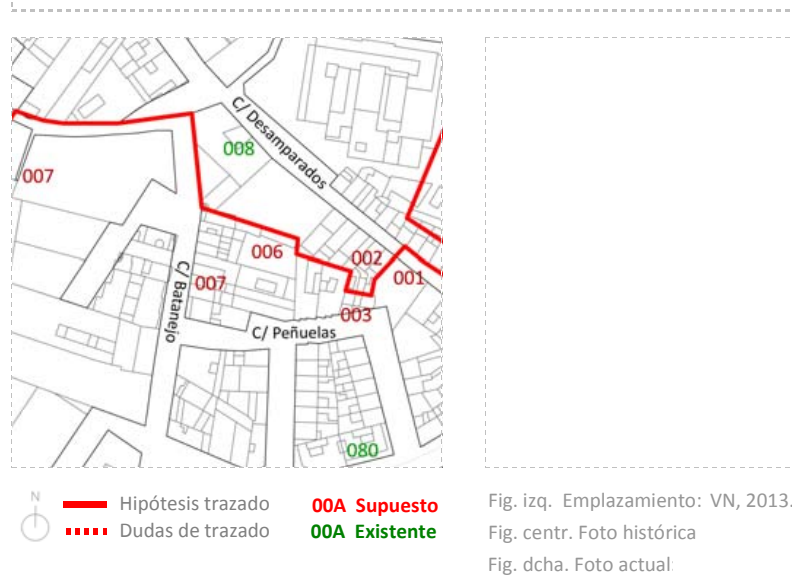

- Referencias en documentación histórica

\section{Referencias numéricas en cartografía sobre fortificación}

-Ref. en el croquis de Ortiz de Pinedo (1837-38, AGM, núm. 262): Sin ref.

-Ref. en plano de Vera Aparici (1993): 012

Referencias en memorias técnicas militare

-Ref. Guillermo Sáez (9/9/1834-5/12/1835): Requena, 5/12/1835 AMR, 1818-50

Se cierran las puertas falsas de la calle.

-Ref. Guillermo Sáez (26/02/1836): Sin ref.

-Ref. P. Ortiz de Pinedo (12/03/1837-30/05/1837): Sin ref.

-Ref Jose María de Orozco (25/03/1838): Sin ref.

-Ref. Carbonell (4/7/1838): AMR, 1818-17, fol. 22

"Se reforzarán las parédes de la casa de Amorós [que] miran á las Ollerias y al camino, dandoles tres pies mas de espésor por su parte interior. En las mismas se abrirán aspilléras en todos los pisos. La puerta de comunicacion con las casas del puente se trasladará al angulo de la derécha; $y$ como en este frente debe abrirse un foso se empleará un puente de madéra para su paso. Las dos lineas que ciérran la comunicacion desde el fortin dich
de 1838, AMR, 1818-17, fol. 22).

\section{- Observaciones a partir de los informes militares}

La actual calle Caracuesta de Requena, que configura un trazado curvo y conformaría el límite construido hasta la puerta de Valencia en su confluencia con la Calle Santa Cruz, donde se emplaza el puente de Santa Cruz o de las Ollerías.

Existe actualmente

Incluido en fichas PGOU 2013

Bien de interés cultural (BIC)

cód. postal: 46340

Comarca: Plana de Requena-Utie

Provincia: Valencia

Autonomia: Comunidad Valencian

$\begin{array}{lll}\text { Datos Jurídicos: } & & \\ \text { Código: } & \text { Fecha Disposición: } & \text { Fecha informe: } \\ \text { Estado: } & \text { Tipo delimitación: } & \text { Fecha Publicación BOP: } \\ \text { Categoría: } & \text { Plan: } & \text { Fecha Publicación DOCV: } \\ \text { Anotación Mo: } & \text { Informe: } & \text { Fecha Publicación BOE: }\end{array}$


$\square \frac{\text { Rellenar en caso de que el elemento sea }}{\text { contemplado con datos del PGOU, 2013 }}$

\section{PROTECCIÓN}

Nivel de protección:

Entorno:

$\square$ Inmueble

$\square$ Recinto arquitectón

$\square$ Entorno especifico

\section{- Descripción histórico-arquitectónica}

Tipología:

Cronologia:

Observaciones a la cronología

\section{Descripción}

- Entorno urbano

Descripción entorno urbano:

Uso actual:

Estado de conservación:

Intervenciones:

Régimen Urbanístico:

Titularidad:

Nivel protección s/catálogo 1996:

Bibliografía: AMR, 1818-17, 1818-24; 1818-50; 1818-52; 1818-53.

Observaciones generales:

$\begin{array}{llll}\text { OBJETIVACIÓN DE INTERÉS } & \text { Soluciones constructivas } & \text { Soluciones ornamentales } & \text { Interés paisajistico } \\ \square \text { Interés tipológico } & \square \text { Estructura } & \square \text { Carpintería } & \square \text { Incidencia visual } \\ \square \text { valor ambiental } & \square \text { Aleros } & \square \text { Rejería } & \square \text { carácter articulador } \\ \square \text { vigencia de la trama } & \square \text { coronación } & \square \text { cubrepersianas } & \square \text { Organización } \\ \square \text { Composición de la fachada } & \square \text { Jambas } & \square \text { Alicatados } & \square \text { Interés cultural } \\ \square \text { Materiales, color, textura } & \square \text { Dinteles } & \square \text { Recercos } & \square \text { Carácter representativo } \\ & & \square \text { Dinteles } & \\ & \square \text { otros ornamentos } & \end{array}$

\section{- Datos específicos catalogación BIC $\square$ Rellenar sólo si está catalogado BIC}

\section{Datos Jurídicos:}

$\begin{array}{lll}\text { Código: } & \text { Fecha Disposición: } & \text { Fecha informe: } \\ \text { Estado: } & \text { Tipo delimitación: } & \text { Fecha Publicación BOP: } \\ \text { Categoría: } & \text { Plan: } & \text { Fecha Publicación DOCV: } \\ \text { Anotación Mo: } & \text { Informe: } & \text { Fecha Publicación BOE: }\end{array}$

AFECCIÓN PATRIMONIAL

$\square$ Bien de interés cultural (BIC)

\section{Casas del Puente}

$\square$ Afectado entorno BIC

Afectado Plan especia

- Identificación
Tramo de estudio: $\quad$ Tramo 6: Puerta de Reinas-Puerta de Valencia
Otras denominaciones:
$\begin{aligned} & \text { Ref. catastral: } \\ & \text { Localización: }\end{aligned}$
Casas junto al Puente de las Ollerías. Lado Noreste de C/
Desamparados.

$\square$ Existe actualmente

Incluido en fichas PGOU 2013

Bien de interés cultural (BIC)

Cód. postal: 46340

Municipio: Requena

Comarca: Plana de Requena-Utiel

Provincia: Valencia

Autonomía: Comunidad Valenciana

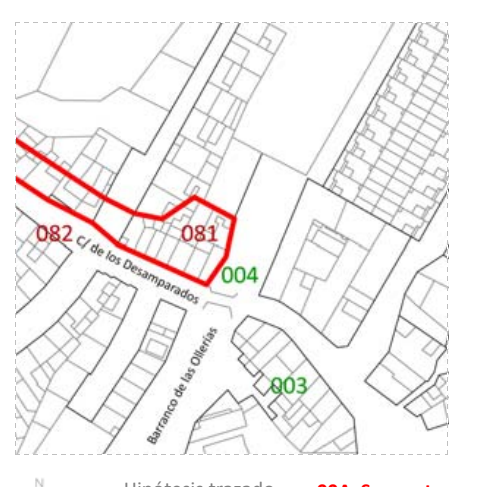

- H

O0A Supuesto

Fig. iza. Emplazamiento: VN, 2013

Fig. centr. Foto histórica

Fig. dcha. Foto actual: Casas de la ribera occidental del puente de las ollerías. Se observan los huertos
tapiados (VN, 2013).

- Referencias en documentación histórica

Referencias numéricas en cartografía sobre fortificación

-Ref. en el croquis de Ortiz de Pinedo (1837-38, AGM, núm. 262): Sin ref.

-Ref. en plano de Vera Aparici (1993): Sin ref.

Referencias en memorias técnicas militares

-Ref. Guillermo Sáez (9/9/1834-5/12/1835): Sin ref.

-Ref. Guillermo Sáez (26/02/1836): Sin ref.

-Ref. P. Ortiz de Pinedo (12/03/1837-30/05/1837): Sin ref.

-Ref Jose María de Orozco (25/03/1838): Sin ref.

-Ref. Carbonell (4/7/1838): AMR, 1818-17, fol. 22

"Estas casas se hallan en tan mal estado que seria necesario derribárlas, si el enemigo atacáse á la Poblacion con recúrsos imponéntes: pero como no hay inconveniente en conserbarlas, mientras no llegue este caso, debe aspillerarse en todos sus pisos, y sujetárse á las prevénciónes que se han hecho para todos los edificios que se hallan en el perimetro de la Ciudad" (Carbonell, Requena, 4 de julio de

- Observaciones a partir de los informes militares

Constituye el conjunto de casas que defienden el puente de las Ollerías.

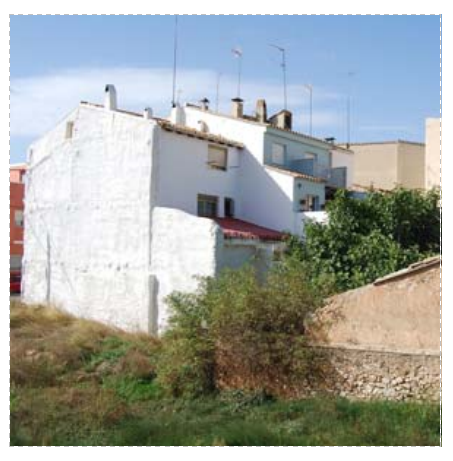


$\square \frac{\text { Rellenar en caso de que el elemento sea }}{\text { contemplado con datos del PGOU, 2013 }}$

\section{PROTECCIÓN}

Nivel de protección:

Entorno:

$\square$ Inmueble

$\square$ Recinto arquitectónico

$\square$ Entorno específico

- Descripción histórico-arquitectónica

Tipología:

Cronologia:

Observaciones a la cronología

Descripción

- Entorno urbano

Descripción entorno urbano:

Uso actual:

Estado de conservación:

Intervenciones:

Régimen Urbanístico:

Titularidad:

Nivel protección s/catálogo 1996

Bibliografía: AMR, 1818-17, 1818-24; 1818-50; 1818-52; 1818-53.

Observaciones generales:

$\begin{array}{ll}\text { OBJETIVACIÓN DE INTERÉS } & \text { Soluciones constru } \\ \square \text { Interés tipológico } & \square \text { Estructura } \\ \square \text { Valor ambiental } & \square \text { Aleros } \\ \square \text { Vigencia de la trama } & \square \text { Coronación } \\ \square \text { Composición de la fachada } & \square \text { Jambas } \\ \square \text { Materiales, color, textura } & \square \text { Dinteles }\end{array}$

$\begin{array}{ll}\text { Soluciones ornamentales } & \text { Interés paisajistico } \\ \square \text { Carpintería } & \square \text { Incidencia visual } \\ \square \text { Rejería } & \square \text { Carácter articulador } \\ \square \text { Cubrepersianas } & \square \text { Organización } \\ \square \text { Alicatados } & \square \text { Interés cultural } \\ \square \text { Recercos } & \square \text { Carácter representativo } \\ \square \text { Dinteles } & \\ \square \text { Otros ornamentos } & \end{array}$

$\square$ Bien de interés cultural (BIC)

$\square$ Afectado entorno BIC

$\square$ Afectado Plan especia

\section{Desde la Casa de Amoroz a la Puerta de Valencia. Casa y Fuerte de Amorós}

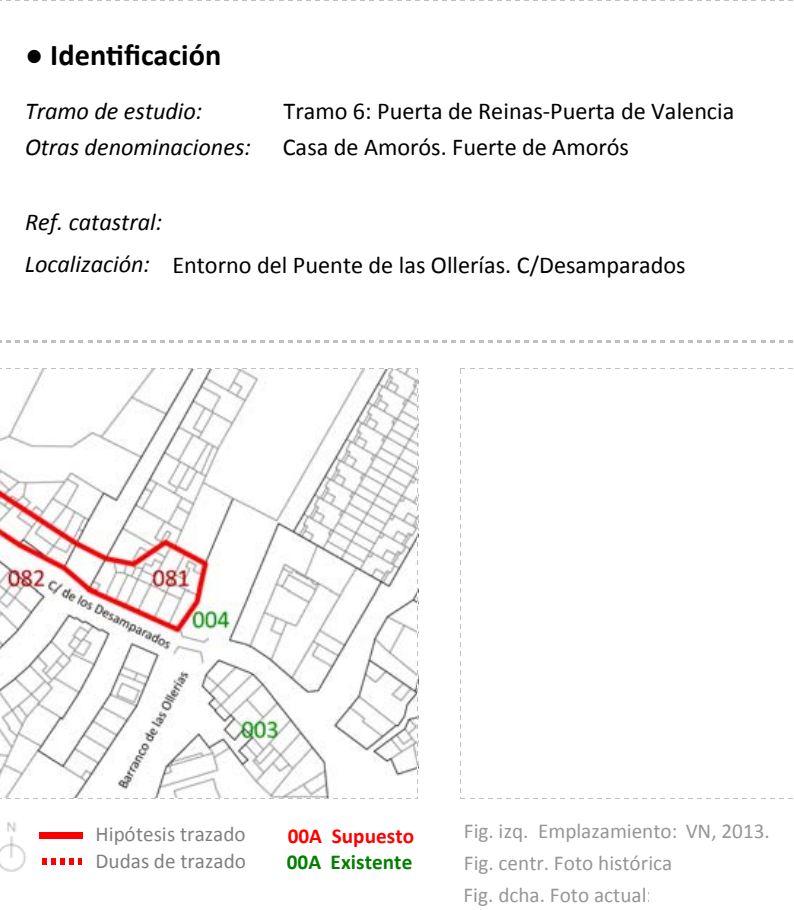

- Referencias en documentación histórica

\section{cartografía sobre fortificación}

-Ref. en el croquis de Ortiz de Pinedo (1837-38, AGM, núm. 262): Sin ref.

-Ref. en plano de Vera Aparici (1993): Sin ref.

Referencias en memorias técnicas militares

-Ref. Guillermo Sáez (9/9/1834-5/12/1835): Sin ref.

-Ref. Guillermo Sáez (26/02/1836): Sin ref.

-Ref. P. Ortiz de Pinedo (12/03/1837-30/05/1837): Sin ref.

-Ref Jose Maria de Orozco (25/03/1838): Requena, 25/03/1838, AMR 1818-24

Según Orozco, se ubica contiguo a la Puerta de Valencia y puede ser batido por el enemigo desde el Barrio de las Ollerías.Tiene poca casa de Manuel Ponce, contigua al puente de las Ollerías tiene poca solidez y defensa. Se propone asi dar más amplitud y consistencia a -Ref. Carbonell (4/7/1838): AMR, 1818-17, fol. 22

"Se aspillerarán las parédes en todos los cuerpos, se masisarán las puertas con buena albanilieria, se arrancarán los balcónes que no se elében mas de ocho baras sobre el tereño, y se tapiarán las ventanas que se hallen en igual caso" (Carbonell, Requena, 4 de julio de 1838

\section{- Observaciones a partir de los informes militares}

Constituye el una casa que se convierte en tambor defensivo asociado a la Puerta de Valencia, de acuerdo con la tónica habitual de habilitar un tambor junto a cada puerta clave del recinto en 1838. La existencia de un tambor en Cantarranas hace suponer la presencia

$\square$ Existe actualmente

$\square$ Biende inteŕs altura (BDI

cód. postal: 46340

tonomia: Comunidad Valenciar

$\begin{array}{lll}\text { Datos Jurídicos: } & & \\ \text { Código: } & \text { Fecha Disposición: } & \text { Fecha informe: } \\ \text { Estado: } & \text { Tipo delimitación: } & \text { Fecha Publicación BOP: } \\ \text { Categoría: } & \text { Plan: } & \text { Fecha Publicación DOCV: } \\ \text { Anotación Mo: } & \text { Informe: } & \text { Fecha Publicación BOE: }\end{array}$


$\square \frac{\text { Rellenar en caso de que el elemento sea }}{\text { contemplado con datos del PGOU, 2013 }}$

\section{PROTECCIÓN}

Nivel de protección:

Entorno:

$\square$ Inmueble

$\square$ Recinto arquitectón

$\square$ Entorno específico

- Descripción histórico-arquitectónica

Tipología:

Cronología:

Observaciones a la cronología

Descripción

- Entorno urbano

Descripción entorno urbano:

Uso actual:

Estado de conservación:

Intervenciones:

Régimen Urbanístico:

Titularidad:

Nivel protección s/catálogo 1996:

Bibliografía: AMR, 1818-17, 1818-24; 1818-50; 1818-52; 1818-53.

observaciones generales:

$\begin{array}{llll}\text { OBJETIVACIÓN DE INTERÉS } & \text { Soluciones constructivas } & \text { Soluciones ornamentales } & \text { Interés paisajistico } \\ \square \text { Interés tipológico } & \square \text { Estructura } & \square \text { carpintería } & \square \text { Incidencia visual } \\ \square \text { valor ambiental } & \square \text { Aleros } & \square \text { Rejería } & \square \text { carácter articulador } \\ \square \text { vigencia de la trama } & \square \text { coronación } & \square \text { cubrepersianas } & \square \text { Organización } \\ \square \text { composición de la fachada } & \square \text { Jambas } & \square \text { Alicatados } & \square \text { Interés cultural } \\ \square \text { Materiales, color, textura } & \square \text { Dinteles } & \square \text { Recercos } & \square \text { carácter representativo } \\ & & \square \text { Dinteles } & \\ & \square \text { otros ornamentos } & \end{array}$

\section{- Datos específicos catalogación BIC $\square$ Rellenar sólo si está catalogado BIC}

\section{Datos Jurídicos:}

Código:
Estado:

Estado:
Categoría:

Fecha Disposición:

Tipo delimitación:

Anotación $M \stackrel{-}{0}$

Plan:

Fecha informe:

Fecha Publicación BOP:

Fecha Publicación DOCV:

\section{Barrio denominado de la Villa}

\section{- Identificación}

Tramo de estudio:

Recinto interior: La Villa

Otras denominaciones:

Ref. catastral:

Localización: Barrio de la Villa. Acceso por Cuesta del Castillo, Carnicerías, El Ángel, El Cristo.

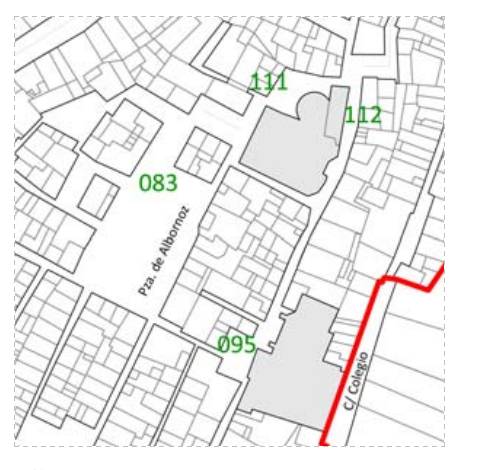

$\begin{array}{cc}\text {-.... Hipótesis trazado } & \text { O0A Supuesto } \\ \text { OOA Existente }\end{array}$

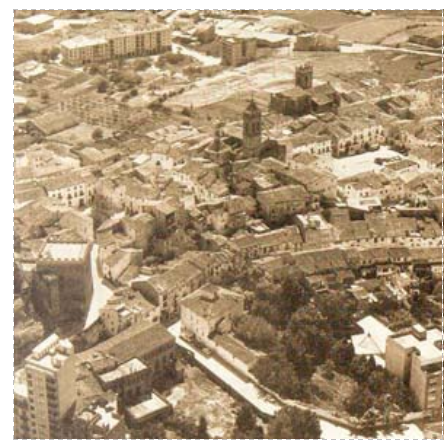

Fig. izq. Emplazamiento: VN, 2013 Fig. centr., Foto histórica Bernabeu, 1982: 68

- Referencias en documentación histórica

\section{Referencias numéricas en cartografía sobre fortificación}

-Ref. en el croquis de Ortiz de Pinedo (1837-38, AGM, núm. 262): Sin ref.

-Ref. en plano de Vera Aparici (1993): Sin ref.

Referencias en memorias técnicas militare

-Ref. Guillermo Sáez (9/9/1834-5/12/1835): Sin ref.

-Ref. Guillermo Sáez (26/02/1836): Sin ref.

-Ref. P. Ortiz de Pinedo (12/03/1837-30/05/1837): Sin ref.

-Ref Jose María de Orozco (25/03/1838): Requena, 25/03/1838, AMR 1818-24

Es la primera vez que se trata a la Villa y al Castillo en una memoria militar en el transcurso de la Primera Guerra Carlista. Para García de Se concibe como ciudadela, en la que con sólo 300 hombres se haría inconquistable la ciudad. Según el comandante no serán necesarios grandes gastos dado que la "posición natural de la Villa y Castillo, la hacen por sí ináccesible y de consiguiente facil á suplir lo que el arte ni pueda aplicarle" (AMR, 1818-24)

-Ref. Carbonell (4/7/1838): AMR, 1818-17, fol. 22

"Se aspillerarán en todos sus pisos que miran á la parte interior, y forman parte del recinto de la Villa" (Carbonell, Requena, 4 de julio de 1838, AMR, 1818-17, fol. 22)

\section{- Observaciones a partir de los informes militares}

Hay una serie de cuevas que se utilizaban como almacenes y silos, debido a la importancia que tenia el municipio como Puerto Seco y Almojarf azgo con ganado, lana y trigo. Tras la conquista cristiana se produce una renovación urbana que se hace patente en el arrabal de la Iglesia de San Nicolás y la I glesia del Salvador. Las tres tuvieron importantes reformas en el siglo XVII, teniendo mayor rango la

arciprestal del Salvador desde 1649. Extramuros se encuentra el barrio de las Peñas, entre el Arrabal y el recinto medieval se encuentra la primitiva judería que será el eje comercial que sustituiráa la villa debido a una mejor accesibilidad. Esto constituirá el crecimiento de la población desplazando a la villa. En la Edad Media existió una consolidación constante de las murallas defensivas, dotadas con diezmos 
desde privilegio de Enrique II en 1397, debido a los acosos por conseguir el monopolio aduanero entre aragoneses y castellanos. Se conservan varias torres del recinto amurallado como la torre Montijana y San Julián edificadas en el siglo XV, y la Torre del Homenaje realizada en argamasa se sustituyó por la actual de sillería en 1423. Tras la unificación de Castilla y Aragón hubo un desarrollo comercia demoráfico La ciudand se expande hacia la vaguadas del arrabal de forma más regular $y$ con edificicos más modernos por el flanco oeste de I villa se realizan edificaciones adosadas a a muralla que enmascaran el desnivel natural del terreno. Los edificios de la Vila no tiene una tipología unitaria. Las fábricas utilizadas son mixtas, es decir, de mampostería y adobe, utilizándose poco la sillería. Los forjados suelen ser de madera y las cubiertas exteriores de teja árabe. Suelen presentar dos o tres plantas. En la actualidad junto a la Alcazaba se encuentra la Torre del Homenaje en la que ubica el Museo de la Fiesta de la Vendimia y una sala para actividades culturales."

(http://www.cult.gva.es/dgpa/bics/Detalles_bics.asp?ldinmueble=168).

$\begin{array}{lll}\square \frac{\text { Rellenar en caso de que el elemento sea }}{\text { contemplado con datos del PGOU, 2013 }} & \text { PROTECCIÓN } & \text { AFECCIÓN PATRIMONIAL } \\ & \text { Nivel de protección: } & \square \text { Bien de interés cultural (BIC) } \\ & \text { Entorno: } & \square \text { Bien de relevancia local (BRL) } \\ & \square \text { Inmueble } & \square \text { Afectado entorno BIC } \\ \square \text { Parcela catastral } & \square \text { Afectado Plan especial } \\ \square \text { Recinto arquitectónico } & \\ & \square \text { Entorno específico } & \end{array}$

\section{- Descripción histórico-arquitectónica}

Tipología:

Observaciones a la cronología

\section{Descripción}

- Entorno urbano

Descripción entorno urbano:

Uso actual:

Estado de conservación:

Intervenciones:

Régimen Urb:

Nivel protección s/catálogo 1996:

Bibliografia: AMR, 1818-17, 1818-24; 1818-50; 1818-52; 1818-53.

Observaciones generales:

\section{OBJETIVACIÓN DE INTERÉS}

$\square$ Interés tipológico

$\square$ Valor ambiental

$\square$ Vigencia de la trama

$\square$ Materiales, color, textura

\section{Soluciones constructivas}

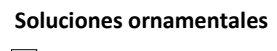

\section{Interés paisajistico}

$\square$ Estructura

$\square$ Aleros

$\square$ Coronación

$\square$ Jambas

$\square$ Carpintería
$\square$ Rejería
$\square$ Cubrepersianas
$\square$ Alicatados
$\square$ Recercos

$\square$ carácter articulador

$\square$ Organización

Interés cultural

Carácter representativo

$\square$ Otros ornamentos

\section{- Datos específicos catalogación BIC}

$\checkmark$ Rellenar sólo si está catalogado BIC

Datos Jurídicos:

Código: 46.17.213-006

Estado: Declaración singular

Categoria: Conjunto historico

Fecha Disposición: 10/03/1966

Fecha informe: $17 / 02 / 2004$

Anotación Mo: R-1-53-0000074
Tipo delimitación: Planeamiento especial Fecha Publicación BOP: 10/10/2005

Plan: Plan Especial de Protección del Conjun Fecha Publicación DOCV:

\section{Casa de Zamora}

- Identificación

Tramo de estudio:

Recinto interior: La Villa

Otras denominaciones: Corral de Zamora, Corral de Manuel Gonzales, Casa de Go

Ref. catastral:

Localización: Área de Casas de la Villa que vuelcan a c/García Montes. Acceso desde C/Casares

Existe actualmente

Incluido en fichas PGOU 2013

Bien de interés cultural (BIC)

cód. postal: 46340

Municipio: Requen

Comarca: Plana de Requena-Utiel

Provincia: Valencia

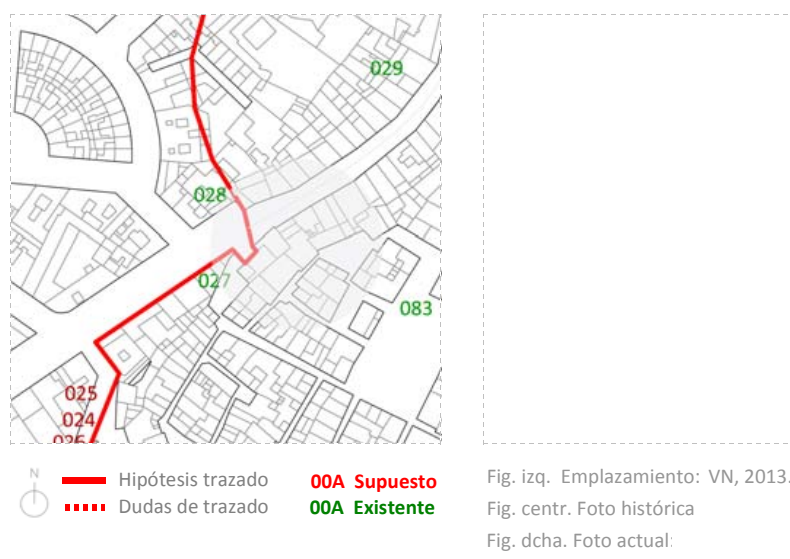

- Referencias en documentación histórica

Referencias numéricas en cartografía sobre fortificación

-Ref. en el croquis de Ortiz de Pinedo (1837-38, AGM, núm. 262): Sin ref.

-Ref. en plano de Vera Aparici (1993): Sin ref.

Referencias en memorias técnicas militares

-Ref. Guillermo Sáez (9/9/1834-5/12/1835): Sin ref.

-Ref. Guillermo Sáez (26/02/1836): Sin ref.

-Ref. P. Ortiz de Pinedo (12/03/1837-30/05/1837): Sin ref.

-Ref Jose María de Orozco (25/03/1838): Sin ref.

-Ref. Carbonell (4/7/1838): AMR, 1818-17, fol. 23

"Se aspillerarán igualménte. Se levantará en forma de parapéto el guardaládo del blanquéador; tanto donde es de tabique como de pared. Las puertas que ahorra están cerradas con obra, se cerrarán con mas perféccion, abriéndo aspilléras: La tapia del corral de Zamóra en la Plaza de Casáres se asphlerard asicomo la del corral de Manuel Gonzales que sigue la misma linea. La comunicacion de este corral con la casa de González se tapiará dejándo el corral en alberca" (AMR, 1818-17, fol. 23).

\section{- Observaciones a partir de los informes militares}

Se trataría de una de las casas que vuelca a Cantarranas para contribuir en su defensa y a la que se accede desde el interior de la Villa. En aquel entonces se accederia desde la denominada Plaza de Casares. Observamos que responde a la misma tipologia de casa asociada a corral. Junto a la casa y corral de Zamora, se encontraría la de Manuel Gonzales. 
$\square \frac{\text { Rellenar en caso de que ele lemento sea }}{\text { contemplado con datas del } 1 \text { PCOU, } 2013}$

PROTECCIÓN

Nivel de protección:

AFECCIÓN PATRIMONIAL

$\square$ Inmueble

$\square$ Parcela catastral

$\square$ Recinto arquitectónico

$\square$ Bien de interés cultural (BIC)

$\square$ Bien de relevancia local (BRL)

$\square$ Afectado entorno BIC

$\square$ Afectado Plan especia

\section{- Descripción histórico-arquitectónica}

Tipología:

Cronología:

Observaciones a la cronología

\section{Descripción:}

- Entorno urbano

Descripción entorno urbano:

Uso actual:

Estado de conservación:

Intervenciones:

Régimen Urbanístico:

Titularidad:

Nivel protección s/catálogo 1996:

Bibliografía: AMR, 1818-17, 1818-24; 1818-50; 1818-52; 1818-53.

observaciones generales:

$\begin{array}{llll}\text { OBJETIVACIÓN DE INTERÉS } & \text { Soluciones constructivas } & \text { Soluciones ornamentales } & \text { Interés paisajistico } \\ \square \text { Interés tipológico } & \square \text { Estructura } & \square \text { Carpintería } & \square \text { Incidencia visual } \\ \square \text { valor ambiental } & \square \text { Aleros } & \square \text { Rejería } & \square \text { carácter articulador } \\ \square \text { vigencia de la trama } & \square \text { coronación } & \square \text { Cubrepersianas } & \square \text { organización } \\ \square \text { composición de la fachada } & \square \text { Jambas } & \square \text { Alicatados } & \square \text { Interés cultural } \\ \square \text { Materiales, color, textura } & \square \text { Dinteles } & \square \text { Recercos } & \square \text { carácter representativo } \\ & & \square \text { Dinteles } & \\ & \square \text { Otros ornamentos } & \end{array}$

\section{- Datos específicos catalogación BIC $\square$ Rellenar sólo si está catalogado BIC}

\section{Datos Jurídicos:}

Datos Juridicos:
Código:

Estado:

Categoria:

Fecha Disposición:
Tipo delimitación:
Plan:

Fecha informe:

Fecha Publicación BOP:

Fecha Publicación DOCV:

Informe:

\section{Corral de Don José Cantos}

\begin{tabular}{|c|c|}
\hline \multicolumn{2}{|l|}{ - Identificación } \\
\hline Tramo de estudio: & Recinto interior: La Villa \\
\hline Otras denominaciones: & Casa de Don José Cantos \\
\hline \multicolumn{2}{|l|}{ Ref. catastral: } \\
\hline $\begin{array}{l}\text { Localización: Área de } \\
\text { desde C/ }\end{array}$ & $\begin{array}{l}\text { asas de la Villa que vuelcan a C/García Montes. Accesc } \\
\text { Casares }\end{array}$ \\
\hline
\end{tabular}

Existe actualmente

Incluido en fichas PGOU 2013

$\square$ Bien de interés cultural (BIC)

cód. postal: 46340

Municipio: Requena

Comarca: Plana de Requena-Utiel

Provincia: Valencia

utonomia: Comunidad Valenciar

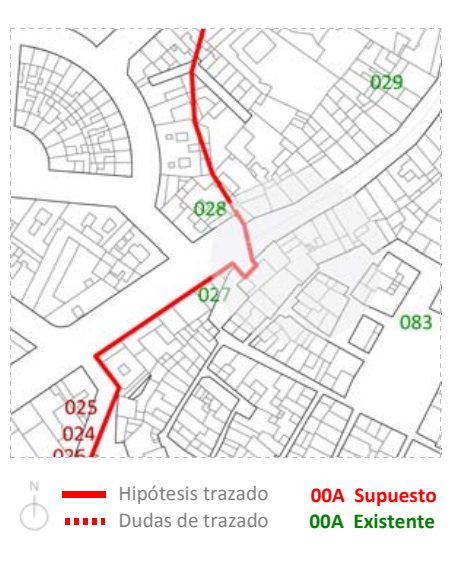

Fig. izq. Emplazamiento: VN, 2013.

Fig. centr. Foto históric
Fig. dcha. Foto actual:

\section{- Referencias en documentación histórica}

Referencias numéricas en cartografía sobre fortificación

-Ref. en el croquis de Ortiz de Pinedo (1837-38, AGM, núm. 262): Sin ref.

-Ref. en plano de Vera Aparici (1993): Sin ref.

Referencias en memorias técnicas militares

-Ref. Guillermo Sáez (9/9/1834-5/12/1835): Sin ref.

-Ref. Guillermo Sáez (26/02/1836): Sin ref.

-Ref. P. Ortiz de Pinedo (12/03/1837-30/05/1837): Sin ref.

-Ref Jose María de Orozco (25/03/1838): Sin ref.

-Ref. Carbonell (4/7/1838): AMR, 1818-17, fol. 23

"Se abrirán aspilléras en la tapia que mira á la calle de Cantarránas, y en la que mira al corral de Manuel González. Las puertas de

comunicacion con las casas de Cantarránas se tapiarán en caso de riesgo. Las vocas calles que caen á la Plaza de Casáres se cerrarán con cortadúras barricádas [signo ilegible] en caso de riesgo. La puerta grande del corral de Don [Cantos] serà la comunicacion unica para la retiráda de los defensóres de la Plaza de Casáres, pero para esto solo se dejara una hoja, Y otra se podrá masisar por detrás en caso critico. (AMR, 1818-17, fol 23).

\section{- Observaciones a partir de los informes militares}

Corral, se supone asociado a la casa de Don José Cantos, que defiende Cantarranas. Ver 084. 
$\square$ Rellenar en caso de que el elemento sea

\section{ROTECCIÓN}

Nivel de protección:

Entorno:

$\square$ Inmueble

$\square$ Parcela catastral

$\square$ Recinto arquitectónico
AFECCIÓN PATRIMONIAL

$\square$ Bien de interés cultural (BIC)

$\square$ Afectado entorno BIC

$\square$ Afectado Plan especia

\section{- Descripción histórico-arquitectónica}

Tipología

Observaciones a la cronologia

Descripción:

- Entorno urbano

Descripción entorno urbano:

Uso actual:

Estado de conservación:

Intervenciones:

Régimen Urbanistico:

Titularidad:

Nivel protección s/catálogo 1996:

Bibliografía: AMR, 1818-17, 1818-24; 1818-50; 1818-52; 1818-53.

Observaciones generales:

\begin{tabular}{|c|c|c|}
\hline BJETIVACIÓN DE INTERÉS & Soluciones constructivas & Soluciones ornamentales \\
\hline Interés tipológico & $\square$ Estructura & $\square$ Carpintería \\
\hline Valor ambiental & $\square$ Aleros & Rejería \\
\hline Vigencia de la trama & $\square$ Coronación & $\square$ Cubrepersianas \\
\hline Composición de la fachada & $\square$ Jambas & $\square$ Alicatados \\
\hline Materiales, color, textura & $\square$ Dinteles & $\square$ Recercos \\
\hline & & $\square$ Dinteles \\
\hline & & Otros ornamentos \\
\hline
\end{tabular}

\section{- Datos específicos catalogación BIC $\quad \square$ Rellenar sólo si está catalogado BIC}

\section{Datos Jurídicos:}

Código:

Fecha Disposición:

Anotación $M$

Plan:

Informe:

Fecha informe:

Fecha Publicación BOP:

Fecha Publicación DOC

\section{Interés paisajistico}

$\square$ Incidencia visual

Carácter articulador

$\square$ Organización

Carácter representativo
Anotación $M-$

\section{Casa de Don Jose Cantos}

Existe actualmente

Existe actualmente

Bien de inteŕs culuna 2013

cód. postal: 46340

Municipio: Requena

Comarca: Plana de Requena-Utiel

Provincia: Valencia

Autonomía: Comunidad Valencian
Ref. catastral: desde C/Casares

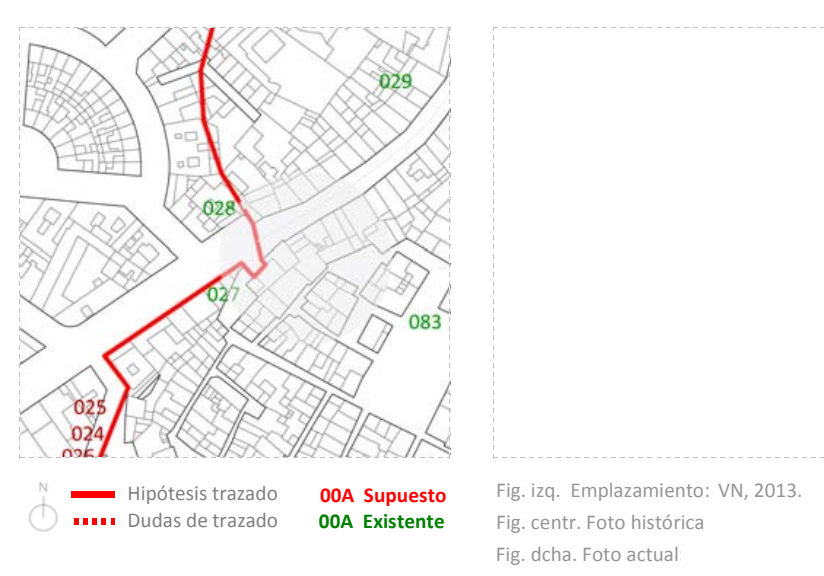

- Referencias en documentación histórica

\section{Referencias numéricas en cartografía sobre fortificación}

-Ref. en el croquis de Ortiz de Pinedo (1837-38, AGM, núm. 262): Sin ref.

-Ref. en plano de Vera Aparici (1993): Sin ref.

Referencias en memorias técnicas militares

-Ref. Guillermo Sáez (9/9/1834-5/12/1835): Sin ref.

-Ref. Guillermo Sáez (26/02/1836): Sin ref.

-Ref. P. Ortiz de Pinedo (12/03/1837-30/05/1837): Sin ref.

-Ref Jose María de Orozco (25/03/1838): Sin ref.

-Ref. Carbonell (4/7/1838): AMR, 1818-17, fol. 23

"Despues de espillerárse como se há dicho se harán parapétos aspillerádos de tabicón en la galeria que cae al corral. Todas las casas desde la de [Cantos] hasta el callejón del pozo del astillo sufrirán el mismo [aspilleramiento] y obras que por regla general se hán establecído. La boca calle del callejón citádo se cerrará en su salida con pared aspilleráda desde la puerta del corral de Victor Comas hasta la de su frente, quedándo ambas interióres. La puerta de la casa (que] hay en frente se masisará, $y$ se derribarán las parédes de los costados de esta casa

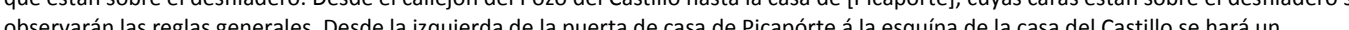

- Observaciones a partir de los informes militares

Ver 084,085 


\section{Rellenar en caso de que el elemento sea
contemplado con datos del PGOU, 2013}

\section{ROTECCIÓN}

Nivel de protección:

Entorno:

$\square$ Inmueble

$\square$ Parcela catastral

Recinto arquitectón

$\square$ Entorno específico

- Descripción histórico-arquitectónica

\section{Tipología:}

Cronología:

Observaciones a la cronologia

Descripción:

- Entorno urbano

Descripción entorno urbano:

Uso actual:

Estado de conservación:

Intervenciones:

Régimen Urbanístico:

Titularidad:

Nivel protección s/catálogo 1996:

Bibliografía: AMR, 1818-17, 1818-24; 1818-50; 1818-52; 1818-53.

Observaciones generales:

\begin{tabular}{|c|c|c|}
\hline BJETIVACIÓN DE INTERÉS & Soluciones constructivas & Soluciones ornamentales \\
\hline Interés tipológico & $\square$ Estructura & $\square$ Carpintería \\
\hline Valor ambiental & $\square$ Aleros & $\square$ Rejería \\
\hline Vigencia de la trama & Coronación & $\square$ Cubrepersianas \\
\hline Composición de la fachada & $\square$ Jambas & $\square$ Alicatados \\
\hline Materiales, color, textura & $\square$ Dinteles & $\square$ Recercos \\
\hline & & $\square$ Dinteles \\
\hline & & $\square$ otros ornamentos \\
\hline
\end{tabular}

\section{- Datos específicos catalogación BIC \\ Rellenar sólo si está catalogado $B$}

Datos Jurídicos:

$\begin{array}{lll}\text { Código: } & \text { Fecha Disposición: } & \text { Fecha informe: } \\ \text { Estado: } & \text { Tipo delimitación: } & \text { Fecha Publicación BOP: } \\ \text { Categoriá: } & \text { Plan: } & \text { Fecha Publicación DOCV: } \\ \text { Anotación Mo: } & \text { Informe: } & \text { Fecha Publicación BOE: }\end{array}$

AFECCIÓN PATRIMONIAL

$\square$ Bien de interés cultural (BIC)

$\square$ Bien de relevancia local (BRL)

$\square$ Afectado entorno BIC

Afectado Plan especial

\section{Castillo y Murallas}

\section{- Identificación}

Tramo de estudio:

Ciudadela

Otras denominaciones:

(n)

Localización: C/ Fortaleza

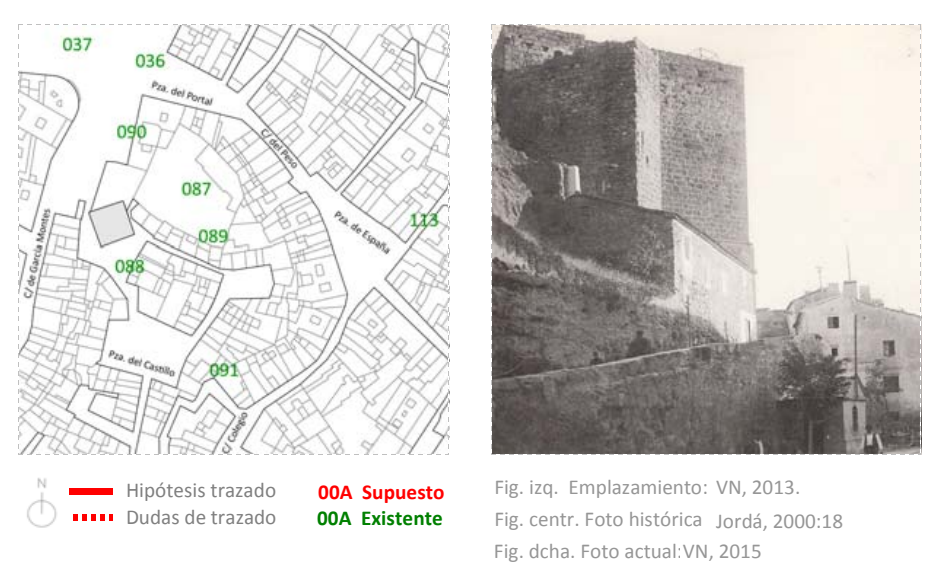

\section{- Referencias en documentación histórica}

Interés paisajístico

$\square$ Incidencia visual

$\square$ Carácter articulador

$\square$ Organización

Carácter representativo

\section{Referencias numéricas en cartografía sobre fortificación}

-Ref. en el croquis de Ortiz de Pinedo (1837-38, AGM, núm. 262): Sin ref.

-Ref. en plano de Vera Aparici (1993): Sin ref.

Referencias en memorias técnicas militares

-Ref. Guillermo Sáez (9/9/1834-5/12/1835): Sin ref.

-Ref. Guillermo Sáez (26/02/1836): Sin ref.

-Ref. P. Ortiz de Pinedo (12/03/1837-30/05/1837): Sin ref.

-Ref Jose María de Orozco (25/03/1838): Requena, 25/03/1838, AMR 1818-24

Es la primera vez que se trata a la Villa y al Castillo en una memoria militar en el transcurso de la Primera Guerra Carlista. Para García de Orozco, constituyen un "alcázar inexpugnable" que hay que considerar como pieza activa de la defensa, como último reducto defensivo. grandes gastos dado que la "posición natural de la Villa y Castillo, la hacen por sí ináccesible y de consiguiente facil á suplir lo que el arte pueda aplicarle" (AMR, 1818-24) Ref Corbonell (4/D).

\section{- Observaciones a partir de los informes militares}

Las fortificaciones neurobalisticas de Requena representadas por sus murallas medievales, ocupan un papel anecdótico en los informes militares. Por ello no se abordan con mas detalle en este trabajo. La situación fronteriza de Requena a finales del siglo XII lleva a un refuerzo de su fortificación por parte del Reino de Valencia. Se incluia el arrabal de San Nicolas. La guerras fronterizas de la Baja Edad Media, entre Aragonn y Castilla produjeron las mayores alteraciones. Durante la ocupacion aragonesa (1370-1374) se refuerzan las torre principal del castillo pasa de tapia a sillerí (1424)-

$\checkmark$ Existe actualmente

$\square$ Incluido en fichas PGOU 2013

Cód. postal: 46340

equena-Utiel

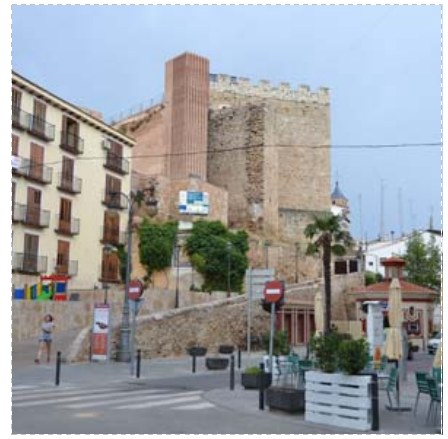


$\square \begin{aligned} & \text { Rellenar en caso de que el elemento sea } \\ & \text { contemplado con datos del PGOU, } 2013\end{aligned}$

\section{PROTECCIÓN}

Nivel de protección:

AFECCIÓN PATRIMONIAL

$\square$ Inmueble

$\square$ Parcela catastral

Recinto arquitectón

$\square$ Entorno específico

$\square$ Afectado entorno BIC

$\square$ Afectado Plan especial

\section{- Descripción histórico-arquitectónica}

Tipología:

Cronología:

Observaciones a la cronologia:

\section{Descripción:}

- Entorno urbano

Descripción entorno urbano:

Uso actual:

Estado de conservación:

Intervenciones:

Régimen Urbanístico:

Nivel protecion

catálogo 1996:

Bibliografia: AMR, 1818-17, 1818-24; 1818-50; 1818-52; 1818-53.

Observaciones generales:

$\begin{array}{llll}\text { OBJETIVACIÓN DE INTERÉS } & \text { Soluciones constructivas } & \text { Soluciones ornamentales } & \text { Interés paisajistico } \\ \square \text { Interés tipológico } & \square \text { Estructura } & \square \text { carpintería } & \square \text { Incidencia visual } \\ \square \text { valor ambiental } & \square \text { Aleros } & \square \text { Rejería } & \square \text { carácter articulador } \\ \square \text { vigencia de la trama } & \square \text { coronación } & \square \text { cubrepersianas } & \square \text { organización } \\ \square \text { composición de la fachada } & \square \text { Jambas } & \square \text { Alicatados } & \square \text { Interés cultural } \\ \square \text { Materiales, color, textura } & \square \text { Dinteles } & \square \text { Recercos } & \square \text { Carácter representativo } \\ & & \square \text { Dinteles } & \\ & \square \text { Otros ornamentos } & \end{array}$

\section{- Datos específicos catalogación BIC $\nabla$ Rellenar sólo si está catalogado BIC}

Datos Jurídicos:

Código: $46.17 .213-007$

Estado: Declaración genérica

Categorí: Monumento

Fecha Disposición: 21/07/2008

Fecha informe: $17 / 02 / 2004$

Anotación Mo: R-1-51-0012146

088 Torre del castillo

\section{- Identificación}

Tramo de estudio

Otras denominaciones:

Ref. catastral:

Localización: C/ Fortaleza

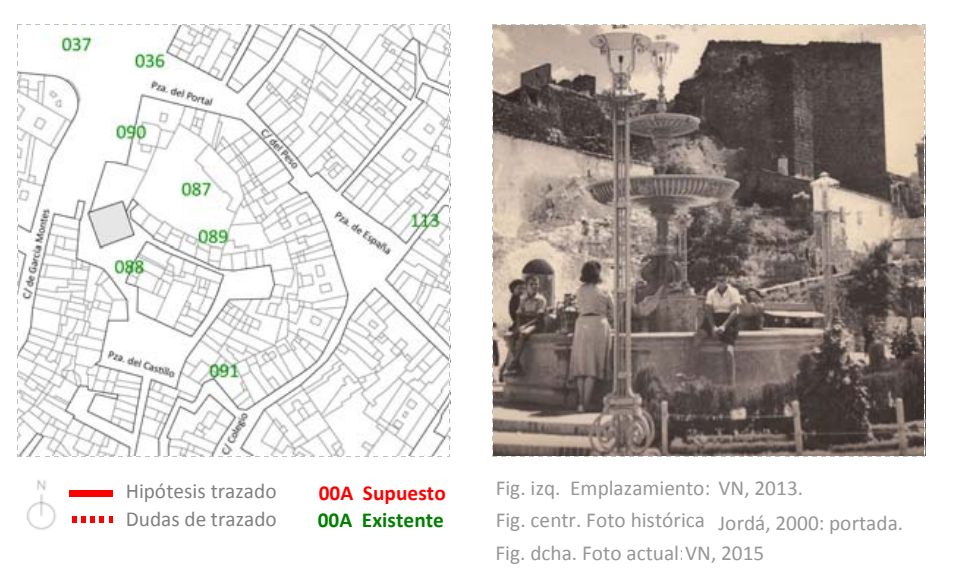

$\checkmark$ Existe actualmente

$\square$ Incluido en fichas PGOU 2013

Bien de interés cultural (BIC)

cód. postal: 46340

Municipio: Requena

Comarca: Plana de Requena-Utie

Provincia: Valencia

Autonomia: Comunidad Valenciarn

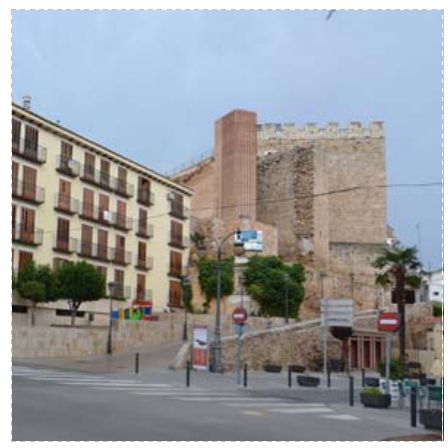

- Referencias en documentación histórica

Referencias numéricas en cartografía sobre fortificación

-Ref. en el croquis de Ortiz de Pinedo (1837-38, AGM, núm. 262): Sin ref.

-Ref. en plano de Vera Aparici (1993): Sin ref.

Referencias en memorias técnicas militares

-Ref. Guillermo Sáez (9/9/1834-5/12/1835): Sin ref.

-Ref. Guillermo Sáez (26/02/1836): Sin ref.

-Ref. P. Ortiz de Pinedo (12/03/1837-30/05/1837): Sin ref.

-Ref Jose María de Orozco (25/03/1838): Sin ref.

-Ref. Carbonell (4/7/1838): AMR, 1818-17, fol. 24

"Su plaza alta se rodeará de un parapéto aspillerado. En cada uno de sus cuatro angulos se establecerá una garita, haciéndo algúnos 政 la plaza baja se dará la comunicacion á la priméra de las [tres] Torres, por una galeria voláda que se dirija bolicuamente á la murálla antigua, y por encima de ella recomponiéndola, parándo por la que sirve de pared á algúnas casas por la priméra Torre. Las parédes de las havitaciónes nuebas incorporádas al Castillo se aspilleraran, cerranndo las ventánas que no sean necesarias y aspillerándolas. La puerta principal que está ahorra inmediáta a la lCuesta] se masisara y aspilierara. Se dará la entrada al Castillo por la parte de levante, haciendo

una entrada comun al Castillo yla Fontaleza. Los to

- Observaciones a partir de los informes militares

La torre del homenaje, originalmente construida por los musulmanes en tapia y, más adelante por los cristianos en sillería (s. XV). Las actuales almenas se añadieron en 1962 


\section{Rellenar en caso de que ele elemento sea
contempladado con datos del PCOU, 2013}

\section{ROTECCIÓN}

Nivel de protección:

Entorno:

$\square$ Inmueble

$\square$ Parcela catastral

$\square$ Recinto arquitectónico
AFECCIÓN PATRIMONIAL

$\square$ Bien de interés cultural (BIC)

$\square$ Afectado entorno BIC

$\square$ Afectado Plan especia
- Descripción histórico-arquitectónica

Tipología:

Cronología:

Observaciones a la cronología:

Descripción

\section{- Entorno urbano}

Descripción entorno urbano:

Uso actual:

Estado de conservación:

Intervenciones:

Régimen Urbanístico

Titularidad:

Nivel protección s/catálogo 1996:

Bibliografía: AMR, 1818-17, 1818-24; 1818-50; 1818-52; 1818-53.

observaciones generales:

\section{OBJETIVACIÓN DE INTERÉS}

$\square$ Interés tipológico

Valor ambiental

Vigencia de la trama

Materiales, color, textura

Soluciones constructiva
$\square$ Estructura
$\square$ Aleros
$\square$ Coronación
$\square$ Jambas
$\square$ Dinteles

Soluciones ornamentales
$\square$ Carpintería
$\square$ Rejería
$\square$ Cubrepersianas
$\square$ Alicatados
$\square$ Recercos
$\square$ Dinteles
$\square$ Otros ornamentos

Interés paisajistico

$\square$ Incidencia visual

$\square$ Carácter articulador

$\square$ Organización

$\square$ Interés cultural

$\square$ Carácter representativo

Otros ornamentos

\section{- Datos específicos catalogación BIC $\quad \square$ Rellenar sólo si está catalogado BIC}

\section{Datos Jurídicos:}

Código:

Estado:

Categoría:

Anotación $M$
Fecha Disposición:

Inform
Fecha informe:

Fecha Publicación BOP:

Fecha Publicación DOCV:

Fecha Publicación BOE:

\section{Fortaleza}

\section{- Identificación}

Tramo de estudio:

Ciudadela

Otras denominaciones:

$\square$ Incluido en fichas PGOU 2013

Bien de interés cultural (BIC)

cód. postal: 46340

Ref. catastral:

Localización: C/ Fortaleza

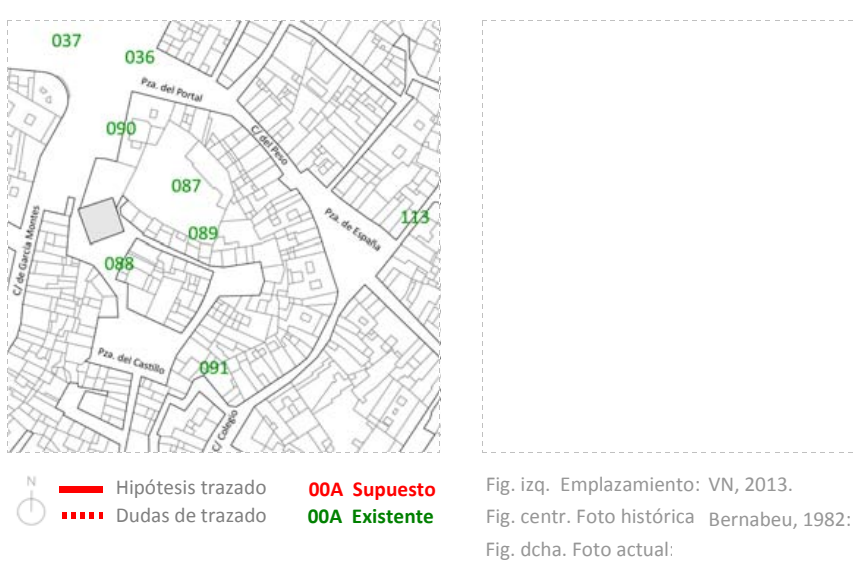

- Referencias en documentación histórica

Referencias numéricas en cartografía sobre fortificación

-Ref. en el croquis de Ortiz de Pinedo (1837-38, AGM, núm. 262): Sin ref.

-Ref. en plano de Vera Aparici (1993): Sin ref.

Referencias en memorias técnicas militares

-Ref. Guillermo Sáez (9/9/1834-5/12/1835): Sin ref.

-Ref. Guillermo Sáez (26/02/1836): Sin ref.

-Ref. P. Ortiz de Pinedo (12/03/1837-30/05/1837): Sin ref.

-Ref Jose María de Orozco (25/03/1838): Sin ref.

-Ref. Carbonell (4/7/1838): AMR, 1818-17, fol. 24

"No se dejará á la Plaza llamáda así mas comunicacion que la que tiene al callejón por donde se debe dejar la unica entráda para el torreon del Castillo. Todas las parédes que están sobre el desfiladéro se repararan y aspillerarán. En los parajes donde sobre salen las gran tambor. Su lado izquiérdo será parte del mismo en todo el recinto, la diréccion del frente será la conveniénte para que sea flanquéado por los torreónes y camino intermédio. Su flanco de la derécha irá á terminar á cuatro ó cinco baras de la actual puerta. La del tambor estará en [dicho] flanco á dos baras de su angulo saliente" (AMR, 1818-17, fol. 24).

- Observaciones a partir de los informes militares

Se hace referencia con este nombre al castillo. 


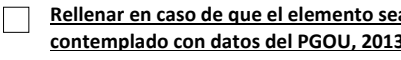

PROTECCIÓN
Nivel de protección:
Entorno:
$\square$ Inmueble
$\square$ Parcela catastral
$\square$ Recinto arquitectónico
$\square$ Entorno específico

AFECCIÓN PATRIMONIAL

$\square$ Bien de interés cultural (BIC)

$\square$ Bien de relevancia local (BRL)

$\square$ Afectado entorno BIC

- Descripción histórico-arquitectónica

Tipología:

Cronología:

Observaciones a la cronología

\section{Descripció}

- Entorno urbano

Descripción entorno urbano:

Uso actual:

Estado de conservación:

Intervenciones:

\section{Titularidad:}

Nivel protección s/catálogo 1996:

Bibliora: AMR, 1818-17, 1818-24; 1818-50; 1818-52; 1818-53.

observaciones generales:

$\begin{array}{llll}\text { OBJETIVACIÓN DE INTERÉS } & \text { Soluciones constructivas } & \text { Soluciones ornamentales } & \text { Interés paisajistico } \\ \square \text { Interés tipológico } & \square \text { Estructura } & \square \text { Carpintería } & \square \text { Incidencia visual } \\ \square \text { Valor ambiental } & \square \text { Aleros } & \square \text { Rejería } & \square \text { Carácter articulador } \\ \square \text { vigencia de la trama } & \square \text { coronación } & \square \text { cubrepersianas } & \square \text { organización } \\ \square \text { Composición de la fachada } & \square \text { Jambas } & \square \text { Alicatados } & \square \text { Interés cultural } \\ \square \text { Materiales, color, textura } & \square \text { Dinteles } & \square \text { Recercos } & \square \text { Carácter representativo } \\ & & \square \text { Dinteles } & \\ & \square \text { Otros ornamentos } & \end{array}$

\section{- Datos específicos catalogación BIC $\square$ Rellenar sólo si está catalogado BIC}

\section{Datos Jurídicos:}

Código:

Estado:
Categoría:

Anotación Mo:

Fecha Disposición:
Tipo delimitación:
Plan:
Informe:

Fecha informe:

Fecha Publicación DOCV:

\section{Cuesta del Castillo}

\section{- Identificación}

Tramo de estudio:

Ciudadela

Otras denominaciones:

$\checkmark$ Existe actualmente

$\square$ Incluido en fichas PGOU 2013

Bien de interés cultural (BIC)

cód. postal: 46340

Municipio: Requena

Ref. catastra:

Localización: C/ Fortaleza

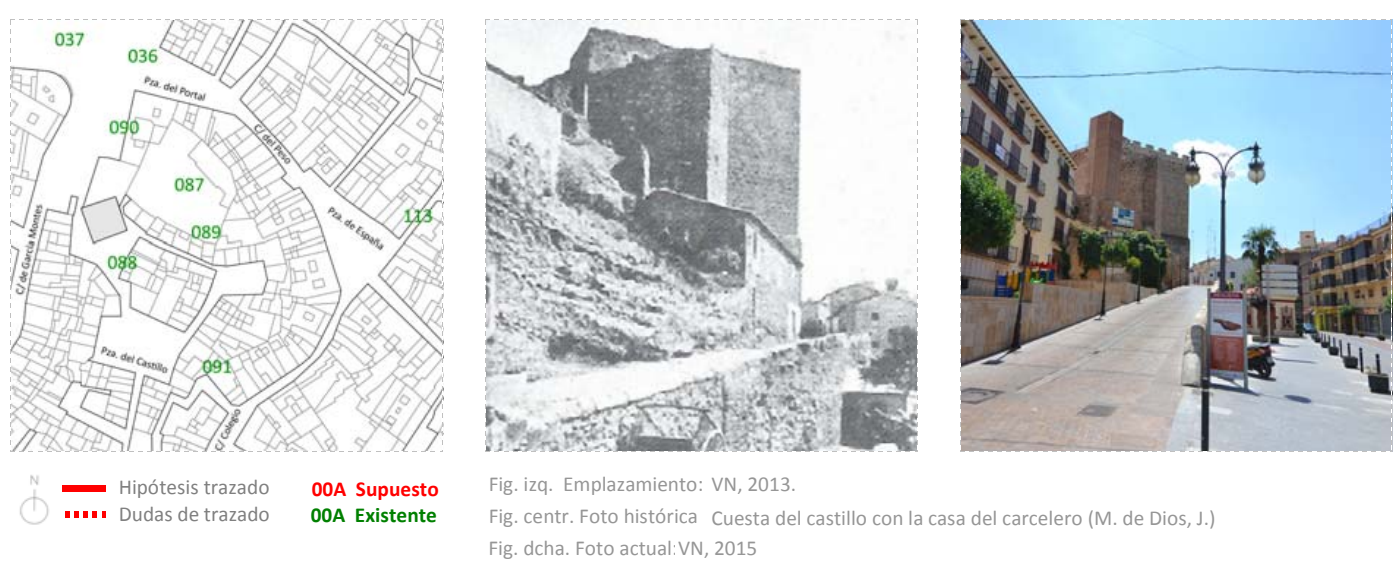

- Referencias en documentación histórica

Referencias numéricas en cartografía sobre fortificación

-Ref. en el croquis de Ortiz de Pinedo (1837-38, AGM, núm. 262): Sin ref.

-Ref. en plano de Vera Aparici (1993): 023

Referencias en memorias técnicas militare

-Ref. Guillermo Sáez (9/9/1834-5/12/1835): Requena, 5/12/1835 AMR, 1818-50

Se propone tapar la puerta y colocarla en la entrada de la fortaleza, habilitando el acceso.

-Ref. Guillermo Sáez (26/02/1836): Sin ref.

-Ref. P. Ortiz de Pinedo (12/03/1837-30/05/1837): Sin ref.

-Ref Jose María de Orozco (25/03/1838): Sin ref.

-Ref. Carbonell (4/7/1838): Sin ref.

- Observaciones a partir de los informes militares

La actual cuesta del Castillo, se orienta al norte, hacia Teruel. Era la principal cuesta y puerta a la Villa.

$\begin{array}{lll}\square \frac{\text { Rellenar en caso de que el elemento sea }}{\text { contemplado con datos del PGOU, 2013 }} & \text { PROTECCIÓN } & \text { AFECCIÓN PATRIMONIAL } \\ & \text { Nivel de protección: } & \square \text { Bien de interés cultural (BIC) } \\ & \text { Entorno: } & \square \text { Bien de relevancia local (BRL) } \\ & \square \text { Inmueble } & \square \text { Afectado entorno BIC } \\ \square \text { Parcela catastral } & \square \text { Afectado Plan especial } \\ \square \text { Recinto arquitectónico } & \\ \square \text { Entorno espećfico } & \end{array}$


- Descripción histórico-arquitectónica

\section{Tipología:}

Cronología:

Observaciones a la cronologi

Descripción:

\section{- Entorno urbano}

Descripción entorno urbano:

Uso actual:

Estado de conservación:

Intervenciones:

Régimen Urbanistico

Titularidad:

Nivel protección s/catálogo 1996:

Bibliografia: AMR, 1818-17, 1818-24; 1818-50; 1818-52; 1818-53.

Observaciones generales:

\section{OBJETIVACIÓN DE INTERÉS}

$\square$ Interés tipológico

$\square$ Valor ambiental

Vigencia de la trama

$\square$ Composición de la fachada

Soluciones constru
$\square$ Estructura
$\square$ Aleros
$\square$ Coronación
$\square$ Jambas
$\square$ Dinteles

Soluciones ornamentales
$\square$ Carpintería
$\square$ Rejería
$\square$ Cubrepersianas
$\square$ Alicatados
$\square$ Recercos
$\square$ Dinteles
$\square$ Otros ornamentos

Interés paisajistico

$\square$ Incidencia visual

$\square$ Carácter articulador

$\square$ Organización

$\square$ Carácter representativo

$\square$ Otros ornamentos

\section{- Datos específicos catalogación BIC $\square$ Rellenar sólo si está catalogado BIC}

\section{Datos Jurídicos:}

Código:
Estado:

Estado:
Categoría:

Anotación M

Fecha Disposición:
Tipo delimitación:
Plan:
Informe.

Informe:

Fecha informe:

Fecha Publicación BOP:

Fecha Publicación DOCV:

Fecha Publicación BOE:
091 Las Carnicerías

\section{- Identificación}

Tramo de estudio:

Recinto interior: La Villa

Otras denominaciones: Cuesta de San Julián o de las Carnicerías. Puerta de San Jull

$\checkmark$ Existe actualmente

Incluido en fichas PGOU 2013

Bien de interés cultural (BIC)

cód. postal: 46340

Ref. catastral:

Localización: Calle de la Cuesta de Carnicerías.

Comarca: Plana de Requena-Utiel

Provincia: Valencia

utonomia: Comunidad Valenciana
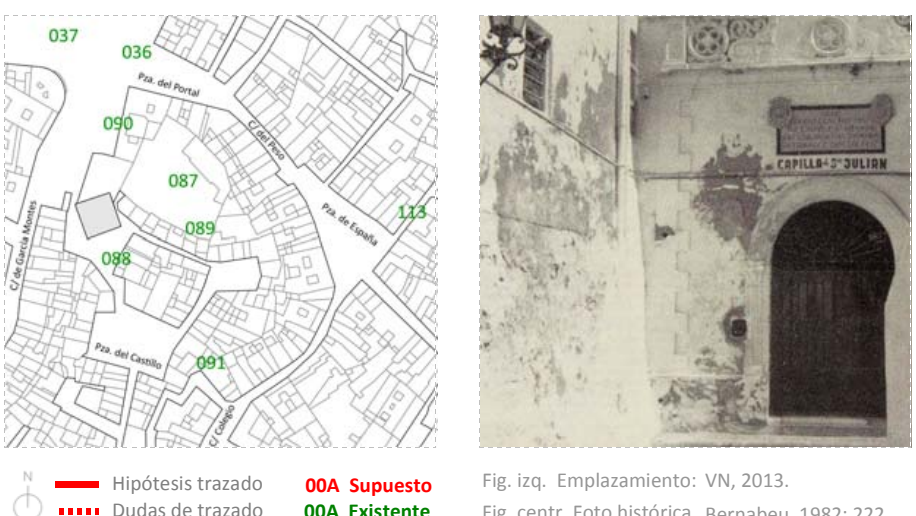

Fig. izq. Emplazamiento: VN, 2013

Fig. centr. Foto histórica Bernabeu, 1982: 222

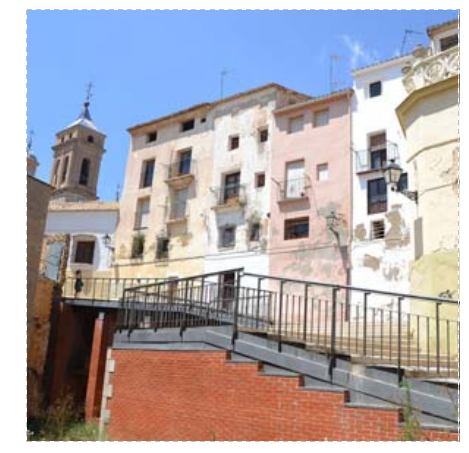

- Referencias en documentación histórica

Referencias numéricas en cartografía sobre fortificación

-Ref. en el croquis de Ortiz de Pinedo (1837-38, AGM, núm. 262): Sin ref.

-Ref. en plano de Vera Aparici (1993): 024

Referencias en memorias técnicas militare

-Ref. Guillermo Sáez (9/9/1834-5/12/1835): Requena, 5/12/1835 AMR, 1818-50

Se pretende colocar una puerta firme.

-Ref. Guillermo Sáez (26/02/1836): Sin ref.

-Ref. P. Ortiz de Pinedo (12/03/1837-30/05/1837): Sin ref.

-Ref Jose María de Orozco (25/03/1838): Sin ref.

-Ref. Carbonell (4/7/1838): Sin ref.

\section{- Observaciones a partir de los informes militares}

En la actualidad existe la denominada Calle de la Cuesta de Carnicerías. Se debían ubicar en ese punto la entrada y salida de la carne, si tenemos en cuenta que la cuesta servia de conexión con el matadero. En este punto se debió ubicar uno de los accesos a la Villa. Sobre e la cuesta se dispusieron las "tablas" o "tablajerís", de los abastecedores de carne.

\begin{tabular}{lll|}
$\square \frac{\text { Rellenar en caso de que el elemento sea }}{\text { contemplado con datos del PGOU, 2013 }}$ & PROTECCIÓN & AFECCIÓN PATRIMONIAL \\
& Nivel de protección: & $\square$ Bien de interés cultural (BIC) \\
& Entorno: & $\square$ Bien de relevancia local (BRL) \\
& $\square$ Inmueble & $\square$ Afectado entorno BIC \\
& $\square$ Parcela catastral & $\square$ Afectado Plan especial \\
& $\square$ Recinto arquitectónico & \\
& $\square$ Entorno espećifico &
\end{tabular}


- Descripción histórico-arquitectónica

Tipología:

Cronología:

Observaciones a la cronología:

Descripción:

- Entorno urbano

Descripción entorno urbano:

Uso actual:

Estado de conservación:

Intervenciones:

Régimen Urbanístico:

Titularidad:

Nivel protección s/catálogo 1996:

Bibliografia: AMR, 1818-17, 1818-24; 1818-50; 1818-52; 1818-53.

Observaciones generales:

$\begin{array}{llll}\text { OBJETIVACIÓN DE INTERÉS } & \text { Soluciones constructivas } & \text { Soluciones ornamentales } & \text { Interés paisajistico } \\ \square \text { Interés tipológico } & \square \text { Estructura } & \square \text { Carpintería } & \square \text { Incidencia visual } \\ \square \text { Valor ambiental } & \square \text { Aleros } & \square \text { Rejería } & \square \text { Carácter articulador } \\ \square \text { Vigencia de la trama } & \square \text { Coronación } & \square \text { Cubrepersianas } & \square \text { Organización } \\ \square \text { Composición de la fachada } & \square \text { Jambas } & \square \text { Alicatados } & \square \text { Interés cultural } \\ \square \text { Materiales, color, textura } & \square \text { Dinteles } & \square \text { Recercos } & \square \text { Carácter representativo } \\ & & \square \text { Dinteles } & \\ & \square \text { Otros ornamentos } & \end{array}$

\begin{tabular}{|c|c|c|}
\hline \multicolumn{3}{|c|}{ - Datos específicos catalogación BIC } \\
\hline & & \\
\hline Código: & Fecha Disposición: & Fecha informe: \\
\hline Estado: & Tipo delimitación: & Fecha Publicación BOP: \\
\hline Categoría: & Plan: & Fecha Publicación DOCV: \\
\hline Anotación $M \cong$ : & Informe: & Fecha Publicación BOE: \\
\hline
\end{tabular}

\section{Casa de Calaforra}

\section{- Identificación}

Tramo de estudio: Intramuros

Otras denom

Ref. catastral:

Localización:

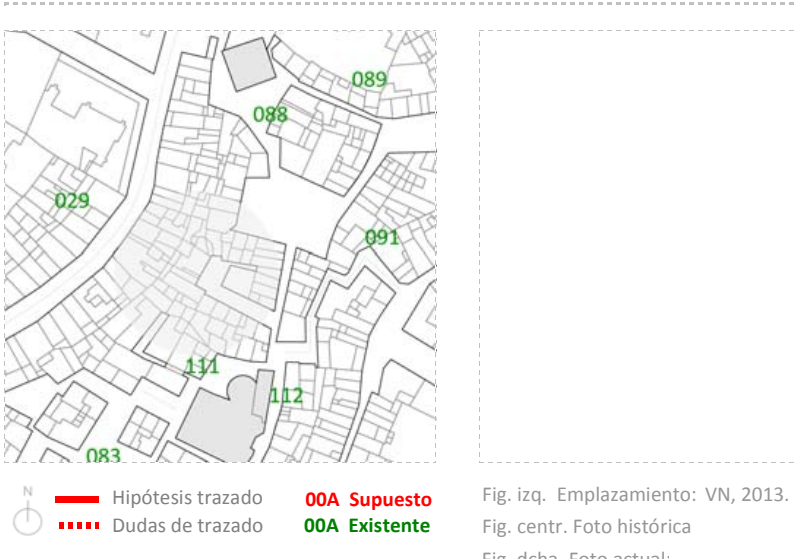

Existe actualmente

Incluido en fichas PGOU 2013

Bien de interés cultural (BIC)

cód. postal: 4634

Municipio: Requen

Comarca: Plana de Requena-Utie

Provincia: Valencia

Autonomia: Comunidad Valencian

\section{- Referencias en documentación histórica}

Referencias numéricas en cartografía sobre fortificación

-Ref. en el croquis de Ortiz de Pinedo (1837-38, AGM, núm. 262): Sin ref.

-Ref. en plano de Vera Aparici (1993): Sin ref.

Referencias en memorias técnicas militares

-Ref. Guillermo Sáez (9/9/1834-5/12/1835): Sin ref.

-Ref. Guillermo Sáez (26/02/1836): Sin ref.

-Ref. P. Ortiz de Pinedo (12/03/1837-30/05/1837): Sin ref.

-Ref Jose María de Orozco (25/03/1838): Sin ref.

-Ref. Carbonell (4/7/1838): AMR, 1818-17, fol. 24

"Se levantará un parapéto aspillerádo en el corral" (AMR, 1818-17, fol. 24).

- Observaciones a partir de los informes militares

Con la referencia a Calaforra se podría hacer referencia, con toda probabilidad al apellido del propietario. No se ha identificado la cas pero cuando se hace referencia a ella se sabe que esta en la Villa. Además debe volcar al frente defensivo de la muralla decimonónica

\section{$\frac{\text { Rellenar en caso de que el elemento sea }}{\text { contemplado con datos del PGOU, } 2013}$}

PROTECCIÓN

Nivel de protección:

Entorno:

$\square$ Inmueble

Parcela catastral

Recinto arquitectónico
AFECCIÓN PATRIMONIAL

Bien de interés cultural (BIC)

$\square$ Bien de relevancia local (BRL)

$\square$ Afectado entorno BIC

$\square$ Afectado Plan especial 


\section{- Descripción histórico-arquitectónica}

Tipología:

ogía:

Observaciones a la cronología

\section{Descripción:}

\section{- Entorno urbano}

Descripción entorno urbano:

Uso actual:

Estado de conservación:
Intervenciones:

Régimen Urbanístico:

Titularidad:

Nivel protección s/catálogo 1996:

Bibliografía: AMR, 1818-17, 1818-24; 1818-50; 1818-52; 1818-53.

Observaciones generales:

$\begin{array}{lll}\text { OBJETIVACIÓN DE INTERÉS } & \text { Soluciones constructivas } & \text { Soluciones ornamentales } \\ \square \text { Interés tipológico } & \square \text { Estructura } & \square \text { carpintería } \\ \square \text { valor ambiental } & \square \text { Aleros } & \square \text { Rejería } \\ \square \text { vigencia de la trama } & \square \text { coronación } & \square \text { cubrepersianas } \\ \square \text { Composición de la fachada } & \square \text { Jambas } & \square \text { Alicatados } \\ \square \text { Materiales, color, textura } & \square \text { Dinteles } & \square \text { Recercos } \\ & & \square \text { Dinteles } \\ & \square \text { Otros ornamentos }\end{array}$

\section{- Datos específicos catalogación BIC}

\section{Rellenar sólo si está catalogado BIC}

$\begin{array}{lll}\text { Datos Jurídicos: } & & \\ \text { Código: } & \text { Fecha Disposición: } & \text { Fecha informe: } \\ \text { Estado: } & \text { Tipo delimitación: } & \text { Fecha Publicación BOP: } \\ \text { Categoría: } & \text { Planf: } & \text { Fecha Publicación DOCV: } \\ \text { Anotación Mo: } & \text { Informe: } & \text { Fecha Publicación BOE: }\end{array}$

\section{Casa del Arte}

\section{- Identificación}

Tramo de estudio.

otras denominaciones:

Ref. catastral:

Localización: C/ Castillo no 5

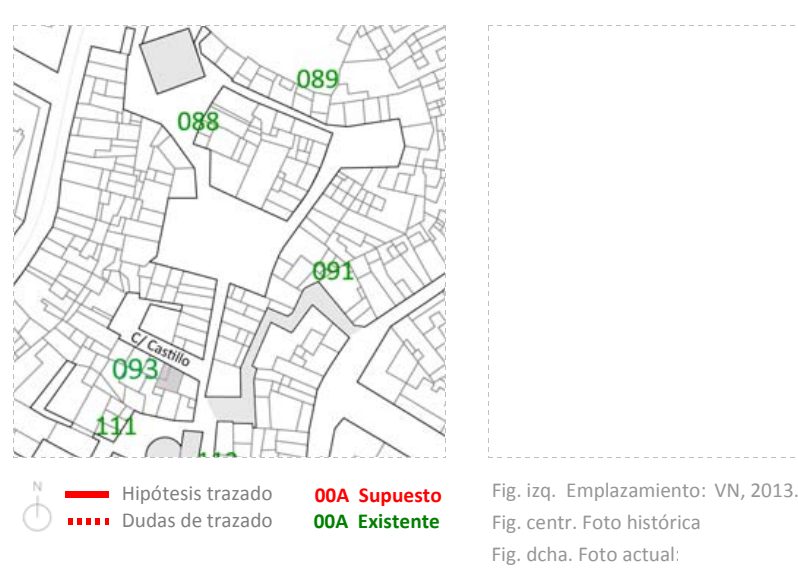

- Referencias en documentación histórica

Referencias numéricas en cartografía sobre fortificación

-Ref. en el croquis de Ortiz de Pinedo (1837-38, AGM, núm. 262): Sin ref.

-Ref. en plano de Vera Aparici (1993): Sin ref.

Referencias en memorias técnicas militares

-Ref. Guillermo Sáez (9/9/1834-5/12/1835): Sin ref.

-Ref. Guillermo Sáez (26/02/1836): Sin ref.

-Ref. P. Ortiz de Pinedo (12/03/1837-30/05/1837): Sin ref.

-Ref Jose María de Orozco (25/03/1838): Sin ref.

-Ref. Carbonell (4/7/1838): AMR, 1818-17, fol. 24 "En todo el corral parapéto aspillerádo; por supuesto, parédes, casas [signo ilegible] se aspillerarán. En todas las demás casas y corráles

\section{- Observaciones a partir de los informes militares}

Con tal denominación no se entiende en la época a otra casa que no sea la del "Arte mayor de la seda", emplazada en la antigua calle del Pozo, en el corazón de la Villa. "Se sabe que en 1740 la casa fue comprada por el Gremio de tejedores de Seda a un particular para fines particulares, $y$ con el paso del tiempo cambió muchas veces de propiedad ... "(www.casasedarequena.com, 2015). No se entiende el pape que puede jugar esta casa salvo el de un enclave estratégico en la Villa, cerca de la Plaza del Salvador y dominando la Cuesta de
Existe actualmente

Incluido en fichas PGOU 2013

Bien de interés cultural (BIC)

Cód. postal: 46340

Comarca: Plana de Requena-Utiel

Provincia: Valencia

Autonomía: Comunidad Valencian Carnicerías. 
$\square \frac{\text { Rellenar en caso de que ele lemento sea }}{\text { contemplado con datas del } P \text { PCoOU, } 2013}$

PROTECCIÓN

Nivel de protección

Entorno:

$\square$ Inmueble

$\square$ Parcela catastral

Recinto arquitectónico

$\square$ Entorno específico
AFECCIÓN PATRIMONIAL

$\square$ Bien de interés cultural (BIC)

$\square$ Afectado entorno BIC

$\square$ Afectado Plan especia

\section{- Descripción histórico-arquitectónica}

Tipología:

Cronología:

Observaciones a la cronología:

Descripción

- Entorno urbano

Descripción entorno urbano:

Uso actual:

Estado de conservación:

Intervenciones:

Régimen Urbanístico:

Titularidad:

Nivel protección s/catálogo 1996:

Bibliografía: AMR, 1818-17, 1818-24; 1818-50; 1818-52; 1818-53.

Observaciones generales:

$\begin{array}{llll}\text { OBJETIVACIÓN DE INTERÉS } & \text { Soluciones constructivas } & \text { Soluciones ornamentales } & \text { Interés paisajistico } \\ \square \text { Interés tipológico } & \square \text { Estructura } & \square \text { carpintería } & \square \text { Incidencia visual } \\ \square \text { Valor ambiental } & \square \text { Aleros } & \square \text { Rejería } & \square \text { carácter articulador } \\ \square \text { vigencia de la trama } & \square \text { coronación } & \square \text { cubrepersianas } & \square \text { Organización } \\ \square \text { composición de la fachada } & \square \text { Jambas } & \square \text { Alicatados } & \square \text { Interés cultural } \\ \square \text { Materiales, color, textura } & \square \text { Dinteles } & \square \text { Recercos } & \square \text { Carácter representativo } \\ & & \square \text { Dinteles } & \\ & \square \text { otros ornamentos } & \end{array}$

\section{- Datos específicos catalogación BIC $\square$ Rellenar sólo si está catalogado BIC}

Datos Jurídicos:

Código:

Estado:

Categoría:

Fecha Disposicion:

Anotación $M \stackrel{-}{0}$

Tpo delimitacion:

Plan:

Fecha informe:

Fecha Publicación DOCV
094 Desde la casa de Don Andrés García hasta el cerramiento de la Cuesta de las Carnicerías

\section{- Identificación}

Tramo de estudio:

Otras denominaciones:

Ref. catastral:

Localización: c/ Castillo
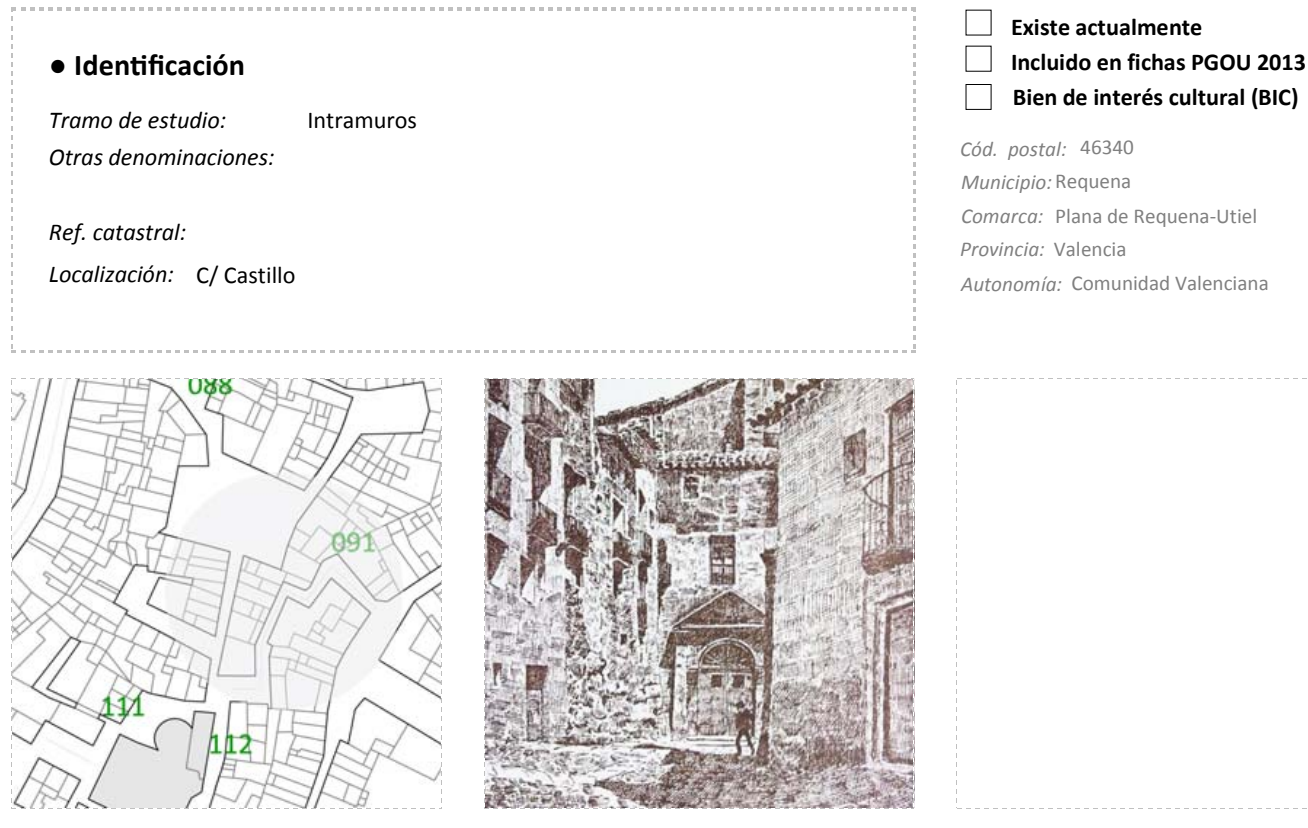

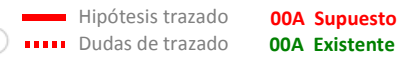

\section{Eig. iza. Emplazamiento: $v w, 2013$}

Fig. centr. Foto historica Morencos, F. Cuesta de Carnicerías. Requena Artística, 1947

Fig. centr. Foto históric
Fig. dcha. Foto actual:

- Referencias en documentación histórica

Referencias numéricas en cartografia sobre fortificación

-Ref. en el croquis de Ortiz de Pinedo (1837-38, AGM, núm. 262): Sin ref.

-Ref. en plano de Vera Aparici (1993): Sin ref.

Referencias en memorias técnicas militare

-Ref. Guillermo Sáez (9/9/1834-5/12/1835): Sin ref.

-Ref. Guillermo Sáez (26/02/1836): Sin ref.

-Ref. P. Ortiz de Pinedo (12/03/1837-30/05/1837): Sin ref.

-Ref Jose María de Orozco (25/03/1838): Sin ref.

-Ref. Carbonell (4/7/1838): AMR, 1818-17, fol. 24

"Las aspilléras y cerramiéntos prevenidos por regla general, las puertas se atráncarán en caso de riesgo [signo ilegible]. Se derribará la casa de Don Nicolás Luján en la parte que pertenecia á las carnecerias. El parapéto que ahora apóya en ellas se rehará á bara y media de la cas casa dicha quedará descubiérto. Este cerramiénto tendrá dos pisos aspillerádos, y la puerta donde ahóra se halla, pero mas fuerte y con cerrójo y llabe" (AMR, 1818-17, fol. 24).

\section{- Observaciones a partir de los informes militares}

Se pretendia generar un último reducto de defensa en el corazón de la Villa que no diera tregua a los enemigos en caso de acceder al García hasta la Cuesta de Carnicerias se aspillera. 


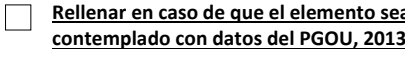

PROTECCIÓN

Nivel de protección:

Entorno:

$\square$ Inmueble

$\square$ Parcela catastral

$\square$ Recinto arquitectón

$\square$ Entorno específico

AFECCIÓN PATRIMONIAL

$\square$ Bien de interés cultural (BIC)

$\square$ Afectado entorno BIC

$\square$ Afectado Plan especial

\section{- Descripción histórico-arquitectónica}

Tipología:

Cronología:

Observaciones a la cronología

Descripción:

- Entorno urbano

Descripción entorno urbano:

Uso actual:

Estado de conservación:

Intervenciones:

Régimen Urbanístico:

Titularidad:

Nivel protección s/catálogo 1996:

Bibliografia: AMR, 1818-17, 1818-24; 1818-50; 1818-52; 1818-53.

Observaciones generales:

\section{OBJETIVACIÓN DE INTERÉS}

$\square$ Interés tipológico

Valor ambiental

Vigencia de la trama

$\square$ Materiales, color, textura

\section{Soluciones constructivas}

Soluciones ornamentales
$\square$ Carpintería
$\square$ Rejería
$\square$ Cubrepersianas
$\square$ Alicatados
$\square$ Recercos
$\square$ Dinteles
$\square$ Otros ornamentos

Interés paisajistico

$\square$ Incidencia visual

$\square$ Carácter articulador

Organización

Coronación

Jambas

\section{Iglesia de Santa María}

- Identificación

Tramo de estudio:

Otras denominaciones:

Ref. catastral:

Localización: c/ Santa María.

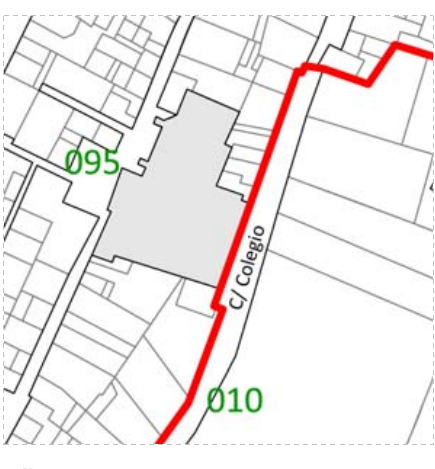

-.... Hipótesis trazado DoA Supuesto

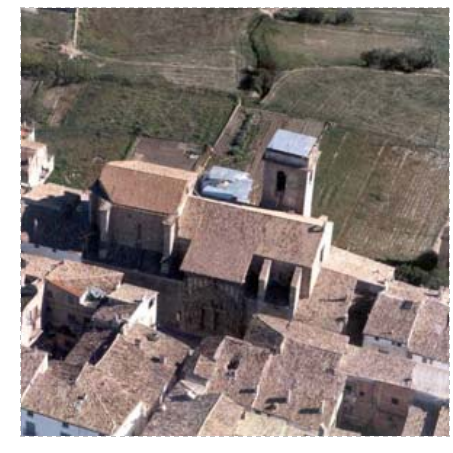

Existe actualmente

Incluido en fichas PGOU 2013

$\checkmark$ Bien de interés cultural (BIC)

cód. postal: 46340

Municipio: Requena

Comarca: Plana de Requena-Utie

Provincia: Valen

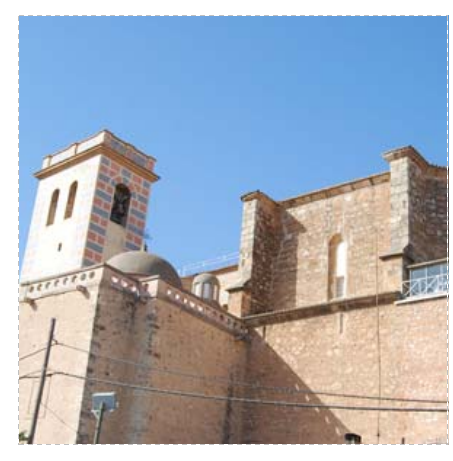

g. izq. Emplazamiento: $\mathrm{VN}, 20$

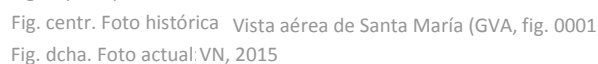

- Referencias en documentación histórica

\section{Referencias numéricas en cartografía sobre fortificación}

-Ref. en el croquis de Ortiz de Pinedo (1837-38, AGM, núm. 262): Sin ref.

-Ref. en plano de Vera Aparici (1993): Sin ref.

Referencias en memorias técnicas militares

-Ref. Guillermo Sáez (9/9/1834-5/12/1835): Sin ref.

-Ref. Guillermo Sáez (26/02/1836): Sin ref.

-Ref. P. Ortiz de Pinedo (12/03/1837-30/05/1837): Sin ref.

-Ref Jose María de Orozco (25/03/1838): Sin ref.

-Ref. Carbonell (4/7/1838): Sin ref.

\section{- Observaciones a partir de los informes militares}

"Situada en el lado oriental del Barrio de la Vila se encuentra encajada en el caserío, debido a su posición tiene acceso lateral. Es la mayor delas tres iglesias de Requena y como las otras es de estilo gótico inicial con intervenciones barrocas del siglo XVIII. Iniciada en el siglo XIV, es contemporánea al Salvador y posterior a San Nicolás, sobre otra anterior dedicada a Nuestra Señora del Populo. En el siglo XVI, en 1536, se construyó el alero de madera sustentado por canes sobre la portada de la iglesia. Ya en el siglo XVIII, entre 1730 y 1734 , intervinieron José Ortiz, Antonio García y Mauro Minget revistiendo la nave y las capillas laterales con una impronta barroca con bóveda de cañón y lunetos, asi como decoraciones en estuco blanco y ocres en pilastras de orden corintio con una cornisa corrida en la parte superior $y$ cornucopias en los huecos. En 1773 se realizo el organo por Jaime de la Fuente, que fue destruido en la Guerra Civil. Se conserva un dibujo en 1815. Se trata de un templo de una sola nave con capillas entre contrafuertes, con acceso lateral. La nave está dividida en 4 tramos y la cabecera en tres, el último de ellos es ochavado y más reducido. La cabecera está cubierta con bóveda crucería con una decoración compleja. Hay una diferencia de altura entre la nave y la cabecera, siendo esta última de mayor altura. La iglesia presenta coro alto a los pies, al que se accede a través de la primera capilla del lado de la epístola (el de la derecha). Las capillas del lado del evangelio son de menor profundidad, la segunda capilla de este lado da acceso al osario, y la tercera se corresponde con la puerta de acceso al templo. En el otro lado, en el cuarto tramo, se encuentra la capilia de Nuestra Señora del Rosario (finales siglo XVIII y principios del XIX) que presenta

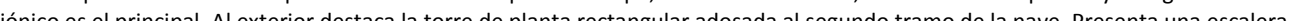


helicoidal que da paso a las diferentes plantas. En el cuerpo de campanas tiene seis vanos, dos en los lados mayores. Tiene tres campanas $y$ remata con un antepecho sobre una cornisa. La portada de acceso es de similares caracteristicas a la del Salvador. Se estructura mediante tres arquivoltas apuntadas y una cuarta conopial. Tiene dos accesos con arco carpanel divididos por un mainel o parteluz, que representa a la Virgen con el Niño y que fue colocado recientemente ya que el original se perdió en la Guerra Civil. En el timpano se doce apóstoles, faltando solamente dos esculturas. En las arquivoltas se representan vírgenes con sus atributos, ángeles músicos $y$ arcángeles con alas entrecruzadas. La portada está flanqueada por pilastras rematadas con pináculos. La fábrica de la iglesia es de mampostería, ladrillo o abobe, reservando los sillares para la cabecera, capillas, recercados y remates de contrafuertes. La portada está realizada en piedra blanda. La torre está realizada con mampostería y argamasa, con revoco que simula sillería." (http://www.cult.gva.es/dgpa/bics/Detalles_bics.asp? ?dllnmueble=170 [2015)

\section{$\square \frac{\text { Rellenar en caso de que el elemento sea }}{\text { contemplado con datos del PGOU, 2013 }}$}

\section{PROTECCIÓN}

Nivel de protección:

Entorno:

\section{$\square$ Inmueble}

Parcela catastral

$\square$ Recinto arquitectónico

$\square$ Entorno específico

\section{- Descripción histórico-arquitectónica}

Tipología: Edificios religiosos

Cronologia:

Observaciones a la cronología:

\section{Descripción:}

\section{- Entorno urbano}

\section{Descripción entorno urbano:}

\section{Uso actual:}

\section{Estado de conservación}

Intervenciones:

\section{Titularidad:}

\section{Nivel protección s/catálogo 1996:}

Bibliografía: AMR, 1818-17, 1818-24; 1818-50; 1818-52; 1818-53.

\section{Observaciones generales:}

$\begin{array}{llll}\text { OBJETIVACIÓN DE INTERÉS } & \text { Soluciones constructivas } & \text { Soluciones ornamentales } & \text { Interés paisajistico } \\ \square \text { Interés tipológico } & \square \text { Estructura } & \square \text { carpintería } & \square \text { Incidencia visual } \\ \square \text { Valor ambiental } & \square \text { Aleros } & \square \text { Rejería } & \square \text { carácter articulador } \\ \square \text { Vigencia de la trama } & \square \text { coronación } & \square \text { cubrepersianas } & \square \text { Organización } \\ \square \text { Composición de la fachada } & \square \text { Jambas } & \square \text { Alicatados } & \square \text { Interés cultural } \\ \square \text { Materiales, color, textura } & \square \text { Dinteles } & \square \text { Recercos } & \square \text { carácter representativo } \\ & & \square \text { Dinteles } & \\ & \square \text { otros ornamentos } & \end{array}$

- Datos específicos catalogación BIC

\section{$\checkmark$ Rellenar sólo si está catalogado BIC}

Datos Jurídicos:

Código: $46.17 .213-003$

Estado: Declaración singular

Categoría: Monumento

Anotación Mํ: R-1-51-0000978

\section{AFECCIÓN PATRIMONIAL}

$\square$ Bien de interés cultural (BIC)

$\square$ Bien de relevancia local (BRL)

$\square$ Afectado entorno BIC

$\square$ Afectado Plan especial

096 Convento de San Francisco

\section{- Identificación}

Tramo de estudio:

Obras exteriores

Otras denominaciones: Ex-Convento e iglesia de San Francisco

Ref. catastral:

32339-01

Localización: C/ Hospital San Francisco, № 3.

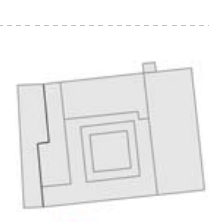

096

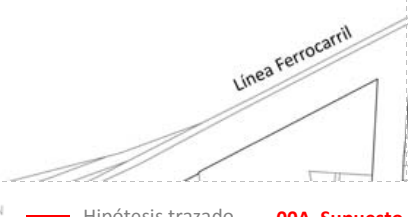

-... Hipotesis trazado O0A Supuesto

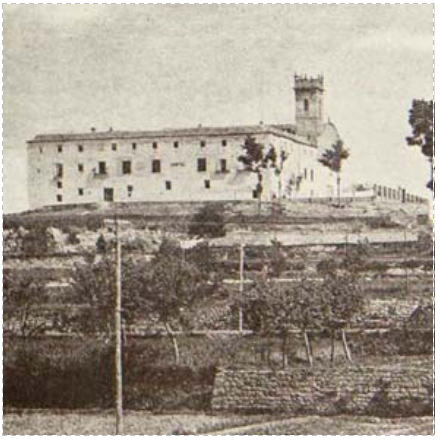

Fig. izq. Emplazamiento: VN, 2013

ig. centr. Foto histórica Bernabeu, 1982: 29 $\checkmark$ Existe actualmente

$\checkmark$ Incluido en fichas PGOU 2013

$\checkmark$ Incluido en fichas PGOU 2013

cód. postal: 4634

Municipio: Requen

Comarca: Plana de Requena-Utiel

Provincia: Valencia

utonomia: Comunidad Valenciana

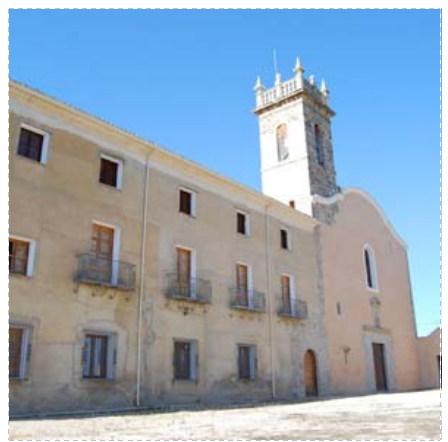

- Referencias en documentación histórica

Referencias numéricas en cartografía sobre fortificación

-Ref. en el croquis de Ortiz de Pinedo (1837-38, AGM, núm. 262): 015

-Ref. en plano de Vera Aparici (1993): 022

Referencias en memorias técnicas militare

-Ref. Guillermo Sáez (9/9/1834-5/12/1835): Requena, 5/12/1835 AMR, 1818-50

Donde hay que rematar el tambor de la puerta y concluir un foso que parece avanzado en su construcción.

-Ref. Guillermo Sáez (26/02/1836): Requena, 26/02/1836 AMR, 1818-53

Se indica que sólo resta tapiar la ventana de la sacristía y cortar "un poco de Piedra á pico en el Foso". La obra depende de particulares. -Ref. P. Ortiz de Pinedo (12/03/1837-30/05/1837): Sin ref.

-Ref Jose María de Orozco (25/03/1838): Requena, 25/03/1838, AMR 1818-24

Es la primera vez que se habla de plantear la defensa de Requena para un ataque en regla (un sitio formal). Por ello se plantea la necesidad de que en caso de que asi suceda, el Barrio de las Lomas y el fuerte de San Francisco deberín destruirse. Pero la situación habitual es un ataque de facciones sin artilieria, por lo que basta con garantizar la cubrición artiliera de estos puntos (se hará desde la

-Ref. Carbonell (4/7/1838): Sin ref.

\section{- Observaciones a partir de los informes militares}

Se convierte en una especie de reducto avanzado al norte de la hoya de Martinete, sobre el promontorio de la Loma. 


\section{$\checkmark \frac{\text { Rellenar en caso de que ele lemento se }}{\text { contempladoco con datas del Pel PCoU, } 2013}$}

\section{PROTECCIÓN}

Nivel de protección: Integral

Entorno:

$\square$ Inmueble

$\square$ Parcela catastral

$\square$ Recinto arquitectónico
AFECCIÓN PATRIMONIAL

$\square$ Bien de interés cultural (BIC)

$\checkmark$ Bien de relevancia local (BRL)

Monumento

$\square$ Afectado entorno BIC

\section{- Descripción histórico-arquitectónica}

\section{Tipología: Arquitectura civil}

Cronología: 1617

Observaciones a la cronología: Se producen intervenciones interesantes en su vida útil como su reconversión a establecimiento c

Descripción: "Conjunto formado por el edificio conventual en torno a un claustro central[...] sillería y mampostería enfoscada, [.... teja curva a dos aguas, con vigas de madera como elemento sustentante de las techumbres, $[. .$.$] torre de sillares de piedra$

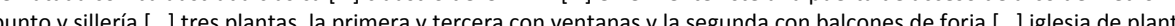
rectangular [...] base de sillería y frontón curvo. En 1713 la iglesia fue concluída; [...] ed dificio barroco de una sola nave con pilastras, arcos de medio punto y bóveda de cañón con lunetos. El coro [.... a los pies de la nave y la torre en el ángulo posterior izquierdo (.... La portada de los ples es barroca tambien, de sileria, con dintel plano, cornisa, y encima centrada hornacina con frontón triangular. [...] Actualmente presenta un estado ruinoso. Tipos de fábrica: Mampostería, sillería,

\section{- Entorno urbano}

\section{Descripción entorno urbano:}

"Se trata de una edificación renacentista enclavada en un entorno[.... rústico[.... alejado del núcleo urbano[..... El desarrollo urbanistico zona [...] [el] Barrio de la Loma" (PGOU, 2013:E.CAS.BRL.66).

Uso actual: Estado de abandono. Ha sido objeto de una intervención reciente de la que apenas hay información.

Estado de conservación: Malo

Intervenciones: 1646 (ampliación), 1835, 1845-1847, s. XX. Reciente intervención sin información

Régimen Urbanístico: S. U.

Titularidad: Privada

Nivel protección s/catálogo 1996: 1 singular

Bibliografia: AMR, 1818-17, 1818-24; 1818-50; 1818-52; 1818-53.

Observaciones generales:

"Las intervenciones en el entorno de protección del bien se atendrán a lo dispuesto en el art. 25.3 de las normas de presente Catálogo" (PGOU, 2013:E.CAS.BRL.66).

\begin{tabular}{|c|c|c|c|}
\hline OBJETIVACIÓN DE INTERÉS & Soluciones constructivas & Soluciones ornamentales & Interés paisajístico \\
\hline $\begin{array}{l}\boldsymbol{\nabla} \text { Interés tipológico } \\
\boldsymbol{\nabla} \text { Valor ambiental } \\
\square \text { Vigencia de la trama } \\
\square \text { Composición de la fachada } \\
\boldsymbol{\nabla} \text { Materiales, color, textura }\end{array}$ & $\begin{array}{l}\square \text { Estructura } \\
\square \text { Aleros } \\
\nabla \text { Coronación } \\
\square \text { Jambas } \\
\square \text { Dinteles }\end{array}$ & $\begin{array}{l}\nabla \text { Carpintería } \\
\square \text { Rejería } \\
\square \text { Cubrepersianas } \\
\square \text { Alicatados } \\
\square \text { Recercos } \\
\square \text { Dinteles } \\
\square \text { Otros ornamentos }\end{array}$ & 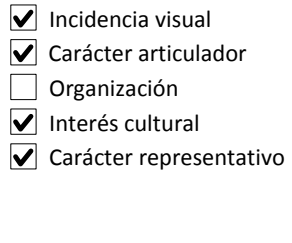 \\
\hline
\end{tabular}

- Datos específicos catalogación BIC

$\square$ Rellenar sólo si está catalogado BIC

Datos Jurídicos:

$\begin{array}{lll}\text { Código: } & \text { Fecha Disposición: } & \text { Fecha informe: } \\ \text { Estado: } & \text { Tipo delimitación: } & \text { Fecha Publicación BOP: } \\ \text { Categoria: } & \text { Plan: } & \text { Fecha Publicación DOCV: } \\ \text { Anotación Mo: } & \text { Informe: } & \text { Fecha Publicación BOE: }\end{array}$

\section{La Loma}

\section{- Identificación}

Tramo de estudio:

Otras denominaciones:

Obras exteriores

\section{Ref. catastral:}

Localización: C/ Loma/ C/ Saliente Loma/ C/Oliveral Loma/ C/ Norte Loma.

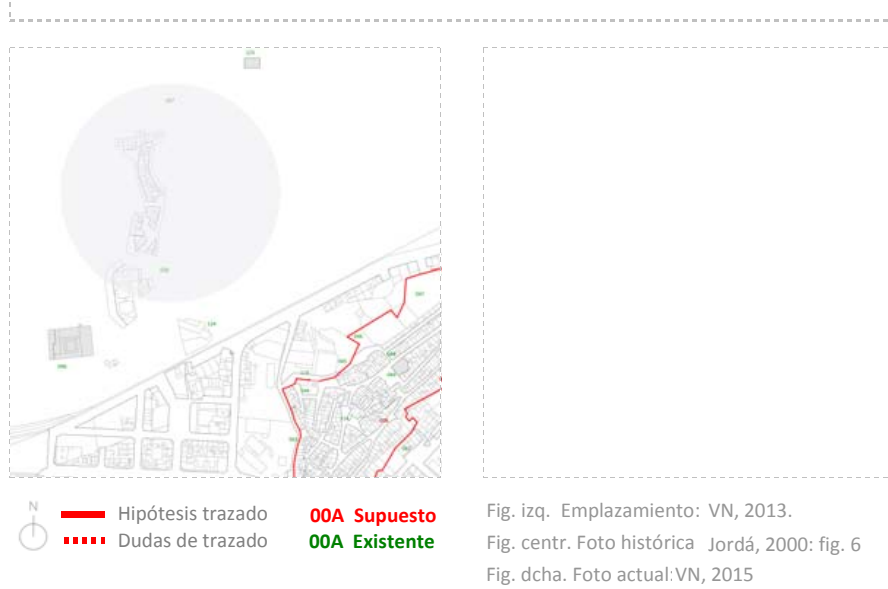

\section{- Referencias en documentación histórica}

\section{Referencias numéricas en cartografía sobre fortificación}

-Ref. en el croquis de Ortiz de Pinedo (1837-38, AGM, núm. 262): 017

-Ref. en plano de Vera Aparici (1993): Sin ref.

Referencias en memorias técnicas militares

-Ref. Guillermo Sáez (9/9/1834-5/12/1835): Sin ref.

-Ref. Guillermo Sáez (26/02/1836): Sin ref.

-Ref. P. Ortiz de Pinedo (12/03/1837-30/05/1837): Sin ref.

-Ref Jose María de Orozco (25/03/1838): Sin re

-Ref. Carbonell (4/7/1838): Sin ref.

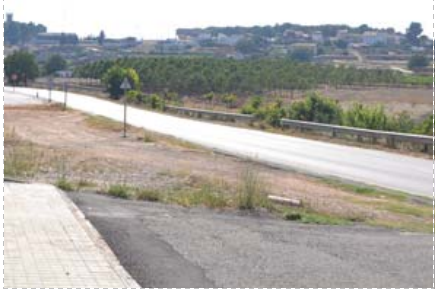

\section{- Observaciones a partir de los informes militares}

Se identifica como la Loma a la dominación alargada que se extiende en la ribera noroeste de la Hoya de Martinete. En su extremo meridional se posiciona el Convento de San Francisco. Según Ortiz de Pinedo, la Loma se extiende conformando una "ceja", un límite que desciende de San Francisco a la ciudad, se diseminan varios molinos (SHM, núm. 262). En la máxima concavidad de la Loma se ubica el barrio del mismo nombre. Al este nace un arroyo, sin definir, en el que se localizan lo que Ortiz define como "Molino de [Catalán]".

\begin{tabular}{|lll}
$\square$ Rellenar en caso de que el elemento sea & PROTECCIÓN & AFECCIÓN PATRIMONIAL \\
contemplado con datos del PGOU, 2013 & Nivel de protección: & $\square$ Bien de interés cultural (BIC) \\
& Entorno: & $\square$ Bien de relevancia local (BRL) \\
& $\square$ Inmueble & $\square$ Afectado entorno BIC \\
$\square$ Parcela catastral & $\square$ Afectado Plan especial \\
& $\square$ Recinto arquitectónico & \\
& $\square$ Entorno especifico &
\end{tabular}

$\checkmark$ Existe actualmente

Incluido en fichas PGOU 2013

cód. postal: 46340 Autonomia: Comunidad Valenciarn $\square$ Bien de interés cultural (BIC)

Comarca: Plana de Requena-Utie 


\section{- Descripción histórico-arquitectónica \\ Tipología:}

Cronologia:

Observaciones a la cronologí

\section{Descripción:}

- Entorno urbano

Descripción entorno urbano:

Uso actual:

Estado de conservación:

Intervenciones:

Régimen Urb

Nivel protección s/catálogo 1996:

Bibliografía: AMR, 1818-17, 1818-24; 1818-50; 1818-52; 1818-53.

observaciones generales:

\begin{tabular}{|c|c|c|}
\hline OBJETIVACIÓN DE INTERÉS & Soluciones constructivas & Soluciones ornamentales \\
\hline $\begin{array}{l}\square \text { Interés tipológico } \\
\square \text { Valor ambiental } \\
\square \text { vigencia de la trama } \\
\square \text { composición de la fachada } \\
\square \text { Materiales, color, textura }\end{array}$ & $\begin{array}{l}\square \text { Estructura } \\
\square \text { Aleros } \\
\square \text { coronación } \\
\square \text { Jambas } \\
\square \text { Dinteles }\end{array}$ & $\begin{array}{l}\square \text { Carpintería } \\
\square \text { Rejería } \\
\square \text { Cubrepersianas } \\
\square \text { Alicatados } \\
\square \text { Recercos } \\
\square \text { Dinteles } \\
\square \text { Otros ornamentos }\end{array}$ \\
\hline
\end{tabular}

\section{- Datos específicos catalogación BIC $\square$ Rellenar sólo si está catalogado BIC}

$\begin{array}{lll}\text { Datos Juridicos: } & & \\ \text { Código: } & \text { Fecha Disposición: } & \text { Fecha informe: } \\ \text { Estado: } & \text { Tipo delimitación: } & \text { Fecha Publicación BOP: } \\ \text { Categoría: } & \text { Plan: } & \text { Fecha Publicación DOCV: } \\ \text { Anotación Mo: } & \text { Informe: } & \text { Fecha Publicación BOE: }\end{array}$

\section{Interés paisajistico}

$\square$ Incidencia visual

$\square$ Carácter articulador

$\square$ Organización

Carácter representativo

\section{Barrio de la Loma}

\section{- Identificación}

Tramo de estudio:

Obras exteriores

Otras denominaciones:

Ref. catastral:

Localización: C/ Loma/C/ Saliente Loma/ C/Oliveral Loma/ C/ Norte Loma.

$\checkmark$ Existe actualmente

$\square$ Incluido en fichas PGOU 2013

Bien de interés cultural (BIC)

cód. postal: 46340

Municipio: Requena

Comarca: Plana de Requena-Utie

Provincia: Valencia

Autonomia: Comunidad Valencian

\section{..... Hipótesis trazado}

O0A Supuesto
00A Existente

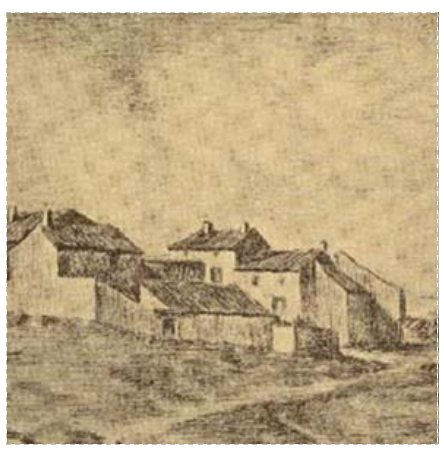

Fig. izq. Emplazamiento: VN, 2013.

$$
\text { Fig. izq. Emplazamiento: VN, } 2013 .
$$

\section{- Referencias en documentación histórica}

Referencias numéricas en cartografía sobre fortificación

-Ref. en el croquis de Ortiz de Pinedo (1837-38, AGM, núm. 262): 018

-Ref. en plano de Vera Aparici (1993): Sin ref.

Referencias en memorias técnicas militares

-Ref. Guillermo Sáez (9/9/1834-5/12/1835): Sin ref.

-Ref. Guillermo Sáez (26/02/1836): Sin ref.

-Ref. P. Ortiz de Pinedo (12/03/1837-30/05/1837): Sin ref.

-Ref Jose María de Orozco (25/03/1838): Sin ref.

-Ref. Carbonell (4/7/1838): Sin ref.

\section{- Observaciones a partir de los informes militares}

Barrio de casas modestas emplazado sobre la prominencia conocida como la Loma, al otro lado de la Hoya de Martinete desde la perspectiva de la ciudad, al Este del Convento de San Francisco.

\begin{tabular}{|c|c|c|}
\hline \multirow[t]{2}{*}{$\square \frac{\text { Rellenar en caso de que el elemento sea }}{\text { contemplado con datos del PGOU, 2013 }}$} & $\begin{array}{l}\text { PROTECCIÓN } \\
\text { Nivel de protección: } \\
\text { Entorno: }\end{array}$ & $\begin{array}{l}\text { AFECCIÓN PATRIMONIAL } \\
\begin{aligned} \square \text { Bien de interés cultural (BIC) } \\
\square \text { Bien de relevancia local (BRL }\end{aligned}\end{array}$ \\
\hline & $\begin{array}{l}\square \text { Inmueble } \\
\square \text { Parcela catastral } \\
\square \text { Recinto arquitectónico } \\
\square \text { Entorno específico }\end{array}$ & $\begin{array}{l}\square \text { Afectado entorno BIC } \\
\square \text { Afectado Plan especial }\end{array}$ \\
\hline
\end{tabular}




\section{- Descripción histórico-arquitectónica \\ Tipología:}

Cronología:

Observaciones a la cronología

\section{Descripción:}

- Entorno urbano

Descripción entorno urbano:

Uso actual:

Estado de conservación:

Intervenciones:

Régimen Urbanístico:

Ritularidad:

Nivel protección s/catálogo 1996:

Bibliografía: AMR, 1818-17, 1818-24; 1818-50; 1818-52; 1818-53.

Observaciones generales:

$\begin{array}{lll}\text { OBJETIVACIÓN DE INTERÉS } & \text { Soluciones constructivas } & \text { Soluciones ornamentales } \\ \square \text { Interés tipológico } & \square \text { Estructura } & \square \text { Carpintería } \\ \square \text { Valor ambiental } & \square \text { Aleros } & \square \text { Rejería } \\ \square \text { Vigencia de la trama } & \square \text { coronación } & \square \text { Cubrepersianas } \\ \square \text { composición de la fachada } & \square \text { Jambas } & \square \text { Alicatados } \\ \square \text { Materiales, color, textura } & \square \text { Dinteles } & \square \text { Recercos } \\ & & \square \text { Dinteles } \\ & & \square \text { otros ornamentos }\end{array}$

\section{- Datos específicos catalogación BIC $\square$ Rellenar sólo si está catalogado BIC}

\section{Datos Jurídicos:}

$\begin{array}{lll}\text { Datos Juridicos: } & \text { Fecha Disposición: } & \text { Fecha informe: } \\ \text { Código: } & \text { Tipo delimitación: } & \text { Fecha Publicación BOP: } \\ \text { Estado: } & \text { Plan: } & \text { Fecha Publicación DOCV: } \\ \text { Categoría: } & \text { Informe: } & \text { Fecha Publicación BOE: }\end{array}$

\section{Camino de los asnos}

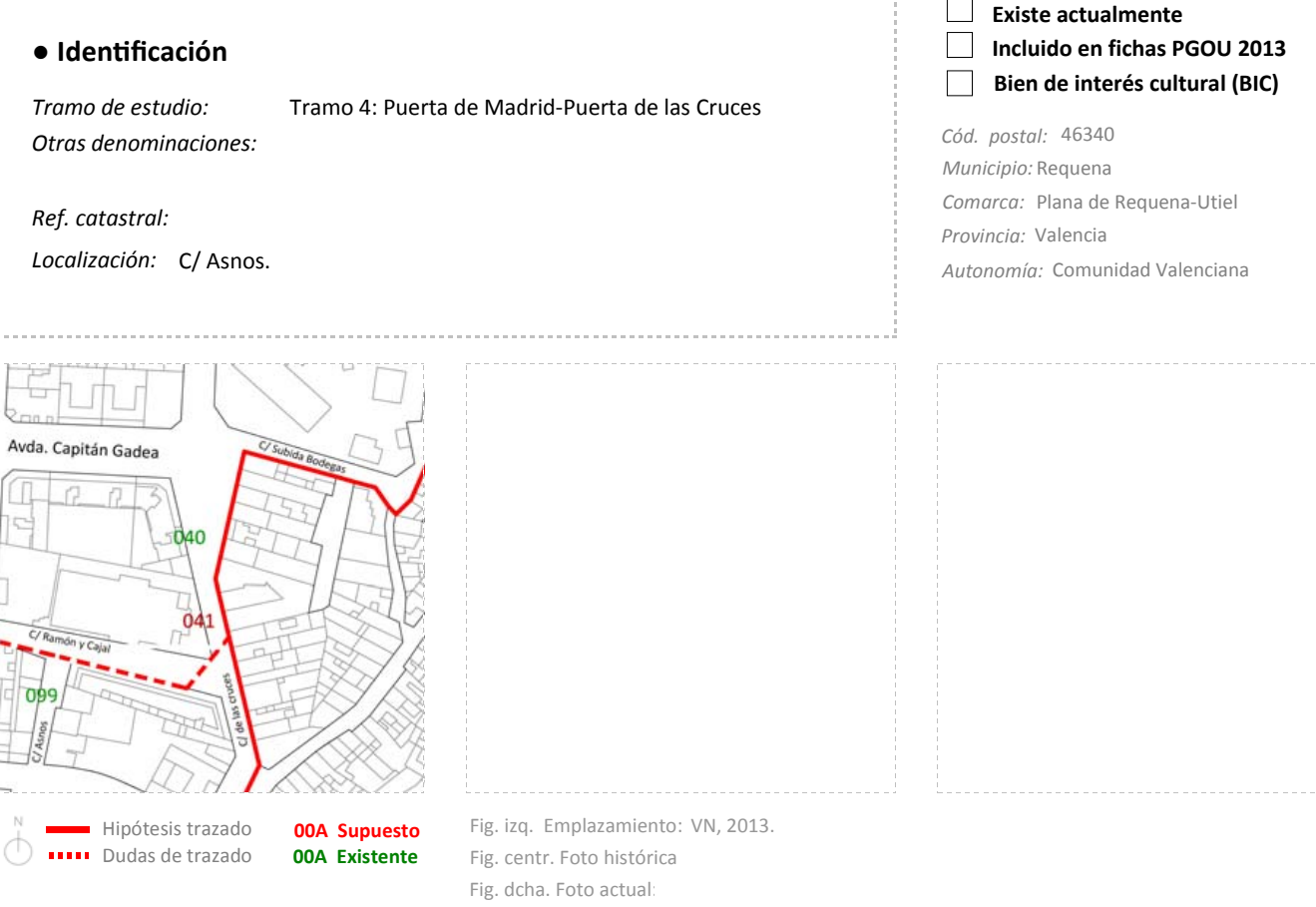

- Referencias en documentación histórica

\section{Referencias numéricas en cartografía sobre fortificación}

-Ref. en el croquis de Ortiz de Pinedo (1837-38, AGM, núm. 262): Sin ref.

-Ref. en plano de Vera Aparici (1993): Sin ref.

Referencias en memorias técnicas militares

-Ref. Guillermo Sáez (9/9/1834-5/12/1835): Sin ref.

-Ref. Guillermo Sáez (26/02/1836): Sin ref.

-Ref. P. Ortiz de Pinedo (12/03/1837-30/05/1837): Sin ref.

-Ref Jose María de Orozco (25/03/1838): Sin ref.

-Ref. Carbonell (4/7/1838): Sin ref.

\section{- Observaciones a partir de los informes militares}

En la actualidad, existe la denominada calle de los asnos, que debió transcurrir extramuros, acompañando la cortina del muro exterior que conectaba con la puerta de las cruces y bajo las bodegas. Precisamente conducía a la subida a San Francisco y la Loma, o, sin cruzar la hoya del Martinete, acompañar el tramo norte de la muralla camino de Chera y Chelva.

\begin{tabular}{|lll|}
$\square \frac{\text { Rellenar en caso de que el elemento sea }}{\text { contemplado con datos del PGOU, 2013 }}$ & PROTECCIÓN & AFECCIÓN PATRIMONIAL \\
& Nivel de protección: & $\square$ Bien de interés cultural (BIC) \\
& $\square$ Entorno: & $\square$ Bien de relevancia local (BRL) \\
$\square$ Inmueble & $\square$ Afectado entorno BIC \\
$\square$ Parcela catastral & $\square$ Afectado Plan especial \\
$\square$ Recinto arquitectónico & \\
\hline Entorno espećfico &
\end{tabular}




\section{- Descripción histórico-arquitectónica}

Tipologia:

Observaciones a la cronología

Descripción:

\section{- Entorno urbano}

Descripción entorno urbano:

Uso actual:

Estado de conservación:

Intervenciones:

Régimen Urbanistico:

Titularidad:

Nivel protección s/catálogo 1996:

Bibliografía: AMR, 1818-17, 1818-24; 1818-50; 1818-52; 1818-53.

Observaciones generales:

$\begin{array}{lll}\text { OBJETIVACIÓN DE INTERÉS } & \text { Soluciones constructivas } & \text { Soluciones ornamentales } \\ \square \text { Interés tipológico } & \square \text { Estructura } & \square \text { Carpintería } \\ \square \text { valor ambiental } & \square \text { Aleros } & \square \text { Rejeria } \\ \square \text { vigencia de la trama } & \square \text { coronación } & \square \text { Cubrepersianas } \\ \square \text { Composición de la fachada } & \square \text { Jambas } & \square \text { Alicatados } \\ \square \text { Materiales, color, textura } & \square \text { Dinteles } & \square \text { Recercos } \\ & & \square \text { Dinteles } \\ & \square \text { otros ornamentos }\end{array}$

\section{- Datos específicos catalogación BIC $\square$ Rellenar sólo si está catalogado BIC}

$\begin{array}{lll}\text { Datos Juridicos: } & & \\ \text { Código: } & \text { Fecha Disposición: } & \text { Fecha informe: } \\ \text { Estado: } & \text { Tipo delimitación: } & \text { Fecha Publicación BOP: } \\ \text { Categoría: } & \text { Plan: } & \text { Fecha Publicación DOCV: } \\ \text { Anotación Mo: } & \text { Informe: } & \text { Fecha Publicación BOE: }\end{array}$

100 Calle de San Fernando

\section{- Identificación}

Tramo de estudio:

Otras denominaciones:

$\checkmark$ Existe actualmente

Incluido en fichas PGOU 2013

Bien de interés cultural (BIC)

cód. postal: 46340

Municipio: Requena

Ref. catastral:

Localización: C/ San Fernando.

rovincia: Valencia

Autonomia: Comunidad Valencian

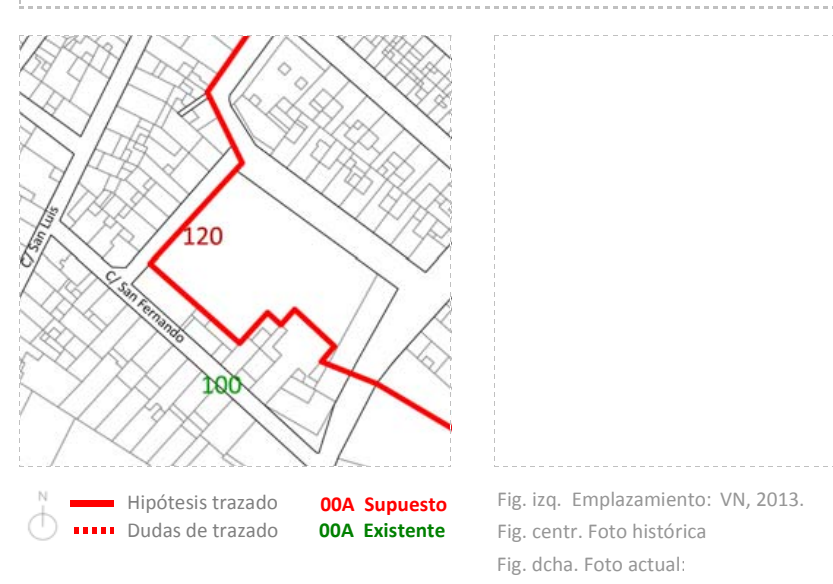

\section{- Referencias en documentación histórica}

Referencias numéricas en cartografía sobre fortificación

-Ref. en el croquis de Ortiz de Pinedo (1837-38, AGM, núm. 262): Sin ref.

-Ref. en plano de Vera Aparici (1993): Sin ref.

Referencias en memorias técnicas militares

-Ref. Guillermo Sáez (9/9/1834-5/12/1835): Sin ref.

-Ref. Guillermo Sáez (26/02/1836): Sin ref.

-Ref. P. Ortiz de Pinedo (12/03/1837-30/05/1837): Sin ref.

-Ref Jose María de Orozco (25/03/1838): Sin ref.

-Ref. Carbonell (4/7/1838): Sin ref.

\section{- Observaciones a partir de los informes militares}

Junto a las calles San Carlos y San Luis constituyen la intervención urbana que el arquitecto Bartolomé Ribelles proyecta a raiz de un encargo de la Sociedad Económica de Amigos del Pais bajo el reinado de Carlos III. Precisamente la C/ San Fernando conformaba e pertenecer a la muralla. $\square \frac{\text { Rellenar en caso de que el elemento sea }}{\text { contemplado con datos del PGOU, 2013 }}$

PROTECCIÓN
Nivel de protección:
Entorno:
$\square$ Inmueble
$\square$ Parcela catastral
$\square$ Recinto arquitectónico
$\square$ Entorno específico

\section{AFECCIÓN PATRIMONIAL}

Bien de interés cultural (BIC)

$\square$ Bien de relevancia local (BRL)

$\square$ Afectado entorno BIC

$\square$ Afectado Plan especial 
- Descripción histórico-arquitectónica

Tipología

Cronologia:

Observaciones a la cronologí

\section{Descripción:}

\section{- Entorno urbano}

Descripción entorno urbano:

Uso actual:

Estado de conservación:

Intervenciones:

Régimen Urbanistico:

Titularidad:

Nivel protección s/catálogo 1996:

Bibliografía: AMR, 1818-17, 1818-24; 1818-50; 1818-52; 1818-53.

Observaciones generales:

$\begin{array}{lll}\text { OBJETIVACIÓN DE INTERÉS } & \text { Soluciones constructivas } & \text { Soluciones ornamentales } \\ \square \text { Interés tipológico } & \square \text { Estructura } & \square \text { Carpintería } \\ \square \text { valor ambiental } & \square \text { Aleros } & \square \text { Rejería } \\ \square \text { vigencia de la trama } & \square \text { coronación } & \square \text { Cubrepersianas } \\ \square \text { composición de la fachada } & \square \text { Jambas } & \square \text { Alicatados } \\ \square \text { Materiales, color, textura } & \square \text { Dinteles } & \square \text { Recercos } \\ & & \square \text { Dinteles } \\ & \square \text { Otros ornamentos }\end{array}$

\section{- Datos específicos catalogación BIC $\square$ Rellenar sólo si está catalogado BIC}

$\begin{array}{lll}\text { Datos Jurídicos: } & & \\ \text { Código: } & \text { Fecha Disposición: } & \text { Fecha informe: } \\ \text { Estado: } & \text { Tipo delimitación: } & \text { Fecha Publicación BOP: } \\ \text { Categoría: } & \text { Plan: } & \text { Fecha Publicación DOCV: } \\ \text { Anotación Mo: } & \text { Informe: } & \text { Fecha Publicación BOE: }\end{array}$

\section{Interés paisajistico}

$\square$ Incidencia visual

$\square$ Carácter articulado

$\square$ Organización

$\square$ Carácter representativo

\section{Camino de San Agustín. Casa del Tinte}

\section{- Identificación}

Tramo de estudio: Tramo 4: Puerta de Madrid-Puerta de las Cruces

Otras denominaciones:

Ref. catastral:

Localización: C/ de San Agustin.

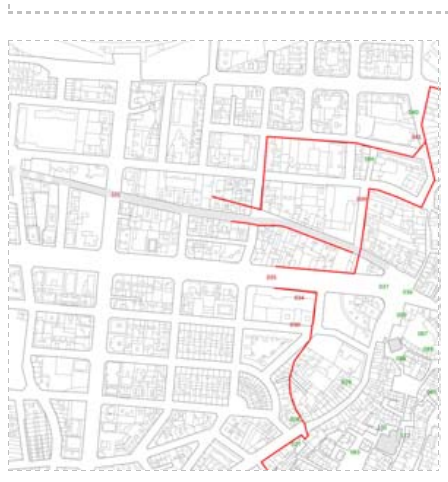

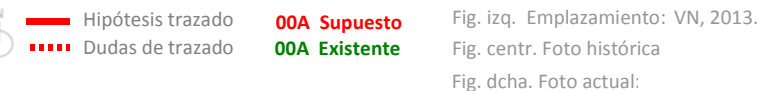

\section{- Referencias en documentación histórica}

\section{Referencias numéricas en cartografía sobre fortificación}

-Ref. en el croquis de Ortiz de Pinedo (1837-38, AGM, núm. 262): Sin ref.

-Ref. en plano de Vera Aparici (1993): Sin ref.

Referencias en memorias técnicas militares

-Ref. Guillermo Sáez (9/9/1834-5/12/1835): Requena, 5/12/1835 AMR, 1818-50

Aspillerar y fortificar la casa del tinte. La obra depende de la villa.

-Ref. Guillermo Sáez (26/02/1836): Sin ref.

-Ref. P. Ortiz de Pinedo (12/03/1837-30/05/1837): Sin ref.

-Ref Jose María de Orozco (25/03/1838): Sin ref.

-Ref. Carbonell (4/7/1838): Sin ref.

\section{- Observaciones a partir de los informes militares}

El camino de San Agustín debía de comunicar con la denominada ermita de San Agustín, o bien recibe el nombre del convento de monjas agustinas secoletas, 'Las monjas, , correspondente con el convento que se emplazaba frente a la plaza del Portal, y que fue demolido para ciudad, partiendo desde la plaza del Portal. En dicho camino debía ubicarse una casa del tinte, próximo a la muralla.

\begin{tabular}{|lll|}
$\square \frac{\text { Rellenar en caso de que el elemento sea }}{\text { contemplado con datos del PGOU, 2013 }}$ & PROTECCIÓN & AFECCIÓN PATRIMONIAL \\
& Nivel de protección: & $\square$ Bien de interés cultural (BIC) \\
& Entorno: & $\square$ Bien de relevancia local (BRL) \\
& $\square$ Inmueble & $\square$ Afectado entorno BIC \\
$\square$ Parcela catastral & $\square$ Afectado Plan especial \\
$\square$ Recinto arquitectónico & \\
\hline & Entorno específico &
\end{tabular}


- Descripción histórico-arquitectónica

Tipología:

Observaciones a la cronología

Descripción:

\section{- Entorno urbano}

Descripción entorno urbano:

Uso actual:

Estado de conservación:

Intervenciones:

Régimen Urbanístico:

Titularidad:

Nivel protección s/catálogo 1996:

Bibliografía: AMR, 1818-17, 1818-24; 1818-50; 1818-52; 1818-53.

Observaciones generales:

$\begin{array}{llll}\text { OBJETIVACIÓN DE INTERÉS } & \text { Soluciones constructivas } & \text { Soluciones ornamentales } & \text { Interés paisajistico } \\ \square \text { Interés tipológico } & \square \text { Estructura } & \square \text { Carpintería } & \square \text { Incidencia visual } \\ \square \text { valor ambiental } & \square \text { Aleros } & \square \text { Rejería } & \square \text { carácter articulador } \\ \square \text { vigencia de la trama } & \square \text { coronación } & \square \text { Cubrepersianas } & \square \text { organización } \\ \square \text { composición de la fachada } & \square \text { Jambas } & \square \text { Alicatados } & \square \text { Interés cultural } \\ \square \text { Materiales, color, textura } & \square \text { Dinteles } & \square \text { Recercos } & \square \text { Carácter representativo } \\ & & \square \text { Dinteles } & \\ & \square \text { Otros ornamentos } & \end{array}$

- Datos específicos catalogación BIC $\square$ Rellenar sólo si está catalogado BIC

$\begin{array}{lll}\text { Datos Jurídicos: } & & \\ \text { Código: } & \text { Fecha Disposición: } & \text { Fecha informe: } \\ \text { Estado: } & \text { Tipo delimitación: } & \text { Fecha Publicación BOP: } \\ \text { Categoría: } & \text { Plan: } & \text { Fecha Publicación DOCV: } \\ \text { Anotación Mo: } & \text { Informe: } & \text { Fecha Publicación BOE: }\end{array}$

\section{Las ceraduras}

\section{- Identificación}

Tramo de estudio:

Intramuros

Otras denom

Ref. catastral:

Localización:

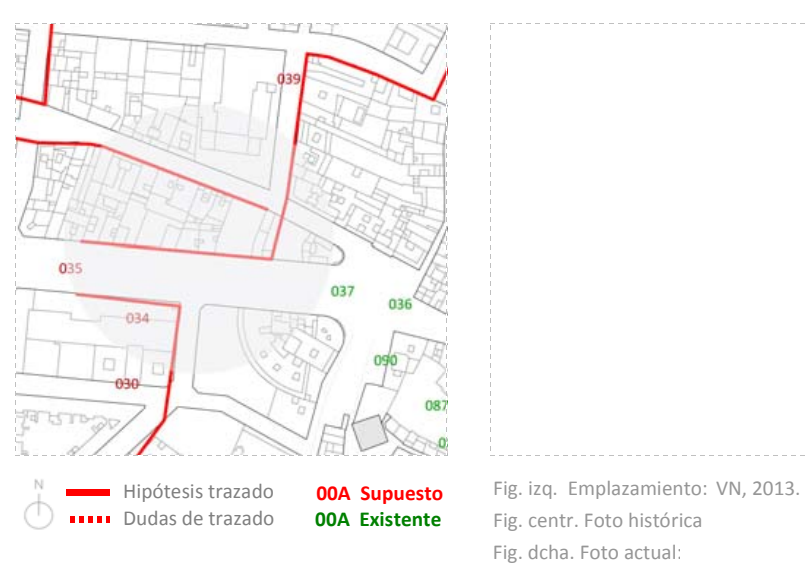

\section{- Referencias en documentación histórica}

Referencias numéricas en cartografía sobre fortificación

-Ref. en el croquis de Ortiz de Pinedo (1837-38, AGM, núm. 262): Sin ref.

-Ref. en plano de Vera Aparici (1993): Sin ref.

Referencias en memorias técnicas militares

-Ref. Guillermo Sáez (9/9/1834-5/12/1835): Sin ref.

-Ref. Guillermo Sáez (26/02/1836): Sin ref.

-Ref. P. Ortiz de Pinedo (12/03/1837-30/05/1837): Sin ref.

-Ref Jose María de Orozco (25/03/1838): Sin ref.

-Ref. Carbonell (4/7/1838): Sin ref.
Existe actualmente

Incluido en fichas PGOU 2013

Bien de interés cultural (BIC)

cód. postal: 46340

Municipio: Requena

Comarca: Plana de Requena-Utie

Provincia: Valencia

Autonomia: Comunidad Valencian

\section{- Observaciones a partir de los informes militares}

No se sabe a ciencia cierta si hace referencia a la denominación de un emplazamiento o al hecho de que en el mismo ubiese "cerraduras", también podría hacer referencia a la producción de cera

\begin{tabular}{|lll|}
$\square \frac{\text { Rellenar en caso de que el elemento sea }}{\text { contemplado con datos del PGOU, 2013 }}$ & PROTECCIÓN & AFECCIÓN PATRIMONIAL \\
& Nivel de protección: & $\square$ Bien de interés cultural (BIC) \\
& Entorno: & $\square$ Bien de relevancia local (BRL) \\
& $\square$ Inmueble & $\square$ Afectado entorno BIC \\
$\square$ Parcela catastral & $\square$ Afectado Plan especial \\
$\square$ Recinto arautectónico & \\
\hline$\square$ Entorno específico &
\end{tabular}


- Descripción histórico-arquitectónica

Tipología:

Cronología:

Observaciones a la cronologi

Descripción:

- Entorno urbano

Descripción entorno urbano:

Uso actual:

Estado de conservación:

Intervenciones:

Régimen Urbanistico:

Titularidad:

Nivel protección s/catálogo 1996:

Bibliografía: AMR, 1818-17, 1818-24; 1818-50; 1818-52; 1818-53.

Observaciones generales:

\begin{tabular}{llll} 
OBJETIVACIÓN DE INTERÉS & Soluciones constructivas & Soluciones ornamentales & Interés paisajistico \\
$\square$ Interés tipológico & $\square$ Estructura & $\square$ Carpintería & $\square$ Incidencia visual \\
\hline$\square$ valor ambiental & $\square$ Aleros & $\square$ Rejería & $\square$ carácter articulador \\
\hline$\square$ vigencia de la trama & $\square$ coronación & $\square$ cubrepersianas & $\square$ organización \\
$\square$ composición de la fachada & $\square$ Jambas & $\square$ Alicatados & $\square$ Interés cultural \\
$\square$ Materiales, color, textura & $\square$ Dinteles & $\square$ Recercos & $\square$ carácter representativo \\
& & $\square$ Dinteles & \\
& $\square$ otros ornamentos &
\end{tabular}

\begin{tabular}{|c|c|c|}
\hline \multicolumn{3}{|c|}{ enar sólo si está catalogado BIC } \\
\hline Datos Ju & & \\
\hline Código: & Fecha Disposición: & Fecha informe: \\
\hline Estado: & Tipo delimitación: & Fecha Publicación BOP: \\
\hline Categoría: & Plan: & Fecha Publicación DOCV \\
\hline Anotación $M \stackrel{0}{ }$ : & Informe: & Fecha Publicación BOE: \\
\hline
\end{tabular}

103 La posada

\section{- Identificación}

Tramo de estudio:

Intramuros

Otras denominaciones: La Posada de afuera

Ref. catastral:

Localización: Al Oeste de la Plaza del Portal. Área del primer tramo de la Avenida.

Existe actualmente

Incluido en fichas PGOU 2013

Bien de interés cultural (BIC)

cód. postal: 46340

Municipio: Requen

Comarca: Plana de Requena-Utie

Provincia: Valencia

Autonomia: Comunidad Valencian

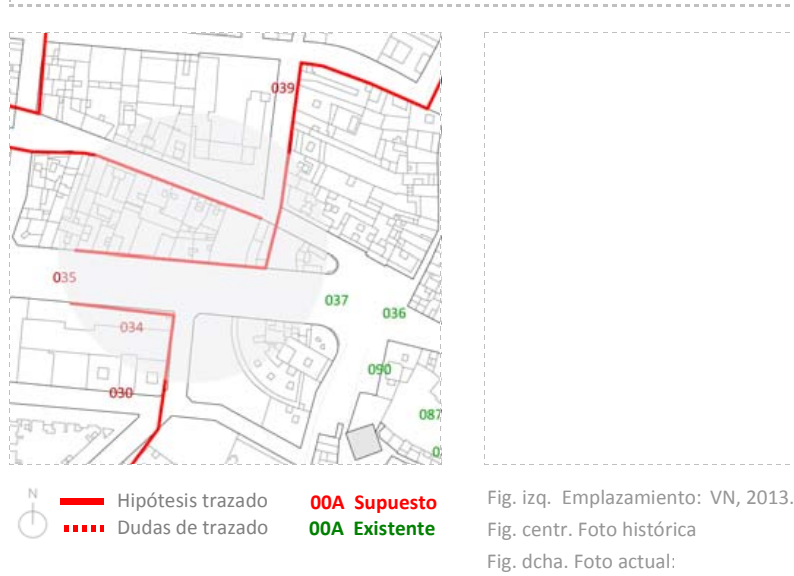

- Referencias en documentación histórica

Referencias numéricas en cartografía sobre fortificación

-Ref. en el croquis de Ortiz de Pinedo (1837-38, AGM, núm. 262): Sin ref.

-Ref. en plano de Vera Aparici (1993): Sin ref.

Referencias en memorias técnicas militare

-Ref. Guillermo Sáez (9/9/1834-5/12/1835): Sin ref.

-Ref. Guillermo Sáez (26/02/1836): Sin ref.

-Ref. P. Ortiz de Pinedo (12/03/1837-30/05/1837): Sin ref.

-Ref Jose María de Orozco (25/03/1838): Sin ref.

-Ref. Carbonell (4/7/1838): Sin ref.

\section{- Observaciones a partir de los informes militares}

Ver la Posada de Afuera, 033.

\begin{tabular}{|c|c|c|}
\hline $\begin{array}{l}\text { Rellenar en caso de que el elemento sea } \\
\text { contemplado con datos del PGOU, } 2013\end{array}$ & $\begin{array}{l}\text { PROTECCIÓN } \\
\text { Nivel de protección: } \\
\text { Entorno: }\end{array}$ & $\begin{array}{l}\text { AFECCIÓN PATRIMONIAL } \\
\begin{aligned} \square \text { Bien de interés cultural (BIC) } \\
\square \text { Bien de relevancia local (BRL) }\end{aligned}\end{array}$ \\
\hline & $\begin{array}{l}\square \text { Inmueble } \\
\square \text { Parcela catastral } \\
\square \text { Recinto arquitectónico } \\
\square \text { Entorno específico }\end{array}$ & $\begin{array}{l}\square \text { Afectado entorno BIC } \\
\square \text { Afectado Plan especial }\end{array}$ \\
\hline
\end{tabular}


- Descripción histórico-arquitectónica

\section{Tipología:}

Cronología:

Observaciones a la cronología

Descripción:

\section{- Entorno urbano}

Descripción entorno urbano:

Uso actual:

Estado de conservación:

Intervenciones:

Régimen Urbanístico:

Titularidad:

Nivel protección s/catálogo 1996:

Bibliografía: AMR, 1818-17, 1818-24; 1818-50; 1818-52; 1818-53.

Observaciones generales:

$\begin{array}{lll}\text { OBJETIVACIÓN DE INTERÉS } & \text { Soluciones constructivas } & \text { Soluciones ornamentales } \\ \square \text { Interés tipológico } & \square \text { Estructura } & \square \text { Carpintería } \\ \square \text { valor ambiental } & \square \text { Aleros } & \square \text { Rejería } \\ \square \text { vigencia de la trama } & \square \text { coronación } & \square \text { Cubrepersianas } \\ \square \text { Composición de la fachada } & \square \text { Jambas } & \square \text { Alicatados } \\ \square \text { Materiales, color, textura } & \square \text { Dinteles } & \square \text { Recercos } \\ & & \square \text { Dinteles } \\ & \square \text { Otros ornamentos }\end{array}$

\section{- Datos específicos catalogación BIC $\square$ Rellenar sólo si está catalogado BIC}

\section{Datos Jurídicos:}

Código:
Estado:

Estado:
Categoría:

Anotación $M$

Fecha Disposición:

Plan:

Informe:

Fecha informe:

Fecha Publicación BOP:

Fecha Publicación DOCV:

Fecha Publicación BOE:

\section{Calle de Poniente}

\section{- Identificación}

Tramo de estudio:

Otras denominaciones:

Tramo 4: Puerta de Madrid-Puerta de las Cruces

Ref. catastral:

Localización:

Existe actualmente

Incluido en fichas PGOU 2013

Bien de interés cultural (BIC)

cód. postal: 46340

Municipio: Requena

Comarca: Plana de Requena-Utiel

Provincia: Valencia

Autonomia: Comunidad Valencian

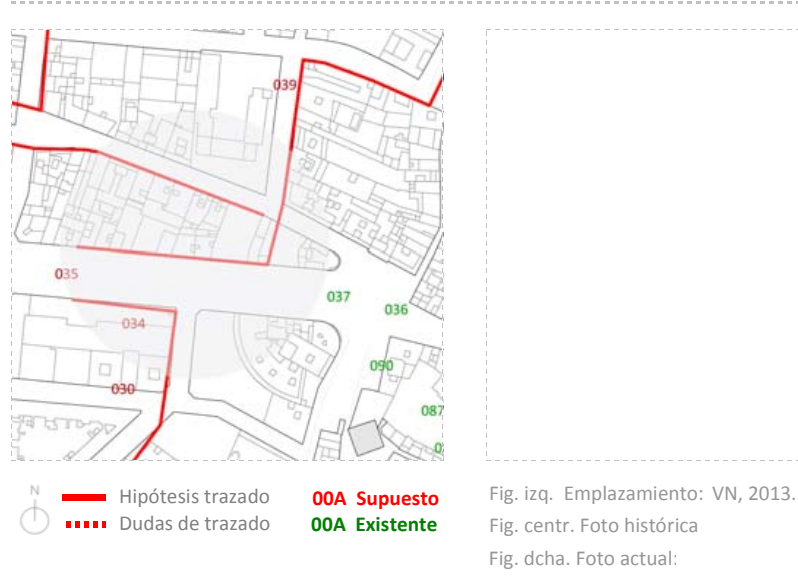

- Referencias en documentación histórica

Referencias numéricas en cartografía sobre fortificación

-Ref. en el croquis de Ortiz de Pinedo (1837-38, AGM, núm. 262): Sin ref.

-Ref. en plano de Vera Aparici (1993): Sin ref.

Referencias en memorias técnicas militares

-Ref. Guillermo Sáez (9/9/1834-5/12/1835): Requena, 5/12/1835 AMR, 1818-50

No se mencionan obras

-Ref. Guillermo Sáez (26/02/1836): Sin ref.

-Ref. P. Ortiz de Pinedo (12/03/1837-30/05/1837): Sin ref.

-Ref Jose María de Orozco (25/03/1838): Sin ref.

-Ref. Carbonell (4/7/1838): Sin ref.

\section{- Observaciones a partir de los informes militares}

Se trata de una calle, en el interior de la villa que comunicaba con la salida oeste de la ciudad, citada por Guillermo Sáez en su informe de se podría hacer referencia al camino de San Agustín o al antiguo paseo de la Glorieta, todos orientados hacia Poniente.

\begin{tabular}{lll}
$\square \frac{\text { Rellenar en caso de que el elemento sea }}{\text { contemplado con datos del PGOU, 2013 }}$ & PROTECCIÓN & AFECCIÓN PATRIMONIAL \\
& Nivel de protección: & $\square$ Bien de interés cultural (BIC) \\
& Entorno: & $\square$ Bien de relevancia local (BRL) \\
& $\square$ Inmueble & $\square$ Afectado entorno BIC \\
& $\square$ Parcela catastral & $\square$ Afectado Plan especial \\
& $\square$ Recinto arquitectónico & \\
\hline & Entorno específico &
\end{tabular}




\section{- Descripción histórico-arquitectónica \\ Tipologia:}

Cronología:

Observaciones a la cronologí

\section{Descripción:}

- Entorno urbano

Descripción entorno urbano:

Uso actual:

Estado de conservación:

Intervenciones:

Titularidad:

Nivel protección s/catálogo 1996:

Bibliografía: AMR, 1818-17, 1818-24; 1818-50; 1818-52; 1818-53.

Observaciones generales:

$\begin{array}{lll}\text { OBJETIVACIÓN DE INTERÉS } & \text { Soluciones constructivas } & \text { Soluciones ornamentales } \\ \square \text { Interés tipológico } & \square \text { Estructura } & \square \text { carpintería } \\ \square \text { Valor ambiental } & \square \text { Aleros } & \square \text { Rejería } \\ \square \text { vigencia de la trama } & \square \text { coronación } & \square \text { cubrepersianas } \\ \square \text { composición de la fachada } & \square \text { Jambas } & \square \text { Alicatados } \\ \square \text { Materiales, color, textura } & \square \text { Dinteles } & \square \text { Recercos } \\ & & \square \text { Dinteles } \\ & \square \text { otros ornamentos }\end{array}$

\section{- Datos específicos catalogación BIC $\square$ Rellenar sólo si está catalogado BIC}

\begin{tabular}{|lll}
\hline Datos Juridicos: & & \\
Código: & Fecha Disposición: & Fecha informe: \\
Estado: & Tipo delimitación: & Fecha Publicación BOP: \\
Cateogría: & Plan: & Fecha Publicación DOCV: \\
Anotación Mo: & Informe: & Fecha Publicación BOE:
\end{tabular}

\section{Interés paisajistico}

$\square$ Incidencia visual

$\square$ Carácter articulador

$\square$ Organización

$\square$ Carácter representativo

\section{Pared de Don Diego Montes}

\section{- Identificación}

Tramo de estudio:

Otras denominaciones:

Tramo 4: Puerta de Madrid-Puerta de las Cruces

Ref. catastral:

Localización: Entorno de la C/ Asnos hacia C/ de las Cruces.

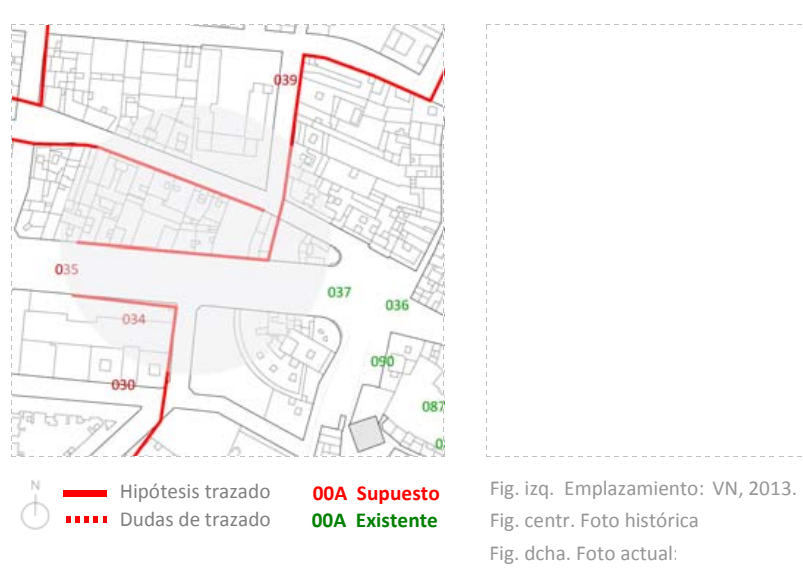

- Referencias en documentación histórica

Referencias numéricas en cartografía sobre fortificación

-Ref. en el croquis de Ortiz de Pinedo (1837-38, AGM, núm. 262): Sin ref.

-Ref. en plano de Vera Aparici (1993): Sin ref.

Referencias en memorias técnicas militares

-Ref. Guillermo Sáez (9/9/1834-5/12/1835): Sin ref.

-Ref. Guillermo Sáez (26/02/1836): Sin ref.

-Ref. P. Ortiz de Pinedo (12/03/1837-30/05/1837): Sin ref.

-Ref Jose María de Orozco (25/03/1838): Sin ref.

-Ref. Carbonell (4/7/1838): Sin ref.

\section{- Observaciones a partir de los informes militares}

Delimitaría el huerto de las Monjas y miraba hacia los molinos. Lo cual testimonia en aquella dirección la presencia de molinos harineros.

\begin{tabular}{|lll}
\hline $\begin{array}{ll}\text { Rellenar en caso de que el elemento sea } \\
\text { contemplado con datos del PGOU, 2013 }\end{array}$ & PROTECCIÓN & AFECCIÓN PATRIMONIAL \\
& Nivel de protección: & $\square$ Bien de interés cultural (BIC) \\
& Entorno: & $\square$ Bien de relevancia local (BRL) \\
& $\square$ Inmueble & $\square$ Afectado entorno BIC \\
& $\square$ Parcela catastral & $\square$ Afectado Plan especial \\
& $\square$ Recinto arquitectónico & \\
& $\square$ Entorno especifico &
\end{tabular}

Existe actualmente

Bien de interés cultural (BIC)

cód. postal: 46340

Municipio: Requena

Comarca: Plana de Requena-Utiel

Provincia: Valencia

Autonomía: Comunidad Valenciana 
- Descripción histórico-arquitectónica

\section{Tipología:}

Cronología:

Observaciones a la cronología:

\section{Descripción:}

- Entorno urbano

Descripción entorno urbano:

Uso actual:

Estado de conservación:

Intervenciones:

Régimen Urbanistico:

Titularidad:

Nivel protección s/catálogo 1996:

Bibliografía: AMR, 1818-17, 1818-24; 1818-50; 1818-52; 1818-53.

Observaciones generales:

\section{OBJETIVACIÓN DE INTERÉS}

$\square$ Interés tipológico

$\square$ Valor ambiental

Vigencia de la trama

$\square$ Composición de la fachada

Soluciones constructivas
$\square$ Estructura
$\square$ Aleros
$\square$ Coronación
$\square$ Jambas
$\square$ Dinteles

Interés paisajistico

$\square$ Incidencia visual

$\square$ Carácter articulador

$\square$ Organización

$\square$ Carácter representativo
Cubrepersia

Alicatados

Otros ornamentos

\begin{tabular}{|c|c|c|}
\hline \multirow{2}{*}{\multicolumn{3}{|c|}{ - Datos específicos catalogación BIC }} \\
\hline & & \\
\hline Código: & Fecha Disposición: & Fecha informe: \\
\hline Estado: & Tipo delimitación: & Fecha Publicación BOP: \\
\hline Categoría: & Plan: & Fecha Publicación DOCV \\
\hline Anotación Mo: & Informe: & Fecha Publicación BOE: \\
\hline
\end{tabular}

\section{Corral de Eugenio Mas}

\section{- Identificación}

Tramo de estudio: Tramo 4: Puerta de Madrid-Puerta de las Cruces

Otras denominaciones:

Ref. catastral:

Localización: Entorno de la C/Asnos hacia C/ de las Cruces.

Existe actualmente

Incluido en fichas PGOU 2013

Bien de interés cultural (BIC)

cód. postal: 46340

Municipio: Requena

Comarca: Plana de Requena-Utie

Provincia: Valencia

Autonomía: Comunidad Valencian

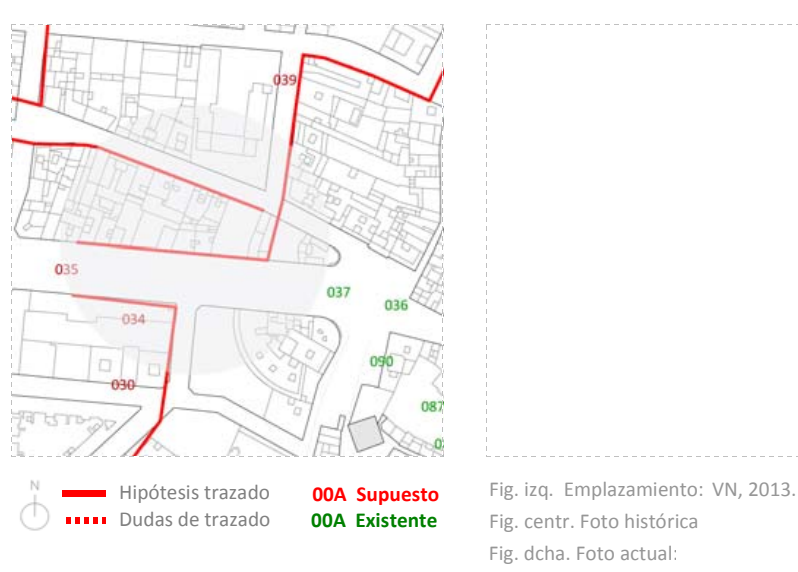

- Referencias en documentación histórica

Referencias numéricas en cartografía sobre fortificación

-Ref. en el croquis de Ortiz de Pinedo (1837-38, AGM, núm. 262): Sin ref.

-Ref. en plano de Vera Aparici (1993): Sin ref.

Referencias en memorias técnicas militares

-Ref. Guillermo Sáez (9/9/1834-5/12/1835): Sin ref.

-Ref. Guillermo Sáez (26/02/1836): Sin ref.

-Ref. P. Ortiz de Pinedo (12/03/1837-30/05/1837): Sin ref.

-Ref Jose María de Orozco (25/03/1838): Sin ref.

-Ref. Carbonell (4/7/1838): Sin re

\section{- Observaciones a partir de los informes militares}

Parece ubicarse en las proximidades de las Monjas, integrando el frente desde la Puerta de Madrid hacia el Cerro de Isabel

$\begin{array}{lll}\square \frac{\text { Rellenar en caso de que el elemento sea }}{\text { contemplado con datos del PGOU, 2013 }} & \text { PROTECCIÓN } & \text { AFECCIÓN PATRIMONIAL } \\ & \text { Nivel de protección: } & \square \text { Bien de interés cultural (BIC) } \\ & \text { Entorno: } & \square \text { Bien de relevancia local (BRL) } \\ & \square \text { Inmueble } & \square \text { Afectado entorno BIC } \\ & \square \text { Parcela catastral } & \square \text { Afectado Plan especial } \\ & \square \text { Recinto arquitectónico } & \\ \square \text { Entorno específico } & \end{array}$


- Descripción histórico-arquitectónica

Tipología:

Cronología:

observaciones a la cronologí

Descripción:

\section{- Entorno urbano}

Descripción entorno urbano:

Uso actual:

Estado de conservación:

Intervenciones:

Régimen Urbanístico:

Titularidad:

Nivel protección s/catálogo 1996:

Bibliografia: AMR, 1818-17, 1818-24; 1818-50; 1818-52; 1818-53.

Observaciones generales:

\begin{tabular}{llll} 
OBJETIVACIÓN DE INTERÉS & Soluciones constructivas & Soluciones ornamentales & Interés paisajistico \\
$\square$ Interés tipológico & $\square$ Estructura & $\square$ Carpintería & $\square$ Incidencia visual \\
\hline$\square$ valor ambiental & $\square$ Aleros & $\square$ Rejería & $\square$ carácter articulador \\
\hline$\square$ vigencia de la trama & $\square$ coronación & $\square$ cubrepersianas & $\square$ organización \\
\hline$\square$ Composición de la fachada & $\square$ Jambas & $\square$ Alicatados & $\square$ Interés cultural \\
$\square$ Materiales, color, textura & $\square$ Dinteles & $\square$ Recercos & $\square$ carácter representativo \\
& & $\square$ Dinteles & \\
& $\square$ otros ornamentos &
\end{tabular}

\section{- Datos específicos catalogación BIC $\square$ Rellenar sólo si está catalogado BIC}

\section{Datos Jurídicos:}

$\begin{array}{lll} & \text { Fecha Disposición: } & \text { Fecha informe: } \\ \text { Código: } & \text { TTipo delimitación: } & \text { Fecha Publicación BOP: } \\ \text { Estado: } & \text { Plan: } & \text { Fecha Publicación DOCV: } \\ \text { Categoria: } & \text { Informe: } & \text { Fecha Publicación BOE: }\end{array}$

Plan:

\section{Corral de Gabriel Justo}

\section{- Identificación}

Tramo de estudio:

Otras denominaciones:

Tramo 4: Puerta de Madrid-Puerta de las Cruces

Ref. catastral:

Localización: Entorno de la C/Asnos hacia C/ de las Cruces.

$\square$ Existe actualmente

Incluido en fichas PGOU 2013

Bien de interés cultural (BIC)

Cód. postal: 46340

Municipio: Requena

Comarca: Plana de Requena-Utie

Provincia: Valencia

Autonomia: Comunidad Valenciana

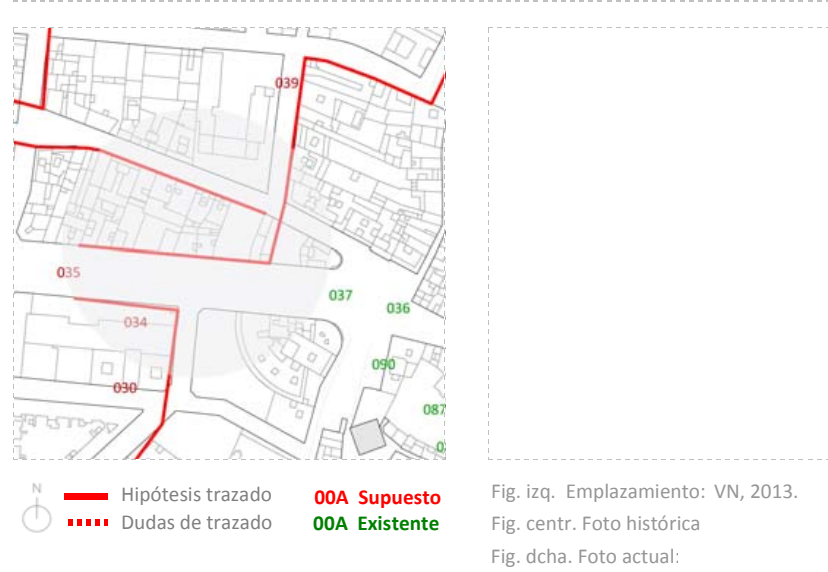

\section{- Referencias en documentación histórica}

Referencias numéricas en cartografía sobre fortificación

-Ref. en el croquis de Ortiz de Pinedo (1837-38, AGM, núm. 262): Sin ref.

-Ref. en plano de Vera Aparici (1993): Sin ref.

Referencias en memorias técnicas militares

-Ref. Guillermo Sáez (9/9/1834-5/12/1835): Sin ref.

-Ref. Guillermo Sáez (26/02/1836): Sin ref.

-Ref. P. Ortiz de Pinedo (12/03/1837-30/05/1837): Sin ref.

-Ref Jose Maria de Orozco (25/03/1838): Sin ref.

Ref. Carbonell (4/7/1838): Sin re

\section{- Observaciones a partir de los informes militares}

Parece ubicarse en las proximidades de las Monjas, integrando el frente desde la Puerta de Madrid hacia el Cerro de Isabel II

\begin{tabular}{|lll}
$\square$ Rellenar en caso de que el elemento sea & PROTECCIÓN & AFECCIÓN PATRIMONIAL \\
contemplado con datos del PGOU, 2013 & Nivel de protección: & $\square$ Bien de interés cultural (BIC) \\
& Entorno: & $\square$ Bien de relevancia local (BRL) \\
& $\square$ Inmueble & $\square$ Afectado entorno BIC \\
& $\square$ Parcela catastral & $\square$ Afectado Plan especial \\
& $\square$ Recinto arquitectónico & \\
& $\square$ Entorno espećfico &
\end{tabular}




\section{- Descripción histórico-arquitectónica}

\section{Tipología:}

Cronología:

Observaciones a la cronología

Descripción:

- Entorno urbano

Descripción entorno urbano:

Uso actual:

Estado de conservación:

Intervenciones:

Régimen Urbanístico:

Titularidad:

Nivel protección s/catálogo 1996:

Bibliografía: AMR, 1818-17, 1818-24; 1818-50; 1818-52; 1818-53.

Observaciones generales:

$\begin{array}{lll}\text { OBJETIVACIÓN DE INTERÉS } & \text { Soluciones constructivas } & \text { Soluciones ornamentales } \\ \square \text { Interés tipológico } & \square \text { Estructura } & \square \text { carpintería } \\ \square \text { Valor ambiental } & \square \text { Aleros } & \square \text { Rejería } \\ \square \text { Vigencia de la trama } & \square \text { coronación } & \square \text { cubrepersianas } \\ \square \text { composición de la fachada } & \square \text { Jambas } & \square \text { Alicatados } \\ \square \text { Materiales, color, textura } & \square \text { Dinteles } & \square \text { Recercos } \\ & & \square \text { Dinteles } \\ & & \square \text { otros ornamentos }\end{array}$

\section{- Datos específicos catalogación BIC $\square$ Rellenar sólo si está catalogado BIC} Datos Jurídicos:

$\begin{array}{lll}\text { Datos Juridicos: } & \text { Fecha Disposición: } & \text { Fecha informe: } \\ \text { Código: } & \text { Tipo delimitación: } & \text { Fecha Publicación BOP: } \\ \text { Estado: } & \text { Plan: } & \text { Fecha Publicación DOCV: } \\ \text { Categoría: } & \text { Informe: } & \text { Fecha Publicación BOE: }\end{array}$

108 Plaza de la Constitución

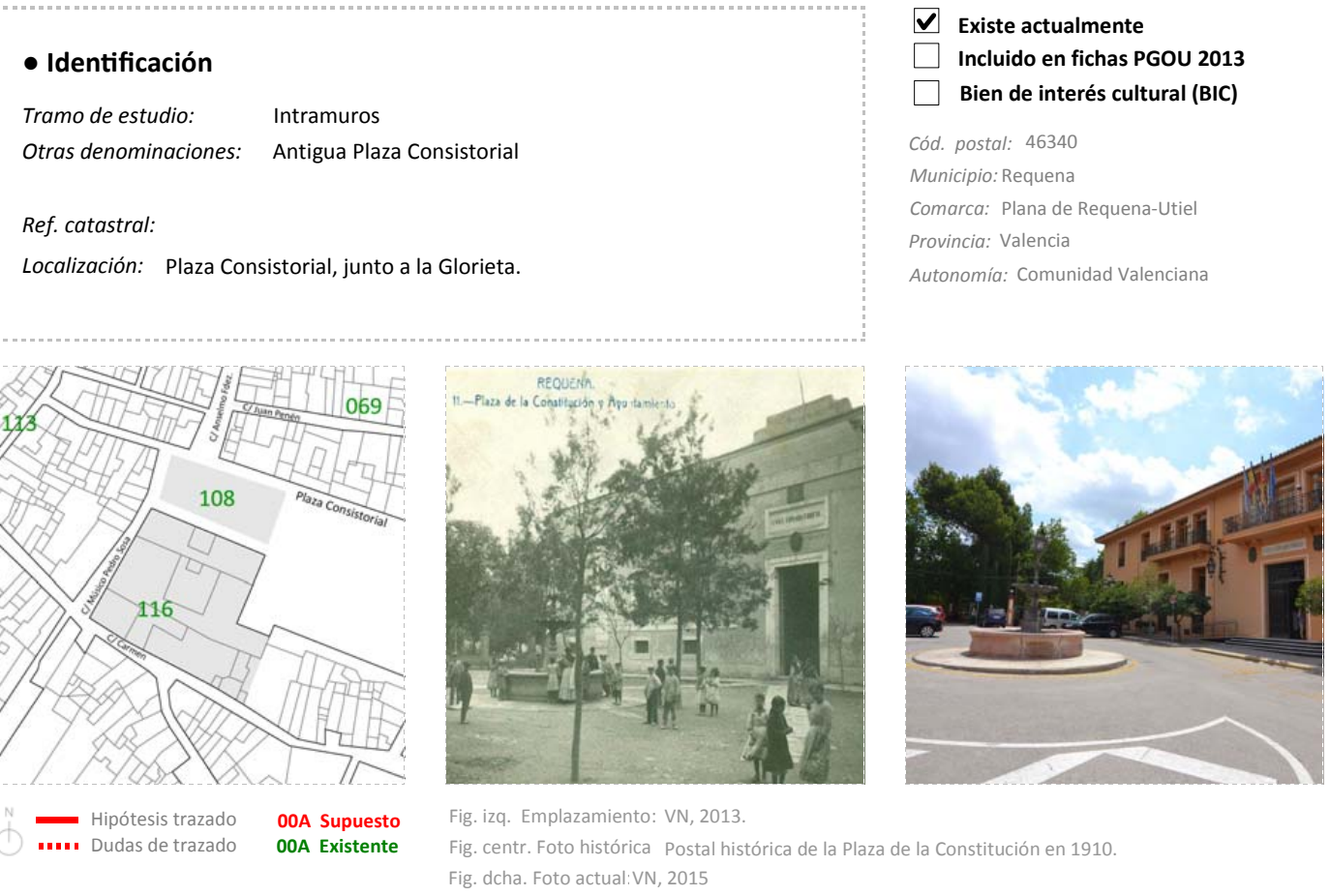

- Referencias en documentación histórica

Referencias numéricas en cartografía sobre fortificación

-Ref. en el croquis de Ortiz de Pinedo (1837-38, AGM, núm. 262): Sin ref.

-Ref. en plano de Vera Aparici (1993): Sin ref.

Referencias en memorias técnicas militare

-Ref. Guillermo Sáez (9/9/1834-5/12/1835): Sin ref.

-Ref. Guillermo Sáez (26/02/1836): Sin ref.

-Ref. P. Ortiz de Pinedo (12/03/1837-30/05/1837): Sin ref.

-Ref Jose María de Orozco (25/03/1838): Sin ref.

-Ref. Carbonell (4/7/1838): Sin ref.

\section{- Observaciones a partir de los informes militares}

Plaza a la que da fachada el actual Ayuntamiento, que ocupa parte del Convento de Carmelitas Observantes

$\begin{array}{lll}\square \frac{\text { Rellenar en caso de que el elemento sea }}{\text { contemplado con datos del PGoU, 2013 }} & \text { PROTECCIÓN } & \text { AFECCIÓN PATRIMONIAL } \\ & \text { Nivel de protección: } & \square \text { Bien de interés cultural (BIC) } \\ & \text { Entorno: } & \square \text { Bien de relevancia local (BRL) } \\ & \square \text { Inmueble } & \square \text { Afectado entorno BIC } \\ \square \text { Parcela catastral } & \square \text { Afectado Plan especial } \\ \square \text { Recinto arquitectónico } & \\ \square \text { Entorno específico } & \end{array}$




\section{- Descripción histórico-arquitectónica}

Tipología:

Observaciones a la cronología

\section{Descripción:}

\section{- Entorno urbano}

Descripción entorno urbano

Uso actual:

Estado de conservación:
Intervenciones:

Régimen Urbanistico:

Titularidad:

Nivel protección s/catálogo 1996:

Bibliografía: AMR, 1818-17, 1818-24; 1818-50; 1818-52; 1818-53.

Observaciones generales:

$\begin{array}{lll}\text { OBJETIVACIÓN DE INTERÉS } & \text { Soluciones constructivas } & \text { Soluciones ornamentales } \\ \square \text { Interés tipológico } & \square \text { Estructura } & \square \text { Carpintería } \\ \square \text { valor ambiental } & \square \text { Aleros } & \square \text { Rejería } \\ \square \text { Vigencia de la trama } & \square \text { Coronación } & \square \text { Cubrepersianas } \\ \square \text { Composición de la fachada } & \square \text { Jambas } & \square \text { Alicatados } \\ \square \text { Materiales, color, textura } & \square \text { Dinteles } & \square \text { Recercos } \\ & & \square \text { Dinteles } \\ & \square \text { Otros ornamentos }\end{array}$

\section{- Datos específicos catalogación BIC $\square$ Rellenar sólo si está catalogado BIC}

$\begin{array}{lll}\text { Datos Juridicos: } & & \\ \text { Código: } & \text { Fecha Disposición: } & \text { Fecha informe: } \\ \text { Estado: } & \text { Tipo delimitación: } & \text { Fecha Publicación BOP: } \\ \text { Categoría: } & \text { Plan: } & \text { Fecha Publicación DOCV: } \\ \text { Anotación Mo: } & \text { Informe: } & \text { Fecha Publicación BOE: }\end{array}$

\section{Corral de las Mudas (actual Plaza de toros)}

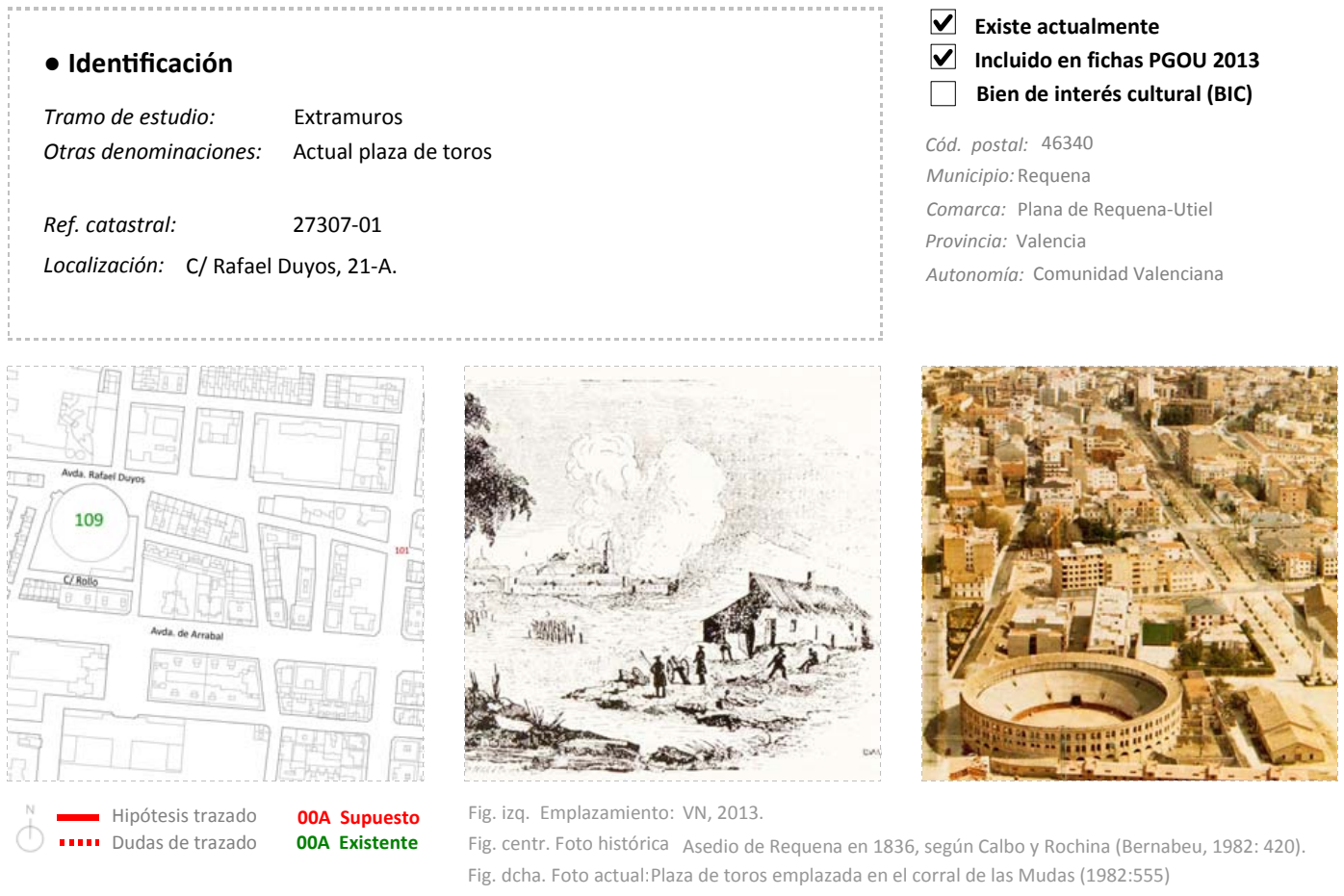

- Referencias en documentación histórica

Referencias numéricas en cartografía sobre fortificación

-Ref. en el croquis de Ortiz de Pinedo (1837-38, AGM, núm. 262): Sin ref.

-Ref. en plano de Vera Aparici (1993): Sin ref.

Referencias en memorias técnicas militares

-Ref. Guillermo Sáez (9/9/1834-5/12/1835): Sin ref.

-Ref. Guillermo Sáez (26/02/1836): Sin ref.

-Ref. P. Ortiz de Pinedo (12/03/1837-30/05/1837): Sin ref.

-Ref Jose María de Orozco (25/03/1838): Sin ref.

-Ref. Carbonell (4/7/1838): Sin ref.

\section{- Observaciones a partir de los informes militares}

El corral de las Mudas, donde el general Gómez dispondrá su batería para atacar Requena en 1836, parece localizarse en el actual emplazamiento de la Plaza de Toros.

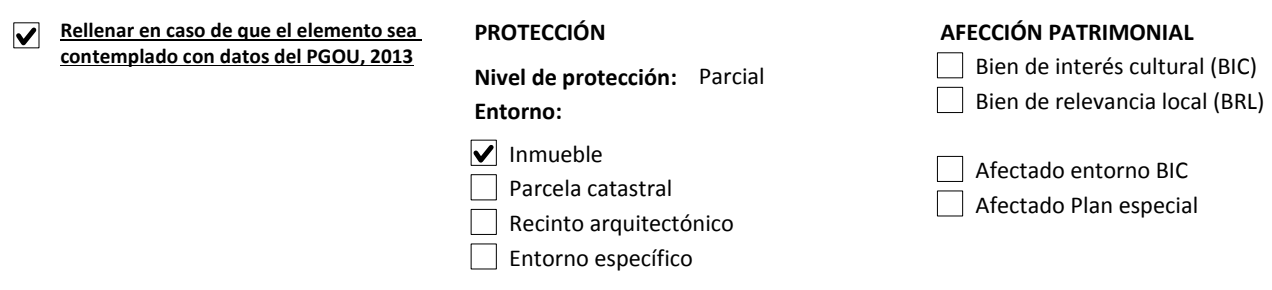




\section{- Descripción histórico-arquitectónica}

Tipología: Arquitectura civil

Cronología: 1905

Observaciones a la cronología: La plaza se implanta sobre las preexistencias de fecha imprecisa

Descripción: "Edificio de estilo neomudéjar construido en 1901. Es una plaza de grandes proporciones, con arcadas en ladrillo, y sin revestimiento en la fachada. Ha sido sometida a procesos de restauración, conservación y consolidación" (PGOU, 2013:E.CAS.CAT.78).

\section{- Entorno urbano}

\section{Descripción entorno urbano:}

"La plaza de toros ubicada sobre la antigua carretera a Madrid, en la parte oeste de la zona de ensanche, hace parte de los primeros desarrollos urbanisticos de esta zona. La proximidad a la antigua Cooperativa vinicola ha generado a

Uso actual: Plaza de toros

Estado de consenacion: Bueno

conservación y restauració

Régimen Urbanistico: S.U.

Titularidad: Pública

6: 1 singular

$1818-24 ; 1818-50 ; 1818-52 ; 1818-53$

Observaciones generales:

\begin{tabular}{|c|c|c|c|}
\hline OBJETIVACIÓN DE INTERÉS & Soluciones constructivas & Soluciones ornamentales & Interés paisajístico \\
\hline$\checkmark$ Interés tipológico & $\checkmark$ Estructura & $\square$ Carpintería & $\checkmark$ Incidencia visual \\
\hline$\checkmark$ Valor ambiental & $\square$ Aleros & Rejería & V Carácter articulador \\
\hline$\checkmark$ Vigencia de la trama & $\square$ Coronación & $\square$ Cubrepersianas & $\bar{\nabla}$ Organización \\
\hline Composición de la fachada & $\square$ Jambas & $\square$ Alicatados & $\bar{\nabla}$ Interés cultural \\
\hline$\sqrt{ }$ Materiales, color, textura & $\square$ Dinteles & $\begin{array}{l}\square \text { Recercos } \\
\square \text { Dinteles } \\
\square \text { Otros ornamentos }\end{array}$ & $\checkmark$ Carácter representativo \\
\hline
\end{tabular}

- Datos específicos catalogación BIC $\square$ Rellenar sólo si está catalogado BIC Datos Jurídicos:
Código:
Fecha Disposición:
Estado:
Categoría:
Plan:
Fecha informe:
Plan:
Fecha Publicación DOCV:
Fecha Publicación BOE:

110 Callejón de Paniagua

\section{- Identificación}

Tramo de estudio:

Intramuros

Otras denominaciones: Callejón de Pan y Agua

Ref. catastral:

Localización: Callejón de Paniagua. $\checkmark$ Existe actualmente

Incluido en fichas PGOU 2013

Bien de interés cultural (BIC)

cód. postal: 46340

Provincia: Valenci

Autonomía: Comunidad Valencian

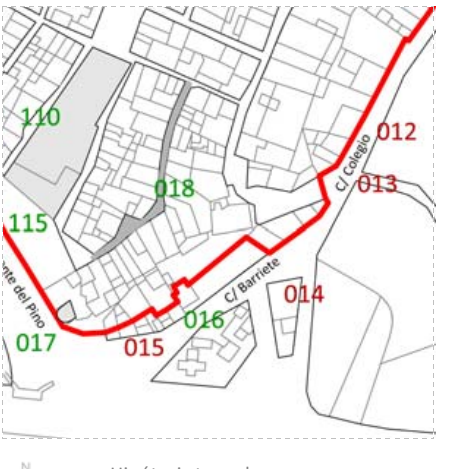

-.... Dipótesis trazazdo

O0A Supuesto

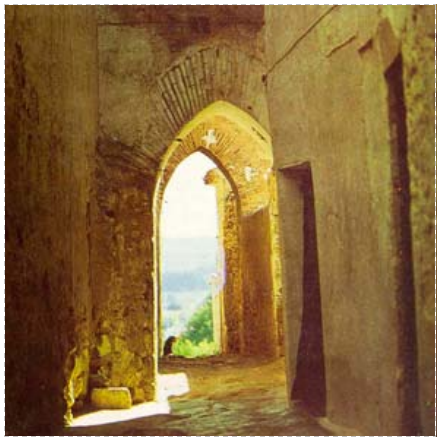

Emplazamiento: VN, 2013

Fig. centr. Foto histórica Bernabeu, 1982:115

Fig. dcha. Foto actual:
- Referencias en documentación histórica

Referencias numéricas en cartografía sobre fortificación

-Ref. en el croquis de Ortiz de Pinedo (1837-38, AGM, núm. 262): Sin ref.

-Ref. en plano de Vera Aparici (1993): Sin ref.

Referencias en memorias técnicas militares

-Ref. Guillermo Sáez (9/9/1834-5/12/1835). Sin ref.

-Ref. Guillermo Sáez (26/02/1836): Sin ref.

-Ref. P. Ortiz de Pinedo (12/03/1837-30/05/1837): Sin ref.

-Ref Jose María de Orozco (25/03/1838): Sin ref.

-Ref. Carbonell (4/7/1838): Sin ref.

\section{- Observaciones a partir de los informes militares}

Se accede a él a través de la cuestecilla del pozo, que perfora la cortina. Es un callejón de características mudéjares al que vuelcan dos contrafuertes de San Nicolás que cabalgan sobre arcos apuntados de ladrillo. La primera casa de la esquina fue cedida en 1535 a los

$\begin{array}{lll}\square \text { Rellenar en caso de que el elemento sea } & \text { PROTECCIÓN } & \text { AFECCIÓN PATRIMONIAL } \\ \text { contemplado con datos del PGOU, 2013 } & \text { Nivel de protección: } & \square \text { Bien de interés cultural (BIC) } \\ & \text { Entorno: } & \square \text { Bien de relevancia local (BRL) } \\ & \square \text { Inmueble } & \square \text { Afectado entorno BIC } \\ & \square \text { Parcela catastral } & \square \text { Afectado Plan especial } \\ & \square \text { Recinto arquitectónico } & \\ \square \text { Entorno específico } & \end{array}$


- Descripción histórico-arquitectónica

\section{Tipología:}

Cronología:

Observaciones a la cronología

\section{Descripción:}

- Entorno urbano

Descripción entorno urbano:

Uso actual:

Estado de conservación:

Intervenciones:

Régimen Urbanístico:

Titularidad:

Nivel protección s/catálogo 1996:

Bibliografía: AMR, 1818-17, 1818-24; 1818-50; 1818-52; 1818-53.

Observaciones generales:

\begin{tabular}{|c|c|c|}
\hline BJETIVACIÓN DE INTERÉS & Soluciones constructivas & Soluciones ornamentales \\
\hline Interés tipológico & & $\square$ Carpintería \\
\hline Valor ambiental & $\square$ Aleros & $\square$ Rejería \\
\hline Vigencia de la trama & $\square$ Coronación & $\square$ Cubrepersianas \\
\hline Composición de la fachada & $\square$ Jambas & $\square$ Alicatados \\
\hline Materiales, color, textura & $\square$ Dinteles & $\square$ Recercos \\
\hline & & $\square$ Dinteles \\
\hline & & $\square$ Otros ornamentos \\
\hline
\end{tabular}

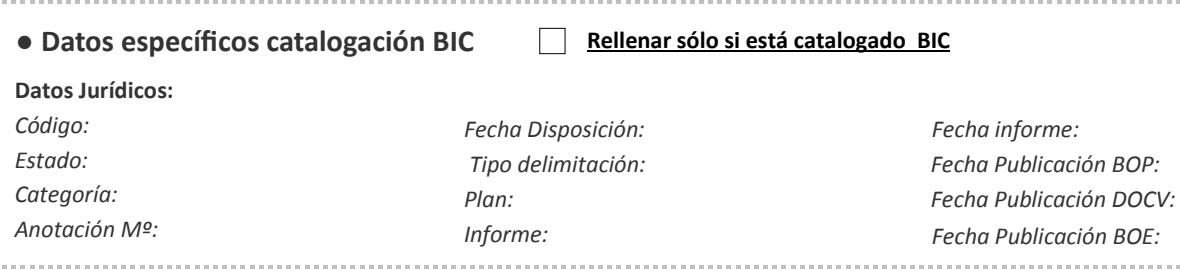

\section{Plazuela del Salvador}

\section{- Identificación}

Tramo de estudio:

Intramuros

Otras denominaciones:

Ref. catastral:

Localización: Plaza del Salvador.

$\checkmark$ Existe actualmente

Incluido en fichas PGOU 2013

Bien de interés cultural (BIC)

cód. postal: 46340

Municipio: Requena

Comarca: Plana de Requena-Utiel

Provincia: Valencia

Autonomia: Comunidad Valencian

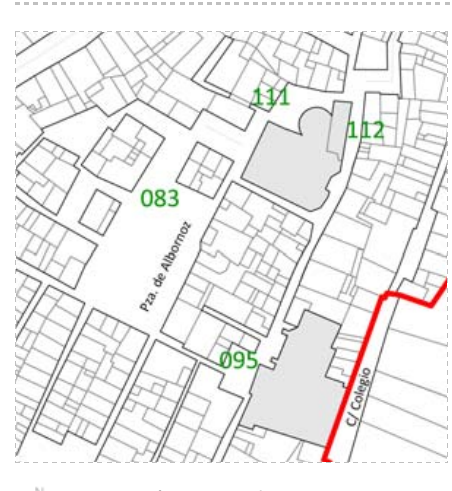

-... Hipótesis trazado OOA Supuesto

$\square$ Incidencia visual

$\square$ Organización

Carácter representativo

..... Dudas de trazado $00 \mathrm{~A}$ Existente

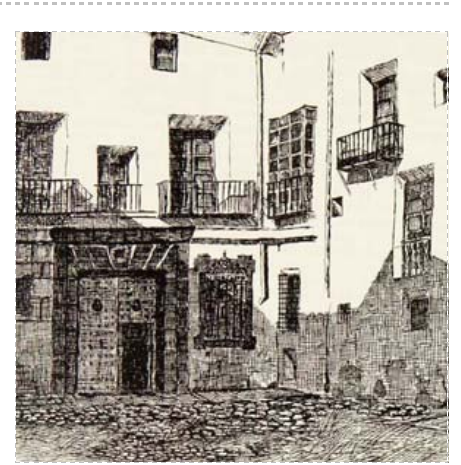

\section{- Referencias en documentación histórica}

Referencias numéricas en cartografía sobre fortificación

-Ref. en el croquis de Ortiz de Pinedo (1837-38, AGM, núm. 262): Sin ref.

-Ref. en plano de Vera Aparici (1993): Sin ref.

Referencias en memorias técnicas militares

-Ref. Guillermo Sáez (9/9/1834-5/12/1835): Sin ref.

-Ref. Guillermo Sáez (26/02/1836): Sin ref.

-Ref. P. Ortiz de Pinedo (12/03/1837-30/05/1837): Sin ref.

-Ref Jose María de Orozco (25/03/1838): Sin ref.

-Ref. Carbonell (4/7/1838): Sin re.

\section{- Observaciones a partir de los informes militares}

A los pies de la Iglesia del Salvador. Cumplió la misión de centro de concentración y conexión de comunicaciones

\begin{tabular}{|lll}
$\square \frac{\text { Rellenar en caso de que el elemento sea }}{\text { contemplado con datos del PGOU, 2013 }}$ & PROTECCIÓN & AFECCIÓN PATRIMONIAL \\
& Nivel de protección: & $\square$ Bien de interés cultural (BIC) \\
& Entorno: & $\square$ Bien de relevancia local (BRL) \\
& $\square$ Inmueble & $\square$ Afectado entorno BIC \\
& $\square$ Parcela catastral & $\square$ Afectado Plan especial \\
& $\square$ Recinto arquitectónico & \\
\hline Entorno específico &
\end{tabular}




\section{- Descripción histórico-arquitectónica}

Tipologia:

Cronología:

Observaciones a la cronologí

\section{Descripción:}

\section{- Entorno urbano}

Descripción entorno urbano:

Uso actual:

Estado de conservación:

Intervenciones:

Régimen Urbanístico:

Titularidad:

Nivel protección s/catálogo 1996:

Bibliografía: AMR, 1818-17, 1818-24; 1818-50; 1818-52; 1818-53.

Observaciones generales:

\begin{tabular}{|c|c|c|}
\hline OBJETIVACIÓN DE INTERÉS & Soluciones constructivas & Soluciones ornamentales \\
\hline Interés tipológico & $\square$ Estructura & $\square$ Carpintería \\
\hline Valor ambiental & $\square$ Aleros & $\square$ Rejería \\
\hline Vigencia de la trama & Coronación & $\square$ Cubrepersianas \\
\hline Composición de la fachada & $\square$ Jambas & $\square$ Alicatados \\
\hline Materiales, color, textura & $\square$ Dinteles & $\square$ Recercos \\
\hline & & $\square$ Dinteles \\
\hline & & $\square$ otros ornamentos \\
\hline
\end{tabular}

\section{- Datos específicos catalogación BIC $\square$ Rellenar sólo si está catalogado BIC}

\section{Datos Jurídicos:}

Código:
Estado:

Estado:
Categoria:

Anotación $M$

Fecha Disposición:

Tipo delimitación:

Plan:

Informe:

Fecha informe:

Fecha Publicación BOP:

Fecha Publicación DocV.

Fecha Publicación BOE:

\section{Iglesia del Salvador}

\section{- Identificación}

Tramo de estudio

Intramuros

Otras denominaciones:

Ref. catastral:

Localización: Plaza del Salvador.
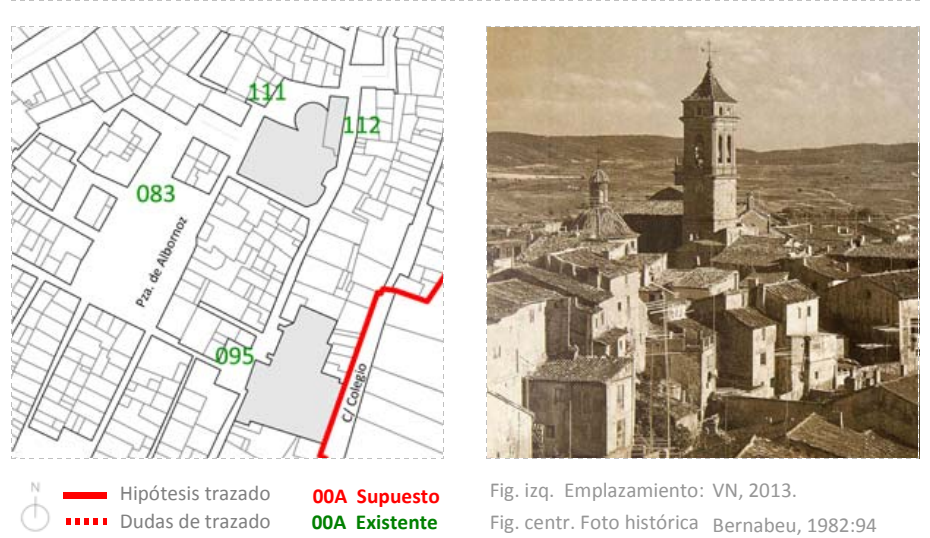

$\square$ organización

$\square$ Interés cultural

$\square$ Carácter representativo

nto: VN, 2013.

Fig. centr. Foto histórica Bernabeu, 1982:94
Eig. dcha. Foto actualiVN 2015

$\checkmark$ Existe actualmente

Incluido en fichas PGOU 2013

$\square$ Bien de interés cultural (BIC)

cód. postal: 46340

Municipio: Requena

Comarca: Plana de Requena-Utiel

Provincia: Valencia

Autonomia: Comunidad Valenciana

\section{- Referencias en documentación histórica}

Referencias numéricas en cartografía sobre fortificación

-Ref. en el croquis de Ortiz de Pinedo (1837-38, AGM, núm. 262): Sin ref.

-Ref. en plano de Vera Aparici (1993): Sin ref.

Referencias en memorias técnicas militares

-Ref. Guillermo Sáez (9/9/1834-5/12/1835): Sin ref.

-Ref. Guillermo Sáez (26/02/1836): Sin ref.

-Ref. P. Ortiz de Pinedo (12/03/1837-30/05/1837): Sin ref.

-Ref Jose Maria de Orozco (25/03/1838): Sin ref.

-Ref. Carbonell (4/7/1838): Sin ref.

- Observaciones a partir de los informes militares

Su campanario hizo la función de torre de señales y punto de recepción de comunicaciones

\begin{tabular}{|lll}
$\square \frac{\text { Rellenar en caso de que el elemento sea }}{\text { contemplado con datos del PGOU, 2013 }}$ & PROTECCIÓN & AFECCIÓN PATRIMONIAL \\
& $\begin{array}{l}\text { Nivel de protección: } \\
\text { Entorno: }\end{array}$ & $\square$ Bien de interés cultural (BIC) \\
& $\square$ Inmueble & $\square$ Afe relevancia local (BRL) \\
& $\square$ Parcela catastral & $\square$ Afectado entorno BIC especial \\
& $\square$ Recinto arquitectónico & \\
& $\square$ Entorno específico &
\end{tabular}

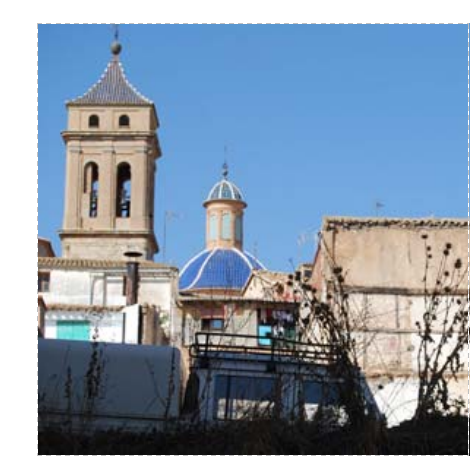

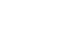




\section{- Descripción histórico-arquitectónica}

Tipología:

Cronología:

aciones a la cronologí

\section{Descripción:}

\section{- Entorno urbano}

Descripción entorno urbano:

Uso actual:

Estado de conservación:
Intervenciones:

\section{Régimen Urbanístico:}

Titularidad:

Nivel protección s/catálogo 1996:

Bibliografía: AMR, 1818-17, 1818-24; 1818-50; 1818-52; 1818-53.

Observaciones generales:

$\begin{array}{llll}\text { OBJETIVACIÓN DE INTERÉS } & \text { Soluciones constructivas } & \text { Soluciones ornamentales } & \text { Interés paisajistico } \\ \square \text { Interés tipológico } & \square \text { Estructura } & \square \text { Carpintería } & \square \text { Incidencia visual } \\ \square \text { valor ambiental } & \square \text { Aleros } & \square \text { Rejería } & \square \text { Carácter articulador } \\ \square \text { vigencia de latrama } & \square \text { Coronación } & \square \text { Cubrepersianas } & \square \text { Organización } \\ \square \text { Composición de la fachada } & \square \text { Jambas } & \square \text { Alicatados } & \square \text { Interés cultural } \\ \square \text { Materiales, color, textura } & \square \text { Dinteles } & \square \text { Recercos } & \square \text { Carácter representativo } \\ & & \square \text { Dinteles } & \\ & \square \text { Otros ornamentos } & \end{array}$

- Datos específicos catalogación BIC $\square$ Rellenar sólo si está catalogado BIC

$\begin{array}{lll}\text { Datos Jurídicos: } & & \\ \text { Código: } & \text { Fecha Disposición: } & \text { Fecha informe: } \\ \text { Estado: } & \text { Tipo delimitación: } & \text { Fecha Publicación BOP: } \\ \text { Categoría: } & \text { Plan: } & \text { Fecha Publicación DOCV: } \\ \text { Anotación M: } & \text { Informe: } & \text { Fecha Publicación BOE: }\end{array}$

Plan:

Informe Fecha Publicación BOE:
113 Barrio del Arrabal

\section{- Identificación}

Tramo de estudio:

Intramuros

Otras denominaciones: Arrabal, Núcleo histórico tradicional El Arrabal

Ref. catastral

Sin ref. cat.

Localización: Barrio del Arrabal. Entre la Villa y las Peñas

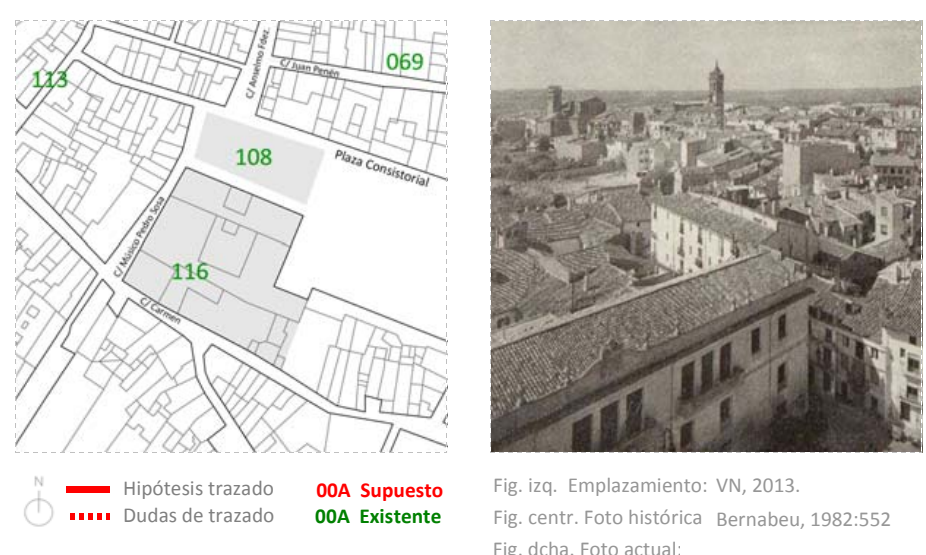

\section{- Referencias en documentación histórica}

Referencias numéricas en cartografía sobre fortificación

-Ref. en el croquis de Ortiz de Pinedo (1837-38, AGM, núm. 262): Sin ref.

-Ref. en plano de Vera Aparici (1993): Sin ref.

Referencias en memorias técnicas militares

-Ref. Guillermo Sáez (9/9/1834-5/12/1835): Sin ref.

-Ref. Guillermo Sáez (26/02/1836): Sin ref.

-Ref. P. Ortiz de Pinedo (12/03/1837-30/05/1837): Sin ref.

-Ref Jose Maria de Orozco (25/03/1838): Sin ref.

-Ref. Carbonell (4/7/1838): Sin ref.

\section{- Observaciones a partir de los informes militares}

El barrio del Arrabal es el barrio histórico que crece entre el Barrio de la Villa y la Peñas. Ver descripción según PGOU.

$\begin{array}{lll}\square \text { Rellenar en caso de gue el elemento sea } & \text { PROTECCIÓN } & \text { AFECCIÓN PATRIMONIAL } \\ \text { contemplado con datos del PGOU, 2013 } & \text { Nivel de protección: Integral } & \square \text { Bien de interés cultural (BIC) } \\ & \text { Entorno: } & \square \text { Bien de relevancia local (BRL) } \\ & \square \text { Núcleo Histórico Tradicional (NH } \\ & \square \text { Parcele catastral } & \square \text { Afectado entorno BIC } \\ & \square \text { Recinto arquitectónico } & \square \text { Afectado Plan especial } \\ & \square \text { Entorno específico } & \end{array}$

$\checkmark$ Existe actualmente

$\square$ Bien de interés cultural (BIC)

cód. postal: 46340

Comarca: Plana de Requena-Utie

Provincia: Valencia

Autonomía: Comunidad Valencian $\checkmark$ Incluido en fichas PGOU 2013 
- Descripción histórico-arquitectónica

\section{Tipología: Núcleo histórico}

Cronología: ss. XVI-XVIII

Observaciones a la cronología:

Descripción: "Ubicado entre la Villa y las Peñas, sirvió de ensanche comercial de la primera, desarrollándose entre los siglos XVI al XVIII. Su delimitación original, apoyándonos en el plano del XIX de C. Pino sería la conformada por tres ejes viarios de relevanci carretera de Albacete a Requen . El límite sur se completaría con el antiguo Convento de Carmen y sus huertos, que es actual Ayuntamiento y el jardín de la glorieta. Al este, el límite lo daría el desnivel con la zona del Batanejo. Sin embargo, dicha extensión ha sufrido una serie de modificaciones en el viario que hacen que la delimitación como Núcleo Histórico se circunscriba a la trama realmente conservada y que mantiene, de alguna manera, los valores patrimoniales iniciales. Las características del barrio son una trama rectilínea pero angosta, y una implantación generalizada de tipologías

\section{- Entorno urbano}

\section{Descripción entorno urbano:}

"Se localiza, de manera amplia, dentro del barrio del Arrabal, ubicado en el centro del casco urbano, a caballo entre el barrio de la Villa (a sur) y el de las Peñas (al norte).

Uso actual: Residencial y comercia

Estado de conservación: Buen

Intervenciones:

Régimen Urbanístico: S.U.

Titularidad:

Nivel protección s/catálogo 1996:

Bibliografía: AMR, 1818-17, 1818-24; 1818-50; 1818-52; 1818-53.

Observaciones generales:

"A todos los inmuebles con valores tradicionales, los cuales son responsables del reconocimiento concedido al ámbito urbano como NHTBRL, se les otorga el nivel de protection ambiental. Los mencionados valores tracicionales para este ámbito, se encuentran descritos en apartado 5.1 de la memoria del Catálogo. Como determinación general, se mantendrá la parcelación historica. Los usos admitidos seŕ̉ pudiendo admitirse el número de plantas que garantice la armonía con la escala tradicional del NHT-BRL, yen concreto con sus inmuebles protegidos. Además, las actuaciones que afecten al espacio público, para poder autorizarse, deberán justificarse sobre la base de estudios documentales de carácter histórico-artístico, urbano y arquitectónico, garantizando el respeto por los valores tradicionales del ámbito. Las intervenciones en el entorno de protección del bien se atendrán a lo dispuesto en el art. 25.3 de las normas del presente Catálogo" (PGOU, 2013: E.CAS.BRL.02).

\begin{tabular}{|c|c|c|c|}
\hline OBJETIVACIÓN DE INTERÉS & Soluciones constructivas & Soluciones ornamentales & Interés paisajístico \\
\hline 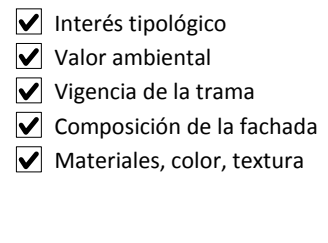 & $\begin{array}{l}\square \text { Estructura } \\
\square \text { Aleros } \\
\square \text { Coronación } \\
\square \text { Jambas } \\
\square \text { Dinteles }\end{array}$ & $\begin{array}{l}\square \text { Carpintería } \\
\square \text { Rejería } \\
\square \text { Cubrepersianas } \\
\square \text { Alicatados } \\
\square \text { Recercos } \\
\square \text { Dinteles } \\
\square \text { Otros ornamentos }\end{array}$ & $\begin{array}{l}\nabla \nabla \text { Incidencia visual } \\
\boldsymbol{\nabla} \text { Carácter articulador } \\
\square \text { Organización } \\
\nabla \boldsymbol{V} \text { Interés cultural } \\
\square \text { Carácter representativo }\end{array}$ \\
\hline
\end{tabular}

- Datos específicos catalogación BIC $\square$ Rellenar sólo si está catalogado BIC

Datos Jurídicos:

$\begin{array}{lll}\text { Código: } & \text { Fecha Disposición: } & \text { Fecha informe: } \\ \text { Estado: } & \text { Tipo delimitación: } & \text { Fecha Publicación BOP: } \\ \text { Categoria: } & \text { Plan: } & \text { Fecha Publicación DOCV: } \\ \text { Anotación Mo: } & \text { Informe: } & \text { Fecha Publicación BOE: }\end{array}$

\section{Barrio de las Peñas}

\section{- Identificación}

Tramo de estudio:

Ref. catastral: Barrio de La Peñas. Se extiende en los alrededores de la Iglesia de San

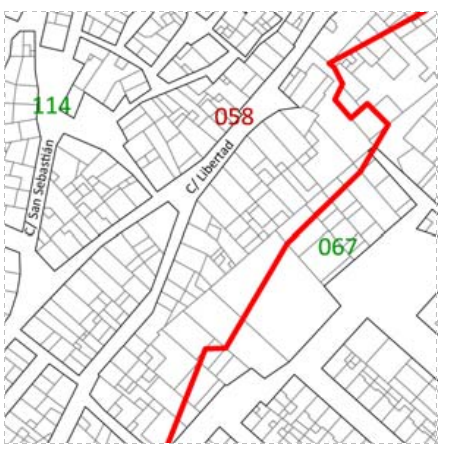

$\begin{array}{cc}\text {-.... Hipótesis trazado } & \text { DoA Supuesto } \\ \text { O0A Existente }\end{array}$

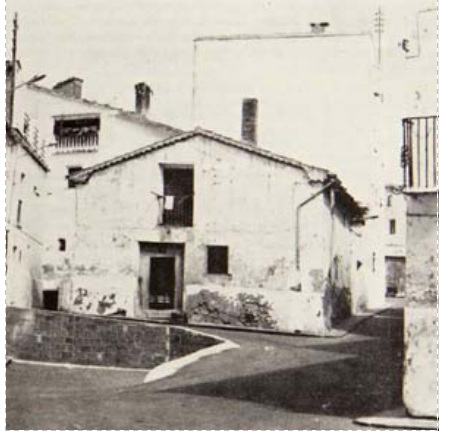

Fig. izq. Emplazamiento: VN, 2013.

Fig. centr. Foto histórica Bernabeu, 1982:427 $\checkmark$ Existe actualmente

$\checkmark$ Incluido en fichas PGOU 2013

$\square$ Bien de interés cultural (BIC)

cód. postal: 46340

Municipio: Requena

comarca: Plana de Requena-Utiel

Provincia: Valencia

\section{- Referencias en documentación histórica}

\section{Referencias numéricas en cartografía sobre fortificación}

-Ref. en el croquis de Ortiz de Pinedo (1837-38, AGM, núm. 262): Sin ref.

-Ref. en plano de Vera Aparici (1993): Sin ref.

Referencias en memorias técnicas militares

-Ref. Guillermo Sáez (9/9/1834-5/12/1835): Sin ref.

-Ref. Guillermo Sáez (26/02/1836): Sin ref.

-Ref. P. Ortiz de Pinedo (12/03/1837-30/05/1837): Sin ref.

-Ref Jose María de Orozco (25/03/1838): Sin ref.

-Ref. Carbonell (4/7/1838): Sin ref.

\section{- Observaciones a partir de los informes militares}

Ver descripción sintética según PGOU

$\begin{array}{ll}\nabla \begin{array}{ll}\text { Rellenar en caso de que el elemento sea } \\ \text { contemplado con datos del PGOU, 2013 }\end{array} & \text { PROTECCIÓN } \\ & \text { Nivel de protección: } \\ & \text { Entorno: } \\ & \square \text { Inmueble } \\ \square & \text { Parcela catastral } \\ \square & \text { Recinto arquitectónico } \\ \square & \text { Entorno específico }\end{array}$

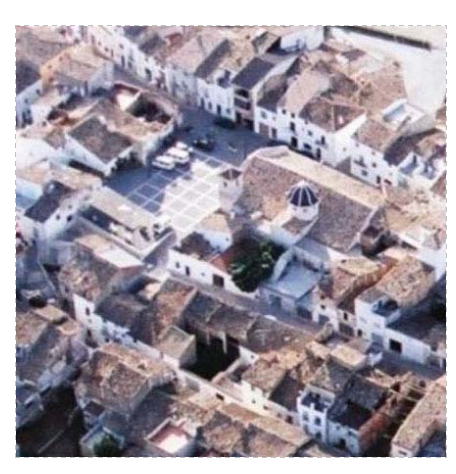

AFECCIÓN PATRIMONIAL

$\triangle$ Afectado entorno BIC 
- Descripción histórico-arquitectónica

\section{Tipología: Núcleo histórico}

Cronología: s. XIII-XIV

Observaciones a la cronología:

Descripción: "Localizado en una colina al norte del núcleo de la población, su origen es el de la capitulación de Requena ante las armas 列

comprende la trama original, la no 'rectificada'. De acuerdo con el plano decimonónico de C. Pino, que recoge la estructura de la población antes de su desarrollo hacia el oeste, se aprecia como el límite este lo conforma la antigua carretera de
Requena a Chera -que continuaba el trazado de la de Albacete a Requena. En el extremo sur del barrio, dicha carretera tiene un encuentro en ángulo agudo con la actual calle bodegas, conformando el limite oeste la prolongación de dicha calle y los campos colindantes -'el cerrillo'- con un desnivel apreciable con respecto a la parte edificada. Al norte el barrio histórico se cierra con ta actual

\section{- Entorno urbano}

\section{Descripción entorno urbano:}

"Se localiza, de manera amplia, dentro del barrio de las Peñas, situado al norte del casco urbano, colindante al sur con el barrio del Arrabal. El entorno urbano está dedicado, en su práctica totalidad, al uso residencial con tipologías tradicionales" (PGOU,

2013:E.CAS.BRL.01).

Uso actual: Residencial

Estado de conservación: Bueno

Intervenciones:

Régimen Urbanistico: S.U.

Titularidad:

Nivel protección s/catálogo 1996:

Bibliografía: AMR, 1818-17, 1818-24; 1818-50; 1818-52; 1818-53.

Observaciones generales:

"A todos los inmuebles con valores tradicionales, los cuales son responsables del reconocimiento concedido al ámbito urbano como NHTBRL, se les otorga el nivel de protección ambiental. Los mencionados valores tradicionales para este ámbito, se encuentran descritos en el apartado 5.1 de la memoria del Catalogo. Como determinación general, se

mantendrá la parcelación histórica. Los usos admitidos serán compatibles con los valores tradicionales. Y el número de plantas permitido por el Plan General se entenderá como el máximo, sólo pudiendo admitise el número de plantas que garantice la armonía con la escala tradicional del NHT-BRL, y en concreto con sus inmuebles protegidos. Además, las

Tarse sobre la base de estudios documentales de en el entorno de protección del bien se atendrán a lo dispuesto en el art. 25.3 de las

normas del presente Catálogo" (PGOU, 2013:E.CAS.BRL.01).

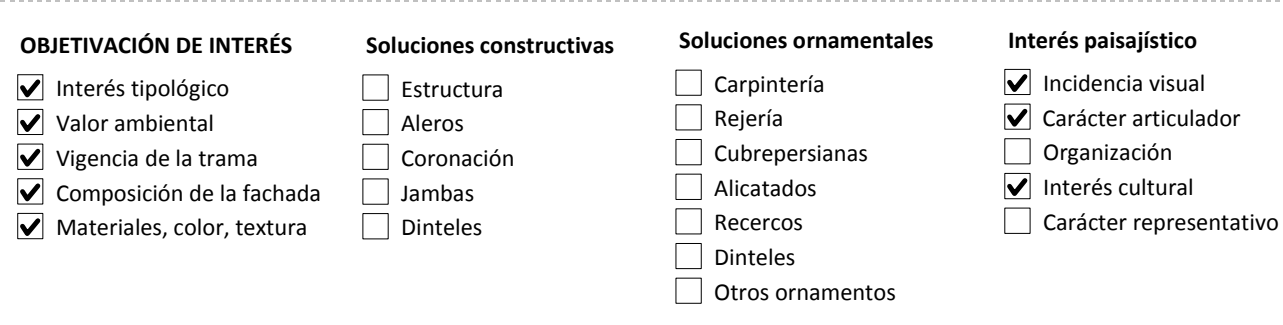

- Datos específicos catalogación BIC $\square$ Rellenar sólo si está catalogado BIC

Datos Jurídicos:

$\begin{array}{lll}\text { Código: } & \text { Fecha Disposición: } & \text { Fecha informe: } \\ \text { Estado: } & \text { Tipo delimitación: } & \text { Fecha Publicación BOP: } \\ \text { Categoría: } & \text { Plan: } & \text { Fecha Publicación DOCV: } \\ \text { Anotación Mo: } & \text { Informe: } & \text { Fecha Publicación BOE: }\end{array}$

\section{Iglesia de San Nicolás. Barrio de San Nicolás}

\section{- Identificación}

Tramo de estudio:

Otras denominaciones:

Intramuros

Ref. catastral:

Localización: Plaza de San Nicolás.

$\checkmark$ Existe actualmente

$\square$ Incluido en fichas PGOU 2013

$\square$ Bien de interés cultural (BIC)

Cód. postal: 46340

Municipio: Requena

Comarca: Plana de Requena-Utie

Provincia: Valencia

Autonomia: Comunidad Valenciarn

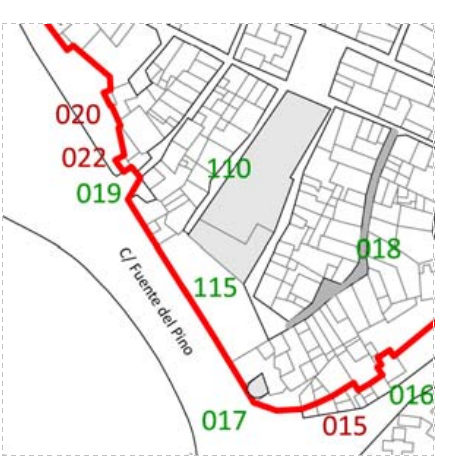

-.... Hipótesis trazado

OOA Supuesto

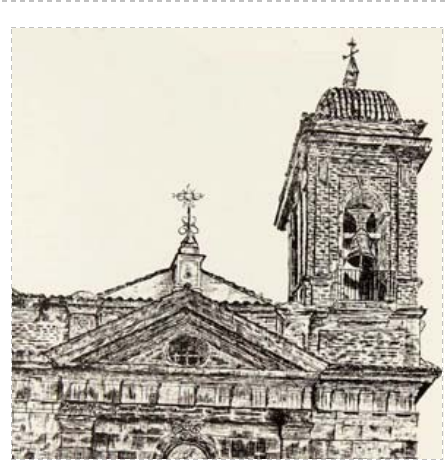

Fig. izq. Emplazamiento: VN, 2013

Fig. centr. Foto histórica Bernabeu, $1982: 528$

\section{- Referencias en documentación histórica}

Referencias numéricas en cartografía sobre fortificación

-Ref. en el croquis de Ortiz de Pinedo (1837-38, AGM, núm. 262): Sin ref.

-Ref. en plano de Vera Aparici (1993): Sin ref.

Referencias en memorias técnicas militares

-Ref. Guillermo Sáez (9/9/1834-5/12/1835): Sin ref.

-Ref. Guillermo Sáez (26/02/1836): Sin ref.

-Ref. P. Ortiz de Pinedo (12/03/1837-30/05/1837): Sin ref.

-Ref Jose Maria de Orozco (25/03/1838): Sin ref.

-Ref. Carbonell (4/7/1838): Sin ref.

\section{- Observaciones a partir de los informes militares}

El barrio de San Nicolás crece a los alrededores de la Iglesia del mismo nombre, recientemente restaurada. Nace de un arrabal musulmán que contaba con sus propias murallas que lo sepraban de la Medina. El arco del ovejero es uno de los resquicios que quedan de los pasos Horadado por cuevas en su base, muchas de ellas han sido cegadas para contener el desmoronamiento y mantener la integridad de las casas que conforman el recinto amurallado. $\square \frac{\text { Rellenar en caso de que el elemento sea }}{\text { contemplado con datos del PGOU, 2013 }}$

\section{PROTECCIÓN}

Nivel de protección:

Entorno:

$\square$ Inmueble

$\square$ Parcela catastral

Recinto arquitectón

\section{AEECCIÓN PATRIMONIAL}

$\square$ Bien de interés cultural (BIC)

$\square$ Bien de relevancia local (BRL)

$\square$ Afectado entorno BIC

$\square$ Afectado Plan especial 


\section{- Descripción histórico-arquitectónica}

Tipología:

Cronología:

Observaciones a la cronología

Descripción:

\section{- Entorno urbano}

Descripción entorno urbano:

Uso actual:

Estado de conservación:

Intervenciones:

Titularidad:

Nivel protección s/catálogo 1996:

Bibliografía: AMR, 1818-17, 1818-24; 1818-50; 1818-52; 1818-53.

Observaciones generales:

$\begin{array}{lll}\text { OBJETIVACIÓN DE INTERÉS } & \text { Soluciones constructivas } & \text { Soluciones ornamentales } \\ \square \text { Interés tipológico } & \square \text { Estructura } & \square \text { Carpintería } \\ \square \text { Valor ambiental } & \square \text { Aleros } & \square \text { Rejería } \\ \square \text { Vigencia de la trama } & \square \text { Coronación } & \square \text { cubrepersianas } \\ \square \text { Composición de la fachada } & \square \text { Jambas } & \square \text { Alicatados } \\ \square \text { Materiales, color, textura } & \square \text { Dinteles } & \square \text { Recercos } \\ & & \square \text { Dinteles } \\ & \square \text { Otros ornamentos }\end{array}$

- Datos específicos catalogación BIC $\square$ Rellenar sólo si está catalogado BIC

$\begin{array}{lll}\text { Datos Juridicos: } & & \\ \text { Código: } & \text { Fecha Disposición: } & \text { Fecha informe: } \\ \text { Estado: } & \text { Tipo delimitación: } & \text { Fecha Publicación BOP: } \\ \text { Categoría: } & \text { Plan: } & \text { Fecha Publicación DOCV: } \\ \text { Anotación } M \text { Mo: } & \text { Informe: } & \text { Fecha Publicación BOE: }\end{array}$

\section{Convento de Carmelitas Observantes (Museo Municipal)}

\section{- Identificación}

Tramo de estudio:

Intramuros

Otras denominaciones: Convento o Monasterio de Santa María del Carmen

$\checkmark$ Existe actualmente

$\checkmark$ Incluido en fichas PGOU 2013

$\square$ Bien de interés cultural (BIC)

cód. postal: 46340

Ref. catastral:

37271-01

Localización: C/Mariano Cuber, noำ

Comarca: Plana de Requena-Utiel

Provincia: Valencia

Autonomía: Comunidad Valenciarn
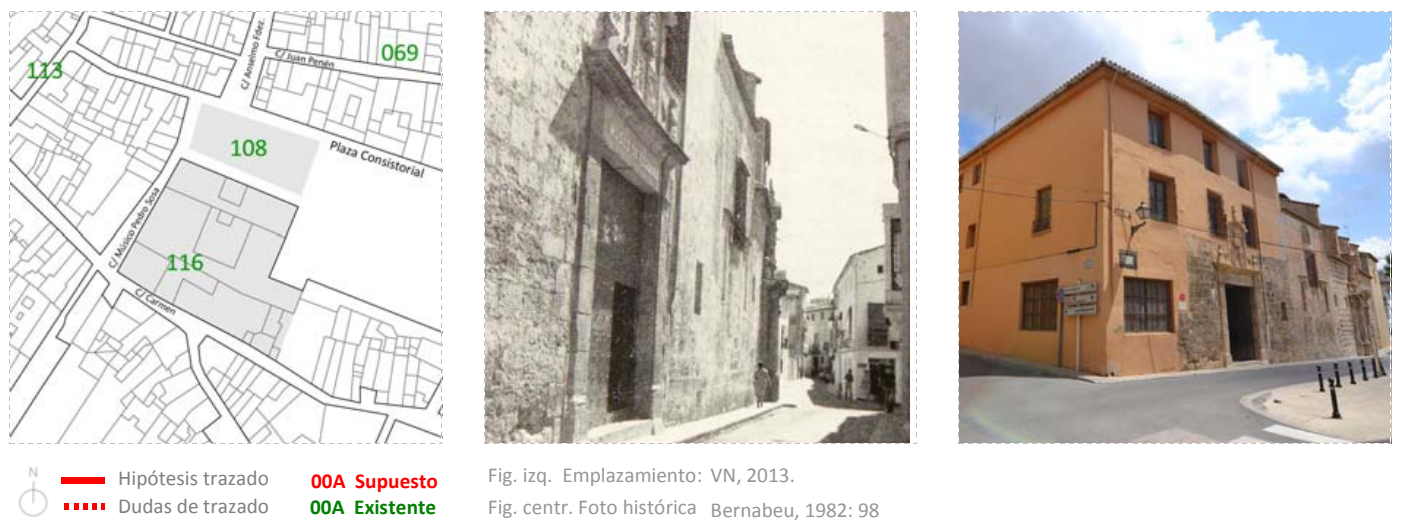

- Referencias en documentación histórica

Referencias numéricas en cartografía sobre fortificación

-Ref. en el croquis de Ortiz de Pinedo (1837-38, AGM, núm. 262): Sin ref.

-Ref. en plano de Vera Aparici (1993): Sin ref.

Referencias en memorias técnicas militares

-Ref. Guillermo Sáez (9/9/1834-5/12/1835): Sin ref.

-Ref. Guillermo Sáez (26/02/1836): Sin ref.

-Ref. P. Ortiz de Pinedo (12/03/1837-30/05/1837): Sin ref.

-Ref Jose Maria de Orozco (25/03/1838): Sin ref.

-Ref. Carbonell (4/7/1838): Sin ref.

\section{- Observaciones a partir de los informes militares}

Convento desaparecido en 1851, tras la Desamortización. En su Sala de Novicios se construyó el actual ayuntamiento. Rehabilitado en .

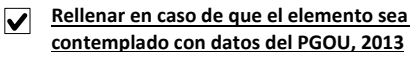

\section{PROTECCIÓN}

Nivel de protección: C.CAS.CAT.01.01-A

Entorno:

$\checkmark$ Inmueble

$\square$ Parcela catastral

$\square$ Entorno específico
AFECCIÓN PATRIMONIAL

$\square$ Bien de interés cultural (BIC)

Bien de relevancia local (BRL)

$\square$ Afectado entorno BIC

$\square$ Afectado Plan especial 
- Descripción histórico-arquitectónica

Tipología: Arquitectura civil

Cronología: S. XIV

Observaciones a la cronologí

Descripción: "Edificio ubicado dentro del conjunto que fue el Convento del Carmen y junto a la iglesia del mismo nombre. El pórtico neoclásico de la entrada está blasonado con los escudos de Castilla y Aragón. Edificio de planta cuadraba, El pórtico sillería, enfoscado y pintado, cubierto por teja árabe a dos aguas. El claustro, secularizado en el S. XIX, fue Instituto de Segunda Enseñanza, y hoy dependencia municipal, de paso a los museos arqueológico y del vino. En sus bóvedas (ángulos) aparecen escudos del Carmen; con pilares de piedra y una portada que da acceso indirecto al claustro, con frontón con dos escudos; el carmelitano y otro, y en medio de ellos, la leyenda 'Celo celatus sum pro Domino deo' (Elías) y 'Anno Domini 1603 ' y el nombre de 'Miguel Pérez, Vicario. Una vez dentro del museo, podemos ver exhibido en sus salas abundante

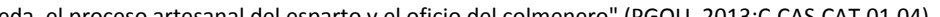

\section{- Entorno urban}

\section{Descripción entorno urbano:}

"El museo forma parte de la edificación que conformaba el Claustro del Carmen, ubicado sobre el antiguo Camino Real. Su entorno corresponde a los primeros desarrollos urbanos extramuros del núcleo urbano, casi todos de la época medieval. La edificación es un punto Uso actual: Museo

Uso actual: Museo
Estado de conservación: Bueno

Intervenciones: Consolidación, conservación y restauración

Régimen Urbanistico: S. U.

Titularidad: Pública

Nivel protección s/catálogo 1996: 3/4 fachada-ambiental

Bibliografía: AMR, 1818-17, 1818-24; 1818-50; 1818-52; 1818-53.

observaciones generales:

Forma parte del conjunto C.CAS.BIC.01.

\begin{tabular}{|c|c|c|c|}
\hline OBJETIVACIÓN DE INTERÉS & Soluciones constructivas & Soluciones ornamentales & Interés paisajístico \\
\hline$\nabla$ Interés & $\square$ Estructura & $\square$ Carpintería & $\checkmark$ Incidencia visual \\
\hline$\checkmark$ Valor ambiental & Aleros & $\square$ Rejería & $\bar{\nabla}$ Carácter articulador \\
\hline$\square$ Vigencia de la trama & $\square$ Coronación & $\square$ Cubrepersianas & $\bar{\nabla}$ Organización \\
\hline ( Composición de la fachada & Jambas & Alicatados & $\nabla$ Interés cultural \\
\hline$\checkmark$ Materiales, color, textura & $\square$ Dinteles & $\begin{array}{l}\square \text { Recercos } \\
\square \text { Dinteles } \\
\square \text { Otros ornamentos }\end{array}$ & $\bar{\nabla}$ Carácter representativo \\
\hline
\end{tabular}

\section{- Datos específicos catalogación BIC $\square$ Rellenar sólo si está catalogado BIC}

Datos Jurídicos:

Código:

Estado:

Fecha Disposición:

Tipo delimitación:

Anotación Mo:

Fecha informe

Fecha Publicación BOP:

Fecha Publicación DOCV

Fecha Publicación BOE:

116 Convento de Carmelitas Observantes (Ayuntamiento)

\section{- Identificación}

Tramo de estudio:

Intramuros

Otras denominaciones: Convento o Monasterio de Santa María del Carmen

Ref. catastral:

37271-01

Localización: Plaza Consistorial, № 2
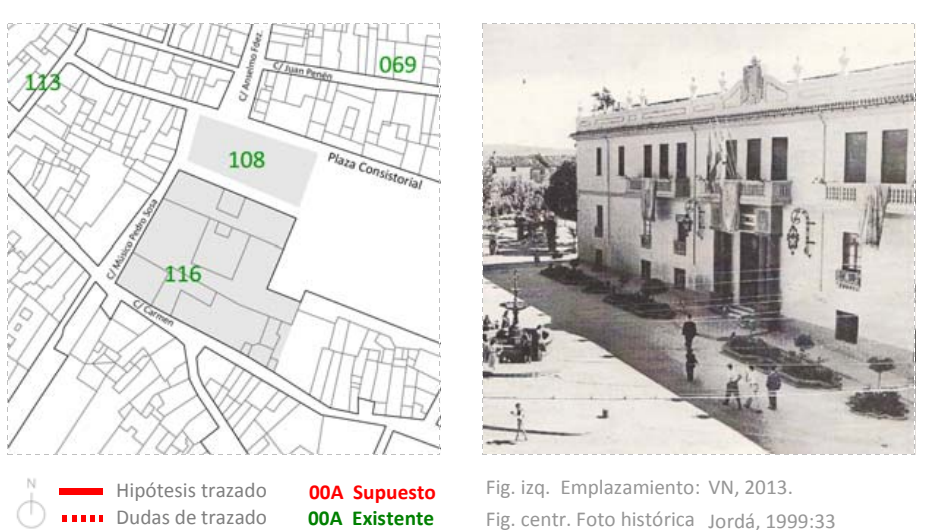

Fig. izq. Emplazamiento: VN, 2013

Fig. centr. Foto histórica Jordá, 1999:33 $\checkmark$ Existe actualmente

Incluido en fichas PGOU 2013

$\square$ Bien de interés cultural (BIC)

cód. postal: 46340

Municipio: Requena

Comarca: Plana de Requena-Utie

Provincia: Valencia

Autonomia: Comunidad Valencian

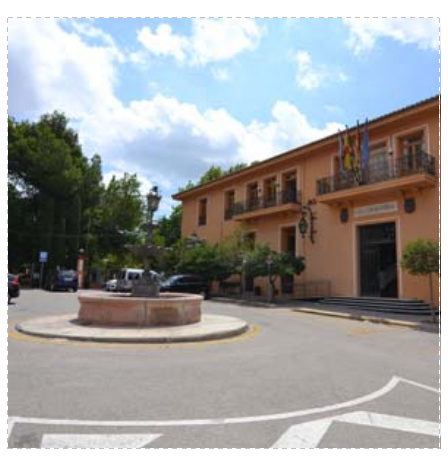

- Referencias en documentación histórica

Referencias numéricas en cartografía sobre fortificación

-Ref. en el croquis de Ortiz de Pinedo (1837-38, AGM, núm. 262): Sin ref.

-Ref. en plano de Vera Aparici (1993): Sin ref.

Referencias en memorias técnicas militares

-Ref. Guillermo Sáez (9/9/1834-5/12/1835): Sin ref.

-Ref. Guillermo Sáez (26/02/1836): Sin ref.

-Ref. P. Ortiz de Pinedo (12/03/1837-30/05/1837): Sin ref.

-Ref Jose Maria de Orozco (25/03/1838): Sin ref.

-Ref. Carbonell (4/7/1838): Sin ref.

\section{- Observaciones a partir de los informes militares}

Convento desaparecido en 1851, tras la Desamortización. En su Sala de Novicios se construyó el actual ayuntamiento. Rehabilitado en de Enseña Media. Su claustro se conserva cerrado con grandes ventanales de madera.

\section{Rellenar en caso de que el elemento sea
contemplado con datos del PGOU, 2013}

PROTECCIÓN

Entorno:

$\checkmark$ Inmueble

Parcela catastral

Recinto arquite

\section{AFECCIÓN PATRIMONIAL}

$\square$ Bien de interés cultural (BIC)

$\square$ Bien de relevancia local (BRL)

$\square$ Afectado entorno BIC

$\square$ Afectado Plan especial 


\section{Descripción histórico-arquitectónica}

\section{Tipología: Arquitectura civi}

Cronología: 1851

Observaciones a la cronología:

Descripción: Edificio de planta rectangular, dos alturas y entresuelo, cubierto por teja árabe a dos aguas, de estilo historicista. El edificio nuevo se construyó en 1851 sobre una parte del antiguo convento del Carmen; concretamente se instaló en lo que fue
sala de novicios' del extinguido convento, conservándose parte del claustro de éste, que comparte con el edificio que alberga el Museo Municipal, además de los muros de sillería originales y una antigua estancia del convento en la primera planta. Sobre esta primera planta se edificó una segunda que ya no conserva ningun elemento original del antiguo convento. La fachada principal conserva los escudos de la ciudad sobre el porton de entrada y cuenta con unos balcones que contribuyen a hacerla más vistosa. Se accede al ayuntamiento por una gran escalinata de mármol. Un siglo después, a reformarse la glorieta y la Casa Consistorial, el salón de actos se convirtio en un espléndido salón de recepciones, con un sometido a diversas reformas: una en 1950, y durante la década de los 90 estuvo cerrada unos años debido a las obras de restauracióm que se estaban efectuando y que finalizaron en 1995" (PGOU, 2013:C.CAS.CAT.01.01).

\section{- Entorno urbano}

Descripción entorno urbano:

"ledfrico se sitúa en pleno centro de la Plaza Consistorial, en la parte posterior de lo que fue el Convento del Carmen, alrededor del cual

Uso actual: Ayuntamiento

Estado de conservacion:

Intervenciones: $\mathrm{Si}$

Régimen Urbanistico: S.

The $3 / 4$ fachada-ambiental

Bibliografia: AMR, 1818-17, 1818-24; 1818-50; 1818-52; 1818-53.

Observaciones generales:

Forma parte del conjunto C.CAS.BIC.01

\begin{tabular}{|c|c|c|c|}
\hline OBJETIVACIÓN DE INTERÉS & Soluciones constructivas & Soluciones ornamentales & Interés paisajistico \\
\hline$\nabla$ Inter & $\square$ Estructura & $\checkmark$ Carpintería & $\checkmark$ Incidencia visual \\
\hline$\nabla$ Valor ambiental & Aleros & $\bar{\nabla}$ Rejería & $\square$ Carácter articulador \\
\hline V Vigencia de la trama & Coronación & Cubrepersianas & $\square$ Organización \\
\hline$\checkmark$ Composición de la fachada & $\bar{\nabla}$ Jambas & Alicatados & $\nabla$ Interés cultural \\
\hline$\checkmark$ Materiales, color, textura & $\nabla$ Dinteles & $\begin{array}{l}\square \text { Recercos } \\
\square \text { Dinteles } \\
\square \text { itros ornamentos }\end{array}$ & $\square$ Carácter representativo \\
\hline
\end{tabular}

- Datos específicos catalogación BIC $\square$ Rellenar sólo si está catalogado BIC

Datos Jurídicos:

$\begin{array}{lll}\text { Código: } & \text { Fecha Disposición: } & \text { Fecha informe: } \\ \text { Estado: } & \text { Tipo delimitación: } & \text { Fecha Publicación BOP: } \\ \text { Categoría: } & \text { Plan: } & \text { Fecha Publicación DOCV: } \\ \text { Anotación Mo: } & \text { Informe: } & \text { Fecha Publicación BOE: }\end{array}$

116 Convento de Carmelitas Observantes (Claustro de la casa consistorial)

\section{- Identificación}

Tramo de estudio:

Intramuros

Otras denominaciones: Convento o Monasterio de Santa María del Carmen

Ref. catastral:

37271-01, 37271-15

Localización: Plaza Consistorial, no2

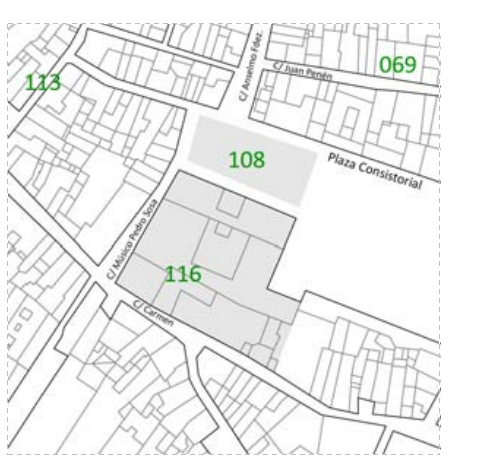

\section{.... Hipótesis trazado $\begin{gathered}\text { O0A Supuesto } \\ \text { O0A Existente }\end{gathered}$}

$\checkmark$ Existe actualmente

Incluido en fichas PGOU 2013

$\square$ Bien de interés cultural (BIC)

cód. postal: 46340

Municipio: Requena

Comarca: Plana de Requena-Utie

Provincia: Valencia

\section{- Referencias en documentación histórica}

Referencias numéricas en cartografía sobre fortificación

-Ref. en el croquis de Ortiz de Pinedo (1837-38, AGM, núm. 262): Sin ref.

-Ref. en plano de Vera Aparici (1993): Sin ref.

Referencias en memorias técnicas militares

-Ref. Guillermo Sáez (9/9/1834-5/12/1835): Sin ref.

-Ref. Guillermo Sáez (26/02/1836): Sin ref.

-Ref. P. Ortiz de Pinedo (12/03/1837-30/05/1837): Sin ref.

-Ref Jose María de Orozco (25/03/1838): Sin ref.

-Ref. Carbonell (4/7/1838): Sin ref.

\section{- Observaciones a partir de los informes militares}

Convento desaparecido en 1851, tras la Desamortización. En su Sala de Novicios se construyó el actual ayuntamiento. Rehabilitado en (nstituto de Enseñanza Media. Su claustro se conserva cerrado con grandes ventanales de madera.

$\checkmark \frac{\text { Rellenar en caso de que el elemento sea }}{\text { contemplado con datos del PGOU, 2013 }}$
PROTECCION

Nivel de protección: C.CAS.BRL.01.01-IN Entorno:

$\square$ Inmueble

$\square$ Parcela catastral

$\checkmark$ Entorno específico
AFECCIÓN PATRIMONIAL

$\square$ Bien de interés cultural (BIC)

Bien de relevancia local (BRL)

Monumento

$\square$ Afectado entorno BIC

$\square$ Afectado Plan especial 


\section{- Descripción histórico-arquitectónica}

Tipología: Equipamientos colectivos. Obras públicas

Cronología: s. XIII-XVII

Observaciones a la cronología:

Descripción: "Está construido con piedra caliza del terreno. Forma parte del antiguo Convento de los Carmelitas, fundado en el siglo XIII, siendo el más antiguo de Castilla. Actualmente este convento está formado por tres edificios bien diferenciados: la acristalados y pilares en piedra caliza, que fue descubierta posteriormente. Se conserva la decoración barroca de los arcos y ángulos, donde destacan los escudos pintados del Carmen. El edificio consta de dos plantas, claramente diferenciadas; Ia inferior, en piedra, conformado por una arcada regular rematada con arcos de medio punto. Y la superior con vanos profundos, rematados con arcos escarzanos, conformando pequeños balconcillos enrasados, con barandillas de forja. Las pilastras de la primera planta se continuan en la segunda, mediante otras más simples que resaltan levemente de la

\section{- Entorno urbano}

\section{Descripción entorno urbano:}

"Junto a la Iglesia del Carmen, forma parte del Convento carmelitano más antiguo de Castilla. El edificio se encuentra

dentro del barrio del Arrabal, dentro del casco urbano de la ciudad" (PGOU, 2013: C.CAS.BRL.01.02).

Uso actual: Museo

Estado de conservación: Bueno

Intervenciones: Consolidación, conservación y restauración.

Régimen Urbanístico: S. U.

Titularidad: Pública

Nivel protección s/catálogo 1996: 2/3/4 tipológico-fachada-ambiental

Bibliografía: AMR, 1818-17, 1818-24; 1818-50; 1818-52; 1818-53.

Observaciones generales:

"Las intervenciones en el entorno de protección del bien se atendrán a lo dispuesto en el art. 25.3 de las normas del presente Catálogo. Forma parte del conjunto C.CAS.BIC.01"

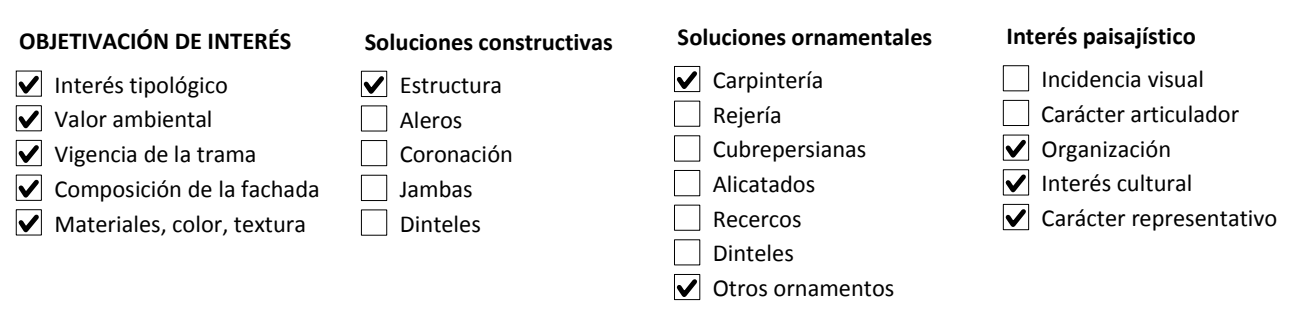

\section{- Datos específicos catalogación BIC $\square$ Rellenar sólo si está catalogado BIC}

Datos Jurídicos:

$\begin{array}{lll}\text { Datos Juridicos: } & \text { Fecha Disposición: } & \text { Fecha informe: } \\ \text { Código: } & \text { Tipo delimitación: } & \text { Fecha Publicación BOP: } \\ \text { Estado: } & \text { Plan: } & \text { Fecha Publicación DOCV: } \\ \text { Categoría: } & \text { Informe: } & \text { Fecha Publicación BOE: } \\ \text { Anotación Mo: } & & \end{array}$

\section{Convento de Carmelitas Observantes (Iglesia del Convento del Carmen)}

\section{- Identificación}

Tramo de estudio

Intramuros

Otras denominaciones: Convento o Monasterio de Santa María del Carmen

$\checkmark$ Existe actualmente

$\checkmark$ Incluido en fichas PGOU 2013

$\square$ Bien de interés cultural (BIC)

cód. postal: 46340

Municipio: Requena

Ref. catastral: $\quad 37271-15$

Localización: C/Mariano Cuber, C/ del Carmen

Provici. Vlana de Requena-Utie

Povincia: Valencia

Autonomía: Comunidad Valencian

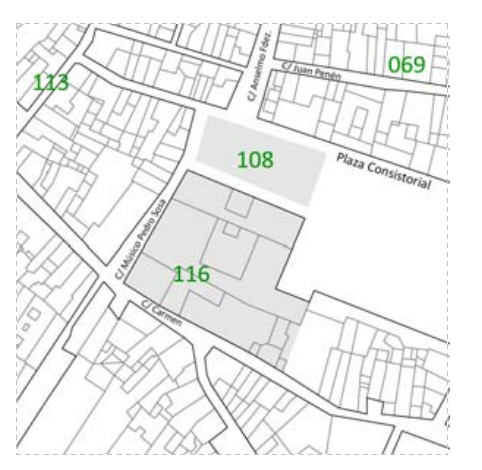

-... Hipótesis trazado

OOA Supuesto
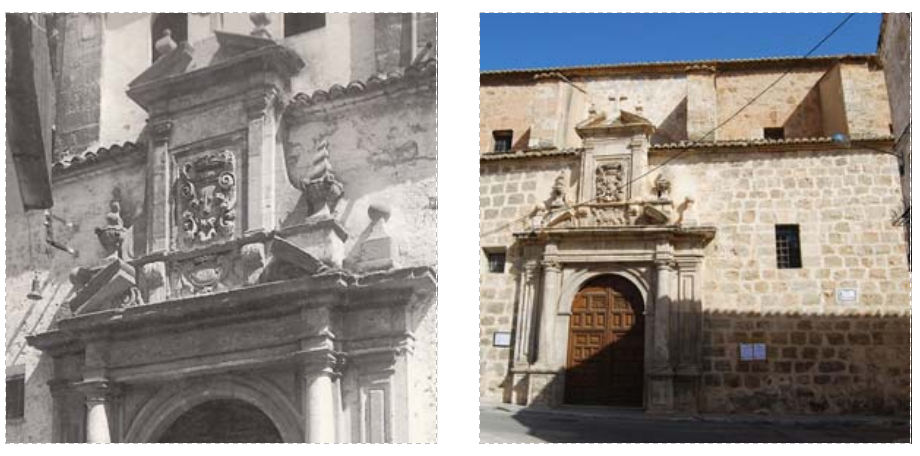

- Referencias en documentación histórica

Referencias numéricas en cartografía sobre fortificación

-Ref. en el croquis de Ortiz de Pinedo (1837-38, AGM, núm. 262): Sin ref.

-Ref. en plano de Vera Aparici (1993): Sin ref.

Referencias en memorias técnicas militares

-Ref. Guillermo Sáez (9/9/1834-5/12/1835): Sin ref.

-Ref. Guillermo Sáez (26/02/1836): Sin ref.

-Ref. P. Ortiz de Pinedo (12/03/1837-30/05/1837): Sin ref.

-Ref Jose Maria de Orozco (25/03/1838): Sin ref.

-Ref. Carbonell (4/7/1838): Sin ref.

\section{- Observaciones a partir de los informes militares}

Convento desaparecido en 1851, tras la Desamortización. En su Sala de Novicios se construyó el actual ayuntamiento. Rehabilitado en de Enseñanza Media. Su claustro se conserva cerrado con grandes ventanales de madera.

\section{Rellenar en caso de que el elemento sea
contemplado con datos del PGOU, 2013}

Proter

Nivel de protección: C.CAS.BRL.01.03-IN

Entorno:

$\square$ Inmueble

$\square$ Parcela catastral

$\checkmark$ Recinto arquitectónico
AFECCIÓN PATRIMONIAL

$\square$ Bien de interés cultural (BIC)

Bien de relevancia local (BRL)

Monumento

$\square$ Afectado Plan especial
Afectado entorno BIC 
- Descripción histórico-arquitectónica

Tipología: Arquitectura religiosa

Cronología: ss. XIII-XVII

Observaciones a la cronología:

Descripción: "Está construida de piedra caliza del terreno. Actualmente el antiguo convento está formado por tres edificios bien diferenciados: la Iglesia, el Museo y el Ayuntamiento. Lo más interesante del conjunto aparte de la Iglesia, es el claustro la crucería nervada del crucero. Se trata de un edificio de planta con nave única, construido en sillería con siete capillas laterales adosadas al muro (la octava se corresponde con la puerta de entrada). En los pies hay un espacio indefinido, y junto con una parte tapiada, configuraría la primitiva capilla de la Virgen de la Soterraña. El crucero apenas sobresale de la nave, y por el ala izquierda se accede a la sacristia. El presbiterio trapezoidal tiene tres lados de fondo. Gran chapado de azulejos en alto y extremo, zócalo en toda la capilla con efigies, alegorias y filacterias letreadas de los Santos carmelitanos. El altar, realizado en mámoles, alberga la talla de la Virgen del Camen, tras la cual se encuentra su camarin y a los lados Transfiguración en ático. La bóveda de la iglesia es de crucería oivval como la puerta de acceso a la sacristría En el interior de las capillas destaca el zócalo de azulejería valenciana. La fachada principal es de estilo neoclásico." (PGOU, 2013: C.CAS.BRL.01.03).

\section{- Entorno urbano}

\section{Descripción entorno urbano:}

Hestilla. El edificio se encuentra en el Barrio del Arrabal dentro del casco urbano de la ciudad" BRL.01.03)

Uso actual: Ayuntamiento, museo, iglesia

Estado de conservación: Bueno

Intervenciones: ss. $X V I, X X X, x X$

Titularidad: Pública

\section{Nivel protección s/catálogo 1996:}

Bibliografia: AMR, 1818-17, 1818-24; 1818-50; 1818-52; 1818-53.

observaciones generales: "Las intervenciones en el entorno de protección del bien se atendrán a lo dispuesto en el art. 25.3 de las normas de

\begin{tabular}{|c|c|c|c|}
\hline OBJETIVACIÓN DE INTERÉS & Soluciones constructivas & Soluciones ornamentales & Interés paisajistico \\
\hline V Interés tipológico & V Estructura & $\nabla$ Carpintería & V Incidencia visual \\
\hline $\bar{\nabla}$ Valor ambiental & $\square$ Aleros & $\square$ Rejería & $\checkmark$ Carácter articulador \\
\hline$\checkmark$ Vigencia de la trama & $\checkmark$ Coronación & $\square$ Cubrepersianas & $\bar{\nabla}$ Organización \\
\hline$\checkmark$ Composición de la fachada & $\checkmark$ Jambas & Alicatados & $\nabla$ Interés cultural \\
\hline $\bar{\nabla}$ Materiales, color, textura & $\bar{\nabla}$ Dinteles & $\square$ Recercos & $\checkmark$ Carácter representativo \\
\hline & & $\begin{array}{l}\square \text { Dinteles } \\
\square \text { Otros ornamentos }\end{array}$ & \\
\hline
\end{tabular}

\section{- Datos específicos catalogación BIC $\square$ Rellenar sólo si está catalogado BIC} Datos Jurídicos:

$\begin{array}{lll}\text { Código: } & \text { Fecha Disposición: } & \text { Fecha informe: } \\ \text { Estado: } & \text { Tipo delimitación: } & \text { Fecha Publicación BOP: } \\ \text { Categoría: } & \text { Plan: } & \text { Fecha Publicación DOCV: } \\ \text { Anotación Mo: } & \text { Informe: } & \text { Fecha Publicación BOE: }\end{array}$

116 Convento de Carmelitas Observantes

\section{- Identificación}

Tramo de estudio:

Otras denominiocion: Intramuros

Ref. catastral:

Convento o Monasterio de Santa María del Carmen

Localización: Plaza Consistorial, C/Mariano Cuber, C/ del Carmen
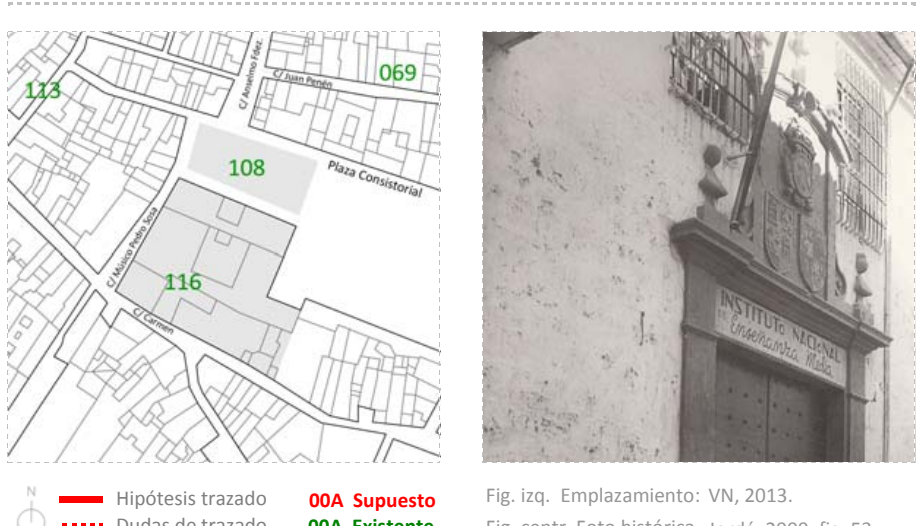

- Hipótesis trazado O0A Supuesto

$$
\begin{aligned}
& \text { Fig. irg. Emplazamiento: VN, } 2013 \text {, } \\
& \text { Fif. centr. Fota historica Jordá, 2000: fig. } 53 \\
& \text { Fig. dcha. Foto actual: VN, 2015 }
\end{aligned}
$$

$\checkmark$ Existe actualmente

$\checkmark$ Incluido en fichas PGOU 2013

$\square$ Bien de interés cultural (BIC)

Cód. postal: 4634

Municipio: Requena

Comarca: Plana de Requena-Utie

Provincia: Valencia

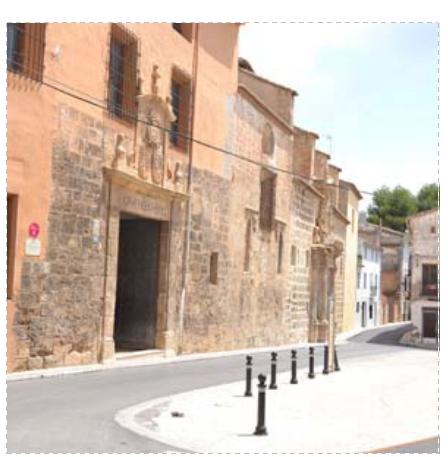

- Referencias en documentación histórica

Referencias numéricas en cartografía sobre fortificación

-Ref. en el croquis de Ortiz de Pinedo (1837-38, AGM, núm. 262): Sin ref.

-Ref. en plano de Vera Aparici (1993): Sin ref.

Referencias en memorias técnicas militare

-Ref. Guillermo Sáez (9/9/1834-5/12/1835): Sin ref.

-Ref. Guillermo Sáez (26/02/1836): Sin ref.

-Ref. P. Ortiz de Pinedo (12/03/1837-30/05/1837): Sin ref.

-Ref Jose Maria de Orozco (25/03/1838): Sin ref.

-Ref. Carbonell (4/7/1838): Sin ref.

\section{- Observaciones a partir de los informes militares}

Convento desaparecido en 1851, tras la Desamortización. En su Sala de Novicios se construyó el actual ayuntamiento. Rehabilitado en se constituto de Enseñanza Media. Su claustro se conserva cerrado con grandes ventanales de madera.

\section{Rellenar en caso de que el elemento sea
contemplado con datos del PGOU, 2013}

PROTECCIÓN
Nivel de protecio

Nivel de protección: C.CAS.CAT.01.01-A

Entorno:

$\checkmark$ Inmueble

$\square$ Parcela catastral

$\square$ Recinto arquitectónico
AFECCIÓN PATRIMONIAL

$\checkmark$ Bien de interés cultural (BIC)

Bien de relevancia local (BRL)

Monumento

$\square$ Afectado Plan especial 


\section{- Descripción histórico-arquitectónica}

Tipología: Arquitectura civil, religiosa

Cronologia: ss. XIII-XIX

Observaciones a la cronología:

Descripción: "Conjunto formado por las edificaciones que formaban el antiguo Convento del Carmen, que actualmente alberga el Ayuntamiento, el Museo Municipal y la antigua Iglesia del Carmen. El edificio del Ayuntamiento fue construido a mediados
del s. XIX, incorporando la estructura del antiguo claustro, reformado en el s. XVIII" (PGOU, 2013: C.CAS.BIC.01)

\section{- Entorno urbano}

Descripción entorno urbano:

"El edificio se encuentra en el Barrio del Arrabal dentro del casco urbano de la ciudad" (PGOU, 2013: C.CAS.BIC.01).

Uso actual: Ayuntamiento, museo, iglesia

Estado de conservación: Bueno

Régimen Urbanístico: S. U.

Titularidad: Pública

Nivel protección s/catálogo 1996: 2/3/4 tipológico-fachada-ambiental

Bibliografía: AMR, 1818-17, 1818-24; 1818-50; 1818-52; 1818-53.

Observaciones generales:

El conjunto se trata en fichas particularizadas para el claustro, el ayuntamiento y la iglesia en el PGOU de 2013.

\begin{tabular}{|c|c|c|c|}
\hline OBJETIVACIÓN DE INTERÉS & Soluciones constructivas & Soluciones ornamentales & Interés paisajístico \\
\hline$\nabla \ln$ & $\nabla \mathrm{E}$ & $\checkmark$ Carpintería & $\checkmark$ Incidencia visual \\
\hline$\square$ va & $\bar{\nabla}$ Al & $\checkmark$ Rejería & $\checkmark$ Carácter articulador \\
\hline$\square$ Vigencia de la trama & $\nabla$ Coronación & $\square$ Cubrepersianas & $\nabla$ Organización \\
\hline$\square$ Composición de la fachada & $\bar{\nabla}$ Jambas & $\square$ Alicatados & $\nabla$ Interés cultural \\
\hline$\nabla$ Materiales, color, textura & $\nabla$ Dinteles & $\begin{array}{l}\square \text { Recercos } \\
\square \text { Dinteles } \\
\nabla \boldsymbol{V} \text { Otros ornamentos }\end{array}$ & $\checkmark$ Carácter representativo \\
\hline
\end{tabular}

- Datos específicos catalogación BIC $\square$ Rellenar sólo si está catalogado BIC

Datos Jurídicos:

$\begin{array}{lll}\text { Código: } & \text { Fecha Disposición: } & \text { Fecha informe: } \\ \text { Estado: } & \text { Tipo delimitación: } & \text { Fecha Publicación BOP: } \\ \text { Categoría: } & \text { Plan: } & \text { Fecha Publicación DOCV: } \\ \text { Anotación Mo: } & \text { Informe: } & \text { Fecha Publicación BOE: }\end{array}$

Categorí:

Anotación $M$

Plan:
Inform :

Fecha Publicación BOE:

\section{Capilla de la Santa Cruz y la Caridad}

\section{- Identificación}

Tramo de estudio:

Extramuros

Otras denominaciones: Ermita de la Santa Cruz y Nuestra Señora de la Caridad, Ce

$\checkmark$ Existe actualmente

$\square$ Incluido en fich PGOU 2013

Bien de interés cultural (BIC)

cód. postal: 46340

Ref. catastral:

Localización: c/ Cementerio.

\section{Comarca: Plana de Requena-Utiel}

Autonomia: Comunidad Valencian

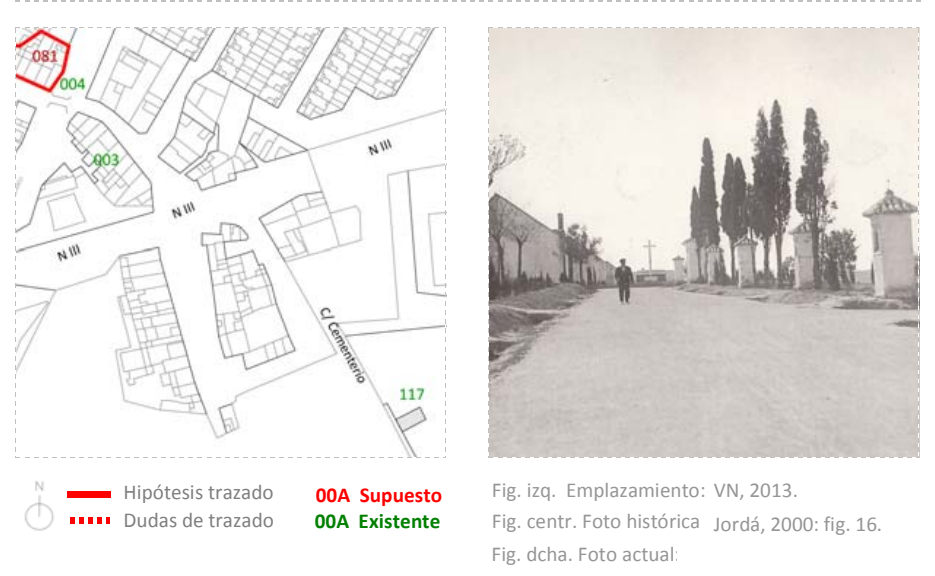

- Referencias en documentación histórica

\section{Referencias numéricas en cartografía sobre fortificación}

-Ref. en el croquis de Ortiz de Pinedo (1837-38, AGM, núm. 262): Sin ref.

-Ref. en plano de Vera Aparici (1993): Sin ref.

Referencias en memorias técnicas militare

-Ref. Guillermo Sáez (9/9/1834-5/12/1835): Sin ref.

-Ref. Guillermo Sáez (26/02/1836): Sin ref.

-Ref. P. Ortiz de Pinedo (12/03/1837-30/05/1837): Sin ref.

-Ref Jose Maria de Orozco (25/03/1838): Sin ref.

-Ref. Carbonell (4/7/1838): Sin ref.

\section{- Observaciones a partir de los informes militares}

Emplazada en el barrio de las Ollerías, en el actual cementerio. Herrero y Moral indica que es de fundación remota, y se levantó para mayo, desde 1679. El Romancero Español sostiene que en esta ental del encargo de una misa cantada que se celebraría todos los 3 de tratarse del templo más antiguo de la ciudad (Herrero, 1890: 132-133). Indica también Herrero, que cuando en 1813 se planteó la erección de un cementerio se decidió emplazarlo en "el terreno plantado de viña propio de mi abuelo paterno D. Antonio Ginés Herrero y Penén, detrás $y$ a los lados de la ermita de Santa Cruz, a cuyas paredes se unieron las que lo cerraban, poniendo entonces en cabeza de su altar la imagen de Nuestra Señora de la Caridad, Yhe aqui el ser conocida desde entonces con los dos nombres, pues desde muy antigua habia se exponian los cadáveres sin enterrar el tiempo reglamentario (Herrero, 1890:246). Bernabeu distingue entre la ermito de San Bartolomén demolida en 1813, también reconocida como la capilla del Cid mencionada en el Romancero: la de la Santa Cruz, junto al puente de las Ollerías, hundida en 1809, y la de la Caridad, "construida hacia 1812 junto al cementerio, convertida en cripta de las víctimas de la revolución última" (Bernabeu, 1980:549). 
Rellenar en caso de que el elemento sea

\section{PRotección}

AFECCIÓN PATRIMONIAL

Nivel de protección: $\quad \square$ Bien de interés cultural (BIC)

Entorno:

$\square$ Bien de relevancia local (BRL)

$\square$ Inmueble

$\square$ Parcela catastral

$\square$ Recinto arquitectónico

$\square$ Afectado entorno BIC

Afectado Plan especial
- Descripción histórico-arquitectónica

Tipología

Observaciones a la cronologia

Descripción:

- Entorno urbano

Descripción entorno urbano

Uso actual:

Estado de conservación:

Intervenciones:

Régimen Urbanístico:

Titularidad:

Nivel protección s/catálogo 1996:

Bibliografía: AMR, 1818-17, 1818-24; 1818-50; 1818-52; 1818-53.

Observaciones generales:

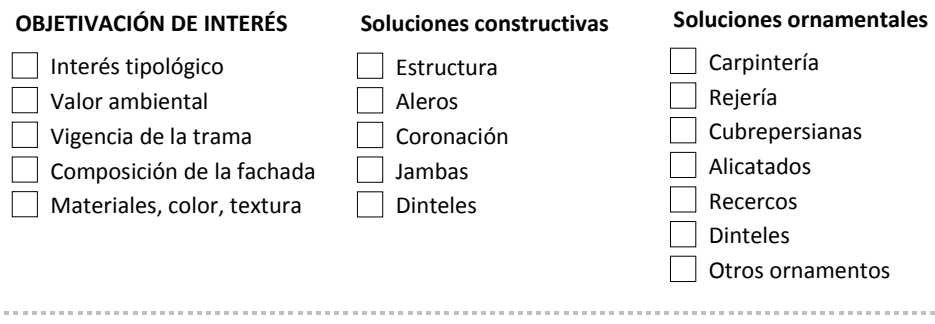

- Datos específicos catalogación BIC $\square$ Rellenar sólo siestá catalogado BIC Datos Juridicos:

$\begin{array}{lll}\text { Datos Juridicos: } & \text { Fecha Disposición: } & \text { Fecha informe: } \\ \text { Código: } & \text { Tipo delimitación: } & \text { Fecha Publicación BOP: } \\ \text { Estado: } & \text { Plan: } & \text { Fecha Publicación DOCV: } \\ \text { Categoría: } & \text { Informe: } & \text { Fecha Publicación BOE: }\end{array}$

\section{Cuestecilla del Pozo}

- Identificación

Tramo de estudio: Tramo 5: Puerta de las Cruces-Puerta de Reinas

Otras denominaciones:

Ref. catastral:

Localización: Cuesta del Pozo.

$\checkmark$ Existe actualmente

Incluido en fichas PGOU 2013

Bien de interés cultural (BIC)

cód. postal: 46340

Municipio: Requena

Comarca: Plana de Requena-Utie

Autonomia: Comunidad Valencian

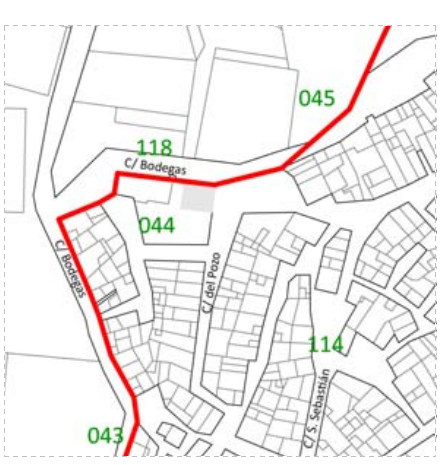

-... Hipótesis trazado

OOA Supuesto
OOA Existente

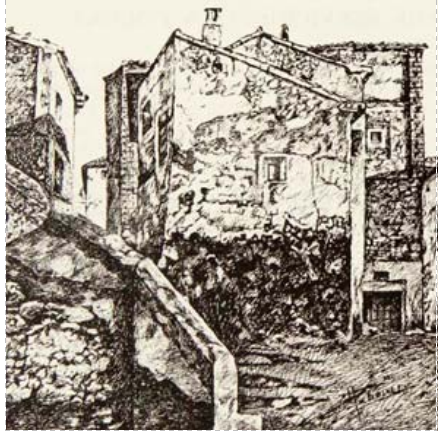

miento: VN, 2013

Fig. centr. Foto histórii:

- Referencias en documentación histórica

Referencias numéricas en cartografía sobre fortificación

-Ref. en el croquis de Ortiz de Pinedo (1837-38, AGM, núm. 262): Sin ref.

-Ref. en plano de Vera Aparici (1993): Sin ref.

Referencias en memorias técnicas militares

-Ref. Guillermo Sáez (9/9/1834-5/12/1835): Sin ref.

-Ref. Guillermo Sáez (26/02/1836): Sin ref.

-Ref. P. Ortiz de Pinedo (12/03/1837-30/05/1837): Sin ref.

-Ref Jose Maria de Orozco (25/03/1838): Sin ref.

-Ref. Carbonell (4/7/1838): Sin ref.

\section{- Observaciones a partir de los informes militares}

Podría tratarse de la pequeña cuesta que asciende hacia la Calle del Pozo y el Pozo de la Nieve desde "bajo de las Bodegas", hoy calle Bodegas.

$\begin{array}{lll}\square \frac{\text { Rellenar en caso de que el elemento sea }}{\text { contemplado con datos del PGOU, 2013 }} & \text { PROTECCIÓN } & \text { AFECCIÓN PATRIMONIAL } \\ & \text { Nivel de protección: } & \square \text { Bien de interés cultural (BIC) } \\ & \text { Entorno: } & \square \text { Bien de relevancia local (BRL) } \\ & \square \text { Inmueble } & \square \text { Afectado entorno BIC } \\ & \square \text { Parcela catastral } & \square \text { Afectado Plan especial } \\ & \square \text { Recinto arquitectónico } & \\ \square \text { Entorno específico } & \end{array}$




\section{- Descripción histórico-arquitectónica}

Tipología:

Cronología:

Observaciones a la cronologia

\section{Descripción:}

\section{- Entorno urbano}

Descripción entorno urbano:

Uso actual:

Estado de conservación:

Intervenciones:

Régimen Urbanístico:

Titularidad:

Nivel protección s/catálogo 1996:

Bibliografía: AMR, 1818-17, 1818-24; 1818-50; 1818-52; 1818-53.

Observaciones generales:

\begin{tabular}{|c|c|c|}
\hline OBJETIVACIÓN DE INTERÉS & Soluciones constructivas & Soluciones ornamentales \\
\hline $\begin{array}{l}\square \text { Interés tipológico } \\
\square \text { Valor ambiental } \\
\square \text { Vigencia de la trama } \\
\square \text { composición de la fachada } \\
\square \text { Materiales, color, textura }\end{array}$ & $\begin{array}{l}\square \text { Estructura } \\
\square \text { Aleros } \\
\square \text { Coronación } \\
\square \text { Jambas } \\
\square \text { Dinteles }\end{array}$ & $\begin{array}{l}\square \text { Carpintería } \\
\square \text { Rejería } \\
\square \text { Cubrepersianas } \\
\square \text { Alicatados } \\
\square \text { Recercos } \\
\square \text { Dinteles } \\
\square \text { Otros ornamentos }\end{array}$ \\
\hline
\end{tabular}

\section{- Datos específicos catalogación BIC $\square$ Rellenar sólo si está catalogado BIC}

$\begin{array}{lll}\text { Datos Juridicos: } & & \\ \text { Código: } & \text { Fecha Disposición: } & \text { Fecha informe: } \\ \text { Estado: } & \text { Tipo delimitación: } & \text { Fecha Publicación BOP: } \\ \text { Categoría: } & \text { Plan: } & \text { Fecha Publicación DOCV: } \\ \text { Anotación Mo: } & \text { Informe: } & \text { Fecha Publicación BOE: }\end{array}$

\section{Interés paisajistico}

$\square$ Incidencia visual

$\square$ Carácter articulado

$\square$ Organización

$\square$ Carácter representativo

\section{Tinte de Alonso (derruido)}

\section{- Identificación}

Tramo de estudio:

Otras denominaciones:

Tramo 6: Puerta de Reinas-Puerta de Valencia

Ref. catastral:

Localización: Sector Oriental a partir de la c/ Antonio Pérez

$\square$ Existe actualmente

Incluido en fichas PGOU 2013

Bien de interés cultural (BIC)

cód. postal: 46340

Municipio: Requena

Comarca: Plana de Requena-Utie

Provincia: Valencia

Autonomia: Comunidad Valencian

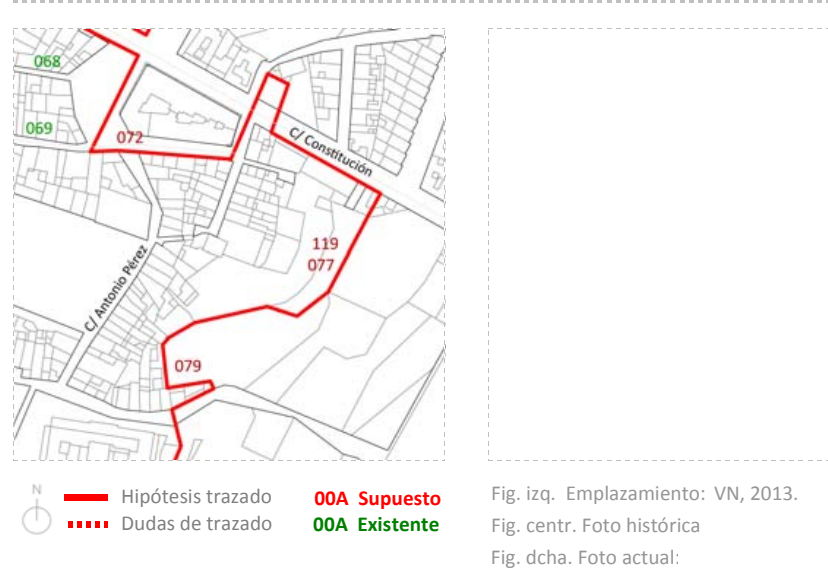

\section{- Referencias en documentación histórica}

Referencias numéricas en cartografía sobre fortificación

-Ref. en el croquis de Ortiz de Pinedo (1837-38, AGM, núm. 262): 027

-Ref. en plano de Vera Aparici (1993): Sin ref.

Referencias en memorias técnicas militares

-Ref. Guillermo Sáez (9/9/1834-5/12/1835): Sin ref.

-Ref. Guillermo Sáez (26/02/1836): Sin ref.

-Ref. P. Ortiz de Pinedo (12/03/1837-30/05/1837): Sin ref.

-Ref Jose Maria de Orozco (25/03/1838): Sin ref.

-Ref. Carbonell (4/7/1838): Sin ref.

\section{- Observaciones a partir de los informes militares}

El plano de Ortiz de Pinedo hace referencia a un tinte derruido que identifica como el tinte de Alonso. Referenciado con el núm. 27, no aperece identificado en el plano. Curiosamente, documentos hallados en el Archivo Municipal de Requena (AMR, 1818-16), hacen la denominada batería de "Honrubia". Vid. Batería de Honrubia.

$\begin{array}{lll}\square \text { Rellenar en caso de que el elemento sea } & \text { PROTECCIÓN } & \text { AFECCIÓN PATRIMONIAL } \\ \text { contemplado con datos del PGOU, 2013 } & \text { Nivel de protección: } & \square \text { Bien de interés cultural (BIC) } \\ & \text { Entorno: } & \square \text { Bien de relevancia local (BRL) } \\ & \square \text { Inmueble } & \square \text { Afectado entorno BIC } \\ & \begin{array}{l}\text { Parcela catastral } \\ \square\end{array} & \square \text { Afectado Plan especial } \\ & \text { Recinto arquitectónico } & \end{array}$




\section{- Descripción histórico-arquitectónica}

Tipología:

ronología:

Observaciones a la cronología

\section{Descripción:}

\section{- Entorno urbano}

Descripción entorno urbano:

Uso actual:

Estado de conservación:

Intervenciones:

Régimen Urbanístico:

Titularidad:

Nivel protección s/catálogo 1996:

Bibliografía: AMR, 1818-17, 1818-24; 1818-50; 1818-52; 1818-53.

Observaciones generales:

\begin{tabular}{|c|c|c|}
\hline OBJETIVACIÓN DE INTERÉS & Soluciones constructivas & Soluciones ornamentales \\
\hline$\square$ Interés tipológico & $\square$ Estructura & $\square$ Carpintería \\
\hline Valor ambiental & $\square$ Aleros & $\square$ Rejería \\
\hline$\square$ Vigencia de la trama & $\square$ Coronación & $\square$ Cubrepersianas \\
\hline$\square$ Composición de la fachada & $\square$ Jambas & $\square$ Alicatados \\
\hline$\square$ Materiales, color, textura & $\square$ Dinteles & $\begin{array}{l}\square \text { Recercos } \\
\square \text { Dinteles }\end{array}$ \\
\hline & & $\square$ Otros ornamentos \\
\hline
\end{tabular}

\section{- Datos específicos catalogación BIC $\square$ Rellenar sólo si está catalogado BIC}

$\begin{array}{lll}\text { Datos Juridicos: } & & \\ \text { Código: } & \text { Fecha Disposición: } & \text { Fecha informe: } \\ \text { Estado: } & \text { Tipo delimitación: } & \text { Fecha Publicación BOP: } \\ \text { Categoría: } & \text { Plan: } & \text { Fecha Publicación DOCV: } \\ \text { Anotación Mo: } & \text { Informe: } & \text { Fecha Publicación BOE: }\end{array}$

\section{Puerta de Higuerillas}

\section{- Identificación}

Tramo de estudio: Tramo 6: Puerta de Reinas-Puerta de Valencia

Otras denominaciones: Puerta de Ygerillas

Ref. catastral:

Localización: Encuentro de C/Higuerillas con C/ Antonio M. Claret.

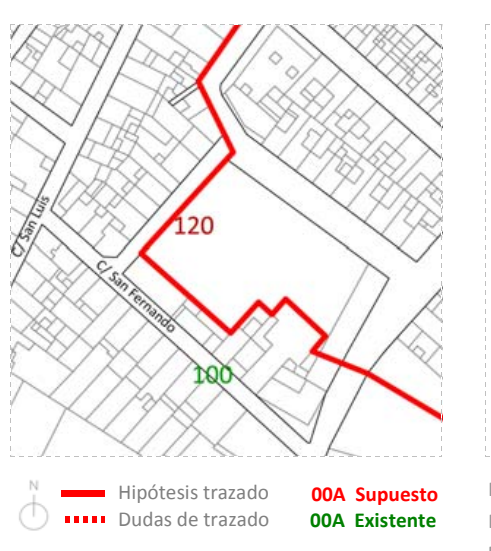

\section{Interés paisajistico}

$\square$ Incidencia visual

$\square$ Carácter articulad

$\square$ Organización

Carácter representativo

\section{-.... Hudapostesis trazado trazado}

O0A Supuesto
OOA Existente $\square$ Existe actualmente

Incluido en fichas PGOU 2013

Bien de interés cultural (BIC)

cód. postal: 46340

Municipio: Requena

Comarca: Plana de Requena-Utie

Autonomia: Comunidad Valencian

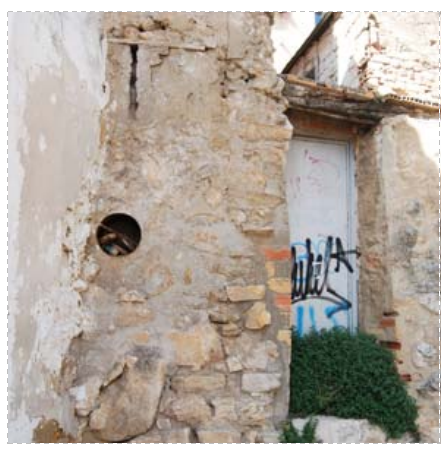

\section{- Referencias en documentación histórica}

\section{Referencias numéricas en cartografía sobre fortificación}

-Ref. en el croquis de Ortiz de Pinedo (1837-38, AGM, núm. 262): 005

-Ref. en plano de Vera Aparici (1993): Sin ref.

Referencias en memorias técnicas militares

-Ref. Guillermo Sáez (9/9/1834-5/12/1835): Sin ref.

-Ref. Guillermo Sáez (26/02/1836): Requena, 26/02/1836 AMR, 1818-53

Guillermo Saez hace referencia a una puerta de Higuerillas. Propone cortar 3 varas de la pared $(2,51 \mathrm{~m})$ que hay entre el camino y los huertos y se une con la puerta.

-Ref. P. Ortiz de Pinedo (12/03/1837-30/05/1837): Sin ref.

-Ref Jose Maria de Orozco (25/03/1838): Sin ref.

-Ref. Carbonell (4/7/1838): Sin ref.

\section{- Observaciones a partir de los informes militares}

La puerta de Higuerillas, identificada por el plano aspillerado de Ortiz de Pinedo (SHM, núm. 262), se emplazaría aproximadamente volcando haci la actual calle Higuerillas, meridionalmente al frente edificado.

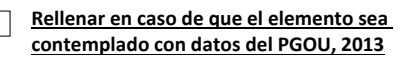

PROTECCIÓN
Nivel de protección:
Entorno:
$\square$ Inmueble
$\square$ Parcela catastral
$\square$ Recinto arquitectónico
$\square$

AFECCION PATRIMONIAL

Bien de interés cultural (BC)

$\square$ Bien de relevancia local (BRL)

$\square$ Afectado entorno BIC

$\square$ Afectado Plan especial 


\section{- Descripción histórico-arquitectónica}

Tipología:

Observaciones a la cronologia

\section{Descripción:}

\section{- Entorno urbano}

Descripción entorno urbano:

Uso actual:

Estado de conservación:

Intervenciones:

Régimen Urbanistico:

Titularidad:

Nivel protección s/catálogo 1996:

Bibliografía: AMR, 1818-17, 1818-24; 1818-50; 1818-52; 1818-53.

Observaciones generales:

\begin{tabular}{lll} 
OBJETIVACIÓN DE INTERÉS & Soluciones constructivas & Soluciones ornamentales \\
$\square$ Interés tipológico & $\square$ Estructura & $\square$ Carpintería \\
\hline$\square$ Valor ambiental & $\square$ Aleros & $\square$ Rejería \\
\hline$\square$ Vigencia de la trama & $\square$ coronación & $\square$ cubrepersianas \\
\hline$\square$ Composición de la fachada & $\square$ Jambas & $\square$ Alicatados \\
$\square$ Materiales, color, textura & $\square$ Dinteles & $\square$ Recercos \\
& & $\square$ Dinteles \\
& $\square$ otros ornamentos
\end{tabular}

\section{- Datos específicos catalogación BIC $\square$ Rellenar sólo si está catalogado BIC}

$\begin{array}{lll}\text { Datos Jurídicos: } & & \\ \text { Código: } & \text { Fecha Disposición: } & \text { Fecha informe: } \\ \text { Estado: } & \text { Tipo delimitación: } & \text { Fecha Publicación BOP: } \\ \text { Categoría: } & \text { Plan: } & \text { Fecha Publicación DOCV: } \\ \text { Anotación Mo: } & \text { Informe: } & \text { Fecha Publicación BOE: }\end{array}$

\section{Tambor de Reinas}

\section{- Identificación}

Tramo de estudio: Tramo 6: Puerta de Reinas-Puerta de Valencia

Otras denominaciones:

Ref. catastral:

Localización: Casas en el sector Noreste de la C/ Libertad

Existe actualmente

Incluido en fichas PGOU 2013

Bien de interés cultural (BIC)

cód. postal: 46340

Municipio: Requen

Comarca: Plana de Requena-Utie

Provincia: Valencia

Autonomia: Comunidad Valencian

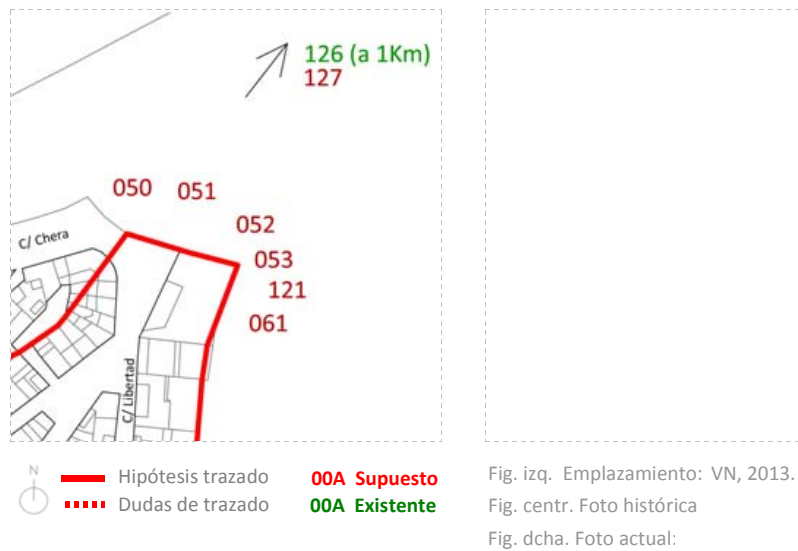

- Referencias en documentación histórica

Referencias numéricas en cartografía sobre fortificación

-Ref. en el croquis de Ortiz de Pinedo (1837-38, AGM, núm. 262): 004

-Ref. en plano de Vera Aparici (1993): Sin ref.

Referencias en memorias técnicas militares

-Ref. Guillermo Sáez (9/9/1834-5/12/1835): Sin ref.

-Ref. Guillermo Sáez (26/02/1836): Sin ref.

-Ref. P. Ortiz de Pinedo (12/03/1837-30/05/1837): Sin ref.

-Ref Jose María de Orozco (25/03/1838): Sin ref.

Ref. Carbonell (4/7/1838): Sin ref.

\section{- Observaciones a partir de los informes militares}

El tambor de Reinas constituye según el plano de Ortiz de Pinedo (SHM, núm. 262), una estructura complementaria a las dos baterias de Reinas (vieja y nueva). Se emplaza a modo de caponera saliente en dirección sureste, batiendo de flanco hacia el sur todo el frente de con la batería antigua de reinas, que resguarda en su confluencia la Puerta de Reinas.

$\begin{array}{lll}\square \frac{\text { Rellenar en caso de que el elemento sea }}{\text { contemplado con datos del PGOU, 2013 }} & \text { PROTECCIÓN } & \text { AFECCIÓN PATRIMONIAL } \\ & \text { Nivel de protección: } & \square \text { Bien de interés cultural (BIC) } \\ & \text { Entorno: } & \square \text { Bien de relevancia local (BRL) } \\ & \square \text { Inmueble } & \square \text { Afectado entorno BIC } \\ & \square \text { Parcela catastral } & \square \text { Afectado Plan especial } \\ & \square \text { Recinto arquitectónico } & \end{array}$




\section{- Descripción histórico-arquitectónica}

Tipología:

Cronologia:

aciones a la cronología:

\section{Descripción:}

\section{- Entorno urbano}

\section{Descripción entorno urbano:}

Uso actual:

Estado de conservación:

Intervenciones:

\section{Régimen Urbanístico:}

\section{Titularidad:}

Nivel protección s/catálogo 1996:

Bibliografía: AMR, 1818-17, 1818-24; 1818-50; 1818-52; 1818-53.

Observaciones generales:

$\begin{array}{llll}\text { OBJETIVACIÓN DE INTERÉS } & \text { Soluciones constructivas } & \text { Soluciones ornamentales } & \text { Interés paisajistico } \\ \square \text { Interés tipológico } & \square \text { Estructura } & \square \text { carpintería } & \square \text { Incidencia visual } \\ \square \text { Valor ambiental } & \square \text { Aleros } & \square \text { Rejería } & \square \text { carácter articulador } \\ \square \text { Vigencia de la trama } & \square \text { coronación } & \square \text { Cubrepersianas } & \square \text { organización } \\ \square \text { Composición de la fachada } & \square \text { Jambas } & \square \text { Alicatados } & \square \text { Interés cultural } \\ \square \text { Materiales, color, textura } & \square \text { Dinteles } & \square \text { Recercos } & \square \text { Carácter representativo } \\ & & \square \text { Dinteles } & \end{array}$

\section{- Datos específicos catalogación BIC $\square$ Rellenar sólo si está catalogado BIC}

$\begin{array}{lll}\text { Datos Juridicos: } & & \\ \text { Código: } & \text { Fecha Disposición: } & \text { Fecha informe: } \\ \text { Estado: } & \text { Tipo delimitación: } & \text { Fecha Publicación BOP: } \\ \text { Categoria: } & \text { Plan: } & \text { Fecha Publicación DOCV: } \\ \text { Anotación Mo: } & \text { Informe: } & \text { Fecha Publicación BOE: }\end{array}$

\section{Calle de la Plaza}

\section{- Identificación}

Tramo de estudio:

Tramo 6: Puerta de Reinas-Puerta de Valencia

Otras denominaciones:

Ref. catastral:

Localización:

Existe actualmente

Incluido en fichas PGOU 2013

Bien de interés cultural (BIC)

cód. postal: 46340

Municipio: Requena
Comarca: Plana de Requena-Utie

Provincia: Valencia

Autonomia: Comunidad Valencian

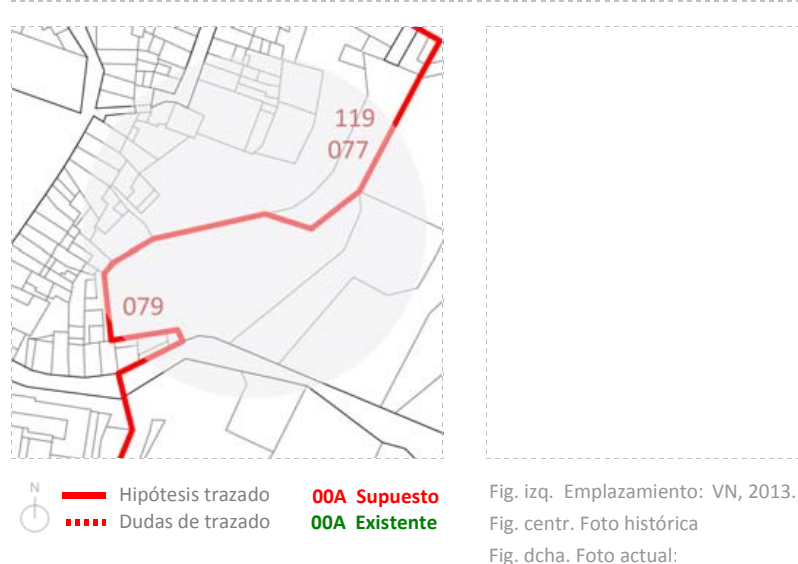

\section{- Referencias en documentación histórica}

Referencias numéricas en cartografía sobre fortificación

-Ref. en el croquis de Ortiz de Pinedo (1837-38, AGM, núm. 262): Sin ref.

-Ref. en plano de Vera Aparici (1993): Sin ref.

Referencias en memorias técnicas militares

-Ref. Guillermo Sáez (9/9/1834-5/12/1835): Sin ref.

-Ref. Guillermo Sáez (26/02/1836): Sin ref.

-Ref. P. Ortiz de Pinedo (12/03/1837-30/05/1837): Sin ref.

-Ref Jose María de Orozco (25/03/1838): Requena, 25/03/1838, AMR 1818-24

Se propone hacer un fortín que arranque del ángulo que configura el tinte de Cecina con el que hace pared con la calle de la Plaza. (Vid.

-Ref. Carbonell (4/7/1838): Sin ref.

\section{- Observaciones a partir de los informes militares}

En el informe de Orozco de 1838 (AMR, 1818-24) se hace referencia a una Calle de la Plaza, cuya tapia actúa de frente defensivo, ubicada en relación con el frente este, la Puerta del Trillero y el tinte de Cecina.

\section{$\square$ Rellenar en caso de que el elemento sea}

PROTECCIÓN
Nivel de protección:
Entorno:
\begin{tabular}{|l}
$\square$ Inmueble \\
$\square$ Parcela catastral \\
$\square$ Recinto arquitectónico \\
$\square$ Entorno específico
\end{tabular}

AFECCIÓN PATRIMONIAL

$\square$ Bien de interés cultural (BIC)

$\square$ Bien de relevancia local (BRL)

$\square$ Afectado entorno BIC

$\square$ Afectado Plan especial 


\section{- Descripción histórico-arquitectónica}

Tipología

Cronologia:

Observaciones a la cronologí

Descripción:

\section{- Entorno urbano}

Descripción entorno urbano:

Uso actual:

Estado de conservación:

Intervenciones:

Régimen Urbanístico:

Titularidad:

Nivel protección s/catálogo 1996:

Bibliografía: AMR, 1818-17, 1818-24; 1818-50; 1818-52; 1818-53.

Observaciones generales:

$\begin{array}{lll}\text { OBJETIVACIÓN DE INTERÉS } & \text { Soluciones constructivas } & \text { Soluciones ornamentales } \\ \square \text { Interés tipológico } & \square \text { Estructura } & \square \text { Carpintería } \\ \square \text { valor ambiental } & \square \text { Aleros } & \square \text { Rejería } \\ \square \text { vigencia de la trama } & \square \text { coronación } & \square \text { Cubrepersianas } \\ \square \text { composición de la fachada } & \square \text { Jambas } & \square \text { Alicatados } \\ \square \text { Materiales, color, textura } & \square \text { Dinteles } & \square \text { Recercos } \\ & & \square \text { Dinteles } \\ & \square \text { Otros ornamentos }\end{array}$

\section{- Datos específicos catalogación BIC $\square$ Rellenar sólo si está catalogado BIC}

$\begin{array}{lll}\text { Datos Juridicos: } & & \\ \text { Código: } & \text { Fecha Disposición: } & \text { Fecha informe: } \\ \text { Estado: } & \text { Tipo delimitación: } & \text { Fecha Publicación BOP: } \\ \text { Categoría: } & \text { Plan: } & \text { Fecha Publicación DOCV: } \\ \text { Anotación Mo: } & \text { Informe: } & \text { Fecha Publicación BOE: }\end{array}$

\section{Molinos de la falda occidental de la Loma (2응 molino de la Loma)}

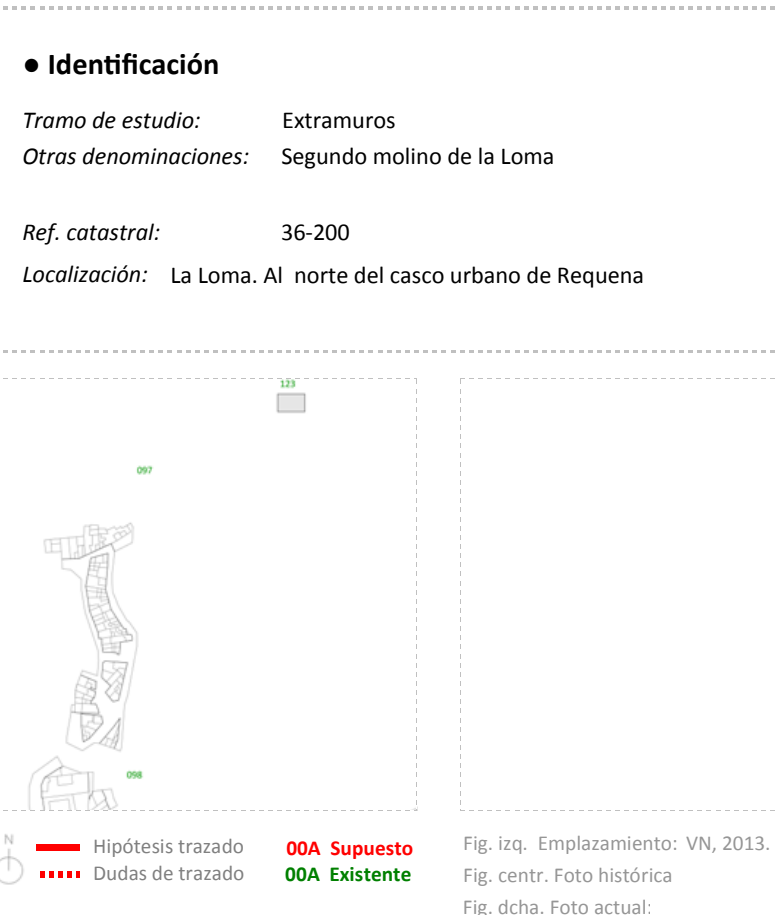

$\checkmark$ Existe actualmente

$\checkmark$ Incluido en fichas PGOU 2013

$\square$ Bien de interés cultural (BIC)

cód. postal: 4634

Municipio: Requena

Comarca: Plana de Requena-Utie

Provincia: Valencia

Autonomía: Comunidad Valencian

\section{- Referencias en documentación histórica}

Referencias numéricas en cartografía sobre fortificación

-Ref. en el croquis de Ortiz de Pinedo (1837-38, AGM, núm. 262): 016

-Ref. en plano de Vera Aparici (1993): Sin ref.

Referencias en memorias técnicas militares

-Ref. Guillermo Sáez (9/9/1834-5/12/1835): Sin ref.

-Ref. Guillermo Sáez (26/02/1836): Sin ref.

-Ref. P. Ortiz de Pinedo (12/03/1837-30/05/1837): Sin ref.

-Ref Jose María de Orozco (25/03/1838): Sin ref.

-Ref. Carbonell (4/7/1838): Sin ref.

\section{- Observaciones a partir de los informes militares}

En el plano de Ortiz de Pinedo se identifican una serie de molinos encaramados en la falda este de la Loma, justo a los pies del Convento de San Francisco. En el norte de Requena, sobrevive uno de los varios molinos que poblaron esta zona, el denominado 20 molino de la
Loma (de los siglos XVIII Y XVIII), emplazado justo en el camino viejo a la Loma, y que debió tenerse presente en los informes militares como el de Ortiz de Pinedo. El Molino 20, o de la tía Paca, se encuentra cruzando la vía del ferrocarril. Tenía una muela en su origen, pero más adelante se instaló una segunda muela. En este molino se ubicaba el partidor que llevaba las aguas hacia la plaza de toros y hacía los molinos 10 o de Piñuelo y Carmen (Argilés, 2006:355). Este Molino del Carmen o del Arrabal, es identificado ya en el siglo XVIII (AMR, Respuestas Generales, Expedientes de Montes, 3ㅇ, s. XVIII). 


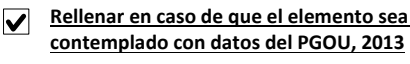

PROTECCIÓN

Nivel de protección: Parcial

AFECCIÓN PATRIMONIAL

Entorno:

$\square$ Inmueble

$\square$ Parcela catastral

$\checkmark$ Recinto arquitectónico

$\square$ Entorno específico

$\square$ Bien de interés cultural (BIC)

$\square$ Afectado entorno BIC

$\square$ Afectado Plan especia

- Descripción histórico-arquitectónica

Tipología: Arquitectura industrial

Cronología: ss. XVII-XVIII

Observaciones a la cronología:

Descripción: "El conjunto se compone de corral, cuadra, huerto y casa vivienda molino. El conjunto está separado del exterior por

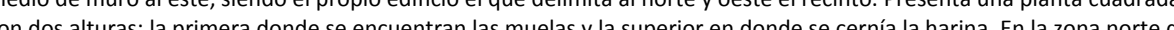
edificio se encuentra el cubo, donde se almacenaba el agua, su profundidad es de $4,5 \mathrm{~m}$. En el ángulo noroeste está situado el caz con el mecanismo que que aprovecha la fuerza del agua. Los materiales son ladrillo y mampostería de cal, vigas de madera y suelos de baldosa de barro rojo. La pared norte de la primera planta aprovecha el desnivel del terreno" (PGOU, 2013:T.TM.CAT.15).

\section{- Entorno urbano}

\section{Descripción entorno urbano:}

"Ubicado al norte del casco urbano de Requena, entre el barrio de la Loma y la autovía A3. Su encuentra rodeado actualmente de tierras de viñedos y algunos eriales" (PGOU, 2013:T.TM.CAT.15).

Uso actual: Ninguno

Estado de conservación: Regular

Intervenciones:

Régimen Urbanistico: S. N.U.

Titularidad: Privado

Nivel protección s/catálogo 1996:

Bibliografía: AMR, 1818-17, 1818-24; 1818-50; 1818-52; 1818-53.

Observaciones generales:

"La protección afecta al conjunto de edificios y su entorno próximo. " (PGOU, 2013:T.TM.CAT.15).

\begin{tabular}{|c|c|c|c|}
\hline OBJETIVACIÓN DE INTERÉS & Soluciones constructivas & Soluciones ornamentales & Interés paisajístico \\
\hline$\nabla$ Interés tipológico & $\checkmark$ Estructura & $\square$ Carpintería & $\checkmark$ Incidencia visual \\
\hline$\checkmark$ Valor ambiental & $\square$ Aleros & $\square$ Rejería & Carácter articulador \\
\hline$\square$ Vigencia de la trama & $\square$ Coronación & $\square$ Cubrepersianas & $\bar{\nabla}$ Organización \\
\hline$\square$ Composición de la fachada & $\square$ Jambas & $\square$ Alicatados & $\bar{\nabla}$ Interés cultural \\
\hline \multirow{3}{*}{$\nabla$ Materiales, color, textura } & $\square$ Dinteles & Recercos & $\checkmark$ Carácter representativo \\
\hline & & $\square$ Dinteles & \\
\hline & & $\square$ Otros orn & \\
\hline
\end{tabular}

\section{- Datos específicos catalogación BIC $\square$ Rellenar sólo si está catalogado BIC}

Datos Jurídicos:

Código:

Estado:

Categoría:

Fecha Disposición:

Anotación $M$

Plan:

Informe:
Fecha informe:

Fecha Publicación BOP:

Fecha Publicación DOCV:

\section{Molinos de Rozaleme. Molino de Esther}

\section{- Identificación}

Tramo de estudio:

Extramuros

Otras denominaciones: Molino de Esther (Molino 3º, Molino de Teodora). Camino

$\checkmark$ Existe actualmente

$\checkmark$ Incluido en fichas PGOU 2013

$\square$ Bien de interés cultural (BIC)

cód. postal: 46340

Ref. catastral: $\quad$ 36-9024

Localización: C/ Ribera de Rozaleme ำ 3

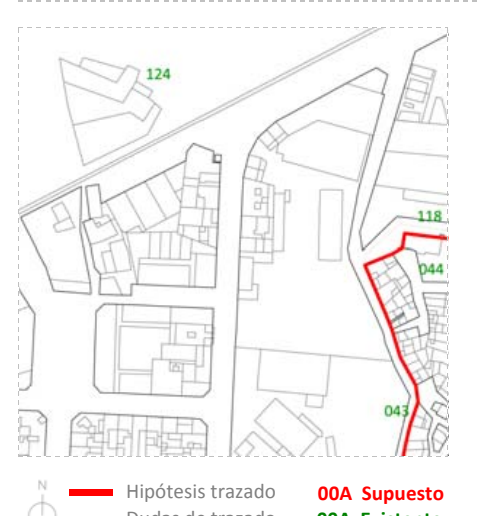

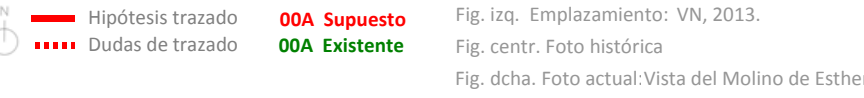

\section{- Referencias en documentación histórica}

\section{Referencias numéricas en cartografía sobre fortificación}

-Ref. en el croquis de Ortiz de Pinedo (1837-38, AGM, núm. 262): 016

-Ref. en plano de Vera Aparici (1993): Sin ref.

Referencias en memorias técnicas militare

-Ref. Guillermo Sáez (9/9/1834-5/12/1835): Sin ref.

-Ref. Guillermo Sáez (26/02/1836): Sin ref.

-Ref. P. Ortiz de Pinedo (12/03/1837-30/05/1837): Sin ref.

-Ref Jose Maria de Orozco (25/03/1838): Sin ref.

-Ref. Carbonell (4/7/1838): Sin ref.

\section{- Observaciones a partir de los informes militares}

En el plano de Ortiz de Pinedo se identifican una serie de molinos encaramados en la falda este de la Loma. Pero también existen molinos entre la Hoya de Martinete y los muros septentrionales de la ciudad. Entre ellos el Molino de Esther, del siglo XVI. En 1790, D. Antonio Ginés Herrero y Gallego narra como hallándose un enfermo en la Vega de Requena el recorrido de la comitiva sacramental sale por el
camino de los molinos al de Madrid, el encuentro de ambos caminos se ubica "próximo a entrar en el callejón que forman la huerta de Convento de las religiosas y las que también posee enfrente". Se hace referencia al camino de los molinos, correspondiente con la Ribera Hoya de los molinos, tamblén denominado Camino de Rozaleme (Argilés Gómez, 2006:328). Estos molinos se encuadrarlan en el conjunto molino $3^{\circ}$, molino de Teodora $y$, actualmente de Esther, pero existían otro conjunto de molinos entre el molino de la Loma o $6^{\circ}$ e l ma del Piñuelo o 10. Existía también un molino dependiente dentro del casco urbano, en el Arrabal, frente al convento del Carmen (Argíśs, 2006:349). Como observamos, en el conjunto de molinos de la ribera de Rozaleme o la Hoya de los molinos se incluyen los molinos de la Loma. Destacan: el molino 60 o de la Loma, el molino 5o o de los Montoya, el molino 4o o del arroz, el molino 300 de Teodora, el molino 2 o molino de la tía Paca (vid. 20 molino de la Loma). El molino 1으, denominado de Piñuelo o Carmen (Argilés, 2006:355). 
$\checkmark \frac{\text { Rellenar en caso de que el elemento sea }}{\text { contempladocon dat tos del pGou, 20as }}$

PROTECCIÓN

Nivel de protección:

Entorno:

$\square$ Inmueble

$\square$ Parcela catastral

$\checkmark$ Rntorno específico

AFECCIÓN PATRIMONIAL

$\square$ Bien de interés cultural (BIC)

Afectado entorno BIC
Bien de relevancia local (B

$\square$ Afectado Plan especial

\section{Casas molino de [Catalán]}

- Identificación
$\begin{aligned} & \text { Tramo de estudio: Extramuros } \\ & \text { Otras denominaciones: }\end{aligned}$
Ref. catastral:
$\begin{aligned} & \text { Localización: } \\ & \text { Paraje no ubicado. En el arco montañoso que supone la prolongación } \\ & \text { de la Loma hacia el Noreste. }\end{aligned}$

$\square$ Existe actualmente

Incluido en fichas PGOU 2013

Bing 2013

Cód. postal: 46340

Municipio: Requena

Comarca: Plana de Requena-Utiel

Provincia: Valencia

Autonomia: Comunidad Valencian

- Descripción histórico-arquitectónica

Tipología: Arquitectura industria

Cronología: s. XVI

Observaciones a la cronología:

Descripción: "Molino hidraúlico del S. XVI. Se trata del último molino hidraúlico de rodezno en funcionamiento. Aprovecha las aguas del estanque de Rozaleme a través de las acequias de riego diseñadas en época árabe. Tiene un sistema de molienda por turistica" (PGOU, 2013:T.CAS.BRL.07).

\section{- Entorno urbano}

Descripción entorno urbano:

del casco urbano de Requena, junto a las vías del ferrocarril. El suelo a su alrededor corresponden

作 Uso actual: Museo

\section{Ustodo de conservación: Bueno}

Pévenciones: $\mathrm{si}$

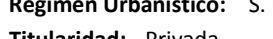

Titularidad: Privada

Nivel protección s/catálogo 1996:

$1818-24 ; 1818-50 ; 1818-52 ; 1818-53$

Observaciones generales:
"Es objeto de protección la estructura general del edificio y su maquinaria, así como la huerta y la acequia que aporta agua al edificio. Las intervenciones en el entorno de protección del bien se atendrán a lo dispuesto en el art. 25.3 de las normas del presente Catálogo."

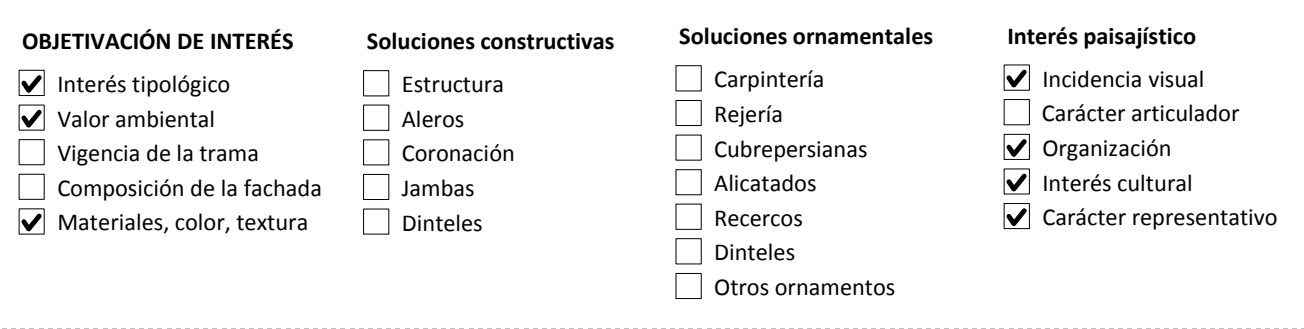

\section{- Datos específicos catalogación BIC $\square$ Rellenar sólo si está catalogado BIC}

Datos Jurídicos:

$\begin{array}{lll}\text { Datos Jurídicos: } & \text { Fecha Disposición: } & \text { Fecha informe: } \\ \text { Código: } & \text { Tipo delimitación: } & \text { Fecha Publicación BOP: } \\ \text { Estado: } & \text { Plan: } & \text { Fecha Publicación DOCV: } \\ \text { Categoría: } & \text { Informe: } & \text { Fecha Publicación BOE: }\end{array}$

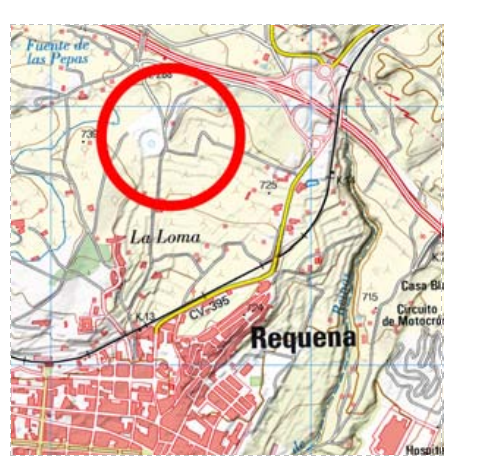

$\begin{array}{ccc}\text {..... Hipótesis trazado } & \text { O0A Supuesto } \\ \text { O0A Existente } & \end{array}$
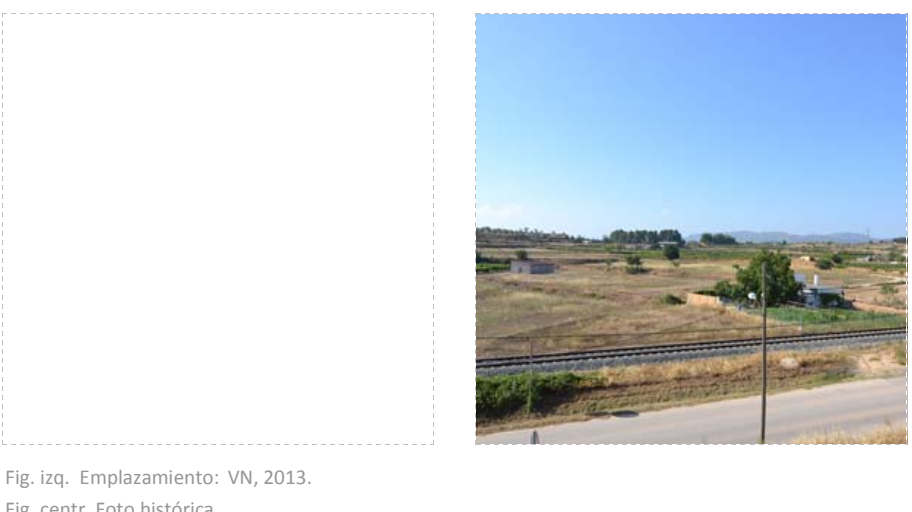

- Referencias en documentación histórica

\section{Referencias numéricas en cartografía sobre fortificación}

-Ref. en el croquis de Ortiz de Pinedo (1837-38, AGM, núm. 262): 019

-Ref. en plano de Vera Aparici (1993): Sin ref.

Referencias en memorias técnicas militares

-Ref. Guillermo Sáez (9/9/1834-5/12/1835): Sin ref.

-Ref. Guillermo Sáez (26/02/1836): Sin ref.

-Ref. P. Ortiz de Pinedo (12/03/1837-30/05/1837): Sin ref.

-Ref Jose Maria de Orozco (25/03/1838): Sin ref.

-Ref. Carbonell (4/7/1838): Sin ref.

\section{- Observaciones a partir de los informes militares}

Según el plano de Ortiz de Pinedo (SHM, núm. 262), las casas molino de [Catalán] se ubican en la máxima concavidad de la Loma. Al Este del Barrio del mismo nombre. El termino de [Catalán], que se aprecia a duras penas, podía hacer referencia al nombre o procedencia del propietario. Pero también a las caracteristicas tipológicas de las muelas del molino, de tipo catalán, habituales en la zona para la molien de piensos (Gómez Martínez, 2006:213). 


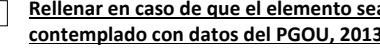

\section{PROTECCIÓN}

Nivel de protección:

AFECCIÓN PATRIMONIAL

\section{$\square$ Inmueble}

$\square$ Parcela catastral

Recinto arquitectónico

$\square$ Entorno especifico $\square$ Bien de interés cultural (BIC)

$\square$ Afectado Plon especil $\square$ Afectado entorno BIC

\section{- Descripción histórico-arquitectónica}

Tipología:

Observaciones a la cronología

\section{Descripción}

- Entorno urbano

Descripción entorno urbano:

Uso actual:

Estado de conservación:

Intervenciones:

Ritularidad:

\section{Nivel protecion}

n/catálogo 1996:

Bibliografía: AMR, 1818-17, 1818-24; 1818-50; 1818-52; 1818-53. observaciones generales:

$\begin{array}{lll}\text { OBJETIVACIÓN DE INTERÉS } & \text { Soluciones constructivas } & \text { Soluciones ornamentales } \\ \square \text { Interés tipológico } & \square \text { Estructura } & \square \text { Carpintería } \\ \square \text { Valor ambiental } & \square \text { Aleros } & \square \text { Rejería } \\ \square \text { Vigencia de la trama } & \square \text { coronación } & \square \text { cubrepersianas } \\ \square \text { Composición de la fachada } & \square \text { Jambas } & \square \text { Alicatados } \\ \square \text { Materiales, color, textura } & \square \text { Dinteles } & \square \text { Recercos } \\ & & \square \text { Dinteles } \\ & & \text { O Dtros ornamentos }\end{array}$

Interés paisajístico

$\square$ Incidencia visual

$\square$ Carácter articulador

$\square$ Organización

$\square$ Carácter representativo

$\square$ Otros ornamentos

\section{- Datos específicos catalogación BIC $\square$ Rellenar sólo si está catalogado BIC} Datos Jurídicos:

Código:
Estado:
Categoria:

Anotación Mo

Fecha Disposición:
Tipo delimitación:
Plan:
Informe:

Fecha informe:

Fecha Publicación BOP:

Fecha Publicación DOCV:

Fecha Publicación BOE:

\section{Fuente de Reinas}

\section{- Identificación}

Tramo de estudio:

Extramuros

Otras denominaciones:

Ref. catastral:

Localización: A $1 \mathrm{~km}$ de Requena por la carretera de Chera.

$\checkmark$ Existe actualmente

Incluido en fichas PGOU 2013

Bien de interés cultural (BIC)

cód. postal: 46340

Municipio: Requen

Comarca: Plana de Requena-Utie

Provincia: Valencia

Autonomia: Comunidad Valencian

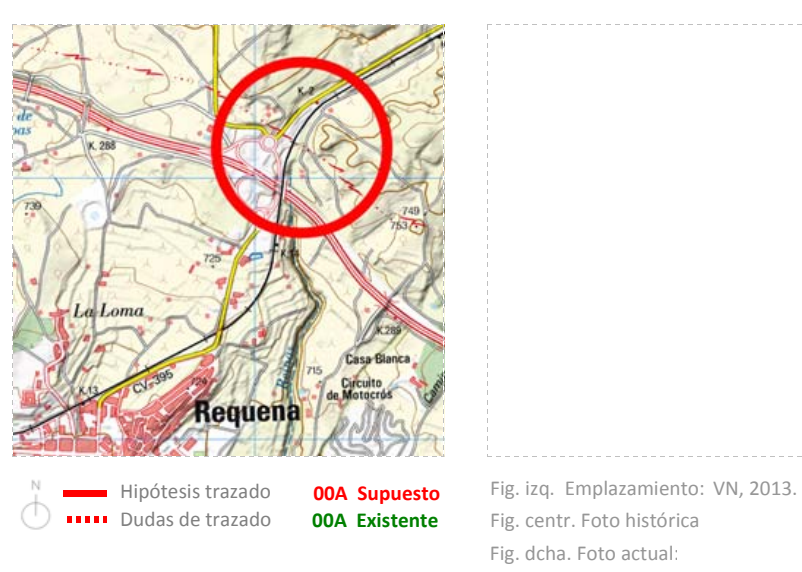

- Referencias en documentación histórica

Referencias numéricas en cartografía sobre fortificación

-Ref. en el croquis de Ortiz de Pinedo (1837-38, AGM, núm. 262): 021

-Ref. en plano de Vera Aparici (1993): Sin ref.

Referencias en memorias técnicas militares

-Ref. Guillermo Sáez (9/9/1834-5/12/1835): Sin ref.

-Ref. Guillermo Sáez (26/02/1836): Sin ref.

-Ref. P. Ortiz de Pinedo (12/03/1837-30/05/1837): Sin ref.

-Ref Jose María de Orozco (25/03/1838): Sin ref.

-Ref. Carbonell (4/7/1838): Sin ref.

\section{- Observaciones a partir de los informes militares}

Emplazada en la confluencia del regajo de Reinas con el antiguo camino de carros a Valencia que partía de la Puerta de Reinas (Según el croquis de Ortiz de Pinedo, SHM, num. 262). Tomó su nombre de los paseos que las Reinas de Castilla y Aragón (madre e hija, 'Na Violan $\square \frac{\text { Rellenar en caso de que el elemento sea }}{\text { contemplado con datos del PGOU, } 2013}$

PROTECCIÓN
Nivel de protección:
Entorno:
$\square$ Inmueble
$\square$ Parcela catastral
$\square$ Recinto arquitectónico
$\square$ Entorno específico

AFECCIÓN PATRIMONIAL

Bien de interés cultural (BIC)

(BRL)

$\square$ Afectado entorno BIC

$\square$ Afectado Plan especial 


\section{- Descripción histórico-arquitectónica}

Tipología:

ciones a la cronología

Descripción:

\section{- Entorno urbano}

Descripción entorno urbano:

Uso actual:

Estado de conservación:

Intervenciones:

Régimen Urbanístico:

Titularidad:

Nivel protección s/catálogo 1996:

Bibliografía: AMR, 1818-17, 1818-24; 1818-50; 1818-52; 1818-53.

Observaciones generales:

$\begin{array}{llll}\text { OBJETIVACIÓN DE INTERÉS } & \text { Soluciones constructivas } & \text { Soluciones ornamentales } & \text { Interés paisajistico } \\ \square \text { Interés tipológico } & \square \text { Estructura } & \square \text { Carpintería } & \square \text { Incidencia visual } \\ \square \text { Valor ambiental } & \square \text { Aleros } & \square \text { Rejería } & \square \text { carácter articulador } \\ \square \text { Vigencia de la trama } & \square \text { Coronación } & \square \text { Cubrepersianas } & \square \text { Organización } \\ \square \text { Composición de la fachada } & \square \text { Jambas } & \square \text { Alicatados } & \square \text { Interés cultural } \\ \square \text { Materiales, color, textura } & \square \text { Dinteles } & \square \text { Recercos } & \square \text { Carácter representativo } \\ & & \square \text { Dinteles } & \\ & \square \text { Otros ornamentos } & \end{array}$

\section{- Datos específicos catalogación BIC}

\section{$\square$ Rellenar sólo si está catalogado BIC}

$\begin{array}{lll}\text { Datos Jurídicos: } & & \\ \text { Código: } & \text { Fecha Disposición: } & \text { Fecha informe: } \\ \text { Estado: } & \text { Tipo delimitación: } & \text { Fecha Publicación BOP: } \\ \text { Categoría: } & \text { Plan: } & \text { Fecha Publicación DOCV: } \\ \text { Anotación Mo: } & \text { Informe: } & \text { Fecha Publicación BOE: }\end{array}$

\section{Molino de Reinas}

\section{- Identificación}

Tramo de estudio:

Extramuros

Otras denominaciones: Molino del batán de Reinas o molino de Alacué

Ref. catastral:

Localización: A $1 \mathrm{~km}$ de Requena por la carretera de Chera

Existe actualmente

Existe actualmente

$\square$ Bien de inteŕs cultural (BIC)

cód. postal: 4634

Municipio: Requena

Comarca: Plana de Requena-Utie

Provincia: Valencia

Autonomia: Comunidad Valenciana

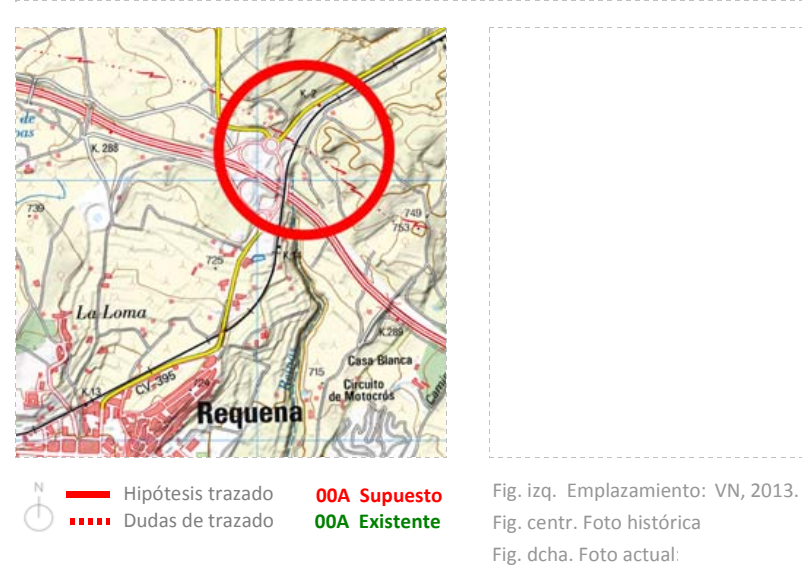

- Referencias en documentación histórica

\section{Referencias numéricas en cartografía sobre fortificación}

-Ref. en el croquis de Ortiz de Pinedo (1837-38, AGM, núm. 262): 020

-Ref. en plano de Vera Aparici (1993): Sin ref.

Referencias en memorias técnicas militares

-Ref. Guillermo Sáez (9/9/1834-5/12/1835): Sin ref.

-Ref. Guillermo Sáez (26/02/1836): Sin ref.

-Ref. P. Ortiz de Pinedo (12/03/1837-30/05/1837): Sin ref.

-Ref Jose María de Orozco (25/03/1838): Sin ref.

-Ref. Carbonell (4/7/1838): Sin ref.

\section{- Observaciones a partir de los informes militares}

Es un conjunto de edificaciones que se localizaban extramuros, siguiendo el camino de Carros a Valencia, que partía de la puerta de Reinas. Se encontraban muy próximas a la Fuente de Reinas, según el plano de Ortiz de Pinedo (SHM, núm. 262). El Molino de Reinas o de derecho a toda el agua del manantial todos los días de la semana, menos unas doce horas del Domingo. En la balsa se bañaban antes de guerra, Rafael Ruiz, enseñaba a nadar a la chiquillería que acudía al baño. Su actual propietario lo usa como almacén y corral. Poséía una piedra y el batán para lanas y mantas. Nombrado como Batán de Reinas en 'Respuestas Generales', Expedientes de Montes, 3ㅇ, siglo XVIII, del Archivo Municipal de Requena" (Argiles, 2006:357) 


\section{Rellenar en caso de que el elemento sea
contemplado con datos del PGOU, 2013}

\section{PROTECCIÓN}

Nivel de protección:

Entorno:

$\square$ Inmueble

$\square$ Parcela catastral

$\square$ Recinto arquitectónic
AFECCIÓN PATRIMONIAL

$\square$ Bien de interés cultural (BIC)

$\square$ Afectado entorno BIC

Afectado Plan especial

\section{- Descripción histórico-arquitectónica}

Tipología:

Cronología:

Observaciones a la cronología

Descripción:

- Entorno urbano

Descripción entorno urbano:

Uso actual:

Estado de conservación:

Intervenciones:

Régimen Urbanistico:

Titularidad:

Nivel protección s/catálogo 1996:

Bibliografia: AMR, 1818-17, 1818-24; 1818-50; 1818-52; 1818-53.

Observaciones generales:

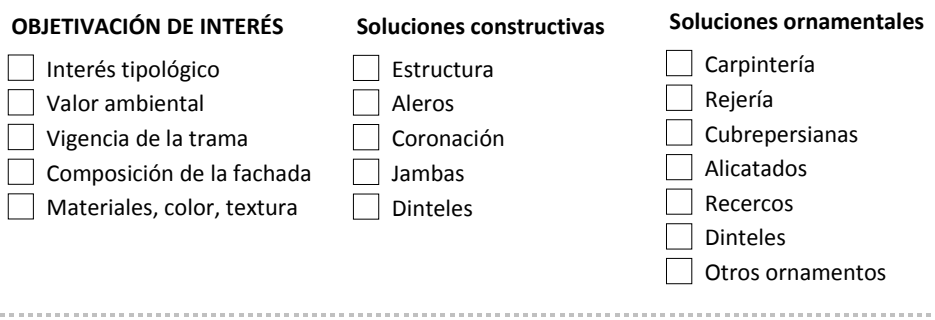

\section{- Datos específicos catalogación BIC $\square$ Rellenar sólo si está catalogado BIC}

Datos Jurídicos:

$\begin{array}{lll}\text { Código: } & \text { Fecha Disposición: } & \text { Fecha informe: } \\ \text { Estado: } & \text { Tipo delimitación: } & \text { Fecha Publicación BOP: } \\ \text { Categoria: } & \text { Plan: } & \text { Fecha Publicación DOCV: } \\ \text { Anotación } M \text { Mo: } & \text { Informe: } & \text { Fecha Publicación BOE: }\end{array}$

128 Las atalayas

\section{- Identificación}

Tramo de estudio: Extramuros

Otras denominaciones: Cerro de la Atalaya. Torre de telegrafía óptica del cerro de

Ref. catastral:

Localización: Partida del telégrafo

\section{$\checkmark$ Existe actualmente}

$\checkmark$ Incluido en fichas PGOU 2013

$\checkmark$ Bien de interés cultural (BIC)

cód. postal: 46340

Municipio: Requen

Comarca: Plana de Requena-Utie

Provincia: Valencia

Autonomia: Comunidad Valencian

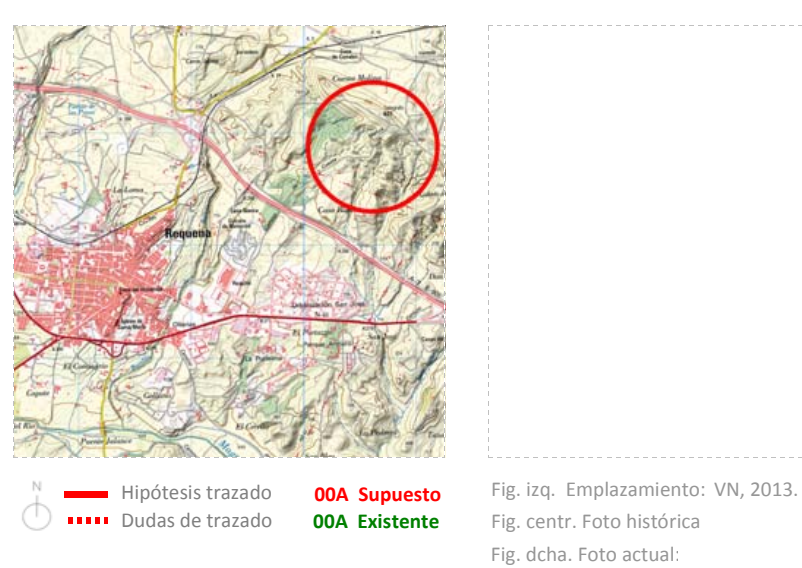

- Referencias en documentación histórica

Referencias numéricas en cartografía sobre fortificación

-Ref. en el croquis de Ortiz de Pinedo (1837-38, AGM, núm. 262): 022

-Ref. en plano de Vera Aparici (1993): Sin ref.

Referencias en memorias técnicas militares

-Ref. Guillermo Sáez (9/9/1834-5/12/1835): Sin ref.

-Ref. Guillermo Sáez (26/02/1836): Sin ref.

-Ref. P. Ortiz de Pinedo (12/03/1837-30/05/1837): Sin ref.

-Ref Jose María de Orozco (25/03/1838): Sin ref.

-Ref. Carbonell (4/7/1838): Sin ref.

\section{- Observaciones a partir de los informes militares}

Con este nombre define Ortiz de Pinedo a las cejas montañosas que encierran Requena, como prolongación de la Loma, al Este del Regajo de Reinas, y por tanto al Este de la ciudad,, definiendo un límite montañoso. En el denominado cerro de la Atalaya se emplazará un punto

\begin{tabular}{|c|c|}
\hline \multirow[t]{2}{*}{$\begin{array}{l}\text { Vellenar en caso de que el elemento sea } \\
\text { contemplado con datos del PGOU, 2013 }\end{array}$} & $\begin{array}{l}\text { PROTECCIÓN } \\
\text { Nivel de protección: } \\
\text { Entorno: }\end{array}$ \\
\hline & $\begin{array}{l}\square \text { Inmueble } \\
\square \text { Parcela catastral } \\
\square \text { Recinto arquitectónico } \\
\square \text { Entorno específico }\end{array}$ \\
\hline
\end{tabular}

AFECCIÓN PATRIMONIAL

$\checkmark$ Bien de interés cultural (BIC)

Bien de relevancia local (BRL)

Monumento

$\square$ Afectado entorno BIC

$\checkmark$ Entorno específico 


\section{- Descripción histórico-arquitectónica}

Tipología: Equipamientos colectivos, obras públicas

Cronología: 1848

Observaciones a la cronología:

Descripción: "Presenta las mismas características arquitectónicas que el resto de ejemplares de su tipo, con sillería en cadenas de esquina y recercados de huecos en piedra. El volumen de la torre está formado por un cuerpo principal prismático de dos plantas sobre zócalo fuertemente ataludado. Por una de las caras del zócalo se accede, a través de una gran puerta dintelada con arco rebajado de fábrica de ladrillo. A cada lado de la puerta, una aspillera perfora esta cara de la torre. El espacios interiores se resolvía mediante una escalera de caracol de planta cuadrada, situada en uno de los ángulos del interior. La estructura mural se conserva prácticamente íntegra, si bien los elementos leñosos. El mecanismo del telégrafo,

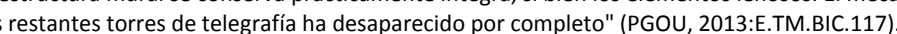

\section{- Entorno urbano}

Descripción entorno urbano:

"Situada entre la autovía A-3 y la vía del ferrocarril, hacia el noreste del actual acceso a Requena desde la autovía, en la parte alta del Monte de la Casa, desde donde se visualiza gran parte del término municipal. Se accede a través de un camino rural perpendicular a la autovía. El paisaje que la rodea es arbolado, destacándose las pinadas" (PGOU, 2013:E.TM.BIC.117).

Uso actual: Sin uso

Estado de conservación: Regular

Intervenciones:

Régimen Urbanistico: S. N. U.

Titularidad: Público

Nivel protección s/catálogo 1996:

Bibliografia: AMR, 1818-17, 1818-24; 1818-50; 1818-52; 1818-53,

Observaciones generales:

\begin{tabular}{|c|c|}
\hline OBJETIVACIÓN DE INTERÉS & Soluciones constructivas \\
\hline Interés tip & $\checkmark$ Estructura \\
\hline Valor ambien & $\square$ Aleros \\
\hline$\square$ Vigencia de la trama & $\checkmark$ Coronación \\
\hline$\square$ Composición de la fachada & $\square$ Jambas \\
\hline$\checkmark$ Materiales, color, textura & $\checkmark$ Dinteles \\
\hline
\end{tabular}

Soluciones ornamentales
$\square$ Carpintería
$\square$ Rejería
$\square$ Cubrepersianas
$\square$ Alicatados
$\square$ Recercos
$\square$ Dinteles
$\square$ Otros ornamentos

\section{Interés paisajistico}

$\checkmark$ Incidencia visual

$\square$ Carácter articulador

$\square$ Organización

$\checkmark$ Interés cultural

Carácter representativo

$\square$ Otros ornamentos

\section{- Datos específicos catalogación BIC $\vee$ Rellenar sólo si está catalogado BIC}

Datos Jurídicos:

Código: $46.17 .213-073$

Estado: Declaración genérica

Categoría: Monumento

Fecha Disposición: 15/3/2011

Fecha informe: 25/2/2013
Fecha Publicación BOP: $\quad 7 / 6 / 20$

Fecha Publicación DOCV:

Fecha Publicación BOE:

\section{Casa Blanca}

\section{- Identificación}

Tramo de estudio

Otras denominaciones: Cxtramuros

Ref. catastral:

Localización: Paraje de Casa Blanca

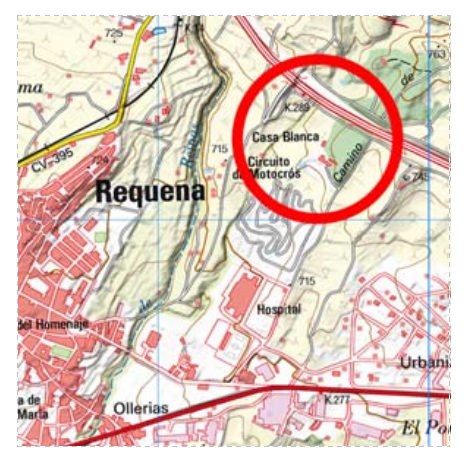

- Hi... Hótesis trazado

OOA Supuesto

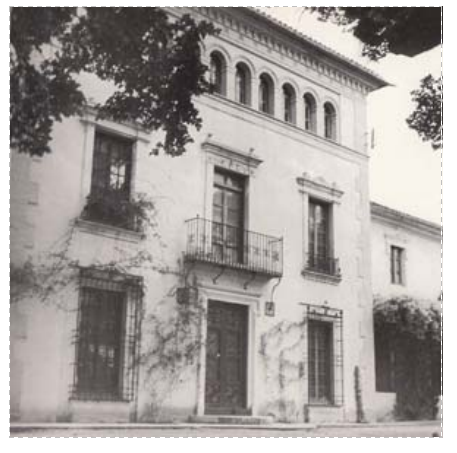

$\checkmark$ Existe actualmente

$\square$ Bien de interés cultural (BIC)

cód. postal: 46340

Municipio: Requena

Comarca: Plana de Requena-Utiel

rovincia: Valencia

Autonomía: Comunidad Valencian

\section{- Referencias en documentación histórica}

Referencias numéricas en cartografía sobre fortificación

-Ref. en el croquis de Ortiz de Pinedo (1837-38, AGM, núm. 262): 023

-Ref. en plano de Vera Aparici (1993): Sin ref.

Referencias en memorias técnicas militares

-Ref. Guillermo Sáez (9/9/1834-5/12/1835): Sin ref.

-Ref. Guillermo Sáez (26/02/1836): Sin ref.

-Ref. P. Ortiz de Pinedo (12/03/1837-30/05/1837): Sin ref.

-Ref Jose María de Orozco (25/03/1838): Sin ref.

-Ref. Carbonell (4/7/1838): Sin ref.

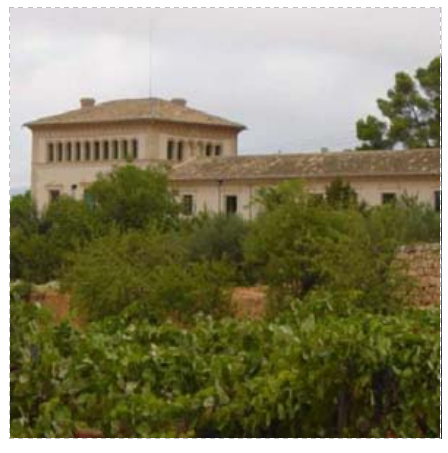

\section{- Observaciones a partir de los informes militares}

Identificada ya en el plano de Ortiz de Pinedo (SHM, núm. 262), Casa Blanca se ubica en la ribera oriental del Regajo de Reinas, a los pies del cerro de a Atalay. Se trata de una casa palacete del siglo XIX.

\section{Rellenar en caso de que el elemento sea
contemplado con datos del PGoU, 2013}

PROTECCIÓN

Nivel de protección: Parcial

Entorno:

$\square$ Inmueble

$\square$ Parcela catastral

Recinto arquitectónico
AFECCIÓN PATRIMONIAL

$\square$ Bien de interés cultural (BIC)

$\square$ Afectado entorno BIC

$\square$ Afectado Plan especial 


\section{- Descripción histórico-arquitectónica}

Tipología: Arquitectura civil

Cronología: s. XIX

Observaciones a la cronología:

Descripción: "Hermosa casa palacete del S. XIX, de planta irregular, con dos alturas y cámara, construida en mampostería enfoscada y pintada, cubierta con teja árabe con vertiente a cuatro aguas. Actualmente se está llevando a cabo un proceso de te artesonados de madera sobre los que se está actuando" (PGOU, 2013: E.TM.CAT.112).

- Entorno urbano

\section{Descripción entorno urbano:}

"La casa se localiza al noreste del núcleo urbano de Requena, muy próximo a la autovía A3 y al norte barrio de San José. Se encuentra en Uso a civa: Explotacín agraiavivenda

Uso acto : Explotacion agrariavivienda

Estado de consenvilon: Bueno

Intervenciones: $\mathrm{Si}$

Regrmentibanistico. S. N. U.

Titularidad: Privado

(1996: Bien inventariado

; 1818-52; 1818-53.

Observaciones generales:

\begin{tabular}{|c|c|c|}
\hline OBJETIVACIÓN DE INTERÉS & Soluciones constructivas & Soluciones ornamentales \\
\hline$\checkmark$ Interés tipológico & $\checkmark$ Estructura & $\checkmark$ Carpintería \\
\hline$\checkmark$ Valor ambiental & $\square$ Aleros & Rejería \\
\hline Vigencia de la trama & $\checkmark$ Coronación & $\square$ Cubrepersianas \\
\hline$\checkmark$ Composición de la fachada & $\square$ Jambas & $\square$ Alicatados \\
\hline $\bar{\nabla}$ Materiales, color, textura & $\bar{\nabla}$ Dinteles & $\begin{array}{l}\square \text { Recercos } \\
\square \text { Dinteles } \\
\square \text { Otros }\end{array}$ \\
\hline
\end{tabular}

Interés paisajistico

$\nabla$ Incidencia visual

$\square$ Carácter articulado

$\checkmark$ Organización

$\checkmark$ Interés cultural

$\checkmark$ Carácter representativo

Otros ornamentos

- Datos específicos catalogación BIC $\square$ Rellenar sólo si está catalogado BIC Datos Jurídicos:

Código:

Estado:

Fecha Disposición:

Tipo delimitación:

Anotación Mo:

Plan:

Fecha informe:

Fecha Publicación BOP:

Fecha Publicación DOC:

Fecha Publicación BOE:

11 Concussiones 
El concepto de "reino mágico" de Cabrera que titula la presente tesis y que se extrae del testimonio de von Rahden (2013: 271), como se ha desarrollado en el apartado 1.2, sintetiza diversos aspectos relevantes que han surgido de este viaje por la historia de un conflicto y por un territorio singular. Como se ha comentado, von Rahden parece pretender forjar en el imaginario internacional una magen mítica de este lugar en torno a la figura del conde de Morella. Esta imagen se asocia al enclave en que el carlismo consolida un control estable det constructivos entre los años 1938 y 1940

A partir del estudio de las fuentes, los acontecimientos, los hitos arquitectónicos y el territorio, se consolida la idea de que el concepto de "reino mágico" de Cabrera, utilizado por von Rahden, es un instrumento para la construcción de un mito que, como tal, acaba haciendo verosímil una realidad dudosa, creíble, pero que extiende una sombra sobre la verdadera existencia de aquel reino. El reino adquiriría consistencia si existiera un límite menos maleable en el tiempo que permitiera definir un dentro y un afuera. Dentro de ese límite existiría un control carlista. Sin embargo, se constata que ese control es un control aparente, o simultáneo al control del territorio por parte de los liberales a partir de otras plazas clave añ ons y lo vías principales que atraviesan el reino. Los "caminos e perdices" a los que hace referencia von Rahden hacen del supuesto tritoro carlista un territorio fragmentado fuera de las principales vías de comunicación, y que es carlista en la medida que las huestes campan o transitan por él hasta la llegada de los efectivos liberales. La permanencia del reino es proporcional al grado de distracción del enemigo y es efímera en la medida que se extingue en el momento en que el ejército liberal centra la totalidad de sus efectivos en la toma de sus principales plazas: Cantavieja y Morella.

Sin embargo, las características de la guerra, que tienen mucho que ver con las características del paisaje, de la historia del territorio, de sus construcciones y fortificaciones, sí que definen un límite de un "territorio m de un "territorio te esa imagen in también esta idea. Así, Don Beltrán de Urdaneta, cuando recaba información acerca de lo que ocurre en los territorios en conflicto en el parador de Viscarrués, en Fuentes de Ebro, concluye que "desde que llegó a Fuentes de Ebro todo le anunciaba la entrada en el reino de lo excepcional y maravilloso. Nada era ya común y vulgar. Personas y cosas traian la impresión de un mundo trágico, el cuño de una poesia ruda y libre, emancipada de toda regla" (Pérez Galdós, 1993: 2429). Más adelante, un oficial le advierte que la guerra «ha resucitado en el país la Edad Media, tan bien acomodada a su naturaleza bravía, a la rudeza de sus habitantes y a la muchedumbre de castillos, monasterios y santuarios que por todas partes se ven" (Pérez Galdós, 1993:2436). Un viejo pastor insiste en esta idea romántica: "si aceptamos la ficción de hallarnos en plena Edad Media. Prepárese usted si persiste en penetrar en el país, a ver milagros, hazañas, casos inauditos de Edad Media. Prepárese usted si persiste en penetrar en el país, a ver milagros, hazañas, casos inauditos de
santidad o sortilegio, brujas, duendes, apariciones; subterráneos que empiezan en un castillo y acaban en un monasterio a siete leguas de distancia; verá usted hombres feroces, hombres heroicos, mujeres endemoniadas o angelicadas; verá usted, en fin, a la hermosa y andante Marcela, con aliento guerrero y olorcillo a santidad, corriendo por montes y barrancos..." (Pérez Galdós, 1993: 2437). 


\subsection{Sobre el territorio físico y la estrategia defensiva territorial}

- La presente tesis identifica un conjunto de plazas convertidas en puntos fortificados de la red defensiva carlista, estructurada durante el establecimiento, expansión, consolidación y repliegue del frente carlista del Maestrazgo, que afecta a las actuales provincias de Castellón, Valencia, Cuenca, Albacete, Teruel, Zaragoza, Lérida, Barcelona y Tarragona.

Tabla 7. Número de plazas identificadas por provincias.

Cód. Provincias en la época $\% \mathrm{~N}^{\circ}$ plazas identificadas Provincia de Barcelo

1,3

CS Provincia de Castellón

CU Provincia de Cuenca en la época

19,2

LL Provincia de Lleida

T Provincia de Tarragona

TE Provincia de Terue

V Provincia de Valencia en la época

-A partir del conjunto de fuentes históricas, incluyendo los testimonios de la época, y de la ubicación de las plazas, se concluye un planteamiento estratégico global que hace del denominado "reino mágico" de Cabrera un gran territorio fortificado, concebido como una red de campos volantes, donde los elementos naturales, especialmente accidentes geográficos, son tratados como elementos clave de la fortificación, junto a una red orbital de poblaciones tributarias que se organizan de un clave de la fortificación, junto a una red orbital de poblaciones tributarias que se organizan de un
modo jerárquico en torno a un conjunto de plazas fuertes. Las primeras, si bien tienen como referencia simultánea o alternante las posiciones de Morella o Cantavieja, pueden operar descabezadas.

-Llegados a este punto es conveniente distinguir entre los sueños u objetivos militares tácticos y estratégicos carlistas y la realidad consolidada. Los acontecimientos históricos, como muchas fuentes han esgrimido, permiten definir una cronología de control del territorio a partir de los procesos de ocupación o abandono de las plazas fuertes. Se puede coincidir con los planteamientos de autores precedentes que en el caso de la Guerra del Maestrazgo se identifican diferentes fases que obedecen a la lógica de todo proceso revolucionario que se extingue desde una fase de alzamiento, una fase a la lógica de todo proceso revolucionario que se extingue desde una fase de alzamiento, una fase
de consolidación, una fase de complemento a las estrategias carlistas en el ámbito nacional, una fase de consolidación, una fase de complemento a las estrategias carlistas en el ámbito nacional, una fase
de resistencia a partir de Vergara y una fase final de repliegue ante la ofensiva liberal. Se ofrece a continuación una propuesta cronológica de las fases de la guerra en Maestrazgo en relación con los criterios de fortificación del territorio. 


\begin{tabular}{|c|c|c|}
\hline $\begin{array}{l}\text { I PERIODO } \\
\text { (13 noviembre } \\
1833-10 \\
\text { diciembre } \\
\text { 1833) }\end{array}$ & $\begin{array}{l}\text { Morella como } \\
\text { base única }\end{array}$ & $\begin{array}{l}\text { Morella como primera base fortificada: almacenamiento de suministros, } \\
\text { control administrativo y otras necesidades. La ciudad cae en manos carlistas a } \\
\text { las pocas semanas de iniciarse la contienda. }\end{array}$ \\
\hline $\begin{array}{l}\text { II PERIODO } \\
\text { (10 diciembre } \\
\text { 1833-marzo } \\
\text { 1836) }\end{array}$ & $\begin{array}{l}\text { Fortificación de } \\
\text { los puertos de } \\
\text { Beceite }\end{array}$ & $\begin{array}{l}\text { Tomada Morella, los carlistas son conscientes de la necesidad de contar con } \\
\text { una base fortificada. Los puertos de Beceite suponen una oportudidad, pues } \\
\text { se trata de un territorio difíilmente accesible, propicio para el refugio de las } \\
\text { partidas carlistas cuando son acosadas por las columnas liberales. Beceite, } \\
\text { dado su acceso estrecho siguiendo el Matarraña y enclavado en una garganta } \\
\text { fácil de defender, rodeada de montañas, es un lugar ideal. Conscientes de ello, } \\
\text { los liberales dejan una guarnición en Beceite, lo que impide que los carlistas } \\
\text { la ocupen y fortifiquen. En } 1834 \text { los carlistas sitian a la guarnición. Cuando } \\
\text { llega la columna de auxilio del coronel Rebollo encuentra a los carlistas } \\
\text { posicionadosen las alturas. Los liberales desalojan a los carlistas y destruyen } \\
\text { aquellas fortificaciones (Pirala, 1984: 334; Caridad, 2013:246). En agosto } \\
\text { de 1835, los carlistas reducen al destacamento liberal (Córdoba, 1844: 190; } \\
\text { Segura, 1991:103,114). Los puertos de Beceite se convierten en base carlista, } \\
\text { con taller para armamento, indumentaria y campamento de adiestramiento } \\
\text { (Pirala, 1984:307, 334; Caridad, 2013: 2466). Se desconoce si existe algún tipo de } \\
\text { fortificación más allá de la arquitectura preexistente o las barreras naturales, } \\
\text { pero parece lógico si se han detectado esfuerzos constructivos en momentos } \\
\text { anteriores. De haber algún trabajo avanzado, es destruido por la columna } \\
\text { liberal de Churruca, que ocupa el lugar en marzo de } 1836 \text { (Pirala, 1984: } 72 \text { ). } \\
\text { Esta ocupación supone que los carlistas se lancen a fortificar otros puntos del } \\
\text { Maestrazgo. }\end{array}$ \\
\hline $\begin{array}{l}\text { III PERIODO } \\
\text { (marzo 1836-31 } \\
\text { octubre 1836) }\end{array}$ & $\begin{array}{l}\text { Primer intento de } \\
\text { fortificación del } \\
\text { Maestrazgo }\end{array}$ & $\begin{array}{l}\text { Tras perder Beceite, los carlistas tratan de fortificar otros puntos del Maestrazgo. } \\
\text { En la primavera de } 1836 \text { construyen una línea de reductos y trincheras desde } \\
\text { la Sénia al Martinete y por el camino de Benifassà (Diario Mercantil de Valencia, } \\
4 \text { de junio de } 1836 ; \text { Pirala, 1984: } 75 \text {; Caridad, 2013: 246). Construyen parapetos } \\
\text { dominando las alturas de Chert, así como una pared aspillerada en el peñasco } \\
\text { de La Muela (Diario Mercantil de Valencia, } 4 \text { de julio de 1836). En esta época } \\
\text { se emprenden las reparaciones del castillo de Culla, donde se registra una } \\
\text { guarnición de } 60 \text { hombres. En los meses de mayo y junio de 1836, las columnas } \\
\text { liberales de Iriarte y Buil se dedican a interceptar este conjunto de obras para } \\
\text { impedir que estén operativas, volviendo a replegar a los carlistas a Beceite. } \\
\text { En abril de } 1836 \text {, Cabrera, enterado de que los liberales quieren fortificar } \\
\text { Cantavieja, se anticipa, la fortifica y abastece para resistir un asedio. Vid. } \\
\text { fortificación de Cantavieja. Pero la plaza fue tomada por el mariscal Evaristo } \\
\text { San Miguel el } 31 \text { de octubre de 1836 (Diario Constitucional de Zaragoza, } 5 \text { de } \\
\text { noviembre de } 1836 \text {; Córdoba, 1844:145, 149; Caridad, 2013: 249). Poco más } \\
\text { tarde, los carlistas son expulsados de los puertos de Beceite. }\end{array}$ \\
\hline
\end{tabular}

\begin{tabular}{|c|c|c|}
\hline $\begin{array}{l}\text { IV PERIODO } \\
\text { (31octubre } \\
\text { 1836-1 enero } \\
1837)\end{array}$ & $\begin{array}{l}\text { Refortificación de } \\
\text { Beceite }\end{array}$ & $\begin{array}{l}\text { Desplazados, los carlistas vuelven a fortificar los puertos de Beceite. Las obras } \\
\text { duran } 6 \text { meses y en ellas trabajan entre } 150 \text { y } 200 \text { operarios (Diario Constitucional } \\
\text { de Zaragoza, } 14 \text { de enero de } 1837 \text { ). Precisamente estas fortificaciones son } \\
\text { detalladas por el general Nogueras (Diario Constitucional de Zaragazaza, } 14 \text { de } \\
\text { enero de 1837, Diario Mercantil de Valencia, } 21 \text { de enero de 1837, Caridad, } \\
2013: 247 \text { ). La fortificación que describe Nogueras hace referencia al territorio, } \\
\text { y no solo a la actual localidad. Se valora el aprovechamiento de la posición } \\
\text { natural. No obstante, no la pueden defender por falta de víveres y municiones } \\
\text { y ellos mismos destruyen lo construido, siendo la posición ocupada por } \\
\text { los liberales el } 1 \text { de enero de } 1837 \text { (Córdoba, 1844:153; Diario Constitucional } \\
\text { de Zaragoza,3 y } 14 \text { de enero de 1837, El Satanás, 21 de enero de 1837, Diario } \\
\text { Mercantil de Valencia, } 21 \text { de enero de 1837, Caridad, 2013:248). }\end{array}$ \\
\hline $\begin{array}{l}\text { V PERIODO } \\
(1 \text { enero } 1837- \\
25 \text { abril 1837) }\end{array}$ & $\begin{array}{l}\text { Conquista de } \\
\text { fuertes enemigos }\end{array}$ & $\begin{array}{l}\text { Sin ninguna base, deciden priorizar la toma de plazas, y se deciden a recuperar } \\
\text { Cantavieja, iniciando esta nueva estrategia. }\end{array}$ \\
\hline $\begin{array}{l}\text { VI PERIODO } \\
25 \text { abril 1837- } \\
26 \text { enero 1838) }\end{array}$ & $\begin{array}{l}\text { Toma de } \\
\text { Cantavieja }\end{array}$ & $\begin{array}{l}\text { La toma de Cantavieja se hace efectiva el } 25 \text { de abril de } 1837 \text { (Mercantil de } \\
\text { Valencia, } 7 \text { de mayo de 1837; Córdoba, 1844: 212-213, 321-323; Caridad, 2013: } \\
\text { 249). Por su parte, Morella es conquistada en enero de } 1838 \text { y se convierte en la } \\
\text { capital del carlismo valenciano-aragonés. }\end{array}$ \\
\hline $\begin{array}{l}\text { VII PERIODO } \\
(26 \text { enero 1838- } \\
31 \text { agosto 1839) }\end{array}$ & $\begin{array}{l}\text { Fortificación } \\
\text { de pueblos } \\
\text { aragoneses y } \\
\text { valencianos }\end{array}$ & $\begin{array}{l}\text { Base de control del territorio y base de operaciones. Se trata de dificultar las } \\
\text { operaciones del enemigo con un conjunto de operaciones que se plantean } \\
\text { como estrategia ante un futuro avance peninsular carlista. Vergara supone la } \\
\text { asunción de una defensa de contención. }\end{array}$ \\
\hline $\begin{array}{l}\text { VIII } \\
\text { PERIODO (31 } \\
\text { agosto 1839- } \\
\text { julio 1840) }\end{array}$ & $\begin{array}{l}\text { Fortificación } \\
\text { de resistencia y } \\
\text { asedio }\end{array}$ & $\begin{array}{l}\text { El acuerdo de Vergara desencadena que toda la atención militar liberal se } \\
\text { centre en el frente del Maesterazgo. Sucesión de ataques liberales a plazas } \\
\text { fuertes carlistas. }\end{array}$ \\
\hline
\end{tabular}

Como se ha explicado en la introducción a este trabajo, Cabrera concibe su "reino" como una gran fortificación, donde los elementos naturales son parte de sus elementos defensivos, los ríos hacen de fosos, sus riberas de caminos cubiertos, los escarpes rocosos de escarpas y las cimas de caballeros. Al trazar las posiciones consolidadas por Cabrera en su momento álgido, y apoyándonos en el plano que traza las líneas tácticas del "reino mágico" de Cabrera, podríamos distinguir unas líneas defensivas asociadas a las diferentes plazas fuertes. 


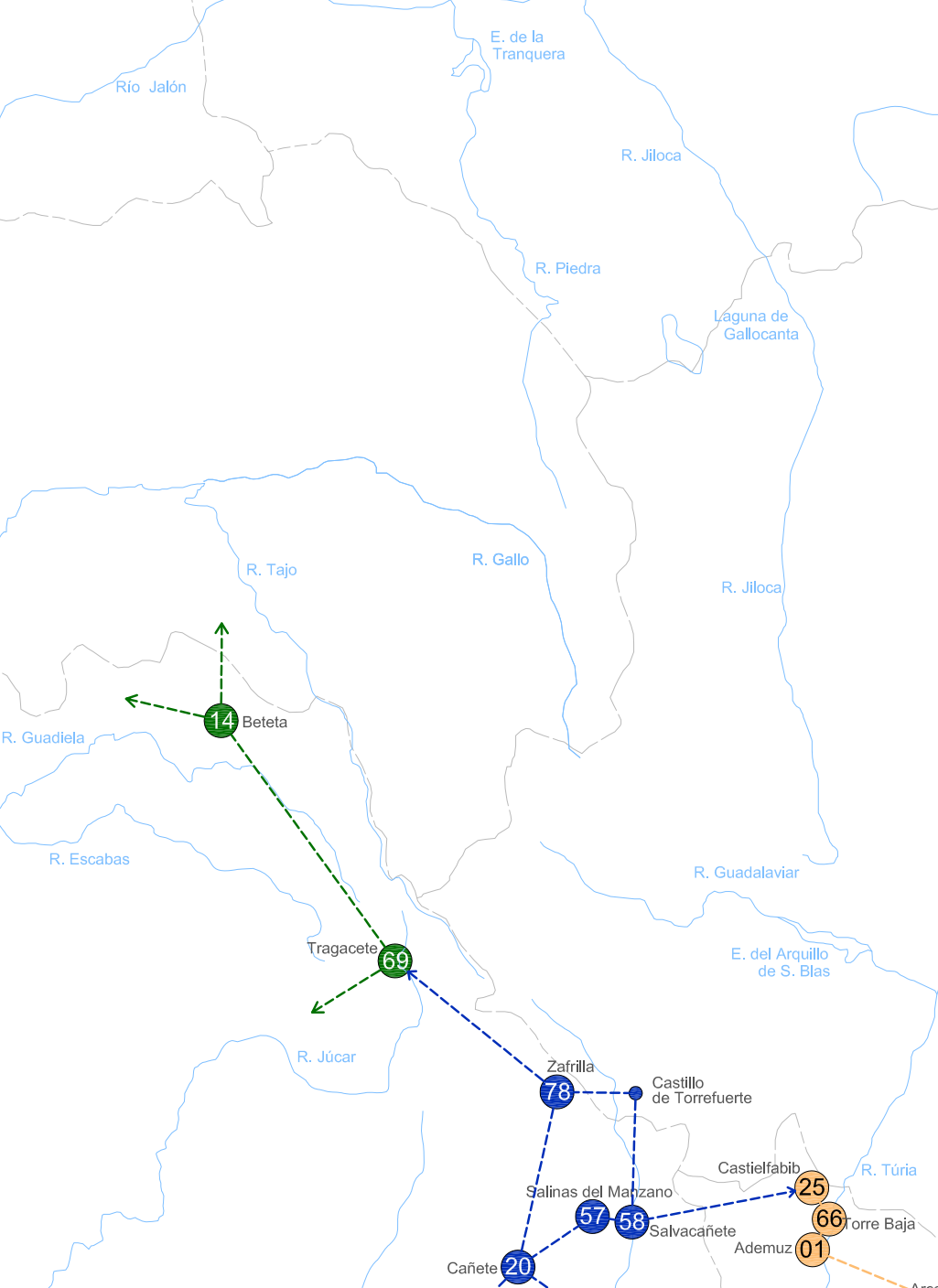

$$
19
$$

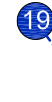

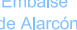

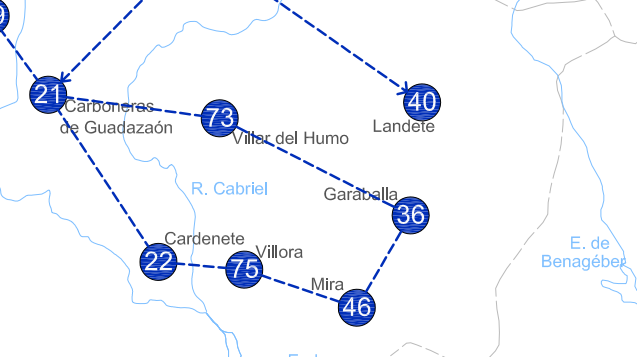

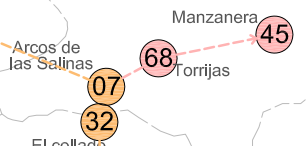

$06 \quad$ Beis 11

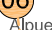

Cheve 2765 28 cruila

(71) Utiel

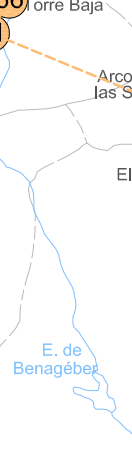

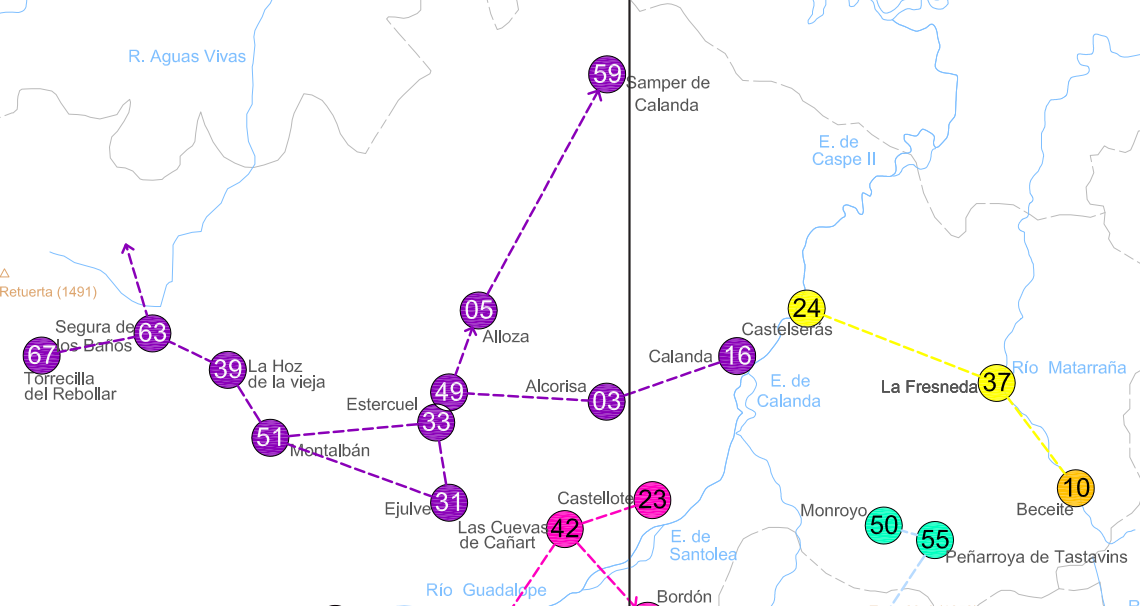

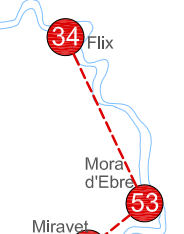

Fig. 829. Líneas defensivas del "reino mágico" de Cabrera.

(01) El gran bastión montañoso de la altiplanicie de Aragón y Valencia

(02) La fortificación de la cuenca media del Turia

(03) La doble línea de comunicación entre la cuenca media del Turia y la altiplanicie

(04) El frente sur de la altiplanicie

(05) El frente suroriental de la altiplanicie

(06) El gran frente oriental de la altiplanicie

(07) La comunicación mediterránea

(08) La línea defensiva del Matarraña

(09) El bastión de Beceite

(10) La linea de comunicación del Sénia

_11) La linea defensiva del Ebro

_12 La linea del Guadalope, o defensa septentrional de la altiplanicie

(13) El reducto avanzado septentrional

(14) La línea ofensiva del Cabriel

15 La llave de Castilla o las cabezas ofensivas del Júcar y el Tajo

(16) El reducto final: Berga 
1. El gran bastión montañoso de la altiplanicie de Aragón y Valencia, dominado por las plazas de Morella y Cantavieja que ocupan el corazón del sistema, que en el mapa adjunto estaría confinado entre las alturas de Torre Miro al norte, Penyagolosa al sur y Peñarroya al suroeste. $Y$ se y el Guadalope al Noroeste. En este macizo se complementan las posiciones de Mirambel y Forcall resguardadas por ambas plazas fuertes.

2. La fortificación de la cuenca media del Turia constituiría otro de los grandes conjuntos defensivos de la red fortificada de Cabrera, integrada por fortificaciones de envergadura como Chulilla, Chelva, Alpuente, el Collado, Arcos y Castielfabib.

Esta línea de puntos defensivos acompaña el valle del Turia. Sus grandes valores serían la posición de Chelva y la de Alpuente. Precisamente en Chelva se repliegan todas las intentonas de invasión de la meseta, donde Utiel es la cabeza de puente. Precis de Ademuz, Castielfabib articula un conjunto defensivo junto a la propia Ademuz y Torrebaja. Avanzando sobre Lliria y protegiendo el acceso a Chelva, capital de este conjunto defensivo desde la posición liberal, encontraríamos el fuerte de Domeño y Torre de Castro.
3. La doble línea de comunicación entre la cuenca media del Turia y la altiplanicie. La comunicación carlista entre la cuenca media del Turia y la altiplanicie es interceptada por el paso del río Palancia, al sur, en cuya desembocadura se posiciona la plaza fuerte de Murviedro (Sagunto), y que enlaza hacia el interior las posiciones fuertes liberales de Segorbe y Jérica. Al norte de esta línea, como una doble barrera, se emplaza el curso del Mijares, que enlaza las posiciones de Vila-real y Onda con Mora de Rubielos. Ambas líneas refuerzan el camino hasta Teruel. Precisamente para sortear esta doble línea se establecen dos cabezas de puente, dos líneas de comunicación carlistas que pretenden franquear esta barrera en puntos alejados de las principales posiciones liberales. Así. al norte de Jérica se consolida la posición de Bejís para interceptar el camino de Teruel o sortearlo, comunicando con las posiciones carlistas de Montán, Ayódar o Tales, entre el Palancia y el Mijares. En dirección a Teruel, entre Jérica y Mora de Rubielos, desciende la otra cabeza de puente integrada por las posiciones de Torrijas y Manzanera que, a través de Albentosa, apoya un nuevo cruce del a dealá de la Selva, Linares de Mora, o Villahermosa del Río.

4. El frente sur de la altiplanicie define dos líneas defensivas, una al sur controlando la ribera sur del Mijares, y otra al norte controlando el área septentrional del Mijares o las faldas meridionales del Penyagolosa al sur y del Peñarroya al norte. En la primera línea se encuentran, de este a oeste, las plazas de Tales, Ayodar y Montán; en la segunda línea, el castillo de Villamalefa, Villahermosa del Río, Linares de Mora y Alcalá de la Selva. Esta última, frente a Teruel, constituye el tapón defensivo para evitar que desde esta capital liberal se puedan lanzar efectivos hacia Cantavieja.

\section{DII}

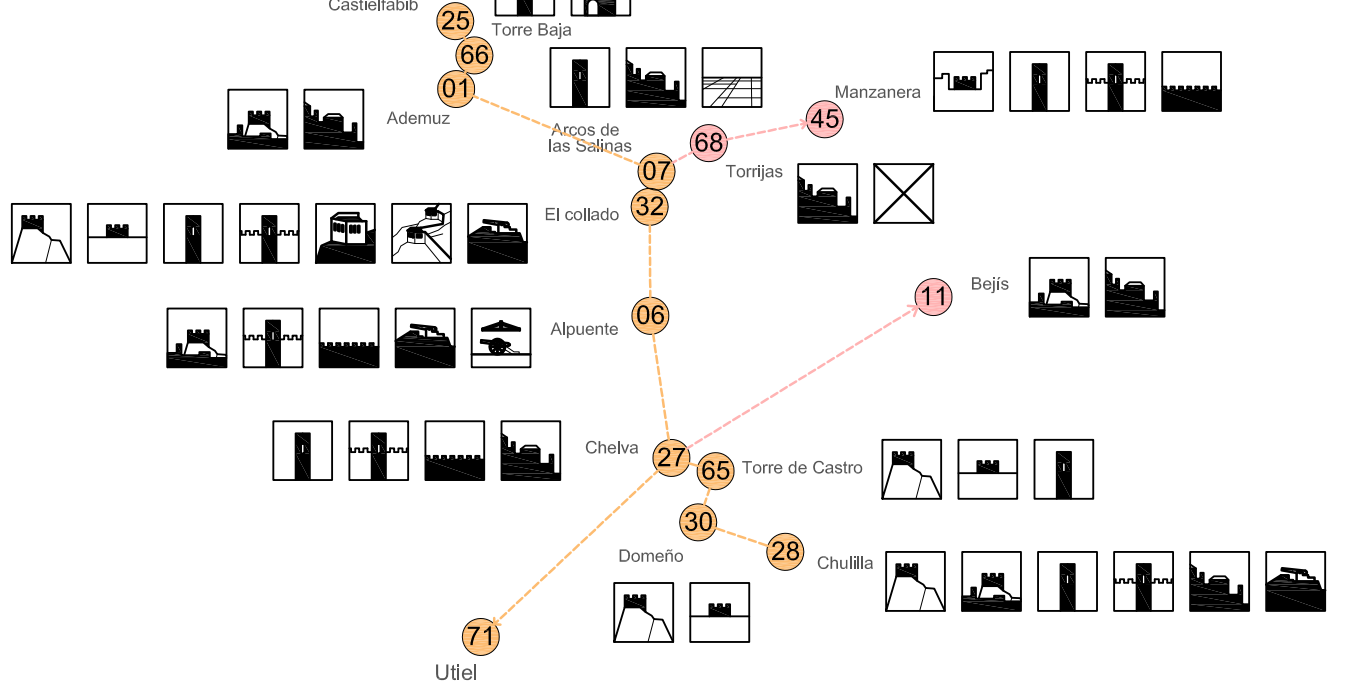

\pm 垪 0 
5. El frente suroccidental de la altiplanicie. En el sector oriental de la altiplanicie, algunas de las fortificaciones anteriores integran una tenaza de sur a norte que frena los avances desde Onda, siguiendo el Mijares, o desde Lucena, siguiendo el río Montlleó, que en definitiva son reforzadas desde la capital liberal de la Plana. Esta tenaza está constituida por las posiciones de Tales, Castillo de Villamalefa, Villahermosa del Río y Culla. Culla enlazaría hacia el norte con Ares del Maestre que se convierte en la llave del camino hacia Morella desde el sur. Todas estas posiciones carlistas amenazan sobremanera la posición de Lucena que es, a su vez, la llave liberal defensiva de la capital de la Plana: Castellón.

6. El gran frente oriental de la altiplanicie. La altiplanicie que conecta Cantavieja y Morella define su frente oriental de norte a sur con las posiciones de Peñarroya de Tastavins, Morella y Ares del Maestre. Como se ha indicado con anterioridad, Ares es la llave de Morella desde el sur y extiende su dominio a la rambla de la Viuda. Precisamente Morella actúa como el gran caballero de este tridente y permite avanzar por la ribera sur del Cèrvol y desembarcar en los planos de Alcalá y Vinaròs. Al norte, Peñarroya constituye un bastión intermedio entre Morella y la línea del Matarraña, apoyada por Monroyo, ambas plazas al norte de Torre Miró.

7. La comunicación mediterránea. Precisamente el camino de Vinaròs, punto marítimo de resistencia liberal, es un camino clave para frenar los ataques a Morella. Cabrera pretende interceptar conexión costera entre Vinaròs y Castellón, por lo que trata de ocupar las posiciones de Xert, Sant Mateo y Càlig e, incluso, dominar Benicarló. Cree encontrar allí el punto ideal protegido para el atraque de pequeñas embarcaciones que favorezca una vía de suministro insospechada e incluso hacer realidad el sueño de una flota carlista que es pronto desdibujado por el rotundo dominio liberal del mar. Con esta línea Cabrera puede amenazar Vinaròs, dificultar el tránsito por la carretera desde la costa a Morella y depredar la plana de Alcalá o el litoral costero, con sus huertas, como hace al atacar Torreblanca.

\section{田国回}

$$
\text { de la sealva } 02
$$

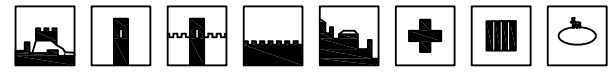
(29) Culla
(44)

政田国 (72)

26

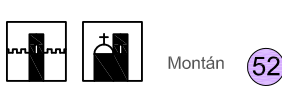

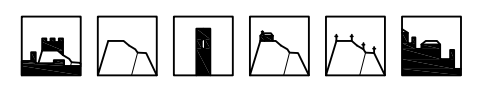

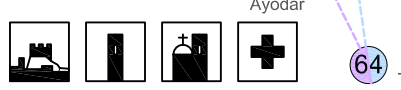

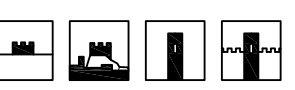

8. La línea defensiva del Matarraña. Al norte de la altiplanicie se plantea un frente defensivo que conecta con el Guadalope aguas arriba de Calanda, en Castelserás, y al sur de Alcañiz, y busca acompañar el curso del Matarraña por La Fresneda, Valderrobres hasta los puertos de Beceite.

9. El bastión de Beceite. Los puertos de Beceite constituyen el gran bastión carlista, una especie de reducto defensivo en el que se pueden refugiar con seguridad los carlistas en el embrión del alzamiento, en el primer repliegue y en la fase final. De algún modo, los puertos de Beceite constituyen la gran conexión con el ejército carlista de Cataluña e incluso con la línea del Ebro y, por tanto, el gran ejército del norte. Cuando la guerra concluya en el norte, Beceite representa la puerta que permite la escapada al exilio. Precisamente en Beceite nace hacia el norte la línea del Matarraña y, hacia el sur, la línea del Sénia, que conecta con el Ebro.

$$
\text { (4) }
$$$$
\text { DI D四 }
$$
(37)

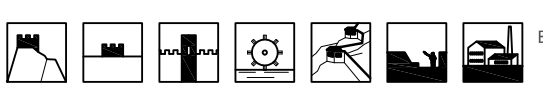

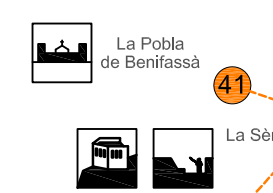$$
\text { Becete } 10
$$

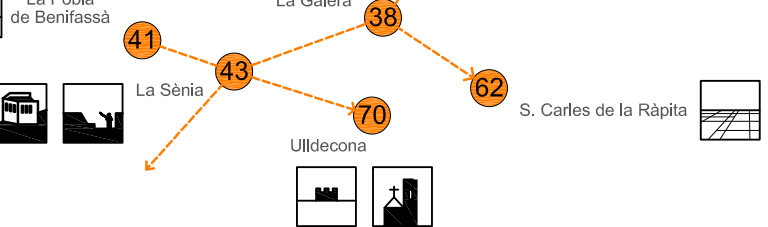

\section{El frente sur de la altiplanicie \\ El frente suroriental de la altiplanicie}

Fig. 832. Líneas defensivas del "reino mágico" de Cabrera.

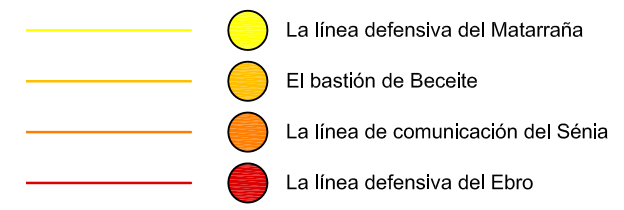

Fig. 833. Líneas defensivas del "reino mágico" de Cabrera. $\longleftarrow 10 \mathrm{~km} . \quad$

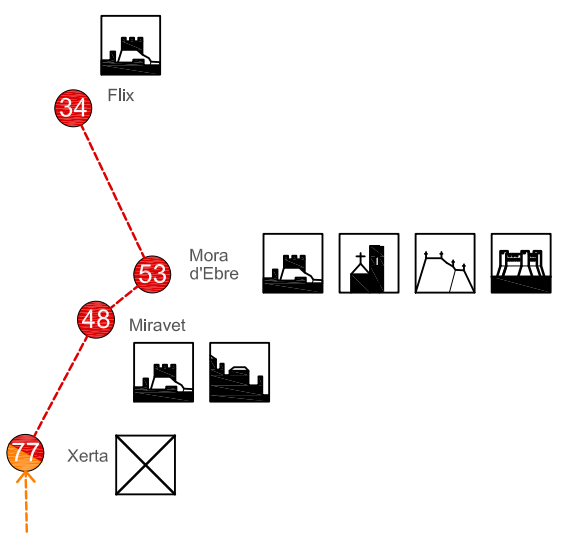

61 Sta. Bàrarar 0

$10 \mathrm{Km} . \quad 20 \mathrm{~km} . \quad 30 \mathrm{~km} . \quad 40 \mathrm{Km} . \quad 50 \mathrm{~km}$. 
10. La línea de comunicación del Sénia. Como indicábamos, desde Beceite los carlistas pueden conectar con las posiciones del Sénia, que se extienden desde el nacimiento del río con las posiciones en el monasterio de Benifassà y La Sénia. Precisamente en esta línea tratarán los carlistas de activar el martinete y defenderse de las numerosas incursiones liberales. La línea del Sénia permite conectar a través de Rossell con las posiciones de Xert y San Mateo, mientras que hacia el norte, buscando el Ebro, alinean varios puntos defensivos que enlazan La Sénia, La Galera, el Molí de Vallés y Xerta el Ebro, alinean varios puntos defensivos que enlazan La Sénia, La Galera, el Molí de Vallés y Xerta, cabeza de puente de la ribera sur del Ebro, equidistante de las posiciones de Amposta-Tortosa y posición provisional de Sant Carles de la Rápita que permite el acceso a sus salinas y a la desembocadura del Ebro. Se supone que esta posición se liga a la línea del Sénia a través de las montañas más que a las posiciones del Ebro debido la dificultad de conexión siguiendo el curso del Ebro por la presencia de los fuertes liberales de Amposta y Tortosa. También se establece una conexión entre la línea de la Sénia y Ulldecona, que permite controlar los accesos directos desde Vinaròs.

11. La línea defensiva del Ebro. La denominada línea del Ebro domina el curso del Ebro aguas arriba de Tortosa con Xerta, Miravet, Móra d'Ebre y Flix y favorece la comunicación con las posiciones del carlismo catalán, resultando efectiva en el momento final al facilitar el cruce del ejército de Cabrera rumbo a Berga.
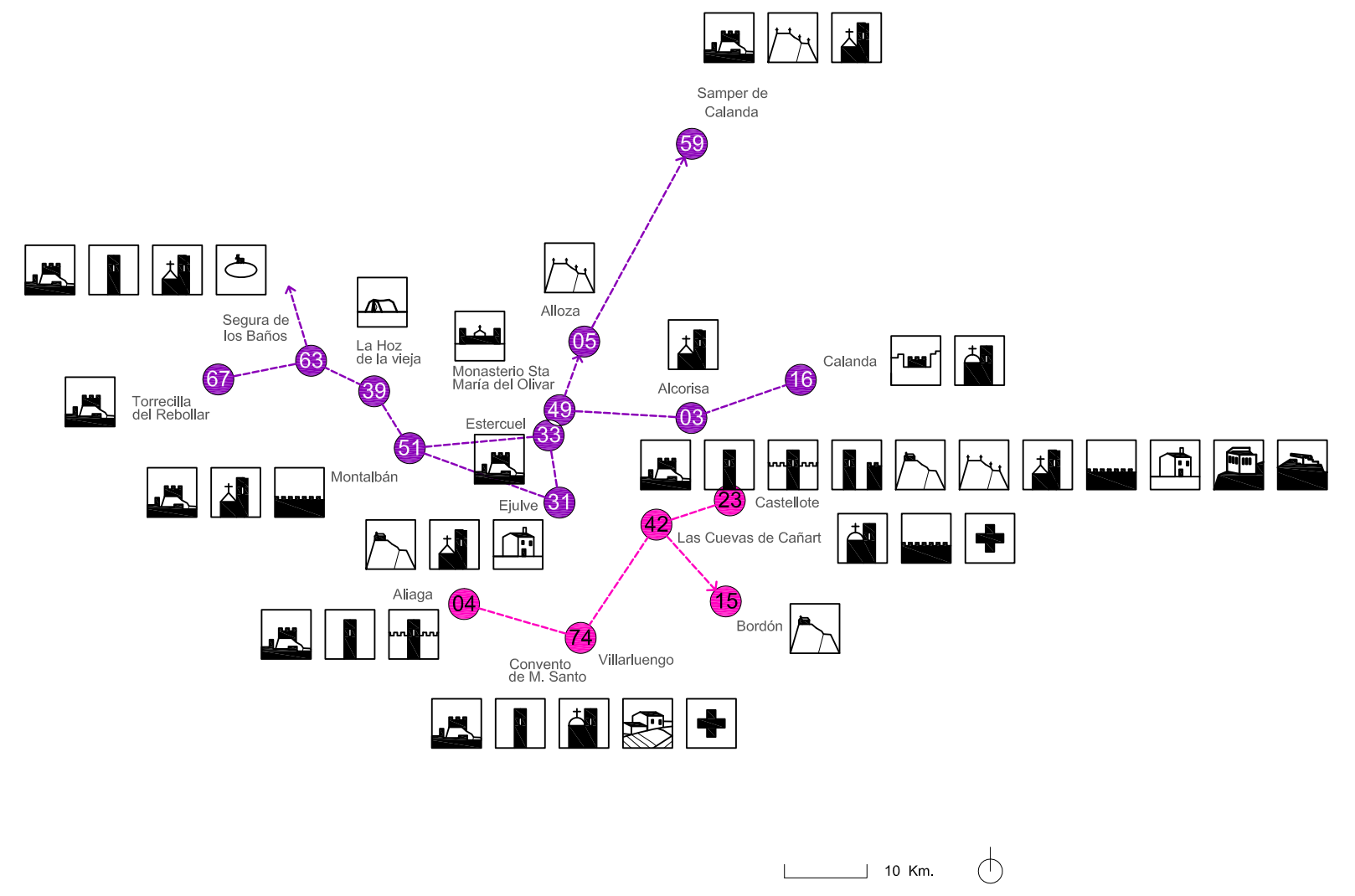

aㅣ

La linea del Guadalope, o defensa septentrional de la altiplanicie

El reducto avanzado septentrional
12. La línea del Guadalope, o defensa septentrional de la altiplanicie, es conformada por las plazas de Aliaga, Villarluengo y el convento del Monte Santo, Las Cuevas [de Cañart] y Castellote,

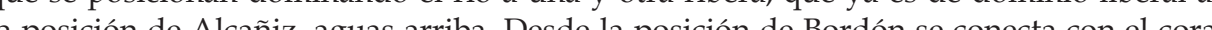
corazón de la altiplanicie.
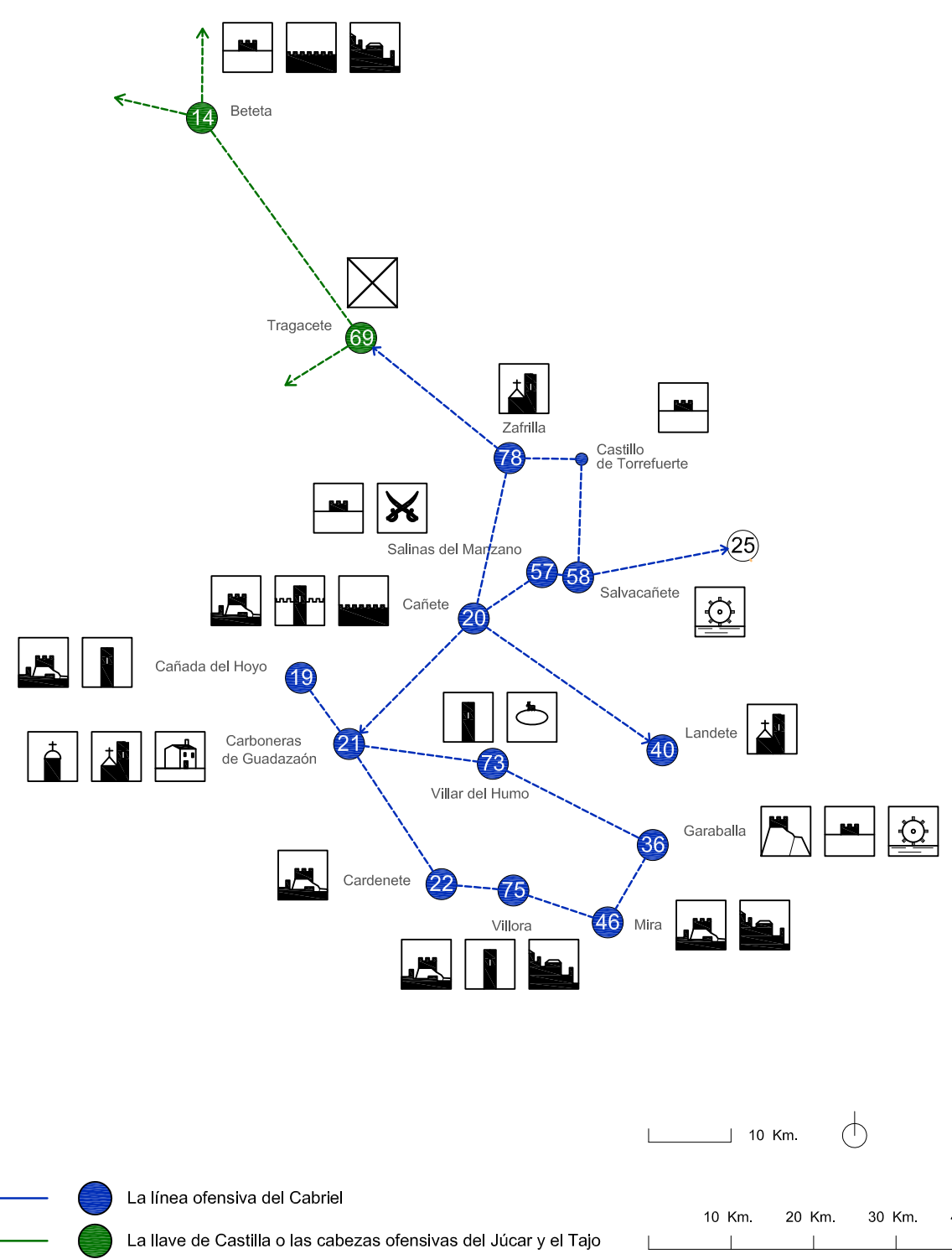

La linea ofensiva del Cabriel

La llave de Castilla o las cabezas ofensivas del Júcar y el Tajo 
13. El reducto avanzado septentrional respecto a la línea del Guadalope lo constituye la posición de Segura [de los Baños]. Su control permite a los carlistas avanzar la frontera noroeste más allá de los límites del "reino mágico" de Cabrera, y se destina a prevenir un avance enemigo hacia la altiplanicie al tiempo que actúa de cabeza de puente para atacar la Cuenca del Cella o del Jiloca e interceptar las comunicaciones entre Zaragoza y Teruel, y, por lo tanto, también Valencia. Obe interceptar las comunicaciones entre Zaragoza y Teruel, y, por lo tanto, también Valencia. Ob-
viamente, esta especie de coracha defensiva, cuya cabeza es Segura, es apoyada por los intentos viamente, esta especie de coracha defensiva, cuya cabeza es Segura, es apoyada por los intentos
de dominar las posiciones que se extienden entre Segura y la línea del Guadalope, que serían, de sur a norte, Torrecilla, el campamento de la Hoz de la Vieja, Montalbán, Estercuel, el Monasterio de Santa María del Olivar o incluso Alcorisa o Calanda. Llama la atención cómo, al norte de este conjunto, la posición de Alloza es un enclave para reunión de las partidas. Más cerca de la línea fuerte del Guadalope, la posición de Ejulve sirve de enlace. En posición septentrional se encuentran Samper de Calanda y Albalate, a la que parecen llegar las correrías carlistas y que, según Córdoba, llegan a ser fortificadas. Los carlistas parecen desparramarse desde sus posiciones como una manlegan a se fortficad cha de aceite por aquellas partes del para a a jada del Ebro y la conexión con el frente del norte, a distancia de las posiciones de Caspe y Zaragoza. Precisamente esta zona es fortificada a posteriori por los liberales tendiendo la línea de vigilancia fortificada de Chiprana, Escatrón y Sástago.

Es conveniente recordar que el principal objetivo de Cabrera antes de asumir el encastillamiento definitivo, es el de abrir la Mancha para lanzar sus partidas por el territorio y, especialmente, tene acceso al objetivo final, que siempre fue Madrid. Por ello son claves las líneas que establece en el frente oriental que definiremos como:

14. La línea ofensiva del Cabriel. El control del río Cabriel lo ofrece el triángulo defensivo constituido por las posiciones de Cañete, Salvacañete y Zafrilla, con el Castillo de Torrefuerte de las Veguillas en las proximidades de esta última y Salinas del manzano en su interior. Desde este triángulo se controla el nudo de comunicaciones de Landete, al sur, y se aísla a la posición libera de Moya que lo protege. Al mismo tiempo se garantiza la conexión con Ademuz y las defensas de Turia. Precisamente los carlistas pueden extender su dominio desde aquí, desde el nacimiento del Guadazaón hasta la Sierra de Mira, a través de las posiciones de Cañada del Hoyo, Carboneras de Guadazaón, Cardenete, Villar del Humo, Víllora y Mira. Son obviamente puntos poco consolidados, un ejemplo de lo cual es el escondrijo de Tejeda la Vieja, en Garaballa, como se indica, más un lugar donde pasar desapercibido que desde el que afirmar el dominio carlista.

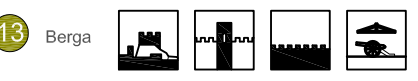

15. La llave de Castilla o las cabezas ofensivas del Júcar y el Tajo. La posición de Cañete permite trazar una línea a través de las montañas con Tragacete, plaza desde la que avanzar por el valle del sobre Castilla son muy preciados por Cabrera porque apuntan hacia la capital.

16. El reducto final: Berga. La posición de Berga, enclave fuerte del carlismo catalán, se ha integrado en este trabajo como posición última, única y ocasional del "reino mágico" de Cabrera, al ser convertida por el general en el último punto de resistencia antes del exilio. En el conjunto de fortificaciones en el contexto catalán se ha contemplado el caso del monasterio fortificado de Pinós, punto avanzado del carlismo catalán y en cuya fortificación participa Von Rahden a las órdenes del Conde de España (Von Rahden, 2013: 263-264).

Von Rahden pone en boca de Cabrera un sueño: "Ahora que he visto cómo se puede trabajar [...] quiero extender una red de fuertes por todo el territorio $[$.] realizando de paso algunas piruetas para que se sorprenda toda España. Primero cuatro fuertes en el Guadalaviar: Chelva, Chulilla, Alpuente y Castielfabib - dijo señalando con trozos de pan, pues estábamos sentados ante la mesa de la cena a medio recoger, la posición de estas poblaciones - Luego tres fuertes en el Cabriel: Cañete, Salvacañete y Zafrillo. Después Tragacete en el Júcar, Beteta en el Tajo y, por último, uno junto al Manzanares, donde quiero establecer mi cuartel general en la ermita de Nuestra Señora de la Torre (a una legua de Madrid)" (Von Rahden, 2013: 297).

Este propósito obviamente cambia a partir del fin de la guerra en el norte. En esta ocasión solo cabe resistir. Pero, por las condiciones de la guerra en el momento, ya todos deben de intuir que la concentración de efectivos enemigos en el territorio y el cerco a las posiciones de Cabrera implican el abandono progresivo de posiciones, el repliegue y la derrota, como demuestran los aconteciel abandon

mientos. y supervivencia del fenómeno militar carlista del Maestrazgo y su neutralización: "Tal era la guerra del Maestrazgo, un tomar y dejar posiciones y un perseguirse y sorprenderse, sin ventaja de los liberales, que no podian abandonar largo tiempo su base de operaciones: el juego sólo aprovechaba a los carlistas, que estaban en su casa, y, desalojados de la sala, se metion en la cocina; perseguidos en ésta, se escabullian por el cañón de a chimenea, $y$ desde el tejado seguín esfuerzos, el ir tomando una a una cada posición y empujar a los carlistas fuera del territorio, podía acabar con esta ocupación, como así sucedió con la ofensiva de Espartero. 
Del conjunto de plazas fuertes analizadas se ha podido verificar un reparto desigual de puntos fortificados en función de las líneas defensivas comentadas que se expone en la tabla a continuación

Tabla 9 . Plazas fortificadas en cada línea defensiva.

Frente

$$
\text { Denominación }
$$

El gran bastión montañoso de la altiplanicie de Aragón y Valencia

La fortificación de la cuenca media del Turia

La doble línea de comunicación entre la cuenca media del Turia y la altiplanicie

El frente sur de la altiplanicie

El frente suroccidental de la altiplanicie

El gran frente oriental de la altiplanicie

La comunicación mediterránea

La línea defensiva del Matarraña

El bastión de Beceite

La línea de comunicación del Sénia

La línea defensiva del Ebro

12 La línea del Guadalope, o defensa septentrional de la altiplanicie

\section{El reducto avanzado septentrional}

4 La línea ofensiva del Cabriel

La llave de Castilla o las cabezas ofensivas del Júcar y el Tajo

16 El reducto final: Berga

plazas

$4 \quad 5,1$

$11 \quad 14,1$

$3 \quad 3,8$

3
7 $\quad 9$

$4+\ldots$

5 ,

5,1

3,8

1,3

$4=5,1$

$5 \quad 6,4$

15,4
, 1 1 (n)

1

.

(1)

Se observa un intento por controlar poblaciones en la línea ofensiva del Cabriel, en el frente septentrional a las espaldas de Segura de los Baños y un gran conjunto de posiciones fortificadas en la cuenca media del Turia.

\subsection{El paisaje}

El conjunto de relatos, crónicas y experiencias en el lugar a raíz de los recorridos por el territorio afectado por la guerra del Maestrazgo permite recuperar la noción de límite que encierra no solo la idea de "reino mágico", sino también un paisaje singular que hace viable la guerra planteada por Cabrera. La proximidad del territorio de Cabrera es anunciado desde la distancia por las características de un paisaje abrupto que coincide exactamente con los límites territoriales antes desarrollados. Este paisaje montañoso resulta sumamente atractivo en la actualidad, pues retiene la belleza romántica que muchos viajeros contemporáneos al conflicto recogieron, la belleza de lo sublime asociada a la naturaleza salvaje, amenazadora. De hecho, el paisaje es clave en las posibilidades de supervivencia de los carlistas en el Maestrazgo, no solo por las condiciones topográficas, que dificultan los movimientos, limitan las grandes agrupaciones de efectivos u obstaculizan el uso de los trenes artilleros, sino por las severas condiciones climáticas que aíslan el territorio en invierno y lo hacen inaccesible, limitando las condiciones de supervivencia de un ejército lejos de sus bases y hostigado por las condiciones térmicas y las dificultades de avituallamiento en el territorio yermo. Cuando en "La campaña del Maestrazgo" los personajes de Beltrán y Nelet se encaminan al Santuario de Vallivana des paisaje: "En el descenso de la montaña, por senderos de ovejas que sorteaban las pendientes con ángulos y curvas dilatadas, pudiendo apreciar el grandioso panorama que a su vista se ofrecía; belleza incomparable de que también gozó don Beltrán, pues, si no apreciaba las menudencias y tonos medios del paisaje, percibía claramente las grandes masas rocosas, que por su coronamiento romo y achatado, en aquella formación geológica, son llamadas muelas. Las vertientes cubiertas de verde espesura son en algunos puntos suaves; en otros caen rápidamente, querenciosas de la vertical; todas de imponente majestad y hermosura. En una de las revueltas vieron el alto de la Virgen de la Salud, cerca de San Mateo, coronado por el santuario eminente; en otra revuelta, hacia el Oeste, la Muela de Ares, cima chata en la sierra de la Higuera. Hacia el norte distinguían el oscuro monte de Vallivana cubierto de verdor, y más allá asomaban el Castell de Cabres, la Moleta del Cid y los montes de la Cenia. Ningún ser humano encontraron en el camino. Llegado que hubieron a un ameno grupo de alisos entre peñas, se sentaron a descansar y a reponerse con un frugal almuerzo, y tumbados alli, en medio de la paz y quietud más deliciosa..." (Pérez Galdós, 1993: 2478). Este paisaje, que altera pocos matices en función de donde nos encontremos, se mantiene en la actualidad convirtiéndose en uno de los grandes valores de este territorio, que se ha intentado recoger en el correspondiente catálogo. Se ha destacado en este trabajo cómo prácticamente sin excepción el conjunto de fortificaciones se emplazan en enclaves considerados en la actualidad de interés paisajístico o, si no, muy próximas a ellos. Casi la mitad de estas fortificaciones, el $48,7 \%$ podría considerarse que tiene una gran presencia en el paisaje y contribuyen a su cualificación. La accesibilidad a las mismas se reparte casi a partes iguales, pues el $53,8 \%$ se podrían considerar fácilmente accesibles, mientras que el $46,2 \%$ plantean un difícil acceso. 


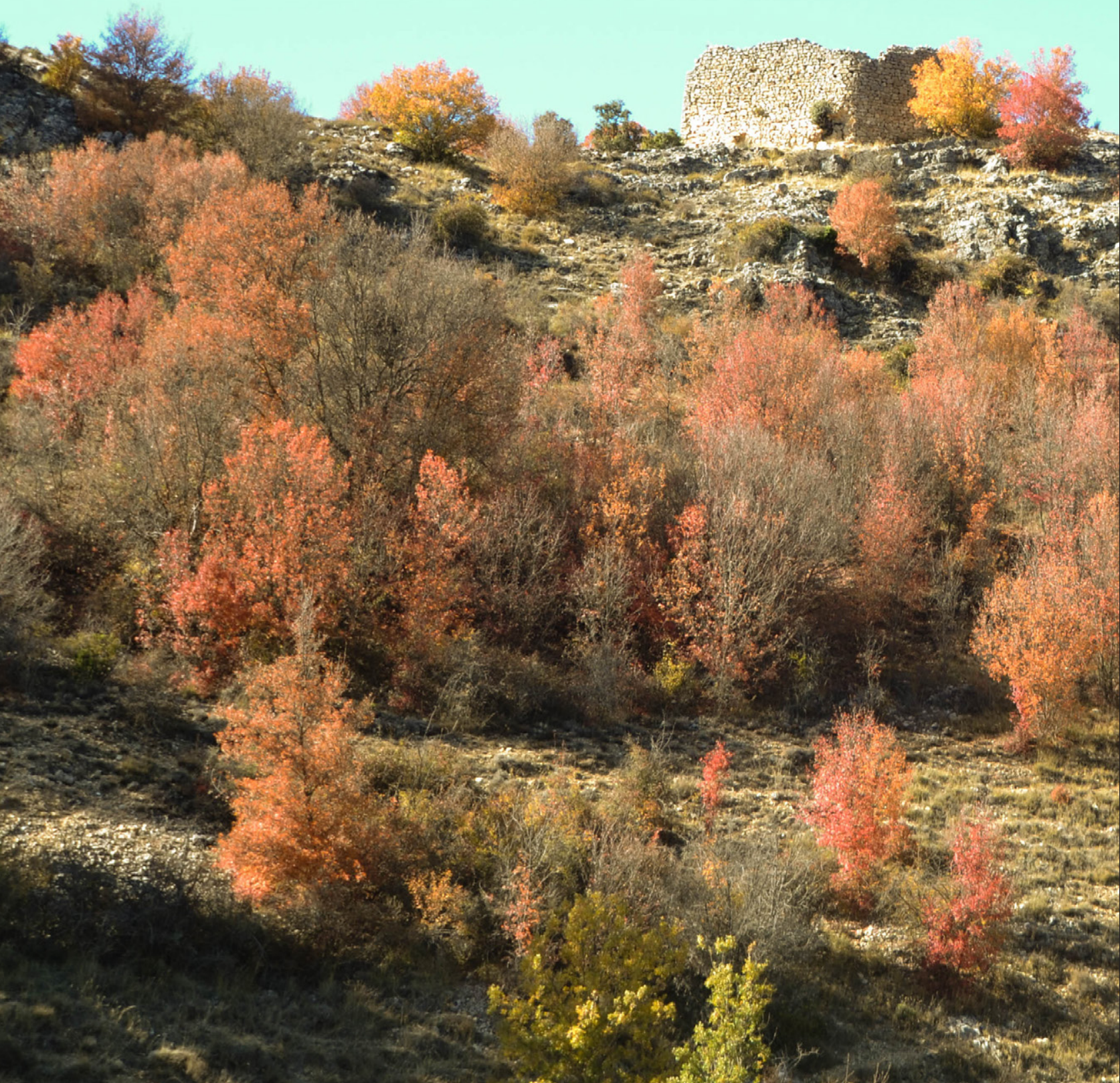

-La presente tesis identifica a través del catálogo el tipo de intervención arquitectónica efectuada por los ejércitos carlistas en el territorio.

-Se concluye una diversidad de modos de intervenir en las fortificaciones en función del papel al que se destinan y el grado de ocupación y sostenimiento de la plaza.

-Se identifica una tipología arquitectónica característica de la guerra del Maestrazgo cuyas señas de identidad son la economía de recursos, la búsqueda de lo apariente (en ocasiones las obras no son más que parapetos mal construidos que apenas se mantienen pero que hacen creer al enemigo que se ha fortificado la plaza), la apuesta por la guerra psicológica y la capacidad de concentración de fuegos de armas cortas, apostando por la precisión en la corta distancia. La pretensión de dotar las plazas de un potencial artillero, obsesión de Cabrera, no deja de ser un sueño, siendo la artillería carlista un instrumento poco eficaz que principalmente entra en acción sin éxito en las operaciones de toma de plazas. Por ello la fortificación ofrece una inédita y efímera evolución al ofrecer un tipo dillezas rtilleras cuando se dispone de ellas, y se combaten las mismas desde las vias de comunicación, tratando de impedir su posicionamiento más que construyendo una fortificación capaz de resistir o eludir su impacto

-La primera guerra carlista supone un hito para el estudio de la historia de la fortificación en territorio español, pues no solo supone la transformación del patrimonio fortificado existente para adaptarlo a las características de la guerra en el Maestrazgo, sino que en los procesos de ocupación y desocupación es la causa de destrucción de gran parte del propio patrimonio. La destrucción de documentación de la época en estos procesos ha dificultado aún más si cabe la identificación del proceso transformador en este periodo. La investigación ha podido probar que es así y ha revelado cómo en muchos casos este proceso radical de transformación es habitualmente pasado por alto en cómo en muchos casos este proceso radical de transformación es habitualmente pasado por alto en
muchos estudios, que tienden a obviarlo ante la fascinación que suscita el patrimonio fortificado muchos estudios, que tienden a obviarlo ante la fascinación que suscita el patrimonio fortificado
medieval, ya sea islámico o cristiano. En contadas ocasiones se contemplan las transformaciones medieval, ya sea islámico o cristiano. En contadas ocasiones se contemplan las transformaciones sión, para dar el salto a más recientes estudios acerca de los episodios de la guerra civil, como sucede en el caso de Flix, que sería un ejemplo representativo de las tendencias de la memoria historica.

-Se detecta una atención desigual al patrimonio fortificado carlista, o fortificado en general, en función de los territorios, posiblemente dependiente de los enclaves geográficos, su accesibilidad, su proximidad a la costa y a polos de atracción turística, y especialmente de los recursos económisu proximidad a la costa y a polos de atracción turística, y especialmente de los recursos económi-
cos o sensibilidad de las diferentes administraciones. Sin querer juzgar las causas que conducen a cos o sensibilidad de las diferentes administraciones. Sin querer juzgar las causas que conducen a
ello se podría trazar un mapa de patrimonio en riesgo que, obviamente, recorre la difusa frontera de la España despoblada. Esta identificación, reconocida como obvia, debería convertirse en una oportunidad para estos territorios.

-El patrimonio fortificado carlista fagocita elementos representativos del patrimonio precedente en los territorios afectados. La infinitud que desvela el proceso de investigación desde la necesaria

Fig. 837. Fuerte reforzado por orden de Cabrera en Salinas del Manzano. 
mirada global ha impedido abordar con detalle cada una de las singularidades que deberían se abordadas desde la perspectiva local. Pero la interesante historia de la fortificación del "reino mági$\mathrm{Co}^{\prime \prime}$ de Cabrera acaba integrando importantes muestras tanto del patrimonio civil rústico y urbano ios, monasterios, conventos, iglesias, ermitas, calvarios.. Buena cuenta de ello da la labor de identificación en los diferentes emplazamientos realizada en esta investigación.

-La investigación ha permitido identificar una serie de tipos arquitectónicos representativos que se han tratado de categorizar de un modo teórico apelando en algunos casos a la terminología, en ocasiones un tanto equívoca, de la época: la torre defensiva, el fuerte, el castillo, la batería, el reducto, el muro aspillerado, la torrecilla, la trinchera, la estacada, el campo volante, la muela fortificada, la casa/masía fortificada...

-Se detecta en este sentido un intento de homogeneizar la denominación de los tipos fortificatorios por parte de las fuentes de entonces y, así, como recoge también Pedro Rújula, "algunas casas, iglesias o ruinas, situadas en puntos elevados, dotadas de aspilleras y defendidas por 50 a 100 hombres, toman en España y señaladamente en la ultima guerra civil el nombre de fuerte o cuartel. Existen frecuentes ejemplo de cómo han llegado a parar a toda una división" (Von Rahden, 2013: 297, n. 178). Este modo de denominar las posiciones genera bastantes equívocos cuando buscando una construcción exclusivamente defensiva nos encontramos con un monasterio, una iglesia, un molino... que, además, fruto de un proceso restaurador, ha perdido cualquier huella de la adaptación militar.

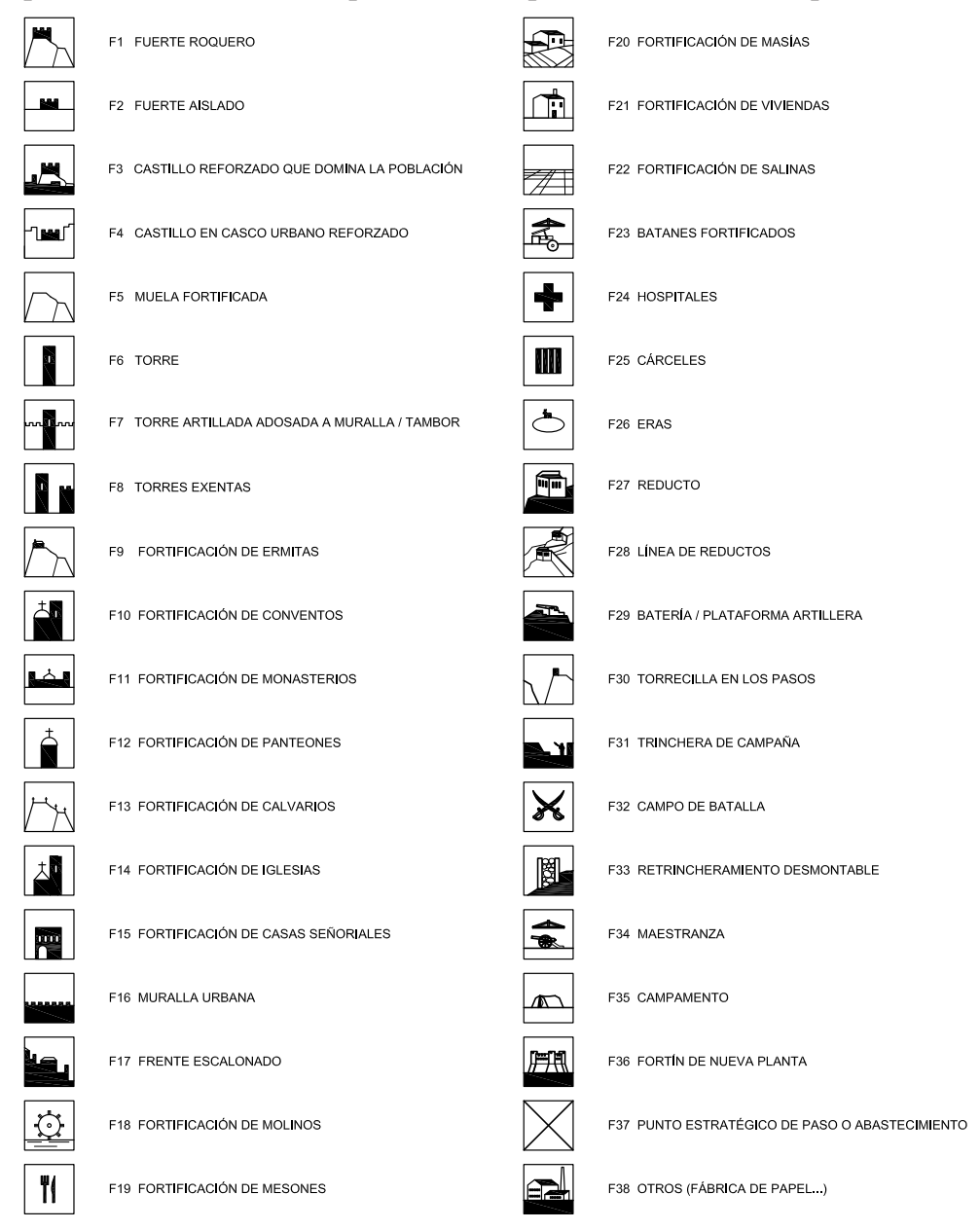

11.5. Procesamiento de datos del catálogo de fortificaciones

A partir del conjunto de posiciones fortificadas identificadas a través de los documentos y verificadas in situ, se puede hablar de un total de $\mathbf{7 8}$ posiciones identificadas, que se corresponden con las recogidas en el catálogo, ordenadas alfabéticamente y numeradas para su identificación en el plano correspondiente. Se han podido avanzar en apartados anteriores datos asociados a las mismas.

-Se han definido los siguientes tipos en función de la intervención de fortificación. En la tabla que se acompaña se identifica la cantidad de ejemplos de cada tipo.

Tabla 10. Cantidad de cada tipo fortificatorio.

\begin{tabular}{|c|c|c|}
\hline Cód. & Denominación & Cantidad \\
\hline F1 & Fuerte roquero & 6 \\
\hline F2 & Fuerte aislado & 10 \\
\hline F3 & Castillo reforzado que domina la población & 35 \\
\hline F4 & Castillo en casco urbano reforzado & 6 \\
\hline F5 & Muela fortificada & 3 \\
\hline F6 & Torre & 26 \\
\hline $\mathrm{F} 7$ & Torre artillada adosada a muralla / tambor & 16 \\
\hline F8 & Torres exentas & 5 \\
\hline F9 & Fortificación de ermitas & 7 \\
\hline F10 & Fortificación de conventos & 9 \\
\hline F11 & Fortificación de monasterios & 4 \\
\hline F12 & Fortificación de panteones & 1 \\
\hline F13 & Fortificación de calvarios & 8 \\
\hline F14 & Fortificación de iglesias & 19 \\
\hline F15 & Fortificación de casas señoriales & 2 \\
\hline F16 & Muralla urbana & 19 \\
\hline F17 & Frente escalonado & 21 \\
\hline F18 & Fortificación de molinos & 4 \\
\hline F19 & Fortificación de mesones & 1 \\
\hline F20 & Fortificación de masías & 3 \\
\hline $\mathrm{F} 21$ & Fortificación de viviendas & 3 \\
\hline F22 & Fortificación de salinas & 2 \\
\hline F23 & Batanes fortificados & 0 \\
\hline F24 & Hospitales & 7 \\
\hline $\mathrm{F} 25$ & Cárceles & 4 \\
\hline $\mathrm{F} 26$ & Eras & 5 \\
\hline $\mathrm{F} 27$ & Reducto & 6 \\
\hline F28 & Línea de reductos & 3 \\
\hline F29 & Batería / plataforma artillera & 7 \\
\hline F30 & Torrecilla en los pasos & 0 \\
\hline F31 & Trinchera de campaña & 2 \\
\hline F32 & Campo de batalla & 1 \\
\hline F33 & Retrincheramiento desmontable & 0 \\
\hline $\mathrm{F} 34$ & Maestranza & 3 \\
\hline F35 & Campamento & 1 \\
\hline F36 & Fortín de nueva planta & 1 \\
\hline F37 & Punto estratégico de paso y abastecimiento & 3 \\
\hline F38 & Otros (fábrica de papel...) & 1 \\
\hline
\end{tabular}



Del conjunto de estas piezas que en su día integraron el patrimonio fortificado carlista una gran bélico como en el destrucción por parte carlista y un 11,5\% por parte liberal, en algunos casos estas acciones coinciden sobre un mismo elemento fortificado. En la mayoría de casos restantes no se ha podido constatar la autoría de la destrucción.

Las causas que justifican los procesos destructivos son diversas. Las fortificaciones son víctimas de asedios violentos, son destruidas por motivos tácticos cuando unos $\mathrm{u}$ otros deben abandonarlas a enemigo, son destruidas en una acción de represalia o destruidas al fin de la guerra para evitar un mal uso futuro. En los casos que se ha podido verificar esta información encontramos el siguiente reparto porcentual respecto al conjunto de las fortificaciones.

Destrucción en asedio: $16,7 \%$

Destrucción por retirada: $14,1 \%$

Destrucción como represalia: $3,8 \%$

Destrucción para impedir uso futuro; $6,4 \%$

Por lo general se han hallado las fortificaciones en muy diverso estado de conservación, desde un relativo buen mantenimiento hasta una desaparición absoluta de los restos. Concretamente el reparto respecto al total es el siguiente:

$\begin{array}{lll}\text { A } & \text { En buen estado } & 43,6 \% \\ \text { B } & \text { En estado de semirruina } & 26,9 \% \\ \text { C } & \text { En estado de ruina } & 24,4 \% \\ \text { D } & \text { Sin restos } & 1,3 \%\end{array}$

Curiosamente, a pesar de la pervivencia de este patrimonio, llama poderosamente la atención el escaso esfuerzo de puesta en valor del patrimonio de época carlista por parte de las administraciones. Tan solo el $6,4 \%$ del total de los emplazamientos visibiliza el papel jugado en la primera guerra carlista. Básicamente se explota este valor en los principales hitos de la guerra del Maestrazgo, Morella y Cantavieja, y sobre todo en algunas piezas del contexto catalán, como Flix o Móra d’Ebre.

Por uno u otro motivo, la visita a los diferentes emplazamientos ha permitido constatar intervenciones patrimoniales recientes, verificándose que aproximadamente el $60,3 \%$ del patrimonio ha experimentado algún tipo de intervención y un 34,6\% no parece haber sufrido intervención reciente. En el caso de las intervenciones acometidas resulta llamativo contraponer las acciones a la escasa puesta en valor del patrimonio carlista comentada, que permite cuestionarse hasta qué punto se $\mathrm{h}$ valorado la huella sobre el patrimonio arquitectónico de este periodo de nuestra historia. Como se ha podido detectar en algunos casos, las intervenciones han contribuido a diluir las huellas del conflicto. La singularidad del patrimonio arquitectónico de época carlista requiere una aproximación específica en su estudio e intervención y, por ello, se aborda más adelante el conjunto de conclusiones relacionadas con la puesta en valor del patrimonio fortificado de época carlista de la ciudad de Requena, embrión de esta investigación.

\subsection{Las partes y el todo}

El proceso investigador de un elemento fortificado parece desvelar un complejo "mise en abîme", lo que viene a ser la inscripción de una forma dentro de otra hasta el infinito (Gide, 2000:30). Si uno pretende abordar el conocimiento de una pieza integrante de un sistema fortificado, requiere del estudio del conjunto para alcanzar el conocimiento completo de esta. El estudio de un cubo defensivo debe amplificarse al estudio de la muralla que integra, extenderse al conjunto de obras defensivas exteriores, implicar a los elementos naturales que contribuyeron y condicionaron la defensa, a las ( no podemos detenernos hasta alcanzar límites de ese Estado que la fortificación defiende. Podría darse incluso el caso de que entraran en juego intereses internacionales, alianzas entre estados, y, así, el organismo defensivo debería entenderse incluso supraestatalmente: por ejemplo la fortificación de Europa durante las guerras napoleónicas. Ha sido así en muchas fases de la historia, no en todas, pero sí al menos en la que nos ocupa.

El todo requiere de la parte, de lo concreto, que es por donde parece tener sentido empezar una investigación, pero lo concreto no es nada, como sucede en esta investigación particular, si no se aborda desde una visión global, desde la complejidad del organismo fortificado. La presente investigación demuestra de entrada como conclusión esta afirmación: el estudio de la parte de la fortificación no es nada sin el todo. Una metodología de estudio del patrimonio fortificado exige una aproximación desde lo general a lo particular. En una visión sesgada de la fórmula renacentista: la parte sin el todo es nada.

Asumida esta afirmación, la investigación se enfrenta a la complejidad del organismo, que requiere desmenuzarlo hasta las partes indivisibles para su comprensión. Aquí se complementa la porción restante de la fórmula albertiana: también es importante la relación de las partes entre sí. En resumen, sí a la relación de la parte con el todo, sí a la relación de las partes, pero, antes que nada, en estos casos donde no hay parte que analizar: el todo.

Esta investigación es el resultado de estos procesos de acercamiento y alejamiento, y, por ello, puede considerarse aún incompleta. Un interés por el patrimonio fortificado en este contexto indujo a un primer acercamiento a la fortificación de la ciudad de Requena. Sorprendentemente, la investigación concreta ha permitido demostrar que estaba equivocada la creencia generalizada que daba por extinguida la muralla liberal de Requena, salvo el vestigio del "tambor de Cantarranas". La comprensión del organismo defensivo ha permitido, desde lo global, la localización de lo particular. Se ha procedido al análisis de una de las partes para poder probar las hipótesis. Este trabajo inicial, con el que se anticipó la tesis, que se consideraba incompleto, ha sido desarrollado en parte con la mirada global hacia el patrimonio fortificado carlista, pero sigue dejando abierto el camino a un conjunto de investigaciones parciales que se emprenderan en la futuras investigaciones que se pueden contemplar e puedo produce desde el caso de Requena una ampliacion de la mirada al territorio del conflicto en el Maestrazgo y una apuesta por el contexto carlista. Este alejamiento ha permitido, conociendo la experiencia de Requena, detectar un conjunto de 78 posiciones en las que se identifican intervenciones materiales que requerirían una aproximación similar a cada caso. Tras este nuevo acercamiento múltiple, sería conveniente una mirada general en el ámbito liberal, que responde a una casuística diferente y posiblemente más compleja, motivo que se intuía a la hora de acotar el ámbito de la presente tesis al territorio carlista. Otro trabajo sería la elaboración de una comparativa de los procesos fortificatorios carlistas en el peculiar caso de la guerra en el Maestrazgo en contraposición con esos mismos procesos en relación con las posiciones carlistas del norte, que se enfrentan a un modo de hacer la guerra más acorde con los tiempos.

guerra más acorde con los tiempos. La metodología que hemos ensayado para abordar esta complejidad podría constituir una nueva aportación de este trabajo, que abordaremos más adelante. 
- El dibujo. El conocimiento de las técnicas de representación gráfica por parte de los ingenieros, materia impartida en las academias que verifica una ortodoxia, permite interpretar la cartografía del momento. Es el caso del plano de Ortiz de Pinedo, donde se entiende el modo de representar los desniveles, el punto de sección (a la altura del cordón) sin que se especifique, el simbolismo de los colores, la escala, las leyendas...

\subsection{Enfoques para abordar cada caso}

El estudio del elemento arquitectónico de la fortificación es complejo y requiere la aportación de numerosos enfoques. Concretamente un estudio riguroso de la fortificación decimonónica de tiempos de la Primera Guerra Carlista se debería interrelacionar con:

La arqueología: se puede hablar de una reconstrucción de la sociedad a través de restos materiales distribuidos en el espacio y conservados en el tiempo.

- La historia: dado que requerimos del conocimiento de los hechos y procesos ocurridos en el pasado para interpretarlos con objetividad. Dentro de este apartado incluiríamos la historia militar para aquellos acontecimientos militares que explican la implicación de la fortificación, pero también la historia de la arquitectura, la historia del arte (para elementos ornamentales), la historia de la construcción.

La heráldica, entendida como la ciencia que se ocupa de explicar y describir los escudos de armas de linajes, ciudades y personas. En la documentación histórica de Requena nos hemos encontrado el debate en torno al escudo de la ciudad (1836). También hallamos determinadas identificaciones de propiedades que son validadas por la presencia de los blasones en muchas casas nobiliarias, como propiedades que son validadas por la presencia de los blasones en muchas casas nobiliarias, como
sucede con los escudos heráldicos de los palacios medievales de la Calle Santa María, cuya espalda sucede con los escudos heráldicos de los palacios medievales de la Calle Santa María, cuya espalda
se adosa a las murallas. En algunos casos, como sucede en el caso de la casa de los Cárcel-Marcilla (Casa Grande), continuamente citada en los informes militares. El tercer escudo emplazado en el patio parece corresponder a los Enríquez, y, por tanto, fue desplazado de su ubicación original. La heráldica resulta también interesante en el estudio de los blasones de muchos documentos históricos consultados.

El arte militar. Hacemos referencia a la misma materia impartida en la Academia de Alcalá de Henares en su segunda etapa, de 1815 a 1823 (a la que pertenecen las promociones de Ortiz de Pinedo y Juan Ramón Carbonell, ingenieros de la fortificación de Requena). Es preciso contemplar la táctica y la estrategia militar para clarificar los condicionantes defensivos.

El arte de la fortificación. Se trata de otra de las materias impartidas en la Academia, que permite entender el trazado y los elementos componentes para su identificación en los vestigios o la comprensión de los documentos históricos. En el caso de estudio, la presencia de un elemento reconocido como la cortina permite entender la presencia de construcciones flanqueantes. También resulta clave conocer la base de la defensa próxima (el alcance del fusil) y de la lejana (el alcance artillero), para determinar las distancias y longitudes de los tramos fortificados.

La balística, entendida como el estudio científico asociado a la trayectoria de los proyectiles y conocimiento del armamento utilizado asociado con la arquitectura que permita entender por ejemplo aquellos alcances que ayudan a clarificar posiciones: se habla de fusiles, cañones, obuses determinantes en la definición de los trazados, como comentábamos en el apartado anterior. En el caso estudiado, a partir de la posición de la batería del Cristo se puede estimar la posición del corral de las Muda, suponiendo que se encuentra al alcance de una batería de campaña del momento, y corroborar su posición en el actual emplazamiento de la plaza de toros. Se puede validar también en el terreno, por ejemplo, el posicionamiento de la batería de Honrubia si cubre el puente de las Ollerías.
- La lingüística: evolución de la lengua, de los términos y sus particularidades geográficas para interpretar los documentos históricos. Sirva como ejemplo el término "piazo" en argot manchego, que se traduce en "pedazo", el cual se define como una porción plana de terreno sin cultivar. En este apartado se incluirían los apartados de terminología específica de cada una de las especialidades que intervienen como la fortificación, la artillería, la construcción...

- La toponimia actual permite clarificar emplazamientos, como la calle del Pozo de Requena, conduciendo al Pozo de la Nieve.

- El urbanismo: la comprensión de las etapas de crecimiento de la ciudad de Requena, trazado de calles, plazas... facilita la ubicación de elementos arquitectónicos - es crucial el posicionamiento de determinadas puertas como la de Valencia, Alcalá, Cantarranas, Madrid, Reinas... - y frentes fortificados, también conexiones interurbanas que, a su vez, permiten abordar el estudio geoestratégico. La expansión urbana permite entender a su vez que áreas fortificadas han sido más agresivamente transformadas, precisamente en las prolongaciones del Arrabal.

- El paisaje: natural y urbano. La fortificación, íntimamente ligada al fenómeno urbano, en la misma medida que este define un paisaje urbano, también condiciona el paisaje natural con presencias muy características que pueden contribuir a la identidad, como es el caso claro de Requena. El paisaje antropogénico que caracterizó el borde de Requena durante siglos, fue apropiado por el patrimonio.

El estudio del patrimonio arquitectónico vernáculo e industrial: donde se contemplarían la gran mayoría de los apartados que desglosamos a continuación. De hecho gran parte del patrimonio edilicio en Requena durante el siglo XIX tiene que ver con el patrimonio vernáculo, que acaba integrando el patrimonio militar:

-El patrimonio civil de la vivienda.

-El patrimonio hidráulico: acequias, molinos, fuentes, balsas

-El patrimonio de la arquitectura productiva industrial: ollerías, tintes, telares, batanes..

-El patrimonio de la arquitectura agraria: huertas, eras.

-El patrimonio de la arquitectura ganadera: corrales.

- Fuera del patrimonio vernáculo, pero aún incluido en el patrimonio edilicio, es preciso hacer referencia al patrimonio religioso que va a integrar las defensas: Los Templos de Santa María, San Nicolás y el Convento del Carmen, como parte de las murallas, la Torre de la Iglesia del Salvador, como elemento de comunicaciones, y el Convento de San Francisco como obra exterior. En el momento del conflicto, el convento ha sido desamortizado y es propiedad privada, haciendo las funciones de hospital a partir de 1850, por lo que hablaríamos de patrimonio sanitario. Aunque en el pasado
ha llegado a funcionar como cuartel (durante la Guerra de Independencia), entre 1833 y 1840 más ha llegado a funcionar como cuartel (durante la Guerra de Independencia), entre 1833 y 1840 más
bien deberíamos hablar de un padrastro, una pieza pendiente de ser integrada eficazmente en el patrimonio defensivo de la ciudad, que constituye una estructura de riesgo en caso de ser tomada por el enemigo.

El patrimonio de la ingeniería civil relacionado con las principales infraestructuras de comunicación: carretera de las Cabrillas, caminos diversos hasta la implantación de la línea férrea en 1887; pero también con las técnicas de comunicación: sistema de telegrafía sin hilos, que se implanta entre 1848-1849 en Requena. 
- La grafología: utilizada para identificar el conjunto de documentos históricos sin identificación En esta investigación ha sucedido con algunos escritos del maestro de obras Guillermo Sáez, sin firma, pero identificados por la caligrafía en el conjunto de legajos de la fortificación localizados en el Archivo Municipal de Requena.

Aunque no ha resultado el caso en esta investigación, sí que se ha deducido la complementariedad de determinadas materias dadas las características de la fortificación decimonónica. La fortificación del momento implica movimientos de tierra y está condicionada por la imposibilidad de seleccionar el terreno en el que cimentar. Así resultan claves la geología, la geotecnia, las matemáticas y la geometría descriptiva como herramientas para la investigación, materias que estaban incluidas en la formación del cuerpo de ingenieros. En este caso, no para construir, sino para plantear hipótesis de reconstrucción de trazados o de taludes.

\subsection{Propuesta teórica de una nueva tipología defensiva propia del contexto militar y geográfico}

Esta investigación aporta la definición del que denominaremos frente defensivo escalonado-aspillerado que se genera en el contexto de la Guerra Carlista en el área del Maestrazgo y que fija un claro prototipo. En su definición intervienen varios factores: en primer lugar las características urbanas de poblaciones menores como Requena, pero extensibles a otras poblaciones del Maestrazgo. Por lo general existe un perímetro defensivo preexistente, normalmente medieval, al que se adosan viviendas en el transcurso del tiempo y que acaba definiendo una masa arquitectónica compacta, en la que se integran otras estructuras, que pueden ser iglesias, molinos, batanes... La realidad es en la que se integran otras estructuras, que pueden ser iglesias, molinos, batanes... La realidad es
la existencia de un límite claro entre perímetro amurallado, arrabal y campo abierto. Precisamente la existencia de un límite claro entre perímetro amurallado, arrabal y campo abierto. Precisamente
los contornos inmediatos de la población se encuentran colonizados por huertas y, adosadas a las los contornos inmediatos de la población se encuentran colonizados por huertas y, adosadas a las
edificaciones perimetrales, se construyen corrales y pequeños huertos particulares asociados a las viviendas.

Esta tipología urbana interactúa con un modo de hacer la guerra: la guerra de partidas y la defensa basada en las columnas móviles. Esta situación no exige unas fortificaciones de envergadura, sino un planteamiento defensivo destinado a repeler los ataques y a resistir el tiempo necesario asegurar el cerco amurallado, sin olvidar principios básicos del momento. Entre dichos principios las ideas académicas del arte de la fortificación, especialmente de la fortificación de campaña: la primacía de la potencia de fuego, la superposición vertical, la credibilidad de los obuses artilleros para la defensa lejana (aunque difíciles de implementar dadas las carencias presupuestarias) y la apuesta de la carga fusilera para la defensa próxima. De este modo los perímetros defensivos se apoyan en la habilitación del máximo número de fusileras (aspilleras), incluso si es posible superpuestas verticalmente, en toda tapia o muro que sea posible. Para ello suelen adosarse banquetas a los paramentos, básicamente de madera. Se procura siempre garantizar los flanqueos, $\mathrm{y}$, si es preciso, se eliminan cuerpos o se añaden otros, pero la reaidad es un trazado con entrantes y salientes (a) de flanqueo. El lugares convenientes, asegura la defensa de la plaza y la campaña. Por ello, entre los diferentes planes de fortificación, se irán incrementando el número de emplazamientos artilleros por todo el recinto. Estos emplazamientos suelen aprovechar construcciones preexistentes pero es preciso comprender que la batería puede consistir en un sencillo terraplén elevado sobre cuya explanada disponer los cañones y, más adelante, los obuses. Estas plataformas han sido ocupadas por la edificación y, en muchos casos, fueron huertos elevados cuyas tapias se desmochaban. Otro elemento extendido en este frente escalonado-aspillerado será el fortín, pequeño emplazamiento, que por lo general en Requena tiene planta cuadrangular, rectangular o casi trapezoidal, cubierto, destinado a convertirse en pequeño elemento saliente, equidistante sobre las cortins, ca milicia. Por lo general estos fortines se emplazaran en puntos clave que los ingenieros consideran mal defendidos, como la puerta de Valencia, la Puerta de Madrid, Cantarranas... La topografía aledaña, normalmente constituida por las tradicionales huertas abancaladas con muros de piedra en seco, se integra en la fortificación aprovechando sus virtudes. Así se genera un frente constituido por dos, tres o más líneas defensivas:

1.-Arroyo o foso.

2.-Talud de la primera huerta. Por lo general estas huertas se tapian y aspilleran, o simplemente se parapetan para garantizar un resguardo.

3.-Taludes de las huertas sucesivas con el mismo tratamiento.

4.-Línea de corrales o viviendas. Se tapian accesos y se aspilleran.

5.-La línea más fuerte, coincidiendo con el frente de las viviendas principales, en la gran mayoría de 
casos con tres o cuatro plantas de altura. Estas posiciones ya tienen sus ventanas para garantizar la defensa de los vecinos y, si es preciso, se aspilleran en los puntos adecuados.

6.-En aquellas zonas del perímetro que se apoyan en el antiguo frente medieval, la línea de la muralla, por lo general, suele ser una segunda línea de viviendas que constituye el límite final.

Asumida esta tipología de frente escalonado aspillerado, se puede afirmar que gran parte de los vestigios de la defensa siguen existiendo, pero hoy no se visibilizan como patrimonio fortificado. Una de las realidades más frecuentes del patrimonio urbano amurallado es que su obsolescencia conduce a su progresiva desaparición. Generalmente su interacción con la expansión urbana induce a su demolición, que suele iniciarse con la apertura de portillos, interposición de viviendas... Aunque en Requena dicha interacción se produce, la fortificación no desparece, sino que simplemente pierde su uso defensivo y experimenta un proceso de maquillaje, especialmente en el sector sur, este y norte: se ciegan aspilleras, se recrecen muros, se construyen nuevos corrales, que se cur, ex y ne se tectónica principal del conjunto desaparezca realmente.

11.9. Aportación sobre las unidades métricas de la época y el lugar utilizadas

Se detecta que, contrariamente a lo que sucedía en el siglo precedente, se ha impuesto la vara del marco de Burgos como medida oficial. Las toesas francesas han desaparecido de la documentación de los ingenieros comisionados en Requena y el sistema métrico decimal que ya ha sido implantado por el régimen revolucionario francés y es el sistema oficial de las tropas francesas en la Guerra de por el régimen revolucionario francés y es el sistema oficial de las tropas francesas en la Guerra de
Independencia aún no ha irrumpido en España. En Requena, tanto el maestro de obras como los Independencia aún no ha irrumpido en España. En Requena, tanto el maestro de obras como los ingenieros trabajan entre otras medidas con cahizes ( $666 \mathrm{l})$, libras ( 16 onzas, $0,46 \mathrm{~kg}$ ), celemines $(4,6$ 1 de cereal, pero especialmente para superficies asociadas con la producción del cereal, es decir, 5,36 $\mathrm{m} 2)$, varas $(0,836 \mathrm{~m})$ y varas cúbicas $\left(0,58 \mathrm{~m}^{3}\right)$, pies $(27,8 \mathrm{~cm})$, palmos $(20,873 \mathrm{~cm})$, pulgadas $(23,22$ (25 céntimos de peseta) para los presupuestos económicos.

-Se produce paralelamente a la investigación un anexo terminológico basado en tratados de referencia que pudieron influir en los ingenieros participantes como los de Pedro de Lucuze (1772) y Raymundo Sanz (1794), e inmediatamente posteriores como el de José Almirante (1869), que recogería toda la terminología hasta el momento. También se ha recogido el testimonio de cronistas y de la cartografía de la época para identificar los términos con los que se hace referencia a los principales elementos defensivos. Se ha recurrido también a trabajos contemporáneos que abordan la terminología de la fortificación (Guimaraens, 2008; Le Halle, 2002) para complementar las definiciones. Se ha pretendido redefinir los términos de estos trabajos de manera sintética para su mejor comprensión. 
lidad muy específica de guerra, donde el sostenimiento del frente carlista es preferentemente de índole militar y recurre por lo general al sistema de partidas. Frente a ello, el gobierno responde en ocasiones con una cierta indiferencia, otras veces tratando de dar una respuesta apelando al sistema de los municipios. Eso sí, además del apoyo del ejército regular en movimiento, encontramos ciertos gestos solidarios con una política de apoyos entre milicias urbanas de localidades próximas, que permiten sostener esta mirada de nexos territoriales y que podrían dar pie a la introducción de un concepto de rutas históricas relacionadas.

Cabello recoge cómo en el transcurso de la Primera Guerra Carlista el conflicto en tierras de Aragón y Valencia se observa desde la política nacional con un cierto abandono e indiferencia. El gobierno tiene problemas mayores, $\mathrm{y}$, en lo que respecta a la guerra contra el carlismo, sus atenciones se centran en los territorios del norte. Esta desatención "se dejó sentir hasta en la fortificación de los pueblos, a cuyo amparo debía operar el ejército. Para fortificar Montalbán habían contribuido los pueblos inmediatos con cuatrocientos mil reales, $c$ yeso y cien mil arrobas de cal. Y esta suma de materiales, que podían haber producido un fuerte respetable, no merecieron un ingeniero que trazara y dirigiera las obras, ni después un cañón de tantos como sobraban en plazas inexpugnables no lejanas.

Como si Cabrera opusiera pocos obstáculos al triunfo de la libertad, los mismos liberales los aumentaban resistiendo la obediencia a las autoridades o provocando motines que las desautorizaban, llevando a pelear en las plazas los soldados que tanta falta hacian en el campo. Cuando Montalbán era reducido a cenizas, cuando eran talados los campos de Requena, cuando apenas podían nuestras tropas asomarse al Maestrazgo ni llegar a Lucena un puñado de díscolos se rebelaban en la huerta de Valencia y sin pretexto siquiera y sin respetar los antecedentes de lar una bullanga y, entrando por la muralla, sorprendieron a una parte de la milicia con el toque de generala, sacaron un cañón y recibieron a tiros al general y sus ayudantes" (Cabello, 2006: 240-241).

El mismo Cabello sintetiza una serie de criterios fortificatorios que se harán extensivos a toda el área afectada, y, por tanto, que podrían caracterizar rasgos comunes. El general Van Halen, responsable del denominado Ejército del Centro, ante la falta de recursos que no llegaban desde el gobierno central, optó por convertirse en administrador, planteándose un sistema de recaudación y de distribución de lo recaudado a fin de controlar el gasto y, a su vez, efectuar un reparto equitativo por el territorio. Para ello "exigió a las intendencias estados semanales de entradas y salidas de fondos, nombró comisiones interventoras, pero todo era en vano. El ministro de Hacienda recomendaba el pago de las libranzas de ciertos contratistas que le habían de sacar de otros apuros, un director recomendaba la empresa de guardacostas, otro recomendaba el Cuerpo de Carabineros. Y no bastando, como no bastaban, las contribuciones e ingresos de las provincias en que hacía la guerra, y cercenándosele como se le cercenaban por los mismos que le ofrecieran aumentarlos, vivía en este punto siempre con la mayor ansiedad. Con las tropas que halló al encargarse del mando, y menos después de la derrota de Maella, no podía llevar la guerra al terreno que ocupaba Cabrera. Pero trató de socorrer los puntos fortificados, de asegurar más la línea militar que había establecida y de reducir el radio enemigo fortificando otros pueblos muy interesantes" (Cabello, 2006: 233-238). Observamos con este testimonio que, como sucede en Requena, se van a acometer medidas de fortificación de índole parecida, urgente, con cierto grado de provisionalidad, aspirando a una cierta permanencia.

El desconocimiento acerca de la guerra en el territorio era absoluto por parte de la opinión pública nacional. Van Halen era conocedor de esta realidad y por eso hizo caso omiso de todos aquellos que recomendaban una estrategia de bloqueo a fin de aislar a las facciones y derrotarlas por el hambre o la inactividad. Sabemos que simultáneamente Cabrera, con sus acciones, demostraba cuan difícil era acometer un proyecto semejante. Por su parte estaba siguiendo una política de ampliar su territorio de acción, precisamente asegurando determinados puntos del territorio y tratando de adueñarse de otros puntos clave liberales o de debilitarlos, como sucede con Peñíscola, Caspe, Montalbán, Villafamés o Lucena, a los que ataca continuamente.

A fin de entender la actividad bélica continua a la que se enfrentan numerosos puntos del territorio afectados por una táctica de guerrilla dinámica y constante, recogemos íntegro el siguiente texto de Cabello: El contexto his ámbito territorial ambicioso.

anterioricie sostener esta área de características singulares ha sido tratado con anterioridad a la presente tesis. Es preciso recalcar cómo este territorio es afectado por una moda- 
"Esta villa [Lucena], que, como veremos más adelante, vino a ser la servidumbre más pesada del ejército, era también el punto que Cabrera elegía para probar y conocer a los generales de la reina, y aquí fue donde vio a Van Halen y le respeto.

Sabiendo que preparaba un convoy de víveres le esperó, como acostumbraba, en las alturas que hay desde la Alcora, y en los parapetos que hizo y con las fuertes posiciones que ofrece el terreno pensaba diezmarle sus soldados como había hecho en otras ocasiones. Pero Van Halen le buscó por donde no le esperaba, y todas sus esperanzas quedaron defraudadas. Mientras se cargaba el convoy en Castellón, marchó con el ejército por la izquierda de Alcora y, cuando hubo pasado las montañas, volvió por la espalda de las posiciones que abandono Cabrera sin ninguna defensa. Dueño de las alturas, hizo que saliera el convoy y sin tirar un tiro lo introdujo en Lucena, reforzó la guarnición con una compañía del batallón de Marina y volvió a Castellón para preparar la fortificación de Onda.

Situado este pueblo en la parte más alta de la Plana, entre Castellón y Murviedro, y al pie de la sierra, debió mirársele desde el principio de la guerra como el dique principal contra las invasiones de Valencia. La circunstancia de ser muy rico y uno de los mayores de la provincia de Castellón, y la más notable todavía de que todos los propietarios, los hombres más influyentes, se habían comprometido de los primeros por la causa de todos los propietarios, los hombres más influyentes, se habian comprometido de los primeros por la causa de nes numerosas, debieron haber decidido a nuestros generales a fortificarlo y guarnecerlo antes de ahora. Van Halen se hizo cargo de estas ventajas y, aunque con muy escasos fondos, llevó a cabo la obra en poco tiempo. Encargado de esta operación el general Azpiroz, preparó los materiales más precisos en pocos días y con la posible reserva, y cuando Cabrera quiso impedirlo, las obras estaban en disposición de resistirle con inferiores fuerzas. Bien pronto los emigrados de Onda que había en Valencia y Castellón marcharon a sus casas y con sus medios y su influjo acabaron por establecer un pueblo bien amurallado y desde el cual podian nuestros generales atacar y rendir a Tales, muy inmediato.

Otro tanto hizo con el castillo de Casto Alto en Almenara, que aseguraba la carretera de Valencin.

El ejemplo de Onda fue seguido por otros muchos pueblos de la huerta y ribera de Valencia. Y aunque no podían ser considerados militarmente como aquél, sus fortificaciones les libraron de otros saqueos que habían sufrido como sufrieron ya en años anteriores y épocas no lejanas.

Si Villamalefa no hubiera sido vendido a Cabrera, Van Halen hubiera fortificado una línea desde Onda a Mora de Rubielos y hubiera protegido mejor el río de Segorbe y el Mijares. Pero era preciso reconquistar Montán, y esto ofrecía bastantes dificultades por el mal camino y por las atenciones a que había de acudir en otras partes. Todavía hizo con este fin un reconocimiento, pero desistió pronto por estas mismas consideraciones.

Cerrado a los facciosos el paso para la huerta de Valencia con la fortificación de Onda y Almenara, se abrió otro por los llanos de Alpuente y Chelva que le conducía a las entradas de Castilla por Requena, y que por las sierras de Cuenca y Albarracín lo llevaba con seguridad a Beteta, en la provincia de Guadalajara. En este concepto fortificó el Collado, Alpuente y Castielfabib. Así Segorbe quedaba entre Montán y Bejís, Mora entre Alcalá de la Selva y el Collado y Arcos, y Moya entre estos dos y Castielfabib y Beteta. Con esta línea desde el Ebro al Tajo Cabrera podía enviar una compañía de cazadores seguro de que no sería batida por un regimiento de caballería.

Al mismo tiempo ocupaba el castillo de Segura con la idea, quizás, de ir al Moncayo por los montes de Herrera y el Frasno, o a Medinaceli y Alcolea por la ribera de Daroca y puerto de Used.

Con la posesión de este punto inutilizaba del todo para el ejército el fuerte de Montalbán y extendía sus merodeos y dominación a los campos de Monreal y Romanos, al Común de Huesa y a la ribera del Jiloca.

Cabrera presumió que ni el ejército ni los aragoneses podían abandonarle un fuerte tan adelantado en la carretera antigua de Aragón a Valencia y en igual distancia de Zaragoza que de Teruel, y se preparó a defenderlo con el mayor empeño.

Necesitaba grande guarnición para cubrir el castillo y el pueblo si los habitantes no tomaban parte a su favor, y quiso comprometerles ofreciéndoles muchas ventajas y amenazándoles, en caso contrario, con que lo arrasaría. Reunidos con este objeto en un concejo general, unánimemente contestaron que nunca harian armas contra la reina y que preferían vivir en los montes. Con la contestación iba la sentencia de su ruina, y en pocos días no quedó de Segura ni señales siquiera de haber existido. La magnífica iglesia con otros edificios públicos y trescientas cincuenta casas con las oficinas de un pueblo labrador y ganadero fueron destruidas por ellos mismos, y mil seiscientas almas tuvieron que emigrar a los pueblos inmediatos y a las cuevas de los pinares. El general Van Halen marchaba a Zaragoza desde Teruel para conducir la artillería de batir y víveres, y mientras tanto Ayerbe se aproximaba para reconocer las posiciones e impedir la fortificación si aún no estaba concluida.
El 23 de marzo de 1839 salió de Cortes con intención de llegar hasta las paredes del castillo, pero Cabrera, con siete batallones y cuatrocientos (y sigue)" (Cabello, 2006: 233-238).

Cabello reconoce un total de 63 puntos fortificados liberales entre los que se cuentan: Jaca, Monzón, Benasque, Barbastro, Huesca, Uncastillo, Zaragoza, Pina, Sástago, Escatrón, Mequinenza, Maella, Caspe, Alcañiz, Torrevelilla, Calanda, La Puebla, Albalate, Alcorisa, Samper, Montalbán, Cariñena, Ateca, Calatayud, Villafeliche, Daroca, Cutanda, Monreal, Segorbe, Murviedro, Almenara, Nules, Burriana, Onda, Castellón, Lucena, Benicarló, Villafamés, Villamalefa, Peñíscola, Vinaroz, Valencia, Alcira, Sueca, Játiva, Gandía, Alcoy, Alicante, Cartagena, Murcia, Albacete, La Roda, Chinchilla, Las Peñas, Buñol, Chiva, Peracense, Teruel, Mora, Rubielos, Liria, Requena, Moya (Cabello, 2006: 319-320). Por su parte, Caridad (2013: 263) hacía referencia a un total de 25 puntos fortificados por los carlistas antes de la redacción de esta tesis que se han convertido en un total de 78 afectados en un momento u otro de la contienda por algún tipo de atención defensiva, tal y como se ha podido verificar. Es preciso tener en cuenta que muchos de estos puntos cambiaron de manos sucesivas (a) tavieja, Cañete, Castellote, Castillo de Villamalefa, Chelva, Chulilla, Collado de Alpuente, Culla, Manzanera, Montán, Morella, Peñarroya, Segura, Tales o Villahermosa del Río, entre otros.

De acuerdo con los documentos consultados y las referencias anteriores se detectaron en origen una serie de puntos de referencia inicial que experimentan obras de fortificación y son considerados como puntos fortificados a raíz del conflicto carlista. Tabla 11. Puntos fortificados por los liberales y los carlistas durante el conflicto detectados al inicio de este trabajo. El
presente listado es el origen para una propuesta de investigación territorial y es susceptible de ampliarse con otros puntos aún no identificados en las fuentes. En el caso carlista, como se puede observar en el catálogo de esta tesis, los 23 puntos de los que se partía han sido ampliados a 78 enclaves susceptibles de haber recibido intervenciones defensivas.

X Obras de fortificación liberal entre 1833 y 1840

Obras de fortificación carlista entre 1833 y 1840

\begin{tabular}{|c|c|c|c|c|c|}
\hline $\mathrm{N}^{\circ}$ & Fortificación & $\begin{array}{l}\text { Nombre } \\
\text { castellano }\end{array}$ & $\begin{array}{l}\text { Nombre en } \\
\text { valenciano }\end{array}$ & Nombre oficial & $\begin{array}{l}\text { Provincia } \\
\text { Actual }\end{array}$ \\
\hline 1 & Albacete & Albacete & No & Albacete & Albacete \\
\hline 2 & Chinchilla & $\begin{array}{l}\text { Chinchilla de } \\
\text { Monte-Aragón }\end{array}$ & No & $\begin{array}{l}\text { Chinchilla de Monte- } \\
\text { Aragón }\end{array}$ & Albacete \\
\hline 3 & La Roda & La Roda & No & La Roda & Albacete \\
\hline 4 & Las Peñas & $\begin{array}{l}\text { Las Peñas de } \\
\text { San Pedro }\end{array}$ & No & Las Peñas de San Pedro & Albacete \\
\hline 5 & Alcoy & Alcoy & Alcoi & Alcoi & Alicante \\
\hline 6 & Alicante & Alicante & Alacant & Alacant & Alicante \\
\hline 7 & Almenara & Almenara & Almenara & Almenara & Castellón \\
\hline 8 & Ares del Maestre & $\begin{array}{l}\text { Ares del } \\
\text { Maestre }\end{array}$ & $\begin{array}{l}\text { Ares del } \\
\text { Maestrat }\end{array}$ & Ares del Maestre & Castellón \\
\hline 9 & Bejis & Bejís & Bejís & Bejís & Castellón \\
\hline 10 & Benicarló & Benicarló & Benicarló & Benicarló & Castellón \\
\hline 10 & Benicarló & Benicarló & Benicarló & Benicarló & Castellón \\
\hline 11 & Burriana & Burriana & Borriana & Borriana/Burriana & Castellón \\
\hline 12 & Castellón & $\begin{array}{l}\text { Castellón de la } \\
\text { Plana }\end{array}$ & $\begin{array}{l}\text { Castelló de la } \\
\text { Plana }\end{array}$ & $\begin{array}{l}\text { Castelló de la Plana, } \\
\text { Castellón de la Plana }\end{array}$ & Castellón \\
\hline 13 & Culla & Culla & Culla & Culla & Castellón \\
\hline 14 & La Puebla (de Arenoso) & $\begin{array}{l}\text { Puebla de } \\
\text { Arenoso }\end{array}$ & $\begin{array}{l}\text { La Pobla } \\
\text { d'Arenós }\end{array}$ & Puebla de Arenoso & Castellón \\
\hline 15 & Lucena & Lucena del Cid & Llucena & Lucena del Cid & Castellón \\
\hline
\end{tabular}




\begin{tabular}{|c|c|c|c|c|c|}
\hline 16 & Montán & Montán & Montant & Montán & Castellón \\
\hline 17 & Morella & Morella & Morella & Morella & Castellón \\
\hline 18 & Nules & Nules & Nules & Nules & Castellón \\
\hline 19 & Onda & Onda & Onda & Onda & Castellón \\
\hline 20 & Peñíscola & Peñíscola & Peníscola & Peñíscola & Castellón \\
\hline 21 & Segorbe & Segorbe & Sogorb & Segorbe & Castellón \\
\hline 22 & Tales & Tales & Tales & Tales & Castellón \\
\hline 23 & Villafamés & Villafamés & Vilafamés & Vilafamés & Castellón \\
\hline 24 & Villahermosa del Río & $\begin{array}{l}\text { Villahermosa } \\
\text { del Río }\end{array}$ & Vilafermosa & Villahermosa del Río & Castellón \\
\hline 25 & Villamalefa & $\begin{array}{l}\text { Castillo de } \\
\text { Villamalefa }\end{array}$ & $\begin{array}{l}\text { El Castell de } \\
\text { Villamalefa }\end{array}$ & Castillo de Villamalefa & Castellón \\
\hline 25 & Villamalefa, Castillo de & $\begin{array}{l}\text { Castillo de } \\
\text { Villamalefa }\end{array}$ & $\begin{array}{l}\text { El Castell de } \\
\text { Villamalefa }\end{array}$ & Castillo de Villamalefa & Castellón \\
\hline 26 & Vinaroz & Vinaroz & Vinaròs & Vinaròs & Castellón \\
\hline 27 & Beteta & Beteta & No & Beteta & Cuenca \\
\hline 28 & Cañete & Cañete & No & Cañete & Cuenca \\
\hline 29 & Moya & Moya & No & Moya & Cuenca \\
\hline 30 & Barbastro & Barbastro & No & Barbastro & Huesca \\
\hline 31 & Benasque & Benasque & No & Benasque & Huesca \\
\hline 32 & Huesca & Huesca & No & Huesca & Huesca \\
\hline 33 & Jaca & Jaca & No & Jaca & Huesca \\
\hline 34 & Monzón & Monzón & No & Monzón & Huesca \\
\hline 35 & Bordes & Las Bordas & Es Bòrdes & Es Bòrdes & Lleida \\
\hline 36 & Cartagena & Cartagena & No & Cartagena & Murcia \\
\hline 37 & Murcia & Murcia & No & Murcia & Murcia \\
\hline 38 & Albalate & $\begin{array}{l}\text { Albalate del } \\
\text { Arzobispo }\end{array}$ & No & Albalate del Arzobispo & Teruel \\
\hline 39 & Alcalá de la Selva & $\begin{array}{l}\text { Alcalá de la } \\
\text { Selva }\end{array}$ & No & Alcalá de la Selva & Teruel \\
\hline 40 & Alcañiz & Alcañiz & No & Alcañiz & Teruel \\
\hline 41 & Alcorisa & Alcorisa & No & Alcorisa & Teruel \\
\hline 42 & Aliaga & Aliaga & No & Aliaga & Teruel \\
\hline 43 & Calanda & Calanda & No & Calanda & Teruel \\
\hline 44 & Cantavieja & Cantavieja & No & Cantavieja & Teruel \\
\hline 45 & Castellote & Castellote & No & Castellote & Teruel \\
\hline 46 & Cutanda (Calamocha) & Calamocha & No & Calamocha & Teruel \\
\hline 47 & Manzanera & Manzanera & No & Manzanera & Teruel \\
\hline 48 & Monreal (¿Del Campo?) & $\begin{array}{l}\text { Monreal del } \\
\text { Campo }\end{array}$ & No & Monreal del Campo & Teruel \\
\hline 49 & Montalbán & Montalbán & No & Montalbán & Teruel \\
\hline 50 & Mora (¿de Rubielos?) & $\begin{array}{l}\text { Mora de } \\
\text { Rubielos }\end{array}$ & No & Mora de Rubielos & Teruel \\
\hline 51 & Peñarroya & $\begin{array}{l}\text { Peñarroya de } \\
\text { Tastavins }\end{array}$ & No & Peñarroya de Tastavins & Teruel \\
\hline 52 & Peracense & Peracense & No & Peracense & Teruel \\
\hline 53 & Rubielos (¿de Mora?) & $\begin{array}{l}\text { Rubielos de } \\
\text { Mora }\end{array}$ & No & Rubielos de Mora & Teruel \\
\hline 54 & Samper (¿de Calanda?) & $\begin{array}{l}\text { Samper de } \\
\text { Calanda }\end{array}$ & No & Samper de Calanda & Teruel \\
\hline 55 & Segura (Castillo de) & $\begin{array}{l}\text { Segura de los } \\
\text { Baños }\end{array}$ & No & Segura de los Baños & Teruel \\
\hline 56 & Teruel & Teruel & No & Teruel & Teruel \\
\hline 57 & Torrevelilla & Torrevelilla & No & Torrevelilla & Teruel \\
\hline
\end{tabular}

\begin{tabular}{|c|c|c|c|c|c|}
\hline 58 & Alcira & Alcira & Alzira & Alzira & Valencia \\
\hline 59 & Alpuente & Alpuente & Alpont & Alpuente & Valencia \\
\hline 60 & Alpuente, Collado de & $\begin{array}{l}\text { El Collado } \\
\text { (Alpuente) }\end{array}$ & Alpont & Alpuente & Valencia \\
\hline 61 & Buñol & Buñol & Bunyol & Buñol & Valencia \\
\hline 62 & Chelva & Chelva & Xelva & Chelva & Valencia \\
\hline 63 & Chiva & Chiva & Xiva & Chiva & Valencia \\
\hline 64 & Chulilla & Chulilla & Xulella & Chulilla & Valencia \\
\hline 65 & Gandía & Gandía & Gandia & Gandia & Valencia \\
\hline 66 & Játiva [San Felipe] & Játiva & Xàtiva & Xàtiva & Valencia \\
\hline 67 & Liria & Liria & Llíria & Llíria & Valencia \\
\hline 68 & Murviedro & Sagunto & Sagunt & Sagunto/Sagunt & Valencia \\
\hline 69 & Requena & Requena & Requena & Requena & Valencia \\
\hline 70 & Sueca & Sueca & Sueca & Sueca & Valencia \\
\hline 71 & Valencia & Valencia & València & València/Valencia & Valencia \\
\hline 72 & Ateca & Ateca & No & Ateca & Zaragoza \\
\hline 73 & Calatayud & Calatayud & No & Calatayud & Zaragoza \\
\hline 74 & Cariñena & Cariñena & No & Cariñena & Zaragoza \\
\hline 75 & Caspe & Caspe & No & Caspe & Zaragoza \\
\hline 76 & Daroca & Daroca & No & Daroca & Zaragoza \\
\hline 77 & Escatrón & Escatrón & No & Escatrón & Zaragoza \\
\hline 78 & Maella & Maella & No & Maella & Zaragoza \\
\hline 79 & Mequinenza & Mequinenza & No & Mequinenza & Zaragoza \\
\hline 80 & Pina (¿De Ebro?) & Pina de Ebro & No & Pina de Ebro & Zaragoza \\
\hline 81 & Sástago & Sástago & No & Sástago & Zaragoza \\
\hline 82 & Uncastillo & Uncastillo & No & Uncastillo & Zaragoza \\
\hline 83 & Villafeliche & Villafeliche & No & Villafeliche & Zaragoza \\
\hline 84 & Zaragoza & Zaragoza & No & Zaragoza & Zaragoza \\
\hline
\end{tabular}


que, como Brusco, también ostenta el mando del batallón de zapadores de la población. En Cantavieja se encuentra al mando un coronel: Cartagena. Como podemos observar, dos de los principale referentes al cargo de la fortificación carlista son extranjeros, Wilhelm Von Rahden, proveniente del ejército prusiano, y Manuel Brusco, que procede del ejército portugués, autor de los escasos son obra del ejército liberal cuando procede a la toma de las plazas. Un ejemplo sería el plano de estado del castillo del Poyo en varas castellanas (Archivo Cartográfico de Estudios Geográficos de Centro Geográfico del Ejército, sign. Ar.G-T.3-C.1-196). Sobre Brusco es el propio Von Rahden el que aporta algo de información, un "joven oficial de ingenieros", "con quien había coincidido por primer vez en Castellote" y que "había prestado excelentes servicios en su cuerpo bajo el rey Miguel durante el sitio de Oporto, en la arriesgada construcción de una trinchera en la que fue el unico de once oficiales en acabar sano y con vida, recibiendo la Orden de la Torre y de la Espada de manos del propio rey. Tras la desgraciada convención de Evora vendió todas sus posesiones con el propósito de abandonar para siempre su patria y ver mundo [a] pronto se vio obligado a regresar a su primer oficio. Llegó a las provincias onscongadas, marchó con la Expedición Real y luchó con el 4 batalón catellano de la Princesa en la batalla que tuvo lugar junto a Cinca, no lejos de Barbastro (5 de junio de 1837), en la que fue gravemente herido y hecho preso. En Zaragoz estuvo a punto de ser fusilado - el sangriento turno siempre era decidido a los dados entre los prisioneros él había sacado en tan celebrada ocasión tres 'unos' - cuando Cabrera logró el canje en el verano de 1838. Tratado por el general con generosidad y auténtica consideración, no conocía el joven oficial otro sentimiento que un fervoroso agradecimiento a Cabrera, que se había convertido en su ideal. Con anterioridad a la de Castellote, había dirigido Brusco también la fortificación de Aliaga" (Von Rahden, 2013: 303-304). Veremos a Brusco también implicado en las reparaciones del fuerte de Segura, y en el verano de 1839 se le pone al cargo de las fortificaciones de Bejís, Collado, Alpuente, Castielfabib, Cañete y Beteta, dirigiendo dos compañías de zapadores (Caridad, 2014: 304). Cuando von Goeben llega a la zona, Brusco le cede una de sus compañías y se dedica únicamente a las obras de la fortaleza de Beteta. A causa de ellas tiene fuertes discusiones con Balmaseda, jefe carlista, lo que provoca su marcha (Caridad 2014: 304, 305). Según el testimonio de Von Goeben, él mismo fue el responsable de la dirección de los trabajos en San Pedro Mártir (Morella), así como el de terminar la fortificación de Villarluengo, alternando con el capitán Verdeja la supervisión de Cantavieja. A este le asignaron los fuertes de Ares del Maestre y de Culla, y al capitán Jiménez los de Castellote y Peñarroya. Manuel Brusco, según Von Goeben "dirigía los trabajos en las fortalezas situadas al otro lado de la carretera de Teruel Segorbe". Cuentan bajo su mando con oficiales subalternos, maestros de obras y compañas Co Como observamos, las fuentes no son precisasen organiz diferentes obras, no apareciendo citados en muchos casos.

-El caso de la fortificación de Requena en el transcurso de la primera guerra carlista, como ya se ha expuesto, es el embrión de este trabajo. A pesar de tratarse de una fortificación liberal, resulta relevante por recoger las características de las defensas urbanas de ciudades o villas de escala intermedia, que responde a la escala máxima de las principales plazas carlistas como Morella o Cantavieja. Requena constituye un ejemplo de defensa a la guerra de partidas característica, con medidas disuasorias que son puestas a prueba en más de un ataque. Precisamente el caso de Requena, favorece la aproximación y sienta las bases metodológicas para aprender a mirar y aproximarse al estudio de la fortificación característica del momento. Obviamente, tras la detección del conjunto de plazas que integran la red defensiva de Cabrera, cabría una aproximación concreta a cada una de ellas siguiendo la metodología planteada.

-Llegados a este punto, se pueden extraer un conjunto de conclusiones particulares para el caso concreto de Requena donde la principal y más relevante, de la que se desligan todas la siguienCarto se han revelado las características del trazado fortificado durante la Primera Guerra Carlista en la ciudad de Requena, sino que se ha probado su existencia física cuando, en el momento de iniciar la investigación, el desconocimiento de dicha presencia era total, a pesar de las recientes intervenciones en el patrimonio arquitectónico de la ciudad y de la redacción del Plan General de Ordenación Urbana (2013) y del Plan Especial de Protección del Patrimonio Histórico del Centro Histórico de la Villa (2004).

1.- Descubrimiento e identificación inédita de porciones de la fortificación olvidadas y aún existentes. El proceso ha sacado a la luz una serie de elementos pertenecientes a la fortificación liberal, muros aspillerados, frentes de batería y todo un conjunto de muros que integraron la defensa decimonónica, principalmente en el sector del Pedazo de los Muertos, pie del Pozo de la Nieve, frente de Higuerillas, frente del Tirador o de la batería de Honrubia y en el área de bajo los Huertos de Santa María.

2.-La investigación ofrece como producto utilizado en el proceso, la base de datos del patrimonio de Requena asociado a la defensa de la ciudad entre 1830 y 1849, diseñada en Microsoft Acces, que identifica los diferentes elementos que integraron el conjunto fortificado, tanto los desaparecidos como los aún existentes, recopilando formas de denominación en los informes militares, papel defensivo, localización, y el grado de protección y tratamiento en el Plan General de Ordenación Urbana de Requena en aquellos casos en que son contemplados.

3.-Se ha sacado a la luz todo un conjunto documental histórico asociado en forma de memorias militares, documentos del catastro y del padrón histórico de Requena, con numeraciones de calle, cuentas del municipio, actas del consejo municipal, expedientes de tasación y expropiación, y se ofrece a posteriores investigadores las transcripciones completas inéditas y la interpretación de los datos del conjunto de memorias militares.

4.-Se han recopilado un conjunto de más de cien fotografías históricas a partir del Archivo Municipal de Requena, postales turísticas de la época y fotos personales de vecinos de la ciudad y apasionados por el pasado requenense. Estas fotografías en forma de postales históricas o instantáneas familiares para recuerdos de eventos puntuales, no se habían analizado hasta el momento como testimonios del estado y grado de alteración de los frentes defensivos de Requena, sino más bien como recuerdos 
nostálgicos de rincones de la ciudad. De ellas se deducen las principales alteraciones del trazado original que no se empiezan a producir hasta el año 1936, poco antes del estallido de la Guerra Civil, en que se incendia el denominado Convento de las Monjas (Convento de las agustinas recoletas). A raiz de este incendio, se dará pie con el tiempo a la reestructuración de la plaza del portal y a la prc gación de la ciud gación de la cio, se dayetan Borso di Carminat a raiz de encargo aprobado en sesion de 10 de novienbre de 1941 y cerrado el 2 de febrero de 1942, de algún modo protegió los barrios historicos de la Villa, el Arrabal y las Peñas, a planificar el crecimiento hacia el oeste, con un planteamiento de avenida jardín que define la actual y popular Avenida Arrabal. Las fotografías suelen ilustrar la apertura de La Avenida, la implantación del mercado y todo un conjunto de equipamientos como el edificio de correos, la estación de ferrocarril, la plaza de toros y el edificio de telefónica. Se suelen centrar en pequeños hitos urbanos como el conjunto de fuentes - Regidores, Bernate, El Peral, Pilas, Fuencaliente... - y en especial la fuente de . ra, Callejón de Santa María, Plazuela del Salvador, Cuestas del Ángel, de la Cortina, del Castillo y de Carnicerías y las portadas de Santa María y El Salvador. Curiosamente, se tiene predilección por determinados frentes panorámicos de la ciudad: Cantarranas, el frente de San Nicolás y los huertos de Santa María, lo cual es indicativo de la trascendencia del perfil de la ciudad en el paisaje natural y antrópico, y por tanto, del valor patrimonial como paisaje cultural de la tipología de frente defensivo sostenida en este trabajo. Fuera de la Villa, aún intramuros, la denominada Plaza Consistorial y el Convento del Carmen, son los lugares más representados.

5.- El análisis y el contraste de las narraciones militares por parte de los diferentes cronistas de Requena, ha permitido dilucidar contradicciones, llenar lagunas y extraer interpretaciones que
no solo tienen que ver con la historia militar - por ejemplo clarificar el sentido del ataque carlista no solo tienen que ver con la historia militar - por ejemplo clarificar el sentido del ataque carlista
de Requena de 1835, el número de intentos de asalto en el ataque por parte de Cabrera, o poner en duda si realmente se produjo una confrontación en el ataque de Gómez de 1836 tal y como se recoge en los documentos oficiales - sino también deducir a partir del análisis de los acontecimiento militares determinadas características urbanas, como el grado de fortificación de la ciudad, la desprotección de las Peñas en el año 1835 y la trascendencia táctica que tiene un punto como la Puerta de Reinas, donde se centran más adelante las principales atenciones de las memorias militares.

6-La identificación de puntos del trazado a través de las denominaciones de la época contrastadas con la toponimia, no solo ha permitido recuperar el significado de etimologías perdidas, sino también dar sentido a etimologías presentes como la calle del pozo (emplazamiento del pozo de la nieve), las troneras (emplazamiento de la batería de Isabel II), el pedazo de los muertos (emplazamiento de los fallecidos del hospital de Caridad), la carrera de San Sebastián (calle que fue antes camino, o trayecto corto que permitía llegar rápidamente a la batería de Isabel II desde San Sebastián), Bajo de las bodegas (límite de la ciudad con un frente de peña en el que se encontraban bodegas excavadas), Calle Colegio (donde se emplazaba la Escuela de Da Emilia en 1914), los huertos de de entrada y slida de carnes donde se disponín lus "tablu" " "tablajerís", de los abasteceros de carne), las Ollerías (emplazamiento de alfareros extramuros) o Cantarranas (la existencia de un emplazamiento encharcado que acabó siendo colonizado por las huertas, a espaldas del convent de las Monjas) entre otros.

7.-Aportación de un catálogo documentado global de los aspectos militares de la ciudad de Requena entre 1833 y 1840 que permita servir de apoyo a estudios particulares. El estudio global, si bien requiere en estos momentos la concreción en determinados puntos, permitirá a los investigaSe permite así que los estudios puntuales puedan implementar información que desde la óptica parcial hubiera pasado desapercibidos, como se ha demostrado que ha estado sucediendo en todas las intervenciones puntuales que se han realizando en la ciudad hasta el momento.
8.-Nuevas aportaciones cronológicas: Contrariamente a lo sostenido por la gran mayoría de las fuentes, la presente investigación ha conseguido demostrar que las obras de defensa de Requena se originan en el año 1834, y no con las supuestas obras de urgencia del verano de 1835 (AMR, 1818/48), que serán dirigidas por el mismo maestro de obras: Guillermo Sáez.

9.-Aportación biográfica asociada a referencias tratadísticas y académicas. La investigación aporta información sobre los principales responsables del proyecto y ejecución de la fortificación liberal. La investigación de archivo ha permitido extraer la implicación de maestros de obra como Guillermo Sáez, formado en la Academia de Bellas Artes de San Carlos de Valencia, e ingenieros militares comisionados como Pedro Ortiz de Pinedo o Juan Ramón de Carbonell. El rastreo de sus expedientes militares en los Archivos de la Academia de San Carlos en Valencia y en los Archivos militares de Segovia ha aportado información de relevancia que se resume en las siguientes aportaciones.

10.-Aportación inédita de los contenidos de un proyecto de edificación en la época y en la zona para el elemento clave constituyente del perímetro fortificado: la casa urbana entre medianeras.

El expediente de evaluación de Guillermo Sáez para acceder al grado de Maestro de Obras (AASC, 61-c/41-2F), contiene su proyecto de "casa de un labrador hacendado situado en una población" [entre medianeras] que permite conocer las técnicas proyectuales, principalmente la definición constructiva y el modo de plantear los cálculos presupuestarios desde la ortodoxia académica de la arquitectura más característica en la época en la ciudad de Requena. El que el maestro de obras obtenga el título con su proyecto, su probada madurez (tiene 39 años), y su larga experiencia en obra desde la niñez bajo las órdenes de su padre albañil, sumado a la presencia de varias propiedades a su nombre y su gran actividad constructiva acumulando las principales obras de fortificación de la ciudad en la década de los treinta del siglo XIX, permiten que su proyecto pueda convertirse en un referente sobre los modos de construcción en la zona de esta tipología urbana. Estas técnicas se han podido validar con el prototipo estudiado de la casa del Retablo.

Curiosamente el proyecto presentado para su evaluación se presenta como "método de construcción" y aborda todas las etapas preceptivas: replanteo, excavación de cimentaciones, construcción de fachadas y elementos estructurales: pilares y forjados, cubiertas, tabiquerías, pozo, pavimentos, y acabados superficiales, con referencias breves al saneamiento centrado en el desagüe de las aguas de lluvia. Se complementa con las mediciones y el presupuesto, en reales de vellón. No hay ningún culo estructural sino un modo de proyectar basado en la tradición. Las fases del proceso distinguen:

- Un replanteo previo. Se fija la separación de los muros en base a la longitud de los maderos disponibles. La referencia para las alineaciones suelen ser trazados paralelos a las medianeras y a las calles.

- Las zanjas de cimentación se separan medio palmo de ambas caras de los paramentos estructurales. El plano inferior del cimiento se lleva hasta la profundidad de asiento aceptable, lo que convierte a la cimentación en la única partida no presupuestable. Se ejecuta con "mampostería maciza" y se nivela con el terreno con mezcla de cal y arena medio palmo antes de salir a la superficie (cinco partes de arena y tres de cal viva). Se espera un tiempo (sin especificar) a que asienten los cimientos. - Paralelamente a los cimientos se abre el pozo, enrasándolo al nivel del empedrado. Sería recomendable levantar su fábrica a la altura de un antepecho (configurando un brocal), para evitar caídas, dejándolo en este estado toda la obra. se recomienda un trazado circular por el efecto de bóveda resistente.

Con los cimientos ejecutados se efectúa un nuevo replanteo para corregir errores. Se señalan los centros de puerta y se levantan las esquinas definiendo el espesor de la tabiquería fijado en proyecto. La galería se ejecutará con ladrillos y buena cal, separando los ladrillos a junta medio dedo para preveer las filtraciones.

-Se inicia la elevación de los paramentos exteriores dándoles "desplomo hacia dentro" ("una línea por palmo"), mientras que los paramentos interiores se elevan a plomo. Los paramentos verticales se construyen por etapas, hasta el plano superior de los huecos, donde se debe iniciar el "arranque de los arcos de puertas y ventanas". 
Los cargaderos de huecos de puertas y ventanas se ejecutan en las obras exteriores con "arcos adintelados" de ladrillo, pero interiormente con madera.

- Paredes y puertas se enrasan horizontalmente a la altura de "20 palmos" (4,17 m) para apoyo de forjados. En este punto se paraliza la obra para facilitar el asiento.

- Los pilares, esquinas y cantos de ventanas y puertas se ejecutan con ladrillo y el resto de las paredes de mampostería.

-Se emplazan los "revoltones". No se hace referencia a vigas pues se interpreta que se construyen viguetas de madera de muro a muro. Para el maestro de obras lo importante es la longitud de estas viguetas y el ancho del revoltón (dos palmos, $42 \mathrm{~cm}$ ).

- Construido el "entrevigado" se enrasan las paredes a la altura del primer piso. Se habla de clavar los revoltones con "suficiente clavazón".

Se replantean los centros de puerta del segundo piso y ventanas.

- Se procede igual que en la planta baja hasta el plano de apoyo de cubierta.

Se acaban todas las paredes hasta el nivel necesario para definir la pendiente de la cubierta.

Se configura el alero con una cornisa regular de ladrillo y yeso "bien trabajada" que tendrá el espesor de las paredes de fachada y el flanco. No podrá volar la cornisa más que el mismo espesor de las paredes de fachada.

Se dispone el "envigado" del tejado con el mismo orden que los revoltones. Las vigas tendrán 1 palmo de altura $(20,87 \mathrm{~cm})$ y siete dedos de canto $(12,2 \mathrm{~cm})$.

"Sobre el "envigado" se clavarán listones.

Sobre los "listones" se clavan listones.

-Sobre los "listones" se "sientan" ladrillos y se dispone el tejado bien calzado con la cal y las tejas correspondientes.

Concluida la cubierta se fabrican las "lomeras".

Se enlucen de cal y yeso "bien arremolinadas" las fachadas.

Se "sientan" las ventanas colocando al mismo tiempo los balcones y las rejas.

En el interior se construyen las escaleras del primer piso y se fabrica el primer piso de bovedillas (objetivo: impedir caídas desde el segundo piso). Las bovedillas se construyen con cascos de teja y pedazos de ladrillo con buen y abundante yeso.

-Se concluye la escalera del segundo piso. Las escaleras se construyen con "bóvedas de adobe doble" (bóveda tabicada doble), colocando encima los escalones bien dirigidos.

Se concluyen las bovedillas del segundo piso.

Se distribuyen habitaciones (albañilería interior). Se construyen tabiques, puertas y se enlucen los tabiques interiores.

Se replantean pavimentos, tomando como referencia el nivel del pavimento de la escalera. Se colocan pavimentos sobre los forjados.

Se colocan barandillas, peldaños, pavimentos y frontispicios de las escaleras. Con lo que se dan las habitaciones interiores por concluidas.

Se recomienda empedrar el patio con una línea de losas pegada a las paredes. La superficie tendrá una ligera pendiente hacia el centro a fin de recoger el agua de lluvia, por medio de pequeñas aspilleras en una losa central que conducirán las aguas a un conducto o albañal dirigido a la calle más conveniente.

más conveniente.
Se hace referencia a la presencia de un lagar (superficie en la que pisar la uva para el mosto). Se interpreta que se recomienda en este espacio enfoscar paredes y suelo hasta la altura conveniente con "hormigón" para garantizar el uso. Se sobreentiende que en este momento, como se verifica en informes militares de la época, hacen referencia al hormigón para su uso en estructuras hidráulicas. Por lo general un mortero de cal que incorpora un aditivo, cenizas o cerámica machacadas, cuyo fino diámetro de árido garantiza unas ciertas propiedades impermeabilizantes. Este recurso se aplica en la casa a las prensas de aceite, caballerizas, gallinero, pajera, cochinera... Espacios que Guillermo Sáez considera habituales en las casas de labrador. Es curioso que no se hace referencia a la letrina, pero sí contempla en el presupuesto junto a la pocilga.

Del presupuesto se extraen la presencia de pilas, chimenea en planta baja con hornillos, cocina superior con chimenea y hornillos y piezas de guardarropía.
Llama la atención que Sáez insiste en un proceso rudimentario de revisión de calidades, especialmente de yeso, ladrillo, tejas "y todo lo demás correspondiente a una obra", y la necesidad de "velar" por el proceso supervisando a los operarios. Asegura que a los operarios les mueve "su verdadero interés" apelando a la "responabilidad" del Maestro pues de lo contrario el "rubor", sino en "la degradación más notable" (AASC, 61-c/41-2F).

11.-Revelación de las influencias académicas y teóricas presentes en la fortificación de Requena de la Primera Guerra Carlista que permiten entender su planteamiento. Se ha desvelado la procedencia de los ingenieros militares, Pedro Ortiz de Pinedo y Juan Ramón de Carbonell. El primero inicia su formación en la Academia de Cádiz, pero se convierte en integrante de la primera promoción (20 de diciembre de 1819) de la segunda etapa (1815-1823) de la Academia de Ingenieros de Alcalá de Henares. El segundo, integra la segunda promoción (20 de diciembre de 1820). A partir de la identificación y el tipo de formación recibida, se deducen una serie de influencias, básicamente tuadas por el marqués Marc-René de Montalembert (1714-1800) apoyando los fuegos verticales y el sistema perpendicular, apostando por una fortificación que basa su defensa en la potencia artillera, debate continuo en las memorias militares

12.-Algunos informes militares, con descripción detallada han permitido reconstruir las características de un fortín tipo del momento. La reconstrucción gráfica inédita del aspecto de los fortines de Requena, se aporta por primera vez en este trabajo.

13.-El estudio particularizado de la casa del retablo con el objeto de determinar la presencia de la fortificación carlista ha permitido aportar el levantamiento gráfico de la casa clarificar las diferentes etapas de construcción y fechar la construcción de la parte principal de la casa en la segunda mitad del siglo XVIII, con ampliaciones en el siglo XIX o principios del siglo XX. El estudio permite la puesta en valor de este patrimonio urbano característico de Requena, propio de la casa urbana de labrador hacendado, implementando el valor histórico defensivo.

14.-La investigación aporta el conocimiento de los sucesivos proyectos de fortificación de Requena entre 1833 y 1840 a partir de los motivos que los impulsan, los criterios aplicados, los procesos administrativos que los acompañan (como expedientes de expropiación designación de comisión de servicios, juntas municipales...), los procesos de diseño y ejecución así como los informes de cuánto de ello se acometió o quedó por concluir.

15.-El trabajo propone una estrategia de intervención basada en la preservación histórica de las partes inalteradas, normalmente la estructura principal de la casa de labrador-hacendado. Se insiste también en la necesidad de preservar los espacios abiertos escalonados que configuran el patrimonio antrópico de los huertos abancalados con muros de piedra en seco. Se admite la alteración en aquellas construcciones adosadas fruto del crecimiento orgánico, normalmente en peor estado, metamorfosis debería estar condicionada. Así se preservarán los patrones de crecimiento orgánico con un límite máximo de crecimiento fijado en el máximo alcanzado hasta el siglo XX. No se puede trabajar fijando una altura de cornisa máxima, que imprimiría una regularidad jamás existente en este tipo de fachadas, como tampoco se puede permitir una libre interpretación del volumen edificable, lo cual podría alterar la percepción de las fachadas posteriores siempre en aras del mayor aprovechamiento superficial por parte del interés de propietarios poco preocupados por el paisaje definido por el límite urbano. El patrón de crecimiento debería atender a anchos de crujía propios de estructuras menores de madera, cubriciones inclinadas de teja y a intentos de respetar un cierto paralelismo en los muros añadidos, propio del sentido común de la construcción tradicional. Nunca se ocupará la totalidad del ancho de la fachada posterior del edificio principal, por lo que la fachada metamórfica debería entenderse como un agregado de volúmenes siempre en gradación jerárquica respecto al edificio preexistente. Deberá considerarse una adecuación técnica, material y cromática, predominando la arquitectura de ladrillo revocada de cal, mampostería o tapia, la cubrición plana, 
con remates de barandillas de reja o cubriciones inclinadas con teja árabe tradicional de la zona. El tratamiento de huecos puede ser diverso respetando los patrones tradicionales, ventanas de formato vertical y, en todo caso, vanos abiertos enmarcados por el elemento estructural tradicional. . en forma de contraventeres en for de mader. Tambien se aceptan rejerlas reinterpretando las tradicionales rejas de hierro forjado. El cromatismo debería respetar el blanco cal que se impone a partir del siglo XVIII, correspondiente a las construcciones que jalonan estos frentes y en todo caso, se puede jugar con colores naturales desnudos, respetando el carácter de provisionalidad con el que se generaron: tapia o mampostería. De este modo se respetan los materiales que constituyeron el frente defensivo y con los que se recrecieron muchos de los muros para la defensa. Se admitirá la construcción de parapetos sobre los actuales bancales siempre que no superen la altura de los parapetos de la época, ejecutados con los mismos materiales antes indicados. Se admitirán huecos que respeten las dimensiones de las aspilleras verticales ture re época siempre y cuando estén emplazados en lugares adecuados para su correcta interpretación y
siempre que no constituyan "falsos históricos". 
Tabla 12. Listado de las plazas fuertes estudiadas.

\begin{tabular}{|c|c|c|c|}
\hline 1 & Ademuz & 40 & Landete \\
\hline 2 & Alcalá de la Selva & 41 & La Pobla de Benifassà \\
\hline 3 & Alcorisa & 42 & Las Cuevas [de Cañart] \\
\hline 4 & Aliaga & 43 & La Sénia \\
\hline 5 & Alloza & 44 & Linares de Mora \\
\hline 6 & Alpuente & 45 & Manzanera \\
\hline 7 & Arcos (de las Salinas) & 46 & Mira \\
\hline 8 & Ares del Maestre & 47 & Mirambel \\
\hline 9 & Ayódar (neutral en cuanto Hospital de Sangre) & 48 & Miravet \\
\hline 10 & Beceite y sus puertos & 49 & Monasterio de Santa María del Olivar \\
\hline 11 & Bejís & 50 & Monroyo \\
\hline 12 & Benicarló & 51 & Montalbán \\
\hline 13 & Berga & 52 & Montán \\
\hline 14 & Beteta & 53 & Mora (d'Ebre) \\
\hline 15 & Bordón & 54 & Morella \\
\hline 16 & Calanda & 55 & Peñarroya [de Tastavins] \\
\hline 17 & Calig & 56 & Pinós \\
\hline 18 & Cantavieja & 57 & Salinas del Manzano \\
\hline 19 & Cañada del Hoyo & 58 & Salvacañete / Torrefuerte de las Veguillas \\
\hline 20 & Cañete & 59 & Samper de Calanda \\
\hline 21 & Carboneras de Guadazaón & 60 & San Mateo / Sant Mateu \\
\hline 22 & Cardenete & 61 & Santa Bárbara \\
\hline 23 & Castellote & 62 & Sant Carles de la Ràpita \\
\hline 24 & Castelserás & 63 & Segura (de los Baños) \\
\hline 25 & Castielfabib / Castiel & 64 & Tales \\
\hline 26 & Castillo de Villamalefa & 65 & Torre de Castro (Calles) \\
\hline 27 & Chelva & 66 & Torrebaja \\
\hline 28 & Chulilla & 67 & Torrecilla del Rebollar \\
\hline 29 & Culla & 68 & Torrijas \\
\hline 30 & Domeño & 69 & Tragacete \\
\hline 31 & Ejulve & 70 & Ulldecona \\
\hline 32 & El Collado de Alpuente / Castillo del Poyo & 71 & Utiel \\
\hline 33 & Estercuel & 72 & Villahermosa del Río \\
\hline 34 & Flix & 73 & Villar del Humo \\
\hline 35 & Forcall/ Horcajo & 74 & Villarluengo / Convento de Monte Santo \\
\hline 36 & Garaballa / Tejeda la Vieja & 75 & Víllora \\
\hline 37 & La Fresneda & 76 & Xert / Chert \\
\hline 38 & La Galera & 77 & Xerta / Cherta \\
\hline & La Hoz (de la Vieja) & 8 & Zafrilla \\
\hline
\end{tabular}


1078 La fortificación del "reino mágico" de Cabrera. Virginia Navalón

$$
\text { E. de la }
$$
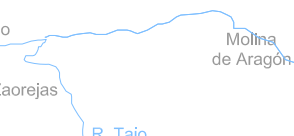

R. Gallo

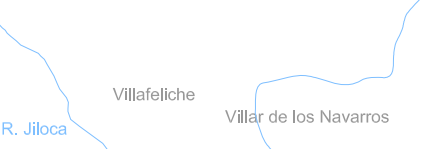

R. Aguas Vivas
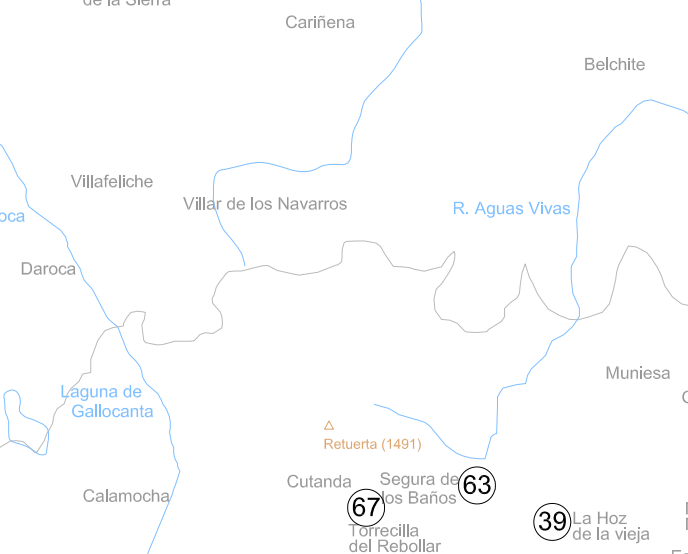

$$
\text { Muniesa }
$$

$$
\text { La puebla de Hijar Chiprana }
$$

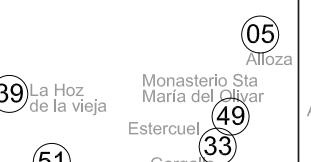

$$
\begin{aligned}
& \text { Ejuvve } 31 \text { Las Cunva: } 42 \text { Castellote } 23
\end{aligned}
$$$$
\text { (51) Montalbán Gargallo }
$$

Campo

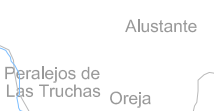

Orihuela del Tremedal

Priego Cañamares

R. Escabas
$\begin{aligned} & \text { Albalate } \\ & \text { de las Nogueras } \\ & \text { Torrecilla }\end{aligned}$ Arcos
de la Sierra

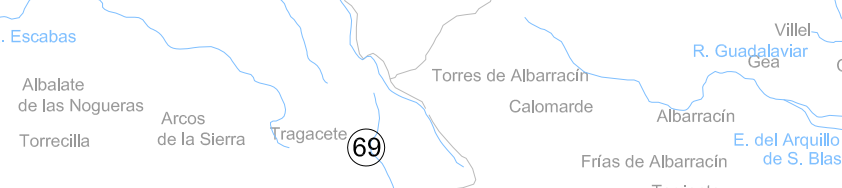

Collados Villaba
de la Sierra

Cuenca

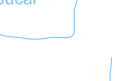

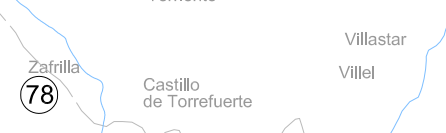
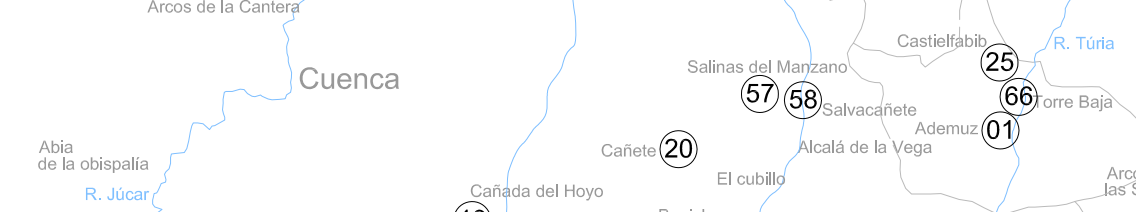

R. Jucar

Albadalejo
del Cuende

Cañada del Hoyo Cañete 20 El cubillo Alcalí de la vegámz (1)

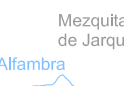

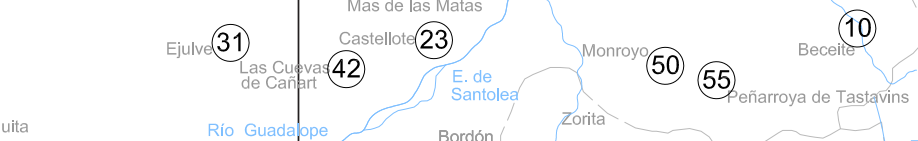

$$
\text { Batea }
$$$$
\text { Mirave } 58
$$

Ascó

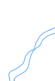

\section{Xert 77}

e Mrro (1259) La pobla R. Sènia Sta. Bàrbara

$$
\text { Amposta }
$$

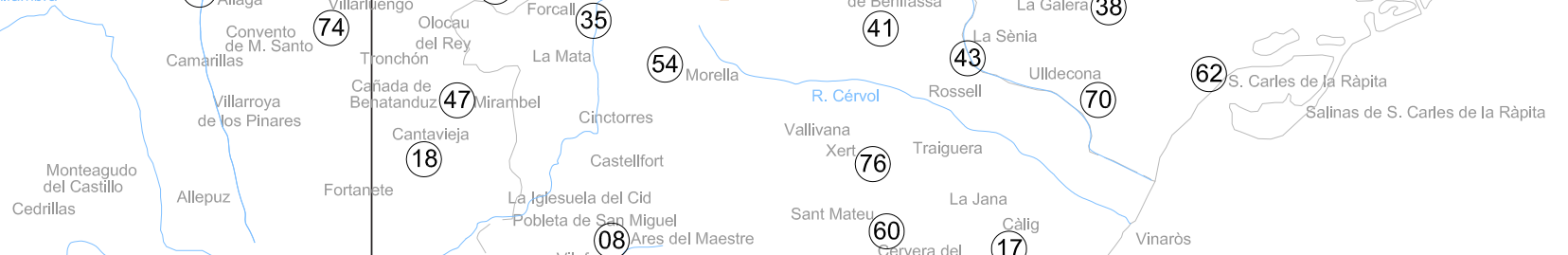


12.2. Listado de recorridos de la tesis 
Listado de recorridos de la tesis. Distancia / tiempo

$$
\begin{aligned}
& \text { km h:min } 20160522
\end{aligned}
$$

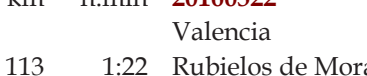

$$
\begin{aligned}
& \begin{array}{ll}
\text { 1:22 } & \text { Rubielos de Mor } \\
0: 07 & \text { Nogueruelas }
\end{array} \\
& \begin{array}{ll}
\text { 0:07 } & \text { Nogueruelas } \\
\text { 0:21 } & \text { Linares de Mora }
\end{array} \\
& \text { 0:18 Mosqueruela } \\
& \text { 2:08 Pobleta de San Miguel } \\
& \text { 2:34 La Iglesuela del Cid } \\
& \begin{array}{ll}
0: 11 & \text { Cantavieja } \\
0: 21 & \text { Vilafranca }
\end{array} \\
& \text { 2:00 Valencia }
\end{aligned}
$$

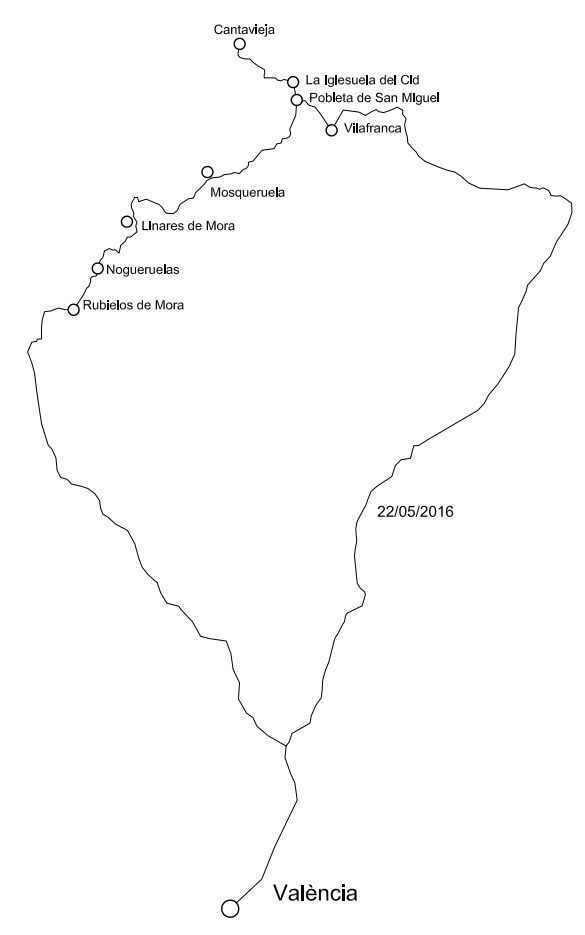

Fig. 842 .

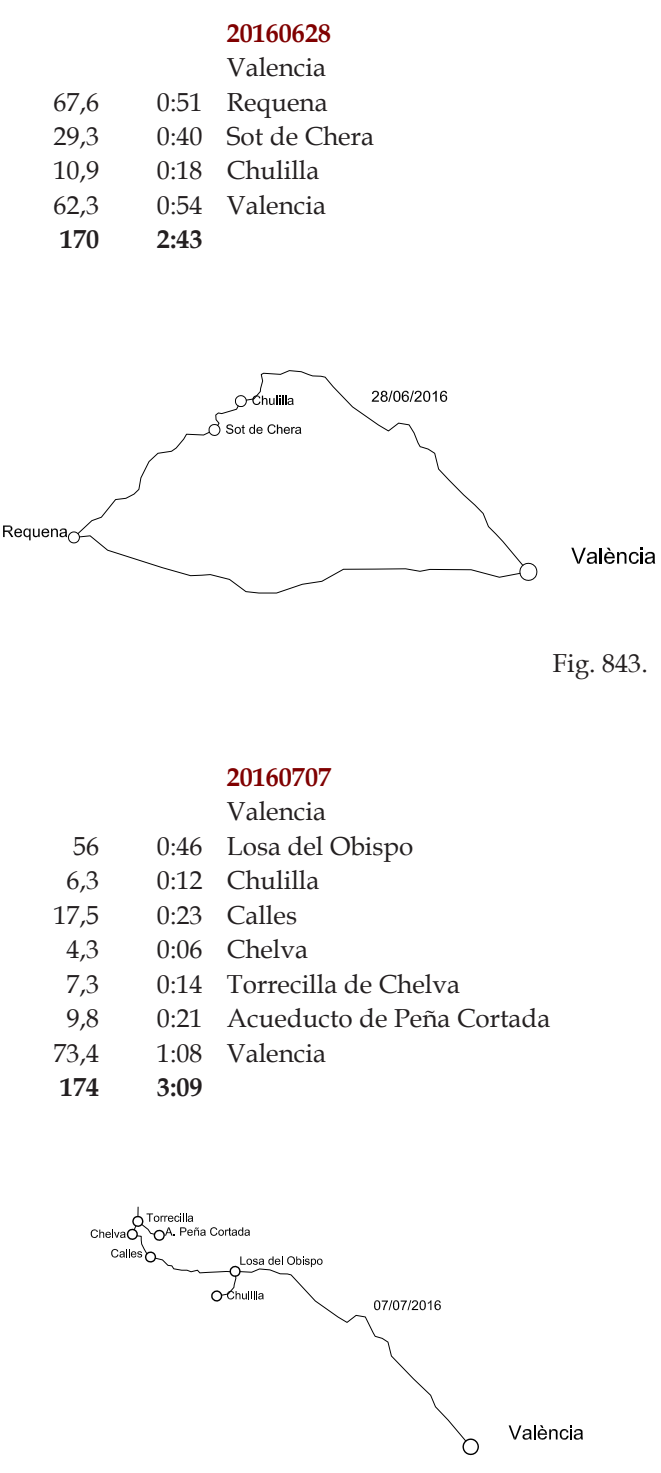

Fig. 844. 


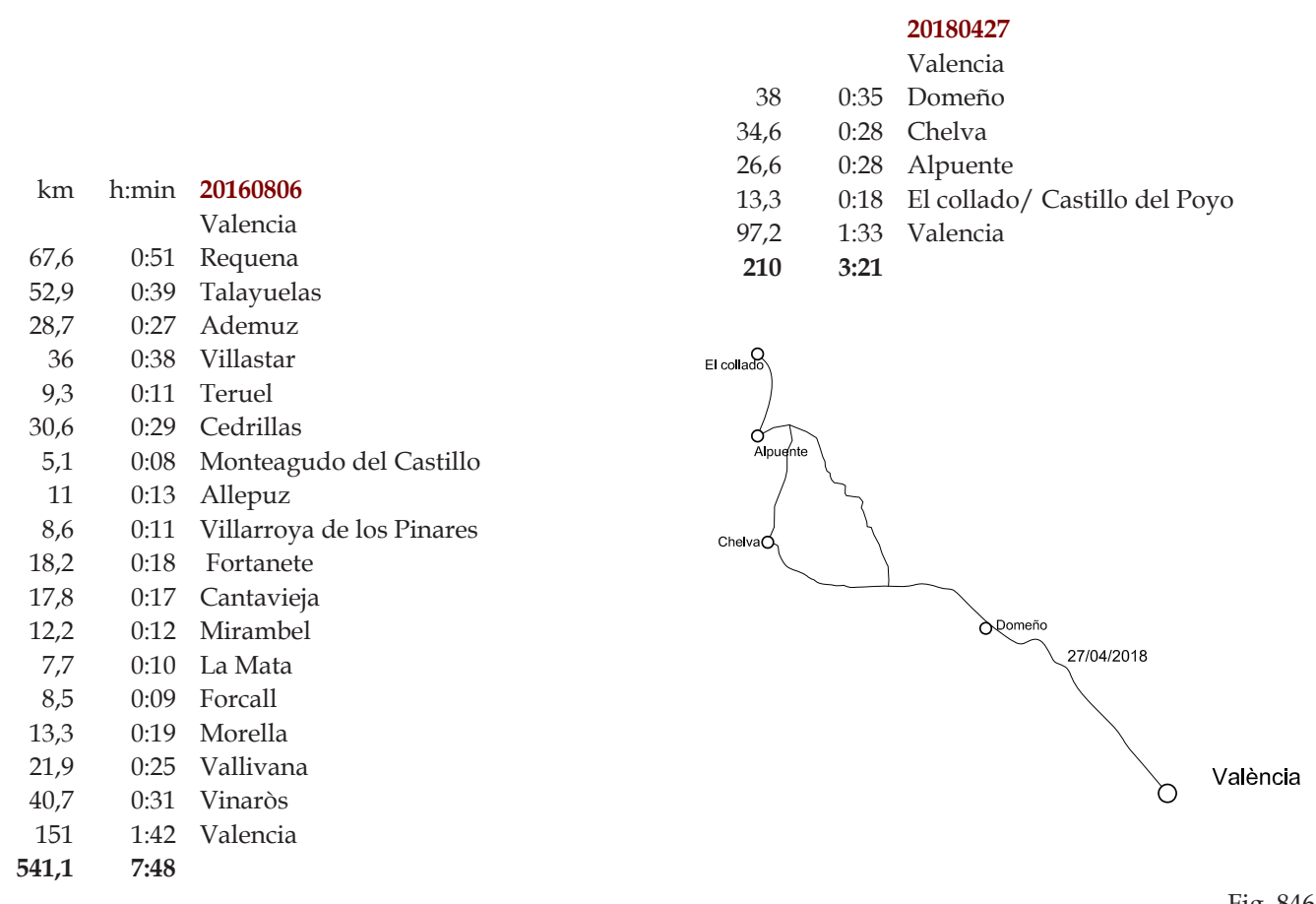

Fig. 846

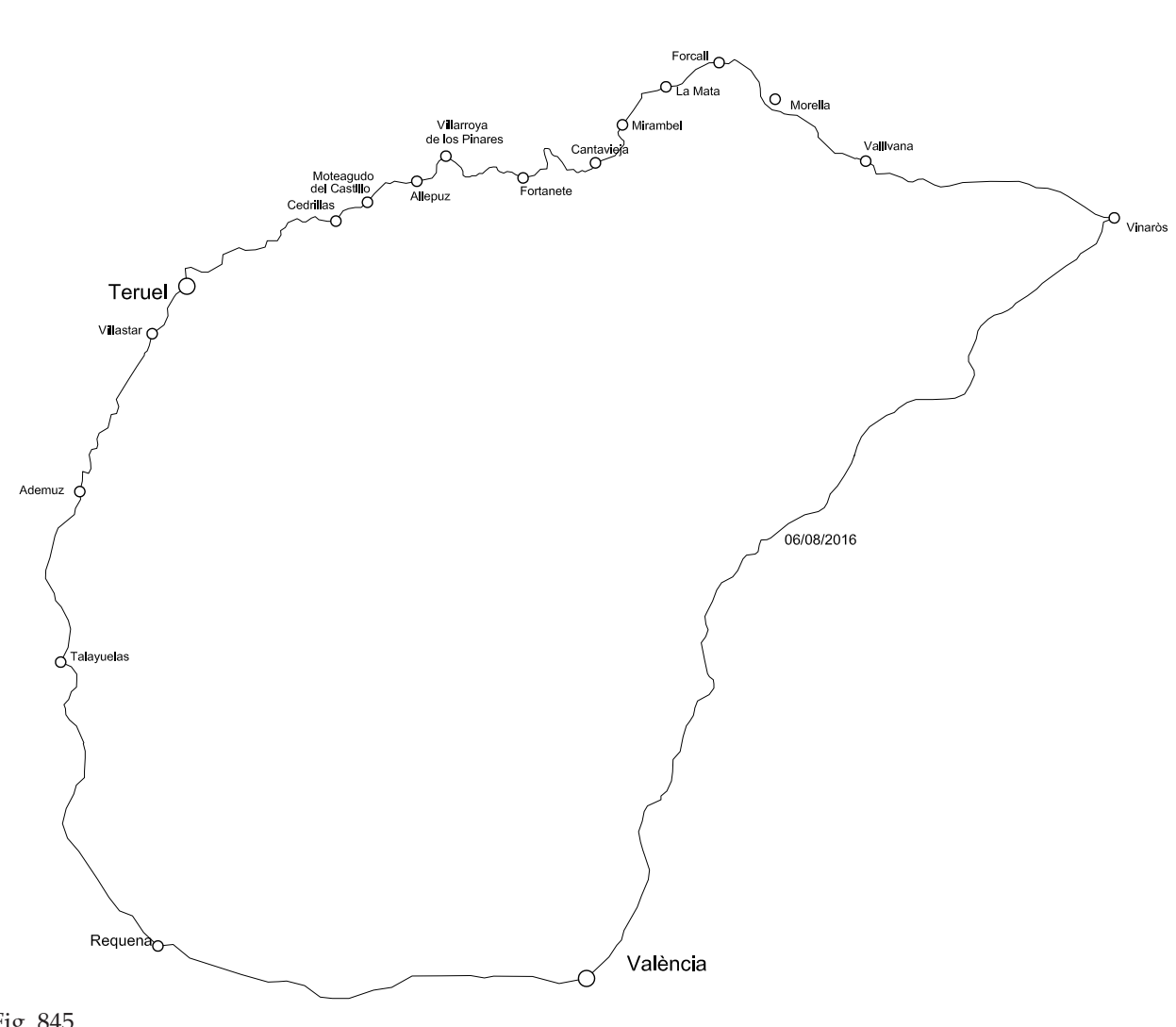

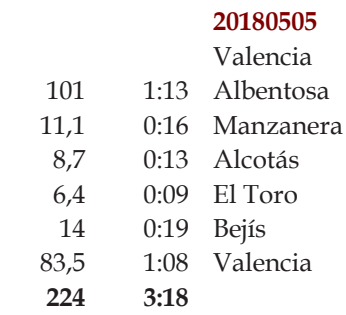

km h:min 20180522

Valencia

38,1 $0: 36$ Sueca

14,4 $0: 18$ Cullera

$\begin{array}{lll}\mathbf{9 8 , 9} & 0: 41 & \text { Valencia } \\ \mathbf{1 : 3 5} & \end{array}$

$224 \quad 3: 18$
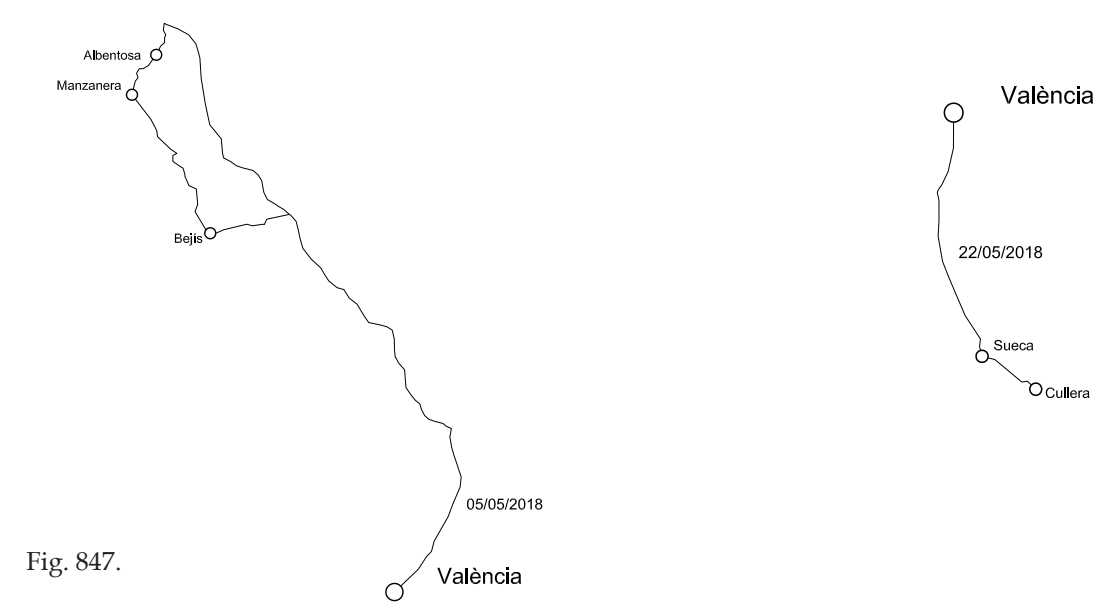

Fig. 849 .

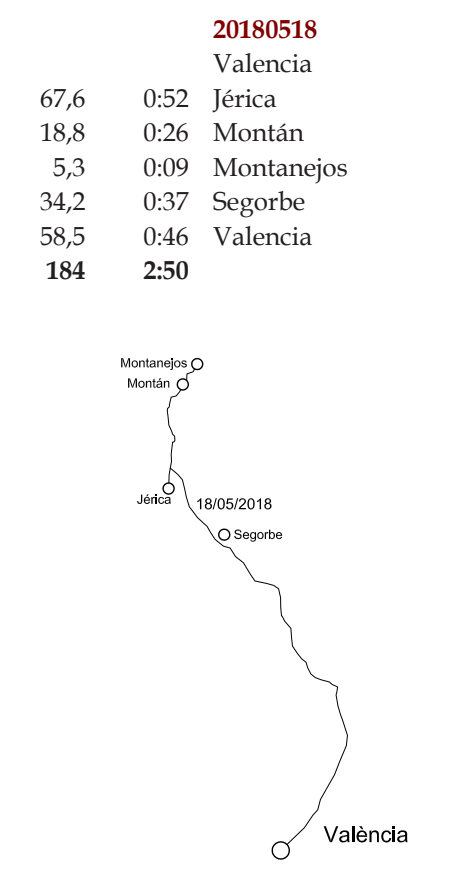

20180613

Valencia 0:55 Onda 0:20 Ayódar $0: 12$ Sueras 0:06 Tales 1:03 Valencia $173 \quad 2: 36$

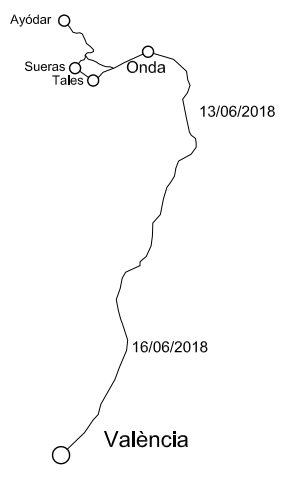

Fig. 850 

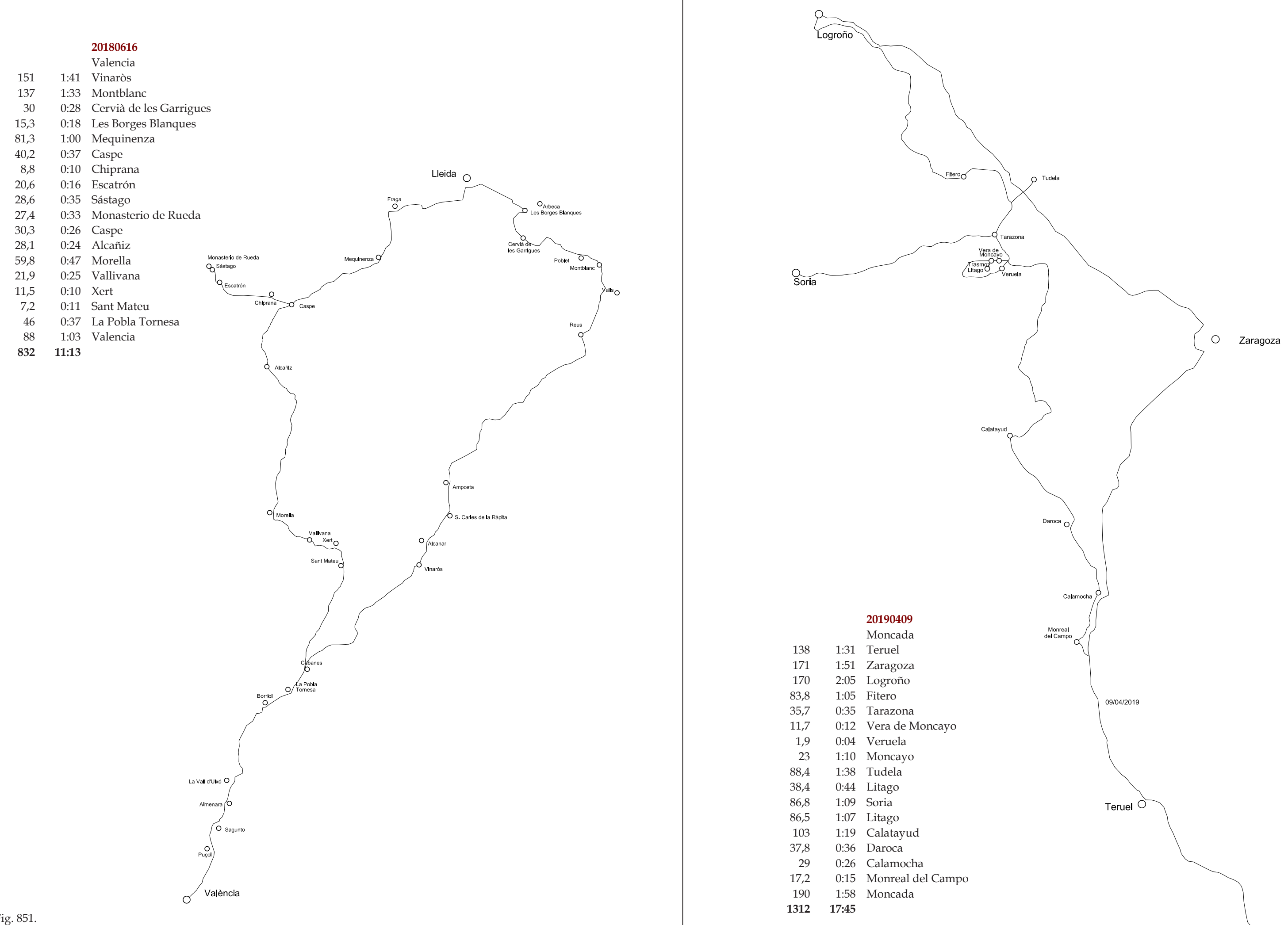
km h:min 20190821

$$
\begin{aligned}
& \text { Moncada } \\
& \text { Teruel }
\end{aligned}
$$

$\begin{array}{ll}\text { 1:31 } & \text { Teruel } \\ \text { 1:51 } & \text { Zaragoza } \\ 0: 54 & \text { Huesca }\end{array}$

0:54 Huesca

0:34 Castillo de Loarre

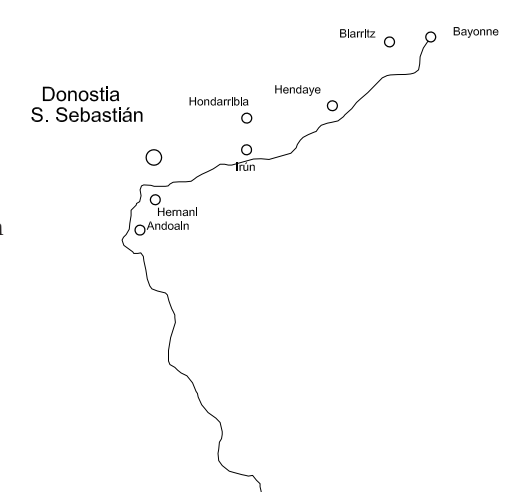

$0: 34$ Ansó

0:20 Hecho

$0: 20$ Puente

$0: 20$ Jaca

$0: 34$ Anso

1:07 Coll de la Pierre St. Martin

Pamplona 0

1:25 Pau

0:37 Auch

0:42 L'Isle Jourdain

1:14 Larressingle

$0: 12$ Fourcès

0:54 Montjoi

0:24 Lauzerte

1:34 L'Isle Jourdain

1:39 Cordes sur
0:33 Najac

1:04 Saint Géry

0:23 Cahors

1:06 Rocamadour

2:19 Martel

2:28 Sarlat-la-Cáneda

0:17 Beynac

0:42 Abrigo de Gageac

1:48 Les Flaujagues

$1: 16$ Blaye

0:54 Burdeos

2:35 Bayonne
0:17 Biarritz

0:17 Biarritz

0:15 Hondarribia

0:13 Irún

0:28 Donostia

0:15 Hernani

0:11 Andoain

0:56 Pamplon

3.54

Moncada

2939,6 $\quad 46: 12$

km h:min 20200804

Moncad

0:33 Casinos

14,7 0:13 Losa del Obispo

11,5 0:12 Calles

1,8 0:05 Torrecilla de Chelva

$3 \quad 0: 08$ Acueducto de Peña Cortada

9,8 0:21 Pico del Remedio

$\begin{array}{lll}9,8,8 & 0: 47 & \text { La Yesa } \\ 21,4 & 0.25 & \text { Higuerus }\end{array}$

10 0:14 Villar del Arzobispo

52,5 0:42 Moncada

206,5

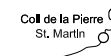

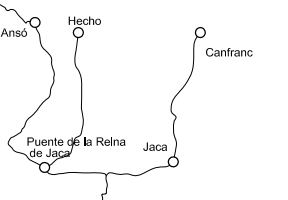

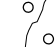

suan dea perta ơ

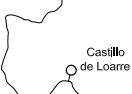

$O_{\text {Huesca }}$ 

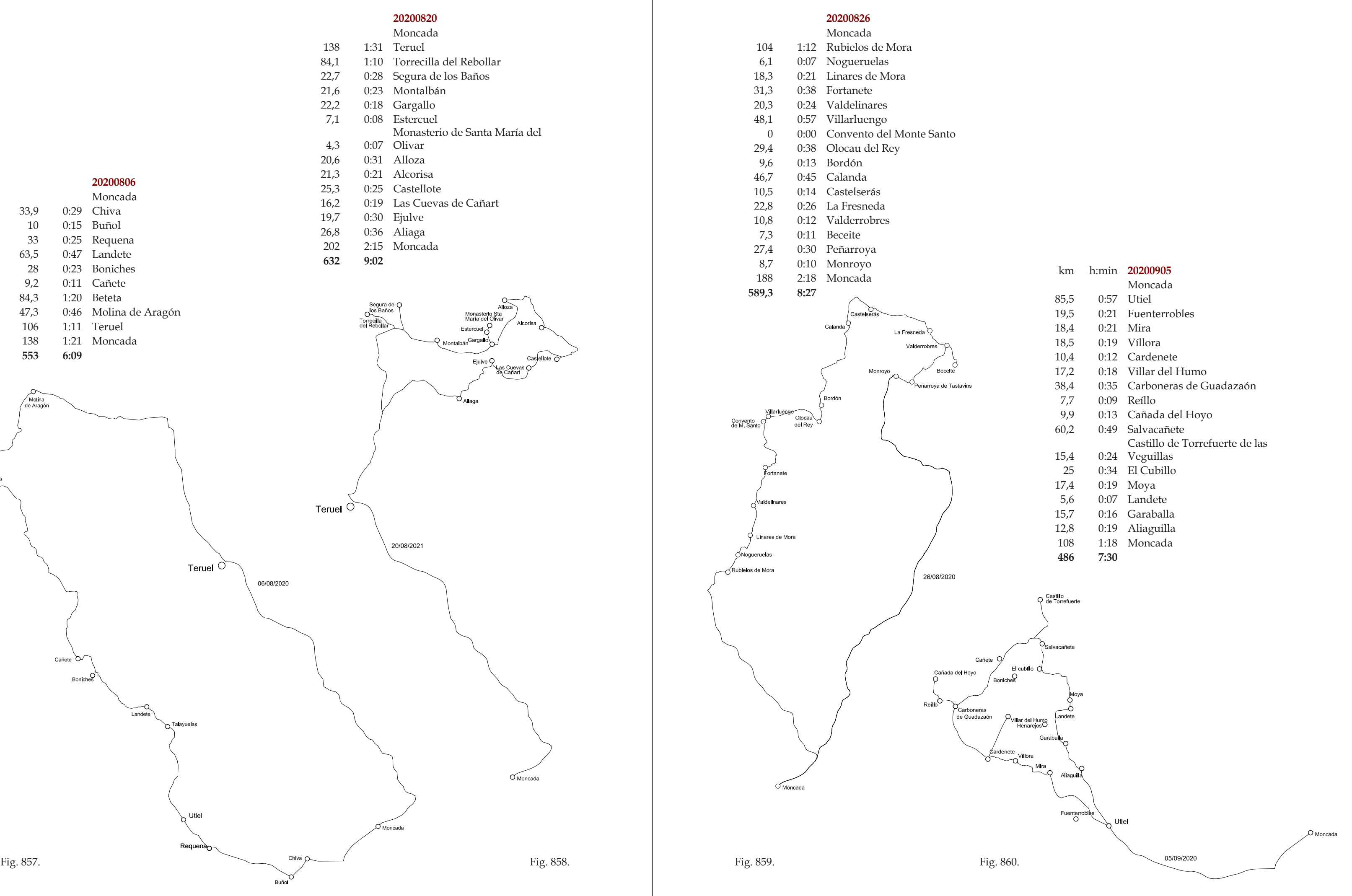


$\begin{array}{rrl} & & 20201024 \\ & & \text { Moncada } \\ 85,5 & 0: 57 & \text { Utiel } \\ 37,7 & 0: 41 & \text { Garaballa-Tejeda la Vieja } \\ 48,7 & 0: 44 & \text { Salinas del Manzano } \\ 25,6 & 0: 25 & \text { Castielfabib } \\ 7,5 & 0: 10 & \text { Torrebaja } \\ 8,2 & 0: 11 & \text { Ademuz } \\ 81,3 & 1: 04 & \text { Requena } \\ 72,3 & 0: 48 & \text { Moncada } \\ 367 & 4: 57 & \end{array}$

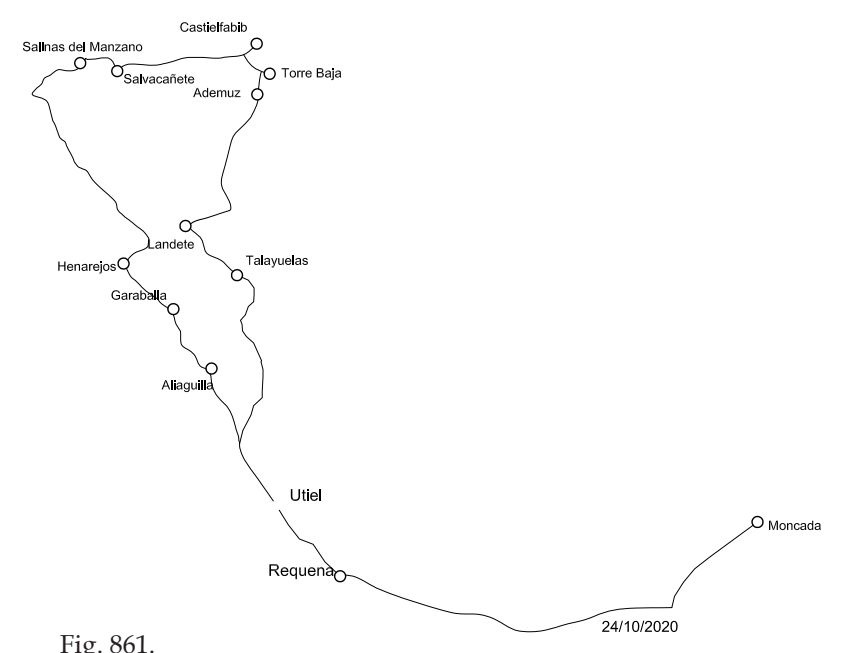

Fig. 861.

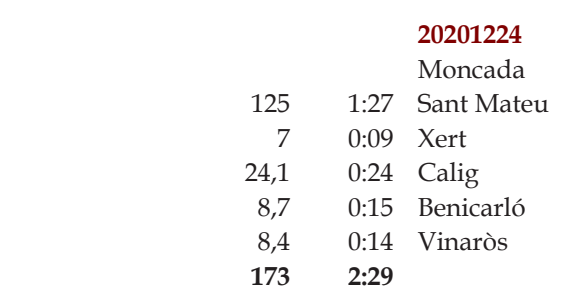

20201031
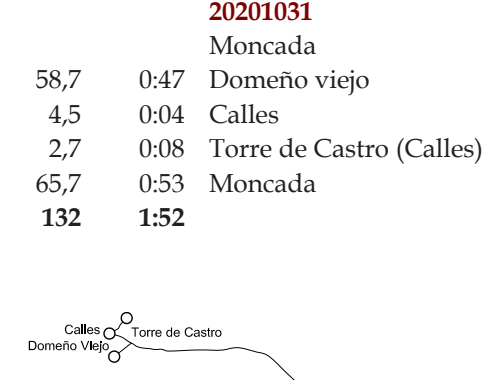

Fig. 862.

Fig. 863 . km h:min 20210102

$$
\text { Vinaròs }
$$

0:22 Ulldecona

0:16 La Galera

0:08 Molí de Vallés (Santa Bàrbara)

0:30 Xerta

0:29 Móra d'Ebre

0:09 Miravet

0:27 Flix

$\begin{array}{ll}\text { 1:23 } & \text { La Sénia } \\ 0: 23 & \text { Bonasterio de Santa María de } \\ \text { Benifassà } & \end{array}$

2:14 Moncada

$440 \quad 6: 22$

\begin{tabular}{|c|c|c|}
\hline & & 20210206 \\
\hline & & Moncada \\
\hline & 20 & More \\
\hline & $0: 39$ & Ares \\
\hline 142 & 1:49 & Moncada \\
\hline & $4: 32$ & \\
\hline
\end{tabular}

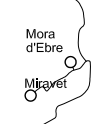

xera 21112021

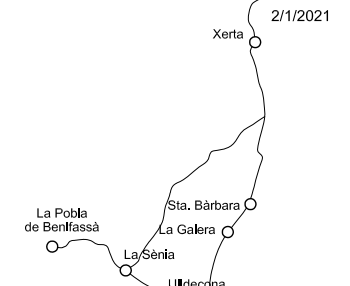

$\int_{\text {Bencarlo }}$

ancenia

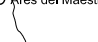

Fig. 864. 


\section{Plano de recorridos efectuados para la realización de la tesis}

Leyenda del plano de la página siguiente

22/05/2016 Rubielos de Mora-Linares de mora-La Iglesuela-Cantavieja-Vilafranca

- 28/06/2016 Requena-Sot de Chera-Chulilla

07/07/2016 Chulilla-Calles-Chelva

06/08/2016 Requena-Ademuz-Cantavieja-Morella-Vinaròs

27/04/2018 Domeño-Chelva-Alpuente-El Collado

- $05 / 05 / 2018$ Albentosa-Manzanera-Bejís

18/05/2018 Jérica-Montán-Montanejos-Segorbe

- $22 / 05 / 2018$ Sueca-Cullera

- 13/06/2018 Onda-Ayódar-Sueras-Tales

- 16/06/2018 Caspe-Chiprana-Escatrón-Sástago-Alcañiz-Morella

- 09/04/2019 Teruel-Logroño-Tarazona-Tudela-Calatayud

21/08/2019 Jaca-Blaye-Burdeos-Biarritz-Hondarribia-Irún-Donostia-Andoain

04/08/2020 Chelva-Torrecilla de Chelva-Pico del Remedios-La Yesa

06/08/2020 Chiva-Buñol-Requena-Landete-Boniches-Cañete-Beteta-Molina de Aragón

- 15/08/2020 Alcora-Lucena-Castillo de Villamalefa-Villahermosa del Río-Linares de Mora-Alcalá de la Selva

19/08/2020 Culla-Benassal-Ares del Maestre-Vilafranca del Cid-Cantavieja-Mirambel-Forcall

20/08/2020 Torrecilla del Rebollar-Segura-Montalbán-Estercuel-Alloza-Alcorisa-Castellote-Cuevas de CañartEjulve-Aliaga

26/08/2020 Linares de mora-Villarluengo-Bordón-Calanda-Castelserás-La Fresneda- Valderrobres-BeceitePeñarroya de Tastavins-Monroyo

05/09/2020 Mira-Víllora-Cardenete-Villar del Humo-Carboneras-Cañada del Hoyo-Castillo de Torrefuerte-Garaball

- 24/10/2020 Utiel-Tejeda la Vieja-Salinas del Manzano-Castielfabib-Torrebaja-Ademuz-Requena

31/10/2020 Domeño viejo-Calles-Torre de Castro

24/12/2020 Sant Mateu-Xert-Càlig-Benicarló, Vinaròs

02/01/2021 Ulldecona-La Galera-Molí del Vallés-Xerta-Móra d'Ebre-Miravet-Flix-La Sénia-Sta. Ma de Benifassà

06/02/2021 Morella 


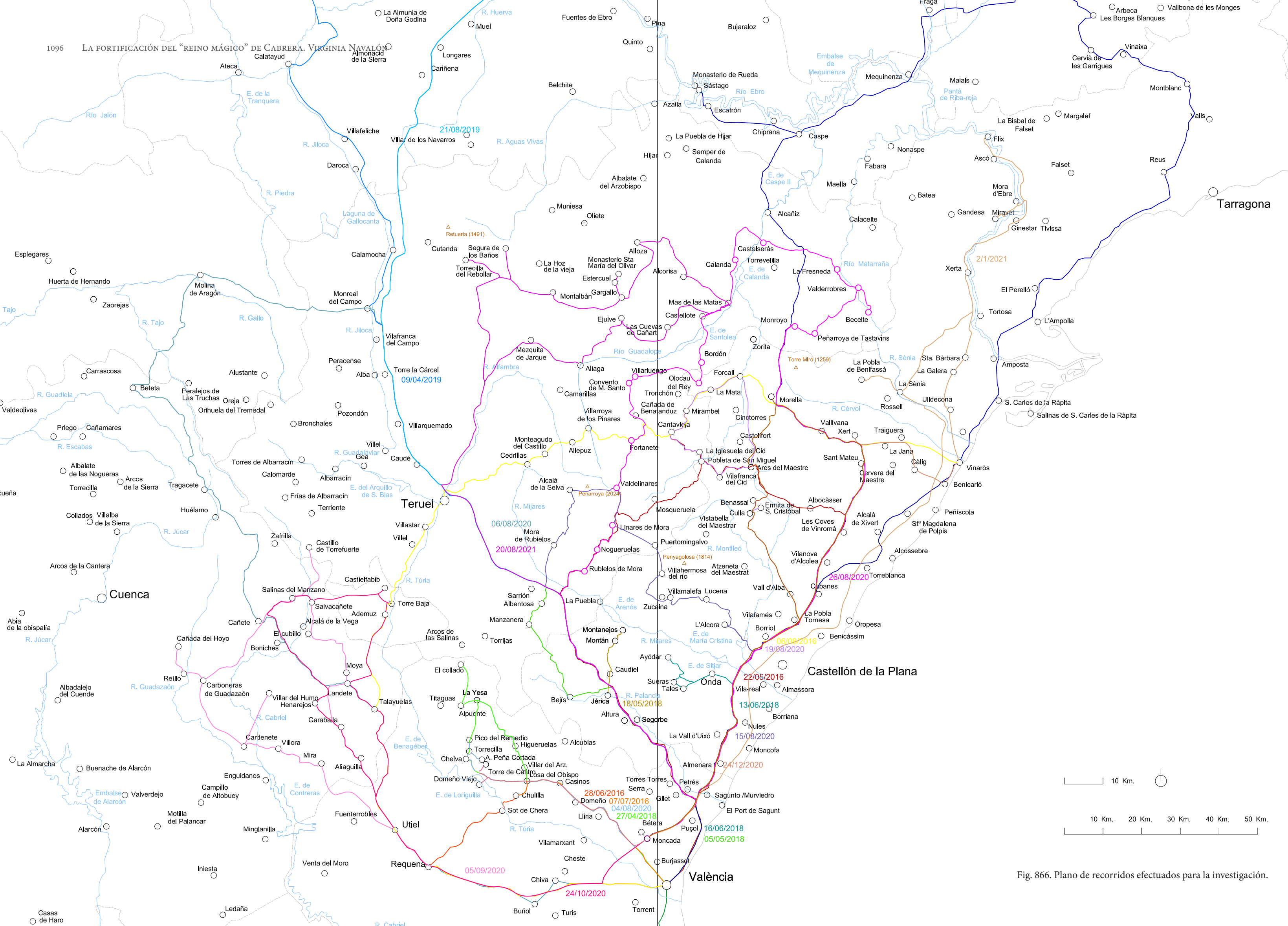


Tabla 13. Campos de batalla identificados.

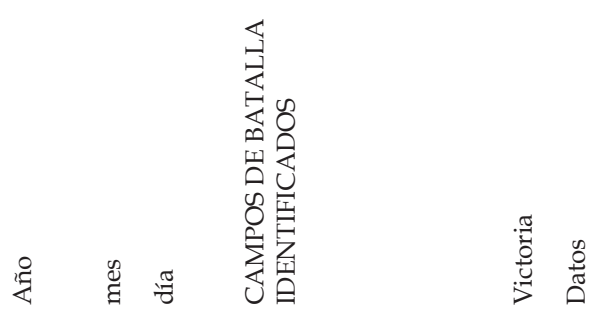
$\begin{array}{llll}1835 & 4 & 23 & \text { Batalla de los pinares }\end{array}$ de Alloza

$1835 \quad 7$

Batalla de la Yesa

1835

18 Batalla de Alcanar

Batalla de la Sierra de Molina de Aragón

$\begin{array}{llll}1836 & 1 & 21 & \text { Batalla de La Galera }\end{array}$

$1836 \quad 2$ Batalla de Torrecilla

Batalla de Montalbá

El brigadier Nogueras alcanza a Cabrera en los pinares de Alloza. 1600 infantes y 200 jinetes liberales frente a 390 infantes y 40 los 50 muertos y más de un centenar de heridos liberales, pueden considerarse favorecidos por el enfrentamiento. Los carlistas ocupan la sierra de Arcos.

Encuentro de la Yesa. Cabrera carga contra los liberales que pierden 300 hombres. Engrosan los efectivos voluntarios tras la victoria y los Se toma Segorbe, donde Cabrera se prepara para un encuentro con Nogueras.

Las tropas de Cabrera, que asedian Alcanar, se revuelven contra una columna de 1000 milicianos de Vinaròs. Dejan centenares de muertos. La guarnición de Alcanar capitula.

La batalla se produce en el cerro de las Tejeras. La vanguardia liberal del general Palarea alcanza a la retaguardia carlista. A punto de ser salvo a parte de su ejército que sortea el río Gallo.

Cabrera cuenta de nuevo con 1000 infantes y 12 jinetes. Derrota una columna de 1500 liberales en La Galera y se repliegan en Beceite. Cabrera derrota a una columna de 1500 hombres en Torrecilla. Tras la victoria, Cabrera ordena fusilar a los alcaldes de Torrecilla y Valdealgorfa.

Es interceptado por Nogueras con 3000 infantes y 400 jinetes. Los carlistas se retiran durante 5 horas atrincherándose en Montalbán sin bajas.

Una columna al mando del coronel Añón y tres batallones al mando de Petegaz, sorprenden a la ciudad de Liria. El general Palarea se halla entonces en Onda. Parte tras los carlistas hacia Manises, mientras éstos se dirigen a Siete Aguas. Ambos ejércitos producen escaramuzas en algún lugar entre Chiva y Requena. Las tropas del campo de batalla pero las tropas carlistas escapan indemnes con el botín capturado en Liria y, en lugar de dirigirse a Beceite, se encaminan a Cantavieja, que ocupan sin resistencia.

Cabrera sorprende a 2 batallones, dos compañías y un escuadrón de caballería con una pieza de artillería en Ulldecona.

El coma El comandante Llagostera ha regruesado las tropas de Valencia: dos batallones, dos escuadrones que aniquilan a una columna isabelin
de 600 hombres en Alcublas. 
1102 La fortificación del "reino mágico" de Cabrera. Virginia Navalón

1837

1837

22 Batalla de Arcos de la Cantera

$1838 \quad 10 \quad 1 \quad$ Batalla de Maella

$\begin{array}{llll}1838 & 12 \quad 2 & \text { Batalla de Cheste }\end{array}$

1839

Batalla de Salinas del Manzano. A cuatro leguas. A los pies del Castillo de

$\begin{array}{llll}1839 & 3 & 23 & \text { Batalla de Segura de }\end{array}$ los Baños

$\begin{array}{llll}1839 & 6 & 12 & \text { Batalla de la Hoz }\end{array}$

18396 fin $\quad$ Batalla de Alcora

$1840 \quad 5 \quad 20 \quad$ Batalla de la Sénia

$\begin{array}{llll}1840 \quad 7 & 4 & \text { Batalla de Berga }\end{array}$
X El brigadier Borso de Carminati con 3000 portugueses del ejército del Centro se enfrenta a los cinco batallones y 700 jinetes de Cabrera. El resultado es incierto, ambos bandos se atribuyen la victoria. Pero Cabrera es herido persiguiendo a los enemigos que huyen y tiene que

C Entre Lliria y Valencia. Orgía sobre los silos de Burjassot (Cabello e altr. 2006: 114-115)

L Derrota carlista. Celebrada y conmemorada por la Reina $\mathrm{M}^{\mathrm{a}}$ Cristina con una medalla conmemorativa. Al oeste de Chiva el paisaje es agreste, pero los carlistas no lo aprovechan y plantean e enfrentamiento en la llanura de Chiva siendo favorable a la caballería isabelina. Las tropas isabelnas eran dirgitas por el general Oraa. sus res mavo ejeritos.

Cabrera, que regresa de la Expedición Real, socorre a las tropas diezmadas del general Sanz que se enfrenta a una columna de Memorarcos de caballería contra el ejército de Cabrera por parte de la caballería isabelina a las órdenes del General Amor.

L Las tropas de Oraá consiguen romper el cerco de Lucena y entrar en la ciudad. Los carlistas levantan el sitio.

El general liberal Ramón Pardiñas ve destruida su mejor división "el ramillete", y pierde la vida ante las tropas de Cabrera. 311

L El coronel isabelino Juan de la Pezuela ataca a la partida de Domingo Forcadell en las inmediaciones de Cheste, destruyendo la retaguardia de los carlistas con 400 bajas y 200 prisioneros.

Las tropas liberales del Comandante en Jefe y Capitán General del Ejército, Narváez, derrotan a una facción a los pies del castillo (Boletín Oficial de Cuenca, $\mathrm{n}^{\circ} 56$, de 12 de julio de 1839)

El liberal Antonio Van Halen y Sarti toma los reductos pero lo carlistas mantienen la fortificación de Segura

Batalla de la Hoz, donde destacan los comandantes de amba caballerías: Balmaseda y Serrano.

Cabrera inicia un nuevo cerco a Lucena. Una columna con 5 batallones liberales al mando de Aznar avanza desde Castellón. Se enfrenta a los carlistas en Alcora y rompe el cerco, pero, rota en dos, parte quedar encerrada en Alcora y la otra debera regresar a Castellón.

Última batalla entre las tropas carlistas de Cabrera y las fuerzas del ejército del Centro (Gaceta e Madrid, 7 de junio de 1840, p. 1. Diario

de Barcelona, 31 de mayo de 1840, p. 2164, Sauch Cruz, 2007: 134)

L Última batalla que se origina con un enfrentamiento en campo abierto de las tropas de Cabrera contra el ejército de Espartero. Cabrera
rompe tácticamente las líneas de Espartero, pero la superioridad numérica y armamentística de Espartero fuerza la retirada a Berga. Tras combates sobre la plaza, los carlistas se retiran hacia Francia. 
Tabla 14. Cronología de Cabrera en la guerra del Maestrazgo.

\begin{tabular}{|c|c|c|c|}
\hline Año & Mes & Día & \\
\hline 1806 & 12 & 27 & Nacimiento en Tortosa \\
\hline 1830 & 3 & 29 & Pragmática Sanción que elimina la ley Sálica \\
\hline 1833 & 9 & 29 & Fallece Fernando VII \\
\hline 1833 & 10 & 1 & $\begin{array}{l}\text { Manifiesto de Abrantes. Don Carlos María Isidro proclama desde Portugal sus derechos } \\
\text { dinásticos }\end{array}$ \\
\hline 1833 & 10 & 3 & Primera proclamación de Carlos VI en Talavera de la Reina \\
\hline 1833 & 10 & 5 & Don Carlos es reconocido rey en Bilbao y Âlava \\
\hline 1833 & 10 & 6 & $\begin{array}{l}\text { Inicio de la guerra. El general Santos Ladrón de Cegama proclama a Don Carlos rey de España } \\
\text { en Tricinio (La Rioja) }\end{array}$ \\
\hline \multirow[t]{5}{*}{1833} & 11 & 16 & Cabrera llega a Morella y se presenta al gobernador de la plaza, don Carlos de la Victoria \\
\hline & & & $\begin{array}{l}\text { Primer combate contra las tropas regulares de Tortosa. Cabrera combate en el batallón de } \\
\text { voluntarios de Vinaroz y obtiene el grado de cabo. }\end{array}$ \\
\hline & & & Los carlistas abandonan Morella, pero son derrotados en Calanda. Se forman partidas. \\
\hline & & & Cabrera integra la partida de Marcoval como sargento. \\
\hline & & & $\begin{array}{l}\text { Cabrera asalta San Mateo con el grado de subteniente, pero el asalto se ve frustrado y tiene que } \\
\text { luchar cuerpo a cuerpo para no ser capturado. }\end{array}$ \\
\hline 1834 & 1 & 16 & Cabrera obtiene el grado de teniente. \\
\hline \multirow[t]{4}{*}{1834} & 1 & 27 & Cabrera es capitán \\
\hline & & & Con 70 soldados derrota en Beceite a dos compañías de milicias provinciales \\
\hline & & & Une su partida a la de Carnicer. \\
\hline & & & Dispersa a la guarnición de Morella y da un golpe de mano en Villafranca \\
\hline 1834 & 3 & 28 & Se toma Daroca \\
\hline 1834 & 3 & 30 & Cabrera derrota a una columna isabelina cerca de Alarba y Carnicer le nombra comandante \\
\hline 1834 & 4 & & $\begin{array}{l}\text { Carnicer cuenta con } 4000 \text { hombres. Se planeta batalla, pero son derrotados en Mayals. Cabrera } \\
\text { es el primero en atacar y el último en abandonar. Las tropas deben dispersarse }\end{array}$ \\
\hline 1834 & 7 & & Don Carlos regresa a España del exilio en Londres y se asienta en las provincias del Norte. \\
\hline 1834 & 7 & & Carnicer y Cabrera se reunen de nuevo y derrotan a los isabelinos en Ariño. \\
\hline 1834 & & & Se recupera de una enfermedad y casi es capturado tras una delación \\
\hline 1834 & 9 & & $\begin{array}{l}\text { Ataque al fuerte de Beceite. Sustracción de provisiones del ejército liberal. Se esquiva a las } \\
\text { tropas del general isabelino Valdés }\end{array}$ \\
\hline 1834 & & & Carnicer es ascendido por Don Carlos a brigadier, y Cabrera a coronel de infantería \\
\hline 1834 & & & Carnicer se dirige a los montes de Alcañiz y Cabrera, con 200 cazadores, a Prat del Comte. \\
\hline 1834 & 11 & 12 & $\begin{array}{l}\text { Sin pólvora y a punto de ser capturado en la Masía de Fontanete, Cabrera ordena la dispersión. } \\
\text { Él se plantea presentarse junto al comandante Francisco García ante el rey, cruzando las líneas } \\
\text { enemigas. }\end{array}$ \\
\hline 1835 & 2 & 11 & $\begin{array}{l}\text { Disfrazados de arrieros aragoneses, se entrevistan con Don Carlos. A su regreso, Cabrera es } \\
\text { casi capturado cerca de Belchite. }\end{array}$ \\
\hline 1835 & 3 & 8 & $\begin{array}{l}\text { Cabrera se reagrupa con Carnicer. El ejército del Maestrazgo cuenta con } 30 \text { infantes y } 10 \\
\text { caballos. En diez días suman } 300 \text { infantes y } 40 \text { caballos. }\end{array}$ \\
\hline 1835 & & & Cabrera está a punto de ser capturado por un destacamento de carabineros. \\
\hline 1835 & 4 & 6 & $\begin{array}{l}\text { Carnicer es reconocido en Miranda de Ebro y fusilado. Cabrera ocupa su puesto al mando del } \\
\text { ejército del Maestrazgo }\end{array}$ \\
\hline 1835 & 4 & 23 & $\begin{array}{l}\text { El brigadier Nogueras alcanza a Cabrera en los pinares de Alloza. } 1600 \text { infantes y } 200 \text { jinetes } \\
\text { liberales frente a } 390 \text { infantes y } 40 \text { caballos carlistas. Los carlistas con } 2 \text { muertos y } 15 \text { heridos, } \\
\text { frente a los } 50 \text { muertos y más de un centenar de heridos liberales, pueden considerarse } \\
\text { favorecidos por el enfrentamiento. Los carlistas ocupan la sierra de Arcos. }\end{array}$ \\
\hline 1835 & 5 & & $\begin{array}{l}\text { Cabrera cuenta con } 1000 \text { soldados. Toma Mosqueruela y toma Caspe en un segundo asalto, } \\
\text { pero debe abandonarla ante la proximidad de Nogueras. }\end{array}$ \\
\hline
\end{tabular}




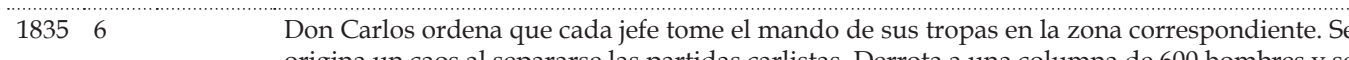
origina un caos al separarse las partidas carlistas. Derrota a una columna de 600 hombres y se dirige al barranco de Prat del Comte a derrotar al coronel Antonio Azpiroz. Victoria carlista completa.

$18357 \quad$ Encuentro de la Yesa. Cabrera carga contra los liberales que pierden 300 hombres. Engrosan los efectivos voluntarios tras la victoria y los fuertes isabelinos se rinden sin disparar: Puebla de Arenoso, Zucaina. Se toma Segorbe, donde Cabrera se prepara para un encuentro con Nogueras.

18358 La columa liberal del coronel Decref es aniquilada por Cabrera, con 350 muertos y perdiendo bagajes, fusiles y demás pertrechos.

Toma de Rubielos de Mora, con defensa encarnizada de la guarnición liberal. Se toma el fuerte tras abrir brecha. Se toma después Mora de Aragón.

$1835 \quad 9$

183510 Cabrera recompone sus tropas

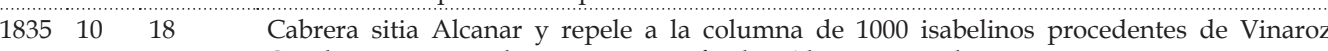
Quedan centenares de muertos y 500 fusiles. Alcanar se rinde.

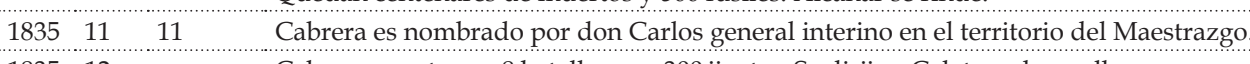

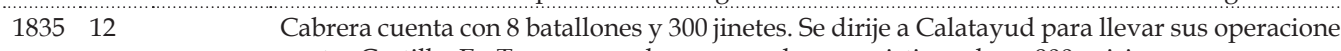
contra Castilla. En Terrer envuelve a una columna cristina y hace 900 prisioneros

$183512 \quad$ El gobierno envía 4000 infantes y 60 jinetes a aproyar en la zona al general Palarea. Los liberales cuentan allí con 10000 efectivos. Cabrera contramarcha hacia Molina de Aragón (60 km en un día)

$183512 \quad$ Batalla de la Sierra de Molina de Aragón. La vanguardia liberal del general Palarea alcanza a la retaguardia carlista. A punto de ser descalabradas las fuerzas carlistas, una maniobra de Cabrera pone a salvo a parte de su ejército que sortea el río Gallo

$183512 \quad$ Cabrera se refugia en Beceite, pero muchos hombres han desertado. Cabrera se une a Forcadel y convoca a todas las partidas.

$1836 \quad 1 \quad$ Cabrera da licencia a sus tropas por 15 días. Los efectivos liberales, ante la ausencia de tropas enemigas son destinados al Norte. los efectivos quedan reducidos a la mitad.

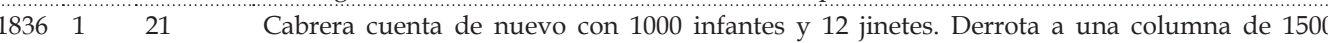
liberales en La Galera y se repliegan en Beceite.

8362 Cabrera derrota a una columna de 1500 hombres en Torrecilla. Tras la victoria, Cabrera ordena fusilar a los alcaldes de Torrecilla y Valdealgorfa, por delatores. Como consecuencia el general Nogueras ordena el fusilamiento de la madre de Cabrera. Orden ratificada por el hermanas del general carlista. La decisión acab Mra. A sur Nogueras, aunque no se admite la dimisión de Mina.

$1836 \quad 2 \quad$ Cabrera marcha sobre Calatayud dejando al coronel Añón al mando del resto de tropas. E interceptado por Nogueras con 3000 infantes y 400 jinetes. Los carlistas se retiran durante 5 Nontalbán sin bajas.

$1836 \quad 3 \quad$ Cabrera se reúne con el ejército en Villarluengo para marchar sobre Hijar, pero la columna de coronel Churruca lo hace desistir.

$\begin{array}{llllll}1836 & 3 & 29 & \text { Una columna al mando del coronel Añón y tres batallones al mando de Petegaz, sorprenden }\end{array}$ a la ciudad de Liria. El general Palarea se halla entonces en Onda. Parte tras los carlistas haci Manises, mientras éstos se dirigen a Siete Aguas. Ambos ejércitos producen escaramuzas en algún lugar entre Chiva y Requena. Las tropas carlistas retroceden ascendiendo las laderas Palarea se adueña del campo de batalla, pero las tropas carlistas escapan indemnes con e ocupan sin resistencia.

1836 Toma y fortificación de Cantavieja, convertida en Cuartel General. Para que las obras no sean importunadas por los liberales, Cabrera decide enviar incursios al bajo Aragon hacia la Academia de Oficiales 1836 Concluidas las obras en Cantavieja Cabrera ordena a Quílez atacar la localidad de Bañón. La

18365 Incursiones carlistas mientras las tropas de Cabrera descansan en Cantaviej.

$1836 \quad 6 \quad$ Med. Cabrera sorprende a 2 batallones, dos compañías y un escuadrón de caballería con una pieza de artillería en Ulidecona. Aumentan los voluntarios realistas y Palarea reconoce que las $\begin{array}{lllll}1836 & 8 & 15 & \text { El gobierno arma un poderoso ejército para tratar de acabar con Cabrera. Carlos VII le conced }\end{array}$ faja de mariscal de Campo.

Cabrera ataca Gandesa con tres batallones, un escuadrón y dos cañones fundidos en Cantavieja. Poco eficaces, tuvieron que replegarse

$1836 \quad$ El comandante Llagostera ha regruesado las tropas de Valencia, dos batallones, dos escuadrones que aniquilan a una columna isabelina de 600 hombres en Alcublas.

$\begin{array}{lllllll}1836 & 9 & 7 & \text { El general Gómez alcanza Utiel con su expedición. Se le unen Quílez y el Serrador. También }\end{array}$ Cabrera con 50 jinetes. Cabrera nombra coronel a Arévalo como jefe de las tropas de Maestrazgo.

18369 Tras intentar sitiar Requena, las tropas relistas se enfrentan con las liberales en Villarrobledo, Se produce la famosa carga de húsares de Diego de León al mando del general Alaix. Los sabelinos derrotan a los carlistas con 1200 prisioneros y 2000 fusiles junto a los bagajes.

$183699 \quad$ La Expedición prosigue su marcha por Úbeda, Baeza, Bailén y Andújar hasta Córdoba.

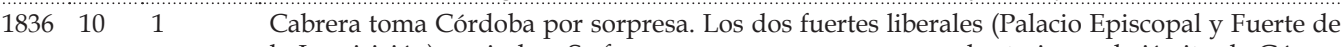
la Inquisición) se rinden. Se forma un nuevo cuerpo con voluntarios y el ejército de Gómez alcanza los 8500 soldados y 2300 jinetes.

$\begin{array}{llllll}1836 & 10 & 3 & \text { Batalla de Castro del Río: Cabrera con } 4 \text { batallones y jinetes de Valencia alcanza a la columna }\end{array}$ del comandante general de Málaga, Juan Escalante, y lo derrota con tres cargas frontales.

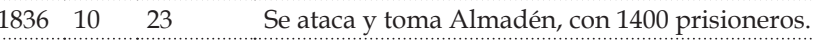

$1836 \quad 10$ La Expedición avanza por Guadalupe, Trujillo y Cáceres, pero llegan noticias de que el genera Evaristo San Miguel se dispone a atacar Cantavieja. No se sabe si Cabrera obtiene permiso de Gómez para acudir a dirigir la defensa o es licenciado por el general carlista ante sus continuas desavenencias. Cabrera y sus tropas, apenas cien jinetes y pocos oficiales aragoneses, deben atravesar el territorio enemigo.

$183610 \quad$ Cabrera se dirige a Cantavieja por Almagro, Calzada de Calatrava y Valdepeñas. A mitad de camino recibe noticias de la toma de Cantavieja. Así Cabrera cambia el rumbo hacia Navarra, avanzando por Tarancón y Sigüenza y reclutando voluntarios

183611 Princip. Cabrera, entrando en la provincia de Soria, es atacado por la columna del general Iribarren, con 3500 infantes, 500 jinetes y dos piezas artilleras. Se tiene que replegar mientras combate y se refugia en Arévalo. Una columna ataca la localidad y debe romper el cerco. Se dice que es herido de bayoneta en la piena, un disparo en la cadera y una cuchillada en la espala además de un fuer El párroco de Almazán lo esconde en su vivienda durante un mes mientras se repone de las

1836

18371 Princip. Cabrera consigue reunirse con sus tropas: 2000 infantes y 200 jinetes. Inicia de nuevo sus ataques en la provincia de Castellón alcanzando la capital provincial y, desde allí, se dirige a Torreblanca

1837 Batalla de Torreblanca. El brigadier Borso de Carminati con 3000 portugueses del ejército del Centro se enfrenta a los cinco batallones y 700 jinetes de Cabrera. El resultado es incierto mbos bandos se atribuyen la victoria. Pero Cabrera es herido persiguiendo a los enemigos

$1837 \quad$ Forcadell derrota a una brigada isabelina en Buñol

18373 Finales Cabrera, recuperado, emprende una expedición sobre Valencia. Sorprende a una columna en Burjassot de 800 hombres. Captura a 727 y ordena el fusilamiento de oficiales y sargento Mueren entre 30 y 42 . El Convenio de Elliot no rige en el frente Valenciano-Aragonés

$1837 \quad$ Forcadell toma Orihuela y forma un nuevo batallón pues crecen las adhesiones. Cabrera forma los batallones $6^{\circ}$ de Valencia, $1^{\circ}$ de Castilla y $3^{\circ}$ de Mora. Mientras, el ejército isabelino eorganización. Cabrera aprovecha y toma San Mateo derrotando a cuatro compañías y un batallón, utilizando la artillería de la recién recuperada Cantavieja. San Mateo había sido refortificada por los

1837

Oraá ha distribuido el ejército en tres cuerpos.... El primero, de Valencia, cuenta con 13 batallones y 4 escuadrones. El segundo, entre Zaragoza y Huesca, cuenta con tres batallone y un escuadrón, con una posición defensiva. El tercero, al mando de Nogueras, se ubica en batallones 6 escuadrones, bajo sus órdenes directas. Hablamos de 30000 infantes y 2000 jinetes en el ejército liberal, frente a los 14000 hombres que sumaban todas las partidas carlistas de la zona.

1837 Se producen enfrentamientos en el área de Vinaroz y la Cenia, donde Oráa trata de hacerse con la artillería de Cabrera. Los carlistas contienen el ataque.

Los carlistas trata de tomar por cuarta vez Gandesa, pero la llegada del general Nogueras les obliga a presentar batalla y a replegarse. 
Las tropas carlistas cruzan el Ebro a la altura de Cherta gracias a la habilidad de Cabrera. Las tropas de Nogueras y las portuguesas de Borso vigilan el cruce del Ebro y han destruido tod embarcación. Cabrera captura embarcaciones en San Carlos de la Rápita y las traslada po tierra a Cherta y dispone a sus tropas para derrotar a Borso. Las ataca antes de la llegada de la Expedición. Nogueras no puede acudir en su ayuda, y Borso se repliega a Tortosa. El paso queda expedito. Cabrera obtiene la Gran Cruz de San Fernando. La Expedición prosigue su camino pasando por San Mateo.

$\begin{array}{llll}1837 & 7 & 15 & \text { Segunda batalla de Chiva tras varias fintas en Castellón, Burjassot y Valencia. Los carlista }\end{array}$ cuentan con 20 batallones incompletos y 6 escuadrones. Los liberales de Oraá cuentan con 15 batallones, 5 escuadrones y 4 piezas. Los carlistas deben replegarse y Cabrera protege 1 retaguardia.

$18378 \quad$ Se reorganizan las tropas en Cantavieja y el territorio de Cabrera.

$\begin{array}{llll}1837 & 9 & 10 & \text { Tras diversas contramarchas eludiendo el combate con el ejército liberal, al que se han unido }\end{array}$ las tropas de Espartero del Norte. Las tropas alcanzan Tarancón.

$\begin{array}{lllll}1837 & 9 & 12 & \text { La vanguardia carlista al mando de Cabrera alcanza Vallecas. Se producen escaramuzas a la }\end{array}$ puerta de la capital. La avanzadilla se reagrupa con el resto en Arganda.

$18379 \quad$ Los carlistas deciden no asaltar la capital ante la proximidad de Espartero. Continua la marcha hacia Guadalajara y Chiloeches. Es alcanzada por Espartero en Aranzueque. La expedición regresa a Navarra y Cabrera decide volver a Cantavieja.

$18379 \quad$ Cabrera socorre a las tropas diezmadas del general Sanz que se enfrenta a una columna de Oraá en Arcos de la Cantera. La columna carlista es dispersada.

$\begin{array}{lllll}1837 & 9 & 28 & \text { Las tropas de Cabrera llegan a Cantavieja. A pesar del eufórico recibimiento, han perdido } 8\end{array}$ compañías aragonesas y Cabrera se lamenta de no haber tomado Madrid.

$183710 \quad$ Cabrera reestructura su tropas como Comandante General de Aragón, Valencia y Murcia. Crea tres sub-mandos y genera 4 divisiones: Aragón, Valencia, Tortosa, Turia.

Ocupación de Torrecilla. Avanza a hacia Amposta, donde deja al mando al coronel Solá y

$\begin{array}{llll}1837 & 10 & 3 & \text { Ocupación de Torrecilla. Avanza a hacia Amposta, donde deja al mando } \\ \text { Cabrera parte hacia Cantavieja donde Oraá ha iniciado un nuevo asedio. }\end{array}$

1837 Los isabelinos avanzan hacia Morella por Catí y Villar de Cañes, pero son hostigados por los realistas y deben desistir. Oraá se dirige a Teruel. Cabrera ordena a la división de Murcia hacer incursiones para recibir suministro y él ataca
Puzol, asediando Lucena. Oráa debe acudir en auxilio de la ciudad y los carlistas pueden cerrar satisfactoriamente la expedición de Murcia, llenando sus almacenes. Los realistas se repliegan a San Mateo y Oraá a Castellón.

1837 Finales Las tropas de Zariategui llegan a Aragón a reforzar las huestes carlistas. Las tropas de Cabrera alcanzan los 21 batallones, 6 escuadrones, 2 compañías de artillería (13000 infantes y 1500 jinetes)

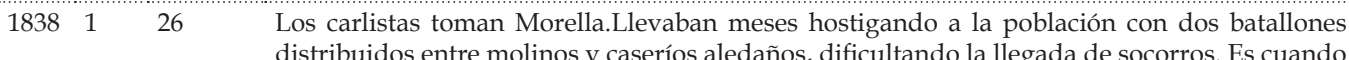
distribuidos entre molinos y caseríos aledaños, dificultando la llegada de socorros. Es cuando se produce el audaz golpe de mano del teniente Alió con 20 voluntarios.

$\begin{array}{llll}1838 & 1 & 27 & \text { Benicarló capitula ante las tropas de Cabrera tras cuatro días de asedio. Un buque británico }\end{array}$ había dificultado la toma

1838 Ocupación de Gandesa

$18383 \quad 3 \quad$ Undécimo asedio a Lucena.

$\begin{array}{llll}1838 & 4 & 5 & \text { Las tropas de Oraá consiguen romper el cerco de Lucena y entrar en la ciudad. Los carlistas }\end{array}$ levantan el sitio

(raslada al bajo Aragón. Se ocupa Calanda y Alcañiz, pero la Cacupacion es efímera y deben replegarse ante la proximidad de 3 divisiones cristinas. cuenta, con bases de dia Zumalacárregui, es crítico con el sistema de expediciones si no se

$1838 \quad 5$ Llegan a Calanda 100 soldados supervivientes de la expedición de Negri a Calanda. También efectivos del Cura Merino.

1838 entran en Zaragoza, momentáneamente. Los objetivos se centran en la toma de Morella

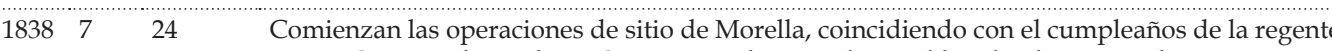
María Cristina de Borbón. Oráa parte de Teruel. Los liberales han armado una Primera División al mando de Borso; una Segunda División, al mando de Pardiñas; una Tercer caballería está al mando de Bartolomé Amor. Su artillería cuenta con 24 piezas.

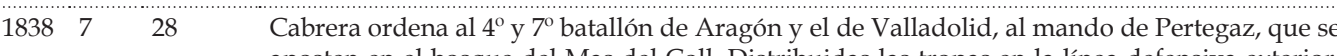
aposten en el bosque del Mas del Coll. Distribuidas las tropas en la linea defensiva queda a la reserva para socorrer a las posiciones más expuestas e iza la bandera negra con la

$1838 \quad 8 \quad$ A principios de agosto los liberales siguen preparando el sitio y obstaculizando los suministros, pero ellos mismos tienen dificultades con sus propios suministros y son hostigados permanentemente por los carlistas. Los liberales no consiguen cerrar las comunicaciones con grafía en su contra.

$\begin{array}{llllll}1838 & 8 & 14 & \text { Las baterías liberales inician el fuego artillero contra Morella. Se abre brecha entre las puertas }\end{array}$ de San Miguel y la Torre redonda, pero los carlistas construyen un espaldón y un parapeto.

$\begin{array}{lllll}1838 & 8 & 15 & \text { Se inicia el asalto liberal pero ante la respuesta, deben retirarse }\end{array}$

$\begin{array}{lllllll}1838 & 8 & 16 & \text { Sigue el fuego artillero y se trata de ubicar un barril de pólvora en la puerta de Nos acaba en }\end{array}$ fracaso.

$\begin{array}{llll}1838 & 8 & 17 & \text { Nuevo intento de asalto liberal donde perece el coronel Portillo. Los liberales deben retirarse }\end{array}$ de nuevo.

$\begin{array}{lllll}1838 & 8 & 18 & \text { Oraá, tras consejo militar, decide levantar el sitio y retirarse a Alcañiz. Morella sigue bajo }\end{array}$ control carlista. Han resistido 19 días, a 300 disparos de cañón y 775 bombas y granadas. Los isabelinos herdido 2000 hombres (muertos y heridos). Los carlistas cuentan con 230 muertos y 758 heridos.

$\begin{array}{llllll}1838 & 8 & 31 & \text { Carlos V publica un decreto por el que nombra a Cabrera Teniente General de los Reales }\end{array}$ Ejércitos y Conde de Morella

18389 El fracaso de Morella conduce a la sustitución honrosa de Oraá por el mariscal de campo Antonio Van Halen.

$\begin{array}{lllllll}1838 & 9 & 25 & \text { Llagostera ataca Bellmunt con } 4 \text { batallones y su guarnición huye. }\end{array}$

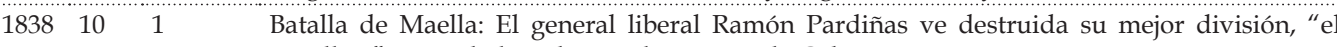
ramillete" y pierde la vida ante las tropas de Cabrera. 3115 prisioneros cristinos. Ese mismo día ocupaba su puesto Van Halen

1838 Finales Van Halen debe socorrer en octubre y noviembre la ciudad de Caspe, asediada por dos veces. Forcadell pasa a Valencia y se repliega hacia Cheste. Cabrera avanza sobre Calatayud, mientras los liberales les persiguen sin exito. Cabrera puede operar desde Levante hasa Guadalajara y desde Valencia al Bajo Aragón. Ha definido el límite de su "reino mágico", tal y como lo describe Von Rahden

$18391 \quad$ Mientras los carlistas acopian víveres desde Sigüenza hasta la Ribera de Valencia, Van Halen ataca Montán pero es repelido. Lo mismo sucede en el Collado y en Alpuente.

18392 En este mes son detenidos y ejecutados en el frente Norte diversos generales carlistas. El brigadier Balmaseda con una escolta de 100 jinetes de húsares de Ontoria, escapa y se une a Cabrera, que regresa de una expedición por Guadalajara y Toledo. Balmaseda le recomiend ir al Norte para imponer el orden. Se sospecha una conjura contra el pretendiente. Cabrera encarga a Balmaseda la toma de Montalbán.

$\begin{array}{lllll}1839 & 3 & 23 & \text { Encuentro en Segura, rápidamente fortificada por los carlistas. El ejército del centro al mando }\end{array}$ Ayerbe se enfrenta a Cabrera. Los liberales se tienen que retirar.

$18394 \quad$ Van Halen merodea Segura por dos veces, pero no intenta el asalto de la población.

$1839 \quad 4 \quad 3 \quad$ Van Halen firma con Cabrera el convenio de Segura o Lécera, por el cual los contendientes

$1839 \quad 4 \quad$ Las precauciones de Van Halen no gustan al gobierno y es destituido. Ocupa su puesto Las precauciones de Van Halen no
interinamente el general Nogueras.

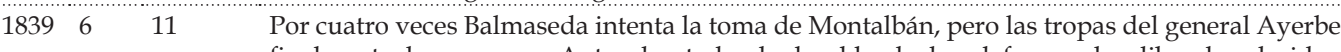
finalmente la socorren. Ante el estado deplorable de las defensas, los liberales deciden derruirlas y abandonar la posición.

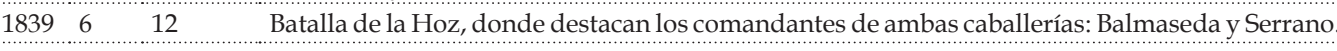
$\begin{array}{lll}1839 & 6 & \text { La situación crítica del ejército liberal en la guerra del Maestrazgo lleva a designar al general } \\ \text { Leopoldo O'Donnell como nuevo responsable del Ejército del Centro. Había sido jefe del }\end{array}$ Leopoldo O'Donnell como nuevo responsable del Ejército del Centro. Había sido jefe del
estado mayor del general Espartero en el Norte. 
110 La fortificación del "Reino má́gico" de Cabrera. Virginia Navalón

$18396 \quad$ Finales Cabrera inicia un nuevo cerco a Lucena. Una columna con 5 batallones liberales al mando de Aznar avanza desde Castellón. Se enfrenta a los carlistas en Alcora y rompe el cerco, pero rota

$\begin{array}{llll}1839 & 7 & & \text { en dos, parte quedará encerrada en Lucena, y la otra deberá regresar a C } \\ 183 & \text { O'Donnel parte de Zaragoza para socorrer Lucena, con } 12000 \text { hombres. }\end{array}$

$\begin{array}{lllll}1839 & 7 & 17 & \text { Los isabelinos rompen el cerco de Lucena y los carlistas deben replegarse al quedarse sin }\end{array}$ munición. O’Donnell recibe por esta acción el título de Conde de Lucena.

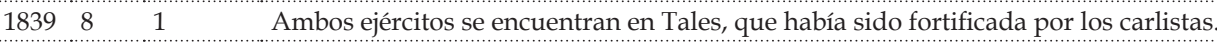

$\begin{array}{llll}1839 & 8 & 14 & \text { La resistencia de Tales se desmorona, los liberales toman la localidad y vuelan las fortificaciones }\end{array}$ para replegarse a Onda.

18398 Finales Simultáneamente al cerco de Tales, el carlista Arévalo derrota a los liberales en Chulilla y Cabreras sitia Carboneras, donde los liberales ofrecen tenaz resistencia al mando del brigadier Pérez hasta su capitulación. Cabrera concede una capitulación honrosa y se hacen 2000 prisioneros.

$\begin{array}{lllllll}1839 & 8 & 31 & \text { El general Maroto firma el Convenio de Vergara que pone fin a la guerra en el Norte. Cabrera }\end{array}$ lo considera una traición, pues las tropas del Norte son entregadas a los liberales.

$\begin{array}{llll}1839 & 9 & 14 & \text { El pretendiente se refugia en Francia con los batallones vascos y navarros que permanecen }\end{array}$ fieles. Previamente, el general Elio ha sondeado la posibilidad de enviar al pretendiente junto a los 8 batallones fieles al Maestrazgo. Cabrera decide seguir combatiendo tras un Consejo de Guerra.

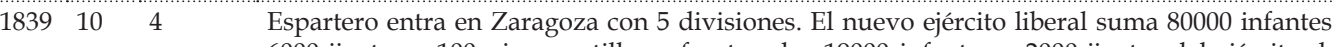
6000 jinetes y 100 piezas artilleras frente a los 19000 infantes y 2000 jinetes del ejército de Cabrera.

$183912 \ldots$ Entre diciembre de 1839 y mayo de 1840, Cabrera cae gravemente enfermo de tosferina. Ha recibido el nombramiento de comandante en jefe de todos los ejércitos carlistas de Cataluña, Aragón, Valencia y Murcia

$18393 \quad$ Cae Segura

$1839 \quad 4 \quad \ldots \ldots \ldots \ldots \ldots \ldots \ldots \ldots$ Cae Aliaga

18395 Caen Alpuente y Cantavieja. Mientras Cabrera se repliega ante las fuerzas de O'Donnell en la Cenia.

$\begin{array}{llll}1840 & 5 & 18 & \text { Se inicia el último sitio de Morella. Los defensores cuentan con } 2095 \text { hombres y } 12 \text { piezas }\end{array}$ artilleras. Cabrera se encuentra combatiendo a O'Donnell en la Cenia, lo que le impide acudir en socorro de la plaza.

$\begin{array}{llll}1840 & 5 & 30 & \text { Capitulación de Morella. }\end{array}$

$18406 \quad$ Cabrera llega a Berga con el ejército carlista, perseguido por las tropas de Espartero.

$\begin{array}{lllllll}1840 & 7 & 4 & \text { El general León se lanza al asalto de Berga, defendida por los carlistas. }\end{array}$

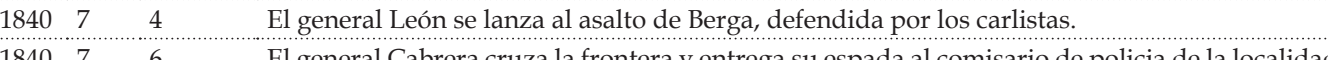

$\begin{array}{llll}1840 & 7 & 6 & \text { El general Cabrera cruza la frontera y entrega su espada al comisario de policia de la localidad }\end{array}$ 
Tabla 15. Cronología y posibles localizaciones de la expedición de Gómez.

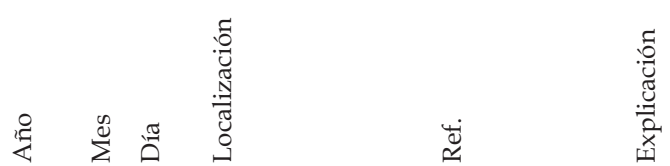

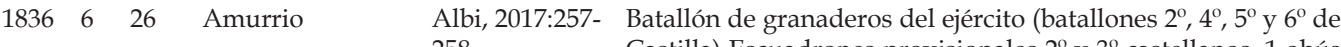
y un cañón de montaña (al mando de 1 sargento). Total: 2700 infantes y 180 caballos.

$\begin{array}{lllllll}1836 & 6 & 29 & \text { Asturias y } & \text { Albi, 2017:258 } & \text { La división liberal de Tello se encuentra con Gómez y es }\end{array}$ montañas de derrotada

$\begin{array}{llll}1836 & 7 & 5-8 & \text { Oviedo }\end{array}$

Albi, 2017:258 Entra en Oviedo sin resistencia y acopia material, forma un nuevo batallon (1 de Asturias) y refuerzan los suyos con prisioneros de Tello. Promueve una junta y un ayuntamient

\begin{tabular}{|c|c|c|c|c|}
\hline 1836 & & & Fonsagrada & Albi, 2017:259 \\
\hline 836 & 7 & $\begin{array}{l}18- \\
19\end{array}$ & $\begin{array}{l}\text { Santiago de } \\
\text { Compostela }\end{array}$ & Albi, 2017:2 \\
\hline 1836 & 7 & 26 & $\begin{array}{l}\text { Entra de nuevo } \\
\text { en Asturias }\end{array}$ & Albi, 2017:260 \\
\hline
\end{tabular}

$1836 \quad 8 \quad 1-4 \quad$ León

Albi, 2017:260 Peticiones de dinero, enrolamientos forzosos, requisa de armamento, caballos, calzado... Germen del 4 escuadrón de Castilla

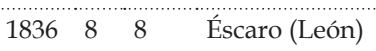

Albi, 2017:260

Ataque de la vanguardia de Espartero. El $5^{\circ}$ de Castilla cambia de bando y la expedición debe dividirse en dos. Espartero da por destruido el ejército de Gómez.

$\begin{array}{llll}1836 & 8 & 12 & \text { Cangas de Onís Albi, 2017:260 }\end{array}$

Confluencia de los dos ejércitos. Tras junta de mandos ante el acoso enemigo, se decide cambiar el objetivo y encaminarse a

\begin{tabular}{|c|c|c|c|c|c|}
\hline \multirow[b]{2}{*}{183} & & & & & \multirow{2}{*}{ 样 } \\
\hline & 8 & 20 & Palencia & Albi, 2017:261 & \\
\hline 1836 & 8 & & Valladolid & Albi, 2017:261 & \\
\hline 1836 & 8 & & Segovia & Albi, 2017:261 & \\
\hline 1836 & 8 & & Guadalajara & Albi, 2017:261 & \\
\hline \multirow[t]{12}{*}{1836} & 8 & 30 & $\begin{array}{l}\text { Matillas } \\
\text { (Guadalajara) }\end{array}$ & Albi, 2017:261 & $\begin{array}{l}\text { Choque con la columna del general López. Los derrota y coge } \\
\text { prisionero al mismo López. }\end{array}$ \\
\hline & & & $\begin{array}{l}\text { Fuente de la } \\
\text { Tabuenca }\end{array}$ & & Paso del Tajo \\
\hline & & & Zahorejas & & \\
\hline & & & $\begin{array}{l}\text { Puente de } \\
\text { Peralejos }\end{array}$ & & \\
\hline & & & Oreja & & \\
\hline & & & $\begin{array}{l}\text { Orihuela del } \\
\text { Tremedal }\end{array}$ & & $\begin{array}{l}\text { Pernoctan. Se encaminan a Cantavieja, pero deben dirigirse } \\
\text { hacia la parte de Cuenca }\end{array}$ \\
\hline & & & Torres & & \\
\hline & & & Terriente & & \\
\hline & & & Salva-Cañete & & \\
\hline & & & Alcalá de la Vega & & \\
\hline & & & Landete & & \\
\hline & & & La Torre & & \\
\hline
\end{tabular}




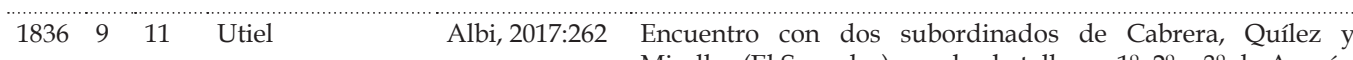
$\begin{array}{lllllllllll}1836 & 9 & 12 & \text { Utiel } & \text { Albi, 2017:262 } & \begin{array}{l}\text { Llega Cabrera, se sorprende ante la presencia de Quílez y } \\ \text { el Serrador y convence a Gómez de que es preferible actuar } \\ \text { contra Requena y Albacete }\end{array}\end{array}$

$18369 \quad$ Requena $\quad$ Albi, 2017:262 Intento fallido de ataque a Requena. La guarnición se muestra

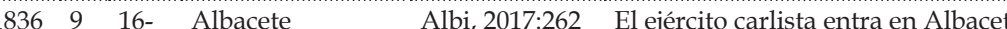

$\begin{array}{lllllll}1836 & 9 & 20 & \text { Villarrobledo } & \text { Albi, 2017:262 } & \text { El ejército de Gómez es sorprendido por los } 150 \text { húsares de }\end{array}$

$\begin{array}{llllll}1836 & 9 & 27 & \text { Andújar } & \text { Albi, 2017:264 Gómez amonesta al Serrador por su indisciplina }\end{array}$

1836930 Córdoba $\quad$ Albi, 2017:264 La caballería entra al galope en Córdoba después de que

$1836 \quad 10 \quad 4 \quad$ Córdoba

Albi, 2017:265 Parte de Córdoba ante la proximidad de la columna de la Reina. Marchas y contramarchas. Cabrera bate a una fuerza libera

$1836 \quad 10 \quad 12 \quad$ Córdoba

Albi, 2017:265 Regreso a Córdoba para partir al día siguiente a escondidas

$\begin{array}{llll}1836 & 10 & 16 & \text { Salida de }\end{array}$ Andalucía y

entrada en
Ciudad Real

$\begin{array}{lllll}1836 & 10 & 23 & \text { Almadén }\end{array}$

$\begin{array}{llll}1836 & 10 & 24 & \text { Almadén }\end{array}$

Albi, 2017:265 Gómez asedia Almadén.

Albi, 2017:265 Capitulación de Almadén. 1700 prisioneros

Posible insurgencia que pretende otorgar el mando a Cabrera. Este reúne a sus subalternos para comunicar que el primero que se insubordinase sería pasado por las armas. Cabrera en el fondo está preocupado por Cantavieja, amenazada por lo liberales y le urge acudir en su socorro.

$1836 \quad 10 \quad 30 \quad$ Trujillo

Albi, 2017:266 Reunión para debatir la situación de Cabrera y la necesidad de acudir en socorro de Cantavieja.

$\begin{array}{llllll}1836 & 10 & 31 & \text { Albi, 2017:267 Cantavieja es tomada por los liberales. }\end{array}$

$1836111^{\text {ss. }}$ Cáceres Albi, 2017:266 Se acuerda que Cabrera parta con la división de Valencia. Se produce una cascada de dimisiones en la unidad.

$1836 \quad 11 \quad 3 \quad$ Cáceres

Albi, 2017:266

Cabrera y Miralles se separan con 450 caballos valencianos. Gómez prácticamente los expulsa, aunque les da un mes de paga. No se sabe exactamente qué pasó.

$\begin{array}{lllllll}1836 & 11 & 7 & \text { Andalucía }\end{array}$

Albi, 2017:267

Albi, 2017:26 entra en Andalucía de nuevo Miralles (El Serrador), con los batallones $1^{\circ}, 2^{\circ}$ y $3^{\circ}$ de Aragón y 3 escuadrones de lanceros del Rey, el $1^{\circ}$ y $2^{\circ}$ de Valencia, y 3 cortos escuadrones de lanceros del Cid. Se sustituye e fusiles capturados al vemigo. Se dice, que Qúlez y el Serrodor se unen a Gómez ante el odio que profesan a Cabrera. contra Requena y Albacete la Princesa del ejército de Alaix. Se defienden en el pueblo que es tomado al asalto. El ejército carlista forma en el lado opuesto. Una carga de la caballería liberal los dispersa. Derrota de Villarrobledo. La derrota lleva internarse en Andalucía y no dirigirse a Madrid. unos simpatizantes les abran las puertas. Villalobos es herido mortalmente. Tienen que tomar cada punto fuerte donde se había refugiado la guarnición: 2800 hombres (milicianos) y 2 piezas. Dueño de la ciudad, Gomez designa una junta, reún dinero y equipa a sus hombres. Forma el $1^{\circ}$ y $2^{\circ}$ batallón de Córdoba con los mozos.

Gomez está en Ronda mientras los mandos liberales son depuestos y sus tropas se amotinan ante los nuevos mandos. Gomez, necesitado de descanso, se plantea establecerse en la Serranía de Ronda, ideal para la guerra de montaña. Pero desiste ante la proximidad de la división de la Guardia del general Ribero. $\begin{array}{lllll}1836 & 11 & 22 & \text { San Roque }\end{array}$

$\begin{array}{llll}1836 & 11 & 22 & \text { Algeciras }\end{array}$

$\begin{array}{lllll}1836 & 11 & 24 & \text { Algeciras }\end{array}$

$\begin{array}{llllll}1836 & 11 & 25 & \text { Majaceit }\end{array}$

$\begin{array}{lll}1836 & 11 & 29\end{array}$ Alcaudete

$\begin{array}{llll}1836 & 12 & 1\end{array}$ Rincón de Soto

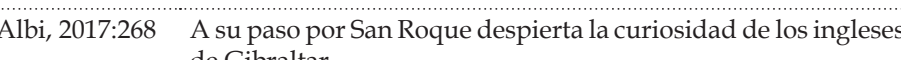
de Gibraltar

Albi, 2017:268 Gómez está en Ronda mientras los mandos liberales son depuestos y sus tropas se amotinan ante los nuevos mandos. Gómez, necesitado de descanso, se plantea establecerse en la Serranía de Ronda, ideal para la guerra de montaña. Pero (1)

lbi, 2017:268 Parte de Algeciras.

Albi, 2017:268 Camino de Arcos de la Frontera. Es atacado por la División de Camino de Arcos de la Frontera. Es atacado por la División de
Vanguardia del Norte. Pudo haber sido un golpe mortal para
Gómez de no existir las desavenencias liberales, que favorecen la inacción de Alaix.

lbi, 2017:268 En la madrugada, vuelve a caer sobre ellos la caballería de Diego de León. Gómez decide que es preciso emprender regreso. propósito de alcanzar Navarra, pero con el paso cerrado, buscó y se dirigió a Torre Arévalo con la infantería. La caballería fue a Arévalo de la Sierra. Allí son sorprendidos y entran en desbandada, Cabrera es herido. Se descomponen en grupos de 3 hombres.
$1836 \quad 12 \quad$ ? Covarrubias

$1836 \quad 12 \quad 14 \quad$ Covarrubias

$1836 \quad 12 \quad 19$ Territorio de d. Carlos

$1836 \quad 12 ? \quad$ Durango

$1836 \quad 12 \quad 31$
Se ha entrado en la provincia de Burgos. Se consulta a los

subordinados y se corrobora la decisión de regresar.

Agria carta de protesta de Gómez al ministro de la Guerra quejandose
tiempo.

El ejército ha llegado al territorio de d. Carlos. Tras 847 leguas (más de $6000 \mathrm{~km}$ en menos de 6 meses. Sale con 2700 infante y regresa con 1953, pero ha perdido 4000 entre muertos, heridos, enfermos y desertores. La caballeria ha pasado de 180 jinetes a 450. Han causado 579 muertos, 2355 heridos y 7996 prisioneros, segun fuentes carlistas. Pero partia con veteranos

5 días después de su llegada. Gómez se entrevista con el Rey que le reprocha por qué no ha batido a Espartero. Le contesta

"Tón es arrestado "entre bayonetas". Gómez y los suyos permanecerán 2 años y medio en prisión, diez meses incomunicados. La acusación. desobedecer la orden de y perder Cantavieja. Se cree que Cabrera fue su princip acusador. 


\begin{tabular}{|c|c|c|}
\hline 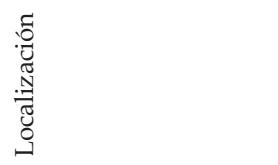 & 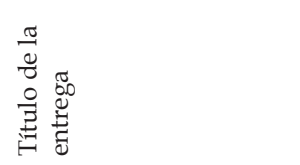 & 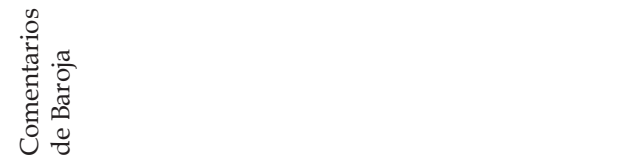 \\
\hline Amurrio & De Amurrio a Reinosa & \\
\hline Respaldiza & De Amurrio a Reinosa & \\
\hline Quejana & De Amurrio a Reinosa & \\
\hline Menagaray & De Amurrio a Reinosa & \\
\hline Arciniega & De Amurrio a Reinosa & \\
\hline Valle de Mena & De Amurrio a Reinosa & \\
\hline Villasana & De Amurrio a Reinosa & \\
\hline Leciñana de Mena & De Amurrio a Reinosa & \\
\hline Bercedo & De Amurrio a Reinosa & \\
\hline Baranda & De Amurrio a Reinosa & \\
\hline La Colina & De Amurrio a Reinosa & \\
\hline Las Rivas & De Amurrio a Reinosa & \\
\hline Villasante & De Amurrio a Reinosa & \\
\hline $\begin{array}{l}\text { Espinosa de los } \\
\text { Monteros }\end{array}$ & De Amurrio a Reinosa & \\
\hline Quintana de Soba & De Amurrio a Reinosa & \\
\hline Quisicedo & De Amurrio a Reinosa & Los carlistas se acantonan \\
\hline Argomedo & De Amurrio a Reinosa & \\
\hline Soncillo & De Amurrio a Reinosa & $\begin{array}{l}\text { Los batallones de Gómez se retiran ante el avance de } \\
\text { Espartero }\end{array}$ \\
\hline Reinosa & Alrededores de Reinosa & \\
\hline Fontibre & Alrededores de Reinosa & \\
\hline Castillo de Argüeso & Alrededores de Reinosa & Un testimonio indica que hubo carlistas \\
\hline Arroyo & Alrededores de Reinosa & \\
\hline Montes Claros & Alrededores de Reinosa & \\
\hline Los Carabeos & Alrededores de Reinosa & Nombre de montes y de un municipio. \\
\hline $\begin{array}{l}\text { Comarca de los } \\
\text { Riconchos }\end{array}$ & Alrededores de Reinosa & $\begin{array}{l}\text { Por esta zona Gómez vadea el Ebro en una jornada } \\
\text { penosa }\end{array}$ \\
\hline $\begin{array}{l}\text { Camino de Asturias } \\
\text { por el Puerto de } \\
\text { Tarna }\end{array}$ & Alrededores de Reinosa & Gómez pone rumbo a Asturias \\
\hline $\begin{array}{l}\text { Cervatos y su } \\
\text { colegiata }\end{array}$ & Alrededores de Reinosa & Camino recorrido por Gómez estudiando los pasos \\
\hline $\begin{array}{l}\text { Quintanilla de las } \\
\text { Torres }\end{array}$ & Alrededores de Reinosa & Estuvo Gómez \\
\hline Aguilar de Campoo & Alrededores de Reinosa & \\
\hline $\begin{array}{l}\text { Cervera del Río } \\
\text { Pisuerga }\end{array}$ & Alrededores de Reinosa & \\
\hline Cillamayor & Alrededores de Reinosa & \\
\hline Barruelo de Santullán & Alrededores de Reinosa & \\
\hline Brasoñera & Alrededores de Reinosa & \\
\hline
\end{tabular}




\begin{tabular}{|c|c|c|}
\hline Oviedo & De Oviedo a Santiago de Galicia & \\
\hline $\begin{array}{l}\text { Soto del Barco/ Soto } \\
\text { de la Ribera }\end{array}$ & De Oviedo a Santiago de Galicia & Enfrentamiento que rechaza a los liberales. \\
\hline Grado & De Oviedo a Santiago de Galicia & $\begin{array}{l}\text { Espartero se acerca y Gómez abandona Oviedo rumbo } \\
\text { a Grado }\end{array}$ \\
\hline Salas & De Oviedo a Santiago de Galicia & \\
\hline Tejera & De Oviedo a Santiago de Galicia & \\
\hline Tineo & De Oviedo a Santiago de Galicia & \\
\hline Polo de Allende & De Oviedo a Santiago de Galicia & \\
\hline Grandas de Salime & De Oviedo a Santiago de Galicia & \\
\hline Puerto del Palo & De Oviedo a Santiago de Galicia & \\
\hline Fonsagrada & De Oviedo a Santiago de Galicia & \\
\hline Lugo & De Oviedo a Santiago de Galicia & $\begin{array}{l}\text { "En Lugo no entra Gómez pero estuvo varias horas a la } \\
\text { vista de la ciudad y a tiro de fusil" }\end{array}$ \\
\hline Mellid & De Oviedo a Santiago de Galicia & \\
\hline $\begin{array}{l}\text { Santa María de } \\
\text { Castañeda }\end{array}$ & De Oviedo a Santiago de Galicia & \\
\hline $\begin{array}{l}\text { Santiago de } \\
\text { Compostela }\end{array}$ & De Oviedo a Santiago de Galicia & $\begin{array}{l}\text { Gómez ocupa Santiago en la mañana del } 19 \text { de julio de } \\
1836\end{array}$ \\
\hline $\begin{array}{l}\text { Marcha desde } \\
\text { Santiago a Palencia } \\
\text { por Asturias }\end{array}$ & De Santiago a León & \\
\hline León & De Santiago a León & \\
\hline Escaro & De Santiago a León & Es atacado por Espartero \\
\hline Orense & De Santiago a León & \\
\hline Monforte de Lemos & De Santiago a León & \\
\hline Pantón & De Santiago a León & \\
\hline Castro-Caldelas & De Santiago a León & \\
\hline Lago de Carucedo & De Santiago a León & \\
\hline Ponferrada & De Santiago a León & \\
\hline Vierzo & De Santiago a León & \\
\hline Villablino & De Santiago a León & Posible punto de paso de Gómez \\
\hline Murias de Paredes & De Santiago a León & Posible punto de paso de Gómez \\
\hline Riello & De Santiago a León & Posible punto de paso de Gómez \\
\hline Sariegos & De Santiago a León & Posible punto de paso de Gómez \\
\hline Trobajos & De Santiago a León & \\
\hline León & De Santiago a León & \\
\hline Riaño & De Santiago a León & \\
\hline Puerto de Tarna & De León a Utiel & \\
\hline Escaro & De León a Utiel & Gómez es derrotado por Alaix y Espartero \\
\hline Tarna & De León a Utiel & \\
\hline $\begin{array}{l}\text { Carretera de } \\
\text { Valladolid }\end{array}$ & De León a Utiel & \\
\hline Albires & De León a Utiel & \\
\hline Santervás del Campo & De León a Utiel & \\
\hline Zorita de la Loma & De León a Utiel & \\
\hline Villada & De León a Utiel & \\
\hline $\begin{array}{l}\text { Carrión de los } \\
\text { Condes }\end{array}$ & De León a Utiel & \\
\hline $\begin{array}{l}\text { Villalcasar de la Sirga } \\
\text { / Villasirga }\end{array}$ & De León a Utiel & \\
\hline Fromista & De León a Utiel & \\
\hline Camino de Palencia & De León a Utiel & mino de Gómez \\
\hline
\end{tabular}

\begin{tabular}{|c|c|c|}
\hline Bertavillo/Vertavillo & De León a Utiel & $\begin{array}{l}\text { Gómez se entera que el general Puig-Samper se dirige } \\
\text { a Tariego }\end{array}$ \\
\hline Peñafiel & De León a Utiel & $\begin{array}{l}\text { Durmieron. Los nacionales se encerraron en el castillo } \\
\text { y propusieron no hacer fuego si no se les molestaba. } \\
\text { Gómez pasó al pie de la fortaleza y no sonó un tiro } \\
\text { entre los bandos. }\end{array}$ \\
\hline Dirección a Segovia & De León a Utiel & $\begin{array}{l}\text { Cambian de planes al saber que allí hay batallones } \\
\text { liberales }\end{array}$ \\
\hline Somosierra & De León a Utiel & $\begin{array}{l}\text { Se pretendía caer sobre Madrid, pero hay fuerzas en } \\
\text { Buitrago. }\end{array}$ \\
\hline $\begin{array}{l}\text { Retroceden por Riaza } \\
\text { y Atienza }\end{array}$ & De León a Utiel & \\
\hline Jadraque & De León a Utiel & El castillo de Jadraque estaba ya en ruinas \\
\hline Bujalaro & De León a Utiel & se instalan los carlistas \\
\hline $\begin{array}{l}\text { Villanueva de } \\
\text { Argecilla }\end{array}$ & De León a Utiel & se instalan los carlistas \\
\hline Hita & De León a Utiel & \\
\hline Matillas de Henares & De León a Utiel & $\begin{array}{l}\text { Los liberales de Don Narciso López son envueltos por } \\
\text { los carlistas y derrotados }\end{array}$ \\
\hline Brihuega & De León a Utiel & \\
\hline Cifuentes & De León a Utiel & \\
\hline Esplegares & De León a Utiel & Gómez sabe que los liberales repasan el Ebro. \\
\hline $\begin{array}{l}\text { Dirección a Orihuela } \\
\text { del Tremedal }\end{array}$ & De León a Utiel & $\begin{array}{l}\text { Gómez pensaba seguir a Cantavieja, pero sabiendo que } \\
\text { San Miguel estaba en camino, cambia de rumbo y se } \\
\text { dirige a Utiel ( } 7 \text { de septiembre) }\end{array}$ \\
\hline $\begin{array}{l}\text { Según Baroja Gómez, } \\
\text { llegado a Utiel, se } \\
\text { dirige a Cantavieja } \\
\text { por Chelva, temeroso } \\
\text { de un ataque, pero } \\
\text { le indican que el } \\
\text { Serrador y Quílez } \\
\text { han llegado a Utiel y } \\
\text { regresa. }\end{array}$ & Utiel, Requena y la Mancha & \\
\hline Utiel & Utiel, Requena y la Mancha & $\begin{array}{l}\text { Cabrera se incorpora, viene frustrado de haber } \\
\text { intentado tomar Gandesa. }\end{array}$ \\
\hline Alborea & Utiel, Requena y la Mancha & \\
\hline Casas Ibáñez & Utiel, Requena y la Mancha & \\
\hline Mahora & Utiel, Requena y la Mancha & \\
\hline Albacete & Utiel, Requena y la Mancha & \\
\hline La Roda & El combate de Villarrobledo & $\begin{array}{l}\text { En él duermen los carlistas en un intento de acercarse } \\
\text { a Madrid }\end{array}$ \\
\hline Villarrobledo & El combate de Villarrobledo & $\begin{array}{l}\text { Un testimonio de principio del siglo XX, El Bravo, } \\
\text { asegura a Baroja que la batalla se inició por la parte } \\
\text { baja, por el campo de San Cristobal donde existe un } \\
\text { torreón ruinoso, donde los carlistas habían emplazado } \\
\text { centinelas que fueron sorprendidos por los liberales. }\end{array}$ \\
\hline Ossa de Montiel & El combate de Villarrobledo & $\begin{array}{l}\text { Tras el descalabro de Villarrobledo los carlistas se } \\
\text { recomponen y se dirigen a Ossa de Montiel. }\end{array}$ \\
\hline Manzanares & Sin título & \\
\hline Villahermosa & Sin título & Pasan los carlistas \\
\hline $\begin{array}{l}\text { Infantes / Villanueva } \\
\text { de los Infantes }\end{array}$ & Sin título & Los carlistas pernoctan \\
\hline Chiclana de Segura & Sin título & Recorrido de Gómez \\
\hline $\begin{array}{l}\text { Villanueva del } \\
\text { Arzobispo }\end{array}$ & Sin título & Recorrido de Gómez \\
\hline Valdepeñas & Sin título & Recorrido de Baroja \\
\hline
\end{tabular}




\begin{tabular}{|c|c|c|}
\hline Venta de Cárdenas & Sin título & Recorrido de Baroja \\
\hline Navas de Tolosa & Sin título & \\
\hline La Carolina & Sin título & \\
\hline Vilches & Sin título & \\
\hline Arquilles & Sin título & \\
\hline Puente de Alcolea & Sin título & $\begin{array}{l}\text { Punto de paso de Gómez, como de las tropas } \\
\text { Napoleónicas, las del Duque de Angulema, y } \\
\text { Novaliches en } 1868 \text {. }\end{array}$ \\
\hline Córdoba & Sin título & $\begin{array}{l}\text { Los liberales se refugian en el Alcázar Viejo, el Alcázar } \\
\text { Nuevo y el Seminario. Cabrera, Villalobos y Arnau } \\
\text { entraron por la puerta de Baeza. }\end{array}$ \\
\hline Conquista & Sin título & Pasa Gómez rumbo a Almadén \\
\hline Pedroches & Sin título & \\
\hline Pozoblanco & Sin título & \\
\hline Torremilano & Sin título & \\
\hline Santa Eufemia & Sin título & $\begin{array}{l}\text { Gómez prepara la toma de Almadén. Cerca se emplaza } \\
\text { el Castillo de Miramonte del que solo queda el torreón } \\
\text { desmochado en tiempos de Baroja. }\end{array}$ \\
\hline Almadén & Sin título & $\begin{array}{l}\text { Los liberales, a la hora de hablar de la defensa de } \\
\text { Almadén, critican que "las murallas del pueblo eran } \\
\text { unas miserables tapias con bardas y corrales, con } \\
\text { una circunferencia de tres cuartos de legua sin forma } \\
\text { regular". Para defenderlo el responsable liberal se } \\
\text { posiciona en el denominado fuerte Cristina. En el } \\
\text { pueblo lo llaman el castillo de Retamary, con torre } \\
\text { y un reloj. Se desmorona con rapidez, según Baroja. } \\
\text { El brigadier Flinter defendería "desde la entrada del } \\
\text { establecimiento minero un fuerte ya desaparecido } \\
\text { llamado la Enfermería" }\end{array}$ \\
\hline Fuencaliente & Sin título & \\
\hline Chillón & Sin título & Se desplazan los carlistas tras la toma de Almadén \\
\hline Vacar & Sin título & Tiene un castillo en un cerro, según Baroja. \\
\hline $\begin{array}{l}\text { Paso del Tajo por el } \\
\text { puente de Alcántara }\end{array}$ & Sin título & $\begin{array}{l}\text { Gómez tiene previsto pasar el Tajo por el Puente del } \\
\text { Arzobispo, pero cambia el destino al haber liberales } \\
\text { apostados. }\end{array}$ \\
\hline Trujillo & Sin título & $\begin{array}{l}\text { Los Carlistas descansan y se da permiso a Cabrera para } \\
\text { ir a socorrer Cantavieja. }\end{array}$ \\
\hline Cáceres & Sin título & $\begin{array}{l}\text { Gómez ordena a Cabrera encaminarse a Aragón con } \\
\text { caballería pero sin infantería. }\end{array}$ \\
\hline Arévalo & Sin título & Cabrera es herido y queda medio muerto. \\
\hline Ecija & Sin título & Recorrido de Gómez \\
\hline Osuna & Sin título & Recorrido de Gómez \\
\hline Marchena & Sin título & Recorrido de Gómez \\
\hline Gaucín & Sin título & Recorrido de Gómez \\
\hline San Roque & Sin título & Recorrido de Gómez \\
\hline Utrera & Sin título & Recorrido de Baroja \\
\hline Jerez & Sin título & Recorrido de Baroja \\
\hline $\begin{array}{l}\text { Puerto de Santa } \\
\text { María }\end{array}$ & Sin título & Recorrido de Baroja \\
\hline San Fernando & Sin título & Recorrido de Baroja \\
\hline Chiclana & Sin título & Recorrido de Baroja \\
\hline Laguna de la Janda & Sin título & Recorrido de Baroja \\
\hline Tarifa & Sin título & \\
\hline Altos de Algeciras & Sin título & \\
\hline Algeciras & Sin título & Confluye el recorrido de Baroja con el de Gómez \\
\hline Gibraltar & Sin tí & \\
\hline
\end{tabular}

\begin{tabular}{|c|c|c|}
\hline San Roque & Sin título & $\begin{array}{l}\text { La columna de Gómez sale de Gaucín y se acerca a } \\
\text { San Roque. De allí se dirigieron a Gibraltar, pero "una } \\
\text { fragata inglesa y varios guardacostas españoles les } \\
\text { dispararon cañonazos" }\end{array}$ \\
\hline Cádiz & Sin título & Baroja va a dormir a Cádiz (No Gómez) \\
\hline Arcos de la Frontera & Sin título & \\
\hline $\begin{array}{l}\text { Puente del Guadalete, } \\
\text { río Guadalcacín o } \\
\text { Majaceite }\end{array}$ & Sin título & $\begin{array}{l}\text { Narváez da una embestida a Gómez que fuerza su } \\
\text { repliegue al Norte. }\end{array}$ \\
\hline Algar, río Algar & Sin título & \\
\hline Alcaudete & Sin título & $\begin{array}{l}\text { Alaix, que no ha cedido el mando a Narvaez, } \\
\text { sorprende a Gómez en Alcaudete y lo dispersa. Gómez } \\
\text { no hará más que huir hasta Orduña (19 de diciembre) }\end{array}$ \\
\hline
\end{tabular}


12.7. Periodos de la fortificación del "reino mágico" de Cabrera 
I PERIODO

$(13$ noviemb
$1833-10$

diciemb

1833)

II PERIODO

(10 diciembre
1833 -marzo

1836)

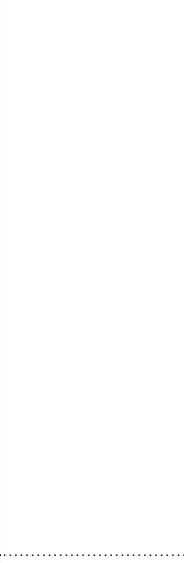

III PERIODO

(marzo 1836-31

Primer intento de fortificación de

\section{Morella como}

base única

Fortificación de

Beceite
Morella como primera base fortificada: almacenamiento de suministros, udad cae en manos carlistas las pocas semanas de iniciarse la contienda.

Tomada Morella, los carlistas son conscientes de la necesidad de contar con una base fortificada. Los puertos de Beceite suponen una oportudidad, pues se trata de un territorio difícilmente accesible, propicio para el refugio de las partidas carlistas cuando son acosadas por las columnas liberales. Beceite, dado su acceso estrecho siguiendo el Matarraña y enclavado en una garganta fácil de defender, rodeada de montañas, es un lugar ideal. Conscientes de ello, los liberales dejan una guarnición en Beceite, lo que impide que los carlistas la ocupen y fortifiquen. En 1834 los carlistas sitian a la guarnición. Cuando posicionados en las alturas. Los liberales desalojan a los carlistas y destruyen aquellas fortificaciones (Pirala 1984: 334: Caridad, 2013.246). Fn agosto de 1835, los carlistas reducen al destacamento liberal (Córdoba, 1844: 190; Segura, 1991:103,114). Los puertos de Beceite se convierten en base carlista, con taller para armamento, indumentaria y campamento de adiestramiento (Pirala, 1984:307, 334; Caridad, 2013: 246). Se desconoce si existe algún tipo de fortificación más allá de la arquitectura preexistente o las barreras naturales, pero parece lógico si se han detectado esfuerzos constructivos en momentos anteriores. De haber algún trabajo avanzado, es destruido por la columna liberal de Churruca, que ocupa el lugar en marzo de 1836 (Pirala, 1984: 72 ). Esta ocupación

Tras perder Beceite, los carlistas tratan de fortificar otros puntos del Maestrazgo. En la primavera de 1836 construyen una línea de reductos y trincheras desde 4 de junio de 1836; Pirala, 1984: 75; Caridad, 2013: 246). Construyen parapetos dominando las alturas de Chert aś como una pared aspillerada en el peñasco de La Muela (Diario Mercantil de Valencia, 4 de julio de 1836). En esta época se emprenden las reparaciones del castillo de Culla, donde se registra una guarnición de 60 hombres. En los meses de mayo y junio de 1836, las columnas liberales de Iriarte y Buil se dedican a interceptar este conjunto de obras para impedir que estén operativas, volviendo a replegar a los carlistas a Beceite. En abril de 1836, Cabrera, enterado de que los liberales quieren fortificar Cantavieja, se anticipa, la fortifica y abastece para resistir un asedio. Vid. fortificación de Cantavieja. Pero la plaza fue tomada por el mariscal Evaristo San Miguel el 31 de octubre de 1836 (Diario Constitucional de Zaragoza, 5 de tarde, los carlistas on expulsados de los puertos de Becite. 


\begin{tabular}{|c|c|c|}
\hline $\begin{array}{l}\text { IV PERIODO } \\
\text { (310ctubre } \\
\text { 1836-1 enero } \\
\text { 1837) }\end{array}$ & $\begin{array}{l}\text { Refortificación de } \\
\text { Beceite }\end{array}$ & $\begin{array}{l}\text { Desplazados, los carlistas vuelven a fortificar los puertos de Beceite. Las obras } \\
\text { duran } 6 \text { meses y en ellas trabajan entre } 150 \text { y } 200 \text { operarios (Diario Constitucional } \\
\text { de Zaragaza, } 14 \text { de enero de } 1837 \text { ). Precisamente estas fortificaciones son } \\
\text { detalladas por el general Nogueras (Diario Constitucional de Zaragozaza, } 14 \text { de } \\
\text { enero de 1837, Diario Mercantil de Valencia, } 21 \text { de enero de 1837, Caridad, } \\
\text { 2013:247). La fortificación que describe Nogueras hace referencia al territorio, } \\
\text { y no solo a la actual localidad. Se valora el aprovechamiento de la posición } \\
\text { natural. No obstante, no la pueden defender por falta de víveres y municiones } \\
\text { y ellos mismos destruyen lo construido, siendo la posición ocupada por } \\
\text { los liberales el } 1 \text { de enero de } 1837 \text { (Córdoba, 1844:153; Diario Constitucional } \\
\text { de Zaragoza, } \text { y } 14 \text { de enero de } 1837 \text {, El Satanás, 21 de enero de 1837, Diario } \\
\text { Mercantil de Valencia, } 21 \text { de enero de 1837, Caridad, 2013:248). }\end{array}$ \\
\hline $\begin{array}{l}\text { V PERIODO } \\
\text { (1 enero } 1837- \\
25 \text { abril } 1837)\end{array}$ & $\begin{array}{l}\text { Conquista de } \\
\text { fuertes enemigos }\end{array}$ & $\begin{array}{l}\text { Sin ninguna base, deciden priorizar la toma de plazas, y se deciden a recuperar } \\
\text { Cantavieja, iniciando esta nueva estrategia. }\end{array}$ \\
\hline $\begin{array}{l}\text { VI PERIODO } \\
\text { (25 abril 1837- } \\
26 \text { enero } 1838)\end{array}$ & $\begin{array}{l}\text { Toma de } \\
\text { Cantavieja }\end{array}$ & $\begin{array}{l}\text { La toma de Cantavieja se hace efectiva el } 25 \text { de abril de } 1837 \text { (Mercantil de } \\
\text { Valencia, } 7 \text { de mayo de 1837; Córdoba, 1844: 212-213, 321-323; Caridad, 2013: } \\
\text { 249). Por su parte, Morella es conquistada en enero de } 1838 \text { y se convierte en la } \\
\text { capital del carlismo valenciano-aragonés. }\end{array}$ \\
\hline $\begin{array}{l}\text { VII PERIODO } \\
\text { (26 enero 1838- } \\
31 \text { agosto 1839) }\end{array}$ & $\begin{array}{l}\text { Fortificación } \\
\text { de pueblos } \\
\text { aragoneses y } \\
\text { valencianos }\end{array}$ & $\begin{array}{l}\text { Base de control del territorio y base de operaciones. Se trata de dificultar las } \\
\text { operaciones del enemigo con un conjunto de operaciones que se plantean } \\
\text { como estrategia ante un futuro avance peninsular carlista. Vergara supone la } \\
\text { asunción de una defensa de contención. }\end{array}$ \\
\hline $\begin{array}{l}\text { VIII } \\
\text { PERIODO }(31 \\
\text { agosto 1839- } \\
\text { julio 1840) }\end{array}$ & $\begin{array}{l}\text { Fortificación } \\
\text { de resistencia y } \\
\text { asedio }\end{array}$ & $\begin{array}{l}\text { El acuerdo de Vergara desencadena que toda la atención militar liberal se } \\
\text { centre en el frente del Maesterazgo. Sucesión de ataques liberales a plazas } \\
\text { fuertes carlistas. }\end{array}$ \\
\hline
\end{tabular}


Tabla 18. Fechas y localizaciones de la Expedición Real.

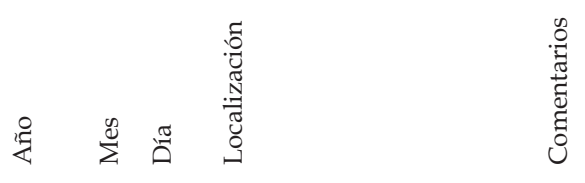

$1837 \quad 5 \quad 15 \quad$ Estella

$1837 \quad 5 \quad$ Acantonados entre Sesma y los Arcos, cerca del Ebro

$1837 \quad 5 \quad 15-$ Echauri $\quad$ Cruce del río Arg

$1837 \quad 5 \quad \begin{aligned} & \text { Desfilan a la vista de } \\ & \text { Pamplona }\end{aligned}$

$1837 \quad 5 \quad 18 \quad$ Pamplona

1837 Gallipienzo $\quad \begin{aligned} & \text { Alcanzan el río Aragón (Cerca, en Caseda, había una guarnición } \\ & \text { isabelina) }\end{aligned}$

$\begin{array}{lllll}1837 & & \text { Luna } & & \\ 1837 & 5 & 23 & \text { Marracos } & \text { Cruce del río Gállego }\end{array}$

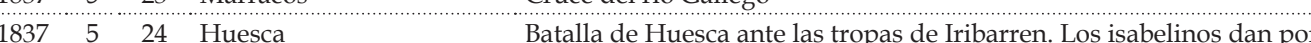

isabelinos dan po pero salvan su artillería. Se reti

$\begin{array}{llllll}1837 & 5 & 27 & \text { Barbastro } & \text { La tropa parte de Huesca por la mañana y llega al atardecer }\end{array}$

$\begin{array}{lllll}1837 & 6 & 2 & \text { Batalla de Barbastro contra las tropas de Oráa, que se retira a Berbegal. }\end{array}$

$\begin{array}{llll}1837 & 6 & \text { Estada } & \text { Alcanzan el río Cinca. Primer revés al cruzarlo. Bombardeados por el }\end{array}$

$\begin{array}{lllllll}1837 & 6 & 8 & \text { E } & 0\end{array}$

Pasan sin problemas el río Noguera Ribagorzana alcanzando el
territorio catalán

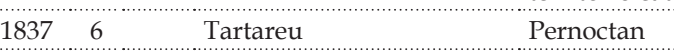

$\begin{array}{llll}1837 & 6 & 12 & \text { Guisona y Grá }\end{array} \quad$ Se despliegan los batallones para dar batalla. Victoria liberal del general Meer.

1837 Por Biosca y Miracle hasta Solsona había sido designada capital de distrito carlista como punto Solsona. de reunión de los jefes catalanes.

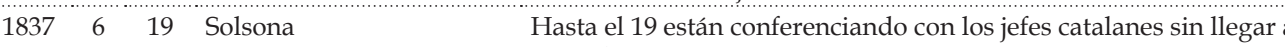

$\begin{array}{llll}1837 & 6 & \text { Suria } & \text { Pasan la noche. }\end{array}$

$\begin{array}{lllllll}1837 & 6 & 20 & \text { Sampedor } & \text { Con algo de fortificación pero sin guarnición, la población se }\end{array}$ defiende. Deciden abandonar Cataluña ante la pérdida de objetivos en Cataluña.

\begin{tabular}{|c|c|c|c|c|}
\hline 1837 & 6 & & Vallbona de las Monjas & \\
\hline 1837 & 6 & & Vinaixa & \\
\hline 1837 & 6 & & Margalef & \\
\hline 1837 & 6 & & Ginestar & \\
\hline \multirow[t]{6}{*}{1837} & 6 & 29 & Cherta & $\begin{array}{l}\text { Alcanzan el Ebro. Los isabelinos tienen dos fuerzas, una en Tortosa } \\
\text { a cargo de Borso de Carminati, y otra en Móra d'Ebre a cargo de } \\
\text { Nogueras. }\end{array}$ \\
\hline & & & Ulldecona & \\
\hline & & & San Mateo & \\
\hline & & & Cabanes & (Calbo y Rochina, 1845: 321) \\
\hline & & & Villarreal & Se reunen todas las fuerzas carlistas \\
\hline & & & Nules & $\begin{array}{l}\text { Los carlistas envían avanzadas a Nules para "intimar" la rendición de } \\
\text { Castellón (Calbo y Rochina, 1845: 321) }\end{array}$ \\
\hline 1837 & 7 & 7 & Castellón de la Plana & $\begin{array}{l}\text { Los Carlistas, con } 18000 \text { hombres, asedian Castellón de la Plana, pero } \\
\text { desisten al llegar la flota con tropas de Borso. }\end{array}$ \\
\hline
\end{tabular}


1136 La fortificación deL “reino mágico" de Cabrera. Virginia navalón

$1837 \quad 7 \quad 7 \quad 10 \quad$ Almenara Sagunto Petrés-Gilet-Torres Tor

$\begin{array}{llll}1837 & 7 & 11 & \text { Sierra Calderona- } \\ \text { Moncada }\end{array}$

$\begin{array}{llll}1837 & 7 & 12 & \text { Burjassot }\end{array}$

$1837 \quad 7 \quad 13 \quad$ Camino de Chiva

$\begin{array}{lllll}1837 & 7 & 15 & \text { Chiva }\end{array}$

Cantavieja

Iglesuela

Vilafranca

Cantavieja

$1837 \quad 7 \quad 30 \quad$ Mirambel

$1837 \quad 8 \quad 1 \quad$ Horcajo (Forcall)-Zorita Pasan cerca de Sagunto y retornan a Burjassot. Oráa está en Liria. de agosto.

Sot de Cher tropas de D. Carlos. D. Carlos alcanzinaela.
Mosqueruel casa Zurita.
Los carlistas pasan por la derecha de Almenara para poder sortear luego los disparos del castillo de Sagunto.

Los carlistas ocupan los puestos de la baronía de Petrés, Gilet y Torres-Torres. Precisamente en Torres torres pernocta el pretendiente. Los Carlistas sortean la Sierra Calderona y desde allí llegan a Moncada, desde donde Cabrera dirige oficios a las poblaciones, pidiendo dinero y raciones (Calbo y Rochina, 1845: 324-325) Acampan cerca de Burjassot, a la vista de Valencia. Pero llega de nuevo la flota con las tropas de Borso. D. Carlos pernocta en Burjassot. Cabrera intenta avanzar sobre Valencia pero es rechazado

Los carlistas parten precipitadamente de Burjassot, sabiendo que

Las tropas de Oráa se reunen con la de Nogueras y, en Valencia, se une a las de Borso para encontrarse con las tropas carlistas en Chiva. Las tropas carlistas son derrotadas. En la batalla de Chiva los carlistas ocupan posiciones de la localidad, como el pueblo como centro de operaciones y la Virgen del Castillo y la colina en su frente (Calbo y Espartero ha partide renar Priego y Calamocha, alcanzando Daroca. Mientras Zaratiegui ha lanzado un ejército desde Navarra que vadea el Ebro entre Haro y Miranda de Ebro (24/7/1837) y ocupa Segovia (3/7/1837). Madrid, a $60 \mathrm{~km}$, es declarada en estado de sitio. Espartero llega a Madrid 13

Los liberales pensaban que los carlistas se dirigirían a Cuenca, por ello se habían posicionado en Requena, conscientes del nuevo rumbo enemigo, avanzan por Chera, Chulilla, Villar del Arzobispo, Alcublás, Jérica hasta alcanzar Viver.

Los carlistas abandonan Rubielos el día 20. El 21 llegan los liberales. Las topas carlistas se encuentran entre Cantavieja, Camarillas y Allepuz. Las tropas de Forcadell están en Onda reunidas con las de
Tallada. Las montañas de Teruel y el Maestrazgo son el refugio de las En este punto es interesante la estrategia de los liberales para disolver
la expedición enemiga. Contando con que el ejército más potente es el del conde de Luchana, del Norte, se trataba de forzar a los Carlistas a un enfrentamiento decisivo o arrinconarlos en Beceite sin recursos o entre el Ebro y el Mediterráneo. Para ello describen dos líneas tácticas sus ejércitos. Un movimiento enlaza Camarillas-Fortanete-ForcallMorella-Cherta-Rossell-La Senia y Amposta. El otro movimiento enlaza Rubielos-Mosqueruela-Castellfort-Cati-Vinaroz-UlldeconaSan Carlos. Si los carlistas trataban de evitar este movimiento, se dirigirían hacia el Bajo Aragon, o desde Beceite a Alcañiz, y serían dificulta sus movimientos, temerosos de internarse en el Maestrazgo sin Víveres por lo que la marcha no se produce hasta el 30 de julio

D. Carlos alcanza la Iglesuela cuando los liberales llegan a

D. Carlos llega a Mirambel procedente de la Iglesuela y se aloja en la

La Expedición come en Forcall y llega a Zorita, por la persecución liberal. Cabrera y los suyos mientras están en "Portell"y Cinc Torres (Calbo y Rochina, 1845: 332).
$1837 \quad 8 \quad 2-8 \quad$ Mirambel

LA FORTIFICACION DEL "REINO MAGICO DE CABRERA. VIRGINIA NAVALÓN

La Expedición regresa..... Mirambel donde permanecen hasta el día 8 (Capital administrativa). Confluyen D. Carlos y Cabrera en Mirambel. Los liberales se encontraban en Forcall. Cabrera y sus los movimientos siguientes se sabe que los liber Foll. Acerca de Castellón, para proveerse y en persecución de las tropas de Sanz y Forcadell, que suministraban desde allí víveres a la expedición. Estos se dirigieron a la huerta de Valencia y Cabrera se dirigió a Albocácer y luego a Ares. Mientras D. Carlos divide sus fuerzas entre Villarluengo, la Cañada [de Benatanduz], Tronchón y Aliaga. $\begin{array}{llll}1837 & 8 & 8 & \text { Fortanete-Villarroya de }\end{array}$ Pinares

Camarillas / El Poyo

Aliaga / Segura / Aguilar

Oliete, Muniesa

$\begin{array}{llll}1837 & 8 & 23 & \text { Villar de los Navarros }\end{array}$

$\begin{array}{llll}1837 & 8 & 25 & \text { Herrera y El Villar }\end{array}$

Calamocha

$1837 \quad 9 \quad 2 \quad$ Monreal del Campo

$\begin{array}{lllll}1837 & 9 & 2 & \text { Villafranca }\end{array}$

Alba [del Campo],

Pozondón y Orihuela del

Tremedal

Bronchales, Calomarde,

$1837 \quad 9 \quad 5 \quad$ Tragacete, Huélamo

Salvacañete

Alcalá de la Vega

Villar del Humo

Cardenete

Campillo de Altobuey

Valverdejo

Buenache de Alarcón

$\begin{array}{llll}1837 & 9 & 10 & \text { Villar de Cañas }\end{array}$

Montalbo

Saélices

Tarancón

Arganda del Maestrazgo. D. Carlos se posiciona en Fortanete desde Mirambel, y Sanz y Forcadell amagan ir hacia Sarrion para simular un avance de Aragon a Valencia, pero el objetivo es reunirse con los demás en Alfambra y Camarillas para invadir Castilla la Nueva.

Las tropas de D. Carlos alcanzan Camarillas. Y las de Sanz, Forcadell Tallada y Esperanza alcanzan el Poyo.

A los pocos dias se encaminan a Aliaga. Mientras las tropas de Tena y Caballero se dirigen a Segura y las de Sopelana a Aguilar.

Mientras Cabrera hace una tentativa sobre Lucena, las tropas de D. Carlos se plantean avanzar a Madrid, para ello buscan un paso a la provincia de Soria, atravesando el Campo de Cariñena. Para eso pasan a Oliete y Muniesa y el día 23 de agosto ocupan Villar de los Navarnos.

Buerens en Azuara se entera.....................ición se encuentra en Herrara y Villar de los Navarros y se decide a presentarle batalla.

La expedición ocupa los pueblos de Herrera y el Villar. Se produce el enfrentamiento. Es la mayor derrota del ejército isabelino. En esta acción fallece Quílez. Después de esta acción, la expedición se mueve fuerzas carlistas que se han quedado en Valencia, ya con la idea de posicionarse a la vista de Madrid.

La expedición avanza hacia Madrid

La expedición avanza hacia Madrid

La expedición pernocta en Villafranca. Al día siguiente llegan los liberles.El día 2 las tropas de Cabrera pasando por Jérica han llegado

Calbo y Rochina, 1845: 337

Los expedicionarios de dirigen por detrás de Bronchales y Calomard hacia Frías de Albarracín

La expedición avanza por Tragacete y Huélamo mientras los liberales de Oraa regresan a Aragon

La expedición avanza hacia Madrid

D. Carlos ocupa Villar de Cañas mientras el resto de la tropa, se acantona en Montalvo, dirigiendo partidas a Villarejo, Villar de Sanz y Palomares.

Tarancón

La expedición avanza hacia Madrid

La expedición avanza hacia Madrid 


\begin{tabular}{|c|c|c|c|c|}
\hline 1837 & 9 & 12 & A las puertas de Madrid & $\begin{array}{l}\text { Sorprendentemente no se toma Madrid y se da orden de regresar a } \\
\text { Arganda. }\end{array}$ \\
\hline & & & Arganda & Retirada a Arganda \\
\hline & & & Alcalá de Henares & Ocupación fugaz \\
\hline & & & Guadalajara & Ocupación fugaz y se refugia en la Alcarria \\
\hline & & & La Alcarria & \\
\hline 1837 & 9 & 19 & Aranzueque & $\begin{array}{l}\text { Encuentro con Espartero. Batalla de Aranzueque. La expedición se } \\
\text { ve obligada a cruzar el río Tajuña con grandes pérdidas, mientras } \\
\text { Cabrera regresa al Maestrazgo. }\end{array}$ \\
\hline & & & Gormaz & Cruce del Duero \\
\hline & & & Aranda de Duero & Encuentro con el ejército de Zaratiegui. \\
\hline & & & Retuerta & Los ejércitos hacen alto y presentan batalla pero Espartero no acepta \\
\hline 1837 & 10 & 14 & Huerta del Rey & $\begin{array}{l}\text { Vuelven a presentar batalla, se despliegan en exceso y Espartero los } \\
\text { desbarata. Los soldados, hartos, entonan el iHule, hule, a casa!. Uno } \\
\text { vadearon el río por la Rioja, otros por Burgos y otros por Cantabria. }\end{array}$ \\
\hline 1837 & 10 & 24 & Arceniega & $\begin{array}{l}\text { El pretendiente cruza el Ebro al Norte y regresa por el Ebro } \\
\text { asentando la corte en Arceniega. }\end{array}$ \\
\hline
\end{tabular}

Movimientos de Cabrera durante la Expedición Real

(según el testimonio de Wilhelm von Rahden (2013: 49))

Tabla 19.

\begin{tabular}{|c|c|c|}
\hline & Samper de Calanda & Conquista para tomar Caspe \\
\hline & Camino de Caspe & Un rayo deja inconsciente al general en un granero \\
\hline & Hijar & $\begin{array}{l}\text { Cabrera recupera el conocimiento. El sitio de Caspe se levanta } \\
\text { ante la carencia de artillería }\end{array}$ \\
\hline \multirow{13}{*}{$1837 \quad 6 \quad 29$} & Cherta & $\begin{array}{l}\text { Para pasar el Ebro. Rodeada de los fuertes enemigos de } \\
\text { Tortosa, Amposta, Vinaroz, Peñíscola, Morella, Gandesa, } \\
\text { Mora y Falset }\end{array}$ \\
\hline & Huerta de Valencia & \\
\hline & Burjassot & \\
\hline & Chiva & \\
\hline & Cantavieja & En aquel entonces, único punto fijo que domina Cabrera \\
\hline & Iglesuela del Cid & Descansa el rey \\
\hline & Fuentidueña & Alcanzan el Tajo \\
\hline & Arganda & \\
\hline & Vallecas & \\
\hline & $\begin{array}{l}\text { Remontan el Valle de Tajuña } \\
\text { hasta Mondéjar }\end{array}$ & \\
\hline & Aranzueque & \\
\hline & Chiloeches & \\
\hline & Alcalá & \\
\hline \multirow[t]{2}{*}{$\begin{array}{lll}1837 & 9 & 19\end{array}$} & Aranzueque & $\begin{array}{l}\text { Batalla. Cabrera y sus divisiones se separan del ejército del } \\
\text { Rey }\end{array}$ \\
\hline & Arcos de la Cantera & Breve combate en el que Cabrera era encerrado por Oráa. \\
\hline \multirow[t]{6}{*}{183710 Med. } & Cantavieja & $\begin{array}{l}\text { Cabrera tiene noticia de que Oráa se aproxima con artillería } \\
\text { pesada desde Valencia }\end{array}$ \\
\hline & Ares & Cabrera aguarda a Oráa en Ares y lo rechaza \\
\hline & Alcañiz & Descenso al valle del Ebro \\
\hline & Alcorisa & Toma del fuerte \\
\hline & Torrevelilla & Toma del fuerte \\
\hline & Corbera & $\begin{array}{l}\text { Bate al general San Miguel, que tiene que evacuar el fuerte de } \\
\text { Gandesa }\end{array}$ \\
\hline
\end{tabular}




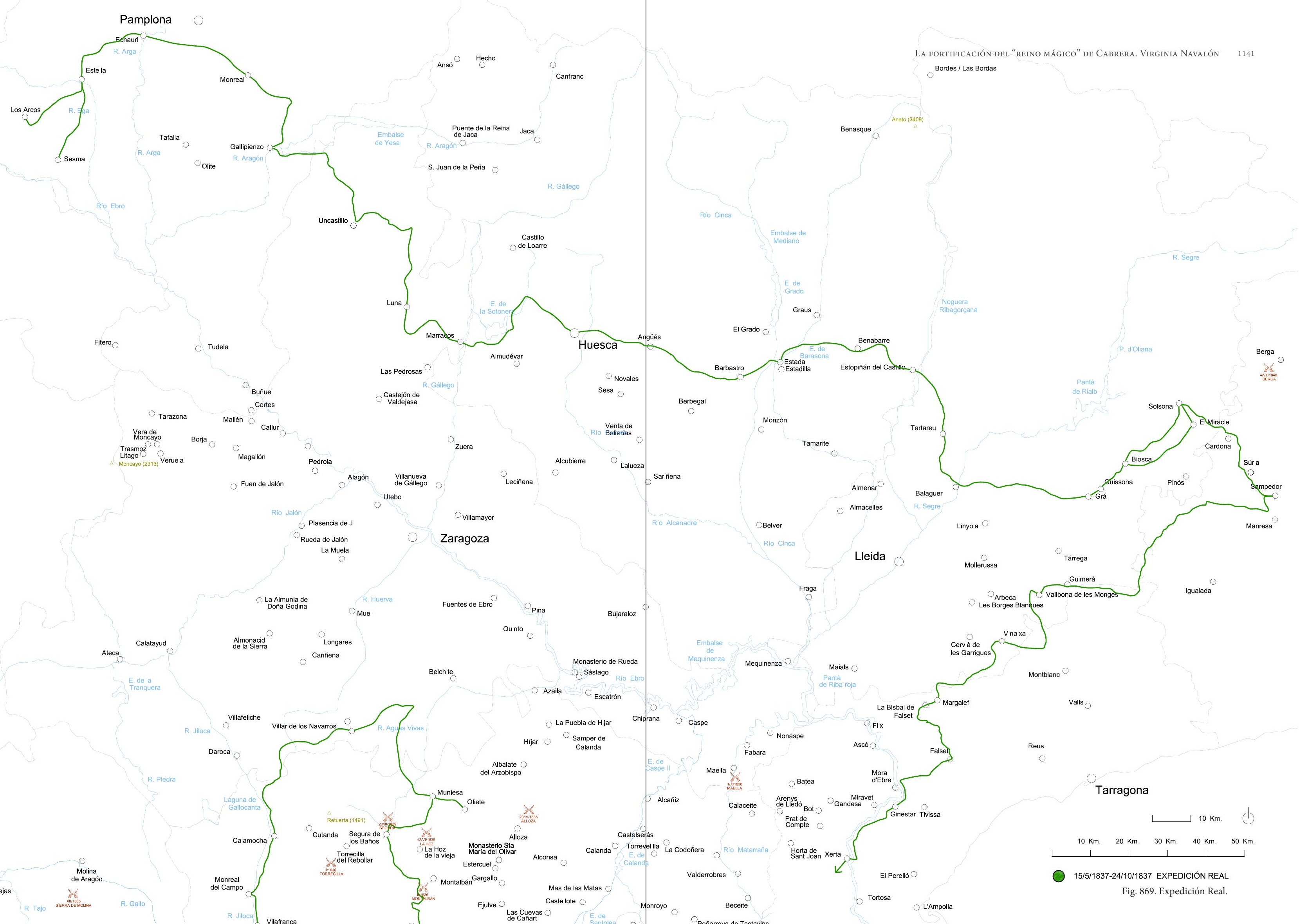




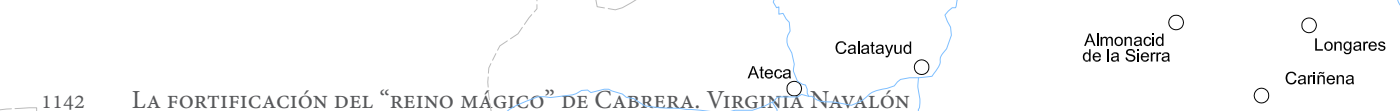

Quinto

Sigüenza $\bigcirc$

E.dela

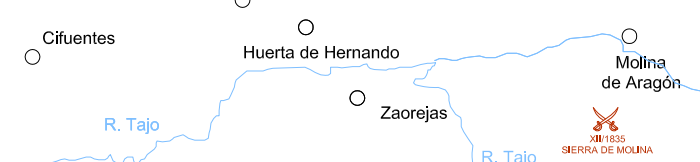

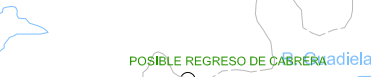

R. Galo

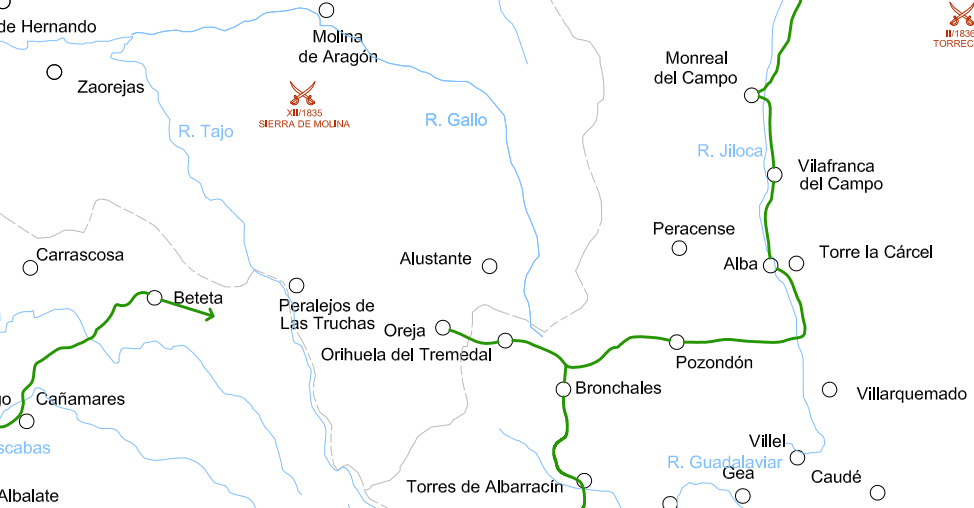

Monreal
del Campo

Daroca $\rho$

Sacedorn
E. de Buendia
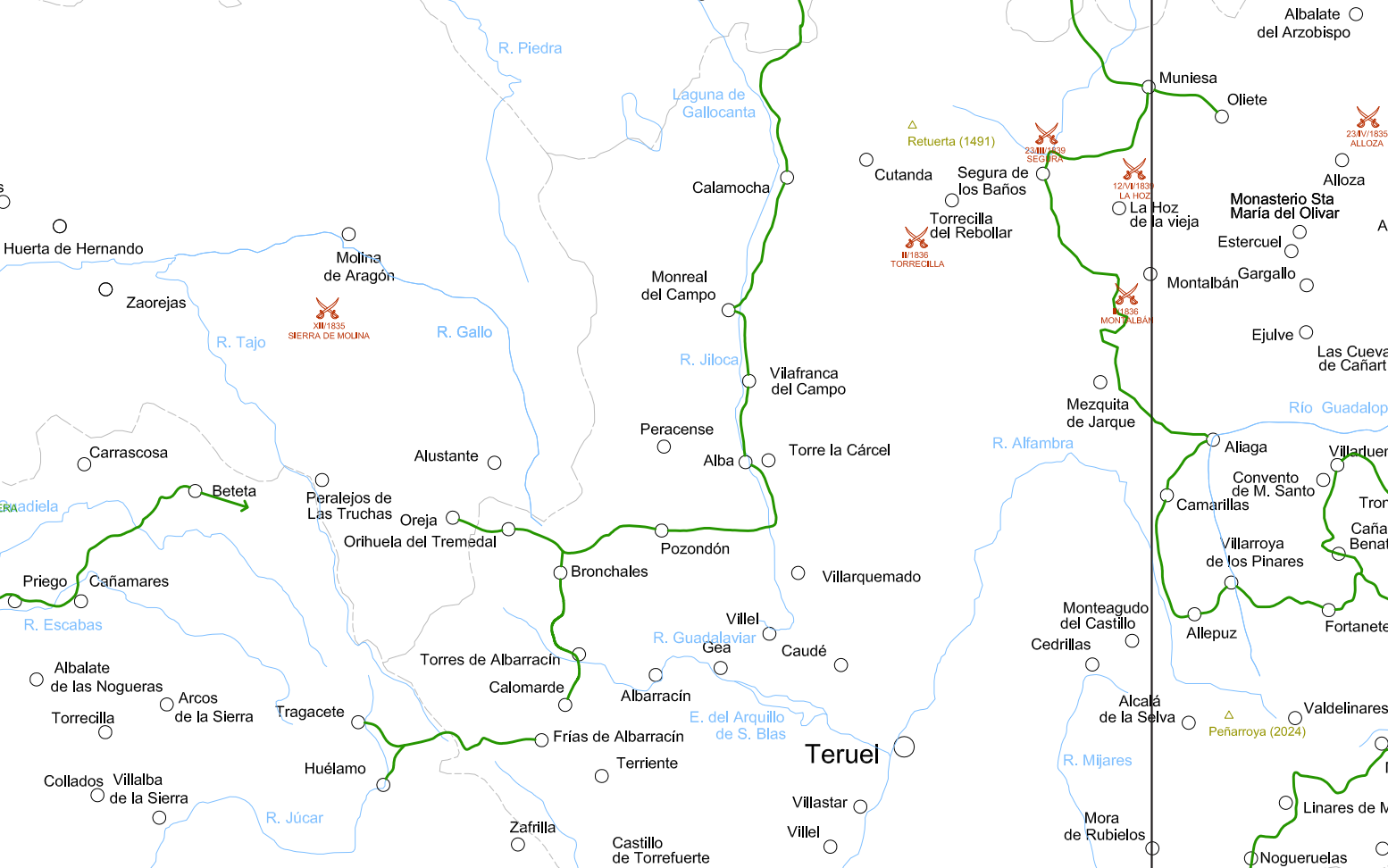

Monasterio de Rueda
Sástago Rio Ebro

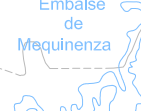

Mequinenza

Maials $\bigcirc$
Pantà

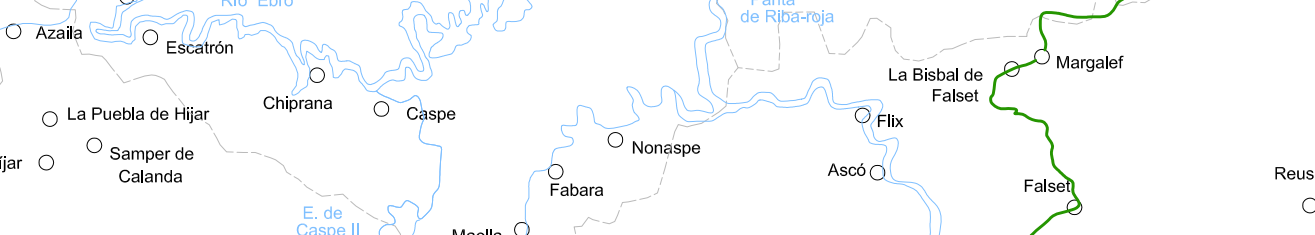

Arcos de la Canter

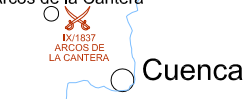

Castielfatio

R. Túra

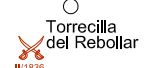

Alloza
Monasterio Sta
Maria del Invar Alcorisa
Estercuel

Castelserés
Calanda Torrevelila La codo

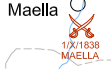

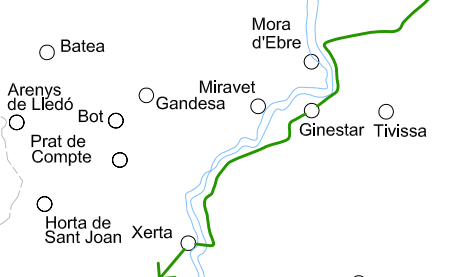

Villar de Cañas 
12.9. Recorrido de don Beltrán de Urdaneta en La campaña del Maestrazgo de Pérez Galdós 
Tabla 20. Recorrido de don Beltrán de Urdaneta en La campaña del Maestrazgo de Pérez Galdós (Pérez Galdós, B.

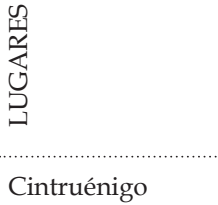

Fuentes de Ebro

(n)

\section{Se detie}

Pretende alcanzar Mora de Rubielos o los montes de Gudara por tierras de Teruel, pero 2415 le advierte que hay que circular con salvoconducto.

Llama la atención que D. Beltrán de Urdaneta, cuando recaba información acerca de 2429 lo que ocurre en los territorios en conflicto cuando se aloja e el parador de Viscarrués en Fuentes de Ebro, reflexiona que "desde que llegó a Fuentes de Ebro todo le anunciaba la entrada en el reino de lo excepcional y maravilloso. Nada era ya común y vulgar. Personas y cosas traian la impresión de un mundo trágico, el cuno de una poesia ruda y libre, emancipada de toda regla" (Perez Galdós, 1993: 2429) Mas adelante, un oficial le advierte que la guerra "ha resucitado en el pais la Edad Media, tan bien acomodada a su naturaleza bravia, a la rudeza de sus habitantes y a la muchedumbre de castillos, monasterios y santuarios que por todas partes se ven" (Perez Gád de, 1las.24 en . Un viejo pastor. Edad Media. Prepárese usted si persiste en penetrar en el país, a ver milagros, hazañas, casos inauditos de santidad o sortilegio, brujas, duendes, apariciones; subterráneos, que empiezan en un castillo y acaban on un monasterio a siete leguas de distancia; verá usted hombres feroces, hombres heroicos, mujeres endemoniadas o angelicadas: verá usted, en fin, a la hermosa y andante Marcela, con aliento guerrero y olorcillo a santidad, corriendo por montes y barrancos..." (Pérez Galdós, 1993: 2437)

Caspe

Llega desde Fuentes de Ebro a caballo a retaguardia de una columna acompañando a 2430 un carro con cuatro mujeres. Allí se encuentra con su amigo don Blas de la Codoñera Alcañiz asistiendo a su hermano.

Alcañiz

Alcanzan Alcañiz acompañados de una columna que Borso de Carminati envía desde 2430 Maella. Se aproximan a zona de conflicto. Caspe había sido saqueada por Cabrera en 1835, y por las inmediaciones de Alcañiz campean el Royo, Graus, Benabarre, Cabañero, Tena y Maestre.

Cerro de Santa

D. Beltrán dialoga con un oficial al que ha conocido en la casona en la que se aloja, 2435 Estercuel, este indica, criticando el juego del gato y el ratón en que se ha sumido la ocupar todas las posiciones y pueblos de importancia a la defensivan tapándoles los boquetes y pasadizos para sus correvíns, matíndoles de hambre y provocíndoles a que se enzarcen unos con otros, tenemos guerra para un siglo" (Pérez Galdós, 1993: 2435). El oficial le acompaña al cerro donde se presume que se encuentra la monja, a la que define como "ermitaña trashumante". No la localizan, pues parece haber partido hacia Estercuel. La monja parece conocer el emplazamiento de ollas enterradas con oro de la fortuna del liberal Jan Luco: en los montes de Gúdar, desfiladero de Vallivana, Mosqueruela, Beceite, Calanda, Peñagolosa... (Pérez Galdós, 1993: 2436)

Margen izquierda El oficial que le acompaña regresa a Alcañiz, y D. Beltrán sigue camino junto a dos 2438 del Guadalope

pastores en busca de la monja siguiendo la margen izquierda del Guadalope

Castellseras Urdaneta se encuentra con la ermitaña

\section{.}

2429


La Codoñera A la vista de la villa aparece una partida carlista a la vuelta del sendero y apresa a la 2445 comitiva. La partida se encamina a la Codonera y, antes de llegar, se les incorpora el grueso de la misma al mando de Tena. Este ordena que no lleven a los prisioneros a l a Codoñera, sino que por un atajo lleguen a Belmonte, de allí, a Valderrobles, donde se reunificarán. Cabrera quiere conocer a la monja.

\section{Belmonte}

Valderrobles

Desfiladero de

Transitan por un "camino endemoniado propio de cabras y guerrilleros"

"aldeuela" próxima La columna al mando del capitán Nelet con los cautivos se suma a una división carlista. 2448 a Albocácer D. Beltrán recibe cuidados de un capellán, Mosén Putxet. Le pone al corriente de la batalla de Torreblanca, donde Cabrera ha sido herido en el muslo y se ha retirado por la Cuevas de Vinromá para alojarse en La Jana.

¿La Plana de D. Beltrán no sabe exactamente dónde se encuentra, pues está aturdido. Ha visto a 2450 Castellón? D. Beltrán no sabe exactamentell. Se oficia una misa.
Forcadel

Olla (?) Han transitado una jornada por senderos agrestes hasta alcanzar el pueblo.

Chestalgar
(Gestalgar) $\begin{array}{ll}\text { Cerca de Buñol o de } & \text { El anciano no sabe exactamente dónde se encuentra. Ha llegado Cabrera y, con él, las } \\ \text { Siete Aguas } & \text { tropas de la Reina. Se habla de una carga gloriosa de Cabrera que abre el camino de }\end{array}$ Buñol (Victoria carlista en la batalla de Buñol)

Venta de Buñol Se procede a fusilar a veintisiete oficiales y sargentos. Cabrera toma la decisión de 2451 enviar a Alcanar a Llangostera y a la Plana al Serrador. Organiza la expedición de Forcadell a Orihuela. Cabrera con sus cautivos amaga marchar hacia Requena pero se dirige a Utiel, donde establece su cuartel general y fortifica la posición.

Encierra a un don Beltrán exhausto en un zaguán húmedo. De allí "le pasaron a una 2452 bodega, con salida a un jardincillo petiseco, cercado de tapias"

Fortificación de Se indica que "determinó Cabrera fotificar a Utiel, y lo primero que puso mano fue el Convento 2452 o Colegio de Escolapios y la iglesia parroquial, gótica, de buena y sólida. Para despejar las inmediaciones del primero de aquellos edificios, mandó demoler varias casas y cortar todos los árboles de una alameda que al camino salía. Empleáronse en tales obras, noche y día, multitud de hombres..." (Pérez Galdós, 1993. 2452). El anciano es obligado a trabajar en las obras. Cabrera sale con sus tropas a hostilizar Requena y, a su regreso, ordena que no excedan con el anciano

Cheste El ejército avanza hacia el llano de Valencia con sus cautivos. D. Beltrán es llamado por 2454 Cabrera que se aloja en la Casa del Ayuntamiento.

Chiva Pernoctan a tres leguas de Chiva. Cabrera anda a la busca de los restos de la división 2456 de Crehuet, derrotada en Buñol.

Pla del Pou Cabrera cae sobre mil doscientos cristinos de Infantería y el escuadrón de Lanceros, 2456 junto a milicianos de Valencia y Liria que descansan confiados en el paraje del Pla del

Burjassot Sin contar con fuerzas para atacar Valencia, Cabrera se aposta en Burjassot y celebra su triunfo. Pérez Galdós no atribuye a Cabrera la matanza denominada el festín de Burjassot, sino a algunos subalternos. Este se desarrolla frente a la ermita de San Roque. Se procede al fusilamiento masivo junto a las tapias del cementerio contiguo a la iglesia. Pérez Galdós describe el horror de la jornada.
Avance por la ribera

derecha del Palancia

eludiendo Segorbe

Sot de Ferrer

Alfandeguilla

(Alfondeguilla)

Nules

Se afirma la amistad entre don Beltrán y el capitán Nelet

Cabrera es recibido en Nules con "arcos del triunfo, cortinas, músicas y danzas populares". 2462 Se celebra una corrida de toros y d. Beltrán pasea por la villa "de construcción arábiga, blanca, de suelo plano y facil, les engañó con la tortuosa red de sus calles; $y$ cuando creian haber andado poco, hallaronse lejos en un arrabal separado del pueblo por anchas acequias. Metiéndose por entre dos tapias, fueron a dar frente a una iglesia de frontispicio blanqueado con excepción (Pérez Galdós, 1993: 2462).

Sitio de Burriana El regimiento de Nelet, y sus cautivos, marchan a socorrer al Serrador en el asedio 2472 de Burriana. Retirados los urbanos de Castellón que la defienden, la plaza es tomada.

Lucen

El regimiento se incorpora a la división de Llangostera y se encamina a Lucena.

Albocácer

Las tropas se encaminan a sitiar Cantavieja, pero a mitad de camino la ciudad ya ha 2472 sido tomada.

Iglesuela del Cid Desde la Iglesuela, el regimiento se encamina por orden de Cabrera a la Cenia.

La Cenia Los liberales de Oráa se dividen en tres ejércitos y Cabrera se apresta a tomar San 2472 Mateo. En La Cenia don Beltrán presencia el ajusticiamiento de los prisioneros tomados en San Mateo.

Rosell-Benifassá El regimiento es destinado a la guarnición de "Benifazá". Concretamente a la "célebre 2473 abadía cisterciense fundada por Don Jaime" por "los desfiladeros del rio de la Cénia faldeando la Peña del Águila, pasaron de la zona de Rosell a Benifazá". Sobre la abadía indica Pérez Galdós que se trataba de un "edificio devastado sucesivamente por tres guerras: la de las Germanias, la de Sucesión y la que ahora se relata. Daba pena ver su noble arquitectura mutilada por barbaras manos: aqui señales de incendios, alla desplomados muros, la iglesia con medio techo de menos, la torre melancólica y sin campanas con sus espadañas ciegas y mudas, las junturas pobladas de jaramagos y ortigas y el claustro, en fin, con solo tres costados, más triste que todo lo demás, y más poetico y ensoñador" (Pérez Galdós, 1993: 2473). En un momento determinado de la novela de Perez Galdos se habla de trabajos defensivos, tiro de fusil dominando el rí y el sendero" (Pérez Galdós, 1993:2474)

Se produce un ataque de Oráa desde Vinaroz hacia la Cenia y Rosell. Tienen que acudir 2476 las fuerzas del Serrador desde "Benifazá" y Cabrera y el Serrador se refugian en la sierra de Bel. Cuando Oraa falto de municiones debe regresar a Vinaroz, los carlistas ocupan de nuevo la Cenia y Rosell. Perez Galdós resume aquella guerra del siguiente modo: "tal era la guerra del Maestrazgo, un tomar y dejar posiciones y un perseguirse y sorprenderse, sin ventaja de los liberales, que no podian abandonar largo tiempo su base de operaciones: el juego solo aprovechaba a los carlistas, que estaban en su casa, y, desalojados de la sala, se metian

Chert $\quad$ En este ínterin se produce el éxito de Oráa de introducir un convoy de víveres a los 2476 sitiados de Morella por la altura de Catí, cuando Cabrera lo esperaba en Chert.

La Jana

Cabrera se mueve de un lado para otro y mientras Urdaneta se encuentra en La Jana percibiendo los combates en los montes "a su parecer fantásticos y aéreos, sostenidos en las

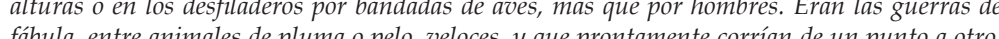
sin dejar rastro" (Ṕ́rez Galdós, 1993: 2477) 
Vallivana Don Beltrán y Nelet se encaminan al Santuario de Vallivana desde Catí. Es la ocasión 2478 que aprovecha Perez Galdós para hacer una descripción del paisaje que acompaña a este trabajo: "En el descenso de la montana, por senderos de ovejas que sorteaban las pendientes con angulos y curvas dilatadas, pudiendo apreciar el grandioso panorama que a su vista se ofrecía; belleza incomparable de que también gozó don Beltrán, pues, si no apreciaba las menudencias y tonos medios del paisaje, percibia claramente las grandes masas rocosas, que por
su coronamiento romo y achatado, en aquella formación geológica, son llamadas muelos. vertientes cubiertas de verde espesura son en algunos puntos surves; en otros caen répidamente, querenciosas de la vertical: todas de imponente majestad y hermosura. En una de las revueltas. vieron el alto de la Virgen de la Salud, cerca de San Mateo, coronado por el santuario eminente: en otra revuelta, hacia el Oeste, la Muela de Ares, cima chata en la sierra de la Higuera. Hacia el Norte distinguían el oscuro monte de Vallivana cubierto de verdor, y más allá asomaban el Castell de Cabres, la Moleta del Cid y los montes de la Cenia. Ningún ser humano encontraron en el camino. Llegado que hubieron a un ameno grupo de alisos entre peñas, se sentaron a descansar y a reponerse con un frugal almuerzo, y tumbados alli, en medio de la paz y quietud más deliciosa..." (Pérez Galdós, 1993: 2478).

Regreso a Catí

Rosell

De Rosell a Gandesa.

Paso de los puertos Pernoctan en la bajada del Monte Caro. Mientras Cabrera debe levantar el sitio de de Beceite. Gandesa ante el ataque liberal y se retira a Bot.

Bot Don Beltrán se reúne con Cabrera y allí le revela que Rapella, el joven oficial que 2497 encontró al inicio de su camino, en Viscarrués, le habia hablado de un posible Convenio

información con indignación (Pérez Galdós, 1993: 2497)

Arenys de Lledó Nelet cae del caballo y es dado de baja por Cabrera, que permite que este y Don Beltrán 2505 se marchen. Se alojan en una masía a la entrada del pueblo.

Horta Nelet y don Beltrán, acompañados de Malaena, se dirigen por atajos a Horta

Cherta Nelet se encamina y regresa de Cherta. Se ha encontrado en Cherta con la llegada de la 2513 Expedición Real, que ha pasado el Ebro.

Alcanzan una ermita en el margen derecho del río seco y se encaminan a Horta

Castillo de Horta Punto de encuentro de Nelet y Malena. Según Pérez Galdós “distante sólo del pueblo 2515 veinte minutos de marcha cómoda, y situado en un mogote de mediana elevación entre el río cuerpos son enterrados en una sepultura por D. Beltrán y los dos qepultureros. que le acompañan.

Camino de Lledó La novela acaba en el camino de Lledó desde el castillo de Horta. D. Beltrán puede ver 2517 la vanguardia de la Expedición Real avanzando hacia la frontera de Aragón. 
Soria

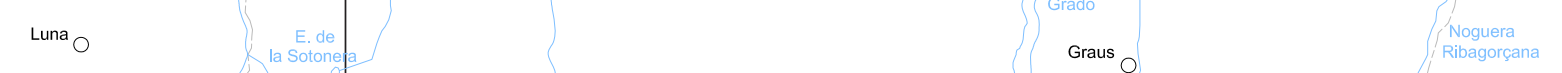


Aleca Calatayud $\quad \begin{gathered}\text { Almonacid } \\ \text { de la Sierra }\end{gathered} \quad \begin{gathered}\text { Longares } \\ \text { Cariñena }\end{gathered}$

1154 La fortificación del "Reino mágico" de Cabrera. Virginia Navalón Rio Jalón
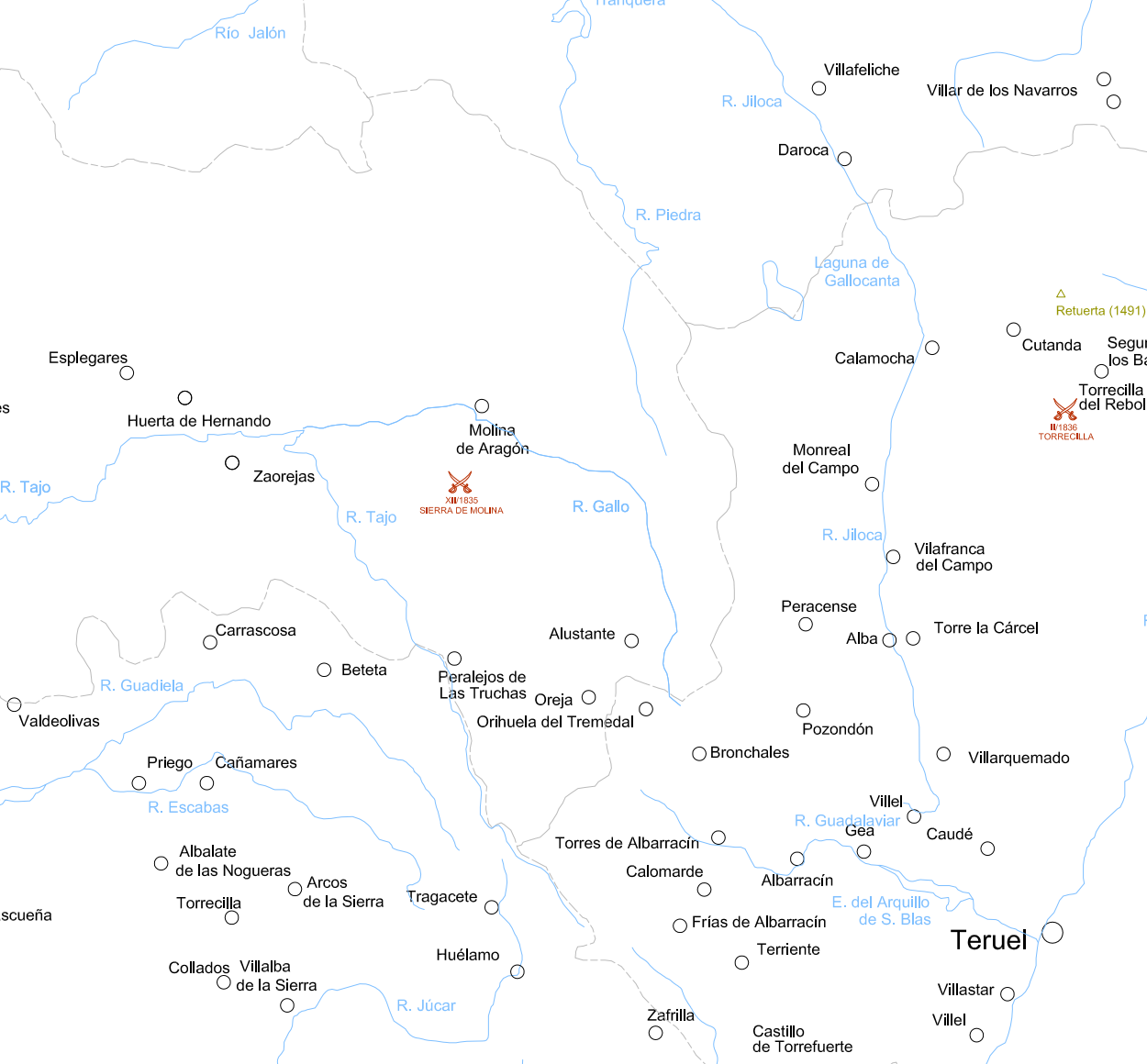

Arcos de la Cantera 0

Abia
de la obispalia
R. Jucar

Cuenca

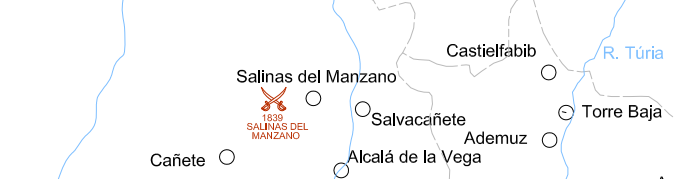

\section{ưra}

de Rubielos

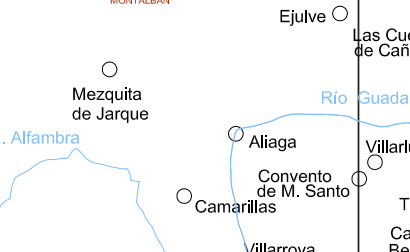

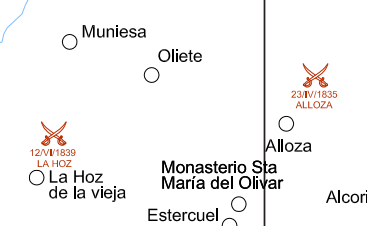

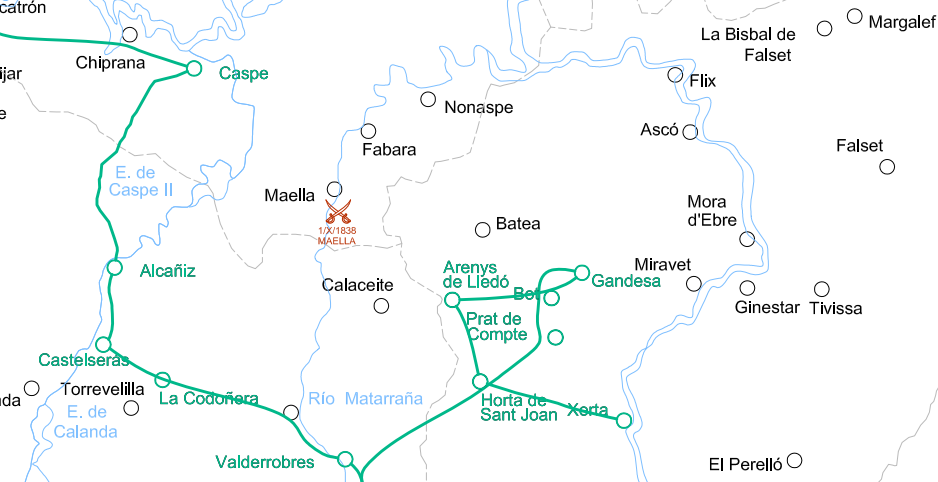

$\underbrace{\substack{\text { Fa Bisbal de } \\ \text { Margalef }}}_{P_{\text {Flix }}^{\text {Lalset }}}$

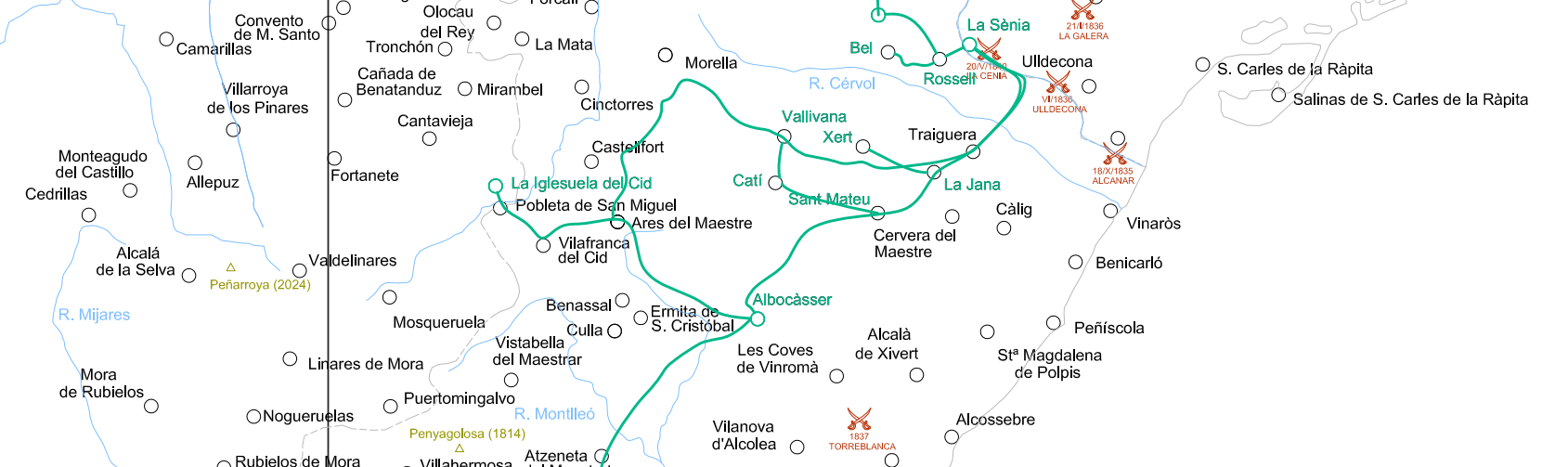

S. Cares de la Ràpta

Reus 
12.10. Informes biográficos de los protagonistas del diseño y ejecución de las fortificaciones
liberales de Requena entre 1833 y 1840

liberales de Requena entre 1833 y 1840 


\section{Carbonell [Miró], Juan Ramón de (?-18?)}

Referencias: Expediente AGMS: Carbonell Miró, Juan Ramón.-Ing., 1832* (AGMS, 1959:204); Ramón de Miró y Carbonell, J. Ing. 1814 (AGMS, 1959:180); Inspección de Ingenieros, 1987: 46-52; Muiños, 1993: 618-620, Cuerpo de Ingenieros, 1911:329-331; Carrillo de Albornoz, 2008; AMR 1818-17.

Sobre este ingeniero no se puede afirmar la correspondencia de los datos expuestos, ya que aparece en ocasiones recogido en los informes con los apellidos cambiados, es decir, D. Juan de Ramón Miró y Carbonell y en el Archivo General Militar de Segovia aparecen referencias a ambos, como integrantes del cuerpo de ingenieros, uno ingresado en 1832 (Juan Ramón Carbonell) y otro en 1814 (Ramón de Miró y Carbonell). El identificado como Juan de Ramón Miró y Carbonell es Cadete del Regimiento de Infantería "Almansa" desde 1814 a 1815, cuando ingresa en la Academia de Alcalá Regimiento
de Henares.

El 20 diciembre de 1820 se gradúa con el grado de teniente en la segunda promoción del la denominada Segunda Época (1815-1823) de la Academia de ingenieros de Alcalá de Henares (1815-1823). Así pues se le pueden atribuir las mismas influencias académicas que hemos abundado en el expediente de Ortiz de Pinedo, al que remitimos para más datos.

En el transcurso de la Primera Guerra Carlista participa en numerosas acciones. En 1835 le es encomendada la fortificación de la línea telegráfica de Madrid a Burgos.

Dirige las fortificaciones de Teruel, Cantavieja, Daroca, Chiva y Alcañiz.

En 1836 participa en el sitio y toma de Cantavieja, adquiriendo el grado de Comandante por los méritos de guerra.

En 1837, integrando el Ejército del Centro, es herido de gravedad en la acción de socorro de Caspe. Por su valor en la acción de Chiva será condecorado con la Cruz de San Fernando de Primera Clase, según Real Orden del 31 de agosto de 1838.

En 1837 repara bajo el fuego enemigo y con la complicidad de la nocturnidad el puente de Carrasco sobre el Júcar que había sido destruido parcialmente por los carlistas.

Se sabe que en el 4 de julio de 1838 ha redactado la memoria que realiza para Requena sobre nuevas obras y obras de reparación de las existentes. Las redacta como Comandante de Infantería y Capitán de Ingenieros, comisionado por el General del Ejército del Centro. Dada la intensa actividad del ingeniero se entiende que no se plantee la elaboración de un levantamiento riguroso de la fortificación, limitándose a describir las obras (AMR, 1818-17).

En 1839 se distingue en la toma del fuerte de Tales (Castellón), donde resistía Cabrera. Recibirá por ello una nueva Cruz de San Fernando de Primera Clase, según Real Orden de 10 de abril de 1841.

En 1853 será destinado a la Dirección-Subinspección de Cuba, donde pasará a la situación de retiro.

No se tiene fecha de su defunción, pero se estima pues que será de 1853 en adelante.

\section{García de Orozco, José (17?-18?)}

Referencias: Expediente AGMS: García Orozco, José.-Inf., 1810*, Exp. matrimonial (AGMS, 1959:79); García Orozco, José.-Inf., 1813. Exp. matrimonial (AGMS, 1959:79); AMR, 1818-24.

En 1810 aparece identificado un "Josef García de Orozco" como Brigadier del ejército en el Estado militar de España (Consejo Supremo de Guerra, 1810:26) pero también aparece como Comandante y Coronel efectivo del Tercer Regimiento de infantería ligera, Segundo Batallón de Voluntarios de Cataluña (Consejo Supremo de Guerra, 1810:78). 
Aparece un Coronel José García de Orozco Comandante del $2^{\circ}$ Batallón de Cataluña distinguido en la Guerra de Independencia (Canga, 1830:367).

Coronel Comandante militar de la plaza de Requena.

Teniente Coronel graduado, Segundo Comandante del Primer Batallón del Regimiento Constitución núm. 29 en el año 1849 (Secretaría de Estado y del Despacho Universal de la Guerra, 1849:75).

\section{Ortiz de Pinedo [y Villodas], Pedro (1797-18?)}

Referencias: Expediente AGMS: Ortiz Pinedo, Pedro.-Ing., 1815 (AGMS, 1815:384); Inspección de Ingenieros, 1987: 46-52; Muiños, 1993: 618-620; Cuerpo de Ingenieros, 1911:329-331; Carrillo de Albornoz, 2008; AMR, 1818-16; AMR, 1818-52; AMR, 1818-34; AMR, 1818-35.

Nació en Tortosa (Tarragona) en 1797.

En 1813 ingresa en la Academia Militar de San Fernando de Cádiz, donde supera el examen de ingreso. En aquellos momentos la Academia de ingenieros se encontraba provisionalmente en la ciudad andaluza debido a la guerra. Cuando esta se traslada a Alcalá de Henares el ingeniero prosigue los estudios en ella.

El 20 diciembre de 1819 se gradúa con el grado de teniente en la primera promoción de la denominada Segunda Epoca (1815-1823) de la Academia de ingenieros de Alcalá de Henares (1815-1823). Es preciso recalcar, dado que los dos ingenieros responsables de la fortificación de Requena forman parte de esta segunda época de la Academia que la singladura de la misma pasa por diversas fases de apertura y cierre por los avatares de la guera. Hasta que se cierre esta Segunda etapa en 1823, de apetura y ciere por los avatares de la gu qu 65 oficiles disibuidos 1823 El plan de estudios, fijado en el Reglamento Adicional del 30 de noviembre de 1816, resulta clave para entender la preparación de estos oficiales. Entre sus características citaremos:

1.-Que por primera vez se permite el ingreso a paisanos, exigiendo en las pruebas de ingreso un conocimiento de matemáticas elementales y nociones de fortificación. En el examen de ingreso debían los aspirantes trazar a partir de un polígono fijado una fortificación de acuerdo con el sistema abaluartado.

2.-La duración del plan de estudios se extendía cuatro años. De ahí que la primera promoción no se produzca hasta diciembre de 1819, de la que forma parte Ortiz de Pinedo.

3.-Durante los dos primeros años se reciben conocimientos de matemáticas puras y mixtas. En el tercer año se centran los esfuerzos en el Arte Militar. En el cuarto, en la Fortificación.

4.-Cada materia citada anteriormente se impartía en una clase diaria, que se complementaba con una cuarta materia, también de clase diaria: dibujo.

5.-Se organiza una junta de profesores para discutir y plantear las reformas que fueran necesarias.

6.-Se separó a los alumnos de ingeniería de todo lo referente al Regimiento Real

El responsable de la jefatura de estudios fue el brigadier Luis María Balanzat. Mariano Zorraquín imparte Geometría Descriptiva. Bartolomé Amat, enseñaba las ideas de Montalembert para la fortificación.

Se habla de un "espíritu de la Academia" basado en el rigor y la disciplina, recurriendo a un sistema Se habla de un "espíritu de la Academia" basado en el
docente que se apoya en clases de pizarra y repasos.

El espíritu de la academia se declaró claramente constitucionalista, abrazando la Revolución oficialmente. En confraternidad con la Universidad de Alcalá, se dice que las clases solían acabar a grito de ¡Viva la Constitución!. La propia Academia organizó patrullas y retenes por la ciudad para disuadir posibles conspiraciones absolutistas y combatió con éxito partidas como la de Bessières en Brihuega.

El avance del ejército de los Cien mil hijos de San Luis obliga al cierre de la academia y a su traslado a Granada.

Con el avance francés muchos alumnos se refugian en las Alpujarras y, desde allí, algunos oficiales se incorporan al Ejército de reserva de Andalucía de Villacampa, entre ellos Balanzat, nombrado
Jefe del Estado Mayor. Los alumnos que aún no se habían graduado tuvieron que desplazarse a Málaga para realizar los exámenes de graduación.

Con la reposición de Fernando VII en el trono, la academia es disuelta el 27 de septiembre de 1823 y sus oficiales depurados, entre ellos el Capitán general Blake, y el brigadier Balanzat.

Es fundamental en un estudio de la formación de los ingenieros durante este periodo de una investigación más exhaustiva de los artífices de la docencia y el plan de estudios durante este periodo de la Academia, como Balanzat, Blake, Zorraquín o Amat. No obstante, atendiendo a las pruebas de acceso y al plan de estudios de los cursos, se puede comprender que la formación es absoluta deudora del arte de la fortificación abaluartada, de la que los ingenieros de la fortificación de Requena son conocedores, pero también de las aportaciones críticas a este sistema, en el ámbito francés, como las efectuadas por Montalembert, dado que se imparte materia exclusiva en este sentido.

Cuando Ortiz de Pinedo se gradúe, en 1820, es destinado a la Dirección-Subinspección de Valencia, donde estará seis años hasta incorporarse al Regimiento del Arma. No vive pues los acontecimientos de disolución de la Academia ni el periodo del Trienio liberal dentro del marco académico, pero sí que lleva consigo el espíritu liberal de la academia.

Cuando estalle la Primera Guerra Carlista en 1833 operará con el cuerpo de zapadores de las columnas móviles de Castilla la Nueva, Guadalajara, Cuenca, Ciudad Real y Toledo persiguiendo a las partidas carlistas.

Obtiene precisamente la Cruz de San Fernando de Primera Clase por sus acciones en Ciudad Real y Toledo según un Real Diploma de 14 de enero de 1840.

Al final de la guerra se encuentra ostentando el grado de Mayor General de Ingenieros de la División del General Concha que opera en la zona de Cuenca.

Precisamente 111 de marzo de 1837 es destinado por el Capitán General de Valencia en comisión de servicios a la ciudad de Requena, a la que llega el 8 de abril de 1837.

Finalizada la guerra, en 1841, ostenta la graduación de jefe del $2^{\circ}$ Batallón del Regimiento del Arma. A partir de 1844 estará destinado en las Direcciones-Subinspecciones de Aragón y de Castilla la Nueva, de la que será Director interino.

No se tiene constancia de la fecha de su fallecimiento.

\section{Ruiz Albornoz, José (1780-1836)}

Referencias: Expediente AGMS: Ruiz Albornoz, Iosé.-Inf., 1796. Noble (AGMS, 1959:383); Pardo Ruiz, 1986; AMR, 4734-2.

Nace en Villar de Cañas (Cuenca) en 1780

Su expediente del Archivo General Militar de Segovia, indica que el 14 de noviembre de 1796 era subteniente del Regimiento Provincial de Cuenca, de origen noble.

Combate en la guerra de Independencia, distinguido como jefe de columna.

En 1810 se identifica un Sargento Mayor del Regimiento de Cuenca "Don Josef Ruiz Albornoz" (Consejo Supremo de Guerra, 1810:135).

El 19 de julio de 1808 participa en la batalla de Bailén, donde obtiene la Medalla de la Batalla de Bailén.

El 13 de enero de 1809 participa en la batalla de Ucles, obteniendo la cruz del mérito militar.

El 11 de agosto de 1809 participa en la batalla de Almonacid, obteniendo la cruz del mérito militar. El 19 de noviembre de 1809 participa en la batalla de Ocaña.

Participa en la batalla de Cazalla, donde es apresado y conducido a Francia en 1812, donde permanecería hasta que se alcance la paz.

El 6 de enero de 1816 obtiene la Cruz de Primera Clase de San Fernando.

El 9 de marzo de 1817 es nombrado Caballero de San Hermenegildo.

El 30 de diciembre de 1819 consta que hacía uso de las cruces obtenidas en las batallas de Aranjuez y Almonacid.

Durante el trienio liberal se posiciona del lado liberal y combate a las facciones realistas y al ejército francés de los Cien Mil hijos de San Luis en 1823. Se distingue como jefe de columna combatiendo 
a los cabecillas "El Ocho" y "Besieres". Su identificación pro-liberal le relega del ejército, pasando en el año 1824 a la situación de excedencia.

Vive en Villar de Cañas hasta el fallecimiento de Fernando VII en 1833.

En 1834 se reintegra en el ejército.

Asciende al grado de coronel de infantería el 8 de septiembre de 1834, por sus 5 campañas y 25 acciones de guerra.

Su nueva andadura en el ejército se inicia de manera exitosa al sorprender a la facción carlista del Conde de Retamoso que se organizaba en el monte de Santa María.

En 1835 se pone a sus órdenes la columna de voluntarios de Záncara.

Al poco tiempo se hace cargo de la Comandancia militar del cantón de Requena donde dirige la resistencia a los ataques carlistas de 1835 y 1836. Es el responsable de organizar a las milicias ciudadanas y de exaltar el espíritu a favor de la causa liberal.

Gracias a su defensa, la villa de Requena obtiene el título de Ciudad por parte de Isabel II en 1836. Madrid la homenajea nombrando así a una calle de la ciudad frente al Palacio Real.

El 25 de novios El 25 de novions de Requena, a los cincuenta y seis años de edad, ostentando el grado de Teniente Coronel de Infantería en excedencia

\section{Sáez, Guillermo (1792-18?)}

Referencias: AASC, 61-c/41-1; AMR, 1818-53; AMR, 1818-50; AMR, 1818-53.

Nace en Requena en 1792.

Maestro de obras graduado por la Academia de Bellas Artes de San Carlos en 1831 a la edad de 39 años.

Cuando accede al examen de la Academia es agrimensor por la misma Academia y práctico en el ejercicio de la Albañilería "que la ha ejercido desde la niñez bajo la dirección de su padre" (AASC, 61c/41-1).

Es responsable de la ejecución de las principales obras de fortificación de Requena entre los años 1834 y 1836. En este último año se sabe que integra una comisión el 26 de febrero de 1836 para analizar el estado de la fortificación, lo que hay realizado y lo que queda por concluir. 
Abaluartada, Se denomina asía a un modo de fortificar que caracterizó los siglos XVI, XVII y XVIII y basaba su fortificación estructura en la presencia del baluarte. Está supeditada a los alcances fusileros y queda obsoleta cuando se incrementan los alcances y el potencial de las armas de fuego.

Abasto Provision de bastimentos y especialmente viven. Tenda pequeña de comestibles.

Abrojos Hierro de cuatro puntas dejado caer en tierra para bloquear avenidas de caballería y de formaciones de infanterí

Abromar Pudrición de la madera en agua marina por presencia del molusco acéfalo denominado broma Acceso en Aquel acceso que se plantea obligando a todo aquel que desea acceder al recinto a discurrir por corredor un corredor que lo somete al ataque desde las alturas o los laterales.

Adarve Plano horizontal superior de una muralla

Afueras Parte exterior sin defensa de un castillo, bajo los efectos de las armas defensivas.

Afuste Paralelepípedo de madera que sirve de base a morteros y pedreros para amortiguar su retroceso. Aguja Flechas, brazos o pescantes de los que cuelga un puente levadizo.

Ala "Un ala ó alas en término de fortificación se llaman comunmente a los lados prolongados, que terminan á derecha é izquierda un hornaveque ú obra coronada: estos dos lados prolongados son defendidos ó diferentes modos, sea del cuerpo de la plaza, si no están fuera del tiro de mosquete, desde al gunos flancos practicados en el extremo de la misma obra, desde el camino cubierto, ó bien desde algunas traversas hechas en su mismo foso. Estas obras hacen el ataque más peligroso por sus costados que por el frente; de suerte, que es necesario adelantarse por trinchera, y servirse de tropas escogidas para poderlas forzar..." (Sanz, 1794:2.).

Alambor Escarpa o rebotadero.

Alberca Depósito artificial de agua ejecutado con muros de fábrica.

Alcabala Impuesto en el Antiguo régimen en la Corona de Castilla que grava el volumen de ventas. Ib destinado a la hacienda real a diferencia del diezmo, cuyo perceptor principal era la islesia con participación del Rey.

Alcance Distancia máxima a la que puede arrojarse un proyectil. Solía considerarse como medida de alcance la distancia adecuada para garantizar el blanco.

Alhóndiga Lugar donde se almacenaba y comerciaba con el grano

Alidada Regla en cuyos extremos se emplazan otras reglas menores denominadas pínulas, de latón, que tienen un agujero en el centro para pasar una cerda que ayuda a prolongar las visuales en y pínula.

Aljibe Construcción excavada en el terreno para el depósito de agua

Almagre O almagra. Antiguo pigmento utilizado para la decoración cromática. También denominado almánguena, almazarrón, ocre rojo o de Prusia, hematites roja... La base del color es la hematita (óxido de hierro deshidratado) que se halla de forma natural en la tierra. Mezclado con arcilla o marga fue empleado para proteger cureñas o portones (Zapatero, 1988: 29).

Almotazán Oficina donde se efectuaba la operación de contrastar las pesas y medidas

Alojamiento "Alojamiento de un hombre de guerra, es el lugar que ocupa, sea casa de un paisano o en quartel..

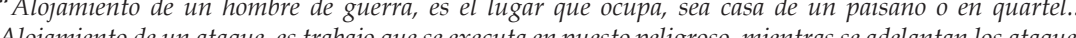
Alojamiento de un ataque, es trabajo que se executa en puesto peligroso, mientras se adelantan los ataques librarse del fuego del enemigo, sea con montones de tierra, sacos de tierra, traversas, cestones llenos, palizadas, sacos llenos de lana, faginas, manteletes, y generalmente con todo aquello que puede asegurar y cubrir al soldado en un terreno que se quiera conservar después de haberlo ganado. Ordinariamente se acostumbra a enarbolar las banderas en el alojamiento, así como está en defensa. Hácese un alojamiento en el camino cubierto con cestones llenos de tierra, y maderos sobre ellos, con lo que se forma una galería" (Sanz, 1794: 20).

Andanada Descarga cerrada de una batería

Angulo de la Angulo que forma la cara y el flanco consecutivo de un baluarte.

espalda

Ángulo de la Ángulo del polígono. 
Ángulo de la Ângulo entre dos fijantes de un mismo frente.

tenaz

Ángulo del centro Ángulo entre dos radios mayores o menores consecutivos del polígono de la fortificación

Ángulo del fuego Ángulo entre la fijante y su flanco.

Angulo del Angulo entre los lados del polígono exterior o interior de una fortificación.

polígono

Ángulo entrante Ángulo de una fortificación que mira hacia el interior de la plaza.

Ángulo Ángulo entre dos caras de un mismo baluarte. Se recomendaba que no fuera excesivamente

flanqueado agudo. Pero tampoco podía exponer demasiado las caras al fuego enemigo, por lo que se tendio a recurrir a un ángulo de $90^{\circ}$ a finales del XVII.

Ángulo Ángulo que forma la cortina con el flanco de un baluarte.

flanqueante

Angulo muerto Aquel ángulo que no puede ser percibido desde otros puntos del recinto fortificado.

Ángulo saliente Aquel ángulo que se asoma a la campaña

Ánima Interior hueco de un cañón desde la boca hasta el fogón (Lucuze, 1772:154)

Ante camino Camino cubierto que discurre por delante del camino cubierto. Suele discurrir por delante de cubierto glacis y se apoya en un antefoso.

Antefoso Contrafoso. Foso que solía ejecutarse al final de la explanada, como una medida defensiva complementaría al trazado tradicional.

Antepuerta Puerta que se antepone a la puerta de una fortificación para defenderla

Antestadura Trinchera, parapeto de emergencia con materiales provisionales para defender un punto en riesgo.

Aproches Trabajos que se efectúan en el asedio de una ciudad para apoderarse de ella. Arbellón Albañal, albollón. Desaguadero de estanques, corrales, patios

Arista Líneas en las que se cortan los diferentes planos de una explanada y acometen al punto intermedio de los ángulos entrantes y salientes (Lucuze, 1772:38).

Aspillera Orificio practicado en un muro para facilitar la defensa a distancia. Suelen ejecutarse en forma de ranura vertical larga y estrecha, aunque existen múltiples formatos.

Ataque Además de las definiciones habituales, un ataque es el conjunto de trabajos de trinchera que se hacen avanzando hacia una plaza para tomarla

Ataque doble Ataque de trincheras que tiene por objeto dos frentes de una plaza.

Atenazado El sistema atenazado es un sistema fortificatorio basado en el elemento de tenaza, concebida El sistema atenazado es un sistema fortificatorio basado en el elen
como líneas entrantes y salientes. Sustituyó al sistema abaluartado.

Avancarga Forma de denominar a aquel armamento de fuego que se carga por su boca

Avat-corps Cuerpo avanzado tanto de ejército como de fortificación.

Bajada O bajada al foso. Es una zapa que permite a los sitiadores descender al foso a cubierto

Bala enramada Proyectil esférico partido en dos, pero que une ambos fragmentos con una cadena. Permite desarbolar navíos o barrer cuerpos de ejército.

Bala hueca o vacía Bomba. Proyectil esférico que se rellenaba de pólvora para que pudiera ser detonada por mecha al alcanzar su objetivo.

Bala roja Proyectil calentado al rojo vivo

Baluarte Podría entenderse como baluarte a todo elemento saliente de una fortificación que pretende garantizar una defensa de flanco. El baluarte fue definiendo su morfología desde la antigüedad en función de su adaptacion al armamento y a los diferentes planteamientos teóricos. Constituyo un elemento clave en el mundo de la fortificación abaluartada, a la que dio nombre

Banqueta Grada que permite elevarse sobre el parapeto

Barbeta Batería que no consta de merlones. Permite así mover los cañones con libertad.

Barreno Receptáculo efectuado en la roca destinado a la carga de pólvora.

Barrer "Barrer, limpia o enfilar, es tirar sobre todo lo largo de una línea recta..." (Sanz, 1794: 49).

Báscula Maquinaria para levantar el puente levadizo

Bastión Baluarte

Batán Mecanismo para transformar los tejidos en otros más tupidos. Recurría a la fuerza hidráulica activando unos mazos que golpeaban el tejido hasta su compactació

Batería Cosntrucción destinada a albergar cañones. Solía estar integrada por cañoneras, merlones y explanadas para los cañones (Lucuze, 1772:11)
Batería baja Elemento arquitectónico, por lo general en forma de explanada, destinado a alojar artilleríá. Su disposición rasante, normalmente a los niveles superiores del foso o del mar, pretendí propiciar el tiro rasante, más efectivo en los primeros siglos de evolución artillera (XVI, XVI de pa............................ a barbet.

Berma Saliente horizontal en la escarpa de una fortificación destinado a retener los desprendimientos para evitar que cieguen el foso

Blinda Protección provisional con la que un atacante se oculta de la enfilada desde la plaza. Se realiza una estructura con dos maderos longitudinales separados, que se unen por otros dos cubre supiom

Blocao Casamata defensiva de hormigón o "búnker"

Bonete de clérigo Tenaza doble a cola de golondrina.

Bóveda a prueba Bóveda construida para evitar el impacto de trayectoria vertical de los proyectiles artilleros.

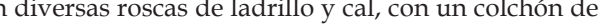
destinado a absorber el impacto.

Bóveda embutida Aquella que se habilitaba en el interior de los terraplenes, generalmente en las cortinas.

Brisura Cuando se diseña un flanco retirado, la línea defensiva que cubre dicho flanco retirado en la prolongación de la cortina y del orejón, rodeando el flanco retirado y cubriéndolo, se denomina brisura.

Brocal Elemento arquitectónico que constituía la protección a la caída en el perímetro de un pozo.

Buarda Balcón en saledizo sobre la muralla para la defensa vertical. Es más rudimentario que el matacán en la medida que constituye una especie de andamio volado.

Buera Orificio en el adarve de una muralla. Especie de matacán interior que servía bien para arroja proyectiles al espacio interior de la fortificacion, bien para conducir estos con la ayuda de un conducto hacia el exterior, proyectándolos horizontalmente en la base gracias a la curvatura de dicho conducto.

Caballero Es una posición elevada sobre el terraplén de una fortificación para dominarlo desde la altura. Se construyen caballeros provisionales también en las labores de sitio para dominar las posiciones defensivas.

Caballo de frisa Obstáculo provisional consistente en un madero grueso y largo agujereado en cruz para disponer en los orificios palos tere en un mas en pursa. Esta y largo agujeredo de cruz para ir el ataque de la caballería.

Cabrestante Torno de eje vertical para izar el rastrillo.

Cabria Estructura para montar o desmontar las piezas de artillería sobre los afustes

Cahices Medida de capacidad para grano, legumbres y alimentos sólidos que equivalía en Castilla a 666 litros.

Calibre Diámetro del ánima de un arma de fuego.

Camino cubierto Todo corredor defensivo resguardado de los proyectiles procedentes de la campaña normalmente mediante un parapeto. En la fortificación abaluartada sirvió para denominar a un camino concreto que discurría por el límite externo del foso más exterior, convertido en primera línea de defensa.

Camino de ronda Corredor de la fortificación por donde se realizan las rondas de vigilancia. Podía estar cubierto por un parapeto o no.

Camino real Vía suburbana principal de acceso a la ciudad

Camisa Revestimiento destinado a contener un talud de tierra en la fortificación.

Campaña Término que hace referencia a un conjunto de operaciones militares ya sean territoriales o estacionales. Servía también para dominar el terreno exterior próximo a la fortificación. S denomina así a toda obra de fortificación de carácter provisional.

Campo volante Cuerpo de ejército en movimiento destinado a labores de ataque o defensa

Campos Conjunto de obras de defensa auxiliares, de campaña o provisionales, destinadas a contornear

atrincherados una plaza para alejar a la fortificación principal del alcance de la artillería de sitio. Preconizado por Claussewitz como "línea de segunda acción".

Canal del foso Cuneta o foseto.

Candelero "es un texido de faginas o de salchichones, arreglados sobre pedazos de madera para servir de parapeto espaldón, y cubrir los trabajos. Para hacer un candelero se ponen dos bigas que estén paralelas, á distancia de seis a siete pies; y que tenga cada uno dos piezas de madera elevadas en ángulos rectos, para sostener en sus intervalos lineas de faginas" (Sanz, 1794:81). 
Cañonera Abertura ejecutada en un parapeto para facilitar el disparo del cañón

Capital Línea que une el ángulo flanqueado de un baluarte con el punto de encuentro de sus semigolas (o centro de la gola). En un polígono regular converge en el centro del polígono

Rendición de una plaza atendiendo respondiendo a unas condiciones pactadas entre el sitiado y el sitiado.

Caponera Galería acasamatada. Avanza desde la cortina por el foso para batir el mismo.

Caponera doble Conexión entre una plaza y las obras exteriores, cuyos laterales están parapetados y permiten una defensa de flanco.

Cara Se llama así a los lados más exteriores de un baluarte. Las caras convergen en el ángulo flanqueado.

Caracol Forma de denominar a las escaleras de caracol

Casamata Estructura fortificatoria cubierta para resguardar a los ocupantes de los fuegos verticales.

Celemín Medida agraria utilizada en algunas partes de España (Requena) antes del Sistema métrico decimal. Utilizada para cereales y semillas. Un celchn equivaldría a poco más de 4,6 decimetros cubicos (litros). Doce celelomines hacen media fanega o cuarto; cinco, una hemina en tres, una cuartilla. Se solía usar para medir la superficie de terrenos agrarios (correspondiendo a unos 537 metros cuadrados), siendo el terreno correspondiente a la siembra de un celemín de trigo.

Cestillos de Cestos que se utilizan para recoger la tierra excavada en la ejecución de la trinchera y se disponen sobres.
zapadores.

Chapuzar Zabullir

Cigoñal Viga del puente para levantar el tablero.

Cinta Cordón.

Circunvalación Obras de asedio para aislar a una fortificación.

Cisterna Aljibe. Depósito de agua. Suelen disponerse preferentemente en los patios de armas y se alimentan del agua de lluvia.

Cisterna Aljibe.

Ciudadela Fortificación autosuficiente emplazada en el interior de una plaza como último reducto. En ocasiones se convierte en punto de control militar ante los desmanes de la propia ciudadanía.

Cofa Pequeña plataforma horizontal que se emplazaba en el extremo de los mástiles.

Cofrar Acción de encofrar

Cofre Alojamiento subterráneo defensivo que se construía en los fosos secos próximo a los flancos de los baluartes.

golondrina Hornabeque constituido por tenazas. Conocido también por "Bonete de Clérigo".

Colisa Plataforma giratoria utilizada en la fortificación en la que se emplaza la cureña sin ruedas de los cañones de artillería para facilitar su maniobra.

Complemento de Tramo de cortina correspondiente a su prolongación desde el flanco por la semigola la cortina correspondiente hasta su extremo.

Contra-aproche Trabajos de trincheras efectuados por el ejército sitiado para anular los avances del sitiador.

Contrabatería Batería dispuesta en oposición a una batería atacante para desmontarla.

Contraescarpa Muro exterior del talud del foso

Contraguardia Fortificación auxiliar que cubre las caras de un baluarte, revellín.

Contramina Galería defensiva destinada a neutralizar los avances subterráneos de los sitiadore

Contramuralla Muralla frente a otra muralla.

Contrataque Contra-aproche.

Contravalación Obras de fortificación de campaña ejecutadas por el sitiador para resguardarse de un ataque por su retaguardia.

Cordón Moldura que remataba los terraplenes de la fortificación abaluartada. Sobre él se disponían los parapetos. La línea que definía el cordón se correspondía con la magistral, línea geométrica de referencia para el proyecto de los ingenieros militares, especialmente en el siglo XVIII. En el referencia para el proyecto de los ingenieros militares, especialmente en el siglo
siglo XIX, la precisión geométrica y el empleo de este tipo de elementos se diluye.

Corona Obra auxiliar exterior poco frecuente dada su magnitud, consistente en un frente constituido por dos semibaluartes.

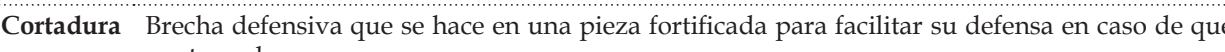
sea tomada.

Cortina Es el espacio de muralla comprendido entre dos baluartes o elementos salientes.

Criadillas Patatas.

Cuartel de Parque de víveres

vivanderos

Cuartel defensivo Tipología fortificatoria propia del siglo XIX destinada al alojamiento de tropas y la defensa. Surgen en paralelo al desarrollo de la estrategia de cuerpos volantes.

Cubo Torreón adosado a una muralla. Su forma no es determinante. Pueden ser tanto torreones de traza circular, cuadrangular u otras.

Cuchillo Dama

Cuernos, Hornabeque

fortificación de

Cuerpo de guardia Conjunto de tropas de una guarnición que queda operativa descontando los efectivos destinados a labores de guardia partida, patrulla Se denominó así a la edificación que alojaba a estas tropas que vigilaban un punto importante, por ejemplo en la entrada de las plazas. Disponían de diversos espacios, principalmente alojamiento de tropa, para el oficial de guardia y para las armas y municiones.

Cuneta Pequeño foso con agua en el interior de un foso seco.

Cureña Soporte de la pieza de artillería para poder dirigir el disparo y facilitar el movimiento del cañón.

Dama Cuchillo. Una galería semejante al cofre que se efectúa en los fosos con agua. Su objetivo es retener el agua del foso si el sitiador intenta sangrarla. Suele disponer de fusileras para la
defensa del foso (Lucuze, $1772: 80$ )

Declivio Pendiente de una muralla

Deflagración Combustión instantánea sin explosión, con llama a baja velocidad de propagación. A diferencia de una detonación, el frente de la onda avanza por difusión térmica.

Derrame Plano inclinado que define los laterales de un hueco en una muralla, destinado a la defensa pretende favorecer el campo visual del defensor y disminuir su exposición al enemigo.

Detonación Combustión instantánea que implica una onda expansiva que avanza por difusión sónica.

Dientes de sierra Entrantes y salientes que se forman en el camino cubierto.

Doble fuego Área sobre la cortina comprendida entre la línea de defensa fijante y la línea de defensa rasante. Permitía que los defensores allí apostados pudieran cubrir la cara y el flanco del semibaluarte correspondiente, es decir, un doble fuego.

Durmiente Maderos que se emplazan en las baterías. Apoyan sus cabezas en un madero transversal batiente. Forman la pendiente de la explanada artillera. Sus intersticios se rellenan de tier apisonada y sobre ellos se clavetean los tablones que configuran la explanada.

Duro Peso fuerte o peso duro, equivalente a 20 reales de vellón (aleación de cobre y plata)

Embrasura $\mathrm{O}$ cañonera. Es la abertura que se hace en un parapeto para que pase el tiro del cañón.

Empalizada Defensa exterior constituida por hileras de estacas, aseguradas con listones horizontales.

Escaraguaita Garita en un ángulo saliente

Escarpa Muro interior del talud del foso.

Espalda Parte posterior de toda construcción orientada. Por lo general se desguarnecía para garantizar la defensa por detrás en caso de ser ocupada la construcción. Se denominó así también a los la defensa por detras en caso de los flancos de los baluartes.
orejes

Espaldón Consiste en un medio baluarte compuesto de una cara y un flanco que pretende cubrir de costado una fortificación. Podrín en terminología militar del siglo XIX hacerse refere cualquier tipo de construcción que protege a los defensores de un fuego de enfilada o de revés.

Espaldón Torneante

Espinos "Los espinos o rejas son tablones, ò enrejados de madera, llenos de clavos puntiagudos, que se echan delante de las barreras, en las avenidas de caballeria, y en las brechas que ha de montar la infanteria, par herirla, desordenarla, o detenerla" (Lucuze, 1772:84).

Estacada Empalizad

Estereometría Cálculo del volumen y magnitud de las cortinas y baluartes de una fortaleza. 
Estrategia En los siglos XVI, XVII y XVIII se entendió por estrate..................................................................... es decir, la organización de los ejércitos en el campo de batalla. Con el desarrollo de la guerra dinámica la estrategia hace referencia también a otros factores como la definición de objetivos, alianzas y pactos, el estudio del enemigo y de las posibilidades propias, definiendo limitaciones,

Estribo Contrafuerte interior de las escarpas y contraescarpas, que se embebía en la tierra que integra....... as fortificaciones abaluartadas.

Explanada Pavimento de piedra o madera para disponer la artillería y evitar que esta se entierre por efecto del retroceso.

Fajina Haz de ramas utilizado para la construcción en tierra. Daba consistencia a los taludes y dificultaba la excavación de los zapadores

Falsa braga Antemuro bajo levantado entre una muralla y el foso.

Fijante Línea de defensa fijante.

Flanco Lados de un baluarte que intersectan con la cortina y permiten la defensa lateral de los lienzos amurallados. También puede hacer referencia a todo lienzo amurallado que cumple una misión flanqueante.

Flanco segundo Doble fuego.

Flecha Construcción exterior constituida por dos caras a 60 o $100^{\circ}$.

Fortín Pequeña fortificación que define un espacio compacto y funciona autónomamente o adherida a una fortificación mayor. Se emplazaron fortines para dominar puntos estratégicos.

Foso Excavación de componente longitudinal que circunda por completo o parcialmente una fortificación. Puede estar seco o con agua.

Frente Es aquella parte de fortificación comprendida entre dos ángulos salientes. También se hace referencia a aquella parte expuesta en la dirección del ataque del sitiador. En el mundo de la fortificación abaluartada el frente abaluartado era un sistema concreto integrado por medio baluarte, la cortina y el medio baluarte del extremo opuesto.

Fuego de la Doble fuego

Fuerte Construcción militar destinada a ocupar y controlar un enclave estratégico. Se denominó así 政 asociarse a estructuras de traza cuadrangular con un baluarte en cada esquina.

Garganta Parte estrecha de una cañonera o aspillera

Garita Pequeñas obras con capacidad para uno o dos ocupantes que se emplazan preferiblemente en ángulos salientes de la fortificación sobre el cordón. Se encuentran infinidad de trazados (pentagonal, circular, cuadrada...). Disponían de aspilleras que facilitaban la vigilancia del foso y la base de las escarpas. Se destinaban a cualquier espacio que requiriese cierta vigilancia. En ocasiones, por su carácter saliente sobre el foso, también se emplazan en ellas retretes que vierten las inmundicias al foso.

Gavión Cestón de mimbre utilizado en la construcción de fortificación de campaña

Glacis Superficie que se extendía circundando a la fortificación desde el camino cubierto hacia las afueras. Tenía una ligera pendiente hacia el exterior y obligaba al enemigo a avanzar a descubierto a contrapendiente antes de acceder a la primera línea defensiva.

Gola Punto de acceso al baluarte desde el interior de la plaza.

Golpe de mano Acción que juega con el factor sorpresa para tomar una plaza sin acometer un asedio en toda regla.

Graduación En tiempos de Carlos III la graduación militar jerarquizaba los siguientes escalafones de mayor a menor rango: Capitán General, Teniente General, Mariscal de Campo, Brigadier, Coronel Espaldón.

Herradura de Tipología de fortificación marítima polar. Caracterizada por un trazado curvo en el frente

caballo maŕtino y un frente abaluartado o atenzzado en el frente de tierra. También se denominaren fortificaciones de 'panza y cola'. fortificaciones de 'panza y cola'.

Hombro Ángulo de la espalda de un baluarte.

Hondidura Distancia que se retira un flanco desde su posición para generar un flanco retirado con orejón.

Horma Pared de piedra seca

Hornabeque Estructura defensiva autónoma pero direccional, integrada por un frente abaluartado Normalmente se calificaba como obra exterior y se destinaba a defender puntos estratégicos: paso de un río, una colina.
Hornabeque Corona.

Hornillo Hueco en el que se introduce una carga de pólvora para detonar una mina

Ichnographia Representación en planta.

Irregular, Toda fortificación constituida por lienzos de longitud desigual y cuyo trazado en planta se fortificación corresponde con lo que denominaríamos un polígono irregular.

Jineta Unidad basica en la que se descompone una compañía de caballería y dragones. Una compañía solía estar constituida por tres o cuatro jinetas.

Juego de armas Accesorios de una batería de artillería: espeques, escobillón, atacador, etc.

Juego de la pelota Conocido juego tradicional que se practica desde la antigüedad. Muy popular en la Corona de Aragón, generó diferentes modalidades. En el Reino de Valencia destacó la particular tradición del trinquete. Como juego de pelota se hace referencia a los espacios dedicados a este juego que en el caso valenciano cuenta con diferentes tipologías. Bien en la misma calle o en espacios concretos como el trinquete, Frontón y la Galotxeta (Monóvar)

Lado exterior Lado del polígono exterior de la fortificación.

Lado interior Lado del polígono interior de la fortificación.

Ladronera Matacán.

Lambor Escarpa. Alambor.

Lavado Técnica gráfica utilizada en la cartografía. Por lo general solía recurrir a unos estándares de color, al menos en el siglo XVIII. Mass adelante este criterio grafico se diliuye. Así se utilizaba verde vejiga para la vegetación; aguamar para ríos, bahí y mar, zumo regalicia para maderas; y añil para hierros (Zapatero, 1988:32).

Lengua de sierpe Pequeña obra exterior conectada con la fortificación con traza de triángulo equilátero.

Libra castellana Unidad de peso. La libra castellana equivalía a 16 onzas, es decir 460,0093 gramos

Línea de defensa Si no se matiza nada más se hace referencia a la Fijante. Línea de defensa fijante.

Línea de defensa Línea que une el vértice saliente del baluarte y el ángulo flanqueante opuesto (unión entre

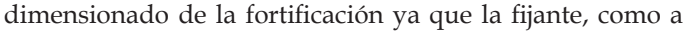
se denominaba por "fijar el fuego", recogía el máximo alcance de las armas de mano en e momento del diseño.

Línea de defensa Es la línea que surge de prolongar la cara del baluarte sobre la cortina correspondiente. Se

rasante denomina así porque desde ese punto de la cortina hasta el flanco opuesto se podía contribuir línea fijante y resante solín coincidir. Si no sucedía así y el ángulo saliente del balmente demasiado agudo aparecía esta línea denominada rasante que favorecía la defensa al genera el citado perímetro de la cortina denominado "doble fuego".

Línea de redientes Trinchera constituida por entrantes y salientes

Línea magistral Magistral

Líneas principales Aquellas líneas clave para la definición geométrica de una fortificación, a las que, según el momento y en función de los alcances, correspondía una dimensión u otra: línea de defensa, cara, flanco, cortina.

Lisera Berma

Llave Fortificación clave en la defensa de un estado

Logística A mediados del siglo XIX se distingue entre estrategia, táctica y la logística. Considerado e arte de mover los ejércitos, y sus complementos. Estudia las marchas y formaciones, modos de establecer los campanm

Luna Fortificación que resguarda un baluarte sin cubrir completamente su cara. Bonete.

Luneta Obra exterior que complementa a la luna o bonete. Solia cubrir la parte posterior de la cara de un revellin no cubierta por una luna o bonete. Extendia pues su protección, por una parte al lateral del revelllín, y por otra a la cara del baluarte correspondiente que flanqueaba dicho revellín.

Macho Máxima dominación de una plaza fortificada.

Magistral Línea definida por el remate de la escarpa: cordón.

Matacán Elemento arquitectónico que, en disposición saliente en la coronación de una fortificación permitía la defensa vertical recurriendo a la gravedad.

Media gola Línea que sobre la proyección de la cortina une el encuentro de esta con el flanco, con el encuentro de la cortina con la línea capital. 
Media luna Especie de revellíín sin flancos...... Es decir, constituido por dos caras en forma de flecha. Su espalda originariamente tenía forma de media luna.

Merlón Parapeto comprendido entre dos cañoneras.

Mina Galería construida para misiones atacantes o defensivas. Generalmente a estas últimas se las denominó contraminas.

Molinillo Dos maderos unidos en aspa y que dispuestos horizontalmente sobre un puntal, permiten regular el paso de las personas de uno a través de un acceso e impedir el paso de caballerías.

Mortero Cañón de tiro parabólico utilizado para el bombardeo de plazas en el siglo XVIII. Suelen medir 12 pulgadas de calibre y los proyectiles suelen ser bombas explosivas.

Mosquete Arma portátil de fuego antecesora del fusil, propia de los siglos XVI, XVII y principios del
XVIII. Arma de avancarga, con bala esférica. Más larga y de mayor calibre que su sucesor, el usil, fue reduciendo su peso, su longitud y aumentando su alcance de $210 \mathrm{~m}$ a $4000 \mathrm{~m}$. En sus (1, $7,6 \mathrm{~kg}$, requería de una horquilla para apoyar 作 disparo de mecha, pasando por el de chispa de pedernal, el sistema de rueda hasta alcanzar el de percutores con cartuchos. En el sistema más rudimentario, se requerían casi veinte operaciones para cargar el mosquete y se conseguía una cadencia de uno, máximo dos, disparos por minuto

Nicho Espacio excavado en el trasdós de un muro para cobijo de los defensores. Suelen realizarse en as contraescarpas

Nido Posición armada fortificada.

Nido de urraca Trinchera circular estrecha que remata el extremo de un aproche para evitar la enfilada.

Obra accesoria Forma de denominar a finales del siglo XVIII a la construcciones menores de una fortificación garitas, cuerpos de guardia, puertas, puentes, rastrillos, caponeras o comunicaciones, cuarteles, almacenes, cisternas, hospital, arsenal, iglesia u otros edificios menores (Lucuze, 1772:125).

Obra accidental Forma de denominar a finales del siglo XVIII a las construcciones ejecutadas por una necesidad defensiva puntual que exige la situación táctica o las condiciones del emplazamiento: caballeros, plazas altas y bajas, coronas, hornabeques, tenazas, bonetes, baluartes, reductos, guardarrenes y espaldones (Lucuze, 1772:24)

Obra avanzada Toda construcción ejecutada más allá del camino cubierto.

Obra conveniente Forma de denominar a finales del siglo XVIII a aquellas obras que mejoraban las condiciones defensivas del trazado básico: flancos retirados, orejones y espaldas, tenazones, revellines, contraguardias, plazas de armas atrincheradas, lunetas, flechas, lenguas de sierpe y contraminas (Lucuze, 1772:24)

Obrador Arsenal. Atarazana.

Obras esenciales Forma de denominar a finales del siglo XVIII a aquellas obras que integraban el trazado básico de una fortificación: muralla, foso, camino Cubierto y explanada (Lucuze, 1772:24)

Obsidional Cualquier línea defensiva construida por un asaltante: circunvalación, contravalación.

Orejón Cuerpo que se originaba en la unión de cara y flanco de un baluarte cuando el flanco se retiraba El vértice solía redondearse, de ahí su denominación ya que el baluarte parecía tener orejas.

Órgano Sistema de cierre constituido por estacas verticales que se trasdosaba a las puertas. Las estacas pendían de un torno elevado y se dejaban caer ante un ataque, actuando de obstáculo para sostener la defensa hasta la llegada de la guarnición. Presentaba la ventaja que su caída no podía ser obstruida por un obstáculo, ya que si una estaca se bloqueaba, el resto caía autónomamente.

Ortographia Representación gráfica en sección vertical

Padrastro Dominación o elevación próxima a la plaza que puede poner en un aprieto a su defensores.

Palenque Fortín de estacas y tierra.

Panera Antigua edificación rural sobre pilares para almacenar el cereal. Parecida al hórreo pero con mas de cuatro pilares (pegollo). La distinción fundamental entre ambas construcciones no es pendiente en un punto central. Las paneras tienen tejado con caballete. $\begin{array}{ll}\text { Pantómetra } & \begin{array}{l}\text { Tablas utilizadas por los ingenieros militares para fijar las proporciones fortificaciones de } \\ \text { diversas dimensiones estándar y evitar aś los trazados reguladores. }\end{array}\end{array}$

Paño Tramo de muralla entre torres o contrafuertes.

Paralela Trinchera de asedio que se ejecutaba paralela al límite de la plaza. Su misión era interconectar las zapas en zigzag o ataques que avanzaban hacia la fortificación.

Parapeto Elemento arquitectónico destinado a resguardar al defensor del fuego enemigo, permitiéndole . cierto espesor para resistir el impacto de la artillería y con declivio hacia el exterior.
Parque de Almacén de pertrechos y material artillero en el interior de una plaza. Lónicamente debe artillería resguardarse del ataque enemigo. Parque de víveres $\begin{aligned} & \text { Espacio delimitado en la retaguardia de los regimientos donde se ubicaban mercaderes o } \\ & \text { "vivanderos" para vender a los soldados (SANZ, 1794:277). }\end{aligned}$

Pasadizo Pasaje cubierto, estrecho y secreto que permite unir partes de la fortificación.

Paseador Adarve

Pastel Plataforma irregular u ovalada con un parapeto de frente que se dispone en zonas pantanosas cuando es preciso cubrir la puerta de una plaza que no puede ser flanqueada (Sanz, 1794:278).

Patio de armas Plaza de armas

Pedrero Mortero primitivo. Denominado así porque recurría a proyectiles de piedra.

Peine Sarracinesca. Estructura de cierre integrada por estacas verticales atadas por travesaños horizontales formando un enrejado que, suspendido con un torno tras las puertas de una plaza se deja caer en caso de ataque. A diferencia del organo tiene el inconveniente de poder ser
bloqueado su descenso con la interposición de un obstáculo.

Perpendicular Radio recto

Perpendicular Radio recto.

Pescante Aguja, flecha, brazo de los que cuelga la estructura de un puente levadizo.

Pie de lámpara Apoyo de la garita. Solía ornamentarse con molduras y un remate inferior esférico. Al menos en el siglo XVIIII

Pie de lámpara Ménsula que sirve de apoyo a una garita. Se remata inferiormente con una esfera.

Pie derecho de Soporte vertical estructural de una bóveda, desde el cimiento hasta el riñón de esta.

Pínula Pequeñas reglas de latón con un orificio en el centro que se disponían a ambos extremos de la alidada, sobre la plancheta. Por cada uno de los orificios se pasaban unas cerdas que ayudaban a prolongar las visuales en el proceso de levantamiento y replanteo. Ver alidada y plancheta.

Pitipie Escala gráfica utilizada en los planos de la fortificación moderna

Plancheta Instrumento para el levantamiento o replanteo de una fortificación sobre el terreno. Consistía en una superficie horizontal sobre un soporte. En ella se apoyaba el papel y se dibujaban sobre él las alineaciones con la ayuda de alidadas y pínulas. Ver alidada y pínula.

Plataforma Batería rectangular o trapezoidal.

Plaza Todo recinto fortificado que aloja a los habitantes de una ciudad además de a su guarnición.

Plaza alta Batería emplazada en un flanco a la altura del terraplén del baluarte.

Plaza baja Batería emplazada en el flanco de un baluarte a la altura del camino cubierto.

Plaza de armas Espacio donde se reúnen las tropas. La plaza principal o patio de armas se ubicaban en el corazón del recinto, en ella se concentraban, arengaban y distribuía a las tropas. No obstante abaluartada, se habilitaron espacios con el mismo nombre en los ángulos salientes y entrantes del camino cubierto para concentrar tropas en los repliegues y para las salidas a campo abierto.

Polígono exterior Es el polígono que se puede trazar a partir de los ángulos más salientes de una fortificación.

Polígono interior Es el polígono que se traza desde los ángulos más entrantes de una fortificación

Poliorcética Término de origen etimológico heleno: 'polis', ciudad; 'ercos', cerco. Se utiliza para hacer referencia al arte de defender y conquistar plazas fuertes.

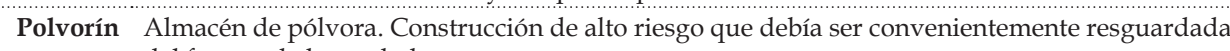
del fuego y la humedad.

Pomerio Término procedente del latín 'pomerium' con el que los romanos designaban al espacio libre a ambos lados de la muralla.

Portillo Pequeñas puertas que se construían al lado de la principal, con su correspondiente puente, para habilitar el paso de una única persona. Evitaba tener que abrir la puerta principal. También se denomina así a las poternas o puertas de socorro.

Pósito Depósito de cereal de carácter municipal que efectuaba préstamos de cereal a los más necesitados

Postigo Puerta pequeña. No principal. Se denomina así también a puertas falsas que abren sobre otra mayor o que abre a otra mayor o a una reja. Puertas pequeñas que se enmarcan dentro de un que una ventana de cristal que se anteponen a la misma para protegerla

Poterna Puerta pequeña, escondida, también denominada falsa. Suelen ser de mayor dimensión que los portillos. Tiene por objeto facilitar salidas por sorpresa. Suele esconderse en los flancos de la quedar expuesta al impacto artillero. 


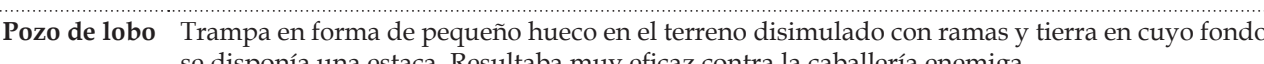
se disponía una estaca. Resultaba muy eficaz contra la caballería enemiga.

Pozo de nieve O nevero

Puente Construcción que permite sortear un foso. Puede ser fijo, pero también levadizo o corredizo.

Puerco espín Obstáculo para cerrar pasos constituido por un madero con púas de hierro que gira sobre una columna vertical dispuesta en su eje. Sus extremos se aseguran con otros dos maderos verticales Uno dispuesto impidiendo el movimiento hacia el exterior y otro impidiendo hacia el interior,
lo que condiciona una única posibilidad de giro.

Pulgada castellana Unidad de medida que equivalía a $23,22 \mathrm{~mm}$

Quebradura Brisura

Radio mayor Radio de la circunferencia en la que se inscribe el polígono exterior que define un frente fortificado

Radio menor Radio de la circunferencia en la que se inscribe el polígono interior que define un frente fortificado

Radio recto Línea que une perpendicularmente el centro del polígono exterior con el punto medio del lado que configura el frente fortificado. Se denomina también 'perpendicular'.

Ramal Retorno. Cada tramo de trinchera en zigzag. La longitud del ramal se reduce conforme se aproxima al objetivo.

Rasante Véase línea de defensa rasante.

Rastrillo Todo tipo de puerta de estacas que abre o cierra cualquier paso en una fortificación. En sus diversas modalidades se denomina órgano o peine.

Rebotadero Superficie destinada a hacer rebotar los proyectiles para dotarlos de una tra................. más efectiva en la defensa. Se emplazaban en la base de muchas fortificaciones para matacanes.

Rebote, batería de Hace referencia a un modo de utilizar la artillería, a partir de una dosificación muy específica de pólvora que impulse el proyectil sin excesiva potencia para evitar que se incruste en los proyectil por encima de los parapetos en el interior de los adarves para que este devastase 10 que encontrara a su paso. El sistema fue ingeniado por Vauban sistema fue ingeniado por Vauban.

Rebufo En una pieza de artillería, es el aire agitado por la pólvora inflamada.

Recamara Parte de un cañón o mortero donde se carga la pólvora.

Redientes, línea Dientes de sierra

Pequeña posición defensiva solo defendida desde su frente. Es muy frecuente en obras de campaña. Se suelen conectar reductos con líneas de comunicación generando líneas de reductos. irregular se denomina pastel.

Reducto del Revellín dentro del revellín.

revellín

Reducto destacado Es aquel reducto que se emplaza avanzado respecto a la fortificación de la plaza. Su objeto es defender algún enclave estratégico próximo. Contaba con su propio foso y camino cubierto y
estaba conectado por la espalda con el camino cubierto principal de la plaza.

Refosete Cuneta o foseto.

Regimiento Unidad básica que integra a partir de las ordenanzas de 1768 el ejército de tierra

Reglas del arte Del francés "Regles de l'Art". Sistema formal de asedio de acuerdo con las premisas de Vauban

Regular, Toda fortificación cuyo trazado en planta coincide con un polígono regular. Lados y ángulos

fortificación de idéntica magnitud.

Rejas Espinos

Reparos Conjunto de elementos constructivos utilizados para protegerse del disparo enemigo come gaviones, parapetos, manteletes, resguardos.

Repuestos Pequeño almacén inmediato a las posiciones de defensa para suministrar a los soldados todo aquello que pueden necesitar en la acción defensiva, especialmente municiones. Suelen

Resalte Alambor

Resguardos Reparos

Retorno Ramal de trinchera.
Ripio Forma de designar a toda obra de tierra construida para incrementar las las características defensivas de una posición.

Retrocarga Forma de denominar a aquel armamento de fuego que se carga por el extremo posterior del cañón.

Revellín Obra exterior que suele emplazarse frente a la cortina. Tradicionalmente tuvo forma pentagonal o triangular, como una especie de baluarte exento destinado a proteger la cortina. Su interposición obliga a los atacantes a atacar primero el revellín antes que los baluartes de frente. Solía utilizarse para cobijar la puerta y el puente, siempre emplazados en el centro de la cortina.

Revés Través

Revestimiento Camisa de una fortificación. Generalmente se ejecutaba con cal y canto, ladrillo o tepes.

Ripio Piedra de pequeño tamaño para asentar los mampuestos.

Roca Fortificación aislada. Característica de las primeras fortificaciones de transición italiana definiendo una tipología de planta cuadrada o rectangular con torreones circulares en sus esquinas.

Rodapié Tableta. Saliente horizontal de la cara superior del cimiento respecto al plano de la escarpa.

Rodillera Porción de parapeto que queda bajo el orificio de una cañonera. La altura de rodillera es determinada por el calibre del armamento.

Ronda Acción de vigilancia nocturna por determinados efectivos que recorre todos los puestos de la plaza. Se denomina también así al personal y al espacio por el que esta ruta de vigilancia espacio en la coronación de la escarpa para garantizar la vigilancia continua del foso que recibiô el nombre de camino de ronda.

Saco de tierra Muy utilizados en la fortificación de campaña para construir parapetos. Los sacos solían ser de lienzo grueso.

Salchicha Tipo de fajina, del mismo grueso pero de 20 a 50 pies de largo. También se denomina así a la mecha de lienzo con la que se detonan las minas.

Salchichón Tipo de fajina constituida por ramas muy gruesas que se rellena de piedras para cegar un fos...... con agua.

Salida secreta Se emplazaban en los orejones y, de no haber, en el flanco del baluarte, escondidas de la visión del atacante. El acceso solía facilitarse con una pequeña poterna. El recorrido en ocasiones se
planteaba en recodo. Solían disponerse trampas de pólvora para detonarlas en caso de ser descubiertas por el enemigo

Santa Bárbara Depósito de pólvora o armamento. Santa Bárbara es la patrona de la artillería.

Sarracinesca Peine

Segundo Fuego Doble fuego. Flanco segundo. Fuego de la cortina.

Semibaluarte Medio Baluarte.

Semigola Línea del baluarte resultante de la prolongación de la cortina desde l. flanco ha........ capital de dicho baluarte. La semigola define la capacidad de acceso al baluarte. Se recomiendan capital de dicho bal

Sirviente Artillero que sirve la artillerín

Sisa Pequeña cantidad de dinero que un comprador se queda para sí al hacer la compra con dinero de otro. Podría entenderse como un hurto o una defraudación, pero también era un impuesto que se cobraba sobre géneros comestibles, menguando las medidas.

Sitio Cerco o cordón que un ejército atacante establece sobre una plaza aislándola de todo posible

Sitio en regla Aquel sitio efectuado de acuerdo con lo que en el siglo XVIII se denominaron "les regles de l'Art" (ver Reglas del Arte).

Sitio real Acción de sitio que recurre al menos a una línea de circunvalación o a la de contravalación.

Sitio simple Acción de sitio que prescinde de las líneas de circunvalación y de contravalación.

Socorro Acción de apoyo exterior a los defensores de una plaza asediada.

Socorro general Aquella acción de socorro en la que se obliga al asediante a levantar el sitio bien por carencia de medios para sostener el asedio, bien debido a una accion sobre una plaza o posesiones del atacante que le obligan a replegarse para acudir en su socorro, o, finalmente, por un enfrentamiento directo.

Socorro particular Aquella acción de socorro basada en introducir en la plaza asediada lo necesario: hombres, pertrechos, avisos que infunden moral.. 
Tablero Puerta del puente.

Tableta Rodapié.

Táctica Es el conjunto de decisiones que se adoptan para conducir una situación de conflicto y dependen en cierta medida de la capacidad del mando: definición de un cambio de orden de las unidades, momento de utilización de la artillería, apuesta por una carga de caballería..

Talud El talud hace referencia a la pendiente de un terreno pero también sirve para definir al cuerpo que define dicha pendiente: Escarpa, lambor, alambor

Telémetro Instrumento para medición de distancias. Utilizado en la artillería.

Tenallón Especie de falsabraga que se emplazaba frente a las cortinas y los flancos de una fortificación Tenazón.

Tenaza Una tenaza es un elemento constructivo que con sus formas define la acción de tenaza, es decir, envolver al enemigo amenazándolo con un fuego desde ambos flancos. No obstante esto se puede conseguir de muy diversas formas. En el sistema abaluartado la tenaza era un elemento concreto constituido por un frente abaluartado que se disponía en el espacio confinado entre los flancos y la cortina principales. En el sistema atenazado se comprobó que se conseguían resultados más efectivo mediante una tenaza definida por dos sencillas líneas convergentes.

Tenaza a cola de Cuando los flancos de la tenaza convergen hacia la gola produciendo que el conjunto de la golondrina tenaza tenga el aspecto de una cola de golondrina.

Cuando los flancos de la tenaza se abren en la gola.

\section{cola de golondrin}

Tenaza cortada Cuando la tenaza se separa de la cortina con un foso.

Tenaza de alas Cuando los flancos de la tenaza son paralelos.

paralelas

Tenaza doble Sencillamente es la unión de dos tenazas.

Tenaza doble a Constituida por dos tenazas cuyos flancos convergen en la gola. Bonete de clérigo.

cola de golondrina

Tenaza sencilla Tenaza simple.

Tenaza simple Tenaza.

Tenazón Obra auxiliar que solía emplazarse por delante de las medias lunas o revellines para defender el foso. Se generaba prolongando las caras del revellín, por lo que se generaban dos cuerpos simétricos respecto a la capital del revellín que configuraban una especie de tenaza en su arista

Tepe Césped. Terrón de tierra con césped o hierba. Se utilizaba para revestir terraplenes de tierra.

Terraplén Masa de tierra apisonada que constituía la base de la fortificación. En terminología de fortificación el término acabó definiendo al plano horizontal superior de dicha masa, es decir, el adarve

Terrón y liza Tipología primitiva de castillo normando, caracterizada por un promontorio dominante y un segundo promontorio dominado por el anterior pero que domina la campaña. Cada conjunto

Tiro a cartucho Cuando se recurre a un cartucho. Envoltorio ejecutado de pergamino, lienzo o lanilla que contiene la pólvora preparada de antemano.

Tiro curvo Tiro por elevación.

Tiro de elevación Tiro por elevación

Tiro de enfilada Tiro que tiene por objeto enfilar al enemigo.......

Tiro de punto en Aquel tiro que pretende alcanzar un blanco determinado

blanco

Tiro por elevación Es aquel que se efectúa calculando la parábola adecuada para que la trayectoria del proyectil tenga el máximo alcance.

Tiro rasante Tiro cuya trayectoria se aproxima a una horizontal al plano de suelo. Era el más efectivo en los tiempos primitivos de la artillería.

Torneante Cuando una zapa se aproximaba a la explanada, debía avanzar rápido en línea recta hacia ella, lo que exponía a los zapadores a la enfilada. Para evitarla se disponía un obstáculo, es decir, un través o espaldón que en estos casos recibia el nombre de torneante, porque dado que los zapadores debian seguir excavando en la misma dirección, debian sortearlo por ambos lados. El nombre procede precisamente del hecho que las tropas, al proceder al asalto, debían transitar sorteándolos.

Torre caballera Pequeña torre levantada sobre la plataforma de otra.

Torre de diamante Torre en pico de espuela.
Torre del La más alta de una fortaleza, que domina defensivamente al resto.

homenaje

Torre en mandorla Torre con trazado geométrico almendrado. Fueron características en la fortificación bastionada del renacimiento italiano

Torre en pico de Torre apuntada. Trazado renacentista que surge de la unión de la torre circular y el pico o espuela espolón que la antecede para anular el ángulo muerto.

Torre hueca Aquellas torres que, como su nombre indica, no aparecen macizadas en su totalidad o en parte. Un caso de torre hueca lo encontramos en las murallas almohades de Baños de la Encina. Torres que se anteponen a los muros y que presentan la singularidad de su vacío interior. Más concretamente, presentan una base maciza mientras que la parte superior se desglosa en do cuerpos huecos que recurren a tablados de madera de rollizo como forjados. Este modo de concebir las torres de una fortificación no se repetira en la historia de la España Musulmana disuasorio de estas moles evitará que jamás el enemigo ose descubrir tamaña debilidad.

Traversa Foso guarnecido de un parapeto, y alguna vez de dos, uno a la derecha y otro a la izquierda, ve te tienta Este nombre se toma a veces por un galería, y también significa retrin
tierra, cestones... (Sanz, 1794: 414).

Través Través. Por lo general se entiende a todo parapeto que proporciona una protección al fuego de flanco. Fue un elemento característico en los caminos cubiertos donde se phion aba un parapeto a prueba con banqueta que se atravesaba al sentido longitudinal del camino. No cerraba totalmente el paso y su misión precisamente era dificultar el mismo al enemigo en caso de que tomara la posición.

Través torneante Torneante

Trincea Trinchera XVII y XVII consit́n en zanjes que avanzaban en zigzag hacia el foso. La tierra excavada se XVII y XVIII consistian en zanjas que avanzaban maigzg hacia c

lanzaba a los bordes y servía de protección de los zapadores.

Trinchera doble La que forma parapetos de tierra a ambos lados de la excavación.

Tronera Apertura efectuada en un muro para embocar la artillería.

Tronera de buzón Tronera de mayores dimensiones que una tronera estándar pero de formato apaisado.

Tronera traidora Aquella efectuada en el flanco para no ser vista por el enemigo.

Toesa Unidad de medida francesa que sería utilizada por los ingenieros militares españoles hasta el siglo XVIII hasta que se oficializa la vara castellana del marco de Burgos. Equivale a 1,949 metros

Utensilio Cuando los soldados debían alojarse en domicilios particulares, la provisión era el mínimo a lo que el soldado tenía derecho: cama guarnecida de colchón, sábanas, una olla, un vaso, una escudilla, un lugar junto al fuego y luz. También se definió como tal el dinero pagado por la habitantes del país

Valla Es el tipo de barrera más sencillo existente. Un madero horizontal emplaza.1.............................. en sobre otro fijo en el terreno que le permite girar horizontalmente del mismo modo que un puercoespín.

Vara castellana Unidad de longitud que equivale a tres pies en el caso de la vara del marco de Burgos $(0,8359$ $\mathrm{m})$.

Verga Arco de acero de las ballestas. Percha labrada convenientemente a la cual se asegura el grátil de una vela. La Verga Rhinlándica ó del Rhin, es una medida que corresponde a 2 toesas, ó doce pies de París. Esta medida emplean ordinariamente los Holandeses en sus fortificaciones (Sanz 1794:421).

Verga seca La verga mayor..........................................................

Vértice Punto inferior de una arista, entendida como la línea que surge, por ejemplo, del encuentro de las dos caras de un baluarte.

Volante, campo Era aquel conjunto de tropas destinadas a movilizarse en función de las necesidades a partir de un punto de alojamiento. Tenían la capacidad de acampar o levantar el campo en función de
dichas necesidades.

Zabullir Descarga de cañón efectuada de arriba abajo

Zapa Excavación ejecutada en el terreno, como por ejemplo una trinchera. Este se corta por escalones.

Zapa cubierta Aquella que el zapador excava a modo de galeria bajo tierra a fin de evitar los bombardeos. En las proximidades del área a atacar, la zapa se acerca a la superficie y se cubre con un techo de madera y tablones con dos pies de tierra por encima.

Zapa doble Aquella en la que el zapador se protege por ambos lados. 
Zapa entera Es una modalidad de zapa propia del siglo XVIII cuyo proceso de construcción según Lucuze es el siguiente: "para la zapa entera, señalada la dirección, ò instruidos los zapadores, se rompe el parapeto de la trinchera, y el primer zapador, ò Xefe, hace rodar ò arrollar delante de sì un mantelete, ò grande cestón lleno de faginas, de que se cubre por el frente, y al lado pone un cestón, que llena de tierra, haciendo una zanja de y le llena, continuando siempre en esta forma. El segundo zapador ensancha y profunda la obra del primero, acaba de llenar los cestones, pone sobre ellos una cama de tres faginas aseguradas à las puntas de las estaces y refuerza la debil unión de los cestones, con faxos de zapa, ò saquillos de tierra. El tercero y quarto zapador, perfeccionan la excavacion, y con la tierra que sobra, se refuerzan exteriormente los cestones, dandola su natural pendiente. Los quatro zapadores que descansan, reemplazan luego los que fueren muertos, o heridos en el trabajo, y hacen pasar acia la cabeza de la zapa los cestones, y faginas, saquillos, ò faxos que se necesitan. A medida que los zapadores han concluido alguna parte de su obra, entran los ordinarios Trabajadores, y la ensanchan lo que fuere necesario " (Lucuze, 1772:149-152). En función de la dimensión hablaremos de una trinchera, una paralela, o una comunicación

Zapa media O media zapa, consiste en una modalidad de zapa apropiada para cuando el fuego del sitiado es menor al haberse destruido parte de sus defensas. Esta situación permite trabajar con acomodo, por lo que se disponen los cestones a descubierto del lado a defender, se aseguran las juntas con

Zapa volante Propia para trabajos alejados de la plaza o nocturnos. Es la más cómoda................................. de toda la zapa con los cestones y cualquier trabajador, no necesariamente los zapadores, se

Zapador Militar encargado de las zapas

Zapapico Pico empleado por los zapadores.

Zarzo Rectángulo de mimbre o ramas que se utiliza para ejecutar parapetos de contención de tierras, guarecer merlones de batería o para actuar de superficie horizontal de paso sobre fajinas en terrenos pantanosos.

Zunchado Operación de ensamblaje de dos piezas una dentro de la otra mediante el calentamiento de la pieza exterior que, al dilatar, permite el alojamiento de la segunda. Al enfriar ambas quedan fuertemente acopladas. Sistema aplicado a la artillería de la segunda mitad del siglo XIX para obtener cañones de gran longitud y menos espesor, impidiendo que deformarán por flexión nte el peso propio. 
Acontecimientos militares de repercusión internacional Acontecimientos en el ámbito nacional relacionados

Acontecimientos en el ámbito local

Guerras carlitas

Fases de la guerra

*Nota: La siguiente tabla no pretende contener la totalidad de acontecimientos militares vinculados, especialmente en el ámbito internacional y nacional, tarea ardua e inabarcable, que podría abrumar con el exceso de información y podría suponer un desvío de los objetivos. Es por ello por lo que se detectarán ciertas ausencias relevantes en ambas investigación.

Siglas de encabezado de tabla:

P: Período cronológico

A: Año

M: Me

D: Día

Tabla 21. Interrelación entre los conflictos internacionales, nacionales y locales.

\begin{tabular}{|c|c|c|c|c|c|}
\hline Periodo & $A$ & $M$ & $D$ & Acontecimiento & Complemento descriptivo \\
\hline & 1713 & & & Auto Acordado & $\begin{array}{l}\text { Se stablece en España la Ley de Suceción } \\
\text { Fundamental, excluyendo a las mujeres de la } \\
\text { posibilidad de heredar el trono, a no ser que no } \\
\text { existiera un varón perteneciente a la línea sucesoria } \\
\text { principal o lateral. }\end{array}$ \\
\hline & 1805 & & & Batalla de Trafalgar & $\begin{array}{l}\text { La flota española queda anulada y las colonias } \\
\text { españolas desguarnecidas. }\end{array}$ \\
\hline & 1809 & 11 & & Líneas de Torres Vedrás & $\begin{array}{l}\text { Se inician en secreto las líneas de defensa de Torres } \\
\text { Vedrás para proteger la península de Lisboa ante el } \\
\text { ataque de André Massena. La obra será paralizada } \\
\text { en septiembre de } 1810 \text { ante la llegada del ejército } \\
\text { francés. }\end{array}$ \\
\hline & 1812 & 3 & 19 & $\begin{array}{l}\text { Las Cortes de Cádiz aprueban la } \\
\text { Constitución }\end{array}$ & \\
\hline & 1815 & 10 & 1 & Congreso de Viena & $\begin{array}{l}\text { Se inicia el Congreso de Viena con el objeto de } \\
\text { fijar las fronteras de Europa tras las campañas } \\
\text { napoleónicas. El Congreso concluirá el } 9 \text { de junio } \\
\text { de } 1815\end{array}$ \\
\hline
\end{tabular}

$1820 \quad 1 \quad 1 \quad$ Riego se revela con sus tropas en

Cabezas de San Juan 
El Duque de Angulema entra

en España con un ejército de

$\begin{array}{llll}1823 & 4 & 7 & \text { unen } 35.000 \text { realistas. Fernando }\end{array}$ VII inicia la década absolutista (1823-1833)

$1827 \quad 3 \quad$ Pronunciamiento de los

$1830 \quad 3 \quad 29 \quad$ Promulgación Pragmática Sanción

$1830 \quad 10 \quad 10 \quad$ Nacimiento de Isabel II

Fernando VII, enfermo, firma en La Granja la derogación de la Pragmática Sanción: don Carlos volvia a ser heredero al trono.

$1832 \quad 9 \quad 18$ Sucesos de la Granja. Se deroga la Pragmática Sanción

$\begin{array}{llll}1832 & 12 \quad 31 & \text { derogatorio de la Pragmática }\end{array}$ Sanción, nunca promulgado

$1832 \quad 11 \quad 15 \quad$ Sitio de Amberes

Último asedio clásico efectuado por las tropas francesas ante la ocupación de la ciudadela por el capitulación se produjo el 23 de dicienbre de 1832 .

$\begin{array}{llll}1833 & 9 & 29 & \text { Fallece Fernando VII }\end{array}$

$1833 \quad 10 \quad 3 \quad \begin{aligned} & \text { Primera muestra del alzamiento } \\ & \text { carlista }\end{aligned}$

El funcionario de correos Manuel María González,

lanza el primer "iViva Carlos V" en Talavera dispersada.

\begin{tabular}{|c|c|c|c|c|}
\hline \multirow[t]{3}{*}{$\begin{array}{l}1833- \\
1840\end{array}$} & 1833 & 10 & 3 & $\begin{array}{l}\text { Guerra de los Siete Años o } \\
\text { Primera Guerra Carlista }\end{array}$ \\
\hline & 1833 & 10 & 3 & $\begin{array}{l}\text { Se inicia en Bilbao la rebelión } \\
\text { carlista del norte }\end{array}$ \\
\hline & 1833 & 10 & 7 & $\begin{array}{l}\text { Toma de Vitoria por Naturales } \\
\text { Realistas Armados al mando d } \\
\text { Valentín de Verástegui }\end{array}$ \\
\hline
\end{tabular}

$\begin{array}{llll}1834 & 2 & 4 & \text { Victoria carlista en Güesa }\end{array}$

$1834 \quad 2 \quad 15 \quad$ Cabrera se une a la partida del Coronel Manuel Carnice

Zumalacárregui derrota a a las tropas de Valdés, sorprende la ciudad de Vitoria y derrota por tres y Gubina.

Se inician sus correrías por pueblos desguarnecidos y masías, exigiendo tributos, racionamiento y reclutas

\section{3- \\ $\begin{array}{llll}1834 & 3 & 18 & \text { Fase Zumalacárregui }\end{array}$ \\ fechada en Villarreal, el mando}

Zumalacárregui a cargo del ejército carlista Zumalacárregui

$\begin{array}{llll}1834 & 7 & 12 & \text { Don Carlos entra en España }\end{array}$

$\begin{array}{llll}1835 & 6 & 10 & \text { Se inicia el sitio de Bilbao }\end{array}$

$1835 \quad 6 \quad 15 \quad$ Zumalacárregui es herido en el

$\begin{array}{llll}1835 & 6 & 24 & \text { Zumalacárregui fallece en }\end{array}$

Dándose a conocer en Elizondo

\section{Periodo A $\quad M \quad D \quad$ Acontecimiento \\ $\begin{array}{llll}835 & 7 & 1 & \text { Los carlistas se ven forzados a }\end{array}$}

Complemento descriptivo

Por la parte Norte, por la fuente y camino de

las Reinas, con una fuerza de 1200 hombres. La

$1835920 \quad$ Cabrera se presenta a la vista de $\quad \begin{aligned} & \text { la ciudad (la puerta de Reinas), cerrada con palos } \\ & \text { y aportaderas de vendimiar. Cabrera entró en el }\end{aligned}$ Convento de San Francisco, donde se le puso al corriente de las fuerzas con que contaba la ciudad, exagera do la cifra. Cabrema desiste en su empeño y se desplaza a Utiel (Herrero y Moral, 1849:49) Somete a su control a todas las autoridades del territorio tras fusilar a los alcaldes de Valdealgorfa

$1836 \quad 1 \quad$ Cabrera toma Tortosa y Torrecilla de Alcañiz

$\begin{array}{llll}1836 & 2 & 16 & \text { Fusilamiento de la madre de }\end{array}$

$\begin{array}{llll}1836 & 6 & 26 & \text { La Expedición de Gómez inicia }\end{array}$

$\begin{array}{llll}1836 & 9 & 7 & \text { La expedicion de Gómez se }\end{array}$ aposta en Utiel

Se divulga en Utiel la noticia

$\begin{array}{llll}1836 & 9 & 13 & \begin{array}{l}\text { de que los carlistas van a } \\ \text { aproximarse a Requena }\end{array}\end{array}$ aproximarse a Requena

$\begin{array}{llll}1836 & 10 & 24 & \begin{array}{l}\text { Se empre } \\ \text { de Bilbao }\end{array}\end{array}$

$\begin{array}{llll}1836 & 12 & 24 & \text { Acción de Luchana } \\ 1836 & & \begin{array}{l}\text { El cura Merino se repliega a } \\ \text { Euskal Herria poniendo fin al } \\ \text { levantamiento en Castilla }\end{array}\end{array}$

$1837 \quad 3 \quad 19$ Se inicia el tercer ataque

$1837 \quad 3 \quad 29 \quad$ Acción de Pla del Pou

Cabrera derrota a dos regimientos de infantería de

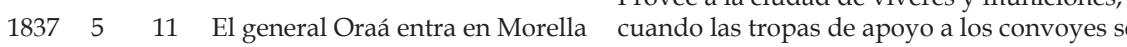

$1837 \quad 5 \quad$ Se emprende la Expedición real

$1837 \quad 9 \quad 12$ Los carlistas alcanzan Arganda

a las puertas de Madrid

Victoria en Maella de Cabrera

$\begin{array}{lllll}837 & 10 & 18 & \text { sobre el general Pardiñas (que }\end{array}$

fallece en el combate)

$\begin{array}{llll}1837 & 10 & 24 & \begin{array}{l}\text { Los carlistas retroceden } y \\ \text { atraviesan el Ebro }\end{array}\end{array}$

$\begin{array}{llll}1838 & 1 & 1 & \text { Los carlistas sostienen el asedio }\end{array}$ de Morella

$\begin{array}{llll}1838 & 1 & 26 & \text { Los carlistas toman Morella }\end{array}$ Saboya. Los oficiales capturados serían llevados Burjassot y fusilados por Cabrera.

Provee a la ciudad de víveres y municiones, pero retiran, Cabrera volverá a bloquear la plaza

tistraer a las tropas cristinas y suma con cerca de 3000 hombres.

Gomez convoca en Utiel a las partidas y fuerzas

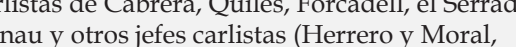
1849:50)

Los carlistas, tras cercar Requena y parlamentar, levantan el cerco esa misma noche.

Espartero derrota a los carlistas en el sitio a Bilba

io

Para ello fortifican el Molino de Adell, la masía del Bosch, Torre del Vale, Querola y Morella la Vella. A su vez mantienen tropas volantes que recorren los montes.

La toma se produce por sorpresa a través del retrete que volcaba a la alameda 


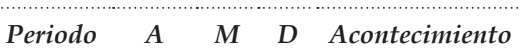
$1838 \quad 1 \quad$ Cabrera toma Benicarló

$1838 \quad 8 \quad 3 \quad$ Oraá formaliza el sitio de Morella

$1838 \quad 8 \quad$ Defensa de Morella ante

$\begin{array}{lllll}1839 & 2 & 18 & \text { Golpe de estado del general }\end{array}$ Maroto en el seno del Carlism

$\begin{array}{llll}1839 & 8 & 31 & \text { Convenio de Vergara }\end{array}$

$1839 \quad 9 \quad 14 \quad$ Don Carlos cruza la frontera

$1840 \quad 5 \quad 26 \quad \mathrm{El}$ general Espartero inicia

$\begin{array}{llll}1840 \quad 5 & 26 & \begin{array}{l}\text { El general Espartero inica } \\ \text { bombardeo de Morella }\end{array}\end{array}$

$1840530 \begin{aligned} & \text { Espartero entra en Morella y } \\ & \text { Cabrera se retira a Berga }\end{aligned}$

$1840 \quad 7 \quad 5 \quad$ Cabrera entra en Francia

\section{$\begin{array}{lllll}\text { 1846- } & 1846 & 0 & 0 & \begin{array}{l}\text { Guerra dels Matiners (o } \\ \text { Segunda Guerra Carlista en el }\end{array}\end{array}$ \\ contexto catalán)}

$\begin{array}{llll}1860 & 4 & 1 & \text { Irdena zarpar a las naves Jaim } \\ \text { II } \mathrm{City} \text { of Norwich del puerto }\end{array}$

de Palma con 4000 hombres

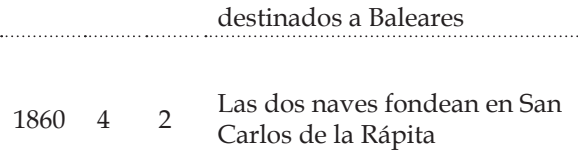

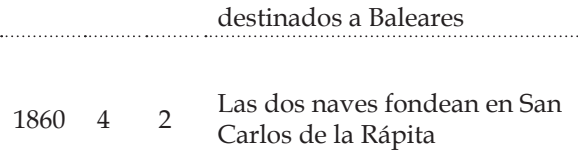

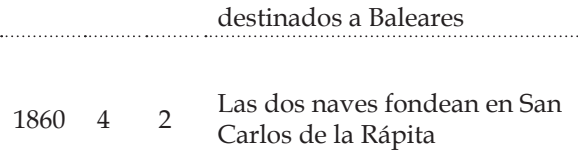

Complemento descriptivo

El ataque se realizaría días más tarde (el 14 de agosto), pero fracasa estrepitosamente, produciend el cese de Oraá y el encumbramiento de Cabrera.

Detención y fusilamiento en Estella de jerarcas conspiradores

Se reconocen los grados militares carlistas,

ambiguas promesas sobre concesión $\mathrm{y} / \mathrm{o}$

modificación de los fueros. Vergara supone la Casmo, y muchos combatientes no se adscriben.

Cabrera seguirá luchando en el Maestrazgo

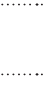
ejército liberal de Ora

El general Ortega y Olleta $\begin{array}{llll}1840 & 7 & 2 & \text { Cae Berga y Cabrera opta por }\end{array}$

$\ldots$

Se expiden telegramas a las Juntas Carlistas de
Madrid, Barcelona, Valencia, Zaragoza y otras

capitales para que se secunde el alzamiento. Nadie esperaba que el general Ortega, de origen liberal, estuviera implicado.

Ortega da una alocución a las tropas en favor de

$1860 \quad 4 \quad 3 \quad$ Fiasco de San Carlos de la Rápita Carlos, interrumpido por un ;Viva la reina y la libertad! Ninguna guarnición secunda la spiración

\begin{tabular}{l}
$1860 \quad 4 \quad 18 \quad$ Ortega es fusilado en Tortosa \\
\hline
\end{tabular} Fallece en Austria el Conde de Montemolín

1861 Combate naval de Hampton

$1862 \quad 3 \quad$ Roads en la guerra de Secesión Americana

Se lleva el secreto de la conspiración a la tumba

La Segunda Batalla de Fort Wagner se desarrollaría

$\begin{array}{ll}\text { Primera batalla de Fort Wagner } & \begin{array}{l}\text { una semana después. Demuestra la eficacia de los } \\ \text { (Guerra de Secesión Americana) }\end{array} \\ \text { bombanes que causan y yran mortandad en el ejército }\end{array}$

$\begin{array}{llll}1863 \quad 7 \quad 11 & \text { Primera batalla de Fort Wagne }\end{array}$

$\begin{array}{ll}\text { Primera batalla de Fort Wagner } & \begin{array}{l}\text { una semana después. Demuestra la eficacia de los } \\ \text { (Guerra de Secesión Americana) }\end{array} \\ \text { bombanes que causan y yran mortandad en el ejército }\end{array}$ federal.

\begin{tabular}{|cccccl} 
Periodo & $A$ & $M$ & $D$ & Acontecimiento \\
\hline 1864 & 4 & 7 & $\begin{array}{l}\text { Batalla de Dybbøl (Düppel) en } \\
\text { la guerra de los Ducados entre } \\
\text { Dinamarca y Prusia }\end{array}$ \\
\hline
\end{tabular}

ento descriptivo

Las fortificaciones de campaña danesa se enfrentaron al portencial artillero prusiano. Supuso la derrota danesa.

18689 Revolución “La Gloriosa”

$\begin{array}{lll}1868 & 10 & 3\end{array}$ Abdica Don Juan de Borbón

$\begin{array}{llll}1869 & 7 & 11 & \text { Carlos VII penetra en España }\end{array}$

\begin{tabular}{|c|c|}
\hline 1869 & Elecciones constituyentes \\
\hline 1870 & $\begin{array}{l}\text { Cabrera dimite y don Carlos } \\
\text { convoca la Junta de Vevey en } \\
\text { Suiza }\end{array}$ \\
\hline
\end{tabular}

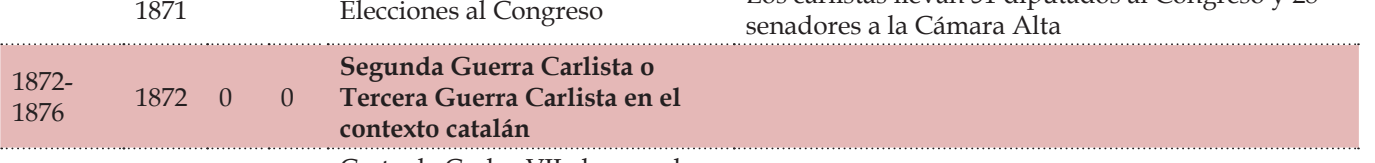

$1872 \quad 4 \quad 14 \quad$ Carta de Carlos VII al genera

$1872 \quad 4 \quad 21 \quad$ Rada penetra en España

Se moverá entre Guipúzcoa, Navarra y la frontera El fracaso carlista en las

$1872 \quad 4 \quad$ elecciones del año incita a los cantistas a tunn. lis annas

$\begin{array}{llll}1872 & 5 & 2 & \text { Entrada a pie de Carlos } \\ \text { enpaña que despierta el }\end{array}$

$\begin{array}{lllll}1872 \quad 5 & 5 & \text { Carlos VII regresa a Francia }\end{array}$

$1872 \quad 5 \quad 24 \quad$ Convenio de Amorebieta

al trono de España

Proclamación por la Asamblea

$\begin{array}{llll}1873 & 2 & 11 & \text { Nacional de la Primera }\end{array}$

$1873 \quad 2 \quad$ Dorregarray penetra en España

$\begin{array}{llll}1873 & 7 & 16 & \text { Don Carlos vuelve a entrar en }\end{array}$

$874 \quad$ Golpe de estado del genera

$\begin{array}{llll} & 1 & 3 & \text { Pavía }\end{array}$

Se disuelve la República Federal y da paso a una República Unitaria bajo la dictadura del general Serrano

$1874 \quad 1 \quad$ Castor Andéchaga toma Portugalete, llave de Bilba

Inicio de la tercera batalla por Andéchaga

$\begin{array}{llll}1874 & 5 & 2 & \text { Serrano y Concha entra } \\ \text { triunfalmente }\end{array}$

La carencia de armamento los aboca al desastre

Convenio entre carlistas vizcaínos y Serrano a cambio de la amnistía Pamplona, que, al no producirse, llevan al rey a

El destronamiento de Isabel II anima la

(

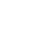

$1873 \quad 2 \quad 11$ Amadeo I de Saboya renuncia

$\begin{array}{llll}1874 & 4 & 27 & \text { Bilbao. Fallecimiento del general } \quad \text { A raíz de la llegada de los refuerzos liberales }\end{array}$

Los carlistas participan en la Cámara como un 
Periodo

A $\quad M \quad D$ Acontecimiento

$\begin{array}{llll}1874 & 6 & 27 & \text { Fallece el general Concha en }\end{array}$

Abárzuza.

$\begin{array}{llll}1874 & 7 & 16 & \text { Manifiesto de Morentín }\end{array}$

Concha trataba de apoderarse de Estella, "arca santa

Don Carlos, ante la caída de la I República, se

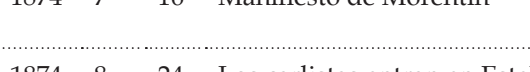
como rey que transije con el liberalismo

......................................................

$\begin{array}{llll}1874 & 12 & 31 & \text { Proclamación de Sagunto }\end{array}$

$\begin{array}{llll}1875 & 2 & 3 & \text { Batalla de Lácar }\end{array}$ Toma de Cantavieja por Jovellar $\begin{array}{llll}1875 & 8 & 25 & \text { Recuperación liberal de la Seo }\end{array}$ de Urgell triunfante

El general Arsenio Martínez Campos proclama rey a Alfonso XII, marcando el fin del regimen provisional y la entrada en el poder politico de Cánovas del Castillo, periodo conocido como la

Alfonso XII casi es apresado por los carlistas de

$\begin{array}{lllll}1876 & 1 & 1 & \text { Cae el Valle del Baztán }\end{array}$

$\begin{array}{lllll}1876 & 1 & 30 & \text { Cae el Fuerte de Santa Bárbara }\end{array}$

$1876-30$ de Oteiza

$\begin{array}{llll}1876 & 2 & 17 & \text { Toma del fuerte de Montejurra }\end{array}$

$\begin{array}{lllll}1876 & 2 & 19 & \text { Toma de Estella }\end{array}$

$\begin{array}{llll}1876 & 2 & 27 & \text { Don Carlos pasa la frontera a }\end{array}$

Francia por Valcarlos

A pesar de exclamar " "Volveréel", no regresará.

\subsection{Transcripción de documentos históricos}

**El presente anexo incorpora el conjunto de documentos históricos transcritos por la autora a partir de la información localizada en el Archivo Municipal de Requena entre 2013 y 2015. Solo se incorporan aquellos que se han considerado de mayor relevancia para la investigación. 


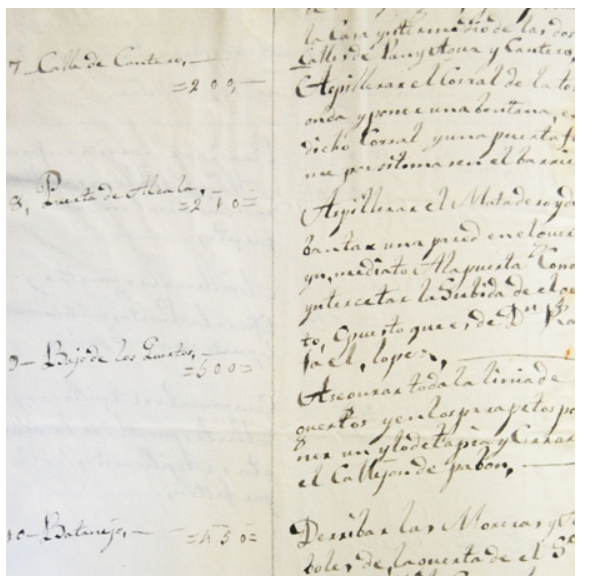

Fig. 873.

Transcripción 1: Relación de los puntos de fortificación que comprende esta Billa de Requena con espresion de reponer los que se notaran y sus yntermedios. Por el Maestro de Obras Guillermo Sáez, Requena, 1835/12/5, AMR, 1818/50.

(Transcripción de la autora)

"Relacion de los puntos de Fortificación que comprende en esta Billa de Requena con espresion de reponer los que se notaran y sus yntermedios, Asaber.

1- Portal de Madrid

$=280=\quad$ Realizar la garita enforma y Abrir Aspilleras en la pared trad bersal entrada $A$ la fuente,

2- Fuente de el Peral

$=200=\quad$ Aspillerar las guertas y Fortificar la Puerta, y el [balor] de la puerta que no esta pagada

3- Cantarranas

$=280=\quad$ Componer las Aspilleras y doblar las puertas de las guertas Aspillerando las casas que falten

4- Puerta del Cristo,

5- Puerta de el Angel

$=245=\quad$ Aspillerar la Casa de Montenegro y Cerrar el Balcon de la citada y el balcon de [Don] [Domingo] Laguna,

6- Sa Cortina

335 Cerrar los dos Balcones y Aspillerar el pretil de Sanchez y cerrar una puerta A el Callejon de Pan y Agua, y Aspillerar la Casa yntermedio de las dos Calles de Pan y Agua y Cantero,

7- Calle de Cantero

$=200-\quad$ Aspillerar el Corral de la torre oria y poner una bentana en dicho Corral y una puerta firme por si tomasen el barriete

8- Puerta de Alcala,

$=240=\quad$ Aspillerar el Matadero y lebantar una pared en el guerto ynmediato A la puerta Como yuntercetar la Subida de el guerto opuesto que es de [Don] Rafael Lopez,

9- Bajo de los Guertos

$=300=\quad$ Asegurar toda la linia de guertos y en los parapetos poner un ylo de tapia y Cerrar el Callejon de pabon 
10- Batanejo

$=450=$ Derribar las Moreras y Arboles de la guerta de el Sr. [Don] Josefla Carzel,

11- Ollerias, O puerta de Valencia

$=500=\quad$ Cerrar las puertas falsas y bentanas bajas, y Aspillerar toda la pared de el [Sr.] [Don] Juan Antonio Ponze, y Concluyr el parapeto O por mejor un ylo de tapia y cerrar las puertas falsas de Casa-Cuerta y poniendo tapia en lugar de el parapeto que termina en el [tirador],

El tirador,

$=945=\quad$ Aspillerar el tinte Asegurando, $O$, cerrando la puerta pequeña y tapiando en forma todos los guertos parapetados que terminan en la Salida de las [Casas]

Calle de las Eras,

Sesuprime Aora, Aspillerar los pisos bajos y Asegurar las puertas, por si la necesidad tubiese que comunicar toda la llinia de Casas,

Calle de los Alamos

$=150=\quad$ La comunicacion de la Casa de Pedro Lopez Con la Casa Contigua y el Asegurar las Aspilleras de el Guerto de Narbon,

Calle de Juan Penen,

Calle de Gil

$=505=\quad$ Asegurar todas las paredes y puertas de toda la linia, Aspillerando la Casa pajar y porche de [Francisco] Fernandez y batir la pared, de el guerto de Nicolas Gallego,

Ygerillas,

$=350=\quad$ Asegurar las puertas de los guertos, y poner tapia A el parapeto,

(pág. 5)

Guerto de [Don] Pedro Martinez,

$=2000=$ tapiar los parapetos $y$ Asegurar la puerta de los Corrales,

\section{Calle de Reynas,}

Camino de S. Sebastian,

$=150=\quad$ Asegurar la pared de la Casa yntermedia de la Calle y el pedazo de los Muertos, Bajada Alos bolos,

Pedazo de los Muertos,

$=790=\quad$ Continuar las tapias Asta el Cerrito; terraplenar el piso y Aspillerar las Costruydas en el frente de la Era,

\section{El cerrito de los bolos}

y paso A el pozo de la niebe

$=825=$ Cojer las paredes Cerrar la Subida y fabricar una Casita para la Guardia y parapetar de esde el Cerrito A la puerta de el pozo de la Niebe,

Pozo de la Niebe

$=1080=$ Conchuyr las Aspilleras $y$ Cojer las paredes,

Calle de Poniente,
Calle de las Cruzes

$=[290]=$ Lebantar un Costado pues Cruzan por sima de la pared, y Aspillerar la Casa becina

(pág. 7)
Pedazo de la Rejuela

$=145=\quad$ Cojer la pared

[San] [Francisco] Concluyr el tambor de la puerta y concluyr el foso,

Cuesta de el Castillo,

$=200=\quad$ tapar la puerta de el Castillo, y colocarla en la entrada de la Fortaleza y Abilitar el punto qual corresponde,

Las Carnicerias

$=346=\quad$ Colocar una puerta firme con todo lo necesario

Ymporta todo lo Anotado, Once mil Nuebe Cientos Beynte [Reales bn.] Requena y Diciembre a 5 de $1835=$ El maestro de Obras Guillelmo Saez" 


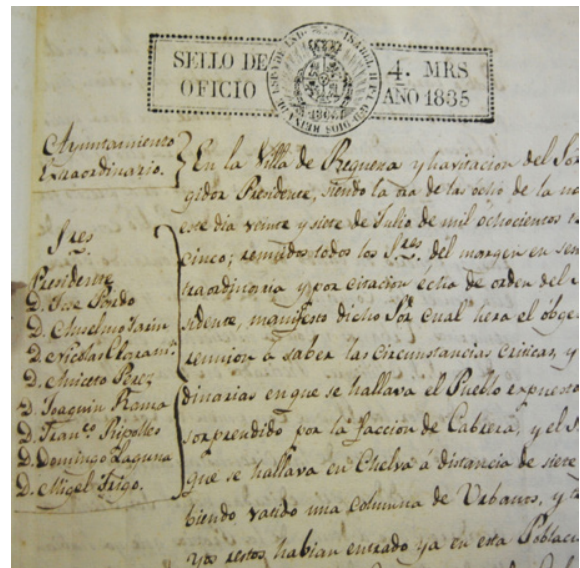

Fig. 874.

Transcripción 2: Acción del Ayuntamiento sobre medidas de defensa en esta [Población] [de] la Sección de Cabrera, Requena, 1835/07/27, AMR, 1818/48 (Transcripción de la autora)

"Accion del Ayuntamiento sobre medidas de defensa en esta [Poblacion] [de] la Seccion de Cabrera

Ayuntamiento extraordinario

En la Villa de Requena y havitacion del [Sor.] Corregidor Presidente, siendo la ora de las ócho de la noche de este dia veinte y siete de Julio de mil ochocientos treinta y cinco; reunidos todos los [Señores] del [mongen] en sesion extraordinaria y por citacion écha de orden del [Sor.] Presidente, manifiesto dicho [Sor.] cual hera el óbjeto de la reunion á saber las circunstancias criticas, y extraordinarias en que se hallava el Pueblo expuesto a ser sorprendido por la faccion de Cabrera, y el Serrado que se hallava en Chelva á distancia de siete leguas habiendo vatido una columna de Urbanos, y tropa, cuyos restos habia entrado ya en esta Poblacion á las ordenes del Teniente Coronel mayor de Caballeria D. Adrian Jacome, que se disponia partir al ámanecer del dir siguiente: Oue la entrada de la tropa en retirada habia ámortiguado vastante el espiritu publico habia escasez de municiones, y expecialmente cartucheria de esc hira á dar la orden para que se presenten todas las que habia en el Pueblo para armar con éllas los Urbanos y serian inutiles si no habia cartuchos de su calibre que hera preciso fabricar inmediatamente recogiendo para éllo el Plomo; y polvora que se hallase: Que á demas seria preciso formar aspilleras, cerrar las entradas del Pueblo con maderas, y ponerlo en estado de defensa; contando para éllo con el [Sor.] Comandante de Armas y el de los venemeritos Urbanos y con la inteligencia en este punto de los S. S. Militares Retirados en esta Villa. Y ohido todo por los S. S. que componen la Corporacion, conociendo lo critico de las circunstancias, combinieron en las medidas premeditadas por el [Sor.] Presidente y acordaron que á demas de los Propios que ya habian salido dirigidos por dicho Señor á los Pueblos de la Subdelegacion de Policia y del Partido Judici para que se prepur este punto de los S. S. Militares retirados en esta Villa. Y ohido todo por los S. S. que componen la Corporacion, conociendo lo critico de las circunstancias, combinieron en las medidas premeditadas por el [Sor.] Presidente y acordaron que á demas de los Propios que ya havian salido dirigidos por [dicho] Señor."

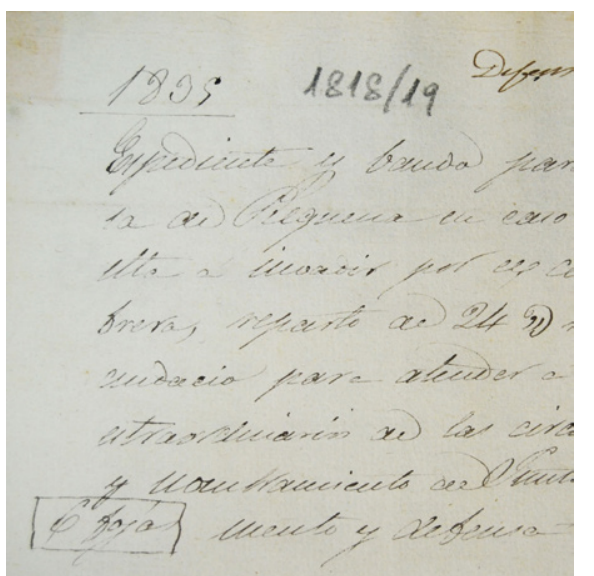

Fig. 875 .

Transcripción 3: Expediente y bando de la defensa de Requena en caso de ser vuelta a invadir por la cabecilla Cabrera y nombramiento de la Junta de armamento y defensa, Requena, 1835/09/18, AMR, 1818/19 E.

(Transcripción de la autora)

"Expediente y bando para la defensa de Requena en caso de ser buelta a invadir por el cabecilla Cabrera, reparto de 24 reales del vecindario para atender á los gastos estraordinarios de las circunstancias, y nombramiento de la Junta de armamento y defensa.

Concejo avierto

En la villa de Requena á diez y ocho de Setiembre de mil ochocientos treinta y cinco; la virtud de citacion se congregaron en la Sala Capitular, El Señor Corregidor de la misma, los Yndividuos del [IItre.] Ayuntamiento, El Señor D. Domingo [Omlin] comandante de armas de este canton. D. Gregorio Tena que lo es del Batallon de Urbanos, D. Iuan Antonio Ponce Abad del Cavildo [secol, varios de los oficiales de [dicho] Batallon, D. Pedro Jose de Croz, D. Jose Garcia Ibañez, D. Santiago Montes y otros diferentes vecinos para tratar en concejo abierto lo que deba adoptarse en las criticas y apuradas Santiago Montes y otros diferentes vecinos para tratar en concejo abierto lo que deba adoptarse en las criticas y apuradas
circunstancias de haber penetrado en esta Provincia desde la de Aragon, por el Partido de Moya segun los abisos recibidos una faccion revelde de mil infantes y cien caballos, mandada por el Cabecilla Cabrera, y que se asegura haber llegado ya al Pueblo de Aliaguilla; cuya direccion puede sea hacia esta de Requena, y presencia de las disposiciones tomadas por el [Ayuntamiento], Señor [Comandante] de armas y algunos vecinos auxiliares, que son haber oficiado a los Pueblos del Valle de Cofrentes, al Señor Comande del Canton Militar de Buñol, a las autoridades superiores de esta Provincia para el asedio de esta Villa caso de ser atacada estarse cortando las entradas de la misma; y ejecutandose otra disposicion de pevencion y defensa, atenta lo ollortad general del vecindario y su venemerita Milicia Urbana, on a los enemigos de [muestrus] Liberta des Patrias y Gobierno legitimo de S. M. La Reyna N. Sra, despues de haber conferenciado detenidamente sobre todos estos puntos acordaron asegurar por todos medios la defensa de toda poblacion contra los invasores de la Faccion revelde a la que por su numero debe y puede resistir este heroico vecindario, al que se le anuncia la proximidad de ella, y que por primera prevencion a la defensa, ningun vecino cabeza de familia y barones desde la edad de diez y seis años abandone su casa y domicilio, vaxo la pena de reputarse infiel, y de confiscacion de Bienes, destierro y demas a que diere lugar por circunstancias agrabantes de su fuga: Que caso de acercarse la Faccion á querer imbadir y hostilizar esta Poblacion, todos los vecinos anteriormente citados, cada uno destro de su Casa á puerta cerrada y tronera á ventana abierta, haga defensa particular con armas ó cualquiera instrumento ofensibo que tubiere á la mano, hostilizando al enemigo al transito o entrada en su propia calle, seguro el vecindario que la fuerza armada de la Milicin Urbana con otras auxiliares que se esperan asistiŕ al [socorrol en todos los puntos que se hiciese necesario: Asimismo y para atender á cuanto concierna al sosten de esta Poblacion en las presentes circunstancias, proveer lo necesario a su defensa armamento del vecindario, articulos de [voca] y Guerra, metalico y demas correspondte., acordaron el establecer Junta de Armamento y defensa, y a su virtud fueron nombredos por Presidente de ella el Señor Corregidor, Vice presidente el Señor D. Domingo Omlin [Comandante] Militar del Cantón, y 
por individuo el Regidor Don Jose Pardo de [Lacarta], el Sindico General D. Miguel Trigo, El Comandante del Batallon de esta Milicia Urbana, D. Gregorio Tena y los vecinos y oficiales D. Pedro Jose de Cros D. José Garcia Ybañez, Manuel Lopez, Don Santiago Montes, D. José Matres, D. Yldefonso Erbella, D. Juan Garcia del Castañar y D. Gregorio Cañete á quienes autorizan con todas las froutades necessins para el desemperio de su cometido. $Y$ con presencia de los muchos gastos que se estru con y para sostener las fuerzas auxiliares que se espera, [igualmente] la Venemerita Milicia Urbana de esta Villa que toda se halla sobre las armas en Servicio extraordinario, y no habiendo ningun fondo publico de que echar mano acordaron que vaxo calidad de reintegro, bien por su parte en todo el vecindario, y o como resuelva SM, se reuna la Cantidad de diez siete mil $r$. con corta diferencia, que adelantaran los vecinos mas pudientes y que tengan mayor proporcion de metalico, Juicio Prudente de la junta, nombrando por depositario de este fondo y cualquiera otro que se recuerde o destine al mismo obgeto al D. Jose Garcia Ybañez, quien satisfará los Libramientos que se le espidan, firmados por la Junta o parte de ella segun las circunstancias lo permitan, pues siendo el que acaba de acordarse de obrar contra la Faccion revelde enemiga del y particular, exige cuantos sacrificios esten al alcanze de este vecindario, y firman el Señor Presidente y algunos de los concurrentes en obsequio de la brevedad doy fe.

Eugenio Rufino Hernandez".

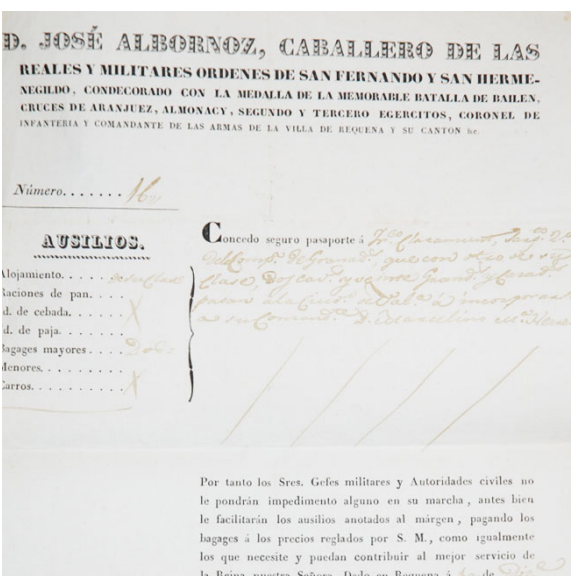

Fig. 876.

Transcripción 4: Pasaporte concedido por el comandante del cantón de Requena, D. José Ruiz de Albornoz, a Francisco Claramunt, sargento segundo de la compañía de granaderos, para que pase a Valencia al frente de una partida de granaderos y cazadores escoltando una carga de fusiles y municiones, Requena, 1835/12/10, AMR, 4734/2 (Transcripción de AMR).

"D. José Albornoz, caballero de las reales y militares órdenes de San Fernando y San Hermenegildo, condecorado con la medalla de la memorable batalla de Bailén, cruces de Aranjuez, Almonacy, segundo y tercero egércitos, coronel de infantería y comandante de las armas de la villa de Requena y su can tón etcétera.

Número 16.

Ausilios:

Alojamiento: de su clase

Raciones de pan: $\mathrm{X}$

Id. de cebada: $X$

Id. de paja: $X$

Bagages mayores: dos.

Menores: $X$.

Carros: X.

Concedo seguro pasaporte a Francisco Claramunt, sargento $2^{\circ}$ de la compañía de granaderos que con otro de su clase, dos cavos y veinte granaderos y cazadores pasan a la ciudad de Valencia á incorporarse a su comandante D. Marcelino María Herrero.

Por tanto los Sres. Gefes militares y Autoridades civiles no le pondrán impedimento alguno en su marcha, pagando los bagages álos precios reglados por S.M., como igualmente los que necesite y puedan contribuir al mejor servicio de la Reina nuestra Señora. Dado en Requena a 10 de diziembre de 1835.

El Coronel Comandante José Albornoz [rúbrica].

Por mandado de S.S. Jacinto Penén y Penén secretario [firma y rúbrica] Gratis. $=$ Valga por el tiempo necesario

..... -

Relación de los individuos granaderos y cazadores con espresión de clases que an conpuesto la partida que a mis órdenes a pasado a la ciudad de Valencia para escoltar las municiones y fusiles que se le an entregado por aquella Capitanía General al capitán de granaderos y comandante accidental de dicho batallón D. Marcelino $M^{a}$ Herrero de quien e percivido los aberes correspondientes en los seis días que emos inbertido en la marcha para la he llebado pasaporte del coronel comandante del cantón. 
Clases

Sargento $2^{\circ}$

Otro id.

Cabo $1^{\circ}$

Otro id

Otro $2^{\circ}$

Granaderos

Cazadores
José Sierra

Mauricio López

Juan Nicolás Garcí

Francisco Sánchez

José Caballos

Ramón Burgos

Sebero Sisto

Rumaldo Caballos

Manuel López

Balentín García Ibáñez

Nicolás Alcocer

Julián García Leonardo

Jose Carrasco

narde 5 t.

Remijio García

Simón Yranzo

Francisco Yranzo

Mariano Huerta

Elías Jiménez

Antonio Morell

Pedro Juan Sosa

Genaro López

Requena 16 Diciembre de 1835

$V^{\circ} B^{o}$ Marcelino María Herrero [firma y rúbrica]

Francisco Claramunt [firma y rúbrica]".

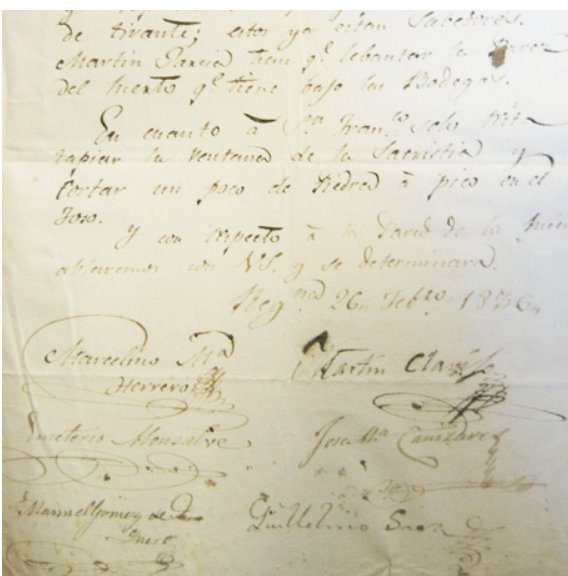

iig. 877

Transcripción 5: Medidas de fortificación: Comisión del 26 de febrero de 1836, en la que el maestro de obras Guillermo Saez verifica el estado de las obras y cuánto resta por concluir de la fortificación de Requena junto a una Comisión del Ayuntamiento, Requena, 1836/02/26, AMR, 1818/53 (Transcripción de la autora).

"[Ebacuando] la Comision y VSS. se sirbio [Cañete] á nuestro examen de [que] esaminaremos las obras de Fortificacion, que las demas, y fat tas que encontraremos de las [que] hubiese aun [que] hazer. Dimos principio ayer y hemos sido acompañados de una comision de este [Iltre.] [Ayuntamiento] compuesta de los [Req.] [Don] Martin Clavijo y [Don] José Cañizares, y de su resultado pasamos á manifestar [por] su [orden], tanto del que deve seguirse en la obra, poniendo las mas hurjentes delante y [que] pertenezcan a [ $C^{\circ}$.] Publico ó Ayuntamto., como á vecinos en particular, que tendran su [reparácion], y en cuanto á los que han quebrantado la [orden] desaciendo obras y abriendo puertas [acompañanlos] nota de ellos.

Primetamte. deve fijarse un bando [para] que se limpien todos los parapetos por los dueños de los pedazos y huertos.

Obras [que] pertenecen á la Villa. Lebantar la pared del huerto de Parra que mira á Reinas, y esta á la derecha de la Puerta. Lebantar dos Espaldones de $8 v$. de largo y Tres de altura en el Pedazo de los muertos, y componer, aspillerar y bardar la pared de dicho Pedazo [que] mira á Reinas. Hazer en el Pozo de la Nibe, y Fortin de [Isabel] $2^{a}$ los reparos que necesita y abrir el Camino Cubierto [que] deve serbir [para] la comunicacion entre ambos. Aspillerar y fortificar la Casa del Tinte en el Camino de [San] Agustin.

Hacer mas aspilleras en la pared [que] mira al Camino de los asnos y es en la [que] hay entre la Posada y huerto de las Monjas, aspillerar la Pared de [Don] Diego Montes en el huerto, mirando á los molinos.

Hazer una puerta Fuerte [para] la entrada en la Fuente del Peral [que] solo se pondrá en caso necesario.

Hacer seis aspilleras en la pared inmediato á la Puerta de Cantarranas.

En la pared del huerto de Fernandez que mira á Reinas un Foso.

Cortar en la puerta de las higuerillas tres baras de pared de la [que] hay entre el Camino y los huertos y se une con la de la Puerta y Componer dos o tres portillos [que] ay en los huertos inmediatos.

Hazer en el Batanejo mirando á la Olleria un poco parapeto [quel falta.

Y componer un poco las paredes del pretil de Sanchez y de Carcel en el Batanejo.

Obras [que] corresponden a Particulares

Eugenio Mas tiene [que] lebantar las paredes de su corral y lo mismo Gabriel Justo.

[Don] Jose Carcel reforzar la Puerta de la Huerta de abajo del Batanejo, y componer un portillo en la de arriba [inmediato] álas Piezas.

Igualmente tiene [que] fortalezer la puerta de la huerta [que] pose bajo los huertos.

[Don] Jose Fernandez lebantar la Pared del huerto [que] mira á Reinas.

Las casas que miran á Reinas y tienen puerta al campo y son [Don] Nicolas Perez, Las [Bobas], Anselmo Biana, y Juan Ant ${ }^{\circ}$ Monsalve, ó tienen que tapiarlas con [ripio] y piedra, ó hazerlas de tirante; estos ya estan sabedores.

Martin Garcia tiene [que] lebantar la parez del huerto [que] tiene bajo las Bodegas. 
En cuanto á [San] [Francisco] solo resta tapiar la ventana de la sacristia y cortar un poco de Piedra á pico en el

$Y$ con respecto á la Pared de la huerta ablaremos con VS. y se determinara. [Requena] 26 [Febrero] 1836

Marcelino $M^{a}$ Herrero

Martín Clavijo

Emeterio Monsalve

Jose $M^{a}$ Cañizares

Manuel Gomez de [Ilegible]

Guillermo Saez".

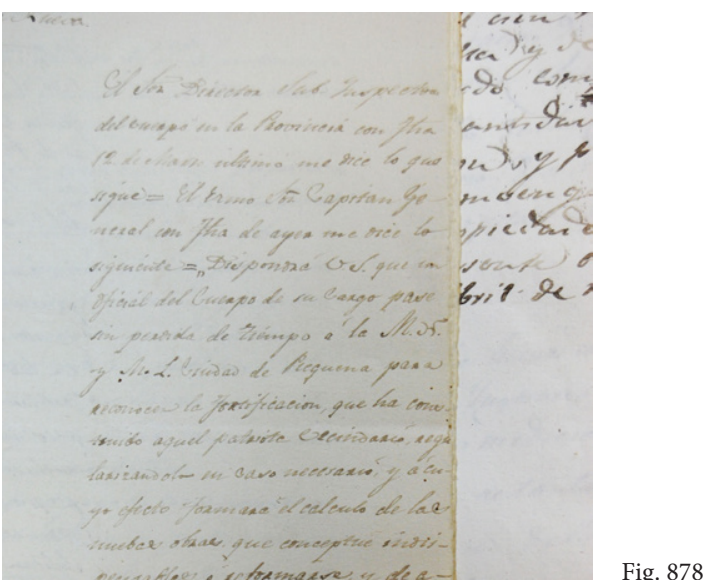

Transcripción 6: Comisión de servicios del ingeniero Ortiz de Pinedo, Requena, 1837/03/12, AMR, $1818 / 16$.

(Transcripción de la autora).

\section{(pág. 4)}

$[\ldots]$

"El sr. Director Sub Inspector del Cuerpo en la Provincia con fecha 12 de Marzo útlimo [1837] me dice lo que sigue = El Excmo. Sr. Capitán General con fecha de ayer me dice lo siguiente $=$ Dispondrá V. E. que un oficial del Cuerpo de su cargo pase sin perdida de tiempo a la M. H. y M. I. Ciudad de Requena Ciudad de Requena para reconocer la fortificación, que ha construido aquel patriota vecindario, regularizándola en caso necesario y a cuyo efecto formara el calculo de las nuevas obras que conceptue indispensables o reformara y de acuerdo con el Ayuntamiento, a quien toca proveer los fondos, procederá a la ejecución, levantando el croquis y estendiendo la memoria de defensa que pasara a mis manos a la mayor brevedad = lo que transcribo a $V$. a fin de que proceda a la ejecución de lo que Excmo Sr. [...]

\section{(pág. 5) (copia del anterior)}

Cuerpo Nacional de Ingenieros P. M. de Castilla la Nuevo

El sr. Director Sub Inspector del Cuerpo en la Provincia con fecha 12 de Marzo útlimo [1837] me dice lo que sigue $=E l$ Excmo. Sr. Capitán General con fecha de ayer me dice lo siguiente $=$ Dispondrá $V$. E. que un oficial del Cuerpo de su cargo pase sin perdida de tiempo a la M. H. y M. I. Ciudad de Requena Ciudad de Requena para reconocer la fortificación, que ha construido aquel patriota vecindario, regularizándola en caso necesario y a cuyo efecto formara el calculo de las nuevas obras que conceptue indispensables o reformara y de acuerdo con el Ayuntamiento, a quien toca proveer los fondos, procederá a la ejecución, levantando el croquis y estendiendo la memoria de defensa que pasara a mis manos a la mayor brevedad = lo que transcribo a $V$. a fin de que proceda a la ejecución de lo que Excmo Sr. [...]

(pág. 6)

Cuerpo Nacional de Ingenieros P. M. de Castilla la Nueva

Instrucción para el comisionario del Y. Ayuntamiento como estracto mas esencial de sus obligaciones en al ordenanza de Ingenieros.

Art 1 Como comisario estará a su cargo proporcionar los trabajadores y materiales y será un fiscal económico en la calidad, precios y sueldos.

$2^{\circ}$ Inspeccionará el número de trabajadores, pasándoles lista cuando le pareciese y despedirá los que fuesen desechados por el ingeniero.

3o Recibirá del sobrestante un parte diario del número de trabajadores que hayan comenzado las obras con espacios de sus jornales, materiales recibidos y sus valores.

$4^{\circ}$ Estará a su cargo el pago de trabajadores y materiales que certificará en publico con asistencia del ingeniero y demás empleados los domingos a la hora oportuna. 
$5^{\circ}$. Formará relación semanal del importe de jornales y materiales, a cuyo pie certificará el ingeniero en virtud de la cual se librará el pago correspondido en el artículo $4^{\circ}$.

Requena 12 de abril de 1837

\section{Pedro Ortiz de Pinedo}

\section{(pág. 7)}

Capitán General dispone y en los términos que lo previene para cuya operación pido al Excmo. Sr. citado el correspondiente pasaporte $=[$ formula de despedida] Dios que a O. m... Madrid 12 de marzo de 1837= [ilegible] $=S r$. D. Pedro Ortiz de Pinedo Capitán del Cuerpo de Ingenieros.

En cumplimiento de la orden que precede incluyo a V. S. I. el presupuesto del gasto a que podrían ascender las obras que creo necesario reformar o construir de nuevo no comprendiendo el otro presupuesto la conclusión de la Batería de Reinas por que esta obra, según se me ha informado, la costea la Comandancia Militar, ni tampoco el cerramiento por concluir en algunos esta obra, segun se me ha informado, la costea la Comandancia Militar, ni tampoco el cerramiento por concluir en algunos
parages desde el Molino de Valero o el Balson, pues que también se me ha informado costean estas obras algunos particulares. parages desde el Molino de Valero o el Balson, pues que también se me ha informado costean estas obras algunos particulares.
$V$. S. I. con presencia de otro presupuesto se tendrían ... los fondos trabajadores y materiales de que se pueden disponer para proceder a la ejecución de estas obras.

\section{(pág. 8) (copia de la página 6$)$}

Copia de la página 6

\section{(pág. 9 )}

inbrando un comisionado que ejerza las funciones de Comisario de Guerra para el que incluye a V. S. I. una instrucción de sus obligaciones principales señaladas en la ordenanza de Ingenieros. Asimismo se ... V. S. I. nombrar un Maestro Mayor y un sobreestante con las dotaciones que estimasen oportunas.

Debo manifestar a V. S. O. que al formar el presupuesto he tenido presente las obras ya egecutadas, los esfuerzos en gasto, que para ellas ha hecho este vecindario, su noble unida y decidida voluntad de defensa, como asimismo la calidad de las [partidas] facciosas que pueden atacarla. Estos datos me han concretado a las obras propuestas, mas si V. S. I. determinase otras mayores, me toca solo la ejecucion y disposicion en conformidad a su aviso, como a todo lo demas en que puedan... útil mi señor en cumplimiento de mi deber.

(pág. 10)

Pie de página: Sr Presidente y Srs. Vocales del Itre.. Ayuntamiento de la M. H. y M. I. ciudad de Requena.

\section{(pág. 11)}

Que si V. I. I. [ilegible]

Requena 12 de abril de 1837

Pedro Ortiz de Pinedo

\section{(pág. 12)}

Los Srs. D. Marcelino Herrero Sindico Procurador, D. Pedro Ant ${ }^{\circ}$ [Monsalve] Dn. Vicente Perez Regidores de este Ytre. Ayunt $t^{\circ}$ y comisionados por el para la medición y tasación de una casa ruinosa y parte de su huerto contiguo situado en la Glorieta y que por acuerdo de otra corporación deben ocuparse para la fortificación previo dictamen de el Ingeniero Comisionado por el Excm, Sr. Capitan General para la modificación de las defensas:

Certificamos que hoy dia de la fecha hemos concurrido al expresado sitio con asistencia del citado ingeniero y perito por parte del Dueño y verificada la medición y tasación ha resultado tener la casa el valor de cinco mil cien reales de vellón y el huerto un cuarto de. y de valor mil cincuenta reales de vellón que en todo componen seis mil ciento cincuenta reales de vellón, cantidad abonada al dueño Alonso Gavaldon... en ests casos damos la presente en Requena a veinte y tres de Abril de mil ochocientos treinta y siete.

Con mi intervención

El ingeniero comisionado (pág. 13)

SELLO DE OFICIO

ISABEL 2 P L G DIOS REYNA DE ESP Y DE LAS IND 1837

4 MRS. AÑ 1837

Habilitado. Publicada la Conts[titución] en 19 de agosto de 183[6]

D. Vicente Perez, D. Marcelino Maria Herrero y D. Pedro Antonio Monsalve, Regidor y Sindicos del I. Ayuntamiento de esta ciudad de Requena y comisionados por el mismo para la medición y tasación de una parte de huerto a las espaldas de la Calle de San Agustín extramuros de esta ciudad y que por acuerdo de otra corporación de ocuparse para la fortificación, previo dictamen del ingeniero comisionado por el Excmo. Señor Capitán general para la modificación de las defensas

Certificamos: que hoy dia de la fecha hemos concurrido al expresdao sitio con asistencia del citado ingeniero y perito por parte del dueño y verificada la medición y tasación, ha resultado ser un octavo de [taula] de tierra regadía, la que debe ocuparse de la pertenencia de Don Manuel [apellido ilegible] y su valor quinientos veinte y cinco Reales de Vellón que deben abonársele. Y para que pueda reclamarlo donde le corresponda según Real Orden sobre reconocimiento de propiedad y en estos casos damos la presente en Requena a veinte y tres de abril de

(pág. 14)

mil ochocientos treinta y siete.

Vicente Perez, Marcelino $M^{a}$ Herrero, Pedro Antonio Monsalve Con mi interv.: El ingo comisionado Pedro Ortiz de Pinedo".

\section{(pág. 15, 16, 17, 18)}

Copia del anterior. 


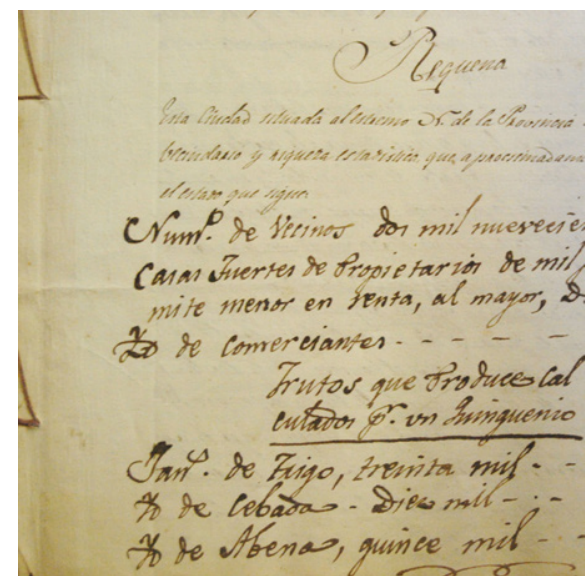

Fig. 879

Transcripción 7: Expediente y bando de la defensa de Requena en caso de ser vuelta a invadir po la cabecilla Cabrera y nombramiento de la Junta de armamento y defensa, Requena, 1835/09/18, AMR, 1818/19 E.

(Transcripción de la autora)

(Pág. 1)

“Cuerpo Nacional de Ingenieros. Memoria Militar de Requena. Año de 1837.

\section{Excmo Señor.}

En cumplimiento de la orden de V. E. de 11 de marzo ultimo he llegado a este punto el ocho del mes actual y reconocida sus defensas me parece puede convenir al servicio adelantar a $V$. E. este escrito pues aunque $V$. E. me previno levantase el croquis como el ejecutarlo exige unos tiempos y es reciente la ogeada militar de $V$. E. en la ciudad de que voy a hablar puede suplirse aquel interin le remito a $V$. E. como prueba de mi aserción debería acompañarlo ahora, pero precede la razón de no hacerlo.

Requena

Esta ciudad situada al extremo $N$. de la Provincia consta de un vecindario y riqueza estadística que aproximadamente manifiesta el estado que sigue:

Número de vecinos, dos mil novecientos 2900 [aprox. 11.600 habitantes]

Casas fuertes de propietarios de mil pesos límite menor en renta, al mayor 12

Id de comerciantes 12

\{Frutos que produce calculados por un quinquenio\}

Fanegas de trigo, treinta mil $\quad 30.000$

Id. de cebada, diez mil $\quad 10.000$

Id. de abena, quince mil $\quad 15.000$

(pág. 2)

Id. de maiz mil $\quad 1.000$

Id de judías mil $\quad 1.000$

Arrobas de criadillas (patatas), cien mil 100.000

En líquidos

Arrobas de vino cien mil........................... 100.000

Id. de aguardiente tres mil.........................

Id de aceite que apenas lo permite el pais treinta 30
Sedas Manufacturadas

Se elaboraban libras castellanas, cuarenta mil

Id al presentey por el estado de la Guerra solo

12.000

El carácter de sus naturales es dócil, franco y fuerte y en ellos se descubre y han dado pruebas evidentes en la historia antigua y presente de espíritu de heroísmo y amor a la libertad de su Patria; así lo prueban hoy el que esta ciudad fue atacada el dia veinte de Setiembre del año treinta y cinco por la facción de Cabrera, cuando apenos estaba formada la Guardia Nacional, y cuando sus calles abiertas presentaba por to y ligera vastaron á defender este suelo de la citada facción, causando perdida en su empeño de ollar á estos habitantes.

Desde este momento emprendieron estos habitantes su fortificación, y al mirar su linea extensa, admira á la verdad, que una Ciudad sin Arbitrios municipales de comunidad, y sin auxilios algunos del Gobierno, haya podido cerrarse con obras continuas que á calcular su coste pasarin de 30.000 duros; comprar cañones y hacerse con medios de defensa con los que mil ochocientos treinta y seis, el honroso titulo de M. N y M.L ciudad de Requena que S. M. les ha dispensado. V. E. mismo en su corta permanencia es el mejor testigo en apoyo de que... que sin diferencia de secso [sexo] hay entusiasmo varonil y heroico hasta en los niños y mujeres llegando a ser ya sin...

(pág. 3)

la presencia de las facciones del vajo Aragón, cual ha sido el dia diez y seis de Marzo proximo pasado ultima correria que ha motivado operaciones Militares dirigidas por $V$. E. en persona.

Se puede decir pues (y V. E. me dispensará un leguaje franco) que esta ciudad todo lo debe a si misma, pues que distando veinte y cuatro leguas de su capital no ha podido recibir de esta socorro oportunamente ya por la distancia y ya porque en esta capital no había fuerzas suficientes con que socorrerla. La residencia de V. E. casi a doble distancia y que no siempre la Capitania General de Madrid haya estado ... en tropas ni escasa en atenciones; han hecho como efecto inevitable el que esta ciudad en sus apuros haya estado abandonada a sus propias fuerzas.

Las mismas razones me parecen sobrado fundamento para que $V$. E. fige su seguridad de modo que no ecsija si la guerra no toma carácter mas grave, clamores de favor y protección militar y creo que V. E. tendrá un placer en hacerlo asi; sin que cause estorbo a su voluntad ni grandes recursos ni excesivos gastos.

Sus defensas aunque no construidas con la solidez que requiere la resistencia al tiempo, pues consisten en tapias de tierra aspillerada y paredes a piedra baxo revocadas de hieso, su dispuesta es sin desperdiciar de provecho al efecto del fusil, son suficientes al estado actual, atendida la calidad de las facciones, que se le pueden presentar como procedentes de Aragon y a la fuerza queda a este vecindario su voluntad unida y noble emulación en los casos de peligro.

El adjunto presupuesto que en cumplimiento de la orden de V. E. he pasado a este Itre. Ayuntamiento a doce del actual cuya copia incluyo a $V$. E. me parece manifestar que las obras construidas por esta ciudad exigen poca modificación en su forma y la resolución del citado Ayuntamiento...

(Pág. 4)

dictará según sus deseos y medios la ejecución de ellas o de nuevas quedando en dar a V. E. conocimiento de lo uno o lo otro. Habiendo recibido esta ciudad algunos medios militares de la Capitania General de Valencia, incluyo a V. E. el adjunto estado de artillería y municiones que hoy tienen ya compradas a costa de la Población o remitidas de Valencia.

Las inmediaciones de la Ciudad son despejadas pues no hay a distancia inmediata altura de dominación capital, pero tiene contra si el que desde la linea de defensa y por todo su perimetro se presenta el terreno en anfiteatro, al Este en descenso y al Oeste en ascenso, cuyos anfiteatros los forman ormas ó cejas mas ó menos altas de las heredades, corriendo al noreste el arroyo que llaman de las Ollerias, bastante profundo en su [Madre]. Esta disposición del terreno exige como arma exclusiva el Obús. Las defensas de esta ciudad son contra el fusil y los cañones que tienen obrarían bien contra zapas o masas descubiertas: lo primero es regular no suceda y de lo segundo tendrá cuidado el enemigo de precaverse, ocultandose en las quiebras del terreno aun dentro del tiro de fusil, así lo verificó Gomez, cuyo ejemplo hizo conocer a la generalidad de estos habitantes la necesidad del proyectil curvo. Entonces reclamaron de S. M. un obús, y S. M. se lo concedió mandando a su Cap. General de Valencia se lo remitiese, mas no se ha verificado aun. Esta arma es tanto mas necesaria cuanto que produce a disminución de carga igual efecto en el proyectil que arroja, calidad que no corresponde el cañon, siendo aquel aun de mejor efecto de la metralla que este. 
(pág. 5)

resultado de mi reconocimiento, considero necesarios tres, uno situado en el Pozo de la Nieve; otro en la casa titulada de Nuebalos: y otro en el Molino de Valero: de este modo estarian vatidas eficazmente las quiebras de todo su circuito, y su efecto unido al del cañón harán una acción activa sobre cualquiera punto en que el enemigo se presente.

Bien quisiera al hablar a V. E.. presentarle la demostración del terreno para que juzgase de mi elección y de la necesidad de esta arma; pero no lo puedo hacer todo a la vez ni podría remitir todos los documentos al mismo tiempo sin que los primero esperasen a el ultimo. V. E. ha visto el punto: esto puede suplir el croquis pues ahora y yo confio en que V. E. se persuadir de que lo que mas necesario para esta ciudad, descansada en varias consideraciones militares, que para ello he tenido presentes y que no habiendo sido prodigo en pedir, como lo prueban documentos que existen en la Capitanía General del cargo de $V$. E. en otras comisiones de igual naturaleza, no lo será en esta.

Dotar a las poblaciones en defensa al fusil del arma del obús será espuesto cayendo en sus manos del enemigo porque su efecto es mas virtual que el del cañon, pero también seria... espuesto el que este cayese en su poder; pero hay un elemento para desechar recelos en esta ciudad. Esta consideración ... seria de influencia en una ciudad dividida en su opinión de un carácter tibio y de poca disposición a la defensa, ... el jefe militar que la dirigiese tendría que tener dentro y fuera, asi sucede en las guerras de Conquista y particularmente en las civiles. Mas Requena no es así si llegase a perder sus armas gruesas, se perdería ella misma en su totalidad después de esfuerzos que ocuparia en la historia militar igual lugar a los de Zaragoza, y ya en otra ocasión la he citado como comparación de la distancia que hay en los sucesos cuando hay o no buena voluntad de

\section{(pág. 6)}

defenderse, así pues... que ningun... puede detener a V. E. en dotar a esta ciudad ... obuses de cnco y... pulgadas por las razones que he espuesto anteriormente y porque parece natural no negar a esta ciudad cuanto necesite para defenderse puesque en ello también hay utilidad del servicio como he indicado anteriormente y como me parece demostrar mi seguridad. Cuenca spolo tiene y aun escasamente las tropas necesarias para su defensa, mal puede pues su comandante general... con oportunidad y fuerza en socorro de Requena y mucho menos si este socorro ha de venir de Madrid cada vez que las facciones se presenten en ella, pues que estas aparecen inopinadamente o partiendo de distancia menor: la situación de este punto la experiencia me parece demuestran esta verdad y la necesidad de que Requena esta asegurada de modo que no de cuidado $a V$. E. aun cuando las facciones se presenten en sus inmediaciones. Descansar en el socorro que podrian dar las columnas de Valencia es my aventurado pues que dividiéndose las facciones con frecuencia, llegando a amenazar Valencia, podra suceder que se hallen ocupadas en atención de su misma Provincia o Capital sin que puedan por ello atender a esta ciudad. El estenso perimetro de esta ciudad accesible casi en todo el hace preciso que la gente de acción que lo defienda sea la sufmantener algunas compañias de tiradores, que la molesten, mantengan en vigilancia continua la Guarnicion, y que aprovechándose de su insomnio y cansancio pudieran aventurar una masa a penetrar en las calles asaltando a sus defensores no considero que lleguen a este extremo, pues que en las calles encontraran su...

\section{(pág. 7)}

principal dificultad, pero aun cuando no sea probable es necesario impedir este suceso.

La fuerza que hoy existe en esta ciudad consiste en 800 Guardias Nacionales de Infanteria, de 30 a 40 de Caballería y dos Compañias de Movilizados con 200 hombres; en todo 1000 infantes y 30 caballos. Esta fuerza me parece, Excmo. Sr. juzgara $V$. E. escasa para defender un recinto que se aproxima a 5000 varas de estensión, faltandoles aun mas de 200 fusiles, así pues considero que la fuerza necesaria a la defensa es la que manifiesta la distribución de puestos que sigue: Puestos $N^{\circ}$ de hombres

De Reinas a la Batería de Isabel $2^{a}$........................ 150 De esta á la de la Nieve

De esta á la Puerta de S. Francisco.............................. 80

De esta á la de Madrid............................................. 120

Casa del Tinte

De la Puerta de Madrid á la de

El Angel..............................................................

Torreon de la Montejana.................................................... 10

De aquí a la Puerta de Alcalá.................................... 20
De esta al Batanejo

De esta á la Puerta de Valencia

De Reynas al Balson........ 60

De esté á las Higuerillas .

De esté ála Puerta del Trillero.

De esta al Tirador......................................... 40

De este a la Puerta de Valencia

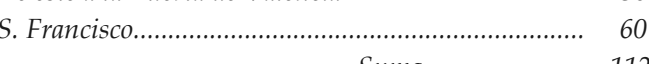

Reservas

Suma.

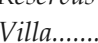

100

Plaza de la Constitución .100

S. Sebastián.

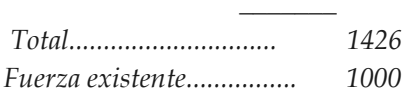

Faltan para el estado de buena defensa 426

y tanto más necesarios cuanto que hay algunas obras aun pendientes. El armamento a lo que ecsiste es dotación que $V$. E. hara. Si lo estima conveniente al servicio; yo lo considero asi y añado de razón.

Si requena tuviese la fuerza del estado y se hallase establecida

(pág. 8)

a columna de operaciones conveniente a Moya, aquella se daría bien la mano con las fuerzas de esta, e impedirirían que tan a salvo, como algunas veces lo han verificado, penetrasen en la provincia de Cuenca las despreciables facciones de .. Peinado, Arcipreste y secciones en corta fuerza de las de Aragon devastando yafligiendo muchas Poblaciones y teniendo fusiles. De esta conveniencia al servicio juzgará V. E. mejor.

Esta ciudad tiene dos cañones de a ocho y cuatro de a cuatro; estos de hierro montados sobre cureñas de batalla construidas a expensas de esta ciudad...dos armones; piezas que por si solas exigen para su mejor conservación y cuidado estar en manos de Artilleros de Plaza. Solo resisten cuntro hombres y un cabo de esta arma, y aunque se hayan servido las piezas por artilleros de la guardia nacional

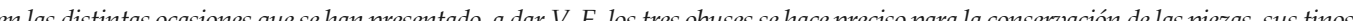
y juegos de armas mayor dotación de artilleros que yo considero en un oficial y veinte hombres, atendido haberlos en la Guardia Nacional pero que estos como artesanos no pueden dedicar a la conservación de las piezas y demás servicios que estas exigen: a si mismo me parece conveniente que en una ciudad tan espuesta en las correrías de las facciones no haya artillería de hierro cuyos defectos y esposicion son mejor conocidos de V. E. y mucho mas cuando se tienen constantemente al aire libre: su remplazo con los de bronce seria conveniente, remitiendo estos a punto cuya acción sea menos probable por su situación mas distante de la esfera de operaciones que han indicado hasta ahora las correrias de las facciones: esto en mi entender tiene otra ventaja y es la facilidad y oportunidad con que una columna ... podría tomarlos en caso necesario con buen efecto en sus operaciones. V. E. juzzara de esta reflexión si la...

(pág. 9)

halla arreglada pues que no me aparto de repetir que mi juicio considera como mas necesario dejar a Requena en seguridad como sin el socorro inmediato de columnas volantes.

Esta población tiene al Sur oeste y a la distancia de el exConvento de S. Francisco bien fortificado, también a espensas de la población sirve de Hospital militar, y este punto... si bien lo es sobrado contra la arma del fusil, tiene el defecto de estar fuera de la población, convirtiéndose por ello el efecto de reducto de seguridad en el de fuerte destacado; aunque también impide la quieta ocupación de la loma y produce algun fuego de espalda a los asaltantes de algunos defensores.

Precisamos en esta memoria de hablar del detalle de defensa de la población por no haber en ella punto con ventajas determinadas de ataque, pues casi todo es accesible, sus calles anchas y de piso fácil, la determinación de ataque determinara al jefe a los habitantes de esta ciudad, que como segundo recinto tiene cerrada en sus avenidas la villa, parte vieja de la ciudad, que abundante en frutas y aguas ofrece la ocasión de suficiente alimento durante el sitio, cuya duración nadie puede fijar en una población grande y que ha tirado el guante para defenderse" 


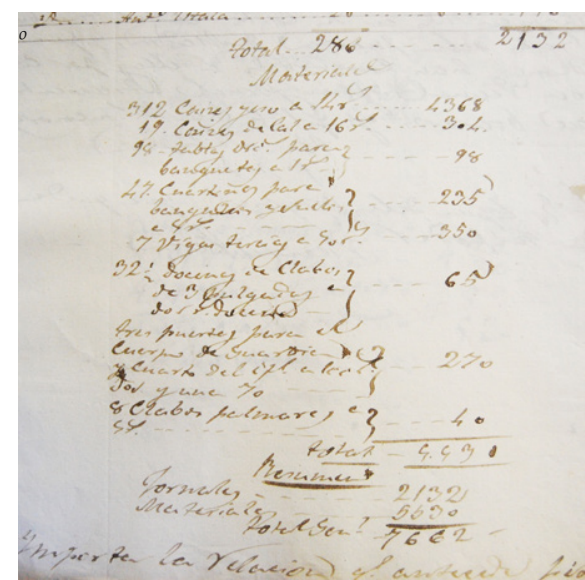

Fig. 880 .

Transcripción 8: Certificaciones de Ortiz de Pinedo sobre las varas, jornales, materiales y precios de las obras de reedificación de la fortificación de Requena Requena, 1837/05/30, AMR, 1818/34E

(Transcripción de la autora)

"Copia de [Certificación] de los Ingenieros que estubieron encargados de la direccion de las obras de [fortificacion], [que] acreditan las varas de longitud que esta tiene; $y$ otros papeles sobre el mismo

\section{Cuerpo [Nacional] de [Ingenieros]}

\section{Fortificacion}

Relacion de los travajadores que han asistido a las obras en el dia de la [citada], con espresion de sus jornales y materiales recividos.

\begin{tabular}{|c|c|c|c|c|}
\hline Clases & Nombres & Jornales & Valor & Rn. Yn. \\
\hline [Alante] & Alonso Martinez & 26 & $a 11 r$ & 286 \\
\hline$Y d$. & Manuel Perez & 26 & 9 & 234 \\
\hline$Y d$. & Juan Lopez & 26 & 9 & 234 \\
\hline$Y d$. & Zacarias Lopez & 26 & 9 & 234 \\
\hline$Y d$. & Timoteo Saez & 26 & 9 & 234 \\
\hline$Y d$. & Julian Saez & 26 & 9 & 234 \\
\hline Peones & [Francisco] Gadea & 26 & 5 & 130 \\
\hline$Y d$. & Maximo Lopez & 26 & 5 & 130 \\
\hline$Y d$. & Julian Saez & 26 & 5 & 130 \\
\hline$Y d$. & Mariano Montés & 26 & 5 & 130 \\
\hline$Y d$. & Antonio [Estala] & 26 & 6 & 156 \\
\hline Braceros & Doce diarios & 24 & 6 & 1728 \\
\hline Caballeria & Seis diarias & 24 & 6 & 864 \\
\hline
\end{tabular}

$\underline{\text { Materiales }}$

Yeso doce cahizes diarios ........, a 14 [reales] cahiz .

Cal diez y nueve cahizes .........., a $16, \ldots . . .$.

Maderas, Puertas y Clavos ........,

" "

4368

1000

$\underline{\text { Resumen }}$

Jornales …………….... 4724

Total . 10.396

[Requena] de Mayo 1837

Mil tres cientos sesenta y dos [reales]

Requena 20 de mayo de 1837

\section{El Comisionado del [Ayuntamiento]}

$$
\text { Vicente Pérez }
$$

D. Pedro Ortiz de Pinedo, [Capitan] del Cuerpo [Nacional] de [Ingenieros] y Comisionado por el [Exmo.] Sor. Capitan [General] de la [Provincia] para la [redificacion] de la [Fortaleza].

Certifico: que los jornales i materiales que comprende la relacion que antecede son los empleados en [dicha] obra comprendido en su coste el del Tambor alzado en la Puerta de Madrid, y que ademas han concurrido á ella y por citacion vecinal y sin jornal, trescientos doce braceros y [y] ciento cincuenta y seis [caballos] menores. Y para que conste pongo la presente que firmo en Req. a 30 de Mayo 1837.

Vicente Perez 


\section{“Cuerpo [Nacional] de Ing. Fortif. Requena año de 1837.}

Relacion de los jornales y [materiales] imvertidos en la obra del Tinte de Gavaldon que dio principio el 21 de Abril y ha concluido en 24 del mes de la fecha.

Clases
Maestro
mayor
Albañ
$Y d$.
$Y d$.
$Y d$.
$Y d$.
$P e o n$
$Y d$.
$Y d$.
$Y d$.
$Y d$.

Nombres
Alonso Martinez
Manuel Perez
Juan Lopez
Zacarias Lopez
Timoteo Saez
Julian Saez
[Francisco] Gadea
Maximo Lopez
Julian Saez
Mariano Montés
Antonio Estala

\begin{tabular}{r}
$\frac{N^{o} d e}{\text { Lornal }}$ \\
\hline 26 \\
\\
26 \\
26 \\
26 \\
26 \\
26 \\
26 \\
26 \\
26 \\
26 \\
26 \\
286
\end{tabular}

Total

286

\section{Materiales}

312 cahizes yeso a 14 [reales]

19. cahizes de cal a 16 [reales]

[madera] para banquetas a 1 [real]

47. Cuartones para banquetas y suelos a 5 [reales]

7 vigas tercias a 50 [reales]

32. docenas de clabos de 3 pulgadas a dos [reales] docena

Tres puertas para el Cuerpo de Guardia y

Cuarto de oficiales a 100 [reales] dos y una 70

8 clabos palmares a 5 [reales]

\section{Valor $\quad$ R.Yn.}

286

234

234

234

234

130

130

130

130

156

2132
Dn. Pedro Ortiz de Pinedo Capitan del Cuerpo Nacional de Ingenieros Comisionado por el Exmo. Sor. Capitan General del distrito para la modificacion y reforma de la fortificacion de Requena.

Certifico ́n slicitud del [Thstrel Ayuntamto de esta Ciudad que el cerramto. aspillerado de la misma formado en parte de tapiales á tierra, aprovech do en otras las paredes de Casas, y en otras de nueva construccion desde la phuta alzado de nuevo en las con yen ot contiene medido ́́ cuerda y pua cinco doscientos cincuenta y siete varas castellanas y contada por altura media la de cuatro varas, es su valor aproximativo el [que] a continuacion se espresa.

\begin{tabular}{|c|c|c|c|c|}
\hline & $\frac{\frac{\text { Varas de }}{\text { Recinto }}}{}$ & Entradas & Precios & $\begin{array}{l}\text { Valor en } \\
\text { Rs. Vn. }\end{array}$ \\
\hline Varas de Recinto en vase & 5257 & 2000 & $21 / 2$ & 5000 \\
\hline Tapias de Tierra & 500 & 2400 & $11 / 2$ & 3600 \\
\hline Aspilleramto. de casas & 600 & 16600 & $61 / 2$ & 107.900 \\
\hline \multirow{2}{*}{$\begin{array}{l}\text { De nueva planta á piedra varro y } \\
\text { yeso }\end{array}$} & 4150 & & & \\
\hline & Total & & & 116500 \\
\hline $\begin{array}{l}\text { Obra nueva del Tinte de } \\
\text { Gavaldon [segun] relacion de } \\
\text { gasto }\end{array}$ & & & & 7662 \\
\hline
\end{tabular}

Resumen

Jornales 2132

Materiales $\underline{5530}$

Total Gral.7662

Importa la relacion que antecede siete mil seiscientos sesenta y dos

Requena 30 Mayo 1837

El comisionado del [Ayuntamiento]" 


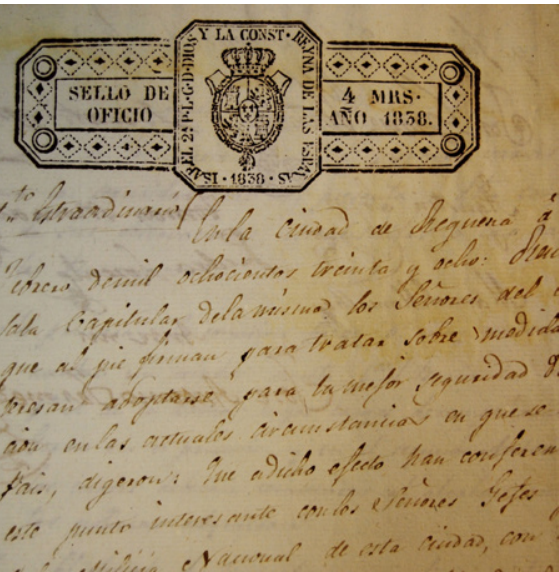

Fig. 881

Transcripción 9: Expediente sobre las medidas tomadas para mejor seguridad de la ciudad, Requena, 1838/02/09, AMR, 1818/8E.

(Transcripción de la autora)

\section{"Medidas}

Para la mejor seguridad de esta Ciudad

[...]

La comisión nombrada por el [Ilte.] [Ayuntamiento] de esta ciudad en cuatro de los corrientes, [para] [que] proponga varias medidas, [que] reclama la seguridad publica; presenta á [dicha] corporacion el fruto de sus observaciones circunscritas a las bases [que] al efecto se le demarcaron.

Sobre la primera. La comision juzga [por] muy conveniente el [que] se nombre un celador secreto [para] el Barrio de las Ollerias, y otro [para] el de la Loma; cuyos cargos desempeñarian bien Joaquin Gorve en el primero, y en el segundo Antonio Salinas, los cuales deberán comunicar al alcalde constitucional cuantas noticias adquieran.

$2^{a}$ El oficial de la milicia, é individuo de [Ayuntamiento], [que] deben ser facultados [para] recorrer ambos barrios, son [Don] Pedro Antonio Monsalve, y [Don] Jose Guillen. Se oficiará sobre ésta medida al Sor. Comandante militar, [para] [que] preste su anuencia á [que] [dichos] señores comisionados salgan, y entren en la plaza á la hora, y [por] el sitio [que] juzguen conveniente; con el obgeto de vigilar [dichos] barrios de Loma y Ollerias, y todas las demas casas [que] se hallan estramuros

La comision crée muy util y aun necesario el [que] se establezcan rondas, [que] cuiden todas las noches de la seguridad interior, amenazada en parte [por] la miseria, [que] principia á dar la casa, y debe ir en aumente; al mismo tiempo [que] pueden evitar con un celo y vigilancia una sorpresa de nuestros enemigos. Estas rondas deben ser presididas [por] un

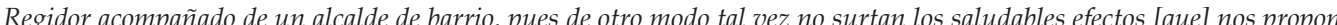
mos, ó al menos carec mos, o al menos careceran de la formalidad, é interes, [que] reclama nuestro estado. El [Ayuntamiento] determinara sobre $3^{a}$ La comision ha reconocido las casas del Barriete, y ha encontrado [que] la [que] pertenece a [Francisco] Perez Duque (a) Pucherero, se halla habitada porcion de mugeres licenciosas, y por consecuencia infunden sospechas de mucho bulto. La comision tiene [por] urgentisimo el [que] se les despida de [dicha] casa en el dia, y se internen en la poblacion. Ademas, las paredes de la misma son bastante debiles, así como las contigüas llamadas de Collado, y otra [que] ecsiste bajo la bateria de Sanchez: por lo cual la comision tiene por indispensable el [que] se mande al maestro de obras [que] reconozca todas las citadas casas, tanto [para] [que] nos cercioremos de su firmeza, ó debilidad; cuanto [para] [que] esponga si seria facil el cortar, y separarlas de la comunicacion con la ciudad.

Con detenimiento ha sido reconocida la Fortificacion: ninguna rotura se ha encontrado en ella; pero si los defectos de alta monta, y que ecsigen pronto, y preciso remedio. El primero ecsiste en la esquina de la posada de Jose Puebla, [que] mira a la fuente del peral: las dos paredes (á poniente y medio dia) [que] forman [dicha] esquina, en un momento, con el instrumento mas pequeño, e insignificante pueden derruirse completamente, e introducirse por alli todo cuanto se quiera con la mayor facilidad. Por otra parte, el [que] cuida de la posada, y el vecino mas procsimo a la misma Manuel Ponce no ofrecen seguridad alguna, pues hablando con la debida franqueza, este ultimo es uno de los mas sospechosos. En este esquina, pues es necesario se construy una pequeño tambor, donde puedon hacer fuego [desrogadomente] cuatro hombres l mismo tiempo barrerá toda la linea de huertos, [que] miran á medio dia, hasta la fortificacion de la Glorieta. Ademas las dos [citadas] tapias se harán de pared maestra.

El segundo defecto capital se halla en la tapia [que] une la ultima casa del puente de las Ollerias, al tinte llamado de Zorrongo, la cual mira á norte: esta es una pared muy interesante [por] todos conceptos, y tenemos la desgracia de [que] sea tierra, y ademas tan bagita [que] los niños de ocho años la saltan sin dificultad: la comision, repitiendo el interes de este punto, juzga [que] debe subirse un hilo cuando menos, y fortificarse algo mas, segun disponga el [Ayuntamiento]. A cuya opinion mas acertada se somete desde luego la comision en todo cuanto tiene el honor de proponer.

\section{Requena y Febro 9 de 1838}

Antonio Laguna

Emeterio Monsalve

Marcelino $M^{a}$ Herrero

Gregorio Cañete

Constantino Cañas

[Ilegible]

Juan Diego Fernandez

Jose Fernandez Albarruiz

Martín Clavijo

$[\ldots]$ 


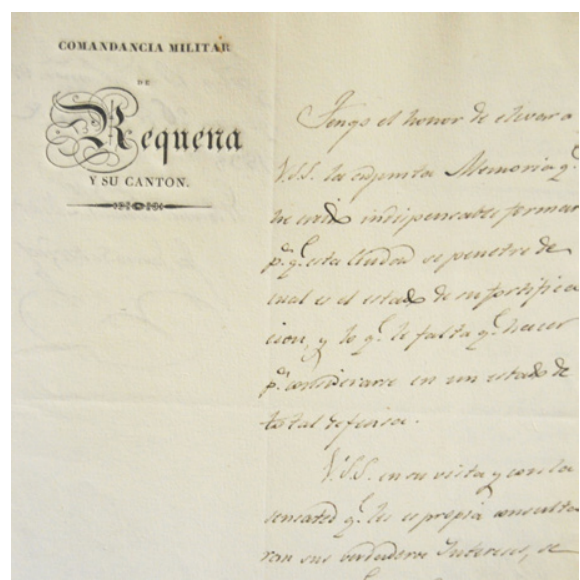

Fig. 882 .

Transcripción 10: Memoria del Comandante militar y Ayuntamiento para la total defensa de Requena y mayores contribuciones a su vista, Requena, 1838/03/25, AMR, 1818/24E

(Transcripción de la autora)

“ $n^{\circ} 7 \quad 1838$

Memoria presentada por el comandte. Militar para la total defensa de Requena, y decision del Ayuntamto. y Mayores contribuientes en [su vista].

Tengo el honor de elevar á V. S. S. la [adjunta] Memoria [que] he creido indispensable formar [para] [que] esta Ciudad [se penetre] de cual es el estado de su fortificacion, y lo [que] le falta [que] hacer [para] considerarse en un estado de total defensa.

V. S. S. en su vista y con la sensatez [que] les es propia consultaron sus verdaderos Intereses, seguros de [que] mis deseos son los de ser util á esta Ciudad y corresponder franca y honrradamente a los deberes [que] me inpuse al tomar el mando de este Punto Militar.

Dios [guarde] a V. S. S. [m.] años Requena 26 de Marzo de 1838.

El Coronel Comandte. Militar.

Jose Garcia de Orozco

Sr. Presidte. y S.S. del [dicho] Ayuntamto. de esta Ciudad.

(Pág. 6)

Memória que presénta el Ilústre Ayuntamiénto de esta Ciudad y á sus heroicos vecinos, el Comandánte Militar de la misma que subscribe.

Siéndo V. S. S. la Corporacion que represénta esta heroíca Ciudad, y cuyo mando Militar hé tenido el honor de que por S. M. se me confié, faltariá a mi deber como Militar y a la gratitud de que mi corazón está poseido por la buena acogida que he debido a V. S. S. y á todos los Naciónales que forman esta Poblacion decidida y valiénte, sino espusiése las reflexiónes que en mi corto enténder, creo necesárias hacer á la ilústracion de V. S. S. y de todos sus representádos.

Segúro como lo estoy, y los hechos hán atestádo, del valor, decision y buena voluntad de los heroicos vecinos de esta Ciudad, no temo decir á la faz de la Nacion entéra, que desafió á todas las facciónes y ordas del obscurantísmo á que vengan á probar la suerte de sus armas contra los muros y los pechos de esta Ciudad y sus havitántes, la fuerza brutal y material podrá tal vez hacer sucunbir por moméntos á los ilústres Guerréros que enciérra este Recínto, pero no á su honor y al renómbre como uno de los que sacrifiquen su ecsisténcia por consérbar el honor y la livertad de este benemerito Pueblo, como Militar esperiméntádo en los lances de la Guerra, y en los sucésos que en ella puedan ocurrir, me deberá ser permitido el que manifiéste á VSS. y á todos los vecinos de esta Ciudad, que para conseguir los caros objétos que este Pueblo se propúso al fortificárse, se necesitan hacer todaviá algúnas obras y dedicárse con esméro á la reparacion de los deféctos que creo tienen las hasta aquí construidas, diré pues cuales son estas y las razónes militáres en que para ello me fundo.

Son acsiómas conocidos entre los Militáres, primero el que para no ser vencido no basta ser valiénte, sino es precabido, y segúndo que los descuidos en la Guerra, se purgan, ó con la perdida de la vida o con la del honor, sentádo esto no se podrá estráñar el que yo desée evitar los males [que] pudiéran suceder á esta Ciudad por falta de precáucion, o de mucha presumcion; despues que hubiesemos sufrido los rebéses de la fortúna, todos diriámos al ver la causa ¿ya que tántos sacrificios y dispéndios hemos hécho y sufrido, porque no nos hemos concluido de poner en un Estado de defénsa, tal que correspónda á nuestras ideas y á nuestros deseos y valor? He aquí de lo que yo quiero que me dio 40 se me haga cargo, y para ello voy á proponer lo que en mi escáso conocimiénto es necesário hacer y reparar.

(pág. 7)

La casa y fuerte llamádo de Amorós, contiguo á la Puerta de Valéncia tiene escasisimos fuegos [para] rebatir los que el enemigo puede hacer contra el desde el Barrio de las Ollerias, estándo muy debilitádo de fuegos todo el frente [que] oresñenta la citáda Puerta, comprehénsibo desde el Huertecillo de la casa de [Don] Juan Antonio Ponce, hasta el camino de las casas de Amorós, y por lo tanto debe darse á este mas consisténcia y mayor numero de fuegos, para que pueda protejer los pocos que en caso de un atáque formal podrián hacer los defensores de las casas de Manuel Ponce que están contiguas al Puente, y que sriá regular tubiesen que abándonar por su poca solidez y defensa, quedándo proteijdos estos, y contenidos los fuegos que por medio de un Tambor en forma que se hiciése á su frente.

A la Bateriá de Onrrúbia debe dársele mas capacidad, así para que la Pieza que há de obrar en ella lo haga con el desáogo [que] ahora no puede, como para que sus fuegos obren contra los puntos mas debiles, que son la Casa de la Garróta y el Tinte de Cecina.

La Casa de la Garróta es quizás el punto mas debil de toda la fortificacion, ya porque sus escásos fuegos y poca solidéz de la Casa, como porque no está protejido por los fuegos de ningún otro punto, este inconveniénte capital puede remediárse reforzándo el frente de [dicha] casa con un doble tambor aspillerádo, al que y á todo el angulo que forma la casa se le debe hacer un foso y estacáda á su frente hasta negar cerca de la Puerta del Trilléro, dando al mismo tiempo protéccion y seguridad á toda esta parte por medio de los fuegos de otros puntos, como en adelánte se dirá. La Cortina de la huerta de [Don] Baltasar [Perez] es por si sola [palabra ilegible] y endéble, y por tanto debe hacersele un foso á su frente, y considerárse como [retrinchramiento] ó segúnda linea de las tapias abanzádas [que] formó el [Comandante] Albornóz; y deben reforzárse y conserbárse [para] robustecer con sus fuegos la defénsa de la linea anterior ó huerta [citada], y protejer con los mismos la parte del frente de la casa de la Garróta y Puerta de Trilléros, que no tiene ningún fuego de flanco [que] la sosténga. El tinte de Cecina está sin fuegos, ni protéccion algúna de otros, y además no presta seguridad por no tener en el un Cpo. de Gua. [que] vigile lo [que] por los angulos entrántes [que] tiene á la derécha é izquiérda pase ó sucéda, [para] evitar todo esto, y hacerlo un punto que no preste cuidádo en un caso de ser atacada la Ciudad, y que pueda al mismo tpo. servir de apóyo á otros, y deféndido todo con poca fuerza, es necésario hacerle un fortin que arránque desde el angulo que forma [dicho] tinte y el que hace la pared que cierra la Calle de la Plaza por la que debe darse la comunicacion al fuerte, y que deberá ser capáz á su frente [que] en diréccion oblicua venga á concluir en el punto que convenga de la linea de tapias construidas por $\mathrm{Al}$ bornóz, con lo cual se consigue dar fuerza á la Cortina de Fernández, y que con un corto numero de hombres esté deféndido en todas dirécciones el recinto comprehéndido desde el arránque de la indicáda Cortina, hasta el Rincón que forma la tapia [que] cierra la Calle de la Plaza, protejiéndo con los fuegos de toda esta parte los rincónes á angulos entrántes [que] quedan á la izquiérda del tinte de Cecina, y además todo el frente como queda [dicho] de la Casa de la Garrota y Puerta de Trilléros, cuya defénsa es foróso tener siempre presente.

En el angulo saliénte del Huerto de la Parra, es indispénsable formar bien y de firme la Banquéta, pues en el dia no hay mas [que] unos palos, por los que es imposible puedan los hombres andar, caso de tener que hacer fuego desde aquel punto. I frente son casinulos por la mala disposicion que se le há dádo á la Plaza ó esplanóda y álas caras de la Bateriá para servir las piezas, por lo tanto [dicha] Bateriá es tal, cual está en el dia, inutil, y solo sirven de ella los fuegos de aspilléra que tiene, pero ya que está hecha era necésario utilizárla en lo posible y con un objéto, el cual puede ser darle fuegos de cañon contra el Barrio de las Lomas, formándo dos Esplanádas en el sitio donde están los Cuerpos de Guardia, y tratándo en lo posible que 
los fuegos de estas piezas puedan fugar sobre su derécha.

Debe tenérse presénte que el punto cardinal de atáque por parte de los enemigos caso de un sitio formal há de ser el Barrio de las Lomas y Fuerte de San Francisco, q ue debe destruirse, [para] protejer á este é inutilizar los fuegos del enemigo con que desde [dichos] puntos ofenderiá á la Plaza, es necesário oponérle ofénsa; la que [casualmente] es la mas olvidáda que se há tenido, por la sencilla razon de considerar aquel puesto bien deféndido y cubiérto por los fuegos del Fuerte de San Francisco, razon muy fundáda [para] cuando solo se trate de invasiónes de facciónes sin artilleriá, y sin tpo. ni recursos [para] ponér razon muy fundáda [para] cuando solo se trate de invasiónes de facciónes sin artilleriá, y sin tpo. ni recursos [para] ponér
un sitio en forma, en cuyo contrário caso es en el [que] yo me pongo. La Bateriá de Isabel $2^{a}$ y Pozo de la Nieve, son las que deben obrar activaménte para este caso, y como según el estado en [que] están en el dia no son suficiéntes para ello, deben en ellas hacérse los repáros [siguientes].

(pág. 9)

A la de Isabel $2^{a}$ debe darsele la disposicion conveniénte [para] [que] fueguen en ella dos pieas de á ocho, de consiguiénte para esto seriá necesário conveniénte, y con un deposito á prueba para municiones, que sirviése al propio tiempo de Cpo. de Gua. ó Cuartel [para] sus defensóres y sirviéntes de las piezas, pues el fuego que allí sufririán del enemigo, necesita todas estas precauciónes, por ser de suyo certéro y á distáncia de punto en blanco.

En el Pozo de la Nieve deberiá colocárse un Obúz, pero á falta de este darle la capacidad y consisténcia debida para otra pieza En el Pozo de la Nieve deberiá colocárse un Obúz, pero á falta de este darle la capacidad y consisténcia debida para otra pieza
de á ocho, con cuyas defénsas y estándo bien servidas las Piezas, deberián costar al enemigo mucha perdida el mantenerse en su posicion de las Lomas, y mayor el poder al abrigo de sus fuegos adelántar su [Infanteria] contra la Plaza.

Los demas puntos hasta la Puerta de Marid y desde esta á la del Cristo, necesitan poca refórma, si se eceptúan algúnos fosos que robustéscan las Cortinas ó tapias que se hallan hechas, pues el tambor bien dirijido que hay en la Puerta de Madrid frente á la Gloriéta y la [Bateria] del Cristo, cubren [afortunadamente] todos los puntos mas debiles [que] hay en esta parte de Recinto.

\section{Fortificacion de la Villa y su Castillo}

No me cansaré de repetir [que] si bien la Ciudad en el todo queda deféndible con las fortificaciones [que] tiene, reparádas según dejo manifestádo, nada se há hecho para un sitio formal, pues [que] en principios del arte es cosa reconocida el que en toda fortificacion debe haber un punto de apóyo y ampáro [para] un ultimo estremo, y en el que asegurádos los sitiádos puedan con honor sacar el fruto de su defensa; en Requéna por desgrácia paréce se há olvidádo este interesánte objéto, siendo tanto mas de admirar el que así se haya hecho, cuanto al menor conocédor en la matéria se le está presentándo á la Villa el que la defénsa de la Ciudad está en la Villa y su Castillo, yo alcínzo muy bien las causas [que] hán mediádo, tan to citada Villa Castillo, pero esto no obsta para que deje de estar en pie este defécto capital, y de que no esté aun en tiempo de subsanárlo; y de aprovechárnos de la seguridad [que] proporcionariá á este invicto vecindário, el Alcázar inespugnáble [que la naturaléza y escelénte posicion de el há concedido á esta Ciudad; es tanto el prestijio y poderio que dariá á esta Ciudad, la fortificacion y utilizacion de la Villa y Castillo, [que] puede asegurárse sin temor de incurrir en presuncion que Requen seriá inconquistáble y con solos 300. hombres [que] quedasén reunidos en aquélla Ciudadéla impondrián la ley al enemigo y se harián respétables, tal es la seguridad [que] me infúnde el proyecto de fortificacion de que hablo.

Yo no creo que para realizárlo sean necesários grandes gastos, [porque] la posicion natural de la Villa y Castillo, la hacen por si ináccesible y de consiquiénte facil á suplir lo que el arte no pueda aplicarle. iY podré yo creér [quel una Ciudad que

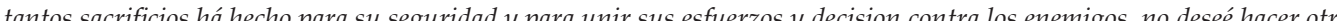
para constituirse en compléta defénsa, y desafiár con seguridad absolúta á todo el poder brutal de esas falánges libérticidas, que amenazan diariamte. a los preciosos bienes [que] encierra esta Ciudad libre y Virtuósa? No me es licito creerlo, nada pongo en duda de los sentimiéntos del Ilústre ayuntamto. [que] tan dignaménte la boviérna, y de la decision, valor y civismo de sus heroicos havitántes.

Pesen VSS. bien mis razónes dictádas por el mas puro celo y por el noble orgúllo [que] me asiste al verme al frente de una Poblacion valiénte y decidida a sacrificárse por sosténer su honor y consérbar sus intéreses, por cuyos compromisos politicos se há colocádo en una posicion que hace llamar así la aténcion de esta Nacion magnanima y la de unos Enemigos sediénto de su sangre y del robo de sus riquézas sin que por las tristes circunstáncias en que nos hallámos, pueeda contar este ve-

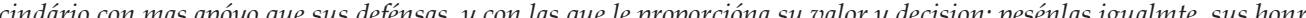
vecinos, y si tal hacen, es indispensáble dejen de convenir conmigo en lo necesaria que es, si quieren contar con su total seguridad, la fortificacion de la Villa y Castillo.

Si como creo llaman la atencion de VSS. y de cuantos moradóres enciérra esta Ciudad las reflexiónes fundádas [que] dejo espuestas, no dudo un moménto de [que] poniéndose de acuerdo entre si, ya [por] medio de una junta al efecto ó ya por otras disposiciones analogas, se encontrarán los medios y recursos [que] para [dicha] fortificacion se necesitan, en la cual no es mi inténcion intervenir soalbo en la diréccion de sus obras que se harián arregládas al parecer y diseño de un oficial de Ingeniéros, que respóndo me mandariá el [Exmo.] Señor Capitán General; y para dar mayor prueba á VSS. y á esta Ciudad de que solo me animan los mejóres deséos por su bien estar y seouridad, desde luego ofrésco gratuitamte. para tan necésario objeto mi paga de un mes que depositaré en el sujéto que se me indique.

Requéna 25. de Marzo de 1838

El Coronel, Comandte. Militar.

Jose Garcia de Orozco

(pág. 12)
Desde que tube el honor de presentar a VSS. la memoria pidiéndo el auménto de fortificacion de esta Ciudad, hán ocurrido tales circúnstáncias pertenecientes á la Guerra en el resto de la Península, que me hacen insistir con mayor empeño en la necesidad de medidas de precáucion y seguridad [para] esta Ciudad que en la indicada memoria emitiá, las espediciónes carlistas que lejos de este Pais hán tenido lugar, auméntan muy de cerca sus peligros, y obligán por moméntos á tomar las providencias mas activas para asegurar este recinto; no pierdan VSS.. un instánte de vista los pasos de aquéllas, pues que las verán á sus Puertas indudableménte si insiguiéndo el plan á que ellas tienden, la fortúna ó la causalidad no les corta sus pasos, las noticias que se me comunican y el conocimiénto [que] por la practica en esta clase de Guerra hé adquirido, todo me confirma en que el pland de los enemigos es ensánchar su escála y dar el carácter de ocupacion á sus planes extratejicos, la capital del Reino en vista de estas observaciónes adelánta sus obras y medios de defénsa, la vecina del de Valéncia, hace otro tanto, la de la Provincia de Teruel, lo mismo, iy esto que es Señóres? no creo sea otra cosa mas sino una prueba de que

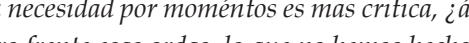
que espéra Requéna? :Será por ventúra posible hacer cuando tengámos a nuestro frente esas ordas, lo que no hemos hecho cuando reinába la tranquilidad?

Insisto pues, Iltres. Señóres en la necesidad de la reparacion de Obras que senté en mi indicáda memória, ahóra añádo lo siguiénte.

La venida de tres piezas de artilleriá mas á esta Ciudad entre ellas un Obúz, lejos de auméntar su defénsa la disminuyen y hacen mas embarazósa por la sencilla razon, de que careciendo de buenos sirviéntes, no es posible hacer el uso debido de estos eleméntos de Guerra y defénsa, que sino son manejádos oportunamte. caúsan el descredito á la fortificacion, y la confusion á los defénsores de ella.

El império de las circunstáncias en que nos hallámos envueltos, y muy particularmente de las en que se encuéntra Requéna, obliga á que ante la razón desaparézca toda otra consideracion, muy buena si se quiere para tiempos menos criticos y en los que pueden tener cavida relaciónes que en el dia solo tiénden á perjudicar al bien general de la Poblacion, y por ello convencido de que ante este debe ceder todo, diré francaménte que la Compa de artilelriá tal cual está organizáda no correspónde á su objéto, y necesita de consiguiente un arréglo pronto y compléto, el cual toca á VSS. hacer y poner en obra inmediatamente, si es que deséan que las nuebe piezas que contiéne el recinto de esta Diudad no sean un estórbo.

Así mismo es necesário crear una Compañiá, tercio, ó como quiera llamarse, con la denominacion de Bombéros ó Zapadóres, la cual sea compuésta de hombres de oficio Albañiles, algúnos Carpintéros y Herréros, cuya creacion es absolutante. indispensáble si con aciérto y sin cor edificios y obstrucion de Calles [signo ilegible], que será preciso oponer á los enemigos, caso de un atáque contra la Ciudad. Yo no dudo un moménto en que VSS. conocerán lo indispensáble y util que es la formacion y reorganizacion de estas dos Yo no dudo un moménto en que VSS. conocerán lo indispensáble y util que es la formacion y reorganizacion de estas dos
Compañilas, pero es preciso convencérse [que] [para] que ellas presten los servicios á que se destínan, no debe introducirse en las mismas, bajo ningún concépto ni categoriá, sujétos estraños á la profesion que constitúya el nombre y destino de ellas, si asi no se hace, inutil será su creacion, este es tiempo de que desaparézcan ideas y deséos aunque sean de buena fee de mandar y manejar lo que no es dado á todos los hombres entender, pues que esto no tiende mas que a relajar las cosas del objeto para que se forman, y á desunir y entibiar las voluntades y buenos eféctos que de tales instituciónes deben esperárse, en este concépto si VSS. se persuaden de [que] mis proposiciones son necesarias, precisas y utiles, y que solo en proponerlas me anima mi buen celo por la seguridad y defénsa en forma de esta Ciudad, me prométo [quel sin levantar mano y con la vista fija en el bien general que ellas deben redúndar á la Poblacion, se dedicarán á la organizacion y formacion de las dos [dichas] [Compañias], para lo cual si lo estiman oportúno daré á VSS. ideas generáles sobre ellos, y que espondré sin contamplacion á sujétos ni categorián y si solo á la consecucion del objéto, mucho mas cuando por lo que hé visto y tocádo, hay en esta Ciudad eleméntos muy suficiéntes para lográrlo. 
Mas si como no espéro, por razónes que no se me ocultan, pero que no puedo persuadirme pesen en el animo y delicadeza de la ilustre Corporacion que VSS. represéntan y de los venemeritos Gefes y Oficialidad de la M. N. de esta Ciudad, viene yo que nada de cuanto tengo espuesto, pedido y dejádo á la alta ilústracion de VSS. tiene efecto, me veré precisádo á suplicar á VSS. me den contestaciones latas y categoricas del motivo que 'cause la oposicion a mis proposiciones para dirijirme con

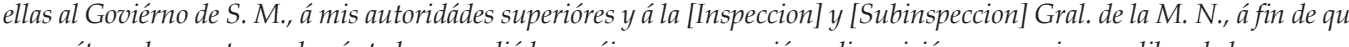
se penétren de cuanto en el asúnto haya mediádo, recáigan sus superióres disposiciónes, y a mi se me libre de la responsabilidad que acarréa un mando sin recursos propios, y del que en un caso desgraciádo, no podrá liverárme de su descredito y con mas sentimto. [que] me acompañariá de que debió evitárse aquel, si con la misma buena fee y sinceridad que yo propóngo las mejóras y medios de defénsa que deben admitirse [para] la conservacion de esta Ciudad, las hubiésen acogido sus representántes y todos sus vecinos, harto comprometidos ya por la situacion en que se hán colocádo, y sin contar para ella con mas recúrsos que los suyos propios.

Los instántes urgen, y por ello sirvánse VSS. dispénsar el lenguáje con que se esprésa un militar [que] no conóce la adulacion, ni mas consideraciónes que las que se deben al bien general, pero que como buen Español y enemigo acerrimo del Bando Rebelde, deseá promover todos los medios de que esta Ciudad es suscéptible para que no sea presa de aquel, y para que se tremóle en ella hasta la conclusion de la fatal lucha que nos aflije al Pabellón de nuestra inocénte Reina Isabel Segúnda.

\section{Dios [guarde] a VSS. muchos años Requena 18. de Abril de 1838.}

El Coronel, Comándte. Militar.

Jose Garcia de Orozco

Sres. Presidente y Muy Ilústre ayuntamto. Constitucional de esta Ciudad.

(pág 18)

Ayuntamto.

En la ciudad de Reuqena à Diez y ocho de Abril de mil ochocientos treinta y ocho: reunidos los Señores de Ayuntamiento que firman, en esta sala capitular, se dio cuénta del oficio que precede que acaba de dirigir el Sor. Comandante Militar del Canton, y enterados digeron: Que la decision de desempeñar el urgante servicio de las diligencias de Junta ha impedido contestar sobre la memoria á que dicho oficio se refiere y si bien el Ayuntamto. tendria el mayor placer en acceder por si solo á la execucion de aumento de obras de Fortificacion que se proponen y aun de otras mayores, que asegurasen la Poblacion contra toda imbasion enemiga, no le es posible convenir en la destruccion del edificio que fue convento de Religiosos Franciscos, por tener echo presente á la Junta de Enagenacion de esta clase de edificios y a otras Autoridades Superiores lo útil que es su conservacion y el pensamiento de destinarlo á Hospital de Caridad y casa de Beneficencia cuando las circunstancias lo permitan, ni tampoco á edificios de propiedad de particular, sin que antes, y acreditado previamente ser perjudiciales á la mejor defensa y seguridad de la Poblacion; se indemnice á [dichos] particulares por cualquier medio, ó conviniendose con estos, [para] verificarlo en otro mejor estado. Y por lo respectibo al convento lo apruebe y permita el Gobierno de S. M. como Junta Nacional, y sin responsavilidad al Ayuntamto. y vecindario de Requena. Que por lo respectibo á las demas obras, careciendose de Fondos para realizarlas como que es notorio que para la que se esta exercitando del Punto titulado Tinte de Cecina, se suple de la cantidad de cuatro mil [reales] que han adelantado de su volsillo particular los

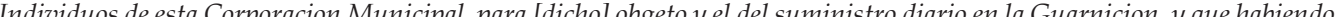
executado todas las de la fortificacion á espensas del vecindario, satisfaciendo unos lo que les fue señalado en los repartimientos acordados por los mayores contribuyentes en Concejo abierto, y otros dando jornales y todos prestandose gustosos á estos sacrificios por lograr su seguridad y mejor defensa; a fin de que nunca pueda atribuirse al Ayuntamto. haber obrado por si solo en la resolucion de las obras que nuebamente se proponen, y que no contó con la voluntad de los vecinos, en punto en que tanto interes deben tener; acuerdan que por medio de estacion y con expresion de causa se isten á todos los mayores contribuyentes de esta Poblacion y por los Hacendados Forasterios á sus representantes para [que] mañana á la ora de las tres de la tarde concurran á esta sala capitular donde se servira hacerlo igualmente el Sor. Comandante Militar, y enterandoles de [dicha] Memoria manifiesten francamente su voluntad en orden al aumento de obras de fortificacion, y se resuelva lo que estime la mayoria, pues al Ayuntamto. solo le anima el bien general del vecindario á cuya cabeza se encuentra; Quen en orden a la Compañia de Artilleria como punto que solo toca al Ayuntamto. conformandose con lo expuesto por el Sor. Comandante esta pronto á organizarla de nuebo declarandola estinguida, y procediendo en seguida á su formacion, tomando de la misma los Individuos que por su mayor instruccion y circunstancias se crean mas utiles, y completandola con los demas Nacionales del [Batallon] que voluntariamente quieran pasar, y cuando no los hubiese sacando de cada compañi los que se necesiten, cuya operacion se verificara el domingo inmediato á presencia de todo el [Batallon] por el Ayuntamto. que primero invitara á [que] voluntariamente se presten y ofrezcan para servicio tan preferente como beneficioso á esta Poblacion, reserbando el Ayuntamto. acordar lo [que] estime oportuno sobre la [Compañia] de Bomberos ó Zapadores [que] se propone y firmar doy fe.

\section{Dionisio Sanchez}

Eusebio Perez

Agustin Oria

Tomas Monsalve

Manuel Monsalbe

Antonio Laguna

Pedio Antonio Monsalve

Pedro Lorente

Pedro Vera

Ante mi

Jose Antonio Jaime 
Junta y resolucion de los Mayores [contribuyentes]

En la ciudad de Requena á diez y nueve de Abril de mil ochocientos treinta y ocho, reunidos los señores del Ayuntamiento en esta Sala Capitular, y por consecuencia del acuerdo precedente y en virtud de citacion de esta misma Fecha con expresion de causa, concurrieron el Sor. [Don] Jose Garcia de Orozco Comandante Militar de este Canton, el Sor [Don] Joaquin [Telesfoxo] Clemot Juez de Primera Instancia del Partido de la misma: el Sor [don] Pedro Gonzales Arcipreste de la Parroquial del SalvaClemot Juez de Primera Instancia del Partido de la misma: el Sor [don] Pedro Gonzales Arcipreste de la Parroquial del Salva-
dor, el Sor [Don] Jose Ortega y Ranz Cura de la de Santa Maria, el Sor [don] Ramon Saez Vicario de la de San Nicolas, y los dor, el Sor [Don] Jose Ortega y Ranz Cura de la de Santa Maria, el Sor [don] Ramon Saez Vicario de la de San Nicolas, y los
ciudadanos [don] Juan Nicolas de Molini, [Don] Norberto Sanchez, [don] Jose Maria Cañizares, [Don] Diego Montes, [Don] ciudadanos [don] Juan Nicolas de Molini, [Don] Norberto Sanchez, [don] Jose Maria Cañizares, [Don] Diego Montes, [Don] [Don] Joaquin [Ramas], [Don] Pedro Jose de [Cros], [don] Marcelino Maria Herrero, [don] Jose Garcia Ibañez, [don] Agustin Lopez, [don] domingo Laguna, [don] Gregorio Cañete, [Don] Martin Claviijo, [don] Dionisio Sanchez, [don] Joaquin Sanon, [Don] Silverio Diaz Hoz, [don] Rafael Santos Martinez, [Don] Agustin Oria, [don] Antonio [Ruvio] de la Peña, [don] Nicolas Herrero, [don] Bartolome Cobo, [Don] [Franciscol Moral y Carabsca y otro barios que fueron presentandose en el intermedo que se dio cuenta del obgeto de la combocatoria instruyendole de la memoria y oficio del Señor Comandente Miltar y acuerdo del Ayuntamto. y despues de haber conferenciado, si bien los ciudadanos concurrentes manifestaron, no podian mezclarse en que se efectuase ó no lo que se indica en [dicha] Mejora con respeto al Fuerte de San [Francisco] y edificios de Particulares en concepto de que prestaban su asistencia; y si [que] el Sor [Comandante] Militar obrase en esta Parte como entendiese á sus atribucciones ó con noticia de las Autoridades Superiores, estaban prontos y se prestaban á que se efectuasen las demas obras que se juzgasen necesarias á mejorar la Fortificacion, por coste del vecindario como se han verificado las executadas y en que todos los habitantes sean prestado voluntarios, pagando jornales, y conduciendo el yeso, sin que ninguno haya formado resistencia en tales aprestaciones, como dirigidas á la mayor seguridad y mejor defensa de la Poblacion; Y en consecuencia de todo convinieron en [auel por un Ingeniero se reconozca la Fortificacion y nterado tambien de la memoria del Sor Comandante Militar propon las obras que sus conimientos faltatibs como se hin weficho todas las demas, se exchut un repartimtento en el que seran contribuyentes a el en metalico todos los [que] por la ultima operacion que han executado los Peritos para [vase] a los repartimtos. de contribuciones, lleven ochocientos [reales] de utilidades [para] arriba y entre las que resulten se distribuyan al tanto por ciento, cuarenta mil [reales] [vn]. Que los demas contribuyentes escepto los Nacionales por consideracion al servicio actibo que prestan, acudiran á [dichas] obras á dar jornales traer yeso ú otros trabajos para las mismas, en la proporcion [que] les corresponda á las Utilidades que esten repartidas: Que para la formacion de este repartimiento, y graduacion de Jornales, entender en su distribucion, y cobranza, y correr con la execucion de obras se nombre una comision compuesta del Sor Alcalde Segundo como Presidente, del [Psor.] [Medico] [don] Pedro de Vera del Sor Arcipreste de la Iglesia del Salvador y de los ciudadanos [Don] Norverto Sanchez [don] Martin Clavijo,

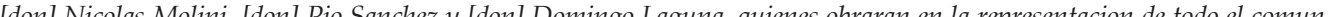

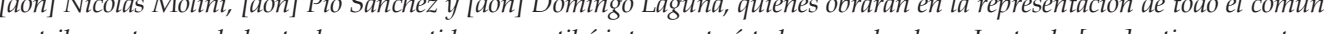

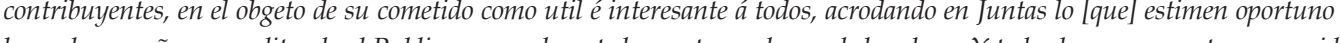
buen desempeño, y acreditando al Publico semanalmente los gastos, y demas de las obras; Y todos los concurrentes convenidos en esta deliberacion se retiraron sin [que] por ninguno se manifestase obgepcion, ni discordancia á que se lleve á efecto, quedand el Sor Comandante Militar, en practicar diligencias [para] la presentacion del Ingeniero al reconocimto. de la Fortificacion y designacion de las obras [para] mejorarla. Firmando los SS. de Ayuntamto. doy fe.

Dionisio Sanchez.

Eusebio Perez

Eusebio Perez

Agustin Oria

Tomas Monsalve
Manuel Molsalbe

Antonio Laguna

Pedro Lorente

Pedro Antonio Monsalve

Pedro Vera

Ante mi

Jose Antonio Jaime"

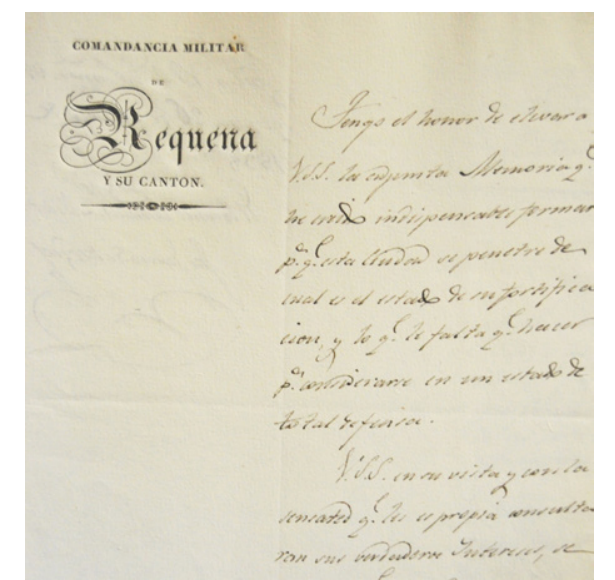

Fig. 883.

Transcripción 11: Fortificación de Requena. Memoria sobre la reparación y obras nuevas que conviene verificar, Requena, 1838/07/04, AMR, 1818/17E.

(Transcripción de la autora)

"2 de julio de 1838. Fortificación de Requena. Memoria sobre la reparación y obras nuevas que conviene verificar. Comandante de Infantería y Capitán de Ingenieros Juan Ramón de Carbonell.

(pág. 3)

[Exerto.] del Centro Cuerpo Nacional de Ingenieros

Memória sobre la reparacion y obras nuebas que conviéne verificar en las Fortificaciones de la Ciudad de Requéna, segun el estado en que se hallan en Junio de 1838 .

Comisionádo por el [Exmo.] Sór. General en Gefe del [Erto.] del Centro para hacerme cargo de las obras efectuadas en esta Ciudad, y trazar las que háyan de aumentárse, hubiéra deseádo tener el tiempo suficiente para levantar el plano de las priméras, y proyéctar en el las segundas. Mas ya que mi corta permanéncia en este punto y la atención que debo á otros encárgos, no me permite un trabájo tan esténso, me limitare á esprésar en esta memória las observaciónes producídas por el reconocimiénto que hé practicádo; la descripcion de las obras que juzgo conveniente se verifiquen, y las mejoras que en mi reconocimiénto que hé practicádo; la descripcion de las obras que juzgo conveniente se verifiquen, y las mejoras que en mi
opinion deben hacérse en las que ecsisten. Afortunadamente basta una ligéra esplicacion para que se percíban mis ideas, y aun será superabundante si toca hacer uno de ellos al Señor Comandánte Militar, que con tanto aciérto como inteligéncia ha emitido las suyas.

La fortificacion de Requéna, consideráda en general, no tiene la perféccion indispensáble para asegurar [completamente] la Poblacion, contra los ataques de las facciónes: pues si bien es cierto que sus heroicos havitántes han sabido rechazárlos aun con medios mas debiles de defensa, no puede, sin embárgo, desconocérse que tal podria ser la excesiba superioridad numerica del enemigo, y sus recúrsos ofensibos, que no bastáse á contrarrestar su agresion ni la constáncia, ni el valor acreditádo de los defensóres, sin el proporcionado auxilio de obras de fortificacion suficiéntemente resisténtes. Estoy muy lejos de creer que ni aun en este caso, llegáse á tremolar impúne el estandarté de la rebelion sobre los muros de la leal Requéna: no, si el enemigo consiguiése forzárlos hallaria á cada paso nuebos obstaculos que vencer; las casas se convertirian en otras tantas fortalézas; las calles en campos de batálla, ¿y quien podria dudar del exito de semejántes contiéndas, sabiéndo de cuanto es capáz un Pueblo que defiénde los caros objetos de Patria y Livertad? Pero aunque con fundamento deban esperárse tamáños esfuérzos de los moradóres de Requéna, ecsije la procedéncia y la humanidad que se evite la ocasion de llevarlos al extrémo, y se economize el Sacrificio de infinitas vidas, y la perdida de excesivas fortunas. Tal es el interesante fin que se consigue cuando se da á las fortificaciones la perféccion que requiéren, y para cuyo logro deben hacerse en las de este recinto los repartos, mejóras y adiciones que recláma su actual estádo. 
(pág. 4)

No se infiéra de lo dicho que preténdo hacer concebir una idea desventajósa de todas las obras defensibas que rodéan esta Ciudad. Lejos de mi semejante proposito, no menos injusto que perjudicial. Entre las referidas obras hay muchas que por su si algunas recláman [imperiosamente] que se varie su confguracion, se auménton sus meliosresitentes, y se dé mejor disposicion á los ofénsibos, es á causa del distinto carácter que há tornádo la guerra desde la epoca en que se construyéron has el dia. Una sola hay á á la verdad que no correspónde de ningúna manéra, ni á un [coste], ni al objéto con que se edificó. Las obras que en mi concépto conviéne verificar para dar á la fortificacion de esta Ciudad mayor grado de importáncia pueden dividirse en tres clases. A la priméra correspónde la reparacion de los desperféctos que la interperie y otras causa han ocasionádo en las obras construidas: cuya reparacion que es sumamente urgénte no dejará de proporcionar trabájo y gasto, si se atiende á los varios trozos de tapias y paredes que deben renobárse, puertas y ventánas que hay que cerrar aspillerar, banquétas y esplanádas que es preciso rehácer, y otras muchas recomposiciónes de que se hablará en lo subcesivo. En la segunda clase se comprénden las obras que ahór se propońn y de los cuales unas hán de levantérse de mueba planta otras se redúcen á dar mas amplitud y reliéve á las actúales, y otras consisten en dispóner de una manéra util á su deféns diversos edificios proximos al recinto. A esta clase pertenéce tambien la escabacion de fosos, y el derribo de unas malas casas que perjudican notablemente á la defénsa. Las obras que se inclúyen en la tercéra clase son interióres y se proyéctan con el objeto de habilitar el Castillo antiguo situádo en la parte de Poblacion llamáda la Villa, y para aprovéchar la ventajosa localidad que esta ocúpo, disponiendo en ella un segúndo recinto que sirva de apoyo á los defensóres del priméro: puesto que lo cerramientos que ahora ecsisten en las vocas calles, son insuficiéntes. Por este medio se conseguira proporcionar á este punto fortificado un reducto de seguridad de que actualmente carece, y cuyas utilidades es escusado encaminar, porque ademas de hallarse demostrádas por la esperiencia y las maximas del Arte de la Guerra, se preséntan á la inteligéncia menos perspicáz. recorriéndo subcesivamente todos los frentes del recinto.

\section{Desde la Puerta de Valéncia á la de Alcalé}

Casa de D. Juan Antonio Ponce: En la pared que mira al barrio de las Ollerias se abriran aspilleras en todos los cuerpos, se tabicará el balcón hasta la altura de 4 1/2 pies. Asi mismo se aspillerarán las demás parédes de esta clase y las inmediátas hasta las del Batanejo, en los frentes y pisos que descubran el campo.

\section{(pág 5)}

Bateria que se proyecta contigua al fortín de la Casa de Don Juan Antonio Ponce: esta Bateria tiene por objeto obrar en convinacion con las de la Puerta de Alcalá, Onrrubia y Molino de Herréro para impedir al enemigo la pacifica posesion del barrio de las Ollerias, y contrarrestar la artilleria que pudiera colocar en el. Además descubre el camino á la Puerta de Valencia y las avenidas á las casas del Batanejo y al Matadero; y cruzando sus fuegos con los del cañon de la referida Puerta de Alcalá, defiende las inmediaciones de todo el recinto Intermedio. Para conseguir evitar estas ventájas se dará al lado exterior de la Bateria el trazado siguiénte. Una cara partira desde la garita del fortin hacia el campo en direccion perpendicular á las [caras] que lindan con el Camino de Valéncia: cuya cara tendrá nuebe baras de largo: la otra formana con esta un angulo de cien grados, mirando por consiguiente al Camino de Cofréntes, y su longitud será de once baras; tercéra cara formará con la segunda un angulo de 115. grados y terminará en las casas de cara-cuesta dando frente á las del un ternatern guesehosteria, tendrá nuebe pies de altúra, puesto que el referido terreno debe rebajarse una bar por la parte exterior, en forma de foso, á fin de aumentar el reliéve. El parapeto se construirá de tapia, dandole dos baras de espesor en las dos priméras [cabas], una bara en la tercéra; y ocho pies de altura en todas. En cada una de las caras se dejara una cañonera, estableciéndo el centro de la tercéra á 3 1/2 baras del angulo saliente interior. Desde esta misma cañonera hasta las [caras] de cara-cuesta, se aspillerará el parapéto hasta la altúra de 4 1/2 pies, y para que en los demás paráges se puede hacer uso de la fusileria por encima de los merlones se construirán aquéllos trozos de banquétas que no perjudiquen al servicio de la pieza. Se hará una esplanada de madera para las tres cañoneras, con tablones de cuatro á cinco pulgadas de grueso, y los durmientes y batientes que correspónden se colocarán en las embrasúras recias, portezuelas de dos hojas, que puedan separárse facilmente de sus marcos para preserbórlas de la interperie en tanto que no sea preciso usírlas. La entrí a
Desde la Bateria á las Casas del Batanejo. Ademas de aspillerarse las paredes de las casas y corrales según se ha dicho, se cerrarán y aspillerarán las ventanas situadas en el recinto. Se reforzarán las tapias y paredes debiles, elebando las mas bajas hasta la altura de cuatro baras.

(pág. 6)

Casas del Batanejo. Se cerrará con tapia aspillerada de cuatro baras de alto al descubiérto de la Casa de [Omtin], efectuándo la competénte banquéta, pues há de tenérse presente que en general las aspilleras deben principiar á la altúra de 6 1/2 ó 7 pies del piso esterior, siempre que no haya foso. En las parédes de levante se reforzarán los [cerramientos] de las Puertas, y algunos trozos algo deviles, recalzándolas y rebocándolas donde sea necesario: se tapiarán las ventánas que se hallen á menos de ocho baras de elebacion, y se harán aspilléras en todos los cuerpos. La pared del medio dia se reforzará por la parte interior hasta el piso principal, y así en este como en los demás se abrirán aspilléras. Se darán dos baras mas de altúra á la tapia que atraviésa el camino formándo parte de este frente de medio dia, se masizará su Puerta y continuarán las aspilleras hasta el ribizo. Delánte de dichn tapia se abrira un foso por el cual pueden diviiirse las aguas del arbellón contiguo. Como Dentente hay un parapeto que cubre las casas, solo deben aspillerárse estas si las havitaciónes principales y desvánes, á escepcion del pequeño espacio que cae al campo sobre el arbellón, donde se hará [precisamente] una aspillera en cada piso.

Para flanqueár el frente abanzádo de las casas del Batanejo, poco defendido ahora de otras partes del recinto, y para flanquear tambien el parapeto de poniénte que forman las tapias de Don Marcelino Herréro e inmediátas, se construirá un fortin que producirá además la ventája de descubrir las avenidas al [retorno] entrante de fortificacion que media entre aquel punto y la Puerta de Alcalá. Este fortín se cimentará sobre el ribázo, y para trazar su lado esterior se efectuará lo siguiénte. Desde el angulo que forma la tapia ya citáda, que cruza el camino con las de D. Marcelíno, se tomarán siete baras sobre la horma, y se

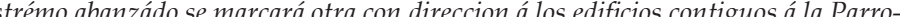

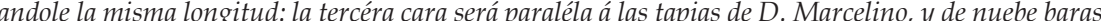
de largo: y ultimamente la cuarta cara que es la que flanquéa la linea parapetáda de poniénte; hará con esta un angulo de 110. grados. Cerca de dicho angulo estará la subida desde el camino ó calle al fortín. Este se compondrá de dos cuerpos: en el bajo las parédes tendrán tres pies de espesor, eceptuándo la del norte: la cual, así como las del segúndo cuerpo serán de 1 1/2 pies. Las aspilléras distarán tres pies de centro á centro: las del piso bajo se elebaran siete pies desde el terreno; menos las que estén sobre el ribázo que principiarán á los cuatro pies, y no necesitan banquéta. La altúra total de la obra descripta queda determinada por la que [ecsijen] sus dos cuerpos. Estará cubiérta con tejádo, por cuyo medio el piso bajo servirá de cuerpo de Guardia, y en el alto estará la centinéla, sin necesitarse de garitas que en esta obra serian mas perjudiciales que utiles.

(pág. 8)

En las tapias que hay desde el fortin proyectádo hasta el granéro de Don Francisco Antonio Herréro debe hacerse lo que á continuacion se indica. Se elebarán hasta que tengan $31 / 2$ baras sobre el terréno esterior, haciéndo aspilléras á la altura de 61/2 pies del mismo, y estableciendo la correspondiente banqueta de madera. Se masiyarán todas las Puertas con el mismo espesor de la tapia.

Para dar comunicacion con la Ciudad á las casas del Batanejo, que quedan ahóra dentro del recinto se abrirá un estrécho portado en el cerramiento, que se halla en la esquina de la Casa de Carcel, colocándo en el una Puerta.

Casa de Carcel. Se renobarán las aspilléras de la trascocina, y se levantará un tabíque aspillerádo en la galería contigua. Grandero de [Don] [Francisco] Antonio Herréro. Se reforzarán sus parédes y tabiques, se tapiarán las ventánas y se harán aspilléras en los dos pisos, puesto que la poca altúra á que resultan las del bajo, no ofréce aquí perjuicios á causa de la horma que hay en frente.

Tapias aspillerádas y edificios intermedios desde el Granéro de Herréro á la Puerta de Alcalá. Esta linea está faborecída por su posicion reentránte, por la protéccion que recibe de algúnas obras, por el fuego que puede hacerse desde las casas de la espálda, y por los obstaculos que presentan los ribázos que la anteceden: sin embargo en el estado en que actualmente se halla no ofrecé la indispensable seguridad mayormente contre una sorpresa. Los defectos de que adolecé quedarán indicádos con la siguiénte enumeracion de lo que ha de hacérse para remediarlos. Se procurará que toda esta finca tenga por lo menos cinco baras de altura sobre el terreno esterior, ó seis sobre el fondo del foso en los [parajes] donde se haga; y como en un [lugar-espacio] una parte de esta altúra la constitúyen las hormas ó ribázos en que [subsisten] las tapias, se tendrá cuidado de escarpárlas y arrancar las matas y arbustos que hay en ellas, para que de ningún modo sea posible la subida. No basta que el parapeto tenga el relieve dicho, sino cubre bien á los defensóres de los tiros de frente, de rebés y de enfilada; este inconveniénte que [ocurre] en varios [frentes] se evitará ya levantando la tapia, ya rebajando á su inmediacion el piso interior, ó bien empleando los dos medios. Hay algúnos angulos donde será indispensáble construir cuchillos elebádos para conseguir la desenfiláda de las caras; á cuyo fin se emplearán también trabesas donde conbenga. Las comunicaciones entre 
todas las partes de esta linea, serán espeditas y á cubierto. En diversos sitios deben recomponérse las tapias, y en aquellos donde ha habido Puerta se masizará el hueco con buena mamposteria, en vez del debil cerramiénto que ahóra tienen. Casi todas las aspilleras son defectuosas, tanto por su colocacion, como por su figura y dimensiónes; es necesario pues reforzarlas en terminos que queden mas desahogadas, que sus caras estén mejor dirijídas, y que disten cuatro pies de centro á centro. Se rebocarán [para] mayor resistencia suya y de toda la obra, y se abrirán en los parajes donde se han dejado á manera de almenas. Su alturá se graduará de modo que por la parte del campo no pueda introducirse en ellos un fusil, y que por el lado almenas. Su alturá se graduará de modo que por la parte del campo no pueda introducirse en ellos un fusil, y que por el lado
interior esten á 4 ó $41 / 2$ pies sobre el piso, ó sobre la banquéta. Se establecerán banquetas de tierra de $31 / 2$ pies de ancho, interior esten á 4 ó 4 1/2 pies sobre el piso, ó sobre la banquéta. Se establecerán banquetas de tierra de $31 / 2$ pies de ancho,
donde sea preciso para [llenar] las condiciónes espuestas: en cuyo caso no se dejarán acequias, ni otro espacio alguno entre ellas y el parapéto.

\section{(Pág 10)}

Para que la esténsa cortina al medio dia quede mejor defendida se levantará una plataforma, apoyáda en el Pajar de Ignacio Moya, por donde se le dará comunicacion. Sus planos apoyarán en las esquinas del Parajar: el de la derécha formará un angulo de 100. grados con la cortina, y tendrá seis baras de lado esterior: la cara tendrá el mismo largo y su diréccion será perpéndicular á las tapias de la huerta de [Domingo] Vives: el otro flanco queda determinádo por este trazádo. Esta plataforperpéndicular á las tapias de la huerta de [Domingo] Vives: el otro flanco queda determinádo por este trazádo. Esta plataforde bara en bara. Sobre la cara habrá un tejádo de bara y media de buelo interior, para abrigo del centinela.

En frente de las dos parédes de la casa de Maluénda que caen á la campaña, y [a] cinco baras de distáncia, se construirá un parapéto aspillerádo, de cuatro baras de alto, formándo una garita en su angulo saliénte. En los pisos altos de [dicha] casa se abrirán todas las aspilléras posibles. Es de absoluta necesidad proporciónar algun flanquéo al estrémo de la [esténsa] linea de levante, que caréce absolutamente de esta proteccion. A este fin se levantará [una] platafórma en la curva que forman las té el rebestimién to del camino contiguo, angulos de 110. grados. Esta obra tendrá dos cuerpos, el espesor de sus muros en el bajo será de 3 pies, en la cara, y en el flanco de la derecha, y en el superior y todo el flanco de la izquierda será de 1 1/2 pies. Las aspilléras bajas estarán á 4 . pies del piso, y todas á tres pies de centro á centro.

Toda la linea de tapia del sitio llamádo Bajo de los huertos, se guarnecerá con foso, cuyo obstaculo correrá por delante de la plataforma que se acába de describir, y parapetos de la casa de Maluénda hasta el ribázo.

Se aspillerarán en todos los pisos las parédes de las casas de la Villa que caen al bajo de los huertos, y se cerrarán en ellas con un recio muro de mampostería las puertas que hay abiértas ó mal tapiádas. No obstante, se dejará la comunicacion alta [que de una escála [amovible] de madéra. Para que esta no sea vista desde el campo se harán los tabiques necesarios.

\section{(pág. 11)}

Corrales altos de la Villa. Se allanará el piso de modo que las aspilléras queden á la altura de cuatro pies: se levantará el parapéto en los paráges donde es necesário para cubrir á los defensores de los tiros de frente y de [enfilada], y se dará comunicacion á los dos corráles entre si. Se cerrará con piedra seca rebocáda las cuebas que hay debájo de la peña, que sirve de suelo á los corráles y Bateria contiguas.

\section{Desde la Puerta de Alcalá á la de Cantarránas}

Puerta de Alcalá y su Batería. En el parapéto que está encima de la puerta se realzarán y ensancharán los huecos de las aspilléras, dejándolas de modo [que] un soldádo en su posicion natural descubra bien toda la campaña: además se cubrirán estas aspillétas por su parte superior, y se dará mas elebacion al parapéto. Las aspilléras bajas que hay en el flanco de la derécha se reformarán, dejándolas todas á cuatro pies sobre el piso, y cerrándo por consiguiénte las que se hallan á mayor altura. Conviniendo aumentar los obstaculos que presenta esta entrada, se hara un cerramiento de dos lados por la par interior dejándo en el una puerta paraléla á la priméra. La nueba puerta estará deféndida por las aspilléras de [dicho] cerramiénto, y por el fuego que puede hacérse por la espálda á los enemigos desde la banquéta alta que viene á quedar á su frente. En la Batería se aumentarála alturá de las rodilléras, y se harán otras pequeñas refórmas que necesitan las cañonéras, y aen sus dimensiónes, ya en la diréccion de sus caras: las cuales no se especifican en este lugar ni en los sucesibos porque hos percibe facilmente una mediana inteligéncia, y sería prolijo describirlas. Se pondrán portezuélas de madéra en las cañonéras. Se compondrá y allanará bien la esplanáda de piedra.
Desde la Puerta de Alcalá al Barrio bajo de la misma. Se aspillerarán las casas que se hallan en el recinto, y aun las inmediátas, en todos los parájes y pisos que descubren el campo; no olvidándose de verificárlo en las parédes que flanqueán las Puerta de Alcalá, ó cualquier otro punto. Se construirán parapétos aspillerádos en los corráles que hay sobre la roca, adelantándolos hasta la orilla de esta.

Por regla general se cerrarán las bocas de las cuebas [quel ecsisten debájo de la misma roca de la Puerta de Alcalá á la de Cantarránas. Se derribarán las tapilas de la huerta del Rojo del Pino.

Barrio bajo de la Puerta de Alcalá. Las pocas y misérables casas que hay en este Barrio deben derribárse, pues perjudican notablemente á la defénsa, entorpeciéndo los fuegos de la fortificacion, y facilitando al enemigo un ascénso [para] introducirse por sitios, que sin este [padrásto] serán inaccesibles. Desde este punto hasta la Puerta de Cantarránas conviéne realizar las indicaciónes que se apúntan en seguida, sin perjuicio de repetirlas en algun caso particular en que intérese llamar la aténcion. Se destruirán las tapias de las huertas procsimas y paralelas al recinto. Se barrenarán las peñas inmediátas, se escarpará la roca en varios puntos, en que, aunque no sin dificúltad, permite la subida. Se abrirán aspilléras en todos los [cpos.] de las casas en que no lo impída el grueso de las parédes, y se aprovecharán las garitas y balónes para establécer sino tambien en las de los costádos que proporcionan fuegos de flunco. Las puertas y ventínas que no se eleben mas de [ocho] baras de los sitios del despeádero á donde un hombre pueda subir, se cerrarán y aspillerarán. Se construirán cerramiéntos aspillerádos sobre los despeñadéros en las bocas calles que no los tienen, y se dará mas altúra á los que ecsisten. En los parájes donde la roca sobresale dejándo algún espácio superior, se levantarán tapias aspilleradas, y como hay algunos corrales altos ya cortádos, pero sin aspilleras, se procurará hacerselas. No se [omitirá] el dar las debidas dimensiones á las aspilléras abiértas hasta [aqui], y á las que se abran de nuebo, disponiéndolas con sujecion á los principios [que] se hán espuésto al [hablar] de otras lineas.

Desde Torregorda á la Casa de [Catórce]. Se cortará verticalmente la roca, en el paráje donde es accesible se cerrarán y aspillerarán las ventánas bajas.

Casas llamadas de Debajo de la Peña Estas tres casas, la galeria de la de Catórce y la obra que hay debájo de estas, deben [demolerse] totalmente, ya porque interrumpen la vista y la accion de los fuegos de Torregorda y otros fortines sobre la inmediacion del recinto, ya porque esponen la ciudad á una sorprésa. Verdad es que pueden havilitárse en terminos que proporcionen ellas mismas la defénsa que ahóra impíden, pero prescindiéndo de que esto ocasionaria gastos aprocsimádos al valor de las casas, y de que estas no podrian havitárse, seria preciso auméntar el servicio de la Guarnicion para evitar el segúndo inconveniente.

Casas de Antonio Herréro y Blas Perez. Se tapiarán las ventánas bajas dejándo en ellas aspilléras.

Bateria de Nuebalos. Se construirá una esplanáda y se elebará el suelo á la inmediacion de las aspilléras, hasta que estas esta calle al despeñadero, se reformarán las aspilléras según las reglas dadas, se levantará el parapéto y se rellenará el piso. Casa de Don Antonio Montenegro. Se guarnecerá con parapéto aspillerádo el pequeño corral que hay sobre la Roca. Casa de Estebána Carcel. Se levantará un parapéto aspillerado en el corral que está encima de la Peña. Las tapias que hay enfrente de la misma se derribarán; y se cerrará la cueba [que] queda descubiérta; según se há dicho ya por [punto] general.

Casa del Angel. Se cerrarán con recia pared el balcón, las ventánas y la puerta; y se abrirán aspilléras en todos los [Cpos.] por el frente y costádos. La escalerá por donde se baja desde el Recinto, debe ser de madéra y amovible. Se escarpará bien

\section{(pág. 13)}

Bateria del Cristo. Se realzarán las rodilléras y la cresta del parapéto. Deben habérse tres esplanádas de madéra; asi como tambien portezuelas para las cañoneras. El parapéto aspillerádo contiguo se reformará con sujecion á los pincipios tantas veces referidos: se hará que algúnas aspilléras se dirijan á la Puerta de Cantarránas, y en todas se ensancharán las bocas.

Desde la Puerta de Cantarránas á la de Madrid.

Puerta de Cantarránas. La pared fronteriza de la garita al cuchillo del angulo entránte se elebará lo necesario para que un [caballeté] pare á 3. pies sobre la entrádas. En el pequéño lienzo de la izquierda de esta se dará mas desahogo á las aspilléras, se establecerá con mas firméza la banquéta de las altas y se abrirá un foso á un frente. Se pondran gruesas puertas nuebas en lugar de las debiles [que] ahóra hay: cuyas puertas tendran su postigo de tres pies de alto en una de sus hojas. Para auméntar la seguridad de esta entráda, se efectuará por la parte interior la obra que sigue. Se levantará un parapéto aspillerádo sobre el rebestimiénto de la rampa por donde se sube á la Villa, con lo cual se consigue tambien la ventája de resguardar esta rampa de los tiros de la campaña, se elebará tres pies mas, y se aspillerará la tapia interior del huertecillo de la derecha, formándo 
un cuchillo en su proximidad con la facháda, á fin de desenfilar la banquéta alta de la misma: estos dos parapétos se unirán por medio de otro paralélo á dicha facháda: en cuyo tercer parapéto se dejará una segúnda entráda, donde pueden colocarse las puertas [que] se desechan en la priméra. En el pequeño huerto que acába de citárse se desenfilará la escalerá de la garita

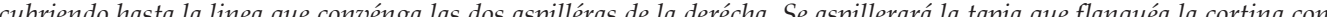
gua, realzándola lo que sea preciso para que su al túra sobre el terréno no baje de cuatro baras. Se desharán los restos de una tapia paraléla á la que se acaba de citar, porque perjudícan á la defénsa.

Cortina de la Calle de Cantarránas. Se dará á todo el parapéto de esta cima una misma altúra, que será la del trozo que ahóra se eléba mas. Se recalzará, compondrán y rebocarán las parédes y tapias en divérsas partes en que lo recláma su actua estado, y se masisarán las puertas que se hallan debilmente tapiádas. Se destruirán dos pasadizos de piedra que ecsisten sobre la acequia contigua, y se cortarán los arboles y arbústos [que] facilitan la escaláda de la cortina. Las casas de la Calle de Cantarránas se aspillerarán en todos los cuerpos que descúbran el campo.

Se tendrá cuidádo de que las aspilléras que se hagan ó refórmen queden desahogádas: que en el paraménto esterior tengan de 16. A 18. pulgádas de alto, y de 3 1/2 a 4 de ancho: que las direcciónes de sus costádos sean las mas conveniéntes; y que su elebacion sobre el terreno se sujéte á las condiciónes que anteriórmente se hán establecido. Las aspilléras distarán de centro á centro cuatro pies en las lineas esténsas, y solo tres en las [reducidas], ó donde interése multipliocar los fuegos: sin centro á centro cuatro pies en las lineas esténsas, y solo tres en las [reducidas], ó donde interése multipliocar los fuegos: sin
embárgo en los edificios no siempre se puede obsérvar esta regla, pero se procurará aprocsimárse á ella todo lo posible. Siendo generáles estas advertencias, no solo se aplicarán á la parte del recinto [que] ahóra se considéra, sino á todos los demas: por lo cual se evitará su repeticion en lo subcesibo. Y por la misma razon se omitirá tambien el repetir otras indicaciones que son igualmente generáles.

\section{(pág. 14)}

Postigo de la Fuente del Perál. Se adelantará tres baras mas sobre el camino el pequéño tambor en que se halla la puerta la cual se colocará en el flanco de la izquierda quedándo por consiguiente cerrádo y aspillerádo el frente. Delánte de esta nueba puerta se escabará un foso en comunicacion con la acequia, y para su paso se empleará un puente amovible de madéra. A este tambor se dará la elebacion que se há dicho para la cortina.

Casa de Don Andrés Ferrer. Se hará el mayor numero de aspilléras posibles en todos los pisos, en la pared que está sobre el camino, y se abrirán algunas en las que descúbren las inmediaciónes por encima de las tapias.

De la Casa de Don Andrés Ferrer hasta la Posáda de afuéra. Las tapias se elebarán lo suficiente [para] que en ningún punto baje un reliéve de cinco baras, y en cuanto á las aspilléras se sujetarán á las reglas dadas. En frente de la Fuente del Perál, se hará aun mas consideráble el relieve dicho; puesto que debe establecérse un orden superior de aspilléras en banquéta correspondiénte para dominár el terréno de lascercanias. Este segundo orden de fuegos se estenderá catorcé bar desde la derécha de la garita, á la que tambien se dará mas altúra. Todas las tapias de huertas procsimas á la fortificacion y á la fuente se hán de demóler.

Posáda de afuéra. Se aspillerará en todos sus cuerpos, cerrándo y aspillerándo las ventanas bajas. Se dará cinco pies mas de altura á la tapia de su izquierda.

Desde la Posáda de afuéra al frente de la Gloriéta. Se repararán con esméro las parédes debiles ó deteriorádas, aumentándo hasta cinco baras la altúra de toda esta linea. Se dará mas longitud al tambor contiguo á la Casa de Ponce: al efecto en el pilar de la tercia se levantará perperdicularmente un flanco de cinco baras de largo, desde cuyo estremo saldrá el frente que se unirá con el que ahóra ecsíste, formándo con el un angulo entránte muy obtuso. No solo se hará en el recinto el mayor numero de aspilléras que sea doble, sino que tambien se aspillerarán [la] casas interiores por los sitios donde desć́bran la campaña y esto se verificará muy particularmente en tolns has mayóres dimensiónes al foso que rodéa este frente.

Desde el Frente de la Glorieta á la Puerta de Madird. Despues de aspillerárse todos los pisos se renobarán con mas solidéz los cerramientos de las puertas. Se tapiarán las ventánas, cuya elebación sobre el camino no exceda de ocho baras, y se arrancarán las rejas y balcónes que facilitan la escaláda. Se daran seis baras de altúra á las tapias que forman el angulo entránte de la Puerta de Madrid.

\section{Desde la Puerta de Madridá la de las [Cruzes]}

Puerta de Madrid. Se dará mas alturá á los tabíques del tambor volado. Se mejorará el mecanísmo para levántar el puente substituyendo á las actuales cadénas, otras mas adecuadas, ó cuerdas de cañámo.

Palomar de D. Jose [Cros]. Se aspillerará en sus dos pisos, no solo por el frente sino por los costados, que descúbren las cercanias. Desde la Garita del huerto de D. Diego Montés á la Puerta de las [Cruzes]. Se procurará que en ningún punto de las tapias baje su elebacion de 2 1/2 baras, y además se las guarnecerá con un foso. En la Calle de las Cruzes conviene reforzar las tapias que ahóra son muy debiles. Respécto á aspilléras se observarán las reglas dadas.
Desde la Puerta de las Cruzes á la de Reinas

Puerta de las Cruzes. Se cubrirá con tambor rectángular que ocúpe el ancho del camino, y tenga doce baras de largo desde la puerta. La altura de su parapéto será de cuatro baras y el espésor de dos pies. Se construirá una banquéta para el uso de las aspilléras. La puerta de este tambor se situará en el flanco de su izquiérda, donde se hará un pequéño puente para el paso de la acequia.

Bajo de las Bodégas. Las tapias de Don Andrés Ferrer deben levantárse para [que] cubran bien á una persona: al mismo tiempo se reformarán las aspilléras, dándoles mas desahógo y mejor diréccion. En las tapias de Don Manuel Nuebalos se masizarán las aspilléras bajas, y se abrirán otras mas arriba. Se abrirá un foso en frente del lienzo que hay desde la garita al despeñadéro.

Bateria del Pozo de la nieve. Esta Bateria se halla en la posicion mas ventajosá para defendér las inmediaciónes de la poblacion, desde la Gloriéta, Fuerte de San Francisco, Loma, olla del martinéte, y Cerro del mísmo, pero para que correspónda á su objéto hay que mejorárla según se propóne á continuacion. En la cara del norte se abrirán dos cañoneras, asó como la que ecsiste al poniénte, se sujetarán á las dimensiónes que el arte prescriba. En todo este espácio se reforzará el parapéto con obra de tapia: hasta que tenga bara y media de espésor, y se levantarán banquétas detrás de los merlones, para que por encima de ellos se pueda hacer uso de la fusilería. Tambien se aumentará la altúra del parapéto dandole la conveniénte para que los artilléros queden á cubiérto y bien desenfilados: con cuyo abjéto será tambien necesário establecer una trabéza que cubre la artilléros queden a cubierto y bien desenfilados: con cuyo abjéto será tambien necesário establecer una trabeza que cubre la
ultima pieza del frente del norte. Por la parte de poniénte terminará el espaldón de la Bateria á una bara á la izquierda de la ultima pieza del frente del norte. Por la parte de poniénte terminará el espaldón de la Bateria á una bara á la izquierda de la
cañonéra: desde cuyo punto hasta la escaléra, al parapéto lo constituirá la paréd que ahóra ecsiste, realzándola y aspillerándola. Dicha escaléra, por donde se baja al arrabal y calles nuebas, se desenfilará por medio de tabiques. Se nivelará el [techo] del [pozo] de la misma, y sobre el se levantará un parapéto aspillerádo: De este modo quedará formádo un pequéño torreon al que se subirá por dentro del actual cuerpo de Guardia que debe destinárse [esclusivamente] á la defénsa. Se pondrán portael paráje mas resonard estableciéndolo de modo que sirva de espáldon [para] cubrir las comunicaciónes con otros puestos. Todas las aspilléras del parapéto [que] hay desde la derécha de la Baterria hasta las casas, deben reformarse y en algúnas, se correjirán las dirécciones.

\section{(pág. 16)}

Bateria de Ysabel $2^{a}$. Se adelantará el frente del norte girándo sobre vertice del angúlo saliénte hasta que su lado esterior quede á la orilla del desfiladéro, [y] se terminará á la distáncia de trece baras: Desde el estrémo de esta linea se diriiirá una cara oblicua de siete baras de lado esterior, de modo que vaya á morir en el lienzo aspillerádo de la derécha. Al parapéto de estas caras se dará bara y media de espésor. El lado interior del frente de poniente no se ignobará, pero si el esterior, pues se aumentará el grueso de su parapeto todo lo que permita la peña que le sirve de base. La garita se situará en el angulo saliente que résulte por este trazádo. La cara de poniénte se unirá con la tapia baja de la izquiérda por medio de un parapéto de dos pies de grueso. El reliéve de los parapetos se graduará por la condicion de que el interior quede cubiérto y desenfiládo. La cara [oblicua] de levánte tendrá una cañonéra, la del norte dos, y la de poniénte otras dos, todas con portezuelas y esplanádas de tablónes. El repuésto de polvora se colocará al abrigo de las quiebras del terreno, ó mas bien en una cueba abiérta debájo del mismo con las precauciones oportunas.

Sitio denominado Pedazo de los Muertos. Se conserbará la linea abanzáda que es de suma utilidad; pero siendo como debe ser baja, es necesario que para que puedan cubrirse los defénsores, se abra una zanja de dos baras de ancho por la parte interior. A la linea del recinto principal se aplicarán los principios establecidos: además se reforzará la puerta de comunicación con la priméra, y delante se hará un trozo de foso con puente amovible.

Bateria nueba de Reinas. Esta obra es en la que se hán empleádo mas recúrsos y por desgracia la que adoléce de mas deféctos: sin embárgo es preciso confesar que su mucho reliéve y robustéz le dán algúna importáncia, y que á fabor de las indispénsábles corrécciónes será de utilidad, En la parte mas saliénte que es la mas elebáda deben reformarse las cañonéras dandoles la configuracion ordinária. Se pondrán en ellas gruesas portezuélas y ademas guarda-cabézas de biga en la cresta del parapeto. Este pequeño espácio donde solo con [estrechez] cabe una pieza, tiene descubiérta á los tiros de rebés la cara de la izquiérda: para remediar este inconveniénte y desénfilar la rampa de madéra se levantarán tabicónes opórtunamente establecidos. La plaza baja debe havilitárse para el emplazamiénto de artilleria: al efécto se destruirán en su mayor parte los actuáles cuerpos de Guardia, conserbando unicaménte el espacio necesário para cinco hombres, á la inmediacion de la gola. los fuegos de la campaña. En cada cara se abrirán dos cañonéras, proveyéndolas de las portezuélas y esplanádas correspóndientes. Se dejarán las aspilléras intermedias, y se dejará el parapéto donde sea preciso para cubrir el interior. Se dará otra forma al cerramiénto de la bajáda que condúce al repuésto de polbora; pues en lugar de la compuerta que hay ahóra, se abrirá la escaléra con un [gariton] de albañileria,.. 
(pág. 17)

.. que la presérbe mejor de las aguas: cuyo garitón tendrá puerta con cerradúra. En el espácio cerrado donde [ecsiste] la subida á la obra que se acába de ecsaminar, se abrirá una comunicacion con la Bateria vieja de Reinas, y se levántarán los espaldónes indispénsables para ocúltar al enemigo esta comunicacion, y la cara interior de los parapétos.

Bateria vieja de Reinas. Se dará mayor elebacion á sus parapétos, se reformarán las aspilleras y se dará á estas mejor diréccion. Deben rehacerse las esplanádas.

Corral de Cepéda. Para proporciónar mayor flanquéo á la puerta de Reinas, se dará mas altúra á la tapia que hay á la izquiérda, estendiéndolo por encima del tejádo procsimo. De este modo se podrá hacer un segúndo orden de aspilléras par cuyo uso se dispondrá la andamiada. Sobre el caballete del tejado se levantará un trozo de tabicón á fin de evitar la enfiláda.

\section{Desde la Puerta de Reinas ála de Valénci}

Desde la Puerta de Reinas al fortin del huerto de Parra. Se realzarán las parédes de modo que partiéndo desde la parte superior de la garita de la puerta, no bajen en ningún punto de 4. baras de altúra. Sobre el nibel del terréno. Tambien convendrá reforzárlas y rebocárlas en algún paráje en que lo necesíten.

convendrá reforzarilas y rebocárlas en algun paraje en que lo necesiten.

Molino de Herrérno. Se hán de levántar las tapias del corral, siendo indispénsáble que así estas como las de la casa se aspilléren. En el huerto se abrirá una cañonéra á la derécha de la garíta.

Desde el huerto de Herréro al Molino de Valéro. En este lienzo del recinto se encuéntran algúnos trozos de rebestimiénto de piedra seca que deben rebocarse para su mayor firméza, y que no formen escalónes. Se cortarán las higuéras y matas arraigadas en las parédes. El escurridor de Francisco Ramón se há de cerrar en prolongacion de las tapias de su izquiérda dejándo un arbellón bajo para la salida de aguas. Conviene no descuidar el pronto aspilleramiénto de las tapias del molino un parapéto con una cañonéra á fin de que sirva de Bateria. Todas las casas interióres deben aspillerárse en las paredes que descúbren las inmediaciónes ó flanquéan el recinto.

Huerto de Valéro. Deben elebárse una bara mas las tapias fronterízas al [cas] del molíno, achicándo el arbellón que hay á su pie, y ensanchándo el mismo [cas] para que sirva de foso. La puerta debe cerrárse con buena obra de Albañileria. Casa de Gregória Moral. Se abrirán algúnas aspilléras, y se reparará la pared.

Desde la Casa de Gregória Moral al tinte de António Monsalve. Se guarnecerán con foso las parédes de la Calle de San Fernándo, se harán de nuebo con mayor elebacion, y las aspilléras [correspondientes], las tapias del corral del [Sopéro]. Las casas de este y demás que forman el contórno del recinto, se hán de aspillerar en todos sus pisos.

\section{(pág. 20)}

Desde el Torreón de Monsálve á la casa de [Francisco] Narbón. En este frente se hará de nuebo la linea [perimetral] de fortificacion, abanzandola hasta las tapias que mandó construir el Señor Coronel Albornóz, lo cual se verificará segun va á indicárse. Desde el angúlo entránte del Torreón se dirijirá una linea que encuéntre á [dichas] tapias dos baras ála izquiérda del estrémo del pedázo del [Contador]: la otra linea dará frente a las casas de la Garróta, seguirá la configuracion del reibázo que le servirá de base, y terminará cerrándo la calle de Gil, en la esquina de la casa de [Francisco] Narbón. De este modo quedar trazáda esta parte de fortificacion, cuya altúra sobre el terréno será por lo menos de cuatro baras, teniéndo además foso en lo paráies donde no se ciménta en el ribázo. Las tapias de Albornóz que quedan fuera del perimétro indicádo se destruirán. La fortificacion interior que ahora ecsiste se conserbará y para su comunicacion con la nueba se abrirá una puerta inmediáta Torreón. Otra comunicacion resúlta por la Calle de Gil, por cuya causa debe colocárse una puerta en su salida.

Desde la Casa de NArbñon á las de la Garróta. Las parédes de las casas se aspillerarán en todos los cuerpos, cerrándo y aspillerándo las ventanas y balcónes cuya altúra no escéda de ocho baras: se masisarán bien las puertas. A las tapias de la derécha que van á unirse con las casas de la Garróta debe darseles una bara mas de elebacion. El postigo del [trilléro] se subirá con un tambor de tres lados: el del frente seguirá la orilla del camino, y tendrá ocho baras de largo: los otros dos se unirán con el recinto en forma de flancos. En el lado del poniénte se establecerá la puerta del tambor, y delante de ella un pequeño y profúndo foso, empleándo para su paso un puente amovible de madéra.

Casas de la Garróta. Se dará mas espésor á la pared del primer piso reforzandolo interiormente, y asi en este piso como en los demás se abrirán todas las aspilléras posibles.

Bateria del huerto de Agustin Monsalve. Se variará su posicion y trazado del modo que va á indicárse. Se adelantará hasta las tapias del huerto sobre las cuales se marcará un frente de nuebe baras de lado esterior en linea recta. Esta será la cara de levánte: la de medio dia formará con ella un angulo de 140. grados, y tendrá otras nuebe baras: la del norte formará con la misma un angulo de 100. grados, y terminará en el rebestimiento de la rampa de que va á hablarse. La rampa [para] subir á la Bateria partirá desde la inmediacion de las tapias que cierran el huerto por la parte del norte, y apoyándose en la paredes de las casas, terminara en el piso de la obra. Tendrá cuatro baras de ancho, y su guardalado será un parapéto aspillerádo. Al [frente] de esta rampa se abrirá una comunicacion para la conducion de estas piezas por la Casa de Roque. Desde el estrémo de la casa de medio dia, y formándo con ella un angulo de 110. grados, se construirá un parapéto aspillerádo que irá á terminar en las tapias, por las cuales seguirá el recínto...

(pág. 21)

hasta la Casa de Onrrubia, en cuyo paráje se hará una entráda para comunicárse con los huértos procsimos. Todas las tapias que quedan fuera del recinto que se ha trazado deben demolerse. La altúra de la Bateria será de dos baras y media sin contar el parapéto, ni la profundidad del foso que debe rodearla por la parte del norte. A un parapeto se dará la elebacion ordinária, el espésor de dos baras por los frentes de levante y medio dia, y el de una bara por el lado del norte. En cada lado se abrira una cañonéra en que se abrirán portezuelas; se hará una esplanáda de madéra que oculte el piso de la Bateria, pero tanto para eso como para gradúar el espesor de los espaldónes, solo se graduará por tal el sitio en que há de revolvérse la piesa. El parapéto que cubre los demás puntos, solo tendrá dos pies de espésor, y estará aspillerádo.

Huerta de Onrrubia. Se elebarán las tapias de este huerto y de los de la derecha hasta que cubran bien á los defensores, aspillerándolas á la conveniente al túra. La cañonera se conserbará, pero dandole mejor forma. En las parédes de la izquierda de esta se reformarán las aspilléras.

Huerto de Tirador. Sus tapias están muy mal cimentadas, por lo que deben reparárse. Se abrirá una aspilléra mas frente del tinte, y se procurará [que] de todas pueda hacérse buen uso. Las parédes del tinte se aspillerarán en todos los pisos por los parájes que descúbran el campo.

Fortín de Cara-Cuesta. Se reforzarán las parédes de la casa de Amorós [que] miran á las Ollerias y al camino, dandoles tres pies mas de espésor por su parte interior. En las mismas se abrirán aspilléras en todos los pisos. La puerta de comunicacion con las casas del puente se trasladaré al angulo de la derécha: y como en este frente debe abrirse un foso se emplearé in puente de madéra para su paso. Las dos lineas que ciérran la comunicacion desde el fortin dicho á las casas del puente, se hán de realzar y aspillerar en debida forma.

Casas del Puente. Estas casas se hallan en tan mal estado que seria necesario derribárlas, si el enemigo atacáse á la Poblacion con recúrsos imponéntes: pero como no hay inconveniente en conserbárlas, mientras no llegue este caso, debe aspillerárse en todos sus pisos, y sujetárse á las prevénciónes que se hán hecho para todos los edificios que se hallan en el perimetro de la Ciudad.

Desde la Casa de Amoróz á la Puerta de Valéncia. Se aspillerarán las parédes en todos los cuerpos, se masisarán las puertas con buena albañileria, se arrancarán los balcónes que no se elében mas de ocho baras sobre el terréno, y se tapiarán las ventanas que se hallen en igual caso.

Villa: Se aspillerarán en todos sus pisos que miran á la parte interior, y forman parte del recinto de la Villa.

(pág. 23)

Casa de [Zamóra]. Se aspillerarán igualménte. Se levantará en forma de parapéto el guardaládo del blanquéador; tanto donde es de tabique como de pared. Las puertas que ahóra están cerrádas con obra, se cerrarán con mas perféccion, abriéndo aspilléras: La tapia del corral de Zamóra en la Plaza de Casáres se aspillerará así como la del corral de Manuel Gonzáles que sigue la misma linea. La comunicacion de este corral con la casa de González se tapiará dejándo el corral en alberca. Corral de Don José [Cantos]. Se abrirán aspilléras en la tapia que mira á la calle de Cantarránas, y en la que mira al corral de Manuel González. Las puertas de comunicacion con las casas de Cantarránas se tapiarán en caso de riesgo.

Las vocas calles que caen á la Plaza de Casáres se cerrarán con cortadúras barricádas [signo ilegible] en caso de riesgo. La puerta grande del corral de Don [Cantos] será la comunicacion unica para la retiráda de los defensóres de la Plaza de Casáres, pero para esto solo se dejará una hoja, y otra se podrá masisar por detrás en caso critico. Las tapias inmediatas á esta puerta se aspillerarán. Todas las casas que se hallan en el recinto se aspillerarán por su frente y flancos.

Casa de Don José [Cantos]. Despues de espillerárse como se há dicho se harán parapétos aspillerádos de tabicón en la galeria que cae al corral.

Todas las casas desde la de [Cantos] hasta el callejón del pozo del astillo sufrirán el mismo [aspilleramiento] y obras que por regla general se hán establecído. La boca calle del callejón citádo se cerrará en su salida con pared aspilleráda desde la rescisará y se derribarán las parédes de los costádos de esta casa que están sobre el desfiladéro. Desde el callejón del Pozo del Castillo hasta la casa de [Picapórte], cuyas caras están sobre el desfiládero se observarán las reglas generales. Desde la izquierda de la puerta de casa de Picapórte á la esquína de la casa del Castillo se hará un cerramiénto aspillerádo con puerta á la inmediacion de [dicho] Castillo. 


\section{Castíllo y Fortaléza}

Torre del Castillo. Su plaza alta se rodeará de un parapéto aspillerado. En cada uno de sus cuatro angulos se establecerá una garita, haciéndo algúnos ahujéros en su base á manera de matacánes para descubrir el pie. En la pequéña plaza baja se rodeará de un parapéto aspillerádo. Desde la plaza baja se dará la comunicacion á la priméra de las [tres] Torres, por una galeria voláda que se dirija bolicuamente á la murálla antigua, y por encima de ella recomponiéndola, parándo por la que sirve de pared á algúnas casas por la priméra Torre. Las parédes de las havitaciónes nuebas incorporádas al Castillo se aspillerarán, cerrándo las ventánas que no sean necesarias y aspillerándolas. La

\section{(pág. 24)}

puerta principal que está ahóra inmediáta a la [Cuesta] se masisará y aspillerará. Se dará la entráda al Castillo por la parte de levante, haciendo una entráda común al Castillo y la Fortaleza. Los torreones se rodearán en sus plazas altas con muro aspillerádo.

Fortaléza. No se dejará á la Plaza llamáda así mas comunicacion que la que tiene al callejón por donde se debe dejar la unica entráda para el torreon del Castillo. Todas las parédes que están sobre el desfiladéro se repararán y aspillerarán. En los parájes donde sobre sálen las casas del arrabál se establecerán banquétas para descubrir por encima de los tejádos. En frente parájes donde sobre sálen las casas del arrabál se establecerán banquétas para descubrir por encima de los tejádos. En frente
de la unica puerta que se deja se hará un gran tambor. Su lado izquiérdo será parte del mismo en todo el recinto, la diréccion del frente será la conveniénte para que sea flanquéado por los torreónes y camino intermédio. Su flanco de la derécha irá á terminar á cuatro ó cinco baras de la actual puerta. La del tambor estará en [dicho] flanco á dos baras de su angulo saliente.

\section{Pasádo el Recinto}

Casa de Calafórra. Se levantará un parapéto aspillerádo en el corral.

Casa del arte. En todo el corral parapéto aspillerádo; por supuesto, parédes, casas [signo ilegible] se aspillerarán. En todas las demás casas y corráles hasta la de D. Andrés Garcia se hará lo mísmo, y se dará comunicacion en las casas y corráles las demás casas y cor
simpre que se pueda.

Desde la Casa de Don Andrés Garcia hasta el cerramiénto de la Cuesta de las Carnicerias. Las aspilléras y cerramiéntos prevenidos por regla general, las puertas se atráncarán en caso de riesgo [signo ilegible].

Se derribará la casa de Don Nicolás Luján en la parte que pertenecia á las carnecerias. El parapéto que ahora apóya en ellas se rehará á bara y media de la casa de Don Andrés Ferrer en la misma diréccion que ahóra tiene, pero dirijiéndo un flanco sobre el despeñadéro que por la demolicion de la casa dicha quedará descubiérto. Este cerramiénto tendrá dos pisos aspillerádos, y la puerta donde ahóra se halla, pero mas fuerte y con cerróio y llabe.

Requéna 4. de Julio de 1838. El comandánte de Infanteria y Capitán de Ingeniéros- Juan Ramón de Carbonéll. Es copia

El Coronel, Comandánte Militar.

Jose Garcia de Orozco"

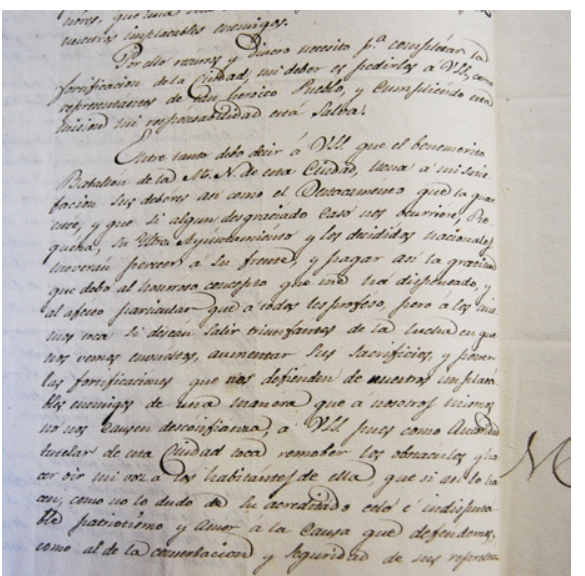

Fig. 884.

Transcripción 12: Expediente sobre la fortificación de la ciudad, Requena, 1839/03/09, AMR, 1818/35E.

(Transcripción parcial de la autora)

"No llevaria bien y cual deséo los debéres que me impóne mi empleo, y mas que todo los que por gratitud he contraido con esta Ciudad heroica y leal que me tiene á su frente, si no espusiera á VSS: los peligros que temo y los conocimientos que acerca de ellos tengo.

Sé positibamente que el Jefe enemigo [que] manda las fuerzas ecsisténtes para nuestra desgrácia en Chelca, se está proporcionando con el mayor afán noticias exactas del estado de la fortificacion de esta Ciudad, y que ya tiene conocimiéntos vastánte suficientes de ella, así como que busca inteligencias fuera y aun dentro de la misma para complétar las idéas que se haya propúesto.

Como un sitio formál, no es temible ni aun prosumible que puede sucedér, por las poderósas razónes que son tan faciles de alcanzar, si solo es de temer que las disposiciones enúnciádas del enemigo tiendan á un golpe de mano, cosa sumamente admisible en la tactica de aquellos de su clase de Guerra; esto sentádo [que] creo no se me negará Requéna para un atáque de esta espécie está insegúra y presentá los medios de obtenérlo, pues no debe ocultarsé a VSS. [que] su fortificacion está imómpleta y que tiene muchisimos puntos de facil acceso, ya por la debilidad de sus obras y situacion de estas, como porque no es posible que la fuerza con que contámos para su custodia guarnésca todos los puntos de la Ciudad, y ya porque de una vez no era dado obstruir tantos puntos peligrósos como por necesidad debe tener un Pueblo [que] no se edificó para ser fortificado.

Con las obras trazádas por el Ingeniéro que este veráno vino Comisionado para el efécto, y Cuya memória tube el honor de pasar á VSS, se asegúra completamente el estádo de fortificacion de esta Ciudad, las que con el fondo que se reunió del modo notório á VSS:, no pudiéron llevárse á Cabo, faltándo aun bastante que hacer aunque nunca del costo de lo que se construyó este veráno, siendo en mi sentir la mayor falta que se nota para evitar un suceso desgraciado, la construccion de todos los fosos que están marcádos y de uno ó dos puntos centricos de defénsa; cosa tan substancial en el arte militar como que sin ellos no puede ecsistir fortificacion algúna que deba contemplárse como tal.

Conósco muy bien que las circúnstáncias, en que se encuéntra esta Ciudad por efécto de los grandes dispendios Iquel para sostener la Guerra desoládora que nos aflije y su propia fortificacion há hecho, la tienen abrumáda y cuasi imposibilitáda de seguir con ol heroismo que le es propio, sacrifićn dose para superary llegar victoriósa al fin de tan injús ta lucha males y pribaciones serán menóres que una sola hora de ocupacion de la Ciudad por nuestros implac"ables enemigos. 
Por ello recúrsos y dinéro necesito [para] complétar la fortificacion de la Ciudad, mi deber es pedirlos á VSS. como representántes de tan heroico Pueblo, y cumpliéndo esta mision mi respónsabilidad está salva.

Entre tanto debo decir á VSS. que el benemerito Batallón de la M. N. de esta Ciudad, llena á mi satisfacion sus debéres así como el Destacaménto que la guarnéce, y que si algun desgraciado caso nos acurriére, Requéna, su Iltre. Ayuntamiénto y los decidídos nacionales me verán perecer á su frente, y pagar así la gratitud que debo al honrroso concépto que tamiénto y los decididos nacionales me verán perecer á su frente, y pagar así la gratitud que debo al honrroso concépto que
me há dispensádo, y al afécto particular que á todos loes proféso, pero á los mismos toca si deséan salir triunfantes de la lucha me há dispensádo, y al afécto particular que á todos loes proféso, pero á los mismos toca si deséan salir triunfantes de la lucha enemigos de una manéra que á nosotros mismos no nos causen descónfíanza, á VSS. pues como autoridad tutelar de esta Ciudad toca remober los obstáculos y hacer oir mi voz á los habitántes de ella, que si así lo hacen, como no lo dudo de su acreditado celo é indisputáble patriotismo y amor á la Causa que deféndemos, como al de la conserbacion y seguridad de sus representados, tendré la satisfacion de ver allanados los imposibles, y á las fortificaciones de Requena tales cual corresponden al renómbre de Heroica y Leal que le tiene tan justamente adquirido.

Dios que á VSS. su. a. Requena 9. de Marzo de 1839.

El Coronél, [Comandante] Militar

Jose Garcia de Orozco"

(el documento sigue en la pág. 7. No transcrito) 
Tabla 22. Toponimia asociada a la documentación histórica.

\begin{tabular}{|c|c|c|}
\hline $\begin{array}{l}\text { Calles, plazas, } \\
\text { avenidas, barrios.. }\end{array}$ & Identificación elemento & $\begin{array}{l}\mathrm{N}^{\circ} \text { de ficha } \\
\mathrm{N}^{\circ} \text { en plano } \\
\text { o información } \\
\text { asociada }\end{array}$ \\
\hline Ángel, Calle del & Puerta del Ángel Custodio, Batería del Ángel & 26 \\
\hline Arrabal, Avenida del & Extensión del Arrabal & 35 \\
\hline Arrabal, Barrio del & Expansión de la ciudad & 113 \\
\hline Asnos, Calle & Camino de los Asnos & 99 \\
\hline Balsa de Moros, Plaza & Balsa de Moros & \\
\hline Barriete, Calle & El Barriete & 16 \\
\hline Batanejo, Calle & El Batanejo (pequeño batán) & 7 \\
\hline Bodegas, Calle & $\begin{array}{l}\text { Bordeando las bodegas bajo las Peñas. "Bajo de las } \\
\text { bodegas" }\end{array}$ & 43 \\
\hline Caracuesta, Calle de & Fortín de Caracuesta & 80 \\
\hline Carmen, Calle & Convento del Carmen & 116 \\
\hline Carnicerías, Cuesta de las & $\begin{array}{l}\text { Venta de carne. Carnicerías. 'Tablas' o 'tablajerías' de } \\
\text { vendedores de carne }\end{array}$ & 91 \\
\hline Castillo, Cuesta del & Cuesta del Castillo & 90 \\
\hline Cementerio, Calle & Cementerio & 117 \\
\hline Chelva, Calle & Camino de Chelva & 47 \\
\hline Chera, Calle & Camino de Chera & 47 \\
\hline Colegio, Calle & Escuela de Doña Emilia. El Colegio & 10 \\
\hline Cortina, Calle & Cortina & 29 \\
\hline Cristo, Calle del & Capilla del Cristo del Amparo, Batería del Cristo & 27 \\
\hline Cruces, Calle & Via Crucis. Camino a San Francisco & 40 \\
\hline Estanque, Camino & Estanque de Rozaleme (Molino) & 124 \\
\hline Ferrocarril, Calle & Paso del Ferrocarril & \\
\hline Fortaleza, Calle & Fortaleza & 89 \\
\hline Fuencaliente, Calle & Fuencaliente & \\
\hline Fuente Baldomero, Calle & Zona de la Fuente Baldomero & \\
\hline Fuente Pilas, Calle & Fuente de las Pilas & \\
\hline Fuente Pino, Calle & Fuente del Pino & 17 \\
\hline Fuente Reinas, Calle & Hacia la Fuente de Reinas & 57 \\
\hline Gil, Calle & Casa de Gil & 68 \\
\hline Gollizno, Calle & Huerta de Gollizno, Canal del Gollizno & \\
\hline Higuerillas, Calle de & Las Higuerillas & 67 \\
\hline
\end{tabular}




\begin{tabular}{|c|c|c|}
\hline $\begin{array}{l}\text { Calles, plazas, } \\
\text { avenidas, barrios... }\end{array}$ & Identificación elemento & $\begin{array}{l}\mathrm{N}^{\circ} \text { de ficha } \\
\mathrm{N}^{\circ} \text { en plano } \\
\text { o información } \\
\text { asociada }\end{array}$ \\
\hline Honrubia, Calle & Huerta de Honrubia & 77 \\
\hline Loma, Calle & La Loma & 98 \\
\hline Ollerías, Barrio de las & Ollerías. Alfareros & 3 \\
\hline Paniagua, Calle & Callejón de Paniagua & 110 \\
\hline Peñas, Barrio de las & Peñas donde se asienta el barrio & 114 \\
\hline Peso, Calle del & Antiguo emplazamiento del peso del Almotazán & 36 \\
\hline Pinos del Florillo, Calle & Hacia los pinos del Florillo (pinada) & \\
\hline Portal, Plaza del & Puerta de Madrid, El Portal & 36 \\
\hline Pozo, Calle del & Pozo de la nieve & 44 \\
\hline Reinas, Avenida de & Hoya de Reinas y hacia Fuente de Reinas & 57 \\
\hline Rollo, Calle & El Rollo & 35 \\
\hline Rozaleme, Calle & Ribera de Rozaleme & 124 \\
\hline Saliente Loma, Calle & Saliente de la Loma & 98 \\
\hline San Agustín, Calle & Ermita de San Agustín, camino de San Agustín & 35 \\
\hline San Blas, Travesía & Hacia la Ermita de San Blas & \\
\hline San Sebastián, Barrio de & Iglesia de San Sebastián & 49 \\
\hline San Sebastián, Calle de & Iglesia de San Sebastián & 49 \\
\hline San Sebastián, Carrera de & Conexión entre San Sebastián y el Cerro de los Bolos & 48 \\
\hline Santa Cruz, Calle de & Ermita de la Santa Cruz & 3 \\
\hline Santa María, Calle de & Iglesia de Santa María & 95 \\
\hline Subida Bodegas, Calle & Subida a las bodegas bajo las Peñas & \\
\hline Tejedores, Calle de & Telares extramuros & \\
\hline Telégrafo, Calle & ¿Telégrafo? O hacia el telégrafo & \\
\hline Vereda Real, Calle & Camino Real & \\
\hline Villa, Barrio de la & Antigua Villa & 83 \\
\hline $\begin{array}{l}\text { Virgen de la Caridad, } \\
\text { Barrio de la }\end{array}$ & $\begin{array}{l}\text { Ermita de la Santa Cruz y Nuestra Señora de la } \\
\text { Caridad }\end{array}$ & 117 \\
\hline
\end{tabular}


AASC, Archivo de la Academia de Bellas Artes de San Carlos (Valencia)

ACCGA, Archivo Central del Cuartel General de la Armada (Madrid)

ACMD, Archivo Central del Ministerio de Defensa (Madrid)

ACP, Archivo y biblioteca del Real Colegio Seminario de Corpus Christi (Valencia)

ACV, Archivo de la Comunidad Valenciana (Valencia)

ADPV, Archivo (General y Fotográfico) de la Diputación Provincial (Valencia)

(MA, Archivo General de la Administración (Madrid)

(Madrid)

(SMG, Archivo General Militar (Madrid)

AGMS, Archivo General Militar (Segovia)

AGS, Archivo General de Simancas.

AHAV, Archivo Histórico del Ayuntamiento de Valencia

AHEA, Archivo Histórico del Ejército del Aire (Madrid)

AHN, Archivo Historico Nacional (Madrid)

AIMV/ AIMC, Archivo intermedio Militar de Valencia (Archivo Intermedio Militar Centro)

AMA, Archivo Municipal de Alcañiz

AMC, Archivo Municipal de Castellfor

AMCU Archivo Municipal de Culla

AMR / AHMR Archivo Histórico

APF, Archivo Parroquial de Forcall

(Valencia)

ARV, Biblioteca Central Militar (Madrid)

BOE, Agencia Estatal Boletín Oficial del Estado. Gobierno de España. Ministerio de la presidencia. Gazeta: colección

historica (Madrid)

BV, Biblioteca Valenciana (Valencia)

BVIFC, Biblioteca Virtual de la Institución Fernando el Católico. Excma. Diputación de Zaragoza (Zaragoza) Botín (Alicante)

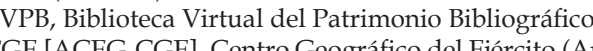

Cenaráfico del Ejército (Archivo Cartográfico y de Estudios Geográficos del Centro Geográ-

CVIGN, Cartoteca virtual del Instituto Geográfico Nacional (Madrid)

DGC, Dirección General del Catastro. Gobierno de España. Ministerio de Hacienda y Administraciones Públicas (Madrid)

FSS, Centro de documentación de la cultura vasca. Fundación Sancho el Sabio (Memoria Digital Vasca) (Vitoria-Gas-

IGNC, Instituto Geográfico Nacional de España (Madrid)

MVM, Museo Virtual del Maestrazgo (Cantavieja)

Cultural Valenciano. Generalitat Valenciana. Conselleria de (Valencia)

M. Archivo digital del Zumalakarregi Museoa. Centro de referencia para el conocimiento y disfrute del siglo XIX en el Pais

Vasco. Museo Zumalakarregui Museoa, Muxika Egurastokia Ormaiztegi (Gipuzkoa). 
13 BïLOCRA FiA, DoCUMENTOS HISTORICOS Y CARTOGRAFía HISTÓRICA DE ReQUeNa 
Bibliografía

Este apéndice bibliográfico incluye únicamente la bibliografía citada en el trabajo. No constituye una recopilación universal sobre la bibliografía especializada en el mundo de la fortificación o de las Guerras Carlist

Abascal, J. M, y Cebrián, R. (2009): Los viajes de José Cornide por España y Portugal de 1754 a 1801. Madrid: Real Academia de la Historia.

Albí de la Cuesta, J. (2017): El ejército carlista del Norte (1833-1839). Madrid: Desperta Ferro Ediciones

Allanegui, V. (1998): Apuntes históricos sobre la historia de Calanda. Zaragoza: Ayuntamiento de Samper de Calanda. Almirante, J. (1869): Diccionario Militar etimológico, histórico, tecnológico, con dos vocabularios francés y alemán por D. José Almirante. Madrid: Imprenta y Litografía del Depósito de la Guerra.

Alonso Baquer, M. (1972): Aportación militar a la cartografía española en la historia contemporánea. Madrid: Consejo Superior de Investigaciones Científicas.

Altaba, J. (1987): Cantavieja y su Baylía. Castellón: Imprenta Armengol

Anónimo (1840): Vida y hechos de los principales cabecillas facciosos de las provincias de Aragón y Valencia desde el pronunciamiento carlista de Morella en 1833 hasta el presente por un emigrado del Maestrazgo. Valencia: Oficina de Lopez. Archiving

Independencia" en Oleana. Cundernos de cultura Ayuntamiento de Requena, $77-90$. Argilés Gómez, V. (2006): "Molinos, batanes, lavaderos y otros usos del agua en nuestra comarca" en Oleana. Cuadernos de cultura comarcal 21, Requena: Centro de Estudios Requenenses. M. I. Ayuntamiento de Requena, 323-378.

Asensio, M. (2011): El carlismo en Castilla-La Mancha (1833-1875) Ciudad Real: Almud.

Asín, F. (1983): El carlismo aragonés 1833-1840. Zaragoza: Librería General.
Asín, F. y Bullón de Mendoza, A. (1987): Carlismo y sociedad 1833-1840. Zaragoza: Aportes XIX editorial.

Ayguals de Izco, W. (1849): El tigre del Maestrazgo ó sea de grumete á general. Historia-novela original. Madrid: Imprenta de . Wenceslao Ayguals de Izco.

Azpiroz, F. J. (1842): Memoria del general D. Francisco Javier de Azpiroz sobre la última campaña de la Primera División del enta del Archivo Militar.

(1836, and of the principen and to dec. Smith, Elder and Co. religiosa de España. Donostia: Txert

Badía Marín, V. (1953): Torre Baja, mi pueblo. Torre Baja: Ayuntamiento de Torrebaja.

Ballesteros, M. (1999): Historia de Utiel. Utiel: Imprenta de Luis Alarcón.

Baroja, P. (1935): "Sobre la ruta del General Gomez por los caminos de España. Utiel, Requena y la Mancha" en Estampa 377, Madrid: Talleres tipográticos de Sucesores de Rivadeneyra. Luis Montiel Balanzat (ed.), 37-39.

Baroja, P. (1977): Los caudillos de 1830. Madrid: Caro Raggio

aroja, P. (1977b): La isabelina. Madrid: Caro Raggio.

: Caro Raggio

:

Baroja, P. (1985): Zalacaín el aventurero. Madrid: Austral. Espasa Calpe.

Baroja, P. (2008): Las Furias en Memorias de un hombre de acción, tomo II. Madrid: Fundación José Antonio de Castro. arrera Ramírez, R. (2011): El Castillo de Chulilla. Trabajo final de Grado en Ingeniería de Edificación. Escuela Técnica Superior de Gestión de la Edificación. Universitat Politècnica de València. Director: Pablo Rodríguez Navarro, http:// hdl.handle.net/10251/12217 (2016).

Barrés du Molard, A. (1842): Mémoires sur la Guerre de la Navarre et des Provinces Basques despuis son Origine en 1833,
jusqu'au traité de Bergara en 1839. Paris: Dentu. (2003): El Matarraña y los Puertos de Beceite. Zaragoza: CAI

Benavente, J. A. (2014): Los fuertes de Cabrera de Beceite (Teruel) en http:// historiasdelbajoaragon. wordpress.com/

Unentario Arquitectónico. Teruel. Zaragoza: Departamento de Cultura y Becion.

(1995): Requena y sus alrededores. Requena: Ed. Fiesta de la Vendimia.

Bernabeu López, R. (1936): Requena durante la $1^{a}$ Guerra Carlista. Requena: s.e.. 
Bernabeu López, R. (1962): Estampas requenenses. Requena: Imp. Artes Gráficas Molina.

Bernabeu López, R. (1982): Historia crítica y documentada de la ciudad de Requena. Requena: Artes Gráficas Molina. Bernaldez, E. (1860): La fortificación moderna o consideraciones generales sobre el estado actual del arte de fortificar las plazas. Borrow, G. (2008 (1843)): La Biblia de España (The Bible in Spain, or the Journey, Adventures, and Imprisonment of an Englishman in an Attempt to Circulate the Scriptures in the Peninsula. Barcelona: Zeta Bolsillo. Bullón de Mendoza, A. (1984): La expedición del General Gómez. Madrid: Editora Nacional. Bullón de Mendoza, A. (1992): La primera guerra carlista. Madrid: Universidad Complutense.

Burgos, Miguel de (ed.) (1839): Historia de la expedición del rebelde Gómez escrita por el Gobernador de su cuartel general y cogida a un prisionero en la acción de Huerta del Rey. Madrid: Imprent de D. Miguel de Burgos.

Cabañas Boyano, A. (1999): Aragón, una tierra de castillos. El Periódico de Aragón, Zaragoza.
Cabello, F.; Santa Cruz, F. y Temprado, M. (1846): Historia de la guerra última en Aragón y Valencia. Madrid: Imprenta del Cabello, F.; Santa Cruz,

Cabello, F.; Santa Cruz, F. y Temprado, M. (2006): Historia de la guerra última en Aragón y Valencia. Zaragoza: Institución Fernando el Católico.
Calbo y Rochina de Castro, D. (1845): Historia de Cabrera y guerra civil en Aragón, Valencia y Murcia. Madrid: Establecimiento tipográfico de Vicente Castello.

Calbo y Rochina de Castro, D. (1864): Curso de religión y moral cristiana católica, apostólica romana. Manuscrito. Biblioteca

Digital Hispánica. Inventario General de Manuscritos.
Calbo y Rochina de Castro, D. (1864): Museo filosófico de la historia de España contemporánea. Manuscrito. Biblioteca Digital

Calbo y Rochina de Castro, D. (1865): Escuela teórica de buenas costumbres morales en 10 lecciones escrita por... Manuscrito. Biblioteca Digital Hispánica. Inventario General de Manuscritos.

Calderón Quijano, J. A. (1985): Bibliografía de las fortificaciones Españolas en América en la Edad Moderna. Madrid: Comisión

Te la monarquía hispánica en los siglos XVII y XVIII. Madrid: Ministerio de Defensa.

Canales, C. (2006): La Primera Guerra Carlistas (1833-1840), uniformes, armas y banderas. Madrid: Ristre. Canga Argüelles, J. (1830): Observaciones sobre
Teniente Coronel Napier. Londres: D. M Calero.

Caridad Salvador, A. (2013): El ejército y las partidas carlistas en Valencia y Aragón (1833-1840). Valencia: Publicacions de la Universitat de València.

Caridad Salvador, A. (2014): Cabrera y compañía. Los jefes del carlismo en el frente del Maestrazgo (1833-1840). Zaragoza: Institución Fernando el Católico (CSIC). Excma. Diputación de Zaragoza.

Caridad Salvador, A. (2017): El carlismo en las comarcas valencianas y el sur de Aragón (1833-1840). València: Institució Cons el Magnànim. Centre Valoncia d Estudis i d Investigació. Diputació de $\mathrm{V}$ al nor

Militar Orden de San Fernando (ingenieros). Madrid: Ministerio de Defensa.

Cassani, J. (1704): Escuela Militar. De fortificación ofensiua, y defensiva. Arte de fuegos y de esquadronar... dedicada al Rey Nuestro señor(que dios guarde) por mano del Excelentissimo Señor Don Joseph de Solís Valderrábano y Dábila, Duque de
Montellano compuesta por el padre... de la Compañía de Iesus, Maestro de Mathematicas en los Reales Estudios del Colegio Imperial de la Misma Compañía. Madrid: Antonio Gonçalez de Reyes.

Castañeda y Alcover, V. (ed.) (1998): Relaciones geográfica, topográficas e históricas del Reino de Valencia. Vol. II. Valencia Generalitat Valenciana. Consell valencià de Cultura.

Cavanilles, A. J. (1797): Observaciones sobre la Historia Natural, Geografía, Agricultura, Población y Frutos del Reyno de Valencia. Tomo II. Madrid: Imprenta Real.

Centro de Estudios Requenenses (1992): Oleana. Cuadernos de Cultura Comarcal, 7. Requena: Centro de Estudios Requenenses. M. I. Ayuntamiento de Requena

(1993): Oleana. Cuadernos de Cultura Comarcal, 8. Requena: Centro de Estudios Requenenses. M. I. Ayuntamiento de Requena.

Centro de Estudios Requenenses (2014): Oleana. Cuadernos de Cultura Comarcal, 28. Requena: Centro de Estudios Requenenses. M. I. Ayuntamiento de Requena.

Cerrato García, J. M. (1991): "Historia postal de la II a guerra carlista” en Gómez, C. (Dir.) (1991): Los carlistas 1800-1876, Vitoria-Gasteiz: Fundación Sancho el Sabio. Caja de Ahorros de Vitoria y Alava, 309-328.

Cifre Fornas, J. V. (1990): “El castillo de Bejís” en Ayuntamiento de Bejís (1990): Programa de fiestas patronales. Bejís Ayuntamiento de Bejí

Cincunnegui, C. y S. (1839): Memoria sobre el espediente y acción del 2 de agosto de 1839 en los campos de Chulilla... Valencia Imprenta de J. de Orga y $C^{a}$.

Clausewitz, C. v. y Viñas, A. (2011): El arte de la estrategia. Madrid: La esfera de los libros.

Colecha Benito, P. (2013): Les muralles carlines de Sueca: 1838-1903. Investigació històrica, geoestratègica-tàctica, constructiva de Conservación del Patrimonio

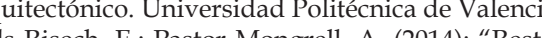

Colls Risech, E.; Pastor Mongrell, A. (2014): "Restauración de las caballerizas del castillo de Miravet" en Papeles del Comellas, J. L. (2009): Historia de España. Vol. III. Barcelona: RBA.
Consejo Supremo de Guerra (1816): Estado militar de España. Madrid: Imprenta Real. Cooper, E. (2012): “El dominio de la pólvora en la arquitectura militar de finales de la Edad Media" en Actas del IV
Congreso de Castellología. Asociación Española de Amigos de los Castillos. Madrid, 7, 8, 9 de marzo de 2012. pp. 97-110. Córdoba, B. (1844): Vida militar y política de Cabrera. Madrid: Imprenta y fundición de D. Eusebio Aguado.

Cruz Orozco, J. (1986): "Huellas del comercio de la nieve en la toponimia de las provincias de Castellón y Valencia" en Actes del X Colloqui General de la Societat d'Plomatica y d'Onomastica Valenciana, Valencia: Universitat de València. Generalitat Valenciana, 101-110.

Cuerpo de estado mayor del ejército (1888): Narración militar de la guerra carlista de 1869 á 1876. Madrid: Imprenta y

Cuerpo de Ingenieros del Ejército (1911): Memorial del cuerpo de ingenieros. Núm. IV. Año LXVI. Abril de 1911. Tomo 66. Madrid: Imprenta del Memorial de Ingenieros.

D'Alaux, Gustave (1985): Aragón visto por un francés durante la Primera Guerra Carlista. Zaragoza: Diputación General de Aragón, Departamento de Cultura y Educación.

De Vargas, M. F. M. (1848): La guerra en Navarra y en las Provincias Vascongadas. Madrid: Baltasar González.

Del Burgo, J. del (1953): Bibliografía de las guerras carlistas y de las luchas políticas del siglo XIX. Pamplona: Diputación Foral de Navarra. Institución Príncipe de Viana.

Del Romero Renau, L. et altr. (2010): El patrimonio bélico de las Guerras Carlistas en Cantavieja. Cantavieja: Comarca del Maestrazgo.

Delgado, D. J. (1943): Relato oficial de la meritísima expedición carlista dirigida por el general andaluz Don Miguel Gómez. Desde las Vascongadas a Asturias, Galicia, León, las dos Castillas, Aragón, Valencia, Murcia, Andalucía, Extremadura, Gibraltar y feliz regreso a Vizcaya con exhorbitante botín y doblados sus efectivos. San Sebastián: Gráfico Editora.

Dembowski, K. (1841): Deux ans en Espagne et en Portugal, pendant la guerr civile 1838-1840. Paris: Charles Gosselin; 2008, Barcelona: Editorial Critica,

(1841)): Dos años en España y Portugal durante la Guerra Civil, 1838-1840. Barcelona: Editorial Crítica. DGPA (Dirección General del Patrimonio Artístico). Ficha BIC del Castillo de Chulilla. Código 46.10.112-001. Ficha de la General de Patrimoni Cultural Valencià. Generalitat Valenciana. http:// www.cult.gva.es/ dgpa/ bics/ detalles bics. asp?IdInmueble $=202(2016)$

Díaz Corbelle, N. P. (1866): Biografía de don Ramón Cabrera. Madrid: Imprenta de Eusebio Aguado (primera edición de 1841).

Díaz de Labandero, G. (1847): Guerra Civil de Cataluña en la última época terminada con la emigración á Francia de las tropas carlistas en julio de 1840. Madrid: Imprenta de la viuda de Jordán e hijos.

Duncan, F. (1997 (1877)): The English in Spain: The Story of the War of Succesion between 1834 and 1840. Vols. 1-6. London: British Library. Historical Print Editions.

(1964): Trabajos históricos, 1966-1993. Forcall: Excmo. Ayuntamiento de Forcall.

(2013): Requeng, ciundad de historia ycia: Imprenta Oficina de López.

Ezpeleta Aguilar, F. (2012): "Las guerras carlistas en la literatura juvenil" en Tejuelo 16, Mérida: Junta de Extremadura.

Fernández de San Román, E., marqués de San Román (1884): Guerra civil de 1833 a 1840 en Aragón y Valencia. Campañas del general Oraa (1837-1838). Madrid: Imprenta y fundición de M. Tello.

Fernández Izquierdo, F. (2014): Castell de Castells con la Orden de Calatrava. La encomienda de Bejís y Castell de Castell: un reducto señorial en el Reino de Valencia durante la Edad Moderna. Alicante: Vision Libros.

Fernández y Domingo, Daniel (1867): Anales ó historia de Tortosa: desde su fundación hasta nuestros días... Barcelona: Establ. Tip. de Jaime Jepús.

errer, M. et altr. (1941): Historia del tradicionalismo español. Sevilla: Ediciones Trajano.

Flavio, E. conde de $\mathrm{X}^{* * *}$ (1870): Historia de don Ramón Cabrera. Madrid: Establecimiento tipográfico-editorial de G.

Flores Román, M. (2015): "ICOFORT. Visión global para la conservación y manejo del patrimonio fortificado" en . Flórez, J. S. (1845): Espartero. Historia de su vida militar y política y de los grandes sucesos contemporáneos. Madrid: Imprenta de Wenceslao Ayguals de Izco.

Flors Ureña, E.; Arasa i Gil, F. (2002): "El castillo de Bejís: noticia de los trabaos arqueológicos efectuados y hallazgo de un fragmento de inscripción romana" en Gátova. núm. 15. pp. 29-32.

Fremont-Barnes, G. (ed.) (2006): The Encyclopedia of the French Revolutionary and Napoleonic Wars: a political, social and military history. Vol. 1. Santa Barbara, California: ABC-Clio.

Fuguet Sans, Joan (2017): “Miravet, un gran castell templer” en Miscel.lània del CERE 27, 2017, pp. 297-331.

Garén revista de la Facultat de Geografia $i$ Història, núm. 40, València: Universitat de Valencia, pp. 101-124.

Garín Ortiz de Taranco, F. M. (1983): Inventario artístico de Valencia y su provincia. Valencia: Patrimonio Cultural.

Garmendia, V. (1991): “Vicente Manterola, decidido conspirador carlista" en Gómez, C. (Dir.) (1991 Vitoria-Gasteiz: Fundación Sancho el Sabio. Caja de Ahorros de Vitoria y Alava, 287-305. 
1244 La fortificación deL "reino mágico" de Cabrera. Virginia Navalón

Garrosa Mayordomo, Jorge (2010): “1839-1840. Primera Guerra Carlista en la Serranía de Cuenca” en revista Mansiegona. 5. Masegosa (Cuenca): Asociación Cultural Mansiegona. pp. 14-17.

(1851): Memoria sobre la defensa de costas. Madrid: Memorial de ingenieros, 6 .

Gelli, I. (1899): Dembowski. I duelli mortali del secolo XIX. Milano: Casa Editrice libraria L. Battistelli.

Gide, A. (2000): Journals, Vol. I, 1889-1913. Champaign: University of Illinois Press.

Gil de la Sierpe, A. (1787): Carta crítica de D. Alvaro Gil de la Sierpe al autor de la obra intitulada Atlante Español... Valencia:

Gi Llistar, I. et altr. (2016): Proyecto de excavación, consolidación y puesta en valor de la entrada y del area palatina del castillo de Alpuente. Ex alto Ayuntamiento de Alpuente.

Gil, Miguel I. (2011): "Visión histórica del Carlismo. El carlismo de Valle-Inclán” en Valle-Inclán, R. (2011): La Guerra Carlista 1. Los cruzados de la causa, Madrid: Austral, 9-77.

(1975): "Dos castillos turolenses casi desconocidos: Cantavieja y Castellote" en Castillos de España. Asociación Cína

on hidráulicos de la partida de Hortunas" en Oleana. Cuadernos de cultura comarcal 21. Requena: Centro de Estudios Requenenses. M. I. Ayuntamiento de Requena, 202-218

Gómez, C. (1991): "Galería de personajes carlistas" en Gómez, C. (Dir.) (1991): Los carlistas 1800-1876, Vitoria-Gasteiz Fundación Sancho el Sabio. Caja de Ahorros de Vitoria y Alava, 371-392.

Gómez, C. (Dir.) (1991): Los Carlistas 1800-1870. Vitoria-Gasteiz: Besaide-Bilduma. Fundación Sancho el Sabio

González de la Cruz, Rafael (1846): Historia de la Emigración Carlista. Madrid: Ensayos históricos.

González de la Cruz, Rafael (1849): El vengador y la sombra de Cabrera: refutación del Tigre del Maestrazgo ó sea De grumete a general, historia-novel de D. Wenceslao Ayguals de Izco: advertencias para la historia. Madrid: Imprenta de Hernández.

Gordillo Bel, Dídac (2016): La fortificación de Amposta. De plaza de primer orden a fortificaciones de circunstancias en Abella
Plantés et altr., 2016: 209-224.

Guerola i Blay, V. (2002): La pintura ceràmica a Carcaixent. Valencia: Universitat Politècnica de Valencia. Ayuntamiento de Carcaixent. (2001): La evolución histórica de la Arquitectura Militar y de las técnicas de ataque a las plazas. Valencia Trabajo de Investigación para la obtención del Diploma de Estudios Avanzados (DEA). Departamento de Composición Arquitectónica. Universidad Politecnica de Valencia.

Guimaraens, G. (2006): “Aires de cambio en la Fortificación Marítima de Cartagena a mediados del siglo XIX: el caso de Fuerte Fusilero de Navidad" en ARCHÉ. Publicación del Instituto Universitario de Restauración del Patrimonio de la UPV 1, Valencia: Universitat Politècnica de València, 305-316.

Guimaraens, G. (2006): “Historical and architectural study of a late bastioned fort: San Julián in Cartagena” en ARCHÉ Publicación del Instituto Universitario de Restauración del Patrimonio de la UPV 3, Valencia: Universitat Politècnica de Vuimaraens, $\mathrm{C}$

(2008): El último hálito de la fortificación abaluartada peninsular. El fuerte de San Julián de Cartagena. Valencia: Tesis doctoral Departamento de Composición Arquitectónica. Universidad Politécnica de Valencia.

Guimaraens, G. (2013): "Estudio histórico arquitectónico de un fuerte abaluartado tardío" en Castillos de España 171-172 Madrid: Asociación Española de Amigos de los Castillos, 103-120.

Guimaraens, G. y Navalón, V. (2013): Odisea o metamorfosis. Diseño de atmósferas con parámetros esquivos. Valencia Editorial Escila.

Guimaraens, G. y Navalón, V. (2018): Pie de lámpara. Tratados de la fortificación abaluartada española. Valencia: Editorial Escila.

Guimaraens, G., Noguera, J. F. y Navalón, V. (2012): “Earth and gunpowder: The earth in the modern fortresses" en Mileto, C., Vegas, F., Cristini, V. (eds.), Rammed Earth Conservation 1, Londres, Leiden: CRC Press/Balkema, Taylor \& Francis Group., 533-528.

Guimata, G. y Noguera, J. F. (2009): “La Fortificación de Cartagena en el transcurso de la Guerra de la Independencia San Julián" en Castillos de España 152-154, Madrid: Asociación Española de Amigos de los Castillos, 99-112.

Guitart Aparicio, C. (1976): Castillos de Aragón. Zaragoza: Librería general.

Guitart Aparicio, C. (1986): Castillos de Aragón II (tercera edicion). Zaragoza, Librería General.

Guitart Aparicio, C. (1999): Los castillos turolenses. Teruel: Instituto de Estudios Turolenses.

Henningsen, Ch. F. (1836): The Most Striking Events of a Twelvemonth's Campaign with Zumalacarregui in Navarre and the Basque Provinces. London: E. L. Carey y A. Hart.

Hernando Sánchez, C. J. (2000): Las fortificaciones de Carlos V. Madrid: Asociación Española de Amigos de los Castillos Ministerio de Defensa.

Hernando Sebastián, P. L.; Sánchez Giménez, S. (2017): “Las grisallas de la ermita del calvario de Bordón y su contexto artístico" en Ars y Renovatio, 5, 2017, pp. 146-161.

(1) Madrid: Imprenta Nacional. .

Hortelano Iranzo, J. L. (2013): “Las milicias en el distrito de Requena-Utiel: 1820-1844” en Oleana. Cuadernos de cultura
La fortificación del "reino mágico" de Cabrera. Virginia Navalón

comarcal 28, Requena: Centro de Estudios Requenenses. M. I. Ayuntamiento de Requena, 299-332.

Ibáñez González, J. (2007): “Origen y evolución del paisaje urbano del Maestrazgo en Ibáñez González" en Ibáñez González. J. (coord.) (2007): Comarca del Maestrazgo. Gobierno de Aragón. pp. 119-136.

Inspección de Ingenieros (1987): Estudio histórico del cuerpo de ingenieros del ejército. Madrid. Sucesores de Rivadeneyra. Izaguirre, F. (1954): "Aragón en la primera guerra carlista: el barón de Hervés" en Cuadernos de historia Jerónimo Zurita 6-7, Zaragoza: Institución Fernando el Católico. Excma. Diputación de Zaragoza, 93-119.

Izquierdo Costa, Guadalupe (1956): Alpuente, notas para su historia. Tesis doctoral. Valencia: Facultad de Filosofía y Letras.

Jomini, H. (1805): Traité de grande tactique, ou, Relation de la guerre de sept ans, extraite de Tempelhof, commentée et comparée aux principales opérations de la derniére guerre; avec un reccueil des maximes les plus important del l'art militaire, justifiées par ces differents evenements. París: Giguet et Michaud.

Jomini, H. (1838): Précis de l'Art de la Guerre: Des Principales Combinaisons de la Stratégie, de la Grande Tactique et de la Politique Militaire. Brussels: Meline, Cans et Copagnie.

Jord́́ Motó C. (1999): Metiel: Gráficas Llogodi.

Jordá Molto, C. (1999): Memoria de unos tiempos vividos. Requena: Gráficas Llogodí Jordá Moltó, C. (2000): Requena. Imágenes de un siglo. Requena: Gráficas Llogodí.
Jordá Sánchez, C. y Pérez García, J. C. (2008): Antigüedad, i cosas memorables de la villa de Requena; escritas, y recogidas por
un vecino apassionado y amante de ella. Requena: M. I. Ayuntamiento de Requena, Archivo Municipal de Requena, Centro de Estudios Requenenses.

Julve, E.; Cuella, O. (1986): La villa de La Fresneda. Historia, monumentos, instituciones. La Fresneda: Ayuntamiento de La Fresneda.

La Parra López, E. (1991): "El carlismo en el País Valenciano" en Gómez, C. (Dir.) (1991): Los carlistas 1800-1876, VitoriaGasteiz: Fundación Sancho el Sabio. Caja de Ahorros de Vitoria y Alava, 245-260.

Larruga, E. (1ón. Mes róras politicas y económicas sobre los frutos, comercio, fábricas y minas de España, con inclusión de los re loza, vidrio, cristales, tintes, batanes y manufacturas de metales de la Provincia de Cuenca. Madrid: Don Antonio Espinosa. Latorre Zacarés, I. (2014): “La acción del 13 de septiembre de 1836” en M. I. Ayuntamiento de Requena: Feria y 67 Fiesta de la vendimia, Requena: M. I. Ayuntamiento de Requena, 9.

Latorre Zacarés, I. (2015): La historia en pildoras: Hechos y sucesos documentados de la meseta Requena-Utiel. Valencia: Novabernia.

Latorre Zacarés, I. (s. f.): Bibliografía de la meseta del Cabriel. Requena: Ayuntamiento de Requena. Archivo Municipal. Le Halle, G. (2002): Précis de la fortification. Louviers: Imprimeries de Champagne.

Lemmi Demandre, L. (1840): Contestación del Sargento Mayor D. Luis Lemmi al Capitán D. Manuel Cincunnegui... a la de López.

Lerner, J. (2005): Acupuntura urbana. Barcelona: IAAC (Institut d'Arquitectura Avançada de Catalunya).

Lichnowsky, F. (1942 (1841)): Recuerdos de la guerra carlista. Madrid: Espasa Calpe.

Lladonosa, J. (1993): Carlins i liberals a Lleida. Lleida: Pagès Editors.

Librer Escrig, J. A. (2014)

Lluch Garín, (1980): Ermitas y paisajes de Valencia. Valencia: Caja de Ahorros de Valencia. Lopez Marin, M. (2013): "Cronologia y hechos de la primera guerra carlista en la zona de frontera entre Teruel, Cuenca de Requena, 359-392

López Marin blogspot.com.

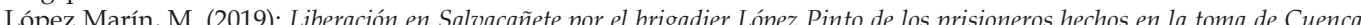
por los carlistas. Referencias documentales en prensa histórica en mlopezmarinhistorialocal.blogspot.com.

López Marín, Mariano (2014): “Cronología y hechos de la primera Guerra Carlista en la zona de frontera entre Teruel, Cuenca y Valencia" en Oleana: Cuadernos de Cultura Comarcal. no 28, 2014. pp. 359-392.
López Muiños, I. (1993): Algunos aspectos ingeniería militar española y cuerpo técnico. Madrid: Servicio de publicaciones del Ministerio de Defensa.

Lucuze, P. (1772): Principios de Fortificación. Barcelona: Thomas Piferrer.

Madoz, P. (1845-1849): Diccionario Geográfico-Estadístico-Histórico de España y sus posesiones de ultramar (1846-1850). Madrid: La Ilustración.

Maguès. M. I. (1837): D. Carlos et ses défenseurs. Collection de 20 portraits originaux. Dessinés d'après nature tant au quartier royal de Durango, qu'au quartier-général de l'armée et représentant Don Carlos, ses Ministres, ses généraux, l'infant Don
Sébastien, ses aides-de-camp \& avec une introduction et une notice biographique sur chacun des personnages par. Toulouse: Chez Tousaint È Mainer, J. C.; Enguita Utill

Euta Utrilla, J. M. (coord.) (1999): Localismo, costumbrismo y literatura popular en Aragón: V curso sobre lengua y literatura en Aragón. Zaragoza: Institución Fernando el Católico.

Martín Etxebarria, Ge. (2016): Arqueología de los espacios construidos. Aproximación al estudio de tres fuertes de los conflictos carlistas en el entorno de la Villa de Bilbao. Trabajo final de grado en Historia. Departamento de Geografía, prehistoria y 
arqueología. Euskal Herriko Unibertsitatea

Martinet, A. (1908): La seconde intervention française et le sège d'Anvers, 1832. Bruxelles: Société Belge de Librairie. Martínez Calvo, P. (1997): Historia de Aliaga y su comarca. Antiguo partido con Linares, Castelvispal y Puertomingalvo. Aliaga: Autor editor. historia" en Oleana. Cuadernos de cultura comarcal 9, Requena: Centro de Estudios Requenenses. M. I. Ayuntamiento de Requena, 56.

Martínez Ortiz, J. (1974): “La glorieta y sus aledaños. Evocación lírica de un paisaje urbano en tres tiempos. El encuentro" en El Trullo Diciembre de 1974, Requena: M. I. Ayuntamiento de Requen

Martínez Ortiz, J. (1975): “La glorieta y sus aledaños. Evocación lírica de un paisaje urbano en tres tiempos. La andadura emocionada" en El Trullo Junio de 1975, Requena: M. I. Ayuntamiento de Requena.

(1) Al mágico conjuro de las le.tén

Medina, F. (coord.) (2005): Hisun, revista del castillo de Morella, $n^{\circ} .1,2005$.

Mellado, F. de P. (1851): Enciclopedia moderna. Madrid: Establecimiento Tipográfico de Mellado.

Metahir, S. (2013): El fuerte de Santa Cruz y el conjunto defensivo español de Orán (Argelia). Valencia: Trabajo final de máster del Máster Oficial de Conservación del Patrimonio Arquitectónico. Universidad Politécnica de Valencia.

Millán, J. (1982): Transición y reacción en el sur del país valenciano. La formación del capitalismo agrario y los orígenes del carlismo: Orihuela, 1680-1840. Valencia: Universidad de Valencia.

Millán, J. (1988): “Els militants carlins del Pais Valencià Central. Una aproximació a la sociología del carlisme durant la Revolució Burgesa " en Recerques: historia, economía, cultura 21, Valencia: Universitat de Valencia, 101-123.

Millán, J. (2000): "Popular y de orden: la pervivencia de la contrarrevolución carlista" en Ayer 38, Madrid: Asociación de Historia Contemporanea. Mar : Pons, Ediciond de Custoria S. A., 16-34.

Madrid: Imprenta a cargo de J. E. Morete. Mohorte, A. (2014): La primera guerra carlista (1833-1840) y la conquista del castillo de Alpuente. https:/ / www.museoliber. $\operatorname{org}(2020)$.

Monleón Francés, José (1910): Episodios Regionales. Valencia: Imprenta y libro de Ortega. aldizkaria" en Revista de estudios históricos de Andoain. n ${ }^{\circ}$ 12. pp. 9-82.

Moreno Chacón, M. (1988): "Visión historiográfica de los viajes por España en la Edad Moderna" en Manuscrits Revista d'història moderna. $\mathrm{n}^{\circ}$ 7, 1988. pp. 189-212.

Muelas Alcocer, D. "En Carboneras de Guadazaón, el panteón de los Marqueses de Moya, Don Andrés de Cabrera Doña Beatriz de Bobadilla" en Cuenca, $\mathrm{n}^{\circ} 10,1976$. p. 5 .

Mundet i Gifre, J. M. (1991): “El carlismo catalán” en Gómez, C. (Dir.) (1991): Los carlistas 1800-1876, Vitoria-Gasteiz

Mundet, J. M. (1990): La primera guerra carlina a Catalunya. Història militar i política. Barcelona: Publicacions de l'Abadi de Montserrat.

Muñoz Corbalán, J. M. (2004): La Academia de Matemáticas de Barcelona. El legado de los ingenieros militares. Madrid: Secretaría General Técnica del Ministerio de Defensa.

Munoz Navarro, D. (2009): La villa de Requena a través de las respuestas generales del catastro del Marqués de la Ensenada (1752). Requena: Ayuntamiento de Requena.

Muro Morales, I. (1989): "Territorio y sociedad en el pensamiento militar español del siglo XIX" en Peset, J. L. (1989): Ciencia, vida y espacio en iberoamerica 3, Madrid: Consejo Superior de Investigaciones Científicas, 143-173.

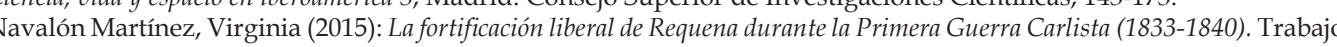
Final de Máster. Valencia: Escuela Técnica Superior de Arquitectura. Universitat Politècnica de Valencia.

Navas Ruíz, R. (1982): El Romanticismo español. Madrid: Cátedra.

Noguera, J. F. y Guimaraens, G. (2005): “Metodología para el analisis de un fuerte abaluartado del siglo XVIII" en

Norberg-Schulz, C. (1975): Genius loci: paesaggio, ambiente e architettura. Saggi \& Documenti. Milan: Architettura, Electa. Odalric de Caixal i Mata, D. (2015): La Primera Guerra Carlista 1833-1840. link: Rutas con historia. http://www. rutasconhistoria.es/

Ortas Durand, E. (1999): “El pintoresquismo de personas, tipos e indumentarias aragoneses según los viajeros de la primera mitad del siglo XIX" en Mainer, J. C.; Enguita Utrilla, J. M. (coord.) (1999:173-200)

Ortega y Gasset, J. (2002 (1925)): La deshumanización del arte y otros ensayos de estética. Madrid: Revista de Occidente en Alianza Editorial.

Ortí Miralles, F. (1979): Síntesis de la Historia de Morella. Valencia: Editorial Ortí.

Oyarzún, R. (1961): Vida de Ramón Cabrera y las guerras carlistas. Barcelona: Aedos.

Palaia Pérez, L. y Esteban Chapapría, J. (s. f.): El plan director del Castillo de Chulilla: su necesidad. Valencia: Universitat

Pardo, F. (1997): “La ermita del Santo en las Peñas y la fiesta de su titular el Glorioso San Sebastián Mártir" en Oleana Cuadernos de cultura comarcal 12, Requena: Centro de Estudios Requenenses. M. I. Ayuntamiento de Requena, 7-16. Pardo, F.; Cebolla, S. (1996): Origen de las parroquias centenarias en las aldeas de Requena. Requena: Colección Semana Santa Requenense. Ayuntamiento de Requena.
Pérez Galdós, B. (1993): La Campaña del Maestrazgo. Episodios nacionales 25. Madrid: Club internacional del libro. Pérez Galdós, B. (1993b): Trafalgar. Episodios nacionales 1. Madrid: Club internacional del libro.

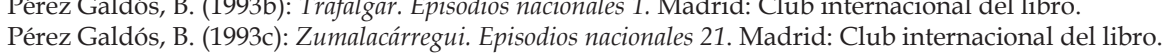
Pérez Galdós, B. (1993d): Mendizábal. Episodios nacionales 22. Madrid: Club internacional del libro. Pérez Galdós, B. (1993e): De Oñate a la Granja. Episodios nacionales 23. Madrid: Club internacional del libro. Pérez Galdós, B. (1993f): Luchana. Episodios nacionales 24. Madrid: Club internacional del libro. Pérez Galdós, B. (1993g): Vergara. Episodios nacionales 27. Madrid: Club internacional del libro. Pérez Galdos, B. (1993h): La estafeta romántica. Episodios nacionales 26. Madrid: Club internacional del libro. Pérez Garcia, J. C. (1993): "La no industrialización de Requena" en Oleana. Cuadernos de cultura comarcal 8, Requen

Centro de Estudios Requenenses. M. I. Ayuntamiento de Requena, 87-108.
Pérez Guillén, I. V. (1996): Cerámica arquitectónica valenciana. Los azulejos de serie (Ss. XVI-XVIII). Valencia: Generalitat

Peset, J. L. (coord.) (1989): Ciencia, vida y espacio en iberoamerica. Vol. III. Madrid: Consejo Superior de Investigaciones

Piqueras Haba,
Valencia, 29-58. Piqueras Haba, J. Et altr (1995): Geografia de les comarques valencianes. Vol. IV. Valencia: Foro Ed..

(1990): "Origen y desarrollo de la fiesta de los toros en nuestra comarca" en Oleana. Cuadernos de cultura comarcal 35, Requena: Centro de Estudios Requenenses. M. I. Ayuntamiento de Requena, 45-46.

Pirala, A. (1869): Historia de la Guerra Civil y de los partidos Liberal y Carlista corregida y aumentada con la historia de la

Pirala, A. (1984): Historia de la Guerra Civil y de los partidos Liberal y Carlista. Madrid: Turner. Historia 16 (primera edición en 1853-1856

Pirala, A. y Rújula, P. (ed.) (2005): Vindicación del general Maroto y manifiesto razonado de las causas del Convenio de Vergara. Pamplona: Urgoiti Editores

(1869): Crónica de la provincia de Cuenca. Madrid: Rubio, Grilo y VItturi

(iteratura inglesa. Madrid: Gredos.

Quintana Segala, J. X.; Morillas Torné, M. (2012): "Algunes problemàtiques de la cartografia històrica. El cas de la Ratheau, A.-F. (1858): Traité des fortifications couls de la Societat Catalana de Geografia, no 73, juny 2012, pp. 193-210. (a) Rettaque et la defense des places fortes. Paris: Ch. Tanera.

(

Rodrigo, R. 2019. “Ramón Cabrera y Griñón. El tigre del Maestrazgo. en https://elgrancapitan.org (fuentes: Flavio, 1870; Cabello, et altr. 1846 y Canales, 2006)

Rodriguez de Coro, F. (191): "El carlismo: una propuesta del Antiguo Régimen (1800-1833)" en Gómez, C. (Dir.) (1991): carlistas 1800-1876, Vitoria-Gasteiz: Fundación Sancho el Sabio. Caja de Ahorros de Vitoria y Alava, 15-33. 1876, Vitoria-Gasteiz: Fundación Sancho el Sabio. Caja de Ahorros de Vitoria y Alava, 65-118.

Rodríguez-Navarro (Ed.) (2015): Defensive Architecture of the Mediterranean. XV to XVIII centuries Vol. II. Valencia: Editorial Universitat Politècnica de València.

Romero Sáiz, M. (1993): Las Guerras Carlistas en Tierra de Cuenca. 1833-1876. Cuenca: Editorial Auto

Romero Sáiz, M. (1994): Las Guerras Carlistas en Tierra de Cuenca. Cuenca: Editorial Autor.

Romero Saiz, M. (2003-2004): “Las Guerras Carlistas en nuestra zona, partes I y II” en Ababol, nº 36-37., 2003-2004: 30-32

Romero Saiz, M. (2010): El saco de Cuenca. Boinas rojas bajo mangana. Cuenca: Diputación Provincial de Cuenca. Romero Saiz, M., (2003-2004): “Las Guerras Carlistas en nuestra zona, partes I y II”, en Ababol, nº 36-37, 2003-2004, pp. $30-32$ y $26-33$

Roselló i Verger, V. (1985): Cincuenta y cinco ciudades valencianas. Valencia: Universidad de Valencia.

Rubio Liniera, M. C. y Talavera Díaz, M. (2007): El carlismo. Madrid: BIHE, Bibliografías de Historia de España 13. Consejo Superior de Investigaciones Cientificas. Ministerio de Educación y Ciencia. Gobierno de Navarra.

Rubio Verdeguer, J. (2012): La defensa de la Ensenada de Moraira en el siglo XVIII: El Fortin de Moraira. Valencia: Trabajo fhal de master del Master Oficial de Conservación del Patrimonio Arquitectonico. Universidad Politécnica de Valencia. Rubio, C. (1869): Historia filosófica de la revolución española de 1868. Madrid: Imprenta y librería de M. Guijarro.

Ruibal, A. (coord.) (2001): Actas del II Congreso de Castellologia Ibérica. Alcalá de la Selva (Teruel): Asociación Española de Amigos de los Castillos. Diputación de Teruel.

Ruiz Checa, J. R. et altr. (2012): “Propuesta metodológica para el estudio de torres exentas en un ámbito territorial

entrarrevolucionarios en el Bajo Aragón: realismo, carlismo y descontento campesino" en Rújula, P. (1995: 109)

Rújula López, P. (1995): Aceite, carlismo y conservadurismo político. El Bajo Aragón durante el siglo XIX. Alcañiz: Taller de Rújula López, P. (2008 (1998)): Contrarrevolución. Realismo y Carlismo en Aragón y el Maestrazgo, 1820-1840. Zaragoza: 
Prensas Universitarias de Zaragoza.

Rújula, P. (2005): "Una guerra literaria" en La aventura de la Historia 77, Madrid: Editorial Arlanza, 59-63. Rújula, P. (ed.) et altr. (2006): Historia de la guerra última en Aragón y Valencia. Zaragoza: Institución Fernando el Católico (CSIC). Excma. Diputación de Zaragoza.

Rujula, P. (2013): “Una mirada legitimista sobre la guerra civil” en Von Rahden (2013: 7-19).
Salinas, P. y Pardo, F. (2014): Calles y callejones de Requeno Historia y anécdotas. Curso Aula Abierta. Biblioteca Municipal: Requena.

Salvador Gaspar, M. (1982): Castillo, murallas y torres de Morella. Morella: Vell i Bell.

Salvador Gaspar, M. (1993): "Fortificaciones de Morella: reconstrucción 1873-1875". Estudis Castellonencs, no 5 Diputación Provincial de Castellón.

Salvador Gaspar, M. (1997): “El Castillo de Morella. Datos sobre su evolución”. Estudis Castellonencs, nº 7. Diputación

San Miguel y Valledor, E. (1836): De la guerra civil en España. Madrid: Imprenta de Don Miguel Burgos.

(1826): Elementos del arte de la guerra. Londres: Imprenta Española de M. Calero.

Sánchez Garzón, A. (2000): Aproximación histórica: La Villa de El Cueroo y su parroquial. El Cuervo: Ayuntamiento de El

Sanmartin i Besalduch, A. (1991): “Vivencias de la I Guerra Carlista: las memorias de don Mariano Miquel y Polo (18341837)" en Boletín de la Sociedad Castellonense de Cultura 67, 1, Castellón: Sociedad Castellonense de Cultura, 131-177. Santirso Rodríguez, M. (1999): “El incierto cenit del carlismo catalán (1837-1840)” en Gerónimo de Uztariz, nº 14-15, 1999 pp. 153-178.

Santirso, M. (1996): “El primer carlisme a Catalunya: del regne a l'exili" en L'Avenç: revista de història i cultura 203, Barcelona: L'Avenç S.L., 22-27.

Santirso, M. (1999): Revolució liiberal i guerra civil a Catalunya (1833-1840). Lleida: Pagès editors.

Jecto de obras de instalación eléctrica para el alumbrado del castillo de Alcalá de la Selva (Teruel). Teruel: Colegio Oficial de Arquitectos de Aragón

Sanz,R. (1794): Diccionario militar o recolección alfabética de todos los términos propios al arte de la guerra. Explicación y práctica histórico del origen y naturaleza de diferentes especies, tanto de empleos antiguos y modernos, como de las armas que se han usado en diferentes tiempos. Madrid: Oficina de D. Gerónimo Ortega y Herederos de Ibarra.

Sauch Cruz, N. (2004): "El primer carlisme a la Sénia: alguns esdeveniments de consideració" en Lo senienc Memòria natura illengua, n. 1, 2004, pp. 52-53.

Sauch Cruz, N. (2007): "El control del territori en temps de guerra ( $1^{\mathrm{a}}$ meitat del s. XIX): Els sistemes defensius i les fortificacions al sud de l'Ebre i el Maestrat" en Recerca, 2007, n.11, pp. 113-136.

Sebastián Fabuel, V. “La Serranía del Turia: sus fortificaciones en la 1ª y 3a guerra carlistas” en Ruibal, 2001: 989-1004. Sebastián Fabuel, V. y Roca, P. (2016): Asalto al fuerte de los Ángeles. 1839. Guerra Carlista en Chulilla. Chulilla Aycranía de Estado y del t

yel Despacho Universal de la Guerra (1849): "Estado militar de España e Indias". Madrid: Imprenta Nacional. Segura y Barreda, J. (1868): Morella y sus aldeas: geografia, estadistica, historia, tradiciones, costumbres, indust,
ilustres, etc. de esta antigua población y de las que fueron sus aldeas. Tomo IV. Morella: Imprenta de F. Javier Soto.

Servicio Histórico Militar (SHM) (1981): Catálogo general de la cartoteca (2 volúmenes). Madrid: Servicio Histórico Militar Sesmero Cutanda, E. (1991): "Partidas paralelas” en Gómez, C. (Dir.) (1991): Los carlistas 1800-1876, Vitoria-Gasteiz Fundación Sancho el Sabio. Caja de Ahorros de Vitoria y Alava, 353-370.

Sociedad de ex-milicianos de Madrid (1844): Vida militar y política de espartero dedicada a la exmilicia nacional del reino. Madrid. Sociedad de Opera Mos del nismo Arte.

Soriano Estivalis, I. (2012): Estudio histórico-arquitectónico de las torres vigía de Felipe II: vigilancia y defensa de la costa de Valencia desde Sagunto hasta Oliva. Valencia: Trabajo final de máster del Máster Oficial de Conservación del Patrimonio

en el Sistema Ibérico Central durante el I milenio a. C. Zaragoza: Tesis de la Universidad de Zaragoza.

Ponce, J. L. (1997): Ejército y política en la España de Carlos III. Madrid: Ministerio de defensa. Terrón Ponce, J. L. (2004): La Fortaleza de Isabel II en el Puerto de Mahón. Menorca: Ministerio de Defensa . Museo Militar Thompson. Ch. W. (1836): Twelve Months in the British Legion, by an Officer of the Ninth Regiment. Oxford: Oxford University.

Thomson Llisterri, T. (2003): "Patrimonio arquitectónico del Matarraña" en Comarca del Matarraña, Colección Territorio, 7. Zaragoza: Gobierno de Aragón. pp. 143-178.

Timoneda, M. S. "Las obras de consolidación del castillo de Calanda empezarán esta semana". Diario de Teruel. 20 de julio de 2020

Torres Faus, F. (coord.) (2000): Guía del Archivo Histórico de Chulilla. Valencia: Generalitat Valenciana. Conselleria de Cuduri J M. (1991): “Fotografí y segunda gue, Arxius i Biblioteques.

1876 Vitoria-Gasteiz: Fundación s segunda guerra carlista en el País Vasco" en Gómez, C. (Dir.) (1991): Los carlistas 1800Ugarte, J. (1991): "La primera guerra carlista y el régimen foral" en Gómez C. (Dir.) (1991):

Vitoria-Gasteiz: Fundación Sancho el Sabio. Caja de Ahorros de Vitoria y Alava, 261-286.
Unamuno, M. de (2009 (1897)): Paz en la guerra. Madrid: Alianza editori .

Urcelay Alonso, J. (2005): "La pérdida del castillo de Morella por los carlistas en el final de la guerra de los siete años" en Medina, F. (coord.) (2005): Hisun, revista del castillo de Morella, nº. 1, 2005, pp. 78-81.

Urcelay, J. (2002): El Maestrazgo Carlista. Vinaròs: Antinea.

Urcelay, J. (2006): Cabrera. El Tigre del Maestrazgo. Barcelona: Ariel. Heritage: Management and Sustainable Development. Pamplona, 15-17 october 2014. Pamplona: Pamplona City Counci.

Valle-Inclán, R. del (1999): La Guerra Carlista III: Gerifaltes de antano. Madrid: Colección Austral. Espasa Calpe.

Valle-Inclán, R. Del (2000): El resplandor de la hoguera. Barcelona: Espasa Libros.

Valle-Inclán, R. del (2011): La Guerra Carlista I: Los cruzados de la causa. Madrid: Colección Austral. Espasa Calpe Vázquez Esparza, A. (2015): La Torreta de Castielfabib, iuna torre defensiva hexagonal tardomedieval? en Rodríguez, 2015:

Vegas, F. y Mileto, C. (2011): Aprendiendo a restaurar. Un manual de restauración de la arquitectura tradicional de la Comunidad Valenciana. Valencia: Colegio Oficial de Arquitectos de la Comunidad Valenciana

Vera Aparici, J. (1991): "Reconstrucción de los puentes de Jalance, Sta. Cruz y de Utiel" en Oleana. Cuadernos de cultura comarcal 6, Requena: Centro de Estudios Requenenses. M. I. Ayuntamiento de Requena, 61-74.

Vera Aparici, J. (1992): "Fortificación de Requena durante la primera Guerra Carlista" en Oleana. Cuadernos de cultura comarcal 7, Requena: Centro de Estudios Requenenses. M. I. Ayuntamiento de Requena, 131-133.

Vera Aparici, J. (1993): "Fortificación de Requena durante la primera Guerra Carlista" en Oleana. Cuadernos de cultura comarcal 8, Requena. Centro de Estudios Requenenses. M. I. Ayuntamiento de Requena, 57-84.

Vidal-Abarca Lopez, J. (1991). "Alava y el carlon la famila Varona" en Gomez, C. (Dir.) (1991): Los carlistas 18001876, Vitoria-Gasteiz: Fundación Sancho el Sabio. Caja de Ahorros de Vitoria y Alava, 161-207.

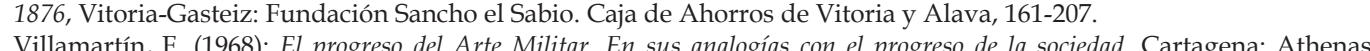
Ediciones.

Vinaixa, J. R. (2006): Set anys de guerra civil (Ribera d'Ebre, 1833-1840). Flix: Centre d'Estudis de la Ribera d'Ebre. Von Goeben, A.K. (1966 (1841)): Cuatro años en España (1836-1840): los Carlistas, su levantamiento, su lucha y su ocaso. Esbozos y recuerdos de la guerra civil. Pamplona: Institución Príncipe de Viana, Diputación Foral de Navarra. Von Rahden, W. (1840): Cabrera. Erinnerungen aus dem Spanischen Bürgerkrieg, Frankfurt am Main, Verlag von Friedrich Wilmans, 1840

Von Rahden, W. (1965 (1851)): Andanzas de un veterano de la Guerra de España. Pamplona: Institución Príncipe de Viana,

Diputación Foral de Navarra.
Von Rahden, W. (2013): Cabrera. Recuerdos de la guerra civil española. Zaragoza: Institución Fernando el Católico, Diputación de Zaragoza, 2013

VV. AA. (2001): Guía de la Comarca del Matarraña. Zaragoza: Prames.

Yeves Descalzo, F. A. (2013): "Las guerras carlistas en la comarca de Requena-Utiel" en Oleana. Cuadernos de cultura

Zapatero, J. M. (1988): Las fortalezas de Puerto Cabello. Madrid: Ministerio de Defensa, Servicio Histórico Militar.

\section{Documentos históricos de Requen}

"Los documentos históricos se aportan ordenados por fecha, y se organizan las referencias del siguiente modo: "Título, Ciudad, Fecha, siglas archivo, signatura".

Remate del pozo de la nieve, Requena, 1725, AMR, 2430/30 PL.

Subasta de los abastos de 1727 aceite y jabón, sisas de carnes, derecho de borras, alcabala del viento, flores de colmenas, abastos de carnes y pozo de la nieve, hasta noviembre de 1729, Requena, 1727, AMR, 2430/37 PL.

Remates de abastos de 1731 aceite y jabro
Requena, 1731, AMR, 2430/42 PL. Subastas y remates de los 1739-1740 ramos: sisas del vino y carne, alcabala del viento, almotazanía, borras, aceite, jabón y tierra de la Serratilla (a fruto sano), para 1740. Subasta del pozo de la nieve y abastos de carne para el año 1741 y del corral de despojos por 6 años, Requena, 1739-1740, AMR, 2435/10 PL

Remate del pozo de la nieve 1760 y la casa mesón de la calle de la Cárcel, Requena, 1760, AMR, 2431/3 PL.

Arrendamiento del pozo de la nieve, Requena, 1764, AMR, 2431/12 PL.

Expedientes sobre la orden de la Diputación Provincial de Cuenca para que se organice, aliste y arme la Milicia Nacional, Requena, 1820, AMR, 1819/4 E.

Armamento de la Milicia Nacional, Requena, 1821, AMR, 1818/49 E.

Expediente para subasta y 1829 remates de las fincas y derechos de propios y arbitrios de la villa: almotazanía, herbaje de Montes Blancos, borras, portazo, asadura, Pozo de la Nieve, juego de pelota, arbitrio para el armamento y equipo de los Voluntarios Realistas y abasto de carnes y aceite, para 1830, Requena, 1829, AMR, 2432/10 PL.
Expediente para la subasta y 1830 remates de las fincas y derechos de propios y arbitrios de la villa: borras, Montes Blancos, almotazanía, correduría, juego de pelota y Pozo de la Nieve, Requena, 1830, AMR, 2432/16 PL. 
Libro de Actas Municipales, Requena, 1831-1839, AMR, 2729 L.

Expediente para formación de dos compañías de Milicia Urbana: alistamiento general, Requena, 1833, AMR, 1818/14 E Bando de alistamiento para la formación de 2 compañias de la Milicia Urbana ante las partidas revolucionarias existentes en las inmediaciones de Buñol, Requena, 1833, AMR, 1819/28 D.

Borrador de carta del Corregidor y Ayuntamiento a la Reina Gobernadora comunicando la celebración de funerales por Fernando VII y la proclamación de Isabel II, Requena, 1833, AMR, 1819/26 D.

Expediente de arriendo de los propios, Pozo de la Nieve, juego de la pelota, herbaje, borras, asadura, portazgo, correduría, almotazaní y alhóndiga, Requena, 1833-1834, AMR, 2288/27 PL

Estados de la fuerza y alistamiento de Milicia Nacional, Requena, 1833-1838, AMR, 1818/51 E.

Documentación sobre municiones, artillería y pertrechos de guerra de la Milicia Nacional y otras unidades, Requena, 1833-1842,

Informe del armamento, vestuario y munición pertenecientes a las extinguidas dos compañía de voluntarios realistas, Requena Esh/11/12, AMR, 1818/16.

Estado de fuerza, uniformados y fallecidos de la Milicia Urbana, Requena, 1834, AMR, 1818/37 E

Estado de la fuerza de la Milicia Ura la Milicia Urbana, Requena, 1834, AMR, 1818/39 E.

Propu de luerza de la Milicia Urbana, Requena, 1834, AMR, 1818/47 E.

Orden de la Comisión de Liquidación de la Provincia a los Aynntamientos desde 1808-1825, Requena, 1834, AMR, 1277/5 PL Expediente de arriendo de los propios: Pozo de la Nieve, juego de pelota, asadura, borras, portazgo y portazzuillo, almotazanía, fie

Relación jurada de Guillermo Saez de la Piedra recibida y por recibir, importe de los cerramientos de las calles de esta población para la conservación de la Salud Publica, Requena, 1834/11/24, AMR, 1818/50.

Relación dada por el maestro de obras Guillermo Saez de lo que falta hacer para [se cumpla] la seguridad, Requena, 1834/9/9,

Expediente de arriendo de los propios: juego de la pelota, Pozo de la Nieve, almotazanía y borras, Requena, 1835, AMR, 2288/39

Estado de la fuerza y armamento de la Milicia Urbana, Requena, 1835, AMR, 1818/27E.
Diligencias practicadas para la nueva forma que se dio a la Milicia Urbana y nuevo alistamiento, Requena, 1835, AMR, 1818/44E Lista de las dos compañias de la Milicia Urbana de nueva creación, Requena, 1835, AMR, 1818/43E

Lista de los sujetos alistados en la Milicia Urbana de Requena, Requena, 1835, AMR, 1818/20E.

Descripción del estado de la Milicia Urbana, Requena, 1835, AMR, 1818/42E.

Recibo de los cartuchos entregados a la Milicia de Utiel, Requena, 1835, AMR, 1818/41E.

Repartimiento de la contribución para sufragar los gastos de los tambores de la Milicia Nacional, Requena, 1835, AMR, 2288/37L Nombramiento de una junta para atender a los ministros de la Milicia Urbana, Requena, 1835, AMR, 1818/38 E

Documentación con relación de haberes y socorros pagados a la Milicia Nacional y Guardia Nacioril morilzados y listados de

(1835-1842, AMR, 1838/11 PL.

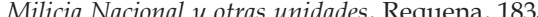
1844, AMR, 4733/25E. $1818 / 48$.

Acuerdo del Ayuntamiento sobre medidas de defensa de esta población de la facción de Cabrera. 27 de julio de 1835, 1835/07/27,

$\mathrm{AMR}, \mathrm{XV} 2.1 .1(1818 / 48)$.
Expediente y bando de la defensa de Requena en caso de ser vuelta a invadir por la cabecilla Cabrera y nombramiento de la Junta de armamento y defensa, Requena, 1835/09/18, AMR, 1818/19 E.

Pasaporte concedido por el comandante del cantón de Requena, D. José Ruiz de Albornoz, a Francisco Claramunt, sargento segundo de la compañía de granaderos, para que pase a Valencia al frente de una partida de granaderos y cazadores escoltando una carga de

Relación de los individuos granaderos y cazadores... que han compuesto la partida que a mis órdenes a pasado a la ciudad de Valencia para escoltar las municiones y fusiles..., Requena, 1835/12/16, AMR, 4734/2. seguridad, Requena, 1835/12/5, AMR, 1818/50.

Relación de los puntos de fortificación que comprende esta Billa de Requena con espresion de reponer los que se notaran y sus yntermedios. Por el Maestro de Obras Guillermo Sáez, Requena, 1835/12/5, AMR, 1818/50.

Expediente de arriendo del Pozo de la Nieve y almotazania, Requena, 1836, AMR, 2288/45 P

Suscripción a la artillería y donativos para su adquisición, Requena, 1836, AMR, 1818/28

Elección de las compañías de la Guardia Nacional, Requena, 1836, AMR, 1818/40E.

Reemplazo de un oficial de la Compañía de artillería y elección de los jefes que le faltaban, Requena, 1836, AMR, 1818/30E.

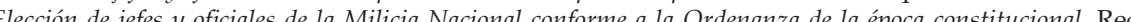

1818/32E.

Estado de la fuerza de la Sección de Caballería de la Guardia Nacional, Requena, 1836, AMR, 1818/29E.
Cuenta de la distribución de fondos hecha por el administrador, Requena, 1836, AMR, 1277/6 PL

Medidas de fortificación: Comisión del 26 de febrero de 1836, en la que el maestro de obras Guillermo Saez verifica el estado de las obras y cúnto rest por concluir de la fortificación de Requena jum to a una Comisión del Ayuntamiento, Requena, 1836/02/26, AMR, 1818/53.
Real Decreto recompensando á la villa de Requena por la defensa que hizo contra la facción de Gómez, Madrid, 1836/09/26, BOE,

Gaceta de Madrid, núm. 651 de 23/09/1836, p. 1 .

Elección de vocales al consejo de Subdirección y disciplina para la elección de compañías de granaderos, fusileros, cazadores, artilleros y caballeria, Requena, 1837, AMR, 1818/22E.

Servicio que deben prestar los pelotones de ciudadanos no pertenecientes a la Milicia en caso de alarma, Requena, 1837, AMR, 1818/21E.

Estado de la fuerza de la sección de la Milicia Nacional de Caballería, Requena, 1837, AMR, 1818/23E

Cuentas y recibos de haberes y socorros pagados a los miembros del Batallón de la Milicia Nacional, Requena, 1837, AMR, 4734/1E.

1861/18doptadas para el reintegro de los fondos que se gastaron en la fortificación y estancias militares, Requena, 1837, AMR,

Expediente de contribución extraordinaria, sobre el anticipo de los 200 millones, Requena, 1837, AMR, 1777/7 PL.

Expediente de contribución extraordinaria, Requena, 1837, AMR, 1861/7 PL.

Comisión de servicios del ingeniero Ortiz de Pinedo, Requena, 1837/03/12, AMR, 1818/16

Memoria militar de Requena: informe militar elaborado por el Capitán de Ingenieros D. Pedro Ortiz de Pinedo y dirigido al Excelentisimo Sr. Capitán General de Castilla la Nueva, Requena, 1837/04/?, AMR, 1818/52E o 4733/25.

Obras de fortificación: incluye la comisión de servicios del ingeniero Ortiz de Pinedo(12 de marzo de 1837) y partes de tasación 23 de abril 1837), Requena, 1837/04/12, AMR, 1818/16

Certificaciones de Ortiz de Pinedo sobre las varas, jornales, materiales y precios de las obras de reedificación de la fortificación de Requena, Requena, 1837/05/30, AMR, 1818/34E

Real Orden autorizando a Requena para echar mano a todos los recursos, para abastecer por 30 días por estar amenazada por las facciones de Bajo Aragon, Requena, 1837/07/02, AMR, 1818/36E

Expediente de arriendo de la almotazania, Pozo de la nieve y abasto de carnes, Requena, 1838, AMR, 2288/47 PL 列

Requena, Requena, 1838, AMR, 1818/7

Estado de la fuerza y de la oficialía de la Milicia de Requena, Requena, 1838, AMR, 1818/6E. Expediente del Comandarte Genevril de la Prociones a la Brigada de operaciones de esta provincia, Requena, 1838, AMR, 1277/7 PL. Expediente: plano y cuentas de la fortificación de la Puerta de Alcalá, Requena, 1838, AMR, R818/15E.

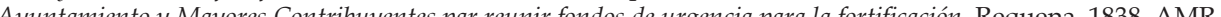
$1818 / 9 \mathrm{E}$.

Repartimiento de la contribución extraordinaria de guerra, Requena, 1838, AMR, 1777/10 PL.

Correspondencia: partes de la 1a Guerra Carlista, Requena, 1838, AMR, 1411 C.
Expediente de arriendo de los arbitrios: Pozo de la nieve, almotazanía y despacho publico de carnes, Requena, 1838-1839, AMR, 2286/2 PL.

Expediente para el alistamiento de todos los habitantes de esta ciudad no pertenecientes a la Milicia Nacional para servicio en caso de alarma, Requena, 1838/02/05, AMR, 1818/26E

Expediente sobre las medidas tomadas para mejor seguridad de la ciudad, Requena, 1838/02/09, AMR, 1818/8E

Memoria del Comandante militar y Ayuntamiento para la total defensa de Requena y mayores contribuciones a su vista, Requena, (8)

Fortificación de Requena. Memoria sobre la reparación y obras nuevas que conviene verificar, Requena, 1838/07/04, AMR,

Expediente para hostilizar a las facciones enemigas y sobre el fusilamiento de 14 leñadores de esta ciudad, Requena, 1839, AMR, Expediente

Acuerdo del Ayuntamiento a consecuencia del fusilamiento hecho por los facciosos a 14 nacionales, Requena, 1839, AMR, $1818 / 4 \mathrm{E}$.

Expediente panu renouacion de enpleos en la Milicia Nacional de Requena en las compañias za y 4a de Fusileros y Caballería, Requena, 1839, AMR, 1818/1E

Repartimiento de trigo que los vecinos y forasteros han de reducir a harina para almacenamiento para la necesidad de un sitio,

Requena, 1839, AMR, 1818/12 E.
Diligencias para la protección de los frutos del campo y huerta amenazadas por los facciosos, Requena, 1839, AMR, 1818/11 E. Solicitud de José Maria Cuartero y José Antonio Ruiz, arrendadores de los impuestos de 6 y 4 maravedíes en libra de carne para el suministro de tropas, para que se liquilde

Lista cobratoria de la contribución extraordinaria de guerra, Requena, 1839, AMR, 1838/6 PL.

Repartimiento extraordinaria de guerra de la contribución 1839, Requena, 1839, AMR, 2832/2 PL. 
1252 La fortificación del "reino mágico" de Cabrera. Virginia Navalón

Repartimiento industrias en la contribución extraordinaria de guerra, Requena, 1839, AMR, 2832/3 PL.

Expediente de arriendo de los arbitrios: Pozo de la Nieve, almotazanía, despacho público de carnes, alhóndiga y aceite, Requena, 440, AMR, 2286/4 PL.

Expediente sobre la fortificación de la ciudad, Requena, 1839/03/09, AMR, 1818/35E.
Expediente para la renovación de conal Re Requena, compañias 1a y 3 a, Requena, 1840, AMR, 1818/2E.

Nombramiento de la Junta del partido de Requena, Requena, 1840, AMR, 1818/5E. Estadística formada a petición del ingeniero que se presentó en la ciudad para formar el itinerario militar, Requena, 1840, AMR,
$1818 / 6 \mathrm{E}$.

Alistamiento de todas las caballerías mayores de esta ciudad y su término con expresión de las declaradas útiles e inútiles para prestación de servicio, Requena, 1840, AMR, 2832/7 PL.

Expediente para el apronto de 15 celemines con destino a la Brigada de las tropas sobre Cañete y Beteta, Requena, 1840-1844, Expediente para el apronto de 15 celemines con destino a la Brigada de las tropas sobre Cañete y Beteta, Requena, 1840-1844,
AMR, 1277/9 PL. Expediente de la Milicia Nacional de renova

caballería, Requena, 1841, AMR, 4733/1E. Expediente de la Milicia Nacional formado para el alistamiento de labradores que viven extram
AMR, $4733 / 3 \mathrm{E}$.

Expediente para la contribución extraordinaria de guerra, Requena, 1841, AMR, 1776/8 PL. Expedientes de acuerdos de Ayuntamientos con renovación de cargos de las compañías de la Milicia Nacional, Requena, 1842, AMR, 4734/8E.

Expedientes con acuerdos del Ayuntamiento sobre renovación de los oficiales de las compañías 2a, 4a cazadores y sección de caballería de la Milicia Nacional, Requena, 1843, AMR, 4734/71

Relación de fusiles entregados a la Milicia Nacional de Requena, Requena, 1844, AMR, 1818/25E.
Listado de miembros de la Milicia Nacional de las compañias de granaderos, plana mayor y compañía de cazadores, Requena, 1844, Listado de miembros de la Milicia Nacional de las compañias de granaderos, plana mayor y compañia de cazadores, Requena, 1844,
AMR, $4733 / 20 \mathrm{E}$.

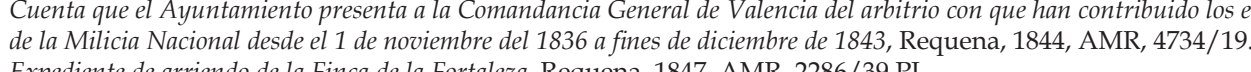
Expediente de arriendo de la Finca de la Fortaleza, Requena, 1847, AMR, 2286/39 PL.

Expediente de arriendo de los arbitrios de: Pozo de la Nieve, alhóndiga, pesos y medidas, panera y casa del Pósito, Requena, 1848 AMR, 2286/40 PL.

Cuentas de la fortificación y de la Milicia de Requena, Requena, 1874-1875, AMR, 1362/5D.

Obras menores y de mantenimiento del edificio El Castillo por filtraciones de agua, Requena, 1894, AMR, 10288/23 D.

Solicitud de licencia de obras para construir casas en el Pozo de las Nieves por parte de los vecinos, Requena, 1894, AMR, 10229/8 E Licencia de obra de V.O. para las obras de la fortaleza, adecuando la piedra tal y como han hecho los vecinos, Requena, 1895, AMR

Licencia de obra de V.O para las obras de la Fortaleza, adecuación de la piedra tal y como han hecho los vecinos, Requena, 1895, AMR, 10229/13 E.

Solicitud de F.P.G para la construcción de una casa en el Pozo de las Nieves, Requena, 1896, AMR, 10229/14 E.

Expediente instruido para la enajenación de Terrenos en: Los Ejidos en la Aldea de la Portera, de El Rebollar, Los Duques, Campo
Arcís, Solares, Solares del Fortín, Solares del Cerrito y solares del Pozo de las Nieves, Requena, 1914-1916, AMR, 10233/1 E Solicitudes de enajenación sobrantes de via pública en Campo Arcís, San Antonio, Los Duques, El Derramador, Turquía, E rebollar, Casas del Río y en Requena en el Pozo de las Nieves, Cuesta del Ángel, calle de las Fuentes, Calle de la Cortina, Requena, 1919, AMR, 10233/2

Plan General de Ordenación Urbana de Requena, Requena, 2013, Ayuntamiento de Requena, sin ref. Informe sobre la situación de la industria sedera emitido por el Ayuntamiento de Requena, Sección Industria, leg. 63, Requena,
s.f, $\mathrm{ADPV}$, leg. 63.

\section{Cartografía histórica utilizada con la información complementaria de los archivos para el caso de Requena}

*La cartografía histórica utilizada se cita ordena por fecha aproximada de ejecución del plano y se organizan las
referencias del siguiente modo: "Título, Ciudad, Fecha, siglas archivo, referencia. Autor (de haberlo). Impresor (de referencias del siguiente modo: "Título, Ciudad, Fecha, siglas archivo, referencia. Autor (de haberlo). Impres
haberlo). Escala (de haberla) Descripción fisica (de haberlo). Descripción cartográfica y notas (de haberlas)".

Planta, perfil y corte para la puerta de Alcala de esta Ciudad; Cortado por la linia, marcada, B A, Dicha Obra sera marcada por la Escala proporcional y Pliego de condiciones, Requena, s. f. AMR, Escala proporcional o pitipie de Palmos Castellanos. Escala: [ca. 1.24.000] 1500 varas castellanas $[5,3 \mathrm{~cm}]$. Descripción física: 1 mapa: ms. col montado sobre tela $\cdot 21$ × 32.7 $\mathrm{cm}$, en h de $25,7 \times 37,1 \mathrm{~cm}$. Descripción y notas: Bajo el título: Las dos lineas paralelas demuestran las trincheras que se han hecho. Manuscrito a plumilla en tinta negra y coloreado a la acuarela en gris, carmín, siena y azul. Relieve representado por sombreado. Indica el curso del río Buñol con flecha. Sello del Estado Mayor. Segundo Ejército. Croquis de Requena (i1809?), s. 1. 1809?, AGMM, Cartoteca del Archivo General Militar de Madrid. Colección: SH.
Signatura: ESP-2/3. Signatura anterior: P-m-11-53. Signatura anterior: A-18-41. Signaturas anteriores: ESP-M-2/3.
La fortificación del "Reino mágico" de Cabrera. Virginta Navalón 1253

1718. Escala: [ca. 1:30.500]. Media legua [= 9,1 cm]. Descripción física: 1 mapa: ms. montado sobre tela ; $15 \times 21 \mathrm{~cm}$. Descripción y notas: Manuscrito a plumilla en tinta negra. Orientado con medio castillo. Indica caminos, convento y núcleo de población. Sello en tinta del Depósito General Topográfico de Ingenieros. Reglamento para las Partidas de guerrilla, Cádiz, 1812, BCM, Biblioteca Central Militar (Madrid). Signatura: 1812-4. Ubicación Anterior: Olim: ML-R-90-A. Notas de ejemplar: An. ms. en port. "Se pasó un exemplar al maior y otro comand. te del $2^{\circ}$. Batallon". Autor: Oficina de Nicolás Gómez de Requena. Descripción física: [2], 19 p. ; $19 \mathrm{~cm}$. Descripción y notas: Texto firmado por José María Carvajal. Copia digital. Madrid: Ministerio de Cultura. Subdirección General de

Coordinación Bibliotecaria, 2007. Signaturizado.
Ruta de Valencia a Fuenti Dueñas. Mapa de España y Portugal [Material cartográfico]: dividido en sus actuales provincias y orlado con los de las posesiones ultramarinas españolas y los planos de las principales ciudades, Madrid, 1852, IGNC, sign. 32-L-7. Compuesto con presencia de datos fidedignos por Pedro Martín de López é individuo de varias corporaciones cientificas y literarias y grabado en acero por Ramón Alabern. Impresor. Gaspar y Roig. Escala. Escala 1 mapa: col a mano, montado sobre tela $: 77,5 \times 98,5 \mathrm{~cm}$ en una h de $79 \times 101,5 \mathrm{~cm}$. Descripción y notas: Comprende la península Ibérica, las islas Baleares. Su autor, fue el continuador de Juan López, hijo de Tomás López, con cuya empresa continuó reeditando mapas. Marco con rotulación de grados. Dibujados meridianos y paralelos formando cuadrícula. Meridiano de origen, Madrid. En el ángulo inferior derecho figura el título, autor, grabador, editor, lugar y fecha de edición. En el inferior derecho, se señalan las escalas gráficas en leguas españolas de 20 al grado, leguas de Portugal de 18 al grado y en kilometros. Junto a ellas una explicacion de los signos convencionales. En el margen superior, aparece un grabado con una serie de figuras alegoricas representando a la industria, las artes, el comercio, la Ciencia, la navegacion y la aginlura, en el cento, una figura femenina representa a lsabel li, apoyada en el escudo real completo, que lleva entrelazado el collar de la Orden de Toisón de Oro. Esta franja superior debió ser grabada aparte e impresa posteriormente con el mapa, ya que a la izquierda dice: "J. Vallejo ino. y.d." y en el otro lado "A con las ciudades representadas por pequeños círculos, red de comunicaciones y división político-administrativa. La hidrografía es bastante completa con denominación de la mayoría de los ríos. La costa aparece realzada con rayado horizontal. Abundante toponimia. Rotulación con letra romanilla e itálica. Datado durante el reinado de Isabel II (1833-1868). Ejemplar deteriorado grado 3. Incluye los siguientes mapas y planos: 1. Mapa de las islas Canarias, [ca. 1:3.000.000].25 Leguas Marítimas de 20 al grado [=3,7 cm]; 2. Mapa de las islas Antillas,[ca. 1:2.000.000].60 Leguas Marítimas de 20 al grado [=3,8 cm]; 3 . Mapa de las Filipinas, [ca. 1:6.000.000].40 Leguas Marítimas de 20 al grado [=3,2 $\mathrm{cm}$; 4 4. Plano de poblacion de San Sebastian, [ca. 1:24.000]. 1000 Varas Castellanas $[=3,5 \mathrm{~cm}] ; 5$. Plano de población de Sevilla, [ca. 1:25.000]. 1000 Varas Castellanas [=3,5 cm]; 6. Plano de población de La Habana, [ca. 1:32.000]. 1000 Varas Castellanas $[=2,6 \mathrm{~cm}] ; 7$. Plano de población de Madrid, [ca. 1:20.000]. 1000 Varas Castellanas $[=4,1 \mathrm{~cm}] ; 8$. Plano de población de Barcelona, [ca. 1:24.000]. 1000 Varas Castellanas [=3,5 cm]; 9 . Plano de población de Valencia, [ca. 1:9.000]. 500 Varas Castellanas $[=4,7 \mathrm{~cm}] ; 10$. Plano de población de Zaragoza, $[\mathrm{ca} .1: 22.000] .1000$ Varas Castellanas $[=3,7 \mathrm{~cm}]$; Castellón de la Plane [Material cartogréfico]. Madrid, 1852 IGNC, sign 30-A-10. A

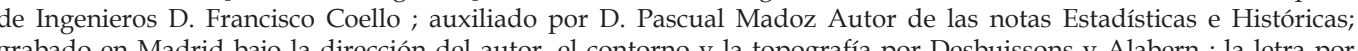
列 $98,5 \mathrm{~cm}$, en h. 80 x $106 \mathrm{~cm}$. Descripción y notas: Comprende la provincia de Castellón, contornostado sobre tela; $73 \times$ de población de municipios de la provincia. Pertenece a Francisco Coello de Portugal y Quesada (1820-1898), que en 1846 fue destinado a la Dirección General de Ingenieros y comenzo a colaborar con Pascual Madoz en la publicación de su Diccionario Geográfico-Estadistico-Historico, encargándose de la confección de los mapas que conformaron el "Atlas de España y sus posesiones de Ultramar" (1848-1800), del que se publicaron 48 hojas de la más lata calidad. Como complemento a los mapas provinciales del referido atlas, Coello inclúa en todos ellos planos de la capital y de los lugares más importantes de la provincia, faltándole espacio en algunos de los mapas par los planos de población previstos. Marco con rotulacion de grados y cada 5 con subdivisiones de 1 . Dibujados los meridianos y paralelos longitudes en el meridiano de Madrid. El mapa sitúa varias notas explicativas a ambos lados del mapa bajo el nombre general de "Notas Estadísticas e Históricas", donde hay varios apartados acerca de los partidos judiciales, población, y clero, costumbres, producciones, comercio, industria y minería. También se señala una lista de los meridianos origen más usuales, junto con el sistema de signos convencionales, notas sobre los signos convencionales y las escalas generales en leguas legales, millas marítimas, leguas de Camino Real y leguas de 8.000 varas, y escalas de los planos particulares. Relieve representado por curvas configuradas. Planimetria con ciudades representadas por pequeños circulos segun su importancia, red de comunicaciones y division politico-administrativa y eclesiastica. La hidrografía aparece representada en su totalidad, con denominación de los ríos más importantes. La costa aparece minuciosamente Inserta los platos de ciubdes 1.10.000 - 9 × $11 \mathrm{~cm}$. 3 . Peñ́scola - 1:10.000 - $9 \times 12 \mathrm{~cm}$. 4 . Contornos de Castellón de la Plana - 1:100.000 - $17 \times 16 \mathrm{~cm}$ Datado durante el reinado de Isabel II (1833-1868). Ejemplar deteriorado: grado 2. Zaragoza (material cartográfico), Madrid, 1853, IGNC, sign. 30-C-8. Autor: Por el Teniente Coronel, Capitán de Ingenieros Francisco Coello ; las notas estadísticas e históricas han sido escritas por Pascual Madoz; el contorno por Descripción física: 1 mapa en 2 h.: col. a mano, montado sobre tela ; 120 × 109 cm en 2 h de 83 × 102 cm.pleg. a 21 × 14 
1254 La fortificación deL "reino mágico" de Cabrera. Virginia navalón

cm. Descripción y notas: Comprende la provincia de Zaragoza. Pertenece a Francisco Coello de Portugal y Quesada (1820-1898), que en 1846 fue destinado a la Dirección General de Ingenieros y comenzó a colaborar con Pascual Madoz en la publicación de su Diccionario Geográfico-Estadístico-Histórico, encargándose de la confección de los mapas que conformaron el Atlas de España sus posesiones de Ultramar (1848-1880), del que se publicaron 46 hojas de la más
alta calidad. Como complemento a los mapas provinciales del referido atlas, Coello incluía en todos ellos planos de la capital y de los lugares más importantes de la provincia, faltándole espacios en algunos de los mapas para los plano de población previstos. Marco con rotulación de grados y cada $5^{\prime}$ con subdivisiones de $1^{\prime}$. Dibujados meridianos paralelos formando cuadrícula. Señalado sólo el N. Dibujado en proyección de Bonne y con origen de longitudes en meridiano de Madrid. Relieve representado por curvas configuradas y cotas altimétricas en pies castellanos. Planimetr con ciudades representadas por pequeños círculos según su importancia, Red de comunicaciones y división políticoadministrativa y eclesiástica. La hidrografía aparece representada en su totalidad, con denominación de los ríos más zona de la provincia y los planos de potaciación en letra de palo, capitular, romanilla e e italica. Hoja no $\mathrm{n}$ 1: Incluye Históricas de las tres provincias de criminal, culto y clero, costumbres, instrucción pública, producciones, ingresos, comercio, riqueza, contribuciones historia, además de los signos convencionales, notas sobre los signos convencionales, escalas generales y escalas de los planos particulares contenidos en ésta y en la segunda hoja. Hoja n ${ }^{\circ}$ 2: Incluye el resto de la provincia, Contorno de Zaragoza a 1/100.000 y los planos de población de Zaragoza, Pina, Caspe, Belchite, Daroca, Ateca, La Almunia de Doña Godina, Tarazona y Calatayud, todos ellos a escala 1/10.000. Datado durante el reinado de Isabel II (1833-1868) Ejemplar deteriorado: grado 2 .

Teruel (material cartográfico), Madrid, 1868, IGNC, sign. 30-C-4. Autor: por el Coronel de Ingenieros Francisco Coello, grabado en piedra por José Reinoso, bajo la dirección del autor. Impresor: [Imp. de Atlas de España]. Escala: Escala 1:400.000. 40.000 Metros, 40 Kilómetros ó Miriámetros [ $=10 \mathrm{~cm}]$. 160.000 Pies Castellanos, 8 Leguas de 20.000 pies pies, 8 Legues de 20 al grado comprenden tres minutos del ecuedor; cada una de 5.565 metros ó 19.973 pies [ $=11,2$ cm]. Descripción física: 1 mapa: Comprende la provincia de Teruel. Pertenece a Francisco Coello de Portugal y Quesada (1820-1898), quien trató de publicar todas las provincias españolas entre 1848 y 1880, unas a escala 1:200.000 y otras a escala 1:400.000. Algunas quedaron casi terminadas en manuscrito pero el gobierno retiró la subvención que daba a Francisco Coello, quedando su trabajo inacabado. Marco con rotulación de grados y cada $5^{\prime}$ con subdivisiones de $1^{\prime}$. Dibujados meridianos y paralelos formando cuadricula. Señalados los cuatro puntos cardinales. Dibujado en proyección de Bonne y co origen de longitudes en el meridiano de Madrid. En el angulo superior izquierdo, título, autor y fecha de edición. En el angulo inferior izquierdo, lista con signos convencionales y nota alaratoria sobre los mismos. En el derecho, las escalas gráficas en metros, pies castellanos, millas marítimas, leguas de 20 al grado, y las numéricas, y otra lista con signos convencionales. Fuera de marco, el nombre del grabador. Relieve representado por curvas configuradas y cotas indicación del número de habitantes cuando son superiores a 10.000, red de comunicaciones, masas de arbolado división político-administrativa y eclesiástica. La hidrografía aparece representada en su totalidad, con denominacion de los ríos más importantes. Abundante y cuidada toponimia Rotulación en letra de palo, capitular, romanilla e itálica. Datado durante el reinado de Isabel II (1833-1868). Ejemplar deteriorado: grado 2. Con manchas. $\mathrm{N}^{\circ} 0240$ del cat́logo de Fondos Cartográficos del IGN, publicado en el año 2000.

Mapa del Reyno de Valencia |Material cartografico|. con las nuevas divisiones, Paris, 1843, IGNC, sign. 30-F-1. Autor formado por A. H. Dufour, Geografo. Impresor. Encasas de Bulla. Calle de Tiquetone N 18. Escala. Escala [ca. 1.561.000 5 Myriametros 10 por un grado decimal de 11937 Varas Castellanas ó $11 \mathrm{~m} / 1000$ al Grado, 8 Leguas Geográficas de España de 7572 Varas Castellanas ó $171 / 2$ al grado, 12 Leguas Legales de España de 5000 Varas Castellanas ó 26 1/2
al Grado [ $=9 \mathrm{~cm}] .8$ Leguas de Aragón de 7361 Varas Castellanas ó 18 al Grado [ $=8,9 \mathrm{~cm}]$. (O 04 $04^{\circ} 05^{\prime}-\mathrm{O} 01^{\circ} 45^{\prime} / \mathrm{N} 41^{\circ} 23^{\prime}$ $\left.\mathrm{N} 37^{\circ} 34^{\prime}\right)$. Descripción física: 1 mapa: col. a mano, montado sobre tela ; $82 \times 54 \mathrm{~cm}$, en una h. $100 \times 71 \mathrm{~cm}$. Descripción y notas: Comprende el reino de Valencia. Pertenece a la obra de Auguste Henri Dufour (1798-1865), que entre los data de 1838 incluyendo la división provincial vigente desde 1833. Existe una 2a edición de 1849 también editada París. El mapa corresponde a la plancha $\mathrm{n}^{\circ}$ 7. Marco con rotulación de grados y subdivisiones de 5'. Dibujados los meridianos y paralelos formando cuadrícula. Meridiano origen de París. En el angulo superior izquierdo título, autor y las escalas gráficas en miriámetros, leguas geográficos, legales y de Aragón. En el ángulo inferior izquierdo los signos convencionales. Relieve representado por normales. Planimetría con ciudades representadas por pequeños círculos, red de comunicaciones, distancias entre poblaciones y división politico-administrativa. La hidrografía representa red principal, con denominación de los ríos más inportantes. La costa aparece realzada con amplio rayado horizontal, representados los escollos. Abundante toponimia. Rotulación en letra romanilla e itálica. El título con rúbrica de fantasía. Datado durante el reinado de lsabel II (1833-1868). Ejemplar con manchas. En: Atlas nacional de España.- $\mathrm{Pl} 7$ To del Mapa Topográfico Nacional a escala 1:25.000, generados por medio de una rasterización digital (conversión vector contenido de las últimasion de sombreado y sin exteriores. Los a chivos no tienen por qué coincidir exactamente con e VECTORIAL), se van incorporando nuevos elementos y resolviendo errores detectados. Los formatos de descarga son TIFF + TFW y ECW, acompañados de un PRJ que contiene información sobre la georreferenciación. Sistema geodésico de referencia ETRS89 en la Península, Islas Baleares, Ceuta y Melilla, y REGCAN95 en las Islas Canarias (ambos sistemas compatibles con WGS84) y proyección UTM en el huso correspondiente.

Plano de la población de Requena, 1950, IGNC.

Provincias de Castellón y Valencia [Material cartográfico]: parte del antiguo Reino de Valencia, Madrid; Barcelona], 1853, IGNC, sign. 41-K-21. Grabado por R. Alabern y E. Mabon ; Imp ${ }^{\circ}$.J. Vazquez. Impresor: Librería Española]. Escala: $\mathrm{cm}]$. 12 Leguas de 5000 Varas castellanas ó $261 / 2$ al Grado $[=8,8 \mathrm{~cm}]$. Descripción física: 1 mapa: col. a mano ; 39 × 29,5 $\mathrm{m}$ en una h. de $44 \times 32 \mathrm{~cm}$. Descripcion y notas: Comprende las provincias de Castellon y Valencia. Pertenece al atlas que acompanaba al "Diccionario Geografico de Espana y de sus Colonias", publicado en 1854; Alabern era miembro de una destacada familia de grabadores de Barcelona, cuyas obras abarcan todo el siglo XIX. Marco con rotulación de grados y subdivisiones de $5^{\prime}$, formando cuadrí́cula. El mapa rompe el marco por cinco sitios. Meridiano origen de izquierdo figuran las escalas gráficas en leguas de 20 al grado, de 7572 y 5000 Varas Castellanas. Relieve representado por normales. Planimetrí con ciudades representadas por pequeños círculos, red de collunicaciones, distancias entre poblaciones y cruces y división político-administrativa. La hidrografía representa la red principal, con denominación de los ríos más importantes. La costa aparece realzada con amplio rayado horizontal. Abundante toponimia. Rotulación en letra romanilla e itálica, iluminados los límites provinciales. Datado durante el reinado de Isabel II (1833-1868). Mapa de la provincia de Valencia [Material cartográfico]. s. 1. 1883, IGNC, sign. 32-I-7. Autor: Por D. Luis B. de Miquel y Roperto Secretario de ciencias del Ateneo de Madrid, Manuel Fernandez dibujo y grabo. Impresor: s. e. Escala: Escala 1:200.000. 40 Kilómetros [ $=21 \mathrm{~cm}]$. Descripción física: 1 mapa: col. montado sobre tela ; $88 \times 67 \mathrm{~cm}$ en una h. de $92 \times$ $7 \mathrm{~cm}$. Descripción y notas. Comprende la provincia de Valescia. El mapa mereció la medalla de Oro en la exposición Regional Valenciana en 1883. Marco con rotulación de grados y cada 30'con subdivisiones de 1', formando cuadrí́cula. Meridiano origen del Observatorio de Madrid. En el angulo superior derecho título, autor, fecha, escala numérica y obra y fuentes documentales para su elaboración. Relieve representado por curvas de nivel cada $100 \mathrm{~m}$ con sombreado, figurando entre los signos convencionales los hitos geodésicos utilizados en la triangulación. Planimetría con ciudades

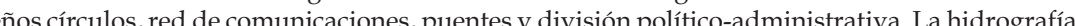
representa la red principal, con denominación de los ríos más importantes. La costa aparece relazada con dibujo de aguas en disminucion. Abundante y muy cuidada toponimia. Rotulación en letra romanilla e itálica. Datado durante le reinado de Alfonso XII (1875-1885).

Croquis del territorio de Requena, Requena, 18--, AGMM, Cartoteca del Archivo General Militar de Madrid. Coleccion:Mapas itinerarios. Signatura: V-1/13. Autor: dado por el Mariscal de campo Dn. C.F. Cabrer / y copiado en la Rl. Academ. Militar por el Alumno Antonio de Henares . Impresor. s. e. Escala. Escala calculada tomando 1 hora de camino $=555.555 \mathrm{~cm}$. Descripción física: 1 mapa: ms. col. ; 44,4x55,3 cm, en h. de 51x68,7 cm. Descripción y notas: Orientado con lecha, $\mathrm{N}$ al SO. Indicados los puntos crastes. Relieve indicado por color. Toponímia. Manuscrito a plumilla en thta negra, ilu de Madrid. Colección:Mapas itinerarios. Signatura: Ar.6-At.208. s. e. Descripción física: 1 perfil: col. ; 68 × $47 \mathrm{~cm}$.

Croquis del Cerramiento aspillerado de Requena, Requena, 181-?/ 1838?, AGMM, Cartoteca del Archivo General Militar de Madrid. Sección: Cartoteca Histórica, Provincia de Valencia, núm. 262. Colección: Mapas itinerarios. Signatura: Ar. tela ; $44,8 \times 79 \mathrm{~cm}$, en h. de $46,2 \times 91,3 \mathrm{~cm}$. Descripción y notas: A plumilla en tinta negra e iluminado a la acuarela en siena, verde y carmín. Orientado con flecha. Relieve representado por sombreado. Relación de las principales fortificaciones,

puertas, pozos, molinos etc. indicados por clave numérica.
Plano croquis de la Casa Fuerte de la Villa de Requena, Requena, 181-?, AGMM, Cartoteca del Archivo General Militar de Madrid. Sección: Cartoteca Histórica, Provincia de Valencia, núm. 261. Signatura: Ar. G-T.3-C.2.261. Autor: Cuerpo de Ingenieros. Impresor: Cuerpo de Ingenieros. Descripción física: 1 plano: ms. col. montado sobre tela ; $31 \times 41 \mathrm{~cm}$ o menos,
en h. $36,5 \times 58,8 \mathrm{~cm}$. Descripción y notas: Comprende la 'Casa Fuerte de la Villa de Requena' en la provincia de Valencia Mención de responsabilidad tomada del Catálogo del SG: 'Región Valenciana, Provincias de Castellón y Valencia Siglos XVI a XIX. 1970, p. 261. Manuscrito a plumilla en tinta negra e iluminado a la acuarela en siena y azul. Relación de las principales dependencias indicadas por clave alfabética. Nota explicativa sobre el estado de la 'Casa Fuerte'. Figura, escrito a lápiz con posterioridad, 'Valencia'. Sello de la Dirección General del Cuerpo de Ingenieros. 
14 CRétros ForockRA HCOS E INDICE DE TABLAS 
Créditos fotográficos

Fig. 1. Virginia Navalón (VN), 2018.

Fig. 2. VN, 2015.

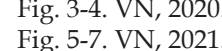

Fig. 8. Hornbrook, Thomas Lyde (1840): San Sebastián desde el convento de San Francisco: pontón sobre el Urumea y principio del nuevo puente de madera, mayo de 1836. Grabado. 24x41 cm. Publicado en Doce imágenes de las provincias vascas, ilustrativas de algunas luchas producidas entre la Legión Británica y los Soldados Carlistas.

Fig. 9. Public Archives of Canada.

Fig. 10. Cuerpo de ingenieros en el asedio de Amberes (1832). Ilustración de Édouard Detaille en Richard, Jules (1885) L'armée Française.

Fig. 11. Mappa das Linhas de Torres Vedras e sua ligaçao com Lisboa nos anos de 1810 e 1811 (Sorian, Luz (1874): História da Guerra Civil e do estabelecimento do governo parlamentar em Portugal. Lisboa: Imprensa Nacional, T.3)

Fig. 12. Posición de los aliados en frente de la torre Malakhoff y el baluarte en la tarde del 17 de junio de 1855. Illus13.

Fig. 13. Langlois, Jean-Charles (1855). Malakoff Tower, Cri
tion. MoMa. The Museum of Modern Art. Nueva York.
Fig. 14. Army \& Navy Journal, Nueva York, Oct. 24, 1863. Fig. 15. Gardner, James B, 44th Mass (1863): Map of the charge of the 54th Massachusetts on Fort Wagner, July 18, 1863, en The Boston Book Company. p. 80 Fig. 16. Toma del pueblo y fuerte de Irún, Grabado. $13 \times 18 \mathrm{~cm}$ en Panorama español, cronica contemporanea. Obra pintoresca 1... destinada a esponer todos los acontecimientos politicos desde octubre de 1832 hasta nuestros dias; con los retratos de los Zumalakarregi Museoa (ZM). Ref. 511 .

Fig. 17. Acción de Arlabán. Grabado. 11 × 16 cm, en Panorama español... ZM. Ref. 489.

Fig. 18. Acción en Ameskoa. Grabado. $16 \times 13 \mathrm{~cm}$, en Panorama español... ZM. Ref. 470.

Fig. 19. Vista del pueblo de Morella y de su castillo (delineado por Rafael Oliamas y litografiado por M. Vicente). Litografía. 44x64cm. Archivo General Militar de Segovia. Colección: ES-DFAMD. Signatura (sign.): $3^{\mathrm{a}} / 3^{\mathrm{a}} / \mathrm{Leg} .87$ Fig. 20. VN, 2021.

Fig. 21-25. VN, 2016.

Fig. 26-33. VN, 2020.
Fig. 34-35. Sánchez O

(1840): Plano del terreno y las inmediaciones del castillo de Alcalá de la Selva. Manuscrito (ms.) a plumilla y acuarela. 45,8 × 61,8 cm. Archivo Cartográfico de Estudios Geográficos del Centro Geográfico del Ejercito (CGE).

Fig. 36. Anonimo (1840): Vista del castillo de Alcalá de la Selva. Propiedad particular.

(18--?): Croquis del fuerte y terreno de las inmediaciones de Alcala. CGE Sign. Ar. F-T.5-C.5-199. (Fig. 38-43. Sanchez Ossorio, Antonio (1840): Plano del terreno y las inmediaciones del castillo de Alcala de la Selva. CGE. Fig. 44-50. Fanti, Manfredo (1840): Croquis de Alcalá, su castillo y sus inmediaciones. CGE. Sign. Ar.F-T.5-C.5-200. Fig. 51-68. VN, 2020.

Fig. 69. Calbo y Rochina, 1845: 495 .

Fig. 70. Ronchi, A. (ed.), 1853: Castillo de Aliaga. Fondo Documental Histórico de las Cortes de Aragón. Fig. 71-76. VN, 2020.

\section{Fig. 83. Calbo y Rochina, 1845: 457.}

Fig 84 . Calb

Fig. 85. Espinosa de los Monteros, Carlos (1875): Croquis del Collado y posiciones que ocuparon las tropas de la 1 Brigada el 18 de Julio de 1875. Ms., col., tela para planos; 47 × $31 \mathrm{~cm}$ en h. de 32 × $43 \mathrm{~cm}$. CGE, sign. Ar.G-T.3-C.1-200.

Fig. 86. Croquis de las posiciones ocupadas por la 1 División del Ejército del Centro en el sitio y rendición de la Villa y Castillo de Alpuente desde el 26 de Abril hasta el 2 de Mayo de 1840. 184-?. Mapa: col., montado sobre tela; 19,5 × 25,1 cm en h. de 25,1 x 38,1 cm. CGE, sign. Ar.G-T.3-C.1-199.

Fig. $87-89$. VN, 2018.

Fig. 90-94. VN, 2020.

Fig. 95-105. VN, 2020

Fig. 106. Cavanilles, 1795: v. 1, 77

Fig. 107. Plano del fuerte de Ares del Maestre tomado el 27 de abril de 1840 / por la 3 División del Ejto. espo. del norte. 1840? Ms., montado sobre tela ; $17,6 \times 24,1 \mathrm{~cm}$. CGE, sign. Ar.G-T.2-C.2-46.

$20 \times 30,2 \mathrm{~cm}$. CGE, sign. Ar.G-T.2-C.2-45. 
Fig. 109-116. VN, 2020

Fig. 117-122. VN, 118.

Fig. 142-148. VN, 2018

Fig. 149. Fanti, Manfredo (1840): Bexis: reconocimiento hecho por las tropas constitucionales sobre el Fuerte enemigo de Bexis en el dia 29 de Diciembre de 1839. Ms., col, sobre tela; 32×44,8 cm. CGE, sign. Ar.G-T.2-C.2-104.

Fig. 150. Vista de la Villa y Castillo de Bexis. 184-?. Ms. a plumilla sobre tela; 16,7x21 cm. CGE, sign. Ar.G-T.2-C.2-103-4.

Fig. 152-153. VN, 2018.

Fig.154-165. VN, 2020.

Fig. 166. Propiedad particular.

Fig. 167. Calbo y Rochina,
Fig. 168. Chao, $1847: 235$.

Fig. 168. Chao, 1847: 235.
Fig. 169-170. Janci y Villa, Pablo (1838): Plano de la Villa de Berga y su castillo. Ms., col., sobre tela; 56,1 x 79,2 cm. CGE, sign. ArF-T. 7-C 2-199.

sign. Ar.F-T.7-C.2-199.
Fig. 171. Plano de Berga. 1840. Ms., col., sobre tela ; 18,1 × 35,3 cm. CGE, sign. Ar.F-T.7-C.2-203.

Fig. 171. Plano de Berga. 1840. Ms., col., sobre tela ; $18,1 \times 35,3 \mathrm{~cm}$. CGE, sign. Ar.F-T.7-C.2-203.
Fig. 172. de Zavas y Vega, Joaquín (1840): Plano de la villa de Berga, su castillo y fuertes esteriores conforme se hallaba el 4 de Julio de 1840, día en que fue tomada a los carlistas, por el Egercito espedicionario del Norte. Ms., col., sobre tela; $47,9 \times 64,4 \mathrm{~cm}$. CGE, sign. Ar.F-T.7-C.2-202.

Fig. 173. Soriano, Ramón; de Vilano, Ladislao; Ruiz de Porras, Joaquin (1840): Plano topográfico de Berga y de los fuertes que la circuyen. Ms., col., sobre tela ; $41,4 \times 51,2 \mathrm{~cm}$. CGE, sign. Ar.F-T.7-C.2-200.

Fig. 174. Soriano, R.; de Velasco, L.; R. Porras, J. (1840): Plano de la Villa de Berga y fuertes exteriores. Ms., col., sobre tela; $41,2 \times 51,9 \mathrm{~cm}$. CGE, sign. Ar.F-T.7-C.2-201.

Fig. $175-199$. VN, 2020.

Fig. 200. Calbo y Rochina, 1845: 9

Fig. 201-207. VN, 2020

Fig. 209-222. VN, 2020

Fig. 223. Calbo y Rochina, 1845: 190

Fig. 224. Calbo y Rochina, 1845: 260.

Fig. 225. Calbo y Rochina, 1845: 199.

Fig. 226. Calbo y Rochina, 1845: 254.

Fig. 227-249: VN, 2020.

Fig. 250. Calbo y Rochina, 1845: 469 .

Fig. 251-283. VN, 2020

Fig. 284. Calbo y Rochina, 1845:487.

Fig. 285. Pirala, 1869 .

Fig. 290. Calbo y Rochina, 1845:491.

Fig. 291-309. VN, 2020.

Fig. 310-314. Fanti, Manfredo (1840?): Castelfavil: Topografia de Castelfavil y de sus alrededores: Reconocimiento hecho por las tropas constitucionales sobre los Fuertes enemigos de Castiel o Castelfavil en el dia 6 de Enero de 1840. Plumilla, ms., col., sobre tela; 39,5x34,2 cm. CGE, sign. Ar.G-T.3-C.1-205.

Fig. 315-350. VN, 2020.
Fig. $351-371$. VN, 2016. Fig. 351-371. VN, 2016.
Fig. 372 . Plano del Fuerte y sitio de Chulilla, 184-. Ms. a plumilla y acuarela, col., sobre tela; $29,5 \times 33,3 \mathrm{~cm}$. CGE, sign. Ar.GT.3-C.1-221.

Fig. 373. Croquis de Chulilla, su castillo e inmediaciones, 1840. Ms. a plumilla, col., sobre tela; $26,6 \times 20,6 \mathrm{~cm}$. CGE, sign.

Fig. 374. Cavanilles, A. J.; Enguídanos, T.L. (180-): Mapa de la Baronía de Chulilla. Sobre tela; 16,8×25 cm. CGE, sign.

Fig. 376. VN, 2016.

Fig. 377-414. VN, 2020.

Fig. 415-425. VN, 2018 .
Fig. 426. Brusco, M. (183)

Fig.427-430. Valdés, Nicolás (1840): Croquis del Collado y Castillo con perfiles elevaciones y vistas del mismo: y las posiciones que tuvieron las tropas en el bloqueo en los dias comprendidos entre el 10 de Julio y 5 de Agosto. Ms. a plumilla y acuarela, col. sobre tela; $18,6 \times 23,5$

Fig. 431. VN, 2018.

Fig. 438-450. VN, 2021

Fig. 451-476. VN, 2020

Fig. 477-482. VN, 2021

Fig. 483. Calbo y Rochina, 1845: 326.

Fig. 484-488. VN, 2020.
Fig. 489-493.VN, 2021.

Fig. 494-501.VN, 2020.

Fig. 506. Calbo y Rochina, 1845. 518

Fig. 507-518.VN, 2021.

Fig. 519-525. VN, 2018.

Fig. 526-543.VN, 2020.

Fig. 544-554.VN, 2021

Fig. 555-573.VN, 2020

Fig. 574-584.VN, 2018

Fig. 585-646.VN, 202

Fig. 647. Calbo y Rochina, 1845: 483

Fig. 649. Calbo y Rochina, 1845: 374

Fig. 650. Calbo y Rochina, 1845: 544

Fig. 651. Vista del pueblo de Morella y de su castillo (delineado por Rafael Oliamas y litografiado por M. Vicente), 1838. Litografía. 44x64cm. Archivo General Militar de Segovia. Colección: ES-DFAMD. Sign. $3^{2} / 3^{a} /$ Leg. 87.

Fig. 652. Plano y vista de la plaza de Morella y sus cercanías (levantado por M. del Castaño y pintado por F. Countines), 1838?. 15,5x16,5 cm. CGE, sign. Ar.G-T.2-C.2-59.

Fig. 653. Plano de la Plaza y Castillo de Morella con el croquis de sus inmediaciones, 1840?. Ms. acuarela col., sobre papel;

Fig. 654. Plano de la ciudad de Morella y perspectiva de su Castillo, 1840?. Lápiz y tinta, ms., sobre tela; 80,5x88,5 cm. CGE, sign. Ar.G-T.2-C.2-66

Fig. 655. Eguia, Pedro de; Unzaga, Eusebio de (1840): Plano topográfico de la plaza de Morella y su castillo en el estado que se Fig 656. Eguía Pedro de; Unzas con la posición de las baterias que se construyeron en el sitio del mes de Mayo de 1840. Acuarela, ms, col, sobre tela: $40,5 \times 36$ cm. CGE, sign. Ar.G-T.2-C.2-64.

Fig. 657-658. VN, 2021.

Fig. 659-662. VN, 2020.

Fig. $663-665$. Ricard Ballo,
Fig. 666-678. VN, 2020 .

Fig. 666-678. VN, 2020.

Fig. 679. www.bp.blogspot.com 23/04/2021

Fig. 680. José Espés, 2020.

Fig. 681. www.castillosdeespaña.es

Fig. 685-692. VN, 2020.

Fig. 693. Calbo y Rochina, 1845: 443.

Fig. 694-695. VN, 2020.

Fig. 696-705. VN, 2021.

Fig. 706-715. VN, 2020.

Fig. 716. Calbo y Rochina, 1845: 407

Fig. 717. Calbo y Rochina, 1845: 475 .

Fig. 718. Calbo y Rochina, 1845: 479

Fig. 719. Pirala, 1869.

Fig. 720. Espartero, 1846

Fig. 721-722. VN, 2020.

Fig. 727. Sitio de Tales, pueblo de la prova. de Castellón en el reino de Valencia: croquis para servir ála esplicación de las operaciones militares... y toma de sus fuertes en el mes de agosto de 1839, 184-?. 15x19,5 cm. CGE, sign. Ar.G-T.2-C.2-103.

Fig 728. Fanti, M. (184-?): Sitio de Tales: croquis para servir a le esplicación de las Operaciones militares. en el Mes de Agosto de 1839 por las tropas constitucionales a las órdenes del General en Gefe del Ejto. del Centro. Plumilla, ms., col., 31,7×25,8 cm. CGE, sign. Ar.G-T.2-C.2-102.

Fig. 729-730. VN, 2018.

Fig. 731-756. VN, 2020.

Fig. $757-762 . \mathrm{VN}, 2021$.

Fig. 767. Caseres (184-?): Plano de la acción dada en Utiel el 6 de Febrero de 1839 al Cabecilla Arnau, mandada por el Sor. Brigadier Comandte. Gral. de la prova. de Cuenca Dn. Martin Jose Yriarte. Plumilla, ms., col., sobre tela; $31,2 \times 26,1 \mathrm{~cm}$. CGE, sign. Ar.GFig. $768-714$.

Fig. 715-721. VN, 2020.

Fig. 715-721. VN, 2121.

Fig. 724. Croquis de las Cabrillas y avenidas por Siete Aguas. Las dos lineas paralelas demuestran los trincherones que se han hecho", 1811. SGE, sign. Ar.G-T.3-C.1-206).

Fig. 725. Croquis de Requena, 1809. AGMM, Cartoteca del Archivo General Militar de Madrid. Col.: SH. Sign. ESP-2/3. 
Signatura anterior: P-m-11-53. Signatura anterior: A-18-41. Signatura anterior: ESP-M-2/3. Signatura anterior: 1718). Fig. 726. Bernabeu, 1982:415.

Fig. 728. Gaceta de Madrid, el 23 de septiembre de 1836

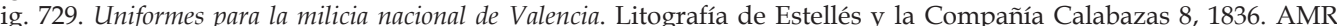
1818-16.

Fig. 730-737. Ortiz de Pinedo, Pedro (1837): Croquis del cerramiento aspillerado de la ciudad de Requena (AGMM, Ar.

G-T.3.C.2.262)

Fig. 738. AMR, 1818-15.

Fig. 739-743. VN, 2015.

Fig. 744. Salinas \& Pardo, 2014: 129

Fig. 745. Jordá, 2000: fig. 62.

Fig. 747. ordá, 2000: fig.

Fig. 748. Bernabeu, 1982: 393 (izq.), VN, 2015 (dcha.).

Fig. 749. Jordá, 2000: fig. 13.

Fig. 450. Jordá, 2000: fig. 9.

Fig. 751. VN, 2015 .

Fig. 752. Jordá, 2000: fig. 52.

Fig. 753. Salinas \& Pardo, 2014:104

Fig. 754. Salinas \& Pardo, 2014: 103

Fig. 755-760. IGN, 2015

Fig. 761. AMR, sin ref.
Fig. 762. Vallejo: El serrador con su columna ataca Lucena. Biblioteca Nacional. Madrid. En Pérez Galdós, 1993: 2508.

Fig. 763. Maré: Acción de Aulestia. Col. Baleztena. En Pérez Galdós, 1993: 2674.

Fig. 764. J. M de Dios, 1935.

Fig. 765. F. Morencos.

Fig. 766-773. VN, 2015

Fig. 774. Ortiz de Pinedo, Pedro (1837): Croquis del cerramiento aspillerado de la ciudad de Requena (AGMM, Ar.

G-T.3.C.2.262).

Fig. 775-776. Google maps, 2015.

Fig. 777. 2013: PGOU de Requena. T.CAS.BRL.2

Fig. 778-781. VN, 2015.

Fig. 782-785. www.sedecatastro.gob.es. 19/08/2015.

Fig. 786. VN, 2015.

Fig. 787. AMR, 2105/26.
Fig. 788-810. VN , 2015.

Fig. 811-812. VN, 2013

Fig. 813-815. VN, 2014

Fig. $816-817$. VN, 2015

Fig. $818-824$. VN, 2014

Fig. $825-826 . \mathrm{VN}, 2015$

Fig. 827. VN, 2013.

Fig. $828 . \mathrm{VN}, 2020$.

Fig. 829. VN, 2020.

Fig. 837. VN, 2020.

Fig. 839. VN, 2016.

Fig. 840. VN, 2015. Plano base: Martín de López, Pedro (1852): Mapa de España y Portugal dividido a sus actuales provincia y orlado con los de las posesiones ultramarinas españolas y los planos de las principales ciudades. IGNC, sign. 0045/32-L-7).

yorlado con los de 1 as
Fig. 841 . VN, 2021.
Fig. $842-872$. VN, 2121

Fig. 873. Relación de los puntos de fortificacion que comprende esta Billa de Requena con espresion de reponer los que se notaran y sus yntermedios. Por el Maestro de Obras Guillermo Sáez, Requena, 1835/12/5, AMR, 1818/50.

Fig. 874. Transcripción 2: Acción del Ayuntamiento sobre medidas de defensa en esta [Población] [de] la Sección de Cabrera

Fig. 875. Expediente y bando de la defensa de Requena en caso de ser vuelta a invadir por la cabecilla Cabrera y nombramiento de la Junta de armamento y defensa, Requena, 1835/09/18, AMR, 1818/19 E.

Fig. 876. Pasaporte concedido por el comandante del cantón de Requena, D. José Ruiz de Albornoz, a Francisco Claramunt, escoltando una carga de fusiles y municiones, Requena, 1835/12/10. AMR 4734/2 Fig. 877. Medidas de fortificación: Comisión del 26 de febrero de 1836, en la que el max

estado de las obras y cuanto resta por concluir de la fortificación de Requena junto a unestro de obras Guillermo Saez verifica el $1836 / 02 / 26$, AMR, 1818/53

Fig. 878. Comisión de servicios del ingeniero Ortiz de Pinedo, Requena, 1837/03/12, AMR, 1818/16.
Fig. 879. Expediente y bando de la defensa de Requena en caso de ser vuelta a invadir por la cabecilla Cabrera y nombramiento de la Junta de armamento y defensa, Requena, 1835/09/18, AMR, 1818/19 E.

Fig. 880. Certificaciones de Ortiz de Pinedo sobre las varas, jornales, materiales y precios de las obras de

reedificación de la fortificación de Requena, Requena, 1837/05/30, AMR, 1818/34E.

Fig. 881. Expediente sobre las medidas tomadas para mejor seguridad de la ciudad, Requena, 1838/02/09, AMR, 1818/8E Fig. 882. Memoria del Comandante militar y Ayuntamiento para la total defensa de Requena y mayores contribuciones a su vista, Requena, 1838/03/25, AMR, 1818/24E.

Fig. 883. Transcripción 11: Fortificación de Requena. Memoria sobre la reparación y obras nuevas que conviene verificar,

Fig. 884. Expediente sobre la fortificación de la ciudad, Requena, 1839/03/09, AMR, 1818/35E.

\section{Índice y créditos de tablas}

Tabla 1 Intervenciones propuestas por Guillermo Sáez el 5 de diciembre de 1835 (AMR, 1818/50). P. 635 Pág. 631

Tabla 2 Intervenciones pendientes a partir del informe de la Comisión Municipal integrada por P. P. 638 Guillermo Sáez del 26 de febrero de 1836 (AMR, 1818/16).

$\begin{array}{llllll}\text { Tabla } 3 & \text { Propuesta de distribución de la Guarnición de Requena según la memoria del ingeniero } & \text { P. } 643\end{array}$ Pedro Ortiz de Pinedo, fechada aproximadamente en abril de 1837 (AMR, 1818-52)

$\begin{array}{lll}\text { Tabla } 4 & \text { Relación de puntos identificados en el croquis del cerramiento aspillerado de Requena } & \text { P. } 647\end{array}$ efectuado por el ingeniero militar Pedro Ortiz de Pinedo (AGMM, Ar. G-T.3.C.2.262).

Tabla 5 Identificación y propuesta de obras según la Memoria del Coronel Comandante Militar de la $\quad$ P. 653 Plaza, José García de Orozco (25 de marzo de 1838).

Tabla 6 Propuesta de intervención del ingeniero Juan Ramón de Carbonell. Requena, 4 de julio de $\quad$ P. 657 1838 (AMR, 1818-17).

Tabla 7 Número de plazas identificadas por provincias. $\quad$ P. 1031

Tabla 8 Periodos de la fortificación del "reino mágico" de Cabrera. $\quad$ P. 1032

Tabla 9 Plazas fortificadas en cada línea defensiva. $\quad$ P. 1044

Tabla 10 Cantidad de cada tipo fortificatorio. $\quad$ P 1049

Tabla 11 Puntos fortificados por los liberales y los carlistas durante el conflicto detectados al inicio de P. 1061 este trabajo. El presente listado es el origen para una propuesta de investigación territorial y
es susceptible de ampliarse con otros puntos aún no identificados en las fuentes. En el caso carlista, como se puede observar en el catálogo de esta tesis, los 23 puntos de los que se partía han sido ampliados a 78 enclaves susceptibles de haber recibido intervenciones defensivas.

Tabla 12 Listado de las plazas fuertes estudiadas.

Tabla 13 Campos de batalla identificados. $\quad$ P. 1101

Tabla 14 Cronología de Cabrera en la guerra del Maestrazgo. Fuente: Rodrigo, R. 2019. Ramón Cabrera P. 1105 y Griñón "El tigre del Maestrazgo" en https:/ / elgrancapitan.org, contrastando fuentes como Flavio, 1870; Cabello, et altr. 1845 y Canales, 2006.

Tabla 15 Cronología y posibles localizaciones de la expedición de Gómez. P. 1113

Tabla 16 Recorrido de Pío Baroja siguiendo la estela de Gómez recogido en la Revista Estampa. $\quad$ P. 1121 Baroja, P. (1935): Sobre la ruta del general Gómez por los caminos de España. La Estampa, 377, p.

Tabla 17 Periodos de la fortificación del "reino mágico" de Cabrera. $\quad$ P. 1131

Tabla 18 Fechas y localizaciones de la Expedición Real. P. 1135

Tabla 19 Movimientos de Cabrera durante la Expedición Real según el testimonio de Wilhelm von $\quad$ P. 1139 Rahden (2013: 49).

Tabla 20 Recorrido de don Beltrán de Urdaneta en La campaña del Maestrazgo (Pérez Galdós, B. P. 1147 (1993): Episodios Nacionales, 25. Madrid: Círculo Internacional de Lectores).

Tabla 21 Interrelación entre los conflictos internacionales, nacionales y locales. $\quad$ P. 118

Tabla 22 Toponimia asociada a la documentación histórica. $\quad$ P. 1233 

